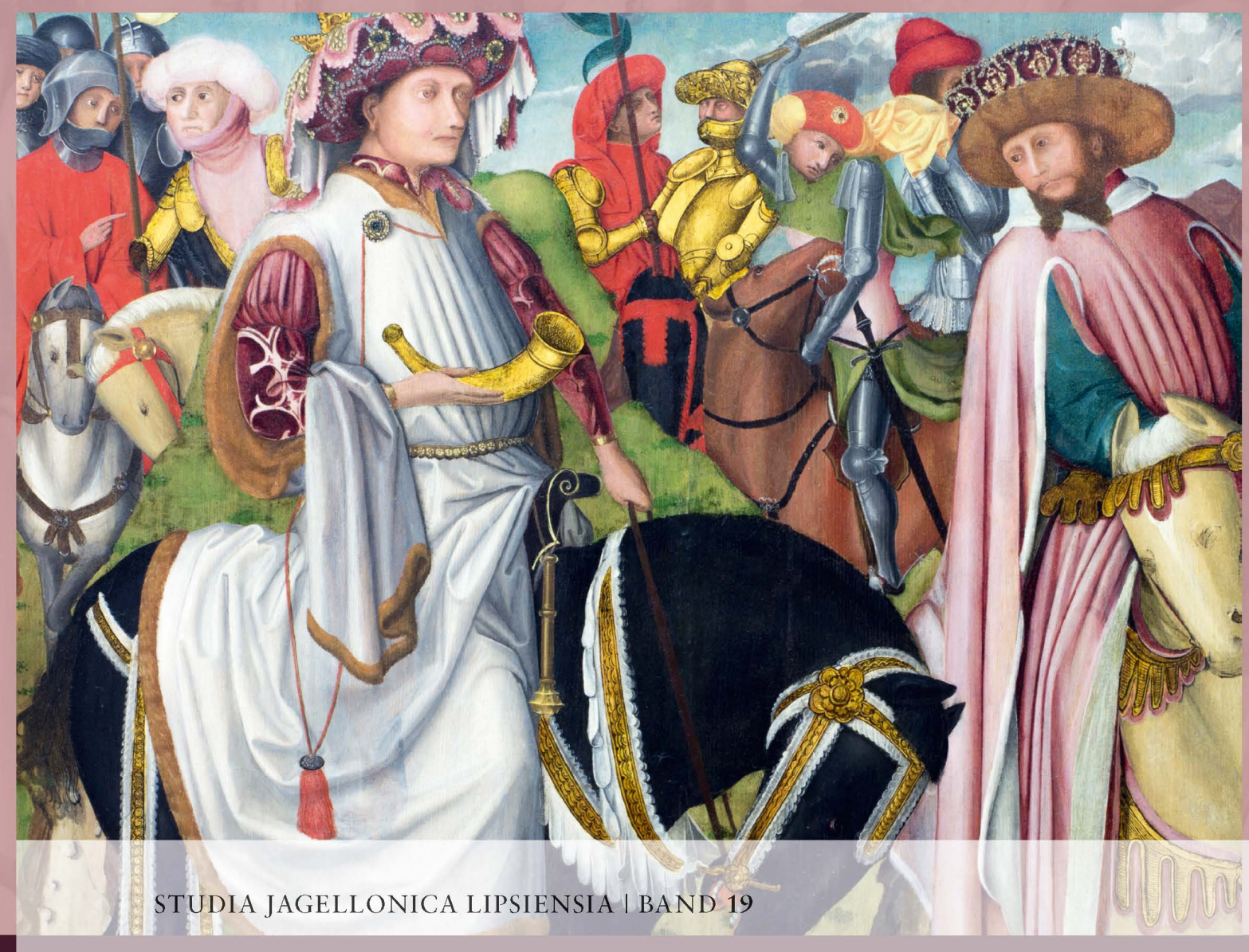

\title{
Vom Weichen über den Schönen Stil zur Ars Nova
}

Neue Beiträge

zur europäischen Kunst

zwischen 1350 und 1470 
를 


\section{STUDIA JAGELLONICA LIPSIENSIA}

im Auftrag des Leibniz-Instituts für Geschichte und Kultur des östlichen Europa (GWZO)

herausgegeben von Jiř́ Fajt und Markus Hörsch

in Zusammenarbeit mit

Winfried Eberhard, Adam S. Labuda, Christian Lübke,

Ernő Marosi, Robert Suckale und František Šmahel

Band 19 


\section{Vom Weichen über den Schönen Stil zur Ars Nova}

Neue Beiträge zur europäischen Kunst zwischen 1350 und 1470

herausgegeben von Jiří Fajt und Markus Hörsch

Böhlau Verlag Wien Köln Weimar 
Open Access: Wo nicht anders festgehalten, ist diese Publikation lizenziert unter der Creative-Commons-Lizenz Namensnennung - Nicht kommerziell - Keine Bearbeitungen 4.0 International (CC BY-NC-ND 4.0); siehe https://creativecommons.org/licenses/by-nc-nd/4.0/

Bibliografische Information der Deutschen Nationalbibliothek:

Die Deutsche Nationalbibliothek verzeichnet diese Publikation in der

Deutschen Nationalbibliografie; detaillierte bibliografische Daten sind im Internet über http://dnb.d-nb.de abrufbar.

(C) 2018 by Böhlau Verlag GmbH \& Cie, Köln, Lindenstraße 14, D-50674 Köln

Alle Rechte vorbehalten. Das Werk und seine Teile sind urheberrechtlich geschützt. Jede Verwertung in anderen als den gesetzlich zugelassenen Fällen bedarf der vorherigen schriftlichen Einwilligung des Verlages.

Umschlagabbildung: Reiterzug der Anbetung der Könige aus Höchstädt/Donau. Augsburger Meister (?). Freising, Diözesanmuseum. Foto: Rainer A. Gimmel, Regensburg

Redaktion: Markus Hörsch unter Mitarbeit von Benno Baumbauer Bildredaktion: Sarah Weiselowski Register: Theo Schley Endredaktion Register: Nicolas Karpf Korrektorat: Ute Wielandt, Baar-Ebenhausen Einbandgestaltung: Michael Haderer, Wien Satz: Michael Rauscher, Wien 


\section{INHALTSVERZEICHNIS}

Vorwort 9

\section{Mobilität, Kulturtransfer und kommunikative Funktion der Kunst 1350-1450}

UwE GAST

Ein Bild zum Fest der Lanze und der Nägel?

Die Kreuzigung Christi im Museum der Stadt Worms 15

Markus T. Huber

Rezeption, Aneignung und Variation

Die Entwicklung der Regensburger Dombauhütte zwischen 1380 und $1425 \quad 29$

Helge Kuppe

Eine Altarsetzung mit sichtbaren Folgen: Sigismund von Luxemburg und das Dreikönigsportal der Liebfrauenkirche in Frankfurt/Main 47

Ute BedNARZ

Retabelskulptur in Obersachsen um 1400 - Annäherung an ein bislang wenig beachtetes Thema

\section{Avignon in der Zeit des Schismas}

Christian Freigang

Päpstliche Hofkunst in Avignon in der Zeit des Schismas 89

Alexandra Gajewski

Art and Architecture in Avignon during the Great Schism

Remarks on Clement's VII foundations of Saint-Martial and Saint-Pierre-Célestin 97

JULIAN GARDNER

Jean de la Grange, Schismatic Cardinals and Avignonese Tomb Sculpture 117

Francesca Manzari

More on Illumination at the Time of the Great Schism

Book Patronage in the two Curias and a Long-Lasting Stage of Gothic Illumination in Rome 129 
Zentralisierung und Diversifizierung

Englische Kunst im Schatten des Hundertjährigen Krieges ca. 1350-1450

Ute ENGEL Und Jens RüFFER

Zentralisierung und Diversifizierung

Englische Kunst im Schatten des Hundertjährigen Krieges ca. 1350-1450 149

Veronika Decker

Windsor - Oxford - Winchester

Ideentransfer und Vermittlungswege in der englischen Kunst des ausgehenden 14. Jahrhunderts 153

Julia Crispin

Politische Botschaften und illustre Geschenke

Richard Beauchamps Handschriftenpatronage zwischen England und Frankreich zur Zeit

des Hundertjährigen Krieges 169

Stefan King Und Ines Stadie

Bischof Hallum und die »Zwiebel«.

Der Weg eines englischen Architekturmotivs ins Konstanzer Münster 183

Antje Fehrmann

Plausible Fiktionen: König Sigismund und die englische Repräsentation während des Konstanzer Konzils

\section{Früher Realismus - Junge Wilde? \\ Malerei an der Schwelle der Neuzeit (1430-50)}

Gerhard Weilandt

Früher Realismus im 15. Jahrhundert?

Einige Überlegungen zur deutschen Malerei an der Schwelle der Neuzeit 231

Stavros Vlachos

Vorläufer des Frühen Realismus in der Malerei um $1400 \quad 243$

AdAm S. LABUdA

Das Zeugnis der künstlerischen Form - das Zeugnis der Schriftquellen

Auf den Spuren der Schöpfer des Breslauer St.-Barbara-Altars und des ehemaligen Hochaltars

der Jakobskirche in Neiße 267

WiLfRIEd FranZen

... heruff von Österland in Schwaben und hochdeutsche landt?

Albrecht VI. von Habsburg und der Meister von Schloss Lichtenstein

Manuel Teget-Welz

Die Höchstädter Anbetung der Könige

Ein Hauptwerk der Tafelmalerei in Augsburg um 1440? 317 
MARKus Hörsch

$\mathrm{Zu}$ Art und Umfang eines Realismus als konstituierendem Merkmal des Werks des Meisters der Karlsruher Passion 327

ULRICH SöDING

Realismus und Symbolik in der deutschen Tafelmalerei von 1430 bis $1450 / 60 \quad 361$

Tafelteil 397

Register 417 



\section{VORWORT}

Vor über zehn Jahren erschien Band 1 der Reihe Studia Jagellonica Lipsiensia - zugegebenermaßen erst nach dem zweiten, dem jagiellonischen Böhmen gewidmeten, der bereits 2004 fertiggestellt worden war -, ein Sammelband unter dem Titel »Künstlerische Wechselwirkungen in Mitteleuropa«, der eine breite, bunte Mischung von Beiträgen enthält, die zeitlich sogar über die im Reihentitel als Richtschnur angegebene Epoche der Jagiellonen hinausging. Damit sollte angedeutet sein, dass wir keine zeitlich oder methodisch streng eingehegte Publikationsreihe beabsichtigten, sondern ein Forum zur Veröffentlichung von Beiträgen ostmitteleuropäischer Thematik, die insbesondere auch immer wieder den kulturellen Austausch innerhalb des gesamten nach 1989 wiedervereinigten Europa ins Auge fassten. Naturgemäß waren dies in erster Linie Beiträge, die mit dem GWZO in einer engen Verbindung standen.

An dieser Ausrichtung wird sich nichts ändern, wenn mit dem vorliegenden Band 19 ein neuer Abschnitt der Geschichte unserer Reihe eröffnet wird: Er ist der erste, der im neuen Verlag und somit in einem etwas veränderten Gewand erscheint. Diese Änderung wurde nicht von den Herausgebern der Reihe, sondern von Reglements der Vergabe öffentlicher Gelder verursacht, die Ausschreibungen selbst von Buchreihen verlangen. Der vorliegende Band 19 setzt somit einen gewissen Akzent, und es traf sich gut, dass wir wiederum eine Sammlung thematisch weit gespannter Beiträge vorbereiteten - zu Themen und Themenfeldern, die die Forschungsinteressen der Herausgeber von Beginn an berührt haben, eben zu den Wechselwirkungen der Kunst im mittelalterlichen und frühneuzeitlichen Europa, insbesondere zur Kunst des 14. und 15. Jahrhunderts.

Es handelt sich bei der Mehrzahl der Beiträge um die schriftliche Version von Referaten, die in verschiedenen Sektionen des in Freiburg im Breisgau abgehaltenen 2. Forums Kunst des Mittelalters im Jahre 2013 gehalten wurden. Die Herausgeber entschlossen sich damals, Beiträge der ihren Forschungsfeldern besonders nahe stehenden Sektionen zu publizieren; an eine wie auch immer geartete »vollständige« Veröffentlichung war schon wegen des unterschiedlichen Charakters und Bearbeitungsstands der jeweiligen Referate nicht zu denken - und so ist es selbstverständlich, dass ein Nicht-Abdruck in diesem Band keine Abwertung nicht berücksichtigter Beiträge und ihres innovativen Potenzials bedeutet.

Das mit dem Jahr 2017 zum Leibniz-Institut für Geschichte und Kultur des östlichen Europa gewordene GWZO gehört so zu sagen zu den Gründungsförderern dieser so wichtigen Veranstaltungsreihe seit ihrer ersten Organisierung in Halberstadt 2011. Für die durchgängige Unterstützung des Forums mit seinen jeweiligen GWZO-Sektionen ist herzlich unserem Direktor, Herrn Prof. Christian Lübke, der Verwaltung des Hauses, insbesondere Frau Antje Schneegaß und Frau Anja Fritzsche, und nun, nach der Neustrukturierung unseres Instituts, auch den Abteilungsleitern Arnold Bartetzky und Matthias Hardt zu danken. Ohne diese und weitere Unterstützung von verschiedenen Seiten wäre ein solch rühmenswertes und zu Beginn gewiss risikoreiches Unterfangen, wie es die Initiatoren des Forums, insbesondere Gerhard Lutz in Hildesheim und der Deutsche Verein für Kunstwissenschaft, zunächst noch unter Leitung von Prof. Rainer Kahsnitz, seit 2011 unter derjenigen von Prof. Wolfgang Augustyn, wagten, nicht möglich gewesen. Der vorliegende Band ist auch als dauerhafte Anerkennung ihres Engagements zu verstehen, hält er doch wenigstens im Ausschnitt etwas fest von den thematisch interessanten, engagierten und zukunftsweisenden Beiträgen, die solch ein Forum ermöglicht, das eine mittlere Position zwischen Fachtagungen und Großveranstaltungen wie etwa dem Deutschen Kunsthistorikertag einnimmt.

Dass der Band mit deutlichem Abstand zu der zu Grunde liegenden Veranstaltung erscheint, ist verschiedenen Ursachen geschuldet. Neben den eingangs genannten Umständen war es vor allem die im Wesentlichen von einem GWZO-Team kuratierte und organisierte große Erste Bayerisch-Tschechische Landesausstellung »Kaiser Karl IV. 1316-2016« in Prag und Nürnberg 2016/17, die andere Vorhaben eine Zeit lang in den Hintergrund treten ließ. Zudem versuchten wir, die Beiträge des Forums noch um einige weitere, thematisch passende zu ergänzen 
- zu nennen ist hier besonders die Publikation zweier, hier zu einem Ganzen verschmolzener Aufsätze von Adam S. Labuda. Wir sind ihm und der Übersetzerin Agnieszka Lindenhayn-Fiedorowicz dankbar, dass wir dieses wichtige, wiederum Fragen aufwerfende Resümee langer Forschungsarbeit hier in deutscher Sprache drucken können.

So kam also eine Auswahl einzelner Themenblöcke zustande, die jeweils in ihrem Bereich weiterführen und vertiefen; sie entsprechen Sektionen des Forums 2013 und bilden die Kapitel dieses Buchs. Am Beginn steht dasjenige, welches das von den Herausgebern als zentral erachtete Thema des Forums anschlägt: "Mobilität, Kulturtransfer und kommunikative Funktion der Kunst (...)«. Es ging uns damals konkret darum, den Zeitraum vor allem der Herrschaft der Söhne Kaiser Karls IV. im Römisch-Deutschen Reich sowie in den Königreichen Böhmen und Ungarn ins Zentrum zu rücken: Er ist von zahlreichen Umbrüchen und Aufbrüchen geprägt, den reformatorischen der Hussiten in Böhmen, den kirchenreformerischen des Konziliarismus in Konstanz und in Basel. Waren zu Anfang des ins Auge gefassten Zeitraums die ökonomischen, politischen und kulturellen Beziehungen zwischen den genannten Ländern eng, florierte der Austausch, wurde er später durch Hussiten-Kriege und Exkommunikation zeitweilig zum Erliegen gebracht. Die Kunstgeschichte neigte dabei ohne eine präzise Untersuchung solcher historischer Hintergründe zu vereinfachenden, plakativen Epochen-Entwürfen: Auf den so genannten »Internationalen Stil« folgte demnach eine "Dunkle Zeit«, die dann wieder von jener »lichteren" abgelöst wurde, in der die niederländische Ars nova intensiv rezipiert wurde. Ziel war es, solche immer noch virulenten (und im Zuge eines Kanonbildungs-Prozesses möglicherweise sogar wieder zunehmenden) Klischees zu differenzieren, und zwar anhand möglichst konkreter Fallbeispiele aus allen Bereichen künstlerischer Medien.

Nach den mitteleuropäischen Themen dieses ersten Teils, der um einen Beitrag von Ute Bednarz, der das 15. Jahrhundert betrifft, ergänzt wurde, lädt unser Band nun zu einer Reise an zwei andere europäische Brennpunkte des 14./15. Jahrhunderts ein: nach Avignon respektive England, die gerade aus mitteleuropäischer Sicht besonders interessant (und noch immer ein wenig vernachlässigt) scheinen. Blickt man auf das katholische Europa des Spätmittelalters, ist leicht zu erkennen, dass es im Zeitalter vor den Nationalstaaten in den Oberschichten kulturell einheitlicher war als der heutige Kontinent. Selbst im Hinblick auf die bekannten Beziehungen Kai- ser Karls IV. zum päpstlichen Hof in Avignon ist es noch sinnvoll, den Blick auf das Papsttum in Avignon und, allgemeiner, auf das schismatische Papsttum zu schärfen, was in diesem Band mit dem von Christian Freigang eingeleiteten Kapitel bestens gelingt. Mehr noch gilt dies für England, das aus mitteleuropäischer Sicht stets ein wenig im Abseits zu liegen scheint - zu Unrecht, wie unter anderem gerade die im vorliegenden Band herausgearbeitete Rolle der englischen Delegation beim Konstanzer Konzil belegt.

Dem Umfang nach bildet Malerei des mittleren 15. Jahrhunderts in verschiedenen Facetten schließlich den Schwerpunkt des Bands, eingeleitet durch einen das Thema überblickend zusammenfassenden Beitrag von Gerhard Weilandt. Etwas übergreifend prägt dieser Teil auch den Titel des Gesamtwerks. Es ist nicht leicht, gute Titel für Sammelbände zu finden - und auch unseren mag man kritisierbar finden. Soll hier nun doch wieder der Gänsemarsch der Stile eingeführt werden, den bereits Wilhelm Pinder kritisierte? Was sollen überhaupt Stilbezeichnungen - geht es der Wissenschaft heute nicht um ganz andere, weit von der alten Stilgeschichte entfernte Erkenntnisziele?

Um hier keine Missverständnisse aufkommen zu lassen: Wir halten Stilkritik nach wie vor für ein wichtiges Instrument der kunstgeschichtlichen Forschung, das freilich seine einstige vermeintliche Autonomie verlieren musste und grundsätzlich nur dann fruchtbar gemacht werden kann, wenn es in Geschichte im weitesten Sinne eingebunden wird, wenn es nicht nach biologistischen Kriterien des Werdens und Vergehens oder nach allzu festen kunstlandschaftlichen Vorstellungen behandelt wird. Wir deuten mit unserem Titel lediglich eine stilistische Entwicklung an, und da man einmal zu Begrifflichkeiten kommen muss, um sich über die großen Züge zu verständigen, gebrauchen wir sie so, wie sie sich aus unserem durch langjährige Forschungen untermauerten Blickwinkel am vernünftigsten anwenden lassen: Der Weiche Stil ist da nicht synonym mit dem Schönen Stil, wie es leider immer noch weithin in der Fachliteratur der Fall ist. Vielmehr kann man bei genauer formaler Analyse den "Schönen Stil« zwischen den 137oer- und den 1420er-Jahren eben kaum als »weich" charakterisieren. Für die Hervorbringungen dieses Zeitraums sollte man bei dem spätestens 1978 mit der großen Kölner Ausstellung Anton Legners grundlegend eingeführten und historisch begründbaren Begriff des Schönen Stils bleiben. Wenn man überhaupt weiterhin den Begriff des 
"Weichen Stils« benötigt, so sollte man damit eher die Phase des aus dem Westen Europas in seine Mitte gewanderten Meisters Theoderich bezeichnen. Denn wo fände man "weichere« Malereien als die der Tafelbilder der Heilig-Kreuz-Kapelle auf Burg Karlstein? Und am Ende steht dann der Übergang vom Schönen Stil zu einer realistischeren, im Wesentlichen von den Kunstzentren der Niederlande geprägten Kunst, die man schon seinerzeit als »ars nova" empfand.

Es ging somit darum, eine gewisse Entwicklung künstlerischen Wollens über ein gutes Jahrhundert hinweg anzudeuten, um durch den Buchtitel Assoziationen bei fachkundigen Lesern und Leserinnen hervorzurufen. Folgerichtig wird man in diesem Band aber keine Diskussion um Definition oder gar Schöpfung stilgeschichtlicher Entitäten finden. Kunstproduktion vollzieht sich nicht ohne Brüche, nicht in fest umrissenen Gebieten, nicht ohne den Einfluss sehr unterschiedlicher, heute zumeist kaum mehr fassbarer Persönlichkeiten, seien es Künstler, seien es Auftraggeber. Ihren Intentionen im Einzelnen nachzuforschen und dies an jeweils bedeutenden, vielleicht aber nicht unbedingt einem Kanon verbundenen Beispielen dies ist die Intention dieses Bandes. Es geht stets um die jeweilige (kunst-)historische Situation, in der bestimmte künstlerische Ausdrucks- und Erzählweisen gefunden werden. Und eines ist kaum zu bestreiten: Die Spanne von der Herrschaftszeit des bedeutendsten Luxemburger-Herrschers, Karls IV. (1346/49-78), über die Zeit der großen Produktivität der Prager Werkstätten um 1400 hin zu den internationalen Austauschplätzen der beiden Konzilien von Konstanz (1414-18) und Basel (1431-49) ist eine an Innovationen und Wechseln überaus reiche Zeit.

Jiří Fajt und Markus Hörsch Leipzig, im Herbst 2017 

Mobilität, Kulturtransfer und kommunikative FunKTION DER Kunst 1350-1450 

UWE GAST

\title{
Ein Bild zum Fest der Lanze und der NäGel?
}

\author{
Die Kreuzigung Christi im Museum der Stadt Worms ${ }^{1}$
}

Das Museum der Stadt Worms im Andreasstift besitzt unter seinen mittelalterlichen Kunstwerken ein Tafelbild mit der Kreuzigung Christi (Taf. I), das - von einer Abbildung in dem Sammlungsführer von Georg Illert abgesehen $^{2}$ - lange Zeit wenig Beachtung gefunden hat. Weder ist die Tafel in Publikationen zur Kunst am Mittelrhein aufgenommen worden, noch wird sie in einem der Standardwerke zur deutschen gotischen Malerei erwähnt. Sie war zuletzt im Langhaus der ehemaligen Stiftskirche ausgestellt und mit der falschen Datierung "um 1450« versehen. Tatsächlich ist die Tafel sehr viel früher entstanden: Wie ich in der ersten, im Jahr 2013 erschienenen Fassung dieses Beitrags nachzuweisen versucht habe, dürfte sie um 1370/80 gemalt worden sein und ist folglich als eines der raren Werke deutscher Tafelmalerei des 14. Jahrhunderts anzusehen. ${ }^{3}$ Zudem ist sie ikonografisch bemerkenswert, da die drei Nägel, mit denen Christus ans Kreuz geschlagen ist, mit Nimben versehen sind. Es sind »heilige Nägel«, und dieses besondere Motiv scheint auf irgendeine Weise mit der Verehrung der Kreuzesnägel Christi in Zusammenhang zu stehen, denen seit dem Jahr 1354 ein eigenes, von König Karl IV. (reg. 1349-78, seit 1355 Kaiser) initiiertes Fest gewidmet war: das »Festum lanceae et clavorum «. ${ }^{4}$ Hatte dieses von Prag ausgehende, für Böhmen und das ganze Reich eingerichtete Fest zu einem neuen ikonografischen Typ der Kreuzigung Christi geführt, der hier überliefert ist, oder handelt es sich um eine singuläre, für einen bestimmten Ort gefundene ikonografische Lösung? Diese Frage soll im Folgenden untersucht werden.

Die Voraussetzungen dafür wären besser, wenn es wenigstens einige grundlegende Angaben zu der Tafel gäbe. Aber weder ihre Provenienz noch ihr Erwerbungsjahr sind bekannt, ja sie wurde anscheinend nicht einmal inventarisiert. Letzteres könnte dafür sprechen, dass sie früh in den Besitz des damaligen Paulus-Museums gelangt war, vor 1912, als mit der systematischen Erfassung der Geschenke und Neuerwerbungen begonnen wurde. Mangels eines Nachweises ist aber auch dies unsicher. ${ }^{5}$ Die ohne ihren modernen Rahmen $80,5 \times 66,9 \mathrm{~cm}$ mes- sende Tafel kann folglich nur mithilfe der Stilkritik eingeordnet werden. ${ }^{6}$

Dargestellt ist Christus am Kreuz zwischen den drei Marien und Johannes Ev., Johannes dem Täufer und Katharina von Alexandrien, zahlreichen gemalten und in den Goldgrund punzierten Engeln sowie einem am Fuß des Kreuzes knienden Stifterpaar (Taf. I). Das Kreuz mit der überproportional großen Figur Christi und die flankierenden Heiligen stehen, vom tief hinabreichenden Goldgrund hinterfangen, auf einem flachen, zu den Seiten hin leicht abfallenden, kargen Bodenstreifen. Christus trägt ein blaues Lendentuch, von dem zwei Stoffzipfel markant abstehen; sein Kopf ist schwer auf seine rechte Schulter gesunken, seine Augen sind geschlossen, aus seinen Wunden an der Seite, an Kopf, Händen und Füßen rinnt Blut. Es wird von Engeln mit Kelchen aufgefangen. Weitere Engel vollführen Gesten der Trauer oder sind damit beschäftigt, einen Teil der Leidenswerkzeuge Christi die Geißelsäule und den Essigeimer - sowie ein liturgisches Buch und Weihrauch herbeizubringen. Maria, von zwei Begleiterinnen gestützt, und Johannes Ev. stehen unmittelbar zuseiten des Kreuzes. Maria trägt ein rotviolettes, blau gefüttertes Gewand und ein weißes Kopftuch, die anderen Marien sind in blaue und rot-grüne Gewänder gehüllt. Mit vor der Brust verschränkten, winzigen Händen und in den Nacken gelegtem Kopf schaut die Gottesmutter mit ernstem Blick zu ihrem Sohn empor. Johannes, angetan mit blau-grün-hellvioletten Gewändern, in seiner rechten Armbeuge ein geöffnetes Buch tragend, scheint halb zu Christus hinauf-, halb zu Maria hinüberzublicken. Johannes der Täufer und Katharina von Alexandrien sind himmlische Zeugen des Kreuzigungsgeschehens. Johannes ist in ein hellbraunes Fellgewand gehüllt und trägt das Lamm auf seinem linken Arm. Katharina, in grün-rot-blauem Gewand und eine Krone tragend, hält Rad und Schwert als Zeichen ihres Martyriums. Die Stifter, die in miniaturhafter Größe betend am Kreuzesfuß knien, tragen Gewänder, wie sie nach der Mitte des 14. Jahrhunderts in Mode waren: auf der heraldisch rechten, höherrangigen Seite die Frau mit einem 


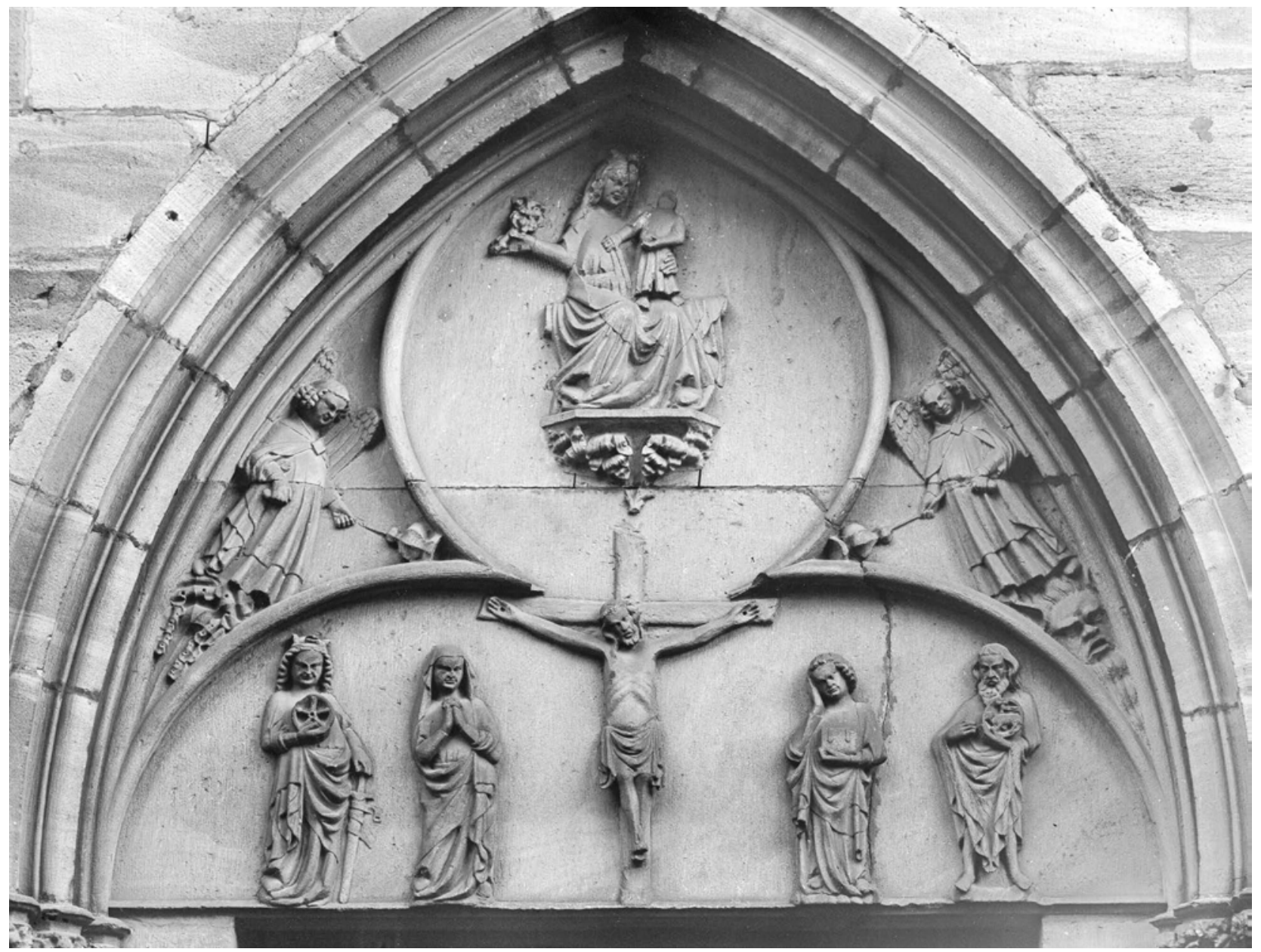

Abb. 1 Kreuzigung Christi im Tympanon der Pfarrkirche St. Gregor der Große in Rappoltsweiler/Elsass, um 1380-1400 (Foto: Bildarchiv Foto Marburg)

Kruseler, heraldisch links der Mann in Beinlingen, kurzer Schecke und einer Gugel mit Sendelbinde. ${ }^{7}$ Ihre Identität bleibt ungeklärt, da Hinweise in Form eines Allianzwappens oder einer Inschrift, die sich auf dem verlorenen originalen Rahmen oder gegebenenfalls auch auf verlorenen Flügeln befunden haben könnten, fehlen. Die unterhalb des Kreuzes zu lesende Inschrift »M 3" scheint eine Inventarnummer aus dem 18./19. Jahrhundert zu sein. ${ }^{8}$

Ikonografisch vertritt die Darstellung einen Bildtyp, der noch im 13. Jahrhundert ausgebildet worden zu sein scheint und im 14./15. Jahrhundert weit verbreitet war: die Kreuzigung Christi mit Heiligen. Dies meint - in Abwandlung der nur auf Breitformate bezogenen Definition von Ursula Binder-Hagelstange - Darstellungen des Gekreuzigten mit Maria und Johannes Ev., zu denen sich
Heilige »ohne notwendigen inhaltlichen Bezug « hinzugesellen, ${ }^{9}$ in diesem Fall Johannes der Täufer und Katharina von Alexandrien. Durch ihre im Grunde nicht mögliche Anwesenheit - Johannes wurde noch zu Lebzeiten Christi hingerichtet (Mt 14,3-12; Mk 6,17-29; Lk 9,9), Katharina starb wohl erst im frühen 4. Jahrhundert den Märtyrertod ${ }^{10}$ - wird das biblisch-historische Ereignis in eine überzeitliche, himmlische Sphäre versetzt, sodass nicht die Kreuzigung an sich, sondern der Opfertod Christi mit der Aussicht auf Heil und Erlösung das Thema der Darstellung ist. ${ }^{11}$ Eben dafür stehen beide Heilige ein: Johannes als derjenige, der in Jesus den Sohn Gottes erkannt und getauft hat (Joh 1,29-34) und daher als Prophet der Erlösung gilt, als welcher er immer wieder in Darstellungen der Kreuzigung Christi aufgenommen worden ist ${ }^{12}$ Katharina als die Angetraute Christi, die bei ihrem Tod mit den Worten »Komm nun meine Geliebte und meine Braut, denn siehe, die Himmelstür ist dir aufgetan « Einlass in das himmlische Paradies gefunden hat. ${ }^{13}$ Zusammen 
sind sie beispielsweise am Westportal-Tympanon der Pfarrkirche St. Gregor der Große in Rappoltsweiler (Ribeauvillé, Département Haut-Rhin) dargestellt (Abb. 1). ${ }^{14}$

Der statisch-repräsentative Bildtyp der Kreuzigung Christi mit Heiligen, wie ihn die Figurengruppe des Rappoltsweiler Tympanons beispielhaft verkörpert, wird in der Tafel in Worms durch zwei narrative Elemente belebt: zum einen durch die exaltierte, ins Dramatische gesteigerte Trauer der drei Marien unter dem Kreuz und zum anderen durch die vielen Engel, die um den Gekreuzigten herum schweben (Taf. I). Beide sind feste Bestandteile der Passionsikonografie seit dem frühen 14. Jahrhundert, wobei die Gottesmutter anstelle der Frauen auch von Johannes Ev. gestützt werden kann. ${ }^{15}$ Ein im Hinblick auf die Gesamtkomposition verwandtes, um 1340/50 entstandenes Werk, das bei kleinerem Format ebendiese Elemente zeigt (allerdings mit einer Maria-Johannes-Gruppe), ist in der Mitteltafel eines Triptychons aus dem ehemaligen Klarissenkloster St. Klara in Köln erhalten. Zuseiten des Gekreuzigten stehen hier Maria, Johannes Ev. und der Gute Hauptmann, flankiert von den heiligen Klara, Franziskus und Paulus. Am Fuß des Kreuzes kniet eine Nonne, die das Holz inbrünstig umschlingt. Christus ist von acht Engeln umgeben, die sein Blut auffangen, Weihrauchfässer schwingen und Trauergesten vollführen (Abb. 2). ${ }^{16}$

Das Beispiel des Kölner Triptychons vermag zu belegen, dass die Wormser Tafel in Ikonografie und Komposition auf Werke der Mitte des 14. Jahrhunderts zurückgeht. Über ihre Herkunft ist damit freilich nichts gesagt; auch deutet sich in ihrem gegenüber dem Kölner Werk anderen Stilbild - den kompakten Figurentypen mit teils gespannten, teils in der Hüfte abknickenden Körpern und eng anliegenden, der freien Bewegung hinderlichen Gewändern - sowie in ihrer Maltechnik - vor allem der reichen figürlichen Punzierung - ein etwas jüngeres Entstehungsdatum an. Ein ikonografisches Detail, das bisher unerwähnt blieb, dürfte zudem ein Indiz dafür sein, dass sie sicher nicht vor $1354-56$, ja vermutlich erst ab den späten $1360 e r$ Jahren entstanden ist.

Die Darstellung des Gekreuzigten folgt dem im 14. Jahrhundert längst vorherrschenden Typ des Dreinagelkruzifixus. ${ }^{17}$ Christus hängt mit weit gespannten, fast in die Waagerechte gezogenen Armen und übereinandergelegten, zur Seite gedrehten Füßen am Kreuz (Taf. I). Nicht nur sein Kopf ist von einem Heiligenschein umgeben, sondern auch die Nägel an Händen und Füßen sind von Nimben hinterfangen. Da zugleich im Bereich der Seitenwunde Christi - des in Patristik und Passionsfröm-

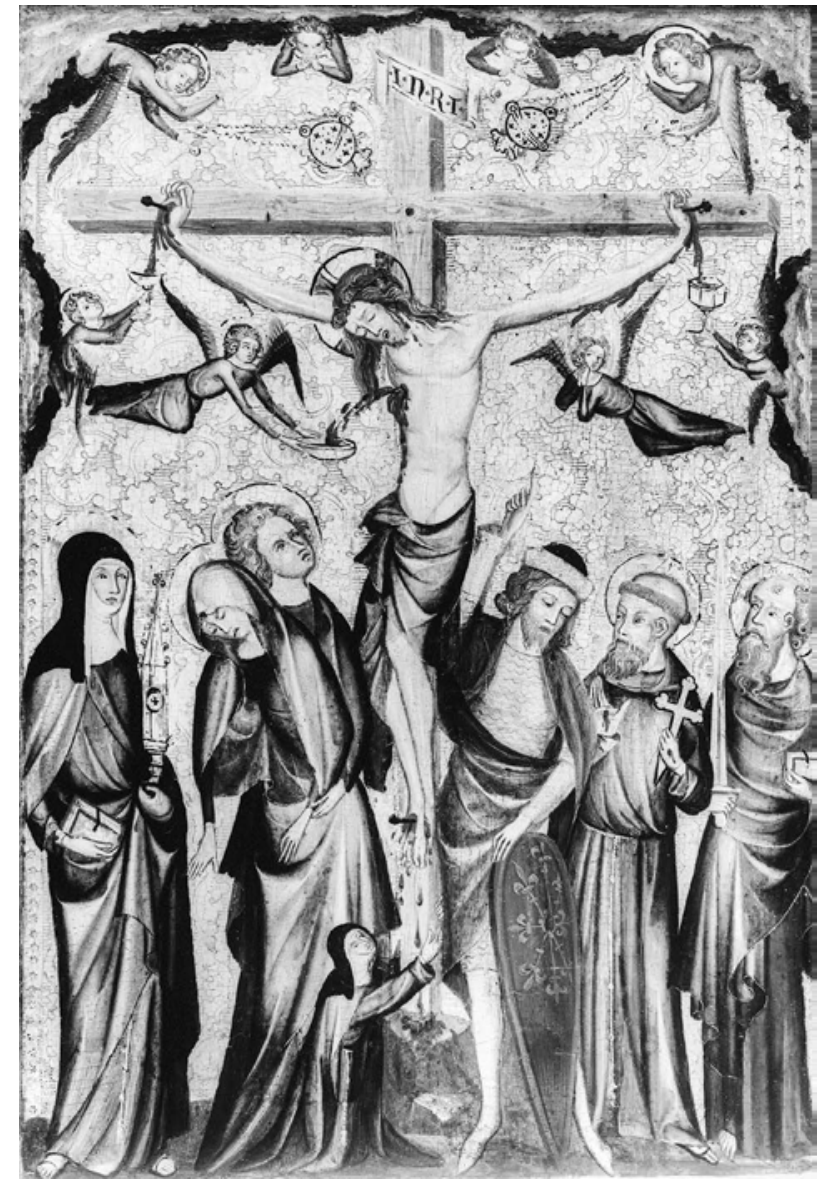

Abb. 2 Kreuzigung Christi. Köln, um 1340/50. Hamburg, Kunsthalle (Foto: Rheinisches Bildarchiv Köln, rba_044002)

migkeit zentralen Wundmals - ein Nimbus fehlt, kann ausgeschlossen werden, dass hier auf eine Verehrung der Wunden Christi abgezielt wurde. ${ }^{18}$ Die drei Nimben beziehen sich vielmehr auf die Nägel, mit denen Christus ans Kreuz geschlagen ist.

Als Gegenstände, die mit dem Leib und Blut Christi in unmittelbarem Kontakt standen, gehören die Kreuzesnägel zu den wichtigsten Christus-Reliquien. ${ }^{19}$ Ihre Verehrung soll bereits um die Mitte des 6. Jahrhunderts im Osten und im Westen verbreitet gewesen sein, doch blieb die Zahl der Stätten, an denen sich Exemplare befanden (ob als »echte" Sekundär- oder künstlich geschaffene Kontaktreliquien), lange Zeit gering. Erst nach der Eroberung Konstantinopels am Ende des Vierten Kreuzzuges 1204 stieg die Zahl der Nagelreliquien im Westen deutlich an, denn dort hatte man die ältesten Nägel Christi aufbewahrt. Sie sollen von der römischen Kaiserin Helena im frühen 4. Jahrhundert gefunden und ihrem Sohn Kaiser 


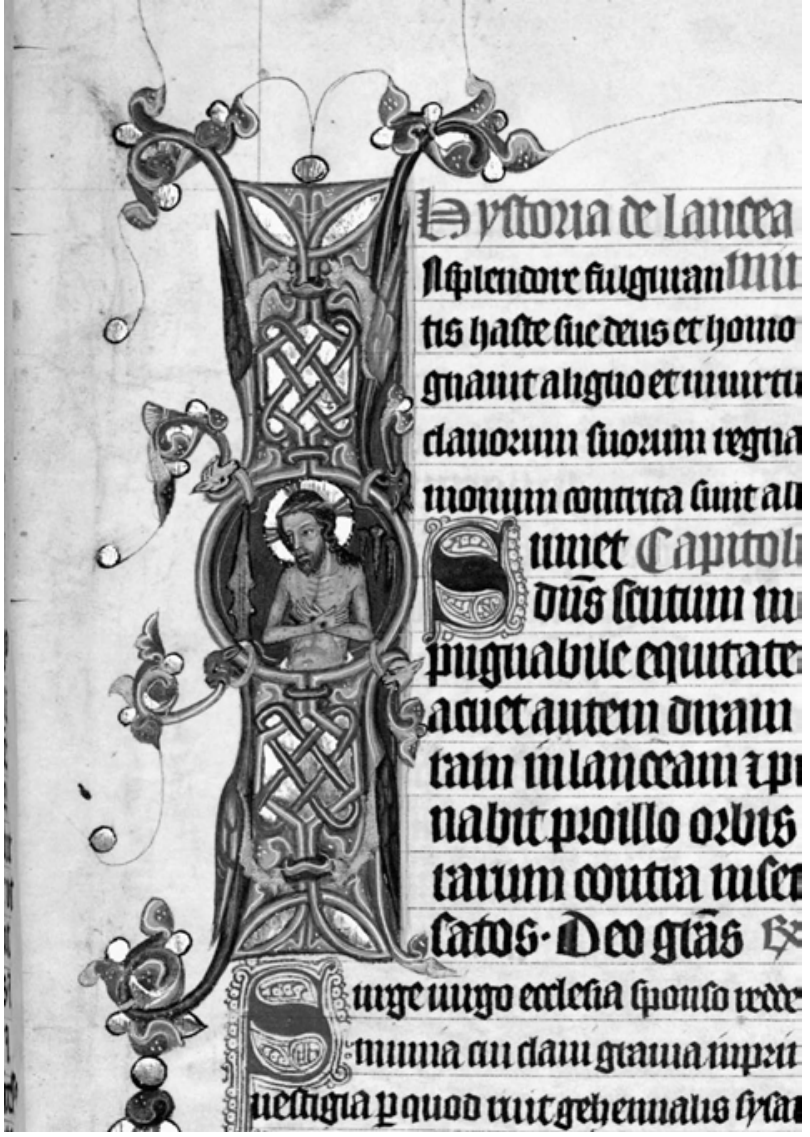

Abb. 3 I-Initiale mit Christus als Schmerzensmann. Prag, um 1355/60. Prag, Knihovna Národního muzea, XIII A 12, fol. 308r (Foto: Prag, Národní muzeum)

Konstantin dem Großen überlassen worden sein. ${ }^{20}$ Zeitlich einher ging damit die Umdeutung der heute in Wien aufbewahrten Heiligen Lanze des Heiligen Römischen Reiches vom Speer des Heiligen Mauritius zur Lanze der Passion, mit der ein Soldat die Seite Christi geöffnet hatte $\left(\right.$ Joh 19,34) ${ }^{21}$

Diese Lanze - eine karolingische Flügellanze, in deren Blatt ein aus drei symbolischen Kreuzesnägeln geschmiedeter, ursprünglich symmetrisch geformter Nagel eingesetzt ist - wurde im März 1350 zusammen mit den anderen Reichskleinodien an den Römisch-deutschen König Karl IV. (reg. 1346/49-78) in Prag übergeben, wo der Schatz am Palmsonntag (21. März) feierlich eingeholt und gewiesen wurde. Größte Aufmerksamkeit wurde dabei den Christus-Reliquien zuteil, die nicht nur in den Urkunden vom 12. März 1350 zur Übergabe und Übernahme des Schatzes an erster Stelle genannt (»unam auream crucem $[\ldots]$ in qua cruce est lancea una cum clauo
Domini nostri« bzw. »ein guldein creucz [...], vnd in dem selben creucz ist das sper vnd eyn nagel vnsers herren«), sondern auch in der zeitgenössischen Chronistik hervorgehoben wurden. ${ }^{22}$ Im vorliegenden Zusammenhang ist von besonderem Interesse, dass Karl sich in der Folge darum bemühte, die Reliquienweisung zu institutionalisieren und ein eigenes Fest zu Ehren der Lanze und der Nägel einzuführen. Ersteres - die jährliche, mit einem Ablass von sieben Jahren und sieben Quadragenen verbundene Weisung der Reliquien - vermochte Karl noch im selben Jahr 1350 von Papst Clemens VI. (reg. 1342-52) zu erwirken. ${ }^{23}$ Letzteres - das "Festum lanceae et clavorum", das im ganzen Reich und in Böhmen am zweiten Freitag nach Ostern gefeiert werden sollte - wurde von Clemens' Nachfolger, Papst Innozenz VI. (reg. 1352-62), am 13. Februar 1354 mit der Bulle »In Redemptoris nostri« eingesetzt. ${ }^{24}$ Erstmals begangen wurde es anscheinend im Jahr 1356, nachdem das Fest-Offizium, das bereits in Prager Handschriften der $1350 e r$ und $1360 e r$ Jahre überliefert ist, abgefasst war. ${ }^{25}$ Hier wie dort spielte die Anzahl der Nägel eine gewisse Rolle. Im Brevier-Offizium wird ihre Dreizahl zum einen in der vierten Psalm-Antiphon der Laudes ausdrücklich genannt (»Tres clauos sole clariores michahel tunc afferet contra peccatores«), zum anderen im Hymnus zur Prim durch die Nägel an den Händen und den Nagel an den Füßen angedeutet (»Claui sanctarum manuum « bzw. »Sacris infixus pedibus clauus«) ${ }^{26}$ Im Liber viaticus des Johann von Neumarkt (Jan ze Středy) ist die I-Initiale zu Beginn der »hystoria de lancea domini« mit einem Bild des Schmerzensmanns zwischen der Lanze und den drei Nägeln geschmückt (Abb. 3). ${ }^{27}$

Dementsprechend wurde bei den Weisungen in Prag, die - nach Karls Reliquienmehrungen um die Mitte der $1350 e r$ Jahre - in vier Gängen erfolgten, im zweiten, dritten und vierten Gang jeweils ein Nagel beziehungsweise eine Nagelpartikel der Kreuzigung Christi gezeigt. ${ }^{28}$ Nach den in München erhaltenen Heiltumslisten waren dies: aus dem Domschatz der Nagel von der linken Hand Christi (»Clauus de sinistra manu«); aus dem Kronschatz der Nagel von der rechten Hand Christi (»Clauus de dextra manu «; ehemals Burg Karlstein [Karlštejn]); aus dem Reichsschatz, zur heiligen Lanze gehörig, der Nagel von den Füßen Christi (»Clauus de pedibus Jhesu «). ${ }^{29}$

Obgleich die Herkunft all dieser Nagelreliquien und in zwei Fällen - auch der Zeitpunkt ihrer Erwerbung nicht bekannt sind, spricht jüngeren Forschungen zufolge doch viel dafür, dass die Reliquienweisungen in Prag, wie sie die Münchner Listen überliefern, im Lauf der 136oer 


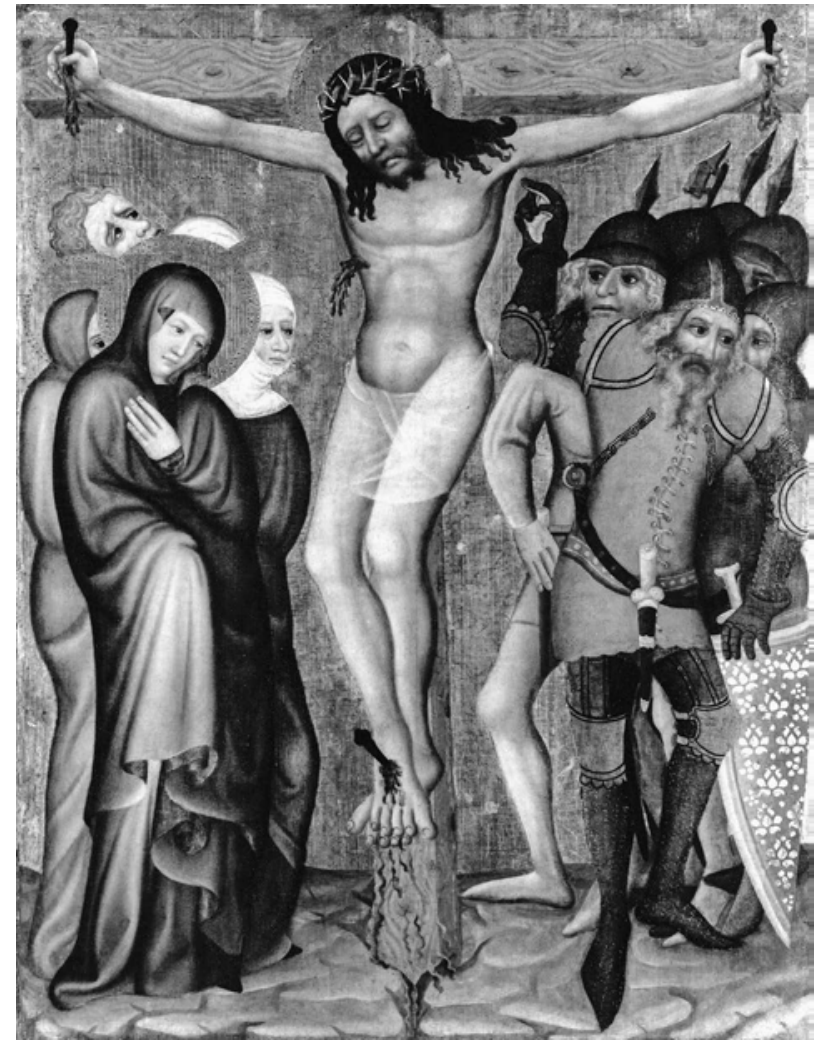

Abb. 4 Kreuzigung Christi aus dem Kloster Na Slovanech (Emauskloster). Prag, um 1365/70. Prag, Národní galerie v Praze (Foto: Národní galerie v Praze)

Jahre konzipiert wurden. ${ }^{30}$ Sie ermöglichten den Gläubigen die Schau zahlreicher Heiltümer, nicht zuletzt der drei Nägel der Kreuzigung Christi, die in ihrer Gesamtheit hier - und nur hier! - verehrt und betrachtet werden konnten.

Wenn nun auf der Wormser Tafel Dreizahl, Heiligkeit und Heilswirkung der Kreuzesnägel Christi in vergleichbarer Weise hervorgehoben sind, dann dürfte dies auf einen Zusammenhang mit der Einführung des Lanzenund Nagel-Festes in der Zeit um 1354-56 beziehungsweise mit den Prager Reliquienweisungen seit den $1360 e r$ Jahren hindeuten. Es wäre nicht das erste, auch nicht das einzige Werk, bei dem die Existenz und die regelmäßige Weisung der Prager Reliquienschätze sich in der Ikonografie niedergeschlagen hätten. So wird beispielsweise ab der Mitte des 14. Jahrhunderts eine Verbreitung des Motivs fassbar, dass die Gottesmutter in Kreuzigungsdarstellungen einen mit dem Blut ihres Sohnes befleckten Schleier trägt beziehungsweise hält. Man vermutet seit Langem, dass diese Steigerung der Beliebtheit des Motivs nicht nur durch die Marien- und Passionsfrömmigkeit

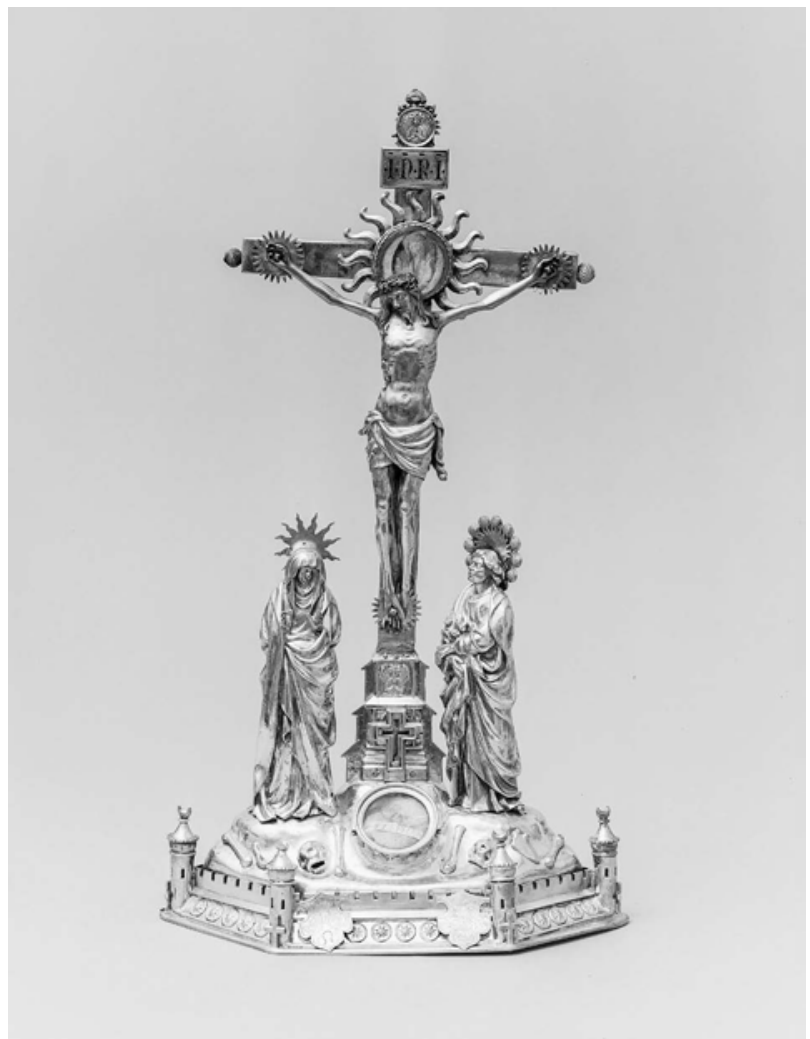

Abb. 5 Kalvarienberg. Um 1420/30. Emmerich, St. Martini (Foto: Rheinisches Bildarchiv Köln, rba_170634)

und ihre literarischen Ausformungen bedingt war, sondern auch durch die kostbare, in Prag befindliche, spätestens ab 1354 im Domschatz aufbewahrte Schleierreliquie selbst, das "peplum cruentatum» beziehungsweise "peplum sagwineum ${ }^{31}{ }^{31}$ In der Buchmalerei findet sich das Motiv erstmals im Missale des Prager Kanonikers Henricus (Heinrich/Jindřich), der mit dem aus Nürnberg stammenden Kanzleibeamten Heinrich Schatz alias Heinricus Thesauri identifiziert wird. ${ }^{32}$ Da Heinrich Schatz erst am 5. November 1345 Kanonikat und Präbende am Prager Dom erhalten hatte, dürfte die Handschrift, deren Stifter ein Schriftband mit der Inschrift »Henric(us) canonic(us) prage(nsis) nepos mag(ist)ri winheri« hält, entgegen ihrer aktuellen Datierung in die 1330er Jahre erst um 1345/50 entstanden sein. ${ }^{33}$ In der Tafelmalerei begegnet das Motiv nahezu gleichzeitig in dem Gemäldezyklus aus Hohenfurth (Vyšší Brod), ${ }^{34}$ etwas später, um 1370/80, mit offensichtlichem Rückbezug auf das Prager Missale, in der Kreuzigungstafel in Hohenfurth (Abb. 12). ${ }^{35}$ Doch anders als für den blutigen Schleier Mariens lassen sich für die hier interessierenden, durch Nimben ausgezeichneten 


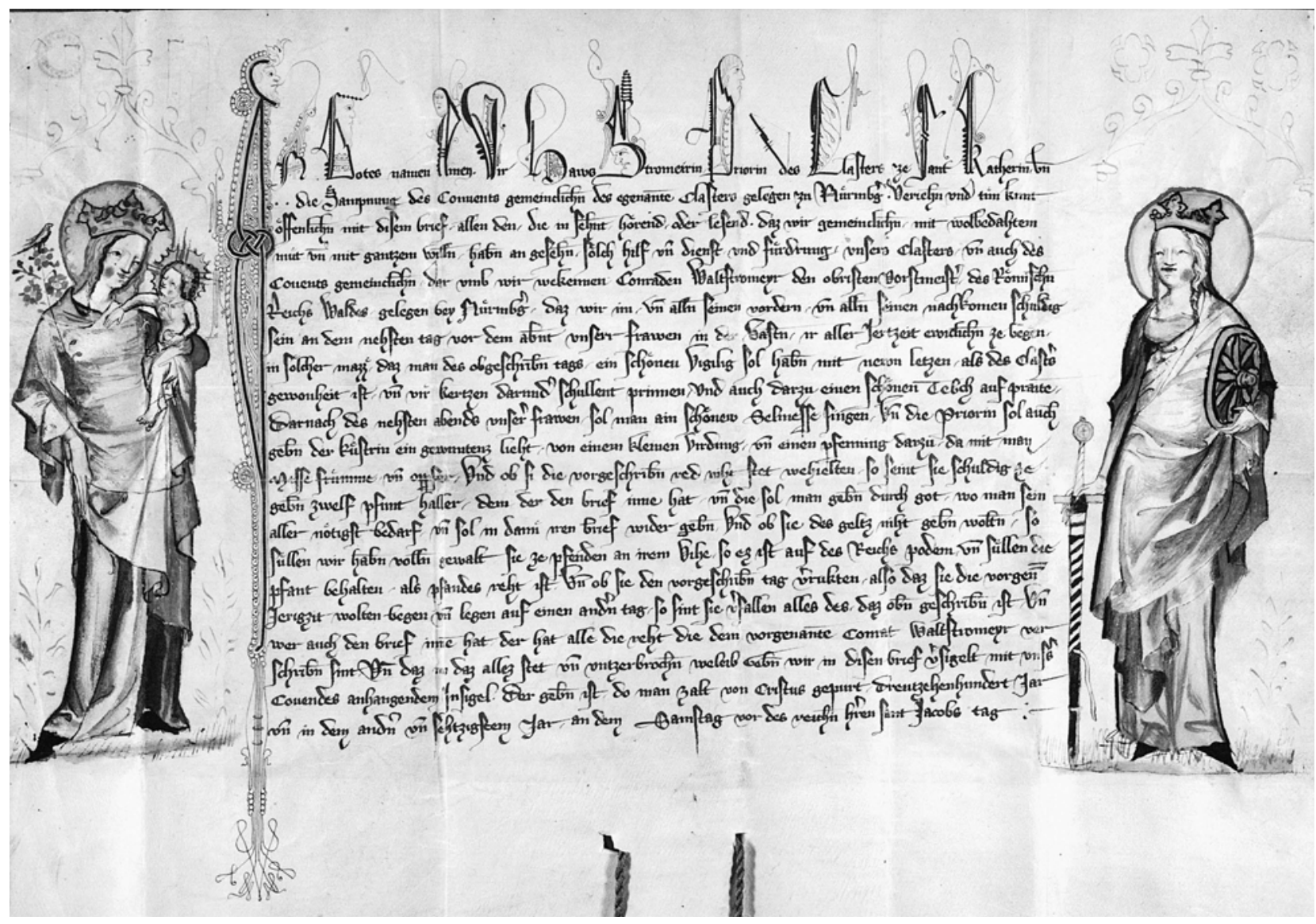

Abb. 6 Urkunde des Dominikanerinnenklosters Nürnberg vom 23. Juli 1362. Nürnberg, Stadtarchiv, A1, Nr. 1362-07-23 (Foto: Stadtarchiv Nürnberg)

Kreuzesnägel keine derartigen Vergleichswerke anführen. Man könnte die massiven, übergroßen Nägel, mit denen Christus in der um 1365 entstandenen Kreuzigung aus dem Kloster Na Slovanech in Prag ans Kreuz geheftet ist (Abb. 4), als eine bildliche Reaktion auf die Einführung des Lanzen-und-Nagel-Festes interpretieren, doch fehlen die Nimben hier ebenso wie bei anderen Tafel- und Buchmalereien der Zeit. ${ }^{36}$ Dass aber auch dieses Motiv nicht ganz isoliert steht, beweist ein Goldschmiedewerk von circa 1420/30, der von Propst Petrus de Mera gestiftete Kalvarienberg im Kirchenschatz von St. Martini in Emmerich, in dem der Gekreuzigte mit nimbenartigen Sternen an Händen und Füßen dargestellt ist (Abb. 5) ${ }^{37}$

Gleichwohl scheint es unter ikonografischen Gesichtspunkten eher unwahrscheinlich zu sein, dass in der Wormser Tafel ein in Prag entstandenes Bildmotiv zitiert wird - es sei denn, das ursprüngliche Werk wäre verloren gegangen und ohne künstlerischen Nachhall in der
Kunst Böhmens geblieben. Die Tafel dürfte vielmehr aus einer Kirche stammen, in deren Schatz sich ein heiliger Nagel befand, und mit den Nimben, die auf seine Verehrung anspielten, wurde seine »Echtheit« bekräftigt. Da nun im Hinblick auf das stilistische Erscheinungsbild der Tafel eine Herkunft aus Böhmen, Italien, Frankreich und den im Westen gelegenen Zentren des Reiches wie etwa Trier, Aachen oder Köln von vornherein auszuschließen ist, kommen letztlich nur wenige Orte für ihre ursprüngliche Aufstellung in Betracht: Bamberg, wo die Verehrung des heiligen Nagels im Dom eine weit zurückreichende Tradition besa ${ }^{38}{ }^{38}$ und Feuchtwangen, wo sich - heute nahezu vergessen - in der Stiftskirche St. Salvator ebenfalls ein Kreuzesnagel befunden haben soll. ${ }^{39}$ Für Nürnberg - das ohne Zweifel wichtigste, mit Prag eng verbundene Kunstzentrum Frankens - lässt sich eine besondere Verehrung der Lanze und der Nägel dagegen nicht nachweisen: Unter den vielen Christus-Reliquien, die Kaiser Karl IV. 1355 der im Bau befindlichen Frauenkirche schenkte, befand sich kein heiliger Nagel, ${ }^{40}$ und auch die zu Karls Lebzeiten einmalige, im Jahr 1361 in Nürnberg erfolgte Weisung der Reichskleinodien und 


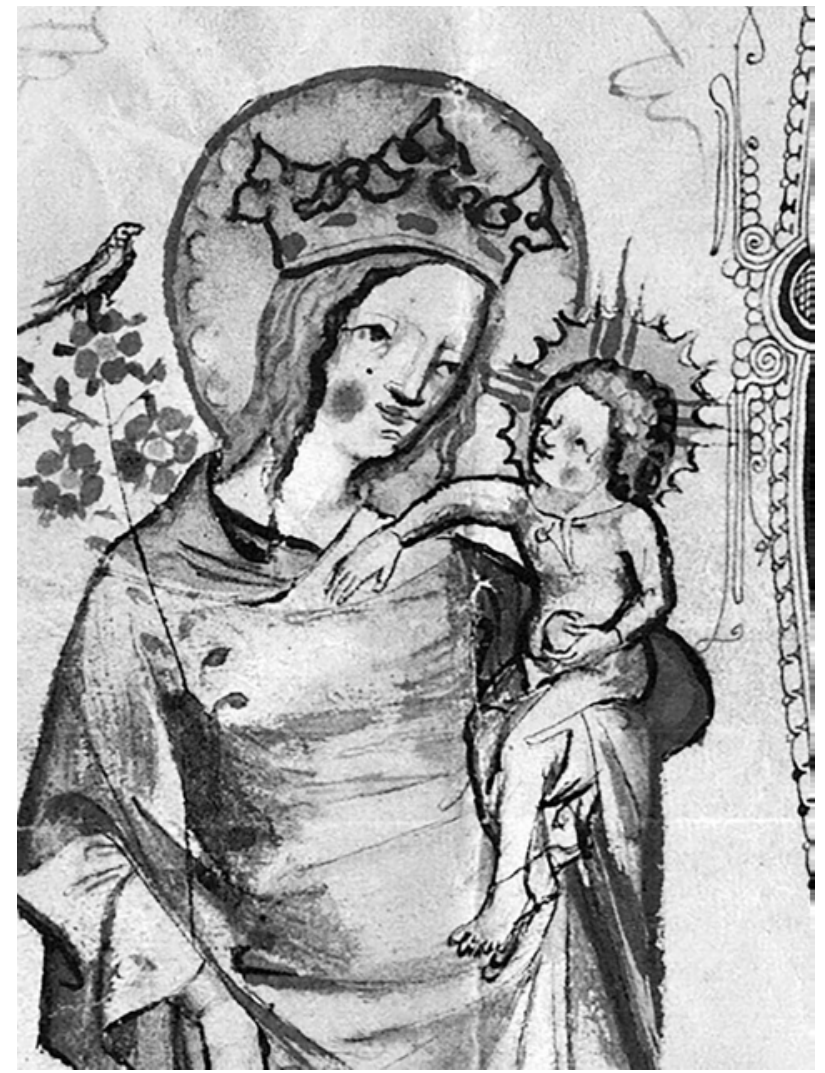

Abb. 7 Maria mit dem Kind, Ausschnitt aus der Urkunde des Dominikanerinnenklosters Nürnberg vom 23. Juli 1362, vgl. Abb. 6 (Foto: Stadtarchiv Nürnberg)

Abb. 8 Heilige Katharina der Wormser Kreuzigung (Foto: Uwe Gast)

Abb. 9 Engel mit Portativ, Detail aus der Marienkrönung eines Baldachinretabels. Nürnberg, um 1350/60. Frankfurt am Main, Städel Museum (ex: KEMPERDICK 2002)

verschiedener Christus-Reliquien aus dem Prager Domschatz scheint die Verehrung der Lanze und der Nägel nicht befördert zu haben. ${ }^{41}$ Dennoch kommt Nürnberg als Entstehungsort der Tafel, deren Herkunft aus Franken naheliegend ist, in die engere Wahl.

Im Gegensatz zu der übergroßen, schlanken Figur des Gekreuzigten sind alle Figuren, die zuseiten des Kreuzes stehen, von gedrungener Statur (Taf. I). Die Gewänder, die sie tragen, liegen eng an den Körpern an, umspannen die Gliedmaßen und betonen, wie bei den Marien, die Bewegungsmotive oder lassen, wie bei Johannes dem Evangelisten und Katharina, die Bäuche kugelig hervortreten. An den Köpfen fallen das italianisierend-grünliche Inkarnat des Jüngers, die rötlichen Inkarnatpartien
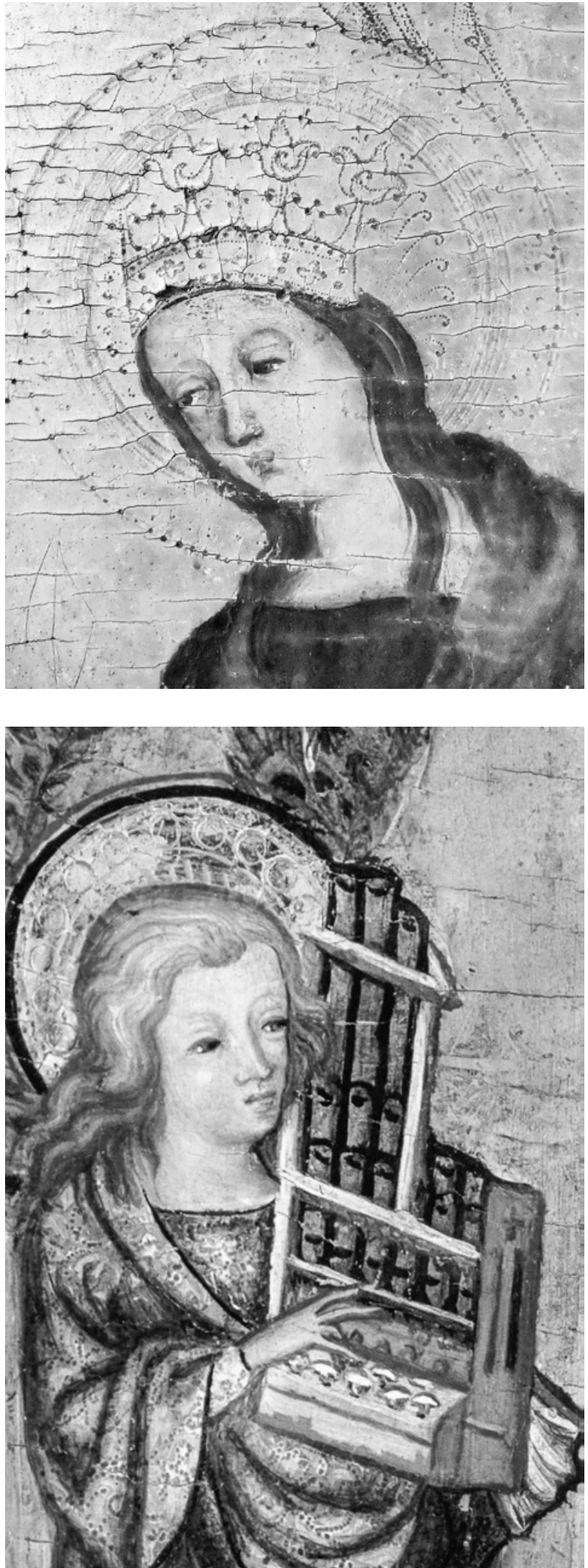


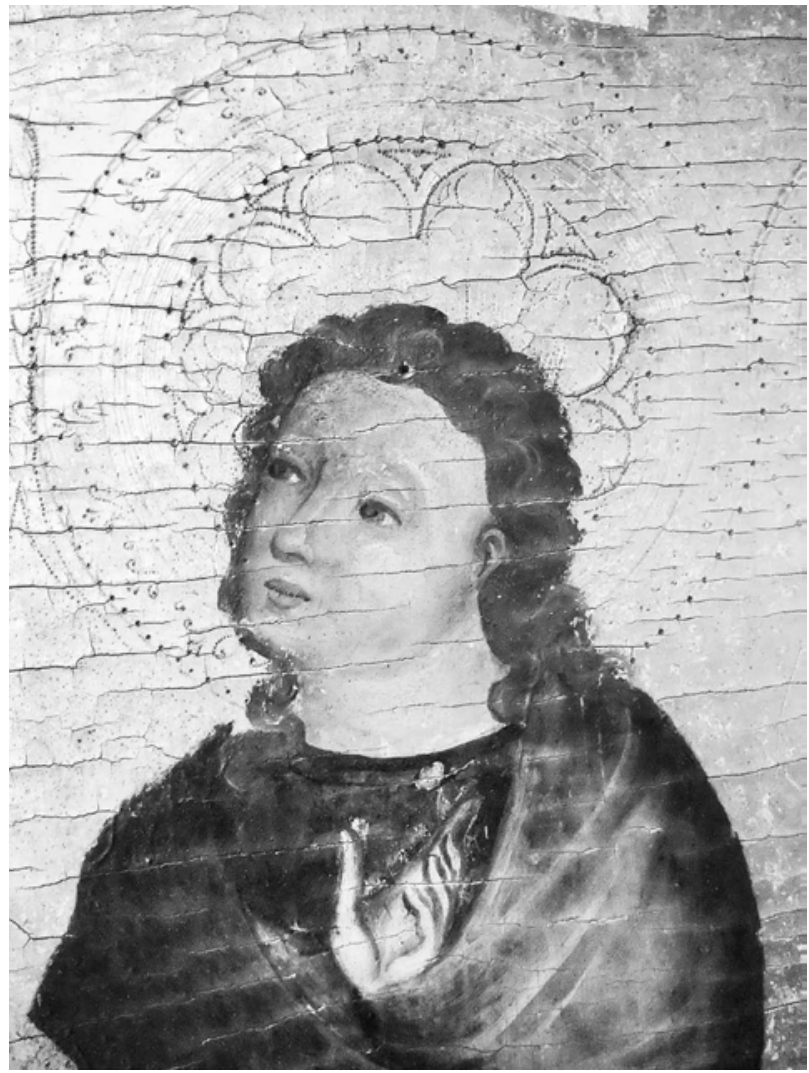

Abb. 10 Heiliger Johannes der Wormser Kreuzigung (Foto: U. Gast)

der Frauen, die bei allen Figuren - auch Christus - kleinen, geschürzten Münder und die übergroßen Nimben von Maria und Johannes Ev. auf. Zwei weitere Besonderheiten sind hervorzuheben: Bei Christus sind die Füße in unnatürlicher Weise fast rechtwinklig nach links gedreht, und bei Maria sind die Hände im Vergleich mit den Körperproportionen sichtlich zu klein geraten.

Manche dieser Charakteristika, wie etwa die Figurenund Gewandbildung, liegen im Zeitstil des dritten Viertels des 14. Jahrhunderts begründet. Doch zwei in Haltung und Gewandung gut vergleichbare Figuren der Madonna und der Heiligen Katharina sind auf einer Urkunde des Nürnberger Dominikanerinnenklosters St. Katharina aus dem Jahr 1362 dargestellt (Abb. 6). ${ }^{42}$

Das Gesicht der Madonna weist mit seinem geschürzten Mund und den fleckig geröteten Wangen zudem eine Verwandtschaft mit dem Gesicht der Katharina auf der Wormser Tafel auf (Abb. 7, 8).

Diese physiognomischen Merkmale verbinden die Madonnenfigur der Urkunde auch mit den Figuren jener um 1360/65 zu datierenden Gruppe von Tafeln mehrerer Retabel, die unter dem Namen »Werkstatt der Nürnberger

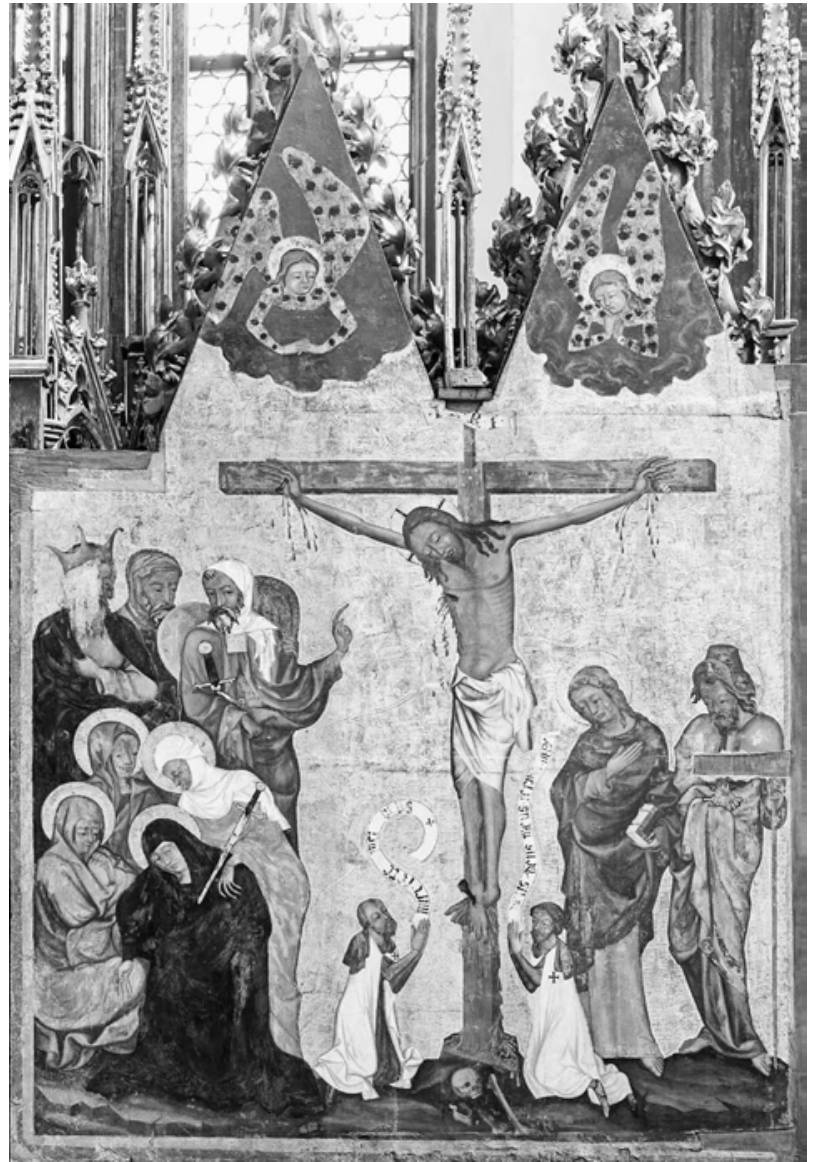

Abb. 11 Kreuzigung Christi, Flügel des Hochaltars der Deutschordenskirche St. Jakob. Nürnberg, um 1360/70. Nürnberg, St. Jakob (Foto: Sarah Weiselowski)

Klarenaltäre « zusammengefasst werden. ${ }^{43}$ Die Vorliebe des Malers der Wormser Tafel für üppige Verzierungen des Goldgrundes und gelegentlich kräftige Konturlinien in den Gesichtern ist in dieser älteren Werkgruppe vorgebildet, doch wirken die Nürnberger Tafeln in ihrer grafischen Anlage flacher. Demgegenüber werden in der Wormser Tafel durch malerische Mittel die Volumina betont, gewinnen die Figuren an Körperlichkeit und Präsenz. Die Tafel steht darin den Flügelgemälden eines ebenfalls nürnbergischen Baldachinretabels aus der Zeit um 1350/60 näher, das vor einigen Jahren rekonstruiert werden konnte und jüngst auf eher schmaler Basis dem Nürnberger Hofmaler Sebald Weinschröter ( $†$ vor 1363) zugeschrieben wurde. ${ }^{44}$ Die Gesichtstypen Christi und vor allem des Engels mit dem Portativ der Tafel in Frankfurt am Main lassen sich, obwohl sie schmaler geschnitten sind, mit den Gesichtern von Christus und Johannes Ev. auf der Tafel in Worms gut vergleichen (Abb. 9, 10). ${ }^{45}$ 


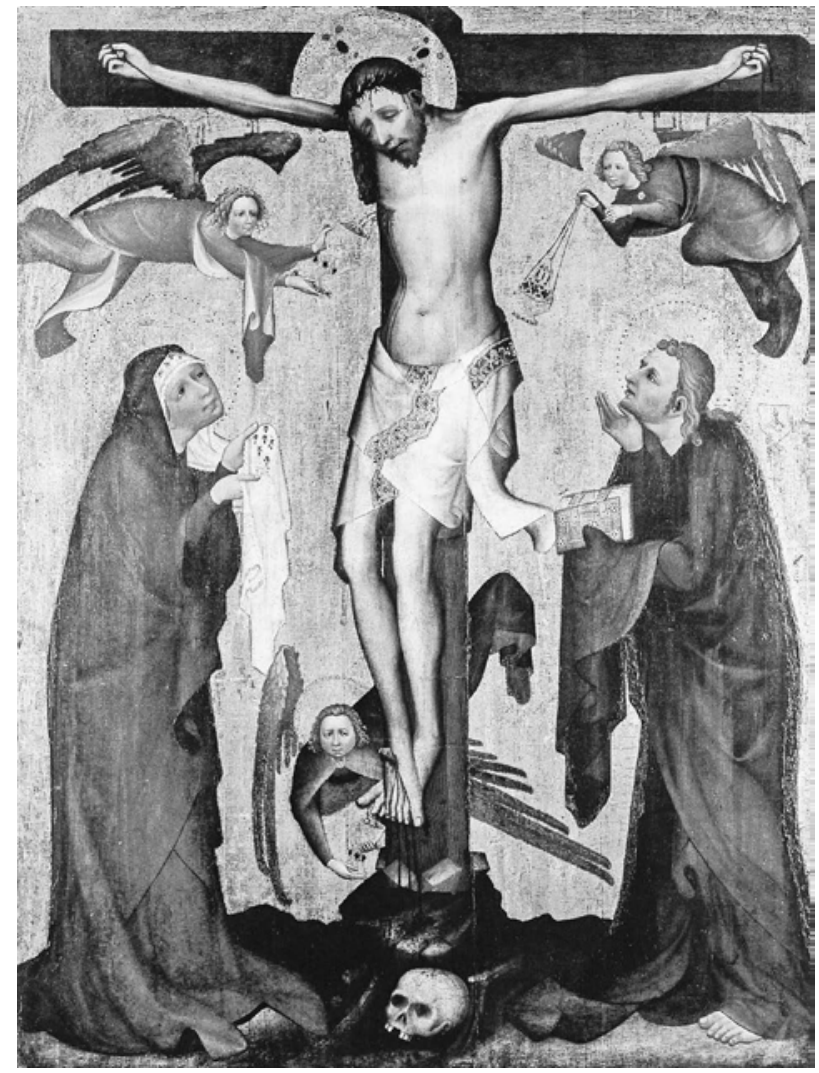

Abb. 12 Kreuzigung Christi. Prag, um 1370/80. Hohenfurth, Zisterzienserabtei (ex: FAJT 2006)

Zeitlich näher dürfte dieser aber das Hochaltarretabel der ehemaligen Deutschordenskirche St. Jakob in Nürnberg stehen, das um 1360/70 datiert wird. ${ }^{46}$ Im Pathos der Figuren, in deren gewundenen Körperhaltungen, einigen Typen (z.B. Johannes Ev.) und den ins Rötliche gehenden Inkarnatpartien weist das Retabel unmittelbar auf die Wormser Tafel voraus, die aber erst ein Dezennium später, um 1370/80, entstanden sein dürfte (Taf. I, Abb. 11).

Für diese Annahme sprechen zwei Motive, die bei einer Entstehung der Tafel in den 5oer oder 6oer Jahren des 14. Jahrhunderts sehr modern anmuten würden: zum einen die abstehenden, wie vom Wind verwehten Zipfel des Lendentuchs Christi, die an Werke wie das Parament von Narbonne, eine Stiftung des französischen Königs aus der Mitte der $1370 e r$ Jahre ${ }^{47}$ und die bereits erwähnte, um 1370/80 entstandene Kreuzigungstafel in Hohenfurth erinnern (Abb. 12); zum anderen die zur Seite gedrehten Füße Christi, die in identischer Stellung in den 1370er bis 1380er Jahren sowohl am Retabel der Stadtkirche in Schotten (Abb. 13) als auch an dem - aus

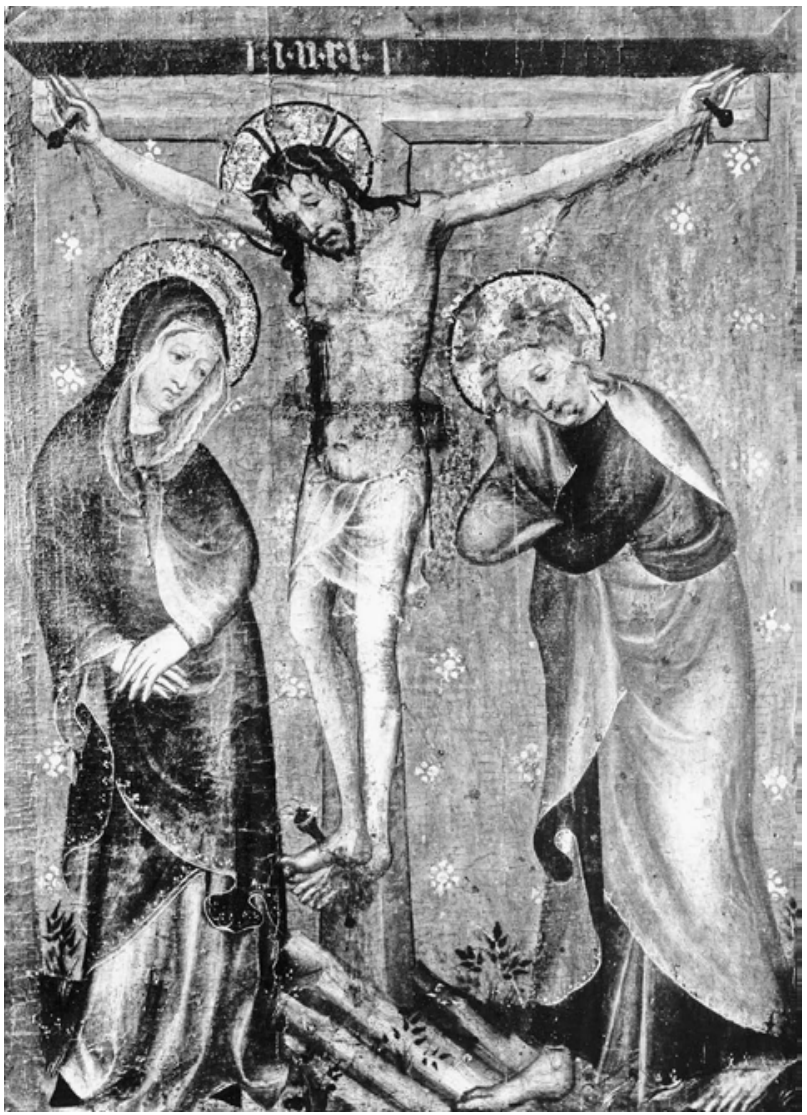

Abb. 13 Kreuzigung Christi. Mittelrhein (?), um 1380/90. Schotten, Stadtkirche (Foto: Bildarchiv Foto Marburg)

Prag importierten - Retabel aus der Veitskirche in Mühlhausen bei Stuttgart begegnen. ${ }^{48}$

Man braucht nicht vorauszusetzen, dass der Maler der Wormser Tafel alle diese Werke kannte. Sein Bild besitzt jedoch einen so ausgesprochen kompilatorischen Charakter, dass er - sei es aufgrund eigener Mobilität, sei es durch die Verbreitung von Vorlagen - umfangreiche Kenntnis von der Kunst des zweiten und dritten Viertels des 14. Jahrhunderts vor allem im süd- und südostdeutschen beziehungsweise im böhmischen Raum gehabt haben muss. Nur so sind die formalen Brüche in der Darstellung zu erklären, etwa das abrupte Nebeneinander kleinerer und größerer Gliedmaßen und Köpfe mit teils übergroßen Nimben. Mögliche Bezüge reichen hier bis zu den beiden Muttergottesfiguren eines in den bayerisch-österreichischen Raum lokalisierten Diptychons von circa 1340 in München, ${ }^{49}$ ja sogar bis zu den 1331 datierten Flügelaußenseiten des Klosterneuburger Altars zurück (Abb. 14). ${ }^{50}$ 


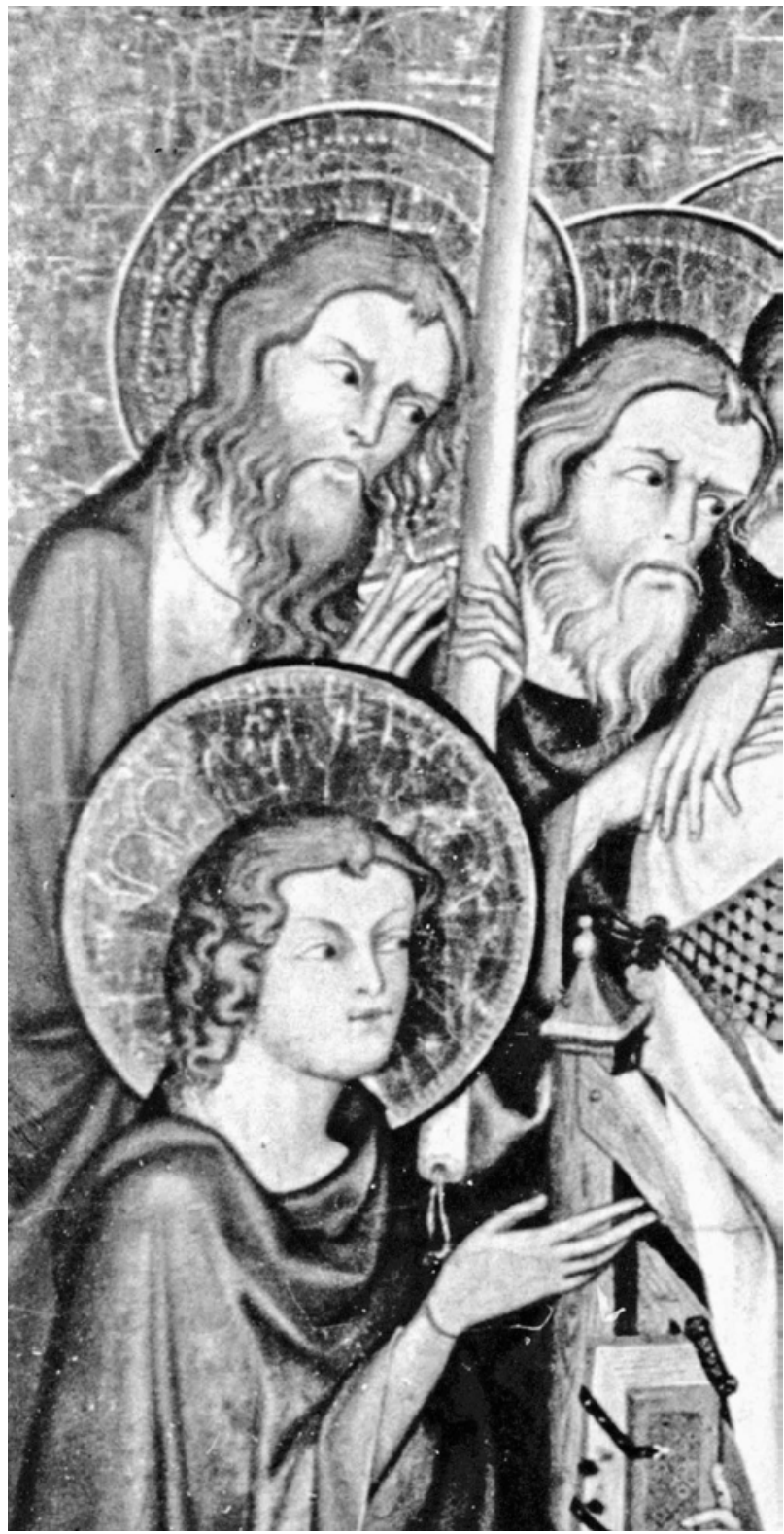

Um die Mitte des 14. Jahrhunderts sind Ausstrahlungen der für Klosterneuburg tätigen Werkstatt auch in Mittelfranken zu fassen, nämlich an einem Retabelflügel mit Passionsszenen in der ehemaligen Zisterzienser-Klosterkirche Heilsbronn. ${ }^{51}$

Schließlich sei zum Schluss noch auf ein späteres Werk aufmerksam gemacht, das in der Forschung ebenfalls noch keine besondere Rolle gespielt hat: die bemalten Türen der Sakramentsnische in der Heilig-Geist-Kirche in Rothenburg ob der Tauber (Abb. 15). ${ }^{52}$

Ausgehend von der rahmenden, plastischen Verkündigungsgruppe ist das Werk wohl in die Zeit um $1400 \mathrm{zu}$

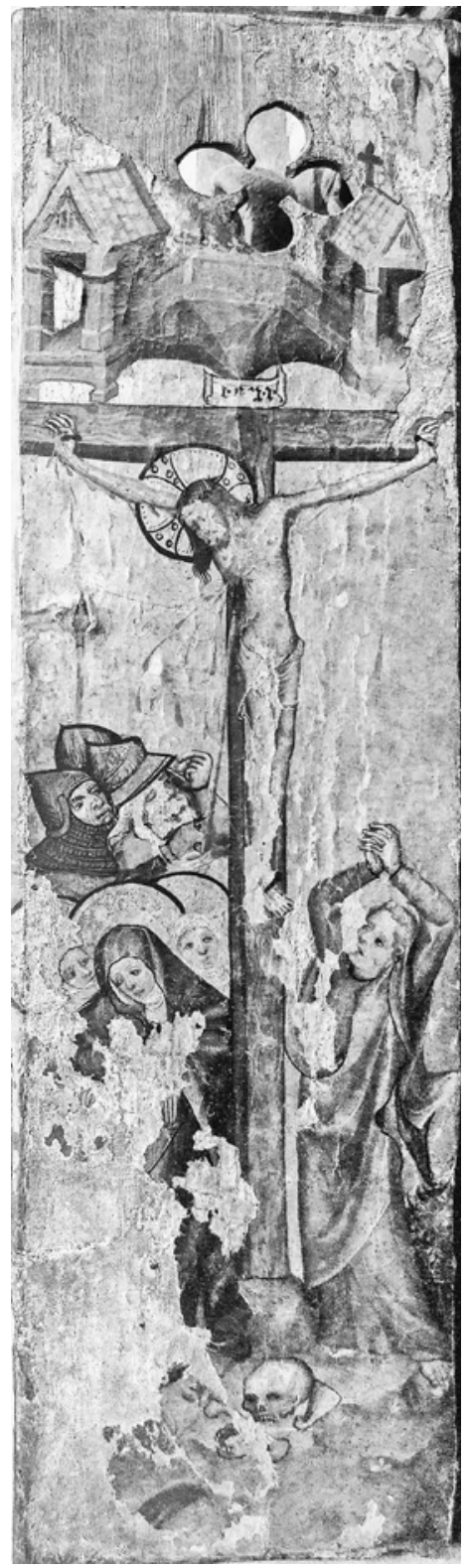

Abb. 14 Nimben, Detail aus dem Marientod des Klosterneuburger Altars. Wien, 1330/31. Klosterneuburg, Stift (Foto: Bildarchiv Foto Marburg)

Abb. 15 Kreuzigung Christi. Franken, um 1400. Rothenburg o. d. T., Heilig-Geist-Kirche (Foto: Reichsstadtmuseum Rothenburg o. d. T., Hellmuth Möhring)

datieren. Die Malereien auf den Innenseiten der Flügel links die Kreuzigung, rechts die Kreuztragung Christi wirken dagegen rückständiger und führen gleichermaßen in den Kreis jener Werke, die auch den Stil der Wormser Kreuzigung geprägt haben. Dabei weist die Rothenburger Kreuzigung einige Gemeinsamkeiten mit der Wormser Darstellung auf: eine ähnliche Farbigkeit im Ganzen, im Einzelnen den markanten Typ des Johannes Ev., die reich punzierten Nimben, die Lichtreflexe in den Augen und auf den Fingernägeln der Figuren, etc.

So bestätigt sich auch in der Rückschau die Annahme einer Herkunft der Wormser Tafel aus Franken. Möchte 
man sie in Zukunft weiter untermauern, wird man bei ihrer noch ungeklärten Provenienzgeschichte ansetzen müssen. Aus museologischer Sicht könnte dabei von Interesse sein, dass im Museum der Stadt Worms im Andreasstift auch ein Konvolut fränkischer Glasmalereien aufbewahrt wird, deren Herkunft und Provenienz noch ebenso unbekannt sind. ${ }^{53}$ Ein sammlungsgeschichtlicher, wenn nicht sogar ursprünglicher Zusammenhang mit der Tafel der Kreuzigung Christi ist jedenfalls zu vermuten. Ganz anders als bislang angenommen, lässt sich diese Tafel nach Franken lokalisieren und um 1370/80 datieren. Sie ist ein rares, in ihrer Ikonografie bisher singuläres Werk deutscher Tafelmalerei des 14. Jahrhunderts.

\section{Literatur}

[Ausst.-Kat. Bonn/Essen 2005]: Ausst.-Kat. Krone und Schleier. Kunst aus mittelalterlichen Frauenklöstern. Bonn, Kunstund Ausstellungshalle der Bundesrepublik Deutschland; Essen, Ruhrlandmuseum, 19.3--3.7.2005. München 2005.

[Ausst.-Kat. Köln 1978]: Ausst.-Kat. Die Parler und der Schöne Stil 1350-1400. Europäische Kunst unter den Luxemburgern. Hg. von Anton Legner. 3 Bde. Köln, Kunsthalle Köln. Köln 1978.

[Ausst.-Kat. Prag 1998]: Ausst.-Kat. Magister Theodoricus. Court Painter to Emperor Charles IV. The Pictorial Decoration of the Shrines at Karlštejn Castle. Hg. von Jiř́ Fajt. Prague, The National Gallery, Collection of Old Masters. Praha 1998.

[Ausst.-Kat. Prag 2006] : Ausst.-Kat. Karl IV. - Kaiser von Gottes Gnaden. Kunst und Repräsentation des Hauses Luxemburg 1310-1437. Hg. von Jiří FAJT unter Mitwirkung von Markus Hörsch und Andrea Langer. Prager Burg, 15.2.-21.5.2006. München/Berlin 2006; tschechische Ausgabe Praha 2006.

[Ausst.-Kat. Prag/Nürnberg 2016]: Ausst.-Kat. Kaiser Karl IV. 1316-2016. Erste Bayerisch-Tschechische Landesausstellung. Hg. von Jiř́i FAJT und Markus Hörsch. Prag, Wallenstein-Reitschule, 15.5.-25.9.2016; Prag, Carolinum, 14.5.31.8.2016; Nürnberg, Germanisches Nationalmuseum, 20. 10.2016-5.3.2017. Praha 2016; tschechische Ausgabe 2017.

Benešovská, Klára (Hg.): King John of Luxembourg (12961346) and the Art of his Era. Proceedings of the International Conference, Prague, September 16-20, 1996. Praha 1998.

BEnZ, Richard (Übers.): Die Legenda aurea des Jacobus de Voragine aus dem Lateinischen übersetzt von (...). Heidelberg 1925.

Binder-Hagelstange, Ursula: Der mehrfigurige Kalvarienberg in der rheinischen Malerei von 1300-1430. Die Ent- wicklung des Kalvarienbergs vom Andachtsbild zum Kreuzigungsdrama. Diss. Berlin 1937.

[BBKL]: Biographisch-bibliographisches Kirchenlexikon. Zunächst bearb. von Friedrich Wilhelm BAutz († 1979), hg. von Traugott BAutz. Bisher 36 Bde. Bd. XXVI Nordhausen 2015.

Bцонм, Katharina: Die Frauenkirche in Nürnberg (13521358). Architektur, Baugeschichte, Bedeutung. Diss. Berlin 1990; Mikrofiche-Ausgabe Berlin 1993.

Brinkmann, Bodo/Kemperdick, Stephan: Deutsche Gemälde im Städel 1300-1500. Mainz 2002 (Kataloge der Gemälde im Städelschen Kunstinstitut Frankfurt am Main V).

Daim, Falko/Drauschke, Jörg (Hgg.): Byzanz. Das Römerreich im Mittelalter, Teil 1. Welt der Ideen, Welt der Dinge. Mainz 2010 (Monographien des Römisch-Germanischen Zentralmuseums 84,1).

FAJT, Jiří: Magister Theodoricus. Court Artist to Emperor Charles IV. In: Ausst.-Kat. Prague 1998, 217-277.

FAJT, Jiří/Hörsch, Markus: Zwischen Prag und Luxemburg. Eine Landbrücke in den Westen. In: Ausst.-Kat. Prag 2006, 357-383.

FAJT, Jiří, LANGer, Andrea (Hgg.): Kunst als Herrschaftsinstrument. Böhmen und das Heilige Römische Reich unter den Luxemburgern im europäischen Kontext. Tagung Prag, Mai 2006. Berlin/München 2009.

Fritz, Johann M.: Goldschmiedekunst der Gotik in Mitteleuropa. München 1982.

Fritzsche, Gabriela: Die Entwicklung des »Neuen Realismus« in der Wiener Malerei. 1331 bis Mitte 14. Jahrhunderts. Diss. Wien 1979; Wien 1983 (Wiener Dissertationen zur Kunstgeschichte 18).

Gast, Uwe: Der Große Friedberger Altar und der Stilwandel am Mittelrhein nach der Mitte des 14. Jahrhunderts. Diss. Freiburg/Br. 1997; Berlin 1998 (Neue Forschungen zur deutschen Kunst I).

GAST, Uwe: Die mittelalterlichen Glasmalereien in Oppenheim, Rhein- und Südhessen. Berlin 2011 (Corpus Vitrearum Medii Aevi Deutschland III,1).

Gast, Uwe: Eine Kreuzigungstafel des 14. Jahrhunderts in Worms. In: Der Wormsgau 30 (2013), 91-105.

Hamburger, Jeffrey F.: Bloody Mary. Traces of the peplum cruentatum in Prague - and in Strasbourg? In: OpAČIĆ/TimMERMANN 2011, 1-34.

HÄRING, Friedhelm: Der Schottener Altar, 1385. Diss. Gießen 1976.

Hergemöller, Bernd-Ulrich: Cogor adversum te. Drei Studien zum literarisch-theologischen Profil Karls IV. und seiner Kanzlei. Warendorf 1999 (Studien zu den Luxemburgern und ihrer Zeit 7).

Hoeps, Reinhard/Hoppe-Sailer, Richard (Hgg.): Deine Wun- 
den. Passionsimaginationen in christlicher Bildtradition und Bildkonzepte in der Kunst der Moderne. Bielefeld 2014.

IlleRt, Georg: Führer durch das Museum der Stadt Worms im Andreasstift. 4. Aufl. Worms 1966.

JАсові, Christoph Fr.: Geschichte der Stadt und des ehemaligen Stifts Feuchtwangen. Ein Beitrag zur vaterländischen Geschichte. Nürnberg 1833.

Kahsnitz, Rainer: Der Hochaltar der St. Jakobskirche in Nürnberg. In: KROHM/KRÜGER/WenIGer 2001, 87-109.

Kemperdick, Stephan: Avantgarde 1360. Ein rekonstruierter Baldachinaltar aus Nürnberg. Frankfurt a. M. 2002.

Kemperdick, Stephan: Deutsche und böhmische Gemälde 1230-1430. Kritischer Bestandskatalog [Gemäldegalerie Berlin]. Berlin/Petersberg 2010.

[Kirchweger 2005/I]: Kirchweger, Franz (Hg.): Die Heilige Lanze in Wien. Insignie - Reliquie - »Schicksalsspeer . Wien 2005 (Schriften des Kunsthistorischen Museums 9).

[Kirchweger 2005/II]: Kirchweger, Franz: Die Geschichte der Heiligen Lanze vom späteren Mittelalter bis zum Ende des Heiligen Römischen Reiches (1806). In: KiRCHWEgER 2005/I, 71-109.

Krohm, Hartmut/Krüger, Klaus/Weniger, Matthias (Hgg.): Entstehung und Frühgeschichte des Flügelaltarschreins. Berlin 2001.

KüHNE, Hartmut: Ostensio reliquiarum. Untersuchungen über Entstehung, Ausbreitung, Gestalt und Funktion der Heiltumsweisungen im römisch-deutschen Regnum. Berlin/New York 2000 (Arbeiten zur Kirchengeschichte 75).

KüHNEL, Harry (Hg.): Bildwörterbuch der Kleidung und Rüstung. Vom Alten Orient bis zum ausgehenden Mittelalter. Stuttgart 1992.

[LCI]: Lexikon der christlichen Ikonographie. Begr. von Engelbert Kirschbaum. Hg. von Wolfgang Braunfels. 10 Bde. Wien 1959/60; Neudruck Freiburg/B./Rom/Basel/Wien 1968/76; Freiburg/B. 1994.

Legner, Anton: Reliquien in Kunst und Kult zwischen Antike und Aufklärung. Darmstadt 1995.

Lentes, Thomas: Der Blick auf den Durchbohrten. Die Wunden Christi im späten Mittelalter. In: Hoeps/Hoppe-SAILeR 2014, 43-61.

LiNCK, Paul: L’église paroissiale Saint-Grégoire à Ribeauvillé. In: Société d'Histoire et d'Archéologie de Colmar 23 (1973), 117-129.

[LThK]: Lexikon für Theologie und Kirche. Hg. von Walter Kasper, mit Konrad Baumgartner, Horst Bürkle, Klaus Ganzer, Karl Kertelge, Wilhelm Korff und Peter WaLTER. Freiburg/Basel/Wien 2006 (Sonderausgabe).

Lutze, Eberhard: Die Buchmalerei. In: Nürnberger Malerei 1350-1450. Anzeiger des Germanischen Nationalmuseums 1930/31. Nürnberg 1932, 7-21.
Machilek, Franz: Die Bamberger Heiltumsschätze und ihre Weisungen. In: RöHRIG 1987, 217-256.

Machilek, Franz/Schlager, Karlheinz/WohnhaAs, Theodor: O felix lancea. Beiträge zum Fest der Heiligen Lanze und der Nägel. Mit Hymnen-Übertragungen von Friedrich Dörr. In: Jahrbuch des Historischen Vereins für Mittelfranken 92 (1984/85), 43-107.

Metsch, Friedrich-August: Johannes der Täufer. Seine Geschichte und seine Darstellung in der Kunst. München 1989.

Möhring, Hellmuth: Gotik in Rothenburg. In: Rupp/BorCHARDT 2016, 371-408.

Murr, Christoph G. von: Diplomatarivm Lipsano-Klinodiographicvm S. Imp. Rom. German. ab A. 1246 ad A. 1764. In: Journal zur Kunstgeschichte und zur allgemeinen Litteratur 12 (1784), 35-216.

Neuwirth, Joseph: Zwei Verzeichnisse der beim Feste der Reliquienzeigung in Prag ausgestellten Reliquien. In: Mittheilungen des Vereines für Geschichte der Deutschen in Böhmen 34 (1896), 117-123.

Opačić, Zoë/Timmermann, Achim (Hgg.): Image, Memory and Devotion. Liber Amicorum Paul Crossley. Turnhout 2011 (Studies in Gothic Art).

OtAvsкŕ, Karel: Drei wichtige Reliquienschätze im luxemburgischen Prag und die Anfänge der Prager Heiltumsweisungen. In: FAJT/LANGER 2009, 300-308.

OtAvsкx́, Karel: Der Prager Domschatz unter Karl IV. im Lichte der Quellen. Ein Sonderfall unter spätmittelalterlichen Kirchenschätzen. In: WendLAND 2010, 181-236.

PeŠInA, Jaroslav: Der Hohenfurther Meister. Hanau 1982.

Podlaha, Antonín/Šittler, Eduard: Der Domschatz in Prag. Prag 1903 (Topographie der historischen und Kunst-Denkmale im Königreiche Böhmen von der Urzeit bis zum Anfange des XIX. Jahrhundertes. Die Königl. Hauptstadt Prag: Hradschin II,1).

Pujmanová, Olga: The Vyšší Brod Crucifixion. In: Bulletin of the National Gallery in Prague 5/6 (1995/96), 105-112.

Pujmanová, Olga: Iconographie de la crucifixion du missel d'Henri Thesauri. In: BenEšovská 1998, 256-259.

Raguin, Virginia Ch./Stanbury, Sarah (Hgg.): Women's Space. Patronage, Place, and Gender in the Medieval Church. New York 2005.

RAu Susanna/Schwerhoff, Gerd (Hgg.): Zwischen Gotteshaus und Taverne. Öffentliche Räume in Spätmittelalter und Früher Neuzeit. Köln 2004 (Norm und Struktur 21).

[RDK]: Reallexikon zur deutschen Kunstgeschichte. Begründet von Otto Sснмітт. Bisher 10 Bde. Stuttgart, später München $1937 \mathrm{ff}$.

Ress, Anton: Stadt Rothenburg o. d. T. Kirchliche Bauten. München 1959 (Die Kunstdenkmäler von Bayern, Reg.-Bez. Mittelfranken VIII). 
Rettich, Edeltraud/Klapproth, Rüdiger/Ewald, Gerhard: Alte Meister. Stuttgart 1992.

Rohault de Fleury, Charles: Mémoire sur les instruments de la Passion de N.-S. J.-C. Paris 1870.

RöHrig, Hans-Günter (Hg.): Diese große Fest aus Stein. Lesebuch zum 750. Weihejubiläum. Bamberg 1987.

Rотн, Elisabeth: Der volkreiche Kalvarienberg in Literatur und Bildkunst des Spätmittelalters. 2. Aufl. Berlin 1967 (Philologische Studien und Quellen 2).

Royt, Jan: Mistr Třeboňského oltáře. Master of the Třeboň Altarpiece. Praha 2013.

Rupp, Horst F./BorchardT, Karl (Hgg.): Rothenburg ob der Tauber. Geschichte der Stadt und ihres Umlandes. Stuttgart 2016.

Schaudig, Wilhelm: Geschichte der Stadt und des ehemaligen Stiftes Feuchtwangen. Feuchtwangen 1927.

Schleif, Corine: Men on the Right - Women on the Left: (A)symmetrical Spaces and Gendered Places. In: Raguin/ STANBURY 2005, 207-249.

Schöffel, Paul: Nürnberger in Kanzleidiensten Karls IV. In: Mitteilungen des Vereins für Geschichte der Stadt Nürnberg 32 (1934), 47-68.

Schramm, Percy E./Fillitz, Hermann: Denkmale der deutschen Könige und Kaiser, Bd. II. Ein Beitrag zur Herrschergeschichte von Rudolf I. bis Maximilian I. 1273-1519. In Zusammenarbeit mit Florentine Mürherich. München 1978 (Veröffentlichungen des Zentralinstituts für Kunstgeschichte in München VII).

Schulze-Dörrlamm, Mechthild: Heilige Nägel und Heilige Lanzen. In: DAIm/DrauschKe 2010, 97-171.

SignORI, Gabriela: Links oder rechts? Zum >Platz der Frau in der mittelalterlichen Kirche. In: RAU/SCHWERHOFf 2004, 339-382.

Sit T, Martina: Die deutschen, englischen, französischen, italienischen und spanischen Gemälde 1350-1800. Unter Mitarbeit von Gerrit WALCZAK. Hamburg 2007 (Die Sammlungen der Hamburger Kunsthalle I).

SörriEs, Reiner: Was von Jesus übrig blieb. Die Geschichte seiner Reliquien. Kevelaer 2012.

ŠronĚK, Michal: The Veil of the Virgin Mary. Relics in the Conflict Between Roman Catholics and Utraquists in Bohemia in the 14th and 15th Centuries. In: Umění 57 (2009), 118-139.

STANGE, Alfred: Kritisches Verzeichnis der deutschen Tafelbilder vor Dürer, Bd. I: Köln, Niederrhein, Westfalen, Hamburg, Lübeck und Niedersachsen. München 1967.

Stange, Alfred: Kritisches Verzeichnis der deutschen Tafelbilder vor Dürer, Bd. III: Franken. Bearbeitet von Peter STrIEDer und Hanna Härtle. Hg. von Norbert Lieb. München 1978.
Sterling, Charles: La peinture médièvale à Paris 1300-1500, Bd. I. Paris 1987.

Strieder, Peter: Tafelmalerei in Nürnberg 1350-1550. Königstein i. T. 1993.

Suckale, Robert: Die Hofkunst Kaiser Ludwigs des Bayern. München 1993.

Wendland, Ulrike (Hg.): ... das Heilige sichtbar machen. Domschätze in Vergangenheit, Gegenwart und Zukunft. Regensburg 2010 (Landesamt für Denkmalpflege und Archäologie Sachsen-Anhalt, Arbeitsberichte 9).

Wolf, Norbert: Deutsche Schnitzretabel des 14. Jahrhunderts. Berlin 2002.

\section{Anmerkungen}

1 Der Beitrag ist die in Teilen erweiterte Fassung eines im Herbst 2013 erschienenen Aufsatzes des Verfassers: GAST 2013.

2 Erstmals abgebildet bei ILLERT 1966, 59.

3 a 2013, 102-105.

4 Gast 2013, 97-102.

5 Gast 2013, 91, Anm. 2.

6 Die Tafel konnte im Jahr 2016 notwendigen konservatorischen und restauratorischen Maßnahmen unterzogen werden, die von Katharina Liebetrau, Bonn, ausgeführt wurden. Ich danke Frau Liebetrau herzlich für die Zusendung ihres Restaurierungsberichts.

7 KüHNEL 1992, 92 f., 150 f., 222. - Zur keineswegs seltenen Platzierung der Frau auf der heraldisch rechten Seite: SIGNORI 2004.SCHLEIF 2005.

8 Freundliche schriftliche Auskunft von Dr. Rüdiger Fuchs, Mainz, 28.6.2012

9 Binder-Hagelstange $1937,5 \mathrm{f}$.

10 BBKL III (1992), Sp. 575-589 (Michael Tilly). - BBKL III (1992), Sp. 1213-1217 (Ekkart SAUSER).

11 GAST 1998, 23.

12 LCI VII (1974), Sp. 164-19o (Elisabeth WEIS). - МetsCH 1989. BBKL III (1992), Sp. 575-589 (Michael Tilly).

13 BenZ 1925, 924.

14 LiNCK 1973, $123 \mathrm{f}$.

15 Binder-Hagelstange 1937, 8-10. - Roth 1967, 21-43 (»Ideenund Bildwandel bis $1300 \ll$ ), 57-74 (»Überlieferung und Bereicherung in der deutschen Hochgotik«).

16 Hamburg, Kunsthalle, Inv.-Nr. 325. - STANGE 1967, 20 f., Kat.-Nr. 19. - SitT 2007, 380-382.

17 RDK IV (1958), Sp. 524 f. (Karl-August Wirth). - LCI I (1968), Sp. 552 f. (Helga NeumanN).

18 LCI IV (1972), Sp. 540-542 (Ekkard SAUSER). - LThK $\times$ (2001), Sp. 1320-1324. - LENTES 2014.

19 LEGNER 1995, 55-77 (»Lignum crucis«), 78-87 (»Christusreliquien«). - SörRIES 2012, 52-68, 250-253.

20 SChulze-Dörrlamm 2010, 150-153.

21 Wien, Kaiserliche Schatzkammer, Inv.-Nr. WS XIII 19. - KIrCHWEger 2005/II, 72-75. - SChUlze-Dörrlamm 2010, 105-110, $140-144,149$. 
22 Kirchweger 2005/II, 75, 101, Anm. 52. - Urkundenzitate nach Schramm/Fillitz 1978, 32 f., Dokument C.

23 Murr 1784, 51 f., Nr. 10. - KüHNe 2000, 111. - KirChWeger 2005/ II, 75 .

24 Murr 1784, 52-57, Nr. 11. - Machilek/Schlager/WohnhaAs 1984/85. - KÜHNE 2000, 112 f. - KirChWEgER 2005/II, 76.

$25 \mathrm{Zu}$ Autorschaft, Datierung und Überlieferung des Offiziums: MACHILEK/SCHLAGER/WOHNhaAs 1984/85, 51-53, 70-72. - Ediert ist mittlerweile die "hystoria de lancea domini« aus dem Reisebrevier (Liber viaticus) des Johann von Neumarkt, um 1355/60: Prag (Praha), Knihovna Národního muzea, XIII A 12. Vgl. HergemöLLER 1999, Anhang 419-452. - Als Kanzler Karls IV. und Bischof von Leitomischl (Lytomyšl) (reg. 1353/54-64) gilt Johann von Neumarkt als einer der Autoren des Offiziums.

26 Zitiert nach Murr 1784, 57-72, Nr. 12, hier 65, 67. - Abweichend die Textedition des Offiziums nach dem Liber viaticus bei HergeMÖLLER 1999, Anhang 436, 439.

$27 \mathrm{Zu}$ den Miniaturen der bereits in Anm. 25 erwähnten Handschrift: Ausst.-Kat. Prag 2006, 95 f., Kat.-Nr. 14 (Jiří FAJT). - Ausst.-Kat. Prag/Nürnberg 2016, 493 f., Kat.-Nr. 12.6 (Jiří FAJT).

28 KüHNE 2000, 115 f. - Die Reliquienerwerbungen Karls (IV.) sind in der jüngeren Literatur vielfach thematisiert worden. Für den vorliegenden Kontext: OTAvsKÝ 2009, 301 f., 304.

29 Zitate aus den Handschriften: München, Bayerische Staatsbibliothek, Clm 6686, fol. 324r; Clm 15956, hintere Innenseite des Einbands. Zitiert nach NeuwirTh 1896, 119. - Zur Überlieferung der Heiltumslisten: KüHne 2000, 108. - OtAvskÝ 2009, 304. - Zur Nagelreliquie im Domschatz, Prag, Metropolitní kapitula u sv. Víta: Podlaha/Šit TLER 1903, 90, Nr. 74. - Zum Reliquienkreuz aus dem Kronschatz, Prag, Metropolitní kapitula u sv. Víta: Ausst.-Kat. Prag 2006, 111-114, Kat.-Nr. 24 (Karel OтAvsкÝ). - Zur Heiligen Lanze s. Anm. 21

30 OtavsKÝ 2009, 304. - Von den Nagelreliquien im Prager Dom- und im böhmischen Kronschatz ist verschiedentlich vermutet worden, sie seien aus dem Nagel der Heiligen Lanze hergestellt worden, was aber wohl nicht zutrifft. Für den Nagel im Domschatz vermutet OTAvsKÝ 2010, 214, eine Abkunft vom Nagel in Trier.

31 Prag, Metropolitní kapitula u sv. Víta. - ŠRONĚK 2009, 118 f. - Als "peplum sagwineum « wird der Schleier in der Münchner Heiltumsliste Clm 6686 bezeichnet (vgl. Anm. 29), zitiert nach NeUwirth 1896, 119. - Zur Ikonografie: ŠronĚK 2009, 122 f. - HAMBURGER 2011.

32 Prag, Knihovna Národního muzea, XVI B 12, fol. 42v. - PujmaNOVÁ 1995/96, 106, 108. - PUjMANOVÁ 1998, mit Fig. 34. - ŠronĚK 2009, 122. - Hamburger 2011, 10.

33 Zur Biografie des Heinrich Schatz SchöFFEL 1934, 56-62.

34 Kreuzigung Christi, Prag, Národní galerie, Inv.-Nr. O 6790. Pešina 1982 (mit Farbabb.). - Ausst.-Kat. Prag 2006, 86f., Kat.-Nr. 9 (Wilfried Franzen).

35 Hohenfurth (Vyšší Brod), Zisterzienserabtei. - Pujmanová 1995/
96. - Ausst.-Kat. Prag 2006, 132-134, Kat.-Nr. 36 (Jiří FAJT/Robert Suckale). - Royt 2013, 177-179. - Ausst.-Kat. Prag/Nürnberg 2016, 505, Kat.-Nr. 12.14 (Wilfried Franzen). - Die Datierung der Tafel schwankt in der zitierten Literatur um fast drei Jahrzehnte (!), zwischen "nach 1368« und "um 1390-1400«.

36 Prag, Národní galerie, Inv.-Nr. O 1252. - FAJT 1998, 269 (und Farbabb. 213). - Ausst.-Kat. Prag/Nürnberg 2016, 430, Kat.-Nr. 9.8 (Wilfried Franzen).

37 Fritz 1982, 246, Kat.-Nr. 432.

38 Rohault de Fleury 1870, 171, Kat.-Nr. 3. - Schulze-DörrLAMM 2010, 160, Kat.-Nr. 17. - Vgl. auch MaChILeK 1987, 225.

39 Jасові 1833, 10. - Laut JАСОві 1833, 186, Nr. 27, führte das Stift drei Nägel in seinem Siegel. - SCHAUdig 1927, $37 \mathrm{f}$.

40 Vgl. die Auflistung der Christus-Reliquien bei Вцонм 1993, 178. Anderen Autoren zufolge soll es in der Frauenkirche eine Nagelreliquie gegeben haben: Rohault de Fleury 1870, 171, Kat.-Nr. 13. - Schulze-Dörrlamm 2010, 161, Kat.-Nr. 34.

41 Machilek/Schlager/WohnhaAs 1984/85, 60. - Kühne 2000, $130 \mathrm{f}$.

42 Nürnberg, Stadtarchiv, Alte Urkunden, Inv.-Nr. 234. - Lutze 1932, 10 f., 14. - Ausst.-Kat. Bonn/Essen 2005, 515, Kat.-Nr. 461 (Robert Suckale). - Ausst.-Kat. Prag/Nürnberg 2016, 594 f., Kat.-Nr. 16.9.a (Benno Baumbauer).

43 Stange 1978, 20-22, Kat.-Nr. 8-11 (»Nürnberger Klaren-Werkstatt«). - Strieder 1993, 20-24, 166-168, Kat.-Nr. 4f. (mit Abb. 205-210).

44 Kemperdick 2002. - Ausst.-Kat. Prag 2006, 123 f., Kat.-Nr. 31 (Jiři FАJT). - Ausst.-Kat. Prag/Nürnberg 2016, 442-448, Kat.-Nr. 10.7 (Jiří FAJT).

45 Frankfurt/M., Städel Museum, Inv.-Nr. SG 443. - BRinkmanN/ Kemperdick 2002, 33-54 (Stephan Kemperdick), mit Abb. 20.

46 Stange 1978, 19, Kat.-Nr. 6. - Strieder 1993, 17-20, 168, Kat.-Nr. 6. - KAHSNITZ 2001. - WOLF 2002, 131-134.

47 Paris, Musée du Louvre, Département des arts graphiques, Inv.-Nr. M.I. 1121. - SteRLing 1987, 219-225 (mit Fig. 127-134).

48 Stuttgart, Staatsgalerie, Inv.-Nr. 1038. - Rettich/KLapproth/ EWALD 1992, 304-311 (Edeltraud RetTich). - FAJT/HÖRSCH 2006, 376f. - Zum Schottener Retabel: HÄrING 1976. - WOLF 2002, 203207. - FАJT/HÖRSCH 2006, 358.

49 München, Bayerisches Nationalmuseum, Inv.-Nr. MA 2293 f. - SUCKALE 1993, 130 und Abb. 112 f., 254 f., Kat.-Nr. 63. - Zur Einordnung zuletzt: KeMPERDICK 2010, 60-66.

50 Klosterneuburg, Augustiner-Chorherrenstift. - Fritzsche 1983, 9-50, Abb. 5, 12, 15, 23.

51 Stange 1978, 17, Kat.-Nr. 2. - Strieder 1993, 14 f., 17, 166, Kat.-Nr. 1.

52 Ress 1959, 408. - Ausst.-Kat. Köln 1978, I, 355 f. (Hans Ramisch). - Möhring 2016, $404 \mathrm{f}$.

53 Gast 2011, 447-449, Fig. 418, Abb. 276-281. 
Markus T. Huber

\section{Rezeption, Aneignung und Variation \\ Die Entwicklung Der Regensburger Dombauhütte ZWischen 1380 und 1425}

Karl IV. (reg. 1347-78, Kaiser ab 1355) zählt unbestritten zu jenen herausragenden Herrscherpersönlichkeiten, die das politische wie auch das kulturelle Profil des Reichs maßgeblich prägten. Im Verlauf seiner Regentschaft als Kaiser und böhmischer König gelang es dem in Prag residierenden Luxemburger, durch die Berufung der führenden Künstler seiner Zeit einen Hofstil zu etablieren, der sich aus der Synthese unterschiedlicher Einflüsse generierte und rasch für das gesamte Reichsgebiet vorbildhaft wurde. In allen Gattungen brachte die Prager Hofkunst innovative Schöpfungen hervor. Die Neuartigkeit der Ideen sowie die Subtilität und handwerkliche Qualität der Ausführung, verbunden mit dem Prestige, das mit der Herkunft aus dem kulturellen Umfeld des Kaiserhofs einherging, führten dazu, dass Kunstwerke aus Prag und Böhmen allenthalben höchste Wertschätzung genossen. ${ }^{1}$ Der im großen Stil betriebene Export exquisiter, in der Moldaumetropole geschaffener Steinskulpturen - namentlich der Vesperbilder und der »Schönen Madonnen « - über weite Wege zählt gewiss zu den erstaunlichsten Phänomenen dieser Epoche; an den kaiserlichen Unternehmungen ausgebildete Werkleute und böhmisch geschulte Wanderkünstler galten im mitteleuropäischen Raum als begehrte Spezialkräfte, denen man vorzüglich repräsentative, aber auch technisch anspruchsvolle Aufgaben anvertraute. Daneben gab es unzählige Handwerker und Künstler, die Hütten und Werkstätten vor Ort betrieben. Sie waren niemals persönlich in Prag gewesen, orientierten sich aber dennoch eng an den dort entwickelten Bild-, Form- und Motiverfindungen. Dies brachte eine bemerkenswerte Homogenität des künstlerischen Ausdrucks in weiten Teilen Mitteleuropas mit sich - erstaunlicherweise insbesondere für die Phase nach Karls erfolgreicher Herrschaft, um 1380 bis in die 1420er Jahre, in der Böhmen und die Luxemburger weiterhin eine zentrale Rolle im Reich spielten.

Wie sich die Übernahme böhmischer Modelle in der Disziplin der Architektur vollzog und welche Transfermechanismen hier denkbar sind, lässt sich am Regensburger Dom aufzeigen (Abb. 1).
An den zwischen etwa 1380 und 1425 errichteten Partien sind bei der künstlerischen Ausrichtung der Bauhütte drei Phasen zu beobachten, die sich in erster Linie durch den Grad der Souveränität im Umgang mit den neu entwickelten Formfindungen unterscheiden.

Vorweg sei mit wenigen Sätzen die Bausituation des Regensburger Kathedralprojekts um 1380 skizziert: ${ }^{2}$

Mit dem Bau des gotischen Doms war nach dem Brand der Vorgängeranlage im Jahr 1273 begonnen worden. ${ }^{3}$ Zunächst entstanden der Chor und das Querhaus sowie die östlichen Teile des Langhauses. Man orientierte sich dabei an Vorbildern, die in Frankreich und im Westen des Reichs lagen. ${ }^{4}$ Der Regensburger Dom folgt damit als einziger Kirchenbau in Bayern dem französischen Kathedraltypus. Gegen 1350/55 gelang es, mit dem südlichen Langhausschiff bis zur geplanten Doppelturmfassade vorzustoßen. ${ }^{5}$ Als Folge des ungünstigen Bauplatzes - das Baufeld der nördlichen Fassadenteile war durch die aus dem ehemaligen Baptisterium hervorgegangene Kirche des Kollegiatstifts St. Johann besetzt - konzentrierten sich die Arbeiten nolens volens auf den Südturm. Über dem letzten Seitenschiffjoch wuchsen bis um 1370 ein erstes ${ }^{6}$ und anschließend, bis gegen 1380 , ein zweites Obergeschoss auf (Abb. 2). ${ }^{7}$

Während man die beiden unteren Turmgeschosse strikt aus bereits vorliegenden Formbeständen der östlichen Bauteile entwickelt hatte und Neuerungen allenfalls bei Details akzeptierte, die der Gesamtorganisation untergeordnet sind, ${ }^{8}$ bedingte der Bau des zweiten Obergeschosses eine gänzliche Neuplanung.

\section{Rezeption}

Für diese Planung schweifte der Blick der Dombauhütte erstmals nach Osten. Eine wesentliche Ursache für die Neuorientierung ist, neben dem Aufblühen Böhmens als europäisches Kunstzentrum, in den von Karl IV. initiierten kirchenpolitischen Umwälzungen zu suchen. Nachdem Prag nämlich 1344 auf Intervention Karls hin zum 


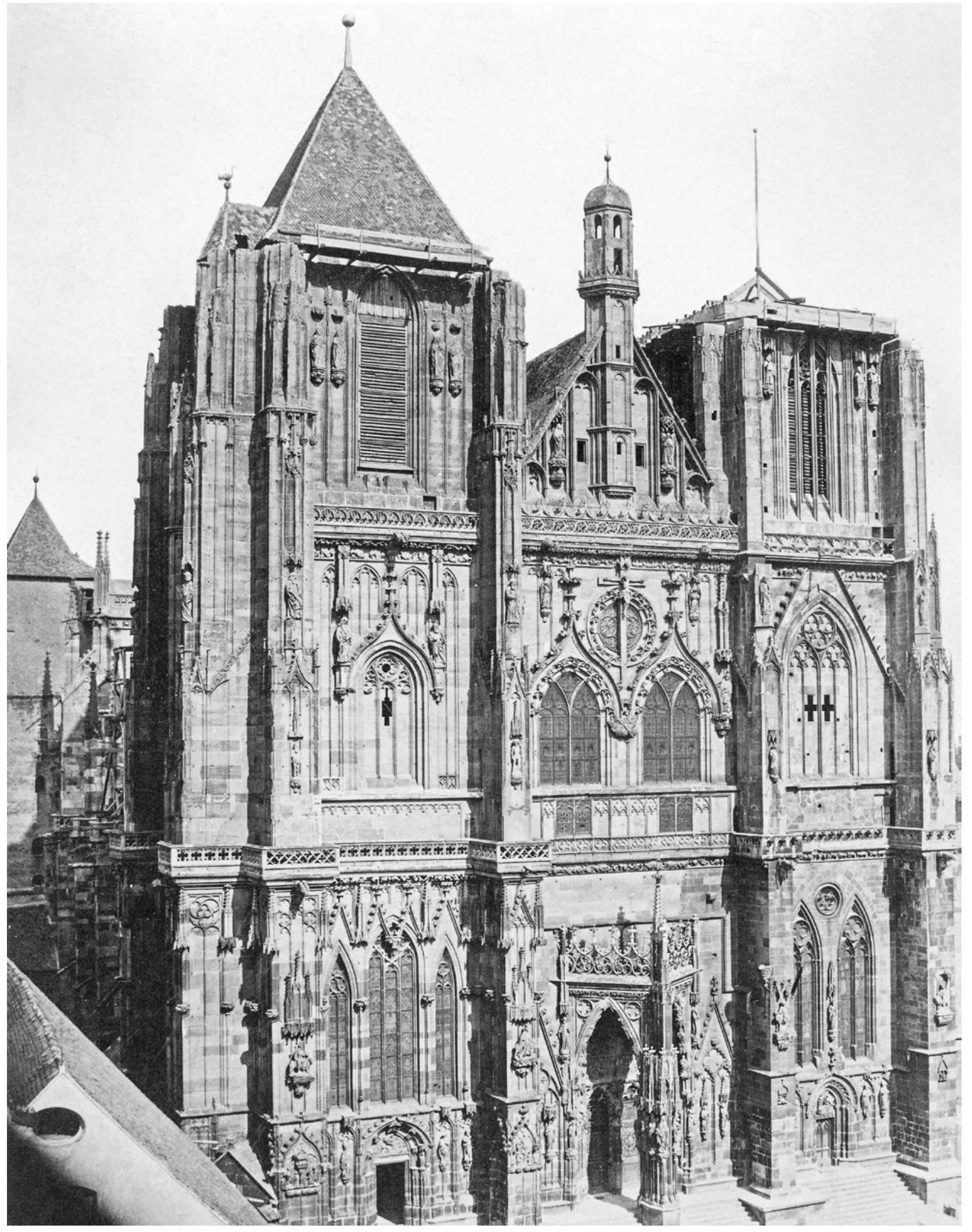

Abb. 1 Regensburg, Dom, Westfassade (Foto: Georg Böttger, 1860; Kunstsammlungen des Bistums Regensburg) 
Abb. 2 Regensburg, Dom, Bauzustand um 1380 (Zeichnung: Katarina Papajanni; ex: HUBEL/SCHULLER 2010, Taf. 22)

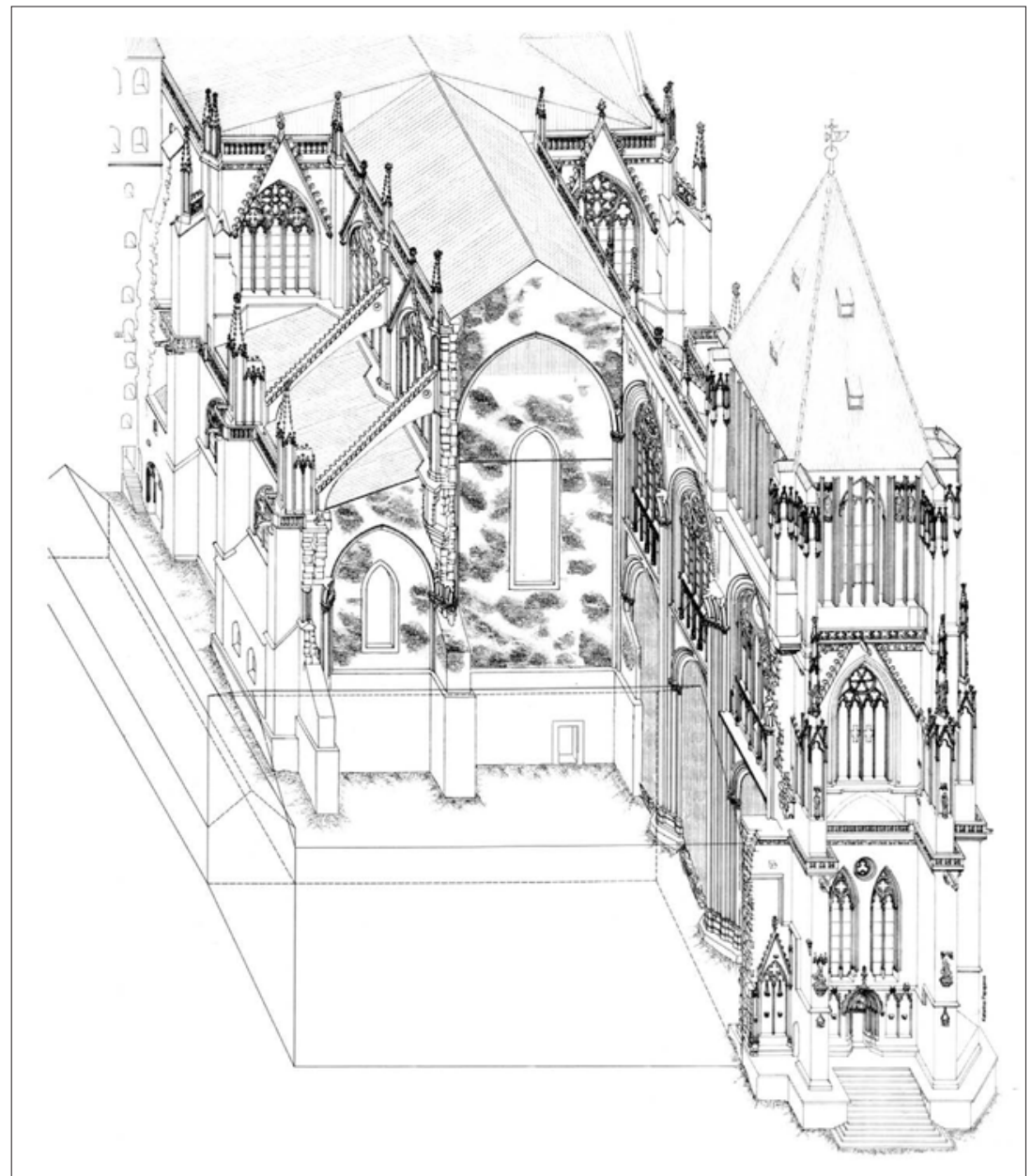

Erzbistum erhoben worden war, verlieh Papst Urban V. (reg. 1362-70) - wiederum auf kaiserliches Betreiben dem Prager Erzbischof 1365 den Rang eines ständigen päpstlichen Legaten, dessen Einfluss sich auch auf das Suffraganbistum Regensburg erstreckte. Noch im Jahr der Rangerhöhung visitierte Erzbischof Jan Očko von Vlašim (reg. 1364-78) in dieser Funktion Regensburg. Zwei weitere Belege für die Wahrnehmung seiner Befugnisse auf die unterstellte Diözese datieren von 1366 und 1368. ${ }^{9}$

Im Jahr des Aufstiegs Prags zum Erzbistum war auf dem Hradschin der Grundstein zu einer neuen Kathedrale gelegt worden. Sie war dem heiligen Veit geweiht, der hier gemeinsam mit dem heiligen Wenzel als Patron des Königreichs Böhmen verehrt wurde. Die Bauleitung lag ab 1356 in den Händen des jungen Peter Parler von Gmünd, den Karl IV. an die Stelle des 1352 verstorbenen ersten Baumeisters Matthias von Arras gesetzt hatte. ${ }^{10}$ Der Veitsdom war zweifellos das ambitionierteste und am meisten Aufsehen erregende Bauprojekt im Reich.
Die enge Bindung Regensburgs an die junge Erzdiözese konnte nicht ohne Auswirkungen auf den eigenen Kathedralbau bleiben. Anhand zweier Beispiele lässt sich die Rezeption neuer Bauideen aus dem Umfeld der Prager Bauhütte illustrieren.

Die erste Neuerung in der Regensburger Domarchitektur besteht in der Instrumentierung der Wandfläche mit Paneelwerk (Abb. 3).

Dieses wurde über das Schallfenster hinweggeführt, wodurch die Stäbe im Bereich der Öffnung frei stehen. Anders als bei der "Harfenbespannung« der Straßburger Münsterfassade, ${ }^{11}$ an die man zunächst erinnert sein mag, ist hier das steinerne Gitterwerk nicht als eine zweite, selbstständige Schicht vor die glatte Wand gestellt. Vielmehr liegen die Paneelbahnen in einer großen Rechtecknische, die in die Mauersubstanz eingeschnitten ist - sie sind also Teil des Wandkörpers. Das Mauerwerk bleibt als schmaler umlaufender Rahmenstreifen in voller Stärke erhalten. Anstelle der Verschleierung und räumlichen 


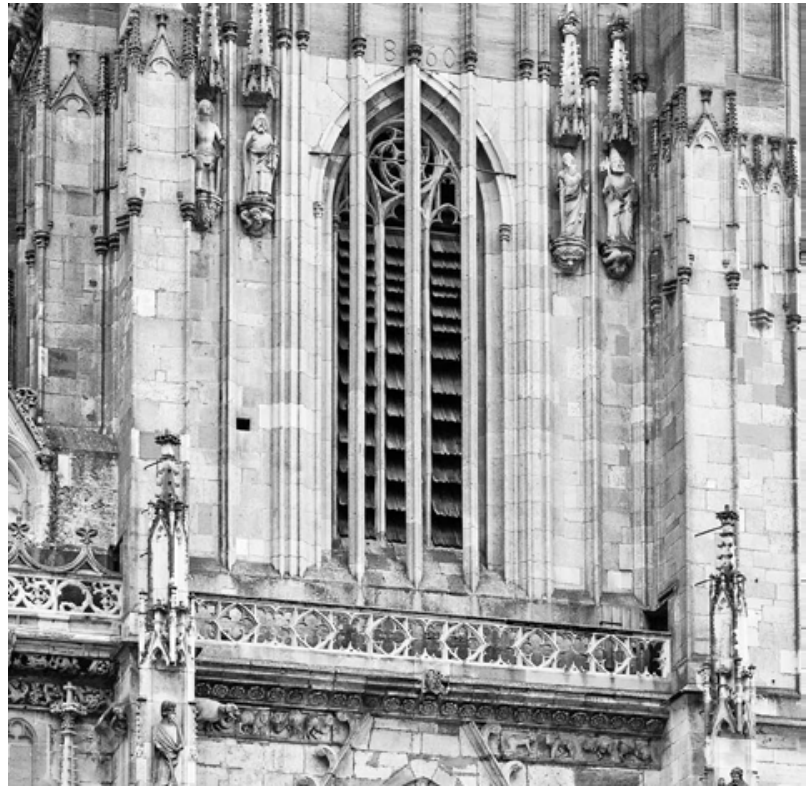

Abb. 3 Regensburg, Dom, Südturm, Glockengeschoss von Westen (Foto: Markus T. Huber)

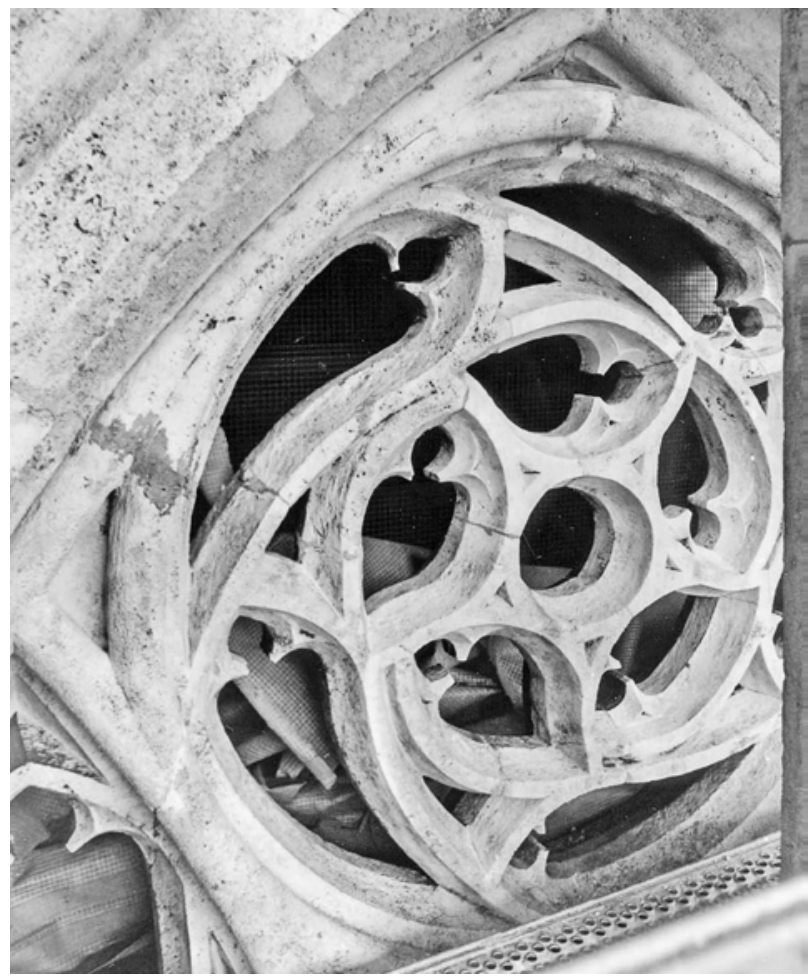

Abb. 4 Regensburg, Dom, Südturm, Westseite, Glockengeschoss, Couronnement des Schallfensters (Foto: Achim Hubel, Bamberg, 1994)

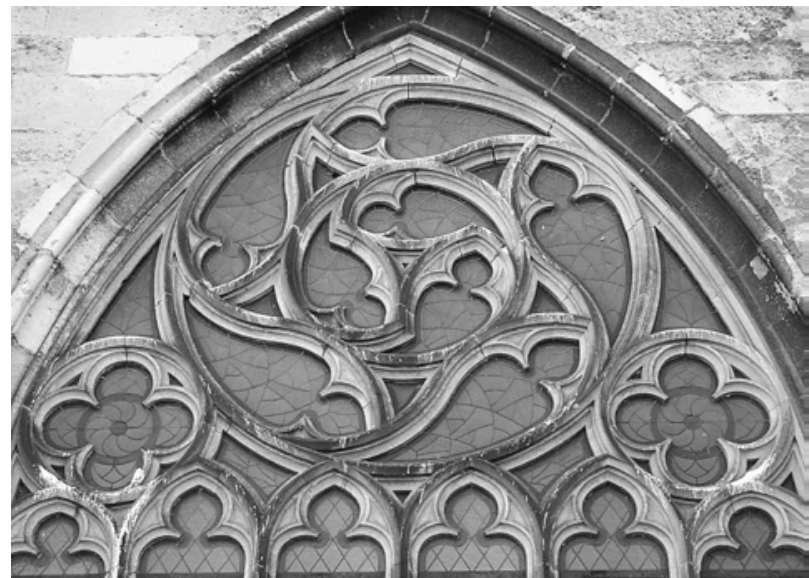

Abb. 5 Kolin, St. Bartholomäus, Chor, Nordseite, Obergadenfenster (Foto: Marc Carel Schurr, Straßburg)

Auflockerung tritt eine Reliefierung und damit eine erheblich kompaktere Behandlung der Mauerfläche. Zwar ist das Paneelieren von Wandfeldern häufig an oberrheinischen Bauten der ersten Hälfte des 14. Jahrhunderts zu beobachten, doch weist die in Regensburg deutlich wahrnehmbare Tendenz hin zu einer Verfestigung der Bauglieder auf die Architektur der Parler in Böhmen.

Dass die Anregungen zur Regensburger Paneelwand tatsächlich wohl eher aus dem Osten kamen, darauf deutet das hier zu beobachtende Spiel mit der kontrapunktischen Interferenz zweier unterschiedlich getakteter Gliederungssysteme: Die Vierzahl der Paneelbahnen ist dergestalt mit der Dreiteiligkeit des Fenstermaßwerks dahinter ins Verhältnis gesetzt, dass die Vertikalstäbe beider Ebenen zueinander auf Lücke stehen. Dieses Gestaltungsprinzip, das Hans Koepf als »Inversion « bezeichnete, ${ }^{12}$ hat Erich Bachmann als ein besonderes Charakteristikum der Architektur Peter Parlers herausgearbeitet. Er beobachtete dieses Kompositionsschema beispielsweise an den Triforienarkaturen sowie den Gewölben und der Südportalvorhalle des Prager Veitsdoms oder dem Chorschluss der Bartholomäuskirche in Kolin an der Elbe. ${ }^{13}$

Vollends greifbar wird die Vorbildwirkung böhmischer Architektur an den um 1380 entstandenen Maßwerkfüllungen der Schallfenster: Im Couronnement der Spitzbogenöffnungen sitzt je ein großer Kreis. Dieser fasst zwei Fünferreihen von genasten Fischblasen ein, die um einen mittigen Okulus kreisen (Abb. 4).

Die Vorbilder für diese Komposition, die zugleich das erste Auftreten dynamisierter Fischblasen in den Regensburger Maßwerken überhaupt markiert, liegen in den Chorfenstern der Bartholomäuskirche in Kolin (Abb. 5). 
Diesen Chor errichtete der kaiserliche Baumeister Peter Parler ab 1360. ${ }^{14}$ Da eine für das Jahr 1378 überlieferte Weihenachricht wohl nicht den Bauabschluss markiert, sondern an dem Werk noch mindestens bis weit in die 1380er Jahre hinein gearbeitet wurde ${ }^{15}$ rücken die Maßwerkfüllungen in Kolin und Regensburg zeitlich eng zusammen. Die Regensburger Bauhütte muss die böhmischen Anregungen also zeitnah rezipiert und umgesetzt haben. Das sich durch ausgesuchte Eleganz auszeichnende Koliner Fischblasenrad wurde in Regensburg in verhältnismäßig schwerfälligen Formen wiederholt, wodurch das Nachfolgeverhältnis unmissverständlich zum Ausdruck kommt.

\section{Aneignung}

Nach jahrzehntelangen Verhandlungen um die Stiftskirche St. Johann glückte es dem Regensburger Domkapitel im Jahr 1380, dem Kollegiatstift das Einverständnis zum Abbruch des Gotteshauses abzuringen. ${ }^{16}$ Der von der Dombauhütte erstellte Ersatzbau war offenbar innerhalb eines Jahres fertiggestellt. ${ }^{17}$ Nach der anschließenden Beseitigung der alten Johanneskirche stand endlich der Bauplatz für den nördlichen Teil der Westfassade, bestehend aus dem zweiten Turm sowie dem zwischen den Türmen liegenden Mittelschiffjoch mit der westlichen Abschlusswand, zur Verfügung.

Bald nach 1384 wurde durch Bischof Johann I. von Moosburg (reg. 1384-1409), einen offiziell anerkannten unehelichen Sohn Herzog Stephans III. von Bayern-Ingolstadt (reg. 1375-1413), ${ }^{18}$ der Grundstein zum Nordturm gelegt. ${ }^{19}$ Eine beträchtliche Aufstockung der finanziellen Ausstattung der Domfabrik brachte in der Folge eine gleichermaßen expansive wie auch innovative Phase für den Regensburger Kathedralbau. ${ }^{20}$

Am Erdgeschoss des Nordturms und am Hauptportal mit seiner Vorhalle wurden Individualität und Formenreichtum zum neuen Leitbild erhoben (Abb. 1). Anstatt sich - wie bislang - bestmöglich dem Bestand anzugleichen, setzte man die neu zu errichtenden Partien mit Nachdruck von der älteren Architektur ab. Beim Entwurf des zunächst zum Bau anstehenden Hauptportaltrichters sowie der Portalzone des Nordturms orientierte man sich nun ganz am modernen Prager Stil.

Die Planungsgrundlage hierzu bot der Zweiturmriss, ein in Regensburg erhaltener Entwurf für den Fassadenmitteltrakt und den Nordturm ohne Helmaufsatz. ${ }^{21} \mathrm{Da}$ die Planung den Südturm offenbar als Bestand voraussetzt, können die älteren Teile der in einem längerdauernden Arbeitsprozess entstandenen Zeichnung etwa zeitgleich mit der Grundsteinlegung des Nordturms um 1380/85 datiert werden. ${ }^{22}$ Das darin verarbeitete Formengut legt nahe, dass man den Riss von einem Meister aus dem Umfeld Peter Parlers bezog.

Wenngleich die in Regensburg zwischen etwa 1385 und 1400/05 errichteten Partien in den Details von der Entwurfsvorlage abweichen, sind an ihnen die Bezüge zu Prager Vorbildern unübersehbar, was wiederum durch zwei Beispiele erläutert sei:

Den neuen Bauteilen liegt ein gewandeltes Verständnis vom Verhältnis der Architekturglieder zueinander zugrunde. Dieses offenbart sich bei der näheren Untersuchung der Reversseite der Fassadenwand: Dreiteilige Blendarkaden flankieren dort das kastenartig aus der Wandebene vorspringende Hauptportal (Abb. 6).

Während das jeweils äußere Ende der Bogenfolgen auf säulenartigen Wandvorlagen ruht, werden die zum Eingangsblock hin orientierten Bögen partiell von dessen geschrägten Flanken verschluckt. In diese Flächen sind jedoch kleine, von lauernden Fabelwesen besetzte Nischen eingelassen, die den Blick auf eine tieferliegende Architekturschicht suggerieren (Abb. 7).

Die in der Höhlung gewissermaßen "freigelegten" Strukturglieder sind als exakte Gegenstücke zu den innerhalb der Blendarkaturen gegenüberliegenden Wandvorlagen gebildet. Durch diesen Kunstgriff wird vorgegeben, das Reststück der Arkade sei, scheinbar vollständig ausgearbeitet, zusammen mit der zugehörigen Säule dem Mauerwerk des Portalkastens inkorporiert und müsse gleichsam nur aus ihm herausgeschält werden. Diese Vorstellung entspricht sehr genau der Architektur des Prager Doms. Auch dort wachsen die Elemente in komplizierten Durchdringungsfiguren ineinander, ist das Bauwerk gewissermaßen als lebender Organismus begriffen. ${ }^{23}$

Ebenfalls auf Vorbilder am Veitsdom gehen die Blendmaßwerke zurück, welche sich außen und innen nahezu flächendeckend über die Sockelzone des Regensburger Nordturms spannen (Abb. 8, 9).

Sie sind gegenüber der Maßwerkfüllung der Südturmschallfenster freier entwickelt, die Zeichnungen erscheinen weicher und organischer; an die Stelle des etwas schwerfälligen formalen Zitats ist eine souveräne Kenntnis der dem neuen Formengut innewohnenden Bildungsgesetze getreten. Die Kompositionen zeichnen sich durch Dynamisierung, Verschleifung, gleitende Linienführung 


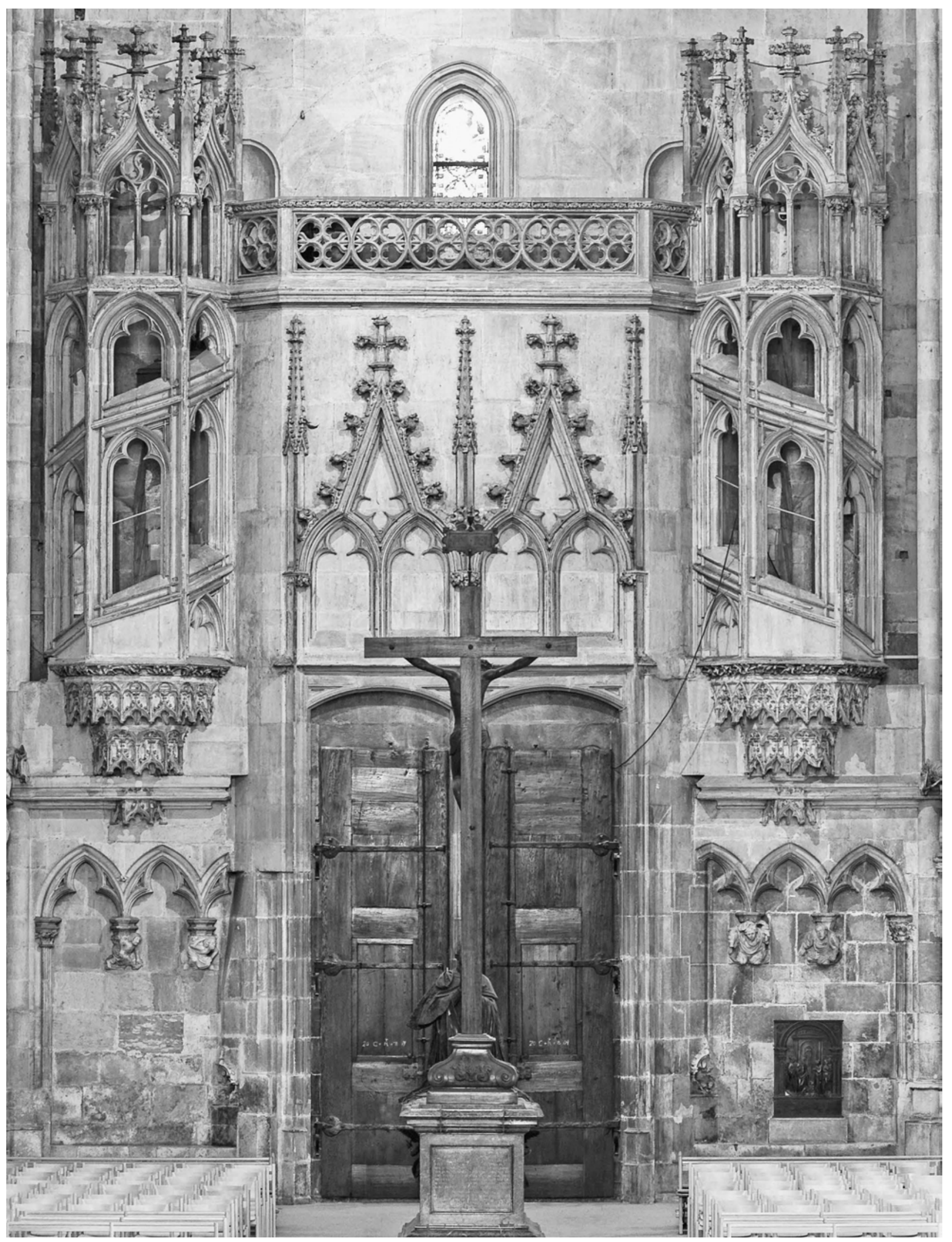


Linke Seite: Abb. 6 Regensburg, Dom, Langhausmittelschiff, innere Westwand, Hauptportalanlage (Foto: M. T. Huber, 2009)

Abb. 7 Dämonennische. Regensburg, Dom, Langhausmittelschiff, innere Westwand, nördliche Schrägwand des Hauptportalvorsprungs (Foto: M. T. Huber, 2009)

Abb. 8 Regensburg, Dom, Nordturm, Westseite, Erdgeschoss, Sockelzone (Foto: M. T. Huber, 2009)

Abb. 9 Regensburg, Dom, nördliche Turmhalle, Nordwand, Sockelzone, Wandgliederung (Foto: M. T. Huber, 2009)
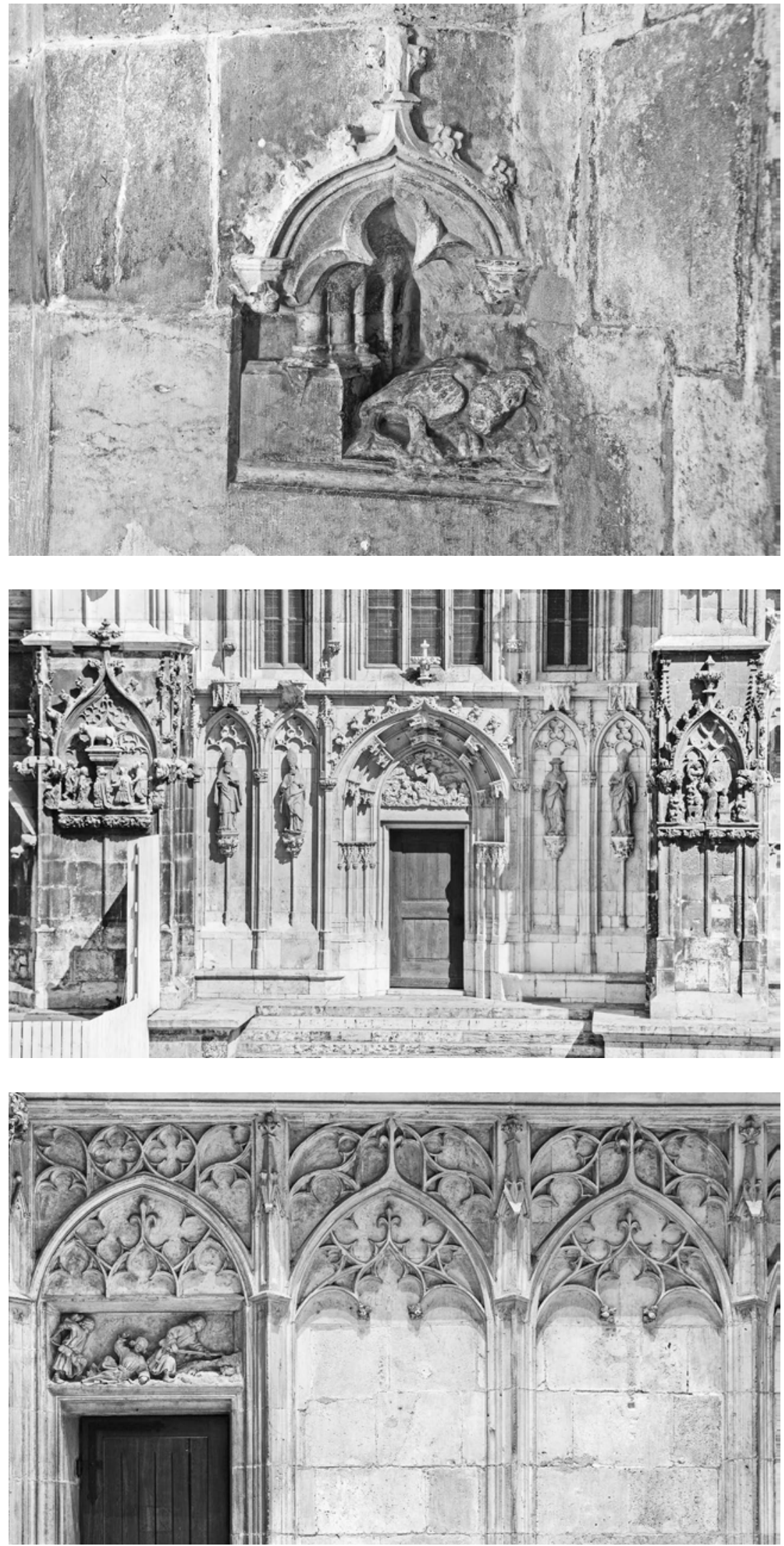


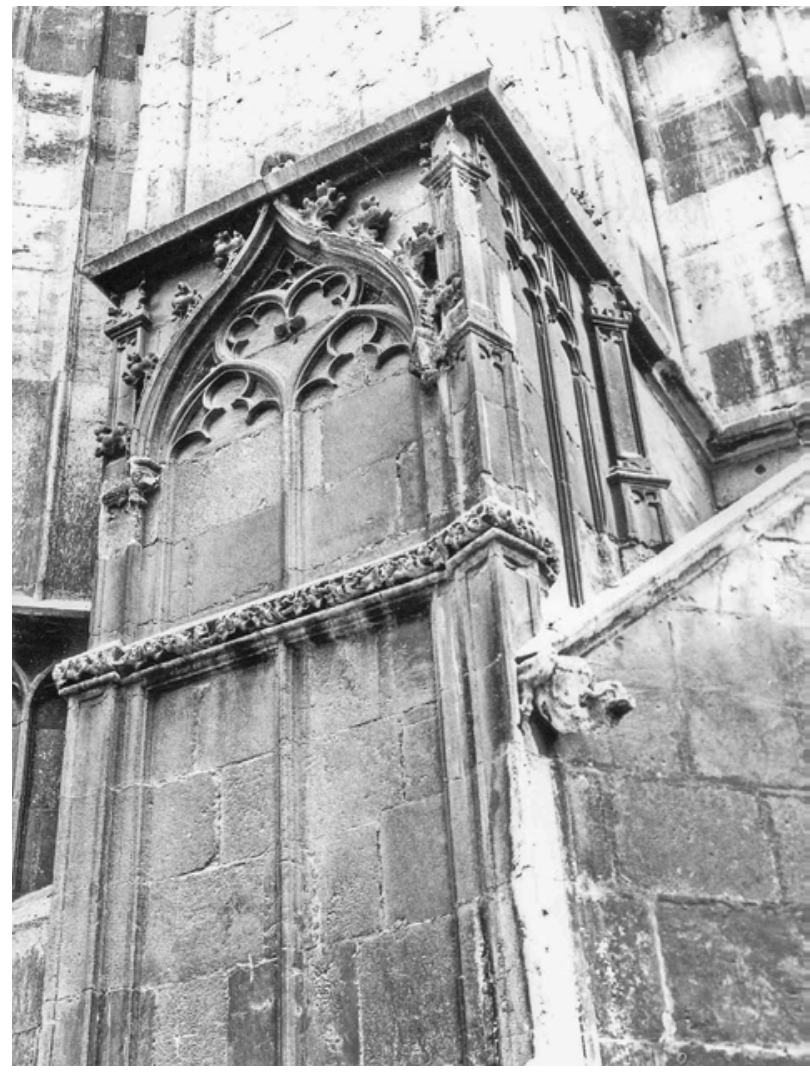

Abb. 10 Regensburg, Dom, Nordturm, Nordseite, Erdgeschoss, Sockelzone, Front des westlichen Strebepfeilers (Foto: A. Hubel, 1984)

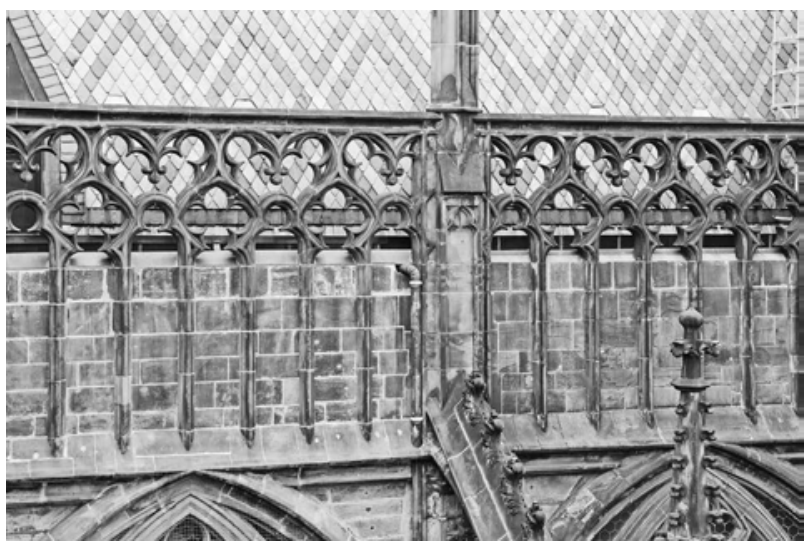

Abb. 11 Prag, Veitsdom, Chor, Maßwerkbalustrade vor dem Dachansatz (Foto: M. T. Huber, 2009)

sowie die reiche Verwendung der flexibel formbaren Figur der Fischblase aus. In hohem Maß wird von aufgebrochenen Formen Gebrauch gemacht, bei denen zwei Figuren durch Auflösung der trennenden Lamellen zu einer Gestalt verschmelzen. Diese Art des Umgangs mit

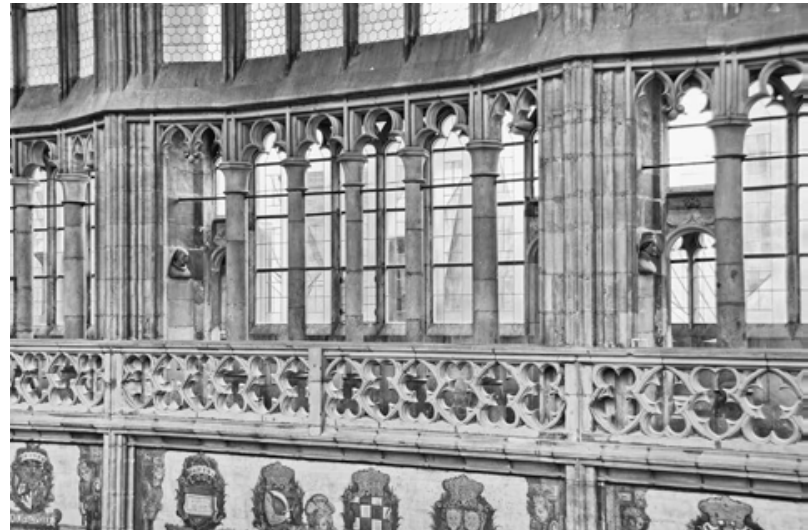

Abb. 12 Prag, Veitsdom, Chor, Nordwand, Triforium (Foto: M. T. Huber, 2009)

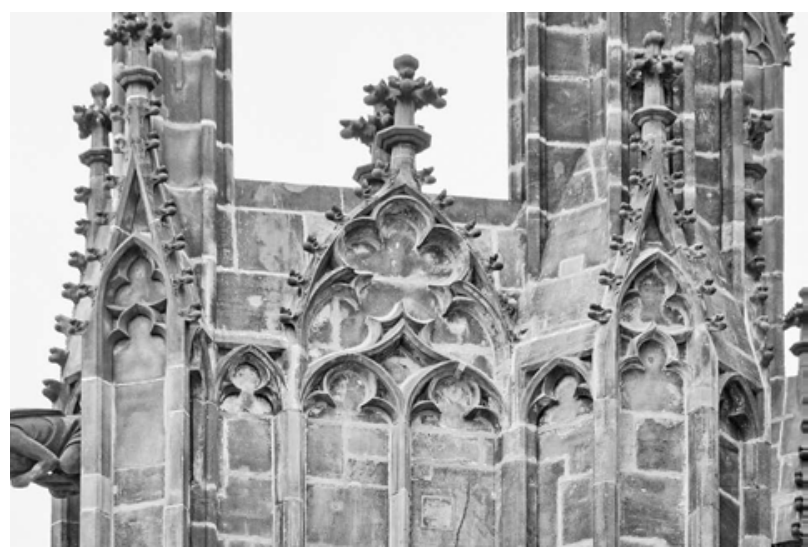

Abb. 13 Prag, Veitsdom, Chorstrebewerk, Blendmaßwerk (Foto: M. T. Huber, 2009)

Maßwerk konnte ein Werkmann der Zeit um 1390 am Prager Veitsdom kennenlernen, wo sich konkrete Parallelen zu den Regensburger Motiven auffinden lassen:

Die an den Schwänzen verschmolzenen Zwillingsfischblasen der Regensburger Strebepfeilerfronten finden sich im Veitsdom am Fenster der Martinizkapelle und an der Maßwerkbalustrade über dem Obergaden vorgebildet (Abb. 10, 11).

Die aus einem liegenden und einem stehenden Dreipass gewonnene Doppelfigur in den Bogenfeldern der Blendlanzetten zuseiten des nördlichen Nebenportals erinnert an ganz ähnliche Bildungen an der Prager Triforienbrüstung (Abb. 8, 12).

Eine zentrale Passfigur, die zwei Flächenstücke mit sich anschließenden Fischblasen teilt, zeigen sowohl das Blendmaßwerk über der Darstellung des Tanzes um das Goldene Kalb in Regensburg als auch die Blendlanzetten der Prager Chorstrebepfeiler (Abb. 8, 13). 


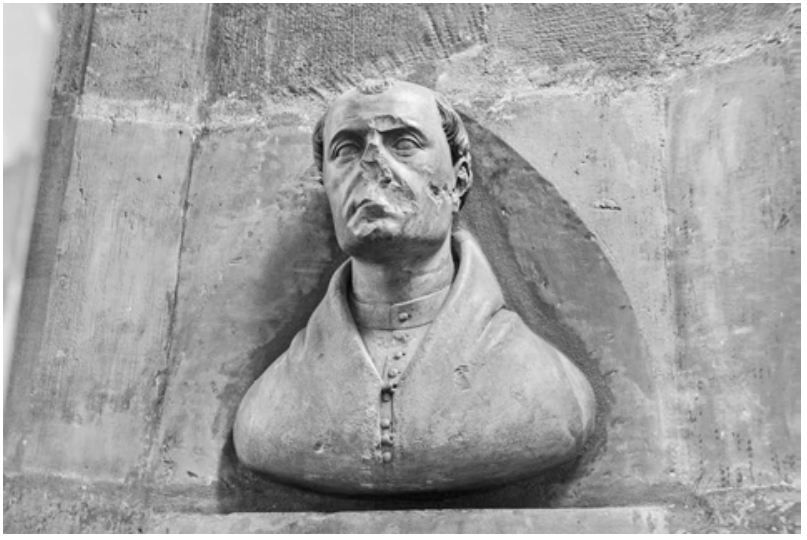

Abb. 14 Portraitbüste des Baudirektors Wenzel von Radeč. Prag, Veitsdom, Triforium (Foto: M. T. Huber, 2009)

Ähnliche aufgebrochene Gestalten sind dort ferner im Maßwerktympanon des Sakristeiportals sowie an der Balustrade vor dem Dachansatz zu beobachten (Abb. 11). Ineinander übergleitende Fischblasen und Blattfiguren waren ursprünglich auch auf den massiven Mittelpfeiler des um die Wende des 19. zum 20. Jahrhundert grundlegend umgestalteten Fensters zur Hasenburgkapelle geblendet. ${ }^{24}$ Alle diese Maßwerkfiguren kehren ebenso auf dem Regensburger Zweiturmriss wieder, jedoch stets an anderer Position als am ausgeführten Bau. ${ }^{25}$

$\mathrm{Zu}$ der konsequenten stilistischen Neuausrichtung mögen neben dem Renommee des Veitsdoms als kaiserliche Unternehmung sowie dem Einfluss des Prager Metropoliten auf sein Suffraganbistum auch personelle Verbindungen beigetragen haben. Über den entsprechenden Einfluss verfügte der Prager Kanonikus Wenzel von Radeč (urkundlich nachweisbar 1379-1417, Abb. 14).

Er bekleidete am Veitsdom das Amt des Bauverwalters und legte als solcher 1392 zusammen mit Peter Parler den Grundstein zum Westteil der Kathedrale. ${ }^{26}$ Daneben hatte er aber auch ein Kanonikat in Regensburg inne. ${ }^{27}$ Wollten sie nicht auf die mit dieser Präbende verbundenen Einkünfte verzichten, waren die Domherren zumindest bei den alljährlichen Generalkapiteln zur persönlichen Anwesenheit verpflichtet. ${ }^{28}$ Radeč muss sich folglich regelmäßig in der Donaustadt aufgehalten haben. Durch seine langjährige Tätigkeit als Bauverwalter an der prominentesten Unternehmung seiner Zeit verfügte der Kleriker gewiss über profunde Sachkenntnis im baukünstlerischen Fach. Wenzel von Radeč dürfte daher die zentrale Figur bei der Vermittlung von Planmaterial und qualifiziertem Personal nach Regensburg gewesen sein.

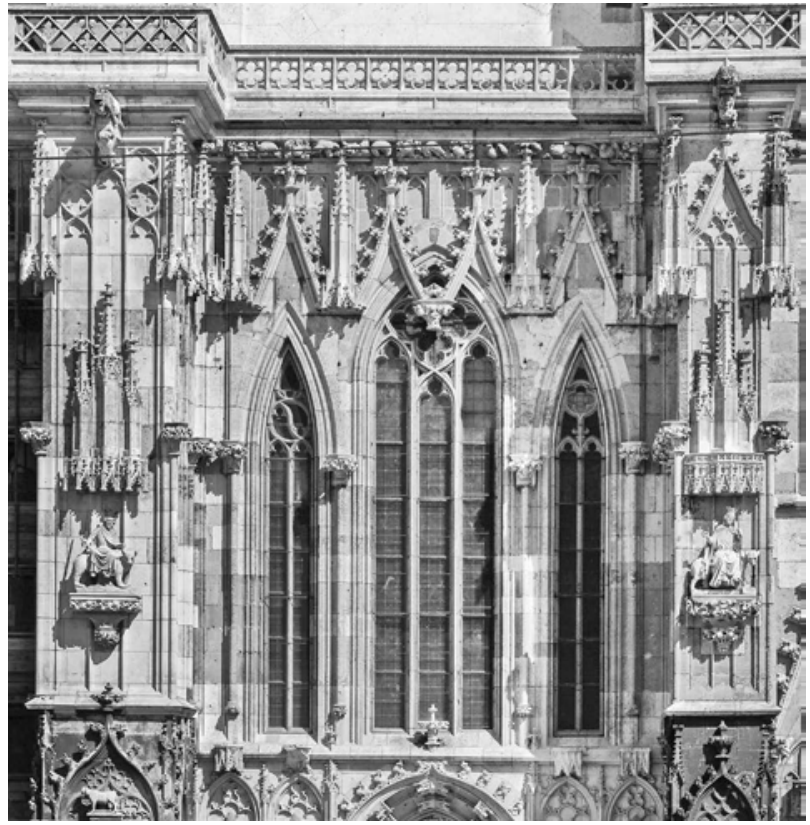

Abb. 15 Regensburg, Dom, Nordturm, Westseite, Erdgeschoss, Fensterzone (Foto: M. T. Huber, 2009)

Ein Zeugnis für die Präsenz eines Mitglieds der ParlerSippe auf der Regensburger Dombaustelle wäre das Parler-Wappen, das auf einem der beiden sogenannten Sammelsteine an der Stirnseite des Strebepfeilersockels südlich des Hauptportals eingemeißelt ist ${ }^{29}$ - vorausgesetzt, es handelt sich nicht um eine Hinzufügung der Parler-Renaissance des späten 15. Jahrhunderts. Die um den reliefartig ausgearbeiteten Schild versammelten Steinmetzzeichen lassen sich Friedrich Fuchs zufolge mit der Bauzeit des Hauptportals in Beziehung bringen. ${ }^{30}$

\section{Variation}

Im Anschluss an den Sockelbereich entstanden bis gegen 1425 die Fensterzone der Nordturmhalle sowie die dreieckig aus der Fassadenwand hervorspringende Hauptportalvorhalle (Abb. 15, 16). ${ }^{31}$

Im Architekturstil geht damit ein unübersehbarer Wandel einher. Das inzwischen etablierte Formenmaterial wird in einem neuen Gestaltungsmodus verarbeitet, der die Züge eines ausgereiften Personalstils trägt. Schlanke, linear angelegte Bauglieder, eine vertikale Zuspitzung der Proportionen sowie kantige, kristalline Formen verleihen der Architektur eine eigentümlich spröde Eleganz. Feines Maßwerkgespinst überzieht die Stützglieder, kleinteilige 


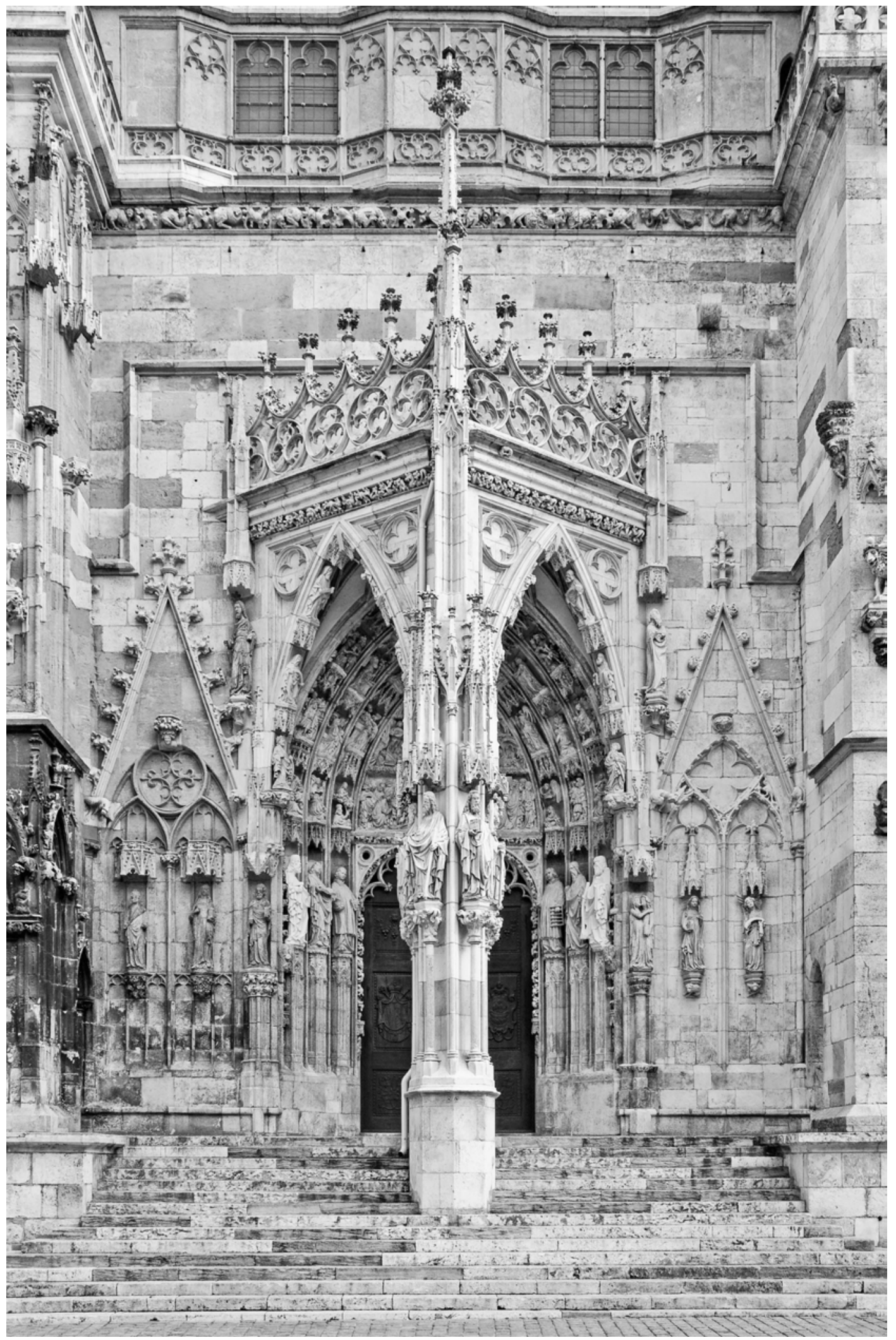

Abb. 16 Regensburg, Dom, mittleres Westportal (Foto: M. T. Huber, 2010) 


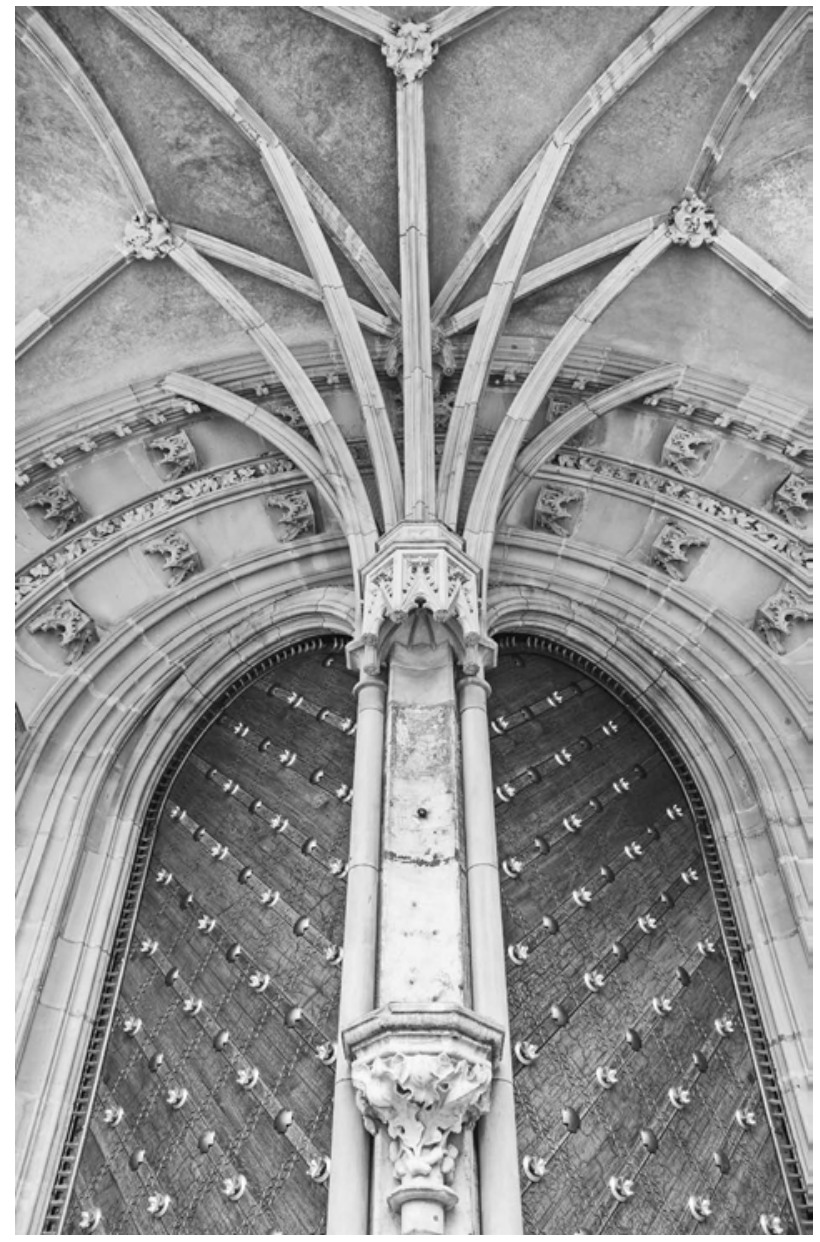

Abb. 17 Prag, Veitsdom, Trumeau des Südportals (Foto: M. T. Huber, 2009)

Plastiken und Ornamente sowie kontrastreich dagegengesetztes schwellendes Blattwerk verschleiern die baulichen Strukturen.

Die Motive fußen einerseits weiterhin auf böhmischer Baukunst, lassen daneben aber auch retrospektive, geradezu »klassische« Tendenzen erkennen. Dass Prager Ideen nach wie vor eine wichtige Rolle spielen, offenbart sich in der Anlage der dem Hauptportal vorgelagerten Arkadenhalle. Diese entwickelt sich aus einem einzelnen, axial zum Platz hin vorgeschobenen Freipfeiler, der über zwei schräg angeordnete Arkadenbögen mit der Portalwand verbunden ist. Während der Regensburger Domforschung - letztlich zurückgehend auf Franz Kugler - lange der um 1330 entstandene Triangel des Erfurter Doms als entscheidender Impulsgeber galt, ${ }^{32}$ wurde von jüngeren Autoren erkannt, dass die Parallelen zu dem 1368 geweihten Südeingang des Prager Veitsdoms weit

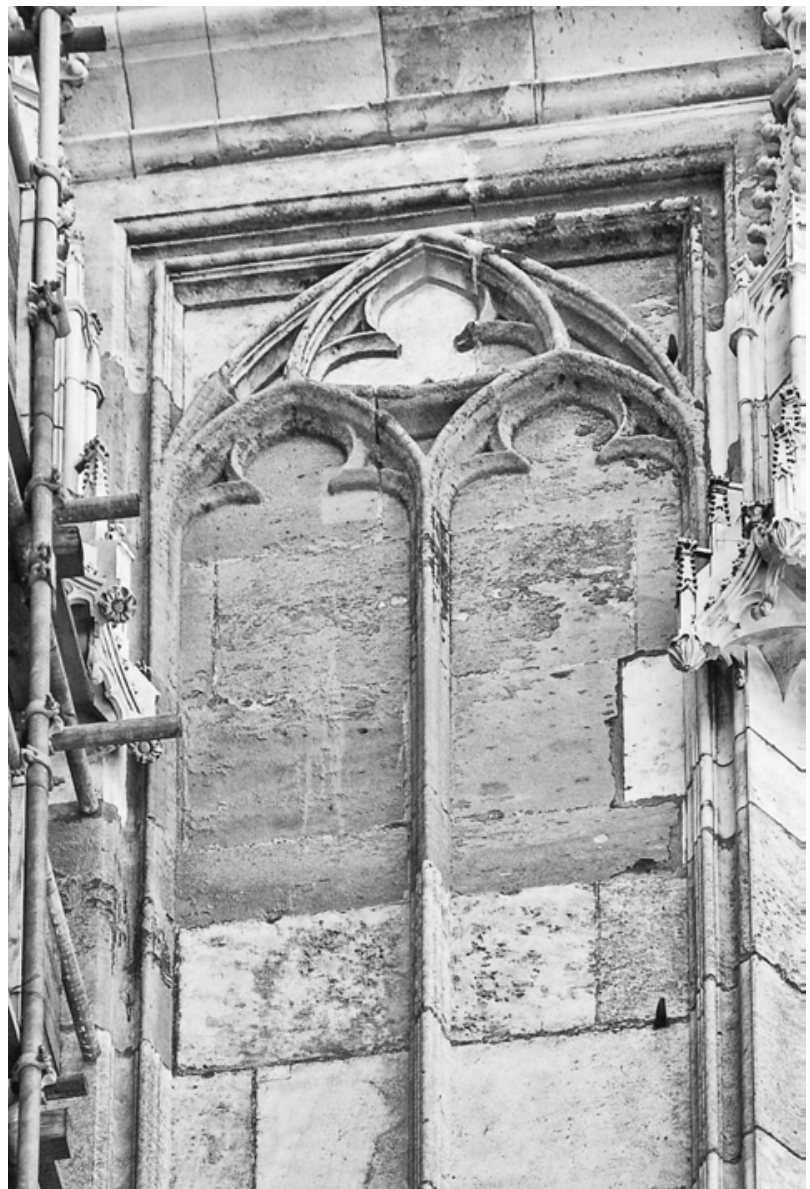

Abb. 18 Regensburg, Dom, Nordturm, Westseite, Maßwerkblende der Nordflanke des nördlichen Strebepfeilers unter der ersten Galerie (Foto: M. T. Huber, 2009)

enger sind und vielmehr dieser als genetischer Vorläufer der Regensburger Halle gelten darf. ${ }^{33}$ In Prag liegt hinter einer dreiteiligen Arkatur ein Doppelportal, dessen Trumeau über ein Bündel aufschießender Luftrippen mit dem Vorhallengewölbe verbunden ist (Abb. 17).

Wie später am Regensburger Triangel ist dieser Mittelpfosten vor die Wandebene gerückt, was eine schräge Orientierung der beiden Durchgangsöffnungen zur Portalwand zur Konsequenz hat. ${ }^{34}$ Damit liegt das Motiv der Regensburger Westvorhalle im Grunde bereits komplett entwickelt vor. Es musste nur noch aus der komplexeren Baustruktur separiert und monumentalisiert werden.

Das für das Werk des Regensburger Meisters kennzeichnende Interesse am Retrospektiven offenbart sich insbesondere in seinen Maßwerkmustern. An die Stelle der vielfältigen Motivkombinationen und Formverschmelzungen, wie sie für die Sockelzone festzuhalten 


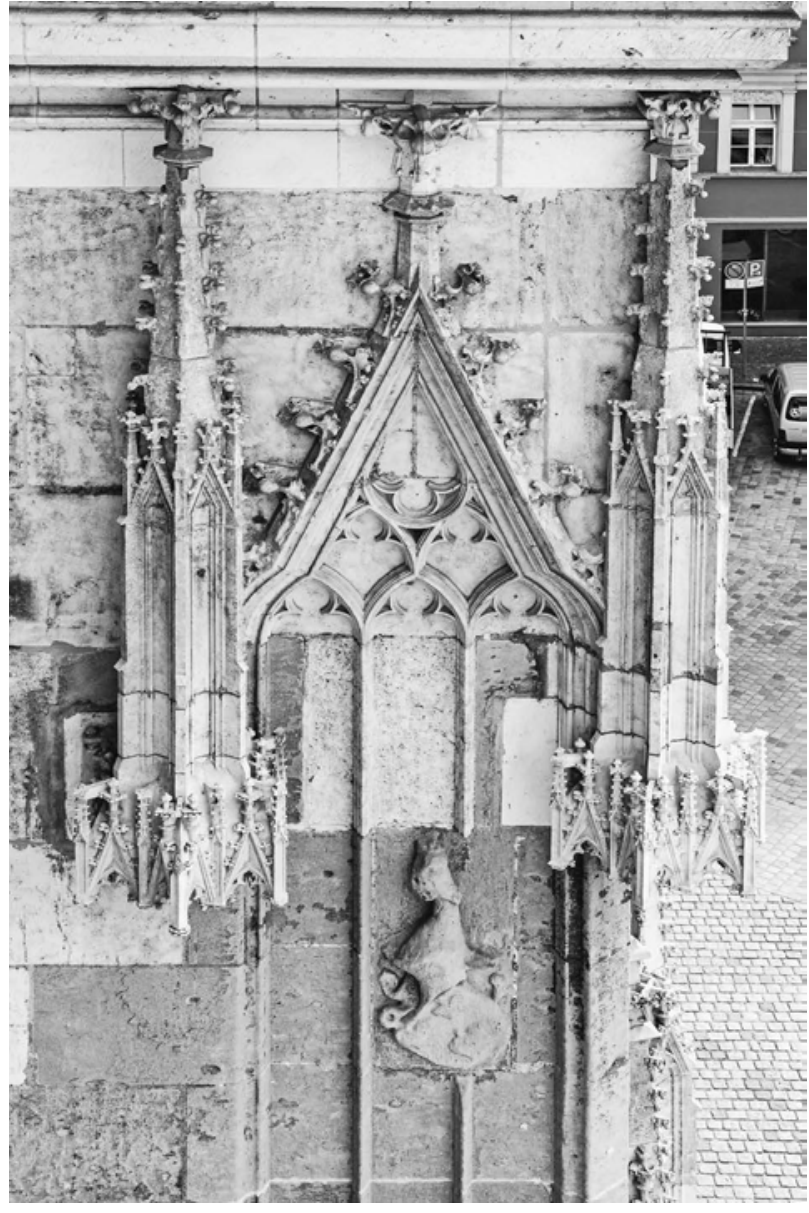

Abb. 19 Regensburg, Dom, Nordturm, Westseite, Erdgeschoss, nördliche Flanke des südlichen Strebepfeilers unter der ersten Galerie (Foto: M. T. Huber, 2009)

waren, tritt nun ein drastisch reduziertes Repertoire, wobei ausgesprochen altertümlich anmutende Figuren die Kompositionen dominieren: So verweist das auf den Scheiteln zweier Lanzettbahnen balancierende, kurvilinear gerahmte Dreiblatt als Füllfigur weit ins 14. Jahrhundert zurück (Abb. 18). ${ }^{35}$

Dreiblattbögen, die von den darunterliegenden Lanzetten scharf beschnitten werden (Abb. 19), lassen sich schon auf dem um 1300 angefertigten Straßburger Riss $\mathrm{B}_{1}{ }^{36}$ und gegen 1320 an der Annenkapelle des Wormser Doms ${ }^{37}$ beobachten.

Typische Formen der Hochgotik finden mit den kreisgefassten Drei- und Vierpässen in den Bogenfeldmaßwerken der Turmfenster sowie in den Zwickeln der Portalvorhalle eine prominente Platzierung (Abb. 16, 20).

Der große stehende, mit Kleeblattbögen ausgesetzte und durch Liliennasen akzentuierte Vierpass, der das
Couronnement des westseitigen Mittelfensters schmückt, trat bereits in den Obergadenfenstern des Kölner Doms als beherrschendes Motiv auf. ${ }^{38}$ Peter Parler verleibte diese Figur seinem Maßwerkfundus ein und zitierte sie im Fenster der Martiniz-Kapelle sowie am Südquerhausgiebel der Prager Kathedrale, dessen Ausführung nach 1400 unter seinem Sohn und Nachfolger Johann erfolgte. ${ }^{39}$

Um ein in der Tradition verankertes Architekturmotiv handelt es sich auch bei dem gestaffelten Fenstertrio über dem nördlichen Nebenportal, wobei zwei schmale, doppelbahnig organisierte und extrem zugespitzte Öffnungen ein breites, dreibahniges Mittelfenster flankieren. Die Anordnung geht auf die Straßburger Münsterfassade zurück. ${ }^{40}$ Dort sind die zwischen 1355 und 1365 ausgeführten $^{41}$ zweiten Turmobergeschosse in ebensolche Fenstergruppen aufgelöst. Unmittelbar vorhergehend hatte die Straßburger Münsterbauhütte diese Konfiguration an der 1349 geweihten Katharinenkapelle erprobt. ${ }^{42}$ In Regensburg übernahm man das Motiv, brachte es in eine gestaffelte Anordnung und bewirkte damit eine ausgeprägte Vertikalisierung der Gliederung, die folgerichtig das Aufwärtsstreben der Architektur aufnimmt. ${ }^{43}$

In diesem Zusammenhang ist Achim Hubels Beobachtung bemerkenswert, wonach für den Skulpturenschmuck des Hauptportaltympanons und der Archivolten eine Kenntnis der Pariser Hofkunst vorauszusetzen ist. An den Regensburger Steinbildwerken überlagern sich nämlich eine ältere Prägung durch die Prager und Ulmer Kunst mit jüngeren Einflüssen aus dem zu dieser Zeit im Westen tonangebenden Kulturzentrum. ${ }^{44}$ Dabei handelt es sich offenbar um das Ergebnis familiärer Beziehungen des Regensburger Bischofs zum Pariser Königshof - Johann I. von Moosburg war ein Halbbruder der französischen Königin Isabeau de Bavière (reg. 1385-1422). ${ }^{45}$ Die klassisch-strengen Architekturformen im Stil der französischen Hochgotik finden damit eine Parallele im figürlichen Schmuck des Hauptportals. Im Bereich des Motivischen wurden weitere individuelle Lösungen formuliert. Sie sind ebenfalls am Fensterfeld der Turmhalle zu exemplifizieren (Abb. 15). Vor den schmalen Wandstreifen zwischen den drei Fenstern sowie an den Ecken und Flanken der Turmstrebepfeiler sind hier Konsolen und Baldachine zur Aufnahme von Figuren vorgesehen; ein Band dicht gereihter, letztlich jedoch unbesetzt gebliebener Figurenstandorte legt sich auf Höhe der Bogenfelder der beiden zweibahnigen Flankenfenster um das ganze Geschoss. Allein das westseitige Wandfeld sowie die beiden angrenzenden Pfeiler bieten Platz für vierzehn 


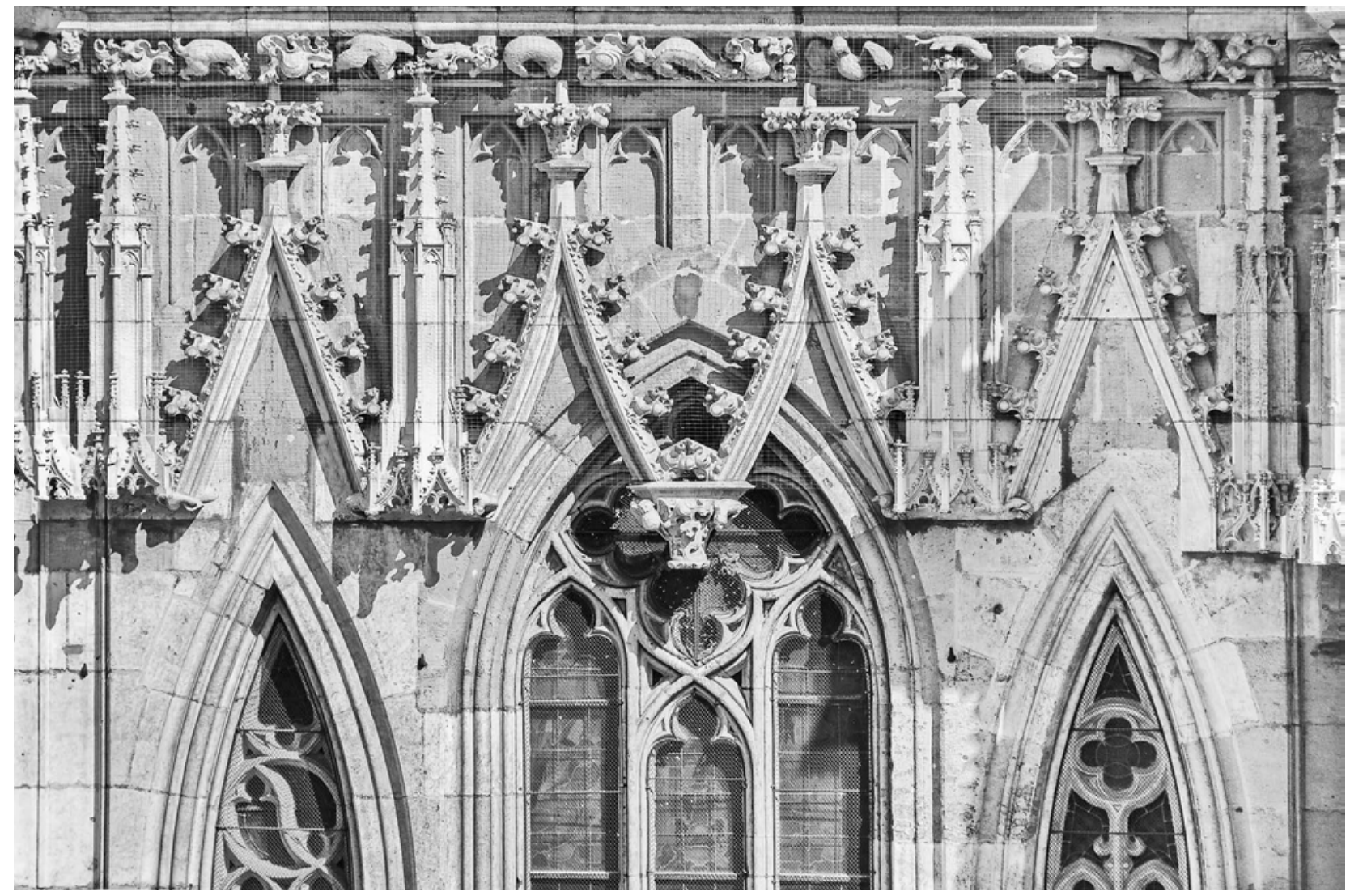

Abb. 20 Regensburg, Dom, Nordturm, Westseite, Erdgeschoss, Fensterzone, Baldachin-Wimperg-Kette (Foto: M. T. Huber, 2009)

Standfiguren. Dazu treten sieben weitere leere Standplätze auf der Nordseite. Da sich das Gliederungssystem dem Betrachter im Sinne des gotischen Formenkanons erst aus dem Zusammenspiel von Konsole, Figur und Baldachin erschließt, bedeutet die durch das Fehlen der Figuren verursachte Lücke auch eine Beeinträchtigung für die ursprünglich intendierte Wirkung der Architektur.

Die vier in der westseitigen Wandfläche sitzenden Baldachine werden durch zwischengeschaltete Wimperge zu einer zusammenhängenden Einheit verkettet, die das Bogenfeld des Mittelfensters vorhangartig überschneidet, sodass die reich skulptierte Hängekonsole axial unter dem Spitzbogenscheitel zu liegen kommt. Eine Vorstufe zu dieser Anordnung stellen die Fenstermotive dar, die auf dem Einturmriss - der zweiten aus den Beständen der Regensburger Dombauhütte überlieferten mittelalterlichen Planzeichnung ${ }^{46}$ - für die Position über den westlichen Nebenportalen vorgesehen sind (Abb. 21).

Auf dem gegen $1400 \mathrm{zu}$ datierenden Entwurf ist über ein großes Einzelfenster eine dreiteilige Arkatur gelegt. Aus diesem Entwurf scheinen die der Flächengliederung zugrundeliegende Dreizahl sowie das Überschneidungsmotiv angeregt. ${ }^{47}$ In der Einbindung der Figurenstandplätze zwischen den Fensteröffnungen entwickelt die ausgeführte Lösung den Einturmriss weiter. Die Komplexität ist sichtlich gesteigert, bilden doch nun Gruppenfenster, Figurenstandorte und Wimpergkette ein organisches Ganzes. Auch das durch die Überlagerung der drei Fenster mit der vierteiligen Ordnung des Wimpergvorhangs erzeugte Inversionsmotiv weist nochmals über den Entwurf hinaus.

Der Meister mit diesem individuellen Zugriff dürfte identisch sein mit jenem "Venczla dem tummaister «, dem das Reichsstift Obermünster 1415 ein Haus und eine Hofstatt in der Regensburger Malergasse zu Lehen gab. ${ }^{48}$ Carl Woldemar Neumann gelang bereits 1886 der Nachweis, dass es sich bei diesem Meister Venczla oder Wenczlaw um das erste in der Reichsstadt nachweisbare Mitglied der Baumeisterfamilie Roriczer handelte. ${ }^{49}$ Schon am Jakobustag des Jahres 1419 wird das Anwesen seiner Frau »Elspeten der tummaisterin « mit ihren beiden minderjährigen Söhnen Venczla und Conrad übertragen. ${ }^{50}$ 


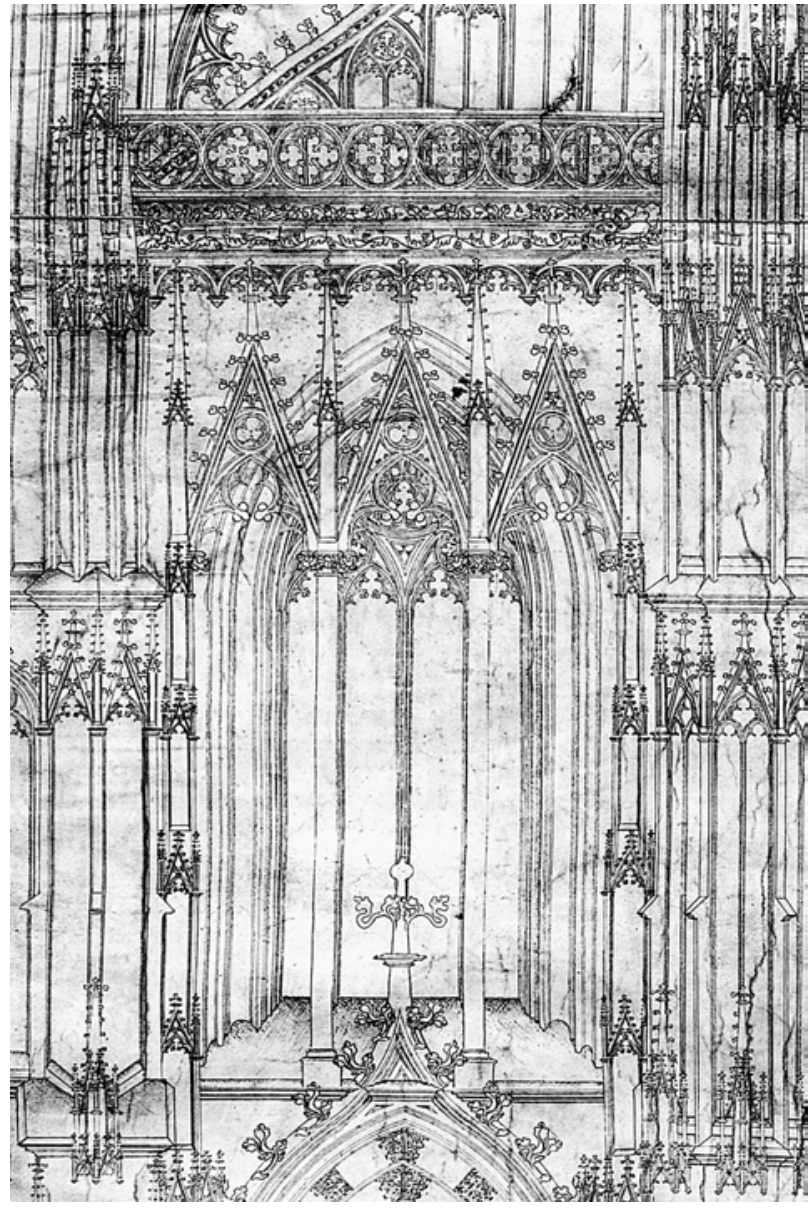

Abb. 21 Regensburg, Einturmriss, Detail Turmhallenfenster (Foto: Kunstsammlungen des Bistums Regensburg)

Nicht lange vor jenem 25. Juli muss also Wenczlaw Roriczer verstorben sein. Sein Nachfolger im Dombaumeisteramt wurde Andre Engel, der Roriczers Stil ohne grundlegende Brüche bis in die Jahrhundertmitte weiterführte. ${ }^{51}$

Nach einer begründeten These Viktor Kotrbas wird heute von einer Herkunft Roriczers aus dem mittelböhmischen Kolin ausgegangen. ${ }^{52}$ Auf der Baustelle der Koliner Bartholomäuskirche, deren Einfluss auf Regensburg bereits an den gegen 1380 ausgeführten Schallfenstern beobachtet werden konnte (s. o.), wäre Wenczlaw demzufolge erstmals mit der Baukunst Peter Parlers in Kontakt gekommen. Dass er zudem das Prager Baugeschehen gekannt hatte, erschiene bei dieser Herkunft und Ausbildung geradezu obligatorisch. Seine auffallende Affinität $\mathrm{zu}$ hochgotischen Formen mag dagegen aus einer Begegnung mit den Kathedralen im Westen des Reichs und in Frankreich resultieren. Dies passt bestens zu einer von
Achim Hubel angenommenen Weiterbildungsreise nach Paris zu Beginn seiner Regensburger Tätigkeit. Noch tiefere Spuren hinterließ diese Erfahrung in seinem bildhauerischen Schaffen. ${ }^{53}$

Die damit in der Regensburger Domarchitektur etablierte böhmische Einfärbung tragen, neben Andre Engel, Wenczlaws Sohn Conrad sowie seine Enkel Matthäus und Wolfgang als Dombaumeister weiter. Dieser »Grundschlag" wird im Laufe des 15. Jahrhunderts mehr und mehr von neu entwickelten Formvarianten überlagert, er bleibt aber stets spürbar. Noch 87 Jahre nach dem Tod Peter Parlers und 67 Jahre nach dem seines Großvaters bringt Matthäus Roriczer seine besondere Verehrung für die Meister des Parler-Kreises zum Ausdruck, wenn er sich im vielfach zitierten Vorwort seines 1486 erschienenen "puechlen der fialen gerechtikait» auf die Autorität der »Junker von Prag« beruft. ${ }^{54}$

\section{Literatur}

Adler, Friedrich: Der Dom zu Regensburg. Eine baugeschichtliche Studie. In: Deutsche Bauzeitung 9 (1875), 131, $141 \mathrm{f}$., 151-153, 171-173, 175, $181 \mathrm{f} ., 191-193,201-203,211-214$, $221 \mathrm{f}$.

Angerer, Martin/Wanderwitz, Heinrich (Hgg.): Regensburg im Mittelalter 1. Beiträge zur Stadtgeschichte vom frühen Mittelalter bis zum Beginn der Neuzeit. Regensburg 1995.

[Ausst.-Kat. New York 2005]: Ausst.-Kat. Prague - the Crown of Bohemian Kingdom 1347-1437. New York, The Metropolitan Museum of Art, 20. 9.2005-3.1.2006. Hg. von Barbara Drake Boehm und Jiří Fajt. New York 2005.

[Ausst.-Kat. Prag 2006]: Ausst.-Kat. Karl IV. - Kaiser von Gottes Gnaden. Kunst und Repräsentation des Hauses Luxemburg 1310-1437. Hg. von Jiří FAJT unter Mitwirkung von Markus Hörsch und Andrea LANGER. Prager Burg, 15.2.-21.5.2006. München/Berlin 2006; tschechische Ausgabe Praha 2006.

[Ausst.-Kat. Prag/Nürnberg 2016]: Ausst.-Kat. Kaiser Karl IV. 1316-2016. Erste Bayerisch-Tschechische Landesausstellung. Hg. von Jiří FAjT und Markus HöRsch. Prag, Nationalgalerie, 15.5.-25.9.2016, Nürnberg, Germanisches Nationalmuseum, 20.10.2016- 5.3.2017. Praha 2016; tschechische Ausgabe 2017.

[Ausst.-Kat. Regensburg 1990]: Ausst.-Kat. Der Dom zu Regensburg. Ausgrabung, Restaurierung, Forschung. Ausstellung anlässlich der Beendigung der Innenrestaurierung des Regensburger Domes, 1984-1988. Hg. von Peter MorsBACH. 3. Aufl. München u. a. 1990 (Kataloge und Schriften der Kunstsammlungen des Bistums Regensburg 8). 
Bachmann, Erich: Zu einer Analyse des Prager Veitsdoms. In: Swoboda/Bachmann 1939, 26-67.

Bauer, Karoline/KNoch, Peter: Der Triforiumsgrundriß im Langhaus und das südliche Turmjoch mit zugehöriger Westwandbaufuge des Regensburger Domes. Abschlussarbeit Bauforschung/Denkmalpflege (Msc.) Bamberg 1987.

Baumüller, Barbara: Der Chor des Veitsdomes in Prag. Die Königskirche Karls IV. Strukturanalyse mit Untersuchung der baukünstlerischen und historischen Zusammenhänge. Berlin 1994.

Behling, Lottlisa: Gestalt und Geschichte des Maßwerks. Das ungegenständliche Bauornament der Gotik. Diss. Berlin 1937. Halle a. d. Saale 1944.

BINDING, Günther: Maßwerk. Darmstadt 1989.

Böker, Johann Josef: Architektur der Gotik. Bestandskatalog der weltgrößten Sammlung an gotischen Baurissen (Legat Franz Jäger) im Kupferstichkabinett der Akademie der bildenden Künste Wien. Salzburg/München 2005.

BöKer, Johann Josef u. a.: Architektur der Gotik. Ulm und Donauraum. Ein Bestandskatalog der mittelalterlichen Architekturzeichnungen aus Ulm, Schwaben und dem Donaugebiet. Salzburg u. a. 2011.

Bork, Robert Odell: The Geometry of Creation. Architectural Drawing and the Dynamics of Gothic Design. Farnham u.a. 2011.

Brommer, Hermann u.a.: Das Konstanzer Münster. 2. Aufl. Regensburg 2005 (Große Kunstführer 163).

Bureš, Jaroslav: Peter Parlers Chor in Kolin und seine Beziehung zur Prager Bauhütte im Lichte der schriftlichen Quellen. In: Gesta 28 (1989), H. 2, 136-146.

Cassanelli, Roberto (Hg.): Die Baukunst im Mittelalter. Düsseldorf u.a. 1995.

Сноте̌воR, Petr: Der große Turm des St. Veitsdoms. Erkenntnisse, die bei den Instandsetzungsarbeiten im Jahr 2000 gewonnen wurden. In: Umění 49 (2001), 262-270.

Сноте̌вor, Petr: Jižní předsíň katedrály sv. Víta. Hledání původní podoby [Die südliche Vorhalle der Kathedrale St. Veit. Auf der Suche nach ihrer ursprünglichen Form]. In: DÁŇova/MeZihoráková/Prix 2012, 144-156, 677f. Mit englischem Resümee: The Southern Entrance Hall of St. Vitus' Cathedral. In Search of its Original Form, $156 \mathrm{f}$.

Codreanu-Windauer, Silvia/Schnieringer, Karl: Die Ausgrabungen im Regensburger Dom. In: Ausst.-Kat. Regensburg 1990, 120-131.

DÁŇova, Helena/MezıHorákovÁ, Klára/Prix, Dalibor (Hgg.): Artem ad vitam. Kniha k poctě Ivo Hlobila [Artem ad vitam. Ein Buch zu Ehren von Ivo Hlobil]. Praha 2012.

Dehio, Georg/Bezold, Gustav von: Die kirchliche Baukunst des Abendlandes, Bd. 2. Stuttgart 1901.

Fuchs, Friedrich: Das Hauptportal des Regensburger Domes.
Portal, Vorhalle, Skulptur. München u. a. 1990 (Kataloge und Schriften der Kunstsammlungen des Bistums Regensburg 9).

Fuchs, Friedrich: Die Steinmetzzeichen am Regensburger Dom. In: Hubel/Schuller 2013, 413-458.

GALL, Günter: Zur Baugeschichte des Regensburger Domes. In: Zeitschrift für Kunstgeschichte 17 (1954), 61-78.

Geldner, Ferdinand (Hg.): Roriczer, Matthäus: Das Büchlein von der Fialen Gerechtigkeit. Faksimile der Originalausgabe Regensburg 1486. Die Geometria Deutsch. Faksimile der Originalausgabe Regensburg um 1487/88. Hürtgenwald 1999.

GRUBER, Johann: Urkunden und andere Quellen zum Dombau (in Auswahl). In: Hubel/SChuller 2013, 1-28.

Hausberger, Karl: Geschichte des Bistums Regensburg 1. Mittelalter und frühe Neuzeit. Regensburg 1989.

Helten, Leonhard: Mittelalterliches Maßwerk. Entstehung, Syntax, Topologie. Teilw. zugl. Habil.-Schr. Halle-Wittenberg 2001. Berlin 2006.

HLedíková, Zdeňka: Die Prager Erzbischöfe als ständige päpstliche Legaten. Ein Beitrag zur Kirchenpolitik Karls IV. In: SCHWAIgER/STABER 1972, 221-256.

Hubel, Achim: Der Regensburger Domschatz. München u.a. 1976 (Kirchliche Schatzkammern und Museen 1).

Hubel, Achim: Kunstgeschichtliche Fragen zum Portal. Ikonographie und Stil. In: SchNeider 2001, 23-32.

Hubel, Achim: Die Plastik des Regensburger Doms und ihr Verhältnis zur Architektur. In: Hubel/SCHUller 2014, 205-386.

Hubel, Achim/Kurmann, Peter: Der Regensburger Dom. Architektur - Plastik - Ausstattung - Glasfenster. München/ Zürich 1989 (Große Kunstführer 165).

Hubel, Achim/Schuller, Manfred: Der Dom zu Regensburg. Vom Bauen und Gestalten einer gotischen Kathedrale. Unter Mitarbeit von Friedrich Fuchs und Renate KRooS. Regensburg 1995.

Hubel, Achim/Schuller, Manfred (Hgg.): Der Dom zu Regensburg. Tafeln. Regensburg 2010 (Die Kunstdenkmäler von Bayern N. F. 7, Teilbd. 5).

Hubel, Achim/Schuller, Manfred (Hgg.): Der Dom zu Regensburg. Textband 1. Regensburg 2013 (Die Kunstdenkmäler von Bayern N. F. 7, Teilbd. 1, Textbd. 1).

Hubel, Achim/Schuller, Manfred (Hgg.): Der Dom zu Regensburg. Textbd. 2. Regensburg 2014 (Die Kunstdenkmäler von Bayern N. F. 7, Teilbd. 2, Textbd. 2).

Hubel, Achim/Schuller, Manfred (Hgg.): Der Dom zu Regensburg. Textband 3. Regensburg 2016 (Die Kunstdenkmäler von Bayern N. F. 7, Teilbd. 3, Textbd. 3).

Huber, Markus T.: Die Westfassade des Regensburger Doms. Konvention und Innovation in einem spätmittelalterlichen 
Hüttenbetrieb. Regensburg 2014 (Regensburger Domstiftung 4).

Jarošová, Markéta/Kuthan, Jiř́í/Scholz, Stefan (Hgg.): Prag und die großen Kulturzentren Europas in der Zeit der Luxemburger (1310-1437). Internationale Konferenz aus Anlass des 660. Jubiläums der Gründung der Karlsuniversität in Prag, 31. 3.- 5. 4.2008. Praha 2008.

KLetZl, Otto: Die Junker von Prag in Straßburg. Frankfurt/M. 1936.

KNAPP, Ulrich: Münster Salem. 2. Aufl. Regensburg 2003 (Kunstführer 875).

KNORR, Walburga/Mayer, Werner: Die Inschriften der Stadt Regensburg, Bd. 2. Der Dom St. Peter. 1. Teil: Bis 1500. Wiesbaden 2008 (Die Deutschen Inschriften 74).

Koepf, Hans: Die gotischen Planrisse der Ulmer Sammlungen. Ulm 1977 (Forschungen zur Geschichte der Stadt Ulm 18).

Kотrвa, Viktor: Okud pocházeli Roritzerové? Přispěvek k otázce pozdnĕgotického stavitelského rodu. In: Umění 11 (1963), H. 1, 65-69. Mit deutschem Resümee: Über die Herkunft der Roritzer. Ein Beitrag zur Geschichte einer Meisterfamilie der Spätgotik.

Kugler, Franz: Geschichte der gothischen Baukunst. Stuttgart 1859 (Geschichte der Baukunst 3).

Kurmann, Peter: Der Regensburger Dom. Französische Hochgotik inmitten der Freien Reichsstadt. In: ANGERER/WANDERWITZ 1995, 387-400.

Kurmann, Peter: Stilgeschichte der Architektur bis 1340. Der Regensburger Dom und sein Verhältnis zur französischen Rayonnant-Gotik. In: Hubel/Schuller 2014, 93-132.

Kuthan, Jiří: Die Herrscher aus dem Haus der Luxemburger. Reichskirchenhierarchie, Reichsfürsten, Reichsstädte. In: JAROŠOvá/Kuthan/SCHOLZ 2008, 27-94.

Leidinger, Georg (Hg.): Andreas von Regensburg. Sämtliche Werke. München 1903 (Quellen und Erörterungen zur bayerischen und deutschen Geschichte N.F. 1)

LiEss, Reinhard: Die Entstehung des Strassburger Risses mit dem Glockengeschoss und seine Stellung im Gesamtbild der Münsterfassade. In: Münchner Jahrbuch der bildenden Kunst 3. F. 37 (1986), 33-112.

MÁDL, Karel B.: Topographie der historischen und Kunst-Denkmale im politischen Bezirk Kolin. Prag 1898 (Topographie der historischen und Kunst-Denkmale im Königreiche Böhmen 1).

Morsbach, Peter: Die Erbauer des Doms. Die Geschichte der Regensburger Dommeisterfamilie Roriczer-Engel. Regensburg 2009.

Müns, Heike/Weber, Matthias (Hgg.): »Durst nach Erkenntnis ...«. Forschungen zur Kultur und Geschichte der Deutschen im östlichen Europa. Zwei Jahrzehnte Immanuel-KantStipendium. München 2007 (Schriften des Bundesinstituts für Kultur und Geschichte der Deutschen im östlichen Europa 29).

Neumann, Carl Woldemar: Neue Nachträge zur Monographie »Die drei Dombaumeister Roritzer und ihr Wohnhaus in Regensburg«. In: Verhandlungen des Historischen Vereins von Oberpfalz und Regensburg 40 (1886), 233-252.

Neuwirth, Joseph: Peter Parler von Gmünd, Dombaumeister in Prag, und seine Familie. Ein Beitrag zur deutsch-österreichischen Künstlergeschichte. Prag 1891.

Nussbaum, Norbert: Deutsche Kirchenbaukunst der Gotik. Entwicklung und Bauformen. Köln 1985.

PaAsche-Kassian, Sabine: Beobachtungen zum Regensburger Domchor. In: Beiträge zur Geschichte des Bistums Regensburg 17 (1983), 39-84.

Rosemann, Heinz Rudolf: Die zwei Entwürfe im Regensburger Domschatz. In: Münchner Jahrbuch der bildenden Kunst N.F. 1. (1924), 230-262.

Rosemann, Heinz Rudolf: Entstehungszeit und Schulzusammenhänge der Regensburger Turmpläne. In: Kunstchronik 15 (1962), 259-261.

Schmidt, Rolf: Hans Engel von Köln der Parlierer und sein Bruder Andreas der Dommeister zu Regensburg. In: Verhandlungen des Historischen Vereins für Oberpfalz und Regensburg 112 (1972), 131-156.

Schneider, Hans Hermann (Hg.): Turm - Fassade - Portal. Colloquium zur Bauforschung, Kunstwissenschaft und Denkmalpflege an den Domen von Wien, Prag und Regensburg. Tagung Regensburg, September 2000. Regensburg 2001.

SCHOCK-Werner, Barbara: Die Münsterbauhütte in Strassburg. Unser Lieben Frauen Werk - Cuvre Notre-Dame. In: CASSANELli 1995, 221-248.

Schuegraf, Joseph Rudolph: Geschichte des Domes von Regensburg und der dazu gehörigen Gebäude. 1. Theil. In: Verhandlungen des Historischen Vereins von Oberpfalz und Regensburg 11 (1847), 1-266.

SChuller, Manfred: Die Baugeschichte des Doms 1270-1500. Ein Überblick. In: Hubel/SCHUller 2013, 363-380.

Schurr, Marc Carel: Die Baukunst Peter Parlers. Der Prager Veitsdom, das Heiligkreuzmünster in Schwäbisch Gmünd und die Bartholomäuskirche zu Kolin im Spannungsfeld von Kunst und Geschichte. Ostfildern 2003.

SChurr, Marc Carel: Die »Junker von Prag« und die mitteleuropäische Spätgotik. In: MüNs/WEBER 2007, 225-246.

Schwaiger, Georg/Staber, Josef (Hgg.): Regensburg und Böhmen. Festschrift zur Tausendjahrfeier des Regierungsantrittes Bischof Wolfgangs von Regensburg und der Errichtung des Bistums Prag. Regensburg 1972 (Beiträge zur Geschichte des Bistums Regensburg 6).

Steinmann, Marc: Die Westfassade des Kölner Domes. Der 
mittelalterliche Fassadenplan F. Köln 2003 (Forschungen zum Kölner Dom 1).

Stockhausen, Hans-Adalbert von: Der erste Entwurf zum Straßburger Glockengeschoss und seine künstlerischen Grundlagen. In: Marburger Jahrbuch für Kunstwissenschaft 11/12 (1941), 579-618.

SwоводA, Karl Maria: Peter Parler. Der Baukünstler und Bildhauer. Wien 1943.

Swoboda, Karl Maria/Bachmann, Erich: Studien zu Peter Parler. Brünn/Leipzig 1939 (Beiträge zur Geschichte der Kunst im Sudeten- und Karpathenraum 2).

Thiel, Matthias: Die Urkunden des Kollegiatstifts St. Johann in Regensburg bis zum Jahre 1400. München 1975 (Quellen und Erörterungen zur bayerischen Geschichte N. F. 28).

ZAHN, Karl: Die Westfassade und das Westportal des Domes in Regensburg und ihre Beziehungen zu den zwei Entwürfen im Domschatz. In: Münchner Jahrbuch der bildenden Kunst N. F. 6. (1929), 365-401.

ZAHN, Karl: Zur Baugeschichte des Domes in Regensburg bis zur Mitte des 14. Jahrhunderts. In: Wiener Jahrbuch für Kunstgeschichte 7 (21) (1930), 34-44.

\section{Anmerkungen}

1 Zuletzt ausführlich dargestellt in kürzerer englischer Version in: Ausst.-Kat. New York 2005 sowie in umfassender Weise in deutscher bzw. tschechischer Sprache in: Ausst.-Kat. Prag 2006 und Ausst.-Kat. Prag/Nürnberg 2016.

2 Zur Baugeschichte zuletzt SCHULLER 2013.

3 Erstmals ausführlich dargestellt bei Schuegraf 1847, 71-89. Eine Zusammenstellung des entsprechenden Quellenmaterials bei Paasche-Kassian 1983, 45-51. - Gruber 2013, 1 f., Nr. 1-3.

4 Adler 1875, bes. 172 f., 211-213. - Dehio/Bezold 1901, $299 \mathrm{f}$. - Gall 1954, 70-76. - Hubel/Kurmann 1989, 31 f. - Hubel/ Schuller 1995, 25-28. - Kurmann 1995, 387, 390 f., 393-399. Kurmann 2014, 109-132.

5 Zahn 1930, 41. - Bauer/Knoch 1987, 4-7. - Codreanu-WindaUer/Schnieringer 1989, 90. - Hubel/Schuller 2010, Tafel 19. - SChUller 2013, 373.

6 Bauer/Knoch 1987, 8 f. - Hubel/Schuller 2010, Tafel 2of. SCHULLER 2013, 375 .

7 Hubel/Schuller 2010, Tafel 22. - Schuller 2013, 375.

8 HUBER 2014, 243-255, 340.

9 ZDEŇKA 1972, 227-229, 238-241, 247, 253. - HAUSBERgER 1989, 196. - FUCHS 1990, 13

$10 \mathrm{Zu}$ Peter Parler zuletzt grundlegend SChurr 2003.

11 Stockhausen 1941, 580, Abb. 1. - Nussbaum 1985, 71, Abb. 43. SCHOCK-Werner 1995, 236 f., Abb. 4.

12 Koepf 1977, $17 \mathrm{f}$.

13 Bachmann 1939, 35, 37. - Swoboda 1943, 2 f. - Schurr 2003, $125 \mathrm{f}$.
14 Bauinschrift auf der Nordseite des Chors zit. bei MádL 1898, 50. BUREš 1989, 145, Anm. 2. - SCHURR 2003, 89.

15 Bureš 1989, 136 f. - Siehe auch MádL 1898, 50.

16 Urkunde abgedruckt bei SChUegraf 1847, 119-122, 242-246. Thiel 1975, 422-428, Nr. 359. - Gruber 2013, 14-17, Nr. 89.

17 Gruber 2013, 17, Nr. 92.

$18 \mathrm{Zu}$ Johann I. von Moosburg KnorR/Mayer 2008, 92 f., Nr. 129, mit älterer Literatur.

19 Andreas Ratisbonensis: Chronica pontificum et imperatorum Romanorum. Abgedruckt bei LeIdinger 1903, 114. Unter Johann I. von Moosburg: "Hic posuit primum lapidem in fundamento turris kathedralis ecclesie versus septentrionem construende."

20 Siehe Gruber 2013, 17, 22-24, Nr. 9o f., 93, 104, 107, 111-114, 116, 120, 122 f. - Hubel/Schuller 2010, Taf. 23.

21 Zuletzt ausführlich behandelt bei BöKer u.a. 2011, 161-166, Kat.-Nr. 75, mit älterer Literatur.

22 Rosemann 1962, 260. - Hubel 1976, 295-298. - Hubel/SchulLER 1995, 119f. - Dass die Zeichnung in einzelnen Planungsabschnitten entstand, erkannten erstmals BöKER u. a. 2011, 164.

23 Nussbaum 1985, 176.

24 Behling 1944, 39. - Binding 1989, 321, Abb. 363. - SChurR 2003, 74 und Abb. 13. - BöKer 2005, 61-65.

25 Huber 2014, $268 \mathrm{f}$.

26 Neuwirth 1891, 31, 132, Urkunde Nr. 32.

27 Kuthan 2008, 34. - Siehe auch NeUwirth 1891, 24, 121, Urkunde Nr. 12.

28 HAusberger 1989, 182.

29 Erstmals publiziert bei KLetzl 1936, 106, Abb. 68.

30 FuCHS 2013, $437 \mathrm{f}$.

$31 \mathrm{Hubel} / \mathrm{S}$ Chuller 2010, Taf. $24 \mathrm{f}$. - SChuller 2013, 376-378.

32 Kugler 1859, 338. - Ebenso bei Rosemann 1924, 238. - Fuchs 1990, $23 \mathrm{f}$.

33 BÖKer 2005, 173. - SCHURR 2007, 236 f. - MorsbaCH 2009, 39 f.

34 Bei den schräg angeordneten Bogenöffnungen handelt es sich zwar um eine Rekonstruktion Kamil Hilberts, der sich dabei nicht auf Befunde stützen konnte (СНотЕ̌воR 2012, 156 f.), doch spricht vieles dafür, dass er die Intention Peter Parlers grundsätzlich richtig erkannte. Josef Mockers Alternativvorschlag beinhaltete dagegen ein breites, ungeteiltes Portal, vor das der Pfeiler mit den ihm entwachsenden Luftrippen als ein rein dekoratives Bauelement ohne funktionale Bedeutung gestellt war (ebd., 153, Abb. 13). Diese Konzeption erscheint für Peter Parler, der jedem Strukturelement eine sinnvolle Aufgabe zubilligte, jedoch fragwürdig, zumal das Spiel mit dem Herauslösen von Baugliedern aus ihrem ursprünglichen tektonischen Kontext wesentlicher Teil von Peter Parlers Handschrift ist. Als Beispiele seien die isoliert in den Wölbflächen sitzenden Schlusssteine des Hochchorgewölbes und die von ihren Kapitellen scheinbar herabgerutschten Konkavgiebel an den Turmstrebepfeilern genannt (BACHMANN 1939, 40, 54). Gegen den Vorschlag Mockers spricht ferner das Fehlen entsprechender Nachfolgebauten, die bei dem nachhaltigen Einfluss der Prager Domarchitektur geradezu zwingend zu erwarten wären.

35 Als frühe Beispiele seien die Chorfenster der Regiswindiskirche in Lauffen am Neckar (um 1300) oder das Südportal des Wormser Doms (vor 1298) angeführt. BINDiNg 1989, 219, Abb. 254, 260, Abb. 293.

36 Steinmann 2003, 159, Abb. 184. 
37 Binding 1989, 288, Abb. 324.

38 Helten 2006, 161-211. - Die reiche Auszierung von Kleeblattbögen und Vierpässen durch zusätzliche Nasungen ist auch auf dem etwa zeitgleich entstandenen Riss B zur Straßburger Münsterfassade zu beobachten. Die Kölner Form tritt dort in liegender Position auf. Steinmann 2003, 155, Abb. 175, 157, Abb. 181.

39 BAumüller 1994, 19. - Сноте̌Bor 2001, 265 f., Abb. 4 f. - SCHURR 2003, 69 .

40 Kletzl 1936, 126f. - Hubel/Schuller 1995, 112.

41 SChOCK-Werner 1995, 227.

42 Stockhausen 1941, 615. - Siehe Liess 1986, 84 f., Abb. 48 f.

$43 \mathrm{Zu}$ Beginn des 15. Jahrhunderts scheint das Straßburger Dreifenstermotiv auf die Gestaltung der Westfassade der Zisterzienserklosterkirche Salem gewirkt zu haben, die man nach einer längeren Bauunterbrechung von etwa 1400 bis um $1422 / 23$ (d) in retrospektiven Formen fertigstellte. KNAPP 2003, 8. - Etwas später wurden auch der Hochchor und die Südquerhausfront des Konstanzer Münsters mit der gestaffelten Dreifensterkombination versehen. Brommer u. a. $2005,35-37$.
44 Hubel 2001, 27-30. - Hubel 2014, 316-332.

45 Hubel 2001, 27-30.

46 Zuletzt bei BöKer u. a. 2011, 30-37, Kat.-Nr. 1, mit älterer Literatur. Bökers versuchsweise Zuschreibung des Planrisses an Heinrich Parler d. J. wirft Fragen, insbesondere nach den Zuschreibungskriterien und zur zeitlichen Einordnung, auf, die bislang noch nicht beantwortet werden konnten.

47 AdLer 1875, 193. - ZAHN 1929, 394f. - BORK 2011, 320.

48 Neumann 1886, 247. - Gruber 2013, 23, Nr. 117. - Vgl. auch SCHMidT 1972, 152, Anm. 94.

49 Neumann 1886, 247-249.

50 Neumann 1886, 247. - Gruber 2013, 24, Nr. 121.

51 HUber 2014, 293-307, $342 \mathrm{f}$.

52 Kotrba 1963, 69.

53 Hubel 2014, 325, 339

54 Geldner 1999, 46. 


\section{Eine Altarsetzung mit sichtbaren Folgen: Sigismund von Luxemburg Und das Dreikönigsportal der LiebFrauenkirche in Frankfurt/Main ${ }^{1}$}

Eine von Donald Ehresmann beschriebene Besonderheit am Dreikönigsportal der Liebfrauenkirche in Frankfurt ist seit ihrer Veröffentlichung 1968 nicht weiter beachtet worden. ${ }^{2}$ Und dies, obwohl sie die grundlegende Frage aufwirft, ob das Portal wirklich nur von einem Baumeister gefertigt wurde. Hinter dem Maßwerkvorhang des in der Südfront gelegenen und heute durch eine angebaute Taufkapelle verdeckten Portals (Abb. 1) befindet sich eine einläufige Archivolte mit vollständig ausgearbeiteten Baldachinen (Abb. 2).

Solche Formüberschneidungen gibt es als bewusstes Zierelement zum Beispiel am Freiburger Münster. Die fast vollständige Verdeckung der aufwändig gefertigten Baldachine in Frankfurt macht es aber unwahrscheinlich, dass dieser heutige Zustand von Anfang an geplant war. ${ }^{3}$

Von dieser Beobachtung ausgehend unterteilte Donald Ehresmann die Entstehung des Portals in zwei Bauphasen: In der ersten habe man ein Archivoltenportal mit schmalem Gewände und Baldachinen als einzigem Bauschmuck errichtet. Die Baldachine im Gewände und die der Archivolte seien sich zu ähnlich, als dass man sie unterschiedlichen Zeiten zurechnen könne. Das reliefierte Tympanon und der Maßwerkvorhang mit den Prophetenbildnissen in Medaillons bezögen sich auf ältere Vorlagen, wie man sie an der Pfarrkirche St. Valentin in Kiedrich und an St. Katharinen in Oppenheim finde, so Ehresmann. Diese Gestaltungselemente habe, angeblich in einer zweiten Phase nach 1430, ein anderer Baumeister hinzugefügt. ${ }^{4}$ Die 1940 von Adolf Feulner vorgenommene und bis heute wirkmächtige Zuschreibung des gesamten Dreikönigportals an den Frankfurter Baumeister Madern Gerthener stellte er mit diesem Argument in Abrede. ${ }^{5}$ Gerthener habe nur das für die angenommene Entstehungszeit um 1420 zeitgemäße Archivoltenportal zu verantworten. Ein Wiederaufleben älterer Portallösungen, wie es der überarbeitete Eingang zeigt, passte nicht in das Bild, das sich Ehresmann von Madern Gerthener gemacht hatte. Er sah ihn ausschließlich als Neuerer, als Erfinder von neuen Maßwerkformen und Gewölbelösungen. ${ }^{6}$

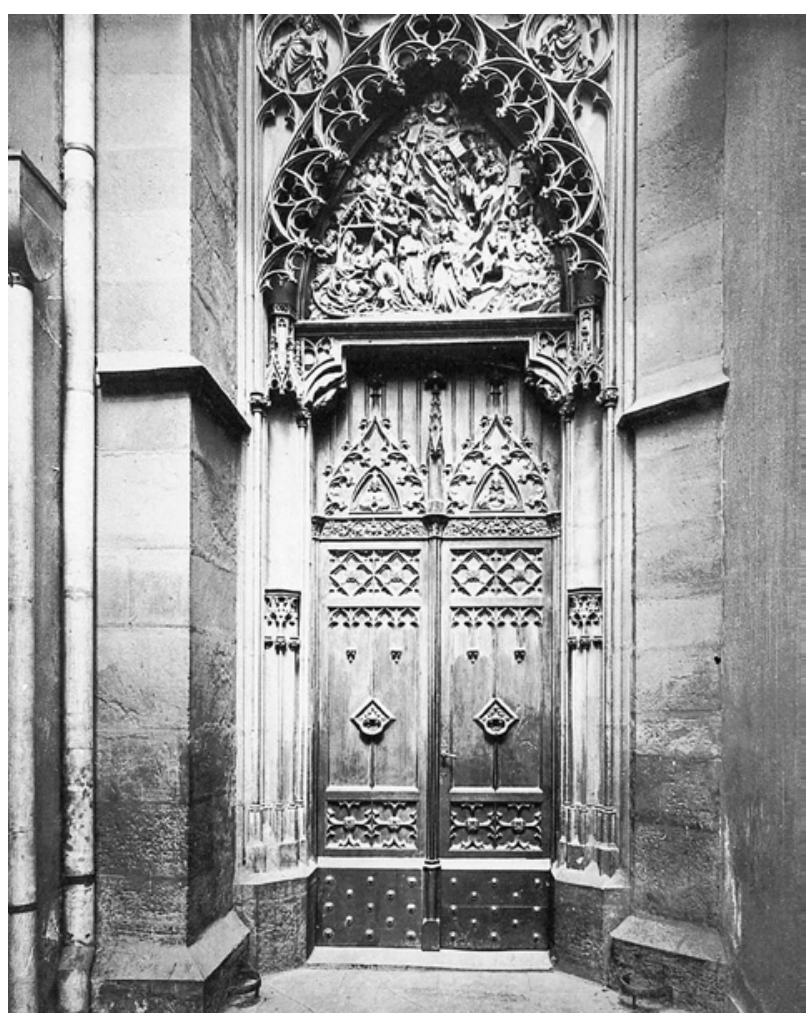

Abb. 1 Frankfurt/M., Liebfrauenkirche, Dreikönigsportal (Foto: Bildarchiv Foto Marburg)

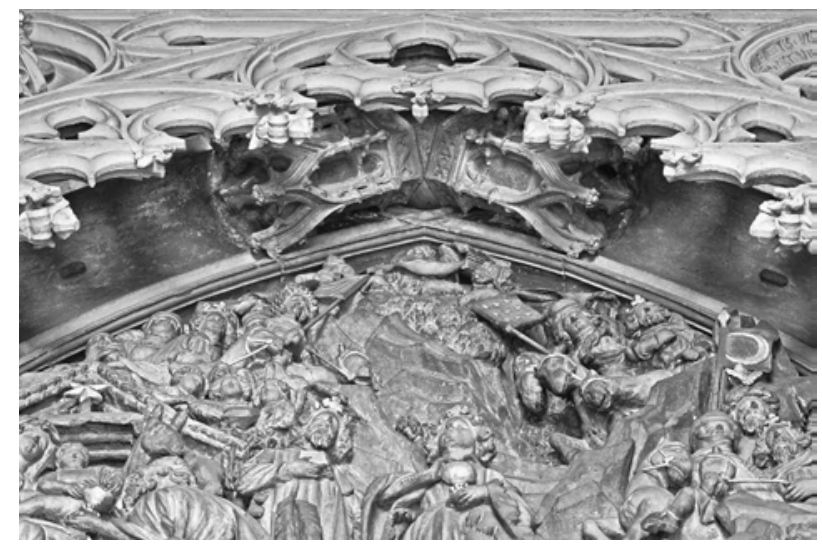

Abb. 2 Frankfurt/M., Liebfrauenkirche, Dreikönigsportal, Blick in die Archivolte, Detail (Foto: Sarah Weiselowski, Stuttgart) 

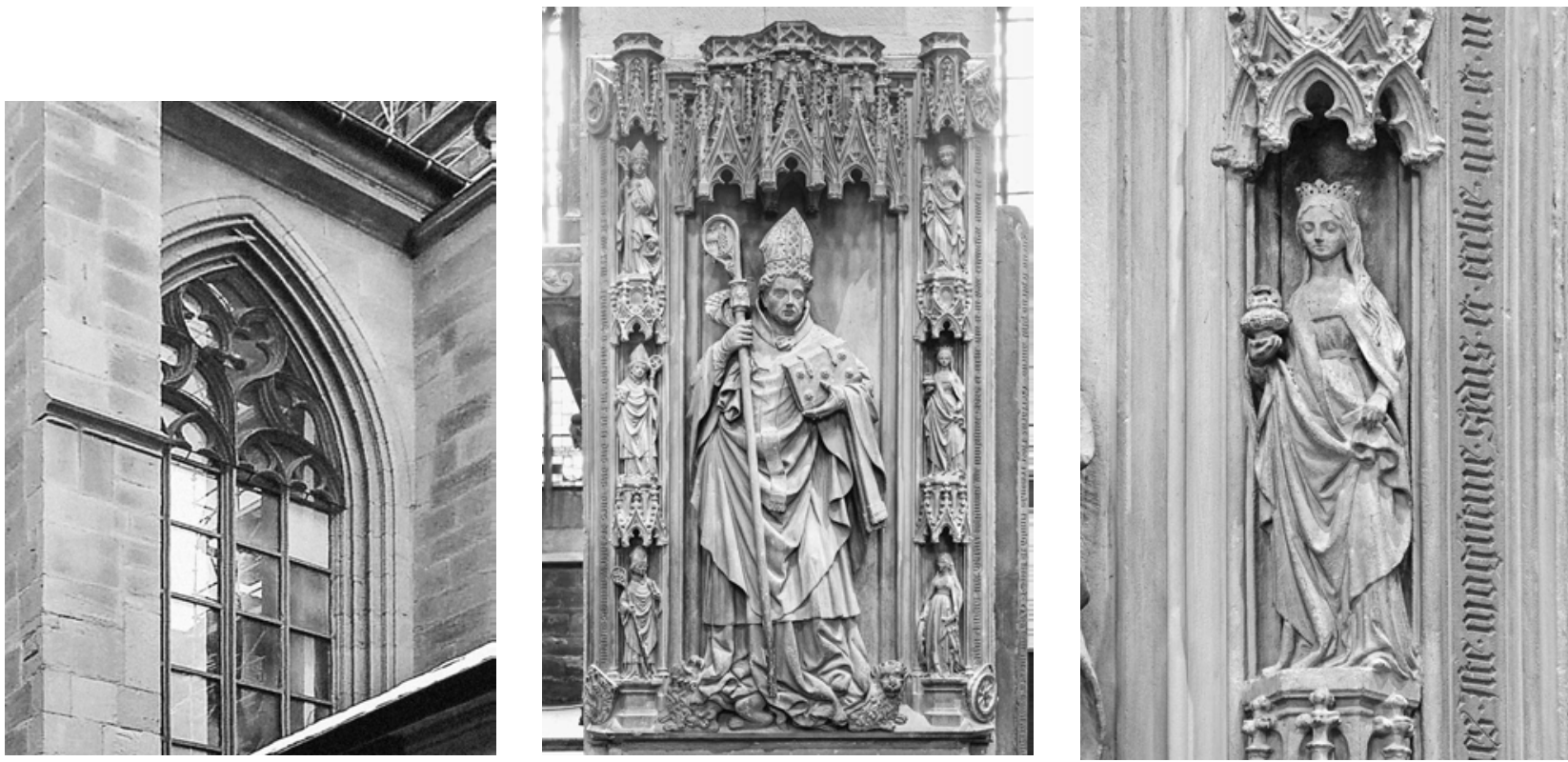

Abb. 3 Mainz, Dom, Nordseite, Marienkapelle (Foto: Helge Kuppe)

Abb. 4 Grabstein Bischof Johanns II. von Nassau (reg. 1397-1419), Gesamtansicht. Mainz, Dom (Foto: S. Weiselowski)

Abb. 5 Hl. Dorothea am Grabstein Bischof Johanns II. von Nassau. Mainz, Dom (Foto: S. Weiselowski)

So klar die von Ehresmann vorgenommene Unterscheidung auch zu sein scheint, so unmöglich ist sie am Original nachzuvollziehen. Er übersah, dass die Gewändebaldachine und der Anfang des Türsturzes beidseits aus je einem Stein bestehen. ${ }^{7}$ Einen Hinweis auf eine spätere Setzung der Baldachinsteine im Gewände findet man erst bei den darüber liegenden Anfangssteinen des Maßwerkvorhangs. Eine breite, mit Zement verschmierte Baunaht zwischen den Anfangssteinen des Maßwerkvorhangs und der Archivolte erlaubt die Vermutung, dass der Vorhang nachträglich eingefügt wurde. Daraus kann man folgern, dass auch seine vorbereitenden Untersteine nicht mehr die ursprünglich versetzten Steine sind. ${ }^{8}$ Dies lässt zwei Schlüsse zu: Entweder kopierte man bei der Überarbeitung des Archivoltenportals mutmaßliche Vorgängersteine im Gewände und übernahm die alten Formen in das überarbeitete Konzept. Oder es gab keinen großen zeitlichen Abstand zwischen den Planungen. Da derselbe Baumeister auch für die Änderungen sorgte, blieb die Einheitlichkeit der Formen gewahrt. Dass Letzteres zutrifft, soll ein Vergleich mit Werken im Mainzer Dom belegen.

Ein Rückgriff auf ältere Formen ist nicht nur bei der Architektur, sondern auch bei der Ikonografie des Reliefs festzustellen. Die Anbetungsszene nimmt Anleihen aus der Hofkunst Kaiser Karls IV. auf. Diese Übernahmen sind aber nicht negativ als das Wirken eines nachrangigen Künstlers zu werten, sondern stellen einen bewussten Verweis auf politische Ereignisse in der Zeit um 1414 dar.

\section{Die Mainzer Dombauhütte und das Dreikönigsportal in Frankfurt}

In Mainz, nicht in Frankfurt, findet man die größten Übereinstimmungen, sowohl was die Architektur und ihre Zierelemente, als auch was die skulpturalen Arbeiten anbelangt. ${ }^{9}$ Eine Besonderheit am Portal kann man direkt aus der Mainzer Bauhüttentradition herleiten: Das Überschneiden der Stabprofile in der Archivolte des Dreikönigportals bei ihrem Zusammentreffen im Bogenscheitel. Im Mainzer Dom wurde dieses Motiv bei den südlichen Seitenkapellen bereits im 14. Jahrhundert eingesetzt (Abb. 3) und fand dann wieder am Kreuzgang Verwendung.

Ein Hauptmerkmal der Architektur des Dreikönigsportals ist die ununterbrochene Fortführung von Linien, auch über die verschiedenen Schmuckelemente hinweg. Beginnend bei dem abgetreppten Sockel findet sich ein emporstrebender Linienverlauf, der sich über die Stäbe des Gewändes fortsetzt, an den floralen Kapitellen nicht endet, sondern am Baldachin vorbei weiterläuft und erst 


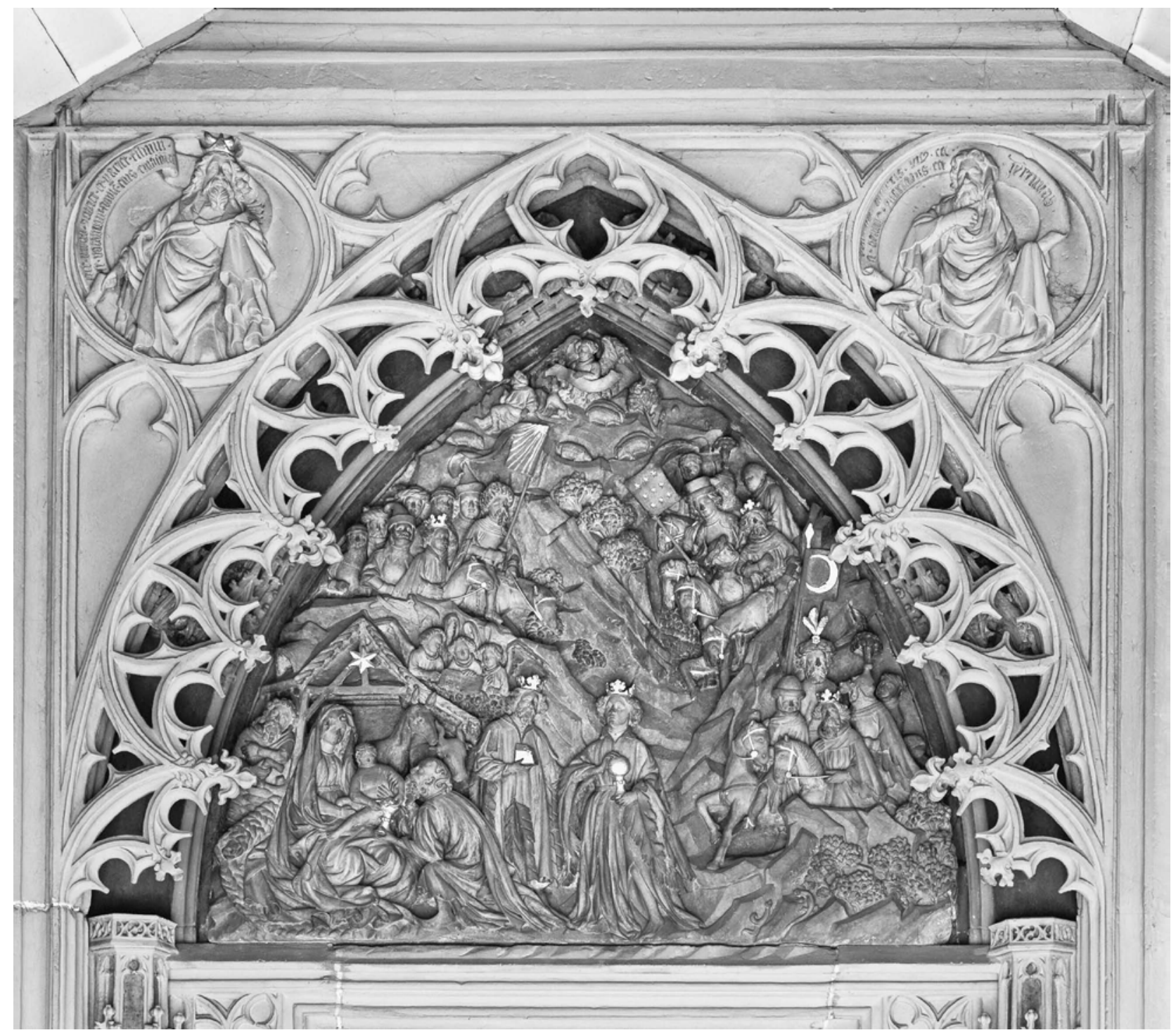

Abb. 6 Frankfurt/M., Liebfrauenkirche, Dreikönigsportal, Tympanon (Foto: S. Weiselowski)

am oberen Ende des Maßwerkvorhangs durch einen horizontalen Stab überschnitten wird. Dieses schon auf das Astwerk vorausweisende Motiv und die verbindende Linienführung wiederholen sich am Grabstein Johanns II. von Nassau im Mainzer Dom (Abb. 4, 5).

Die am unteren Ende des Steins einsetzenden Stäbe setzen sich über den großen Ehrenhimmel des Erzbischofs hinaus fort bis zum oberen Rand des Steins. Dort überschneiden sie sich mit einem horizontal verlaufenden Stab.

Die Ausführung des Maßwerks am Dreikönigsportal macht deutlich, dass es sich um Zierformen und nicht um tragende Bauelemente handelt. Die schmalen äußeren
Dienste müssen den mächtigen Maßwerkvorhang vorbereiten. Durch dieses Überspielen der Lasten bekommt die Zierarchitektur eine Leichtigkeit, fast etwas Schwebendes, das sie als zweites Merkmal, neben der durchgehenden Verbundenheit, kennzeichnet. Am Grabstein sind die den großen Baldachin tragenden Stäbe im Verhältnis viel zu schmal, um den Himmel über der Erzbischofsfigur wirklich abzustützen. $\mathrm{Zu}$ seinen Seiten ragen die kleinen Baldachine über den Grabstein hinaus. Es ist ein Überspielen der durch die Großform gesetzten Grenze. Am Dreikönigsportal findet man diese »Grenzverletzung « bei den Baldachinen im Gewände: Sie enden nicht am Türsturz, sondern ragen bis in die Archivolte hinein. 


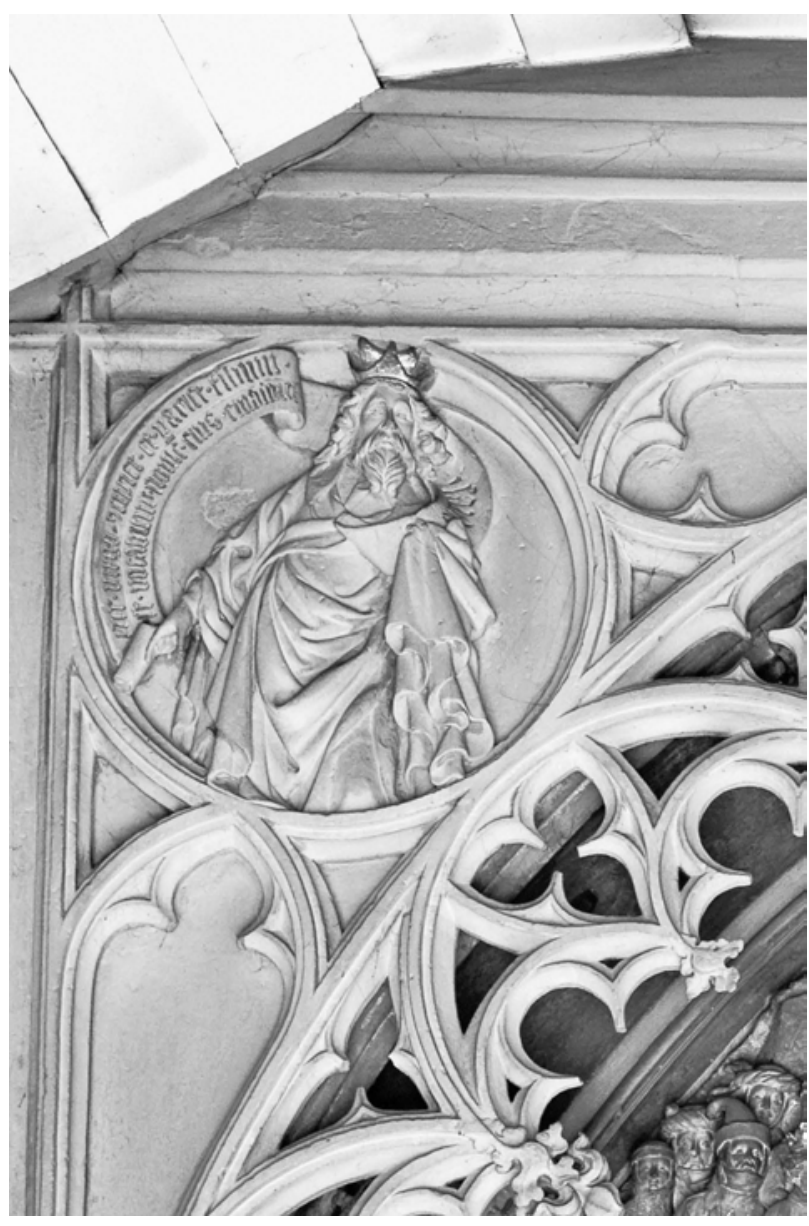

Abb. 7 Prophet Jesaja. Frankfurt/M., Liebfrauenkirche, Dreikönigsportal (Foto: S. Weiselowski)

Diese Beobachtung allgemeiner konzeptioneller Übereinstimmungen wird durch die Ausführung der kleinen Baldachine bestätigt. Die Verdachungen an den Seiten des Grabsteins begegnen in der Archivolte am Dreikönigsportal wieder. ${ }^{10}$ Die Baldachine im Gewände des Dreikönigsportals heben sich in ihrer Gestaltung nur dadurch ab, dass sie die Mainzer Vorlagen neu zusammensetzen. Verdrehte Wimperge, wie sie am rechten Baldachin zu sehen sind, sieht man bei den mittleren Baldachinen des Grabsteins; den hohen Turm mit dem aufgelegten Fenstermaßwerk findet man am oberen Ende des Steins vorgebildet. Der Maßwerkvorhang des Dreikönigportals schließt sich eng an die Mainzer Werke an und übernimmt deren Gestaltungsprinzipien. Das Dreikönigsportal ist keine Kopie der Mainzer Werke, sondern die Variation einer elaborierten und als eigener Stil fassbaren Handschrift der Mainzer Bauhütte. ${ }^{11}$

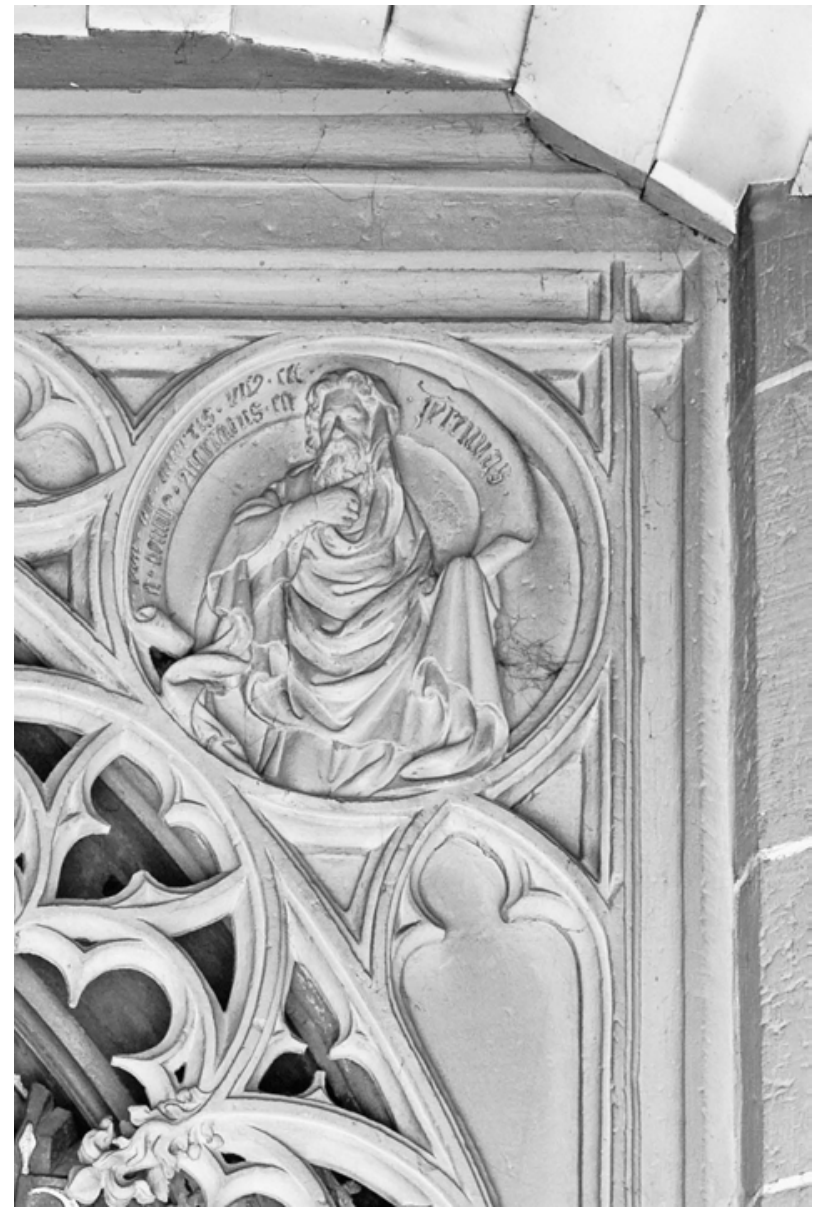

Abb. 8 Prophet Jeremia. Frankfurt/M., Liebfrauenkirche, Dreikönigsportal (Foto: S. Weiselowski)

\section{Das Kunstzentrum Mainz und die Skulptur am Dreikönigsportal}

Das verbindende Prinzip, das sich schon über die Einzelformen der Architektur hinwegsetzte, macht auch an der Gattungsgrenze nicht halt - allerdings mit einer anderen Wirkung. Das Überspielen bei der Architektur betont das pflanzlich-organische Moment der Zierformen. Beim Aufheben der Grenze zwischen skulpturalem Werk und Zierelement wird die Scheidewand zwischen Bildraum und Außenwelt entfernt. Die Bildwerke sind nicht mehr in ihre Rahmen gesperrt, sondern ragen in die Wirklichkeit des Betrachters hinein. Beim Dreikönigstympanon verschwimmt diese Grenze zwischen Rahmen und Tympanon am Türsturz, der die Gesteinsformation des Reliefs aufnimmt (Abb. 6). 


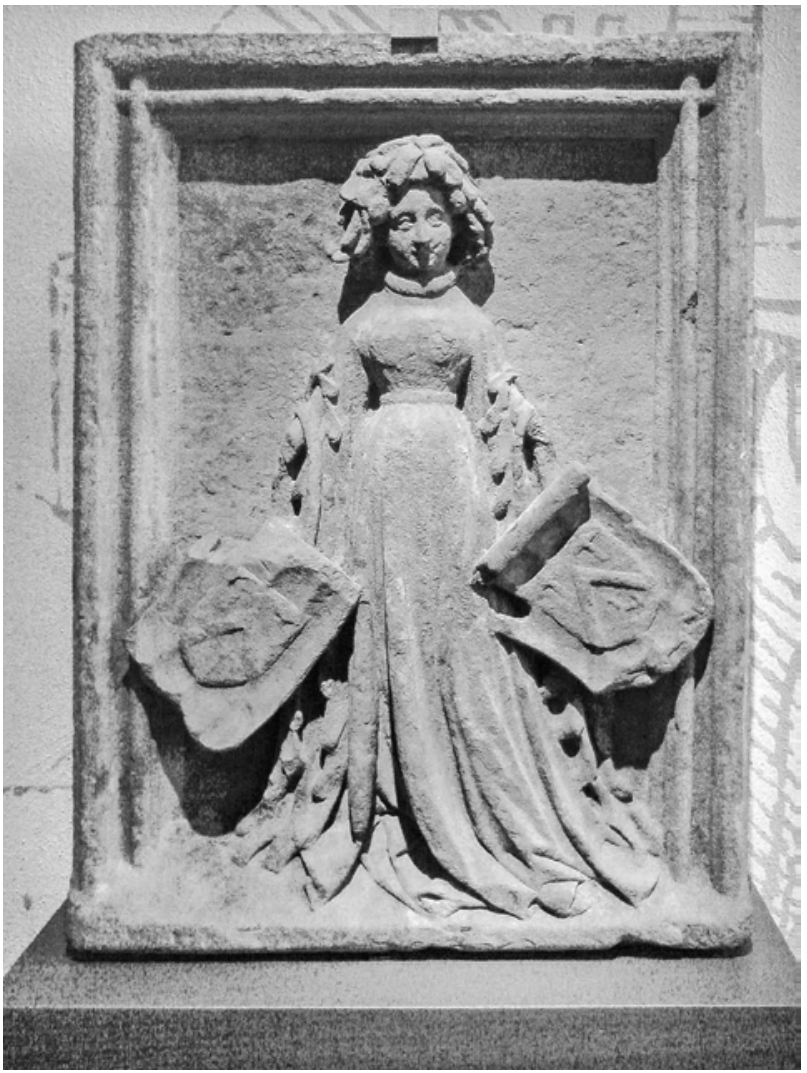

Abb. 9 Wappenhalterin. Mainz, Rheinisches Landesmuseum (Foto: Helge Kuppe)

Bei den Prophetenbildnissen fallen die Gewänder über den Rahmen des umgebenden Maßwerkkreises (Abb. 7, 8).

Dieses Heraustreten aus der Bildwirklichkeit findet sich auch bei einer Reihe Mainzer Werke. Den unteren Rand als Standfläche nutzend, kommt uns die Wappenhalterin des Mainzer Landesmuseums (um 1420) entgegen (Abb. 9).

Einen ähnlichen Eindruck vermittelt der Grabstein Johanns II. von Nassau. Der untere Teil des Rahmens, der die Standfläche für die Erzbischofsfigur bildet, ist breiter ausgebildet und ermöglicht dadurch ein Heraustreten der Figur aus ihrem Rahmen.

Das Verwischen der Grenze zwischen Zierelementen und bildlicher Darstellung zeigt sich auch bei einem Schlussstein des Kreuzgangs am Mainzer Dom mit Maria und dem Jesusknaben (Abb. 10). ${ }^{12}$

Das Maßwerk dient dort Maria als Sitz. Ihr Gewand am unteren Rand des Schlusssteins ersetzt nicht einfach den Rahmen. Der Rahmen setzt sich vielmehr unter ihrem Gewand fort.

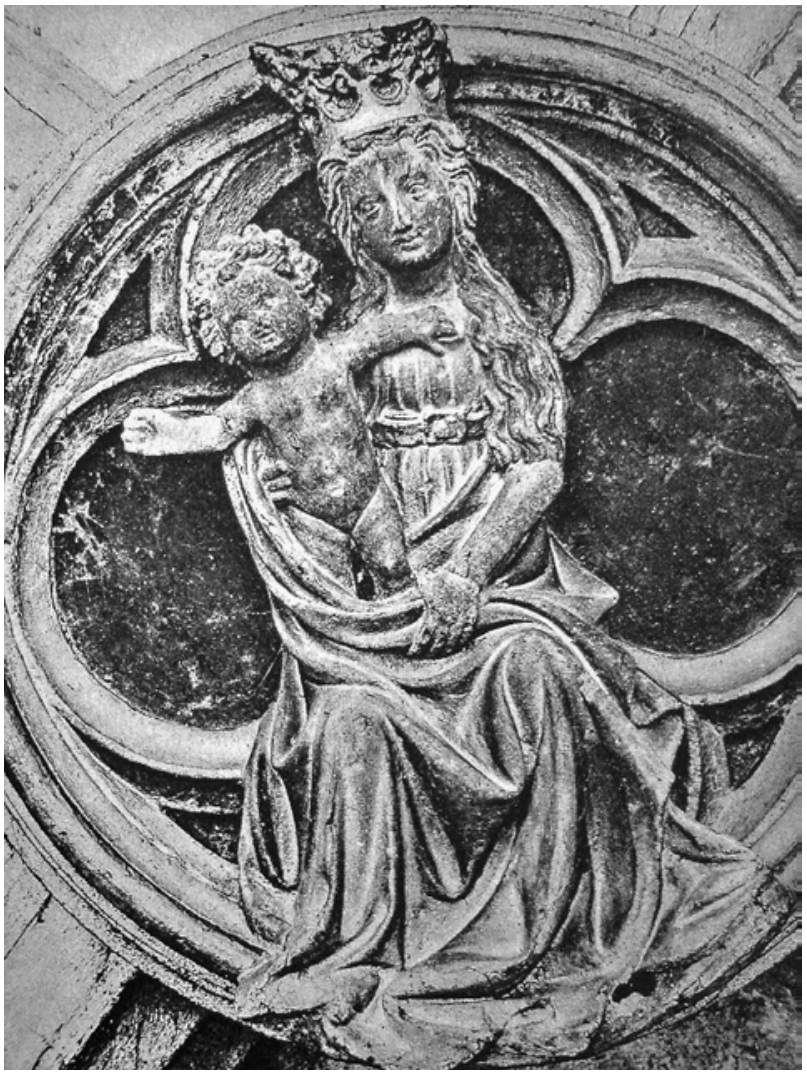

Abb. 10 Schlussstein mit thronender Madonna. Mainz, Dom, Kreuzgang, Südflügel (ex: ZIMMERMANN-DEISLER 1924)

Mit dem Ortenberger Altar (um 1420, Abb. 11) ${ }^{13}$ hat das Frankfurter Werk nicht nur das Thema der Anbetung, dort auf der rechten Tafel, gemeinsam.

Dieser vermutlich in Mainz entstandene Altar zeigt wie das Frankfurter Tympanon die Heiligen Drei Könige in unterschiedlicher Kleidung: Der älteste König trägt einen ärmellosen langen Mantel, der mittlere einen Tabard und der jüngste König eine aufwendig gestaltete Houppelande. Beide Werke verbindet auch die Kompositionsweise. Die beim Ortenberger Altar in eine Dreieckskomposition eingepassten Figurengruppen hält ein Netz aus Diagonalen und Horizontalen zusammen. ${ }^{14}$ Dies kann man gut auf der Haupttafel bei Maria sehen, die mit den beiden in der unteren Bildebene sitzenden Engeln ein Kompositionsdreieck bildet (Abb. 12).

Die beiden Reihen der Köpfe formen eine große Horizontale. Verbunden werden sie durch die kleinen Diagonalen, die sich zwischen den Bildebenen hin und her ziehen und die durch ihren Zick-Zack-förmigen Verlauf die Figuren zusammenbinden. Beim Frankfurter Tympanon erstreckt sich vom Kopf der Maria eine Komposi- 

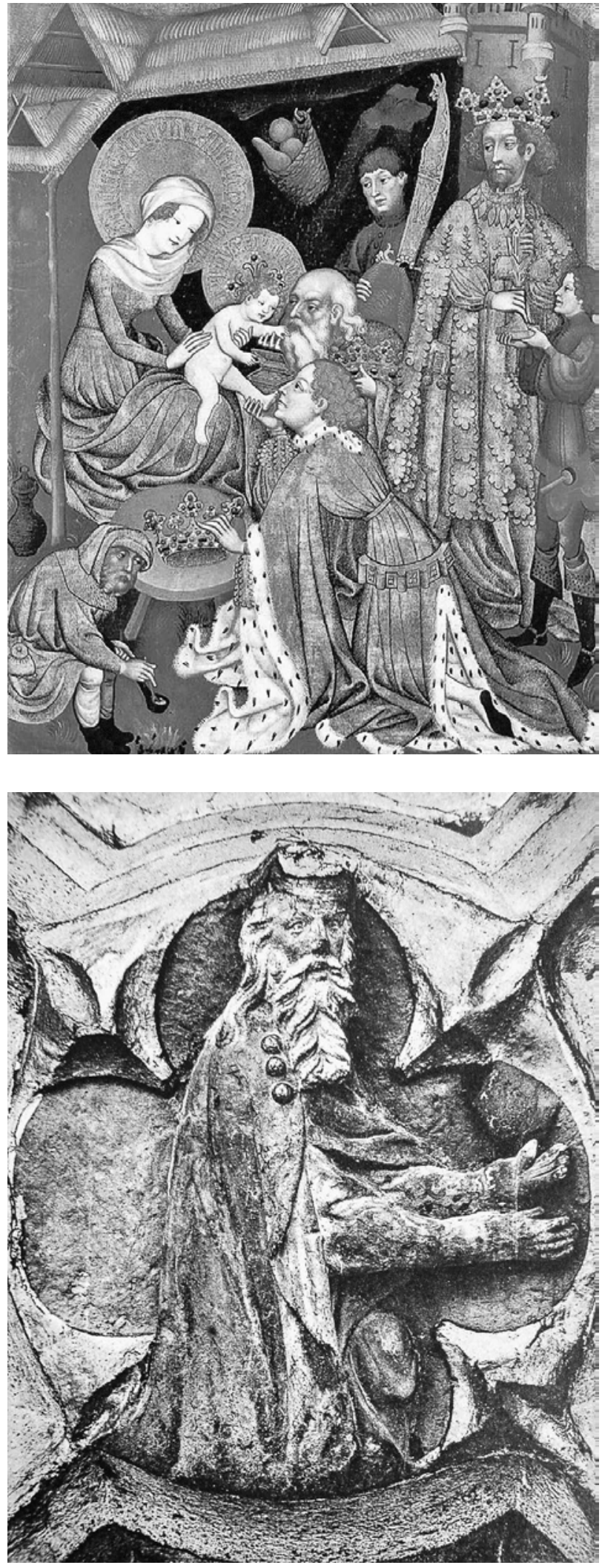

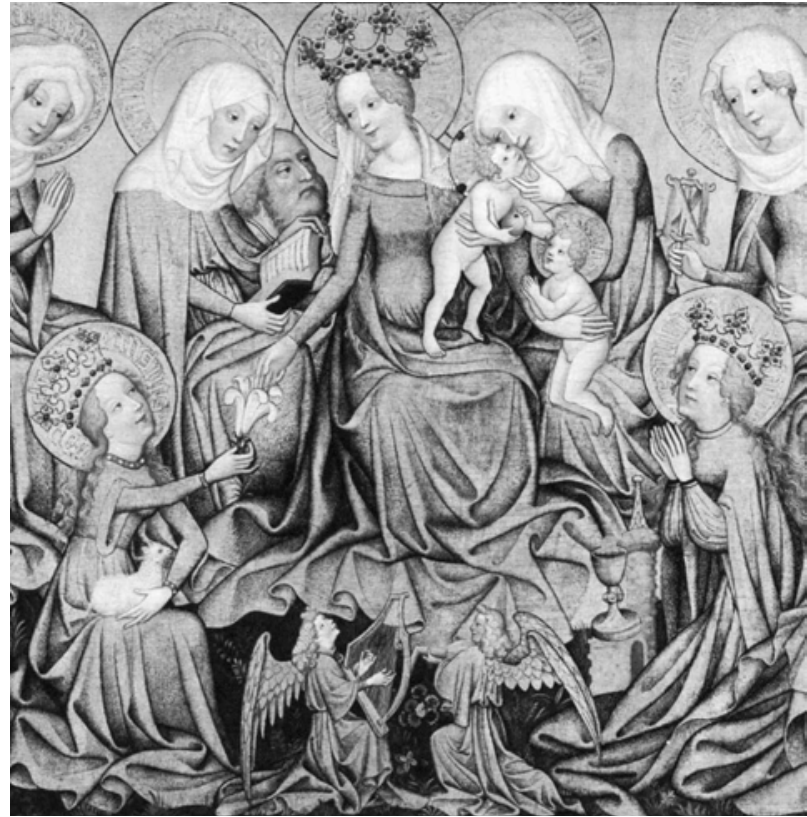

Abb. 11 (links) Anbetung der Könige, Ortenberger Retabel. Darmstadt, Hessisches Landesmuseum, Inv.-Nr. GK 4B (Foto: open source)

Abb. 12 (rechts) Maria mit Heiligen auf der Mitteltafel des Ortenberger Retabels. Darmstadt, Hessisches Landesmuseum, Inv.-Nr. GK 4B (Foto: open source)

Abb. 13 (links unten) Schlussstein mit kniendem König. Mainz, Dom, Kreuzgang, Ostflügel (ex: ZIMMERMANN-DEISLER 1924)

tionslinie über den Kopf des Knaben absteigend bis zum Kopf des Königs, weitergeführt durch dessen Gewand nach unten. Demgegenüber führt die Linie über den Rücken Mariens zur schräg gesetzten geflochtenen Matte, zur Basis des Dreiecks. Anbindung findet die Gruppe durch eine Kompositionslinie, die vom linken Bein des Jesusknaben ausgehend nach schräg oben verläuft. Über den Kopf des ältesten und den rechten Arm des mittleren Königs führt sie zum Haupt des jüngsten Königs, um am Kopf des Fahnenträgers zu enden. Dieser Anschluss über die Diagonalverbindungen ergänzt eine horizontal verlaufende Linie. Die Köpfe des Josef, der Maria, des Esels, des jüngsten Königs und das Haupt des ältesten Königs der Reitergruppe befinden sich auf einer Höhe.

Neben diesen beiden allgemeinen Gestaltungsprinzipien, dem Überschreiten der Bildgrenze und der durch ein diagonales Netz gestützten Dreieckskomposition, verraten die Details der Kopf- und Gewandgestaltung die Mainzer Herkunft. Ein Schlussstein des Mainzer Kreuzgangs (um 1400, Abb. 13) lässt sich mit dem Propheten 


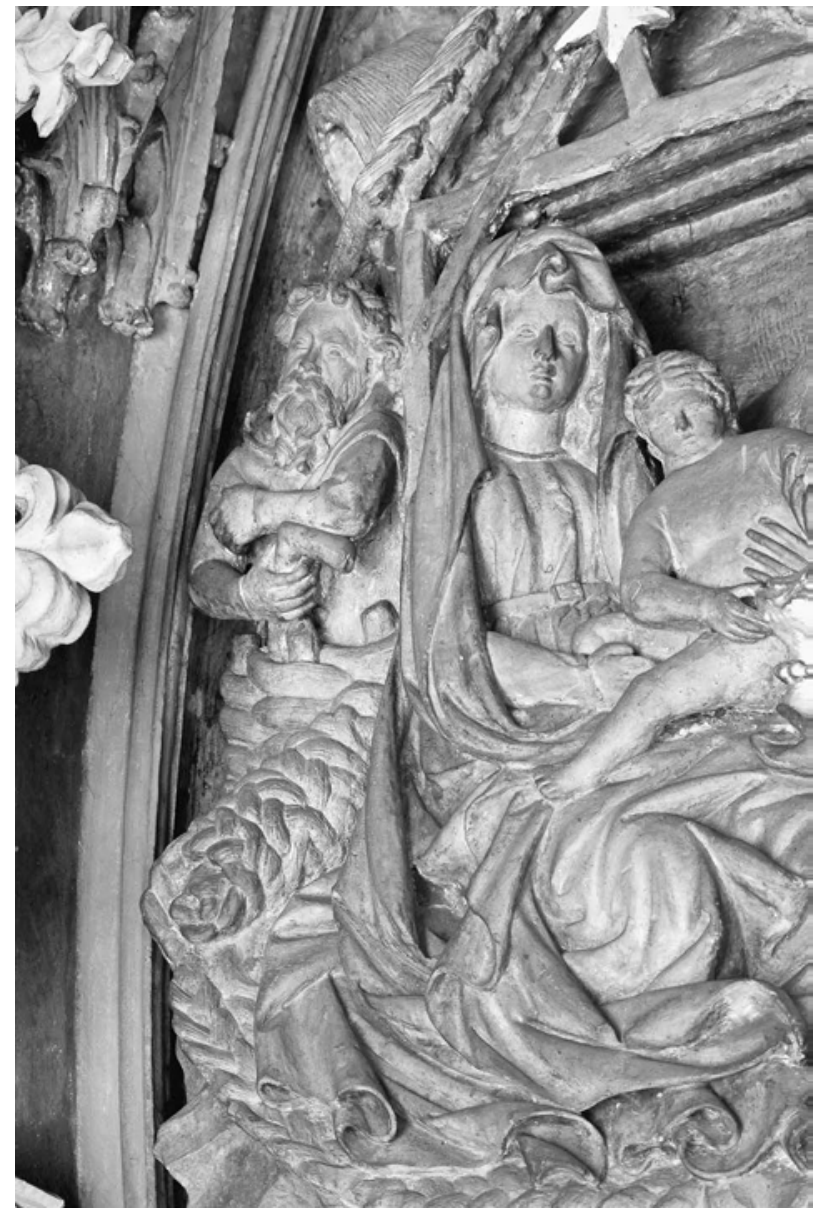

Abb. 14 Frankfurt/M., Liebfrauenkirche, Dreikönigsportal, Blick in die Archivolte, Detail Josef (Foto: S. Weiselowski)

Jesaja am Dreikönigsportal und dem Josefskopf des Tympanons vergleichen.

Die längliche Kopfform mit den hohen Wangenknochen, die gerade hervortretende Nase und der Mund mit dem kräftigen Bart des Königs ähneln denen des Jesaja am Dreikönigportal. Die Art der Bartgestaltung in Form gedrehter Spiralen, die man auf dem Schlussstein des Mainzer Kreuzgangs sieht, findet man am Dreikönigsportal in Frankfurt bei Jesaja und auf dem Relief bei der Figur des Joseph wieder. Den erstaunten Gesichtsausdruck mit den weit geöffneten Augen und dem leicht geöffneten Mund, der von einem dichten Bart umrahmt wird, zeigt auch der Josef des Dreikönigportals (Abb. 14).

Das markante, von kräftigem Haupt- und Barthaar gefasste Gesicht des Josef mit leicht geöffnetem Mund und in Falten gelegter Stirn zeigt eine sehr enge Verwandt-

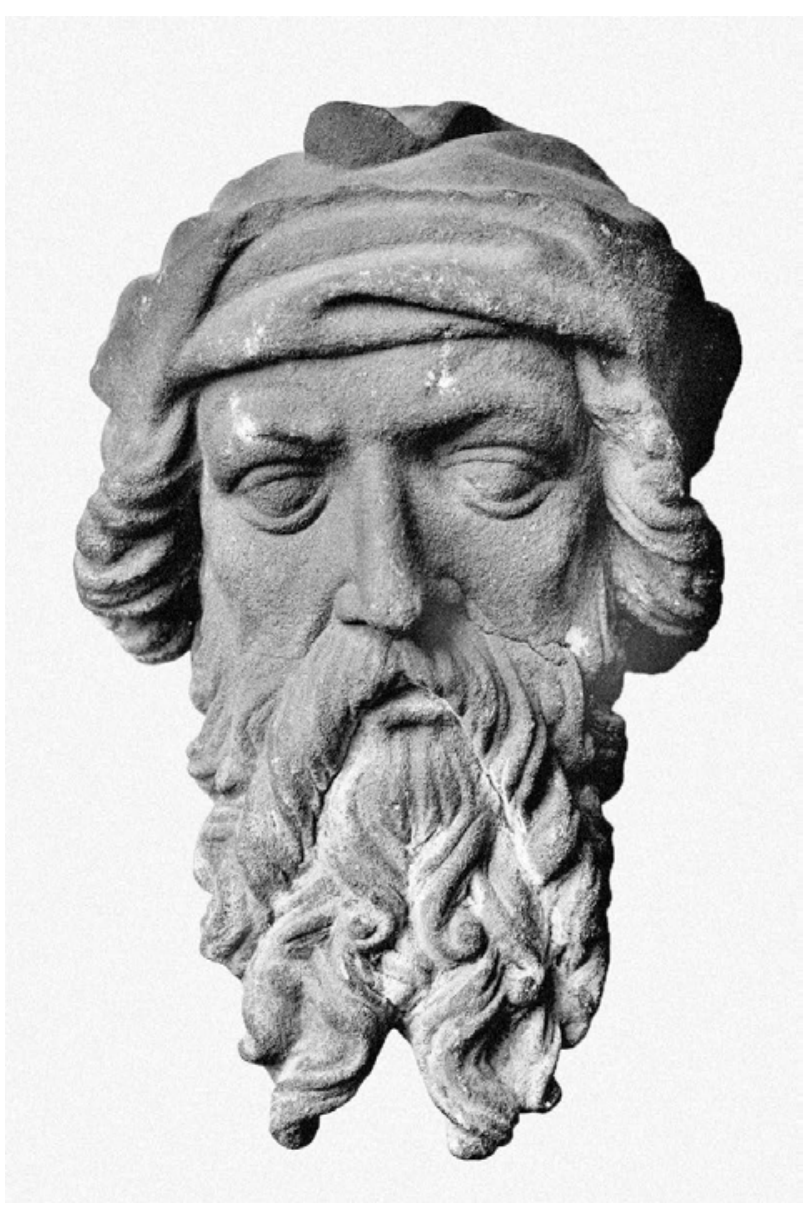

Abb. 15 Kopf eines Propheten vom Schönen Brunnen zu Nürnberg. Berlin, Staatliche Museen - Preußischer Kulturbesitz, Skulpturensammlung, Inv.-Nr. 365a (Foto: H. Kuppe)

schaft zu einem der Prophetenköpfe vom Schönen Brunnen in Nürnberg (Abb. 15). ${ }^{15}$

Jeder Kopf bekommt ein eigenes Gesicht, jeder Körper ein eigenes Kostüm oder, wie bei den Christus begleitenden Frauen zu sehen, eine eigene Faltenlegung. Das Bemühen um eine individuelle Gestaltung bei den Köpfen und der Kleidung teilt die vermutlich aus Mainz stammende Lorcher Kreuztragung (um 1410, Abb. 16) ${ }^{16}$ mit dem Tympanon der Liebfrauenkirche.

Detaillierte Übereinstimmungen zeigen sich zwischen der Maria Magdalena der Kreuztragung und der Maria des Tympanons. Der schlanke Hals ist bei beiden durch eine leichte Schwellung betont. Die weichen Gesichtszüge werden bestimmt durch die fleischige Nase mit tiefen Nasolabialfalten und den kleinen Mund, der über einem betonten Kinn mit kleiner Kerbe sitzt. Die mandelförmigen Augen rahmen betonte Unter- und Oberlider. Nur 


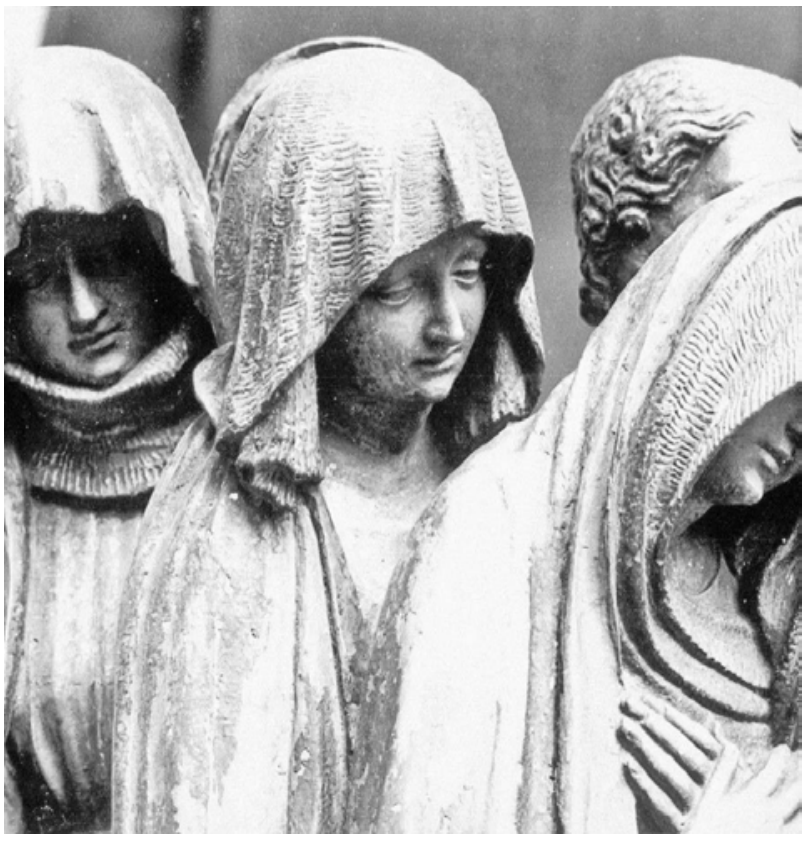

Abb. 16 Trauernde Frauen der Kreuztragung aus Lorch am Rhein. Berlin, Staatliche Museen - Preußischer Kulturbesitz, Bodemuseum, Inv.-Nr. 8499 (Foto: Bildarchiv Foto Marburg)

Abb. 17 Kreuzszeptermadonna. Mainz, Karmeliterkloster (Foto: Bildarchiv Foto Marburg)

das sorgenvolle Zusammenziehen der Augenbrauen unterscheidet das Gesicht der Maria Magdalena von der Frankfurter Maria.

Die Maria des Frankfurter Tympanons kann man als zur Seite gewendete Version der Mariendarstellung des erwähnten Schlusssteins aus dem Mainzer Domkreuzgang bezeichnen, obwohl die eine Figur auf dem Boden sitzt, die andere erhöht auf dem Maßwerk thront (Abb. 10). Beide tragen einen Mantel über einem hoch gegürteten Kleid, dessen quadratische Gürtelschnalle leicht nach rechts verrutscht ist. Die herabfallenden Stoffbahnen der Mäntel werden nach links gezogen und bilden zwischen den Knien eine große Schüsselfalte aus. Bei der gestalterischen Nähe der Figuren wundert es nicht, dass sich auch die Gesichter und Frisuren ähneln.

Dem Gewand der Maria am Dreikönigsportal vergleichbar sind die Gewandlösungen der Seitenfiguren am Grabstein Johanns II. von Nassau. ${ }^{17}$ Das zweidimensionale Verständnis in der Art der Faltengestaltung stimmt überein. Und dies, obwohl es sich am Grabstein um Statuetten im Hochrelief handelt. Besonders auffällig ist die Nähe der Frankfurter Maria zur heiligen Dorothea des

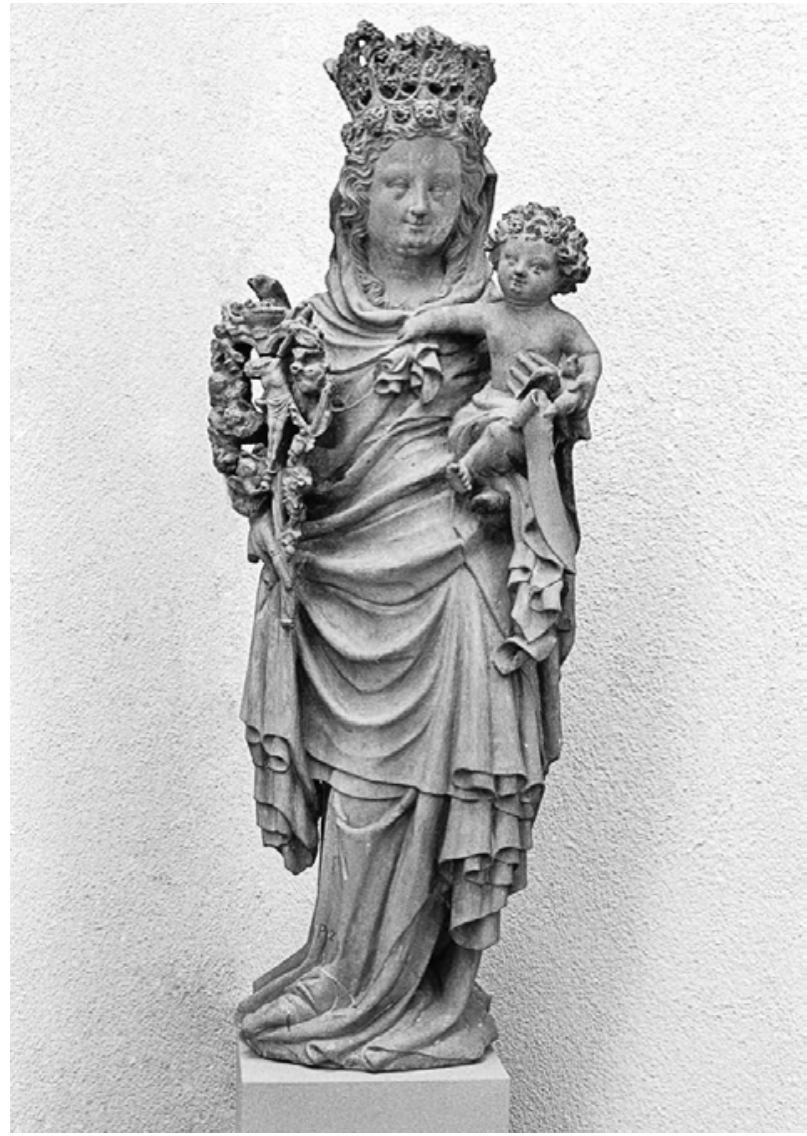

Grabsteins (Abb. 5). Der weit oberhalb der Taille sitzende Gürtel schafft bei beiden parallele Faltenstege über der Brust. Die Gürtelschnalle ist seitlich versetzt und Dorotheas Übergewand wie bei den Mariendarstellungen in Frankfurt und Mainz trichterartig mit einem Zug nach rechts und der tiefen Schüsselfalte ausgeführt.

Das fein gestaltete Gesicht des jüngsten Königs vom Dreikönigsportal und die Ausführung des Gewands, das in großen Bahnen den Körper entlang läuft, ohne eine Schüsselfalte auszubilden, führten zum Vergleich mit der Wappenhalterin (Abb. 9). ${ }^{18}$ Die dem jüngsten König des Tympanons nahestehende Wappenhalterin auf der einen Seite und die mit dem Gewand des Propheten am Dreikönigsportal vergleichbare Kreuzszeptermadonna des Mainzer Karmeliterklosters (um 1400, Abb. 17) auf der anderen zeigen an, wie unterschiedlich in Mainz in der Zeit um 1400 gearbeitet wurde.

Diese Beobachtung unterstreicht die Einschätzung Uwe Gasts, der Mainz bereits für die Zeit um 1350 als »ein produktives, künstlerischen Neuerungen aufgeschlossenes Zentrum« beschreibt. ${ }^{19}$ Und für beide Arten der Gewandgestaltung, für die parallel gesetzten Faltenbah- 
nen der Wappenhalterin und für das mit Schüsselfalten zwischen den Ärmelkaskaden versehene Oberkleid der Kreuzszeptermadonna, finden sich Vertreter in der Mainzer Bauhütte.

Faltenkaskaden und Schüsselfalten kombiniert auch das Gewand des Jesaja am Dreikönigsportal (Abb. 7). Durch seine Körperhaltung steht er aber dem Grabstein Johanns II. von Nassau näher als der Kreuzszeptermadonna. Durch beider Körper geht ein S-Schwung, der von einer Rotation des Leibes begleitet wird. Deutlicher als der Erzbischof zeigt der Prophet sein linkes Knie und betont damit die Funktion seines rechten Beins als Standbein. Um das Faltenmuster des Erzbischofs auf die Figur des Jesaja übertragen zu können, musste ein gestalterischer Trick angewendet werden. Die Haltung des Propheten am Frankfurter Portal lässt keine Schüsselfalten zu. Dafür müssten beide Arme sich mindestens in Taillenhöhe befinden, wie man es am Grabstein sieht. Um bei Jesaja trotzdem Schüsselfalten zu erzeugen, wird sein Spruchband oberhalb der Hüfte in eine Art Gürtel umfunktioniert. Dieser zieht das Gewand an dieser Stelle nach oben, was durch den sich über dem Spruchband stauenden Stoff sichtbar gemacht wird. Dieser Kunstgriff erlaubt die Angleichung an die Gestaltung der Kasel des Erzbischofs. Die erste große Schüsselfalte leitet den Blick des Betrachters zu dem mit der linken Hand gehaltenen Schriftband. Jesaja presst mit abgespreiztem Daumen seine Weissagung mit der Linken gegen seinen Oberkörper wie Johann II. die Heilige Schrift.

Der nur leichte S-Schwung der Figur Johanns II. von Nassau findet sich auch beim zweiten Propheten des Dreikönigportals (Abb. 8). Jeremias zeigt nicht nur den S-Schwung des Mainzer Erzbischofs, sondern wiederholt auch dessen Armhaltung. Sein rechter Arm zielt allerdings weiter zur Körpermitte und wird am Tympanon vom jüngsten König wiederholt. Seine Gewandfalten dagegen beziehen sich auf diejenigen am Grabstein Johanns II. von Nassau im Mainzer Dom (Abb. 4) ${ }^{20}$ Die vielen kleinen Schüsselfalten folgen einem Rhythmus von an- und abschwellenden Faltenmulden. Anfangs eine U-Form ausbildend, wechseln sie allmählich zu einer V-Form. ${ }^{21}$

Der Vergleich mit den Grabsteinen ist für die Datierung des Dreikönigportals wichtig. 1418 stiftete Johann II. von Nassau ein Totengedächtnis für sich und seinen Bruder Adolf von Nassau. Nach dieser Stiftung datierte man bisher Johanns Grabstein. ${ }^{22}$ Der Grabstein vor dem Mainzer Ostchor ist aber kein singuläres Werk.
Er gehört zusammen mit dem Grabstein des Bruders zu einer größeren Umbauplanung im Mainzer Dom. ${ }^{23} 1414$ waren diese Arbeiten vor dem Ostchor fertig und die Werkstatt hatte Kapazitäten frei. 1415 stellte der Mainzer Erzbischof einen ersten Ablass für die Liebfrauenkirche aus, woraus man schließen kann, dass sich die Kirche zu diesem Zeitpunkt bereits im Ausbau befand. ${ }^{24}$

\section{Die karolinisch-luxemburgische Hofkunst und das Dreikönigstympanon}

Das Relief am Dreikönigsportal vereint die Verkündigung an die Hirten, das Zusammenkommen der Heiligen Könige sowie deren Anbetung des Jesusknaben in einem gemeinsamen Landschaftsraum. Das selten dargestellte Zusammenkommen der Heiligen Könige am Berge Golgatha geht auf die um 1364 erschienene ${ }^{25}$ Legende der Heiligen Drei Könige des Johann von Hildesheim zurück. ${ }^{26}$ Die Legende verbindet durch die Anspielung auf den Ort der Kreuzigung den Anfang der Geschichte der Menschwerdung Gottes bereits mit ihrem Ende. ${ }^{27}$ Für den Verzicht auf die Einteilung in Register und den Einsatz eines einheitlichen Bildraums im Tympanon macht Erwin Panofsky den Parler-Stil verantwortlich und listet eine Entwicklungsreihe von Tympana auf, zu der auch das Frankfurter Relief zählt. ${ }^{28}$ Anders als bei den Tympana in Ulm oder Thann, die den Reigen eröffnen, müssen die Könige der Anbetungsszene in Frankfurt ohne ihr Gefolge auskommen (Abb. 14); ihre Reiterzüge begleiten sie nur auf der Reise. Das Gefolge der Könige ist auf dem Frankfurter Relief nur kompositorisch mit der Anbetung verbunden. Die Kompositionslinien der anreitenden Züge der Könige treffen sich im stehenden jüngsten König der Anbetung und verbinden so die beiden ikonografisch getrennten Szenen. Diese Kompositionsweise überdeckt eine für die Zeit bereits altmodische Art der Inszenierung und erweckt den Anschein eines großen Gefolges in der Szene der Anbetung der Könige. Am Dreikönigsportal beschränkt sich das Personal der Anbetungsszene aber auf Maria mit dem Christuskind, Joseph und die Könige. Wie bei der Anbetungsszene des Ortenberger Altars ist der Jesusknabe mit dem Gold beschäftigt, während der älteste König mit der linken Hand den Pokal hält und mit seiner rechten nach der Hand des Knaben greift, um sie an seinen Mund zu führen.

Ein früher Vorläufer (um 1330), die heute im Schnütgenmuseum ausgestellte plastische Anbetungsgruppe, 


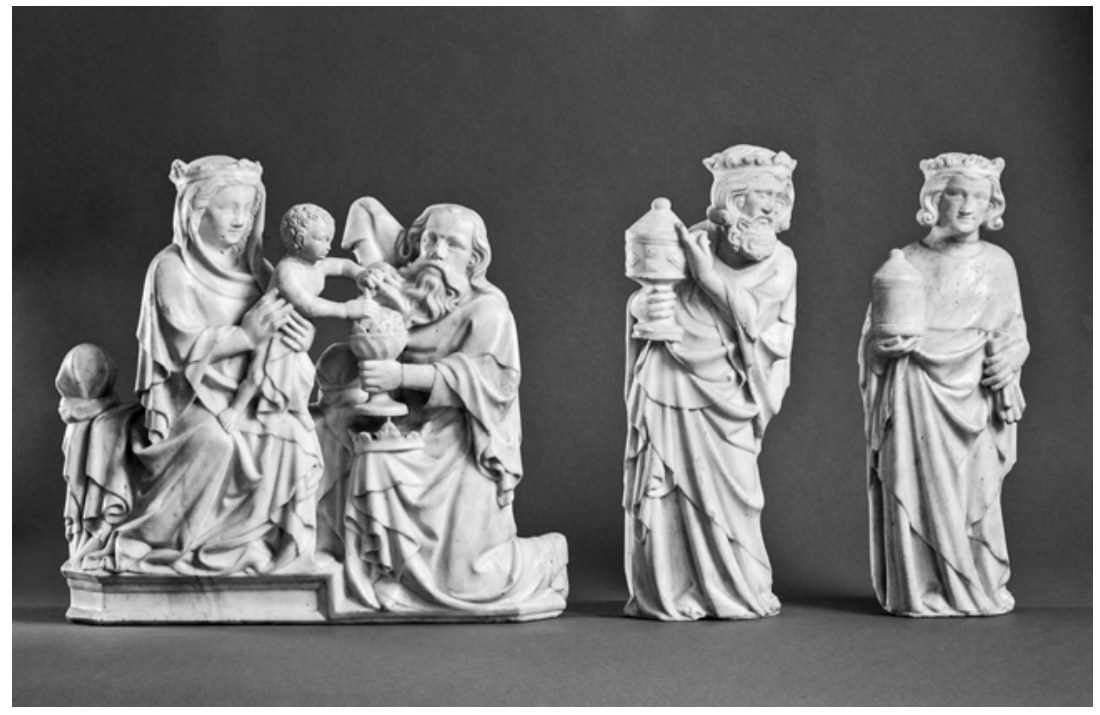

Abb. 18 Epiphanie von der Rückseite des Kölner Dom-Hochaltars. Köln, Schnütgenmuseum, Inv.-Nr. 210a, e, m (Foto: Rheinisches Bildarchiv Köln, Wolfgang F. Meier)

Abb. 19 Huy, Notre-Dame, Betlehem-Portal (Foto: Bildarchiv Foto Marburg)

Abb. 20 Anbetung der Könige. Meister von Hohenfurth, um 1346/47 (?). Prag, Nationalgalerie, Inv.-Nr. 06786-6794 (Foto: open source, bearb. durch S. Weiselowski)

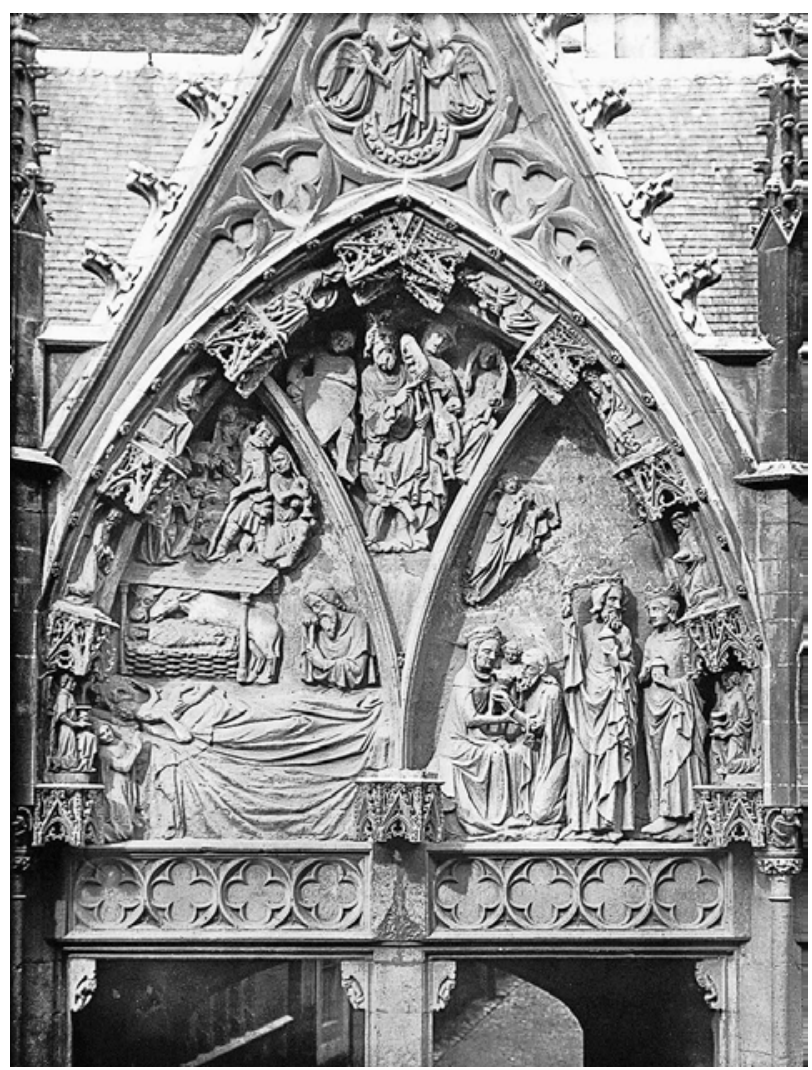

befand sich bis 1766 auf der Rückseite der Hochaltarmensa im Kölner Dom (Abb. 18). ${ }^{29}$

Einst begleiteten Prophetenbildnisse die Anordnung der Heiligen Könige mit der Muttergottes. Der Jesusknabe greift mit beiden Händen nach dem Gold, das ihm vom ältesten König in einem Pokal präsentiert wird.

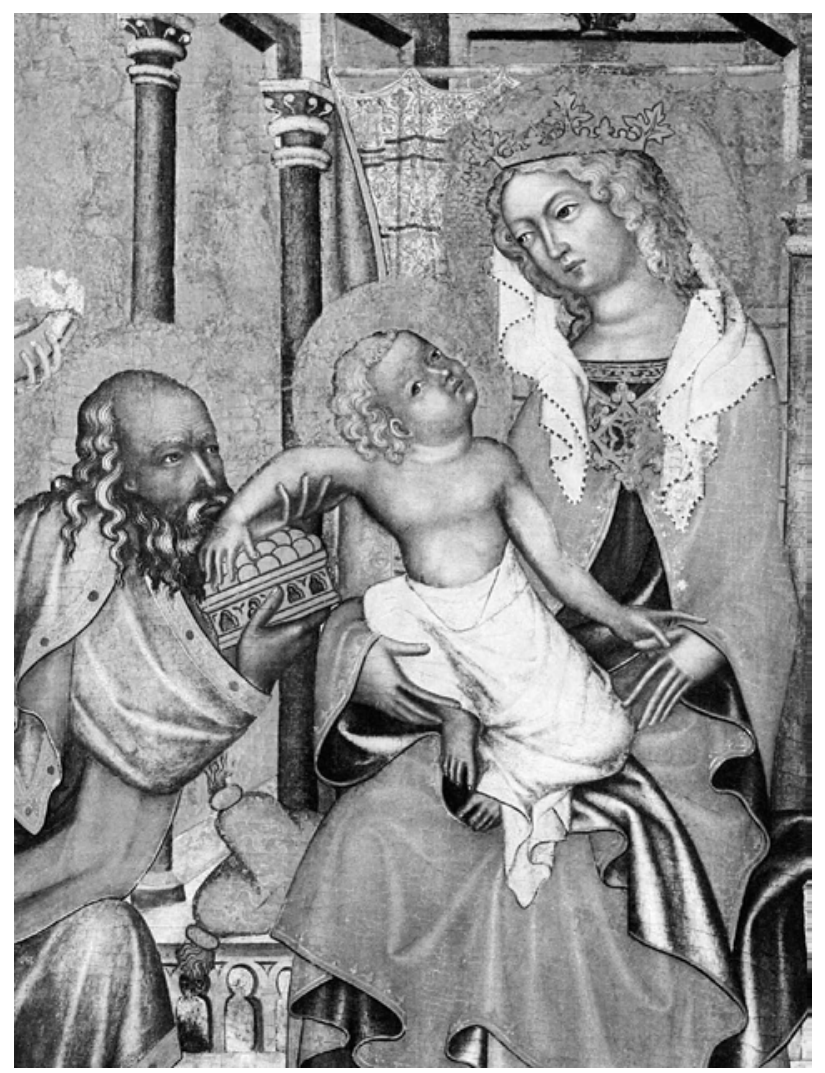

Um einen zu engen Kontakt zu dem Knaben zu vermeiden, muss der König den rechten Arm stark angewinkelt schräg nach oben drehen. Die größte Annäherung zeigen die Handrücken der rechten Hand des Königs und der linken Hand des Jesuskinds, die sich nur leicht berühren. Ein etwas späteres Beispiel am sog. Betlehem-Portal der 
Abb. 21 Anbetung der Könige. Nürnberg, 1350er Jahre. Nürnberg, Frauenkirche, Tympanon des inneren Westportals (Foto: open source, bearb. durch S. Weiselowski)

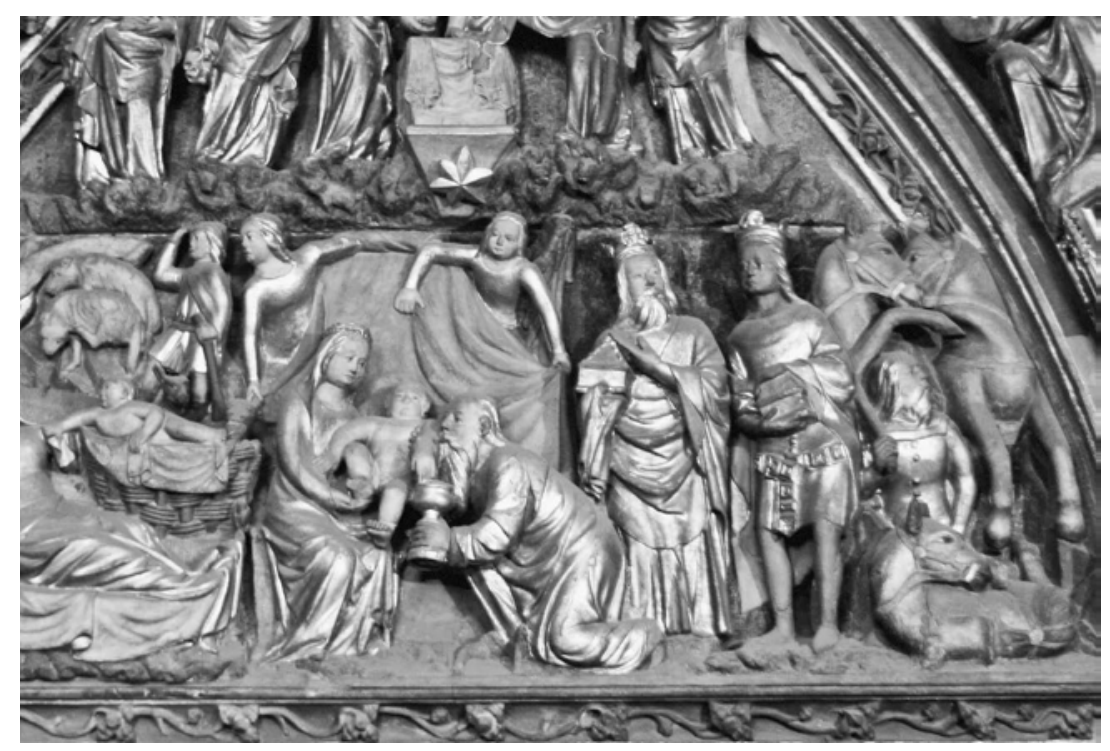

Stiftskirche Notre-Dame in Huy/Maas (Abb. 19) hingegen nutzt den Augenblick der Geschenkübergabe zur Schilderung einer intimen Begegnung zwischen Jesus, Maria und dem ältesten König.

Die rechte Hand des Königs hält das linke Handgelenk des Jesusknaben umfasst und zieht dessen Hand vom verschobenen Pokaldeckel weg an seinen Mund. Der Pokal des ältesten Königs ist aber nicht mit einer Hand zu halten, weshalb Maria den linken Arm des Königs am Handgelenk abstützt.

Zwischen diesen beiden Polen, der Distanz wahrenden Ehrfurcht der Kölner Gruppe und der den direkten körperlichen Kontakt herstellenden Anordnung in Huy, liegen die böhmisch-karolinischen Lösungen, die für das Dreikönigstympanon als Vorbilder dienten. ${ }^{30}$ In der böhmischen Kunst um Karl IV. wird die körperliche Nähe zwischen Maria und dem ältesten König zurückgenommen. Sie beschränkt sich auf den Blickkontakt der Protagonisten. Das Geschenk sticht durch seine im Verhältnis zu den Figuren größere Darstellung stärker hervor. Das Umgreifen des Armes Jesu ermöglicht dem ältesten König einen Kuss auf den Handrücken des Kindes, was auf die Meditationes der Birgitta von Schweden zurückgeht. ${ }^{31}$ Vermutlich aus Anlass der böhmischen Krönung Karls IV. 1347 gefertigt, zeigt die Tafel des Meisters von Hohenfurth den Luxemburger wahrscheinlich zum ersten Mal als Identifikationsporträt in der Rolle des mittleren Königs (Abb. 20). ${ }^{32}$

Bei einer etwas späteren Anbetungsszene der karolinischen Hofkunst, dem Morgan-Diptychon, ${ }^{33}$ wird die
Nähe zwischen ältestem König und Maria intensiviert. Dabei geht man aber nicht so weit wie bei dem Beispiel in Huy: Nur die Handrücken Marias und des Königs werden dicht aneinander geführt. An dieser Stelle findet sich ein markantes, sich wiederholendes V-förmiges Muster der Finger, wie man es auch beim Frankfurter Dreikönigstympanon sieht. In Frankfurt sieht der Handkuss des ältesten Königs allerdings eher aus wie ein Ellenbogenkuss. Der zum Kuss bereite Mund und das Halten des Ellenbogens sind ein Verweis auf das nachfolgende Geschehen: Der König wird die Hand des Kindes an seinen Mund führen. Diese scheinbar verunglückte Handlung ist zuvor schon am Tympanon in der Vorhalle der 1355 von Karl IV. gestifteten Frauenkirche in Nürnberg zu sehen (Abb. 21).

Dort zielt der Mund des Königs ebenfalls scheinbar auf den Ellenbogen des Kindes, was stark an die Anbetung in Huy erinnert.

Durch den Verzicht auf einen Thronsitz für die Muttergottes musste eine Möglichkeit gefunden werden, ihre Erhabenheit im Bild zu erhalten. Im zweidimensionalen Bildverständnis des Gemäldes setzte der Künstler des Morgan-Diptychons deswegen Maria in eine höhere Position. Dies erreichte er, indem er Maria nicht bildparallel gibt, sondern sie leicht schräg ins Bild setzt, ohne dabei ihre Körpergröße im Verhältnis zum König zu verkleinern. Die Stoffmassen ihres Gewands verunklären ihre Sitzhaltung, was dem Maler zusätzlich die Möglichkeit verschafft, sie erhabener erscheinen zu lassen. Der Maler der Deckengemälde (1360-64) der Heilig-Kreuz-Ka- 


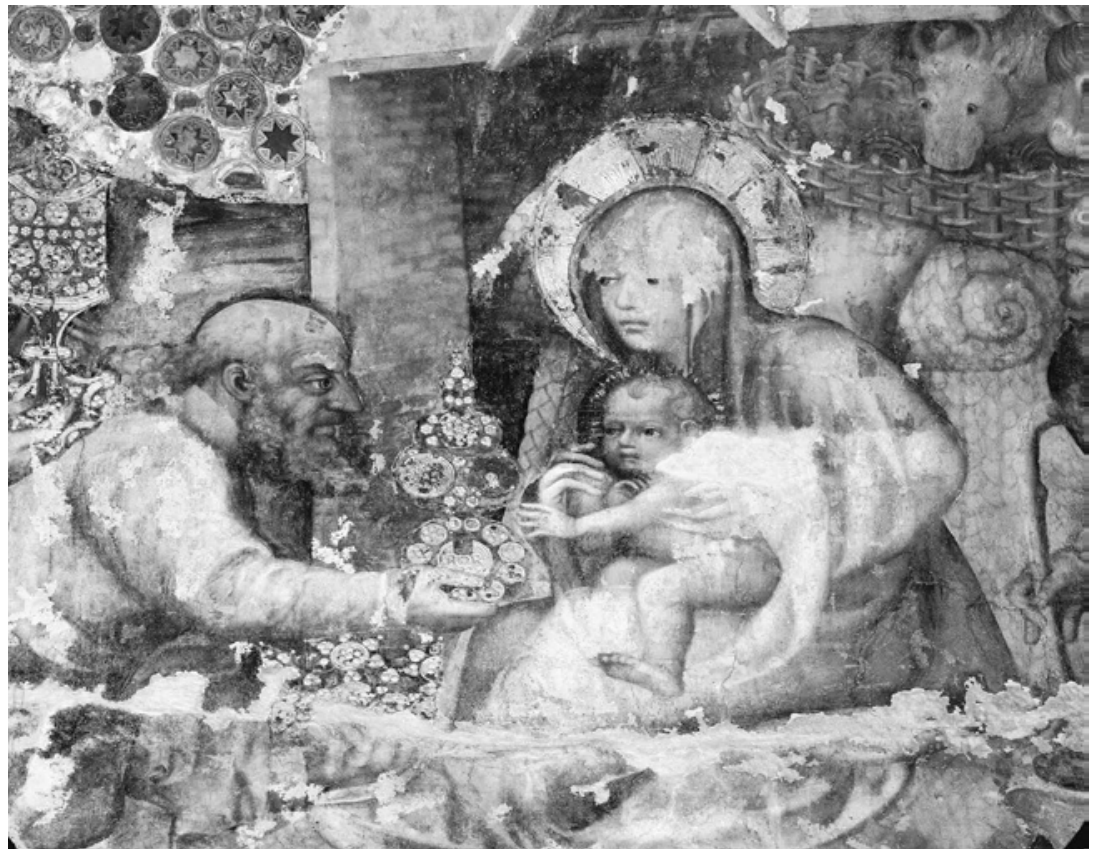

Abb. 22 Anbetung der Könige. Fresko, Stuck, eingelegte Glasspiegel, 1363/64. Karlstein, Heilig-Kreuz-Kapelle, Gewölbetonne der nordöstlichen Fensternische (Foto: AKG images)

Abb. 23 Anbetung der Könige auf der Außenseite des rechten Flügels eines Marienkrönungsretabels. Ehemals Müncheberg, Marienkirche, seit 1945 verschollen (ex: KNÜVENER 2009, 499, Abb. 5)

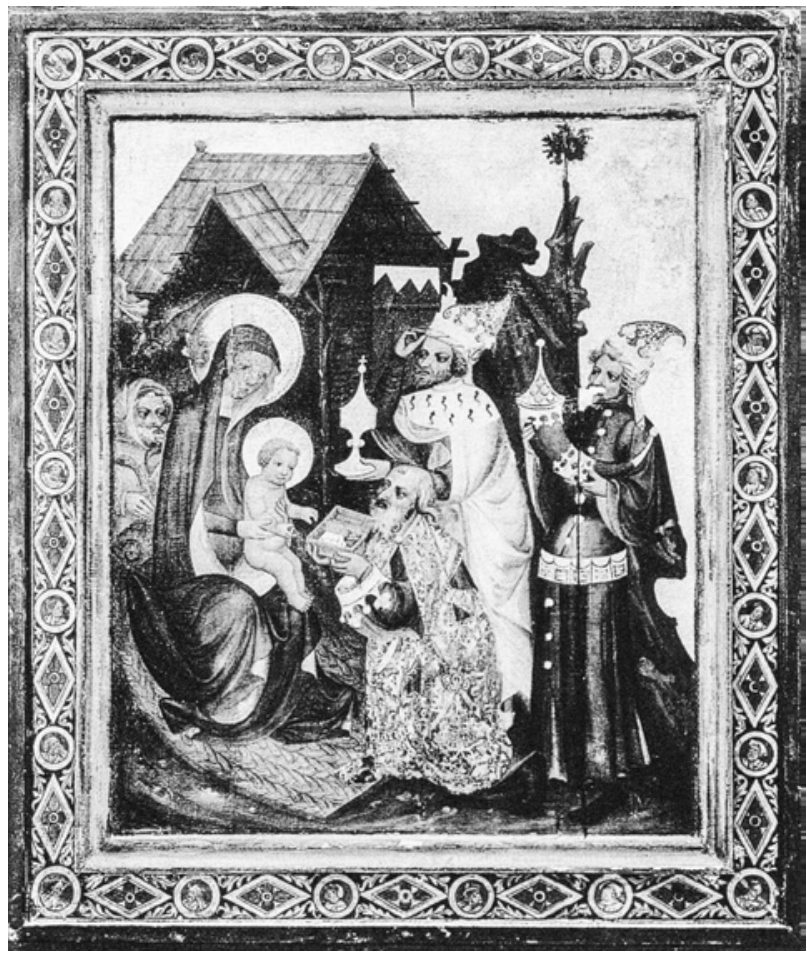

pelle auf Burg Karlstein, vermutlich Nikolaus Wurmser von Straßburg, übernimmt dies und schmückt die Szene weiter aus (Abb. 22), wobei er ein Motiv einsetzt, das auf dem Frankfurter Relief wiederkehrt.

Auf Karlstein und in Frankfurt sitzt die Muttergottes auf einer geflochtenen Matte, die sich hinter ihrem Rü- cken schneckenförmig zusammenrollt. ${ }^{34}$ In Karlstein dient der aufgerollte Teil als Kopfstütze. In Frankfurt wird die Mattenrolle in den Rücken Marias gesetzt. In Karlstein, bekanntlich einem der bedeutendsten Kristallisationspunkte karolinischer Kunst, findet sich zudem ein frühes Beispiel für die Identifikation Karls IV. mit einem der Heiligen Drei Könige, hier dem jüngsten. ${ }^{35}$ Die Position der Matte und die Anordnung des Josef vermittelnd, steht zwischen Karlstein und Frankfurt eine heute verschollene Anbetung aus Müncheberg (Abb. 23). ${ }^{36}$

Die Abstammung des Dreikönigsreliefs der Liebfrauenkirche von der Karlsteiner Darstellung verdeutlicht die Kombination der aufgerollten Matte mit einem dahinter gezeigten Zaun aus geflochtenen Ruten.

Die Lösung der Sitzposition des Jesuskinds in Frankfurt findet man auf Karlstein bei der um 1357 datierten Stifterszene der Marienkapelle vor (Abb. 24).

Der Knabe wird, weil er etwas vorgerückt auf den Oberschenkeln seiner Mutter sitzt, nicht mehr vom Oberkörper Marias hinterfangen. Im Frankfurter Tympanon wendet er sich dem ältesten König zu, wodurch eine Körperdrehung entsteht. Seine Beine sind, nur leicht angewinkelt, über den Schoß Marias ausgestreckt.

Ein weiteres Motiv, das sich aus der karolinischen Hofkunst ableiten lässt, ist das unregelmäßige, kantige $\mathrm{Ob}$ jekt, das der mittlere König in der Hand hält. Seine Enden sind verschieden stark abgeschrägt (Abb. 25). 


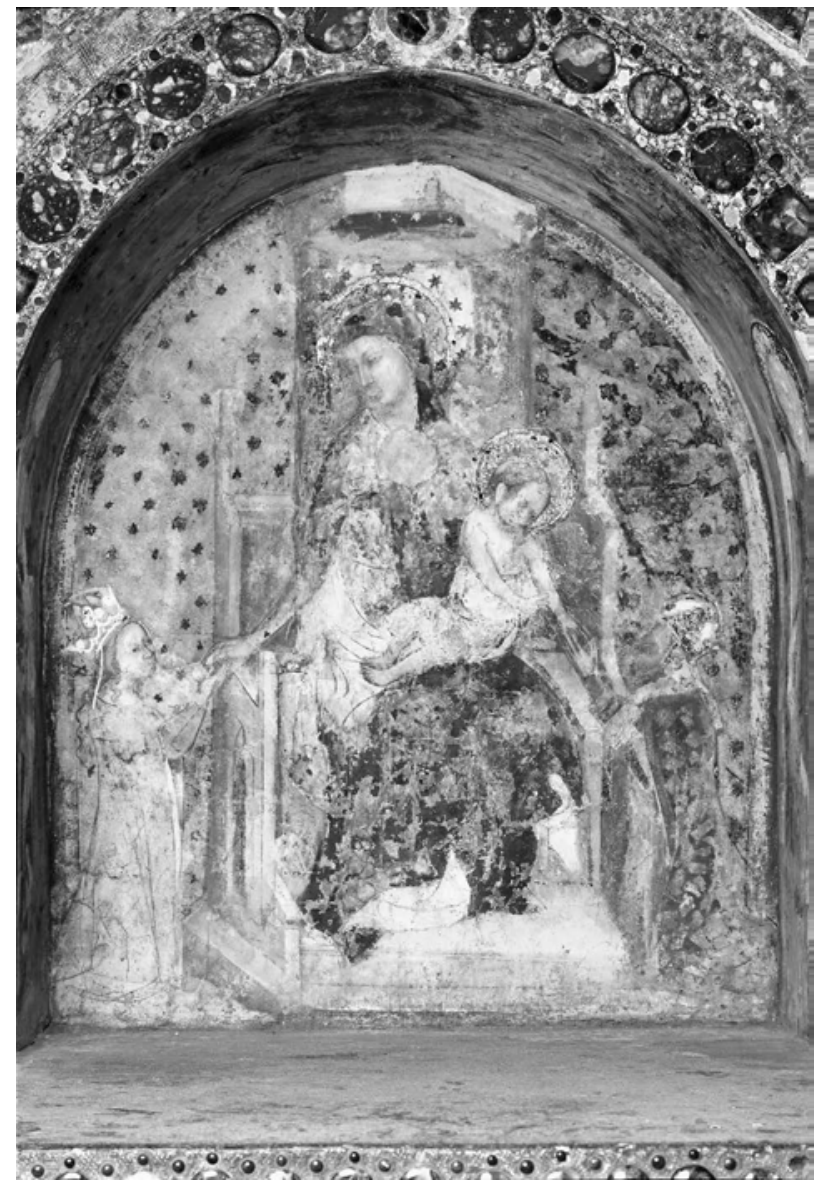

Abb. 24 Thronende Madonna mit Karl IV. und Anna von Schweidnitz. Um 1357. Karlstein, Kleiner Turm, Marienkapelle (Foto: Radovan Boček, Prag)

Abb. 25 Mittlerer König der Anbetung mit Gabe. Frankfurt/M., Liebfrauenkirche, Tympanon (Foto: Bildarchiv Foto Marburg)

Abb. 26 Initiale O mit Anbetung der Könige. Liber viaticus des Johannes von Neumarkt. Prag, Knihovna Národního muzea, Sign. XIII A 12, fol. 97 (Foto: Prag, Nationalmuseum)

In der auf älteren Abbildungen überlieferten Form scheint es sich schlicht um ein großes Stück Gold gehandelt zu haben. Eine Darstellung der Heiligen Drei Könige in dem Liber viaticus genannten Brevier des Johann von Neumarkt, ${ }^{37}$ des Kanzlers Karls IV., zeigt eine vergleichbare Abweichung von der üblichen Ikonografie: Hier hält der jüngste König, vielleicht ein Identifikationsporträt Wenzels von Luxemburg, einen Goldklumpen anstelle der sonst gezeigten aufwändig künstlerisch gestalteten Behältnisse in der Hand (Abb. 26).

Dabei handelt es sich vermutlich um eine Anspielung auf eine Stiftung Karls IV. an das Aachener Marienstift:
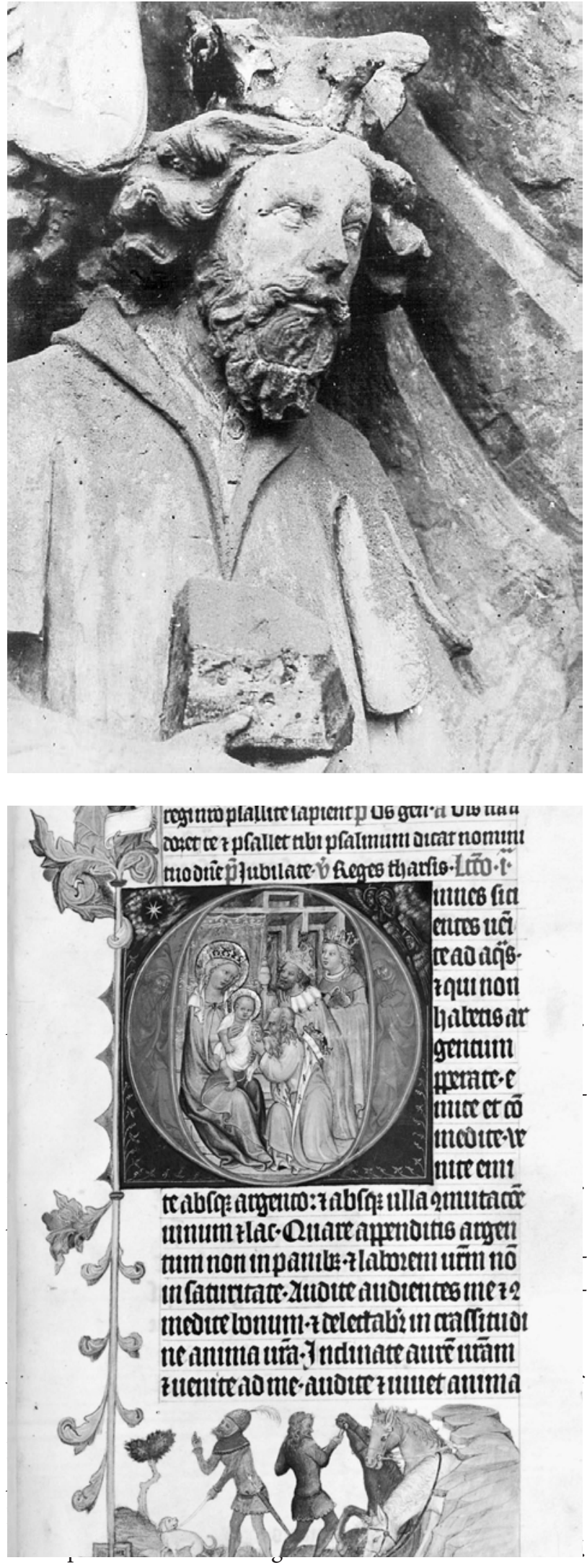


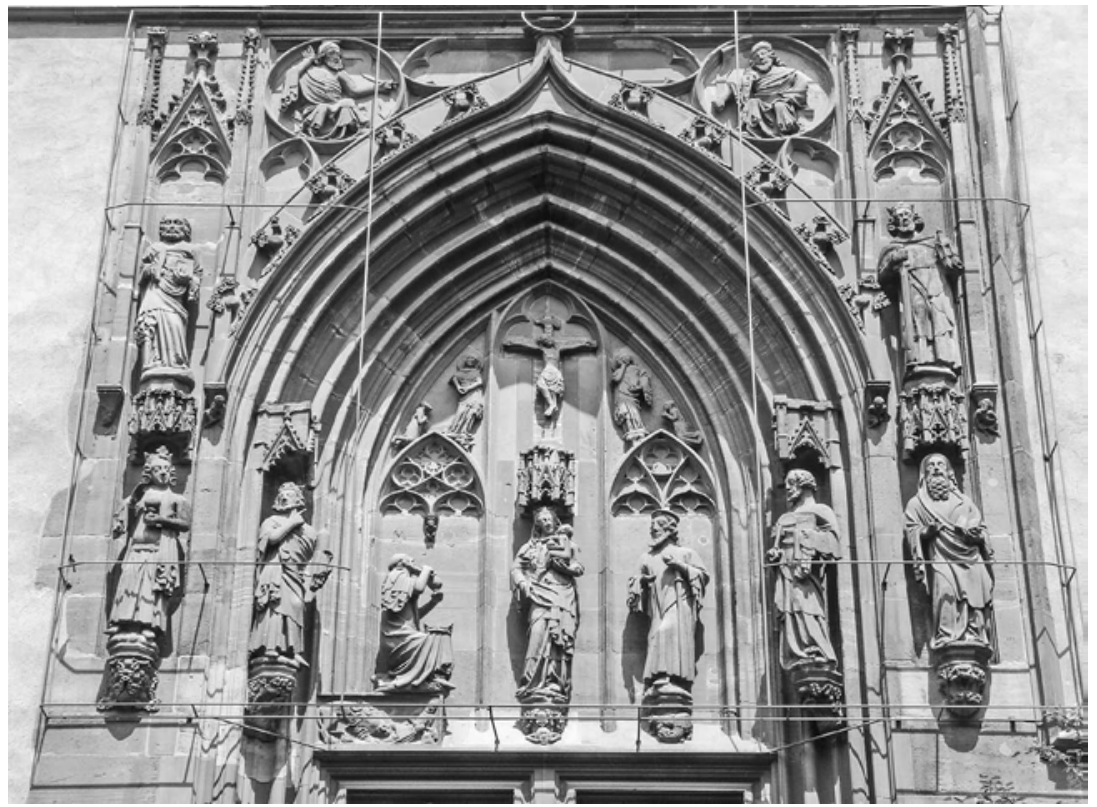

Abb. 27 Frankfurt/M., St. Bartholomäus, Querhaus, Südportal, Tympanon, Zustand 1866 (ex: Вотт 1962)

belegt. Dieses Selbstverständnis Karls als Nachfolger der Heiligen Könige aus dem Morgenland war keine Erfindung des Luxemburgers. Die Römisch-deutschen Könige sahen sich generell in der Tradition der Heiligen Könige dies wurde bei jeder Krönungsfeier verdeutlicht, indem man die Zeremonie möglichst am Dreikönigstag feierte. Seit der Krönung Heinrichs VII. von Luxemburg am Dreikönigstag 1309 verwendete man dafür Teile aus der Dreikönigsliturgie. ${ }^{41}$

\section{Eine Anbetung in Frankfurt als Vorbild: Karl IV. und das Stifterportal der St.-Bartholomäus-Kirche}

In Frankfurt selbst gibt es ein Portal, das den Aufbau des Dreikönigsportals vorwegnimmt: das Südportal des Frankfurter Doms (Abb. 27) ${ }^{42}$

In einem rechteckigen Rahmen sitzen in den Ecken durch Fischblasen gerahmte Medaillons mit Prophetenbildnissen. In ihren Händen halten die Propheten ge schwungene Bänder, einst mit ihren Prophezeiungen. Beide Portale verbindet das Hauptthema, die Anbetung der Heiligen Drei Könige. ${ }^{43}$ Am Dreikönigsportal der Liebfrauenkirche wiederholt sich der Aufbau der Figuren vom Südportal am Dom in spiegelbildlicher Form. Der älteste König kniet vor Maria, die beiden anderen Könige sind miteinander im Gespräch gezeigt.

Der Arm des mittleren Königs am Dom zeigt auf den im oberen Feld des Tympanons zu sehenden Christus am Kreuz und verbindet so die deutlich kleiner gegebene Kreuzigung mit der Anbetung. Eine Allusion auf die Kreuzigung findet sich beim Dreikönigsrelief der Liebfrauenkirche oberhalb der Anbetungsszene: Die Komposition am Dreikönigsportal schafft eine Verbindung zwischen der Szene der Anbetung und dem Treffpunkt der Könige am Fuße des Berges Golgatha. Weitere Gemeinsamkeiten zwischen dem Dreikönigsportal der Liebfrauenkirche und dem Südportal am Dom finden sich bei den Gaben der Heiligen. Der älteste König und der jüngste halten Pokale in der Hand. Sogar die Gesten der jeweiligen jüngsten Könige ähneln sich: Beide fassen mit ausgestellten Daumen den Pokal an seinem Fuß. Am Dom ist seine rechte Hand noch erhoben, um auf den Wink des mittleren Königs, der auf den Stern von Bethlehem verweist, zu reagieren. Da dieser Verweis am Dreikönigsportal entfällt, konnte nun die Hand des jüngsten Königs gesenkt werden, was wie eine Fortsetzung der Handlung am Dom erscheint.

Obwohl Guido Schoenberger bereits 1927 darauf hingewiesen hat, dass es für die Fertigstellung des Südquerhauses keine schriftliche Quelle gibt, ${ }^{44}$ hält sich bis heute das von Latomus angegebene Jahr 1353 als Datum der Vollendung. ${ }^{45}$ Gegen eine Vollendung 1353 sprechen die bis 1358 fortlaufenden Bauzahlungen der Stadt Frankfurt und die zum Nordportal unterschiedlichen Maßwerkformen. ${ }^{46}$ Wahrscheinlich hat Latomus, dem ein Abschlussdatum für das südliche Querhaus fehlte, die Angaben für den Nordflügel einfach auf den südlichen Teil des Baus 


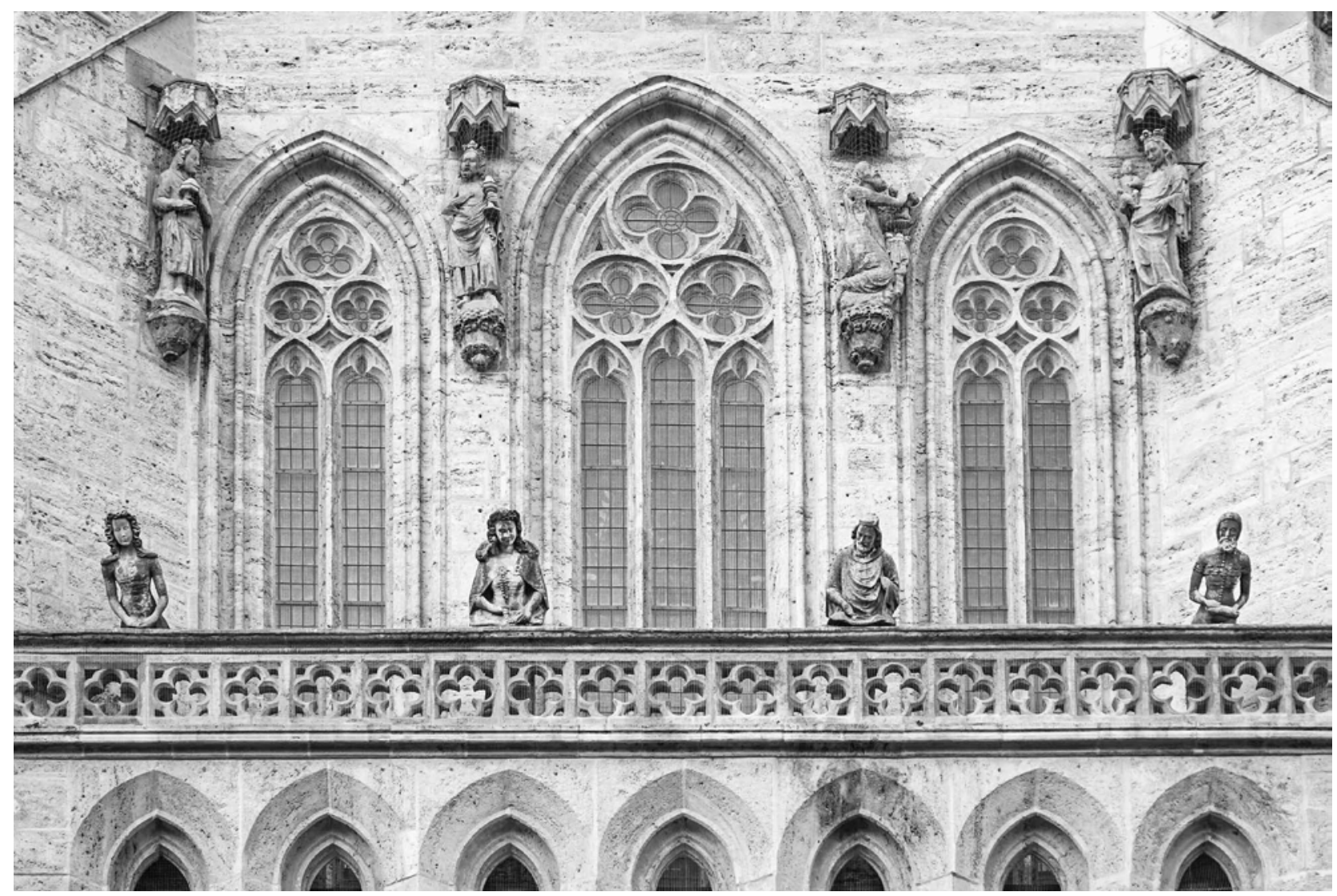

Abb. 28 Anbetung der Könige. Mühlhausen/Thür., Marienkirche, Südquerhaus (Foto: Markus Hörsch)

übertragen. Für das südliche Querhaus schlug Christian Freigang eine Bauzeit von 1353-57 vor. ${ }^{47}$

Für Lilli Fischel war an der Bartholomäuskirche eine Abspaltung der an der Westfassade der Nürnberger St.Lorenz-Kirche tätigen Werkstatt tätig. ${ }^{48}$ Sie erkannte bei den Köpfen der Frankfurter Skulpturen einen Kopftypus wieder, der sich zuvor am Lorenzer Portal ausgebildet hatte. Die schmale Kopfform mit dem betonten Kinn und der spitzen Nase, die von großwelligen Haarsträhnen gerahmt werden, verbindet die Frankfurter Maria mit der Nürnberger Madonna am Trumeau des Westportals der St. Lorenzkirche. Lilli Fischel schlug eine Datierung zwischen 1360 und 1365 vor. ${ }^{49}$ Barbara Bott setzte das Portal früher an. Sie vermutete, dass ein in den Quellen nachweisbarer Meister Antze die Portalplastik bereits im Jahre 1353 schuf. ${ }^{50}$ Da 1353 das Südportal noch nicht errichtet war, ist das von Bott vorgeschlagene Datum unwahrscheinlich. Sie selbst hebt die Nähe zwischen den Reliefs des Nordportals, dessen Bauschmuck sie um 1360 datiert, und den Arbeiten des Südportals hervor, ohne die nötige Schlussfolgerung daraus zu ziehen. ${ }^{51}$ Jiří Fajt und Mar- kus Hörsch nahmen 2006 an, dass eine Abspaltung von der zuvor an der Nürnberger St. Lorenkirche beschäftigten Werkstatt in Frankfurt tätig war. Der für Frankfurt neue Stil zeigte, nach Auffassung der beiden Autoren, den Wechsel des Domkapitels weg von Kaiser Ludwig dem Bayern und hin zu Karl IV. an. ${ }^{52} 2008$ betonte Christian Freigang den Einfluss der Stadtpfarrei beim Bau des Südflügels. Christian Freigang zog daraus den Schluss, dass das Südportal »eine neue städtische Identität $\aleph^{53}$ widerspiegelt. Für den Autor war diese bedeutender als die »Symbolik der Wahlkirche«. ${ }^{54} 2016$ schloss sich Markus Hörsch den Überlegungen Christian Freigangs zum Südportal an. Der neue Stil der Portalskulpturen ist für Markus Hörsch »ohne tiefergehende Absicht« eingeführt worden. ${ }^{55}$

An der um 1360 entstandenen Südfront der Marienkirche in Mühlhausen sieht man ebenfalls eine vollplastische Anbetung der Drei Könige (Abb. 28).

Die beiden Darstellungen am Frankfurter Dom und in Mühlhausen verbindet neben den Ähnlichkeiten bei der Ausführung des ältesten Königs die Einführung 


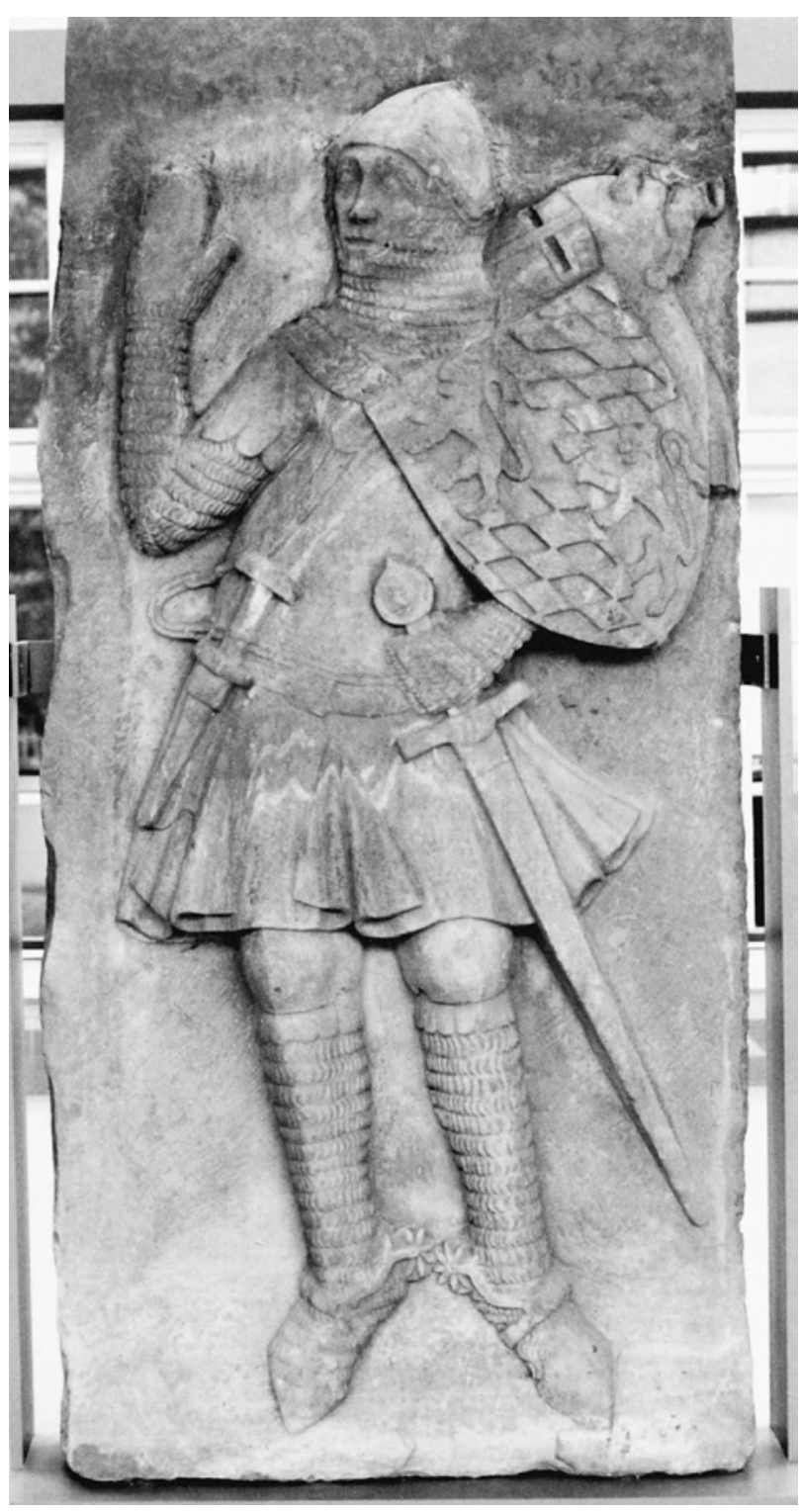

Abb. 29 Relief des Kurfürst-Pfalzgrafen bei Rhein vom ehem. Mainzer Kaufhaus. Mainz, Landesmuseum (Foto: M. Hörsch)

einer vertikalen Leserichtung. Wie bei dem Frankfurter Portal verweist der mittlere König auf das nachfolgende Geschehen, indem er mit seinem Finger auf den im Giebel in Mühlhausen gezeigten Christus als Weltenrichter zeigt. Und wie in Frankfurt wird der älteste König durch ein unter ihm angebrachtes Kunstwerk näher bestimmt. Die Figur Karls IV. unterhalb der Anbetung ist die einzige auf dem Scheinaltan, die in eine Achse mit einer Figur der Anbetung gebracht wurde. Dadurch wird eine Identifikation Karls IV. mit dem ältesten König hergestellt. ${ }^{56}$
In Frankfurt ist die Anspielung auf Karl IV. subtiler und gleichzeitig liefert sie den Schlüssel für das Verständnis des Tympanons. Unterhalb des ältesten Königs sieht man einen Ritter mit einem Löwen kämpfen (Abb. 27). Sein Schwert kann ihm bei der Abwehr des angreifenden Löwen nicht mehr helfen. Die Spitze ist abgebrochen und der Löwe hat ihn am Bein gepackt. Der Ausgang ist entschieden: Der Ritter ist zu Boden gegangen. Genauer bestimmen lässt sich die Ritterfigur, wenn man die Kurfürstendarstellungen vom Mainzer Kaufhaus als Vergleich heranzieht (1317, Abb. 29).

Dort findet man nicht nur das Kettenhemd mit dem darüber gezogenen Lederwams. Auch die eiförmige Mütze und deren zum seitlichen und hinteren Schutz des Kopfs angeknüpfte Kettenglieder sind hier vorgebildet. Die Schwerter der Kurfürsten haben alle einen zweiten aufgesetzten kleineren Kreis im Knauf, wie man ihn auch bei dem am Boden liegenden Ritter in Frankfurt sieht. Zwei Merkmale zeigen aber nur der kleine Ritter und einer der Kurfürsten des Mainzer Kaufhauses: Der Helm mit den schmalen rechteckigen Sehschlitzen und der ovalen Spitze ist nur beim Pfalzgrafen bei Rhein zu finden. Und nur beim pfälzischen Kurfürsten fallen die beiden Ketten, an denen das Schwert und der Dolch befestigt sind, so zusammen, dass man sie, wie es beim Ritter am Dom zu sehen ist, für dieselbe Kette halten könnte. Unterstrichen wird die Nähe der beiden Darstellungen durch die Gestik und Beinstellung, wobei sich der kleine Ritter spiegelbildlich zum Kurfürsten verhält. Das linke angewinkelte Bein des Kurfürsten entspricht dem rechten abgespreizten des Ritters. Der angewinkelte Arm mit dem Schwert kann, da teilweise durch den Schild verdeckt, nur gedanklich nachvollzogen werden. Bei der gedrängten Situation ist ein scharfer rechter Winkel wie bei dem Ritter in Frankfurt zu vermuten, während der andere Arm nicht den spitzen Winkel des pfälzischen Kurfürsten annehmen muss, sondern entspannter als 90-Grad-Winkel gegeben wird. Der Ritter benutzt diesen Arm als Stütze. Der Pfälzer Kurfürst des Mainzer Kurfürstenzyklus ist aber kein anderer als Ludwig der Bayer, der in seiner Frankfurter Version als zu Fall gebrachter Ritter mit gebrochenem Schwert erscheint. Gezielt wurde er als Kurfürst und nicht als römischer König dargestellt, wie er auch am Kaufhaus zu sehen war. Dadurch wurde seine Krönung negiert. Dass ihn ein Löwe, das Wappentier der Luxemburger, stürzt, versinnbildlicht den Kampf Karls IV. gegen den Wittelsbacher und den letztendlichen Sieg des Luxemburgers. 
Am Dom kombinierte man die Heiligen Drei Könige mit zwei der St.-Bartholomäus-Kirche eng verbundenen Heiligen. Oberhalb der Anbetung, heraldisch rechts des Tympanons, steht der namensgebende Patron der Kirche und auf der anderen Seite Karl der Große. In seiner Hand hält er einen polygonalen Zentralbau als Kirchenmodell. Wenn man Karl den Großen in Frankfurt als Stifter des Doms kennzeichnen wollte, gab man ihm aber ein Kirchenmodell in Form eines Longitudinalbaues mit vier schlanken Türmen an den beiden Enden in die Hand, so an dem etwa zehn Jahre zuvor gefertigten Chorgestühl der Barthomoläuskirche (Abb. 30).

Seit der Mitte des 14. Jahrhunderts förderte man in Frankfurt den Mythos von Karl dem Großen als Gründer von Kirche und Stift. ${ }^{57}$ Das Kirchenmodell Karls des Großen am Portal verweist dagegen auf eine andere Kirche: Ein solcher von Giebelfronten umstellter Zentralbau mit hoher Turmspitze begegnet ähnlich bei einem Modell der Aachener Marienkirche, das man Karl dem Großen an einem Reliquiar in Aachen in die Hand gegeben hat $(1346 / 55) .{ }^{58}$ Dieses Kirchenmodell erklärt das stärkere Hervortreten eines der Giebel an dem Kirchlein in Frankfurt. Das Münster ist bei dem Aachener Kirchlein mit Chor und Westwerk ausgestattet, wobei der Chor noch seinen alten karolingischen, geraden Abschluss zeigt, der bei dem Frankfurter Kirchlein durch sein stärkeres Hervortreten betont wird. Als wichtiger Ort der Krönungszeremonie bleibt er beim Neubau des Chors in Aachen durch den Grundriss der Marienkapelle erhalten. Das Reliquiar ist vermutlich Teil des Bemühens Karls IV. um die Erinnerung an seinen bedeutenden Amtsvorgänger und gleichsam Namenspatron, Karl den Großen. Aus Anlass seiner eigenen Krönung gab er ein Büstenreliquiar Karls des Großen für das Aachener Münster in Auftrag, mit dem er »sein bewusstes Anknüpfen an die karolingische Traditionslinie bekundete. ${ }^{59}$ In Anlehnung an die Marienkirche in Aachen wurde die Karlshofer Kirche in Prag (Praha) als achteckiger Zentralbau erbaut. ${ }^{60}$ Für dieses Anknüpfen an die Tradition Karls des Großen konnte Karl IV. seine verwandtschaftlichen Beziehungen geltend machen. ${ }^{61}$ Unterstützt wird dies in Marignolas Geschichte Böhmens, in der eine legendarische Abstammungstafel Karls IV. entworfen wird, mit Karl dem Großen als einem der Ahnherren des Luxemburgers. Vermutlich auf diese Ahnentafel ging der heute verlorene, aber rekonstruierbare gemalte Luxemburger-Stammbaum auf Burg Karlstein zurück, der auch ein Bild Karls des Großen zeigte. ${ }^{62}$ Einen Zusammenhang zwischen Karl dem Großen und

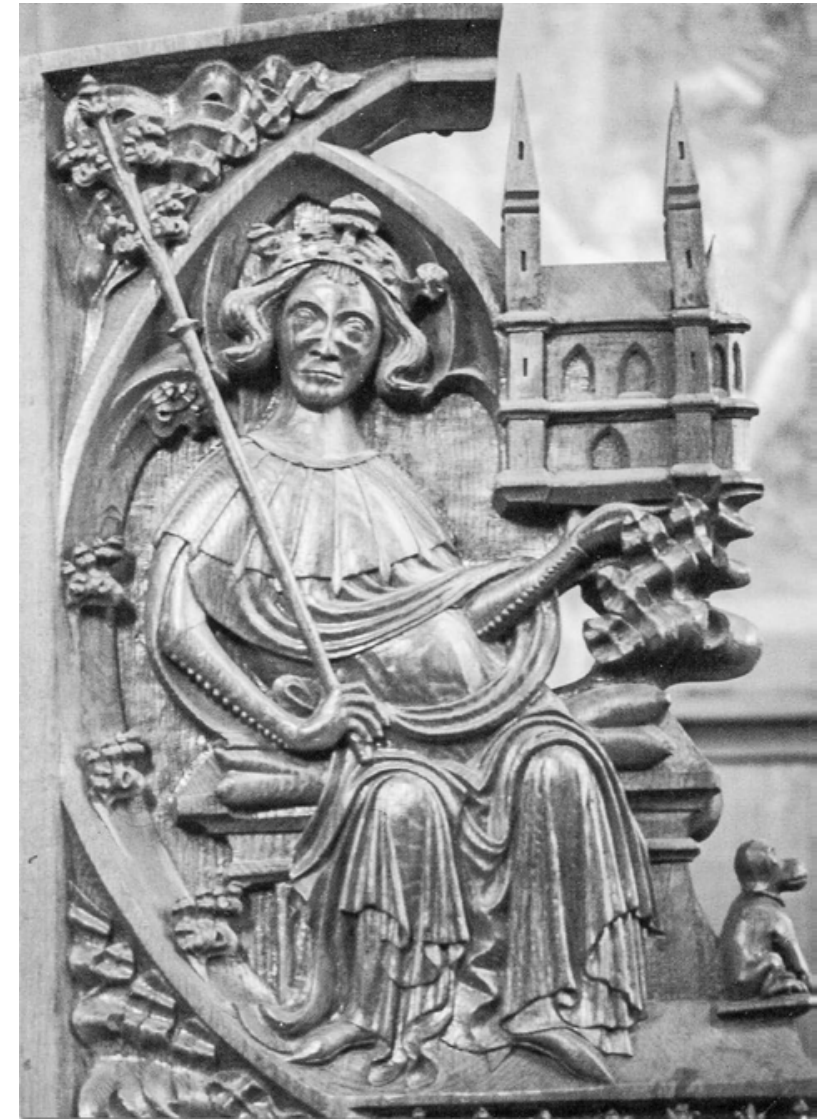

Abb. 30 Darstellung Kaiser Karls des Großen als Stifter des Frankfurter Kollegiatstifts auf einer Wange des Chorgestühls. Frankfurt/M., St. Bartholomäus (Foto: hist. Postkarte, Archiv M. Hörsch)

der Bartholomäuskirche stellt die Bestätigungsurkunde Karls IV. für das Stift vom 19. Januar 1359 her, in der auf Karl den Großen ausdrücklich Bezug genommen wird. ${ }^{63}$

Die St.-Bartholomäus-Kirche war gleich mehrfach in die Zeremonie der Königswahl eingebunden. Sie war der Ort der Wahl; dem höchsten Geistlichen des Bartholomäusstifts kamen im Zeremoniell wichtige Aufgaben zu, und der Heilige Bartholomäus selbst bezeugte die Wahlfeier. ${ }^{64}$ Das Reliquiar des »Reichsersatzpatrons $«{ }^{65}$ stand während der Wahlmesse auf dem Hochaltar, an dem, so wünscht es die Goldene Bulle, die Eröffnungsmesse zum Heiligen Geist gefeiert werden sollte. ${ }^{66}$ Wie bei den Heiligen Drei Königen gibt es beim Heiligen Bartholomäus einen besonderen Bezug zu Karl IV., denn in der Familiengeschichte der Luxemburger kam ihm eine besondere Stellung zu: Der erste römisch-deutsche König und Kaiser aus dem Hause Luxemburg, Heinrich VII., starb am St.-Bartholomäus-Tag (24. August). Sein 1494 aus dem Chor entferntes Grabmal in Pisa war ursprünglich mit 
einem Altar verbunden, der Reliquien des heiligen Bartholomäus verwahrte. Im Volksmund als »Kaiserlicher Altar « bezeichnet, befand sich auf seiner Mensa, neben einer Statuette der Madonna mit dem Kind, eine Figur des heiligen Bartholomäus. ${ }^{67}$ Dass man sich an diese Umstände erinnerte, legt die Feier der Altarsetzung nahe. Heinrich VII. war vermutlich der erste römisch-deutsche König, bei dessen Krönung diese Zeremonie in Frankfurt gefeiert wurde. ${ }^{68}$

Das bereits erwähnte Morgan-Diptychon, entstanden im Umkreis Karls IV., verbindet die Heiligen Drei Könige mit dem Heiligen Petrus, und, auf einer zweiten Bedeutungsebene, Karl IV. mit Innozenz VI. Der mittlere König auf dem Bild trägt die Züge Karls IV, und vermutlich handelt es sich bei dem auf dem Marientod gegenüber gezeigten Petrus um ein Portrait Innozenz' VI. ${ }^{69}$ Für Olga Pujmanová erinnert es an die engen Beziehungen, die zwischen Karl IV. und Innozenz VI. bestanden. ${ }^{70}$ Die Unterstützung durch den Papst war eine der Voraussetzungen für die Einsetzung Karls IV. als römischer König. ${ }^{71}$ In Frankfurt zeigen der große Schlüssel in der einen Hand und das Evangeliar in der anderen, dass es sich um den Apostel Petrus in seiner Funktion als Bischof von Rom handelt. Vielleicht ist die neben ihm stehende Figur der Apostel Paulus. Dies würde im Zusammenhang mit der königlichen Aussage des Portals an ottonische Krönungsdarstellungen erinnern, auf denen die beiden Heiligen die Aufgabe übernehmen, die Insignien an den Herrscher zu übergeben. ${ }^{72}$

Karl IV. zelebrierte 1349 in Frankfurt die Altarsetzung und in Aachen seine Thronsetzung. Es sind nur Bestandteile der Wahl- bzw. Krönungszeremonie, die die bereits an anderen Orten durchgeführten Zeremonien nicht in Gänze wiederholen. Das Südportal erinnert mit seinem Programm an die Herrschererhebung Karls IV., indem es durch den heiligen Bartholomäus auf das Wahlverfahren verweist und durch Karl den Großen auf die Krönung. Ins Zentrum der Darstellung wird die Anbetung des ältesten Königs gerückt, der hier als Vorläufer der römisch-deutschen Könige vor Maria und dem Jesusknaben kniet. Durch das Relief zu seinen Füßen wird eine Verbindung zu Karl IV., dem »Bezwinger« Kaiser Ludwigs des Bayern, hergestellt. In Frankfurt gab es ein Zeremoniell, das die Niederlage Ludwigs des Bayern zum Ausdruck brachte. Am 17.6.1349 fand die Altarsetzung Karls IV. in der St.-Bartholomäus-Kirche statt. Diese Feier markierte den Übertritt der Freien Reichsstadt zu Karl IV., die bis zum Tode Ludwigs auf dessen Seite gestanden und da- nach Günther von Schwarzburg unterstützt hatte. Aus diesem Grund musste seinerzeit die Wahl Karls IV. in Rhens stattfinden. Für Karl IV. bedeutete der feierliche Einzug in die Freie Reichsstadt mit der anschließenden Zeremonie in der Bartholomäuskirche eine zusätzliche Legitimation seiner Herrschaft und ein Anknüpfen an die Tradition seines Großvaters Heinrich VII. Aus städtischer Sicht und aus Sicht des Bartholomäusstifts kam den nachgeholten Feiern hohe Bedeutung zu: Die erst kurze Tradition der Bartholomäuskirche als Wahlort des römischen Königs wäre ohne diese Feiern unterbrochen worden und der Wahlort damit zukünftig in Frage gestellt gewesen. Als Initiator des Programms muss man deswegen einen Mann vermuten, der an der Schnittstelle zwischen diesen Institutionen wirkte.

\section{Ein Mann Karls IV. in Frankfurt: Siegfried zum Paradies als Stifter des Südportals}

Die Namen der Stifter, die zu beiden Seiten der Kreuzigung am Südportal dargestellt sind, kennt man nicht. Den Vorschlag, in der männlichen Figur denselben Stifter wie für das Grabmal Günthers von Schwarzburg anzunehmen, hat schon Christian Freigang in Frage gestellt. ${ }^{73}$ Der Stadtschultheiß Rudolf von Sachsenhausen war ein Parteigänger Ludwigs des Bayern. Die deutlich auf Karl IV. bezogene Ikonografie des Portals legt es vielmehr nahe, unter den Anhängern des Luxemburgers nach dem Stifter zu suchen. Unter ihnen sticht ein Mann hervor: Siegfried zum Paradies. In Marburg geboren, hatte er 1347 die Frankfurter Bürgerrechte erworben. Hier wurde Siegfried zum wichtigsten Vermittler zwischen der Stadt und Karl IV. ${ }^{74}$ Durch Unterstützung Karls gelangte er auf eine Schöffenstelle und wurde am 18. April 1366 Stadtschultheiß. Michael Lindner weist darauf hin, dass es Siegfried zum Paradies zu verdanken ist, dass Frankfurt als erste Stadt eine Abschrift der Goldenen Bulle Karls IV. erhielt. Besondere Auszeichnung erfuhr Siegfried, indem ihn Karl IV. zu seinem Rat ernannte. Lindner bezeichnete diesen Vorgang als »eine Würde, die vor ihm bei keinem anderen reichsstädtischen Großbürger belegt ist. ${ }^{75}$ Karl IV. band Siegfried zum Paradies in die Wahlzeremonie ein. Ihm und seinen Erben wurde am 12. Juni 1376, zwei Tage nach der Wahl Wenzels IV., für die Zukunft das Anrecht auf das Pferd zugesprochen, auf dem der designierte römisch-deutsche König zur Wahlkirche ritt. ${ }^{76}$ Auch nach dem vom Frankfurter Rat am 2. Juni 1372 
beim Kaiser durchgesetzten Rücktritt Siegfrieds vom Amt des Stadtschultheißen ${ }^{77}$ stand dieser weiterhin in der Gunst Karls IV. Aus der Ehe mit seiner zweiten Frau Katharina zum Wedel entstammt Peter vom Paradies, der 1416 einen Ablass des Mainzer Erzbischofs zum weiteren Ausbau der Frankfurter Liebfrauenkirche erwirkte. ${ }^{78}$

Zur Identifizierung der Stifterfigur am Südportal trägt ein Vergleich mit dem Grabstein des Siegfried zum Paradies in der St. Nikolaikirche bei. ${ }^{79}$ Beide Figuren, mit einer Gugel bekleidet, sind kniend im Betgestus gezeigt. Auf dem Grabstein besteht der Unterschied nur darin, dass die Figur in Profilansicht statt in Dreiviertelansicht gegeben wurde. Sogar das Abknicken des Kopfes zur rechten Seite übernimmt der Grabstein. In beiden Darstellungen entsteht durch diese Hinwendung eine Verbindung zwischen dem Kopf Jesu und dem Beter. Die Gesichter der Anbetenden am Tympanon und auf dem Stein der Nikolaikirche verfügen über feine Züge und eine zierliche Nase. Die mittellang geschnittene Frisur lässt bei beiden die Stirn und das rechte $\mathrm{Ohr}$ frei.

Das Motiv der Kreuzanbetung am Südportal unterstützt die Vermutung, dass mit der Stifterfigur Siegfried zum Paradies gemeint ist. Er war im Besitz einer vermutlich von Karl IV. geschenkten Kreuzpartikel. Eingefügt in ein kunstvoll verziertes Reliquiar stiftete Siegfried sie der Frankfurter Liebfrauenkirche. ${ }^{80}$

\section{Erinnerung an einen Staatsakt: Sigismund von Luxemburg in Frankfurt}

Die Stadt Frankfurt musste bis zum Jahr 1414 warten, bis Sigismund von Luxemburg endlich Einzug hielt. Anders als bei seinem Vater Karl IV. hinderte ihn nicht die Freie Reichsstadt am Einzug, vielmehr hielten ihn die politischen Umstände in Ungarn von dem Besuch ab. Und dies, obwohl es zwei Anlässe gab, die dringend seiner Anwesenheit bedurft hätten: 1410 und 1411 fanden in St. Bartholomäus Wahlzeremonien statt, die ohne den »Hauptdarsteller « auskommen mussten. Sigismund 1410 auf den Altar zu setzen wäre allerdings am Wirken des Mainzer Erzbischofs gescheitert, der dafür sorgte, dass den Anhängern des Luxemburgers der Zugang zur Bartholomäuskirche verwehrt wurde. 1411, nach dem raschen Tod Josts (Jobsts) von Mähren, war nun auch der Mainzer Kurfürst bereit, Sigismund zu unterstützen. Die Frage, ob die Feier am 21. Juli 1411 eine Wahl oder nur den Übertritt der Wähler Josts von Mähren zu Sigismund darstellen sollte, wurde mit Hilfe eines Kompromisses in der Schwebe gehalten. Die Vertreter Kölns und Triers verließen für die Zeit der Wahlhandlungen die Kirche. Über die anschließende Altarsetzung heißt es in einem Berichtschreiben der Stadt Nürnberg: "daz fürware unsere herren die kurfürsten und ir machtpoten, als sie iczunder zu Franckfürt waren, auf den eritag nechstvergangen den allerdurchleuchtigsten fürsten unsern gnedigen herren hern Sigmunden künig zu Ungern etc. zu einem Römischen kunig erwelt haben, und haben an seiner stat unsern gnedigen herren burggraf Johansen ewern bruder alspald auf den Altar gesaczt ... « ${ }^{81}$ Der Ordo für diesen besonderen Anlass verdeutlicht, dass es sich dabei nur um eine Ersatzhandlung handelte. Er hält ausdrücklich fest, dass der römisch-deutsche König die Altarsetzung persönlich wiederholen müsse, sobald er erstmals in Frankfurt Einzug halte. ${ }^{82}$

Wenn wir auch keine schriftlichen Quellenbelege für das Ereignis haben, so gibt es doch weitere Hinweise auf die Feier der Altarsetzung Sigismunds. Ein von der Stadt Frankfurt am 10. Dezember 1414 ausgestellter Geleitbrief belegt den gleichzeitigen Aufenthalt des Mainzer Erzbischofs und des römischen Königs in der Stadt. ${ }^{83}$ Der römische König reiste selber über Mainz an. Demnach muss es einen besonderen Anlass für das Zusammentreffen der beiden in Frankfurt gegeben haben, der sich über die vorausgegangenen Reiseziele Sigismunds erschließt.

Auf seinem Umzug im Jahre 1414 besuchte Sigismund der Reihe nach Orte, die bei der Erhebung Karls IV. eine bedeutsame Rolle gespielt hatten. Deswegen lässt sich sein Reiseweg am besten als eine Erhebung in Etappen bezeichnen. Neben seiner Krönung am 8. November in Aachen kam er nach Rhens, den Wahlort seines Vaters, und feierte dort am Königsstuhl ein Festmahl. Wie sein Vater reiste er nach Köln, um den Heiligen Drei Königen Gold zu spenden. Eine der wichtigsten Stationen auf der Reise Karls IV. war die Wahlstadt Frankfurt, in der höchstwahrscheinlich seine Altarsetzung stattfand.

Ein Indiz dafür liefert das Dreikönigsportal der Liebfrauenkirche mit seiner deutlichen Bezugnahme auf die karolinische Kunst. ${ }^{84}$ Mit Zitaten aus ebendieser Kunst aus dem höfischen Umfeld des kaiserlichen Vaters verweist das Dreikönigsportal auf die Luxemburger. ${ }^{85}$ Die Heiligen Drei Könige nahmen in der Ikonografie Karls IV. eine herausregende Stellung ein. Das belegt neben der bereits erwähnten hohen Zahl der Darstellungen der Könige das dabei oft eingesetzte Mittel des Identifikationsporträts. Sigismund tritt auch hierin die Nachfolge des Vaters 
an: Sein Porträt findet sich in der Anbetung der Heiligen drei Könige des Ortenberger Altars. Eine Vorlage für ein Identifikationsporträt Sigismunds befand sich in Mainz, dem wahrscheinlichen Entstehungsort des Ortenberger Altars. Für Mainz ist durch die Beschreibung Eberhard Windeckes die Erinnerung an ein Wandgemälde erhalten, auf dem Sigismunds Antlitz bei einem der Könige eingefügt worden war. ${ }^{86}$ In England wurde zu seinen Ehren ein Dreikönigsspiel aufgeführt. ${ }^{87}$

Den Hinweis auf die Familie Sigismunds am Dreikönigsportal kann man noch konkreter benennen, entstammt doch auch das Motiv des Goldklumpens als Geschenk des mittleren Königs der karolinischen Ikonografie. Eine Darstellung der Heiligen Drei Könige im Stundenbuch des Johann von Neumarkt, Kanzler Karls IV., spielt in einer Initiale mit einer bis dahin einmaligen ikonografischen Lösung auf die Taufe Wenzels an. Nach Auffassung Olga Pujmanovás ist mit der Figur des jüngsten Königs in der Initiale Wenzel IV. selbst gemeint. ${ }^{88}$ Dies würde erklären, warum am Frankfurter Tympanon der Goldklumpen als Geschenk des mittleren und nicht des jüngsten Königs zu sehen ist. Der jüngste König aus dem Hause Luxemburg war in der Zeit der Entstehung des Dreikönigstympanons Sigismund von Luxemburg, der jüngere Bruder Wenzels. Versteht man den jüngsten König als Anspielung auf Sigismund, dann begreift man auch die hervorgehobene Stellung, die er in der Inszenierung des Reliefs einnimmt. Zum einen hebt ihn seine kompositorische Funktion als Bindeglied zwischen der Szene der Anbetung und den anreitenden Zügen heraus. Zum anderen zieht er, rechts von der Mittelachse stehend, mit seiner auffallenden Kleidung die Blicke auf sich.

Am Südportal der Bartholomäuskirche weisen der Heilige Bartholomäus und Karl der Große auf die Einsetzungszeremonien für Karl IV. hin. Diese Aufgabe übernehmen meiner Ansicht nach am Dreikönigsportal die Propheten Jeremias und Jesaja, denn sie spielen mit ihren Gewand- und Gestenzitaten auf die Darstellungen der Mainzer Erzbischöfe an. Diese bestimmten als Wahlleiter über den Zeitpunkt der Wahl, fragten der Reihe nach die Stimmen der anderen Kurfürsten ab und entschieden mit einem in der Goldenen Bulle garantierten Letztstimmrecht die Königswahl. Die Erzbischöfe aus dem Hause Nassau waren den Luxemburgern besonders verbunden. Gerlach von Nassau stimmte 1348 für Karl IV." ${ }^{89}$ Adolf von Nassau wechselte 1381 endgültig auf die Seite Wenzels IV. ${ }^{90}$ und Johann II. von Nassau unterstützte bei der Wahl 1411 Sigismund von Luxemburg. ${ }^{91}$
Der erste Ablass des Mainzer Erzbischofs aus dem Jahre 1415 zeigt an, dass sich die Liebfrauenkirche bereits im Ausbau befand. Ein Archivoltenportal sollte als neuer Haupteingang dienen, geschmückt durch einen Figurenkranz, wie ihn auch das Memorienportal in Mainz aufweist. Als Ende des Jahres 1414 Sigismund Einzug hielt, um den letzten Akt für seine Legitimation als römischdeutscher König zu feiern, veränderte dies die ursprünglichen Pläne. Entwickelt wurde ein Portalprogramm, das mit seinen Rückgriffen auf die karolinische Kunst auf die Tradition des Hauses Luxemburg verweist und mit dem Zitieren des Südportals der Bartholomäuskirche den Anlass für die Veränderung genauer bestimmt. Das Portal der St.-Bartholomäus-Kirche versinnbildlicht die Anerkennung Karls IV., die sich im zeremoniellen Akt seiner Altarsetzung manifestierte. Dies wird am Dreikönigsportal ergänzt um eine Anspielung auf die Mainzer Erzbischöfe. Durch ihre herausgehobene Rolle im Wahlverfahren konnten sie den römischen König sozusagen prophetengleich antizipieren. Sie leiteten, zusammen mit dem höchsten Geistlichen am Bartholomäusstift, die abschließende Feier der Wahl, die Altarsetzung des römischen Königs. Veranlasst wurden die Bauänderungen am Dreikönigsportal, so darf man vermuten, durch ein Mitglied einer seit Karl IV. mit den Luxemburgern verbundenen Familie: den mit einer geborenen Gerthener verheirateten Peter zum Paradies. ${ }^{92}$

\section{Literatur}

Altmann, Wilhelm: Die alte Frankfurter Deutsche Übersetzung der goldenen Bulle Kaiser Karls IV. In: Zeitschrift der Savigniy-Stiftung für Rechtsgeschichte, Germanistische Abteilung 18 (1897), 107-147.

Arens, Fritz: Der Dom zu Mainz. Darmstadt 1982.

[Ausst.-Kat. Frankfurt/M. 1975]: Ausst.-Kat. Kunst um 1400 am Mittelrhein. Ein Teil der Wirklichkeit. Hg. von Herbert Beck, Wolfgang BeEH und Horst BredeKamp. Frankfurt/M., Liebieghaus Museum Alter Plastik, 10.12.1975-15.2.1976. Frankfurt/M. 1975.

[Ausst.-Kat. Frankfurt/M. 2006]: Die Kaisermacher. Frankfurt am Main und die Goldene Bulle 1356-1806. Hg. von Evelyn Broскноғғ u. a. Frankfurt/M., Institut für Stadtgeschichte; Historisches Museum; Dommuseum; Museum Judengasse, 30.9.2006-14.1.2007. Bd. 2: Aufsätze. Frankfurt/M. 2006.

[Ausst.-Kat. Köln 1978] : Ausst.-Kat. Die Parler und der Schöne Stil 1350-1400. Europäische Kunst unter den Luxemburgern. Hg. von Anton Legner. 3 Bde. Köln 1978. 
[Ausst.-Kat. Mainz 2011]: Ausst.-Kat. Der verschwundene Dom. Wahrnehmung und Wandel der Mainzer Kathedrale im Lauf der Jahrhunderte. Hg. von Hans-Jürgen Kotzur. Mainz, Bischöfliches Dom- und Diözesanmuseum, 15.4.-16.10.2011. Mainz 2011.

[Ausst.-Kat. Prag 2006]: Ausst.-Kat. Karl IV., Kaiser von Gottes Gnaden. Kunst und Repräsentation unter den Luxemburgern 1347-1437. Hg. von Jiří FAJT unter Mitwirkung von Markus Hörsch und Andrea LANGER. Prager Burg, 15.2.-21.5.2006. München/Berlin 2006; tschechische Ausgabe Praha 2006.

[Ausst.-Kat. Prag/Nürnberg 2016]: Ausst.-Kat. Kaiser Karl IV. 1316-2016. Erste Bayerisch-Tschechische Landesausstellung. Hg. von Jiř́i FAJT und Markus Hörsch. Prag, Wallenstein-Reitschule, 15.5.-25.9.2016; Prag, Carolinum, 14.5.31.8.2016; Nürnberg, Germanisches Nationalmuseum, 20. 10.2016-5.3.2017. Praha 2016.

BACK, Friedrich: Mittelrheinische Kunst. Beiträge zur Geschichte der Malerei und Plastik im vierzehnten und fünfzehnten Jahrhundert. Frankfurt/M. 1910.

BeEH, Wolfgang: Die Werkstatt Madern Gertheners. In: Ausst.Kat. Frankfurt/M. 1975, 49-55.

BAUCH, Kurt: Das mittelalterliche Grabbild. Figürliche Grabmäler des 11. bis 15. Jahrhunderts in Europa. Berlin/New York 1976.

Behland, Max: Die Dreikönigslegende des Johannes von Hildesheim. Untersuchungen zur Niederrheinischen Übersetzung der Trierer Handschrift 1183/458 mit Textedition und vollständigem Wortformenverzeichnis. München 1968.

Bering, Kunibert: Die Bauten Karls IV. in Prag und Karlstein. Ein Reflex staufischer Konzepte? In: BerIng/MöNIG 1988, 91-124.

Bering, Kunibert/Mönig, Roland: Herrschaftsbewußtsein und Herrschaftszeichen. Zur Rezeption staufischer Architekturformen in der Baupropaganda des 13. und 14. Jahrhunderts. Essen 1988 (Kunst, Geschichte und Theorie 10).

Boeselager, Dela von: Zur Salbung und Krönung in der Liturgie des Ordo. In: Ausst.-Kat. Frankfurt/M. 2006, 338-345.

Bogade, Marco: Kaiser Karl IV. Ikonographie und Ikonologie. Diss. Bamberg 2004; Stuttgart 2005.

Вотт, Barbara: Gotische Plastik in Frankfurt. Ein Beitrag zur Geschichte der mittelrheinischen Skulptur 1300-1430. Frankfurt/M. 1957.

Bотт, Barbara: Die Plastik der Frankfurter Domportale. In: Schriften des Historischen Museums Frankfurt am Main 10 (1962), 5-52.

BRÜCK, Anton Philipp (Hg.): Willigis und sein Dom. Festschrift zur Jahrtausendfeier des Mainzer Domes 975-1975. Mainz 1975 (Quellen und Abhandlungen zur Mainzer Kirchengeschichte 24).

Büttner, Andreas: Der Weg zur Krone. Rituale der Herrscher- erhebung im spätmittelalterlichen Reich. 2 Bde. Ostfildern 2012 (Mittelalter-Forschungen 35).

[Christern 1963]: Hildesheim, Johannes von: Die Legende von den Heiligen Drei Königen. Übertragen von Elisabeth Christern. München 1963.

Christmann, Daniela (Hg.): RückSicht. Festschrift Hans-Jürgen Imiela. Mainz 1997.

Crossley, Paul: The Politics of Presentation. The Architecture of Charles IV of Bohemia. In: ReEs Jones/Marks/Minnis 2000, 99-172.

EdLer, Josef: Die Liebfrauen-Kirche zu Frankfurt a. M. und ihre Kunstwerke. Diss. Frankfurt/M. 1938; Düren 1938.

Ehresmann, Donald L.: Middle Rhenish Sculpture 1380-1440. Diss. New York 1966.

Ehresmann, Donald L.: The Frankfurt Three Kings Portal, Madern Gerthener, and the International Gothic Style on the Middle Rhine. In: The Art Bulletin 50 (1968), 301-308.

FAJT, Jiř́l/Hörsch, Markus: Karl IV. und das Heilige Römische Reich. Zwischen Prag und Luxemburg - eine Landbrücke in den Westen. In: Ausst.-Kat. Prag 2006, 357-383.

FAJT, Jiří/LANger, Andrea (Hgg.): Kunst als Herrschaftsinstrument. Böhmen und das Heilige Römische Reich unter den Luxemburgern im europäischen Kontext. Tagung Prag, Mai 2006. Berlin/München 2009.

FAJT, Jiří/Royt, Jan: Magister Theodoricus. Hofmaler Kaiser Karls IV. Die künstlerische Ausstattung der Sakralräume auf Burg Karlstein. Praha 1997.

Feulner, Adolf: Der Bildhauer Madern Gerthner. In: Zeitschrift des Deutschen Vereins für Kunstwissenschaft 7 (1940), 1-26.

Fischel, Lilli: Mittelrheinische Plastik des 14. Jahrhunderts. München 1923 (Kompendien zur deutschen Kunst 1).

Fischer, Friedhelm Wilhelm: Die spätgotische Kirchenbaukunst am Mittelrhein 1410-1520. An charakteristischen Beispielen dargestellt, nach Schulen geordnet und mit historisch-topographischen Darlegungen verknüpft. Diss. Heidelberg 1959/60; Heidelberg 1962 (Heidelberger Kunstgeschichtliche Abhandlungen N. F. 7).

Folz, Robert: Le souvenir et la légende de Charlemagne dans l'Empire germanique médiéval. Diss. Paris 1950; Genève 1973.

Franzen, Wilfried: Das Bornhofener Retabel, Johann IV. von Katzenelnbogen und die Hofkunst Sigismunds von Luxemburg. In: FAJT/LANGER 2009, 424-439.

Freigang, Christian: Bauen im Schatten des Prager Doms. Die Frankfurter Stiftskirche St. Bartholomäus zwischen Reichspolitik und städtischen Interessen. In: FAJT/LANGER 2009, 101-115.

Froning, Richard (Bearb.): Frankfurter Chroniken und an- 
nalistische Aufzeichnungen des Mittelalters. Frankfurt/M. 1884 (Quellen zur Frankfurter Geschichte 1).

Gast, Uwe: Der Große Friedberger Altar und der Stilwandel am Mittelrhein nach der Mitte des 14. Jahrhunderts. Diss. Freiburg/Br. 1997; Berlin 1998 (Neue Forschungen zur deutschen Kunst 1).

Gordon, Dillian/Monnas, Lisa/Elam, Caroline (Hgg.): The Regal Image of Richard II and the Wilton Diptych. London 1997.

Heinig, Paul-Joachim: Die Mainzer Kirche im Spätmittelalter 1305-1484. In: JÜRGENSMEIER 2000, 416-554.

Hoensch, Jörg K.: Die Luxemburger. Eine spätmittelalterliche Dynastie gesamteuropäischer Bedeutung 1308-1437. Stuttgart 2000 (Urban-Taschenbücher 407).

Hörsch, Markus: Stützen des Kaisers? Die Reichsstädte und die kaiserliche Repräsentation. In: Ausst.-Kat. Prag/Nürnberg 2016, 195-201.

Hohensee, Ulrike (Hg.): Die Goldene Bulle. Politik - Wahrnehmung - Rezeption. Bd. 1. Berlin 2009 (Berlin-Brandenburgische Akademie der Wissenschaften. Berichte und Abhandlungen. Sonderband 12).

Hruza, Karel/KaAr, Alexandra (Hgg.): Kaiser Sigismund. Zur Herrschaftspraxis eines europäischen Monarchen (13681437). Wien/Köln/Weimar 2012 (Forschungen zur Kaiserund Papstgeschichte des Mittelalters. Beihefte zu den Regesta imperii 31).

Jürgensmeier, Friedhelm: Das Bistum Mainz. Von der Römerzeit bis zum II. Vatikanischen Konzil. Frankfurt/M. 1989 (Beiträge zur Mainzer Kirchengeschichte 1).

Jürgensmeier, Friedhelm (Hg.): Christliche Antike und Mittelalter. Würzburg 2000 (Handbuch der Mainzer Kirchengeschichte 1).

KavKA, František: Am Hofe Karls IV. Leipzig 1989 (Herrscher, Höfe, Hintergründe).

Kellner, Wolf Erich: Das Reichsstift St. Bartholomäus zu Frankfurt am Main im Spätmittelalter. Diss. Marburg 1960; Frankfurt/M. 1962 (Studien zur Frankfurter Geschichte 1).

Kerber, Ottmar: Denkmäler des Domes in Mainz. In: BrüCK 1975, 393-435.

KLARE, Wilhelm: Die Wahl Wenzels von Luxemburg zum römischen König 1376. Diss. Münster 1989; Münster/W. 1990 (Geschichte 5).

KLOFT, Matthias Theodor: „Weil dessen Oberhaupt ... Gesalbter des Herrn und auf keine Weise zu verletzen und anzutasten ist.« Die Rolle der Liturgie bei Königswahl und Kaiserkrönung in Frankfurt. In: Ausst.-Kat. Frankfurt/M. 2006, II, 326-337.

KNIfFler, Gisela: Die Grabdenkmäler der Mainzer Erzbischöfe vom 13. bis zum frühen 16. Jahrhundert. Untersuchungen zur Geschichte, zur Plastik und zur Ornamentik. Köln 1978 (Dissertationen zur Kunstgeschichte 7).

Knüvener, Peter: Unbekannte Retabel und Skulpturen des späten 14. Jahrhunderts in Brandenburg und benachbarten Gebieten. In: FAJT/LANGER 2009, 495-514.

Kotzur, Hans-Jürgen/Ecker, Diana: Das verschwundene Martins-Chörlein. Auf den Spuren eines architektonischen Kleinods. In: Ausst.-Kat. Mainz 2011, 239-261.

Koziol, Geoffrey: Begging, Pardon and Favor. Ritual and Political Order in Early Medieval France. Ithaca 1992.

Kreytenberg, Gert: Fragments of an Altar of St. Bartholomew by Tino da Camaino in Pisa Cathedral. In: The Burlington Magazine 124 (1982), 349-353.

Latomus, Johannes: Antiquitates. In: Froning 1884, 67-136.

Lindner, Michael: Es war an der Zeit. Die Goldene Bulle in der politischen Praxis Kaiser Karls IV. In: Hohensee 2009, 93-140.

Macek, Josef/Marosi, Ernő/Seibt, Ferdinand (Hgg.): Sigismund von Luxemburg. Kaiser und König in Mitteleuropa 1387-1437. Beiträge zur Herrschaft Kaiser Sigismunds und der europäischen Geschichte um 1400. Tagung, Budapest, 8.-11.7.1987. Warendorf 1994 (Studien zu den Luxemburgern und ihrer Zeit 5).

MaIER, Wilhelm: Grab beim Grabe Christi. Die Memoria des Mainzer Erzbischofs Johann von Nassau. In: MAIER/ SCHMID/SCHWARZ 2000, 231-258.

Maier, Wilhelm/Schmid, Wolfgang/Schwarz, Michael Viktor (Hgg.): Grabmäler. Tendenzen der Forschung an Beispielen aus Mittelalter und früher Neuzeit. Tagung, Trier, 24.-26.9.1997. Berlin 2000.

MatтнӓUs, Michael: Das Frankfurter Exemplar der Goldenen Bulle. In: Ausst.-Kat. Frankfurt/M. 2006, 40-63.

PANOFSKy, Erwin: Über die Reliefs an den Seitenschiffportalen der Sebalduskirche in Nürnberg. In: Belvedere 8 (1929), 13-18.

Pujmanová, Olga: Portraits of Kings depicted as Magi in Bohemian Painting. In: Gordon/Monnas/Elam 1997, 247-266.

Puth, Andreas: „Christus Dominus de hoc Seculo«. Charles IV., Advent and Epiphany on the South Transept Facade of St Mary's in Mühlhausen. In: FAJT/LANGER 2009, 515-533.

Rauch, Günter: Pröpste, Propstei und Stift von Sankt Bartholomäus in Frankfurt. 9. Jahrhundert bis 1802. Frankfurt/M. 1975.

Reber, Horst: Madern Gerthener und das Grabmal des Erzbischofs Konrad von Dhaun im Mainzer Dom. In: CHRISTMANN 1997, 59-62.

Rees Jones, Sarah/Marks, Richard/Minnis, Alastair J. (Hgg.): Courts and Regions in Medieval Europe. York 2000.

RiEger, Fritz: Die Altarsetzung der deutschen Könige nach der Wahl. Diss. Berlin 1885. 
SCHÄFER, Dorit: Der Ortenberger Altar als Mittelrheinisches Kunstwerk um 1400. In: VetTer 2000, 63-124.

Schenk, Gerrit Jasper: Von den Socken. Ein Beitrag zur Kulturgeschichte der Politik am Beispiel des Einzugs König Sigismunds zum Konzil in Basel 1433. In: HrUzA/KaAR 2012, 385-409.

Schmid, Wolfgang: Zur Geschichte und Kunstgeschichte der Luxemburger. In: SCHWARZ 1997, 9-26.

Schneider, Wolfgang Christian: Imago Christi - Mirabilia Mundi. Kaiser Otto III. im Aachener Evangeliar. In: Castrum Peregrini 173/174 (1986), 98-153.

Schoenberger, Guido: Beiträge zur Baugeschichte des Frankfurter Doms. Habil.-Schr. Frankfurt/M. 1926; Frankfurt/M. 1927 (Schriften des Historischen Museums 3).

Schultes, Lothar: Der Skulpturenfund von Buda und der Meister von Großlobming. In: MaceK/Marosi/SeibT 1994, 293-306.

Schwarz, Michael Viktor (Hg.): Grabmäler der Luxemburger. Image und Memoria eines Kaiserhauses. Luxembourg 1997 (Publications du CLUdeM 13).

StudničKová-Cerná, Milada: Sigismund von Luxemburg und die Hofkunst Karls IV. Ein Beitrag zur Ikonographie Karls IV. und Sigismunds von Luxemburg. In: MACEK/MAROSI/SEIBT 1994, 271-278.

SuCKAlE, Robert: Die Hofkunst Kaiser Ludwigs des Bayern. München 1993.

Vetter, Ewald M.: Der Ortenberger Altar. Mit Beiträgen von Dorit SCHÄFER und Renate KüHNEN. Wiesbaden 2000.

Weizsäcker, Julius (Hg.): Deutsche Reichstagsakten. Ältere Reihe, Bd. 1. 1376-1377. München 1868. Online: Http:// www.mdz-nbn-resolving.de/urn/resolver.pl?urn=urn:nbn: de:bvb:12-bsb10798053-8 (10.10.2015).

Weizsäcker, Julius/Kerler, Dietrich u.a. (Hgg.): Deutsche Reichstagsakten. Ältere Reihe, Bd. 7, Abt. 1. 1410-1420. Gotha 1878; Neudruck Gotha u. a. 1956.

Zimmermann-Deissler, Eva: Vier Meister mittelrheinischer Plastik um 140o. In: Städel Jahrbuch 3/4 (1924), 9-46.

\section{Anmerkungen}

1 Am Anfang meiner Beschäftigung mit den Werken Madern Gertheners stand meine Magisterarbeit, die mich zum Thema meiner Dissertation über den Baustil Johanns II. von Nassau führte. Die Promotion wird von Jiří Fajt betreut, dem ich wichtige Anregungen und Hinweise auch für die Ausarbeitung dieses Aufsatzes verdanke.

2 Ehresmann 1968.

3 Unterhalb der Verdachungen sieht man kleine rostige Eisenhaken, eine Vorrichtung zur Anbringung von Statuetten. Die nie gefertigten Figuren wären durch das Maßwerk völlig verdeckt worden. Anscheinend rechnete man noch nicht mit dem Maßwerkvorhang, als man die Haken anbrachte. Sie belegen, dass es sich nicht um eine gewollte Überschneidung von Archivolte und Maßwerk handelt, wie man sie beispielsweise am Freiburger Münster sehen kann.

4 Ehresmann 1968, 304. - Er nimmt damit die Datierung Friedrich Backs wieder auf, der einen Zusammenhang der Werke des Dreikönigsportals mit dem Grabmal Erzbischof Konrads III. von Daun sah und sie deswegen auf 1430 datierte. BACK 1910, 22. - Gisela Kniffler sieht nur Teile des Portals von Madern Gerthener gefertigt. Sie übernimmt die Datierung für das Relief und den »Architekturrahmen« und setzt sie auf 1425-30. KNIfFLeR 1978, 78.

5 Feulner 1940. - Die Zuschreibung wurde zuerst von Barbara Bott in Frage gestellt. Die mit Gertheners Namen verbundene Bauskulptur unterscheidet sich ihrer Meinung nach in der Qualität zu sehr von demTympanonrelief, um sie als Vergleich heranziehen zu können. Für Bott ist die Zuschreibung des Reliefs ein »Provisorium«; trotzdem bezeichnet sie es als Gertheners künstlerischen Höhepunkt und datiert es wegen seiner hohen Qualität in die späte Lebenszeit des Stadtbaumeisters, auf 1425. Вотт 1957, 105, 13 O.

6 Ehresmann 1968.

7 Die ebenfalls an diesen Steinen beiderseits zu findenden Engelsreliefs sah Feulner 1940, 8, als Beleg für die Einheit von Architektur und Skulptur an.

8 Dies zeigt sich auch daran, dass der erste Stein der Archivolte und der letzte Stein im Gewände nicht genau übereinander sitzen, während der erste Stein des Maßwerkvorhangs genau über dem Kragstein anschließt.

9 Als erstes machte Josef Edler auf die Nähe zwischen Mainzer Werken und dem Dreikönigstympanon aufmerksam. Er zieht zum Vergleich die sog. Mainzer Wappenhalterin heran (Mainz, Landesmuseum, Inv.-Nr. S 3123). EDLER 1938, 33.

10 Auf die Gemeinsamkeiten der Baldachine verwies KNIfFLer 1978, 76.

11 Beeh 1975, 50, folgte Feulner 1940, 19, und ging von einer umkehrten Entwicklung aus. Für ihn wechselte Madern Gerthener, veranlasst durch Erzbischof Johann II. von Nassau, von Frankfurt nach Mainz. Feulner machte dafür noch Konrad von Daun, den Nachfolger Johanns II. von Nassau als Erzbischof, verantwortlich.

12 Für Ehresmann war diese Verschmelzung, da er den Mainzer Schlussstein nicht wahrnahm, einer der Hauptgründe, zwischen der Mainzer und der Frankfurter Bauhütte zu trennen. EHresMAnN 1966, 190.

13 Darmstadt, Hessisches Landesmuseum, Inv.-Nr. GK 4, 4A, 4B.

14 Siehe SCHÄFER 2000, 64.

15 Berlin, Staatliche Museen - Preußischer Kulturbesitz, Skulpturensammlung, Inv.-Nr. 365a. - Ausst.-Kat. Prag 2006, 391 f., Kat.-Nr. 128.a-c (Julien ChapUIs).

16 Berlin, Staatliche Museen - Preußischer Kulturbesitz, Bode-Museum, Inv.-Nr. 8499.

17 Вотт 1957, 133, unterschied streng zwischen Frankfurt und Mainz. EHRESMANN 1966, 219, hingegen erkannte Ähnlichkeiten zwischen dem Dreikönigsportal und dem Grabstein Johanns II. von Nassau und gab beide Werke einem von ihm "Annenmeister" genannten Künstler. - KNIffler 1978, 73, veranlasste diese Beobachtung 1978 zur Zuschreibung an denselben Künstler, Madern Gerthener, womit sie Adolf Feulner folgte. - Dieser Zuschreibung schließt sich auch Reber 1997, 60, an.

18 Siehe u. а. Вотт 1957, 115. 
19 GAST 1998, 95.

20 Kerber 1975, 403, sieht einen weiteren Bildhauer neben Madern Gerthener in Mainz tätig, den er mit dem Notnamen "Meister der Karmelitermadonna« benennt. Johann II. von Nassau, so vermutet Kerber, veranlasste die Fertigung des Steins.

21 Auffällig ist, dass die beiden hier gleichsam in ihren Gewändern zitierten erzbischöflichen Grabmäler vor dem Ostchor des Domes den Altar unter dem Martinschörlein genannten Baldachin flankierten; dieser Altar war auch den Heiligen Drei Königen geweiht. Ob damit bei der Gestaltung des Tympanonbereichs des Dreikönigsportals bewusst auf das Raum- und Formkonzept der Kathedrale im Bereich vor deren Ostchor angespielt wurde (dazu vgl. im Folgenden), sei dahingestellt.

22 Kniffler 1978, 142. - Arens 1982, 74. - Maier 2000, 240.

23 Von der zwischen den beiden Steinen errichteten Doppelkapelle hat sich nur der untere Teil erhalten, der heute als Nassauer Unterkapelle bezeichnet wird. - Zur Datierung des Martinschörleins КотZUR/ECKER 2011, 259.

24 EDLER 1938, 9 .

25 Behland 1968, 11, sieht einen Zusammenhang zwischen der Entstehung der Legende und der Zweihundertjahrfeier der Reliquienübertragung der Gebeine der Könige nach Köln.

26 BEEH 1975, 55.

27 »Zuerst kam König Melchior mit seinem Gefolge vor Jerusalem auf dem Kalvarienberge an, auf dem später der Herr gekreuzigt wurde (...) Der Kalvarienberg ist ein hoher Fels, fast zwölf Stufen hoch, hier wurden damals die Verbrecher hingerichtet. In der Nähe liefen drei Straßen zusammen, dort blieb Melchior, weil er im Nebel den rechten Weg nicht wusste.« Und einen Abschnitt weiter unten stellt Johannes fest: "An dieser Kreuzung dreier Straßen trafen sich die Könige.« Zit. nach CHRISTERN 1963, $29 \mathrm{f}$.

28 PANOFSKY 1929, 14

29 Köln, Schnütgenmuseum, Inv.-Nr. K 210a, e, m.

30 Feulner 1940, 3, 21, führt die Miniaturen der Gebrüder Limburg an, sieht aber auch schon die Kunst Albrecht Altdorfers in dem Relief vorweggenommen, das er als »ein Märchen, aber für große Kinder " beschreibt, und vermutet burgundische Plastik als Vorbild. - Fischer 1962, 26, folgt ihm und sieht das Relief angeregt durch »niederländisch- französische [...] Buchmalerei«. Es erinnert ihn an Gentile da Fabriano, das wichtigste Vorbild aber sei André Beauneveu.

31 So Vetter 2000, 43: „Das Motiv [des Handkusses, H. K.] hat aber in dieser Zeit [um 1400, H. K.] bereits eine längere Tradition in der böhmischen Kunst und den davon beeinflussten Gebieten, angefangen vom Hohenfurther Dreikönigsbild, um 1350, auf dem der ältere König das Ärmchen des Kindes umgreift, ähnlich wie in Ortenberg «. 32 Pujmanová 1997, 253.

33 New York, The Morgan Library and Museum, Inv.-Nr. AZo22.1-2. Zuletzt Ausst.-Kat. Prag/Nürnberg 2016, 329, Kat.-Nr. 4.2 (Wilfried FrANZEN; mit älterer Literatur und Abbildung).

34 Die geflochtene Matte findet man kurz zuvor schon bei der Anbetung in der sächischen Kapelle im St. Veitsdom, "womit die Herkunft aus dem Zentrum karolinischer Hofkunst bestätigt werden kann.« Nachfolgend dann bei der Wandmalerei im Chor der Pfarrkirche St. Jakob in Libiš bei Mělník. KNÜvener 2009, 497.

35 Fajt/Royt 1998, 25. - Crossley 2000, 146.

36 Ehemals Müncheberg, Marienkirche; seit 1945 verschollen.
37 Prag, Knihovna Národního muzea, XIII A 12.

38 Pujmanová 1997, 254.

39 Puth 2009, 527.

40 Puth 2009, 528.

41 Boeselager 2006, 338

42 Darauf machte schon EdLer 1938, 30, aufmerksam. - Siehe auch FISCHER 1962, 26.

43 Mit Ausnahme des Bartholomäus und der Figur neben St. Peter, die nach den heute verlorenen Skulpturen als Kopien angefertigt wurden, handelt es sich bei den restlichen Skulpturen um Originale. Siehe Вотт 1962, 10.

44 Schoenberger 1927, $142 \mathrm{f}$.

45 Froning 1884.

46 Schoenberger 1927, 143. - Bott sieht das Nordportal als spätere Zutat zum Querhaus und datiert es um 1365. Ausst.-Kat. Köln 1978, I, 238, (Barbara Вотт).

47 Freigang 2009, 104.

48 Fischel 1923, 105.

49 Fischel 1923, 105.

5 Вотт 1957, 27.

51 Die Skulpturen des Nordportals wurden erst 1884 gefertigt. Вотт 1962, 25.

52 FAJT/HÖRSCH 2006, 358.

53 Freigang 2009, 112.

54 Freigang 2009, 113.

55 HÖRSCH 2016, 200.

56 Das Kaiserpaar empfängt imaginär die Huldigung der Menge, wie Maria mit dem Jesuskind die Huldigung durch die Heiligen Könige erfährt. KAVKA 1989, 97. - Durch die Huldigung drückt sich nicht nur die Unterordnung aus, sondern auch die Anerkennung der Göttlichkeit im Gegenüber. Kozıol 1997, 79.

57 Über die Fälschung einer Urkunde Karls des Dicken durch Baldemar von Petterweil um 1350, die das Barthomlomäusstift durch "primo per Bippinum et Karolum magnum « gegründet sieht, RAUCH 1975, 216

58 Aachen, Domschatz, Inv.-Nr. Gr 70.

59 Aachen, Domschatz, Inv.-Nr. Gr 69. - Hoensch 2000, 117.

6o BERING 1988, 96.

61 Folz 1973, 439.

62 FolZ 1973, 442. - Schmid 1997, 16.

63 Kellner 1962, 19.

64 KLOfT 1993, 343.

65 Suckale 1993, 93.

66 Goldene Bulle: Kap II. $\$ 2,4$.

67 Kreytenberg 1982, 353. - Ebd., 349, hält es Gert Kreytenberg für möglich, dass die Reliquien des Heiligen erst im Zuge der Grabmalsgestaltung nach Pisa gelangten.

68 Allerdings nicht in der St. Bartholomäuskirche, sondern im Dominikanerkloster.

69 Bogade 2005, 76 .

70 Pujmanová 1997, 254.

71 In einer Angelegenheit, die das Bartholomäusstift betrifft, wandte sich der Papst am 8. Oktober 1353 an Karl IV.: Innozenz VI. bat in dem Schreiben um Mithilfe bei der Durchsetzung des von ihm eingesetzten Kardinals Arnaldus als neuem Propst in Frankfurt. KeLLNER 1962, 70.

72 So bei den Herrscherbildern Ottos III. in der Bamberger Apokalypse 
und Heinrichs II. im Bamberger Perikopenbuch. Schneider 1968, 113.

73 Freigang 2009, 111.

74 KLARE 1990, 253.

75 LINDNER 2009, 108.

76 Weizsäcker 1868, I, 83, 22. - Rieger 1885, 22.

77 MATthäUs 2006, 42.

78 EDLER 1938, 9.

79 Der Stein befand sich ursprünglich in der Heilig-Geist-Kirche, wurde aber nach deren Abriss in der St. Nikolaikirche aufgestellt. Feulner wollte eine Ähnlichkeit zwischen den Engeln des Liebfrauenportals und den Engeln des Grabsteins erkennen. Beide trennt aber die unterschiedliche Gestaltung der Gewänder. Am Portal der Liebfrauenkirche sieht man ein Untergewand und einen Wasserfallkragen, worauf der Gestalter des Grabsteins verzichtet hat. Ebenso bestehen große Unterschiede bei der Fertigung der Köpfe. Die größer gegebenen Locken der Dreikönigsengel fallen bis auf den Kragen und verdecken die Ohren. Mühsam durch ein Stirnband gezähmt, stehen sie in gewellten Bäuschen mehr vom Kopf ab, als dass sie fallen. Im Gegensatz dazu bilden die Locken am Grabstein Wellenkringel, die den Engelskopf nachvollziehen, bis sie an der oberen Ohrmuschel enden. Feulner 1940, 12 f. - Feulners späte Datierung auf 1420 und seine Zuschreibung an Madern Gerthener wurden trotzdem immer wieder unkritisch übernommen. - Вот т 1957, 128, hält an der Zuschreibung an Gerthener fest, datiert aber auf 1400. BAUCH 1976, 205, datiert das Grabmal auf 1420 und schreibt es ebenfalls Gerthener zu. - Dagegen datiert Ehresmann 1966, 204, den Stein mit Verweis auf die Kleidung um 1386. - KNIffler 1978, 68 , stellt einen Bezug des Grabsteins zur Parlerplastik her.

8 O LINDNER 2009, 111.

81 Weizsäcker/Kerler U. a. 1956, 129 f. - Rieger 1885, 29.

82 FOLZ 1973, 447.

83 BÜtTNER 2012, II, 512.

84 Die Wahlfeier Sigismunds im Jahre 1410 vermutete Lothar Schultes als Anlass für die Anfertigung eines Statuenzyklus' für die Budaer Burg. Schultes 1994, 299.

85 Milada Studničková-Cerná bemerkt hierzu: „Die Kultur des Prager Hofes der Luxemburger stellt zusammen mit der Tradition des Hauses Anjou in Ungarn den grundlegenden stilistischen sowie geistigen Ausgangspunkt der Hofkunst Sigismunds dar. Am Vorbild des Vaters orientierte sich Sigismund auch später als römischer König und Kaiser.«STUdNIČKovÁ-CERnÁ 1994, 271.

86 Pujmanová 1997, 261.

87 SCHENK 2012, 404.

88 PujManová 1997, 254.

89 HEINIG 2000, 472.

90 JÜRGENSMEIER 1989, 143.

91 WeIzsÄCKer/KerLer u. a. 1956, $114 \mathrm{f}$.

92 Eine vergleichbare Konstellation beschreibt Wilfried Franzen bei der Herstellung der Bornhofener Tafeln: Deren Anfertigung im Auftrag des Grafen von Katzenelnbogen sah er im Zusammenhang mit der Krönung Sigismunds. Franzen 2009. 



\section{Retabelskulptur in ObersaChSEN UM 1400 - ANNÄHERUNG AN EIN BISLANG WENIG BEACHTETES THEMA}

Einen Überblick über die heute noch erhaltenen Holzbildwerke der Zeit um und kurz nach 1400 in Obersachsen zu gewinnen, gestaltet sich noch immer schwierig. Die in den Museen verwahrten Bestände sind wenig bis gar nicht publiziert und abgesehen vom Schlossbergmuseum in Chemnitz zumeist im Depot gelagert. ${ }^{1}$ Noch schwieriger ist es bei Bildwerken, die sich in Kirchen befinden. Nach wie vor sind in vielen Fällen die Inventarbände des späten 19. und frühen 20. Jahrhunderts oder kurze Hinweise im Handbuch der deutschen Kunstdenkmäler die einzigen Hinweisgeber. Dennoch gibt es Grund zu Optimismus. Dank der Kooperation des GWZO in Leipzig mit dem Lehrstuhl für Sächsische Landesgeschichte an der Universität Leipzig, dem Lehrstuhl für Europäische Geschichte an der Technischen Universität Chemnitz und den Kunstsammlungen Chemnitz konnten 2012/13 in der Ausstellung »Des Himmels Fundgrube« im Schlossbergmuseum mit Schwerpunkt auf der Stadt Chemnitz und dem sächsisch-böhmischen Erzgebirge im 15. Jahrhundert sowie 2016 in deren Nachfolgeausstellung "Gotik ohne Grenzen« zu dem Thema »Sachsen und Böhmen im Spiegel der Kunst um 1500 « umfangreiche neue Forschungsergebnisse präsentiert werden. ${ }^{2}$

Das Zentrum Obersachsens bildete das Herrschaftsgebiet der wettinischen Markgrafen von Meißen und Landgrafen von Thüringen, die sich seit 1307 als selbstständige Territorialmacht hatten etablieren können. ${ }^{3}$ Die endgültige Wahl Karls IV. 1349 zum deutschen König und späteren Kaiser war nicht ohne Folgen für das wettinische Herrschaftsgebiet geblieben. Im Interesse seiner Hausmacht war es dem böhmischen König gelungen, eine Reihe kleinerer Gebiete im Meißnischen Land in seinen Besitz zu überführen, letztlich mit dem Ziel, neben der Oberpfalz und später der Mark Brandenburg auch die Markgrafschaft Meißen zu erwerben. ${ }^{4}$ Seit 1373 wurde der wettinische Herrschaftsbereich an drei seiner Grenzen von böhmischen Landen tangiert. ${ }^{5}$ Der Versuch, durch die direkte Unterstellung des Meißner Bischofs unter den Prager Erzbischof, um die Karl IV. 1356 Papst Innozenz VI. ersucht hatte, nachhaltig Einfluss auf das dortige Bistum zu nehmen, brachte allerdings nicht den gewünschten Erfolg, da dies von den Bischöfen nicht beachtet wurde. ${ }^{6}$ Nach dem Tod Karls IV. 1378 begann sich die Lage zu entspannen, auch wenn die Beziehungen zum böhmischen und römischen König und Kaiser, vor allem unter Karls Sohn Sigismund, nicht unproblematisch waren. $^{7}$

Die markgräfliche Burg, Vorgängerbau der späteren Albrechtsburg, stand in Meißen in unmittelbarer Nähe des Doms. Dieser teilte den Burgberg in den markgräflichen Teil auf der Nordseite und den bischöflichen auf der Südseite. ${ }^{8}$ Seit etwa 1260 war mit dem Neubau des gotischen Doms anstelle des Vorgängerbaus aus dem 12. Jahrhunderts begonnen worden. Seit Wilhelm I. versuchten die meißnischen Markgrafen, stärker Einfluss auf das Bistum und letztlich auch auf den Bau zu nehmen. Wilhelm I. hatte die Errichtung der Kirche mit reichen Stiftungen gefördert und 1401 zum Abschluss gebracht. ${ }^{9}$ Im Ergebnis seiner Politik war es ihm gelungen, die geistliche Macht der Bischöfe der weltlichen Herrschaft zu unterstellen. Seine letzte Ruhestätte fand er vor dem Hochaltar der Bischofskirche.

In der dem Evangelisten Johannes und dem hl. Donatus geweihten Domkirche haben sich aus mittelalterlicher Zeit überwiegend Steinbildwerke erhalten. Dazu zählt mit seinem figurenreichen Programm - dem Weltgericht oberhalb der Portallaibung, der Krönung Mariä sowie der Geburt Jesu und der Anbetung der Könige im Tympanon, ergänzt um die beiden das Portal seitlich flankierenden Bistumspatrone Johannes Evangelist und den hl. Donatus - das Portal auf der Westseite von 1360/70, das in engem stilistischen Bezug zum sog. Magdeburg-Halberstädter Kunstkreis steht und dem vermutlich noch vor 1428, dem Todesjahr Friedrichs des Streitbaren, die Fürstenkapelle vorgesetzt worden war. Etwas jünger, in die Zeit um 1400, zu datieren sind die sieben Skulpturen des bereits $1310-20$ errichteten Südportals. ${ }^{10}$ Aus Sandstein gefertigt ist das Annenretabel in der Allerheiligenkapelle, in dessen breitem, eingetieftem und so an einen Schrein erinnernden Bildfeld die hl. Anna Selbdritt von 


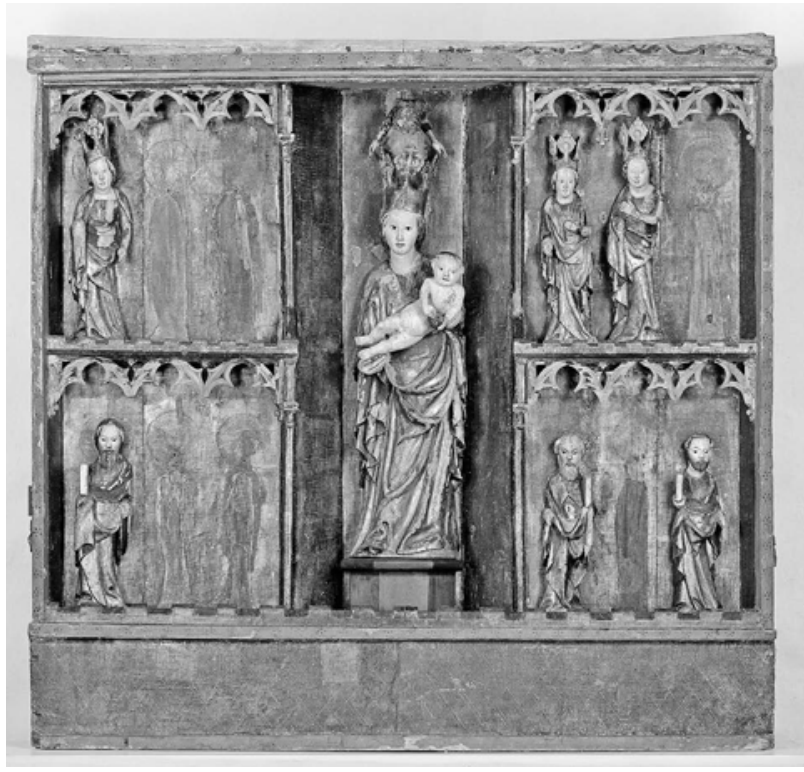

Abb. 1 Mittelschrein des Retabels aus Topfseifersdorf. Chemnitz, Schlossbergmuseum (Foto: SKD/Elke Estel und Hans-Peter Klut)

Abb. 2 Mittelschrein des Hausaltars des Bischofs von Meißen, Dietrich von Schönberg, aus Rothschönberg. Chemnitz, Schlossbergmuseum (Foto: SKD/E. Estel und H.-P. Klut)

den hll. Katharina und Sebastian sowie zwei kleineren Stifterfiguren in Anbetung flankiert wird (um 1400/10). Die Skulpturen zeigen in Figurenaufbau und Gewanddrapierung deutliche Bezüge zur böhmisch-schlesischen Kunst um $1400 .{ }^{11}$ Einzig sieben der überlebensgroßen Skulpturen in der Fürstenkapelle, sehr schlanke, stark überlängte Figuren, sind aus Linden- oder Pappelholz geschnitzt und gegen Mitte des 15. Jahrhunderts vermutlich in einer einheimischen Werkstatt entstanden. ${ }^{12}$ Bei den zwischen 1,76 und 2,06 m großen Figuren handelt es sich um eine Maria mit Kind, die Heiligen Drei Könige und die Apostel Jakobus Major und Paulus. ${ }^{13}$ Weitere spätmittelalterliche Holzbildwerke aus dem Meißner Dom sind nicht überliefert.

Die Mehrzahl der in Obersachsen erhaltenen Schnitzretabel der Zeit um 1400 und der ersten Hälfte des 15. Jahrhunderts haben nur fragmentarisch überdauert. Vielerorts geben Einzelskulpturen oder Reliefs Hinweise auf ehemals vorhandene Schreine wie beispielsweise die 1340-50 datierten kleinen Holzskulpturen einer Maria und eines bärtigen Heiligen in der Kirche in Brünlos. ${ }^{14}$ Beklagenswert sind die großen Verluste der durch die Bombardierung des Palais im Großen Garten zerstörten Sammlung des ehemals Königlich Sächsischen Alter-

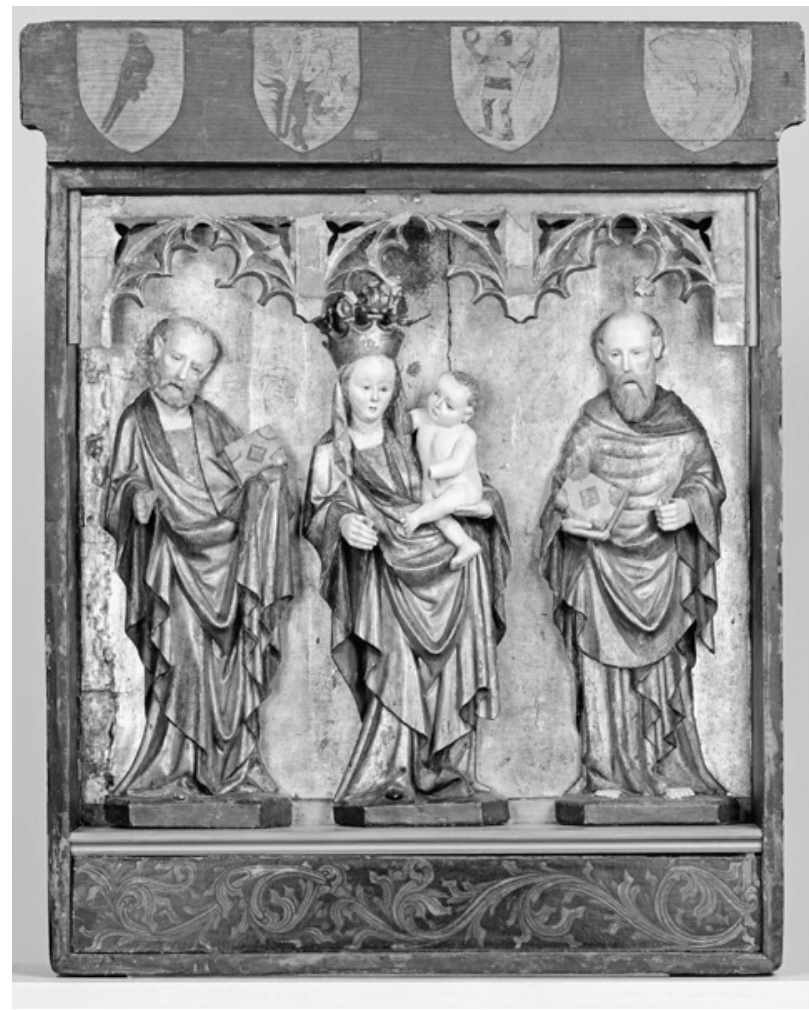

tumsvereins in Dresden. 1973 publizierte Walter Hentschel die Verluste mittelalterlicher Kunst durch den Zweiten Weltkrieg. ${ }^{15}$ Für den Zeitraum bis 1450 waren immerhin etwas über 40 Objekte der Skulpturenabteilung in Dresden betroffen. $\mathrm{Zu}$ den zerstörten Kunstwerken zählen neben den Schreinen aus Ulbersdorf (1415/25) und Ehrenberg (1420/30) sowie den Flügeln des Retabels aus Topfseifersdorf (um 1385/90) vor allem Einzelskulpturen wie Kruzifixe, Marien- und Heiligenfiguren. ${ }^{16}$ Die Konzentration spätmittelalterlicher Kirchenausstattung im Palais im Großen Garten in Dresden ging auf die sehr engagierte Arbeit des ehemals Königlich Sächsischen Altertumsvereins zurück. Seit dem 19. Jahrhundert hatten sich historisch interessierte Bürger zusammengefunden, um auf Exkursionen quer durch das Land nach gefährdeten, nach besonders interessanten und erhaltenswerten Ausstattungsstücken in den Kirchen Ausschau zu halten. 1837 hatte sich der Königlich Sächsische Verein für Erforschung und Erhaltung vaterländischer Alterthümer mit dem Verein der sächsischen Alterthumsfreunde zum Königlich Sächsischen Alterthumsverein zusammengeschlossen. Im Laufe des Geschäftsjahrs 1840/41 gelangten die Mitglieder zu der Erkenntnis, dass der ursprüngliche Grundsatz, die Altertümer so weit wie möglich an Ort 


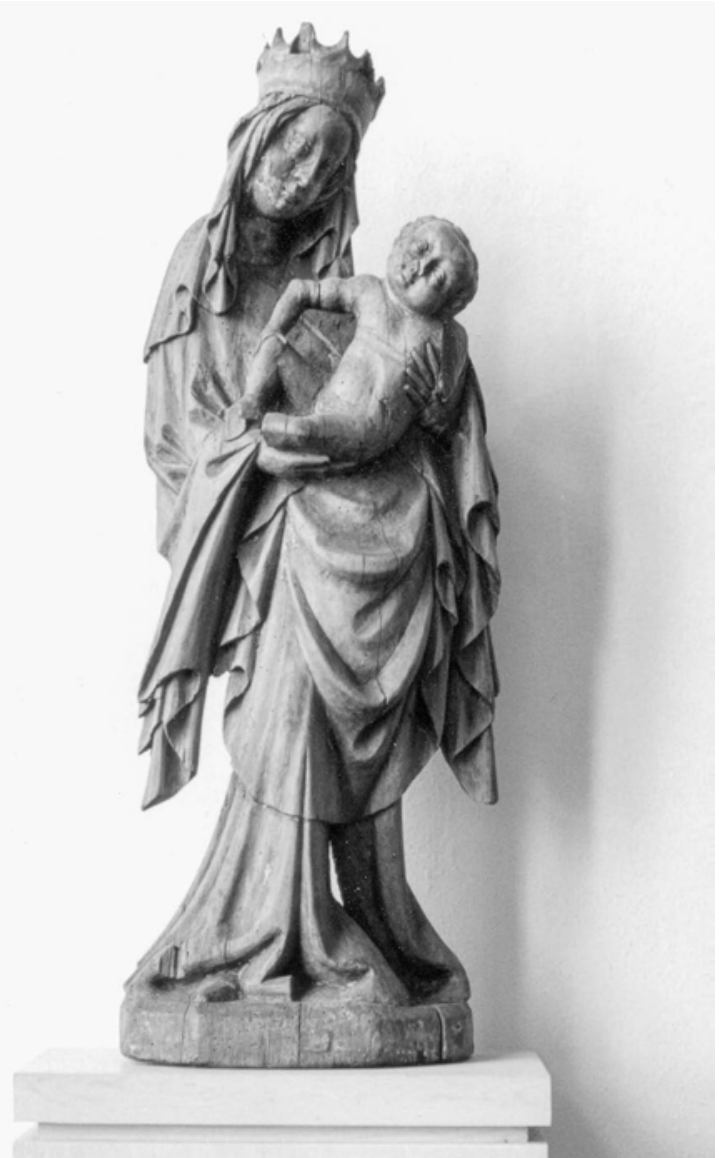

Abb. 3 Maria mit Kind aus Wilsdruff. Chemnitz, Schlossbergmuseum (Foto: M. Hörsch)

Abb. 4 Maria mit Kind aus Oberhermersdorf. Chemnitz, Schlossbergmuseum (Foto: May Voigt, Chemnitz)

Abb. 5 Hl. Katharina, Maria mit Kind und HI. Barbara aus Gersdorf. Chemnitz, Schlossbergmuseum (Foto: SKD/ E. Estel und H.-P. Klut)

und Stelle zu belassen, nicht in jedem Falle deren Schutz und Erhalt gewährleisten konnte und dass sich stattdessen die Einrichtung einer musealen Sammlung zur Aufbewahrung der gefährdeten Stücke als notwendig erwies. Eingerichtet wurde das Museum im Königlichen Palais im Großen Garten in Dresden. ${ }^{17}$ Spätmittelalterliche Werke der Skulptur bildeten einen wesentlichen Bestandteil der Sammlung, umso schwerer wiegt deren Verlust durch die Zerstörung 1945. Die davon verschont gebliebenen Sammlungsstücke sind heute, nachdem sie zuvor für einige Jahre auf der Albrechtsburg in Meißen gezeigt wurden, im Schlossbergmuseum in Chemnitz ausgestellt.

Zum Bestand der bis 1450 entstandenen Werke zählen heute noch nach dem 2009 publizierten Führer durch die
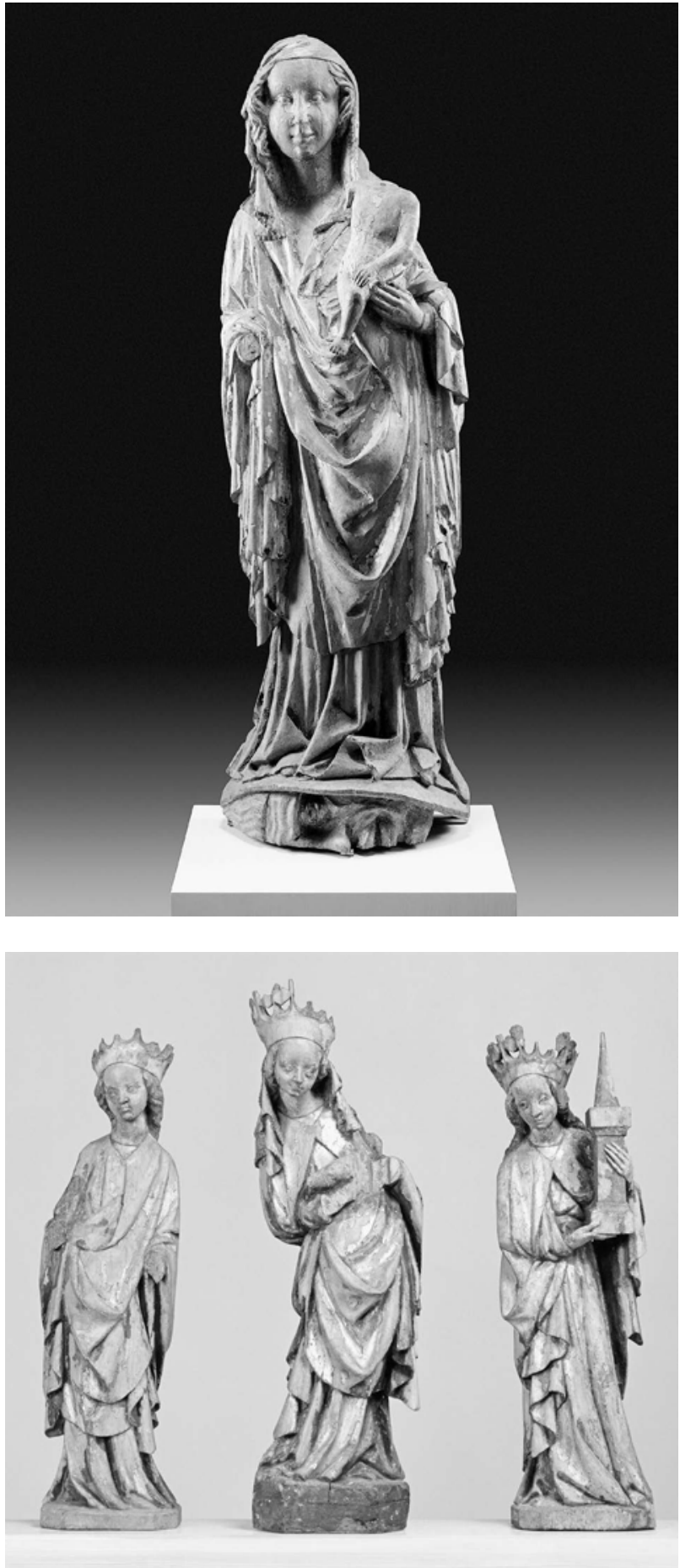

Sammlung neun Katalognummern. ${ }^{18}$ Darunter befinden sich der Mittelschrein des Retabels aus Topfseifersdorf von etwa $1385 / 90$ (Abb. 1) und derjenige eines Hausaltars des Meißner Bischofs Dietrich von Schönberg der Zeit um 1430 (Abb. 2). 


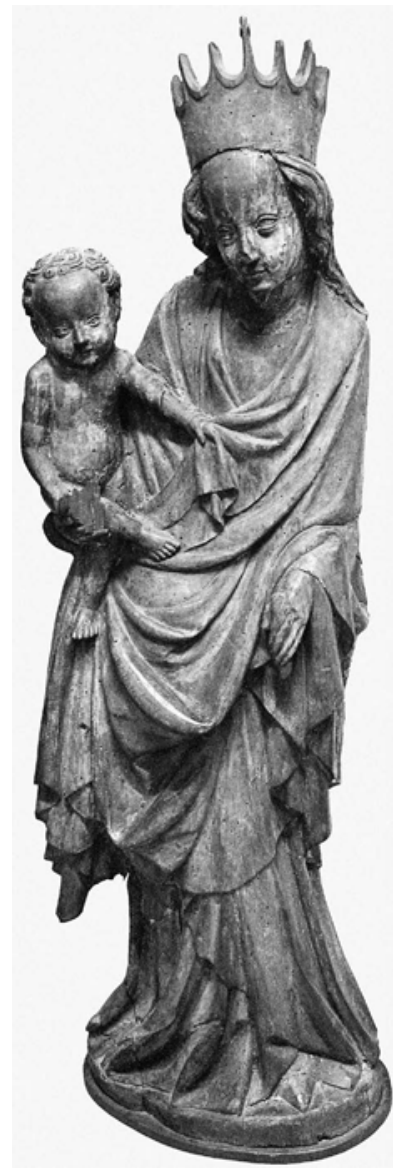

Abb. 7 Schrein des Retabels aus Leipzig-Eutritzsch. Leipzig, Stadtgeschichtliches Museum (ex: WANCKEL/ FLECHSIG 1900)
Bei den übrigen Exponaten handelt es sich um Einzelfiguren, darunter den Torso eines Kruzifixes aus der Chemnitzer Jakobikirche (1380-1400), weitere Heiligenfiguren wie die Marienfiguren aus Wilsdruff (1400/10) und Oberhermersdorf (um 1420) sowie weibliche Heiligenfiguren aus Gersdorf, gleichfalls vom Anfang des 15. Jahrhunderts (Abb. 3-5).

Neben weiteren Einzelskulpturen, die sich noch in Kirchen Obersachsens befinden wie die erwähnten Holzskulpturen in Brünlos, haben sich mit einer Maria mit Kind unbekannter Herkunft (um 1430, Abb. 6) und den Reliefs eines ehemaligen Retabels aus der Pfarrkirche in Leipzig-Eutritzsch (Abb. 7) einige wenige Stücke auch im Stadtgeschichtlichen Museum in Leipzig erhalten. ${ }^{19}$

Das Eutritzscher Retabel war im 19. Jahrhundert gemeinsam mit zwei weiteren Altarschreinen der Zeit um 1500 aus derselben Kirche in die Sammlung des Königlich Sächsischen Altertumsvereins gelangt, der es in den 1920er Jahren an das Stadtgeschichtliche Museum Leipzig abgab, obwohl es im Katalog als ein Werk von »besonders hohem Kunstwert « ausgewiesen wurde. ${ }^{20}$ Von dem Altaraufsatz, der in einer Abwandlung vom Typus des Viereraltars - welcher nach Erich Wiese seine Wurzeln in Schlesien haben soll ${ }^{21}$ - der mittleren Madonnenfigur vier Reliefs in jeweils zwei Registern übereinander zur Seite stellte und in den Flügeln je sechs Apostel aufnahm, sind seit der Auslagerung während des Zweiten Weltkriegs nur noch die vier Reliefs erhalten.
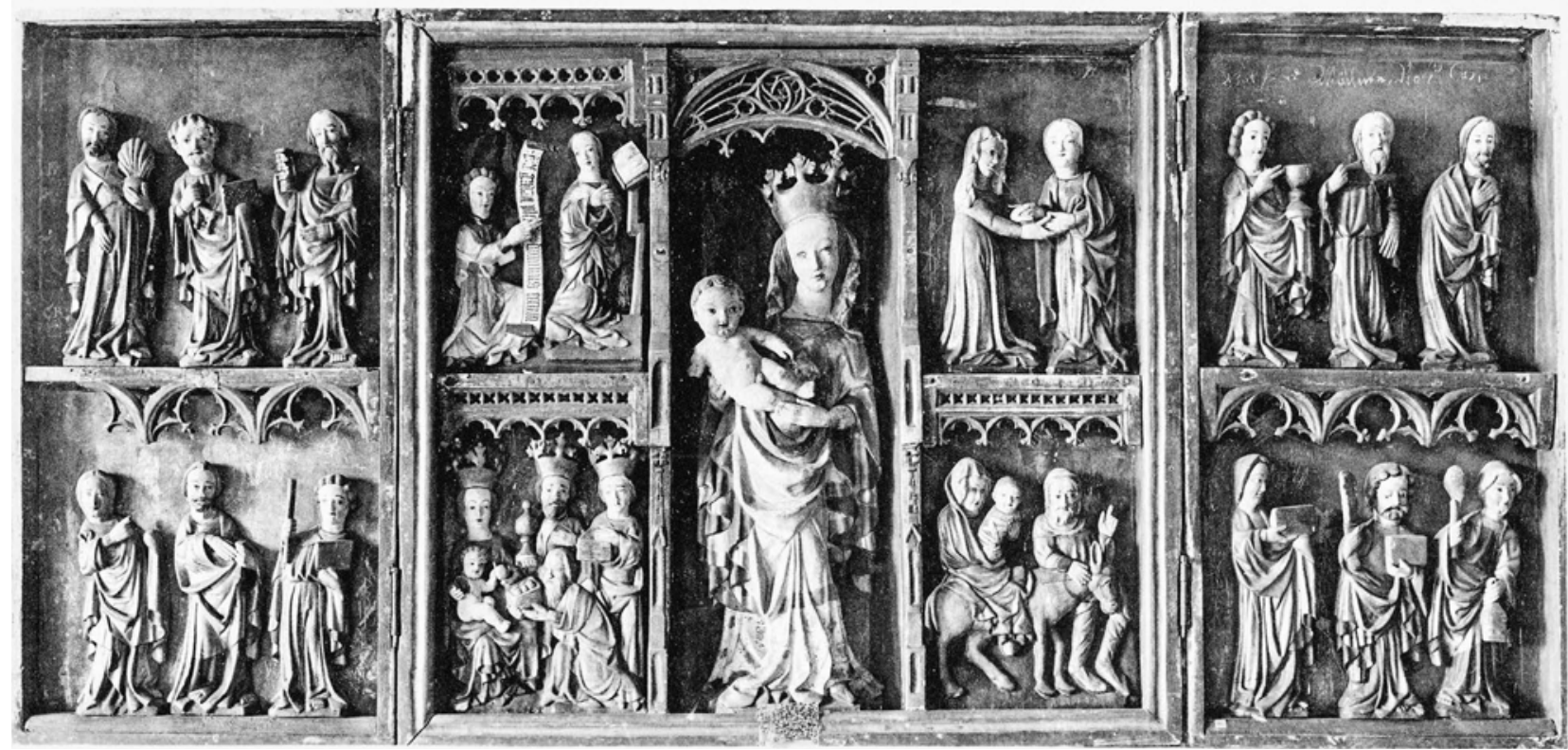
Abb. 8 Chemnitz-Ebersdorf, Ev. Pfarrkirche (ehem. Wallfahrtskirche), Inneres nach Osten (Foto: U. Bednarz)

Abb. 9 Thronende Maria mit Kind. Chemnitz-Ebersdorf, Ev. Pfarrkirche (Foto: U. Bednarz)
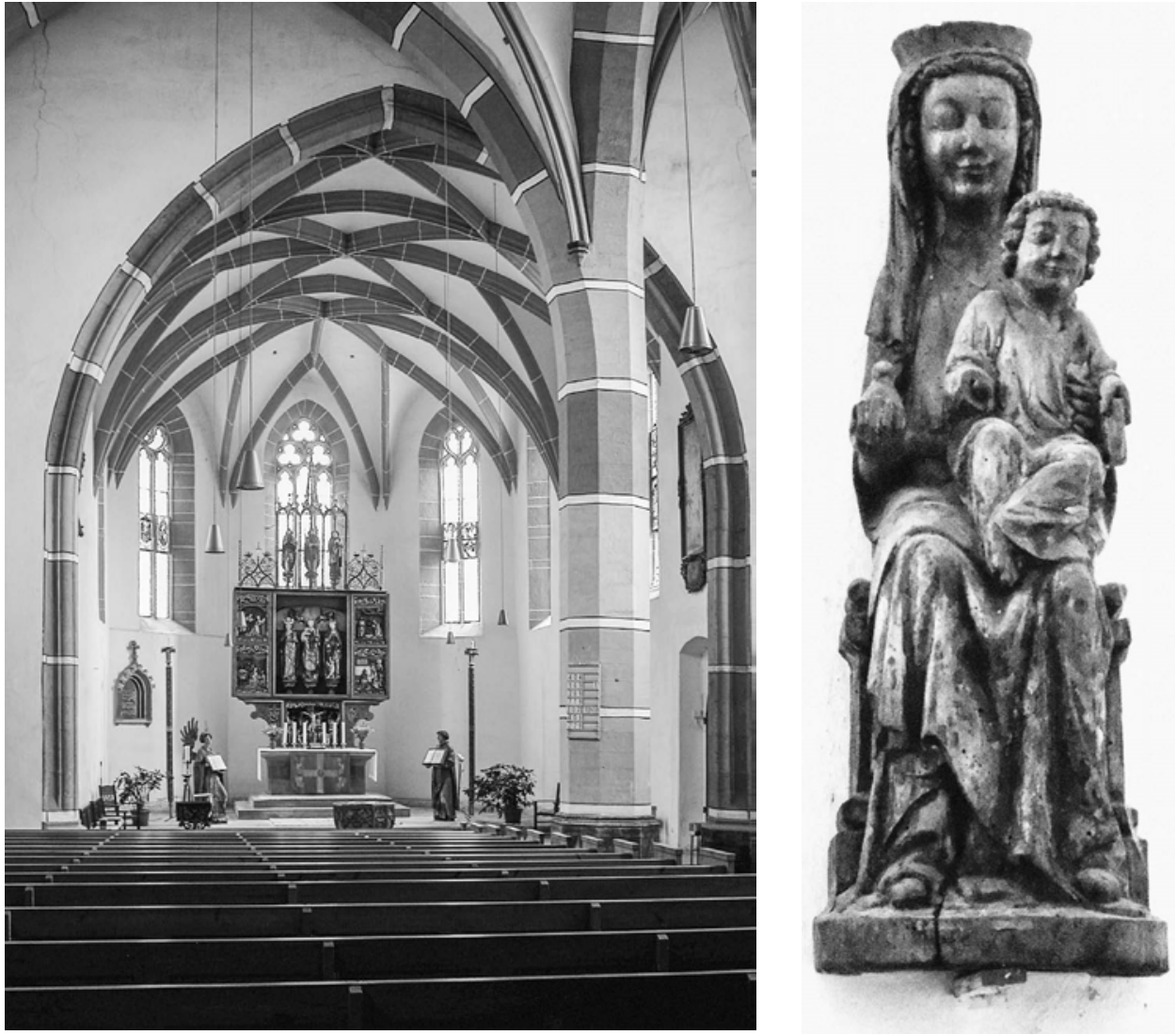

In den Hintergrund gedrängt wurden und werden die heute noch erhaltenen Werke der ersten Hälfte des 15. Jahrhunderts in Obersachsen durch den weitaus gröBeren Bestand an Retabeln und Skulpturen des ausgehenden 15. Jahrhunderts. So hatte beispielsweise zwischen Chemnitz, Freiberg und Zwickau, basierend auf den bedeutenden Silbererzfunden seit 1469, eine rege Bautätigkeit eingesetzt. Neue, größere Kirchen wurden erbaut, bereits bestehende erhielten repräsentativere Ausstattungen. Stellvertretend seien die Marienkirche in Zwickau, die Annenkirche in Annaberg oder die Wolfgangskirche in Schneeberg genannt.

Besonders anschaulich kann diese Entwicklung am Beispiel der ehemaligen Wallfahrtskirche in ChemnitzEbersdorf aufgezeigt werden (Abb. 8). ${ }^{22}$

Ihre überregionale Bekanntheit verdankt die Kirche vor allem den Werken des Meisters HW. ${ }^{23}$ Die lebensgroßen Pulthalterfiguren werden gegen 1513, das Entstehungsjahr des Hochaltars mit Schnitzfiguren der Werkstatt des sog. Flöhaer Meisters, datiert. Etwa im gleichen Zeitraum entstand das Grabmal für den 1499 verstorbenen Ritter Dietrich von Harras, der seit 1450 in kurfürstlich- sächsischen Diensten gestanden und 1465/66 zum Hofgesinde Kaiser Friedrichs III. gehört hatte. ${ }^{24}$

Durch Grabungsfunde 1959-61 nachgewiesen ist ein erster Bau einer kleinen romanischen Saalkirche mit Chor und Apsis vermutlich aus der 2. Hälfte des 12. Jahrhunderts. ${ }^{25}$ Noch in das 14. Jahrhundert geht die Einrichtung einer Wallfahrt zurück, deren Grundlage vermutlich ein wundertätiges Marienbild bildete. ${ }^{26} \mathrm{Ob}$ es sich dabei um jene noch heute erhaltene Figurengruppe einer Thronenden Muttergottes mit Kind von etwa 1325 (Abb. 9) handelt, ist unklar, denn nach den Archivrecherchen von Kathrin Iselt wurden mehrere Kleinodien, darunter ein »schönes hohes Marienbild«, zu dem eine mit edlen Steinen besetzte Krone gehörte, im Jahr 1555 an einen Goldschmied verkauft. ${ }^{27}$

Ebersdorf lag an einem Abzweig einer bereits seit dem 10. Jahrhundert genutzten Handelsstraße von Richtung Leipzig über Rochlitz kommend nach Böhmen und bot nicht nur den vorrangig mit Tuchen und Salz handelnden Kaufleuten Gelegenheit zur Rast. Recht profane Dinge, wie der Streit zwischen Chemnitz und Ebersdorf um das Schankrecht, resultierten aus einer nicht unerheblich ge- 


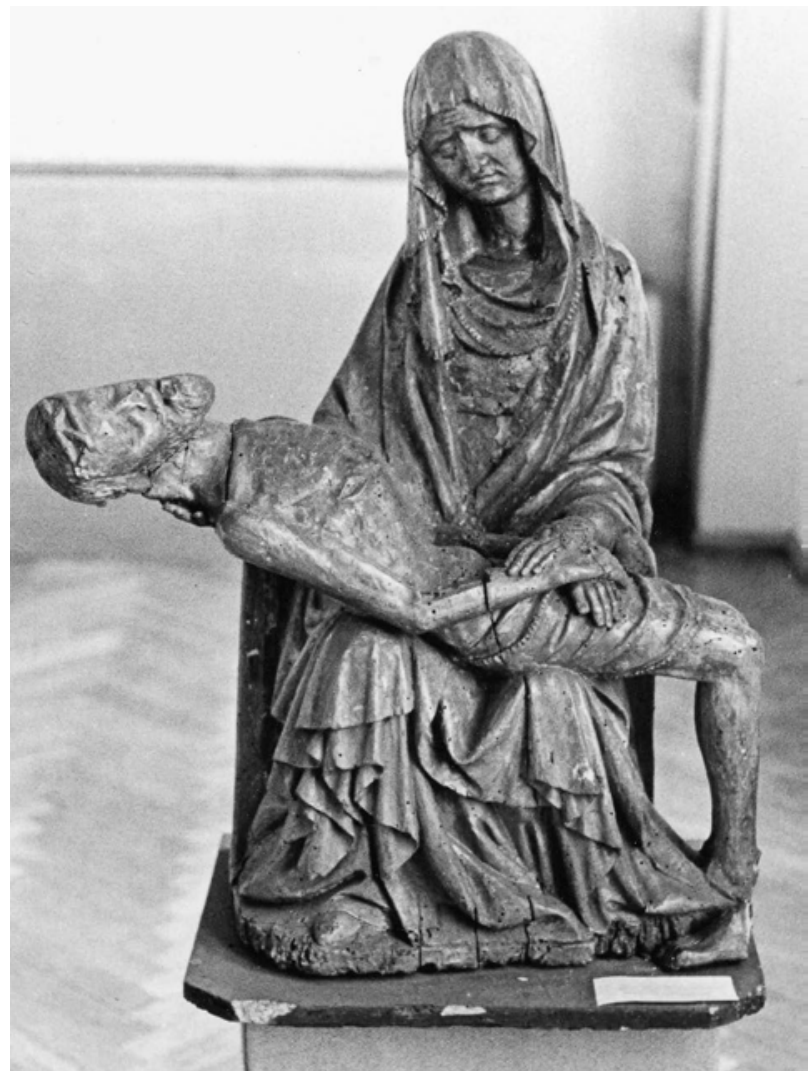

Abb. 10 Pietà. Chemnitz-Ebersdorf, Ev. Pfarrkirche (Foto: Hist. Aufnahme Slg. M. Hörsch)

stiegenen Nachfrage nach Bier und können als Indiz für die zunehmende Popularität der Ebersdorfer Wallfahrt interpretiert werden. ${ }^{28}$ Der Tatbestand ist insofern von Interesse, als in Ebersdorf noch Mitte des 16. Jahrhunderts nur etwa 150 Einwohner lebten. Doch schon zu Beginn des 15. Jahrhunderts hatten die stetig zunehmenden Pilgerströme den Neubau einer größeren Kirche erforderlich gemacht.

Zum bildplastischen Schmuck der Ebersdorfer Kirche gehörte neben der genannten thronenden Madonna ein Vesperbild der Zeit um 1430 (Abb. 10), das dem Typus der horizontalen Pietà, einer vermutlich parlerischen Bilderfindung, folgt und das sich, die Gewandbehandlung betreffend, mit dem Vesperbild aus Ossegg (Osek) im Regionalmuseum in Teplitz (Teplice; 2. V. 15. Jh.) oder jenem aus Schwertz b. Brüx (1420er Jahre) im Regionalmuseum in Brüx (Most) vergleichen lässt. ${ }^{29}$

Die erste in den Quellen belegte Wallfahrerin in Ebersdorf war die sächsische Markgräfin Katharina, Gattin Friedrichs IV. und Tochter Herzog Heinrichs von Braunschweig-Lüneburg. Die Wallfahrt ist schriftlich dokumentiert und datiert auf den 15 . November $1421 .^{30}$

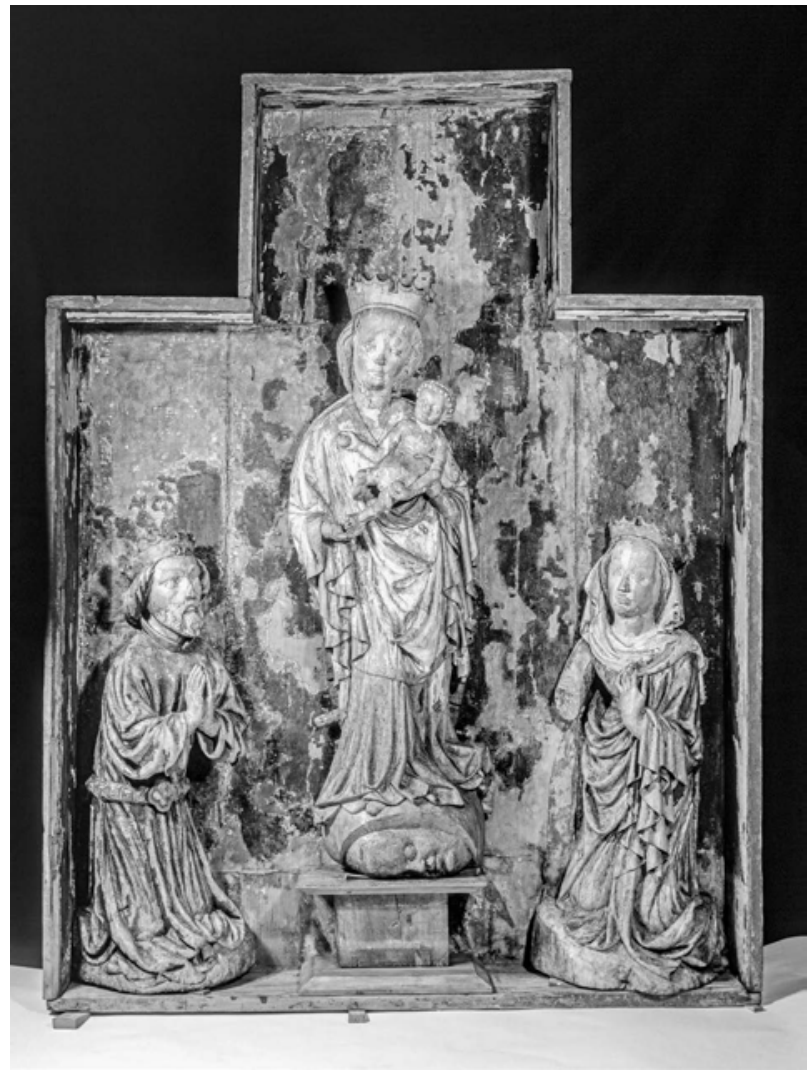

Abb. 11 Mittelschrein eines Votivretabels. Chemnitz-Ebersdorf, Ev. Pfarrkirche (Foto: Landesamt für Denkmalpflege Sachsen)

Mit dieser Wallfahrt in Verbindung gebracht wird ein Schreinkasten mit zwei zu Füßen der Madonna knienden Stifterfiguren (Abb. 11).

Der Schrein ist heute eher unscheinbar an der südlichen Langhauswand angebracht und verrät beim flüchtigen Betrachten nur wenig von seiner einstigen Bedeutung. Im überhöhten Mittelteil steht auf einem Sockel eine Madonna im Strahlenkranz mit dem Mond zu ihren Füßen. Etwas niedriger angeordnet knien seitlich neben ihr zwei gekrönte Personen, links vom Betrachter eine männliche, rechts eine weibliche, die durch ihre Körperhaltung - die männliche hat die Hände zum Gebet gefaltet, die weibliche führt ihre Linke zur Brust, der rechte Unterarm ist verloren - als Stifter zu interpretieren sind.

Hervorzuheben ist die Position der Stifterfiguren in Ebersdorf, die deren Repräsentationsanspruch unterstreicht. Traditionell fanden Stifter in Retabeln jener Zeit ihren Platz auf den Flügeln, zumeist in Begleitung eines Schutzheiligen, so zum Beispiel auf der Votivtafel des Prager Erzbischofs Jan Očko von Vlašim (vor 1371), ${ }^{31}$ oder untergeordnet in einer separaten Zone unterhalb des hei- 
ligen Geschehens, zumeist auch deutlich kleiner als die von ihnen angebeteten heiligen Personen. Genannt sei des Weiteren das 1404 datierte, äußerst kostbar ausgestattete sogenannte »Goldene Rössl«, gestiftet von Isabeau de Bavière, die diesen aus Goldemail und Edelsteinen gefertigten Altar am Neujahrstag 1405 ihrem Gemahl, dem französischen König Karl VI., zum Geschenk gemacht hatte. ${ }^{32}$

Weitere frühe, wiederum französische Beispiele finden sich in den Petites Heures von $1410^{33}$ und in den Très Riches Heures ${ }^{34}$ des Herzogs Jean de Berry, letztere entstanden 1410-16. Die dem Text beigefügten quadratischen Bildfelder zeigen den Herzog in Anbetung Gott Vaters und der Madonna.

Die Tatsache, dass die beiden knienden Figuren in Ebersdorf ungewöhnlicherweise von gleicher Körpergröße wie die Madonna sind, unterstützt die Annahme, dass es sich bei den beiden Personen um hochrangige Stifter handelt. Im konkreten Fall wohl um den sächsischen Markgrafen Friedrich den Streitbaren und dessen Gemahlin Katharina von Meißen. Dem Wettiner Friedrich IV., 1370 geboren, war nach dem Tod seines Onkels Wilhelm I. 1407 die Markgrafschaft Meißen zugefallen. Bereits unter diesem war es den Wettinern gelungen, ihr Territorium nicht unerheblich zu erweitern. Große Verdienste hatte sich Friedrich IV. mit der Gründung der Universität Leipzig 1409 und der Aufnahme der aus Prag abgewanderten Professoren und Studenten erworben. 1419 hatte er Kaiser Sigmund im Kampf gegen die Hussiten militärisch unterstützt und war 1423 mit der Kurwürde belehnt worden.

Der aus Nadelholz gefertigte Schreinkasten misst $1,93 \times 1,46 \times 0,26 \mathrm{~m}$. Eine dendrochronologische Untersuchung am linken Brett des Kastens erbrachte ein Fälldatum im frühen 15 . Jahrhundert. ${ }^{35}$

Ein Flügel (Abb. 12), auf dem noch umfangreiche Reste der Tafelmalerei, einer Verkündigung an Maria und darunter der Darbringung Jesu im Tempel, erhalten sind, kann nicht, wie bisher vermutet, als dem Schrein zugehörig angenommen werden, da weder die Maße übereinstimmen noch die Nagellöcher der ehemaligen Scharniere deckungsgleich sind. Somit ist der Flügel der Rest eines weiteren Retabels aus dem Beginn des 15. Jahrhunderts in der Ebersdorfer Kirche.

Der Schrein und mit ihm weitere Skulpturen waren über einen langen Zeitraum den Augen der Besucher der Kirche entzogen. Sie fristeten ihr Dasein in der sog. Bilderkammer in einem Zwischengeschoss des Westturms. 1882 gelangte der größere Teil der schnitzplastischen

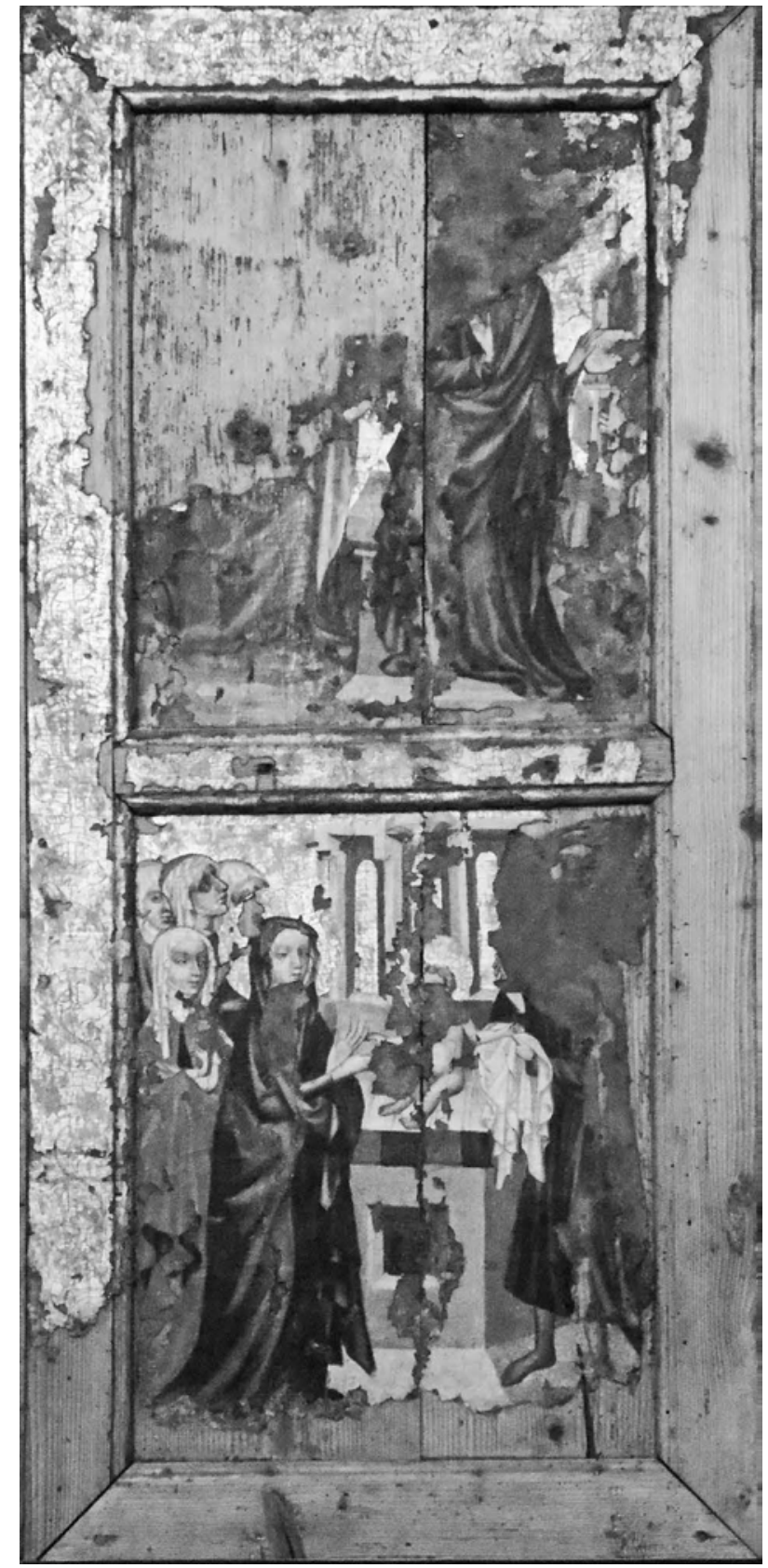

Abb. 12 Flügel mit Verkündigung und Darstellung im Tempel. Chemnitz-Ebersdorf, Ev. Pfarrkirche (Foto: U. Bednarz)

Werke aus der Kirche nach Dresden in die Sammlung des Königlich Sächsischen Altertumsvereins und in die Ausstellung, kehrte aber 1921 nach Ebersdorf zurück. ${ }^{36}$

Der Schrein fand einen Platz an der Südwand des Chors. ${ }^{37}$ Die eigentlich zu ihm gehörende Muttergottesfigur, die nach Müller gegenüber, an der Nordwand des Chors, Aufstellung gefunden hatte, war durch eine deut- 


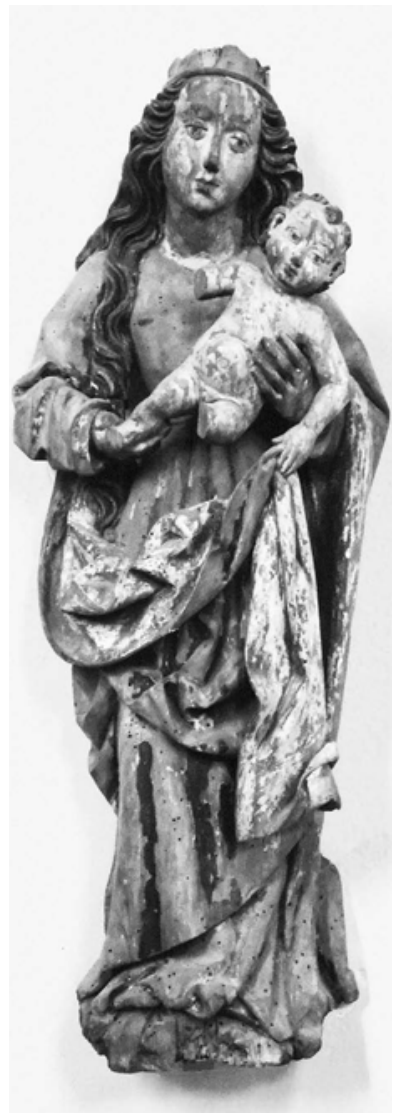

Abb. 13 Maria mit Kind. 3. V. 15. Jh. Chemnitz-Ebersdorf, Ev. Pfarrkirche (Foto: U. Bednarz)

lich kleinere und jüngere Marienfigur (Abb. 13) ersetzt worden, wodurch die Größenverhältnisse zwischen der Marienfigur und den knienden Stiftern gestört wurden. ${ }^{38}$

Eine Restaurierung 1962-65 im Landesamt für Denkmalpflege Sachsen in Dresden stellte die ursprüngliche Figurenzusammengehörigkeit wieder her. Im Vorfeld der sächsischen Landesausstellung 1998 im Zisterzienserinnenkloster St. Marienstern in Panschwitz-Kuckau wurde der Schrein umfassend restauratorisch begutachtet und konserviert. ${ }^{39}$

In seiner Konstruktion ist der Schrein auffallend schlicht gearbeitet. Die Rückwand besteht aus vier miteinander verleimten Brettern. An den Seiten- und Deckbrettern ist die rote Farbe direkt auf die Borkenkante aufgetragen worden, ohne zusätzliche Rahmenleiste. Im Gegensatz zu dieser einfachen Konstruktionsweise ist die Fassung des Schreins, wie Annegret Michel bei der letzten Restaurierung nachweisen konnte, von erheblich höherer Qualität. ${ }^{40}$ Die inneren Rück- und Seitenwände sind über einer dicken Grundierung mit einer zweifachen Azuritschicht gefasst. Darauf wurden aus Kreidegrund geformte, mit Zwischgold gefasste Sterne angebracht.
Kleine Leisten an den oberen Brettern über den Stifterfiguren können als Rest eines ehemaligen Schleierwerks gedeutet werden.

Feuchteschäden und Anobienbefall haben die Holzsubstanz geschädigt und teilweise zu Verlusten beispielsweise der Kronenzacken bei beiden Stifterfiguren, des rechten Unterarmes der weiblichen Stifterfigur, größerer Teile des Strahlenkranzes und des rechten Unterschenkels des Kindes geführt.

Die beiden knienden Stifterfiguren sind rückseitig tief ausgehöhlt. Der weiche Schwung ihrer Körper wird von der Drapierung der Gewänder wiederholt, die sich schlaufenförmig über den Plinthen ausbreiten. Die männliche Figur, der Markgraf respektive Kurfürst, trägt über seinem roten Obergewand zeittypisch in Hüfthöhe einen Gürtel mit einer Schnalle in Vierpassform (Abb. 14).

Die als Katharina von Meißen gedeutete rechte Figur trägt in lockerem Schwung einen weißen Schleier über dem Haar, den sie elegant vor der Brust über die linke Schulter gelegt hat (Abb. 15). Das Obergewand ist, dabei vielfach Schüsselfalten vor dem Körper bildend, von rechts über den linken Unterarm gelegt, wo es in üppigen Faltenkaskaden herabfällt. In Gestaltung und Ausstattung zeigt sich Katharina von Meißen der Muttergottes ebenbürtig, was durch die Krone unterstützt wird und zusätzlich den Repräsentationsanspruch der Stifter unterstreicht. Als Fragment einer Grafen- bzw. Fürstenkrone lässt sich auch der Reif auf dem Kopf des Markgrafen interpretieren.

Von gleichfalls hoher Qualität zeugt die, heute leider nur noch zu etwa $40 \%$ erhaltene, Fassung der aus Lindenholz geschnitzten Skulpturen, die nach den jüngsten Untersuchungen keinerlei Übermalungen aufweisen. Die Fassung des Mantels des Markgrafen zeigt Zinnoberrot auf Blattsilber mit darunter liegendem rotem Poliment. An einigen verdeckten und dadurch geschützten Stellen sind noch Reste einer ursprünglichen Silberradierung auf dem Zinnober zu erkennen.

Die Maria in Ebersdorf (Abb. 16) ist als Madonna auf der Mondsichel vor einem plastisch gearbeiteten Strahlenkranz dargestellt.

In einem dezenten S-Schwung steht sie leicht erhöht auf einem erneuerten Sockel. Das Gewand weist noch die für die Kunst um 1400 typischen Drapierungsmuster auf. Der Mantel ist in großzügigem Schwung vor den Körper gelegt und zeigt die charakteristischen, hier bereits spitz gebrochenen Schüsselfalten, die für eine Datierung um 1420 sprechen. Eingefasst wird die Mantelschürze 

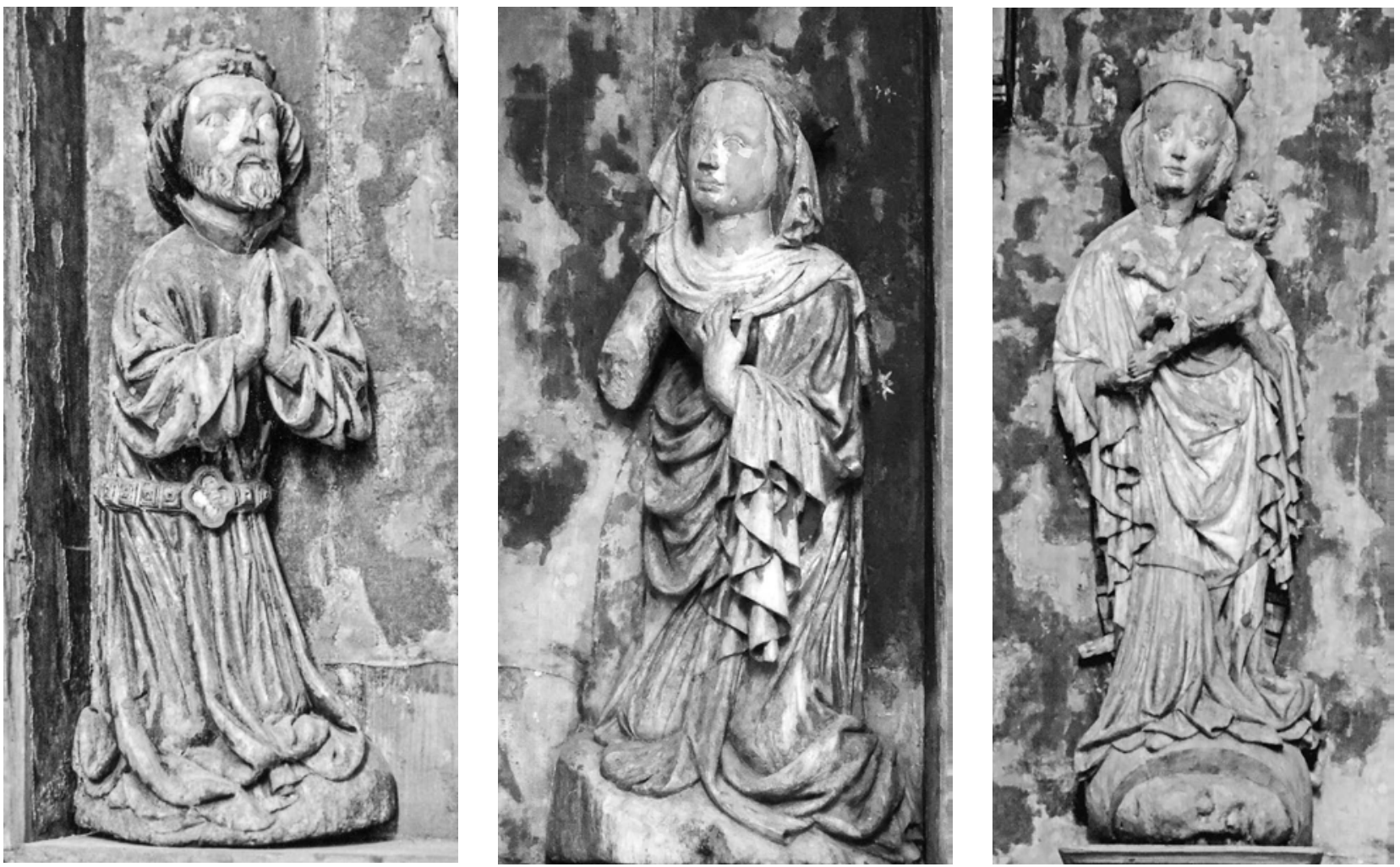

auf beiden Seiten von kleinteiligen Faltenkaskaden. Das Untergewand fällt in weichem Schwung auf den Boden. Das auf dem linken Arm über dem Standbein getragene Kind liegt diagonal vor dem Körper der Mutter, in beiden Händen eine kleine ehemals rote Frucht haltend, vermutlich einen Granatapfel, hier wohl als Hinweis auf die Auferstehung Christi. Generell stehen die Ebersdorfer Schreinskulpturen in der Tradition des Schönen Stils, die Madonna folgt dem Typus der Schönen Madonna aus Krumau (um 1390) und der etwas älteren, nach einer Ablassurkunde vor $1384 \mathrm{zu}$ datierenden Pilsener Madonna. ${ }^{41}$ Im Unterschied zu den vorrangig aus Stein gearbeiteten Skulpturen ist die aus Lindenholz geschnitzte Ebersdorfer Marienfigur in ihrer Komposition deutlich ruhiger. Die Falten des den Körper umschließenden Gewands sind, wie die gesamte Figur, flacher gearbeitet, besitzen nicht die Dynamik ihrer steinernen Vorbilder, die Drapierung ist kleinteiliger und partiell scharfkantiger. Darin steht die Ebersdorfer Skulpturengruppe in ihrer Formensprache in der Nähe zu schlesischen, böhmisch geprägten Werken Breslauer Provenienz. Friedrich Staemmler verwies auf die Kreuzigungsgruppe aus der Dumlose-Kapelle der Breslauer Elisabeth-Kirche. Zum Vergleich herangezogen sei auch eine von Bożena Guldan-Klamecka auf 1410-20
Abb. 14 Stifter im Schrein eines Retabels, wohl Markgraf / Kurfürst Friedrich IV. Chemnitz-Ebersdorf, Ev. Pfarrkirche (Foto: M. Hörsch)

Abb. 15 Stifterin im Schrein eines Retabels, wohl Katharina von Meißen. Chemnitz-Ebersdorf, Ev. Pfarrkirche (Foto: U. Bednarz)

Abb. 16 Maria mit Kind auf der Mondsichel im Schrein des Votivretabels. Chemnitz-Ebersdorf, Ev. Pfarrkirche (Foto: U. Bednarz)

datierte Madonnenfigur im Nationalmuseum in Breslau (Wrocław). ${ }^{42}$

Der Typus der Ebersdorfer Madonnen ist kein Einzelfall, sondern lässt sich auch bei dem eingangs erwähnten Retabel aus Topfseifersdorf bei Rochlitz, jetzt im Schlossbergmuseum Chemnitz, beobachten. ${ }^{43}$ Der Altaraufsatz, im 19. Jahrhundert in die Sammlung des Königlich Sächsischen Altertumsvereins aufgenommen, wurde während des Zweiten Weltkriegs stark beschädigt. Der Mittelschrein präsentiert in der mittleren Nische die Muttergottes mit Kind in der Nachfolge der Schönen Madonnen. Ihr zur Seite standen ursprünglich jeweils in zwei Registern übereinander sechs Heilige, oben Jungfrauen unten männliche Heilige. Die Topfseifersdorfer Madonna, in ihrem Körperschwung sichtbar verhalten, steht den genannten böhmischen Vorbildern im Vergleich mit 
Ebersdorf insofern näher, als ihr Obergewand in großem Schwung, wulstige Faltenstege bildend, zu Boden fällt. Darin ähnlich ist ihr auch die leider verlorene Maria mit Kind (um 1420) des Eutritzscher Retabels (Abb. 7). ${ }^{44}$ Sie zeigt leichte Variationen, indem das Kind auf den rechten Arm gewechselt ist, vor allem aber das Aufgreifen der üppigen symmetrisch angelegten Kaskadenfalten auf beiden Seiten des Körpers. Das Retabel, ein weiteres Beispiel eines Viereraltars, zeigt in den vier die Mittelfigur flankierenden Reliefs links die Verkündigung an Maria und die Anbetung der Hl. Drei Könige, rechts die Heimsuchung und die Flucht nach Ägypten.

Trotz grundsätzlicher Beibehaltung der Komposition wie des s-förmigen Körperschwungs, der weich fließenden Schüsselfalten der Mantelschürze und seitlichen Kaskadendrapierungen sind Variationen in der Gestaltung der Figurengruppe zu beobachten. Bei der Madonna aus Tanneberg (1. V. 15. Jh.) beispielsweise ist das Kind aus der diagonalen Liegeposition in eine aufrecht sitzende Haltung gewechselt und erinnert damit an die Maria mit Kind aus Poissy, nach Robert Didier das Urbild eines sich im Laufe des 14. Jahrhunderts weit verbreitenden $\mathrm{Ma}$ donnentyps. ${ }^{45}$ Die Skulptur stammt vermutlich aus dem Zisterzienserkloster Altzelle bei Nossen, das Markgraf Otto 1162 als Grablege der Wettiner gestiftet hatte. Nach einer schriftlichen Überlieferung wurden 1540 mehrere Ausstattungsstücke an die Dorfkirche im Kreis Mittweida abgegeben. ${ }^{46}$

Das beschriebene Sitzmotiv wiederholt sich auch auf dem Hausaltar des Dietrich von Schönberg im Schlossbergmuseum Chemnitz (Abb. 2). Das Retabel von etwa 1430 ist eine Stiftung des späteren Meißner Bischofs Dietrich von Schönberg (um 1400-76), in dessen Mittelschrein die Muttergottes mit Kind von den Aposteln Petrus und Paulus flankiert wird. Auch hier sitzt das Kind aufrecht auf dem linken Arm. Auf der breiten oberen Rahmenleiste erscheinen vier Ahnenwappen derer zu Schönberg. Die Rückseite des Schreins zeigt den Stifter in Anbetung einer weiblichen Heiligen, bei der es sich aufgrund des Lamm-Attributs auf dem rechten Arm um die hl. Agnes handelt. Die Reihe lässt sich fortsetzen mit der eingangs erwähnten Madonna auf der Mondsichel aus Oberhermersdorf (um 1420, Abb. 4), die ähnlich wie die Ebersdorfer Marienfigur in der Kubatur relativ beruhigt wirkt. Das Gewand zeigt auch hier die charakteristischen symmetrisch angelegten Kaskadenfalten. Wiederum ist das Kind auf dem linken Arm aufrecht sitzend platziert. Vom linken auf den rechten Arm gewechselt ist das Kind bei einer Madonna unbekannter Herkunft (um 1430) im Stadtgeschichtlichen Museum zu Leipzig (Abb. 6).

Die genannten Skulpturen und Retabel erweisen sich als von böhmisch-schlesischen Stileinflüssen geprägt. Konkretere Werkstattzuweisungen sind nicht möglich, sodass es nach wie vor bei dieser allgemeinen Zuordnung bleiben muss. Sowohl zu Böhmen als auch zu dem seit 1348 endgültig der böhmischen Krone inkorporierten Schlesien und vor allem dem Bistum Breslau bestanden Kontakte unterschiedlichster Art auf herrschaftspolitischer, kirchenpolitischer, wirtschaftlicher oder rein persönlicher Ebene. Vermittelnd können hierbei ebenso die wettinischen Markgrafen gewirkt haben wie die Meißner Bischöfe, allen voran Johann von Jenstein, der das Bistum bis 1379 leitete und anschließend zum Prager Erzbischof gewählt wurde. Auf ihn folgende Meißner Bischöfe wie Johann von Kittlitz (1393-98/99), Thimo von Colditz (1399-1410) und Johann Hoffmann von Schweidnitz (1427-51) unterhielten Verbindungen unterschiedlichster Art nach Böhmen und Schlesien und können als Vermittler in Anspruch genommen werden. ${ }^{47}$

Zusammenfassend sei nochmals angemerkt, dass die in Obersachsen anzutreffenden Madonnen im Unterschied zu den prominenten Vorbildern wie der Pilsener oder der Krumauer Madonna zurückhaltender in ihrer Gesamterscheinung sind. Diese Zurückhaltung findet ihren Ausdruck in einem reduzierten Körperschwung, in einer geschlosseneren Figurenkubatur. Das Gewand zeigt auch hier die mehrfach beschriebenen typischen, vor den Unterkörper gelegten Schüsselfalten und die seitlich durch die Raffung des Obergewands vielteilig herabfallenden Kaskadenfalten. Die Skulpturen verfügen aber im Vergleich über weniger Volumen, das Gewand liegt flacher am Körper, die Drapierungen sind weniger stark hinterarbeitet, wodurch wiederum der ästhetische Effekt der Licht-Schatten-Wirkung in den Hintergrund tritt.

Für Obersachsen lassen sich um 1400 bisher keine ortsansässigen Werkstätten nachweisen. Dafür war zu diesem Zeitpunkt die Nachfrage wohl noch zu gering. Das schließt nicht aus, dass zeitweilig Bildschnitzer vor Ort tätig waren. Die unmittelbaren Vorbilder sind dann wohl auch nicht in erster Linie in Prag zu suchen, sondern vielmehr in Werkstätten, die sich im weiteren böhmischen Umland etabliert hatten, wie dies beispielsweise eine Madonna aus Budweis (České Budějovice; nach 1400) und eine weitere aus St. Nikolai in Suchdol nahelegen, oder eben auch in Schlesien. ${ }^{48}$ So wohl auch im Falle des Ebersdorfer Schreins, der ein bedeutendes Bei- 
spiel für die Retabelkunst zu Beginn des 15. Jahrhunderts abseits der großen Zentren darstellt.

\section{Literatur}

[Ausst.-Kat. Chemnitz 2012]: Ausst.-Kat. Des Himmels Fundgrube. Chemnitz und das sächsisch-böhmische Gebirge im 15. Jahrhundert. Hg. von Uwe FIEdLer, Hendrik Thoss und Enno BüNz. Chemnitz, Städtische Kunstsammlungen, Schlossbergmuseum, 3.10.2012-20.1.2013. Chemnitz 2012.

[Ausst.-Kat. Chemnitz 2016]: Ausst-Kat. Gotik ohne Grenzen. Sachsen und Böhmen im Spiegel der Kunst um 1500. Hg. von Uwe FIEdler, Stefan ThielE, Antonia Krüger und Markus Hörsch. Chemnitz, Städtische Kunstsammlungen, Schlossbergmuseum, 8.5.-4.9.2016. Chemnitz 2016.

[Ausst.-Kat. Köln 1978]: Ausst.-Kat. Die Parler und der Schöne Stil 1350-1400. Europäische Kunst unter den Luxemburgern. Hg. von Anton Legner. 3 Bde. Köln 1978.

[Ausst.-Kat. München 1995]: Ausst.-Kat. Das Goldene Rössl. Ein Meisterwerk der Pariser Hofkunst um 1400. Hg. von Reinhold Baumstark. München, Bayerisches Nationalmuseum, 1995. München 1995.

[Ausst.-Kat. Prag 2006] : Ausst.-Kat. Karl IV. Kaiser von Gottes Gnaden. Kunst und Repräsentation des Hauses Luxemburg 1310-1437. Prager Burg, 15.2.-21.5.2006. Hg. von Jiří FAJT unter Mitwirkung von Markus HöRsCH und Andrea LANGER. München/Berlin 2006.

[Ausst.-Kat. Prag/Nürnberg 2016]: Ausst.-Kat. Kaiser Karl IV. 1316-2016. Erste Bayerisch-Tschechische Landesausstellung. Hg. von Jiří Fajt und Markus Hörsch. Prag, Wallenstein-Reitschule, 15.5.-25.9.2016; Prag, Carolinum, 14.5.31.8.2016; Nürnberg, Germanisches Nationalmuseum, 20. 10.2016-5.3.2017. Praha 2016; tschechische Ausgabe 2017.

[Ausst.-Kat. St. Marienstern 1998]: Ausst.-Kat. Zeit und Ewigkeit. 128 Tage in St. Marienstern. Erste Sächsische Landesausstellung St. Marienstern. Hg. von Judith OexLE, Markus Bauer und Marius Winzeler. St. Marienstern (Panschwitz-Kuckau), Zisterzienserinnenkloster, 13.6.-18.10.1998. Halle/Saale 1998.

Bachmann, Manfred/Marx, Harald/WÄchtler, Eberhard (Hgg.): Der silberne Boden. Kunst und Bergbau in Sachsen. Leipzig 1990.

Blaschкe, Karlheinz: Geschichte Sachsens im Mittelalter. Berlin 1990.

[Brünlos 2010]: Die Dorfkirche zu Brünlos im Erzgebirge. Hg. von der Altenburger Akademie, Evangelische Erwachsenenbildung. Altenburg 2010 (Der kleine sakrale Kunstführer 19). BuČınA, Ferdinand: Gotische Madonnen. Praha 1958.
DÁŇová, Helena/Gubíková, Renáta (Hgg.): Aller Welt zum Trost. Bildhauerei und Malerei im Komotauer und Kaadener Land 1350-1590. Katalog zur Dauerausstellung im Regionalmuseum Komotau. Komotau 2014.

[Dokumentation Michel 1998]: Michel, Annegret: Das Retabel in der Kirche zu Chemnitz-Ebersdorf. Msc. 1998, LfDA Sachsen, Nr. 2714.

Donath, Matthias: Der Meissner Dom. Monument sächsischer Geschichte. Fotografien Steffen Wirtgen. Beucha 2002.

Eikelmann, Renate (Hg.): Das Goldene Rössl und Meisterwerke der französischen Hofkunst um 1400. München 2006.

FAJT, Jiří: Kampf um den Dom. Markgraf Wilhelm, die Meißner Bischofskirche und der lange Schatten Kaiser Karls IV. In: Thieme/Grässler/Kleiner 2009, 125-140. - Neuere Fassung in: FAJT 2016.

FAJT, Jiří: Der lange Schatten Kaiser Karls IV. Zur Rezeption der luxemburgischen Herrschaftsrepräsentation im Heiligen Römischen Reich. Habil.-Schrift Karls-Universität Prag 2011. Praha 2016. - Tschechische Ausgabe: Dlouhý stín císaře Karla IV. Praha 2016.

FAJT, Jiří/Hörsch, Markus (Hgg.): Künstlerische Wechselwirkungen in Mitteleuropa. Ostfildern 2006 (Studia Jagellonica Lipsiensia 1).

[Forschungen zur spätgotischen Retabelkunst 2016]: Forschungen zur spätgotischen Retabelkunst. Dresden 2016 (Arbeitshefte des Landesamtes für Denkmalpflege Sachsen 25).

Franke, Birgit: Mittelalterliche Wallfahrt in Sachsen. Ein Arbeitsbericht. In: Arbeits- und Forschungsberichte zur sächsischen Bodendenkmalpflege 44 (2002), 299-389.

GubíkovÁ, Renáta/Prontekerová, Markéta (Hgg.): Josef Opitz a umění na Chomutovsku a Kadaňsku 1350-1590/Josef Opitz und die Kunst im Komotauer und Kaadner Land 1350-1590. Sammelband der internationalen wissenschaftlichen Konferenz Komotau, 17.-18.10.2013. Chomutov 2015.

Guldan-Klamecka, Bożena/Ziomecka, Anna: Sztuka na Slasku XII-XVI w. [Kunst in Schlesien, 12.-16. Jh.]. Wrocław 2003.

Hannig, Peter/Perssen, Karin: Stilgeschichtliche Probleme und Datierungsfragen am Topfseifersdorfer Altar. In: Bildend Kunst 1 (1982), 40-45.

Hentschel, Walter: Denkmäler sächsischer Kunst. Die Verluste des zweiten Weltkriegs. Berlin 1973 (Akademie der Wissenschaften der DDR. Schriften zur Kunstgeschichte 15). HöRsCh, Markus: Paris - Prag - Würzburg. Die Madonna in Nordheim am Main und ihre kunstgeschichtliche Stellung. In: FAJT/HÖRSCH 2006, 27-51.

Hrdina, Jan/Kühne, Hartmut/Müller, Thomas T. (Hgg.): Wallfahrt und Reformation. Zur Veränderung religiöser Praxis in Deutschland und Böhmen in den Umbrüchen der Frü- 
hen Neuzeit. Frankfurt/Main 2007 (Europäische Wallfahrtsstudien 3 ).

Hütter, Elisabeth/Kavacs, Günter/Kirsten, Michael/MAGIRIUS, Heinrich: Das Portal an der Westturmfront und die Fürstenkapelle. Hg. vom Landesamt für Denkmalpflege Sachsen. Halle/S. 1999 (Forschungen zur Bau- und Kunstgeschichte des Meißner Domes 1).

Hütter, Elisabeth/Kavacs, Günter/Magirius, Heinrich/MaGirius, Magdalene/Vohland, Peter: Beiträge zur Architektur und Skulptur des 13. und 14. Jahrhunderts. Weimar 2001 (Forschungen zur Bau- und Kunstgeschichte des Meißner Domes II.2).

Hummel, Günter: Die beiden alten Schnitzfiguren und das Tafelbild. In: Brünlos 2010, 12-17.

IsELT, Kathrin: Quellen und Legenden zur Wallfahrtsgeschichte der Ebersdorfer Stiftskirche. In: HRdina/KüHNE/MüLleR 2007, 185-199.

Kelm, Christine: Fasstechniken des Meisters HW. In: Forschungen zur spätgotischen Retabelkunst 2016, 145-155.

Kirsten, Michael: Kunst im 14. und 15. Jahrhundert. In: BACHMANN/MARX/WÄChtLER 1990, 127-138.

Kirsten, Michael: Das Retabel vom Annenaltar in der Allerheiligenkapelle. In: Ecclesia Misnensis. Jahrbuch des Dombau-Vereins Meißen 2000, 27-31.

Kirsten, Michael: Plastik in Obersachsen aus der Zeit zwischen 1350 und 1450. In: Denkmalpflege in Sachsen. Mitteilungen des Landesamtes für Denkmalpflege Sachsen 2000. Beucha 2001, 34-41.

Kutal, Albert: Gotische Kunst in Böhmen. Praha 1971.

Magirius, Heinrich: Die Baugeschichte des Klosters Altzella. Berlin 1962.

Magirius, Heinrich: Die Stiftskirche zu Ebersdorf und ihr romanischer Vorgängerbau. In: Wissenschaftliche Zeitschrift der Karl-Marx-Universität Leipzig 12 (1963), Gesellschaftliche und Sprachwissenschaftliche Reihe H. 2, 407-423.

Michel, Annegret: Der Votivaltar der ehemaligen Stiftskirche Unserer Lieben Frauen in Chemnitz-Ebersdorf. Untersuchungs- und Restaurierungsbericht. In: Dresdner Kunstblätter 2 (2007), 135-144.

Müller, Josef: Die geschichtliche Bedeutung einer Gruppe älterer Bildwerke in der Stiftskirche zu Ebersdorf. In: Sächsische Heimatblätter 5 (1959), 108-115.

Petersen, Gert: Ältere Geschichte der Stiftskirche Chemnitz-Ebersdorf. 2. Aufl. Chemnitz 2002 (Beiträge zur Ebersdorfer Heimatgeschichte).

Petersen, Gert: Dietrich von Harras um 1430 bis 1499. Leben und Taten eines Adligen im Dienste Sachsens und des Heiligen Römischen Reiches Deutscher Nation. Chemnitz 2006 (Beiträge zur Ebersdorfer Heimatgeschichte).

Schellenberger, Simona: Bildwerke des Meisters HW. Diss.
Berlin (HU) 2005. Online: https://edoc.hu-berlin.de/handle/ 18452/16272 (23.09.2017).

SchröDer, Albert: Die Plastik 1350-1550. Leipzig 1931 (Veröffentlichungen des Stadtgeschichtlichen Museums zu Leipzig).

Schulz, Heinrich Wilhelm: Führer durch das Museum des königlich sächsischen Vereins zur Erforschung und Erhaltung vaterländischer Alterthümer im Königlichen Palais des Großen Gartens. In: Mittheilungen des königlich sächsischen Vereins zur Erforschung und Erhaltung vaterländischer Aklterthümer 6 (1852), 45-108.

Staemmler, Friedrich: Die Skulptur des Schönen Stils in der Region Chemnitz. Ihr Bezug zu Böhmen und Schlesien. In: Ausst.-Kat. Chemnitz 2012, 241-253.

Staemmler, Friedrich/Lasch, Gunter: Skulpturen, Altäre und Tafelgemälde aus der Zeit zwischen 1340 und 1440 im sächsischen Erzgebirge und ihre stilistischen sowie kunstpolitischen Verbindungen nach West- und Nordwestböhmen. In: Gubíková/Prontekerová 2015, 285-297.

Thieme, André/Grässler, Ingolf/Kleiner, Anne (Hgg.): Wilhelm der Einäugige, Markgraf von Meißen (1346-1407). Dresden 2009 (Saxonia. Schriften des Vereins für sächsische Landesgeschichte 11).

Tofahrn, Silke: Gotische Skulptur in Sachsen. Bielefeld 2009.

WANCKEL, Otto: Führer durch das Museum des Königlich Sächsischen Alterthums-Vereins im Palais im Großen Garten zu Dresden. Dresden 1895.

Wanckel, Otto (Hg.)/Flechsig, Eduard (Text): Die Sammlung des Königlich Sächsischen Altertumsvereins zu Dresden in ihren Hauptwerken. Dresden 1900.

Wiese, Erich: Schlesische Plastik. Vom Beginn des XIV. bis zur Mitte des XV. Jahrhunderts. Leipzig 1923.

\section{Anmerkungen}

1 Die im Chemnitzer Schlossbergmuseum gezeigten Werke gehören zum Bestand der Staatlichen Kunstsammlungen Dresden und entstammen der im Zweiten Weltkrieg stark dezimierten Sammlung des Sächsischen Altertumsvereins.

2 Ausst.-Kat. Chemnitz 2012. - Ausst.-Kat. Chemnitz 2016. - Nicht unberücksichtigt darf auch die grenzübergreifende Zusammenarbeit mit dem Regionalmuseum Komotau (Chomutov) bleiben, aus der neben einer Tagung im Oktober 2013 zum Thema "Josef Opitz und die Kunst im Komotauer und Kaadener Land 1350-1590" auch eine die Ergebnisse zusammenfassende Publikation hervorgegangen ist: Gubíková/Prontekerová 2015. - 2014 erschien unter dem Titel »Aller Welt zum Trost« der Katalog der Dauerausstellung zur Bildhauererei und Malerei im Komotauer und Kaadener Land 1350-1590 im Regionalmuseum Komotau (DÁŇová/GuBíková 2014). 
3 Der Beitrag berücksichtigt im Wesentlichen den erhaltenen Skulpturenbestand in der Mark Meißen.

4 Karl IV. hatte inmitten des wettinischen Herrschaftsbereichs mehrere Besitzungen der böhmischen Lehnshoheit unterworfen. BLASCHKE 1990, 273.

5 Im Osten grenzte die Oberlausitz an das wettinische Herrschaftsgebiet, 1353 kam die Oberpfalz im Süden hinzu und 1373 im Norden die Mark Brandenburg.

6 BLASCHKE 1990, 273.

7 König Sigismund hatte dem Meißner Markgrafen auf dem Konstanzer Konzil 1417 die wettinischen Reichslehen übertragen, nicht aber die ihnen traditionell zustehenden böhmischen Lehen. BLAschKE 1990, 286.

8 HÜtter/Kavacs u.a. 1999, 11 (Heinrich Magirius).

9 Donath 2002, 79. - Zu Wilhelm I. Thieme/Grässler/Kleiner 2009.

10 Zum Westportal Hütter/Kavacs u.a. 1999, 167-171 (Michael Kirsten). - Fajt 2009. - Zum Südportal Hütter/Kavacs u.a. 2001, 379-431 (Magdalene MAgirius).

11 KiRSTEN 2000.

12 HÜtter/Kavacs u. a. 1999, 277 f. (M. Kirsten).

13 Hütter/Kavacs u. a. 1999, 284 f. (M. Kirsten).

14 Hummel 2010, 12-17, mit Abb. - Staemmler/Lasch 2015, $286 \mathrm{f}$.

15 Hentschel 1973.

16 Hentschel 1973, Abb. 21, 26, 369 f.

17 Über die Sammlung des Königlich Sächsischen Alterthumsvereins SChUlZ 1852. - WancKel 1895. - Hentschel 1973.

18 TOFAHRN 2009.

19 SChröDER 1931, 13, Abb. S. 45; 14 f., Abb. S. 46.

20 Die Sammlung des Stadtgeschichtlichen Museums Leipzig war größtenteils aus der Sammeltätigkeit des 1867 auf Initiative Oscar Mothes und Ernst August Rommels gegründeten Vereins für die Geschichte Leipzigs hervorgegangen. Vgl. hierzu auch den kleinen Katalog zur Plastik 1350-1550 (SCHRÖDER 1931). - WANCKeL 1895 hatte in seinem Führer durch die Dresdener Sammlung jene Objekten, denen er besonderen Kunstwert beimaß, mit einem Asterisk $\left({ }^{*}\right)$ gekennzeichnet.

21 WIESE 1923, 58.

22 Petersen 2002.

23 Schellenberger 2005. - Kelm 2016.

24 Petersen 2006.

25 Magirius 1963.

26 Franke 2002, 346-350.
27 ISELt 2007, 188.

28 Iselt $2007,188 \mathrm{f}$.

29 Immer noch als ein frühes Beispiel des Typus' des horizontalen Vesperbilds gilt die Pietà der ehem. Augustinerstiftskirche St. Thomas in Brünn von ca. 1385, die Albert Kutal Heinrich Parler zuschrieb. Kutal 1971, 137, Abb. 113. - Aust.-Kat. Köln 1978, II, 673 (Jaromír НомоцкA). - Zu den Vergleichsbeispielen DáŇová/Gubíková 2014. 148, Abb. $105 \mathrm{f}$.

30 ISELT $2007,185$.

$31 \mathrm{Im}$ oberen Register Anbetung der Madonna durch Kaiser Karl IV. und seinen Sohn Wenzel IV., begleitet von den Heiligen Sigismund und Wenzel als Landespatrone Böhmens, unten der Erzbischof, der seine Hände in die Rechte des hl. Adalbert legt, empfohlen vom Dompatron Veit und begleitet von den Landesheiligen Prokop und Ludmilla. Prag, Národní galerie, Inv.-Nr. O 84. Zuletzt Ausst.-Kat. Prag/Nürnberg 2016, 374-377, Kat.-Nr. 6.11 (Jiří FAJT).

32 Vgl. die ausführliche Beschreibung durch Rainer Kahsnitz. Ausst.Kat. München 1995, 58-89. - Eikelmann 2006.

33 Paris, Bibliothèque nationale de France, ms. lat. 18014.

34 Chantilly, Musée Condé, Ms. 65.

35 Sämtliche Angaben zu Konstruktion, Fassung und Zustand basieren auf der Dokumentation von Annegret Michel aus dem Jahre 1998: Dokumentation MicheL 1998.

36 WANCKEL 1895.

37 MÜLler 1959, 110, Abb. 1.

38 MÜLleR 1959, 109-111.

39 Vielmals danken möchte ich an dieser Stelle der Restauratorin Annegret Michel vom Landesamt für Denkmalpflege und Archäologie Sachsen, die mir sehr großzügig Einblick in die Restaurierungsdokumentation gewährt hat.

40 Dokumentation Michel 1998. - Michel 2007.

41 Ausst.-Kat. Prag 2006, 508 f. (im Kat.-Beitrag zum hl. Petrus aus Slivice von J. Fajt und Robert Suckale).

42 GULdan-KLAMECKa/Ziomecka 2003, $232 \mathrm{f}$.

43 Hannig/Perssen 1982.

44 Wanckel/Flechsig 1900. - SChröder 1931, 13 f., Abb. 46.

45 Ausst.-Kat. St. Marienstern 1998, 97, mit Abb. - HöRSCH 2006, 3134 (mit dem Verweis auf Didier). - Zuletzt Ausst.-Kat. Prag/Nürnberg 2016, 426f., Kat.-Nr. 9.5 (M. HÖRSCH).

46 Magirius 1962, $155 \mathrm{f}$.

47 Staemmler 2012.

48 Beide jetzt in der Südböhmischen Aleš-Galerie in Frauenberg (Hluboká nad Vltavou). BučinA 1958, o. S. 

Avignon in Der Zeit des Schismas 



\section{Päpstliche Hofkunst in Avignon in der Zeit des Schismas}

Hauptthematik des II. Forums Kunst des Mittelalters war die Zeit um 1400, in besonderem Hinblick auf das Konstanzer Konzil. Da auf diesem das Große Abendländische Schisma beigelegt wurde, rückte auch der Ort in den Fokus, der Ausgangspunkt jener institutionellen und räumlichen Spaltung der lateinischen Kirche gewesen war: Avignon. Die Stadt war seit dem Pontifikat Johannes' XXII. ( ${ }^{*} 1245 / 49$, reg. $\left.1316-34\right)$ der Hauptsitz des Papsttums und entsprechend zu einem Zentrum der Hofkultur aufgestiegen. Als 1378 zwei Päpste gewählt wurden, blieb diese Hauptstadtfunktion auch für die ersten schismatischen - erst seit dem 19. Jahrhundert als Gegenpäpste bezeichneten - Pontifices erhalten: Clemens VII. ( ${ }^{*} 1342$, reg. 1378-94) und Benedikt XIII. $\left({ }^{*} 1342 / 43\right.$, reg. 1394-1423) residierten bis 1403 in der provenzalischen Stadt. ${ }^{1}$ Auch wenn sie sich jeweils als legitime Inhaber des Petrusamts erachteten, blieb dieser Status international der Zankapfel der europäischen Mächte. Für die Päpste entstand ein erhöhter Legitimationsdruck, und sie sahen sich mit polarisierenden Allianzen und schrumpfenden finanziellen Ressourcen konfrontiert. Ausgangspunkt der Sektion war also die Frage, inwieweit dieser kontroverse und prekäre Status sich in der künstlerischen und architektonischen Produktion unter den beiden Potentaten niederschlug. Die Thematik einer Kunstpolitik der Avignoneser Gegenpäpste erscheint aber auch insofern relevant, als es im Schisma nicht einfach um die Konkurrenz zweier Päpste untereinander ging, sondern um komplexe widerstreitende Modelle von kirchlicher Herrschaft und Repräsentation. Der Anspruch auf Suprematie des Papstes, einer absoluten Monarchie vergleichbar, kollidierte mit den Ambitionen des Kardinalskollegiums auf politische Macht, was mitunter mit einer konstitutionellen Monarchie verglichen wird. ${ }^{2}$ Aber auch die vielfach im Vorfeld des Schismas geäußerte Kritik an der rücksichtslosen finanziellen Ausbeutung, dem amoralischen Opportunismus und der Verschwendungssucht der Avignoneser Päpste, vor allem unter Clemens VI. ( ${ }^{\star}$ um 1290, reg. 1342-52), ließ als Gegenmodell Armutsideale innerhalb einer Reform der Kirche von oben entstehen. Zumindest der Absicht nach war eine solche Neuorientie- rung auch mit der vorübergehenden Rückkehr Urbans V. ${ }^{*} 1310$, reg. 1362-70) nach Rom (1367-70) und der seit 1377 dauerhaften Neuinstallierung dort unter Gregor XI. $\left({ }^{*} 1329\right.$, reg. $\left.1370-78\right)$ und Urban VI. $\left({ }^{*} 1318\right.$, reg. $1378-$ 89) verbunden. Solch konkurrierende Modelle kirchlicher Oberherrschaft berühren ebenso die Frage einer künstlerischen Repräsentation der Päpste, wie dies auch der seit dem Pontifikat Clemens' VII. entwickelte und vor allem von der Pariser Universität formulierte Gedanke des Konziliarismus tun musste. Antworten darauf sind allerdings, darauf ist schon im Vorfeld zu warnen, nicht einfach zu geben, denn die Verlustrate der damaligen Produktion ist geradezu verzweifelt hoch.

Im Folgenden soll ein Überblick über die rezente Forschung zu diesem Thema gegeben werden, um den folgenden Aufsätzen von Alexandra Gajewski, Francesca Manzari und Julian Gardner einen gemeinsamen Hintergrund zu geben. Zunächst seien aber einige wesentlich erscheinende historische Umstände in Erinnerung gerufen. Bekanntlich war kurz nach der Rückkehr der Päpste nach Rom im Jahr 1377 Gregor XI. überraschend im Folgejahr gestorben. Unter dem massiven Druck der römischen Bevölkerung, die auf einem italienischen, wenn nicht gar römischen Papst bestand, wählte das Konklave den Erzbischof von Bari, Bartolomeo Prignano, der den programmatischen Namen Urban VI. annahm, sich also klar zur Neuinstallation in der urbs bekannte und überdies an die reformorientierten, prorömischen Aktivitäten Urbans V. anknüpfte. Das Kardinalskollegium änderte daraufhin seine Einstellung zu Prignano, erklärte ihn nach wenigen Monaten für illegitim und kürte Robert von Genf zum Gegenpapst, der den Namen Clemens VII. annahm. Der Versuch, den Stuhl Petri mit Gewalt einzunehmen, scheiterte indes. So zog sich Clemens wieder nach Avignon zurück und konnte dort das südfranzösische Exil der Päpste praktisch ohne Unterbrechung weiter fortführen. Die gewaltige Infrastruktur des päpstlichen Hofs war zu dieser 
Zeit noch nicht nach Rom überführt worden, und so vermochte Clemens auf Kontinuität zu setzen. Dies drückte sich nicht zuletzt auch in seinem Namen aus, der wie ein Gegenprogramm zu Urban VI. zu verstehen war, bezog er sich doch auf die zentrale Avignoneser Papstfigur, Clemens VI. Dieser war nicht nur der letzte große Bauherr der Papstresidenz gewesen, sondern hatte eine ostentativ verschwenderische Hofhaltung von Papst und Kurie betrieben. Diese Ausrichtung setzte sich zunächst auch unter dem Nachfolger Benedikt XIII. - auch hier besteht die Anknüpfung an den Avignoneser Papst Benedikt XII. ( ${ }^{*}$ um 1285, reg. 1334-42) - fort. Da dieser aber der von der französischen Fürstenkoalition vorgeschlagenen via cessionis - Rücktritt beider Päpste und Wahl eines einzigen Papstes unter französischer Observanz - nicht folgte, wurden Stadt und Papstpalast zwischen 1398 und 1411 mehrfach belagert, angegriffen und beschädigt, sodass der Papst schließlich 1403 über mehrere Stationen nach Peñiscola im Königreich Aragon floh.

Das große Schisma ist nicht zuletzt ein Resultat der vielfach zuvor geforderten Reform der Kirche von oben, die sich neben der Eindämmung des Nepotismus auf eine Reduzierung der massiven päpstlichen Aneignung von Steuern, Hinterlassenschaften und Kirchenämtern bezog. Dadurch drohte indessen, wie Stefan Weiß zuletzt dargestellt hat, eine empfindliche Kürzung der Einnahmemöglichkeiten zumal der Kardinäle. Nach dem Umzug nach Rom und der Wahl Urbans VI. wurden derartige Maßnahmen tatsächlich überraschend konsequent von diesem in Angriff genommen. ${ }^{3}$ Der Abfall eines Großteils der Kardinäle und die Wahl eines neuen Papstes dienten also auch dem Ziel, die politische und wirtschaftliche Potenz der Kurienmitglieder zu erhalten. Damit war insbesondere die Notwendigkeit einer aufwändigen Hofhaltung verbunden. Clemens VII. stand programmatisch für diese Politik, dem Kardinalskollegium seine Privilegien zu garantieren und somit in der verschwenderischen Haushaltung an seinen Vorgänger Clemens VI. anzuschließen. In der Selbstwahrnehmung der Kurie bedeutete der Verbleib in - bzw. die rasche Rückkehr nach - Avignon also, institutionelle und politische Kontinuität zu sichern. Dazu kam, dass zwar die Einnahmen aus den Diözesen römischer Obödienz entfielen, doch das galt ebenso für die immensen Kriegskosten zur Rückeroberung Italiens, die bislang auf der päpstlichen Kasse gelastet hatten. Die Avignoneser Gegenpäpste reihten sich zudem in eine fest etablierte Administration ein. Wie Jean Favier am Beispiel des Finanzwesens gezeigt hat, übernahm Cle- mens VII. eine gut organisierte, effizient arbeitende und überschaubare Verwaltung, die sich deutlich von ihrem von neu auf zu organisierenden und zudem unvergleichlich umfänglicheren Pendant in Rom unterschied. ${ }^{4}$

\section{II}

Kontinuität war insoweit Ausdruck ungebrochener Legitimität, und das war politisch umso dringlicher, als beide Päpste um mächtige Alliierte werben mussten, deren politische Motivationen unterschiedlich und wechselhaft waren. Hierbei spielte eine entwickelte, luxuriöse und verschwenderische Hofkultur als angemessene Repräsentation eine wesentliche Rolle. Untersucht ist dies aber bislang nur in Ansätzen. Die von Marie-Claude Léonelli 1978 organisierte Ausstellung zur Avignoneser Kunst zwischen 1360 und 1410 führte zwar viele Stücke zusammen, beließ es aber resümierend bei dem Statement, dass die Stadt weiterhin künstlerisch prosperierte. ${ }^{5}$ Vor allem Cathleen S. Fleck hat unlängst in einem maßgeblichen Aufsatz die Kunstproduktion im schismatischen Avignon detailreich zusammengefasst. ${ }^{6}$ Dies kann zunächst anhand der Schatzkunst verdeutlicht werden. Auch wenn sich viele Provenienzen aufgrund mannigfaltiger Verstreuung der Objekte - Benedikt XIII. nahm offenbar viele Stücke als diplomatische Geschenke mit sich ${ }^{7}$ - bzw. einem reichen Import von außerhalb nicht klar nach Avignon als Herstellungs- bzw. Verwendungsort zuordnen lassen, so zeigen die Quellen, dass die Nachfrage an wertvollen Goldschmiedearbeiten unter Clemens VII. ungebrochen blieb. Manche der mehrheitlich aus Italien in die Rhônestadt gekommenen Handwerker kehrten, nachdem sie für kurze Zeit nach Rom gegangen waren, wieder nach Avignon zurück, so der aus Siena stammende Giovanni di Bartolo Guidi. ${ }^{8}$ Wie sehr programmatische Traditionsfortführung wichtig erschien, hat Fleck auch anhand der Appropriation von wertvollen Büchern durch Clemens VII. gezeigt. Eine in den Jahren 1330/40 in Neapel angefertigte und überreich ausgestattete Vollbibel, die sog. Clemensbibel (BL Additional MS 47672), war unter Benedikt XII. an den Hof gekommen und hatte eine der wichtigsten Zimelien im päpstlichen Studiolo abgegeben. Unter Clemens VII. blieb die Handschrift Teil des engsten päpstlichen Umfelds, allerdings wurden die Anjou-Wappen in den Zierleisten sorgfältig durch die Wappen des neuen Papstes übermalt. Dieser eignete sich somit symbolisch eine der wichtigsten Avignoneser Handschriften 
an, die nicht ohne Grund seither mit seinen Namen verbunden wurde. Diese Wertschätzung blieb auch unter Benedikt XIII. erhalten, der das Buch mit auf seine Flucht nahm. ${ }^{9}$

Diese recht vereinzelten Befunde sind durch die vielfältigen Ergebnisse der Spezialistin zur Avignoneser Buchmalerei, Francesca Manzari, zu ergänzen. Gemäß ihren Forschungen stieg die Buchproduktion in Avignon unter den Gegenpäpsten deutlich an. ${ }^{10}$ Die Aufträge kamen zum einen von den Päpsten und den Kardinälen, doch wurde zum anderen auch für den Markt gearbeitet, der durch angesehene Buchhändler betrieben wurde. Diese Konjunktur hing sicherlich mit der Bedeutsamkeit der Buchproduktion für den diplomatischen Geschenkeverkehr zusammen, was wiederum die politische Stellung von Clemens zu festigen geeignet war. ${ }^{11}$ Als neuen Vorgang konnte Manzari ermitteln, dass die Gegenpäpste große Buchmalerateliers offenbar fester in ihren Umkreis einbanden, als dies für die Zeit zuvor festzustellen ist. Den Buchmaler Jean de Toulouse vermochte Francesca Manzari ab dem Pontifikat Clemens' VII. nachzuweisen, und zwar als Leiter eines großen Ateliers. In etwa fünfzig Handschriften kann man seine Zusammenarbeit mit mehreren anderen Buchmalern erkennen. Auffällig ist, dass die Mitarbeiter aus verschiedenen Regionen kamen, etwa Böhmen und Italien, und ihre stilistische Prägung erkennbar beibehielten. In offenbar wechselnden Konstellationen teilten sich mehrere Ateliers die Illuminierungsaufträge auf, wobei aber anscheinend Jean de Toulouse zumeist die Gesamtkoordination übernahm. Obwohl nordfranzösische Einflüsse deutlich dominieren, verbinden sie sich in Ornamentik, Raum- und Figurendarstellung erkennbar mit anderen Idiomen. ${ }^{12}$ Fleck vermutet hier eine programmatisch diversifizierte Buchmalereiproduktion, die auf Clemens' Anspruch reagierte, im gesamten Europa, über die durch das Schisma gegebenen politischen Abhängigkeiten hinaus, zu agieren. ${ }^{13}$ Bemerkenswert ist die enge Bindung von Jean de Toulouse an den Papsthof. Die recht häufigen Quellenerwähnungen setzen erst während des Pontifikats Clemens' VII. ein, nach dem Tod des Papstes war er weiter bis 1410 ein offensichtlich wohlhabender Bürger Avignons und als Buchilluminator auch für Benedikt XIII. tätig. Danach übernahm er dann aber vor 1412 einen großen Auftrag für die Capitouls - die Stadtregierung - von Toulouse. Manzari deutet dies als Weggang aus Avignon. ${ }^{14}$ Ein Mitarbeiter des Malers, der aus Spanien stammende, aber offenbar in Bologna ausgebildete Sancho Gonthier, beglei- tete Benedikt XIII. auf den ersten Stationen seines Exils. ${ }^{15}$ Ähnlich wie Jean de Toulouse bewegte sich auch Gonthier also im unmittelbaren Umfeld des Papstes.

Angesichts des klar eklektischen Befunds vieler Miniaturen enthält sich Manzari des Versuchs, ein spezifisch Avignonesisches Idiom zu definieren. Immerhin scheint es, dass nordfranzösische Einflüsse in der Zeit des Schismas dominieren, was angesichts der intensiven diplomatischen Verbindungen zu Frankreich, Anjou, Berry und Burgund auch nicht weiter verwunderlich wäre. So verdienstvoll und erhellend die Forschungen von Francesca Manzari für Fragen der Stilgeschichte und der Werkstattorganisation sind, so fehlen doch weiterhin intensive Einzeluntersuchungen zu den vielen in Avignon entstandenen Handschriften. ${ }^{16}$ Der hier folgende Aufsatz Manzaris widmet sich einem weiteren Desiderat, nämlich der Buchmalerei der römischen Päpste zur Zeit des Schismas, die vor allem Traditionen aus den Abruzzen aufnahm und damit - trotz gleicher Buchgattungen an beiden Papsthöfen - sich künstlerisch klar von Avignon absetzte.

Ein gewisser Wandel deutet sich auch im Bereich der Tafel- und Wandmalerei mit der Zeit des Schismas an, denn wenn auch den Quellen zu entnehmen ist, dass Clemens VII. und Benedikt XIII. zahlreiche Maler beauftragten, so nimmt der vormalige Rekurs auf italienische Kunst offenbar ab. Der berühmte Matteo Giovanetti aus Viterbo, der vor allem in den $1360 e r$ Jahren zusammen mit seiner Werkstatt im Bereich des Papstpalasts, aber auch der Kartause in Villeneuve-lès-Avignon tätig war, folgte Urban V., als dieser 1367 für drei Jahre nach Rom zurückkehrte, kehrte aber nicht mehr in die provenzalische Stadt zurück. An malerischen Werken aus den Amtszeiten der Gegenpäpste in Avignon hat sich allerdings derart wenig erhalten, dass keine klaren Aussagen möglich sind. ${ }^{17}$ Dies ist umso auffälliger, als sich seit den 1440er Jahren bekanntermaßen eine subtile, qualitativ hochstehende Malerei fassen lässt, deren Hauptmeister der aus Laon stammende Enguerrand Quarton war und die man mit einigem Recht als provenzalische Schule bezeichnet hat. ${ }^{18}$

III

Der vorgenannte Aspekt programmatischer Kontinuität gilt auch für das Baugeschehen am Papstpalast in den Zeiten des Schismas. Nachdem Urban V. auf der Ostseite des Palasts die sog. Roma, eine zeremonielle Raumfolge 
mit programmatischem Verweis auf die Stadt Petri, hatte anbauen lassen, finden sich keine nennenswerten Anfügungen oder Veränderungen seit den 1370er Jahren. Clemens VII. ließ eine Kapelle in der Roma einrichten und gab Wandmalereien hierfür in Auftrag. ${ }^{19}$ Ansonsten scheint es aber keine Änderungen etwa der zeremoniellen Nutzung gegeben zu haben. Doch unter Benedikt XIII. wendete sich das Blatt. Als Avignon seit 1398 belagert wurde, um den Papst zum Rücktritt zu zwingen, wurde der Palast zur Festung. Der Papst ließ sämtliche Häuser vor dem Papstpalast schleifen und eine lange Schutzmauer um die Residenz errichten, um die Verschanzungsmöglichkeiten der Belagerer zu verringern. Nach der Abtragung dieser Umwallung entstand hier der auch heute noch bestehende große Vorplatz westlich vor dem Palast. Diese Fortifizierungsmaßnahmen waren bittere Notwendigkeit, denn mit allen Mitteln versuchte Geoffrey Boucicauts Armee, den Palast zu erobern. Doch dieser hielt stand, und ein Überraschungsmanöver mithilfe eines unterirdischen Tunnels schlug fehl. Die Schäden waren allerdings umfangreich, aber schon 1413-15 ließ sie Johannes XXIII. reparieren. Auch wenn der Papst nicht in Avignon residierte und schließlich auf dem Konzil von Konstanz mit seiner Resignation den Weg für die Wahl des einhellig legitimierten Martin V. freimachen sollte, galt der Palast offenbar weiterhin als päpstliche Residenz und Zeremonialort. ${ }^{20}$ Zumindest sind die Räume in den erhaltenen Rechnungen mit ihren ehemaligen Funktionsbezeichnungen (etwa Audienz oder Consistorium; nur beim Großen Tinnelum wird eingeschränkt: "vocatur «) benannt, und die Abzeichen der römischen Kirche und Johannes' waren nicht nur auf dem Banner, das bei Abschluss der Arbeiten auf dem Trouillas-Turm aufgesetzt wurde, sondern auch in der erneuerten Ausstattung präsent. ${ }^{21}$

Die Weiternutzung des Palasts unter Clemens VII. und zur Anfangszeit seines Nachfolgers gilt entsprechend auch für die Kardinalsresidenzen, die sogenannten Livrées, in Avignon sowie in Villeneuve-lès-Avignon auf der anderen Rhôneseite. Hier waren, wie zuletzt Sournia und Vayssettes vielschichtig herausgearbeitet haben, ${ }^{22}$ während des 14. Jahrhunderts über ein Dutzend aufwändige Residenzen der Kardinäle entstanden. Ihre Hauptbestandteile - Festsaal, groß dimensionierte Kapelle, Arkadenhof - wurden nach dem Ableben der Kirchenfürsten zu Klosteranlagen umgewandelt. So entstand aus dem Anwesen von Arnaud de Via in den 1330er Jahren das Kollegiatstift Notre-Dame. Die ehemalige Residenz von Etienne Aubert wurde schrittweise zum Kartäuserkloster Notre-Dame-du-Val-de-Bénédiction (gegr. 1356) ausgebaut und diente als Grablege Innozenz' VI. Diese Anlagen wurden selbstverständlich nach 1378 weiter genutzt, doch umfangreiche Bautätigkeit lässt sich in dieser Zeit nicht mehr nachweisen. Kardinal Jean de La Grange bezog gleich mehrere der teilweise von ihren Vorbewohnern verlassenen Kardinalspaläste. ${ }^{23}$ Auch die von Marc Dykmans veröffentlichten Bewohnerlisten der Avignoneser Livrées, deren letzte aus der Zeit um 1400 stammt, bezeugen, dass gerade in der Zeit des Schismas die Kontinuität der Nutzung festgehalten werden sollte, als jeweils die Reihen legitimer Kardinäle als Vorbenutzer notiert wurden. ${ }^{24}$ Nach dem Auszug Benedikts XIII. wurden die Residenzen umgenutzt oder verfielen vielfach. ${ }^{25}$ Dies erklärt, dass die meisten dieser Stadtpaläste heute zerstört oder stark umgebaut bzw. mutiliert sind. Ihre einst überreiche Ausstattung ist bis auf kümmerliche Reste verloren, und dies erschwert weitergehende Aussagen über die Kunstpolitik der Avignoneser Kardinäle beträchtlich.

\section{IV}

Bedeutende Ausnahmen davon bilden zwei Konventskirchen im Südteil der mittelalterlichen Stadt, die Cluniazenerprioratskirche St-Martial und die Coelestinerkirche St-Pierre. Beide weisen eine Reihe von Gemeinsamkeiten auf. St-Martial war durch Clemens VII. unter Mitwirkung eines der Anführer des schismatischen Kardinalskollegiums, Pierre de Murat de Cros, 1379 gegründet worden. Dieser verfügte 1388 hier seine Grablege. Um 1390 ließ eine weitere herausragende Figur des Schismas, Kardinal Jean de la Grange, den Chor nach einem neuen Plan erbauen und sich hier eines der aufwändigsten Grabmäler des Mittelalters errichten.

Der Konvent der Coelestiner ging ebenfalls auf eine Gründung von Clemens, im Jahr 1394, zurück und wurde bald Grabstätte von Kardinal Pierre de Luxembourg, der 1387 im Ruf der Heiligkeit gestorben war. Von 1396 bis ca. 1402 errichtete der Baumeister Pierre Morel Chor, Querschiff und zwei Langhausjoche. Hier, an der Chorseitenwand, fand auch Clemens VII. seine Grabstätte, unweit derjenigen von Pierre de Luxembourg am Querhaus.

Die Bautätigkeit an beiden Kirchen folgte seit den 1390er Jahren sehr ambitionierten Zielen; trotzdem fehlt bislang jede intensivere architekturgeschichtliche Forschung dazu! ${ }^{26}$ Erst der hier publizierte Artikel von 
Alexandra Gajewski stellt nunmehr weiterführende Betrachtungen an, die insbesondere deutlich machen, dass St-Martial als Pantheon des Avignoneser Papsttums dienen sollte, in dem der als heilig verehrte Urban V. ein Kenotaph erhalten sollte. Bei St-Martial zeigt sich der architektonische Anspruch darin, dass die deutlich in einer Avignoneser Bautradition stehende erste Kirche mit relativ gedrückten Proportionen und recht schmalen Fenstern nunmehr von einem hoch aufsteigenden Chor mit großen Fenstern abgeschlossen wurde. Bei der Coelestinerkirche wurde zwar der Plan einer siebenschiffigen Kirche mit Querhaus nie vollendet. Doch trotz einer langwährenden Verwahrlosung und Zweckentfremdung gehört das Innere der Ostteile zu den großartigsten $\mathrm{Ar}$ chitektur- und Bildhauerleistungen Avignons. Der Chor ist länger als bei den anderen Kirchen der Stadt und durch ein in dieser Zeit ungewöhnliches Querhaus vom Langhaus abgesetzt. Das Chorgewölbe prunkt mit reicher Ausgestaltung. Die Kappen sind durch untergeordnete Dreistrahlgewölbe strukturiert, die Rippen mit hängenden Bögen festonniert. Am Scheitelschlussstein schwebt gleichsam ein thronender Christus in einer Aureole von Cherubim. Diese wiederum wird von einem Kranz von sechs großen skulpierten Medaillons umfasst, die von den Schlusssteinen der Dreistrahlgewölbe abhängen. Sie zeigen die Intercessoren sowie die vier Evangelisten.

Die Berufung des für eremitanische Askese stehenden Coelestinerordens entsprach der Karriere von Kardinal Pierre de Luxembourg. Der blutjunge Adelige (* $\left.{ }^{*} 369\right)$, Sohn von Graf Guy de Luxembourg, aber weitläufig auch mit König Karl VI. (* ${ }^{*} 368$, reg. 1380-1422) verwandt, war von Clemens seit seiner Inthronisation als opportune Verbindung zum Kaiserhaus mit höchsten kirchlichen Ämtern versehen worden (darunter 1384 dem Stuhl der auf Reichsgebiet gelegenen Metzer Diözese) und 1386 zum Kardinal in Avignon erhoben worden. Der in extremer Askese lebende Kirchenmann starb mit kaum achtzehn Jahren und kam umgehend in den Ruf der Heiligkeit. ${ }^{27}$ Gemäß seinem Armutsgelübde wurde er zunächst lediglich auf dem Friedhof St-Michel der Pfarrei Saint-Didier bestattet, doch bald ließ Marie de Blois, die Witwe von Louis I. von Anjou, eine Kapelle über dem Grab errichten, und 1394 ordnete Clemens den Bau eines großen Konvents der Coelestiner an dieser Stelle an. Beim Bau der Kirche wurde Pierre ein aufwändiges, restlos untergegangenes Grabmal nördlich des Querhauses, wohl über seiner Grabstätte, errichtet. Das französische Königshaus unternahm bis das 15 . Jahrhundert hinein - letztlich er- folglos bleibende - Kanonisierungsanstrengungen. Clemens seinerseits trug auch maßgeblich zur liturgischen Ausstattung der Kirche bei, etwa durch die Stiftung eines aufwändig ausgemalten Exemplars der Constitutiones des Ordens. ${ }^{28}$ Die Handschrift war ursprünglich für die geplante, aber nie realisierte Gründung eines Coelestinerkonventes in Annecy durch Clemens vorgesehen, kam dann aber umgehend zu den Ordensbrüdern nach Avignon. Auffällig ist das Frontispiz der Handschrift, das eine großformatige Darstellung der Abdankung Coelestins V. zeigt. Wieso hier vonseiten des schismatischen Papstes derart prominent das Argument vortragen werden konnte, auf den Stuhl Petri könne zugunsten von Askese und wahrer Frömmigkeit entsagt werden, bleibt noch zu ergründen.

Jedenfalls war die Wahl der Coelestiner höchst programmatisch. Zum einen galt der Orden seit der Auseinandersetzung zwischen Bonifaz VIII. ( ${ }^{\star}$ um 1235, reg. 1294-1303) und dem französischen König als profranzösisch, hatte doch Philipp IV. $\left({ }^{*} 1268\right.$, reg. 1285-1314) die Sache des zum Rücktritt gezwungenen Coelestin V. (* 1209/10-96, Papst 1294) vertreten. Im 14. Jahrhundert stieg gerade in Frankreich die Zahl der Coelestinerkonvente an, die 1380 , also unter Clemens VII., in der neu gegründeten Provinz Francia zusammengefasst wurden. Zum anderen unterstützte der französische König massiv die Errichtung des Avignoneser Konvents; Karl VI. drang sogar darauf, in den Rang des Fundators erhoben zu werden; und bei der Grundsteinlegung der Kirche 1395 waren die Herzöge von Burgund, Berry und Orléans anwesend. ${ }^{29}$ Die ersten zwölf Mönche kamen aus Paris. Von diesem Engagement zeugt noch heute die Fleur-de-lysFormation im Maßwerk mehrerer Chorfenster. Dass nun auch Clemens VII. als weiterer Fundator in der Kirche begraben wurde, proklamierte nicht nur den Anspruch auf das Ideal asketischer Frömmigkeit, sondern bedeutete unmissverständlich, sich in Sphäre des französischen Königs zu begeben. Der damals regierende Herrscher Karl VI. wiederum, von Wahnsinnsanfällen angegriffen, erwartete von dieser weit entfernt von Paris liegenden, aber hochrangigen Stätte wirkungsvollen geistlichen $\mathrm{Zu}$ spruch. Unterstützt wurde dies auch durch den königlichen Statthalter, Louis d'Orléans, der in seinem Testament 1403 unter Anrufung von Pierre de Luxembourg 4000 Francs zugunsten des Seelenheils der königlichen Familie, und insbesondere Karls VI., stiftete. Die Verbundenheit des Avignoneser Konvents mit dem Pariser Milieu ging so weit, dass er unter Benedikt XIII. zum 
Sprachrohr des von der Pariser Universität vertretenen Konziliarismus werden konnte und damit angesichts der Renitenz des Papstes das ehemalige Bündnis mit dem Avignoneser Papsttum konterkarierte. ${ }^{30}$

An der Coelestinerkirche wie am Chor von St-Martial zeigen sich auffällige Parallelen sowie eine bemerkenswerte Konzentration bestimmter leitender Künstler. Diese verfügten offenbar über leistungsfähige Ateliers und waren zudem eng mit ihrem päpstlichen Auftraggeber verbunden. Beide Choranlagen mit ihren weit ausladenden, oben nicht zurückspringenden Strebepfeilern, den flamboyanten Maßwerkfenstern mit Fleur-de-lysMotiven sowie den festonnierten und teilweise durchbrochenen Rippen, die auf großen Figurenkonsolen aufsetzen, gleichen sich in beiden Fällen à l'identique. Die Avignoneser Architektur, die bis dahin eigenartig schlicht und retardierend war - das gilt ja auch für den Großteil des Papstpalasts, trotz seiner kühnen Konstruktionen etwa im Bereich der riesigen Kapelle und der großen $\mathrm{Au}-$ dienz -, erreicht hier schlagartig ein verfeinertes, internationales Idiom. ${ }^{31}$ Dies geht offenbar auf eine gezielte Initiative Clemens' VII. zurück, die mit dem Engagement herausragender Buchmaler wie im Fall des Jean de Toulouse vergleichbar erscheint. Alexandra Gajeweskis Aufsatz führt diese Diskussion mit weiteren Argumenten weiter, kann sie doch beide Kirchen als Teil des "cult of the Avignon Papacy« herausstellen: nicht nur die Baugeschichte und die damit einhergehende konzertierte Vereinnahmung des südlichen Stadtviertels außerhalb der romanischen Stadtumringung gehen parallel, auch die Stiftungsumstände weisen zahlreiche Vergleichbarkeiten auf. Die für beide Institutionen relevante Präsenz eines Quasi-Heiligen (Urban V. bzw. Pierre de Luxembourg) überschneidet sich mit der Verehrung je eines Avignoneser Papstes (Urban V. bzw. Clemens VII.) und mehrerer programmatisch pro-avignonesisch eingestellter Kardinäle (u. a. Pierre de Cros bzw. Jean de la Grange).

Auch die Grabskulpturen - die Fragmente des LaGrange-Grabmals aus St-Martial und der Kopf als das einzig erhaltene Fragment des Papstgrabmals aus der Coelestinerkirche (beide im Musée du Petit Palais in Avignon) - weisen zahlreiche Übereinstimmungen auf. Anne Morganstern hat - nicht ganz unumstritten - als Bildhauer und Werkmeister Pierre Morel und seine Werkstatt identifiziert, welche ganz offenbar im Zusammenhang dieser umfangreichen Arbeiten eigens aus der Gegend um Lyon berufen wurden. ${ }^{32}$ Dort hat Morganstern zahlreiche Analogien in der Bauskulptur der Westfassade der Kathedrale von Vienne ausgemacht. Stilistisch muss Morel aber am ehesten im Umfeld des frühen Claus Sluter eingeordnet werden. Insgesamt kann man feststellen, dass Clemens VII. nicht nur dafür verantwortlich war, dass eine äußerst innovative, nordfranzösisch geprägte Hofkunst in Avignon eingeführt wurde. Sie war auch eindeutig auf ihn als Auftraggeber bezogen und erhielt zudem einen neuen Grad von Öffentlichkeit. Denn beide Ensembles befanden sich an Stätten, die außerhalb des Papstpalasts lagen und vor allem im Fall von St-Pierre-Célestin intensiv frequentiert wurden, wie die Verehrung des quasi-heiligen Pierre de Luxembourg andeutet.

Die Aktivität der Werkstatt Pierre Morels setzte sich noch lange nach dem Tod Clemens' VII. unter Benedikt XIII. fort; auch dies bildet eine Parallele zum Wirken von Jean de Toulouse. Morganstern hat dafür plädiert, dass der Anbau der Chorapsis von St-Martial mit dem Grabmal La Grange vor dem Tod Clemens' begonnen haben muss, aber erst nach 1402 abgeschlossen wurde auch dazu sei auf die weitere Diskussion durch Gajewski verwiesen. Im Kontrast zu dem innovativen künstlerischen Idiom fällt die eigentümlich retrospektive Ikonografie des La-Grange-Grabmals auf. Die Reliefs, die sich in fünf Registern über dem Kenotaph anordnen, zeigen Stationen des Marienlebens, die je durch Orantendarstellungen von Louis d'Orléans, Clemens VII., Karl V. und Karl VI. sowie von La Grange selbst begleitet werden. Dies ist von Christine Tauber so gedeutet worden, dass hier noch nach dem Tod Clemens' VII. eine nostalgische Idealsituation beschworen werden sollte, in der die historischen Verdienste La Granges im Dienste der Krone beschönigend memoriert wurden. In anachronistischer Weise wurde hier ein persönliches Netzwerk herausgestellt, bei dem eine ideale Bezugnahme der französischen Könige Karl V. und Karl VI., des Regenten Louis d'Orléans als Vertreter des psychisch kranken Karl VI. sowie des Papsts Clemens VII. auf die Person des Kardinals evoziert ist. Als retrospektiv hat dies deshalb zu gelten, weil sowohl Karl V. wie eventuell auch Clemens VII. zur Zeit der Anfertigung des Grabmals bereits verstorben waren. Als anachronistisch ist die evozierte Konstellation aber insofern zu deuten, als La Grange von seiner ehemaligen Rolle als Mitinitiator des Schismas mittlerweile abgerückt war und sich zur Zeit der Errichtung des Grabmals nachdrücklich gegen das Papsttum Benedikts XIII. gewandt hatte. ${ }^{33}$ Dies differenziert Julian Gardner in seinem Beitrag insofern, als er das Grabmal mit den parallel entstehenden römischen Kardinalssepulturen vergleicht. An- 
gesichts ihrer zukunftweisenden Innovationen erscheint das Avignoser Grabmals in diesem Licht als hypertrophe Monumentalisierung überkommener Dispositionen und Ikonografien.

\section{Literatur}

[Ausst.-Kat. Avignon 1978]: Ausst.-Kat. Avignon 1360-1410. Art et histoire. Hg. von Marie-Claude LÉonelli. Avignon, Musée du Petit palais, 25.9.-25.11.1978. Avignon 1978.

Сомте, Sonia: Les Célestins du Midi, une antenne de la cour de France à Avignon. In: Cahiers de Fanjeaux 39 (2004), 175-208.

Dubois, Jacques/Guillouet, Jean-Marie/Van den Bossche, Benoît (Hgg.): Les transferts artistiques dans l'Europe gothique (XIIe-XVIe siècles). Repenser la circulation des artistes, des œuvres, des thèmes et des savoir-faire. Paris 2014

Dyкmans, Marc: Les palais cardinalices d'Avignon. In: Mélanges de l'Ecole française de Rome. Moyen-Age, Temps modernes 83 (1971), Nr. 2, 389-438.

FAure, Claude: Les réparations du palais pontifical d'Avignon au temps de Jean XXIII (1413-1415). In: Mélanges d’archéologie et d'histoire 28 (1908), 185-206.

FAvier, Jean: Les finances pontificales à l'époque du grand schisme d'occident, 1378-1409. Paris 1966 (Bibliothèque des Écoles Françaises d'Athènes et de Rome 211).

FleCK, Cathleen A.: Seeking Legitimacy. Art and Manuscripts for the Popes in Avignon from 1378 to 1417. In: RolloKoster/IzBiCKi 2009, 239-302.

FLECK, Cathleen A.: The Clement Bible at the Medieval Courts of Naples and Avignon. A Story of Papal Power, Royal Prestige, and Patronage. Farnham/Burlington (USA) 2010.

Hasenohr, Geneviève: Pierre de Luxembourg. In: Dictionnaire de spiritualité XII, 2 (1986), Sp. 1612-1614.

[Hayez 1980/I]: Hayez, Philippe (Hg.): Genèse et débuts du grand schisme d'Occident. Avignon, 25-28 sept. 1978. Paris 1980 (Colloques internationaux du Centre national de la recherche scientifique 586).

[Hayez 1980/II]: Hayez, Anne-Marie: Clément VII et Avignon. In: HAYEZ 1980/I, 126-141.

Karsten, Anne (Hg.): Das Grabmal des Günstlings. Studien zur Memorialkultur frühneuzeitlicher Favoriten. Berlin 2011.

Laclotte, Michel/Thiébaut, Dominique: Lécole d’Avignon. Paris 1983.

Manzari, Francesca: La miniatura ad Avignone al tempo dei Papi. 1310-1410. Modena 2006.

MANZARI, Francesca: Harley MS. 2979 and the books of hours produced in Avignon by the workshop of Jean de Toulouse. In: Electronic British Library journal, Article 11 (2011) http://www.bl.uk/eblj/2011articles/pdf/ebljarticle112011. pdf (08.02.2018).

Manzari, Francesca: Mobilité des artistes et migration des styles. Les cours papales d'Avignon et de Rome durant le Grand Schisme. In: Dubois/Guillouet/Van Den BossCHE 2014, 289-302.

Morganstern, Anne McGee: Quelques observations à propos de l'architecture du tombeau du cardinal Jean de La Grange. In: Bulletin monumental 128 (1970), 195-209.

Morganstern, Anne McGee: The La Grange Tomb and Choir. A Monument of the Great Schisme of the West. In: Speculum 48 (1973), 52-69.

Morganstern, Anne McGee: Pierre Morel, Master of Works in Avignon. In: The Art Bulletin 58 (1976), 323-349.

Morganstern, Anne McGee: Le mécénat de Clément VII et maître Pierre Morel. In: Hayez 1980/I, 423-429.

PAnsier, Pierre: Les palais cardinalices d'Avignon aux XIVème et XVème siècles. 3 Bde. Avignon 1926-31.

Rollo-Koster, Joëlle: Avignon and its Papacy, 1309-1417. Popes, Institutions, and Society. Lanham u. a. 2015.

Rollo-Koster, Joëlle/Izbicki, Thomas M. (Hgg.) : A Companion to the Great Western Schism (1378-1417). Leiden/Boston 2009 (Brill's Companions to the Christian Tradition 17).

Schürenberg, Lisa: Die kirchliche Baukunst in Frankreich 1270-1380. Berlin 1934.

Sournia, Bernard/VAyssettes, Jean-Louis: Villeneuve-lèsAvignon. Histoire artistique et monumentale d'une villégiature pontificale. Paris 2006.

Tauber, Christine: Homo novus zwischen König und Kurie. Das Grabmal des Kardinals Jean de la Grange als legitimatorische Autobiographie post mortem. In: KARSTEN 2011, 21-42.

WeIss, Stefan: Luxury and Extravagance at the Papal Court in Avignon and the Outbreak of the Great Western Schism. In: Rollo-Koster/IzBicki 2009, 67-87.

\section{Anmerkungen}

1 Als aktuelle Einführung in das Avignoneser Papsttum sei verwiesen auf Rollo-Koster 2015. - Zum Schisma eingehend etwa RolloKoster/Izbicki 2009. - S. a. Hayez 1980/I.

2 Rollo-Koster 2015, $247 \mathrm{f}$.

3 WeISS 2009.

FAVIER 1966.

Ausst.-Kat. Avignon 1978.

FLECK 2009.

Ausst.-Kat. Avignon 1978, Kat.-Nrr. 18-22, 79. 
8 Ausst.-Kat. Avignon 1978, 35.

9 Siehe v. a. Fleck 2010, 235-277.

10 MANZari 2006, passim.

11 FLECK 2009, 285.

12 MANZari 2006, 203-291.

13 FleCK 2009, $290 \mathrm{f}$.

14 Manzari 2006, $284 \mathrm{f}$.

15 ManZari 2006, 204

16 Eine Ausnahme bildet Manzari 2011.

17 Fleck 2009, 251 f. - Laclotte/Thiebaut 1983, 56-62. - Ausst. Kat. Avignon 1978, passim.

18 Sournia/Vayssettes 2006, 239-243, haben wichtige Beobachtungen vor allem zum Anbringungsort der Louvre-Pietà vorgestellt. Die Maße und Abstände der Profilstäbe, die auf der Rahmenoberkante noch heute zu sehen sind, stimmen mit denjenigen des Maßwerkfensters in der Westwand überein. Trotzdem (wohl, weil die Fenstersohlbank zu hoch liegt, um darunter ein Retabel zu rekonstruieren) nehmen sie an, das Retabel sei hinter dem Hauptaltar im Scheiteljoch des Polygons angebracht gewesen. Allerdings stößt hier unmittelbar der Kirchturm an, der Fensteröffnungen mit Fensterstäben nicht erlaubt. Seit der Neuzeit kommunizieren Kirchenschiff und
Clocher durch eine hohe Öffnung, die es nicht erlaubt, die Form einer ehemals hier befindlichen Chorapsis zu erahnen.

19 FleCK 2009, 260.

20 FaUre 1908.

21 Faure 1908, $195 \mathrm{f}$.

22 Sournia/Vayssettes 2006, 67-243.

23 Sournia/Vayssettes 2006, $229 \mathrm{f}$.

24 Dykmans 1971, v. a. Liste D.

25 PANSIER 1926-31.

26 Zu St-Martial Schürenberg 1934, $132 \mathrm{f}$. - Kursorisch bei MorGANSTERN 1976 und 1980.

27 Hasenohr 1986.

28 Avignon Bibliothèque municipale, Ms. 727. - Manzari 2006, 270, mit Abb. 141.

$29 \mathrm{Zu}$ diesen Sachverhalten eingehend Сомте 2004. - S. a. Hayez 1980/II, $133 \mathrm{f}$.

30 Сомте 2004, 200-202.

31 Morganstern 1976.

32 Morganstern 1980. - Morganstern 1976.

33 Morganstern 1970. - Morganstern 1973. - Tauber 2011. 


\title{
Art and Architecture in Avignon during the Great Schism
}

\author{
Remarks on Clement's ViI foundations of Saint-Martial and Saint-Pierre-Célestin
}

At Sperlonga on 21 April 1379, six months after his divisive election to the papacy at Fondi that inaugurated what came to be known as the Great Schism, Pope Clement VII turned his thoughts to the papal city on the banks of the Rhone. ${ }^{1}$ During the three preceding days he had issued two bulls aimed at funding a war to be led by Louis, duke of Anjou, against the Papal States in Italy, promising the duke a kingdom carved out of these lands if he could liberate Rome from the previously elected pope, Urban VI. ${ }^{2}$ While trying to establish himself in Italy, Clement kept open the possibility of a return to Avignon where, prior to Gregory's XI return to Rome in 1377 , the popes had resided for more than half a century. Clement had already written to Avignon on 1 January 1379 announcing the possible return of his chamberlain, Pierre de Cros, during the spring. ${ }^{3}$ A rival pope was clearly a far more serious obstacle to his claims than living far from Rome, as Cardinal Lagier explained after the death of Gregory XI to a group of anxious burghers from Trastevere, who were calling for a Roman or an Italian pope because they feared that a French pope would return the papacy to Avignon. Lagier argued that a pope's diocese was the world and the pope would remain pope of Rome even when his residence was outside Italy. ${ }^{4}$ Thus when he turned to Avignon affairs on 21 April, Clement finally acceded to the wish of Androin de la Roche ( $†$ 1369), late cardinal and former abbot of Cluny, by authorising Cluny's abbot, Jacques de Causans, to found a priory-college on the lands the order had held at Avignon since the time of Urban V. ${ }^{5}$ The abbey church was to be dedicated to Martial, a saint whose cult had been introduced to Avignon by Clement's VII predecessor and namesake, the luxury- and pomp-loving Clement VI († 1352). In one neat move, Clement VII not only established the first male Benedictine institution within the walls of Avignon's city, but also assured himself of the obedience of the motherhouse of the order and added a presumably pro-Clementine contingent to the university. ${ }^{6}$

Thirteen years later, on 24 September 1394, having rarely left Avignon after his return to the city on 20 June 1379 , Clement founded a second monastery, that of Saint-
Pierre-Célestin. It was to be built in the cemetery where a vibrant cult had developed around the tomb of his noble relative, Cardinal Pierre de Luxembourg ( $\dagger 1387$ ). This new institution was entrusted to Celestine monks, an austere branch of the Benedictine order, founded in 1251 by the hermit Pierre de Murrone, who was later to become Pope Célestin (r. 1294, † 1296). ${ }^{7}$ The order had risen to prominence through the support of the Valois, the royal family, a vital connection for Clement. A descendant of the Counts of Geneva, Clement was related to the Valois through his mother Mahaut de Boulogne and he relied on the royal family as the principal supporters of his claims to the papacy. ${ }^{8}$ Clement VII thus founded two new abbeys within the walls of Avignon, something that none of the Avignon popes had done before. ${ }^{9}$ This is just one of the many changes papal and curial patronage structures were subject to at the start of the Great Schism at Avignon.

This paper re-evaluates the patronage of these two institutions by considering the networks of patronage associated with these projects in order to investigate the complex motives for artistic commissions during these momentous years. As the nineteenth-century art historian Eugène MÜNTZ remarked, far from inaugurating a period of decline in artistic creativity, the reign of Clement VII ushered in a lively new phase of activity in the city. Clement VII and his successor, Benedict XIII - at least initially - continued the tradition of luxury patronage maintained by the earlier Avignon popes. ${ }^{10}$ Unsurprisingly, however, Clement's patronage was shaped by the difficult political situation in which he found himself in Avignon, unable to convert the Emperor to his obedience and relying largely on the support of the Valois family and Queen Jeanne of Naples. During this period, the recipients of the Golden Rose, offered annually by the pope to a candidate of his choice, include Otto of Brunswick, the husband of Queen Jeanne, and the Valois duke of Berry. ${ }^{11}$ As both historians and art historians have highlighted, the artistic commissions made by the pope and some of the cardinals at this time were motivated by the necessity to legitimise the Avignon position. ${ }^{12}$ Saint-Pierre-Célestin and 


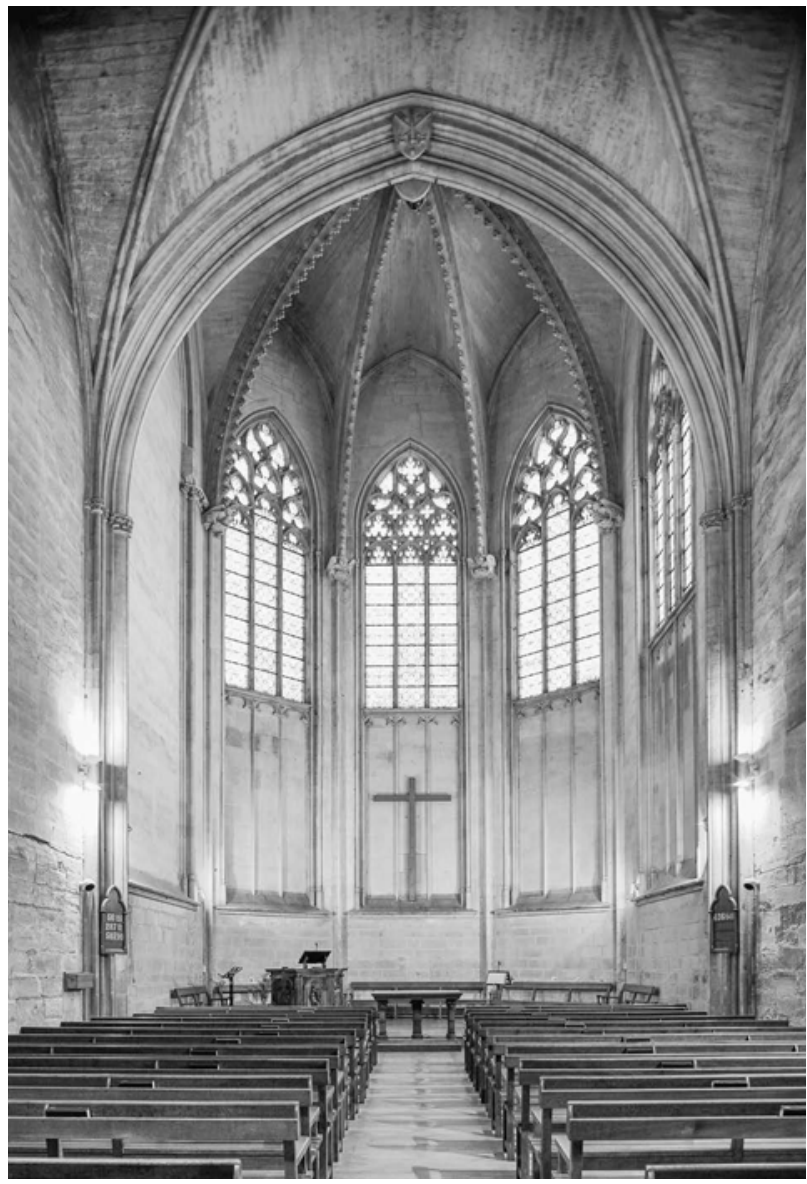

Fig. 1 Avignon, St-Martial, view to east (Foto: Alexandra Gajewski)

Saint-Martial, the latter including the tomb of Cardinal Jean de La Grange, have been interpreted as evidence of a propaganda attempt by the Avignon papacy. However, although they were initiated by Clement, the buildings and fittings of these abbeys were only completed under Benedict XIII, at a time of warfare and division for the city. Focusing specifically on 1378 to 1403 , when Charles VI of France withdrew his support and obedience from the pope (known as the subtraction of obedience), Joëlle Rollo-Koster interpreted Saint-Martial, with de La Grange's tomb, and Saint-Pierre-Célestin in a political light. ${ }^{13}$ For Rollo-Koster, the art and the activities taking place at Saint-Martial and Saint-Pierre-Célestin at this time are evidence of the cardinals' attempt to assert themselves against the new pope and, at Saint-Pierre-Célestin, also against the French king.

Saint-Martial and Saint-Pierre-Célestin are not only linked through their papal patronage but also through their architectural and stylistic similarities. This was first

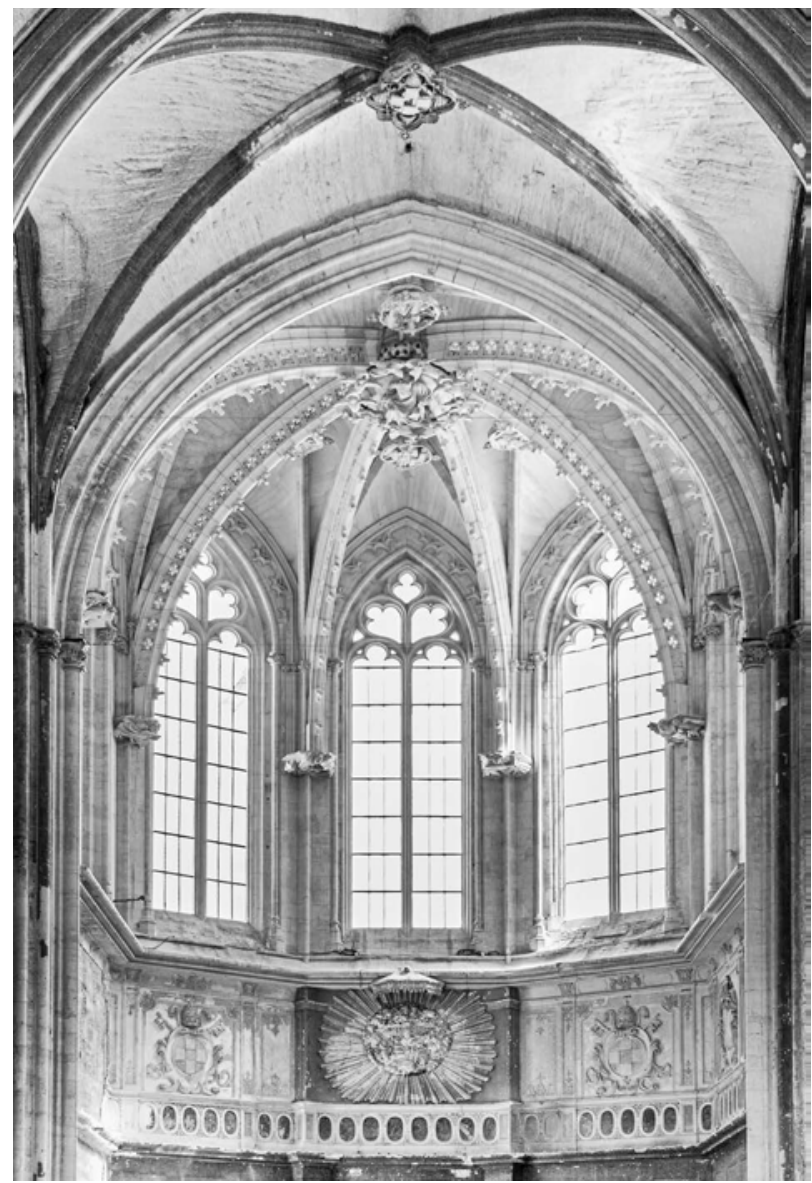

Fig. 2 Avignon, St-Pierre-Célestin, view to east (Foto: A. Gajewski)

recognised by Anne McGee Morganstern in a series of studies from the 1970 s based on her doctoral thesis. ${ }^{14}$ Morganstern's interest was not primarily centred on the politics of patronage but on the artist Pierre Morel who, together with his son Jacques, had first attracted the attention of nineteenth-century archivists. ${ }^{15}$ There is reason to believe that the Pierre Morel active as a sculptor in Lyon in the 1380 os is the same Pierre Morel who first worked for the pope in Avignon in 1393 and then directed the workshop of Saint-Pierre-Célestin from 1396 onwards. ${ }^{16}$ The first building contract was signed for Saint-PierreCélestin on 11 April 1396 between the abbey's officials and "magistro petro morelli lapicide", Master Pierre Morel, stonecutter. Further contracts and documents attest to Morel's activity at the Celestine church until his death on 13 September 1402, when he was buried in the Celestine cemetery. ${ }^{17}$

Crucially, Morganstern observed the many resemblances between the apses of Saint-Pierre-Célestin and 

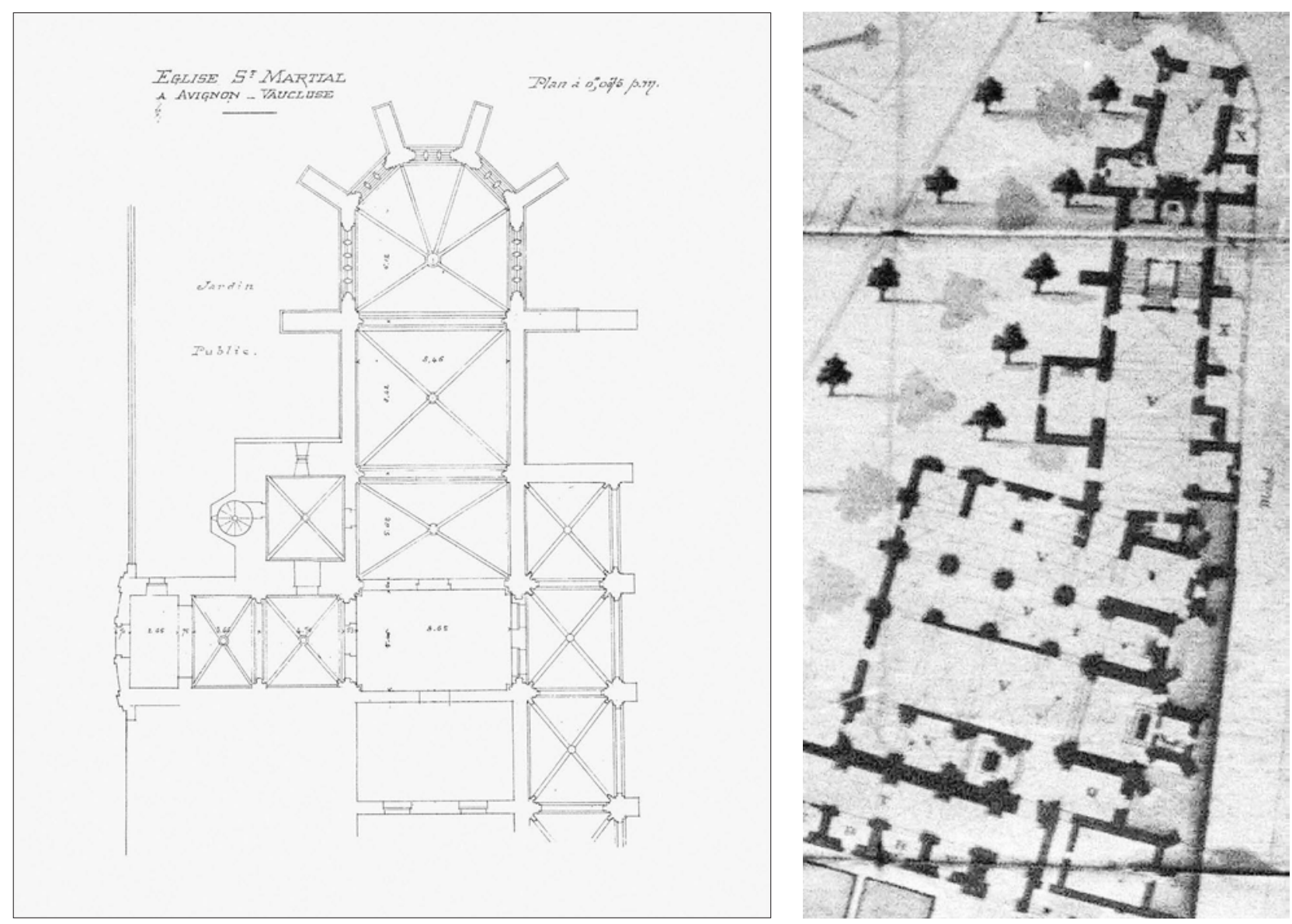

Saint-Martial, including similarities of plan, elevation and sculptural decoration; she concluded that the same architect/sculptor must have been at work in both places (figs. 1 and 2). ${ }^{18}$

Both apses are planned as five sides of an octagon, with each side offering space for a large window (figs. 3 and 4 ). ${ }^{19}$

In both churches the westernmost sides of the apses were lengthened to allow for wider windows; the westernmost section of the apse therefore forms something of a straight bay to the three eastern turning bays. Angel busts serve as corbels to carry the rib-vault of the apses in both churches. At Saint-Martial the angels carry coats of arms; at Saint-Pierre-Célestin they hold musical instruments. Strikingly, in both churches the rib vaults of the eastern apses have a filigree quality. Each rib projects deeply into the space of the apse, consisting of series of quatrefoils within square frames set on a dosseret at an angle to the cells and capped with pendant cusping (fig. 5).

The window tracery in both churches includes curvilinear motifs, such as soufflets and mouchettes. ${ }^{20}$ In particular, both churches boast complex tracery patterns

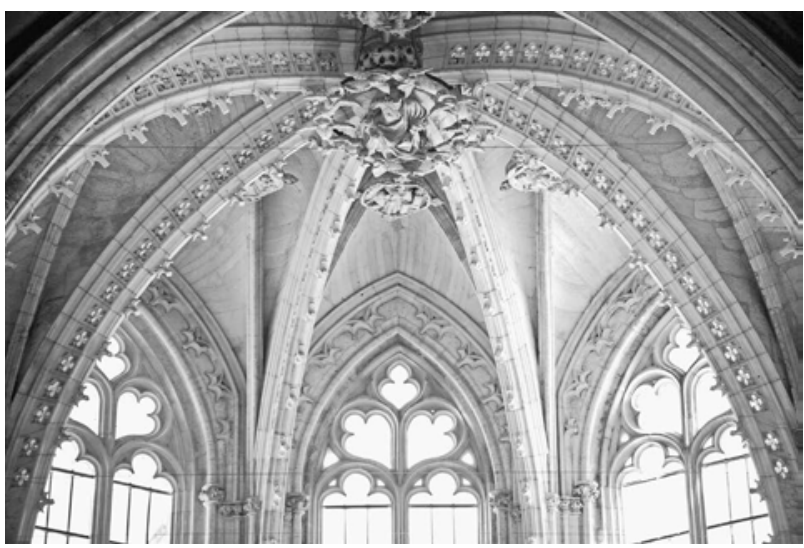

Fig. 3 Avignon, St-Martial, ground-plan without the southern chapels. Avignon, Archives municipales, 39217 (Foto: Yves Schleiss, Avignon, Archives municipales)

Fig. 4 Avignon, St-Pierre-Célestin, ground-plan, detail of plan Pampany. Avignon, Bibliothèque municipale, Est Fol 206/9 (Foto: Camille Jordan, Avignon, Bibliothèque municipale)

Fig. 5 Avignon, St-Pierre-Célestin, eastern apse, ribs (Foto: A. Gajewski) 


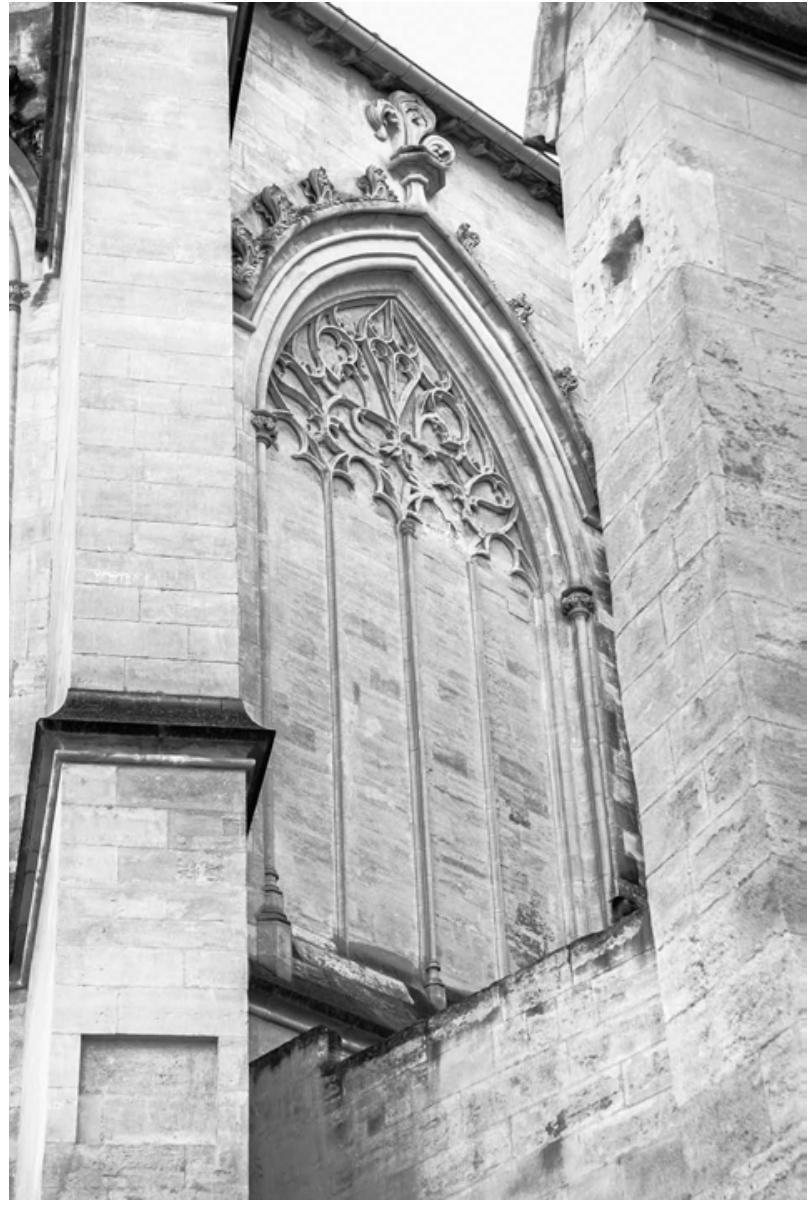

Fig. 6 Avignon, St-Pierre-Célestin, north side of the apse (Foto: A. Gajewski)

in the windows of the western bay of the apse. At Saint Pierre-Célestin both of these windows are blind and the internal and external blind tracery that decorates the window on the north side is generally recognised as describing a fleur-de-lis (fig. 6). At Saint-Martial, there is also a blind window situated on the north side. The blind window tracery on the exterior of that wall is more complex than that of Saint-Pierre-Célestin and at the same time more worn and unrestored but has also been identified as a fleur-de-lis (fig. 7). ${ }^{21}$

Morganstern's attribution of the Saint-Martial apse to Pierre Morel is tantalizing, partly because the apse once held the famous tomb of Cardinal Jean de La Grange, originally located in the blind bay on the north side of the apse. ${ }^{22}$ It was destroyed in the Revolution but in the late nineteenth century Eugène MüNTZ discovered a seventeenth-century annotated drawing in the Vatican library in Rome that showed the tomb with its many registers

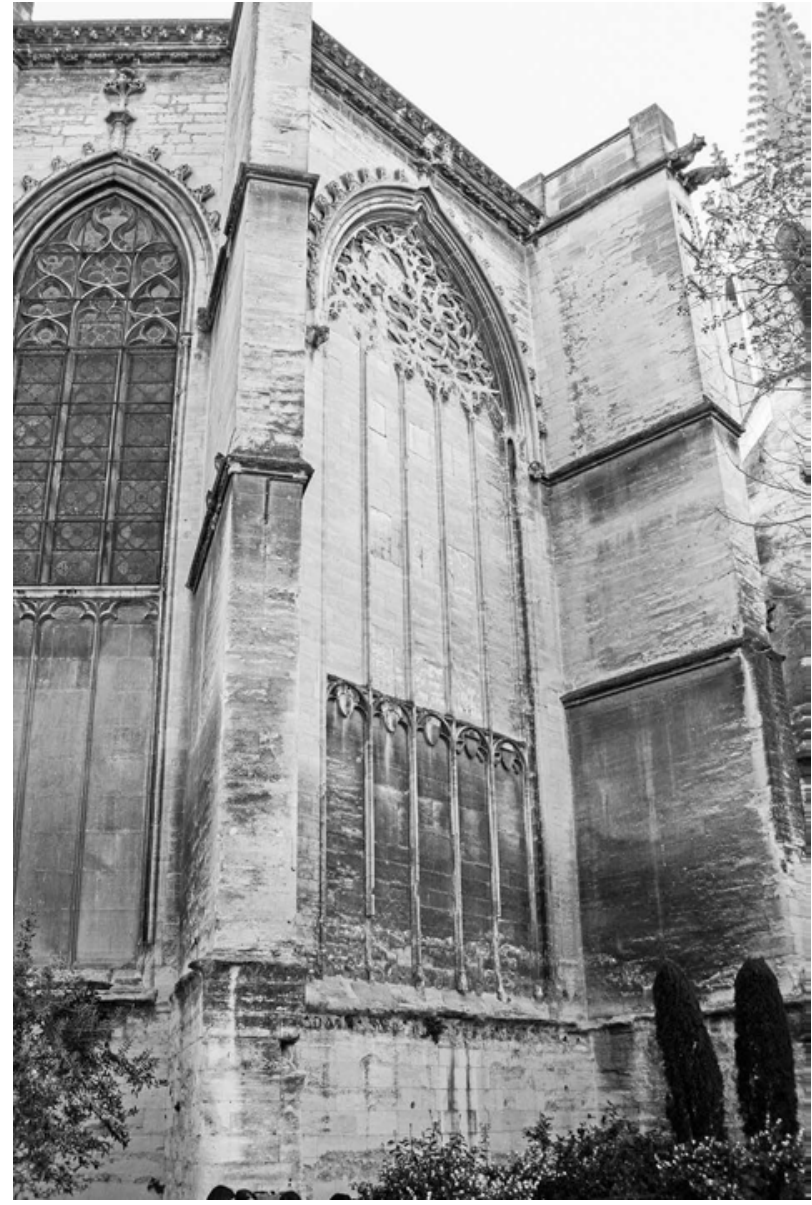

Fig. 7 Avignon, St-Martial, north side of the apse (Foto: A. Gajewski)

occupying the entire space of the bay underneath the formeret (see fig. 1 in Julian Gardner's essay in this volume). ${ }^{23}$ The figures can be roughly identified from this drawing and from the surviving elements of the sculpture. In the lower section, de La Grange's effigy was shown dressed in his bishop's robes and mitre, and prostrated beneath a row of apostles. Positioned below the effigy was a transi that showed the cardinal's naked, decaying body. Above this section, there were five more registers showing scenes from the Life of the Virgin, each observed by a kneeling dignitary, including a pope and a cardinal, and presented by a standing saint. The whole tomb was crowned by a large, micro-architectural baldachin.

Because, like the window tracery in the apse, the surviving micro-architectural elements from the tomb include curvilinear tracery and because the coats of arms in the apse also include papal heraldry, Morganstern argued that the sculpture that survives from the tomb and the archi- 


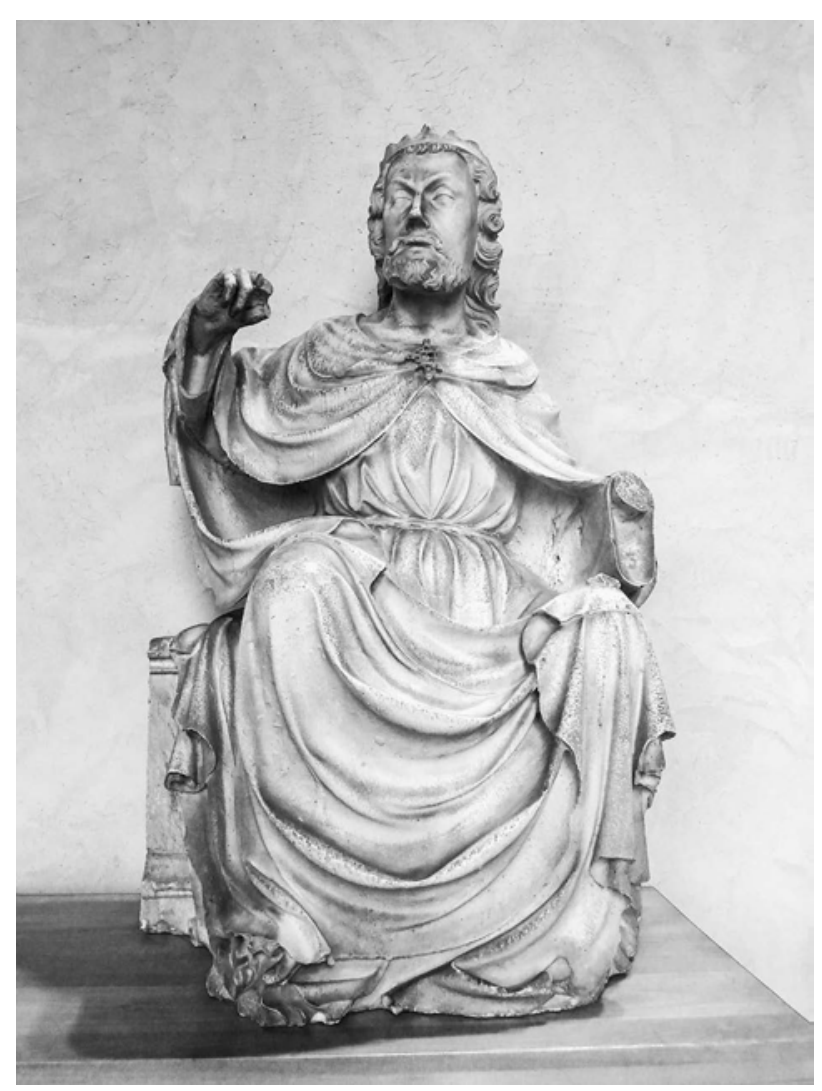

tecture of the apse of Saint-Martial belong to a single construction project. Although she identified several hands working on the tomb, she proposed that the main master was Pierre Morel. She found close comparisons between the angel busts from the corbels of Saint-Martial and SaintPierre Célestin with the de La Grange tomb sculptures, and especially also between the seated Christ from the top register of the tomb and the Christ on the suspended keystone in the apse of the Celestines church (figs. 8 and 9).

Morganstern also observed small differences, like an increased freedom in the handling of the Celestine angels' robes or their hair, but for her these did not cast any doubt on the direct relationship between the sculptures, evidenced in the representation of the bodies, heads and draperies. She therefore attributed both apses and their sculpture, together with de La Grange's tomb, to Pierre Morel and his workshop. Since Morel is reported to have received the stone for Clement VII's tomb in the Celestine church on 14 April 1402, she further attributed the surviving severely-damaged head of the effigy from this tomb to the same master. ${ }^{24}$

Although the date of Saint-Martial is less well documented than the construction of Saint-Pierre-Célestin,

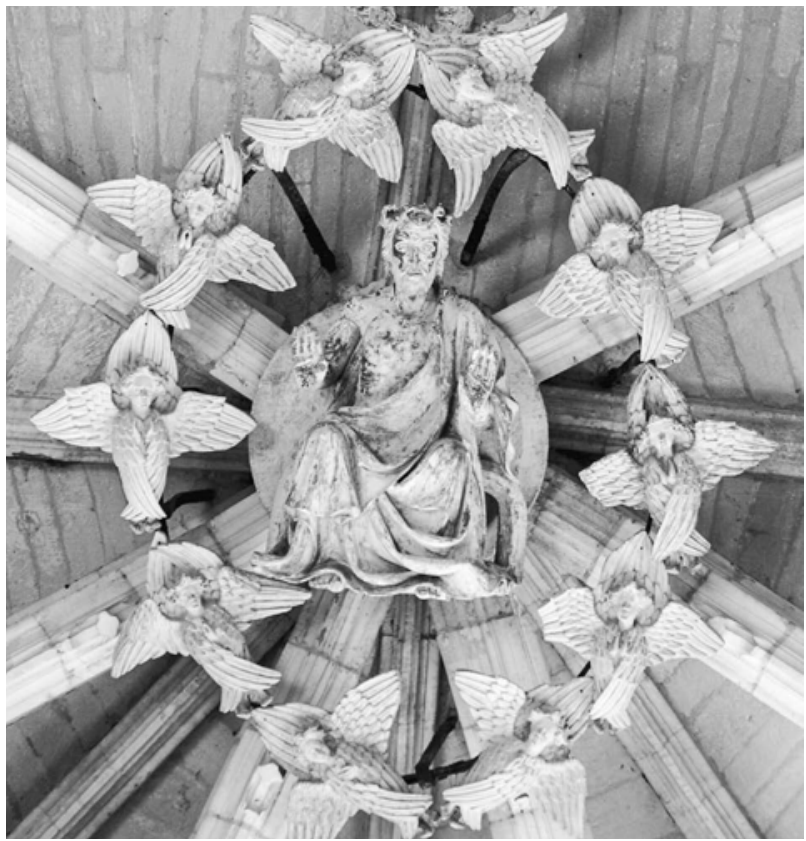

Fig. 8 (left) Tomb of cardinal Jean de la Grange († 1402), figure of Christ from top register. Avignon, Musée du Petit Palais (Foto: A. Gajewski)

Fig. 9 (right) Figure of Christ from the key-stone of the apse. Avignon, St-Pierre-Célestin (Foto: A. Gajewski)

a number of details nevertheless suggested to Morganstern that Saint-Pierre was the later of the two buildings. At Saint-Pierre-Célestin, the foundation stone was laid in the presence of the dukes of Burgundy, Berry and Orléans on 25 or 26 June $1395 .{ }^{25}$ The contract of 11 April 1396 envisaged the construction of the presbytery and the crossing. It is likely that these parts were indeed completed when the body of Clement was transferred to Saint-Pierre-Célestin on 8 September 1401. Since Pierre Morel continued to work at the church until his death, he may also have completed the transepts and the liturgical choir situated in the first two bays of the nave. The unfinished church was consecrated in $1406 .{ }^{26}$

At Saint-Martial the earliest mention of construction dates from November 1388. On 13 November, Pierre de Cros, the pope's former chamberlain who had been made cardinal in 1383 , stated in a will made three days before his death that he was to be buried at Saint-Martial and left funds for the completion of the construction ("opus") he had started. ${ }^{27} \mathrm{~A}$ contract for a tower was concluded on 2 December between the executors of his will and two Avignon stone-masons, Berengarius and Petrus Montanhac. ${ }^{28}$ Nothing else is known about the construction of the 
church until it is mentioned in Jean de La Grange's will of 12 April 1402. In the text, the cardinal makes reference to the apse ("caput") started by him, the tomb, the glass and the altar furnishings that were to be completed, and he made provisions in case they were not finished before his death. ${ }^{29}$ On the basis of this evidence, Morganstern suggested that de La Grange built the apse that had been left unfinished by de Cros and argued further that the in complete state mentioned in de La Grange's will related not so much to the construction of the apse and to the sculpting of the tomb figures, both of which she thought were completed in 1402, but to the furnishings and to the assembly of the tomb. Generally she felt that the design of Saint-Pierre-Célestin was more unified and successful, and therefore that it was a later design than Saint-Martial. The fact that the apse vault of the Celestine church is more elaborate - the webs are decorated with tri-radials and the ribs project even more deeply - and that, in her view, the angel corbels are treated with greater freedom suggested to her an earlier date for Saint-Martial. Since Pierre Morel can be found in documents from Lyon only until 1390, she proposed that the artist must have arrived in Avignon soon after that date to start building the apse of Saint-Martial. For the de La Grange tomb, Morganstern dated its design to before the death of Clement VII in 1394, arguing that the references to the popes in the sculptures would hardly have fitted the political circumstances of Benedict XIII's reign. ${ }^{30}$

The de La Grange tomb, with its representations of five lay and ecclesiastical dignitaries, had long attracted the interest of art historians. The Vatican drawing identified the figures only as types: "ibi cardinalis, ibi comes, ibi dux, ibi rex, ibi pontifex maximus". ${ }^{31}$ Only the cardinal shown with the Birth of the Virgin in the lowest register of the upper section could be identified, as he was likely to represent de La Grange himself. New light was thrown on the identity of the figures in the 1950s, when Pierre Pradel compared the cardinal's tomb with another, earlier commission by de La Grange, the so-called "beau pilier" at Amiens, where de La Grange had been bishop from $1373-75{ }^{32}$ Around 1375, de La Grange built the two westernmost chapels on the north side of the cathedral and, as part of that campaign, added a massive cruciform buttress pier on the north-western corner of the westernmost chapel. He commissioned groups of three superimposed figures under baldachins for each of the two narrow faces of this buttress pier and for the face of the buttress separating the two chapels, forming an en- semble that cannot be easily viewed together because of the varying orientation of the buttresses. Read from west to east, they show the Virgin, John the Baptist and Saint Firmin on the uppermost level of the three buttresses, King Charles V and his sons - the dauphin Charles and Louis, duke of Orléans - below, and, on the lowest level, Jean de La Grange as cardinal, the chamberlain Bureau de la Rivière and the admiral Jean de Vienne. All figures except the saints are identified by coats of arms, by their attire and by certain individualizing features. The princes, for example, are shown as the adolescents they were in the mid 1370s, and de La Grange's face is carefully carved. ${ }^{33}$ Based on the comparison with Amiens and despite the fact that there are no coats of arms attributed to the sculptures on the de La Grange tomb, Pradel argued that the dignitaries on the de La Grange tomb were in fact portraits and showed the same three members of the royal family, the by then late Charles V, the dauphin (who by then had become King Charles VI), and his brother, the duke of Orléans. ${ }^{34}$ As on the Amiens buttresses, de La Grange occupied the lowest level on the Saint-Martial tomb but, whereas at Amiens, de La Grange had associated himself with two other royal administrators, here at Avignon he was the only one to be represented and he chose to feature Pope Clement VII in top position. For Pradel, the explanation for the choice of individuals on the de La Grange tombs lay in their personal relationships with the cardinal, representing "léchafaudage des amis et protecteurs" and thus commemorating the capital events of de La Grange's life. ${ }^{35}$

Morganstern, on the other hand, was cautious about reading a primarily personal message into the tomb. For her, the personal aspect was only one facet of the in tended meaning. She contended that the tomb could not be understood without an appreciation of the political situation of the popes in the late fourteenth century and their dependency on the French royal family. Reminding her readers that, at this time, personal identity was still inferior to corporate identity, she suggested that the main theme of the tomb was the solidarity between church and state. $^{36}$

Recent research into the de La Grange tomb and the wider papal and curial patronage at the time of the Great Schism has been based on these interpretations. ${ }^{37}$ For Christine Tauber, the five upper registers of the tomb were, on the one hand an autobiographical document, representing the figures that assisted de La Grange's social ascension. On the other hand, it also represented a 
Fig. 10 Map of Avignon in the 14th century (ex: ROLLO-KOSTER 2003, 75, with kind permission of the author)

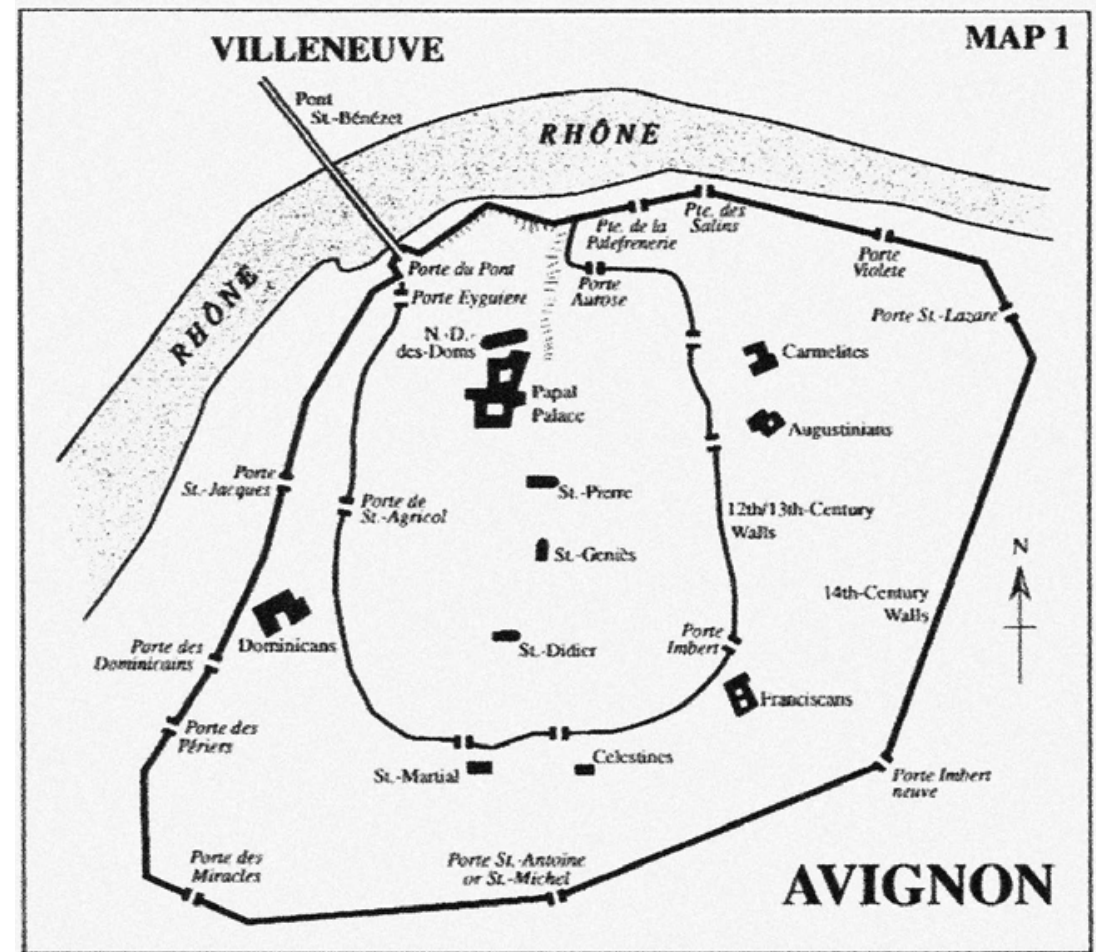

petrified vision of an idealized social order centred on the king. ${ }^{38}$ Cathleen Fleck, in her study of Clement's patronage, shifted the emphasis from de La Grange's royal network as depicted on the tomb to the presence of the pope, arguing that the tomb ultimately "glorified the pope" and that the presence of members of the royal family, of two kings and of the heavenly authorities, were intended to lend legitimization to Clement's position. She made parallels between the message of the tomb and Clement's motivations for the Celestine foundation, which was intimately associated with the royal family from the beginning. By choosing Saint-Pierre as his burial place, Clement associated himself with the cult of Pierre de Luxembourg, a Clementine cardinal and saint, thus demonstrating the rightfulness of the Avignon papacy. For Fleck this was "a clear way to validate himself as the 'true' pope and apostolic heir for posterity".39

For Rollo-Koster, on the other hand, rather than being designed as a means of propaganda for the Avignon papacy, the two churches and, in particular, the de La Grange tomb were the place and the products of anti-papal sentiment during the subtraction period, when the French king withdrew his obedience from the pope $(1398-1403){ }^{40}$ She looked at Saint-Martial and Saint-Pierre-Célestin in the context of the effects of the subtraction on Avignon's topography. ${ }^{41}$ Rollo-Koster noted that urban space within the walls of Avignon was contested by different powers. Traditionally, the popes dominated the foot of the northern rock overlooking the Rhône, where the papal palace lay next to the old cathedral that contained tombs of two popes. This became even more evident during the period of subtraction, particularly during the siege of the palace by Marshal Boucicaut in 1398-99 when Pope Benedict became a prisoner in his own palace. Significantly, both Saint-Martial and Saint-Pierre-Célestin were founded on the other side of the city, within the southern zone between the twelfth-century walls and the new mid-fourteenth-century walls (fig. 10).

This zone was, in the second half of the fourteenth century, still free of public or governmental edifices. Arguing that dominance was achieved through displays in the city, Rollo-Koster contended that in 1401, when Clement's VII body was transferred from the cathedral to the new church of Saint-Pierre-Célestin, the cardinals, who were in open revolt against Pope Benedict, relocated papal power from the northern rock to the southern fringe of the city and appropriated the saint, Pierre de Luxembourg. They thus demonstrated their own power to both the pope and the French king, who at this stage was considering a return to obedience. It is, of course, possible 


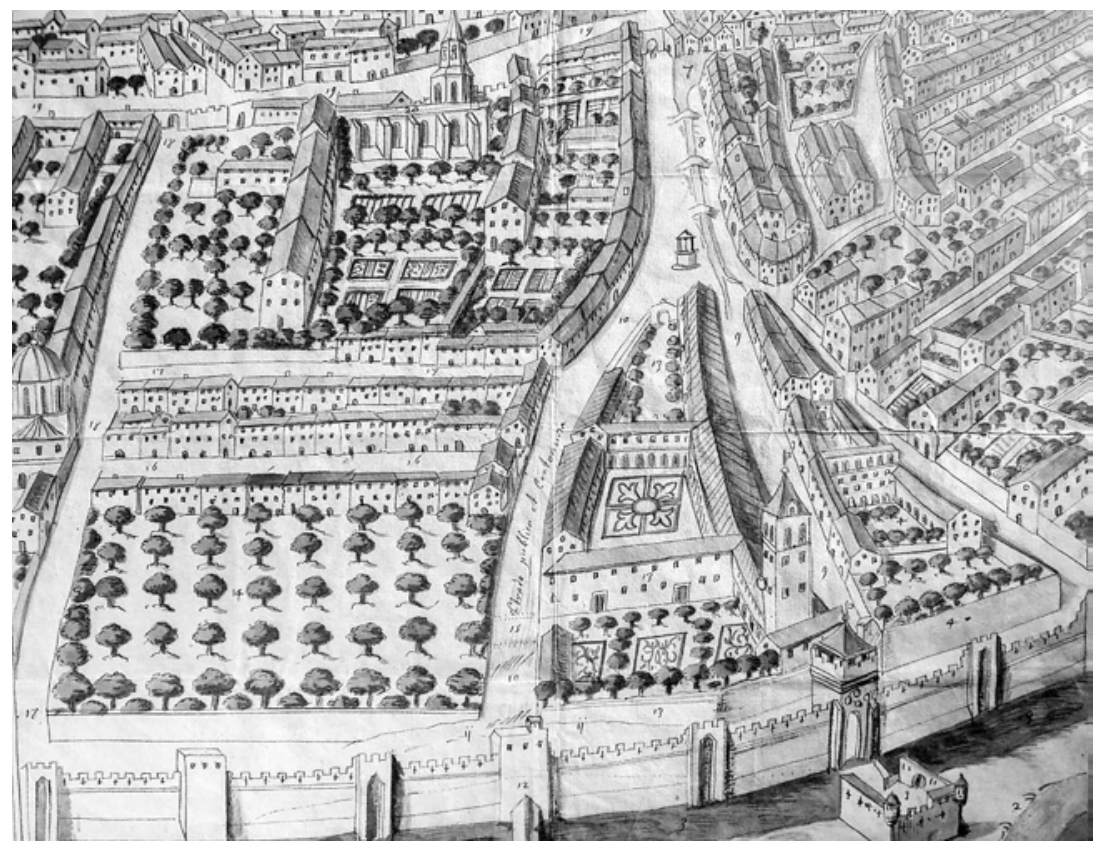

Fig. 11 Map of Avignon. Attributed to François d'Elbène, 17th century. Avignon, Archives départementales de Vaucluse, $1 \mathrm{Fi}$ Avignon 29 (Foto: A. Gajewski)

to reconcile Rollo-Koster's reconstruction of Clement's funeral with the interpretation of Saint-Pierre-Célestin as a pro-papacy foundation. Whatever Clement intended for his new foundation, in the extreme situation in which the cardinals found themselves in 1401, they may well have manipulated the original intention in order to turn the situation to their favour. Nonetheless, Rollo-Koster's thesis raises serious questions not only about the allegiances of the Celestine monks, whose order was under the protection of the king since 1396 , but also about the building. Most of the construction took place during the period of the subtraction of obedience. In 1400, the king granted the privilege to display royal arms on the portals and other prominent places of the abbey. Indeed, as mentioned above, the blind tracery on the north side of the apse represents a fleur-de-lis. Was this display meant to defy the pope and underline the royal connections of the community? How would the monks have accommodated the cardinals' display of power aimed at the French king ? $^{42}$

It is even more problematic to reconcile Rollo-Koster's analysis of the de La Grange tomb with the observations of earlier commentators. Dating the tomb to between 1394 and 1402, and therefore to after the death of Clement VII, and noting its location in the southern zone of the city, close to the Celestines, she argued that its display of royal portraits reflected the cardinal's support of the king and opposition to the new pope. Therefore, depending on how we date the design of the tomb and the apse of Saint-Martial with its papal heraldry, we can see the tomb as Morganstern and Tauber do, as a monument designed under Clement that was already behind the times when it was assembled after the cardinal's death in $1402 .{ }^{43}$ Or, alternatively, we can follow Rollo-Koster's interpretation and see it as an up-to-date representation of the cardinal's reaction to the subtraction crisis.

It is beyond the parameters of this paper to address the questions raised by these opposing interpretations fully, a task that would entail, for example, a long-overdue architectural analysis of the two churches and a re-evaluation of their stylistic evidence in the context of contemporary Flamboyant architecture. Instead, for now, I would like to suggest that, following Morganstern's reminder of corporate identity in the late Middle Ages, it is instructive to shift the focus away from the individual patronage of Clement VII and Jean de La Grange and to analyse and compare the networks of patronage behind these two foundations. In this respect, research on Saint-Martial is somewhat behind that of the Celestine church, which has gained greater limelight because of its royal connections. Yet by paralleling the patronage of Saint-Martial with that of SaintPierre Célestin and by comparing the role of the respective institutions within Avignon, patterns start to emerge that suggest that the urban and artistic projects of these years were not so much (or not only) politically inspired, but had a spiritual dimension relating to Avignon's role as the seat of the - in these patrons's eyes - true papacy. 
The dramatic changes in architectural design that occurred in Avignon during the last twelve years of the fourteenth century are best appreciated at Saint-Martial. Unfortunately, the precise analysis of the construction campaigns of Saint-Martial is impeded by the many changes and alterations the structure underwent over the course of the centuries. Today, the two eastern bays of the central nave and the apse are used as a parish church by the Protestant community of Avignon (figs. 1 and 3). The next bay to the west serves as an entrance vestibule and the westernmost bay and a half are used as a storage room with a lower ceiling inserted. The nave arcades that once gave onto a south aisle have been walled up. The remains of this aisle, together with those of three southern chapels and the cloister, can now be seen within the public garden that surrounds the church. In trying to reconstruct the original church, it soon becomes clear that it was an irregular structure, presumably because it had to be integrated into an already existing street pattern limited on the north side by the river Sorgue and the remains of the twelfth-century city walls (fig. 11).

Originally, it consisted of a central nave of four and a half bays length. The main entrance was situated on the north side (fig. 3). A two-bay narthex connected the entrance portal to the second nave bay from the west, and the bell tower rose in the eastern angle between the narthex and the nave. ${ }^{44}$

Lisa Schürenberg was one of the first scholars to comment on the difference between the nave and the eastern apse (fig. 1). ${ }^{45}$ The curvilinear tracery that decorates the apse windows of Saint-Martial is the earliest example of Flamboyant design in Avignon together with the windows at Saint-Pierre-Célestin. Moreover, the vaults of the apse are set higher and the windows are larger than those in the nave. Blind tracery decorates the zone below the windows, whereas the nave walls remained undecorated. The differences also concern the detailing of the capitals and moulding profiles. They indicate that the break between the construction campaigns occurred within the rectangular eastern bay of the nave that precedes the apse. With its small lancet window on the south side, the bay resembles the other nave bays. ${ }^{46}$ Nonetheless, there is evidence that this bay was re-vaulted during the second campaign. The responds of the western piers of that bay, both on the north and on the south side, belong to two separate campaigns (fig. 12).

Facing east, above the lower capitals, the vaulting shafts of the ribs have a roll and fillet moulding that matches

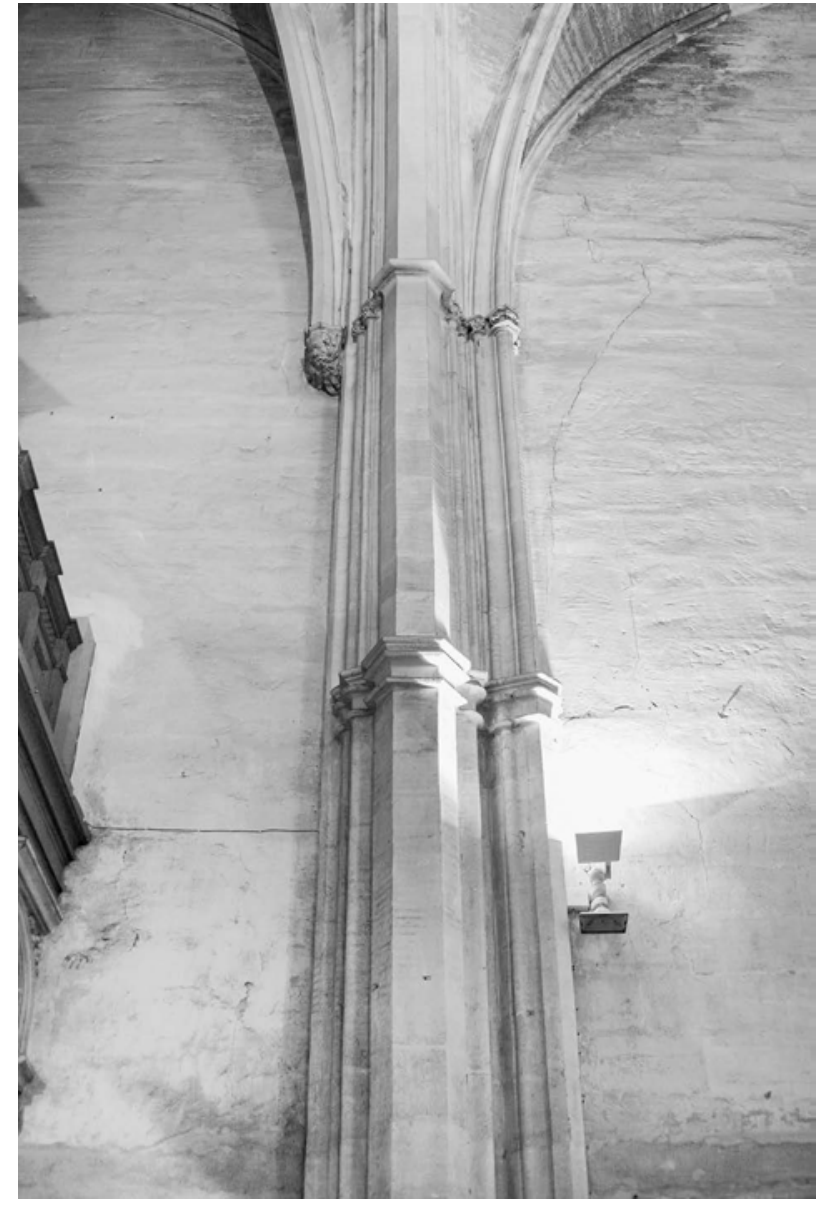

Fig. 12 Avignon, St-Martial, western respond of the eastern nave bay, north side (Foto: A. Gajewski)

the ribs of that bay. It is the same type of responds that can be found on the eastern piers of that bay and in the apse. Below the capitals, by contrast, the responds have a flat central element with chamfered sides that matches the similarly shaped responds of the nave piers, and the vaulting shafts facing west have a simple roll moulding without a fillet. ${ }^{47}$

The break in construction is also a break between two different visions of architectural design. The nave clearly belongs to the fourteenth-century generation of churches in and around Avignon, such as Saint-Didier or NotreDame de Bon-Repos at nearby Montfavet. ${ }^{48}$ Both these churches are simple, rather austere constructions consisting of a nave with lateral chapels, small lancet windows in the clerestory and a lower, five-part eastern apse. The architecture plays on the contrast between the extensive undecorated wall space and the simple but sophisticated detailing of the responds, including mouldings 


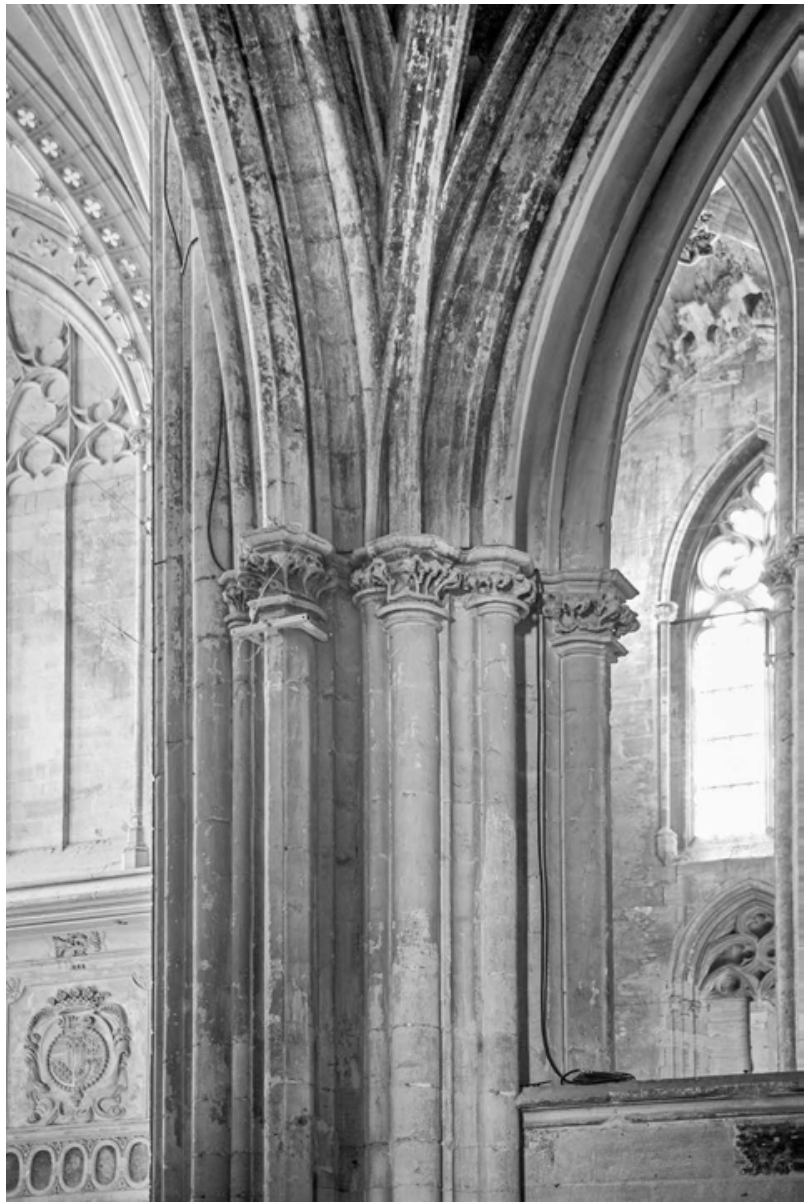

Fig. 13 Avignon, St-Pierre-Célestin, north-western crossing pier, detail (Foto: A. Gajewski)

that cross each other above the springing point of the ribs at Saint-Didier. On the outside, these buildings are supported by slabs of undecorated buttresses and have an attached bell-tower. The nave of Saint-Martial closely resembles this type of church. In particular, the chamfered ribs and pier responds, the simple capitals without foliage and the small double light lancet windows can be compared to those of Saint-Didier. There are no crossing ribs at Saint-Martial, but the architect introduced variation in the vaulting by replacing some of the responds in the nave and in the narthex with sculpted corbels. The parish and collegiate church of Saint-Didier housed the tomb of Cardinal Bertrand de Deaux, whose money - assigned in his will of 1355 - paid for the reconstruction of the church by the master-masons Jean Postier of Salon, who had worked as a mason at the papal palace, Guillem Ébrard of SaintMaximin and Jaume Laugier from Avignon, according to a design by Master Jaume Alasaud. ${ }^{49}$ The similarities between the two churches are perhaps unsurprising. Not only was Saint-Martial located in the parish of Saint-Didier but also, at least as far as is known from the bell tower contract, the building site of Saint-Martial included local architects from Avignon, Berengarius and Petrus Montanhac, who would have been familiar with Saint-Didier. ${ }^{50}$

The architecture of the east end of Saint-Martial, commissioned by Jean de La Grange and attributed to Pierre Morel and his workshop, introduced a new architectural language to Avignon that deserves more attention than it can be given here. Although Morel maintained some of the features that characterise the earlier Avignon type, such as the small lancet windows found in the nave of Saint-Pierre-Célestin, his architecture is at once more decorative and more skeletal. As Schürenberg remarked: "For the first time (at Avignon), the choir of Saint-Martial seriously realises a verticality of space, not only because of the steep proportions, but also because of its rich and consequential organisation of the structure with the help of responds, window jambs and tracery." ${ }^{51}$ As the choir of Saint-Martial and the church of Saint-Pierre-Célestin show, the self-effacing sophistication of earlier Avignon masters was not for Pierre Morel (fig. 13).

This is evident not only in the extraordinary decoration of the ribs of the apse, which seem to be well ahead of their time, but also in his system of supports. ${ }^{52}$ A great afficionado of the filleted roll, he combined that old staple design of a moulding with simple fat rolls and undulating profiles that gave an idiosyncratic force to his architecture and an old-fashioned air that is betrayed only on second sight by the crossing ribs and moulding profiles.

Morganstern's aesthetic and stylistic arguments for dating the apse of Saint-Martial to 1390-94, and therefore earlier than the Celestine church, are not particularly strong. It is true, for example, that the vault in the apse of Saint-Pierre-Célestin project appears more elaborate than that at Saint-Martial but we have lost the hanging key-stone at Saint-Martial and one could argue that the tracery decoration of the blind north-western window of the apse of Saint-Martial is more decorative than the same blind window at Saint-Pierre (figs. 6 and 7). The difference in the handling of the angel busts could be due to a slightly different team of sculptors if both churches were built roughly at the same time. Moreover, there are other, more practical problems with Morganstern's early dating of Saint-Martial. The fact that, in 1388, the church was under construction because Pierre de Cros left money for its completion does not allow us to conclude that the 
church would have been left with the eastern apse unfinished until it was eventually completed under de La Grange at the end of the century. It is unlikely that there was a shortage of money since de Cros had reaped a fortune in benefices and left his wealth to Saint-Martial. ${ }^{53} \mathrm{~A}$ comparable building, Saint-Didier, took little more than three years to build. ${ }^{54}$ There is, furthermore, no reason to assume that de La Grange did not refer to the building, when he said that Saint-Martial was under construction in $1402 .{ }^{55}$ In fact, all the indications are that de La Grange rebuilt an existing apse at the same time as his tomb was carved, and that these events took place, like the construction of Saint-Pierre-Célestin, after the death of Clement VII in 1394. They may well have coincided with the subtraction period from 1398 to 1403 .

However, as eventful as this period was, dating the construction of the apse and the carving of the tomb to these years does not in itself prove that the intentions behind those commissions were shaped by contemporaneous events or that the commissions were ordered in reaction to them. And although the introduction of a new architectural idiom for the apse of Saint-Martial suggests that the campaign under the patronage of de La Grange had a different artistic horizon than the earlier campaign under Pierre de Cros, the more avant-garde features of the apse compared to those of the nave should not be taken as a cue to discard Pierre de Cros as an important patron or to ignore his role as founder of the institution. In fact, for a better understanding of de La Grange's patronage of the priory and his commissioning of the tomb it is necessary to start by questioning his motivations for choosing burial at Saint-Martial in the first case and to investigate the institutional profile of the priory-college. It is, therefore, necessary to go back to its foundation and to the charter given by Clement VII at Sperlonga in the early days of his pontificate.

In 1379, Clement VII was not alone in establishing a Cluniac abbey for the community that Urban V ( $† 1370)$ had settled in Avignon. As he mentioned twice in the foundation charter, he did so on the advice of his chamberlain Pierre de Cros. ${ }^{56}$ De Cros was a leading figure in the curia and a close confidant of Clement. He had been one of the driving forces behind the election of Robert of Geneva. Although he was not a cardinal at the time - his older brother, Jean, was one of the cardinals present at the Fondi election - as chamberlain he was responsible for the treasure and the papal insignia and therefore, as Daniel Williman has shown, in a key position. ${ }^{57}$ Swiftly securing the treasure, the tiara and the papal archives after Urban's VI election and taking them to Anagni made the second election possible. ${ }^{58}$ De Cros' recompense soon arrived: in 1383 he gained the cardinal's hat that features on his coat of arms on the keystones in the nave of Saint-Martial. In his will, he asserted Clement's position as pope by divine providence and recalled their relationship with fondness. ${ }^{59}$ For de Cros and his peers, the choice of burial place was closely bound up with - undoubtedly sometimes conflicting - loyalties of kinship or Church. Some members of the fourteenth-century curia were buried in their family's traditional burial church, some in monasteries where they had been professed or had held an appointment, and others chose interment in Avignon, either in the cathedral or in their own foundations. ${ }^{60}$ Their choice allows us an intimate insight into their personal attitudes and their spiritual inclinations. In an earlier will of February 1388, de Cros had left it open to the executors whether he should be buried together with his cardinal brother at the cathedral or at Saint-Martial. Only a couple of months later, in November, however, he made a firm decision in favour of Saint-Martial, bequeathing all his possessions to the abbey. ${ }^{61}$ Undoubtedly, having assisted Clement in the foundation would have encouraged de Cros to seek burial there. Moreover, as a former Benedictine monk and abbot of Tournus he was entrusting the care of his soul to his own order. In 1401 a second cardinal was buried at Saint-Martial, Guillaume d'Aigrefeuille the Younger, who had also been present at Fondi. ${ }^{62}$ At the time of d'Aigrefeuille's death in January of that year, the cardinal had left the obedience of Pope Benedict XIII, turned his back on Avignon and moved to Villeneuve. ${ }^{63}$ But he stayed true to his decision to be buried at Saint-Martial, which he had made in September 1394, just before Pedro de Luna was elected pope later that month. D'Aigrefeuille had not been a Benedictine monk and there must have been reasons other than the order to which Saint-Martial belonged that persuaded him to seek burial there. In contrast, the last member of that generation to choose his burial at Saint-Martial, Jean de La Grange, had been abbot of the Benedictine abbey of Fécamp since 1357 before being elected bishop of Amiens in 1372 . Sometime before 1375 , this lavish patron of the arts had already made provisions for his burial at Amiens Cathedral. ${ }^{64}$ An effigy was carved in Paris and brought to Amiens to be placed in the choir, and the two nave chapels mentioned above were built for his commemoration. In 1380 , five years after he had been created cardinal 
and at a time when he had left the Paris court and settled in Avignon, he requested a dispensation to separate his body in order to have a second tomb. ${ }^{65}$ Perhaps already at this time, but certainly before 1402 , he decided that this second burial should take place at Saint-Martial. In choosing a double interment, de La Grange was probably prompted by a yearning for more commemoration and perhaps also by the fact that he owed ties of loyalty to more than one place. His last will of 1402 demonstrates the deep devotion he vowed to King Charles V, for whom he ordered 4800 masses and commemorations in all the churches to which he made bequests. ${ }^{66}$ Yet another tie was the allegiance he vowed to Clement VII and to the Avignon papacy. De La Grange had been absent from the 1378 conclave that elected Urban VI, and it is generally recognized that, together with Pierre de Cros, he was the driving force behind the election of Robert of Geneva at Fondi. ${ }^{67}$ The unstinting support he gave to Robert was a prolongation of the policies of his distinguished benefactor and patron, Cardinal Gui de Boulogne ( $\dagger 1373$ ), a relative of the Valois family through the marriage of his niece Jeanne de Boulogne with the future King Jean le Bon and an uncle of Robert of Geneva. As a young man, de La Grange belonged to the cardinal's familia, and as the son of a mere notary, he owed him his brilliant career. ${ }^{68}$ The heraldry in the apse of Saint-Martial shows how important these connections were for de La Grange. The angel bust on the left of his tomb carried the coat of arms of Gui de Boulogne (fig. 14).

By choosing Clement's foundation in Avignon as a burial place and by commissioning a tomb that depicted Charles V and his sons as well as Clement VII, de La Grange paid homage not only to Charles V and Clement VII individually but also the whole idea of an Avignon papacy founded on the pact between the French kings and the pope. The fact that the pact was broken in 1402, when de La Grange was close to death and had already prepared his tomb, must have been bitter for the old cardinal, but it does not mean that the ideal that his tomb at Saint-Martial represented was less important to him than before the death of Clement in 1394 .

There was, however, another reason behind the cardinals' choice of burial place at Saint-Martial. It is most clearly expressed in the will of Guillaume d'Aigrefeuille, who recalled that it was Pope Urban V, "of blessed memory", who promoted him to the rank of cardinal-priest. ${ }^{69}$ Among the many sculptural fragments held at the Musée de Petit Palais is the head and torso of an effigy repre- senting Pope Urban V that comes from Saint-Martial (fig. 15). ${ }^{70}$

Urban died on 19 November 1370 and in 1372, according to his wishes, he was taken to his former abbey of Saint-Victor in Marseille for burial. ${ }^{71}$ The late Urban was connected in a number of ways to the Cluniac foundation of 1379 in Avignon. Amongst the popes, Urban was the only one who had been a Cluniac monk and abbot. Noticeably, the effigy from Saint-Martial shows the pope in his monk's cowl rather than his papal vestments. ${ }^{72}$ Urban was also something of a founder of the institution, having granted the monks the house in Avignon that was their base before the 1379 foundation. ${ }^{73}$ But what made these connections so significant was the fact that Urban was considered a saint. At the time of his death and during the 1372 translation of his body to Marseille, a cult flared up and representations of the dead pope proliferated all over Western Europe. ${ }^{74}$ Clement was obviously sensitive to the advantages that a saintly Avignon pope offered in support of his own position. In 1381, two years after the foundation of Saint-Martial, he decreed an official investigation into Urban's life and miracles. In 1382, the Liber de vita et Miraculis beati Urbani pape quinti was presented to those who had commissioned it by Pierre Oliver. ${ }^{75}$ It seems likely that the carving of an effigy for Saint-Martial was related to this attempt at canonizing Urban V. In the priory church, Urban's cenotaph was given the position of a saint's tomb, behind the high altar. ${ }^{76}$ Clearly, what made Saint-Martial so attractive an institution for the cardinals who founded the church, built it in differing styles, and endowed it with chapels and altars, and the reason for Saint-Martial becoming the cardinals' mausoleum was that it was a place of cult centred on Urban V and therefore, in a wider sense, on the Avignon papacy.

Saint-Martial always remained an exclusive institution, within the tradition of the Cluniac order, and apart from cardinals and Cluniacs few laymen were buried there. The cult that developed around Pierre de Luxembourg, by contrast, was highly popular. The importance of the cult to a cardinal of Clementine obedience must have been clear to Cardinal Pierre Ameilh ( $\dagger 1389$ ) who sought burial in the wooden chapel that Marie d'Anjou had built over the tomb of Pierre de Luxembourg in the cemetery, where later the new church of Saint-Pierre would be constructed to the south of the wooden chapel. ${ }^{77}$ Earlier in 1378, when he was still Archbishop of Embrun, Ameilh wrote a letter to Paris University that was instrumental in persuading the scholars, and ultimately the 


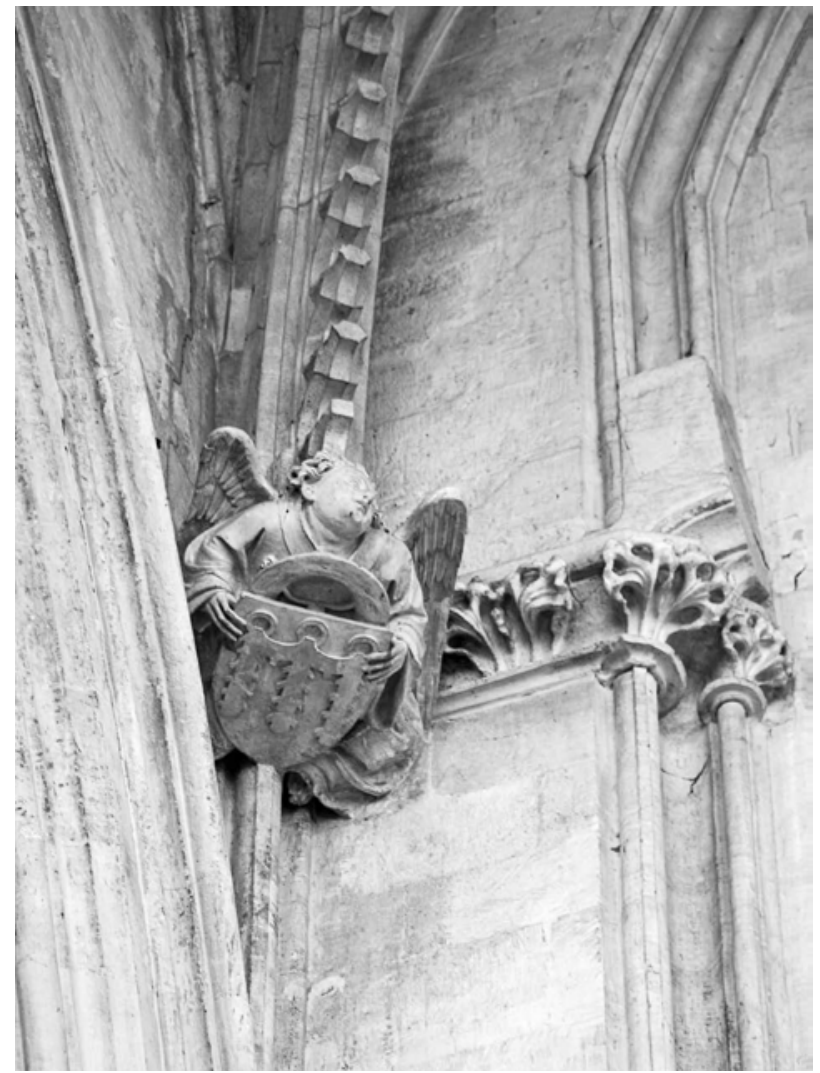

Fig. 14 Angel bust. Avignon, St-Martial, north-western corner of the eastern apse (Foto: A. Gajewski)

king, to accept Clement's VII election. ${ }^{78}$ We know something about Pierre Ameilh's motivations from his own letters. Ameilh, who in his youth had also been part of Gui de Boulogne's familia, was among the cardinals who did not wish for a return to Rome. ${ }^{79}$ In Ameilh's mystical conception of the world, Rome was Babylon and Avignon the New Jerusalem. ${ }^{80}$ Being buried close to Pierre de Luxembourg he must have felt that his absolute belief in the Avignon papacy had been founded in truth. While not all cardinals may have shared Ameilh's mystical views, many of them also chose burial close to Pierre de Luxembourg's tomb. A third of the cardinals listed in the obituary of Saint-Pierre-Célestin were cardinals that had been present at Fondi. ${ }^{81}$ And most importantly, they were joined by the tomb of Clement VII himself, located in the crossing of Saint-Pierre. Whatever the feelings of the cardinals and of the monks of Saint-Pierre may have been during the subtraction period, the enduring memories they carved in stone and wrote in their obituaries bestowed honour on both the royal family and the Avignon papacy.

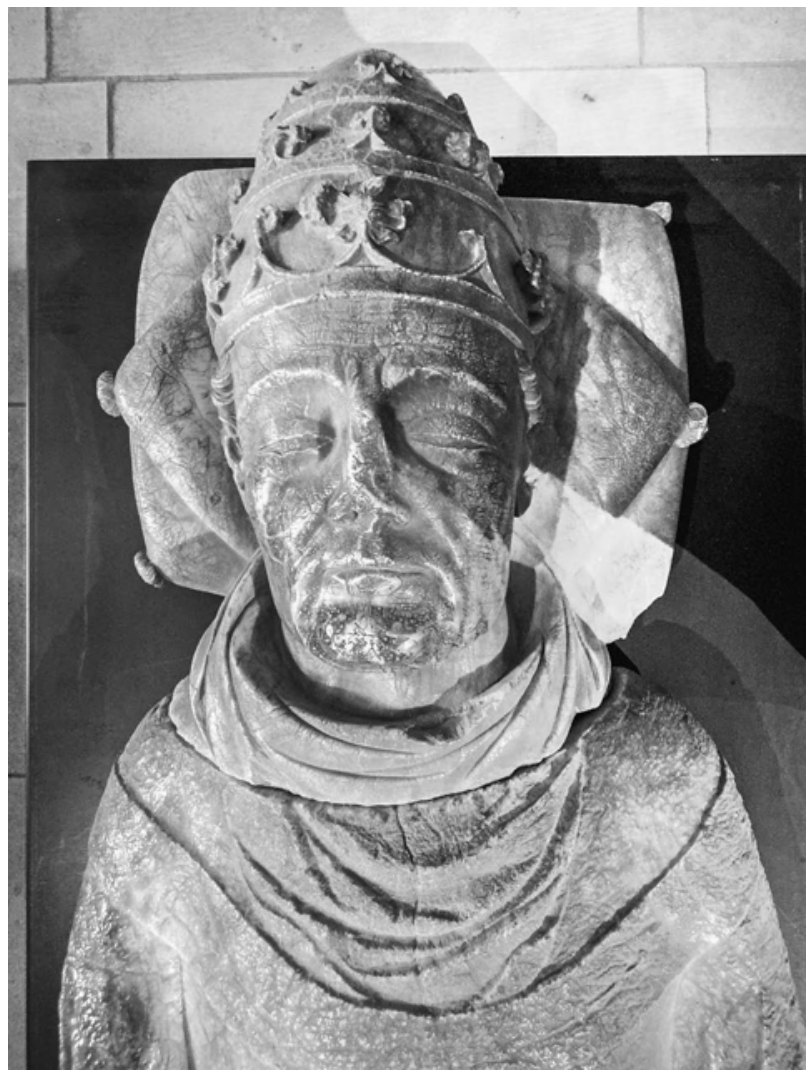

Fig. 15 Effigy of Pope Urban V. Avignon, Musée de Petit Palais (Foto: A. Gajewski)

It is easy to see the similarities between the two foundations, both of which were centred on a cult of the Avignon papacy. The fact that the same architect was working on both churches is further evidence of the close connection between the patrons. In fact, behind this connection was a network of curial members with similar upbringing, convictions and outlook..$^{82} \mathrm{It}$ is, therefore, telling that one of the Avignon processions moved from Saint-Martial to Saint-Pierre-Célestin. The evidence for processions at Avignon goes back only as far as the early modern period; it was collated by Marc Venard and brought to scholarly attention by Rollo-Koster. ${ }^{83}$ Venard believed, however, that the early modern processions reflect traditions that go back to the Middle Ages. The routes taken by these diverse processions rarely led them outside the late twelfth century walls of the town. An exception is the Corpus Christi procession, where one route went beyond the twelfth-century walls to reach the Belle Croix on the north-east side of the city, and another alternative route ventured south beyond the limits of the twelfth-century walls to stop at Saint-Martial and the Celestine church. 
After the return of the papacy to Rome, Corpus Christi was one of the few occasions, periodically attended by the pope, when the procession left the papal palace and lead through the Borgo of St. Peter. ${ }^{84}$ At Avignon, it is perhaps unlikely that a pope would ever have attended the Corpus Christi procession that stopped at Saint-Martial and the Celestine church. After Clement's death, Benedict was besieged in the palace and, as Rollo-Koster has shown, the balance of power shifted away from the popes. But the inclusion of these two churches in the Avignon procession routes may well reflect the memory of papal favour for these churches or even of the procession that brought Clement's body to the Celestine chuch.

In their conception, the foundation of the two churches and the patronage the two institutions received reflected ideas that predated the subtraction period. In fact, the projects were born out of the specific situation created by the schism. Returning to Avignon in 1379, the curia must have felt much more keenly than before the separation from Rome and St. Peter, as the presence of Urban VI there made a hypothetical return to Rome impossible. The curia's taking possession of the southern zone of the city, which Rollo-Koster demonstrated, was undoubtedly a reaction to this situation. The scheme deviated from the tendency of previous popes at Avignon, and also of later popes at Rome, to focus their ceremonies and life increasingly on their palace. As Schimmelpfennig has argued for the period prior to the schism, the papal palace at Avignon replaced the city of Rome and ceremonies were confined to the palace. ${ }^{85}$

The foundation of the two abbeys in Avignon's southern zone may suggest that the complex situation on their return from Italy in 1378/79 inspired Clement and his confidants with new plans for Avignon's city. Schimmelpfennig noted that it was at the time of the schism that the name Roma was given to Urban's V garden building behind the papal palace and that the main portal of the palace was dedicated to Peter and Paul. He concluded that the topographical realisation of the device "ubi papa, ibi Roma" was intensified during the schism. ${ }^{86}$ The fact that the curia created another pole of papal sanctity away from the papal palace, in a part of the town that was at opposite ends, shows that the palace alone was no longer enough as a replacement for Rome. Finally, the city itself was to become an altera Roma. The fact that, at the time the construction campaigns came to completion, the political situation and the cardinals' allegiances had changed and that the project had been overtaken by events does not necessarily mean it had therefore failed. If, until the French Revolution, the altera Roma device continued to appear on urban monuments and remained part of the city's identity, it was undoubtedly because, during the schism, the Avignon papacy had pushed that idea outside the walls of the Papal Palace and into the city itself. ${ }^{87}$

\section{Bibliography}

André, Aurélien: Le Beau Pilier de la cathédrale Notre-Dame d'Amiens. Sa place dans l'iconographie politique du XIVe siècle. In: Bulletin de la Société des Antiquaires de Picardie 167 (2003), H. 667, 543-565.

Armagier, Paul: Urbain V. Un homme, une vie. Marseille 1987.

Baluze, Etienne/Mollat, Guillaume (Hgg.): Vitae paparum Avenionensium. Hoc est historia pontificum romanorum qui in Gallia sederunt ab anno Christi MCCCV usque ad annum MCCCXCIV. 4 Bde. Paris 1914-28.

BARon, Françoise: Collèges apostoliques et couronnement de la Vierge dans la sculpture avignonnaise des XIVe et XVe siècles. In: Revue du Louvre 29 (1979), 169-186.

Baron, Françoise: Découvertes en Avignon. In: Revue du Louvre 31 (1981), 155-158.

BARON, Françoise: Le tombeau et la chapelle funéraire de Charles VI à Saint-Denis. In: Bresc-BAutier/BAron/Le POGAM 2007, 68-77.

Berlière, Ursmer: Le collège de Saint-Martial d'Avignon. In: Revue bénédictine 11 (1894), 346-357.

Bolgia, Claudia: Cassiano's Popes rediscovered. Urban V in Rome. In: Zeitschrift für Kunstgeschichte 65 (2002), 562574 .

Bresc, Henri (Hg.): La correspondence de Pierre Ameilh, archévêque de Naples, puis d'Embrun, 1363-1369. Paris 1972.

Bresc, Henri: La genèse du Schisme. Les partis cardinalices et leurs ambitions dynastiques. In: Genèse et débuts 1980, 45-57.

BResc, Henri: La mystique de la Rome avignonnaise et la numérologie chrétienne de Pierre Ameilh. In: Cahiers de Fanjeaux 39 (2004), 109-132.

Bresc-Bautier, Geneviève/Baron, Françoise/Le Pogam, Pierre-Yves (Hgg.): La sculpture en Occident. Études offertes à Jean-René Gaborit. Dijon 2007.

Breton, Alain: À Saint-Martial, deux œuvres baroques méconnues. In: Annuaire de la Société des Amis du Palais des Papes et des Monuments d'Avignon 61-62 (1984-85), 67-85.

Breton, Alain: La chapelle du bienheureux Pierre de Luxembourg aux Célestins. In: Annuaire de la Société des Amis du 
Palais des Papes et des Monuments d'Avignon 65-66 (198889), 55-68.

Brown, Elizabeth A. R.: Death and the Human Body in the Later Middle Ages. The Legislation of Boniface VIII on the Division of the Corpse. In: Viator 12 (1981), 221-270.

Castelnuovo, Enrico: Avignone. In: Romanini et al. 1991, $760-$ 777. Online: http://www.treccani.it/enciclopedia/avignone_ \%28Enciclopedia-dell\%27-Arte-Medievale\%29/ (27.10.2017).

Chiffoleau, Jacques: Sur l'usage obsessionnel de la messe pour les morts à la fin du Moyen Âge. In: Vauchez 1981/ II, 235-256.

Chiffoleau, Jacques: Comptabilité de l'au-delà. Les hommes, la mort et la religion dans la région d'Avignon à la fin du Moyen Âge. Paris 2011.

Chinaia, Pavel: Immortalité et décomposition dans l'art du Moyen Age. Madrid 1988.

Clément, Eusèbe: Le monastère-collège de Saint-Martial d'Avignon, les moines et les étudiants d'autrefois. Avignon 1893.

Сомте, Sonia: Les Célestins, le roi et le pape, les monastères d'Avignon et de Gentilly et le pouvoir. In: Provence Historique 184 (1996), 229-251.

Cомте, Sonia: Les Célestins du Midi, une antenne de la cour de France à Avignon. In: Cahiers de Fanjeaux 39 (2004), $175-208$.

[GARMs-]Cornides, Elisabeth: Rose und Schwert im päpstlichen Zeremoniell von den Anfängen bis zum Pontifikat Gregors XIII. Diss. Wien 1966; Wien 1967 (Wiener Dissertationen aus dem Gebiete der Geschichte 9).

Du Chesne, François: Histoire de tous les cardinaux françois de naissance, Bd. 2. Paris 1660.

Duhamel, Léopold: Les œuvres d'art du monastère des Célestins d'Avignon. In: Bulletin monumental 54 (1888), 109-130, 217-244.

Ehrle, Franz (ed.): Martin de Alpertils Chronica actitatorum temporibus domini Benedicti XIII. Paderborn 1906.

[Exhib. cat. Avignon 1978]: Exhib. cat. Avignon 1360-1410, art et histoire. Ed. by Marie-Claude LÉonelli. Avignon, Musée du Petit Palais, 25.9.-25.11.1978. Paris 1978.

Favier, Jean: Les finances pontificales à l'époque du Grand Schisme d'Occident, 1378-1409. Paris 1966.

FAVIER, Jean: Les papes d'Avignon. Paris 2006.

Fleck, Cathleen A.: Seeking Legitimacy. Art and Manuscripts for the Popes in Avignon from 1378 to 1417. In: RoLLO-Koster/IzBICKI 2009, 239-302.

FLECK, Cathleen A.: The Clement Bible at the Medieval Courts of Naples and Avignon. A Story of Papal Power, Royal Prestige, and Patronage. Farnham/Burlington (USA) 2010.

Fournier, Marcel: Les statuts et privilèges des universités françaises depuis leur fondation jusqu’en 1789. Ouvrage publié sous les auspices du Ministère de l'instruction publique et du Conseil général des facultés de Caen, Bd 1. Paris 1890.

Frankl, Paul/Crossley, Paul: Gothic Architecture. New Haven u.a. 2000 (The Yale University Press Pelican History of Art).

GAGNiÈre, Sylvain: Récentes découvertes archéologiques à Avignon. In: Mémoires de l'Académie de Vaucluse 9 (196364), 131-144.

Gagnière, Sylvain/Granier, Jacky/Poly, Jean-Pierre et al.: Histoire d'Avignon. Aix-en-Provence 1979.

Gajewski, Alexandra (Hg.): The Year 1300 and the Creation of a new European architecture. Turnhout 2007 (Architectura medii aevi 1).

Gardner, Julian: The Tomb and the Tiara. Curial Tomb Sculpture in Rome and Avignon in the Later Middle Ages. Oxford 1992 (Clarendon Studies in the History of Art 6).

Genequand, Philippe: Une politique pontificale en temps de crise. Clément VII d'Avignon et les premières années du grand schisme doccident (1378-1394). Basel 2013.

[Genèse et débuts 1980]: Genèse et débuts du Grand Schisme d'occident. Colloque international du Centre Nationale de la Recherche Scientifique, 25.-29.9.1978. Paris 1980 (Colloques internationaux du C. N. R. S. 586).

Girard, Alain: L'aventure gothique entre Pont-Saint-Esprit et Avignon du XIIIe au XIVe siècle. Aix-en-Provence 1996.

GIRARD, Joseph: Avignon, ses monuments, ses hôtels, ses trésors d'art. Marseille 1930.

GIRARD, Joseph: Évocation du vieil Avignon. Paris 1958.

Guillemain, Bernard: Cardinaux et société curiale. Aux origines de la double élection de 1378. In: Genèse et débuts 1980, 19-30.

[Hayez 1980/I]: Hayez, Anne-Marie: Clément VII et Avignon. In: Genèse et débuts 1980, 126-141.

[Hayez 1980/II]: Hayez, Michel: Avignon sans les papes (1367-1370, 1376-1379). In: Genèse et débuts 1980, 143157.

Hayez, Michel: Cros, Jean de, Kardinal († 1383). In: Lexikon des Mittelalters, Bd. 3. München/Zürich 1986, Sp. 355.

Hourihane, Colum (ed.): Medieval Patronage. Patronage, Power and Agency in Medieval Art. Princeton NJ 2013 (The index of Christian art occasional papers 15).

JANZ, Bernhard (Hg.): Collectanea II. Studien zur Geschichte der Päpstlichen Kapelle. Tagungsbericht Heidelberg 1989. Città del Vaticano 1994 (Capellae Apostolicae Sixtinaeque Collectanea Acta Monumenta 4).

Johnson, Eric: La ville sonnant. The politics of sacred space in Avignon on the eve of the French Revolution. In: SPICER/ Hamilton 2005, 319-335.

Joubert, Fabienne: Lartiste et le clerc. Commandes artistiques 
des grands ecclésiastiques à la fin du Moyen Âge (XIVe-XVe siècles). Paris 2006 (Cultures et civilisations médiévales 36).

Jugie, Pierre: Lactivité diplomatique du cardinal Gui de Boulogne en France au milieu du XIVe siècle. Paris/Genève 1987 (Bibliothèque de l'Ecole des Chartes 145).

Karsten, Arne (Hg.): Das Grabmal des Günstlings. Studien zur Memorialkultur frühneuzeitlicher Favoriten. In Zusammenarbeit mit Anett Ladegast, Tobias C. Weissmann und Laura Windisch. Berlin, Tagung am Institut für Kunst- und Bildungsgeschichte der Humboldt-Universität zu Berlin, 8.9.5.2009. Berlin 2011 (Humboldt-Schriften zur Kunst- und Bildgeschichte 15).

LABANDE, Léon-Honoré: Catalogue général des manuscrits des bibliothèques publiques de France. Départements, Bd. 27. Avignon. Paris 1894.

Labande, Léon-Honoré: Le tombeau de Clément VII, Robert de Genève. In: Revue savoisienne 38 (1897), 93-98.

LABANDE, Léon-Honoré: La dernière fondation des papes avignonais. Le couvent des Célestins d'Avignon. In: L'Art 62 (1903), Nr. 770, 585-599; 63 (1904), Nr. 771, 15-25; Nr. 772, 70-78; Nr. 774, 153-169; Nr. 775, 209-214.

Labande, Léon-Honoré: Avignon. In: Congrès Archéologique de France. Société Française d’Archéologie 76 (1909), Vol. 1, $6-93$.

Laclotte, Michel/Thiébaut, Dominique: Lécole d’Avignon. Paris 1983.

[Le Midi et le grand schisme 2004]: Le Midi et le grand schisme d'Occident. 39e colloque de Fanjeaux, 2003. Toulouse 2004 (Cahiers de Fanjeaux 39).

LerCH, Charles-Henri: Le cardinal Jean de La Grange. Sa vie et son rôle politique jusquà la mort de Charles V (1350-1380). Paris 1955 (Positions des thèses de l'École des Chartes).

Lơ̈e, Georges de/Mognetti, Élisabeth/Thiébaut, Dominique: Avignon, Musée du Petit Palais. Paris 1983.

Manzari, Francesca: La miniatura ad Avignone al tempo dei papi (1310-1410). Modena 2006.

Mérimée, Prosper: Notes d'un voyage dans le Midi de la France. Paris 1835 .

Monti, Elizabeth: Art for an Antipope. Patronage at the Court of Clement VII (1378-1394). Diss. New York University 2013.

[Morganstern 1970/I]: Morganstern, Anne McGee: Pierre Morel and sculpture in Avignon during the Period of the Schism. Diss. New York University 1970.

[Morganstern 1970/II]: Morganstern, Anne McGee: Quelques observations à propos de l'architecture du tombeau du cardinal Jean de La Grange. In: Bulletin monumental 128 (1970), 195-209.

Morganstern, Anne McGee: The La Grange Tomb and Choir.
A Monument of the Great Schism of the West. In: Speculum 48 (1973), 52-69.

Morganstern, Anne McGee: Pierre Morel, Master of Works in Avignon. In: The Art Bulletin 58 (1976), 323-349.

Morganstern, Anne McGee: Le mécénat de Clément VII et maître Pierre Morel. In: Genèse et débuts 1980, 423-429.

Müntz, Eugène: L'antipape Clement VII. Essai sur l'histoire des arts à Avignon vers la fin du XIVe siècle. In: Revue archéologique 11 (1888), 8-18, 168-183.

Müntz, Eugène: Le mausolée du Cardinal de Lagrange à Avignon. Extrait de la revue: L'ami des monuments et des arts 1887. Paris 1890 .

NAPP, Anke: Urbain V et Marseille, une relation spirituelle profitable. In: PÉcout 2009, 407-410.

Paravicini Bagliani, Agostino: Le Corps du pape. Translated from Italian by Catherine Dalarun Mitrovitsa. Paris 1997.

Paravicini, Werner: Zeremoniell und Raum. Symposium der Residenzen-Kommission der Akademie der Wissenschaften in Göttingen, Potsdam, 25.-27.9.1994. Sigmaringen 1997 (Residenzforschung 6; Symposium der Residenzen-Kommission der Akademie der Wissenschaften in Göttingen 4).

PÉcout, Thierry: Marseille au Moyen âge, entre Provence et Méditerranée. Les horizons d'une ville portuaire. MéolansRevel 2009.

Perkinson, Stephen: The Likeness of the King. A Prehistory of Portraiture in Late Medieval France. Chicago 2009.

PrADEL, Pierre: Le visage inconnu de Louis d'Orléans frère de Charles VI. In: La Revue des arts 2 (1952), 93-98.

Pradel, Pierre: Séance du 6 Février, tombeau du cardinal Jean de La Grange à Avignon. In: Bulletin de la Société Nationale des Antiquaires de France 1952-53, 33-34.

Pradel, Pierre: Lauteur des statues du "Beau Pilier" de la cathédrale d’Amiens. In: Recueil Brunel 1955, 390-396.

[Recueil Brunel 1955]: Recueil des travaux offerts à M. Clovis Brunel par ses amis, collègues et élèves. 2 Bde. Paris 1955 (Mémoires et documents de l'École des Chartes 12).

Rey-Courtel, Anne-Lise: Les Cardinaux du Midi pendant le Grand Schisme. In: Cahiers de Fanjeaux 39 (2004), 49-108.

Robın, Françoise: Midi gothique. De Béziers à Avignon. Paris 1999 (Collection Les monuments de la France gothique).

Rollo-Koster, Joëlle: The politics of body parts. Contested topographies in late-medieval Avignon. In: Speculum 78 (2003), 66-98.

Rollo-Koster, Joëlle: Avignon and its Papacy, 1309-1417. Popes, Institutions, and Society. Lanham u. a. 2015.

Rollo-Koster, Joëlle/Izbicki, Thomas M. (Hgg.): A Companion to the Great Western Schism (1378-1417). Leiden/ Boston 2009 (Brill's Companions to the Christian Tradition 17). 
Romanini, Angiola Maria et al. (ed.): Enciclopedia dell'arte medievale. Vol. 2. Roma 1991.

SANDron, Dany: La fondation par le cardinal Jean de La Grange de deux chapelles à la cathédrale d'Amiens. Une tradition épiscopale devenue manifeste politique à la gloire du roi Charles V. In: JouberT 2006, 155-170.

Schimmelpfennig, Bernhard: Die Funktion des Papstpalastes und der kurialen Gesellschaft im päpstlichen Zeremoniell vor und während des großen Schismas. In: Genèse et débuts 1980, 317-328.

Schimmelpfennig, Bernhard: Der Palast als Stadtersatz. Funktionale und zeremonielle Bedeutung der Papstpaläste in Avignon und im Vatikan. In: Paravicini 1997, 239-256.

Schimmelpfennig, Bernhard: Die Funktion der Cappella Sistina im Zeremoniell der Renaissancepäpste. In: JANZ 1994, 123-174. Republished in: SCHIMmelpFenNig 2005.

Schimmelpfennig, Bernhard: Papsttum und Heilige, Kirchenrecht und Zeremoniell. Ausgewählte Aufsätze. Ed. by Georg Kreuzer and Stefan Weiss. Neuried 2005.

SchürenberG, Lisa: Die kirchliche Baukunst in Frankreich zwischen 1270 und 1380. Berlin 1934.

Setton, Kenneth M.: Archbishop Pierre d'Ameilh in Naples and the Affair of Aimon III of Geneva (1363-1364). In: Speculum 28 (1953), 643-691.

Simon, Pierre (Hg.): Bullarium sacri ordinis Cluniacensis. Lyon 1680.

Spicer, Andrew/Hamilton, Sarah (edd.): Defining the Holy. Sacred space in medieval and early modern Europe. Aldershot 2005.

Stein, Henri: Une dynastie d'architectes, les Morels. In: Le Moyen âge. Bulletin mensuel d'histoire et de philologie, second series 14 (1910), 235-244.

Swanon, Robert N.: Universities, Academics and the Great Schism. Cambridge 1979.

Tauber, Christine: Homo novus zwischen König und Kurie. Das Grabmal des Kardinals Jean de la Grange als legitimatorische Autobiographie "post mortem". In: KARSTEN 2011, 21-41.

[Temple Saint-Martial 2007]: Temple Saint-Martial (XIVe s.-XVIIIe s.). Dossier établi par le service Gestion du patrimoine. Avignon 2007.

VAloIs, Noël: La France et le Grand Schisme d'Occident. 4 Bde. Paris 1896-1902.

VAlous, Guy de: Un collège clunisien. Le prieuré-collège de Saint-Martial d'Avignon. In: Revue Mabillon 18 (1928), 284-301.

[VAUChez 1981/I]: VAUCHEZ, André: La sainteté en occident aux derniers siècles du moyen age. D’après les procès de canonisation et les hagiographiques. Roma 1981 (Bibliothèque des Écoles Françaises d’Athènes et de Rome 241).
[Vauchez 1981/II]: Vauchez, André (Hg.): Faire croire. Modalités de la diffusion et de la réception des messages religieux du XIIe au XVe siècle. Table ronde, Rome, 22.-23.6.1979. Roma 1981 (Collection de l'Ecole Française de Rome 51).

Vauchez, André: Sainthood in the later Middle Ages. Cambridge 1997 .

Venard, Marc: Itinéraires de processions dans la ville de Avignon. In: Ethnologie françaises 7 (1977), 52-62.

Williman, Daniel: The Camerary and the Schism. In: Genèse et débuts 1980, 65-69.

Wilson, Christopher: Not without Honour save its own country? Saint-Urbain at Troyes and its contrasting French and English posterities. In: GAJEWSKI 2007, 107-121.

Zutshi, Patrick: Jean de Cros and the Papal Penitentiary on the Eve of the Great Schism. In: Francia 37 (2010), 335-351.

\section{Notes}

1 In 1348, Pope Clement VI had bought Avignon from Queen Jeanne of Naples. See Gagnière/Granier/Poly et al. 1979, 189f. - For the election at Fondi and the start of the Great Schism, see Valois 1896-1902, I, 1-144. - The articles in Genèse et débuts 1980 can now be supplemented by the articles in RoLlo-Koster/IzBicki 2009. - See also Rollo-Koster 2003 and 2015. - Helpful are also the account by Favier 2006, 549-726, and the articles in Le Midi et le grand schisme 2004. - More literature on the subject will be quoted below.

2 VAloIs 1896-1902, I, 165-169.

3 Hayez 1980/II, 145. - With reference to Avignon, Archives municipales, Pintat 77/2569.

4 Baluze/Mollat, 1914-28, II, 594f: "Respondit cardinalis quod papa Romanus erat totius mundi et mundus cedebat sibi pro diocesi, et poterat morari ubi vellet, et propter hoc non desinebat esse papa Romanus." - See also VAloIS 1896-1902, I, 9 f. - For the idea of "ubi papa, ibi Roma" see Paravicini Bagliani 1997, 79-81.

5 Simon 1680, $190 \mathrm{f}$. - A slightly different version of the charter was published by Fournier 1890, 320-322. - Four later copies of the bull survive from Saint-Martial (Archives départementales de Vaucluse, $4{ }_{4}$ 3). - See also Clément 1893, 46-48. - Berlière 1894. VAlOUS 1928.

6 Clément 1893, 46-48. - Monti 2013, 166-179. - Benedictine nuns were already present at Avignon at the convent of Saint-Laurent, see GIRARD 1958, 177. - For the university of Avignon during the schism, see SWANSON 1979.

7 Cомте 1996 and 2004.

8 On Robert of Geneva, who took the name Clement VII, see GeNEQUAND 2013, 68-77.

9 However, Cardinal Bertrand de Deaux had transformed the parish church of Saint-Didier into a collegiate institution and reconstructed the building, and several cardinals had founded monasteries outside Avignon, notably Étienne Aubert, later to become Pope Innocent VI, founded a Carthusian abbey at Villeneuve-lès-Avignon.

10 MÜntZ 1888. - Exhib. cat. Avignon 1978. - Morganstern 1980. - 
Laclotte/Thiébaut 1983, 57-61. - Castelnuovo 1991. - ManZARI 2006, 203-291. - FleCK 2009 and 2010. - MONTI 2013.

11 [GARMS-]CORNIDES 1967, $85 \mathrm{f}$.

12 Comte 1996, 249 f. - Rollo-Koster 2003. - Fleck 2009. - Monti 2013, viii, 5, 90 f., $165,207,367$ f., 375 f.

13 Rollo-Koster 2003.

14 Morganstern 1970/I, 1970/II, 1973, 1976, 1980.

15 See Stein 1910. - Morganstern 1970, i-ii. - Morganstern 1973, 1976,1980 .

16 Morganstern 1976, 342. - For Saint-Pierre-Célestin see also Duhamel 1888. - Labande 1903-04. - Labande 1909, 37-46. Robin 1999, 155-167. - BReton 1988-89. - Cомte 1996 and 2004.

17 The 1396 contract survives in the Archives départementales de Vaucluse, $19 \mathrm{H} 7$. It was published by Duhamel 1888, 119-128. - See also Morganstern 1976, 323, note 4.

18 Morganstern 1976, 339-343. - For Saint-Martial see also LABANDE 1909, 35-37. - RoBIN 1999, 155-167. - GAGNiÈre 1963-64, 137-144. - Breton 1984-85. - Temple Saint-Martial 2007.

19 For this type of plan, see WiLson 2007, 109.

20 Frankl/Crossley 2000, 217: "The French call figures with two points and with one concave curve and one double curve 'mouchettes', and those with two double curves 'soufflets."'

21 Mérimée 151. - Morganstern 1973, 59. - Fleurs-de-lis and dauphins also decorated the exterior parapet of Saint-Martial, which was restored in 1917-1920. See Avignon, Archives Municipales, Dossier $39 \mathrm{Z}_{17}$. Today only one panel of the parapet remains over the south-east bay of the apse. See also Morganstern 1973, 58, note 36 .

22 For the original location of the tomb, see GAGNière 1963-64.

23 Vatican Library, Barb. Lat. 4426, fol. 25. - See MüntZ 1890, 9.

24 Morganstern 1973, 56. - Morganstern 1976, 335-341. - However, because of the varying quality of the remains of the de La Grange tomb, BARON 1979 and 1981 and CASTELNUOVO 1991 have questioned the attribution of the entire tomb to Pierre Morel. - For Clement VII's tomb, see LABANDE 1897.

25 Valois 1896-1902, III, 59. - Labande 1903-04, Nr. 770, 592.

26 Labande 1903-04, Nr. 770, 593 f. - Morganstern 1976, 341. - A further bay was added in the early fifteenth century, when the nave was closed with a temporary wall, never to be completed. See LABANDE 1903-04, Nr. 770, 595.

27 The will was published by Baluze/Mollat 1914-28, IV, 323-327. 28 The contract was published by LABANDE 1894, xlvii-xlix.

29 Paris, Archives nationales, X1a, 9807, fol. 70v-78. - The will was published by Du CHeSNe 1660, 467-476. - See also MORGANSTERN 1970/I, 15-19. - Morganstern 1973, 55.

30 Morganstern, 1973, 54-55, 60. - Morganstern 1976, 335-339.

31 Pradel 1955, 95.

32 Pradel 1952-53 and 1955. - André 2003. - Sandron 2006.

33 Pradel 1952-53, 94. - See also Perkinson 2009, 139, 247-249.

34 There were code-of arms included in the blind window tracery on the exterior face of the wall. The present shields are restored and blank. See Morganstern 1973, 60.

35 Pradel 1952-53, 96.

36 Morganstern 1976, 61.

37 For the de La Grange tomb, apart from the authors mentioned below, see also Lơ̈e/Mognetti/Thiébaut 1983, 122-125. - Chinaia
1988, 233-254. - GARDNER 1992, 157-159. - CASTElnUOVO 1996. ChiffoleaU 2011, 174-176. - Monti 2013, 192-194, 204-208.

38 TAuber 2011, $28 \mathrm{f}$., 30, 32.

39 FLECK 2009, 263, 265.

40 Rollo-Koster 2003, 88-91.

41 See also Monti 2013, $186 \mathrm{f}$., who concluded that the foundation of the two churches established a new spiritual topography.

42 For the Celestin's privilege to display royal arms see LABANDE 190304, Nr. 771, 17, note 1. - For the close association between the Avignon Celestines and the royal family, see Сомте 2004, 198-202.

43 Morganstern 1973, 61. - Tauber 2011, 29.

44 The entrance portal was rebuilt in the Baroque period. See BRETON 1984-85.

45 SCHÜRENBERG 1934, 132 f. - Schürenberg clearly did not have full access to the south aisle and chapels, which in 1934 were used as glazed studios. Therefore, she was not able to appreciate the homogeneity of the western parts and wrongly concluded that there was an evolution of forms from west to east.

46 The nave clerestory windows are restored.

47 Although the key-stone in the eastern nave bay shows the arms of Pierre de Cros with a cardinal's hat, it seems to have been carved during the later construction campaign. While in the western bays, in the narthex and in the tower the hat's tasselled strings frame the shield quite rigidly, in the eastern bay they loop around with a complex series of knots and tassels and two feathery tassels flowing from the back of the hat. Morganstern, 1970/I, 17, note 15, wondered whether the keystones in the two eastern nave bays are modern replacements because LABANDE 1909, 37, describes them as "comme celui de Pierre de Cros". The keystones are, however, present in the photos taken by Patrice Molinard, probably in 1947 and before the 1963 restoration, during which the easternmost angel busts in the apse (that had been replaced with Baroque corbels) were recarved. See Mediathèque Patrimoine, Paris http://www.mediatheque-patrimoine.culture.gouv.fr/pages/bases/memoire_cible. html (29.10.2017)

48 For these churches, see Schürenberg 1934, 127-131. - Girard 1996, 88-90. - Robin 1999, 149-161.

49 Robin 1999, 155.

50 "... discretis viris Berengario et Petro Montanhac, lapicidis, civibus et habitatoribus Avionionis". LABANDE 1894, xlvii.

51 SCHÜRENBERg 1934, 132.

52 In the 14th century, trefoils or pendant cusping were used for arches but rarely for vault ribs. At Saint-Denis, in the early fifteenth-century chapel of Saint-Aventin that holds the tomb of Charles VI, the ribs have pendant cusping and a restored keystone showing a Coronation of the Virgin surrounded by cherubim that closely resembles the one from Saint-Pierre-Célestin. For the chapel, see BARON 2007.

53 For De Cros' wealth at the time of his death, see Genequand 2013, 437; for the hanging key-stone see CLÉMENT 1893, 206: “... une clef de voûte, décorée par un pendentif formé d'un faisceau d'armoires”.

54 For the time it took to build Saint Didier, see RoBIN 1999, 155. Neither of the two excavations that took place in the east end of Saint-Martial (1829 and 1963) reported finding the foundations of an earlier apse, see GAGNIÈRE 1963-64.

55 “... mandaverim et ordinaverim compleri caput ecclesie collegii sancti martialis avinionensis (...). Item volo et ordino quod Capella capitis huiusmodo necnon sepultura quam ibi edificari et construe 
feci, tam de opera lapideo quam vitreo de bonis executionis mee, si ante obitum meum non fuerint adimpleta, bene et decenter compleantur.", see Du Chesne 1660, 472 f., and Morganstern 1973, 55, with notes 19-20. - The toothing of the upper walls of the apse, facing west and visible above the roof line, may even suggest that construction was meant to continue westwards and that de La Grange intended a complete rebuilding of the earlier church.

56 "... cum consilio venerabilis fratris nostri archiepiscopi Arelatensis, camerarii nostri .... Fournier 1890, 321. - Pierre de Cros` assistance is mentioned twice more. He became archbishop of Arles in 1374, see Rey-Courtel 2004, 55.

57 Williman 1980. - Hayez 1986. - Zutshi 2010, 346-348.

58 Favier 1966, 42. - Williman 1980, 68. - Rey-Courtel 2004, 63; 100, note 113 .

59 “... dominum nostrum dominum Clementem divina providentia papam septimum .... BALUze/Mollat 1914-28, IV, 323, and also 326.

60 GARDNER 1992, 131-164.

61 Baluze/Mollat 1914-28, IV, 318-322, 323-327.

62 Rey-Courtel 2004, 57; 91, note 17; 95, note 60. - The head of Guillaume's effigy survives at the Musée du Petit Palais in Avignon, see Lơ̈e/Mognetti/Thiébaut 1983, $120 \mathrm{f}$.

63 See Martin Alpartil's chronicle in EhrLe 1906, $35 \mathrm{f}$.

64 SANDron 2006, 158.

65 Morganstern 1973, 54, with note 14. - See Brown 1981 for the burial of body parts.

66 Du Chesne 1660, 468. - TAuber 2011, 34. - For the profusion of masses at this time see CHIFFoleaU 1981 and 2011.

67 For example Valois 1896-1902, I, 69. - Rey-Courtel 2004, 65. -
Guillemain 1980, 24. - Favier 2006, 557. - On Jean de La Grange, see LERCH 1955, which has not been available to me.

68 BRESC 1980, 46. - Against the idea of a "conspiracy" to elect Robert de Genève, see Genequand 2013, 55-65. - For Guy de Boulogne see Jugie 1987.

69 “... per sancte memorie dominum Urbanum papam quintum ..." Baluze/Mollat 1914-28, IV, 365-368 (366).

70 Lơ̈e/Mognetti/Thiébaut 1983, 117. - Gardner 1992, 150-153.

71 Armagier 1987, 129-132.

72 The tomb at Saint-Victor showed Urban in his papal vestments. GARDNER 1992, plate 203.

73 Simon 1680, $181 \mathrm{f}$.

74 Bolgia 2002, 562 f. - NAPP 2009, $408 \mathrm{f}$.

75 Bolgia 2002, 562. - VAuCheZ 1997, 80, 318-323.

76 GAGNiÈRE 1963-64, $141 \mathrm{f}$.

77 BReton 1988-89.

78 BRESC 1980.

79 Guillemain 1980, 25.

80 Bresc 2004. - For Pierre Ameilh, see also Setton 1953, 650. BresC 1972, xxxii-xlv. - Rey-Courtel 2004, 67f., $101 \mathrm{f}$.

81 Сомте 1996, 249.

82 A fact that did not, of course, prevent them from disagreeing violently with each other on occasion, as in the case of Jean de La Grange and Pierre Ameilh. See Rey-Courtel 2004, 78.

83 Venard 1997. - Rollo-Koster 2003, 76, note 33.

84 Schimmelpfennig 1994/2005, 344, $372 \mathrm{f}$.

85 Schimmelpfennig 1980 and 1997.

86 Schimmelpfennig 1980, 319. - Schimmelpfennig 1997, 245.

87 Johnson 2005, 320. - Until the Revolution, Avignon remained the property of the popes. 



\section{Jean de la Grange, Schismatic Cardinals and Avignonese Tomb Sculpture}

My aim is to place the Avignon tomb of Cardinal Jean de la Grange (fig. 1) more accurately in its curial context. Since, at the time of his death, there were competing papal Curias at Rome and Avignon, this will require comparisons with contemporary cardinals' tombs in Rome.

All these tombs need to be placed in wider historical and liturgical contexts, and given the fact La Grange had a greater personal awareness of Italian monuments than has previously been acknowledged, his Avignonese tomb commission will be reconsidered with this aspect in mind.

Torture did not normally enter the curriculum vitae of Trecento cardinals. Hanging by the thumbs might indeed be seen as a distinctly uncanonical punishment. Nonetheless the Benedictine Adam Easton was tortured on the orders of Urban VI, who accused six of his cardinals of conspiracy (for his tomb see figs. 2,3 ). ${ }^{1}$

Reinstated by Boniface IX in December 1389, Adam died in Rome in July 1398 and was buried in his titulus Santa Cecilia in Trastevere. ${ }^{2}$ His testimony concerning the outbreak of the Great Schism provided damning evidence against his fellow Benedictine, Jean de la Grange. ${ }^{3}$ Yet another Frenchman, Philippe d'Alençon, who out of pique deserted the Avignonese obedience, normally de rigueur for French-born cardinals, was also buried in Rome, at Santa Maria in Trastevere (figs. 4, 5). ${ }^{4}$

Their tombs allow us to reconsider the monument of La Grange in its contemporary context. Too often seen in isolation, its political and doctrinal charge has in consequence been exaggerated.

The documents concerning the testamentary wishes, funeral, and transference of the corpse of Cardinal Guillaume de Chanac, a Benedictine promoted by Pope Urban V in 1370 , clarify current custom. ${ }^{5}$ Guillaume died at Avignon in 1384. He left a will - which we also possess for both Philippe d'Alençon and Jean de la Grange - which made precise stipulations about his funerary arrange-

Fig. 1 Tomb of Cardinal Jean de la Grange († 1402). Drawing. Biblioteca Apostolica Vaticana, Barb. Lat. 4426, fol. 34 (Foto: Photo Biblioteca Apostolica Vaticana)

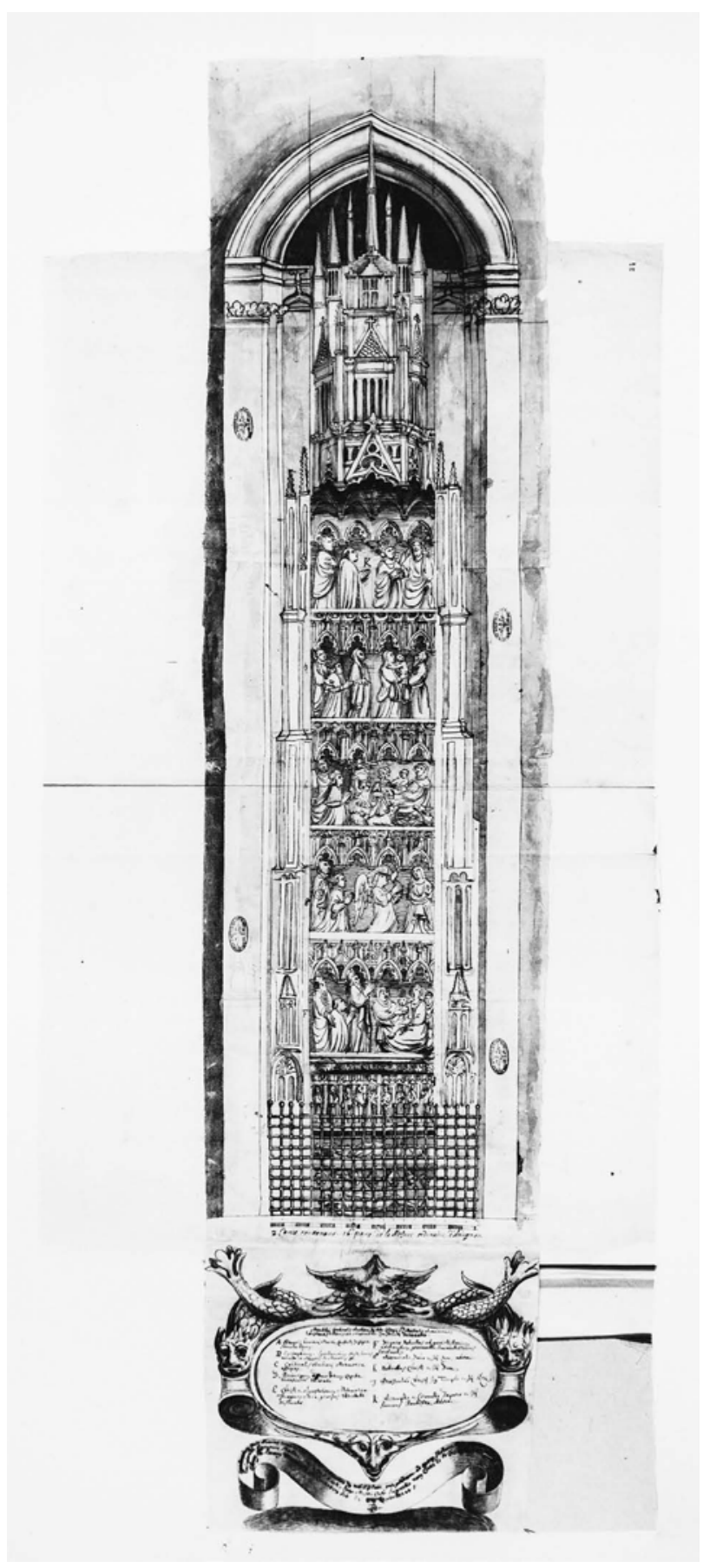



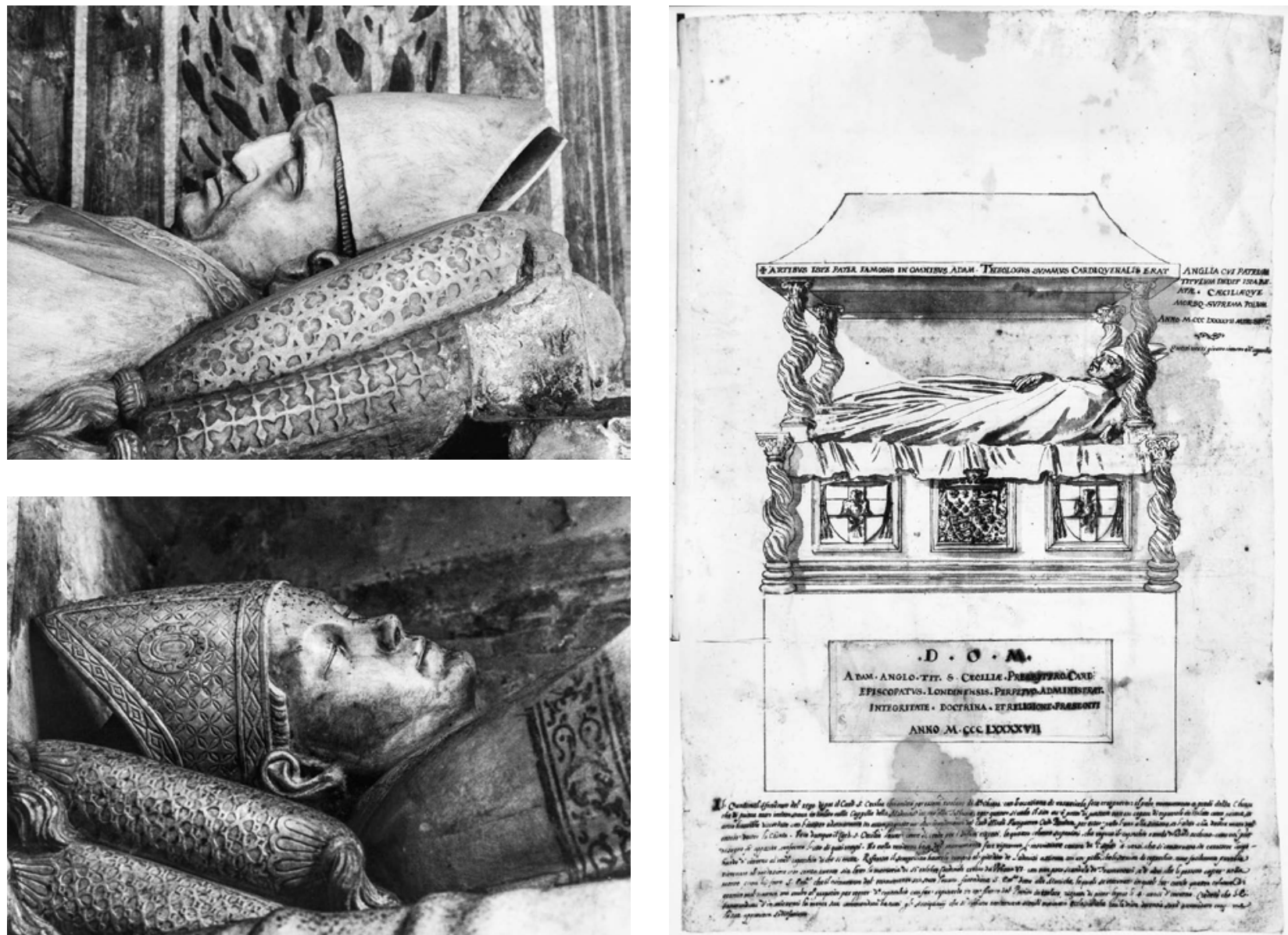

Fig. 2 Tomb of Cardinal Adam Easton († 1398). Rome, Santa Cecilia in Trastevere (Foto: Julian Gardner)

Fig. 3 (above right) Tomb of Cardinal Adam Easton († 1398). Drawing. Biblioteca Apostolica Vaticana, Barb. Lat. 3084, f. 282r (Foto: Biblioteca Apostolica Vaticana)

Fig. 4 (right) Tomb of Cardinal Philippe d'Alençon († 1397). Rome, Santa Maria in Trastevere (Foto: J. Gardner)

Fig. 5 Tomb of Cardinal Philippe d'Alençon, detail bier. Rome, Santa Maria in Trastevere (Foto: J. Gardner)

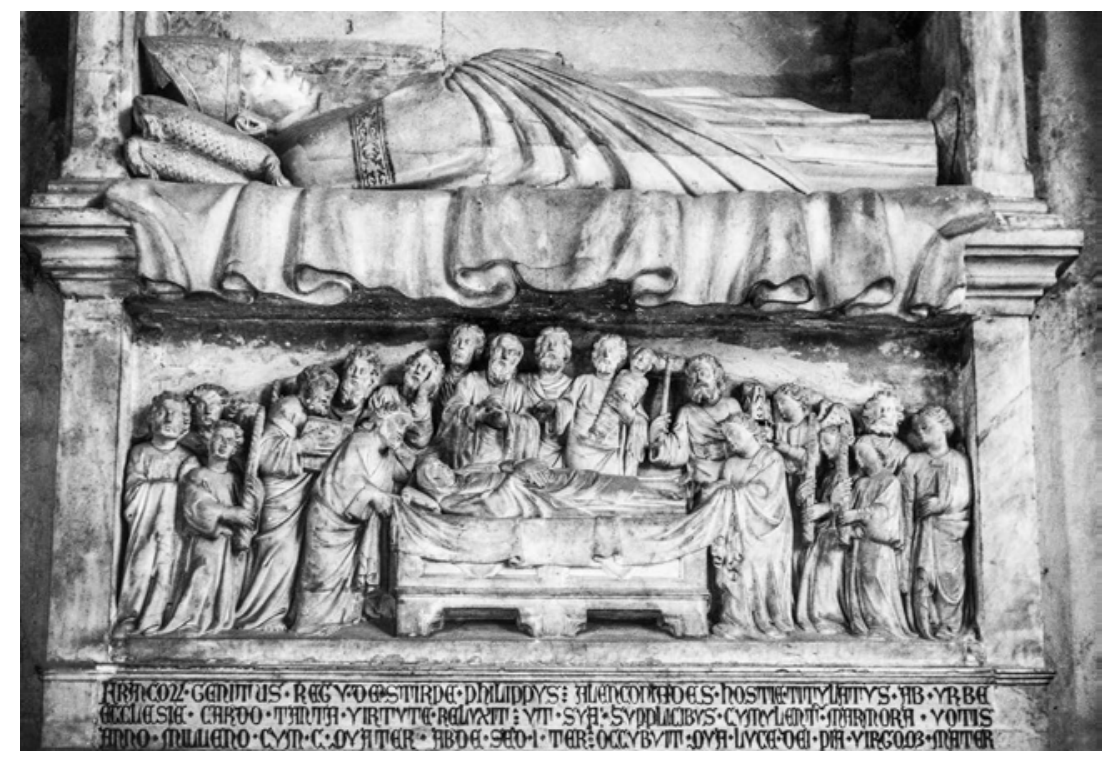


ments and burial. On the day of his funeral his livrée or residence in Avignon was draped in black cloth at a cost of 450 florins: 40 florins were paid for embalming Guillaume's corpse and another 23 for vestments to clothe it. The will makes it clear that these expenses were considered moderate. ${ }^{6}$ Guillaume's monument was to be placed to the right of the high altar in St-Martial at Limoges. ${ }^{7}$ It was to be of alabaster, well-made and appropriate to his status, with an effigy and his coat of arms. ${ }^{8}$ The tomb's purpose was precisely stated: "so that my relations, friends and acquaintances passing my tomb will remember me and commend my soul to the Almighty". ${ }^{9}$ His corpse was to be transported from Avignon to Limoges as soon as conveniently possible - without however any boiling or other process to separate the flesh from the bones. ${ }^{10}$ Chanac's documents also name the tomb sculptor, the source of the stone used and its cost - all pieces of evidence we lack for the monuments of Adam Easton, Philippe d'Alençon or Jean de la Grange. "Magister Johannes Lecourt lapicida habitator Avinionis" was paid $530 \mathrm{fl} 50 \mathrm{fr}$. d'or "for transporting the stone necessary for the monument by land and water from the Dauphiné to Avignon". ${ }^{11}$ Guillaume de Chanac's tomb is lost but its documentation of the funerary procedure and tomb commission by a cardinal of La Grange's own religious order is revealing.

Recently Jean de la Grange's monument has been characterized as the tomb of a "favourite" ("Günstling"). ${ }^{12}$ But this is somewhat misleading. At the time of his death La Grange belonged to that endangered species, the ex-favourite. ${ }^{13}$ Hated as the predatory finance minister of Charles $\mathrm{V}$ of France, he was swiftly disgraced by Charles VI, and by the time of his death in 1402, Clement VII - the pope of the Avignonese obedience, who as Robert of Geneva had been La Grange's vociferous accomplice in fomenting the Schism -, had been succeeded by Benedict XIII. ${ }^{14}$ By 1398 the French crown had withdrawn its obedience from the Avignon papacy. La Grange had thus outlived both his protectors, and it is probably mistaken to read any specific political message, even a retrospective one, into the programme of his tomb.

First however, I want to discuss the tomb of another French cardinal who pre-deceased La Grange, but who adhered to the Roman obedience. The tomb of Philippe d'Alençon survives in a damaged state in the left transept of Santa Maria in Trastevere at Rome. ${ }^{15}$ Philippe was the second son of Charles de Valois, the younger brother of Philippe VI of France $(1328-1350) \cdot{ }^{16}$ He was thus a royal

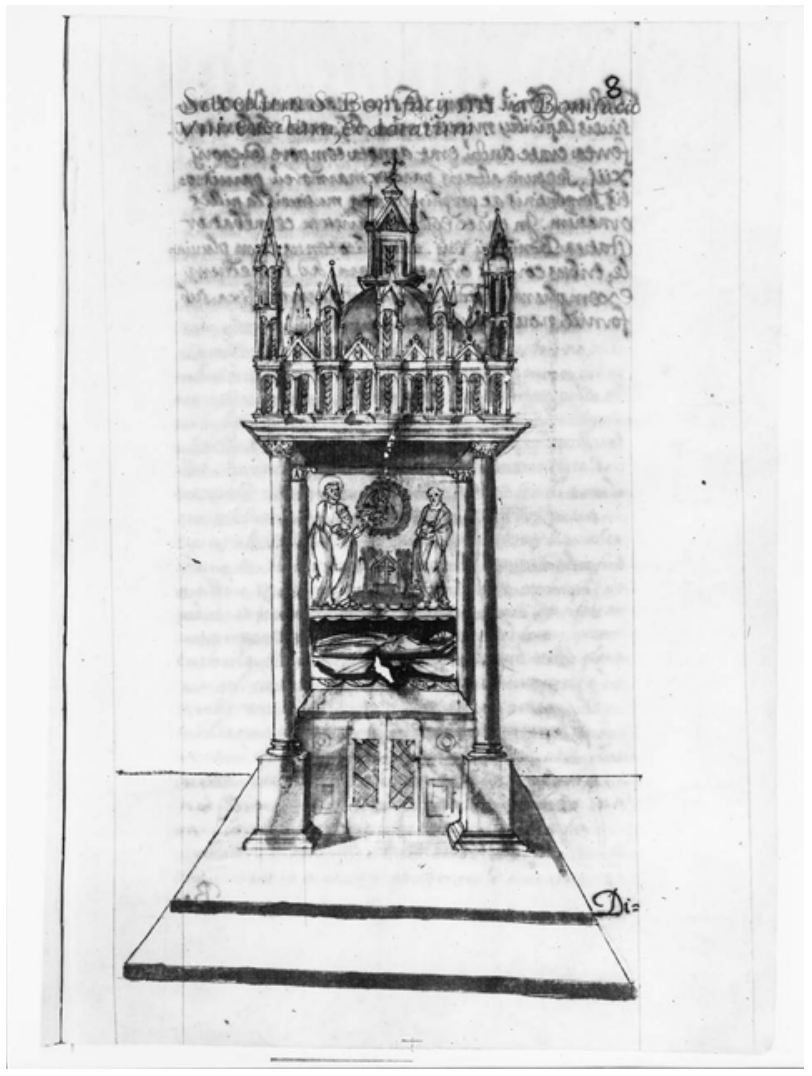

Fig. 6 Tomb of Pope Boniface VIII († 1303), formerly in Old Saint Peters. Drawing. Biblioteca Apostolica Vaticana, Barb. Lat. 2733, fol. 8r (Foto: Biblioteca Apostolica Vaticana)

nephew and a cousin of Charles V. In both rank and prestige he eclipsed La Grange. He had, in his early twenties, been Archbishop of Rouen, while Amiens, La Grange's former see, was a suffragan of Reims. A prelate of epic arrogance, Philippe had been effectively removed from his archbishopric and parked in the Patriarchate of Aquileia. ${ }^{17}$ With the outbreak of Schism he was an obvious candidate for the cardinalate, a dignity which Gregory XI had prudently refused, despite Charles V's earnest requests. Consuming rancour with the king, who had overridden his archiepiscopal prerogatives, drove Philippe into the arms of the Roman obedience. ${ }^{18}$ Eye-witness accounts of his Roman entourage demonstrate that he was one of the most prominent and ostentatious of Urban's cardinals. In February 1379 the Gonzaga ambassador, Cristoforo da Piacenza, recorded "The lord cardinal of Alençon cousin of the French king and of the blood royal entered Rome. He was so honoured, that had he been pope, he could not have been more honoured. He had many horsemen riding before caparisoned in the French royal coat of arms. 


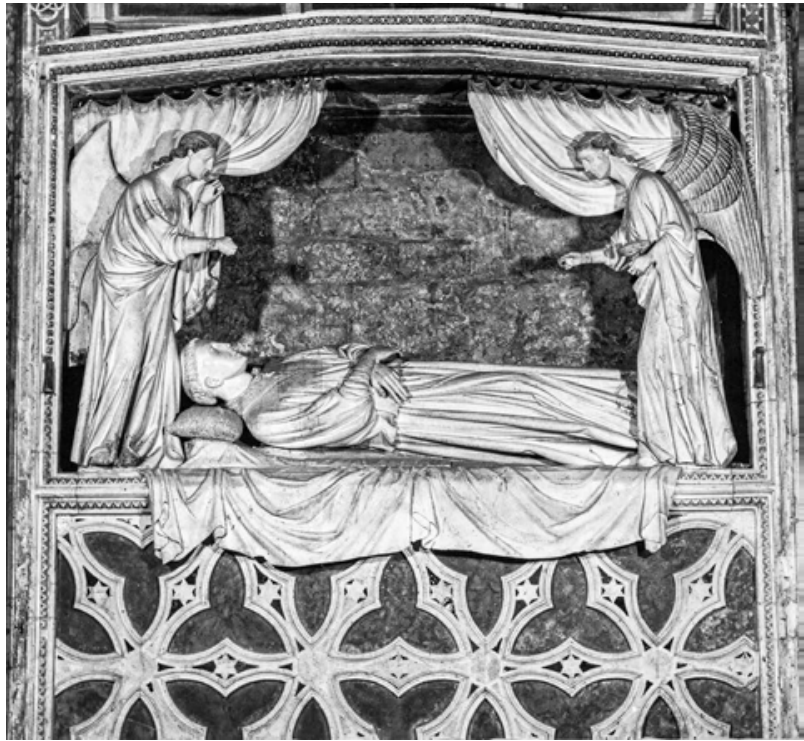

Fig. 7 Tomb of Giangaetano Orsini († 1294?). Assisi, San Francesco, Lower Church, Cappella S. Nicola (Foto: Gerhard Ruf)

Before him went three bearers with cloaks lined with ermine 'more regali"'. ${ }^{19}$ Philippe died at Rome eighteen years later: A patron of huge wealth his tomb thus makes a particularly apposite comparator for that of Jean de La Grange. Here the comment of another eye-witness, the Bordeaux cathedral canon who had spent four months in Rome in 1380, sets the context: "never in Avignon had he seen more solemn exequies or tombs for cardinals than he had recently seen in Rome, particularly for two cardinals who had died in the last month, the Cardinal of Naples, or Cardinal Colonna." ${ }^{20}$

Philippe d'Alençon's monument has been shifted and mutilated, but is still possible to suggest a reliable reconstruction. ${ }^{21}$ It developed a model well-established in central Italy since the revolutionary tomb chapel of Boniface VIII, which the pope himself had had constructed in Saint Peter's during his pontificate (fig. 6). ${ }^{22}$

Boniface's effigy occupied a loculus above the altar, where it was in the direct sightline of the celebrant. It brusquely abandoned current rules concerning the orientation of corpse and effigy. Subsequent tombs modified this model, either by integrating it into a discrete chapel space, as with the tomb of Giovanni Gaetano Orsini in the Cappella S. Nicola at Assisi (fig. 7), or adapting it to the wall tomb type, like the tombs of Bonifatian cardinals such as Gonzalez Pérez Gudiel ( $\dagger$ 1299) in Santa Maria Maggiore or Matteo d'Aquasparta ( $\dagger$ 1302) at Santa Maria in Aracoeli. ${ }^{23}$
Philippe d'Alençon's tomb is self-evidently an elaborately developed version of this altar-tomb type. Set beneath an elaborate polychrome canopy studded with statuettes of saints, the cardinal's effigy was originally oriented toward the high altar. Unusually, and perhaps unprecedentedly, the cardinal's effigy was combined with two episodes from the Virgin's life, her death and her corporeal assumption into Heaven. The tomb was later brutally truncated in the late sixteenth-century modification of the transept by Cardinal Marcus Sitticus Altemps. ${ }^{24}$

Alençon's monument has been plausibly ascribed to the Florentine atelier of Giovanni d'Ambrogio, who is documented as working in the Duomo workshop from May $1382 .{ }^{25}$ The paired Marian scenes derive directly from the great tabernacle over the miraculous Virgin of Orsanmichele in Florence completed by Andrea di Cione in $1359 .{ }^{26}$ The Orsanmichele tabernacle draws, in genial fashion, on a Roman model, the Pantheon - itself the setting of a miraculous Madonna panel. ${ }^{27}$ However the canopy which frames the tomb of Philippe d'Alençon is more indebted to the high altar canopy of the Lateran, recently erected in Rome after the return of Pope Gregor XI in January $1377 .{ }^{28}$ This huge reliquary canopy prominently displays the arms of Charles V, who had presumably contributed significantly to its cost. ${ }^{29}$

Alençon's will suggests an explanation for this formal amalgam. His principal executor was Angelo Acciaiuoli, cardinal priest of San Lorenzo in Damaso and a former bishop of Florence. ${ }^{30}$ Alençon's other executors were either Frenchmen or ultramontane. The testament also makes clear that it was the executors who had had the final choice: "our corpse, when we are taken from this earth, we commend to our executors: wishing that it be interred in the Holy City in a consecrated place following the manner and praiseworthy custom approved by the Holy Roman Church." ${ }^{31}$ In the crowning relief of the Assumption of the Virgin on the Roman tomb both St. Louis IX and St. Louis of Toulouse are present.

Adam of Easton was re-instated as Cardinal priest of Santa Cecilia in Trastevere 1389. His tomb survives, once again in an incomplete condition, in his titulus. Although located in a Roman church it was in origin an English table-tomb type, and the English royal arms feature prominently on the bier. It was the insistent pressure of King Richard II which had the cardinal released from captivity and, very likely, murder. ${ }^{32}$ Adam had earlier been the principal executor of the last English cardinal Simon Langham - another Benedictine like La Grange, 
and Langham's table-tomb in Westminster Abbey is suggestively similar in design to that of the Santa Cecilia monument, although there were clearly differences of detailing and materials in the later Roman tomb. ${ }^{33}$

In his testimony of 1379 to the Spanish ambassadors Easton passionately defended the legitimacy of Bartolomeo Prignano's election as Urban VI and skewered his fellow Benedictine Jean de La Grange as one of the principal agents of the Schism. ${ }^{34}$ In 1386 , Adam was asked to examine the Office of the Visitation of the Virgin promoted by Jan of Jenštejn (Jan z Jenštejna), archbishop of Prague. ${ }^{35}$ A commission of four cardinals, which included Easton and Philippe d'Alençon, was set up, and in April 1389 , the Feast was approved. Its import was utterly political - the Feast was part of the war against the Avignonese obedience. As Jenštejn himself stated in a sermon "the institution of the feast thus places a snare between the serpent and the woman. I say that the curling serpent is the schismatic Robert (of Geneva / Clement VII) and the woman the Church that is the holy and ever virginal Mary who alone destroys heresies." ${ }^{36}$ Boniface IX confirmed the feast on November 9 th. 1389.

Gregor XI had already accepted the Feast of Mary's Presentation initiated by Philippe de Mézières in $1372 .{ }^{37}$ This alerts us to a surprising fact. Neither the tomb of Philippe d'Alençon at Rome nor Jean de La Grange includes any "new" feast. The way in which the Virgin's life was represented in tomb compositions was often innovatory, notably in the intrusion of the laity, or of "modern" saints such as Louis IX or Louis of Toulouse, but the iconographies of the Nativity, Annunciation, the Presentation of Christ in the Temple - here in its Marian context -, the Dormition, Assumption and Coronation were well-established. In contrast to the La Grange monument the scenes on Alençon's tomb are more comprehensively conceived within their original historical moment. This suggests that it was in Rome where novel iconographical initiatives came to halting fruition. Both French Benedictines, and their executors, shunned "new" feasts. Seen in context their tombs mark rather the swan song of the late mediaeval wall tomb design than any breakthrough in sepulchral imagery.

Both Philippe d'Alençon and Adam of Easton were personally known to Jean de la Grange: Adam's loathing of La Grange is documented, and it is improbable that Alençon thought warmly of him either. Their Roman tombs however provide an essential contemporary context, customary as well as iconographical, for the tombs

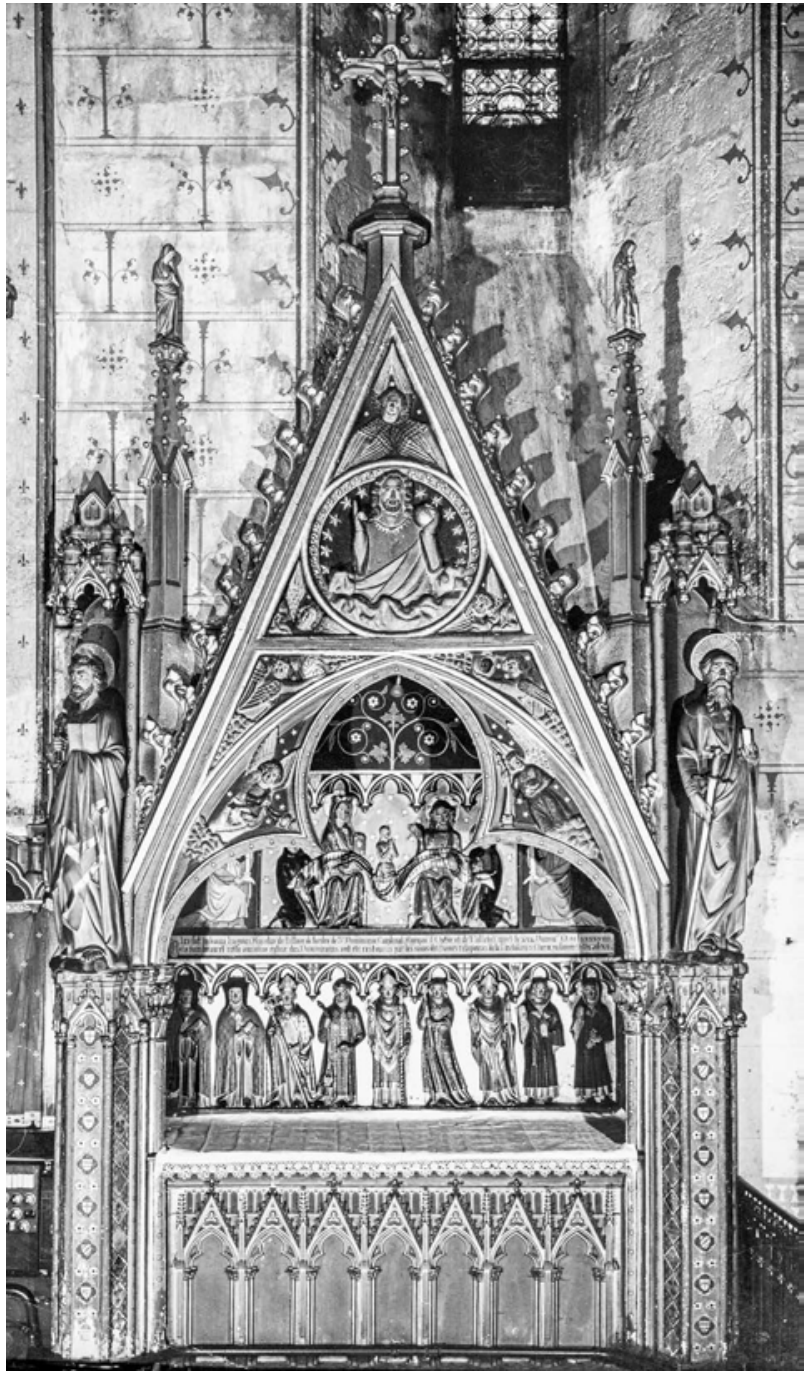

Fig. 8 Tomb of Cardinal Hugues Seguin († 1297). Clermont-Ferrand, former Jacobins; Billom (Puy-de-Dôme), St-Cerneuf (Foto: J. Gardner)

of Jean de la Grange. Like other French cardinals, notably the French Dominican Hugues Aycelin (Seguin de Billom; $†$ 1297), La Grange envisaged a tomb for his viscera and another for the permanent burial of his bones. ${ }^{38} \mathrm{Se}-$ guin died in Rome, but his final resting place was SaintCerneuf at Billom in the Auvergne (fig. 8). ${ }^{39}$

Commonly the viscera were buried at the place of death and the bones in a more elaborate tomb elsewhere. This was the case for La Grange, although the Amiens tomb where he joined his fellow bishops was completed substantially earlier than the Avignon monument: As his will states; "sepultura quam ego fieri feci Parisius diu". ${ }^{40}$ It, like the great decorated buttress, the Beau Pilier, which the cardinal had erected at Amiens, 


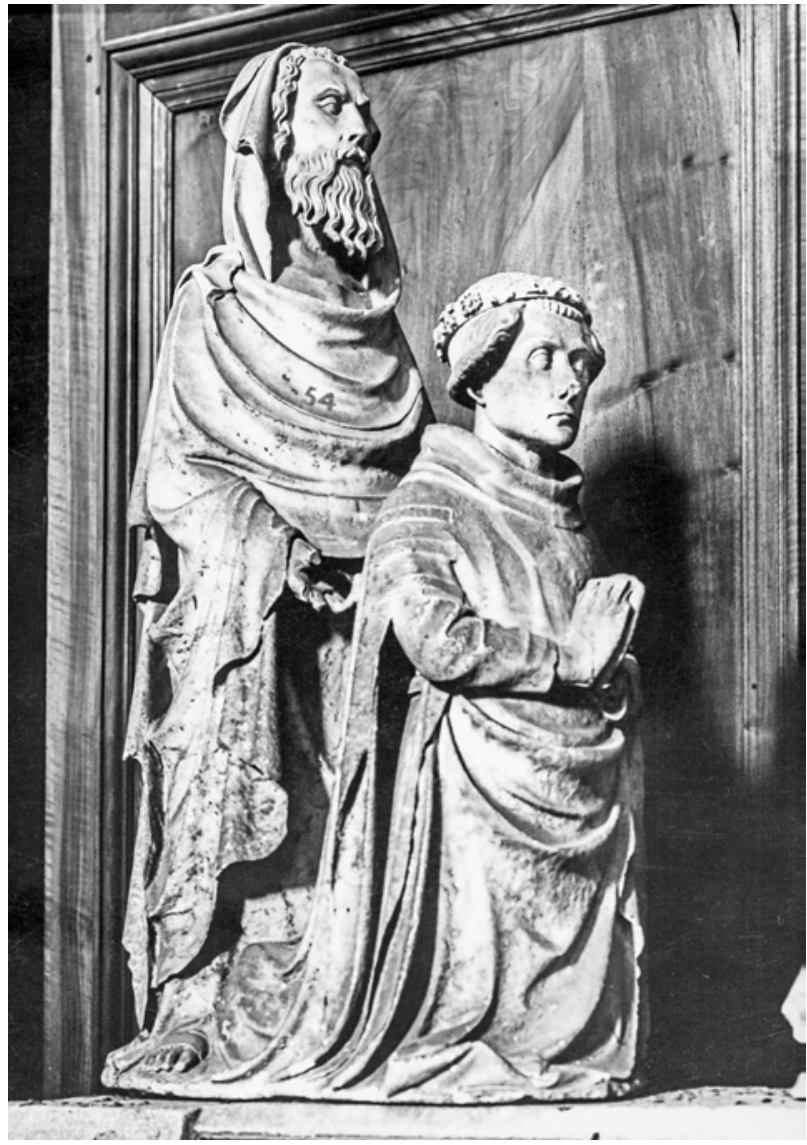

Fig. 9 Tomb of Cardinal Jean de la Grange (†1402), Louis of Anjou. Avignon, Musée du Petit Palais (Foto: J. Gardner)

is retrospective. ${ }^{41}$ The tomb setting recalls other earlier French double-sided episcopal tombs, and a more elaborate contemporary example is provided by the Benedictine archbishop of Narbonne Pierre de la Jugie. ${ }^{42}$ The sculpture of the Beau Pilier attests a political situation long disappeared, where Charles $\mathrm{V}$ and his sons stood beneath their heavenly patrons and were themselves supported by their loyal bureaucrats, Jean de la Grange pre-eminent among them. This is the political universe of Nicholas Oresme's translation of Aristotle for the personal use of Charles $\mathrm{V}^{43}$ The political programme of the Beau Pilier represented a power-structure very different from the tense and artificial conjunctures of Jean de la Grange's second tomb.

The Avignon tomb remained incomplete in 1402. The testament of that year explicitly states, "if it is still unfinished at my death, it should be well and appropriately completed." ${ }^{44}$ A traditional design, using the cardinal's effigy, the Apostolic college and Coronation of the Vir-

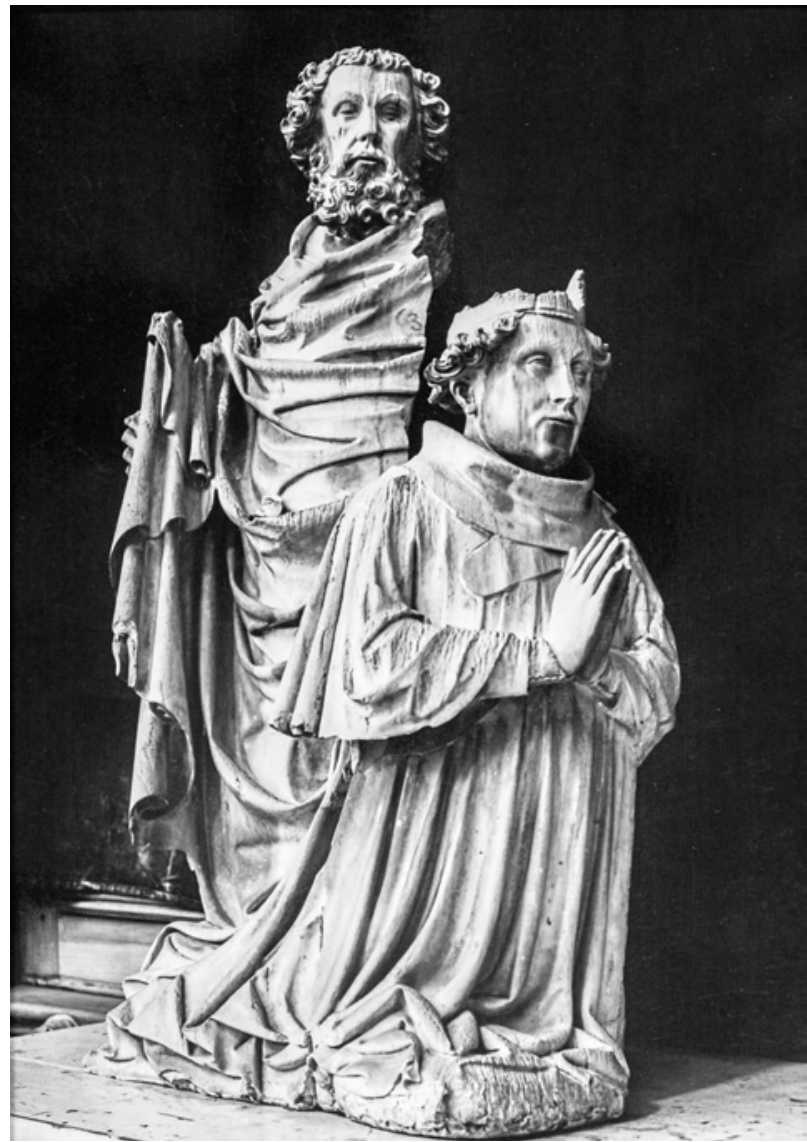

Fig. 10 Tomb of Cardinal Jean de la Grange († 1402), Charles VI. Avignon, Musée du Petit Palais (Foto: J. Gardner)

gin, provides its basis. Interspersed are five Virgin scenes, "cum repraesentatione aliquorum festorum B(eatae) Mariae", given a new immediacy by the intrusion of members of the royal family (figs. 9, 10).

This can probably be seen within the context of the exceptional increase of representative royal images in sculpture and architecture during the last quarter of the fourteenth century. ${ }^{45}$ Although not as precocious as has been claimed, they are numerous and, more importantly, represent different people. Whether one regards them as true portraits in the modern sense or not, their function in the La Grange tomb composition is clear: They drag the Marian narratives into a modern time-frame. This remarkable temporal dislocation is virtually absent from the Alençon monument. The saints presenting the royal personages are not name saints. Perhaps, as Wolfgang Brückle suggested, they evince a courtly rhetoric, a "monumentale Herrschaftsrepräsentation im Modus der humilitas." ${ }^{\prime 6}$ Be that as it may, the iconographies of the 


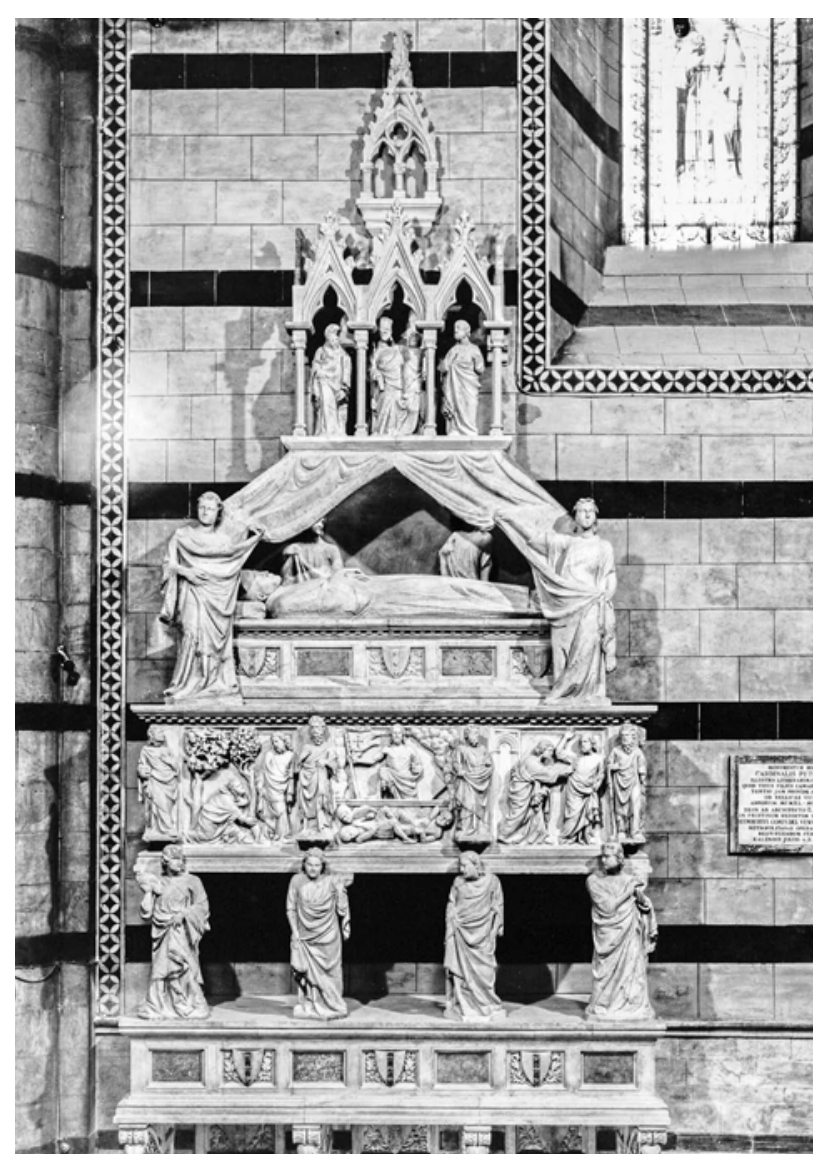

Fig. 11 Tomb of Cardinal Riccardo Petroni (†1314). Tino di Camaino. Siena, Duomo (Foto: Grassi)

Marian scenes are traditional - they are given factitious contemporaneity by their human Assistenzfiguren.

What has been completely overlooked is La Grange's direct personal experience of the most prominent and innovatory Italian tombs. As cardinal legate in the last days of Gregor XI he negotiated with the Tuscan cities and Bernabò Visconti. ${ }^{47}$ The chronicler Ranieri Sardo describes his visit to Pisa when he attended high mass (despite the Interdict). ${ }^{48}$ There he would have confronted Tino di Camaino's tomb of the Emperor Henry VII. ${ }^{49}$ The cardinal celebrated mass in Santa Caterina where stood Andrea Pisano's tomb of the Dominican Archbishop Simone Salterelli $(\dagger 1342) .{ }^{50}$ Donato di Neri's Cronaca Senese records how La Grange was magnificently entertained in Siena, where at mass in the Duomo he would have seen another tomb by Tino, that of Cardinal Riccardo Petroni (fig. 11). ${ }^{51}$

These monuments included features which later reappeared in his tomb in Saint-Martial: portraiture, a tem-

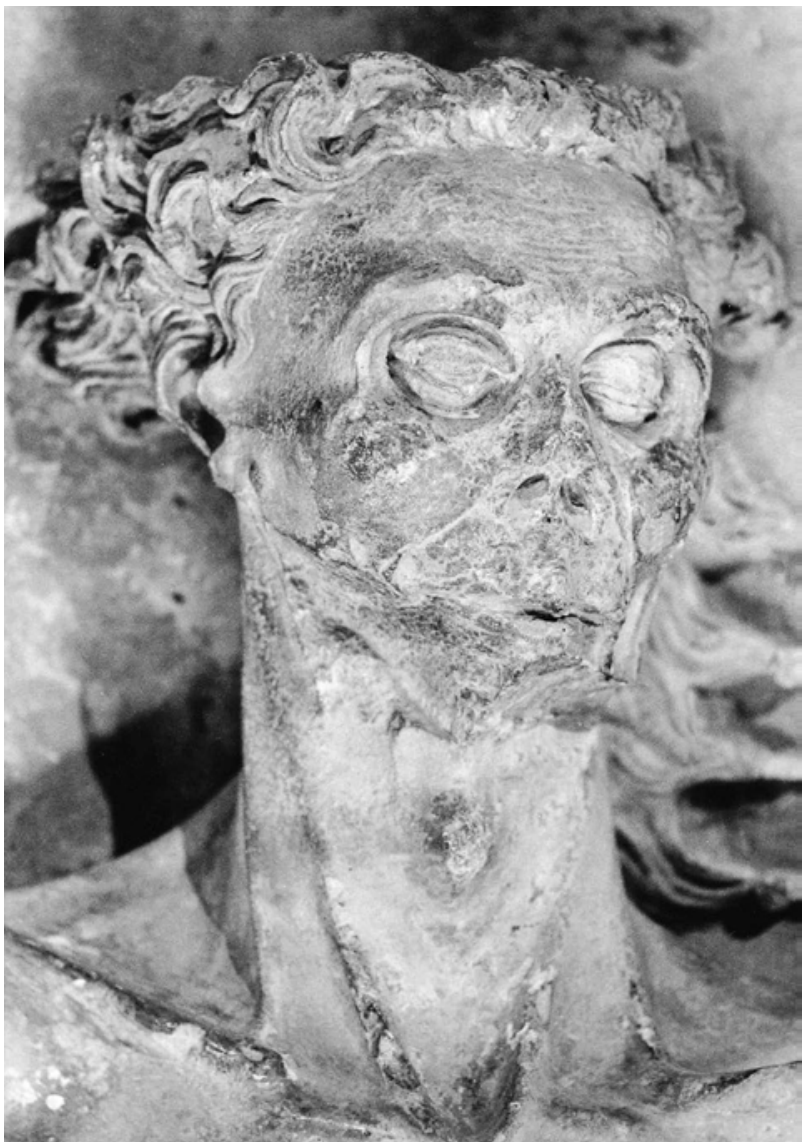

Fig. 12 Tomb of Cardinal Jean de la Grange († 1402), transi. Avignon, Musée du Petit Palais (Foto: J. Gardner)

poral ruler, New Testament episodes and the Apostolic College. The transi motif had been preceded by several earlier tombs, such as La Sarraz, although here the heads of pope and cardinal behind it give it a sharper, more particularized aspect (fig. 12). ${ }^{52}$

Like Boniface VIII and Clement VI, Jean de la Grange had commissioned his own tomb monuments.

This contemporary sepulchral context shows that despite its colossal scale and doubtless enormous cost, the La Grange monument in Saint-Martial was perhaps not quite the compositional and iconographic breakthrough which has been canvassed (fig. 1). In a number of significant elements it perhaps indicates the growing isolation and retrospective aspect of the tombs of the Avignonese obedience circa $1400 .{ }^{53}$ Could it be that the tomb of the ex-favourite, the subversive who bore such a weighty responsibility for the outbreak of the Great Western Schism, is more retrospective than revolutionary? 


\section{Bibliography}

Amon, Karl (Hg.): Ecclesia Peregrinans. FS Josef LenzenWEGER. Wien 1986.

André, Aurélien: Le Beau Pilier de la cathédrale Notre-Dame d'Amiens. Sa place dans l'iconographie politique du $14 \mathrm{e}$ siècle. In: Bulletin de la Société des Antiquaires de la Picardie 167 (2003), 543-568.

Autrand, Françoise: Charles V le Sage. Paris 1994.

BAввітT, Susan M.: Oresme's livre de politiques and the France of Charles V. Philadelphia 1985 (Transactions of the American Philosophical Society 75,1).

BAcci, Pèleo: Monumenti danteschi. Lo scultore Tino di Camaino e la tomba dell'“Alto Arrigo" per il duomo di Pisa. In: Rassegna d'arte antica e moderna 21 (1921), 73-84.

BALdelli, Francesca: Tino di Camaino. Morbio Inferiore 2007.

Banti, Ottavio (ed.): Cronaca di Pisa di Ranieri Sardo. Roma 1963 (Fonti di Storia d'Italia 99).

BAron, Françoise: Le Mausolée de Saint Elzéar de Sabran à Apt. In: Bulletin monumental 136 (1978), 267-283.

Bolgar, Robert Ralph (ed.): Classical Influences on European Culture. Vol. 1: A.D. 500-1500. Conference Cambridge, April 1969. Cambridge 1971.

Brandmüller, Walter: Papst und Konzil im Großen Schisma (1378-1431). Studien und Quellen. Paderborn/München 1990.

BrandT, Hans-Jürgen: Kardinal Philippe d'Alençon (1338/391397). Zur Biographie eines päpstlichen Legaten römischer Obedienz für Deutschland während des großen abendländischen Schismas. In: AMON 1986, 119-132.

Brock, Bazon/Preiss, Achim (Hgg.): Ikonographia. Anleitung zum Lesen von Bildern. FS Donat de Chapeaurouge. Munich 1990.

BRÜCKLE, Wolfgang: Civitas Terrena. Staatsrepräsentation und politischer Aristotelismus in der französischen Kunst. 1270-1380. Diss. Hamburg 2001. München 2005 (Kunstwissenschaftliche Studien 124).

Burns, Howard: Quattrocento Architecture and the Antique. Some Problems. In: Bolgar 1971, 269-287.

CARqué, Bernd: Stil und Erinnerung. Französische Hofkunst im Jahrhundert Karls V. und im Zeitalter ihrer Deutung. Diss. Berlin (TU) 2000. Göttingen 2004 (Veröffentlichungen des Max-Planck-Instituts für Geschichte 192).

CARqué, Bernd: Krise des Königtums - Krise der Repräsentation? Höfische Kunstaufträge unter den Bedingungen polyzentrischer Herrschaft in Frankreich um 1400. In: OeXLE/ BojCOV 2007, 315-360.

Coleman, William E. (ed.): Philippe de Mézière's Campaign for the Feast of Mary's Presentation. Toronto 1981 (Toronto Medieval Latin Texts).

[DBI]: Dizionario Biografico degli Italiani. Ed. by Alberto M. GhisAlberti et. al. Roma 196off. Online: http://www.treccani.it/biografie/ (15.07.2014).

Deprez, Eugène/Mirot, Léon: Un Conflit de juridiction sous Charles V. L'affaire de Philippe d'Alençon, archevêque de Rouen. In: Le Moyen Âge 10 (1897), 129-174.

Desportes, Pierre/Millet, Hélène: Fasti ecclesiae Gallicanae. Répertoire prosopographique des évêques, dignitaires et chanoines de France de 1200 à 1500. Vol. 1: Diocèse d'Amiens. Turnhout 1996.

[DictHistGE]: Dictionnaire d'histoire et de géographie ecclésiastiques. Publié sous la direction de Alfred Baudrillart, Albert Vogt et Urbain Rouziès. Paris 1912 ff.

Dombrowski, Damian: Das Grabdenkmal Heinrichs VII. in der Ausstattung der Pisaner Domapsis. Bemerkungen zu Chronologie, Rekonstruktion und Ikonographie. In: MrsSOK/WIENER 2007, 125-143.

Duchesne, François: Histoire de tous les cardinaux françois de naissance. Paris 1660.

FInke, Heinrich: Über Schismapublikationen. Ein Vergiftungsversuch gegen Urban VI. In: Historisches Jahrbuch 52 (1932), 457-464.

Foronda, François/Genet, Jean-Philippe/Nieto Soria, JoséMaria (Hgg.): Coups d'État à la fin du Moyen Âge. Aux fondements du pouvoir politique en Europe occidentale. Conference Madrid, 2002. Madrid 2005 (Collection de la Casa de Velázquez 91).

Gardner, Julian: Arnolfo di Cambio and Roman Tomb Design. In: The Burlington Magazine 115 (1973), 420-439.

Gardner, Julian: The Tomb and the Tiara. Curial Tomb Sculpture in Rome and Avignon in the Later Middle Ages. Oxford 1992 (Clarendon Studies in the History of Art 6).

Garms, Jörg/Juffinger, Roswitha/WArd-Perkins, Bryan (Hgg.): Die mittelalterlichen Grabmäler in Rom und Latium vom 13. bis 15. Jahrhundert. 2 Bde. Roma/Wien 1981/94 (Publikationen des Österreichischen Kulturinstituts in Rom, Abt. 2: Quellen, Reihe 5).

Garms, Jörg/Romanini, Angiola M. (Hgg.): Skulptur und Grabmal des Spätmittelalters in Rom und Italien. Konferenz Rom, 4.- 6.6.1985. Wien 1990 (Publikationen des Historischen Instituts beim Österreichischen Kulturinstitut in Rom $1,10)$.

Guibert, Louis: Le tombeau du cardinal Guillaume de Chanac à Saint-Martial de Limoges. In: Le Cabinet Historique 28 (1882), 233-242.

Guillemain, Bernard: Pierre de la Jugie, Archevêque de Narbonne (1347-1375). In: Narbonne 1973, 163-168. 
Harvey, Margaret M.: The Household of Cardinal Langham. In: The Journal of Ecclesiastical History 47 (1966), 18-44.

Harvey, Margaret: The English in Rome 1362-1420. Portrait of an Expatriate Community. Cambridge 1999 (Cambridge Studies in Medieval Life and Thought 4,45).

Herzner, Volker: Herrscherbild oder Grabfigur? Die Statue eines thronenden Kaisers und das Grabmal Heinrichs VII. von Tino di Camaino in Pisa. In: Brock/Preiss 1990, 27-77.

Hoogewerff, Godfried Joannes: Le Tombeau-autel du cardinal Philippe d'Alençon à Sainte-Marie du Trastevere. In: Mélanges d'archéologie et d'histoire 43 (1926), 43-6o.

Jamme, Armand: Renverser le pape. Droits, complots et conceptions politiques aux origines du Grand schisme d'Occident. In: Foronda/Genet/Nieto Soria 2005, 433-482.

Joubert, Fabienne (ed.): L'Artiste et le clerc. Commandes artistiques des grands ecclésiastiques à la fin du Moyen Age (14e-16e siècle). Paris 2006 (Cultures et civilisations médiévales 36$)$.

Kantorowicz, Ernst: The King's Two Bodies. A Study in Mediaeval Political Theology. Princeton 71997.

Karsten, Arne (Hg.): Das Grabmal des Günstlings. Studien zur Memorialkultur frühneuzeitlicher Favoriten. In Zusammenarbeit mit Anett Ladegast, Tobias C. WeissMANN und Laura Windisch. Conference HU Berlin, 8.9.5.2009. Berlin 2011 (Humboldt-Schriften zur Kunst- und Bildgeschichte 15).

Kreytenberg, Gert: Andrea Pisano und die toskanische Skulptur des 14. Jahrhunderts. Habil-Schr. Bochum 1982. München 1984 (Italienische Forschungen, 3. F. 14).

Kreytenberg, Gert: Orcagna Andrea di Cione. Ein universeller Künstler der Gotik in Florenz. Mainz 2000.

Kreytenberg, Gert: Die Bildhauer von Altarziborium und Grabmal des Kardinals Philippe d'Alençon in Santa Maria in Trastevere in Rom. Giovanni d'Ambrogio, Lorenzo di Giovanni und Piero di Giovanni Tedesco. In: Arte Medievale N. S. 1 (2002), 91-126.

Kreytenberg, Gert: Das Grabmal für Kardinal Adam Easton in Santa Cecilia in Trastevere und seine Bildhauer. Giovanni d'Ambrogio und Lorenzo di Giovanni aus Florenz. In: Mitteilungen des Kunsthistorischen Institutes in Florenz 53 (2009), 197-216.

KüHlental, Michael: Zwei Grabmäler des frühen Quattrocento in Rom. Kardinal Martinez de Chiavez und Papst Eugen IV. In: Römisches Jahrbuch für Kunstgeschichte 16 (1976), 17-56.

Lauer, Philippe: Le Palais de Latran. Étude historique et archéologique. 2 vols. Paris 1911.

Lerch, Charles-Henri: Jean de la Grange. Sa vie et son rôle politique jusq’à la mort de Charles V (1350-1380). In: Positions des thèses soutenues par les élèves de l'École Nationale des Chartes 107 (1955), 59-62.

Lisini, Alessandro/Iacometti, Fabio (eds.): Cronache Senesi. Bologna 1931 (Rerum Italicarum Scriptores 15,6).

Lobies, Jean-Pierre (ed.): Dictionnaire de Biographie française. Lacombe - La Vallée. Bd. 19. Paris 2001.

Maccarrone, Michele: Il sepolcro di Bonifacio VIII. nella Basilica Vaticana. In: Romanini 1983, 753-771.

Мегвом, Heinrich (ed.): Doctoris Gobelini Personae, Decani Bilfeldensis et officialis Paderbornensis, Cosmodromium hoc est Chronicon Universale complectens res ecclesiae et reipublicae ab orbe condito usque ad annum Christi 1418 (...) nunc in lucem editum, studio et opera Henrici Meibomii lemgoviensis. Frankfurt/M. 1599. Online: http://reader. digitale-sammlungen.de/resolve/display/bsb10159830.html. - Https://archive.org/stream/bub_gb_DykHv2LWqj4C\#page /n3/mode/2up (14.02.2018).

[Oxford DNB]: Oxford Dictionary of National Biography. Ed. by Henry C. G. Matthew, 6o voll. Oxford/New York 2004.

MacFarlane, Leslie J.: An English Account of the Election of Urban VI, 1378. In: Bulletin of the Institute of Historical Research 26 (1953), 75-84.

Mollat, Guy/Baluze, Étienne (eds.): Vitae paparum Avenionensium. Vol. 4. Paris 1922.

Monferini, Augusta: Il ciborio lateranense e Giovanni di Stefano. In: Commentari N. S. 13 (1962), 182-212.

Moretti, Pietro: Ritus dandi presbyterium Papae, Cardinalibus et Clericis (...). Roma 1741.

Morganstern, Anne McGee: Quelques observations à propos de l'architecture du tombeau du cardinal Jean de la Grange. In: Bulletin Monumental 128 (1970), 195-209.

Morganstern Anne McGee: The La Grange Tomb and Choir. A Monument of the Great Schism in the West. In: Speculum 48 (1973), 52-69.

Morganstern, Anne McGee: Pierre Morel, Master of Works in Avignon. In: The Art Bulletin 58 (1976), 323-349.

Morganstern, Anne McGee: Liturgical and Honorific Implications of Gothic Wall Tombs. In: Hortus Artium Medievalium 10 (2004), 81-96.

Morlière, Adrian de la: Les Antiquitez de la ville d'Amiens. Recueil de plusieurs nobles et illustres maisons vivantes \& esteintes en l'estenduë du diocèse d'Amiens. Ed. 3. Paris 1642.

Moskowitz, Anita: The Sculpture of Andrea and Nino Pisano. Cambridge 1986.

MüNTz, Eugène: Le Mausolée du cardinal de Lagrange à Avignon (fin du 14e, commencement du 15e siècle). In: L'Ami des monuments et des arts parisiens et français 4 (1890), 5-13.

Mrssok, Johannes/Wiener, Jürgen (eds.): Docta Manus. Stud- 
ien zur italienischen Skulptur für Joachim POESCHKE. Münster 2007.

[Narbonne 1973]: Narbonne. Archéologie et histoire. 45e Congrès organisé par la Fédération historique du Languedoc méditerranéen et du Roussillon. Congress Narbonne, 14-16.4.1972. Vol. 2: Narbonne au Moyen-Age. Montpellier 1973.

Oexle, Otto Gerhard/Bojcov, Michail A. (eds.): Bilder der Macht in Mittelalter und Neuzeit. Byzanz - Okzident - Russland. Göttingen 2007 (Veröffentlichungen des Max-PlanckInstituts für Geschichte 226).

Pfaff, Richard W.: New Liturgical Feasts in Later Medieval England. Oxford 1970 (Oxford Theological Monographs).

Polc, Jaroslav V.: La Festa della Visitazione e il giubileo del 1390. In: Rivista di storia della chiesa in Italia 29 (1975),149-172.

Pradalier-Schlumberger, Michèle: Le Tombeau du cardinal Pierre de la Jugie à Narbonne. In: Narbonne 1973, 271-288.

Rafanelli, Lisa M.: Seeking Truth and Bearing Witness. The 'Noli Me Tangere' and Incredulity of Thomas on Tino di Camaino's Petroni Tomb (1313-1317). In: Comitatus 37 (2006), 32-64.

Romanini, Angiola Maria (ed.): Roma Anno 1300. Conference Roma, 19.-24.5.1980. Roma 1983 (Mediaevalia 1).

Romano, Serena: Giovanni di Cosma. In: Garms/Romanini 1990, 159-171.

SANDRON, Dany: La Fondation par le cardinal Jean de la Grange de deux chapelles à la cathédrale d'Amiens. Une tradition épiscopale devenue manifeste politique à la gloire du roi Charles V. In: Joubert 2006, 155-170.

Segrè, Arturo: I dispacci di Cristoforo da Piacenza Procuratore mantovano alla Corte pontificia (1371-1383). In: Archivio Storico Italiano Ser. 5, 43 (1909), 27-95; 44 (1909), 253-326.

Seidlmayr, Michael: Die Anfänge des großen abendländischen Schismas. Studien zur Kirchenpolitik inbesondere der spanischen Staaten und zu den geistigen Kämpfen der Zeit. Münster 1940 (Spanische Forschungen der Görresgesellschaft 2, Reihe 5).

Soyez, Edmond: Le Sanctuaire de la cathédrale d'Amiens. Amiens 1873.

Suyskens, Constantin: Acta Sanctorum 7. Anvers 1760.

TAuber, Christine: Homo novus zwischen König und Kurie. Das Grabmal des Kardinals Jean de la Grange als legitimatorische Autobiographie post mortem. In: KARSTEN 2011, 21-41.

Tribout de Morembert, Henri: Jean de la Grange. In: Lobies 2001, col. $277 \mathrm{f}$.

Weltsch, Ruben Ernest: Archbishop John of Jenstein (13481400). Papalism, Humanism and Reform in Pre-Hussite Prague. Den Haag 1968 (Studies in European History 8).
Wirth, Jean: L'image à la fin du Moyen Âge. Paris 2011.

Zervas, Diane: Orsanmichele a Firenze, Vol 1. Testi. Modena 1996 (Mirabilia Italia 5).

\section{Notes}

1 For Easton see Dobson 2004. - For the details of his torture MEIвом 1599: "Ipsi vero dum chordarum tormentis afficerentur, crimen ipsum confessi sunt, sed Dominus Adam, Cardinalis de Anglia cum eis comprehensus, dum tormentis subdebatur, consilium reliquorum se scivisse, non tamen eis consensum praebuisse dicebat."

2 Gardner 1992, 130-132. - Garms/Juffinger/WARd-Perkins 1981/94, II, 31-36, no. 5, Abb. 6-9. - Kreytenberg 2009.

3 MacFarlane 1953.

4 Mollat 1914. - Brandt 1986.

5 Guillaume de Chanac OSB † 30. 7.1384. His will of 29. 7.1384 is published in Mollat/Baluze 1922, 275-289.

6 Guibert 1882.

7 Mollat/Baluze 1922, 276: "in monasterio Sancti Marciali Lemovicensis ordinis Sancti Benedicti cujus ordinis professor existo* videlicet in arcu a parte dextera juxta majus altare monasterii predicti post cathedras in quibus sedent presbyter, dyaconus et subdyaconus et ante januam ecclesia ipsius monasterii per quam intratur de ecclesia predicta ante dictum majus altare a parte dextra".

8 Mollat/Baluze 1922, 276: "Volo et ordino quod in dicto loco fiat pro corpore meo sepulchrum de alabastro honestum et decens statui meo cum ymagine et armis meis".

9 Mollat/Baluze 1922, 276: "ad finem ut parentes, amici et noti mei ibidem facientes transitum de me recordantes, altissimo creatori meam habeant animam re commendare".

10 Mollat/Baluze 1922, $276 \mathrm{f.:} \mathrm{"ad} \mathrm{quod} \mathrm{quidem} \mathrm{sepulchrum} \mathrm{deferri}$ volo et iubeo ut citius commode fieri poterit absque ulla / 277 coctione vel qualibet alia difficili carnium ab ossibus separatione".

11 Guibert 1882, 238, n. 3: "Magister Johannes Lecourt lapicida habitator Avinionis" "super pedagiis expensis et nonnullis aliis expositis et factis per terram et aquam in conducentis lapidibus monumenti necessariis de partibus delphinatus Vienne ad presentem civitatem Avenionensem." The cost of the tomb amounted to $530 \mathrm{fl} 50 \mathrm{fr}$. d'or $(238$, n. 3.). When the tomb was opened in 1753 the cardinal's body was found complete in a leather sack (241). - Chanac's epitaph is given by GUIBERT 1882, $240 \mathrm{f}$.

12 TAuber 2011.

13 LeRCH 1955.

14 Jean de la Grange OSB was promoted Cardinal Priest of S. Marcello in the second creation (20.7.1375) of Gregory XI. Between 1394 and 1402 he was Cardinal-bishop of Tusculum. See Seidlmayr 1940, 9. - Desportes/Millet 1996, 64 f. - Tribout de Morembert 2001. - JAMME 2005, 466.

15 Gardner 1992, 126-130. - Garms/Juffinger/WARd-Perkins 1981/94, II, 119-126, No. 36, Abb. 117-135. - Kreytenberg 2002. - See also Hoogewerff 1926.

16 Mollat/Baluze 1922, 275-289.

17 Deprez/Mirot 1897.

18 The Spanish emissary Rodericus Bernardi reported 4.12.1380 of Alençon: "in materia scismatis erat odiosus nimis et multum rigorosus." Seidlmay R 1940, 238. 
19 Segrè 1909, 277. 20. 2.1379: "Successive dominus card. de Alenchonis, germanus regis Franchorum et de propia domo regis die quarta presentis mentis urbem, more cardinalibus et regali, intravit [...] et tantum honoratus, quod si fuisset papa, plus honorari non potuisset. Nam habebat multos equos ipsum precedentes, copertos pannis et armis regis Francie. Habebat etiam tres portantes tres clamides plicatas foderatas de ermelinis more regali."

20 Finke 1932. - The anonymous Canon of Bordeaux was interrogated in Barcelona in early 1381: "Interrogatus de statu cardinalium curie sue, dixit, quod est bonus et stant bene solenniter. [...] Dicebat etiam dictus canonicus, quod nunquam Avinione existens viderat solenniores sepulturas vel exequias cardinalium, quam viderit nunc in Urbe sepulturas seu exequias duorum dominorum cardinalium, qui mortui sunt infra mensem, scilicet dominus de Neapoli et dominus de Columpna." - Finke 1932, 462, n. 8, suggested that Ludovicus de Altavilla was the dominus de Neapoli, whereas the Colonna cardinal was Agapito Colonna. - For whom see Dyкmans 1982.

21 Michael Kühlenthal proposed a reconstruction of Alençon's tomb. KüHLENTAL 1976, 36. - GARDNER 1992, 127-130. - KREYTENBERG 2002, 91-94, Fig. 5. - Both Kühlenthal and Kreytenberg omit to place steps beneath the altar in their reconstructions, although this was a canonical necessity, and in consequence partially invalidates their reconstructions.

22 Maccarrone 1983. - Gardner 1992, 107-109, Figs. 106-108.

23 Gardner 1973. - Gardner 1992, 82-84. - For the tombs of Gudiel and Aquasparta see Romano 1990, 159-172. - GARDNER 1992, 52 f., 82-84, Figs. 56, 61. - Garms/Juffinger/Ward-Perkins 1981/94, II, $83-87$, no. 25 , Abb. $74-80 ; 73-76$, no. 19 , Abb. 57-66.

24 Ulianich 1960, 556.

25 Kreytenberg 2002, 95-119. - Kreytenberg 2009, 207-209.

26 Zervas 1996. - Kreytenberg 2000, 97-139, Taf. 29.

27 BURNS 1971, 271.

28 Monferini 1962. - Baron 1978, 278. - SuYskens 1760, 570: "ad instar Romani S. Ioannis in Laterano".

29 LAUer 1911, I, 266. - Monferini 1962, $199 \mathrm{f}$.

30 The will is published in Moretti 1741, 341-349. - For Acciaiuoli see D'AdDARIO 1960.

31 Moret ti 1741, 342: "et corpus nostrum, dum nos ab hac luce decedere contigerit, infrascriptis nostris executoribus commendamus. Volentes, ut illud infra Sanctam Urbem in loco sacrato de quo ipsius sepeliant sepeliri faciant secundum modum \& consuetudinem laudabilem in talibus per S. R. Ecclesiam approbatos." - GARMS/JUfFINGER/WARD-PERKINS 1981/94, II, Abb. $123 \mathrm{f}$.

32 Harvey 1999, 201.

33 Harvey 1966, 23. - For Langham's tomb Gardner 1992, 163, 171, Figs. 224, 225.

34 MacFarlane 1953, 85: "Item vidi oculis meis omnes dominos diaconos cardinales recipere Corpus Christi de manu nostri pape [...]. Item de domino Gebenense inter omnes dominos pluries affirmavit de veritate papatus istius domini Urbani, et ipse suos cariores anulos sibi dedit, et sibimet loquebar de domo mea in Anagnia quam quasi funditus reparavi. [...] Item vidi litteras quas dominus Gebenensis per se misit domino imperatori de creacione libera domini nostri pape [...]. Item vidi litteras consimiles de domino [...] Ambianense".

35 MacFarlane 1953, 84: "Item fui cum domino Iacob de Ursinis [Cardinal of S. Giorgio in Velabro] in prandio in Roma et commisit ii magistri et mihi examen cuiusdam festi ordinati de transficcione beate Virginis". - For his subsequent and separate work on the Visitation see HARVEY 1999, 202.

36 WeLtsch 1968. - For John of Jenstein's sermon p. 90, n. 51 (Cod. Vat. Lat. 1122 f. 241v): "Namque in institucione festi huiusmodi insidie veraciter iam posite sunt inter serpentem et mulierem: serpentem inquam tortuosum illum Rupertum scismaticum et mulierum ecclesiam scilicet sanctam et ymmo et ipsam virginem Mariam que cunctas hereses sola interemit."

37 Pfaff 1970, 104-110. - Polc 1975. - Coleman 1981.

38 Gardner 1992, 17, 19, 90 f., 164.

39 Gardner 1992, 91.

40 Morlière 1642, 216-219. - Soyez 1873, 14-17, 72: Drawing by L. Duthoit of tombs La Grange and Jean de Boissy. - SANDron 2006.

41 Autrand 1994, 469. - André 2003. - Carqué 2004, 586 f. BRÜCKLE 2005, 159-161.

42 Guillemain 1973. - Pradalier-Schlumberger 1973, 288. GARDNER 1992, 152-154, Figs. 208-210.

43 BАввітT 1985.

44 Duchesne 1660, vol. 2, 467-475: "Item, volo et ordino quod Capella capitis hujusmodi, nec non sepultura quam ibi aedificari et construi feci, tam de opere lapideo quam vitreo, de bonis executionis meae, si ante obitum meum non fuerunt adimpleta, bene et decenter compleantur" (468).

45 Carqué 2007.

46 Carqué 2004, 590. - See also BrüCKLe 2005, 159-161.

47 BRANDMÜller 1990, 23.

48 Banti 1963, 217: "Giuovedi mattina morì uno chardinale in Pisa che era in chonpangnia chol papa, uno de' dodici chardinali. Amalò in Livorno; fessi l'asequio in duomo, in venerdì mattina, chon tucta la cherecieria et debbe grandissimo honore. [...] Lo suo nome si era : lo chardinale di Nerbona, chugino charnale del sancto padre, et dera riccho singniore." - 218: Gregory XI arrives Rome. - 219: "Nota che ogi, a dì 6 di marzo 1378, entrò in Pisa per la porta di San Marcho, che veniva da Roma missere lo chardinale di Damiens per inbasciatore del sancto padre [...] Domenicha mactina a dì $7 \mathrm{di}$ marzo [...] missere lo chardinale venne a duomo et fevvi dire una messa, e llo decto dì si disse messa a sancta Chaterina et a San Michele di borgho".

49 BACCI 1921. - DombrowsKi 2007. - BALDelli 2007, 105-140. See also Herzner 1990.

50 Kreytenberg 1984, 120 f., Abb. 157-183. - Moskowitz 1986, 80 f. 51 Lisini/Lacometti 1931, 670 (Cronaca Senese di Donato e di suo figlio Neri): "El cardinale Ambranensis arcivescovo di Narbona [= Jean Roger] e vescovo di Pampaluna [= Martino Salva,] co' molti arcivescovi entrro in Siena a dì 2 di marzo [...]. E' Sanesi li vide(ro) e ricev(ero) gratisosamente con grande onore, e presentoro ognuno di per sè onorevolmente; e stéro in Siena 3 dì con molto grande onore." - GARDNER 1992, 112-114. - RAFANELLI 2006.

52 For the transi motif see still Kantorowicz 1997. - TAUber 2011, 24-28. - Wirth 2011, 121: "Le dédoublement du mort dans les tombeaux à transi était assez général et relativisait fortement la prétention à l'humilité, une vertue que la monumentalité des tombeaux n'exemplifiait pas davantage."

53 Müntz 1890. - Morganstern 1970. - Morganstern 1973. Morganstern 1976. - Morganstern 2004, 90-92. 

Francesca Manzari

\title{
More on Illumination at the Time of the Great Schism
}

\author{
Book Patronage in the two Curias \\ and a Long-Lasting Stage of Gothic Illumination in Rome
}

I have discussed the illuminated book production for the popes and antipopes in the past, arguing that their patronage was influenced both by their competition with one another and by their desire to assert their own legitimacy. ${ }^{1}$ Papal book patronage seems to follow the same pattern in the two centres and in both cases it fueled a new and distinctive phase of late Gothic illumination, which developed thanks to the the presence of foreign artists. $^{2}$

Over the past several decades, research on the illuminated books produced in Avignon for Clement VII (137894) and Benedict XIII (from 1394 to 1403 , the year in which he fled the Avignon Palace) and in Rome for Boniface IX (1389-1404), has, in fact, shed light on previously unknown ateliers and artists, active in the two papal cities at the turn of the century and producing illuminations which have enlarged our perception of late Gothic art in Southern Europe. ${ }^{3}$ In both instances these late Gothic phases had long been forgotten, but in the case of Rome it can be shown that this style lasted well into the second quarter of the 15 th century.

Although there are traces of book patronage dating from the time of Boniface's predecessor, Urban VI (1378$89),{ }^{4}$ the most striking comparison is still that which can be established between the liturgical books made during the first decade of the 15th century for Benedict XIII and Boniface IX (figs. 1, 2). ${ }^{5}$

The surviving material shows parallel strategies in the use of illuminated books as means of affirming legitimacy, although a contact between the two productions can only be surmised. ${ }^{6}$

The recovery of a long-forgotten phase of illumination in Rome dating from the years of the Schism can be further enriched thanks to a manuscript produced at a later date, for the first time connected to the style originating from the illuminators active for Boniface (Taf. III). This manuscript shows that the late Gothic phase of illumination in Rome did not die out as Boniface IX's successors moved out of the city again, but survived at least till

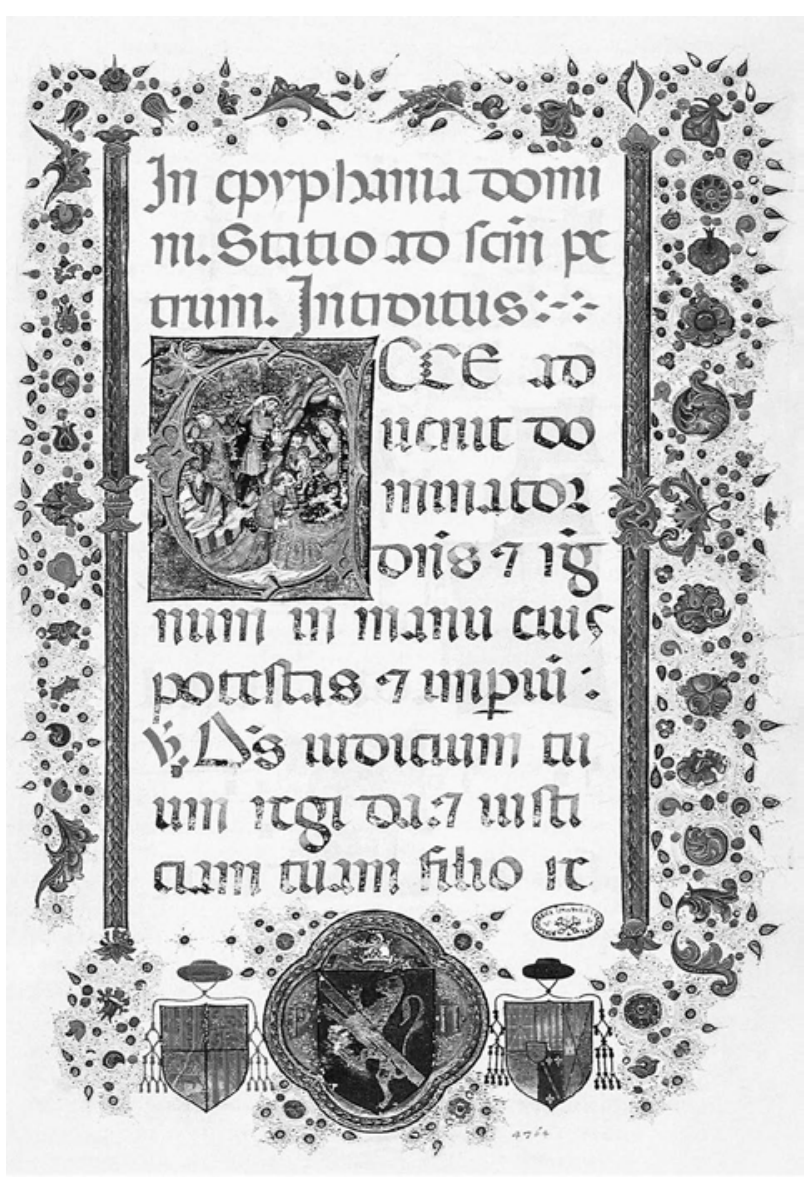

Fig. 1 Adoration of the Magi. Missal of Benedict XIII, f. 1r. Città del Vaticano, Vatican Library, Vat. lat. 4764 (Foto: Biblioteca Apostolica Vaticana)

the return of Martin V (1417-31) and up to the end of the third decade of the 15 th century. ${ }^{7}$ Therefore in Rome this late Gothic stage was considerably more long-lived than in Avignon, lasting from the very beginning of the popes' re-establishment in the city, under Urban VI, to the papacy of Martin V, well before the arrival of artists from central Italy introduced Renaissance illumination at the Papal court. ${ }^{8}$ The portrait of a city in which the book 


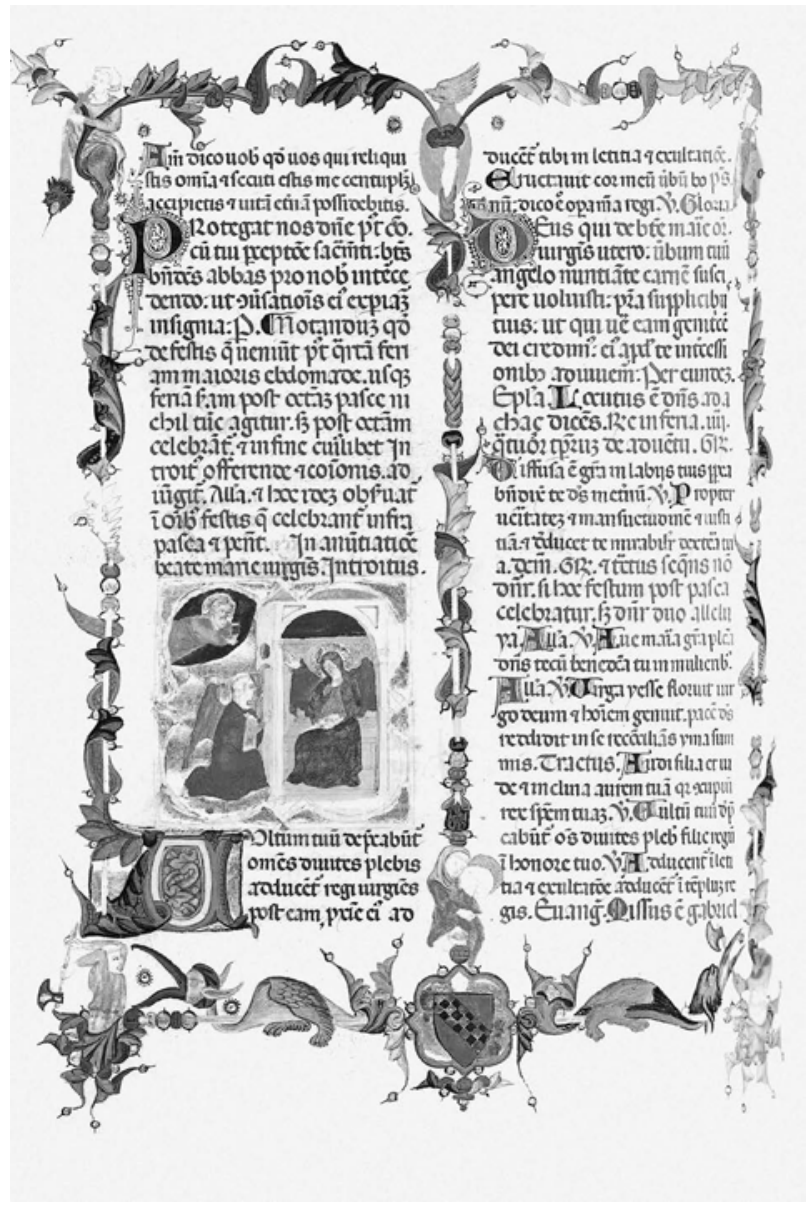

Fig. 2 Annunciation. Missal of Boniface IX, f. 168v. Saint Petersburg, Hermitage Museum, ORr-23 (Foto: Hermitage Museum, Saint Petersburg)

market was only revived by the advent of the Renaissance popes - still widespread in recent literature - must therefore be abandoned. ${ }^{9}$

During the Schism the two rival popes continuously struggled to affirm their legitimacy, with entire countries and prominent individuals changing allegiance from one obedience to the other. Within the strategy of asserting the role of rightful pope, both contenders made use of book patronage of precisely the same type. Exactly in the same years, in the first decade of the 15th century, both Benedict XIII and Boniface IX commissioned liturgical books for the celebration of the Mass. In these books the rubrics, the texts and the illuminated decoration all underline their papal destination. In doing this, both popes reproduced a type of book patronage first introduced by the Avignon popes. ${ }^{10}$

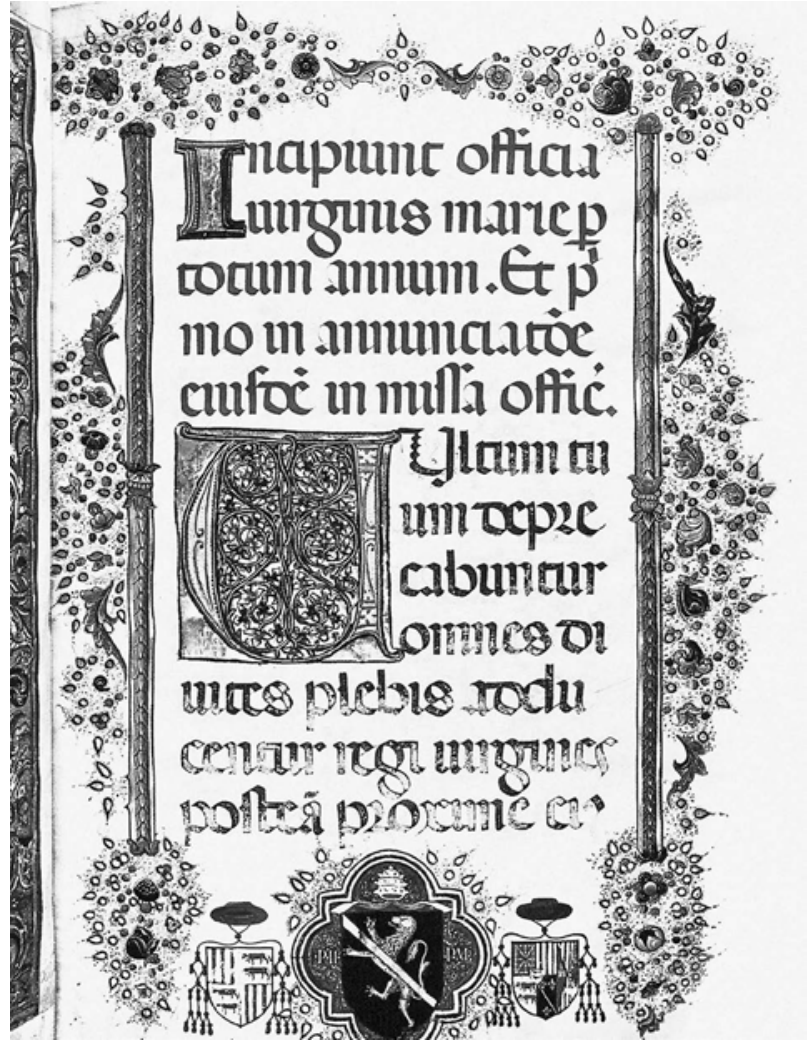

Fig. 3 Missal of Benedict XIII, f. 1r. Toledo, Biblioteca Capitular, 38.4 (ex: Exhib. cat. Madrid 2010, fig. 8.43)

Benedict XIII ordered a new multi-volume Missal, between 1400 and 1405 (figs. 1, 3, 4), although the multipart Missal made for his predecessor Clement VII in 1392-93 was still available and reasonably up to date. ${ }^{11}$

The extensive use of papal symbols and of personal heraldry in both series of books reveals how the patronage of instruments for the celebration of papal Masses was considered by the two rivals as an important means by which to affirm legitimacy. ${ }^{12}$

Recent discoveries have broadened our knowledge of Benedict's Missal: in the past I had identified three parts of this multi-volume Missal for papal use - two manuscripts in the Vatican library (Vat. lat. 4764-4765; fig. 1) and one in Montecassino (Archivio dell'Abbazia, Ms. 539; fig. 4$)^{13}$-, while a fourth volume was later discovered by Elena de Laurentiis in Toledo (Biblioteca Capitular, 38.4; fig. 3). ${ }^{14}$ I have now traced two more fragments from this group: a cutting (New York, The Metropolitan Museum, 28.140), ${ }^{15}$ with an illuminated $\mathrm{T}$ with the Crucifixion and decorated letters on the back (fig. 5), ${ }^{16}$ presumably cut out from a fifth volume, and a detached leaf (fig. 6), 


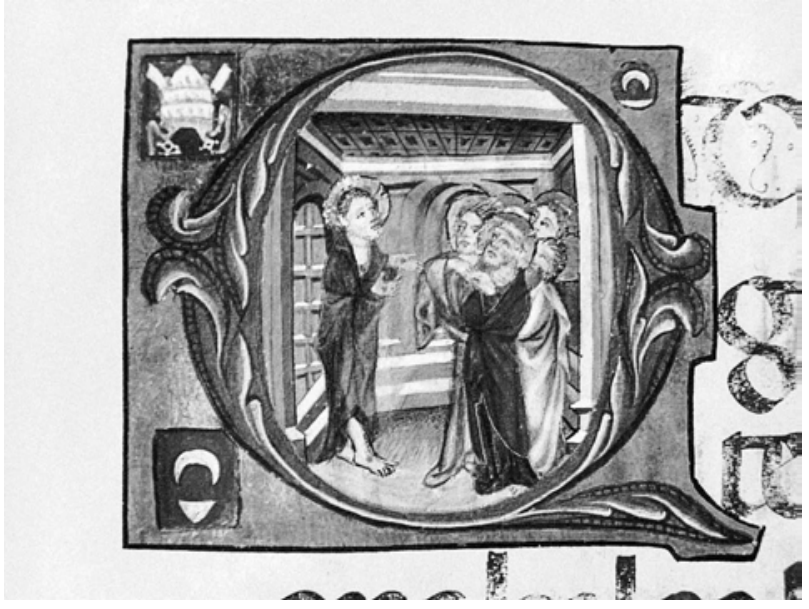

Fig. 4 Christ in front of the Apostles, detail. Missal of Benedict XIII, p. 149. Montecassino, Archivio dell'Abbazia, Ms. 539 (Foto: Archivio dell'Abbazia di Montecassino)

Fig. 5 Cutting with the Crucifixion from the Missal of Benedict XIII. New York, The Metropolitan Museum, 28.140 (Foto: Marquand Fund, 1928)

Fig. 7 Pope blessing from the Lateran Loggia. Praeparatio ad missam of Boniface IX, f. 39v. Città del Vaticano, Vatican Library, Vat. lat. 3747 (Foto: Biblioteca Apostolica Vaticana)

which appeared on the market in $2013^{17}$ and which I have identified as cut out from a missing quire in the Montecassino volume. ${ }^{18}$

The Metropolitan cutting shows initials close to the Montecassino volume on one face, possibly by the Spanish artist Sancho Gonthier, working in Avignon with a Bolognese style; on the other side of the fragment, the Crucifixion was illuminated by the Maitre d'Orose (fig. 5). ${ }^{19}$ The detached leaf (fig. 6), with a decorated letter and a historiated initial with Christ and the Apostles, at the incipit of Saturday in albis, ${ }^{20}$ is by the same artists as the historiated letters in the Montecassino volume from which it comes from. This workshop shows more Germanic traits, probably connected with Cologne, in comparison with the illuminators, probably coming from Guelders, active in the volume now in the Vatican Library (Vat. lat. 4764), for example in the initial with the Adoration of the Magi (fig. 1). ${ }^{21}$

The different artistic cultures of the illuminators working in these manuscripts demonstrate how the international milieu characteristic of Avignon throughout the 14th century was greatly enhanced during the papacy of Benedict XIII. The same can be said of the papal court
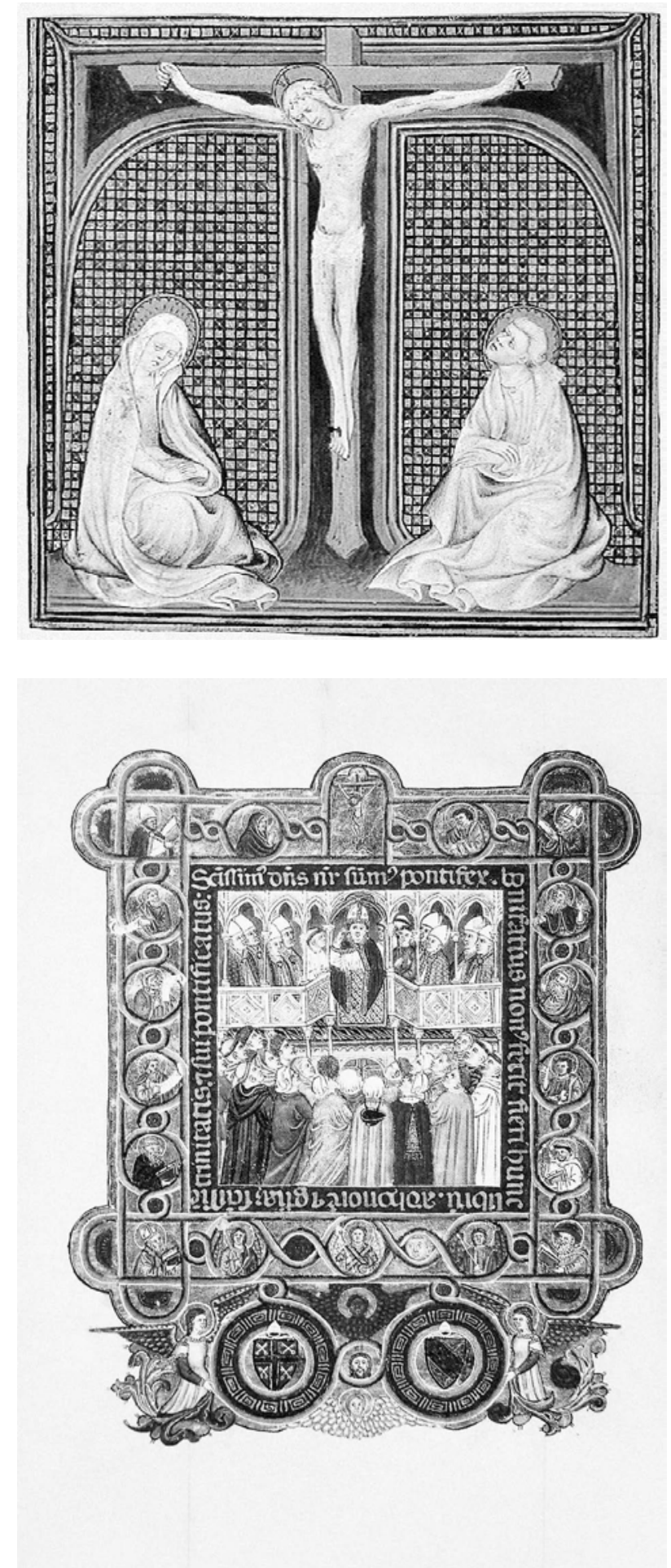

in Rome in the same years, where central Italian illuminators worked side by side with northern European artists. ${ }^{22}$

Dynamics in patronage similar to those in Benedict's Avignon early 15th century multi-volume Missal are re- 


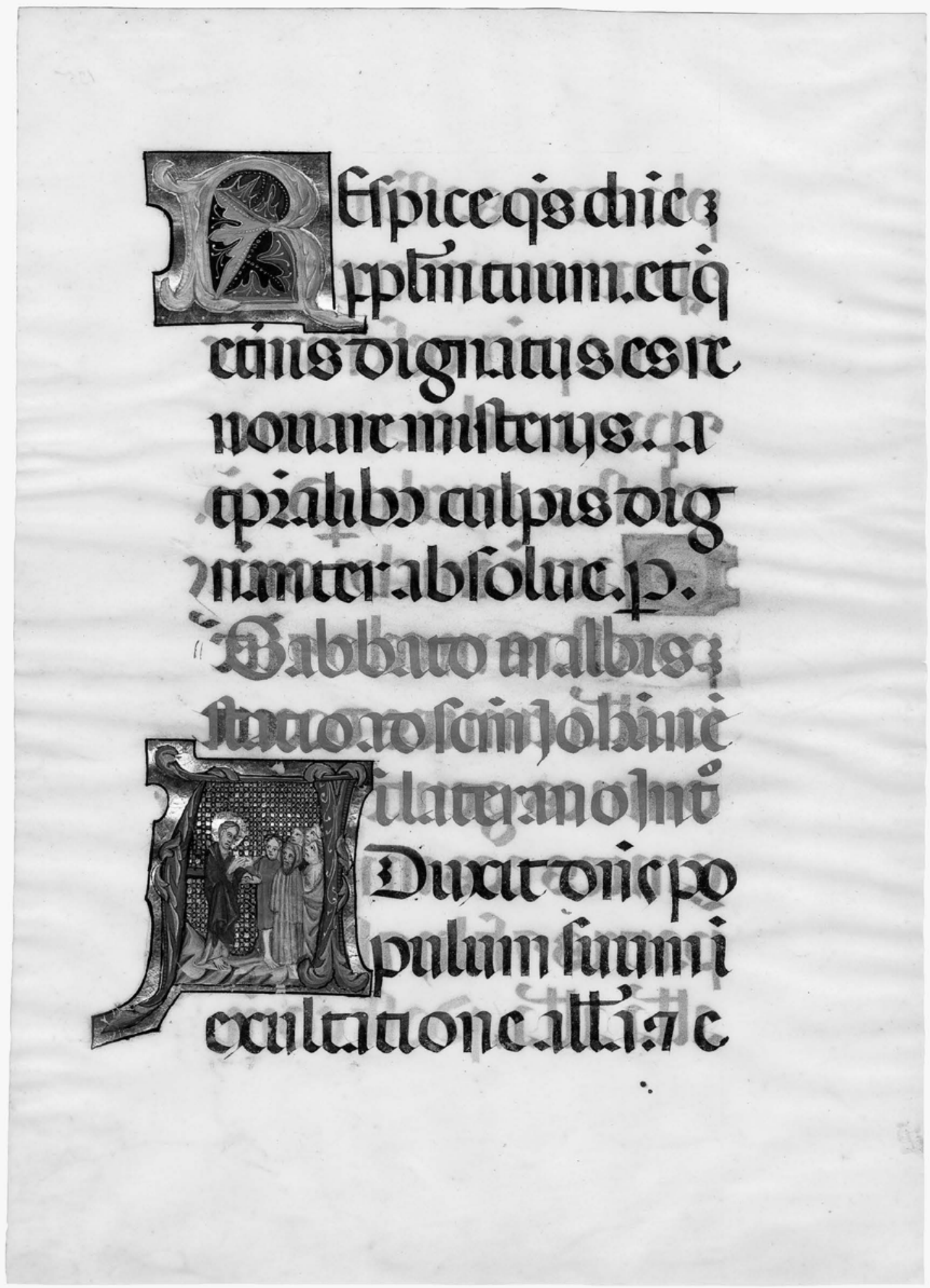

Fig. 6 Detached leaf with the Incipit of the dominica in albis from the Missal of Benedict XIII. Paris, Les Enluminures (Foto: Les Enluminures, Paris) 


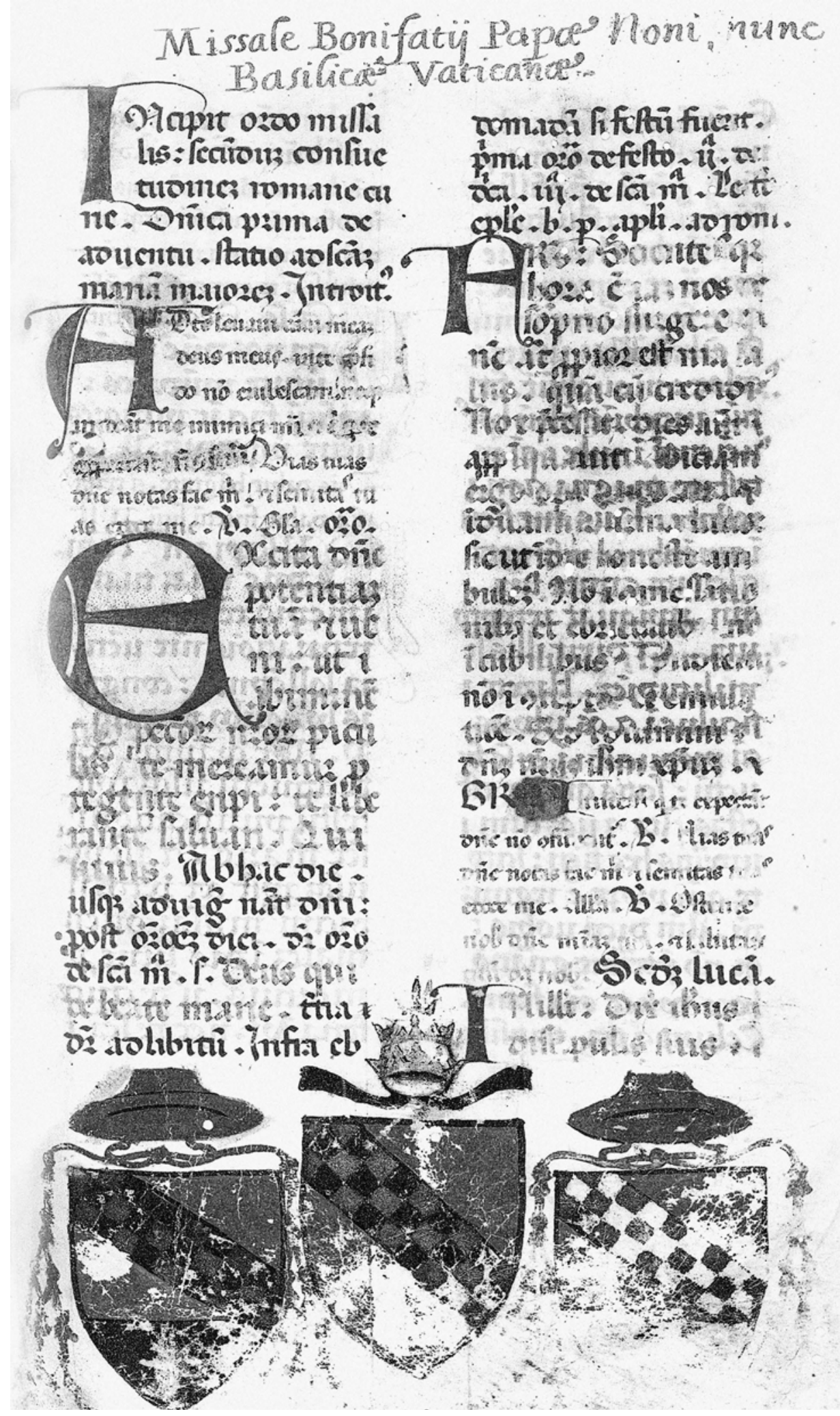

Fig. 8 Tomacelli coat-of arms and those of Antonio Pancera in the lower margin. Missal for Boniface IX, f. 1r. Città del Vaticano, Vatican Library, Arch. Cap. S. Pietro E.3 (Foto: Biblioteca Apostolica Vaticana) 


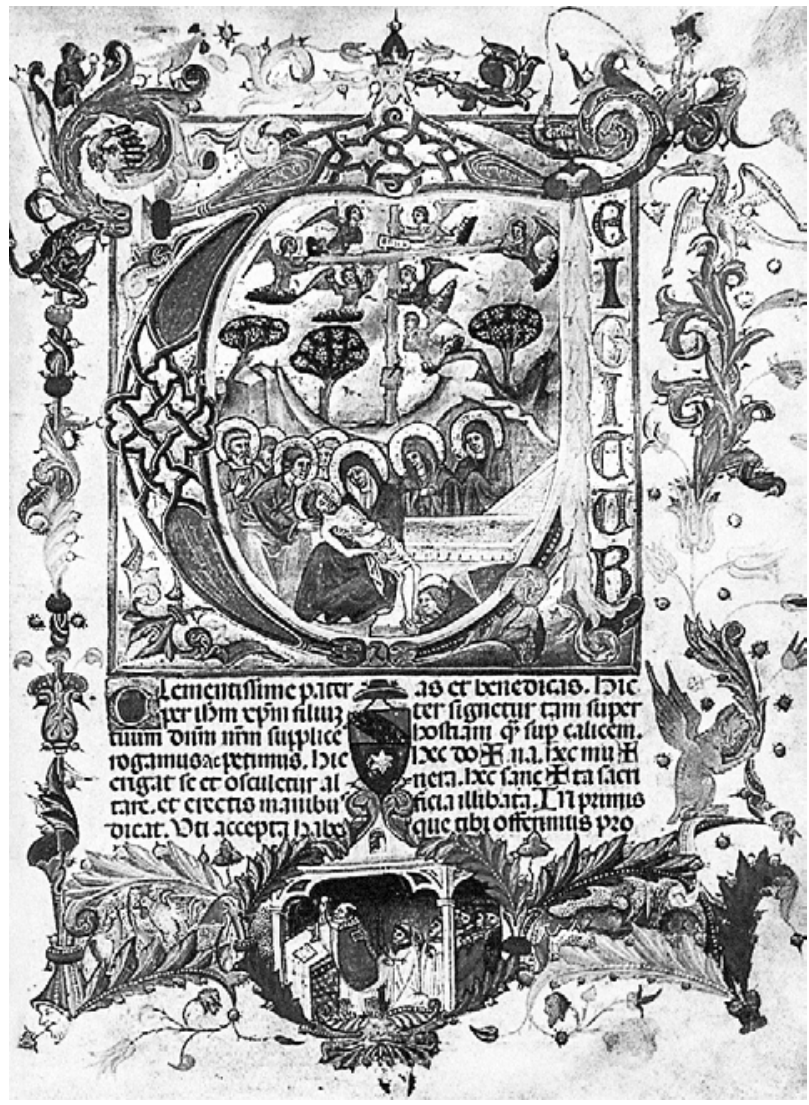

Fig. 9 Deposition. Missal of cardinal Antonio Pancera, f. 143r. Blackburn, Museum, Hart Ms. 20918 (Foto: Hart Museum, Blackburn)

vealed by the illuminated books made in Rome for Boniface IX between 1400 and 1404. Besides the two liturgical books for the Mass produced for him, a Missal (Saint Petersburg, Hermitage, ORr-23: fig. 2) and a Praeparatio ad Missam (Vat. lat. 3747; fig. 7), ${ }^{23}$ both showing exactly the same intention to assert legitimacy through the use of papal arms and emblems, ${ }^{24}$ I have also placed within the same artistic context a small group of manuscripts.

These include a fragment of a Missal from Santa Maria del Popolo, associated with Boniface, at least chronologically, by the presence of cults promoted by him (now bound together with the so-called Missal of John XXIII: Los Angeles, John Paul Getty Museum, Ms. 34, ff. 262267) $;{ }^{25}$ a pen and ink drawing in the margins of a wellknown polyphonic manuscript (Chantilly, Bibliothèque du Château, Ms. 564, f. 37r), which can be connected to his music chapel $;^{26}$ another Missal directly linked to Boniface IX (Vatican Library, Arch. Cap. S. Pietro E.3), although it is not illuminated except for the heraldry on the bas-de-page of the first leaf (fig. 8). ${ }^{27}$
This manuscript bears the Tomacelli coat-of-arms under the papal tiara (pope Boniface IX was Pietro Tomacelli), accompanied by two other shields, placed under cardinals' hats and divided horizontally: these contain the Tomacelli arms in the upper section and a star in the lower portion (clearly visible in one of the two). ${ }^{28}$ I have recently recognized this shield as that of cardinal Antonio Pancera (1350-1431), a prelate very close to Boniface IX, acting as his secretary, whom I have also identified as the owner of another manuscript from the same workshop. ${ }^{29}$ The identification of Pancera as the patron of liturgical manuscripts produced in Rome is a very important acquisition, because the book patronage of this prelate had previously been investigated only in relation to the books he left in Friuli, as the Patriarch of Aquileia (1402-12). ${ }^{30}$

After formerly following an erroneous 17 th century identification, I recognized this coat-of-arms in the so-called Serra Missal (Blackburn, Museum, Hart Ms. 20918), which was illuminated by the same ateliers working for Boniface IX (fig. 9). ${ }^{31}$

The arms painted in this manuscript can also be identified in those carved on the fragments of a tomb in the Vatican grottoes. ${ }^{32}$ Both the arms in the Blackburn Missal and those on the tomb had previously been incorrectly identified with those of cardinal Pedro Serra, due to their mistaken identification with those of this Catalan anti-cardinal by Ciaconius in his Vita et gesta Romanorum pontificum et cardinalium, published after his death in $1601 .^{33}$

On the contrary, the rightful owner of this coat-ofarms, present in the Blackburn Missal, in the Missal for Boniface IX (Arch. Cap. S. Pietro E.3) and in the tomb fragments, can be identified with cardinal Antonio Pancera. The coat-of-arms bearing the Tomacelli arms and the gold star corresponds to that marking books which were certainly produced for this prelate, patriarch of Aquileia and cardinal from 1411, perfectly fitting in the context of book patronage at the court of Boniface IX, as he was closely tied to this Roman Pope. ${ }^{34}$ Exactly the same set of coats-of-arms as in the Roman Missal, in fact, appears in a manuscript written expressly for him (Cividale del Friuli, Biblioteca Guarneriana, Guarner. 138, f. 1r). ${ }^{35}$ Furthermore, Cesare Scalon has recently referred this coat-of-arms to a bull, granting Pancera and his family the right to employ the Tomacelli arms in their own arms (1 September 1392). ${ }^{36}$

At first glance, nonetheless, the career of this prelate of Northern Italian origin might seem to pose some problems with respect to the dating of the campaign of 
illumination in the Blackburn Missal, because Pancera (who died in 1431) became cardinal in 1411, eleven years after the copyist of the book had written the colophon in the manuscript, stating that he had finished writing it in July $1400 .{ }^{37}$ To justify the distance between the two dates there are various possible explanations: we must either suppose that the arms were added to the Missal in a second moment, or that the book was completed a decade after having been written, or that Pancera had been using cardinal red for his hat before rising to this office. Although the arms on the incipit of the Blackburn Missal (f. 7r) may well have been added, I think that the other two coats-of-arms inserted in the decorated borders (ff. $142 \mathrm{~V}, 143 \mathrm{r}$ ) are part of the original campaign. ${ }^{38}$ In a previous study, supposing that a date in 1411 might be too late for the continued activity of workshops which were not further documented after Boniface IX's death in 1404, I suggested that Pancera might have been using red as patriarch of Aquileia, since among the privileges of this office was the right to use red, like the cardinals. ${ }^{39}$ Nonetheless, the discovery of a further manuscript following the same style and dated even later has opened up new possibilities; although it is likely that Pancera simply asked for the red hat to be added to the two original coats-of-arms (ff. 142v-143) when he became a cardinal, it cannot be excluded that he had the Missal illuminated when he moved to Rome in 1412, after giving up the title of patriarch of Aquileia. ${ }^{40}$

Therefore, in the second instance, the Pancera Missal, written in Trisulti - but simply because the scribe Johannes de Berlandia, also documented in Rome while working in the papal chancery, was staying there during the summer months $-{ }^{41}$ might have remained without illumination for slightly more than a decade, before the vast illuminated programme was carried out. In that case, Pancera, might not necessarily be the book's original patron, and it is possible that he may have acquired it some time after its production by the scribe, deciding to have it completed by the workshops active in Rome. This would not be surprising, as it was a rather frequent practice: books completed only in the transcription of the text were perfectly usable and many unfinished books, with the campaign of illumination left incomplete at different stages, have been preserved, as an example from the same context demonstrates: the Missal in St Petersburg, started under the patronage of Boniface IX, and which passed to his successor Innocent VII (1404-06), without being completed (fig. 2). ${ }^{42}$

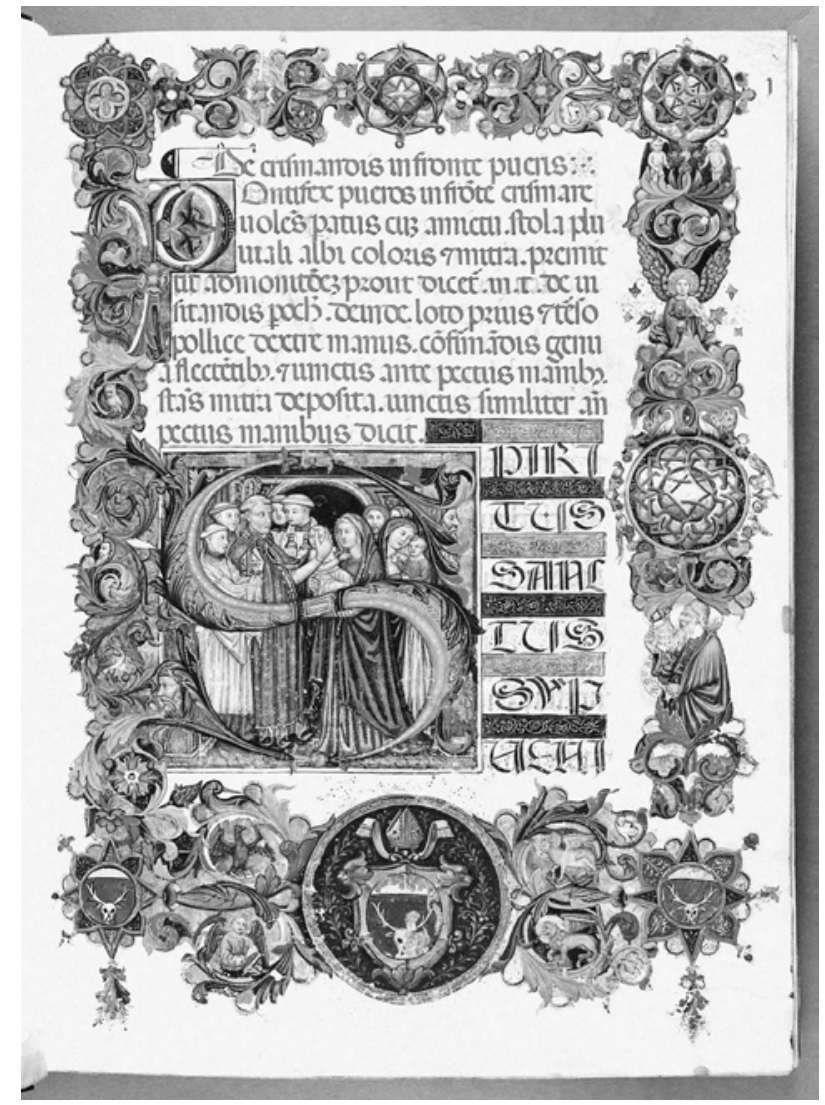

Fig. 10 Confirmation. Pontifical of Andrea Calderini, f. 1r. Harvard (Mass.), Houghton Library, Typ. 1 (Foto: Houghton Library, Harvard)

The discovery that a part of the illuminations in a manuscript copied in Rome in $1427^{43}$ still follows the same style used by the workshops active for Boniface IX shows that illumination did not decline in Rome when the popes moved out of the city again during the years of the Councils, and while the various contenders were itinerant around Italy. In fact the workshops working for Boniface IX and his circle must have remained active throughout the first quarter of the century. This extended time-span makes this long-forgotten phase of Gothic illumination in Rome even more significant, within the framework of the art produced during the Schism.

Furthermore, as I have suggested, this style was in fact elaborated earlier than the last decade of the 14th century, as two other examples, close to the illuminators of Boniface IX, but assignable to a different and more elegant artist, can be dated during the papacy of the first Roman pope Urban VI (1378-89), at the outbreak of the Schism. ${ }^{44}$

To this earlier stage I have assigned a detached leaf (bound in a later volume from the Sistine Chapel: Toledo, 
ms. 39.1, f. 69r), with an illumination of the Resurrection (Taf. II), which I believe was produced by an artist working in Rome and closely related to the illuminators later active for Boniface IX. ${ }^{45}$ This leaf, in my opinion, was illuminated by the same artist who started the decorative campaign in a further Roman manuscript (fig. 10), the Pontifical made for the north Italian bishop Andrea Calderini (Harvard, Houghton Library, Typ. 1 ). ${ }^{46}$ This manuscript had already been connected to Rome by François Avril, who had recognized the pen-work initials in it as the work of the calligrapher Stephanus de Aquila, active in Rome, in the chancery of both Urban VI and Boniface IX. ${ }^{47}$ I absolutely agree with the Pontifical's localization to Rome, where Andrea Calderini (bishop from 1378-85) was residing, at Urban VI's court, as it appears that he never went to his diocese of Ceneda, in the Veneto. ${ }^{48}$ I therefore think that both the Calderini Pontifical and the detached leaf must be assigned to a date during Urban's papacy, approximately $1380-83$ (Taf. II, fig. 10). ${ }^{49}$

The importance of this artist is considerable, not only because of the high quality of his work, but also because it suggests that the roots of this Roman late Gothic style in which many foreign components, especially Flemish, are present $t^{50}$ - largely derive from illumination produced in the Abruzzi, another area whose late Gothic production has only recently been systematically studied. ${ }^{51}$

Not only is this the area from which the calligrapher Stefano dell'Aquila came from, but I also think that the illuminator of the Calderini Pontifical himself was educated in the city of L'Aquila, and, moreover, precisely in the workshop of the artist who, ca. 1375, illuminated the Missal of Santa Maria Paganica (Vatican Library, Ross. 276), for whom I have suggested the name of Second Master of the Rossiano Missal. ${ }^{52}$ The activity in Rome of an illuminator trained in the Abruzzi is perfectly consistent with what is known about the the book market in Rome in the late 14th century, as various artists and scribes from this region are documented in the papal city at the time. ${ }^{53}$ In fact, there is every reason to suppose that the presence of artists and artefacts from the Abruzzi was consistent in Rome throughout the 14th century, even during the Curia's absence, in the decades of the Avignon papacy, and especially in connection with the Chapter of St Peter. ${ }^{54}$

That this style - originating in the Abruzzi and used in Rome in the last quarter of the 14th century - was also maintained in this region, or eventually went back there from Rome, exactly in the 1420 s, is proved by the new dating of a liturgical manuscript still kept in the Abruzzi: the Trasacco Gradual (Avezzano, Curia vescovile), closely connected to the Roman context by a possible link of its patronage to the Colonna family. ${ }^{55}$ The wide dissemination of the style originating at L'Aquila in central Italy is further documented by manuscripts produced in the Marche, such as the Offida Missal (Parma, Biblioteca Palatina, Pal. 670), datable to the beginning of the 15th century. ${ }^{56}$

The Toledo leaf and the Calderini Pontifical, therefore, mark the beginning of a new phase of illumination in Rome, at the beginning of the Schism, long before the advent of the Renaissance popes. Although it is possible that the production of illuminated manuscripts in the city was not wholly abandoned during the absence of the Curia, in the first three quarters of the 14 th century, ${ }^{57}$ this material - for the moment - is the first sign of an extremely high quality production for the popes and their court.

At the opposite end of this time-span is a Missal, coming from the Sacristy of St Peter's (Vatican Library, Arch. Cap. S. Pietro B.65), dated 1427 (Taf. III), showing that this phase of illumination in Rome stretched from the mid-1380s to the end of the 1420 s, as late Gothic art did in northern Europe. Besides containing illuminations still related to Boniface's workshops, the interest of this manuscript also lies in a second group of illuminations (Taf. IV, fig. 11), carried out by another artist.

This Missal is firmly placed and dated by its opening rubric (f. $7 \mathrm{r}),{ }^{58}$ which claims it was written in Rome in 1427 for Johannes Montanus, praepositus of Viviers, and licterarum apostolicarum scriptor and abbreviator, during the papacy of Martin V (Taf. IV). ${ }^{59}$ The illuminated letter at the incipit is clearly a later interpretation of the same type of border decoration used in the first decade in the context of Boniface's court (figs. 2, 7, 9), while a different artist has completed other illuminations, such as the incipit of the Canon and the full-page Crucifixion beside it (Taf. IV, fig. 11). At a first glance he appears marked by a more old-fashioned, less refined style. Nonetheless, having been entrusted with two of the most important illuminations in the book, and also many others, such as the historiated initial with the Resurrection at the incipit of the Easter mass (f. 154V), he was definitely a reputed artist, perhaps working in association with the illuminator still using the Boniface workshops' style (who was responsible for the incipit and other letters: ff. $7 \mathrm{r}, 15 \mathrm{~V}, 209 \mathrm{r}, 210 \mathrm{r}, 251 \mathrm{r}, 272 \mathrm{~V}$ ). The archaic aspect of this artist's work (fig. 11) can partly be explained by the fact that he was certainly not Italian, 


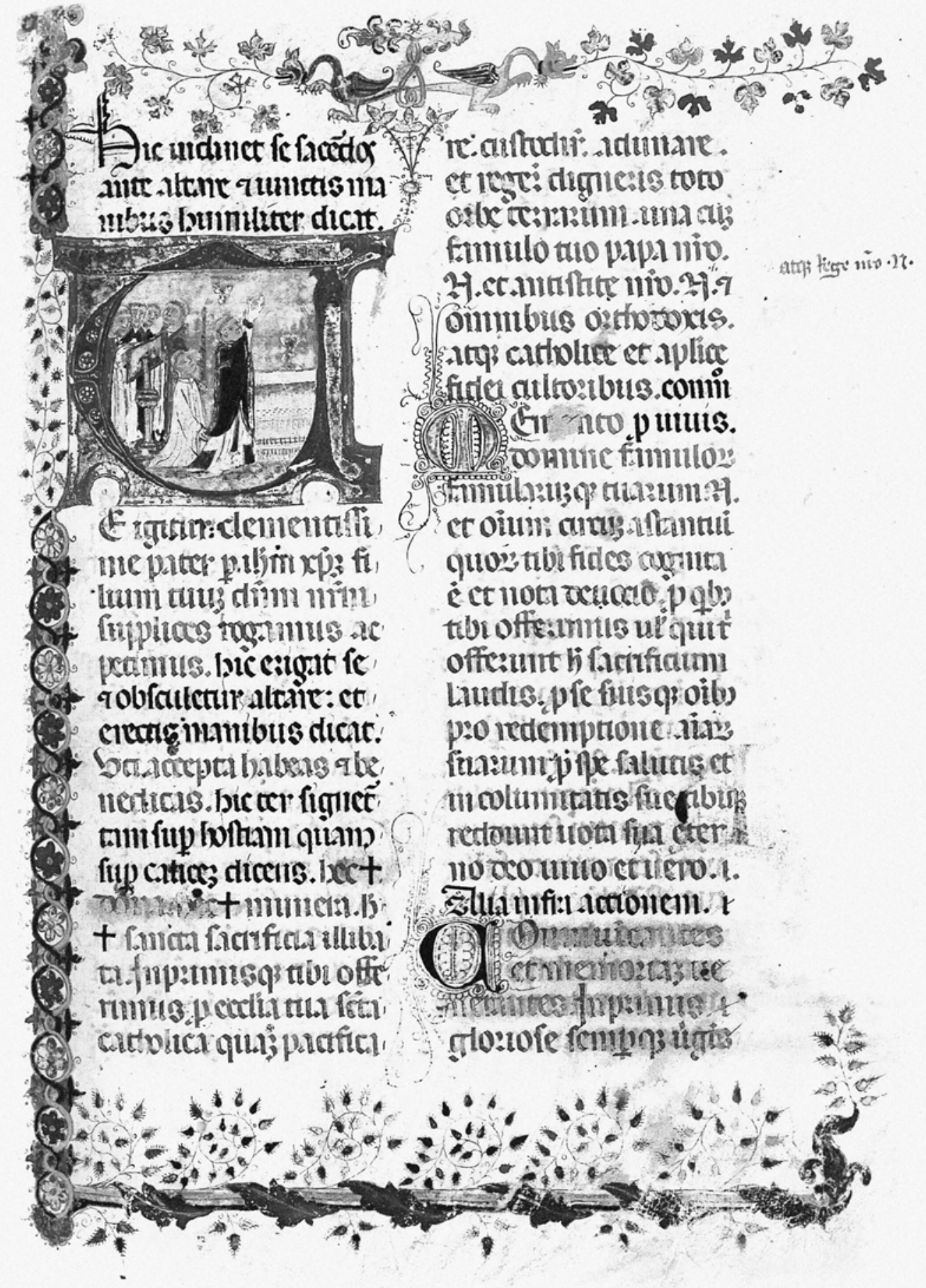

Fig. 11 Elevation of the Host. Missal of Johannes Montanus, f. 149r. Città del Vaticano, Vatican Library, Arch. Cap. S. Pietro B.65 (Foto: Biblioteca Apostolica Vaticana) 


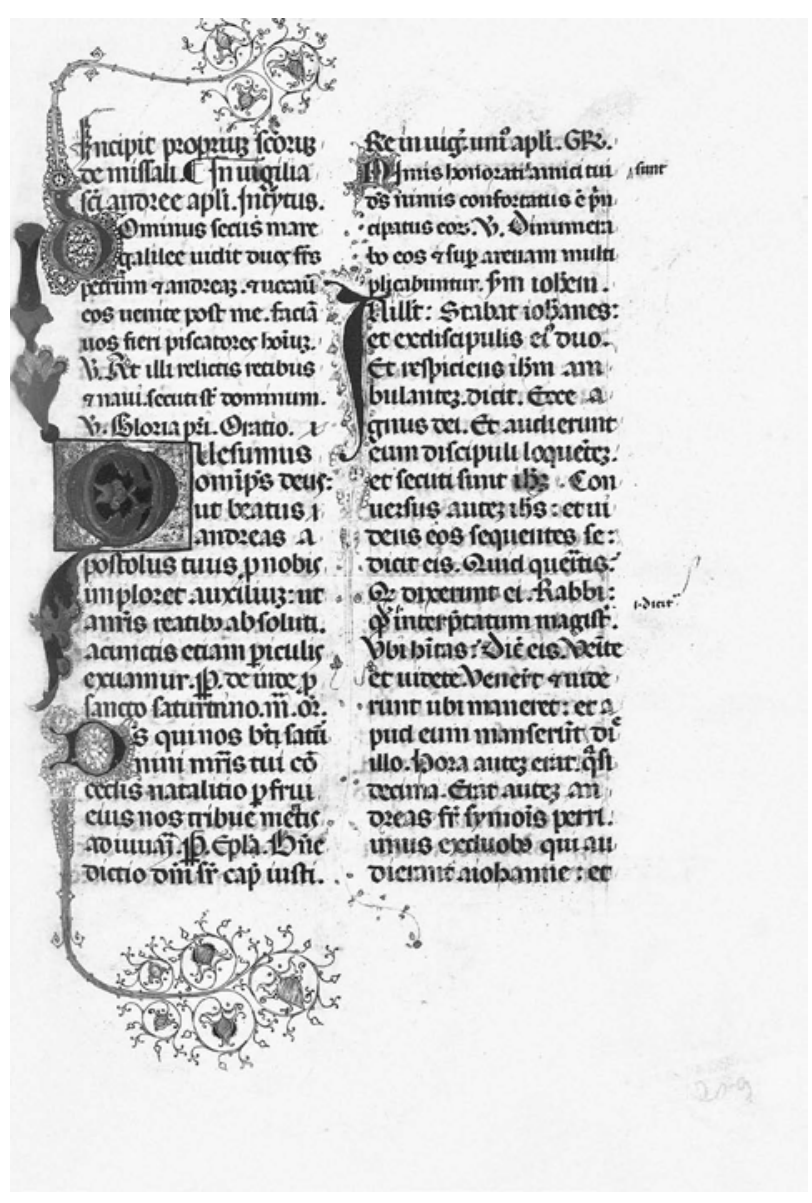

Fig. 12 Decorated and pen-work initials. Missal of Johannes Montanus, f. 209r. Città del Vaticano, Vatican Library, Arch. Cap. S. Pietro B.65 (Foto: Biblioteca Apostolica Vaticana)

because the models of his crude figures, abstract use of colour, small dragons and vegetable borders testify to a transalpine, either French or Flemish, origin. Furthermore, he was probably an older artist, endowed with an even more archaic figurative culture than the first artist, who was himself still using a late Gothic repertory, about forty years after its appearance in Rome. It is possible that the northern artist was somehow connected with the patron of the book, Johannes Montanus, who is represented under the Crucifixion, introduced to the suffering Christ by his patron Saint John the Baptist (Taf. IV). ${ }^{60}$

As with the tempera illuminations, the secondary decoration in this Missal can also be connected to two different workshops, one more archaic and less sophisticated (for example ff. 15V, 251r, 272r), the other more elegant and totally fitting with the beautiful pen-work decorative repertory introduced in Rome in the late 14th century by pen-flourishers like Stefano dell'Aquila (for example ff. 154r, 210r, and 209r, where the two styles appear side by side: fig. 12). ${ }^{61}$

The long-lasting persistence of this style of pen-work decoration, documented both in Rome, in the Abruzzi and the Marche, is shown by the above mentioned Gradual of Trasacco, dated in the 1420 s, but also by another Roman manuscript from the same decade, the Breviary made for cardinal Giordano Orsini (Vatican Library, Arch. Cap. S. Pietro B.82), whose tempera illuminations must be assigned to a different workshop, strongly influenced by an artist of Florentine origin and close to Battista di Biagio Sanguigni, active in Rome in the third decade of the $15^{\text {th }}$ century. ${ }^{62}$ This complex manuscript, bearing the arms of cardinal Giordano Orsini (1405-38), ${ }^{63}$ was dated 1423 by its pen-work flourisher Antonius de Ysimbardis de Mediolano (f. 244v). The style of his beautiful pen-work initials, comprising vegetable and animal ornaments, drawn in multicoloured inks (fig. 13), suggests that Antonio de Isimbardi must have been among the followers of Stefano dell'Aquila. ${ }^{64}$

Nonetheless his origin from Milan also connects him to another important school of pen-work decoration, exemplified by the alphabet model sheets signed by the Milanese Guiniforte da Vimercate in 1450 (Bloomington, Indiana University, Lilly Library, Ricketts 240). ${ }^{65}$ This pen-work style is closely linked with the production of choir books for the Olivetan order by itinerant Lombard monks, as shown by the activity of Venturino Mercati ${ }^{66}$ and of other pen-flourishers who produced the choir books for the monastery of Monteoliveto Maggiore (now in Chiusi, Museo del Duomo). ${ }^{67}$

The map of the dissemination of these types of artistic repertories throughout Italy still has to be charted. It seems plausible, for example, that the marvelous penwork decorated incipits in the group of Olivetan choir books from the church of Sant'Angelo Magno at Ascoli Piceno (Biblioteca Comunale, Cod. 4, 8, 10 and dismembered sheets ${ }^{68}$ may also be the fruit of the same type of relationship between Olivetans and Lombard artists, as the single surviving tempera initial from these volumes can be attributed to the Olivetan Master. ${ }^{69}$

Nonetheless the beautiful pen-work filigree letters in the Arch. Cap. S. Pietro B.82 Breviary and those in the Arch. Cap. S. Pietro B.65 Missal are both precisely linked to the tradition initiated in Rome by Stefano dell'Aquila and his colleagues, and they are much earlier in date than the above mentioned Lombard examples of Olivetan patronage. ${ }^{70}$ 
It is, in fact, not impossible that the school of Lombard pen-work, used in different areas of central Italy in the second half of the 15th century, should derive from the decorative pen-work repertory developed in the Abruzzi and in Rome in the first quarter of the century, which certainly acquired diffusion and reknown through its elaboration within the circles of the Curia. Although the abandon of Rome in the years of the Councils might have precipitated the diffusion of this type of decoration around Italy, it is also possible that a direct path towards its appearance in Lombardy should be attributed to a specific link with the Olivetan order.

A clue to this route in the spreading of the Roman pen-work to Lombardy and from there back to central Italy through the Olivetan monks might be indicated by the emblem of this Order visible in the marginal decoration of the Toledo leaf (Taf. II), which was detached from a volume made for the Papal Chapel. This can perhaps be explained by the ties between Urban VI and cardinal Marino Bulcano (1384-94), who was titular cardinal of the church of Santa Maria Nova, where the Olivetans were centred in Rome. ${ }^{71}$ Although the leaf with the Resurrection does not comprise pen-work decoration, another possible connection is provided by the Orsini Breviary itself. As Labriola has pointed out, in reconsidering Orsini's opportunities of contacts with Tuscan illuminators, cardinal Giordano may have admired Florentine illuminations around 1410 in Bologna, where he resided in the Olivetan monastery of San Michele in Bosco. ${ }^{72}$ Besides having the opportunity of admiring the illuminations by Don Simone Camaldolese in the monastery's liturgical manuscripts, his residence in the Olivetan monastery also provides a link between Giordano Orsini and this order.

It is at the moment impossible to say if the pen-work artist Antonio Isimbardi da Milano (fig. 13), certainly trained in Rome within the tradition of Stefano dell'Aquila, was a member of the Order, and if he came in contact with cardinal Orsini at Bologna, or only met his patron in Rome in the third decade of the century. A definite line leading from pen-work produced in Rome in the years of the Schism and the kind of decoration which spread throughout Italy in the second half of the century, produced by Olivetans originating from Lombardy, probably exists, but it is still difficult to define. New light on this subject will certainly be acquired through a comprehensive reconsidering of the Olivetan patronage in the field of book illumination. ${ }^{73}$

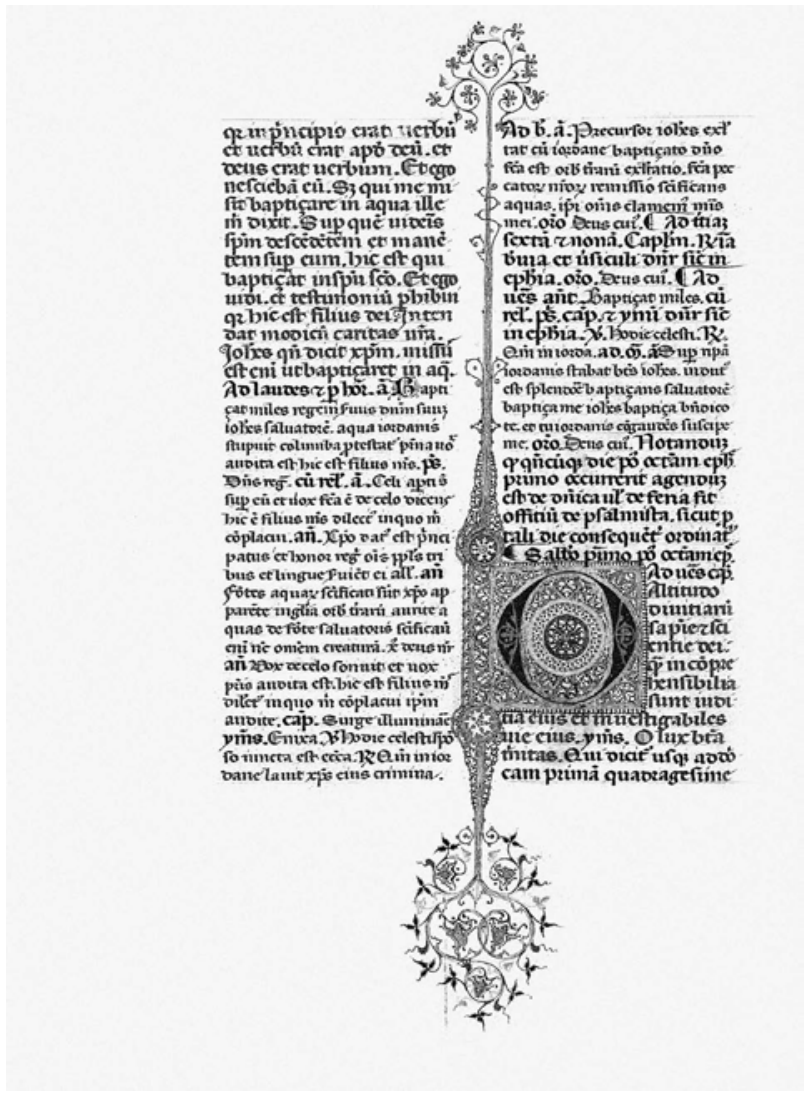

Fig. 13 Pen-work initial. Breviary of Giordano Orsini, f. 185v. Città del Vaticano, Vatican Library, Arch. Cap. S. Pietro B.82 (Foto: Biblioteca Apostolica Vaticana)

Lastly, two further manuscripts can be added to the group of illuminated books I have connected to the illuminators working in the context of the Roman popes during the Schism, dating from the beginning and from the end of this stage. One is a copy of Giovanni Cavallini's Polistoria, illuminated for the abbot of San Paolo fuori le mura, and later bishop, Giovanni Capogalli: this manuscript, once in the Chapter Library at Novara (Biblioteca Capitolare, Ms. 24, olim Ms. XLII), is reportedly lost since $1992 .{ }^{74}$ The decorated letter on the incipit reproduced Capogalli's coat-of-arms, while the border decoration comprised the portrait of a bearded monk (f. 7 or) $;^{75}$ on the facing leaf there was an illuminated personification of Rome (f. 69v), portrayed as a crowned lady, with sceptre and globe, on a throne exhibiting the Capogalli coat-of-arms and the shield with SPQR. ${ }^{76}$ This manuscript was dated within Capogalli's office as abbot of San Paolo, between 1386-94, as his bishop's hat was added on top of the initial at the incipit of the prologue. ${ }^{77}$ What can be seen from 


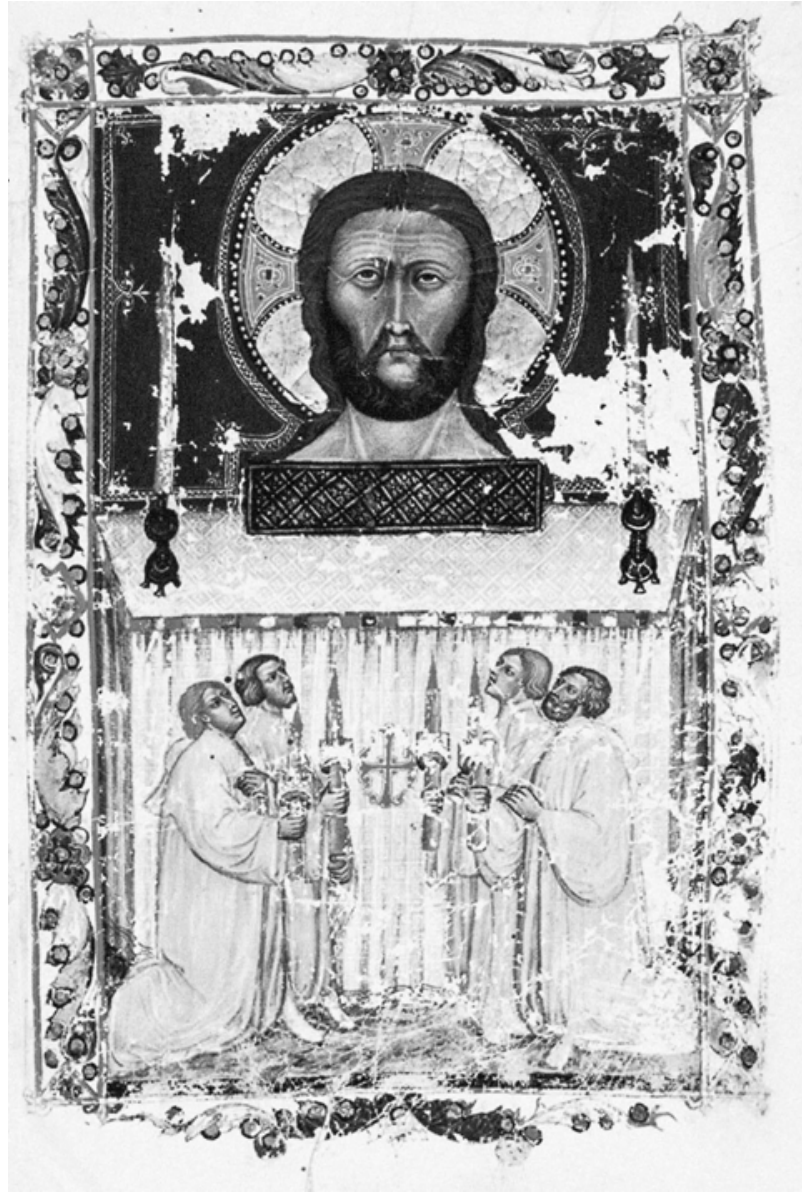

Fig. 14 Members of the Confraternity in prayer before the image of the Holy Face. Roma, Archivio di Stato, Ospedale del SS. Salvatore ad Sancta Sanctorum, vol. 1006, f. 1r (Foto: Ministero dei Beni e delle Attività culturali e del Turismo)

the reproductions of the marginal decoration is perfectly fitting with the decorative culture of the workshops active at Boniface's court, although the figure of Rome, with its monumental traits, is rather unusual in comparison to the other illuminations here examined.

A similarly monumental and volumetric rendering of draped figures, in fact, appears in a manuscript produced in Rome in the second decade of the 15 th century, which I suggest must also be reconsidered within the production of the artists connected with the style originating in Boniface's circle. In the volume produced in 1419 for the Confraternity of the Raccomandati del SS. Salvatore (Rome, Archivio di Stato, Ms. 1006), a full-page illumination, representing the Confraternity members worshipping the icon of the Saviour of the Sancta Sanctorum (fig. 14), has been assigned to the Sienese artist Taddeo di Bartolo. ${ }^{78}$
A stylistic contact between the illuminator and the Tuscan painter is not implausible, although only for the main scene, especially if accepting the idea of this artist's possible trip to Rome, suggested by the attribution to him of the fresco in the Brancacci tabernacle in Santa Maria in Trastevere, and of a panel coming from the cathedral at Orte (Museo Diocesano). ${ }^{79}$ Notwithstanding the possibly Tuscan characters of the main scene, the border decoration, illuminated around it, undoubtedly pertains to the Boniface workshops tradition, and the date of the manuscript, 1419, perfectly fits in the sequence of work continuing this style, between the Pancera Missal, illuminated ca. 1411, and the Missal for Johannes Montanus, dated $1427 .^{80}$

A clearer outline of illumination in Rome in the years between the outbreak of the Schism and the first years of Martin V's new installation in the city is slowly starting to be outlined. Further research will have to consider the possible impact of certain religious orders, whose scriptoria might have assumed an important role, in addition to the activity of lay professionists, such as in better known cases, for example in late 14th century Florentine illumination. ${ }^{81}$ Considering that when my attention was first brought to it, in 2006, through research on the Avignon Antipopes, illumination in Rome at the time of the Schism was not a topic which had ever been considered, the still partial view that we now have appears to be greatly enriched.

\section{Bibliography}

Anselmi, Salvatore Enrico/Principi, Lorenzo (eds.): Il Museo d'Arte Sacra di Orte. Orte 2013.

Avril, François: Stephanus de Aquila. In: Exhib. cat. Chieti 2012, 51-57.

Bollati, Milvia (ed.): Dizionario biografico dei miniatori italiani. Secoli IX-XVI. Milano 2004.

Brandmüller, Walter: Papst und Konzil im Großen Schisma (1378-1431). Studien und Quellen. Paderborn 1990.

CAldelli, Elisabetta: Copisti a Roma nel Quattrocento. Roma 2006.

Cappelletti, Giuseppe: Le Chiese d'Italia, X. Venezia 1854.

Ciammaruconi, Clemente/Pistilli, Pio Francesco/Quaranta, Gabriele (eds.): La Castiglia in Marittima. L'Oratorio dell'Annunziata nella Cori del Quattrocento. Pescara 2014.

Celenza, Christopher: Orsini, Giordano. In: Dizionario biografico degli italiani, LXXIX. Roma 2013, 657-662.

Cherubini, Paolo/Nicolaj, Giovanna (eds.): Sit liber gratus, 
quem servulus est operatus. Studi in onore di Alessandro Pratesi per il suo $90^{\circ}$ compleanno. Città del Vaticano 2012.

Condello, Emma/Signorini, Maddalena: Minima trisultina, II. I codici originari. In: CHERUBINI/NiCOLAJ 2012, II, 761798.

D’Achille, Anna Maria/Iacobini, Antonio/Toscano, Gennaro (eds.): Voyages et conscience patrimoniale. AubinLouis Millin (1759-1818) entre France et Italie. Roma 2011.

D’Attanasio, Marco: Aggiunte alla miniatura marchigiana. I frammenti tardoduecenteschi di antifonario della Biblioteca Comunale di Ascoli Piceno. In: Rivista di Storia della Miniatura XIX (2015), 31-45.

Delle Foglie, Anna/Manzari, Francesca: Riscoperta e riproduzione della miniatura in Francia nel Settecento. Labbé Rive e l'Essai sur l'art de vérifier lâge des miniatures des manuscrits. Roma 2016.

De MARChI, Andrea: Per la miniatura marchigiana. Un libro dore decorato da Giovanni Antonio da Pesaro. In: Toniolo/ Toscano 2012, 217-221.

Di Manzano, Francesco: Cenni biografici dei letterati ed artisti friulani. Dal secolo IV al XIX. Udine 1884-87; reprint Sala Bolognese 1974 .

Di Simone, Paolo: Scheda 36. In: Exhib. cat. Chieti 2012, 229230.

Dubois, Jacques/Guillouët, Jean-Marie/VAn den Bossche, Benoît (eds.): Les transferts artistiques dans l'Europe gothique (XIIe-XVIe siècles). Repenser la circulation des artistes, des œuvres, des thèmes et des savoir-faire. Proceedings of the Journée d'études. Liège, 16.11.2012. Paris 2014.

Elsig, Frédéric/Etienne, Noémie/Extermann, Grégoire (eds.): Il più dolce lavorar che ci sia. Mélanges en l'honneur de Mauro Natale. Cinisello Balsamo 2009.

[Exhib. cat. Ancona/Jesi 2005]: Exhibition catalogue Collectio thesauri. Dalle Marche. Tesori nascosti di un collezionismo illustre. Ed. by Mauro MeI. Ancona, Jesi, 15.1.-30.4.2005. Firenze 2005.

[Exhib. cat. Boston/Harvard 2016]: Exhibition catalogue Beyond Words. Illuminated Manuscripts from Boston Collections. Ed. by Jeffrey F. Hamburger, William P. Stoneman, Anne-Marie Eze, Lisa Fagin Davis and Nancy Netzer. Boston and Harvard, 11.2016-1.2017. Boston 2016.

[Exhib. cat. Chieti 2012]: Exhibition catalogue Illuminare l'Abruzzo. Codici miniati tra Medioevo e Rinascimento. Chieti, 10.5.-31.8.2013. Ed. by Gaetano Curzi, Francesca ManZari, Francesco Tentarelli and Alessandro Tomei. Pescara 2012.

[Exhib. cat. Città del Vaticano 1995]: Exhibition catalogue Liturgia in Figura. Codici liturgici rinascimentali della Biblioteca Apostolica Vaticana. Ed. by Giovanni Morello and Silvia MAdDALO. Città del Vaticano, 29.3.-10.11.1995. Roma 1995.
[Exhib. cat. Firenze 1982]: Exhibition catalogue Codici liturgici miniati dei Benedettini in Toscana. Ed. by Maria Grazia Ciardi Duprè dal Poggetto. Firenze 1982.

[Exhib. cat. Firenze 2003]: Exhibition catalogue Miniatura del '400 a San Marco. Dalle suggestioni avignonesi all'ambiente dell'Angelico. Ed. by Magnolia Scudieri and Giovanna Rasario. Firenze, Museo di San Marco, 1.4.-30.6.2003. Firenze 2003.

[Exhib. cat. Firenze 2006]: Exhibition catalogue Lorenzo Monaco. Dalla tradizione giottesca al Rinascimento. Ed. by Daniela Parenti and Angelo Tartuferi. Firenze, Galleria degli Uffizi, 9.5.-24.9.2006. Firenze 2006.

[Exhib. cat. Firenze 2012]: Exhibition catalogue Il Gotico Internazionale a Firenze. 1375-1440. Ed. by Antonio Natali, Enrica Neri Lusanna and Angelo Tartuferi. Firenze, Galleria degli Uffizi, 19.6.-4.11.2012. Firenze 2012.

[Exhib. cat. Madrid 2010]: Exhibition catalogue Códices de la Capilla Sixtina. Manuscritos miniados en collecciones españolas. Ed. by Elena De Laurentiss and Emilia Anna TAlamo. Madrid, 19.10.2010-9.1.2011. Madrid 2010.

[Exhib. cat. Manchester 1976]: Exhibition catalogue Medieval and early Renaissance treasures in the North West. Ed. by Jonathan J. G. Alexander and Paul Crossley. Manchester, Whitworth Art Gallery, 15.1.-28.2.1976. Wilmslow 1976.

[Exhib. cat. San Daniele nel Friuli 1988]: Exhibition catalogue La Guarneriana. I tesori di un'antica biblioteca. Ed. by Laura CASARSA. San Daniele nel Friuli, 10.6.-30.10.1988. San Daniele nel Friuli 1988.

FACHeCHI, Grazia Maria: Appunti sulla miniatura 'marchigiana'. In: Exhib. cat. Ancona/Jesi 2005, 51-58.

Frapiccini, David: Una consorteria fiorentina nella Marittima di Martino V. In: Ciammaruconi/Pistilli/Quaranta 2014, 89-99.

Gnaccolini, Laura Paola: Mercati, Venturino d'Andrea da Milano. In: Bollati 2004, 758-760.

[HAmburger in print]: Hamburger, Jeffrey et. al. (eds.): Beyond Words. The Symposium. Proceedings. Boston and Harvard, 4.-6.11.2016 (in print).

Hamesse, Jacqueline (ed.): Roma, magistra mundi. Itineraria culturae medievalis. Mélanges offerts au Père Leonard E. Boyle à l'occasion de son $75 \mathrm{e}$ anniversaire. Louvain-LaNeuve 1998 (Textes et études du Moyen Âge 10).

Hofmann, Walther von: Forschungen zur kurialen Behörden vom Schisma zur Reformation, II. Roma 1914.

Http://www.librideipatriarchi.it/notabilia-da-opere-di-fran cesco-petrarca-e-di-marco-tullio-cicerone/ (04.07.2017).

[Jамме in print]: Jамme, Armand (ed.): La Papauté et le Grand Schisme. Avignon/Rome. Langages politiques, impacts institutionnels, ripostes sociales et culturelles. Colloque International, Avignon, 13.-15.11.2008 (in print). 
LABriola, Ada: Lorenzo Monaco miniatore tra il 1410 e gli ultimi anni di attività (e alcune proposte per la miniatura fiorentina del tempo). In: Exhib. cat. Firenze 2006, 85-95.

LABRIOLA, Ada: Miniature fiorentine e committenza romana: il Breviario del cardinale Giordano Orsini. In: PArenti/TarTUFERI 2007, 128-137.

LAbriola, Ada: I libri miniati fra Tre e Quattrocento: innovazione nella continuità. In: Exhib. cat. Firenze 2012, 71-81.

Maddalo, Silvia: "R(egalis) O(rigo) M(ater) A(micorum)" di una 'perduta' immagine di Roma. In: Hamesse 1998, 549561.

Maddalo, Silvia (ed.): Il libro miniato a Roma nel Duecento. Riflessioni e proposte. 2 Bde. Roma 2016.

Maddalo, Silvia/Lori Sanfilippo, Isa (eds.): Civiltà urbana e committenze artistiche al tempo del Maestro di Offida (secoli XIV-XV). Atti del convegno di studio svoltosi in occasione della XXIII edizione del Premio internazionale Ascoli Piceno. Ascoli Piceno, 1.-3.12.2011. Roma 2013.

Manfredi, Antonio (ed.): Le origini della Biblioteca Vaticana tra Umanesimo e Rinascimento (1447-1534). Città del Vaticano 2010.

[Manzari 1995/I]: Manzari, Francesca: Da Avignone a Roma. Committenza e decorazione di alcuni codici liturgici. In: Exhib. cat. Città del Vaticano 1995, 59-65.

[Manzari 1995/II] : Manzari, Francesca: Scheda 9. In: Exhib. cat. Città del Vaticano 1995, 105-109.

Manzari, Francesca: Commande épiscopale et pontificale. Manuscrits avignonnais de la Bibliothèque Apostolique Vaticane. In: Memoires de l'Académie de Vaucluse, s. VIII, VI (1997), 29-36.

Manzari, Francesca: La miniatura ad Avignone al tempo dei Papi. 1310-1410. Modena 2006.

[MAnZari 2007/I]: MAnzari, Francesca: Libri liturgici miniati nel palazzo di Avignone. Tre serie di Messali solenni per l'uso del papa. In: Quintavalle 2007, 604-611.

[MANZARI 2007/II] : MANZARI, Francesca: Libri liturgici miniati per Bonifacio IX. Il codice Vat. lat. 3747 e la miniatura a Roma e nel Lazio all'epoca dello Scisma. In: PIAzZoni 2007 49-116.

MANZARI, Francesca: Libri liturgici miniati in Italia centromeridionale all'inizio del Quattrocento. In: Pistilli/MaNZARI/CURZI 2008, I, 109-136.

Manzari, Francesca: The International Context of Boniface IX's Court and the Marginal Drawings in the Chantilly Codex (Bibliothèque du Château, Ms. 564). In: Recercare XXII (2010), part 1-2, 11-33.

MANZARI, Francesca: La miniatura abruzzese di epoca gotica e tardogotica. In: Exhib. cat. Chieti 2012, 58-88.

Manzari, Francesca: Pittori e miniatori tardogotici tra Marche e Abruzzo. Un Messale miniato destinato ad Offida. In: MAdDALO/Lori SANFILIPPo 2013, 161-188.

[MANZARI 2014/I]: MAnZARI, Francesca: La ripresa della miniatura a Roma durante lo Scisma. Miniatori, copisti e calligrafi attivi tra fine Trecento e inizio Quattrocento. In: Mariani Canova/Perriccioli Saggese 2014, 401-423.

[MAnzari 2014/II]: Manzari, Francesca: Mobilité des artistes et migration des styles. Les cours papales d'Avignon et de Rome durant le Grand Schisme. In: Dubois/Guillouët/ VAN DEN BOSSCHE 2014, 289-302.

[MAnzari 2014/III]: MAnZARI, Francesca: Miniatori all'Aquila nell'ultimo quarto del XIV secolo. Il corredo liturgico della chiesa di Santa Maria Paganica. In: Pasqualet ti 2014, 117-130.

[Manzari 2016/I]: Manzari, Francesca: Presenze di miniatori e codici miniati nella Roma del Trecento. In: Maddalo 2016, I, 615-646; II, figs. 196-210.

[MAnZari 2016/II] : Manzari, Francesca: Entry 220. In: Exhib. cat. Boston/Harvard 2016, 274-276.

MAnZARI, Francesca: La tradizione tardogotica nella Roma di Martino V. Nuovi contributi sul Breviario di Giordano Orsini (Arch. Cap. S. Pietro B.82) e sulla miniatura romana degli anni venti del Quattrocento. In: Planas 2017, 27-43.

[MAnzari in print/I]: MAnzari, Francesca: Committenza libraria e legittimità tra Avignone e Roma. I codici liturgici prodotti per Benedetto XIII e per Bonifacio IX durante lo Scisma. In: JAMME in print.

[Manzari in print/II]: Manzari, Francesca: Scribes, Penflourishers and Illuminators in Papal Charters from the Great Western Schism to the Age of the Councils (1378-1447). In: ROLAND in print.

[MAnzari in print/III]: MAnzari, Francesca: Patronage and Artists in the Calderini Pontifical (Harvard, Houghton Library, Typ. 1). The revival of illumination in Rome during the Schism and its flowering in Florence during the Council. In: HAMBURGER in print.

Mariani Canova, Giordana/Perriccioli Saggese, Alessandra (eds.): Il codice miniato in Europa. Libri per la chiesa, per la città, per la corte. Padova 2014.

Miarelli Mariani, Ilaria: Séroux d'Agincourt e l'histoire de l'art par les monuments. Riscoperta del Medioevo, dibattito storiografico e riproduzione artistica tra fine XVIII e inizio XIX secolo. Roma 2005.

KNALL-BRsкovsky, Ulrike (Hg.): Die mittelalterlichen Grabmäler in Rom und Latium vom 13. bis zum 15. Jahrhundert, Bd. 2. Die Monumentalgräber. Wien 1994.

Moretti, Simona: Séroux d'Agincourt e il patrimonio librario. In: D'Achille/Iacobini/Toscano 2011, 261-272.

[Niccolò V nel sesto centenario 2000]: Niccolò V nel sesto cen- 
tenario della nascita. Atti del convegno internazionale, Sarzana, 8-10 ottobre 1998. Città del Vaticano 2000.

Parenti, Daniela/Tartuferi, Angelo (eds.) : Nuovi studi sulla pittura tardogotica. Intorno a Lorenzo Monaco. Livorno 2007.

PAsqualetti, Cristiana: Il Libellus ad faciendum colores dell'Archivio di Stato dell'Aquila. Origine, contesto e restituzione del 'De arte illuminandi'. Studio introduttivo, facsimile, testo e traduzione a fronte. Firenze 2011.

Pasqualetti, Cristiana (ed.): La via degli Abruzzi e le arti nel Medioevo. Proceedings of the conference L'Aquila/Castelvecchio Subequo, 11.-12.5.2012. L'Aquila 2014.

PAsut, Francesca: Per la miniatura a Roma alla metà del Quattrocento. Il "miniatore di Niccolò V". In: Niccolò V nel sesto centenario 2000, 103-130.

PAsut, Francesca: Libri miniatori e artisti alle origini della Vaticana. In: MANFredi 2010, 413-465.

Piazzoni, Ambrogio Maria (ed.): Il Pontificale di Bonifacio IX. Commentary to the facsimile. Modena/Città del Vaticano 2007.

Pistilli, Pio Francesco/Manzari, Francesca/Curzi, Gaetano: Universitates e Baronie. Arte e architettura in Abruzzo e nel Regno al tempo dei Durazzo. Proceedings of the Conference Guardiagrele/Chieti, 9.-11.11.2006. 3 voll. Pescara 2008.

Planas, Josefina: Un manuscrito desconocido perteneciente a la Biblioteca Pontificia de Pedro Martínez de Luna (Benedicto XIII). In: Boletín Museo e Instituto Camón Aznar 108 (2011), 285-329.

Planas, Josefina: Benedicto XIII y el “Scriptorium” Papal instalado en Peñiscola: nuevas reflexiones. In: MARIAnI CANova/Perriccioli SAggese 2014, 375-400.

Planas, Josefina (ed.): Manuscrits il-luminats. La Tardor de l'Edat Mitjana i les noves llums del Renaixement. III cicle internacional de conferències de Història de l'Art [Illuminierte Handschriften. Der Herbst des Mittelalters und das neue Licht der Renaissance. III. Internationaler Zyklus von Konferenzen der Kunstgeschichte]. Lleida, Universität, 17.-18.11.2014. Lleida 2017.

[Planas in print]: Planas, Josefina: Le scriptorium de Benoît XIII et le schisme de l'Église. Manuscrits enluminés à Peñiscola. In: RAINER in print.

Putaturo Donati Murano, Antonella: La miniatura a Roma. In: Putaturo Donati Murano/Perriccioli Saggese 2009, 423-425.

Putaturo Donati Murano, Antonella/Perriccioli SagGESE, Alessandra (eds.): La miniatura in Italia, vol. II. Dal tardogotico al manierismo, vol. II. Napoli/Città del Vaticano 2009.

Quintavalle, Arturo Carlo (ed.): Medioevo. La Chiesa e il
Palazzo. Atti dell'VIII Convegno internazionale di studi. Parma, 20.-24.9.2005. Milano 2007.

[RAIner in print]: RaIner, Berndt (Hg.): Der Papst und das Buch im Spätmittelalter (1350-1500). Bildungsvoraussetzung, Handschriftenherstellung, Bibliotheksgebrauch. Sammelband der Tagung Mainz, 4.9.2014- 6.9.2014 (in print).

[RolAnd in print]: Roland, Martin et al. (Hgg.): Illuminierte Urkunden. Von den Rändern zweier Disziplinen ins Herz der Digital Humanities./Illuminated Charters. From the Margins of two Disciplines to the Core of Digital Humanities. International Conference Vienna, Wien, Haus-, Hof- und Staatsarchiv, 12.-14.9.2016 (in print).

Romano, Serena: Taddeo di Bartolo a Roma? In: Elsig/ Etienne/EXTERMANn 2009, 15-19.

[SCAlON 2014/I]: SCAlon, Cesare (ed.): I Libri dei Patriarchi. Un percorso nella cultura scritta del Friuli medievale. Pasian di Prato 2014.

[SCAlON 2014/II]: SCAlon, Cesare: Pancera, Antonio. In: Dizionario biografico degli Italiani, Bd. LXXX. Roma 2014, 679-681.

Scheller, Robert: Exemplum. Model-Book Drawings and the Practice of Artistic Transmission in the Middle Ages (ca. 900-ca. 1470). Amsterdam 1995.

Toniolo, Federica/Toscano, Gennaro (eds.): Miniatura lo sguardo e la parola. Studi in onore di Giordana Mariani Canova. Cinisello Balsamo 2012.

Tosini, Patrizia: Miniature dall'Ospedale del SS. Salvatore ad Sancta Sanctorum. Decorazione, rituali, iconografia. In: Rivista di Storia della miniatura 12 (2008), 123-136.

Zanichelli, Giuseppa: Guiniforte da Vimercate. In: Bollati 2004, 338-342.

\section{Notes}

1 Manzari in print/I.

2 I would like to thank the organizers for inviting me to take part in this session dedicated to Avignon during the Schism and for allowing me to extend the subject of my paper to Rome, as my research over the past years has shown how important it is to consider the illuminated book production in the two cities, during the decades of the Schism, in a comprehensive view. Many thanks also to Sharon Dale, for patiently reading through my English text.

3 My research on the illuminated books made for the Avignon antipopes dates back to the discovery of the multi-volume Missals for Clement VII and Benedict XIII: MAnzari 1995/I. - MANZARI 2007/I. - My discoveries on this phase of illumination in Avignon are systematically examined in: MANZARI 2006, 205-211, 294-325. - It was while investigating the patronage of Benedict XIII that I first started to speculate about the Roman pope's book production and to work on the only known manuscript at the time, the so-called Pontifical of Boniface IX (Vatican Library, Vat. lat. 3747). My research 
on illumination in Rome during the Schism stems from a first article on this book: MANZARI 2007/II. - I published my first results on the manuscripts which can be assigned to Boniface IX's patronage in: MANZARI 2008, 123-133; then enlarged the group with new additions: MANZARI 2010. - The artists working in Rome appear to have come from all over Europe, including the less known areas in central Italy, like the Abruzzi, therefore my research on Roman gothic illumination interwove with my parallel research on this area. I have summed up my investigations on illumination in the Abruzzi in a recent exhibition: MANZARI 2012, 73-79. - My research on the scribe and pen-flourisher Stefano dell'Aquila is greatly indebted to François Avril, who not only let me use an unpublished text dating from 1990, but also lent me the entire folder dedicated to this extraordinary artist. I am very happy that he agreed to publish his text in the same exhibition catalogue: AvriL 2012. - I published a general reconsideration of Roman illumination during the Schism in the proceedings of a conference held in Padua in 2010: MANZARI 2014/I. - For new findings on Stefano dell'Aquila and on his activity as a scribe in the Roman chancery: MANZARI in print/II.

4 ManZari 2014/I, 419-421.

5 It must be underlined that the illuminated borders in the multi-volume Missal for Benedict XIII, representing the coat-of-arms of pope Paul II, have been added in Rome between 1464 and 1471: MANZARI 1995/I, 59.

6 MANZARI in print/I.

7 For illumination produced in later decades, for pope Nicholas V, see Pasut 2000 and 2010.

8 For bibliography on early Renaissance illumination in Rome, see Putaturo Donati Murano 2009; for a broad overview of the Renaissance manuscript production from a paleographical outlook CALDelli 2006.

9 As already pointed out in MANZARI 2014/I, 401.

10 ManZari 2007/I, 604-611.

11 ManZari $2007 /$ I, 607.

12 MANZARI 2007/I, 604.

13 Manzari 2006, 294-299. - On the patronage of Benedict XIII, after he abandoned Avignon and moved to Peñiscola, see Planas 2011; Planas 2014. - Josefina Planas has further considered the patronage of Benedict XIII in a paper presented in Mainz, in September 2014, at a conference on Papal book patronage in the late Middle Ages: Planas in print.

14 Exhib. cat. Madrid 2010, 113-118. - ManZari 2014/II, 291. - On initials added in this volume in the area of Valencia: PLANAS 2014, 390-392.

15 The recto and verso are reproduced on the Museum website: http:// www.metmuseum.org/collections/search-the-collections/170 006622?img=o (28.10.2014); http://www.metmuseum.org/collectio ns/search-the-collections/170006622?img=1 (28.10.2014). - Peter Kidd has recently discovered that this cutting was owned by Capt. Edward G. Spencer-Churchill in the 1920 and exhibited in The Burlington Fine Arts Club Exhibition, in the winter of 1926/27: https:// mssprovenance.blogspot.it/2016/09/the-burlington-fine-arts-club. html (5.7.2017).

16 ManZari 2014/I, 403. - ManZari 2014/II, 291.

17 Christie's, 18 June 2103, lot 4. - Now at Les Enluminures, Paris: http://www.lesenluminures.com/inventory/expo-2248o/christ-before-the-apostles-in-a-historiated-initial-a-22505 (28.10.2014). I would like to thank Monsieur Avril for pointing out the leaf to me and Sandra Hindman for generously sharing images and information on it.

18 MANZARI 2014/II, 291.

19 Attributed by François Avril: MANZari 2014/II, $291 \mathrm{f}$.

20 Not only do the artists, but the scribe and the lay-out of the pages perfectly correspond to the Montecassino Missal. The other side of the leaf, comprising a decorated initial, is numbered 135, and one of the quires missing from the Montecassino manuscript is pp. $130-138$, which was followed precisely by the Sunday in albis, still in place. The quire was certainly detached before the volume was restored in 1954, perhaps during the Second World War, according to the late Don Faustino Avigliana, whom I would like to remember with gratitude for his help: MANZARI 2014/II, 300, n. 30 .

21 For the multi-cultural context of Benedict's Avignon court: MANZARI 2006, 294-325. - MANZARI 2014/II, 289-294.

22 MANZari 2010.

23 Once referred to as a Pontifical, but in fact only containing the rites of the clothing of the pope before the Mass: MANZARI 2007/II, 49.

24 The Praeparatio ad missam had been noticed in the late 18 th century by Jean-Baptiste Séroux d'Agincourt, who reproduced the last illumination, with pope Boniface blessing from the Loggia delle Benedizioni, on Plate LXXV of the 5 th volume of his Histoire de lart par les monumens, published in Paris (1810-23): see Delle Foglie/ MAnZARI 2016, p. 101, fig. V.3. - For further considerations on Séroux d'Agincourt and on his interest towards illumination MorETti 2011. - On Séroux in general Miarelli Mariani 2005.

25 ManZari 2008, $132 \mathrm{f}$ - - ManZari 2014/I, $403 \mathrm{f}$.

26 MANZARI 2010.

27 MANZARI 2014/I, 412.

28 In the shield on the left a gold star in blue ground is clearly visible, while the lower portion of the shield on the right is badly damaged and illegible. I have suggested elsewhere that Boniface IX was the earliest pope for whom the practice of allowing followers to use the papal coat-of-arms is documented. His arms were also incorporated in the coat-of-arms represented on the late 14th century reliquiary of St John the Baptist, at San Silvestro in Capite in Rome, made under the patronage of the bishop of Florence, Angelo Acciaiuoli. MANZARI 2014/I, 405.

29 MANZARI 2014/I, 405, 412.

30 A large part of his books, after passing into the library of Guarnerio d'Artegna, are now the Biblioteca Guarneriana at Cividale del Friuli. Exhib. cat. San Daniele nel Friuli 1988. - These have recently been investigated in SCALON 2014/I, 393-409. - Also see the website 'I libri dei Patriarchi': http://www.librideipatriarchi.it/notabilia-da-operedi-francesco-petrarca-e-di-marco-tullio-cicerone/ (04.07.2017).

31 ManZari 2007/II, 79-84. - ManZari 2008, 129-131. - ManZari 2014/I, 404 f., 412 f. - MANZARI 2014/II, $296 \mathrm{f}$.

32 KNALL-BrSKovsKy 1994, 156 f., n. 49.

33 For a resumé of the incorrect tradition, which I too have followed in my earlier publications: MANZARI 2014/I, 404f. - MANZARI 2014/II, 296f. - It was Emma Condello who noticed that the coatof-arms of cardinal Pedro Serra, also bishop of Catania, was in fact different from this one, and that the connection between these arms and Serra, a follower of Benedict XIII, was a mistake by the erudite Alfonse Ciaconius (Alfonso Chacón, 1540-90), taken up by all the modern bibliography, including myself: CONDELLo/SIGNORINI 
2012, $772 \mathrm{f}$. - The identification of the arms as those of Pancera has erased the difficulties posed by the idea that an atelier associated with the Roman pope could have been working for a Barcellonese prelate, created cardinal by the Aragonese antipope.

34 On this under-studied prelate, also cited by Sharon Dale (Baldassare Coscia and papal diplomacy around the Council of Pisa, unpublished paper read at the Meeting of the Renaissance Association of America, Venice 2010): Di Manzano 1884-87/1974, 147. - Brandmüller 1990, 191. - Now see SCalon 2014/I, 395-397, 399 f., 404. - SCALON 2014/II, 379-381.

35 Manzari 2014/I, 404, 412. - ManZari 2014/II, 297. - The manuscript, comprising Notabilia from the work of Petrarch and Cicero, also contains a poem dedicated to Pancera. It has been reproduced and described in Exhib. cat. San Daniele nel Friuli 1988, 94, and more recently, in SCALON 2014/I, $408 \mathrm{f}$., but it had never been connected to the Missals in the Vatican Library and at the Blackburn Museum, until Manzari 2014/I. Also from Pancera's library: San Daniele del Friuli, Biblioteca Guarneriana, Ms. 75 (Seneca, Tragoediae), with illuminated borders and cut out initials, and Ms. 220, with Pancera's coat-of-arms and illuminated borders and initials (SCAlon 2014/I, 396f., 406f.). For both now see the above mentioned website 'I libri dei patriarchi'. All of the illuminations in these volumes, which stayed in Friuli as they were inherited by Guarnerio d'Artegna, seem to have been illuminated in this area and are linked to the Roman material exclusively through the heraldry.

36 SCALON 2014/I, 404.

37 Manzari 2008, 136, note 157.

38 Exhib. cat. Manchester 1976, 34 .

39 ManZari 2014/I, 412.

40 For the history of the transmission of his books to Guarnerio, see SCALON 2014/I, 404.

41 Manzari 2014/I, 404.

42 Manzari 2014/I, 402.

43 Caldelli 2006, 157.

44 ManZari 2014/I, $420 \mathrm{f}$.

45 This fragment was added to a 17th century Missal coming from the Sistine Chapel now in Toledo, Ms. 39.1. The illumination was first published by Elena De Laurentiis who attributed it to a Sienese artist known as Maestro del Codice Rossiano: Exhib. cat. Madrid 2010, 205.

46 Manzari 2014/I, 420.

47 François Avril read the paper concerning this artist in 1990, but it was only recently published: AvRIL 2012, 51, 54. - I first made reference to this unpublished work, thanks to Monsieur Avril's kindness, in MANZARI $2007 / \mathrm{II}, 50,75,77,86,89$, and I have repeatedly referred it in all my subsequent work.

48 Cappelletti 1854, 279. - Manzari 2014/I, 420.

49 Manzari 2014/I, 421. - Manzari 2016/II, 274-276. - ManZari in print/III.

50 Manzari 2010.

51 ManZari 2012.

52 MANZari 2012, 73-78. - ManZari 2014/III, 128-130.

53 ManZari 2012, 73-78. - MANZARI 2014/I, 419. - MANZARI 2014/ II, 296.

54 MAnZari 2016/I.

55 Di Simone 2012, $229 \mathrm{f}$.

56 MANZARI 2013.
57 Manzari 2016/I, 617-644.

58 The manuscript is described by Elisabetta Caldelli. CALDELLI 2006, 157.

59 Hofmann 1914, 78.

60 The miniature also contains his coat-of-arms, upheld by two angels, and a second saint, a deacon, holding a book, at the opposite end. For further information on Johannes Montanus, now see: MANZARI in print/II.

61 According to the present state of research, this style seems to stem from the Missal of Paganica, made for L'Aquila in the mid 1370s, and from there it was adopted in the Marche and in Rome: MANzarI 2012, 74-77. - MANZARI in print/III.

62 The attribution to an artist close to Battista di Biagio Sanguigni, which I had suggested in 1995 , has been confirmed by a further study of the Breviary's tempera illuminations by Ada Labriola: MANZARI 1995/II. - LABRIOLA 2007. - The presence of Florentine followers of Lorenzo Monaco and Battista di Biagio Sangugni in an area close to Rome has been noted by David Frapiccini, in the frescoes dated 1426 in the oratory of the Annunziata at Cori. Frapiccini 2014. - On Giordano's Breviary, now see: MANZARI 2017.

63 Celenza 2013.

64 As noted by François Avril already in 1990: Avril 2012, 56 f., n. 15.

65 Scheller 1995, 85 f. - Zanichelli 2004.

66 Gnaccolini 2004.

67 For Olivetan manuscripts: Exhib. cat. Firenze 1982, 253-547.

68 These previously unknown manuscripts were discovered in the Library at Ascoli Piceno by Marco D'Attanasio, while investigating the 13 th century Antiphonary first published by Grazia Maria Fachechi. FACHECHI 2005, 55. - This research has recently been published (D’Attanasio 2015) and I would like to thank the author for showing me all the manuscripts and allowing me to read his unpublished text and cite the 15th century materials. I am certain that a systematic study of these manuscripts, in the broader context of Olivetan patronage, which Marco D'Attanasio is preparing, will lead to further important discoveries.

69 For earlier attributions to Lombard School FaCHECHI 2005, 55. - DE MARCHI 2012, 221, note 8.

70 Furthermore, as I have already pointed out, the Gradual of Trasacco and the Missal for Offida show how the Roman style was already being used in other areas of central Italy in the first quarter of the 15 th century.

71 ManZari 2014/I, 421.

72 LABRIOLA 2007, 131.

73 I look forward to further studies of the hitherto unknown liturgical series in Ascoli, by Marco D'Attanasio, author of the above-mentioned article on the 13th century series at Ascoli (D'AttanAsio 2015), for the new light that might be shed on this question.

74 Maddalo 1998, 550.

75 Maddalo 1998, ill. 1.

76 Maddalo 1998, ill. 3.

77 Maddalo 1998, ill. 2.

78 Tosini 2008, 123-126.

79 Tosini 2008, 134, note 9. - For Taddeo di Bartolo's work in Rome and Orte Romano 2009. - Anselmi/Principi 2013, 20-22.

80 I will consider this manuscript, and the more elaborate style of the figures in the illumination, in a further contribution, still in preparation. 
81 For a general and up-to-date overview of late 14th century illumination in Florence Exhib. cat. Firenze 2003. - Labriola 2006. LABRIOLA 2012. 


\section{Zentralisierung UND Diversifizierung}

Englische Kunst im Schatten des Hundertjährigen Krieges Ca. 1350-1450 

Ute ENGel Und Jens RÜFfeR

\title{
Zentralisierung und Diversifizierung
}

\author{
Englische Kunst im Schatten \\ des Hundertjährigen Krieges Ca. 1350-1450
}

Die Periode des Hundertjährigen Krieges zwischen England und Frankreich (1337-1453) gilt als prägend für die Nationalstaatsbildung in beiden Ländern. Dieser Prozess, so wird weithin in der kunsthistorischen Literatur angenommen, habe auch in der Kunstproduktion seinen Niederschlag gefunden, wofür meist auf die Ausbildung des Perpendicular Style als charakteristisch englischem Stil der Spätgotik verwiesen wird, der die Architektur und weite Gestaltungsbereiche dominiert habe.

Tatsächlich ist die englische Kunstgeschichte in diesem langen Zeitraum sehr komplex und heterogen. Besonders die Zeit um 1400 stellt eine entscheidende Umbruchphase dar. Mit der 1399 erfolgten Absetzung Richards II. (reg. 1377-99, † 1400), des letzten Königs aus dem Haus Plantagenet, und der Machtübernahme durch Heinrich IV. (reg. 1399-1413) aus dem konkurrierenden Haus Lancaster wechselte nicht nur die Dynastie, sondern auch die Ausrichtung des Königtums. Richard II. hatte gerade mit den Mitteln der Kunst die mediale Inszenierung und Sakralisierung des Königtums entschieden vorangetrieben, u. a. durch die Stiftungen des berühmten Wilton-Diptychons, seines Staatsporträts im königlichen Ornat, seines Doppelgrabmals mit Königin Anna von Böhmen sowie durch den Neubau der großen Halle im königlichen Palast von Westminster. Die Lancaster erfanden neue Strategien, um ihre Legitimation zu untermauern. Sie erweiterten die Formen der Repräsentation durch die Inszenierung politischen Handelns. Durch die Siege Heinrichs V. (reg. 1413-22) im Hundertjährigen Krieg und seine Hochzeit mit der französischen Königstochter Katherina von Valois ( $†$ 1437) im Jahr 1420 stand dabei kurzfristig die Allianz mit Frankreich im Mittelpunkt. Doch schon bald hatte England seine sämtlichen Festlandsbesitzungen und damit den Krieg endgültig verloren. Das Land versank in den Rosenkriegen (1455-85) zwischen den Häusern Lancaster und York.

Die Sektion »Zentralisierung und Diversifizierung. Englische Kunst im Schatten des Hundertjährigen Krieges ca. 1350-1450« fragt danach, wie Kunst und Archi- tektur auf diese Umbrüche, insbesondere in der Zeit um 1400 , reagierten. Allgemein lässt sich feststellen, dass sich einerseits eine Zentralisierung der Kunstproduktion in der Hauptstadt London vollzog, wo sich die großen königlichen Aufträge und damit auch die bedeutendsten Werkstätten konzentrierten. Andererseits fand eine offensichtliche Diversifizierung statt, sowohl regional als auch in der sozialen Schichtung der Auftraggeber. Adelsfamilien, die im Krieg mächtig und reich geworden waren, oder Kleriker, die über eine Verwaltungslaufbahn aufstiegen, wie William von Wykeham, traten zunehmend als Stifter von Grabkapellen (Chantry chapels) und Grabmälern auf. Andere wie Richard Beauchamp gaben Luxushandschriften in Auftrag. Wykeham förderte zudem auch die Wissenschaften und ließ Colleges errichten, eine Bauaufgabe, die in jener Zeit zu innovativen Lösungen führte. Das Bedürfnis nach alternativen Formen der Repräsentation führte u. a. auch zum Wechsel von der befestigten Burg zum repräsentativen Palast. Damit bekam die Sakralarchitektur, die sich in den Kathedralen und großen Abteikirchen manifestierte und bis dahin aus künstlerischer Sicht führend war, nicht nur eine ebenbürtige Konkurrenz im Profanbau, sondern sie verlor auch ihre ästhetische Vorreiterrolle. Über das ganze Land verteilt wuchsen die Städte, insbesondere in den großen Gebieten der Woll- und Tuchproduktion im Osten und Südwesten Englands, und die Bürgerschaften wetteiferten im Bau imposanter Pfarrkirchen und kommunaler Gebäude. Für deren prächtige Ausstattung verwendeten sie häufig das neue, kostengünstige Material Alabaster, das bei Nottingham gebrochen, aber oft in Londoner Werkstätten bearbeitet wurde. Die Kunstproduktion wurde insgesamt, dies ist allgemein festzuhalten, diverser, regionaler, auch lokaler und in ihrem Aufgabenspektrum vielfältiger.

Neben den Umbrüchen in England, einschließlich der zeitgenössischen künstlerischen Produktion, sind vor allem Fragen des Kultur- und Kunsttransfers für eine interdisziplinär ausgerichtete kunsthistorische Forschung von eminenter Bedeutung. Dieser Transfer konnte eher 
zufällig erfolgen, wie der Import des geschulterten Zwiebelbogens am Schnegg des Konstanzer Münsters zeigt. Er lässt sich aber auch in genreübergreifenden Inszenierungsstrategien nachweisen, wie sie der englische König Heinrich V. verfolgte. Von besonderem Interesse sind vor allem die Wechselwirkungen, die sich zwischen den kontinentalen Entwicklungen in der Kunst und jenen auf den britischen Inseln ergaben.

Für derartige Transferleistungen sind zwei Aspekte grundlegend: Mobilität und dynastische Verflechtungen. Es gab eine hohe Mobilität auf unterschiedlichen Ebenen und eine große Bandbreite von Austauschbeziehungen zwischen England und Nordfrankreich, Flandern, aber auch dem Reich nördlich der Alpen. Neben den traditionellen Besitzungen englischer Adliger auf dem Kontinent, ihren die politischen Grenzen übergreifenden dynastischen Verflechtungen und dem die Epoche dominierenden Hundertjährigen Krieg dürfte außerdem für den hier zu betrachtenden Zeitraum das Konstanzer Konzil (1414-18) eine besondere Rolle gespielt haben. Dieses Ereignis von europäischem Rang ermöglichte potenten Auftraggebern, die aus verschiedenen Gründen am Konzil teilnahmen, eine nachhaltige visuelle Erfahrung hinsichtlich aktueller Gestaltungsparadigmen in unterschiedlichen Genres. In verschiedener Weise fanden diese Erfahrungen auch in der Kunstproduktion ihren Niederschlag. Da die Austauschbeziehungen oft widersprüchlich und selten eindeutig im Sinne einer Ursache-Wirkungs-Beziehung zu beschreiben sind, ist es wichtig, die Aspekte des Kunst- und Kulturtransfers an konkreten Beispielen zu erarbeiten, um zeigen zu können, welche Faktoren unter den gegebenen Umständen wirksam gewesen sind. Mit Blick auf die englischen Beziehungen zum Kontinent wird eine große Vielfalt von Gestaltungsparadigmen deutlich, die konservativ, konventionell, innovativ, vielleicht sogar retrospektiv angelegt sein können und die die für das englische Spätmittelalter so oft postulierte Englishness of English Art in Frage stellen.

Der Beitrag von Veronika Decker zeigt an der Person Williams von Wykeham (ca. 1324-1404), wie Bauideen transferiert und adaptiert werden konnten. Wykeham stammte aus bescheidenen Verhältnissen, er erhielt seine erste Ausbildung in Winchester und trat anschließend in königliche Dienste. Vom König als Ministeriale gefördert, stieg er bis zum Lordkanzler auf. Im Jahr 1367 wurde er zum Bischof von Winchester geweiht, ein Amt, das er mehr als drei Jahrzehnte ausübte. Wykeham avancierte zu einem der größten Patrone der Künste und der
Wissenschaft in seiner Zeit. Er verwaltete nicht nur im königlichen Auftrag prestigeträchtige Bauprojekte wie Windsor Castle, sondern verfolgte zugleich auch eigene Projekte wie den Neubau des Langhauses von Winchester Cathedral oder die Errichtung von Winchester College bzw. New College in Oxford. Durch seine unterschiedlichen Positionen und Aufgaben kannte er die bedeutendsten englischen Baumeister jener Zeit (u. a. William Wyneford, Henry Yevele). Er war außerdem in den weltlichen wie in den kirchlichen Hierarchien hervorragend vernetzt und über architektonische und künstlerische Entwicklungen bestens informiert. Im Mittelpunkt von Deckers Darstellung steht die Analyse des Transfers von Gestaltungselementen sowie Raumkonzepten, die eigentlich aus dem Schlossbau stammen und die für die relativ neue Gestaltungsaufgabe akademischer Colleges adaptiert wurden.

Julia Crispin widmet ihren Beitrag Richard Beauchamp (1382-1439) und dessen Leidenschaft für Manuskripte. Der Earl von Warwick war der letzte männliche Spross eines prominenten Geschlechts. Die Handschriften von beiden Seiten des Ärmelkanals, die von Beauchamp in Auftrag gegeben, gesammelt oder gelesen wurden, enthalten Texte in den Landessprachen. Richard war in seinen besten Zeiten nicht nur ein guter Kämpfer, ein Militärstratege, Diplomat, Berater und Pilger, sondern auch ein Exponent einer galanten und zugleich gebildeten höfischen Kultur. Zudem wusste er, seinen Reichtum in Architektur und Kunst zu investieren. Mit Blick auf die Handschriften, die auch komplexe Bild-Text-Beziehungen enthalten, interessiert sich Crispin vor allem für Fragen, die auf die Nutzung der Manuskripte mit Blick auf deren unterschiedliche Zwecksetzungen und Rezipienten zielen. Ein besonderes Augenmerk liegt auf den Nutzungskontexten, die internationale oder nationale $\mathrm{Be}$ züge aufweisen und sich auf konkrete politische Anlässe oder kulturelle Gegebenheiten beziehen lassen. Darüber hinaus wird nicht nur der Beitrag thematisiert, den Beauchamp für die zeitgenössische kulturelle Entwicklung in England und Frankreich leistete, sondern auch sein Anteil an der Übertragung politischer Ideen herausgearbeitet. Oder anders formuliert: Welche literarischen, liturgischen und künstlerischen Traditionen vermittelten die von Beauchamp in Auftrag gegebenen Werke und welche Entwicklungen haben sie möglicherweise stimuliert? Inwieweit sind mit diesen Werken politische Botschaften und Konzepte über die Grenzen der einzelnen Reiche hinweg transportiert worden? Mit Blick auf die Buchma- 
lerei wird letztlich nach Visualisierungsstrategien gefragt, die es vermochten, politische Vorstellungen im Medium der Kunst zu transportieren.

Der dritte Beitrag von Stefan King und Ines Stadie stellt eine Fallstudie dar, in der am Beispiel des Motivs des geschulterten Kiel- oder Zwiebelbogens am Schnegg des Konstanzer Münsters der Frage nach dem Formentransfer nachgegangen wird. Der Schnegg, ein offen gestaltetes Treppentürmchen im Nordquerhaus des Münsters, wurde zwischen 1438 und 1446 von maister antoni errichtet. Die zur Diskussion stehende Bogenform ist in jener Zeit in der Region völlig unbekannt, in England allerdings ein allgemein verbreitetes Bogenmotiv. Der Formentransfer könnte über eine Grabplatte erfolgt sein, die zum Grabmal des 1417 während des Konstanzer Konzils verstorbenen Bischofs von Salisbury, Robert Hallum, gehört. Der Bischof wurde standesgemäß im Konstanzer Münster beigesetzt. Die Grabplatte, die den Bischof unter einer Kleinarchitektur zeigt, wurde wahrscheinlich in England angefertigt und dann nach Konstanz geliefert. Dafür sprechen das Material (Purbeck marble) und die metallenen Einlegearbeiten (brasses). Auf der Grabplatte ist jener geschulterte Kielbogen zu finden, der dann modifiziert am Schnegg wieder erscheint. Dieser Formentransfer, wenn er sich wirklich so ereignet haben sollte, ist eher dem Zufall als einer bewussten Inszenierung geschuldet. Das Motiv überzeugte den Schöpfer des Schneggs offenbar rein visuell, ohne jede ikonografische oder symbolische Bedeutung, und von hier aus fand das Motiv später weitere Verbreitung in der Region.

Im letzten Beitrag innerhalb des Sektionsschwerpunkts beschreibt Antje Fehrmann, wie der englische König Heinrich V. sich selbst, die Krone und England sowohl innerhalb als auch außerhalb seines Königreichs auf neue Weise repräsentierte und inszenierte. Heinrich war ungewöhnlich gebildet und sehr ambitioniert. Durch seinen frühen Tod blieben jedoch viele seiner Vorhaben unvollendet, und das Resümee seiner Regierungszeit ist ambivalent. Im Mittelpunkt des Aufsatzes stehen nicht einzelne Kunstwerke, sondern vielmehr die Wahrnehmung und Überlieferung von zeitgenössischen Chronisten, die die vielschichtigen repräsentativen Bemühungen des Königs aufmerksam registrierten. Der Herrscher, aber auch Personen aus dessen engerem Umfeld, setzten durch ihr Verhalten und ihre Kleidung besondere Akzente. Dabei nutzte der englische König nicht nur das Konstanzer Konzil als große Bühne, um seinen Rang und Machtanspruch innerhalb der bedeutenden europäischen Herrscherhäuser zu verdeutlichen, sondern auch die Englandreise des römisch-deutschen Königs Sigismund (reg. 1411-37), der $1416 \mathrm{zu}$ politischen Vermittlungsgesprächen nach England reiste. Diese großangelegte royale Inszenierung durchdringt konzeptionell viele Bereiche der höfischen Gesellschaft, angefangen bei der Architektur über die Musik und das Theater bis hin zur Festkultur. Der deutsch-römische König wird dabei zum nobelsten Kronzeugen dieser kulturellen Aktivitäten mit politischen Hintergründen. Sigismund, der von Heinrich in den Hosenbandorden (Order of the Garter) aufgenommen wurde, schenkte der Ordenskapelle in Windsor im Gegenzug einen Leuchter und eine Monstranz, in der eine Reliquie des Schutzpatrons, des hl. Georg, eingeschlossen war. Die Aufnahme in diese elitäre Gesellschaft wurde u. a. durch das Tragen einer prachtvollen Kette visualisiert, die in den zeitgenössischen Texten weiterhin präsent war, obwohl Sigismund diese schon längst in Brügge verpfänden hatte lassen.

Die Beiträge, und darin liegt deren Reiz, befassen sich aus unterschiedlichen Perspektiven mit der Thematik. Sie sind damit ein Spiegel der Vielfalt historischer Optionen, deren Fülle eher zu betonen als methodisch einzugrenzen ist. 



\title{
WINDSOR - OXFORD - WINCHESTER
}

\author{
IDEENTRANSFER UND VermitTLUNGSWEgE \\ IN DER ENGLISCHEN KUNST DES AUSGEHENDEN 14. JAHRHUNDERTS
}

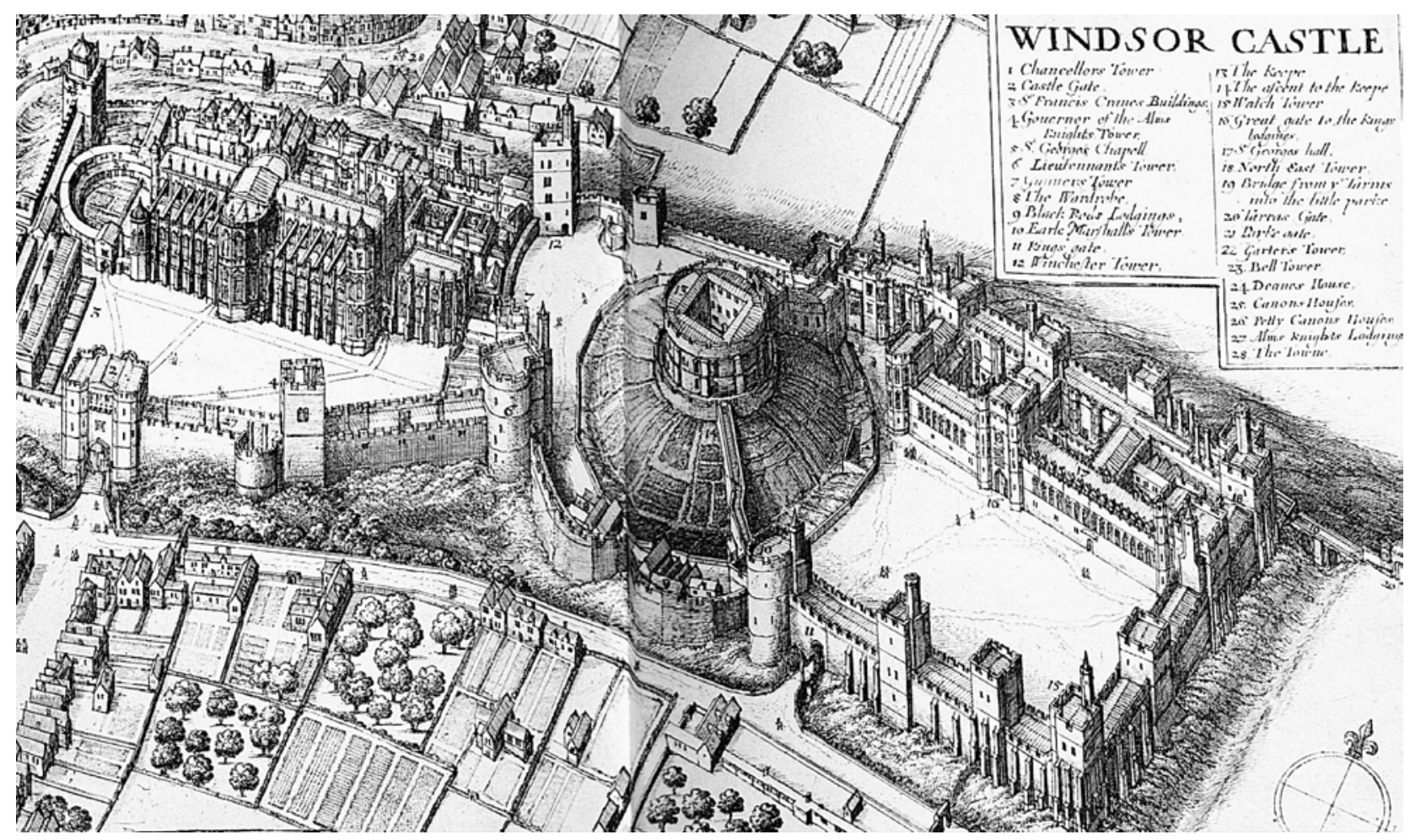

Abb. 1 Schloss Windsor, Vogelschauansicht. Wenzel Hollar, 1672. Kupferstich für Elias Ashmoles History of the Most Noble Order of the Garter (ex: HOPE 1913, I, Taf. 32)

Der von Eduard III. (1327-77) um die Mitte des 14. Jahrhunderts initiierte Neubau von Schloss Windsor war untrennbar verbunden mit den militärischen Erfolgen Englands in der ersten Phase des Hundertjährigen Krieges und Eduards aktiver Förderung einer ritterlich-höfischen Kultur an seinem Geburtsort Windsor. ${ }^{1} 1344$ griff der König im Anschluss an ein in Windsor veranstaltetes Turnier das Konzept der idealen Rittergemeinschaft in der Tradition der arthurischen Tafelrunde neu auf und gab im oberen Burghof einen in den Quellen als »domus tabule rotunde" bezeichneten Zentralbau in Auftrag. ${ }^{2}$ Zwar wurde dieses Projekt bald aufgegeben, doch gelang es dem König mit der Gründung des Hosenbandordens im Jahr 1348, Schloss Windsor dauerhaft als Ordens- sitz eines exklusiven Ritterordens, dem der König, der Prinz von Wales und 24 auserwählte Ritter angehörten, $\mathrm{zu}$ etablieren. ${ }^{3}$ Als Ordenskapelle fungierte die St. George's Chapel im unteren Burghof, wo Eduard auch ein neu gegründetes, dem hl. Georg gewidmetes Kanonikerkolleg ansiedelte. ${ }^{4}$ In den folgenden Jahren kam es zu einer völligen Neugestaltung der königlichen Burg. Ab 1350 wurden die Kollegiatsgebäude erbaut und anschließend der mittlere Hof und der Rundturm umgestaltet, bevor zwischen 1357 und 1368 das königliche Appartement am oberen Hof und die angrenzenden zwei Trakte mit den Unterkünften der Gefolgsleute errichtet wurden (Abb. 1). ${ }^{5}$

Das Ausmaß des ehrgeizigen Neubaus, dessen Gesamtkosten sich auf ca. 51.00o Pfund beliefen, muss maßgeb- 
lich durch die veränderten finanziellen Möglichkeiten des Königs nach der Gefangennahme Johanns II. von Frankreich bei der siegreichen Schlacht von Poitiers 1356 bestimmt gewesen sein, als Eduard mit dem Erhalt einer enormen Lösegeldsumme rechnen konnte. ${ }^{6}$

Zur Bewältigung dieses großangelegten Bauunternehmens wurden alle Kräfte des Landes in Windsor gebunden. Eduard machte hierbei von dem königlichen Privileg Gebrauch, Handwerker für seine Baumaßnahmen einziehen zu können, und ließ diese aus allen Teilen des Landes herbeiholen. ${ }^{7}$ Allein im Jahr 1361 kamen über tausend Arbeitskräfte nach Windsor, nachdem unter anderem die Sheriffs von London und Middlesex, Wiltshire, Somerset und Dorset, Gloucestershire, Worcestershire, Staffordshire, Oxfordshire und Berkshire, Bedfordshire und Buckinghamshire, Cambridgeshire und Huntingdonshire, Lincolnshire, Norfolk und Suffolk sowie Essex und Hertfordshire, Kent, Surrey und Sussex dazu aufgefordert worden waren, je 80 Handwerker auszusenden. ${ }^{8}$ Diese starke Vereinnahmung des Bauwesens durch den König kommentierte bereits ein Zeitgenosse, der in seinem Bericht über den Neubau des Schlosses anmerkte: "Beinahe alle Steinmetze und Zimmermeister aus ganz England wurden für jenen Bau herangezogen, sodass kaum ein anderer einen guten Steinmetz oder Zimmermeister anstellen konnte, außer im Geheimen, aufgrund des königlichen Verbots. «"

Diese überregionale Bündelung von Arbeitskräften in einem hochambitionierten Bauprojekt, das die Wirkungsmöglichkeiten des Perpendicular Style im Palastbau erfolgreich erprobte, beschrieb John Goodall als einen der Faktoren, die Eduards Umbau zur vielleicht einflussreichsten Bauunternehmung des Spätmittelalters in England machten. Dieses Bauprojekt habe maßgeblich zur Verbreitung und Wertschätzung des Perpendicular Style beigetragen, da viele der fähigsten Bauleute des Landes vorübergehend an dessen Ausführung beteiligt waren, und so architektonische Detailformen und baukünstlerische Inventionen an andere, in verschiedenen Regionen des Landes befindliche Baustellen übermittelt wurden. Als neu inszeniertes Herrschaftszentrum Eduards III., das nur vom Palast in Westminster an Bedeutung übertroffen wurde, und Sitz des Hosenbandordens sei das Schloss aber auch auf Auftraggeberebene eine Inspirationsquelle für die Gründungsmitglieder des Ritterordens und den Hof generell gewesen. ${ }^{10}$

Die von Goodall beschriebene Rolle Windsors als Kraftzentrum künstlerischer Produktivität, aus dem Bau- herren und Baumeister gleichermaßen schöpften, kann an der Bautätigkeit wohl kaum eines anderen Auftraggebers aus dem Umfeld des Königs besser nachvollzogen werden als an der Patronage Williams of Wykeham, der als Bischof von Winchester (1367-1404) auch der Prälat des Hosenbandordens war. In seiner Diözese trug Wykeham maßgeblich zum Neubau des Langhauses seiner Bischofskirche bei und veranlasste größere Baukampagnen in den Bischofspalästen in Winchester, Highclere und Bishop's Waltham sowie im bischöflichen Haus in East Meon. Für die von ihm gegründeten Bildungseinrichtungen - das Universitätskollegium New College in Oxford und die Grammatikschule Winchester College in seiner Bischofsstadt - ließ er monumentale Baukomplexe errichten, die bis heute in weitgehend unveränderter Form bestehen. ${ }^{11}$

Aufgrund der gut dokumentierten Position Wykehams als Bauverwalter des Umbaus von Schloss Windsor in den 1350er Jahren bestimmte bereits Leopold Wickham-Legg den Nordtrakt am oberen Burghof als wichtiges Vorbild für die von William beauftragten Kollegienbauten in $\mathrm{Ox}$ ford (Abb. 2) und Winchester. ${ }^{12}$

Der seither viel zitierte Vergleich wurde jedoch meist mit wenigen Sätzen abgehandelt und konzentrierte sich darauf, das Abhängigkeitsverhältnis der Bauten des Bischofs von Schloss Windsor zu betonen. ${ }^{13}$ Der folgende Beitrag will hingegen den Aspekt des Ideentransfers untersuchen und darstellen, wie Gestaltungselemente und Raumkonzepte des Schlossbaus für die relativ neue Bauaufgabe des Kollegiums fruchtbar gemacht wurden. Zugleich soll an Wykehams Patronage gezeigt werden, wie ein bedeutender klerikaler Auftraggeber, der durch führende Positionen in der königlichen Verwaltung, und insbesondere in der Bauverwaltung, gesellschaftlich aufgestiegen war, im England des ausgehenden 14. Jahrhunderts zur Vernetzung zwischen königlichen und regionalen Baustellen beitrug.

Bereits die Geschichtsschreibung des 14. Jahrhunderts stellte Wykehams Tätigkeit als königlicher Bauverwalter auf Schloss Windsor als entscheidende Weichenstellung für seine beachtliche Karriere dar. So beschrieb ein Chronist in der Nachfolge Ranulph Higdens Wykeham als Mann von zwar niedriger Herkunft, doch großem Tatendrang, der die Gunst Eduards III. zu gewinnen wusste, »indem er ihn beriet, das Schloss so zu bauen, wie es dem Betrachter heute vor Augen steht $«{ }^{14}$ Auf Wykehams Betreiben habe der König "gute Gebäude « abgerissen, um noch schönere und prächtigere $\mathrm{zu}$ errichten. ${ }^{15}$ Auch 
Abb. 2 Oxford, New College, Gesamtansicht von Westen. David Loggan, Oxonia Illustrata, 1675 (ex: RASHDALL/RAIT 1901, Taf. 1)

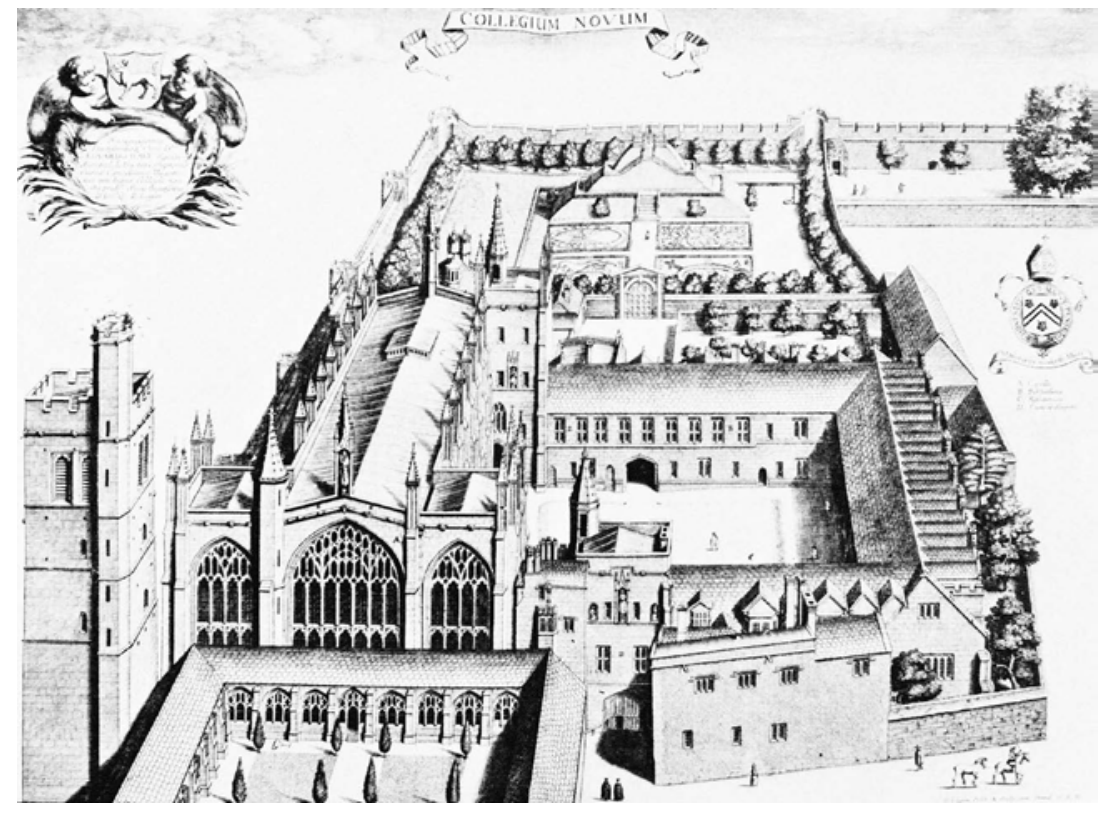

Froissart kündigte in seinem kurzen Bericht zum Baugeschehen in Windsor bereits den kometenhaften Aufstieg des königlichen Bauleiters an. Nach seiner Beschreibung standen die Arbeitskräfte »unter der Aufsicht eines Beamten, der ihre Löhne auszahlte und William Wickham genannt wurde. Später zählte er als Bischof und Kanzler zu den bedeutendsten Männern Englands, alles ging durch seine Hände und er stand so hoch in der Gunst des Königs, dass zu dieser Zeit alles in England durch ihn geschah und nichts ohne ihn «. ${ }^{16}$

Tatsächlich ist über Wykehams Leben vor seiner Beschäftigung in Windsor wenig bekannt. ${ }^{17}$ Einer unbedeutenden Familie im südlichen Hampshire entstammend, dürfte er sich mit Unterstützung mehrerer Förderer im administrativen Dienst auf regionaler Ebene kontinuierlich emporgearbeitet und so für das Tätigkeitsfeld der königlichen Bauverwaltung empfohlen haben. ${ }^{18} \mathrm{Im}$ Mai 1356 ist er als Bauleiter in den königlichen Häusern von Henley-on-the-Heath (Surrey) und Easthampstead (Berkshire) fassbar, ${ }^{19}$ nur fünf Monate später wurde er mit der Organisation der Großbaustelle auf Schloss Windsor betraut. ${ }^{20}$ Damit war er für Beschaffung und Transport der Baumaterialien und für Rekrutierung, Koordination und Bezahlung der Handwerker verantwortlich. ${ }^{21}$ Der Zeitraum seiner Beschäftigung in Windsor (1356-61) ist in sechs von ihm erstellten Sammelabrechnungen durchgehend dokumentiert. $^{22}$

Unter Wykehams Leitung spannte sich die Bautätigkeit im Schloss von der Fortführung der Arbeiten an den
Kollegiatsgebäuden am unteren Burghof über die Umgestaltung des mittleren Hofs bis zur Neuplanung des oberen Burghofs. In den ersten Jahren wurden neben dem Kreuzgang auch die Unterkünfte der Kanoniker auf der Vorburg fertiggestellt, die königlichen Gemächer im Rundturm adaptiert und das zum oberen Burghof führende Norman Gate errichtet (Abb. 1) ${ }^{23}$ Mit dem Abriss von Gebäuden ging der Ankauf von Baumaterial für die Umgestaltung des oberen Burghofs einher. ${ }^{24}$ Das Ende der Amtsperiode Wykehams markierte den Beginn des Neubaus des königlichen Appartements an dessen Nordseite. Wykeham rekrutierte eine große Zahl an Arbeitskräften und schloss Werkverträge mit Handwerkern zur Errichtung einzelner Räume ab, die unter seinem Nachfolger William of Mulsho ausgeführt wurden. ${ }^{25}$ In den Folgejahren wurde am Neubau des königlichen Appartements gearbeitet, dessen Südfassade 1363-65 hochgezogen wurde. ${ }^{26}$

Wykeham leitete jedoch nicht nur jene zentrale Phase des Umbaus dieses Schlosses, sondern war ab Juli 1359 zudem Bauverwalter von über einem Dutzend anderer königlicher Schlösser im Südosten Englands und im Umkreis Londons, zu denen unter anderem die Paläste von King's Langley, Sheen und Eltham sowie Dover Castle gehörten. ${ }^{27}$

Er muss diese verantwortungsvolle Aufgabe gut bewältigt haben, denn binnen Kurzem stieg er zum engen Vertrauten Eduards III. auf. 1363 stand Wykeham dem König als Sekretär zur ständigen persönlichen Verfügung, ${ }^{28}$ 
als Lordsiegelbewahrer erhielt er 1365 ein zusätzliches Gehalt für die Erledigung privater Angelegenheiten des Königs, mit denen er speziell betraut worden war. ${ }^{29}$ Das gute Verhältnis zum König eröffnete Wykeham, der 1362 zum Priester geweiht wurde, auch die Perspektive auf eine kirchliche Laufbahn und sicherte ihm zahlreiche lukrative Pfründen, die zur Anhäufung seines Vermögens beitrugen. ${ }^{30}$ Seine Karriere erreichte ihren Höhepunkt, als Wykeham im Sommer 1367 zum Lordkanzler ernannt und wenig später, am 10. Oktober, zum Bischof von Winchester geweiht wurde..$^{31} »$ Von goldenen Briefen und Bitten geleitet ${ }^{32}$ habe Urban V. dem vom König gewünschten Kandidaten schließlich zugestimmt, nachdem Eduard nicht weniger als 28 Briefe an den Papst und die Kardinäle gesandt hatte, um die Bestellung seines "trescher clerc ${ }^{33}$ zum Bischof der reichsten Diözese Englands durchzusetzen. Wykeham sollte jenes Amt für die nächsten 37 Jahre innehaben und sein bischöfliches Einkommen von jährlich bis zu 4000 Pfund $^{34}$ zur Finanzierung eines Bauprogramms verwenden, das zu den ambitioniertesten seiner Zeit gehörte.

Zur Umsetzung seiner Projekte griff Wykeham einige der in Windsor zusammengelaufenen Fäden der King's Works auf, um sein eigenes Netzwerk an Künstlern zu knüpfen. ${ }^{35}$ Wykeham lernte den Architekten William Wynford, der ab den $1350 e r$ Jahren in Windsor beschäftigt war und ab 1361 gemeinsam mit John Sponlee die Werkleitung innehatte, ${ }^{36}$ und vermutlich auch den Zimmermeister Hugh Herland im königlichen Schloss kennen. ${ }^{37}$ Beide waren ab den $1380 e r$ Jahren regelmäßig gemeinsam für den Bischof tätig, wie aus den Abrechnungen und Gästelisten von New College, Winchester College, Bishop's Waltham und Highclere hervorgeht. ${ }^{38}$ Nachdem Wynford auch die Werkleitung des Umbaus der Kathedrale von Winchester innehatte ${ }^{39}$ und seine Beteiligung zudem in East Meon belegt ist, ${ }^{40}$ dürfte er alle Projekte Wykehams betreut haben. Mit der gemeinsamen Beschäftigung Wynfords und Herlands griff Wykeham jedoch nicht nur auf Kontakte aus seiner Zeit als königlicher Bauleiter Eduards III. zurück, sondern machte sich zugleich jene Konstellation zu eigen, in der die beiden als Baumeister und Zimmermann des Königs oftmals zusammen mit Henry Yevele in laufenden Projekten Richards II. tätig waren. 1385 sind sie gemeinsam in Carisbrooke Castle dokumentiert, ${ }^{41}$ in den $1390 e r$ Jahren übertrug ihnen Richard II. Reparatur- und Instandhaltungsarbeiten in Winchester Castle. ${ }^{42}$ Wykeham dürfte auch früh Kontakte zu Henry Yevele geknüpft haben, dem damals bedeutendsten Architekten in London, der ab 1378 das Amt des ersten königlichen Baumeisters innehatte. ${ }^{43}$ Aus einem Eintrag in den Close Rolls im Januar 1375 geht hervor, dass der Architekt die Bürgschaft für die Freigabe eines bei Dover beschlagnahmten Schiffs übernahm, das unter anderem »einen großen Stein für den Bischof von Winchester « transportierte. ${ }^{44}$ Möglicherweise brachte Henry Yevele Purbeckstein für verschiedene Klienten nach London. ${ }^{45}$ Im Folgejahr war Yevele im Londoner Palast des Bischofs für die Neugestaltung eines Kamins in der Great Chamber verantwortlich. ${ }^{46}$ Im Zuge von Yeveles Tätigkeit für den König in Southampton mag sich 1379 zudem die Gelegenheit geboten haben, den Architekten auch auf der nahegelegenen Baustelle des Bischofs in South Waltham hinzuzuziehen, wo seine Anwesenheit in diesem und im folgenden Jahr dokumentiert ist. ${ }^{47}$

Es greift daher zu kurz, Wykehams Wahl der Künstler einzig von seinen in Windsor geknüpften Kontakten abzuleiten. Vielmehr zeigt sie den hohen Anspruch eines Bauherren, der die führenden königlichen Baumeister für seine Aufträge verpflichtete und durch die Verflechtungen seiner Bauunternehmungen mit Werken der königlichen Kunstpatronage sein Nahverhältnis zum Königshaus artikulierte. ${ }^{48}$ So war beispielsweise Hugh Herland, der in den 1390er Jahren die Oberaufsicht über die Holzarbeiten im Schloss in Winchester innehatte, parallel dazu für Wykeham in Winchester College tätig, als er in dem damals bedeutendsten königlichen Bauprojekt in London die Verantworung für die Konstruktion der komplexen Hammerbalkendecke der Westminster Hall übernahm. ${ }^{49}$ Die vorbereitenden Arbeiten für Westminster Hall fanden nach Holzankäufen im königlichen Odiham Forest und in Alice Holt in Farnham vermutlich nahe Farnham Castle im Besitz des Bischofs von Winchester statt, bevor 1395 die hölzernen Bauteile von Chertsey aus auf der Themse nach London transportiert wurden. ${ }^{50}$ Wykeham konzentrierte sich zu diesem Zeitpunkt als Bauherr auf den Umbau des Langhauses seiner Bischofskirche, der bereits unter seinem Amtsvorgänger William Edington (gest. 1366) begonnen worden war und spätestens in den 1390er Jahren weitergeführt wurde. ${ }^{51}$ John Hare wies darauf hin, dass am Gesims über der Langhausarkade in den östlichen Jochen der südlichen Mittelschiffwand und an der nördlichen Mittelschiffwand mehrfach das Motiv des liegenden Hirschs angebracht wurde, das er als Bilddevise Richards II. identifizierte. ${ }^{52}$ Bei genauerer Betrachtung zeigt sich, dass nur ein Hirsch, nämlich jener im sechsten Joch der Nordseite, die für Richards Abzei- 


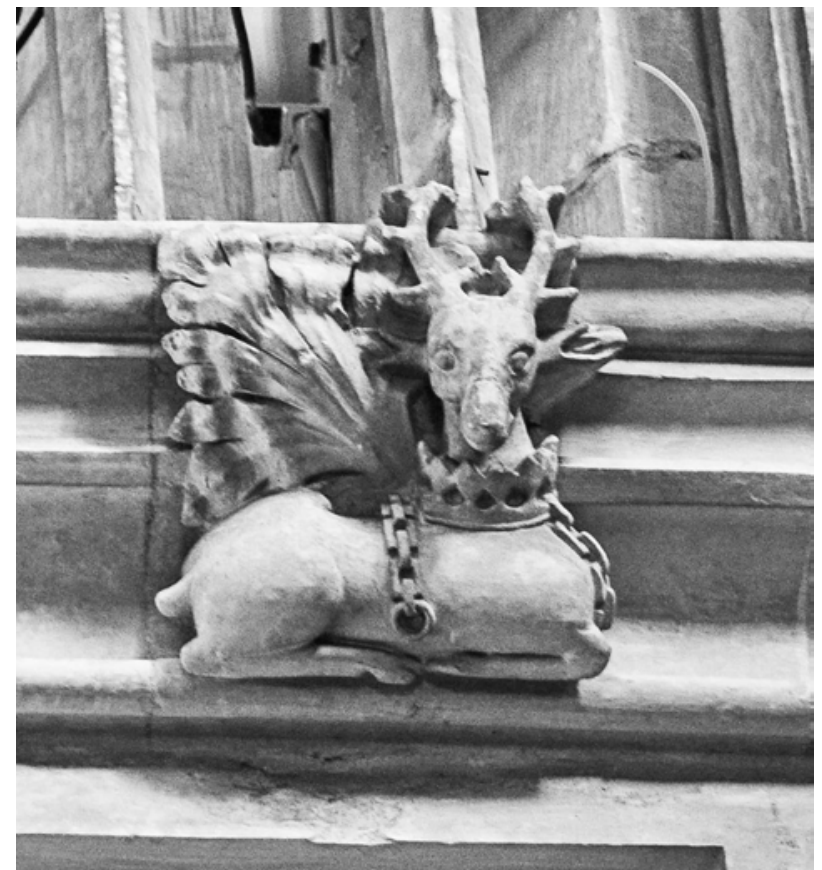

chen typische, an einer Kette befestigte Halskrone trägt (Abb. 3). ${ }^{53}$

Im benachbarten Joch wurde das Motiv der von Straußenfedern gerahmten Leopardenhelmzier angebracht (Abb. 4), das in ähnlicher Form abwechselnd mit dem Hirschmotiv das Konsolgesims der Westminster Hall schmückt. ${ }^{54}$ Durch die Frontalansicht des Kopfes und das Tragen einer Halskrone mit zwei Ketten unterscheidet sich der von Blattdekor hinterfangene Hirsch in der Kathedrale von Winchester von anderen Darstellungen des liegenden Hirschs, wie jener an der Außenseite des Wilton Diptychons (London, National Gallery, um 1395-99) oder jener an einem Kapitell im südlichen Seitenschiff des Chores von York Minster, das ebenfalls mit Richard II. in Verbindung gebracht wurde. ${ }^{55}$ Den Blick zum Betrachter und die Kombination mit Blattwerk zeigen jedoch die Hirschdarstellungen am Gesims der Westminster Hall, dessen Dekor die Steinmetze nach einer vom leitenden Architekten Henry Yevele zur Verfügung gestellten Vorlage im Jahr 1395 ausführten. ${ }^{56}$ Dies würde dafür sprechen, dass die motivisch verwandte Bauplastik in Winchester zu diesem Zeitpunkt, oder jedenfalls vor der Absetzung Richards II. im Jahr 1399, gefertigt wurde und dass durch Wykehams Kontakte ein direkter Austausch zwischen der Baustelle in Westminster und jener in Winchester stattfand. Die Anbringung der Hirschdevise, die auch als Zeichen der Gefolgschaft des Königs

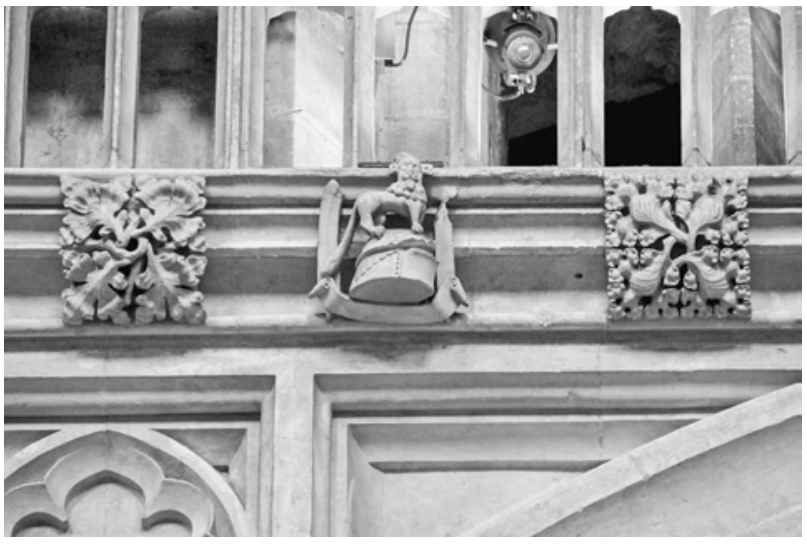

Abb. 3 Liegender Hirsch mit Halskrone. Winchester, Kathedrale, Langhaus, sechstes Joch der nördlichen Hochschiffwand, Bauskulptur am Gesims (Foto: Veronika Decker)

Abb. 4 Helm mit Leopardenzier. Winchester, Kathedrale, Langhaus, siebtes Joch der nördlichen Hochschiffwand, Bauskulptur am Gesims (Foto: V. Decker)

galt, ${ }^{57}$ könnte ähnlich der von Wykeham beauftragten bildlichen Darstellung Richards II. im Ostfenster der Kapelle von Winchester College als Ausdruck der Verbundenheit des Bischofs mit dem König zu verstehen sein. ${ }^{58}$ Eventuell entstand sie auch in Zusammenhang mit einem Aufenthalt Richards in Winchester, beispielsweise jenem im Mai $1395 .^{59}$

Durch seine Bau- und Auftraggebertätigkeit in der Universitätsstadt, die außerhalb seiner Diözese lag, trug Wykeham im Bereich der Glasmalerei zur Vernetzung der Kunstproduktion in Winchester und Oxford bei. Ab Mitte der 138oer Jahre ist die regelmäßige Anwesenheit des Glasmalers Thomas', den Wykeham in Folge bei allen Projekten beschäftigen sollte, in New College dokumentiert. ${ }^{60}$ Sein Atelier fertigte zu diesem Zeitpunkt vermutlich die umfangreichen Glasfensterzyklen für die Kapelle an. ${ }^{61}$ In den folgenden Jahren erhielt Thomas weitere Aufträge in der Universitätsstadt, die dafür sprechen, dass er in Oxford eine Werkstatt führte: 1395/96 war Thomas Glasyer in Canterbury College tätig, 1397/98 wurde ein Glasmaler Thomas aus Oxford für seine Arbeit in der Kirche von Adderbury nördlich von Oxford entlohnt. ${ }^{62}$ In der Marienkirche in Oxford ist seine Tätigkeit 1409/10 dokumentiert. ${ }^{63}$ Parallel dazu arbeitete Thomas in Wykehams Residenzen in Highclere im nördlichen Hampshire und dem gut $15 \mathrm{~km}$ südöstlich von Winchester gelegenen Bishop's Waltham, wo er Glasfenster für verschie- 


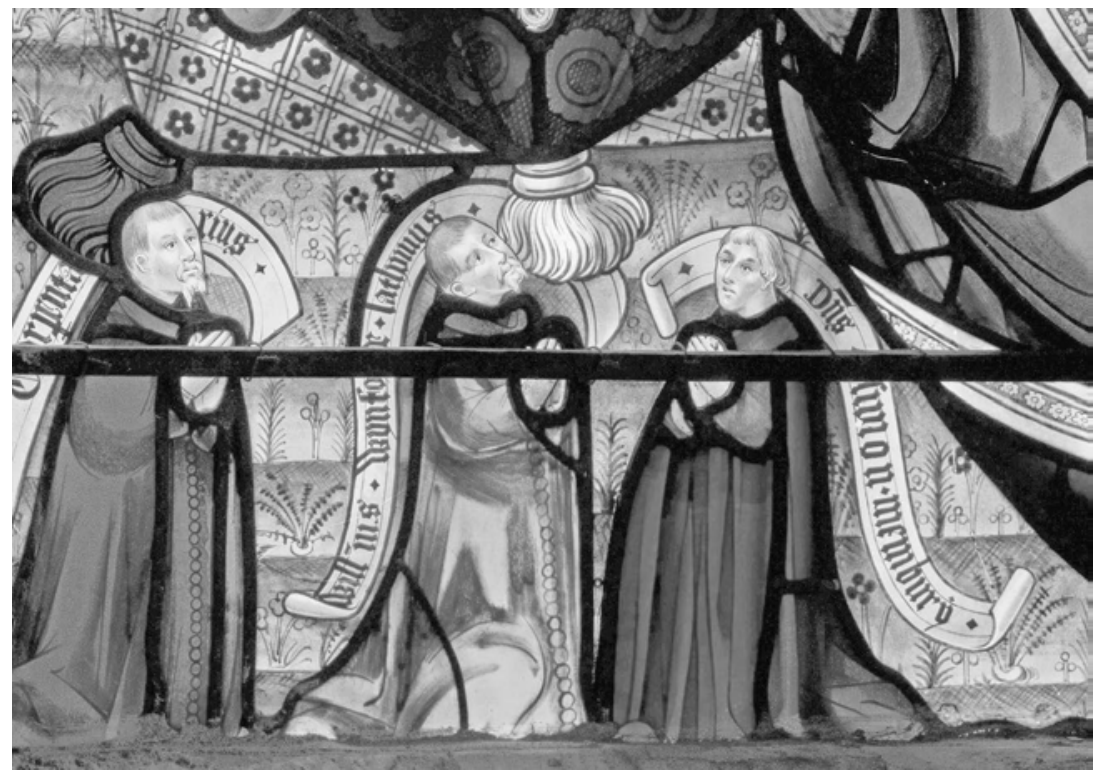

Abb. 5 Darstellung des »carpentarius«, des »lathomus "William Wynford und des Bauleiters Simon Membury. Kopie von 1821/22. Winchester College, Kapelle, Ostfenster (Foto: Gordon Plumb)

dene Räumlichkeiten des bischöflichen Appartements anfertigte. ${ }^{64}$ Von Oxford aus lieferte er auch Glasfenster für Wykehams College in Winchester. Ein Eintrag in der Haushaltsrolle des Bischofs von 1393 schildert anschaulich, wie in jenem Jahr zwei Wägen, die Glasscheiben für Wykehams College transportierten, von Wykehams $\mathrm{Pa}$ last in Esher nach Oxford und von dort über das bischöfliche Highclere nach Winchester fuhren: Sechs Männer und zwölf Pferde brachten das Glas in einer neuntägigen Reise nach Winchester. ${ }^{65}$ Es handelte sich hierbei vermutlich um Scheiben für den großen Jessebaum im Ostfenster der Kapelle, der kompositorisch wie stilistisch der ursprünglichen Verglasung des Westfensters von New College sehr nahe steht (Taf. 5.a-b). ${ }^{66}$ Die durch Wykehams Patronage aufgebauten Beziehungen zwischen Winchester und Oxford setzten sich auch nach dem Tod des Bischofs fort. ${ }^{67}$ In seinem 1403 verfassten Testament hinterließ er 500 Mark für die Verglasung des Langhauses der Kathedrale. ${ }^{68}$ Vermutlich erhielt Thomas diesen Auftrag, da eine der heute im Seitenschiff des Langhauses eingesetzten Figuren, die hl. Genoveva, den vermutlich von seiner Werkstatt gefertigten Aposteln und Propheten der Süd- und Nordfenster der Kapelle von Winchester College stilistisch eng verwandt ist. ${ }^{69}$ Andere Figuren der Langhausverglasung, die sich heute im Obergaden des Chores befinden, stehen stilistisch einer Gruppe von Heiligenfiguren, die vermutlich um 1420 für das Nordquerhauses der Kapelle von Merton College entstanden, nahe. Auch bei dieser Verglasung eines bedeutenden Sakralrau- mes in Oxford ist daher die Beteiligung der Werkstatt des bis 1427/28 aktiven Thomas' oder eines Glasmalers aus seinem unmittelbaren künstlerischen Umfeld vorstellbar. ${ }^{70}$

Aufgrund der Erfahrungen des Bischofs in der königlichen Bauorganisation beschrieb Gervase Jackson-Stops Wykehams Zusammenstellung einer für ihn an verschiedenen Orten tätigen Künstler-Equipe als "private version of the King's Works «. ${ }^{71}$ Allerdings ist anhand der Quellen nur für Wynford nachzuweisen, dass er eine klar definierte Position als Baumeister des Bischofs innehatte, da er in einer Baurolle von 1378 als »Baumeister und Meister aller Steinmetzarbeiten des Herrn « bezeichnet wurde. ${ }^{72}$ Zwei bemerkenswerte Quellen erlauben es zudem, das Verhältnis zwischen dem Auftraggeber und seinem Bauteam genauer $\mathrm{zu}$ bestimmen. In seinem biografischen Handbuch über die englischen Baumeister des Mittelalters führte Harvey an, dass im Jahr 1393 Henry Yevele und Hugh Herland je neunmal und William Wynford sogar 13-mal mit dem Bischof von Winchester speisten. ${ }^{73}$ Daraus ist allerdings nicht unbedingt abzuleiten, dass 1393 ein entscheidendes Jahr in der Zusammenarbeit mit dem Bischof war. Vielmehr handelt es sich bei der Aufstellung um die Ergebnisse der Auswertung der einzigen erhaltenen Haushaltsrolle des Bischofs, die den Zeitraum von April bis September 1393 abdeckt. ${ }^{74}$ Sie gibt einen wertvollen Einblick in die starke Einbindung der Architekten und des Zimmermeisters in den Haushalt des Bischofs, an dessen Tafel sie regelmäßig als Ehrengäste speisten. Dieses enge Verhältnis zwischen einem bischöf- 


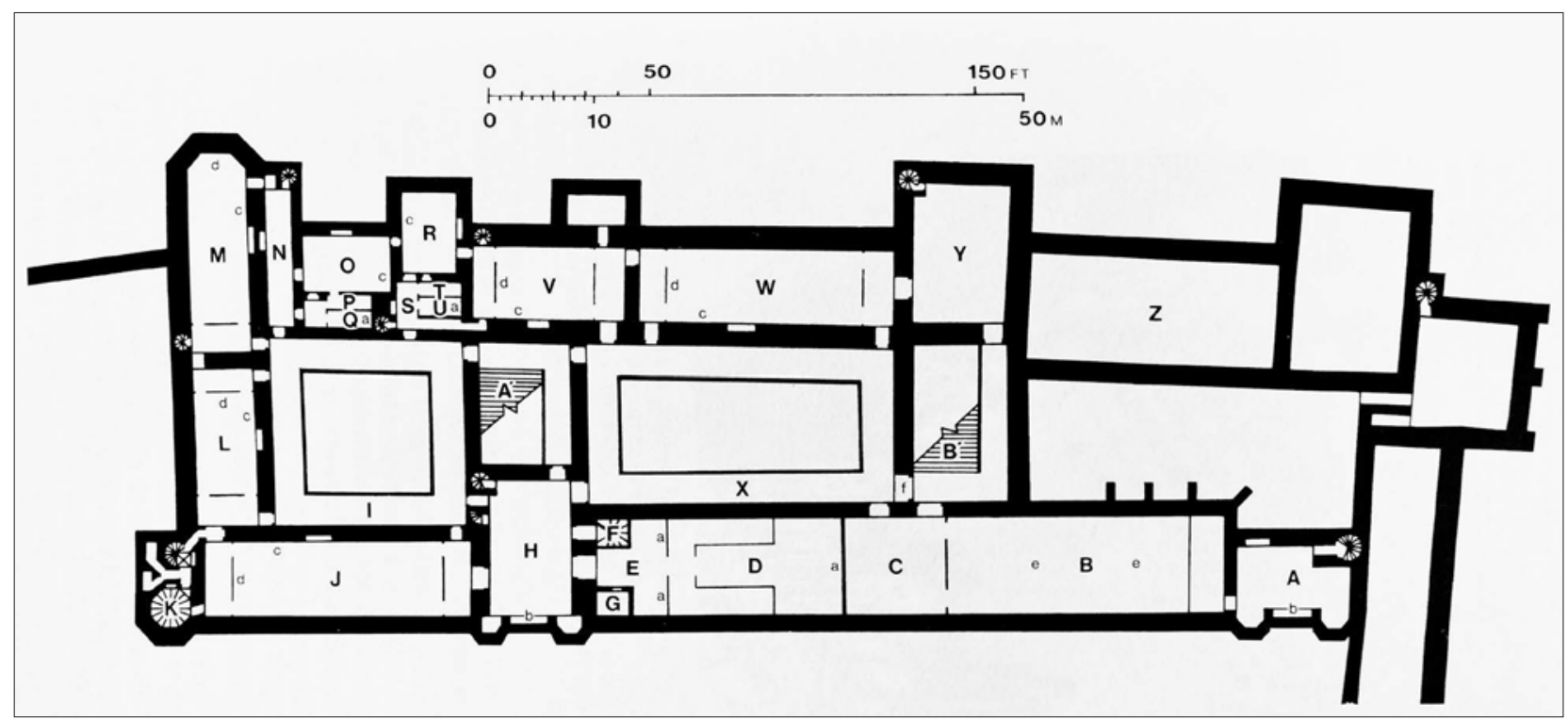

Abb. 6 Schloss Windsor, oberer Burghof, Nordtrakt mit königlichen Appartement Edwards III., Rekonstruktion der ursprünglichen Raumanordnung im ersten Stock nach C. Wilson. A: Zimmer des Stewards, B: großer Saal, C: Bereich westlich des Screens, D: Kapelle, E: Antechapel, H: Wache des Königs, J: Great Chamber des Königs (ex: WiLSON 2002, Abb. 7)

lichen Bauherrn und seinem Bauteam ist im England des 14. Jahrhunderts jedoch keine Ausnahme. Bereits John Grandisson, Bischof von Exeter, bezeichnete den Kathedralbaumeister Thomas Witney in einem Schreiben 1329 als »dilectus familiaris noster.$^{75} \mathrm{Im}$ Zuge von Wykehams Stiftung in Winchester wurde diese persönliche Bindung an den Auftraggeber jedoch auch bildlich artikuliert. In dem 1821/22 durch eine getreue Kopie ersetzten Ostfenster der Collegekapelle ließ Wykeham William Wynford, Hugh Herland und den Glasmaler Thomas gemeinsam mit dem Bauleiter Simon Membury als kleine betende Figuren zu Füßen des lagernden Jesse darstellen (Abb. 5).

Auf Höhe der beiden Stifterbilder des Bischofs angebracht, veranschaulichten ihre im Miniaturformat ausgeführten, mit »carpentarius«, »Willelmus Wynford lathomus« und »Thomas operator istius vitri« nur knapp beschrifteten Darstellungen den individuellen Beitrag der Künstler zu dem vom Bischof gestifteten Werk, das auch ihrem Seelenheil zugutekommen sollte. ${ }^{76}$

Vor dieser Zusammenarbeit in Winchester College war mit der Errichtung und Ausstattung des 1379 in Oxford gegründeten New College ein noch größeres Bauprojekt des Bischofs, das sich als impulsgebend für die Entwicklung der englischen Universitätsarchitektur erweisen sollte, erfolgreich umgesetzt worden. Der ab 1380 in nur wenigen Jahren hochgezogene Baukomplex von enormen Dimensionen schloss erstmals alle für das Zusammen- leben eines Kollegiums relevanten Räumlichkeiten in einem stringenten Raumprogramm zu einer regelmäßigen Vierflügelanlage zusammen, die zum Vorbild für die Kollegienarchitektur des 15. Jahrhunderts wurde. ${ }^{77}$

Die Hofanlage des Colleges wird durch einen monumentalen Nordtrakt mit Kapelle im Westen und Saal im Osten bestimmt, um den sich die drei niedrigen Flügel mit den Unterkünften der Kollegiaten, des Collegevorstandes sowie der Bibliothek fügen $(\mathrm{Abb} 2) .^{78} \mathrm{An}$ der Ostseite schließen die Küche und die Vorratskammern an, die zum Servieren der Speisen direkt mit dem Saal verbunden wurden, vom zentralen Hof aus jedoch nicht sichtbar sind. Westlich der Kapelle wurden in einer zweiten Bauphase um die Mitte der 1390er Jahre Kreuzgang und Glockenturm errichtet. ${ }^{79}$ Die axiale Anordnung von Kapelle und Saal hatte im Kollegienbau des 14. Jahrhunderts keine Tradition, lässt sich jedoch in dem unter Eduard III. neu errichteten königlichen Appartement im Nordflügel am oberen Burgberg von Schloss Windsor nachweisen. Zwar wurde dessen mittelalterliche Substanz durch die unter Karl II. durchgeführten Umbauarbeiten 1675-84 weitgehend zerstört, ${ }^{80}$ doch konnten die Anordnung der Räume und das ursprüngliche Erscheinungsbild durch die Auswertung von Schrift- und Bildquellen rekonstruiert werden. So zeigte Wilson, dass die drei wichtigsten Repräsentationsräume des Palastes, die Great Chamber des Königs, die Kapelle und der große Saal, in 
einer Achse im ersten Stock des Nordflügels lagen. ${ }^{81} \mathrm{Ge}-$ meinsam erstreckten sie sich über die ganze Südfassade des Trakts, unterbrochen nur von einem Wachraum über dem Hauptportal (Abb. 6). Diese Koppelung von Kapelle und Saal war eine wichtige Neuerung des königlichen Appartements und dürfte, wie oft betont, die Idee für den Raumplan in New College gegeben haben. ${ }^{82}$ Als weitere Parallele zwischen den Bauten lässt sich die Gestaltung der Ostwand der Kapelle, die aufgrund des angrenzenden Saals fensterlos war, durch ein raumhohes Altarretabel anführen. ${ }^{83}$ In Windsor sind um 1365 Arbeiten an einem Retabel dokumentiert, im New College ist das Retabel in Form einer vermutlich weitgehend getreuen Rekonstruktion aus dem 19. Jahrhundert überliefert. ${ }^{84}$

Jedoch müssen der Raumeindruck und das Verhältnis der beiden Räume zueinander in den beiden Bauten völlig unterschiedlich gewesen sein. So lagen in Windsor Saal und Kapelle auf einer Ebene, während im College unterschiedliche Niveaus vorhanden sind. Der im ersten Stock angesiedelte Saal grenzt im Westen an eine Collegekapelle, die sich über die ganze Höhe des Nordflügels erstreckt. Ihr Grundriss ist nicht nur durch einen westlichen, dreischiffigen Querriegel erweitert (Abb. 2), ihr langgestreckter fünfjochiger Chor ist zudem weit größer als der Saal (Abb. 7). Ein genau gegenteiliges Raumverhältnis lag in Windsor vor, wo die St. George's Hall mit elf Fensterachsen der monumentale Bauteil war.

Eine der wichtigsten Innovationen des Schlosses wurde jedoch in modifizierter Form aufgegriffen und für die neue Aufgabenstellung des Collegebaus nutzbar gemacht. In seiner Analyse der verschiedenen Ansichten des oberen Burgbergs, die Wenzel Hollar vor dem barocken Umbau anfertigte, beschrieb Wilson die zugleich nüchterne wie imposante Monumentalität der einheitlich gestalteten Südfassade als die bemerkenswerteste Qualität des Neubaus (Abb. 8). Die übereinstimmenden Fensterformen der Great Chamber, des Saals und der Kapelle, deren unterschiedliche Funktionen und Raumgrenzen am Außenbau nicht in Erscheinung traten, verliehen dem nur durch das Hauptportal unterbrochenen Baukörper große Geschlossenheit und betonten zugleich die enormen Dimensionen der $118 \mathrm{~m}$ langen Fassade. ${ }^{85}$ Dieses Zusammenschließen der Haupträume, das deren Differenzierung von außen nicht ermöglicht, durch die übereinstimmende Gestaltung der Fenster liegt beim New College zwar nicht vor, ${ }^{86}$ eine geschlossene Fassadenwirkung wurde jedoch durch die Verschleierung der Geschoßdifferenzen zwischen Kapelle und Saal ebenfalls erreicht (Abb. 7). Die abgestimmte Positionierung der Fenster, deren Querbalken trotz unterschiedlicher Entwürfe auf einer Höhe liegen, und die übereinstimmende Dachhöhe überspielen die Niveauunterschiede der beiden Räume am Außenbau und schließen den vom Querriegel der Kapelle und dem Muniment Tower eingefassten Baukörper horizontal zusammen. Ein durchlaufendes Gesims betont den zweizonigen Wandaufriss.

Diese Anregungen wurden in New College jedoch für ein völlig anderes Baukonzept nutzbar gemacht. Im königlichen Appartement von Schloss Windsor lagen Kapelle und Saal an der den oberen Burghof überblickenden Südseite eines großen Gebäudekomplexes, in dem um drei Höfe die königlichen Wohn- und Repräsentationsräume und der dazugehörige Küchen- und Versorgungsbereich angeordnet waren (Abb. 1). Die Vielteiligkeit der Anlage wurde durch die gleichförmige Gestaltung der zum Hof ausgerichteten Fassade verblendet, die den Nordflügel als geschlossenen, monumentalen Baukörper erlebbar machte. Während die Schlossfassade also gerade durch die Unterordnung der einzelnen Raumfunktionen im Gesamtensemble ihre imposante Wirkung entfaltete und zentrale Räume am Außenbau nicht gesondert in Erscheinung traten, wurde in New College ein genau gegenteiliges Prinzip wirksam. Unter Beibehaltung der in Windsor erarbeiteten Monumentalität wurde das Raumpaar aus einem größeren Baukomplex herausgelöst und als architektonisch herausgehobenes Ensemble in die Anlage des Colleges eingeführt (Abb. 2).

Dies ermöglichte es, bisher wenig strukturierte Raumanordnungen und Baulösungen der englischen Universitätsarchitektur mit einem klaren Konzept zu versehen, das die Ideale der kollegialen Lebensform in gebauter Form zu verwirklichen suchte.

Wykeham hatte das New College im November 1379 als St. Mary College of Winchester für siebzig bedürftige Scholaren, die in Gemeinschaft leben und an der Universität Oxford verschiedene Fächer studieren sollten, gegründet. ${ }^{87}$ An ältere englische Kollegiatsstiftungen anknüpfend, legte er in einem umfangreichen Corpus von 68 Statuten Regeln für das Zusammenleben der Studenten vor und beschrieb die Grundprinzipien kollegialen Lebens, wie sie erstmals im Pariser Collège de la Sorbonne mit dem Motto "Vivere socialiter et collegialiter et moraliter et scholariter " prägnant formuliert worden waren. ${ }^{88}$ Die Kollegiaten sollten in völliger Harmonie miteinander leben und ein starkes Gruppenbewusstsein entwickeln. Zusammengehörigkeit wurde zuallererst im gemeinsa- 
Abb. 7 Oxford, New College, Ansicht des Nordtrakts mit Kapelle und Saal (Foto: V. Decker)

Abb. 8 Schloss Windsor, Ansicht des oberen Burghofs nach Westen. Wenzel Hollar, um 1660. London, British Museum, Department of Prints and Drawings (ex: WILSON 2002, Taf. I (B))
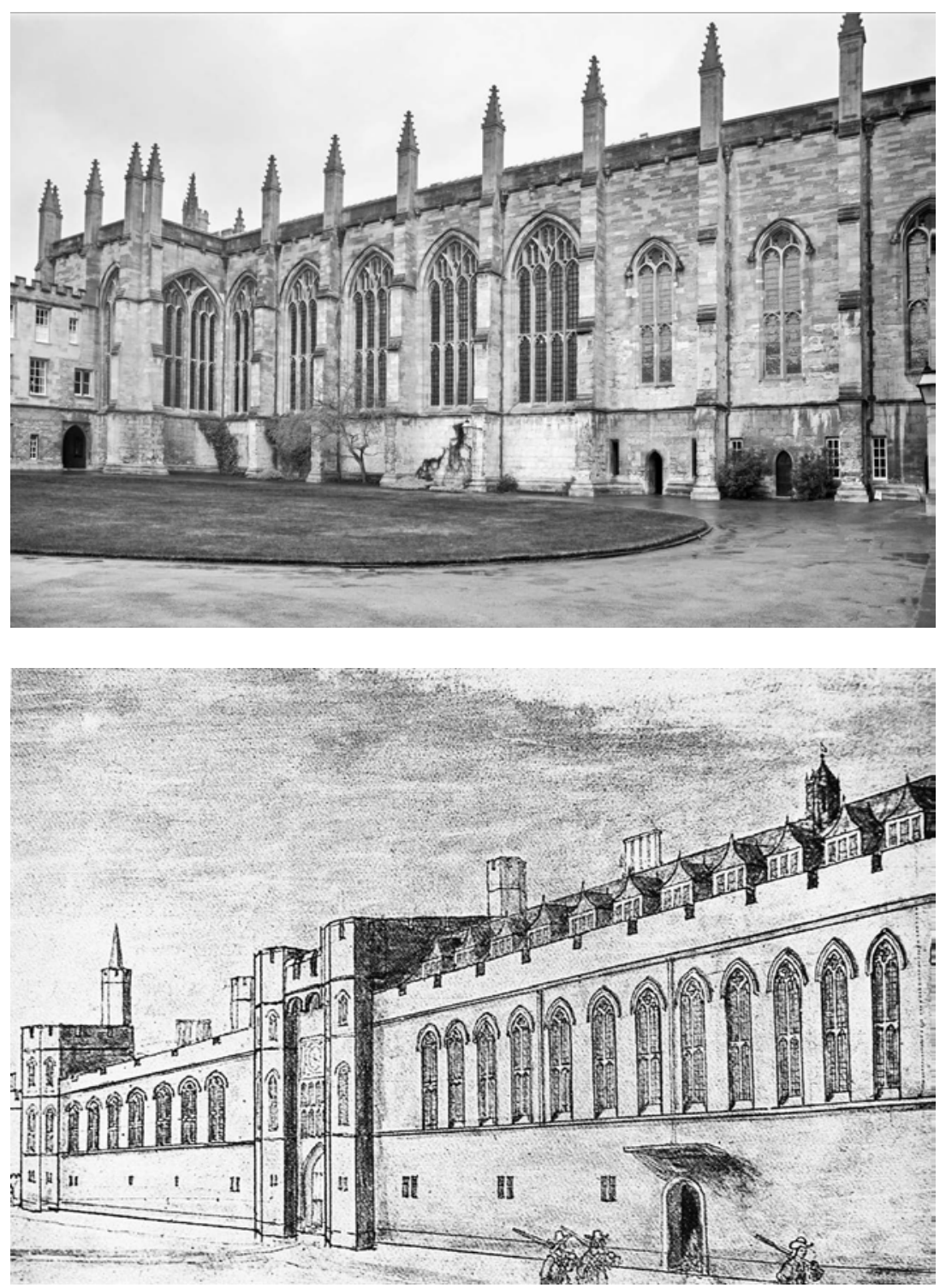

men Mahl erlebt, zu dem sich das gesamte Kollegium im Speisesaal versammelte und einer klaren Sitzordnung folgend Platz nahm. ${ }^{89}$ Eine Ordnung der Gemeinschaft nach akademischen Graden und Disziplinen war auch im Chorgestühl der Kapelle vorgesehen und musste bei den Prozessionen eingehalten werden. ${ }^{90}$ Die Verbundenheit der Mitglieder wurde durch einheitliche Kleidung zum Ausdruck gebracht, die es erlaubte »mit äußeren Zeichen versehen innere Eintracht zu bewahren und in gegenseitiger Nächstenliebe stärker zusammenzuwachsen $« .{ }^{91}$ Die starke Bindung der Mitglieder sollte nach Wykehams Vorstellung letztlich zu einer völligen Verschmelzung des Personenverbands zu einer Einheit, dem Kollegium, füh- ren, das nach dem Vorbild der Jerusalemer Urgemeinde (Apg 4,32) und dem monastischen Gemeinschaftsleben der Augustinerregel (Kap. 1,3), »cor unum et anima una«, agierte. ${ }^{92}$

Architektonisch wurde die Idee der engverbundenen, auf sich konzentrierten, streng geordneten Gemeinschaft in Form einer regelmäßigen geschlossenen Vierflügelanlage umgesetzt, die sich bereits in älteren englischen Colleges als für die kollegiale Lebensform geeignet erwiesen hatte. Im dritten Viertel des 14. Jahrhunderts wurden in Cambridge mit dem Old Court im Corpus Christi College und dem alten Hof des Pembroke College (Abb. 9) erstmals geschlossene Hofanlagen errichtet. ${ }^{93}$ Auch im 


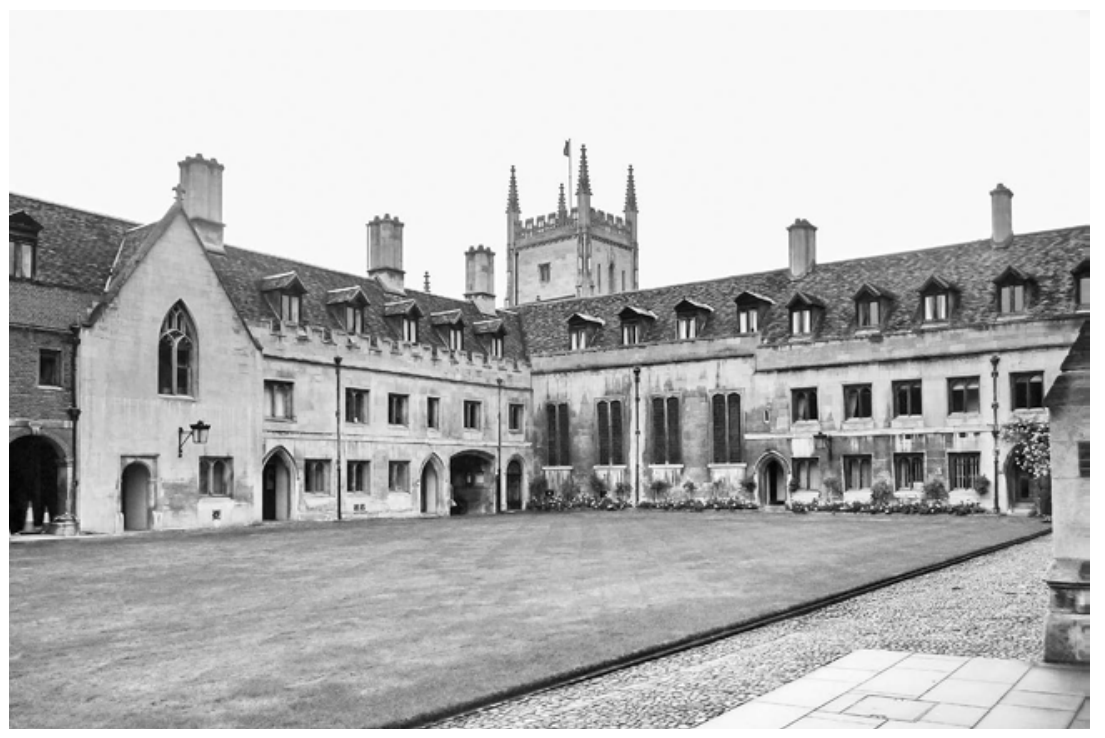

Abb. 9 Cambridge, Pembroke College, Überreste des Old Court (Foto: V. Decker)

Abb. 10 Oxford, New College, Ansicht des Nordtraktes mit Saal und Muniment Tower (Foto: V. Decker)

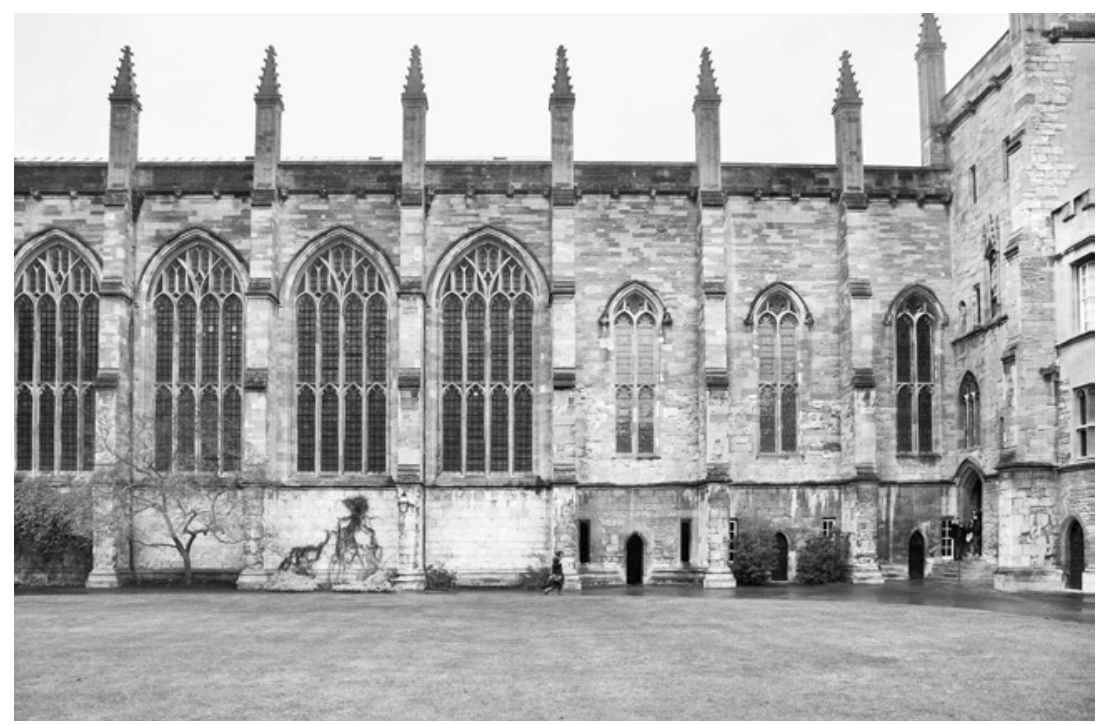

Merton College in Oxford war über mehrere Jahrzehnte sukzessive eine Vierflügelanlage gewachsen, die knapp vor dem Baubeginn des New College 1378 vollendet wurde. $^{94}$

Durch die Übernahme von Raumstrukturen aus dem Palastbau wurde der Raumplan des New College jedoch so neustrukturiert, dass die Kapelle und der Saal in ein neues bauliches Verhältnis zum Gesamtkomplex traten (Abb. 10). Die Monumentalität der Kapelle entsprach ihrer Bedeutung als Sakralraum eines Colleges, das hundert Personen beherbergte und Ort einer großangelegten Memorialstiftung des Bischofs mit sieben täglichen Messen war. ${ }^{95}$ Die Aufwertung des Saals durch einen architektonisch hervorgehobenen Eingangsbereich - er wurde durch den angrenzenden Muniment Tower über eine direkt in den ersten Stock führende, mit einem Sterngewölbe überfangene Treppenfolge betreten - steht Baulösungen im Schloss- und Palastbau des 14. Jahrhunderts nahe.

So gelangte beispielsweise der Besucher des unter Richard II. erneuerten Schlosses in Portchester, Hampshire (1396-99), über eine vorgesetzte Portalanlage direkt in die im ersten Stock gelegene Hall. ${ }^{96}$ Die erhöhte Lage des Saals, die Emery als »sign of status in major episcopal and magnate houses ${ }^{97}$ bezeichnete, und ihr repräsentativer Eingang mit der darüber angebrachten Stiftergruppe gaben dem Ort der Tischgemeinschaft, dem Zentrum des kollegialen Lebens, angemessene bauliche Gestalt. Der 
Saal war somit, anders als im Corpus Christi College zu Cambridge, von den Wohntrakten der Kollegiaten abgesetzt, aber - im Gegensatz zu jenem im Merton College - dennoch Teil der Vierflügelanlage. Da in der Kapelle und im Saal auch die Disputationen abgehalten wurden, fanden somit genau jene Handlungen, die ein akademisches Kollegium nach zeitgenössischen Vorstellungen ausmachten - das gemeinsame Mahl, die Gemeinschaft in Liturgie und Stiftergedenken und der akademische Diskurs - im architektonisch hervorgehobenen Nordtrakt statt. Die aus dem Schlossbau gewonnenen Anregungen zur Monumentalisierung dieses Bauteils trugen daher maßgeblich zur Veranschaulichung der zentralen, identitätsstiftenden Bedeutung jener beiden Räume bei, in denen sich das Kollegium als Gemeinschaft versammelte und in seiner hierarchischen Ordnung als Gruppe definierte.

An der Zusammenarbeit von Wynford und Wykeham in New College ist daher weniger die Tatsache bemerkenswert, dass sie auf ihre gemeinsame Erfahrung im königlichen Schlossbau zurückgriffen, als die Kreativität, mit der bekannte Baulösungen für eine neue Aufgabenstellung adaptiert wurden. Aufgrund seines Aufstiegs aus dem Baumanagement ist Wykeham als Ausnahmeerscheinung unter den bischöflichen Bauherrn zu bezeichnen, ${ }^{98}$ der es gelang, den neugewonnenen gesellschaftlichen Status durch die Bezugnahme auf königliche Projekte zu veranschaulichen. Dies zeigt sich gerade in der Verknüpfung von Wykehams eigener Bautätigkeit mit jener des Königs durch Beauftragung der führenden Baumeister der King's Works. Wie erfolgreich er damit war, erschließt sich nicht zuletzt aus einer kleinen Notiz in einer Rechnungsrolle von New College, die im Februar 1393 den Besuch Johanns von Gent, des Herzogs von Lancaster, mit zahlreichen Gefolgsleuten im College vermerkt. ${ }^{99}$ Der Empfang des einflussreichen Sohns Eduards III. im College macht nicht nur greifbar, wie sehr jener Bau in der Universitätsstadt auch der Repräsentation des Bischofs diente, sondern belegt auch die Anwesenheit gerade einer jener Personen, die den Anspruch des Projekts am besten verstehen und einordnen konnten. Neben dem New College war es bekanntermaßen insbesondere Johanns in den 1370er Jahren in Auftrag gegebener Umbau von Kenilworth Castle, Warwickshire, an dem die leitenden Baumeister die imposante Monumentalität Windsors aufzugreifen und in eigenständiger Weise umzusetzen wussten. $^{100}$

\section{Ungedruckte Quellen}

Oxford, New College Archives, NCA 7333: Computus Bursariorum. 1388-1389.

Oxford, New College Archives, NCA 7340: Computus Bursariorum. 1393.

Oxford, New College Archives, NCA 9303: Liber Senescalli Coquinae. 1386-1397.

Winchester College Archives, WCM 1: Haushaltsrolle des Bischofs von Winchester. April-September 1393.

Winchester College Archives, WCM 22078: Computus magistri Johannis Morys. 1394-1395.

\section{Literatur}

Ayers, Tim: The Medieval Stained Glass of Merton College Oxford. 2 Bde. Oxford 2013 (Corpus Vitrearum Medii Aevi, Great Britain 6).

Bond, Edward Augustus (Hg.): Statutes of the Colleges of Oxford. With Royal Patents of Foundation, Injunctions of Visitors, and Catalogues of Documents relating to the University Preserved in the Public Record Office I. London 1853.

Brindle, Steven/Priestley, Stephen: Edward III's Building Campaigns at Windsor and the Employment of Masons, 1346-1377. In: SAUL 2005, 203-224.

Brown, Reginald Allen/Colvin, Howard Montagu/Taylor, Arnold Joseph (Hgg.): The History of the King's Works. The Middle Ages. 2 Bde., 1 Kartenteil. London 1963.

Brown, Sarah: 'Our Magnificent Fabrick'. York Minster. An Architectural History c 1220-1500. Swindon 2003.

Burgess, Clive: St. George's College, Windsor. Context and Consequence. In: SAUL 2005, 63-96.

Buxton, John/Williams, Penry (Hgg.): New College, Oxford. 1379-1979. Oxford 1979.

[Calendar of Close Rolls 1909]: Calendar of the Close Rolls preserved in the Public Record Office, Edward III, A. D. 13601364. London 1909.

[Calendar of Close Rolls 1913]: Calendar of the Close Rolls preserved in the Public Record Office, Edward III, A. D. 13741377. London 1913.

[Calendar of Patent Rolls 1902]: Calendar of the Patent Rolls preserved in the Public Record Office, Richard II, A. D. 1388-1392. London 1902.

[Calendar of Patent Rolls 1909]: Calendar of the Patent Rolls preserved in the Public Record Office, Edward III, A. D. 1354-1358. London 1909.

[Calendar of Patent Rolls 1911]: Calendar of the Patent Rolls preserved in the Public Record Office, Edward III, A. D. 1358-1361. London 1911. 
[Calendar of Patent Rolls 1912/I]: Calendar of the Patent Rolls preserved in the Public Record Office, Edward III, A. D. 1361-1364. London 1912.

[Calendar of Patent Rolls 1912/II] : Calendar of the Patent Rolls preserved in the Public Record Office, Edward III, A. D. 1364-1367. London 1912.

CARLIN, Martha: The Reconstruction of Winchester House, Southwark. In: London Topographical Record 25 (1985), 33-57.

Cartae de fundatione Collegii Beatae Mariae Wynton in Oxon. Oxford 1879.

CAтto, Jeremy Inch (Hg.): The History of the University of Oxford, Bd. 1: The Early Oxford Schools. Oxford 1984.

Catto, Jeremy Inch/Evans Ralph (Hgg.): The History of the University of Oxford, Bd. 2: Late Medieval Oxford, Oxford 1992.

Colvin, Howard Montagu/Crook, Joseph Mordaunt/Downes, Kerry (Hgg.): The History of the King's Works, Band V, 1660-1782. London 1976.

Courtenay, Lynn T.: The Westminster Hall Roof and its 14th-Century Sources. In: Journal of the Society of Architectural Historians 43 (1984), 295-309.

Crook, John/Kusaba, Yoshio: The Perpendicular Remodelling of the Nave. Problems and Interpretation. In: CROOK 1993 , 215-230.

Crook, John (Hg.): Winchester Cathedral: Nine Hundred Years. 1093-1993. Chichester 1993.

Custanze, Roger (Hg.): Winchester College. Sixth-Centenary Essays. Oxford 1982.

DAvis, Virginia: William Wykeham. A Life. London 2007.

Decker, Veronika: William of Wykeham als Collegegründer und Bauherr. Architektur und Glasmalerei zur Zeit Richards II. Kiel 2017.

Dunlop, George Gerald Derne: Pages from the History of Highclere, Hampshire. Oxford 1940.

Eavis, Anna: The Commemorative Foundations of William of Wykeham. In: Luxford/Mc NeILl 2011, 169-195.

EMERY, Anthony: Greater Medieval Houses of England and Wales 1300-1500. Southern England. Cambridge 2006.

Flöter, Jonas/Ritzi, Christian (Hgg.): Bildungsmäzenatentum. Privates Handeln - Bürgersinn - kulturelle Kompetenz seit der Frühen Neuzeit. Tagung Leipzig, 2005. Köln 2007 (Beiträge zur historischen Bildungsforschung 33).

Freigang, Christian: Werkmeister als Stifter. Bemerkungen zur Tradition der Prager Baumeisterbüsten. In: KLEIN/WOLTER-Von Dem Knesebeck 2002, 244-264.

Gabriel, Astrik L.: Motivation of the Founders at Mediaeval Colleges. In: Wilpert 1964, 61-72.

GeelhaAr, Tim: Stiftungszweck Bildung? Die mittelalterlichen Pariser Universitätskollegien im interkulturellen Vergleich mit der islamischen Madrasa. In: Flöter/Ritzi 2007, 3972 .
Goodall, John: The English Castle 1066-1650. London/New Haven 2011.

Gordon, Dillian / Monnas, Lisa / Elam, Caroline (Hgg.): The Regal Image of Richard II and the Wilton Diptych. London 1997.

Hare, John N.: Bishop's Waltham Palace, Hampshire. William of Wykeham, Henry Beaufort and the Transformation of a Medieval Episcopal Palace. In: The Archaeological Journal 145 (1988), 222-254.

Hare, John: The Architectural Patronage of Two Late Medieval Bishops. Edington, Wykeham and the rebuilding of Winchester Cathedral Nave. In: The Antiquaries Journal 92 (2012), 273-305.

Harvey, John H.: The Wilton Diptych. A Re-examination. In: Archaeologia: or Miscellaneous Tracts relating to Antiquity 98 (1961), 1-28.

Harvey, John H.: The Buildings of Winchester College. In: Custanze 1982, 77-128.

Harvey, John H.: English Mediaeval Architects. A Biographical Dictionary down to 1550. Including Master Masons, Carpenters, Carvers, Building Contractors and Others Responsible for Design. 2. Aufl. London 1987.

Harvey, John H.: Architecture in Oxford 1350-1500. In: CAtto/Evans 1992, 747-768.

Harvey, John H./KING, Dennis: Winchester College Stained Glass. In: Archaeologia: or Miscellaneous Tracts relating to Antiquity 103 (1971), 149-177.

Hayter, William: William of Wykeham. Patron of the Arts. London 1970.

Highfield, John Roger Loxdale: The Promotion of William of Wickham to the See of Winchester. In: Journal of Ecclesiastical History 4 (1953), 37-54.

Highfield, John Roger Loxdale: The Early Colleges. In: Catto 1984, 225-263.

Hingeston-Randolph, Francis Charles (Hg.): The Register of John de Grandisson, Bishop of Exeter (1327-1369). 3 Bde. London 1894.

Hope, William Henry St. John: Windsor Castle. An Architectural History. 3 Bde. London 1913.

JACKson-Stops, Gervase: The Buildings of the Medieval College. In: Buxton/Williams 1979, 147-192.

Keen, Laurence/Scarff, Eileen (Hgg.): Windsor. Medieval Archaeology, Art and Architecture of the Thames Valley. Tagung Windsor Castle, 2002. Leeds 2002 (British Archaeological Association Conference Transactions 25).

Kervyn de Lettenhove, Joseph Marie Bruno (Hg.): Le premier livre des Chroniques de Jehan Froissart. Texte inédit publié d'après un manuscrit de la Bibliothèque du Vatican, Bd. 2. Bruxelles 1863.

Kiene, Michael: Die englischen und französischen Kollegien- 
typen. Universitätsbaukunst zwischen Sakralisierung und Säkularisierung. Diss. Münster 1981.

Klein, Bruno/Wolter-Von Dem Knesebeck, Harald (Hgg.): Nobilis arte manus. Festschrift zum 70. Geburtstag von Antje Middeldorf Kosegarten. Dresden/Kassel 2002.

Knoop, Douglas/Jones, G. P.: The Impressment of Masons in the Middle Ages. In: The Economic History Review Ser. 1, 8 (1937), 57-67.

Lowth, Robert: The Life of William of Wykeham, Bishop of Winchester. London 1759.

Lobel, Mary/Salter, Herbert Edward (Hgg.): The Victoria History of the County of Oxford, Bd. 3. The University of Oxford. London 1954.

Lumby, Joseph Rawson (Hg.): Polychronicon Ranulphi Higden Monachi Cestrensis, together with the English Translations of John Trevisa and of an unknown Writer of the Fifteenth Century, Bd. 8. London 1882 (Chronicles and Memorials of Great Britain and Ireland during the Middle Ages 41,8).

Luxford, Julian/Mc Neill, John (Hgg.): The Medieval Chantry in England. Tagung Oxford, April 2009. Leeds 2011 (The Journal of the British Archaeological Association 164).

Marks, Richard: Stained Glass in England during the Middle Ages. Toronto 1993.

Munby, Julian: Carpentry Works for Edward III at Windsor Castle. In: SAUL 2005, 225-237.

Munby, Julian/BArber, Richard/Brown, Richard: Edward III's Round Table at Windsor. The House of the Round Table and the Windsor Festival of 1344. Woodbridge 2007 (Arthurian Studies 68).

Munby, Julian: The Late-14th-Century Reconstruction of Westminster Hall. In: Rodwell/TAT TON-Brown 2015, 120-132.

Ormrod, William Mark: For Arthur and St. George. Edward III, Windsor Castle and the Order of the Garter. In: SAUL 2005, 13-34.

PAge, Mark: The Medieval Bishops of Winchester: Estate, Archive and Administration. Winchester 2002 (Hampshire Papers 24).

Pantin, William Abel: The English Church in the Fourteenth Century. Cambridge 1955.

Phillpotts, Christopher: Plague and Reconstruction: Bishops Edington and Wykeham at Highclere, 1346-1404. In: SAUL 2000, 115-129.

RASHDALL, Hastings/RaIt, Robert Sangster: New College. London 1901 (University of Oxford: College Histories).

RoACH, John (Hg.): The Victoria History of the County of Cambridge and the Isle of Ely, Bd. 3. City and University of Cambridge. London 1959.

Rodwell, Warwick/Tatton-Brown, Tim (Hgg.): Westminster. The Art, Architecture and Archaeology of the Royal
Palace. Tagung London, Juli 2013. Leeds 2015 (British Archaeological Association Conference transactions 39, 2).

Roberts, Edward: William of Wykeham's House at East Meon, Hants. In: The Archaeological Journal 150 (1993), 456-481.

Rogers, James Edwin Thorold (Hg.): Oxford City Documents, Financial and Judicial 1268-1665. Oxford 1891 (Oxford Historical Society Series 18 ).

Salzman, Louis F.: Building in England down to 1540. A Documentary History. Oxford 1952.

SAUL, Nigel: Richard II. New Haven / London 1999.

SAul, Nigel (Hg.): Fourteenth Century England, Bd. I. Woodbridge 2000 .

SAul, Nigel (Hg.): St. George's Chapel, Windsor, in the Fourteenth Century. Tagung Windsor Castle, 11.-13. 9.2002. Woodbrigde 2005.

Siddons, Michael Powell: Heraldic Badges in England and Wales. 3 Bde. Woodbridge 2009.

Spooner, Jane: An admonitory wall painting at the Tower of London. In: The Burlington Magazine 158 (2016), 940-949.

Stratford, Jenny: Richard II and the English Royal Treasure. Woodbridge 2012.

TAIt, James (Hg.): Chronica Johannis de Reading et Anonymi Cantuariensis 1346-1367. Manchester 1914 (Publications of the University of Manchester. Historical Series 20).

Weijers, Olga: Collège, une institution avant la lettre. In: Vivarium 21 (1983), 73-82.

Wickнam-Legg, Leopold: Windsor Castle, New College, Oxford, and Winchester College. A Study in the Development of Planning by William of Wykeham. In: The Journal of the British Archaeological Association Ser. 3, 4 (1938), 83-95.

Willis, Robert: The Architectural History of Winchester Cathedral. London 1846 (Proceedings at the Annual Meeting of the Archaeological Institute of Great Britain and Ireland).

Willis, Robert: The Architectural History of the University of Cambridge and the Colleges of Cambridge and Eton, hg. v. John Willis CLARK. 4 Bde. Cambridge 1886.

Wilpert, Paul (Hg.): Beiträge zum Berufsbewusstsein des mittelalterlichen Menschen. Vorträge der Kölner Mediaevistentagungen 1960 und 1962. Berlin 1964 (Miscellanea mediaevalia 3).

Wilson, Christopher: Rulers, Artificers and Shoppers. Richard II's Remodelling of Westminster Hall, 1393-99. In: Gordon/Monnas/Elam 1997, 33-59.

Wilson, Christopher: The Royal Lodgings of Edward III at Windsor Castle: Form, Function, Representation. In: KeEN/ SCARFF 2002, 15-94.

Woodforde, Christopher: The Stained Glass of New College Oxford. Oxford 1951. 


\section{Anmerkungen}

1 Dieser Artikel beruht auf meinem Beitrag für die Sektion »Zentralisierung und Diversifizierung. Englische Kunst im Schatten des Hundertjährigen Krieges, ca. 1350-1450 « beim Forum Kunst des Mittelalters 2013 in Freiburg im Breisgau und wertet Teile meiner Dissertation aus, die nun in publizierter Form vorliegt: DeCKER 2017.

2 Brindle/Priestley 2005, 203f. - Munby 2005, 227 f. - Munby/ BArber/Brown 2007. - Goodall 2011, 283.

3 Ormrod 2005, 20. - Goodall 2011, 283.

4 Zur Geschichte des Kollegiums Burgess 2005.

5 Brown/Colvin/Taylor 1963, II, 872-880. - Wilson 2002, 16 . GoOdALL 2011, 283-285.

6 Brown/Colvin/Taylor 1963, II, 881. - Wilson 2002, 15-17. Das Lösegeld wurde von den Franzosen zwischen 1360 und 1369 im Umfang von einer Viertelmillion Pfund gezahlt.

7 Knoop/Jones 1937, 57 Anm. 3. - Brown/Colvin/TAYlor 1963, I, 180-185. - Brindle/Priestley 2005, 213-215.

8 Calendar of Close Rolls 1909, 88 f., 178 f. - Brindle/Priestley $2005,213 \mathrm{f}$

9 Übersetzung der Verfasserin. „Omnes enim fere latomi et carpentarii per totam Angliam ad illam aedificationem fuerunt adducti, ita quod vix aliquis posset habere aliquem bonum latomum vel carpentarium nisi in abscondito propter regis prohibitionem. « LuMBY 1882, 359. Vgl. Brown/Colvin/TAYlor 1963, I, 184.

10 Goodall 2011, 282, 287-289.

$11 \mathrm{Zu}$ den von Wykeham beauftragten Bauten: HAYTER 1970. - JACKson-Stops 1979. - Harvey 1982. - Hare 1988. - Crook/Kusaba 1993. - Roberts 1993. - Phillpotts 2000, 123-129. - Eavis 2011. - Hare 2012. - Decker 2017.

12 WickHAM-Legg 1938 , bes. 87-89.

13 Jackson-Stops 1979, 151. - Kiene 1981, 142 f. - Emery 2006, 143, 205. - EAVIS 2011, $181 \mathrm{f}$. - Wilson hingegen hebt einige Unterschiede hervor: Wilson 2002, 80.

14 Übersetzung der Verfasserin. »Fuerat autem dictus Willelmus Wikham de infimo genere, ut puta dicebatur servilis conditionis, tamen fuit multum astutus et vir magnae industriae. Videns qualiter possit regi placere et ipsius benevolentiam adipisci, consuluit regi dictum castrum de Windeshore taliter sicut hodie patet intuenti aedificare." Lumby 1882, Appendix, $359 \mathrm{f}$.

15 »Circa annum Domini millesimum trecentesimum quinaquagesimum nonum dominus rex, ad instigationem Willelmi Wikham clerici, in castro de Wyndeshore multa bona aedificia fecit prosterni, et alia plura pulchra et sumptuosa aedificari.« Lumby 1882, Appendix, 359

16 Übersetzung der Verfasserin. "Et pour avanchier les ouvrages de Windesore qui furent empris pour faire et commenchier, l'an de grâce mille CCC et XLIII, ouvrier furent envoyet querre parmi tout le roiaulme d'Engleterre, et mis en œvre et payet et délivret au samedi, et eurent chil ouvrier un clerc qui entendoit sus euls et qui les faisoit payer, lequel on appella Willaume Wiquam, et chils fu depius si grans mestres en Engleterre que évesques et canceliers, et se passoient toutes coses par lui, et fu tellement en la grâce dou roi que par lui, son temps durant, fu tout fait en Engleterre, et sans li n'estoit riens fait.« Kervyn De Lettenhove 1863, Kap. CLXXII, 126.
$17 \mathrm{Zu}$ Wykehams Biografie liegt eine rezente Monografie vor: DAvis 2007.

18 DAVIS 2007, 1-7.

19 Calendar of Patent Rolls 1909, 383. - DAVIS 2007, 17.

20 Calendar of Patent Rolls 1909, 463.

21 Calendar of Patent Rolls 1909, 463. - Der lateinische Text wurde in Hope 1913, I, 204, Anm. 2, abgedruckt.

22 Wilson 2002, 17. - Brindle/Priestley 2005, 213. - Diese sind in Hope 1913, I, 212-219, publiziert.

23 Hope 1913, I, 182, 212-219. - Wilson 2002, 16, 28, 54, 83, Anm. 37. - Brindle/Priestley 2005, 210-213.

24 Hope 1913, I, 181 f., 215. - Brindle/Priestley 2005, 211.

25 Hope 1913, I, 185, 206. - Brindle/Priestley 2005, 215.

26 Wilson 2002, 30 f., 55.

27 Calendar of Patent Rolls 1911, 243.

28 Calendar of Patent Rolls 1912/I, 444. - DAVIS 2007, 31.

29 Calendar of Patent Rolls 1912/II, 97.

30 DAVIS 2007, 26-30, 41-50.

31 DAvis 2007, 51.

32 "Cui sedi papa, literis aureis pulsatus ac precibus, providit de quodam serviente domini regis Willelmo Wikham, timore plus quam amore pulsatus relicitis dignioribus praeelectis. «TAIT 1914, 178.

33 Als »trescher clerc « bezeichnete Eduard Wykeham in einem Brief an den Papst im Zuge seiner Bemühungen um dessen Bestellung zum Bischof von Winchester: Highfield 1953, 47, Dokument in Appendix 2

34 Page 2002, 2. - Davis 2007, 120.

35 JACKSON-STOPS 1979, 151.

36 Hope 1913, I, 218. - Brown/Colvin/Taylor 1963, I, 213.

37 Brown/Colvin/Taylor 1963, I, 213. Harvey 1987, 138. Brindle/Priestley 2005, 220. - Goodall 2011, 319.

38 So sind in der Rechnungsrolle von New College für den Zeitraum 1388/89 Ausgaben für »in rewardis Datis Dispensatori pro diversis victualibus per ipsum emptis custode Magistro Nicolao Wykeham Magistro Hugoni Herlond et Willelmo Wynford diversis temporibus ad Collegium venientibus iiii s« verzeichnet. Oxford, New College Archives, NCA 7333. - Transkription nach JACKson-Stops 1979 160. - Deren Anwesenheit in New College ist auch vermerkt in: NCA 9303 (Liber Senescalli Coquinae, 1386-1397). - Zu Winchester College z. B. Winchester College Archives, WCM 22078 (Computus magistri Johannis Morys, 1394-1395). - Zu den Quellen zu Highclere DUNLOP 1940, 57. - Zu Bishop's Waltham HARE 1988, 239.

39 In seinem Testament legte Wykeham 1403 fest, dass die »dispositio et ordinatio « des neuen Werks der Kathedrale von Winchester nach seinem Tod in Wynfords Händen liegen sollte. Es spricht alles dafür, dass Wynford bereits zu Wykehams Lebzeiten den Umbau leitete. Das am 24. Juli 1403 erstellte Testament wurde von Robert Lowth publiziert: Low

40 Roberts 1993, 464.

41 Brown/Colvin/Taylor 1963, I, 213.

42 Calendar of Patent Rolls 1902, 237. - Brown/Colvin/Taylor 1963, I, 213.

43 Brown/Colvin/Taylor 1963, I, 178, 210.

44 Calendar of Close Rolls 1913, 59.

45 Brown/Colvin/Taylor 1963, I, 210. - Harvey 1987, 360. 
46 Carlin $1985,37$.

47 Brown/Colvin/Taylor 1963, I, 210. - Hare 1988, 239.

48 Die Nähe zur königlichen Kunstproduktion lässt sich auch im Medium der Glasmalerei nachvollziehen. Die Arbeiten des in New College und Winchester College tätigen Glasmalers Thomas können als wichtiges Vergleichsbeispiel zur Datierung der vermutlich während der Regierungszeit Richards II. entstandenen Wandmalereien im Byward Tower des Towers of London herangezogen werden: MARKs 1993, 174. - EAVIS 2011, 180. - SPOONER 2016, 942.

$49 \mathrm{Zu}$ Herlands Decken in Westminster und Winchester: Courtenay 1984. - WiLson 1997, 55-59.

50 Munby 2015, 123.

51 Zur Bauchronologie: Willis 1846, 54-75. - СRоoK/KusabA 1993. - Hare 2012. - Decker 2017, 70-107.

52 HARe 2012, 10.

53 Zur Hirschdevise Richards II. Siddons 2009, II, 1, 134-142.

54 Nur ein geringer Teil der ursprünglichen Gesimsfiguren in Westminster Hall ist original erhalten. Viele wurden im 19. Jahrhundert kopiert oder überarbeitet: Harvey 1961, 5, Anm. 8, 8, Anm. 2. Siddons 2009, II, 1, 140. Wie in der Westminster Hall ist der Leopard statant guardant dargestellt und trägt - soweit der Erhaltungszustand erkennen lässt - keine Krone.

55 Eine Abbildung des Kapitells findet sich bei Brown 2003, 177 Abb. 5.11, und Decker 2017, 102, Abb. 38.

56 Abbildung der Hirschdarstellungen in Westminster Hall bei HARVey 1961, Abb. 10b, und Decker 2017, Abb. 33 - Erhalten ist der Vertrag mit den Steinmetzen, die die Bauplastik am Gesims nach einer "forme et molde faitz par conseil de Mestre Henri Yeveley» anfertigen sollten: SAlzman 1952, Appendix B, 472. - Dazu auch: WiLson 1997, 46, 282, Anm. 58.

57 Siddons 2009, II, 1, 134.

58 Diese drückte Wykeham, der unter der Herrschaft Richards II. erneut Lordkanzler (1389-91) und danach auch weiterhin ein wichtiger Berater des Königs war, auch durch die Gabe von kostbaren Geschenken an den König aus. Unter diesen befanden sich auch zwei mit Hirschen geschmückte Trinkgefäße: STRATFord 2012, $101 \mathrm{f}$. - Zu Richards Darstellung im Ostfenster der College-Kapelle EAvis 2011, 179 f. - DeCKER 2017, 302-305.

59 Richard II. war im Winter 1393, als das Parlament in Winchester tagte, für einen längeren Zeitraum in der Stadt, wo sein Haushalt im Palast des Bischofs von Winchester untergebracht wurde. Er verbachte auch den Sommer dieses Jahres teilweise in der Diözese Winchester und wurde am 25. Juli 1393 und am 16.-17. September 1393 vom Bischof empfangen: Winchester College Archives, WCM 1 (Haushaltsrolle des Bischofs, 1393). Harvey 1961, 12. - Davis 2007, 93 f., 138 f. Zum Aufenthalt Richards in Winchester im Mai 1395: SAUL 1999, 473.

60 Woodforde 1951, 4. Er ist in dem seit 1386 im New College geführten Liber Senescalli Coquinae regelmäßig als Gast im Speisesaal: Oxford, New College Archives, NCA 9303 (Liber Senescalli Coquinae, 1386-1397).

61 Marks 1993, 171-174. - Eavis 2011, 180. - Decker 2017, 58-60.

62 WOODFORDE 1951, 4-8. - MARKS 1993, 173.

63 Woodforde 1951, 6. - Marks 1993, 173. - Ayers 2013, I, lxxxi.

64 Dunlop 1940, 57. - HaRe 1988, 241.

65 Winchester College Archives, WCM 1 (Haushaltsrolle des Bischofs, 1393). Der Eintrag befindet sich auf der Rectoseite der Rolle ohne
Angabe eines Datums: "In expensis .ij. chariettorum de Esshere usque Oxoniam et de ibidem usque Clere et Wyntoniam cariantium vitrum pro fenestris Collegii domini Wyntonie per .ix. dies cum .xij. equis et .vj. hominibus charettivis, xix.s. iij. d.« Transkription nach Harvey 1961, 11, Anm. 1.

66 WoOdforde 1951, 102. - Die erhaltenen Fragmente des ursprünglichen Westfensters von New College befinden sich heute in einem Chorfenster (sVIII) im York Minster.

67 Ayers 2013, I, lxxxi.

68 Lowth 1759, xxxvii.

69 Die Heilige befindet sich heute im nördlichen Seitenschiff des Langhauses der Kathedrale. Die einzigen drei erhaltenen Figuren aus den Süd- und Nordfenstern der Kapelle von Winchester College werden heute im Victoria and Albert Museum in London aufbewahrt. Bei den Scheiben in der Kapelle handelt es sich um Kopien des 19. Jahrhunderts.

70 Marks 1993, 178. - Ayers 2013, I, lxxxi; II, 277, 282.

71 JACKSON-STOPS 1979, 152.

72 HARE 1988, 239.

73 Harvey 1987, 139, 354, 364.

74 Winchester College Archives, WCM 1 (Haushaltsrolle des Bischofs von Winchester, 1393).

75 Hingeston-Randolph 1894, I, 219.

76 Zum ursprünglichen Ostfenster der Kapelle Harvey/King 1971. - Decker 2017, 189-196. - Christian Freigang untersuchte die Tradition der gemeinsamen Kommemoration von Architekten und Bauherrn und deren bildliche Vergegenwärtigung ausgehend vom Büstenzyklus im Prager Veitsdom: Freigang 2002.

77 Zur Stellung des Baus in der Typengeschichte der Universitätsarchitektur: Willis 1886, III, 256. - Kiene 1981, 90-94. - Harvey 1992, 754-756. - EMERY 2006, 143.

78 Die Ansicht Loggans zeigt den Zustand der Wohntrakte vor deren Erhöhung um ein Geschoß im späten 17. Jahrhundert: JACKsoNStops 1979, 199.

79 Eine erhaltene Rechnungsrolle dokumentiert den Bau des Turms 1397: Rogers 1891, 306-314. Erst zu diesem Zeitpunkt erfolgte auch der Ankauf von Grundstücken westlich der Kapelle zur Errichtung des Kreuzgangs.

80 Colvin 1976, 315-328.

81 WILSON 2002, $20 \mathrm{f}$.

82 Wickham-Legg 1938, 86 f. - Wilson 2002, 39. - Emery 2006, 143. - EAVIS 2011, $118 \mathrm{f}$.

83 Wickham-Legg 1938, 87 f. - EAvis 2011, $118 \mathrm{f}$.

84 Zahlungen an den Bildschnitzer John Lindsey und John »the king's painter « sowie den Hofmaler William Burdon zwischen 1365 und 1367 geben Aufschluss über Kosten, Material und farbige Fassung des Retabels in Windsor: WiLson 2002, 38.

85 WILSON 2002, 58.

86 Bereits bemerkt bei WILSON 2002, 80 .

87 Cartae de fundatione Collegii Beatae Mariae Winton (1879), 15.

88 Wykeham ließ die Statuten seines Colleges mehrfach überarbeiten. Die letzte Fassung entstand um 1400 und ist abgedruckt in BonD 1853, Kap. 5, i-121. - Zu mittelalterlichen Kollegien und den ersten Gründungen in Oxford: Gabriel 1964. - Weijers 1983. - HighFIELD 1984. - Zum Motto des Collège de la Sorbonne: GeElHAAR $2007,52$. 
89 Die Bedeutung der Tischgemeinschaft wird beispielsweise in den Statuten von Merton College, Oxford, Oriel College, Oxford, und New College speziell hervorgehoben: Bond 1853, Kap. 2, 26; Kap. 3, 7; Kap. 5, 35. - Zur Sitzordnung im Saal des New College: Kap. 5 , 40.

90 Bond 1853, Kap. 5, $79 \mathrm{f}$.

91 Übersetzung der Verfasserin nach den Statuten des New College: Bond 1853, Kap. 5, 44.

92 Bond 1853, Kap. 5, 2 f.

93 Willis 1886, III, 256. - RoACH 1959, 347. - Kiene 1981, 122-124.

94 Lobel/Salter 1954, 100-102. - Emery 2006, 136.

95 Zum Memorialaspekt des Colleges Eavis 2011, $175 \mathrm{f}$.

96 Emery 2006, 386-396.

97 Emerr 2006, 143.
98 Während in England in der zweiten Hälfte des 14. Jahrhunderts zwar sehr viele Bischöfe zuvor in der königlichen Verwaltung tätig gewesen waren, war der Karrierweg über den Bereich der Bauverwaltung höchst ungewöhnlich. Zu den Karrierewegen der englischen Bischöfe im 14. Jahrhundert Pantin 1955, bes. 11.

99 Oxford, New College Archives, NCA 7340 (Computus Bursariorum, 1393): "Et in expensis factis pro Domino Duce Lancastriae cum iiij militibus et aliis multis de familia sua venientibus ad collegium xiij die Februarii, viz. in ij libris de confectis, et dimidio librae dragetorum, et vj lagenis vini, vj s. x d.« - LowTH 1759, 205.

100 Wilson 2002, 81. - Goodall 2011, 292-296. Der Umbau wurde von Henry Spenser und William Wintringham geleitet, die beide zuvor in Windsor tätig gewesen waren. 
Julia Crispin

\title{
Politische Botschaften und illustre Geschenke
}

\author{
Richard Beauchamps Handschriftenpatronage \\ ZWischen England und Frankreich zur Zeit des Hundertjährigen Krieges ${ }^{1}$
}

Das Bild Richard Beauchamps, des dreizehnten Grafen von Warwick und eines der politisch einflussreichsten Akteure der dritten Phase des sogenannten Hundertjährigen Krieges, ${ }^{2}$ ist vor allem von zwei Faktoren geprägt: Auf der einen Seite stehen seine militärischen Aktivitäten auf dem Kontinent im Dienste des englischen Königshauses Lancaster in den Auseinandersetzungen um die Krone Frankreichs und vor allem seine Erfolge auf dem Parkett internationaler Verhandlungen. ${ }^{3}$ Auf der anderen Seite ist er als Auftraggeber und Förderer literarischer, insbesondere englischer Handschriften bekannt. ${ }^{4}$ Tatsächlich scheinen diese beiden Punkte jedoch enger verzahnt zu sein als bisweilen angenommen: So lassen sich nicht nur englische, sondern auch verschiedene französische Werke, die im Rahmen seiner Tätigkeiten auf dem Festland entstanden, mit der Auftraggeberschaft des Grafen von Warwick verbinden oder wurden zumindest von ihm genutzt.

Eben diese Nutzung von Handschriften zu unterschiedlichen Zwecken steht im Fokus der vorliegenden Studie. Hierbei ist nicht nur der jeweilige Textinhalt, sondern auch die in einigen Fällen nachweisbare illustrative Ausstattung der betreffenden Werke von Interesse. Eine maßgebliche Rolle spielen der Nutzungskontext, d. h. das internationale wie auch innerenglische politische und kulturelle Geschehen, sowie Beauchamps Positionierung darin. Funktion und Kontext der Handschriften sind zudem eng mit der Frage nach ihren jeweiligen Rezipienten verwoben. Diese variierten bisweilen stark und sollen im Einzelnen erörtert werden.

Einen zweiten Schwerpunkt der vorliegenden Untersuchung stellt die Frage nach dem Beitrag des Grafen von Warwick zu den kulturellen Strömungen zwischen England und Frankreich im Spätmittelalter sowie zum Transfer politischer Ideen über den Kanal hinweg dar. Es wird also einerseits danach gefragt, inwieweit die von Beauchamp in Auftrag gegebenen Werke zur Vermittlung literarischer, künstlerischer und liturgischer Traditionen und Entwicklungen beitrugen. Zum anderen ist zu disku- tieren, ob und auf welche Weise der Graf Handschriften nutzte, um politische Konzepte und Botschaften über die Reichsgrenzen hinweg zu verbreiten, und welche Rolle Kunst, in diesem Falle Buchmalerei beziehungsweise die Illustration von Texten allgemein, bei der Visualisierung seiner politischen Vorstellungen spielte. Es versteht sich von selbst, dass auch hinsichtlich der Frage nach Beauchamps Beitrag zum Kulturtransfer zwischen England und Frankreich seine Funktionen in der Regierung Englands wie in der Verwaltung der France Anglaise von maßgeblicher Bedeutung sind. ${ }^{5}$ Ein Abriss seines politischen Werdegangs und seiner hiermit im Zusammenhang stehenden kulturellen Kontakte wird daher den Anfang der folgenden Überlegungen bilden.

\section{Politischer Werdegang und kulturelles Umfeld}

Beauchamps Vita und sein politischer Werdegang können aufgrund einer großen Anzahl zeitgenössischer Schriftquellen verhältnismäßig gut rekonstruiert werden. ${ }^{6}$ Der im Jahr 1382 geborene Sohn Thomas Beauchamps unterstützte Henry Bolingbroke of Lancaster, den späteren Heinrich IV., im Sommer 1399 bei der Usurpation des englischen Throns. Seine Loyalität gegenüber dem Hause Lancaster zahlte sich insbesondere seit der Regierungsübernahme Heinrichs V. im Jahr 1413 und der Wiederaufnahme der militärischen Unternehmungen der Engländer auf dem Kontinent aus. Als enger Vertrauter des Königs wurde er 1414 zum Captain of Calais und damit zum Träger eines der einflussreichsten und prestigeträchtigsten Ämter der France Anglaise ernannt. Außerdem wurde er mit zahlreichen diplomatischen Missionen betraut, etwa den Vorverhandlungen zum Vertrag von Troyes. ${ }^{7}$

Mit dem Tod Heinrichs V. im August 1422 nahm Beauchamps Einfluss keineswegs ab. Vielmehr gehörte er seit Dezember dieses Jahres dem Kronrat des wenige Monate alten Heinrich VI. an. In den folgenden Jahren bekleidete er zahlreiche hochrangige militärische Ämter im besetzten 
Frankreich, insbesondere der Normandie, und setzte sich für die Durchsetzung der Ansprüche des jungen Königs auf die französische Krone und die Etablierung einer dauerhaften Herrschaft im besetzten Gebiet ein. ${ }^{8}$ Hierbei arbeitete er eng mit John of Lancaster, dem Herzog von Bedford, der anstelle seines unmündigen Neffen Heinrich die Regentschaft in Frankreich innehatte, und John Talbot, dem Grafen von Shrewsbury und Ehemann von Beauchamps ältester Tochter Margaret, zusammen. ${ }^{9}$ Sowohl Bedford als auch Talbot sind von großem Interesse, wenn es um die Frage nach möglicherweise vorbildhaft wirkenden Auftraggebern und Sammlern illuminierter Handschriften in Beauchamps höfischem und politischem Umfeld geht.

Verpflichtungen in der Verwaltung seiner umfangreichen englischen Ländereien und innerenglische politische Auseinandersetzungen erforderten zudem die regelmäßige, zum Teil mit längeren Aufenthalten verbundene Rückkehr des Grafen von Warwick auf die Insel. Überdies wurde er am 1. Juni 1428 zum persönlichen Gouverneur und Tutor Heinrichs VI. ernannt. ${ }^{10}$ Dieses illustre Amt brachte seine Gegenwart bei den Krönungen des jungen Königs in exponierter Position mit sich: Er trug ihn persönlich zu seiner Krönung zum englischen König durch den Kardinal und Bischof von Winchester Henry Beaufort in Westminster Abbey am 6. November 1429 und nahm an der fast zwei Jahre währenden Krönungsexpedition teil, die Heinrich im April des folgenden Jahres nach Calais und von hier aus über Rouen nach Paris zu seiner Krönung zum französischen König führte. ${ }^{11}$

In den Jahren 1432 und 1434 wurde Beauchamps Ernennung zum Tutor Heinrichs erneuert und bestätigt und damit die die Erziehung des Königs betreffenden Abmachungen revidiert. Dies stand sehr wahrscheinlich mit dem zunehmenden, unerwünschten Einfluss Humphreys of Gloucester, Heinrichs Onkel, in Verbindung. ${ }^{12}$ Humphrey hatte durch seine Auseinandersetzungen mit Philipp dem Guten um Holland, Zeeland und den Hennegau bereits in den 1420er Jahren für Konfliktpotential gesorgt und dadurch die von Bedford und Beauchamp angestrebte anglo-burgundische Allianz in Gefahr gebracht. Im Rahmen innenpolitischer Auseinandersetzungen zwischen dem hocheinflussreichen Kardinal Beaufort und dem Herzog von Gloucester um die Autorität im englischen Kronrat in den 1430er Jahren kann Beauchamp ebenfalls im politischen Lager Bedfords und Beauforts verortet werden. ${ }^{13}$

Auf außenpolitischer Ebene jedoch brachten die Entwicklungen der Mitte der 1430er Jahre - der Tod des
Herzogs von Bedford im September 1435 und der Kongress von Arras, der bekanntermaßen den Zusammenbruch des anglo-burgundischen Bündnisses und den für die Engländer fatalen Friedensschluss zwischen Burgund und Karl VII. besiegelte, - eine Kooperation Beauchamps und Herzog Humphreys mit sich: Im August 1436 beteiligte sich der Graf an einer militärischen Expedition Humphreys nach Calais und Flandern gegen den burgundischen Herzog Philipp. ${ }^{14}$ Im Jahr 1437 wurde Beauchamp als Lieutenant General of France and Normandy ein letztes Mal auf den Kontinent geschickt, wo er bis zu seinem Tod im April 1439 in Rouen blieb. ${ }^{15}$

\section{Beauchamps Handschriften - Funktionen und Nutzungsumfeld}

Im Folgenden soll untersucht werden, zu welchen Zwecken und in welchem Rahmen Richard Beauchamp illuminierte Handschriften nutzte und welche Rezipienten jeweils angenommen werden können. Hierbei wird es sowohl um originäre Aufträge als auch um Übersetzungen und Abschriften bereits bestehender Texte gehen. Von Interesse sind dabei nicht nur erhaltene Werke, sondern auch verlorene, aber in Teilen rekonstruierbare Handschriften und Texte, ebenso wie allgemeine Hinweise zu Beauchamps Buchbesitz und seiner Bildung. Darüber hinaus lassen sich anhand von Aufträgen aus seinem kulturellen Umfeld unter Vorbehalt Vermutungen zur Nutzung der Werke anstellen. Diese können überdies Auskunft darüber geben, ob und in welcher Form nicht mehr erhaltene, von Beauchamp in Auftrag gegebene Werke illuminiert waren.

Zunächst soll ein Blick auf eine englische Handschrift geworfen werden, die heute in der Morgan Library in New York aufbewahrt wird, die so genannten Psalter and Hours of Henry Beauchamp. ${ }^{16}$ Für die mit 22 halbseitigen Miniaturen und umfangreicher Randdekoration ausgestattete Psalter-Stundenbuch-Kombination nach englischem Gebrauch kann Richard Beauchamp zwar als Auftraggeber nicht nachgewiesen, aber doch vermutet werden. $\mathrm{Zu}$ Beginn des Marienoffiziums auf Folio 12r wurde die Handschrift mit den kaum noch lesbaren Einträgen "Warrewyk « und "Deserving causyth», dem Motto von Beauchamps im Jahr 1425 geborenem Sohn und Nachfolger Henry, versehen. Die weitestgehend einhellige stilistische Verortung der Illumination in die Londoner Buchmalerei der frühen 1430er Jahre fügt sich 
zwar in die oben ausgeführte, wiederholte und auch längerfristige Tätigkeit Richard Beauchamps auf der Insel, spricht jedoch gegen seinen zu diesem Zeitraum noch minderjährigen Sohn als Auftraggeber. Stattdessen ist es denkbar, dass der Auftrag der Handschrift durch den Vater als Geschenk für Henry erfolgte. ${ }^{17}$ Hierauf weist auch die Miniatur der Gregorsmesse auf Folio 106r, die ein Gebet an den gekreuzigten Christus, die sogenannten Fünfzehn Os der Heiligen Birgitta von Schweden, einleitet (Taf. 6). Die Miniatur zeigt zwei kniende Betende - einen Mann mittleren Alters und einen Jungen -, und es ist nicht unwahrscheinlich, dass es sich hierbei um Richard und Henry Beauchamp handelt. Heraldische Symbole wie Wappen oder Devisen, die eine solche Identifizierung stützen könnten, sind jedoch nicht vorhanden. ${ }^{18}$

Insgesamt scheint die öffentliche oder gar politische Selbstdarstellung des Auftraggebers oder Nutzers anhand der Illumination keine für dieses Werk vorgesehene Funktion gewesen zu sein - wenn man von dem Prestige, das eine verhältnismäßig kostspielige, illuminierte Handschrift grundsätzlich mit sich brachte, absieht. ${ }^{19}$ Stattdessen diente das Gebetsbuch in erster Linie seinem eigentlichen Zweck, nämlich als Hilfsmittel zur privaten Andacht im alltäglichen Gebrauch, und es ist anzunehmen, dass es zwar gezeigt wurde, allerdings beschränkt auf den engeren familiären und höfischen Umkreis. ${ }^{20}$

Das Beauchamp-Gebetsbuch steht mit seinem privat-familiären Zweck im Gegensatz zu einer Handschrift, der im Rahmen der Patronage Beauchamps bisher wenig Beachtung geschenkt wurde: Es handelt sich um eine heute in der Bibliothèque nationale in Paris aufbewahrte illuminierte Version einer Übersetzung von Giovanni Boccaccios Decamerone ins Französische. ${ }^{21}$ Dem Prolog ist zu entnehmen, dass die Übersetzung des Texts 1414 durch Laurent de Premierfait in Paris angefertigt wurde. Ein Eintrag am Ende des Texts informiert darüber, dass Humphrey, der Herzog von Gloucester, das Buch von Beauchamp als Geschenk erhalten habe: »Cest livre est à moy Homfrey, duc de Gloucestre, du don mon treschier cousin le conte de Warrewic «. ${ }^{22}$ Die Illumination kann in die Normandie in das zweite Viertel des 15. Jahrhunderts lokalisiert werden; der Tod Beauchamps im Jahr 1439 liefert unter Vorbehalt einen Terminus ante quem. ${ }^{23}$ Mindestens zwei Künstler oder Werkstätten scheinen an den Miniaturen beteiligt gewesen zu sein. Eine dieser Werkstätten ist stilistisch in der Nähe der sogenannten Talbot-Illuminatoren anzusiedeln (Abb. 1, 2). ${ }^{24}$
Die Talbot-Illuminatoren waren Beauchamp mit Sicherheit bekannt, ist doch in mehreren Fällen ihre Tätigkeit für seine Tochter Margaret und deren Ehemann John Talbot nachweisbar: Neben zwei in Cambridge und Aberdeen aufbewahrten Stundenbüchern ist hier vor allem das sogenannte Shrewsbury Book zu nennen, eine reich illuminierte Kompilation von Heldenliedern, Chroniken und Traktaten, die der Graf von Shrewsbury der Prinzessin Marguerite d'Anjou schenkte, höchstwahrscheinlich im Jahr 1445 anlässlich ihrer Eheschließung mit dem englischen König Heinrich VI. ${ }^{25}$ Die Qualität der Illumination des Decamerone ist vergleichsweise bescheiden, allein ihr Umfang von fast hundert knapp halbseitigen Miniaturen spricht für einen relativ großen finanziellen Aufwand.

Aus welchem Anlass der Graf von Warwick dem Herzog von Gloucester die Handschrift schenkte, ist nicht eindeutig festzustellen; spätestens Beauchamps Ernennung zum Gouverneur und Tutor Heinrichs VI. im Jahr 1428 und seine damit einhergehende regelmäßige Involvierung in die Belange des Kronrats brachte mit Sicherheit eine Vielzahl potenzieller Gelegenheiten mit sich. Es wurde die Annahme geäußert, dass die Schenkung anlässlich des Osterfests 1428, welches Beauchamp in Gesellschaft des Herzogs verbrachte, erfolgt sein könnte. ${ }^{26}$ Ebenso gut möglich ist, dass er ihm die Handschrift im Rahmen der gemeinsamen Expedition gegen Philipp den Guten im Jahr 1436 oder anlässlich einer anderen Gelegenheit überreichte. Wie ausgeführt, kann Richard Beauchamp in politischer Hinsicht bis zu seinem Tod recht eindeutig dem Lager des Herzogs von Bedford und Kardinal Beauforts zugerechnet werden - und war somit gewissermaßen innenpolitischer Gegner des Herzogs von Gloucester. Es ist also anzunehmen, dass es sich bei dem kostspieligen, repräsentativen Buchgeschenk nicht um eine rein freundschaftliche Geste handelte, sondern dass ein bestimmtes Ziel verfolgt wurde. Ob es Beauchamp hierbei lediglich um die Darstellung seines eigenen Status' und politischen Gewichts mittels eines kostbaren Geschenks oder um einen konkreteren politischen Anlass ging, ist nach derzeitigem Wissensstand nicht zu klären. Eine weitere Möglichkeit ist, dass hier weniger politische Erwägungen im Vordergrund standen, sondern dass der Textinhalt und sein Transfer nach England eine größere Rolle für den Grafen von Warwick spielten als bisher angenommen. Diese Überlegungen sollen an späterer Stelle wieder aufgegriffen werden. 

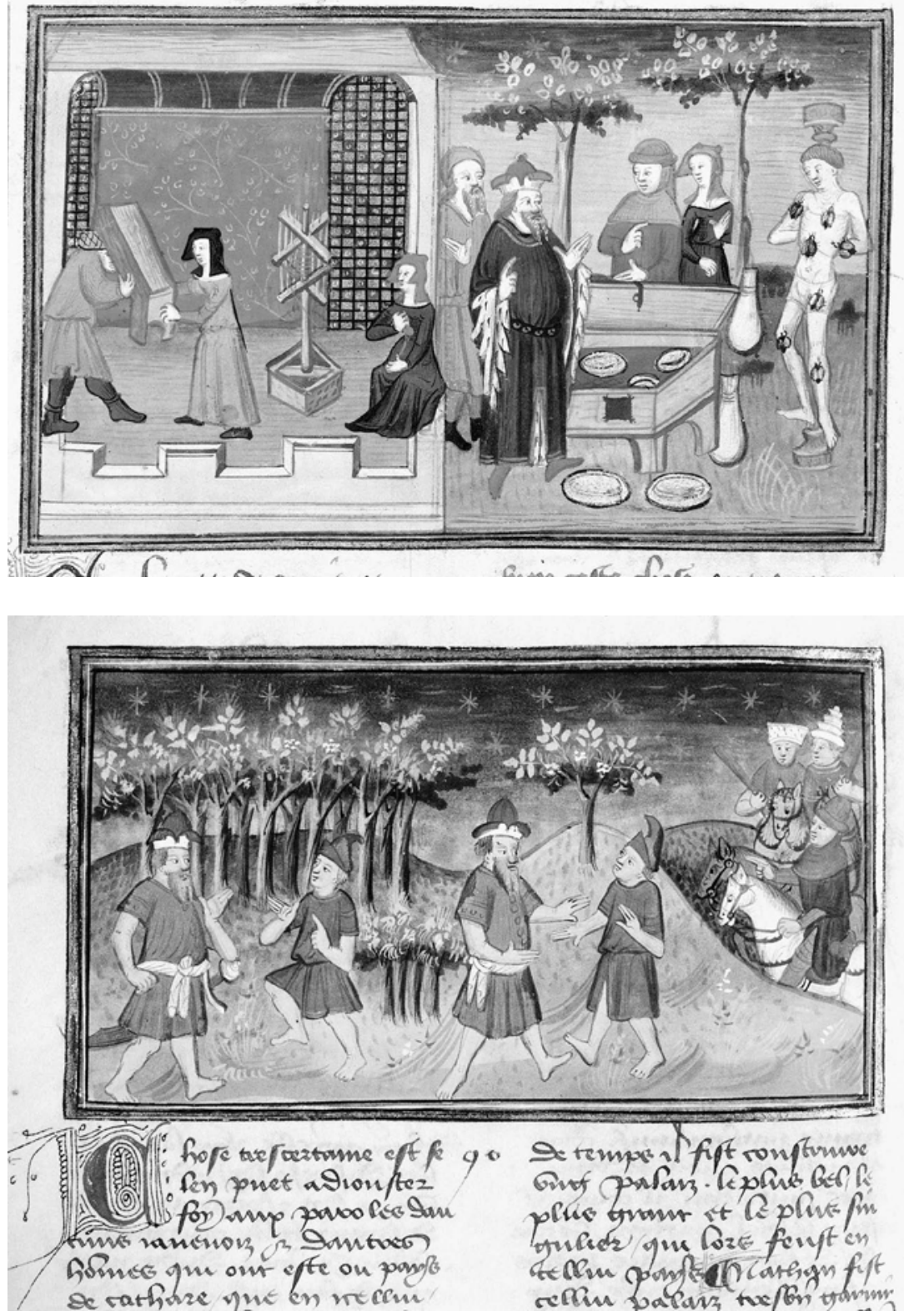

Abb. 1 Boccaccio, Decamerone in französischer Sprache. Paris, Bibliothèque nationale de France, MS fr 12421, fol. 97v (Foto: (c) Bibliothèque nationale de France)

Abb. 2 Boccaccio, Decamerone in französischer Sprache. Paris, Bibliothèque nationale de France, MS fr 12421, 411v (Foto: (๑) Bibliothèque nationale de France)
Deutlicher als im Falle des Decamerone tritt Beauchamps Instrumentalisierung von Handschriften zu politischen Zwecken bei dem im Folgenden zu diskutierenden Auftrag zutage. Dieser bietet zugleich interessante Hinweise auf die kunstpolitische Kooperation der Vertreter der englischen Krone in Frankreich: Zu Beginn des Jahres 1423 hatte der Regent, John of Bedford, den im Dienste der Engländer stehenden Notar Laurence Calot ein französisches Gedicht über den Anspruch Heinrichs VI. auf die Krone Frankreichs verfassen lassen. ${ }^{27}$ In diesem wird der Krieg zwischen England und Frankreich beklagt und vollständig dem Dauphin Charles angelastet. Heinrichs Abstammung von der englischen und französischen Linie, insbesondere von Ludwig dem Heiligen, sowie sein rechtmäßiger und gottgewollter Anspruch auf die Kronen beider Länder werden betont. Der Text wurde offenbar zusammen mit nicht mehr erhaltenen genealogischen Tafeln Heinrichs, die ebenfalls von Calot angefertigt worden waren, an der Kathedrale von Paris sowie höchstwahrscheinlich einer Reihe weiterer Kirchen im Norden Frankreichs ausgehängt. ${ }^{28}$ Der Auftrag des Regenten stand im Kontext einer Reihe kunstpolitischer 
Maßnahmen zur Propagierung des Anspruchs Heinrichs auf die französische Krone, bei denen er nicht selten von französischen Traditionen Gebrauch machte und sie für seine Zwecke nutzte. ${ }^{29}$

Im Jahr 1426 wurde Calots Gedicht im Auftrag Richard Beauchamps von John Lydgate vom Französischen ins Englische übersetzt. ${ }^{30}$ Ausführlich informiert Lydgate in seinem Prolog zur Übersetzung über die Auftragserteilung durch Beauchamp - »the nobly prince and manly man / Which is so knyghtly \& so moche can / My lord of Warrewyk, so prudent and wise « - und die Umstände der Auftragserteilung im Jahr $1426 .^{31}$ Es folgen eine Erörterung der Notwendigkeit, die Ansprüche Heinrichs VI. auf England und Frankreich zu verdeutlichen, und die Beschreibung des entsprechenden Auftrags durch Bedford an Calot. ${ }^{32}$ Lydgate schließt seinen Prolog mit der Beteuerung, Calots Vorlage in seiner Übersetzung weitestgehend zu folgen: "In substaunce filowyng the substaunce / Of his writyng and compilacioun. / All be pat I in my translacioun [...] I folow my maistre douteles, / Calot, and be not recheles «. ${ }^{33}$ Offenbar machte eine zunehmende Unzufriedenheit in England über den mit erheblichen Steuerbelastungen verbundenen Krieg in Frankreich es in den Augen Beauchamps beziehungsweise des Kronrats nötig, die Rechtmäßigkeit der Doppelmonarchie auch gegenüber der englischen Bevölkerung zu propagieren. Für diese wurde der Textinhalt zudem leicht modifiziert: Im Gegensatz zu Calots Vorlage enthält Lydgates Fassung eine Laudatio auf den im Krieg gegen Frankreich außerordentlich erfolgreichen und in England entsprechend beliebten Heinrich V. Zweifelsohne konnte man hiermit bei der englischen Bevölkerung eher punkten als bei der nordfranzösischen, die erheblich unter den Einfällen des zweiten Lancasterkönigs in den 1410er Jahren gelitten hatte. ${ }^{34}$

Beauchamps Teilnahme an Inszenierungen der französischen Abstammung Heinrichs und der Doppelmonarchie ist nicht nur im Falle des Übersetzungsauftrags, sondern auch im Rahmen zeremonieller Ereignisse in England und Frankreich belegt: So spielte etwa die Fleurde-Lis in Kombination mit dem englischen Leoparden und der Lancaster-Antilope eine wichtige Rolle in der Dekoration des Festmahls nach der Krönung zum englischen König in Westminster 1429; in Schauspielen, die die einzelnen Gänge begleiteten, instrumentalisierte man neben den »englischen « Heiligen Eduard und Georg die »französischen « Heiligen Ludwig und Dionysius. ${ }^{35}$ Eine Vielzahl von Mysterienspielen und Tableaux vivants be- gleiteten auch die Zeremonien im Zusammenhang der Pariser Krönung Heinrichs Ende 1431. Beispielhaft genannt sei das vom Bourgeois de Paris beschriebene Tableau vivant der Krönung Heinrichs beim Châtelet in Form von »deux couronnes pendans, qui estoient tres riches à veoir à ung chascun, sur sa teste, à son costé dextre estoit tout le sanc de France, c'est assavoir, tous les grans signeurs de France [...] et à senestre estoient tous les grans signeurs d'Angleterre ${ }^{36}{ }^{36}$ Es ist nicht sicher zu sagen, inwieweit der Graf von Warwick an der Konzeption der Festivitäten im Detail beteiligt war, jedoch war er als Tutor und Übersetzer des Königs in jedem Fall in prominenter Position involviert, und Inszenierungen wie diese bildeten den kulturellen Kontext seiner eigenen Aufträge.

Wie im Falle von Calots Auftrag ist auch von Lydgates Übersetzung weder das Autograph erhalten, noch sind es zeitgenössische Abschriften des Texts, die mit Illustrationen ausgestattet wären. Es lässt sich also nicht mit letzter Sicherheit sagen, ob Lydgates Text ebenfalls mit genealogischen Tafeln illustriert war. Der Leser wird jedoch verschiedentlich aufgefordert, eine "portratur of pe pedegre « oder "genelagye« zu betrachten: »That we may se with euery circumstaunce / Direct the lyne of England and of Fraunce / On pe othir part byhold \& ye may se / How this Herry in pe eight degre / Is to Seint Lowys sone \& very heir «. ${ }^{37}$ Es ist natürlich denkbar, dass es sich hierbei lediglich um aus der Übersetzung resultierende Überbleibsel ohne eigentlichen Zweck handelt. Dagegen spricht jedoch, dass Lydgate schon im Prolog sein Anliegen zum Ausdruck bringt, dass die Darlegung des Anspruchs Heinrichs auf die Kronen beider Länder nicht nur gelesen, sondern auch gesehen werde (»pat shall hit sene or rede $\left.\aleph^{38}\right)$. Es ist demnach wahrscheinlich, dass auch Lydgates Text und damit Beauchamps Auftrag von einer illustrierten Genealogie begleitet war, die den im Gedicht vermittelten politischen Inhalt bildlich zum Ausdruck brachte. Zahlreiche derartige Darstellungen haben sich aus dem zweiten Viertel des 15. Jahrhunderts erhalten. Die Qualität und der Aufwand der Illustrationen schwanken dabei zwischen monochromen Skizzen, wie etwa in der Handschrift Cambridge University Library, MS Ll. V. 20 (fol. 34r), und äußerst elaborierten Miniaturen, wie im Falle der Widmungsdoppelseite des bereits angesprochenen, im Jahr 1445 in Rouen kompilierten Shrewsbury Book in der British Library (Taf. 7, 8). ${ }^{39}$ In letzterem Fall informiert der französischsprachige Widmungstext über den Schenkenden der Kompilation, John Talbot, und die Rezipientin, Marguerite d'Anjou, und nennt eine Reihe 
guter Wünsche, die Talbot der Prinzessin mit auf den Weg geben wolle. Überdies wird auf die Abstammung Heinrichs VI. von Ludwig dem Heiligen, die deutlich in der begleitenden Genealogie zu erkennen sei, verwiesen. ${ }^{40}$ Dass Talbot den von seinem Schwiegervater bei John Lydgate in Auftrag gegebenen Text kannte, ist mehr als wahrscheinlich. Ob er sich jedoch direkt auf die in England zirkulierende, den Lydgate-Text illustrierende Genealogie - sofern es eine solche gab - stützte, ist eher fraglich. Wahrscheinlicher ist, dass beide Darstellungen und damit beide kunstpolitischen Unterfangen auf die nicht erhaltenen genealogischen Tafeln, die der Regent im Jahr 1423 in Auftrag gegeben hatte, zurückgehen.

Auch in einer weiteren Hinsicht kann das Shrewsbury Book möglicherweise Hinweise zur Frage nach der Funktion literarischer Aufträge geben, wobei vorangestellt werden muss, dass hier der entsprechende Auftrag kaum eindeutig Richard Beauchamp zugewiesen werden kann: Ebensogut ist eine Auftragserteilung durch seine Tochter Margaret oder ihren Ehemann Talbot möglich. Denis Conlon und John Frankis konnten in ihren Untersuchungen zur im Shrewsbury Book enthaltenen Übertragung der Legende des Guy von Warwick von anglonormannischer Vers- in französische Prosaform herausstellen, dass die Vorlage vermutlich in den $1420 e r$ Jahren in Warwickshire, im direkten familiären Umfeld Beauchamps, angefertigt wurde. ${ }^{41}$ Maßnahmen zur Wiederbelebung des Kults um Guy, den legendären Ahnherren der Grafen von Warwick, seien im gleichen Zeitraum auch anderweitig greifbar, etwa um 1423 die Errichtung einer Kapelle an der mutmaßlichen Stelle der Einsiedlerhöhle Guys in Warwick durch Richard selbst oder um 1425 die Beauftragung John Lydgates mit der Übersetzung eines lateinischen Gedichts über Guy von Warwick ins Englische durch Richards Tochter Margaret. ${ }^{42}$ Die Übertragung des anglonormannischen Texts ins Französische scheint demnach im Kontext einer Reihe Maßnahmen der Familie Beauchamp zur Inszenierung ihrer Tradition und damit implizit zur Steigerung ihres Prestiges gestanden zu haben. Ob sie jedoch wie der Bau der Guy gewidmeten Kapelle auf Veranlassung des Grafen von Warwick selbst oder aber eines Mitglieds seines engeren familiären Umfelds erfolgte, lässt sich nicht eindeutig klären.

Es wurde darauf hingewiesen, dass Beauchamp im Jahr 1428 zum Tutor Heinrichs VI. ernannt wurde, eine Zuständigkeit, die mehrfach erneuert wurde. Offenbar galt er in den Augen der Zeitgenossen als besonders geeignet für diese Aufgabe. Bereits im Zusammenhang mit dem Tod Heinrichs V. im Jahre 1422, der verfügt hatte, dass sein Sohn nach seinem Ableben der Obhut des Grafen von Warwick anvertraut werden solle, nannte der Chronist Brut ihn »best-nurturet man of Englond «. ${ }^{43}$ Der mittelenglische Begriff "nurture "kann hier neben guter Erziehung auch Bildung im Allgemeinen bezeichnen. ${ }^{44}$ Leider ist es nahezu unmöglich, detailliertere Aussagen zu Beauchamps Bildung und seinem Buchwissen zu machen. Neben den hier diskutierten Handschriften sind nur zwei weitere erhalten, die mit seinem Besitz in Zusammenhang gebracht werden können: Bei der ersten handelt es sich um eine im Jahr 1394 fertiggestellte Sammlung von Gedichten Jean Froissarts, die vermutlich nicht vor 1401 in den Besitz des Grafen von Warwick überging. ${ }^{45}$ Die zweite Handschrift ist eine Kompilation von drei durch John Trevisa wahrscheinlich im Auftrag von Beauchamps Schwiegervater Thomas Berkeley ins Mittelenglische übersetzten Texten, dem Dialogus inter militem et clericum, der Predigt Defensio Curatorum und dem Polychronicon. ${ }^{46}$ Das an zwei Stellen auftretende Wappen Beauchamps macht, gestützt durch den stilistischen Befund der Randdekorationen, eine Auftragserteilung durch den Grafen selbst wahrscheinlich. ${ }^{47}$ Zeitgenössische Zeugnisse weisen darüber hinaus auf weitere nicht erhaltene Handschriftenaufträge sowie die zum Teil längerfristige Beschäftigung von Dichtern und Autoren hin. Genannt sei, neben dem bereits erwähnten John Lydgate, John Shirley, der von 1403 bis in die späten $1420 e r$ in Beauchamps Gefolge nachweisbar ist, teilweise explizit als dessen Sekretär. ${ }^{48}$ Ebenfalls von Interesse ist ein Hinweis im Reisebericht William Worcesters aus dem späten 15. Jahrhundert, in welchem an zwei Stellen ein Master John Brewster als Autor einer Chronik und Gefolgsmann Richard Beauchamps aufgeführt wird. Mit Referenz auf den »lib[er] Magistri Brewster « werden eine Reihe historischer Begebenheiten von der Antike bis ins Spätmittelalter aufgeführt. ${ }^{49}$ Die Ereignisse, an denen Beauchamp maßgeblich beteiligt war, etwa dem Besuch Kaiser Sigismunds in England 1416 und den Vorverhandlungen von Troyes, werden besonders ausführlich beschrieben, und es ist denkbar, dass Beauchamp selbst der Auftraggeber dieser nicht erhaltenen Chronik war. All diese Hinweise und nicht zuletzt Beauchamps Wohlstand lassen annehmen, dass er nicht nur über eine nennenswerte Bibliothek verfügte, sondern auch selbst Übersetzungen und Neuverfassungen in Auftrag gab. ${ }^{50}$ Zudem ist ein recht breites Spektrum unterschiedlicher Textarten feststellbar. 
Im Hinblick auf die vorliegende Studie stellt sich die Frage, ob er auch im Rahmen seiner Pflichten als Tutor und Erzieher des Königs Bücher zum Einsatz brachte, sie also zu didaktischen Zwecken nutzte. Den Akten des Privy Council zufolge waren Beauchamps Aufgaben als Tutor: »to exhorte sture and lerne pe Kyng to love worship and drede God and generally norysshe hym and drawe to vertues and to eschewyng of vices by weyes and menes covenable suche as his eage shal mow lykly comprehende leiying before hym mirrours and examples of tymes passed « sowie »to teche pe Kyng and make hym to be taught nurture lettrure langage and oper maner of cunnyng as his age shal suffre hym to mow comprehende suche as it fitteth so grete a prince to be lerned of. ${ }^{51}$ Zweifelsohne ist Alexandra Sinclair in ihrer Annahme zuzustimmen, dass für die einzelnen Ausbildungsfelder Heinrichs VI. Spezialisten zuständig waren und dass Beauchamp die Erziehung des Königs vor allem koordinierte und generell beaufsichtigte. ${ }^{52}$ Dennoch ist denkbar, dass Beauchamp auch in Form von Buchgeschenken Einfluss auf den König ausübte. Aus seinem direkten Umfeld ist mit dem bereits mehrfach erwähnten Shrewsbury Book ein Werk erhalten, das einem solchen Zweck diente: Talbot schenkte die Handschrift der 15-jährigen zukünftigen Königin Marguerite d'Anjou, um sie zu erfreuen und zu unterhalten, aber auch um ihr die edlen Taten großer Fürsten vor Augen zu führen, wodurch sie zu gutem und angemessenem Betragen bewegt werden sollte. ${ }^{53}$

\section{Beitrag zum kulturellen Austausch zwischen England und Frankreich}

Im Folgenden soll auf Basis des bisher Gesagten die Frage nach Richard Beauchamps Beitrag zum Transfer kultureller Strömungen und politischer Ideen zwischen Frankreich und England mittels seiner Handschriftenaufträge diskutiert werden.

Besonders deutlich greifbar wird Beauchamps vermittelnde Rolle über die Grenzen der beiden Königreiche hinweg beim Auftrag an John Lydgate zur Übersetzung des Gedichts über Heinrichs Anspruch auf die französische Krone. Anhand des Prologs des englischen Dichters kann Beauchamp als maßgebliche Kraft hinter dem Transfer des programmatischen Textes nach England zum Zweck der Vermittlung desselben an die englische Bevölkerung festgestellt werden. Es versteht sich von selbst, dass hiermit nur eine bestimmte Gruppe innerhalb der Gesellschaft, ein Teil der sozialen Elite oder die Hofgesellschaft, gemeint sein kann. ${ }^{54}$ Der Text wurde dabei nicht einfach übernommen, sondern durch die Übersetzung vom Französischen ins Englische und die stärkere Hervorhebung Heinrichs V. für den neuen Rezipientenkreis modifiziert. Lydgates Werke erfreuten sich bereits $\mathrm{zu}$ seinen Lebzeiten in England großer Beliebtheit. Es ist daher nicht unwahrscheinlich, dass auch dieser Text eine verhältnismäßig weite Rezeption fand. ${ }^{55}$

Beauchamps Beitrag zur Verbreitung des grundsätzlichen politischen Anliegens sollte nicht überbewertet werden, und es sollte nicht übersehen werden, dass der bereits sechs Jahre zuvor in Troyes formulierte Anspruch des englischen Königs auf die Kronen beider Länder keine neue Idee war, sondern sowohl diesseits als auch jenseits des Kanals auch in anderer Form propagiert wurde. Überdies ist es möglich, dass Beauchamp in Absprache mit dem Kronrat oder auf dessen Veranlassung agierte, vielleicht sogar auf Veranlassung des Regenten Bedford. ${ }^{56}$ Dennoch spielte der Graf von Warwick als Auftraggeber der Übersetzung fraglos eine maßgebliche Rolle im Transferprozess. Ob im Zuge dessen nicht nur der Text, sondern auch die entsprechenden Illustrationen übertragen wurden, ist nicht eindeutig zu klären, kann aber, wie oben ausgeführt, angenommen werden. Inwiefern es hierbei auch zum Transfer konkreter ikonografischer und stilistischer Elemente von Frankreich nach England kam, muss jedoch im Dunkeln bleiben.

Im Kontext der Übersetzung des Gedichts Calots vom Französischen ins Englische sei darüber hinaus an den, möglicherweise mit Beauchamps Auftrag in Zusammenhang zu bringenden, umgekehrten Fall erinnert: Es ist, wie oben ausgeführt, denkbar, dass er die Übertragung des anglonormannischen Gedichts über Guy von Warwick in französische Prosa veranlasst hatte, die dem im Shrewsbury Book enthaltenen Text als Vorlage gedient hatte. In diesem Fall wären ihm - vereinfacht gesagt - die Perzeption und Modifizierung spezifisch englischer Traditionen für einen französischsprachigen Rezipientenkreis zuzuschreiben. Auch hier gilt die Prämisse, dass damit erstens nur ein vermutlich sehr geringer Teil der Gesellschaft erreicht werden sollte und erreicht wurde, und dass sich dieser Kreis zweitens fraglos nicht auf französische Rezipienten beschränkte, sondern explizit auch auf andere Personen erstreckte, die des Französischen kundig waren.

Ebenfalls unter Vorbehalt kann auf Basis der Analyse des Decamerone in der Bibliothèque nationale ein Beitrag 
Beauchamps zum Kulturtransfer zwischen Frankreich und England, in diesem Fall zur Verbreitung humanistischer Schriften auf der Insel, vermutet werden. Willard Farnham zufolge handelt es sich bei der Übersetzung des Decamerone, die der Graf dem zeitgenössischen Eintrag zufolge dem Herzog von Gloucester schenkte, um das früheste in England nachweisbare Exemplar des Texts. ${ }^{57}$ Dies schließt natürlich nicht aus, dass weitere, heute verlorene Exemplare bereits vorher in England zirkulierten. Dass der Mitte des 14. Jahrhunderts verfasste Text Giovanni Boccaccios in irgendeiner Form bereits Geoffrey Chaucer bekannt war, als er seine Canterbury Tales zu Papier brachte, ist mehr als wahrscheinlich. ${ }^{58}$ In jedem Fall scheint es sich jedoch um ein frühes Exemplar des Texts zu handeln, damit kann Beauchamp - gesetzt den Fall, dass man ihn als Schenkenden annimmt - zumindest eine Mitwirkung an der Verbreitung des Decamerone in England zugesprochen werden. Zeitgenössische Zeugnisse sprechen dafür, dass der Graf von Warwick in seiner Zeit als ungewöhnlich gebildet galt; es ist also möglich, dass er selbst Interesse an dem Werk, vielleicht auch an Giovanni Boccaccio als Autor im Allgemeinen, hegte. Ebenfalls denkbar ist jedoch, dass hier nicht die Interessen Beauchamps, sondern die des Empfängers der Handschrift widergespiegelt werden, ist doch zumindest für Humphrey of Gloucester seit Langem ein ausgeprägtes Interesse an den Werken des italienischen Humanismus bekannt. ${ }^{59}$

\section{Schlussbetrachtung}

Die erhaltenen Werke, die mit dem zeitweiligen Besitz und der Nutzung durch Richard Beauchamp in Zusammenhang gebracht werden können, zeigen, dass sich seine Handschriftenpatronage keineswegs auf England beschränkte. Vielmehr profitierte er durch seine politische Karriere und die damit verbundenen Aufenthalte sowohl in England als auch auf dem Festland vom englischen wie auch dem französischen Markt und trug dadurch zum kulturellen Austausch zwischen den beiden Ländern in der letzten Phase des Hundertjährigen Krieges bei.

Beauchamps Patronage im Allgemeinen und die jeweiligen Handschriften im Einzelnen weisen eine weite Spanne unterschiedlicher Zweckbestimmungen auf: So setzte er etwa die Lydgate-Übersetzung zu politischen Zwecken ein, nämlich zur Propagierung des Anspruchs Heinrichs VI. auf den französischen Thron. Möglicher- weise nutzte er Handschriften und Texte aber - im Kontext der internationalen politischen Entwicklungen - auch zur Förderung und Stärkung seines eigenen politischen Status' beziehungsweise des Ansehens seines Hauses. In diese Richtung mögen die Maßnahmen zur Wiederbelebung des Kults um Guy von Warwick, den legendären Ahnherren der Beauchamps, gedeutet werden, wobei Beauchamp als Auftraggeber der Übertragung der Guy-Legende nur vermutet werden kann. Hinter der Schenkung des aufwändig ausgestatteten Decamerone an den Herzog von Gloucester stand mit Sicherheit ebenfalls der Wunsch nach Prestigesteigerung, vielleicht verband sie sich jedoch darüber hinaus mit einem konkreteren politischen Zweck. Völlige Sicherheit lässt sich hier jedoch ebenso wenig erlangen wie bezüglich der Frage, inwiefern Beauchamp in seiner Funktion als Tutor Heinrichs VI. Handschriften, etwa zu gezielten didaktischen Zwecken, zum Einsatz brachte. Letzteres ist jedoch durchaus denkbar: Neben den erhaltenen Handschriften des Grafen weisen eine Reihe zeitgenössischer Zeugnisse auf verlorene literarische Aufträge in relativ großem Umfang und Spektrum. Dass dabei auch etwas für den über mehrere Jahre in seiner Obhut befindlichen Schützling abfiel, ist nicht unwahrscheinlich, zumal Heinrichs späterer Werdegang vermuten lässt, dass er an Büchern und Bildung interessierter war als an militärischem Ruhm. ${ }^{60}$

Im Gegensatz zu Bedford, Talbot und vielen anderen spätmittelalterlichen Buchbesitzern lässt sich im Falle Richard Beauchamps keine Nutzung von liturgischen Handschriften zur politischen Selbstdarstellung feststellen, was jedoch in der Überlieferungssituation begründet sein mag. Das einzige erhaltene liturgische Werk, das überhaupt mit ihm in Zusammenhang gebracht werden kann, ist die Psalter-Stundenbuch-Kombination, die er vermutlich seinem Sohn schenkte. Dies wiederum gibt keine Hinweise auf seine eigene Verwendung liturgischer Werke, wohl aber auf die für seinen Sohn intendierte. Hier ist eine Nutzung im engeren familiären Umfeld, zur privaten Andacht anzunehmen.

Zur Frage, welche Funktion die Illumination und das dekorative Programm in Beauchamps Handschriften zu erfüllen hatten, ist zu sagen, dass zwar alle erhaltenen oder diesbezüglich rekonstruierbaren Handschriften zumindest in geringem Umfang illuminiert sind beziehungsweise waren, in den meisten Fällen jedoch fraglich ist, ob mit der malerischen Ausstattung mehr bezweckt wurde als die ästhetische Erbauung und die Steigerung des Prestiges durch kostbare Aufträge. Eine Ausnahme 
bildet die Lydgate-Übersetzung, deren ursprüngliche Fassung höchstwahrscheinlich illuminiert war. Hier wurden die Illustrationen gezielt zur Vermittlung einer politischen Aussage in Kombination mit dem Text eingesetzt.

Die Lydgate-Übersetzung bildet gleichzeitig einen wichtigen Anhaltspunkt zur Beantwortung der Frage nach Beauchamps Beitrag zum Transfer kultureller Strömungen und politischer Ideen zwischen England und Frankreich. Offenbar stellte der Graf ein maßgebliches Bindeglied im Prozess der Übermittlung einer anhand von Text und Bild zum Ausdruck gebrachten politischen Idee dar: Bedford hatte mit seinem illustrierten Gedicht über Heinrichs Anspruch auf die französische Krone französische Bild- und Texttraditionen aufgegriffen und zum Zweck der Vermittlung des Anspruchs Heinrichs auf die französische Krone gegenüber dem französischen Publikum umgenutzt. Beauchamp wiederum führte den Übermittlungsprozess fort: Er modifizierte das Ensemble aus Text und Illustration durch den Auftrag zur Übersetzung ins Englische und passte es auf diese Weise dem Publikum jenseits des Kanals an. Geht man von ihm als Auftraggeber zur Übertragung der Guy-Legende aus dem Anglonormannischen ins Französische aus, war er zudem an einem Transferprozess in die andere Richtung beteiligt.

Überdies trug Beauchamp durch sein Buchgeschenk an den Herzog von Gloucester mit der Verbreitung der französischen Übersetzung des Decamerone in England in einem weiteren Bereich zum Transfer kultureller Errungenschaften bei. Es ist möglich, dass es ihm hierbei lediglich darum ging, den Herzog zu beeindrucken. Ebenso denkbar ist jedoch - und dies suggerieren erneut das weite Spektrum sonstiger literarischer Aufträge wie auch sein zeitgenössischer Ruf als »best-nurturet man of Englond «-, dass er aus genuinem Interesse an humanistischen Schriften und dem Austausch über sie agierte.

\section{Quellen und Literatur}

\section{Nicht EDIERTE HandSChriften}

Aberdeen, University of Aberdeen, Scottish Catholic Archives, Blair's College MS 1.

Cambridge, Fitzwilliam Museum, MS 40-1950.

Cambridge, Fitzwilliam Museum, MS 41-1950.

London, British Library, Add. MS 16165.

London, British Library, Add. MS 24194.

London, British Library, Royal MS 15 E VI.
New York, The Morgan Library and Museum, MS M. 893.

Paris, Bibliothèque nationale de France, MS fr. 831.

Paris, Bibliothèque nationale de France, MS fr. 12421.

\section{Gedruckte Quellen und Literatur}

[Armstrong 1983/I]: Armstrong, Charles A. J.: England, France and Burgundy in the Fifteenth Century. London 1983 (History Series 16).

[Armstrong 1983/II]: Armstrong, Charles A. J.: La double monarchie France-Angleterre et la maison de Bourgogne (1420-1435). Le déclin d'une alliance. In: Armstrong 1983/I, 343-374.

[Ausst.-Kat. London 2003] : Ausst.-Kat. Gothic. Art for England 1400-1547. Hg. von Richard Marks und Paul Williamson. London, Victoria and Albert Museum, 9.10.2003-18.1.2004. London 2003.

[Ausst.-Kat. London 2011] : Ausst.-Kat. Royal Manuscripts. The Genius of Illumination. Hg. von Scot McKendrick, Kathleen Doyle und John Lowden. London, British Library, 11.11.2001-13.3.2012. London 2011.

[Ausst.-Kat. Paris 1993]: Ausst.-Kat. Les manuscrits à peintures en France 1440-1520. Hg. von François Avril und Nicole Reynaud. Paris, Bibliothèque Nationale, 16.10.199316.1.1994. Paris 1993.

Avril, François: La Normandie. In: Ausst.-Kat. Paris 1993, 169. Bates, David/Curry, Anne (Hgg.): England and Normandy in the Middle Ages. London/Rio Grande 1994.

BrancA, Vittore (Hg.): Boccaccio visualizzato. Narrare per parole e per immagini fra Medioevo e Rinascimento. 3 Bde. Torino 1999 (Biblioteca di storia dell'arte 30).

BRIE, Friedrich (Hg.): The Brut or the Chronicles of England, Bd. 2. London 1908 (Early English Text Society 136).

Bryant, Lawrence M.: Ritual, Ceremony and the Changing Monarchy in France. 1350-1789. Farnham u.a. 2010 (Collected Studies Series 937).

[Carpenter 2004/I]: Carpenter, Christine: Art. Henry Beauchamp. In: Oxford DNB IV (2004), 588-589.

[Carpenter 2004/II]: Carpenter, Christine: Art. Richard Beauchamp. In: Oxford DNB IV (2004), 592-595.

Cokayne, George E.: The Complete Peerage of England, Scotland, Ireland, Great Britain and the United Kingdom. Extant, Extinct or Dormant. London 1907-38; sechsbändiger Neudruck Gloucester 1982.

Coleman, Joyce: Public Reading and the Reading Public in Late Medieval England and France. Cambridge/New York 1996 (Cambridge Studies in Medieval Literature 26).

Conlon, Denis Joseph (Hg.): Le Rommant de Guy de Warwik et de Herolt d'Ardenne. Diss. Lille 1966; Chapel Hill 1971 (University of North Carolina Studies in Romance Languages and Literatures 102). 
Connolly, Margaret: John Shirley. Book Production and the Noble Household in Fifteenth Century England. Aldershot u. a. 1998.

Crispin, Julia: Kunst als Medium politischer Repräsentation? Richard Beauchamp von Warwick als Bauherr, Kunstförderer und Literaturmäzen. In: Dis|kurs 2 (2010), 4-19.

Crispin, Julia: French Book Illumination in Time of War. Migrating Artists Between France, Normandy and England from 1420 to 1450. In: WAGNER/DAVID/KLEMENČIČ 2017, 72-90.

[Curry 2003/I]: Curry, Anne: The Hundred Years War. London 2003.

[CURry 2003/II]: Curry, Anne: The 'Coronation Expedition' and Henry VI's Court in France, 1430 to 1432 . In: StratFORD 2003, 29-52.

De Hamel, Christopher: A History of Illuminated Manuscripts. Oxford 1986.

[The Dictionary of Art]: Jane Turner (Hg.): The Dictionary of Art. 34 Bde. London 1996.

Duffy, Eamon: Marking the Hours. English People and their Prayers 1240-1570. New Haven/London 2006.

Farnham, Willard: England's Discovery of the Decameron. In: Proceedings of the Modern Language Association 39 (1924), H. 1, 123-139.

Fehrmann, Antje: Grab und Krone. Königsgrabmäler im mittelalterlichen England und die posthume Selbstdarstellung der Lancaster. Diss. Marburg 2005. München u.a. 2008 (Kunstwissenschaftliche Studien 140).

Floran, Mary: Document relatif à l'entrée du roi d'Angleterre, Henri VI, à Paris en 1431. In: Revue des études historiques 75 (1909), 411-415.

Frankis, John: Taste and Patronage in Late Medieval England as Reflected in Versions of Guy of Warwick. In: Medium Aevum 66 (1997), 80-93.

Fresco, Karen/Hedeman, Anne D. (Hgg.): Collections in Context. The Organization of Knowledge and Community in Europe. Columbus 2011.

Gairdner, James (Hg.): The Historical Collections of a Citizen of London in the Fifteenth Century. London 1876.

Giraud, Cédric (Hg.): Notre-Dame de Paris 1163-2013. Actes du colloque scientifique tenu au Collège des Bernardins, à Paris, du 12 au 15 décembre 2012. Turnhout 2013.

Goodall, John A. A.: The Chantry Chapel at Guy's Cliffe, Warwick. In: MONCKTON/MORRIS 2011, 304-317.

Gramaccini, Norberto/Schurr, Marc Carel (Hgg.): Kunst und Kulturtransfer zur Zeit Karls des Kühnen. Tagung Bern, 2008. Bern u. a. 2012 (Neue Berner Schriften zur Kunst 13).

Grassnick, Ulrike: Ratgeber des Königs. Fürstenspiegel und Herrscherideal im spätmittelalterlichen England. Diss. Münster 2002/2003; Köln u.a. 2004 (Europäische Kulturstudien 15).
Griffiths, Ralph Alan: The Reign of King Henry VI. The Exercise of Royal Authority, 1422-1461. London 1981.

Guenée, Bernard/Lehoux, Françoise (Hgg.): Les entrées royales françaises de 1328 à 1515. Paris 1968 (Sources d'histoire médiévale 5).

Hamburger, Jeffrey/Korteweg, Anne S. (Hgg.): Tributes in Honor of James H. Marrow. Studies in Painting and Manuscript Illumination of the Late Middle Ages and Northern Renaissance. London 2006.

Harriss, Gerald L.: Cardinal Beaufort. A Study of Lancastrian Ascendancy and Decline. Oxford 1988.

Harvey, John H. (Hg.) : William Worcestre. Itineraries. Oxford 1969.

Hedeman, Anne D.: Collecting Images. The Role of the Visual in the Shrewsbury Book (BL Ms. Royal 15 E. vi). In: Fresco/ HEDEMAN 2011, 99-119.

Hicks, Michael A.: Between Majorities. The 'Beauchamp Interregnum' 1439-49. In: Bulletin of the Institute of Historical Research 72 (1999), 27-43.

Hughes, Jonathan: Educating the Aristocracy in Late Medieval England. In: History Today 49 (Februar 1999), 26-33.

[Kintzinger/Schneidmüller 2011/I] : Kintzinger, Martin/ Schneidmüller, Bernd (Hgg.): Politische Öffentlichkeit im Spätmittelalter. Tagung Reichenau, 2008. Ostfildern 2011 (Konstanzer Arbeitskreis für Mittelalterliche Geschichte. Vorträge und Forschungen 75).

[Kintzinger/Schneidmüller 2011/II]: Kintzinger, Martin/Schneidmüller, Bernd: Politische Öffentlichkeit im Spätmittelalter - eine Einführung. In: Kintzinger/ SCHNEIDMÜLLER 2011/I, 7-20.

Koff, Leonard Michael/Schildgen, Brenda Deen (Hgg.): The Decameron and the Canterbury Tales. New Essays on an Old Question. Madison u. a. 2000.

Lebigue, Jean-Baptiste: Lordo du sacre d'Henri VI à Notre-Dame de Paris (16 décembre 1431). In: Giraud 2013, 319-363.

LiU, Yin: Richard Beauchamp and the Uses of Romance. In: Medium Aevum 74 (2005), H. 2, 271-287.

MacCracken, Henry N. (Hg.): The Minor Poems of John Lydgate, Bd. 2. Secular Poems. 2. Aufl. London/Oxford 1961 (Early English Text Society 192).

McFarlane, Kenneth Bruce: The Nobility of Later Medieval England. Oxford 1973.

McKendrick, Scot: A European Heritage. Books of Continental Origin Collected by the English Royal Family from Edward III to Henry VIII. In: Ausst.-Kat. London 2011, 42-65.

McKenna, John W.: Henry VI of England and the Dual Monarchy. Aspects of Royal Political Propaganda, 1422-1432. In: Journal of the Warburg and Courtauld Institutes 28 (1965), 145-162. 
Melville, Gerd/Moos, von, Peter (Hgg.): Das Öffentliche und Private in der Vormoderne. Köln u. a. 1998 (Norm und Struktur 10).

[MLLK]: Metzler Lexikon Literatur- und Kulturtheorie. Ansätze - Personen - Grundbegriffe. Hg. von Ansgar NüNNING. 4. Aufl. Stuttgart/Weimar 2008.

Monckton, Linda/Morris, Richard K. (Hgg.): Coventry: Medieval Art, Architecture and Archaeology in the City and its Vicinity. Tagung Coventry 21.-25.7.2007. Leeds 2011 (The British Archaeological Association. Conference Transactions 33).

Moos, von, Peter: Das Öffentliche und das Private im Mittelalter. Für einen kontrollierten Anachronismus. In: Melville/ Moos 1998, 3-83.

Moos, von, Peter: »Öffentlich« und »privat« im Mittelalter. $\mathrm{Zu}$ einem Problem der historischen Begriffsbildung. Vorgetragen am 22.6.1996. Heidelberg 2004 (Schriften der Philosophisch-historischen Klasse der Heidelberger Akademie der Wissenschaften 33).

Nicolas, Harris: Proceedings and Ordinances of the Privy Council of England, 7 Bde. London 1834-37, hier Bd. 3 (1834); Bd. 4 (1835).

Orme, Nicholas: From Childhood to Chivalry. The Education of the English Kings and Aristocracy 1066-1530. London u. a. 1984.

[Oxford DNB]: Oxford Dictionary of National Biography. Hg. von Henry C. G. Matthew. 6o Bde. Oxford/New York 2004.

Pearsall, Derek Albert: John Lydgate. London 1970 (Poets of the Later Middle Ages).

Petrina, Alessandra: Cultural Politics in Fifteenth Century England. The Case of Humphrey, Duke of Gloucester. Leiden u. a. 2004 (Brill's Studies in Intellectual History 124).

Pollard, Anthony James: John Talbot and the War in France. 1427-1453. 2. Aufl. Barnsley 2005.

Rathmann-Lutz, Anja: »Images« Ludwigs des Heiligen im Kontext dynastischer Konflikte des 14. und 15. Jahrhunderts. Berlin 2010 (Orbis mediaevalis 12).

Reynolds, Catherine: Illustrated Boccaccio Manuscripts in the British Library (London). In: Studi sul Boccaccio 17 (1988), $113-181$.

Reynolds, Catherine: The Shrewsbury Book, British Library, Royal MS 15 E. VI. In: StratFord 1993/II, 109-116.

Reynolds, Catherine: English Patrons and French Artists in Fifteenth-Century Normandy. In: BATEs/Curry 1994, 299313 .

Reynolds, Catherine: Art. Talbot Master. In: The Dictionary of Art 20 (1996), 772.

Rowe, Benedicta J. H.: King Henry's Claim to France in Picture and Poem. In: The Library 4th Series 13 (1933), 77-88.

SAYgin, Susanne: Humphrey, Duke of Gloucester (1390-1447) and the Italian Humanists. Leiden u. a. 2002 (Brill's Studies in Intellectual History 105).

Scotт, Kathleen L.: Later Gothic Manuscripts. 1390-1490. 2 Bde. London 1996 (A Survey of Manuscripts Illuminated in the British Isles 6).

Sinclair, Alexandra: The Beauchamp Earls of Warwick in the Later Middle Ages. Diss. London 1986.

Sinclair, Alexandra: The Beauchamp Pageant. Donington 2003 (Richard III and Yorkist History Trust).

Steigerwald, Jörg: Art. Kulturtransfer. In: MLLK 2008, 404.

[STRATFORD 1993/I] : STRATFORD, Jenny: The Bedford Inventories. The Worldly Goods of John, Duke of Bedford, Regent of France (1389-1435). London 1993 (Reports of the Research Committee of the Society of Antiquaries of London 59).

[STrAtFord 1993/II] : Stratford, Jenny (Hg.): Medieval Art, Architecture and Archaeology at Rouen. Leeds 1993 (British Archaeological Association. Conference Transactions 12).

Stratford, Jenny (Hg.): The Lancastrian Court. Tagung Harlaxton, 2001. Stamford 2003 (Harlaxton Medieval Studies $13)$.

Taylor, Craig D.: The Treatise Cycle of the Shrewsbury Book, BL Ms. Royal 15 E.vi. In: Fresco/Hedeman 2011, 134-150. Thompson, Guy Llewelyn: Paris and its People under English Rule. The Anglo-Burgundian Regime 1420-1436. Diss. Oxford. Oxford 1991.

Tuetey, Alexandre (Hg.): Journal d'un bourgeois de Paris. 1405-1449. Paris 1881.

VAn der Velden, Hugo: A Prayer Roll of Henry Beauchamp, Earl of Warwick. In: HAMBURGer/Korteweg 2006, 521549.

Wagner, Kathrin/David, Jessica/Klemenčıč, Matej (Hgg.): Artists and Migration 1400-1850. Britain, Europe and Beyond. Cambridge 2017.

Wieck, Roger S.: Painted Prayers. The Book of Hours in Medieval and Renaissance Art. New York 1997.

Wieck, Roger: Time Sanctified. The Book of Hours in Medieval Art and Life. New York 1988.

Wolffe, Bertram Peray: Henry the Sixth. London 1981.

\section{Anmerkungen}

1 Diese Studie präsentiert Teilergebnisse meiner im Oktober 2015 an der Universität Münster eingereichten Dissertation, die 2018 unter dem Titel Krieg und Kunst. Die Visualisierung englischer Herrschaftsansprüche in Frankreich (1422-1453) in den Veröffentlichungen des Deutschen Historischen Instituts London (Bd. 80) publiziert werden wird.

2 In der Aufgliederung der kriegerischen Auseinandersetzungen Englands und Frankreichs um die französische Krone folge ich Anne Curry, die den Krieg in drei Abschnitte einteilt, von denen der letzte 
mit der Wiederaufnahme der militärischen Unternehmungen unter Heinrich V. im Jahr 1415 beginnt. CURRY 2003/I, 3 f.; vgl. S. 1-27 zur Begriffsproblematik und Forschungsgeschichte zum Hundertjährigen Krieg.

3 Sinclair 2003, 31-48. - Sinclairs Studie, eine kommentierte Edition des sogenannten Beauchamp Pageant, der im späten 15. Jahrhundert vermutlich im Auftrag von Richard Beauchamps Tochter Anne entstand, wird von einer Untersuchung zur Biografie und zum mäzenatischen Wirken des Grafen von Warwick eingeleitet. Sie stellt gleichzeitig die umfassendste Arbeit zur Kunstpatronage Beauchamps dar. - Siehe hierzu auch LIU 2005. - CrisPin 2010.

4 Vgl. etwa Connolly 1998, bes. 14-26, 114-116.

5 Der in der gegenwärtigen Forschung vielfach und in unterschiedlicher Form verwendete Begriff »Kulturtransfer" wird hier weitgefasst verstanden und sowohl auf die gegenseitige Übermittlung und Rezeption literarischer, künstlerischer und liturgischer Strömungen und Traditionen als auch auf den Transfer politischer Ideen angewandt. Siehe zum Begriff allgemein und zu weiterführender Literatur GRAMACCINI/SCHURR 2012, dort bes. die Einleitung $7 \mathrm{f}$. Steigerwald 2008. - Insbesondere zum künstlerischen Transfer zwischen England und Frankreich im Spätmittelalter siehe auch Reynolds 1994. - Fehrmann 2008.

6 Zum Werdegang Beauchamps siehe McFarlane 1973, bes. 187201. - CoKAYNe 1982, 378-382. - SinClair 1986, bes. 81-149. SinClAIR 2003, 24-49. - CARPENTER 2004/II.

$7 \mathrm{Zu}$ Beauchamps Werdegang bis zum Tod Heinrichs V. siehe CoKAYNe 1982, 378-381. - Sinclair 1986, bes. 81-115. - Sinclair 2003, 25-39. - CARPENTER 2004/II, $592 \mathrm{f}$.

8 Spätestens im Januar 1423 wurde Beauchamp zum Captain of Rouen ernannt, Ende 1425 wurde er für die Dauer der Abwesenheit des Regenten Bedford mit der Verwaltung der Normandie betraut. In den Jahren 1426 und 1427 war er an zahlreichen militärischen Aktionen in der Normandie beteiligt. CoKAYNE 1982, 380 f. Dort auch detaillierte Quellenangaben. - SINCLAIR 2003, 38-40 - CARPENTER 2004/II, 594.

9 Zu Bedford Stratford 1993/I. - Zu Talbot Pollard 2005. - Siehe außerdem Frankis 1997.

10 Zur Ernennung zum Tutor Heinrichs VI. siehe Griffiths 1981, 52-55. - CoKayne 1982, 381. - Orme 1984, 21 f. - Sinclair 1986, 123 f. - SAYgin 2002, 50 f. - SinClair 2003, 42.

$11 \mathrm{Zu}$ den Festivitäten und Zeremonien um die Krönung in Westminster und Beauchamps Rolle dabei siehe die Chronik Gregory Skinners. GAIRDNER 1876, 165-168. - Siehe hierzu auch Griffiths 1981, 189f. - WolfFe 1981, 49-51. - Sinclair 2003, 43. - Zur Krönungsexpedition nach Frankreich Griffiths 1981, 190-194. WolfFe 1981, 51-63. - Harriss 1988, 191-213. - ThOMpson 1991, 199-205. - CURrY 2003/II. - Sinclair 2003, 44f. - Bryant 2010, 63-93, bes. 72-78. - LeBIGUe 2013.

12 Griffiths 1981, 59 f. - Orme 1984, 31, 43. - Sinclair 2003, 45. $\mathrm{Zu}$ den Abmachungen vom 29. November 1432 im Einzelnen die von Harris Nicolas edierten Akten des Privy Councils: Nicolas 1835, 132-137. - Zu Humphrey of Gloucester Petrina 2004 - SAYGIN 2002, zu Humphreys Einfluss auf die Erziehung Heinrichs bes. $57-68$.

$13 \mathrm{Zu}$ den Auseinandersetzungen zwischen Bedford, Beaufort und Humphrey of Gloucester HARRISS 1988, 134-166, 191-252. Stratford 1993/I, 6-19. - Saygin 2002, 30-71. - Petrina 2004,
117-127, 132-135. - Zur anglo-burgundischen Allianz ARMSTRONG 1983/II. - Tном Pson 1991. - Bereits vor dem Tod Heinrichs V. war Beauchamp über mehrere Jahre in Streitigkeiten um das Erbe der Berkeley-Ländereien verwickelt, auf das er über seine erste Ehefrau Elizabeth Berkeley Ansprüche erhob. Auch hierbei agierte Humphrey of Gloucester zugunsten seines Kontrahenten James Berkeley. Sinclair 2003, 37, 39. - CARPENTER 2004/II, 593.

14 Cokayne 1982, 381. - Harriss 1988, 262 f. - Sinclair 2003, 46. CARPENTER 2004/II, 594.

15 Cokayne 1982, 381 f. - Sinclair 2003, 46 f. - Carpenter 2004/II, 594f. - Van der Velden 2006, 524-526.

16 New York, The Morgan Library and Museum, MS M. 893. Pergament, 261 Blatt, $27,1 \times 18,5 \mathrm{~cm}$. Siehe hierzu Sсот 1996, II, 248251. - Ausst.-Kat. London 2003, 227, Kat.-Nr. 91 (Alixe Bovey). Crispin 2010, $17 \mathrm{f}$.

17 Zur stilistischen Einordnung der Handschrift und zu Richard Beauchamp als vermutlichem Auftraggeber Sсотт 1996, II, 248-251.WIECK 1997, 124. - Zu Kindern als Nutzern religiöser Handschriften Orme 1984, 128-133.

18 Denkbar ist außerdem, dass es sich bei den zahlreich in den Randbordüren auftretenden zeitgenössischen Portraitköpfen und Figuren um Richard und/oder Henry Beauchamp handeln könnte; auch hier fehlen jedoch heraldische oder persönliche Hinweise, die eine solche Deutung stützen könnten. Für die grundsätzliche Verortung der Handschrift in die Familie Beauchamp spricht neben den Eintragungen auf fol. 12r auch der Vermerk des Geburtstags des zweiten Ehemanns Cecily Nevilles, die in erster Ehe mit Henry Beauchamp verheiratet gewesen war, auf fol. 7r. ScOTT 1996, II, 251.

19 Dass dies nicht immer der Fall war und dass dem eigentlichen Zweck nach private Gebetsbücher ähnlichen Umfangs und Kostenaufwands häufig als Mittel zur Selbstdarstellung im politischen Kontext dienten, zeigt der Vergleich mit einer Reihe von im gleichen Zeitraum angefertigten Handschriften, etwa den drei Stundenbüchern John Talbots und Margaret Beauchamps. In allen drei Fällen werden die liturgischen Texte von einer ganzseitigen Miniatur eingeleitet, die Talbot und Margaret in Anbetung der Jungfrau zeigt; die Seiten sind oder waren jeweils reich mit Wappen, Motti und Devisen dem Talbot-Hund und dem Beauchamp-Bären - sowie den Initialen des Paars und dem Symbol des Hosenbandordens verziert, dem der Graf von Shrewsbury angehörte. Cambridge, Fitzwilliam Museum, MS 40-1950, fol. 7v; MS 41-1950, fol. 2v. - Aberdeen, University of Aberdeen, Scottish Catholic Archives, Blair's College MS 1, fol. 4v.

20 Zur privaten Andacht De Hamel 1986, 168-198. - Wieck 1988. Moos 2004, 28 f. - Duffy 2006, 53-64. - Knappe Ausführungen zur Nutzung devotionaler Texte im spätmittelalterlichen höfischen Umfeld auch bei Coleman 1996, 122 f., 138-140. - Zur Problematik des Begriffs des Privaten im Mittelalter Moos 1998. - Moos 2004.

21 Paris, Bibliothèque nationale de France, MS fr. 12421, 452 Blatt, 29,2 $\times 22,5 \mathrm{~cm}$. Siehe hierzu Branca 1999, III, 230-235. - Knappe Ausführungen bei Farnham 1924, $132 \mathrm{f}$. - SAYGIN 2002, 122. - SinClair 2003, 42. - Petrina 2004, 188. - McKendrick 2011, 47.

22 Paris, Bibliothèque nationale de France, MS fr. 12421, fol. 1r, 449r-452r, hier fol. 452r. Weitere vermutlich in das 15 . Jahrhundert datierende Inschriften finden sich auf fol. 353r, 373r und 451r; sie stammen jedoch wahrscheinlich nicht mehr aus der Zeit, in der Humphrey of Gloucester die Handschrift besaß. - Zur weiteren Provenienz BrANCA 1999, III, 230, $234 \mathrm{f}$. 
23 Es ist nicht völlig ausgeschlossen, dass mit dem »conte de Warrewic « nicht Richard Beauchamp, sondern sein Sohn Henry gemeint ist, der diesen Titel zwischen 1439 und seiner Erhebung zum Herzog im Jahr 1445 führte. Henrys Minderjährigkeit und die Tatsache, dass er sich während dieses Zeitraums vorwiegend in England aufgehalten zu haben scheint, sprechen jedoch gegen diese Deutung: Er dürfte dort wenig Gelegenheit gehabt haben, sich mit der in England vermutlich noch weitestgehend unbekannten Übersetzung des Decamerone zu befassen. - Zu Henry Beauchamp Hicks 1999, 31-33. CARPENTER 2004/I, $588 \mathrm{f}$.

$24 \mathrm{Zu}$ den Talbot-Illuminatoren Avril 1993, 169. - Ausst.-Kat Paris 1993, 170 f., Kat.-Nr. 88 (François AvriL). - Reynolds 1993, bes. 113. - Reynolds 1996. - CRisPin 2017. - Den Talbot-Illuminatoren kann auch die Ausstattung weiterer Boccaccio-Handschriften zugeschrieben werden. Reynolds 1988, 159-166.

25 Cambridge, Fitzwilliam Museum, 40-1950. - Aberdeen, University of Aberdeen, Scottish Catholic Archives, Blair's College MS 1.London, British Library, Royal MS 15 E VI. - Trotz einer Vielzahl jüngerer Arbeiten zum Shrewsbury Book, die hier nicht im Einzelnen aufgeführt werden können, ist Catherine Reynolds' Studie aus dem Jahr 1993 nach wie vor maßgeblich für die Handschrift und die beteiligten Künstler: Reynolds 1993. - Siehe außerdem etwa TAYlOR 2011. - Hedeman 2011.

26 Sinclair 2003, 42.

27 Siehe hierzu und zum Folgenden erstmals Rowe 1933. - Außerdem McKenna 1965, 151-154. - Griffiths 1981, 217-219. - RAthMANN-LutZ 2010, 286-289. - Mary Floran edierte im Jahr 1909 ein nicht genauer bezeichnetes Dokument aus dem Archiv des Schlosses Beauvoir, Sammlung Beaulaincourt-Marles, bei dem es sich höchstwahrscheinlich um eine Abschrift des Originaltexts von Calot handelt. Floran 1909, 412-415.

28 Siehe zu den Quellenbelegen über die Bezahlung Calots und zu Hinweisen auf die Aufhängung der Ensembles an den nordfranzösischen Kirchen Rowe 1933, 82, 85 f. - Griffiths 1981, 219.

29 Vgl. hierzu etwa McKenna 1965. - Rathmann-Lutz 2010, $286-$ 291. - Hedeman 2011, $112 \mathrm{f}$.

30 Im Folgenden wird Lydgates Text nach der Edition von MaCCraCKEN 1961, 613-622, zitiert. - Siehe hierzu und zur Verbindung zwischen Lydgate und Beauchamp auch PEARSALL 1970, 126, 161196, bes. $166-168$.

31 MacCracken 1961, 614.

32 MacCracken 1961, 614 f.: "And God graunt that it may be so,/Septure and crowne that he may in dede,/As he hath right, in peas to possede./And to put his title in remembraunce,/Whiche that he hath to Inglond and to Fraunce,/The noble, that worthi varioure,/Whiche may be callid a very conquerour [...] this prince, most discrete \& sad,/My lord of Bedford, of Fraunce the regent,/Was the first that did his entent,/By grete advys and ful hy prudence,/Thurugh his labour \& his diligence,/That made serche in cronycle full notable,/By the clerk which he knew most able,/Renomed of wysdom and science,/ Worthie eke of fame and of credence."

33 MacCracken 1961, 615.

34 MacCracken 1961, 619.

35 Die Festivitäten und Zeremonien, insbesondere das Festmahl, werden detailliert in der zeitgenössischen Londoner Chronicle of Gregory Skinner beschrieben. GAIRDNER 1876, 169 f. - Vgl. hierzu auch Anm. 11.
36 Zitiert nach der Edition Tuetey 1881, a. 1431, Nr. 591. - Ausführliche Beschreibungen finden sich auch in zahlreichen weiteren sowohl englischen als auch französischen zeitgenössischen Chroniken. Vgl. hierzu auch die Literaturhinweise in Anm. 11.

37 MacCracken 1961, 617.

38 MacCracken 1961, 615. - Hierzu auch Rathmann-Lutz 2010, 286-288.

39 Cambridge, University Library, MS Ll.V.20, fol. 34r. - London, British Library, Royal MS 15 E VI, fol. 2V-3r.

40 London, BL, Royal MS 15 E VI, fol. 2v: "Princesse tres excellente./ Ce livre cy vous presente./De schrosbery le conte. [...] Peult a toute creature./Ou livre a vue figure./Geneaulogie nommee/Par la quelle est tres bien prouvee/Verite demonstrant a plain/Que le roy nostre souverain/Le vostre affye que dieux gart./Est venu de si noble part./ Comme du bon roy saint louys./Si estes vous certain en suys./Par celle hystoire veoir pourrez/De quel et quantiesme degrez./Le roy nostre dit souverain/Est descendu il est certain/Cest en luitiesme degre./Plaise vous recevoir en gre."

41 Conlon 1971, 16-26, 33-40. - Frankis 1997, bes. 82, 84, 89.

42 Frankis 1997, 85-88. - Zu Margarets Auftrag siehe auch Pearsall 1970, 71, 167. - Zur Kapellenstiftung durch Beauchamp siehe GooDALL 2011, bes. 306. - Zur Instrumentalisierung Guys von Warwick siehe außerdem LIU 2005.

43 Zitiert nach der Edition BRIE 1908, 563 f. "And to Richard, Erle of Warrewik, was commyttit pe kepyng of hym, for-as-much he was countet and hold pe best-nurturet man of Englond «.

44 Siehe hierzu auch Sinclair 2003, 42, Anm. 70.

45 Paris, Bibliothèque nationale de France, MS fr. 831. - Knapp zur Handschrift, die lediglich mit einer einzigen Miniatur ausgestattet ist und auf dem Vorsatzblatt die Eintragung »Ce livre est a Richart le gentil fauls conte de Warrewyck« enthält, ConNolly 1998, 115.

46 London, British Library, Add. MS 24194. Der Dialogus inter militem et clericum stammt aus dem späten 13. Jahrhundert und wurde am Hof Karls V. ins Französische übersetzt, die anderen beiden Texte stammen aus der Mitte des 14. Jahrhunderts. - Vgl. zur Handschrift SCOtt 1996, II, 82 f. - Connolly 1998, 114 f. - Crispin 2010, 16 f.

47 Hier folge ich Sсотт 1996, II, 83. - Connolly 1998, 114, hingegen hält eine Auftragserteilung durch Thomas Berkeley für wahrscheinlich.

$48 \mathrm{Zu}$ Shirley siehe Connolly 1998, 14-26, 114-116. - Eine in der British Library aufbewahrte Kompilation von Gedichten und Prosatexten Shirleys enthält ein möglicherweise der Autorschaft Richard Beauchamps selbst zuzuweisendes Gedicht, bezeichnet als »balade made of Isabelle, countasse of Warr- and Lady Despencer, by Richard Beauchamp Eorlle of Warrewyk «. British Library, Add. MS 16165, fol. 245v-246v. Vgl. zur Handschrift und zur Frage der Autorschaft ConNOLLY 1998, 27-51.

49 Worcesters Reisebericht wurde ediert und übersetzt von HaRvey 1969, 208-218, bes. 208, 210.

50 Frankis 1997, 89f. - Connolly 1998, 114-116.

51 Nicolas $1834,298-300$.

52 Sinclair 2003, 42. - Siehe hierzu auch Orme 1984, bes. 17, 21 f., 31 , 43. - Zur Erziehung von Fürsten im spätmittelalterlichen England allgemein siehe Orme 1984. - HugheS 1999. - Grassnick 2004.

53 Dies geht aus dem Widmungstext der Handschrift hervor. London, British Library, Royal MS 15 E VI, fol. 2v: "Esperant qu'a vostre loisir/Vous vueillez prendre plaisir/En passant temps pour y lire/Pour 
oster ennuy qui nuire [...] Et que vous voyez les hystoires./Qui bien sont dignes de memoires/Pour les tres haultes entre prinses/Qui ou dit livre sont comprinses/Ou quel a volumes plusieurs/Faisans mencion des greigneiurs/Des plus saiges des plus vaillans/Qui ayent este puis mil ans./Et plus dont il fait bon ouyr/Pour chevaleire esiouyr/Et esmouvoir a tout bien faire/Dont l'effect saurez bien retraire." - Das einzige nachweisbare Geschenk, das Beauchamp Heinrich in seiner Funktion als dessen Tutor machte, ist um 1430 zu datieren. Es handelte sich um eine kleine, mit Gold dekorierte Rüstung für den etwa neunjährigen König. Hierzu und zu den entsprechenden Quellen Orme 1984, 184.

54 Allgemein zu dieser Problematik und zu weiteren Literaturhinweisen Moos 1998, etwa 34f. - Moos 2004, etwa 55 f. - Kintzinger/ SCHNEIDMÜLLER 2011/II, bes. 12.

55 Siehe hierzu auch MacCracken 1961. - McKenna 1965, 154 f. Pearsall 1970, 1 f. - Petrina 2004, 8.
56 Bedfords Bemühungen, Heinrichs französische Ansprüche gegenüber dem englischen Parlament zu bewerben, sind in mehreren Fällen überliefert. Hierzu und zu entsprechenden zeitgenössischen Quellenbelegen STRATFORD 1993/I, 17-19.

57 Farnham 1924, bes. 132 f. - Hierzu auch knapp MCKendrick 2011, 47. - Es ist denkbar, dass Beauchamp als Teilnehmer des Konstanzer Konzils mit zeitgenössischen humanistischen Ideen und Schriften in Kontakt kam. Siehe hierzu den Beitrag von Antje Fehrmann in diesem Band.

58 Siehe hierzu die Beiträge im Sammelband Koff/Schildgen 200o. Zudem gibt Farnham 1924, 132, selbst an, seine Schlüsse lediglich aus der Sichtung der Bestände der British Library und der Bibliothèque nationale de France zu ziehen; es ist also keinesfalls gesichert, ob nicht weitere relevante Exemplare erhalten sind.

59 Siehe hierzu Farnham 1924, 133 f. - Saygin 2002. - Petrina 2004. 6o Siehe hierzu Griffiths 1981, 242-248. 


\title{
Bischof Hallum Und die »ZWiebel«
}

\author{
Der Weg eines englischen Architekturmotivs ins Konstanzer Münster
}

Im Konstanzer Münster fällt ein Bogenmotiv auf, das in der spätgotischen Kunst und Architektur Südwestdeutschlands keine Parallele hat, sondern zeitgenössisch nur in England anzutreffen ist. Wie es seinen Weg nach Konstanz gefunden hat, ist Thema dieses Aufsatzes.

\section{Der Schnegg im Konstanzer Münster}

Im Thomaschor im nördlichen Querschiffarm des Konstanzer Münsters findet sich ein Kleinod spätgotischer Architektur, wohl eines der originellsten Gebilde, das die Spätgotik in der Bodenseeregion ersonnen hat: der so genannte Schnegg (Abb. 1).

Wie die Bezeichnung schon vermuten lässt, handelt es sich um eine Wendeltreppe. Sie windet sich in einem feingliedrigen, durchbrochenen Gehäuse nach oben. Trotz dieser kunstvollen Machart bietet sie heute lediglich $\mathrm{Zu}$ gang zu den Dachräumen, was Anlass zu Spekulationen über ihre einstige Funktion gab. ${ }^{2}$ Man hätte auf sehr viel einfachere Weise einen Aufgang über die obere Sakristei einrichten können, sodass aufgrund der Lage innerhalb des Kirchenraums und der aufwändigen Architektur davon auszugehen ist, dass der Schnegg einstmals eine Funktion innerhalb des Gottesdienstes zu erfüllen hatte.

Das Domkapitel hatte seine Versammlungsräume im Domherrenhof, der bis zu seiner Zerstörung durch Brand 1824 nördlich des Münsters stand. ${ }^{3}$ Die Wendeltreppe könnte als direkte Verbindung von dessen zweitem Obergeschoss durch den Dachraum des Kreuzgangs ins Münster gedient und einen würdevollen Einzug der Domherren ermöglicht haben. ${ }^{4}$ Möglicherweise führte der Weg zuvor durch das eine Ebene tiefer gelegene Obergeschoss des Kreuzgangs, wo aber im frühen 15. Jahrhundert durch Vergrößerung und Einwölbung der Raum der heutigen Oberen Nikolauskapelle geschaffen worden war. Vielleicht muss die Funktion des Schneggs auch in Verbindung mit einer weiteren, nicht weniger prominent platzierten, durchbrochenen Wendeltreppe betrachtet werden, die zur gleichen Zeit an der Nordwestecke des

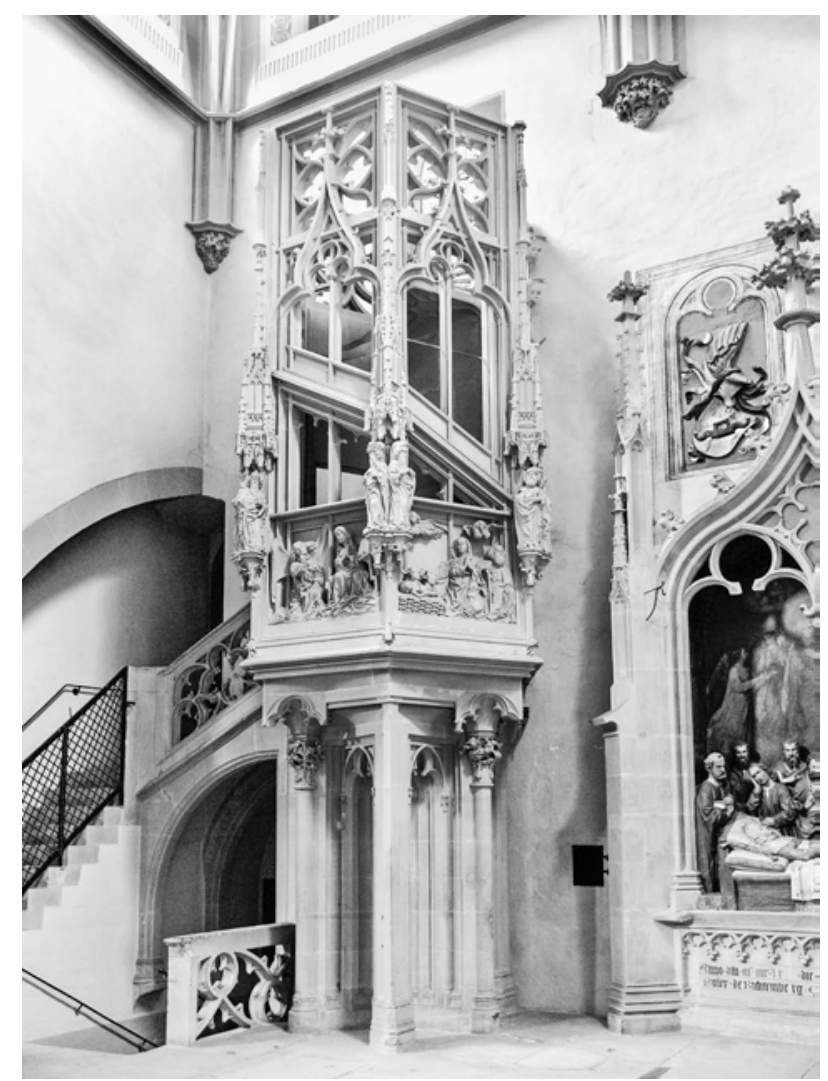

Abb. 1 Konstanz, Münster, der Schnegg im Thomaschor, Höhe $8 \mathrm{~m}$ (Foto: Stefan King / Ines Stadie)

nördlichen Querhausgiebels ihren Platz fand und in Fortsetzung des Schneggs ins Hauptdach hinaufführt. Der Aufstieg zum Läuten der Glocken im Vierungsdachreiter während des Gottesdienstes könnte damit in Szene gesetzt worden sein. Zumindest in späterer Zeit hingen jedoch Glockenseile zum Läuten während der Gottesdienste direkt im Chorraum, danach im Thomaschor. ${ }^{5}$

Wie Konstanzer Chroniken berichten, wurde mit der Planung und Ausführung des Schneggs 1438 begonnen, und 1446 wurde das Werk vollendet. Seine Errichtung steht in Verbindung mit dem Umbau des nördlichen Querhausarms, der damals neue Fenster, ein figuriertes Rippengewölbe, besagte außenliegende Wendeltreppe 


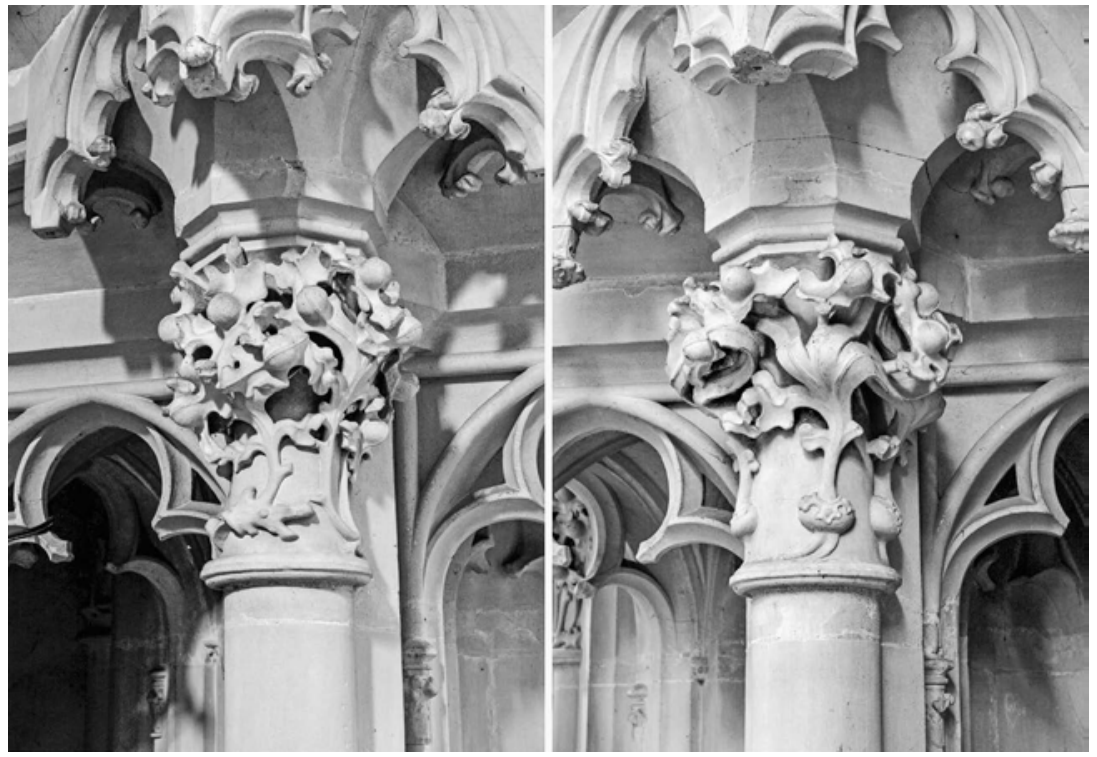

Abb. 2.a-b Konstanz, Münster, Schnegg, Kapitelle des Unterbaus mit hinterschnittenem Laubwerk aus Zweigstücken und Knollen wachsend (Foto: S. King / I. Stadie)

und ein mit Maßwerk zweischichtig aufgebautes Giebeldreieck erhielt. Diese Maßnahme war Teil einer spätgotischen Erneuerung von Chor und Querhaus in der Zeit zwischen 1430 und $1451 .{ }^{6}$ Als Schöpfer des Schneggs wird in den Chroniken "maister Antoni« genannt, der Kaplan am Ottilienaltar war. ${ }^{7}$ Er ist nach widersprüchlichen Angaben entweder kurz nach Beginn der Arbeiten oder nach Fertigstellung des Schneggs verstorben, sodass es einem seiner Schüler oblag, die Arbeiten an der Wendeltreppe bzw. am damit verbundenen Umbau des Querhausarms zu Ende zu führen. ${ }^{8}$ Über Meister Anton ist sonst nichts weiter bekannt. Theodor Müller schrieb demselben Bildhauer auch das Portal des ehemaligen Zunfthauses Zum Rosengarten zu, in dem sich heute das Rosgartenmuseum befindet, und brachte die Liegefigur Bischof Ottos III. von Hachberg in der Unteren Margaretenkapelle in dessen Nähe. ${ }^{9}$

Das Autorenteam Johann Josef Böker, Anne-Christine Brehm, Julian Hanschke und Jean-Sébastien Sauvé trennten stilistisch zwischen Unterbau und Gehäuse und schrieben letzteres Vincenz Ensinger zu, der vor 1459 als Baumeister an die Konstanzer Bauhütte kam und dort bis 1489 tätig war. ${ }^{10}$ Begründet wurde dies mit einer inschriftlichen Datierung des Gewölbes 1451, wonach der unterhalb liegende Schnegg vorher nicht hätte gebaut werden können, sowie Ähnlichkeiten mit der Südportalvorhalle. Ersteres kann argumentativ nicht aufrecht erhalten werden, da der Schnegg nach seiner Fertigstellung in einfacher Weise hätte abgedeckt oder eingehaust werden können, um ihn im weiteren Bauvorgang vor Be- schädigungen zu schützen. Zur Südportalvorhalle lassen sich nach Ergebnissen des Verfassers keine stilistischen Bezüge herstellen und auch sie kann Ensinger nicht zugeschrieben werden. ${ }^{11}$ Da sich Angaben aus den Chroniken an anderen Stellen durch Baubefunde und dendrochronologische Datierungen als zutreffend erwiesen haben, muss die genannte Bauzeit von 1438 bis 1446 nicht angezweifelt werden.

\section{Die Architektur des Schnegg}

Der Schnegg ist vor der hohen Querhauswand aufgestellt, zusammengesetzt aus einem Unterbau von $3 \mathrm{~m}$ Höhe und einem Gehäuse mit der eigentlichen Wendeltreppe von weiteren $5 \mathrm{~m}$. Tatsächlich war das Bauwerk ursprünglich noch etwas höher, denn das Bodenniveau im Thomaschor wurde in späterer Zeit um $20 \mathrm{~cm}$ angehoben, sodass der untere Sockelbereich des Schneggs heute im Boden steckt, gut erkennbar an der Maßwerkbrüstung neben der Treppe zum Kreuzgang. Der Aufgang beginnt mit einer älteren Treppe, die in einer ins Mauerwerk eingetieften, gewölbten Nische zur Oberen Nikolauskapelle führt und ein eisernes Geländer besitzt. Vom Podest am oberen Ende führt ein zweiter Treppenlauf mit Maßwerkbrüstung zum Gehäuse hinauf, der einen unterhalb liegenden Durchgang zum Kreuzgang überbrückt. Die Ecke zwischen beiden Treppenläufen zierte einst eine Tiergestalt, von der jedoch nur der Umriss in Form von Abarbeitungsspuren übrig geblieben ist. Erst innerhalb des 
Abb. 3 Brüstungsplatte mit Verkündigung an Maria. Die Brüstungsplatten bilden zusammen mit dem angrenzenden Eckpfeilerabschnitt, den Konsolen und einem Paar der Prophetenfiguren ein einziges großes Werkstück (grafisch hervorgehoben), sodass sich Bildszenen und rahmende Profile vielfach überlagern konnten. Konstanz, Münster, Schnegg (Foto: S. King / I. Stadie)

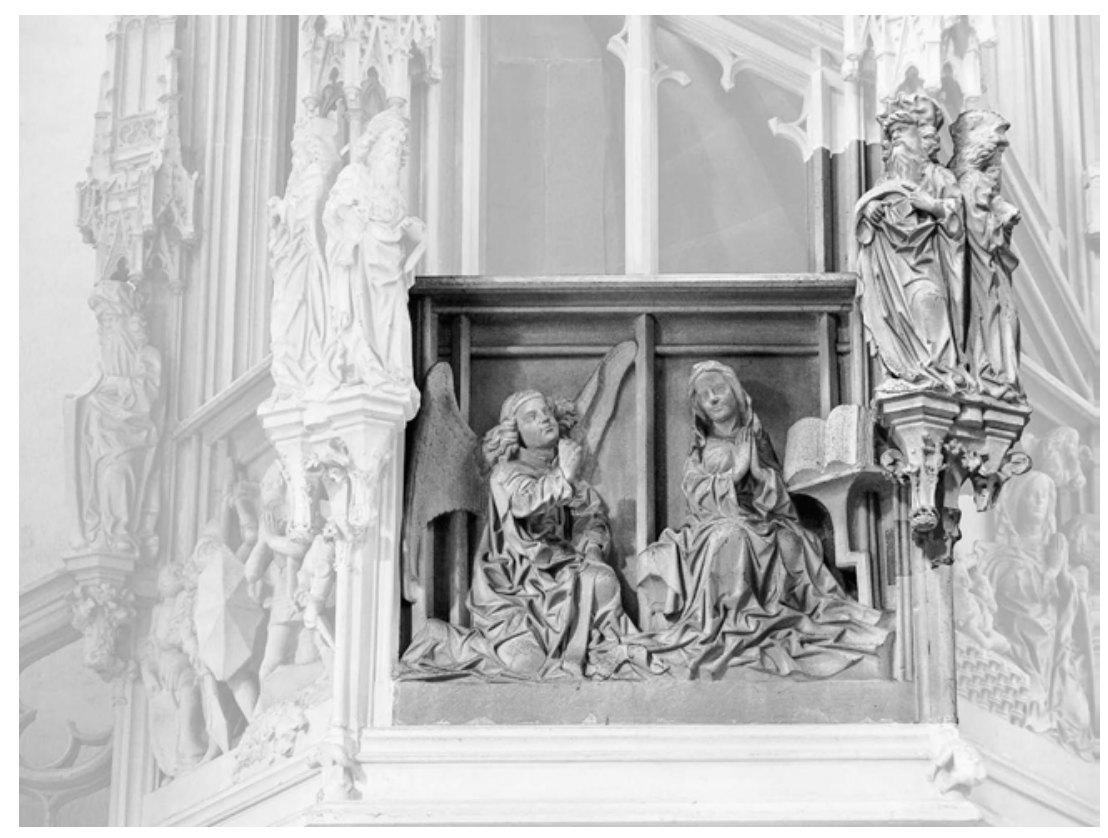

Gehäuses beginnt die Wendeltreppe, und sie endet nach einer vollen Windung an einer hochliegenden Pforte in der nördlichen Giebelmauer, wo man den Dachraum des Kreuzgangflügels betritt.

Der Grundriss des Unterbaus basiert auf der Durchdringung zweier Dreiecke. Eines davon bildet den massiven Schaft. Freistehende Ecksäulen unter quadratischen Schirmen besetzen die Ecken des anderen Dreiecks, deren bemerkenswerte Kapitelle feines, aus Zweigstücken und Knollen wachsendes Laubwerk tragen (Abb. 2).

Eines davon befindet sich kaum sichtbar auf der Rückseite. Komplexe Formen leiten zu einer Platte über, die dem Gehäuse als Basis dient. Kleine Hündchen saßen auf den vortretenden Ecken des Gesimses zwischen Unterund Oberbau, von denen nur eines unbeschädigt erhalten geblieben ist.

Der Grundfigur folgend erhebt sich das Gehäuse über einem regelmäßigen Sechseck, bestehend aus reich profilierten Eckpfeilern, die mit feingliedrigem Stab- und Maßwerk verbunden sind. Hier gibt sich die Raffinesse des Entwurfs in Überlagerungen und Durchdringungen mehrerer Maßwerkebenen zu erkennen. Eine Seite des Gehäuses nimmt den Zugang auf und eine andere ist als Rückseite zur Querhauswand geschlossen. Die verbleibenden vier Seiten tragen in den Brüstungsfeldern biblische Szenen aus Altem und Neuem Testament in sinngemäßer Gegenüberstellung: Tau auf Gideons Fell und Verkündigung Mariens, Geburt Christi und Moses vor dem brennenden Dornbusch. ${ }^{12}$ Die Szenen aus dem Alten Testament sind jeweils außen platziert, sodass Verkündigung und Geburt in der Mitte direkt nebeneinander angeordnet werden konnten. An den Ecken sind acht Prophetenfiguren paarweise angeordnet, die auf sechseckigen Konsolen und unter gemeinsamen Baldachinen stehen. Den oberen Abschluss des Gehäuses bildet eine Maßwerkbrüstung. Weitere Aufbauten in Form von Fialen oder Kreuzblumen sind in der Architektur nicht vorbereitet und es finden sich auch keinerlei Anschlussspuren dafür.

Das Bauwerk ist in Gänze aus Werksteinen zusammengefügt, die mit eisernen Klammern und Stangen miteinander verbunden sind. Der untere Bereich des Gehäuses weist einen besonders raffinierten Steinschnitt auf. Hier ist jeweils eine der figürlich gestalteten Brüstungsplatten zusammen mit einem angrenzenden Eckpfeilerabschnitt samt Konsolen und einem Paar der Prophetenfiguren aus einem einzigen Stein herausgearbeitet worden (Abb. 3).

Diese Herstellungsweise ermöglichte vielfache Überlagerungen von Szenen und rahmendem Profil, sodass Teile der Bildszenen gewissermaßen den Bildrahmen überlagern und sogar vom mittigen Stab durchlaufen werden. Architektur und Skulptur gehen hier eine besondere Verbindung ein, sowohl bezüglich der Herstellung aus großteiligen Werkstücken als auch bezüglich der engen Verwobenheit in der Komposition. Daher dürfte beides sicherlich ein und demselben Meister zuzuschrei- 


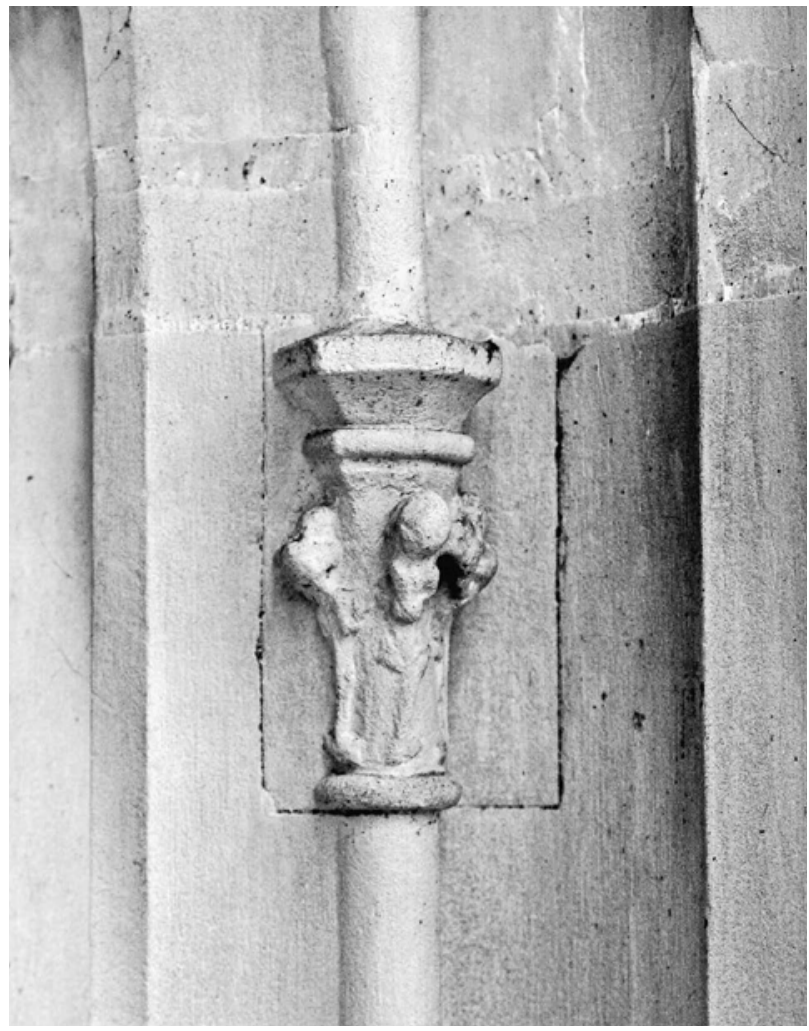

Abb. 4 Konstanz, Münster, Schnegg. Am Unterbau wurden sechs kleine Laubkapitelle nachträglich passgenau eingeklebt und oberhalb eine zusätzliche dünne Steinlage mit winzigen Konsolen unter den Bogenrippen eingefügt. (Foto: S. King / I. Stadie)

ben sein, denn nur aus einer Hand war die geschilderte Verflechtung zu erreichen.

Obwohl der Schnegg das wohl filigranste und komplexeste gotische Bauwerk des gesamten Bodenseegebiets ist, wurde er von der kunsthistorischen Forschung zeitweise stiefmütterlich behandelt. Der ungewöhnliche Steinschnitt und angeblich zu einer Seite verzogene Eckprofile, hergeleitet aus einer fehlerhaften Aufmaßzeichnung, wurden 1940 von Georg Troescher als Kennzeichen einer nicht werkgerechten Ausführung gebrandmarkt. ${ }^{13}$ Seine herabwürdigende Interpretation wurde von vielen der nachfolgenden Autoren weitergetragen. Doch das Gegenteil ist der Fall, denn die unkonventionellen Lösungen erforderten eine durchdachte Planung, einen hohen Aufwand und eine besondere Sorgfalt bei der Herstellung. Sie zeugen nicht von Unvermögen, sondern von einem hohen Anspruch an Entwurf und Ausführung.

Im Kupferstichkabinett der Akademie der Bildenden Künste in Wien hat sich eine Architekturzeichnung des Schneggs aus dessen Entstehungszeit erhalten, bestehend aus einem Aufriss und zwei Grundrissen. ${ }^{14}$ Die dort wiedergegebene Architektur steht qualitativ weit hinter dem ausgeführten Bauwerk zurück. Aufschlussreicher als die Übereinstimmungen zwischen Zeichnung und Bauwerk sind daher die Abweichungen. So sind etwa die Profilabwicklungen in den Grundrissen lediglich hingekritzelt und erscheinen sehr viel gedrungener und plumper als in der baulichen Umsetzung, die zahllosen Profilüberstabungen des Bauwerks sind in der Zeichnung nicht zu finden, und es fallen dort die seltsam unruhige Anordnung der Maßwerknasen und die stark vereinfachte Architektur im höheren Bereich auf. Der Riss dokumentiert ganz offensichtlich ein Vorentwurfsstadium, in dem die Gedanken und Ideen zusammengeführt und visualisiert wurden, bevor sie in einem weiteren Schritt eine gründliche Durcharbeitung und Weiterentwicklung erfuhren. Manche Dinge, wie die genaue Abwicklung der Profile oder die Ausformung des höheren Bereichs, waren nurmehr angedacht, sodass der Riss einen aufschlussreichen Einblick in den Entwurfsprozess bietet. Gemeinhin unterstellt man der gotischen Architektur, sie sei aus geometrischen Figuren und Proportionen aus dem Grundriss heraus entwickelt worden, doch im Gegensatz dazu erweist sich hier, dass der Grundriss in seinen ganzen Einzelheiten erst im Nachgang ausgetüftelt worden ist.

Die schrittweise Durcharbeitung fand eine Fortsetzung selbst noch in den Herstellungsprozess hinein. Um das Werk zu vervollkommnen, schreckte man offensichtlich auch vor aufwändigen Nachbesserungen nicht zurück. Am Unterbau können zwei gestalterische Änderungen beobachtet werden, die nach der Herstellung der Werkstücke, aber noch vor der Errichtung vorgenommen worden sind (Abb. 4).

Zunächst wurden nachträglich sechs kleine Laubkapitelle am inneren Stamm ergänzt und als Vierungen in passgenaue Aussparungen geklebt - eine damals gängige Praxis, mit der aber üblicherweise Fehlstellen im Steinmaterial und Schadstellen aus Bearbeitung oder Transport mit Hilfe von Baumharzen repariert wurden. ${ }^{15}$ Erst danach entschloss man sich zur Einfügung einer zusätzlichen Steinlage von $5 \mathrm{~cm}$ Höhe und verlieh damit den zwischen Stamm und Eckschäften liegenden Gewölben winzige Konsölchen. Bei den freistehenden Eckschäften hätte ein zusätzliches dünnes Werkstück unterhalb des Kapitells wie Flickwerk gewirkt, weshalb man es in den Sockelbereich einfügte. Dadurch entstand allerdings eine etwas unglückliche Höhendifferenz zwischen den großen Laubkapitellen und den eingeklebten kleinen Kapitellen, 
doch war in diesem Stadium der Herstellung nur noch ein Kompromiss möglich.

Von einer farbigen Fassung sind keine Reste oder Spuren zu finden. Ohnehin wurden Werke der Spätgotik häufig steinsichtig belassen, sicherlich um die filigranen Formen intensiver wirken zu lassen. ${ }^{16}$ In diesem Zusammenhang kann auch auf das große Wandbild über dem Grab des Bischofs Otto von Hachberg in der Margaretenkapelle des Konstanzer Münsters verwiesen werden, wo der dargestellte Baukörper ganz im grauen Ton des lokal verwendeten Rorschacher Sandsteins gehalten ist. ${ }^{17}$

Sichtbar gemachte Bauelemente zur Besteigung und Begehung in Form von Treppen, Galerien und Umgängen sind charakteristisch für die Architektur der Spätgotik und haben oft überreiche Gestaltung und prominente Platzierung erfahren. Inspirationsquelle für den Schnegg könnten die nur wenige Jahre zuvor errichteten Wendeltreppen am Nordturm des Straßburger Münsters gewesen sein. ${ }^{18}$ Es wurden auch Vorbilder in der höfischen Baukunst Frankreichs gesucht, wo ähnliche Ziertreppen 1365 am Louvre in Paris und 1385 am Schloss des Herzogs Jean de Berry in Bourges entstanden waren. ${ }^{19} \mathrm{Im}$ Unterschied zu den genannten Beispielen erscheint der Schnegg wie ein frei aufgestelltes Ausstattungsstück, da sein Aufbau aus Stamm und Gehäuse an Predigtkanzeln, Sakramentshäuser oder Monstranzen erinnert und die eigentliche Wendeltreppe erst hoch oben beginnt. Der Hinweis auf mögliche Vorbilder beträfe jedoch lediglich das Aufgreifen einer Bauidee und nicht die direkte Übernahme einer Bauform.

\section{Das Motiv des Schulterzwiebelbogens}

Die Einzelformen der Architektur fallen nicht aus dem zeitgenössischen südwestdeutschen Formenrepertoire und bieten für die Annahme einer Herkunft des Meisters aus einer entfernten Region keine Anhaltspunkte - mit einer Ausnahme: Das auffällige Bogenmotiv, das die Seiten des Gehäuses ziert und Stäben und Brüstungsmaßwerk als zweite Schicht vorgelegt ist, fällt aus dem Rahmen der regional gebräuchlichen Stilformen. Auf viertelkreisförmigen Kragschultern sitzt ein eingezogener Kielbogen, der dadurch den Umriss einer Zwiebel annimmt (Abb. 5).

Der Zwiebel ist ein kreisrunder Pass einbeschrieben und diesem wiederum drei kleinere Pässe. Den nach innen gerichteten Spornen, von denen die meisten abgebrochen sind, war jeweils ein Weinblatt aufgelegt. Diese

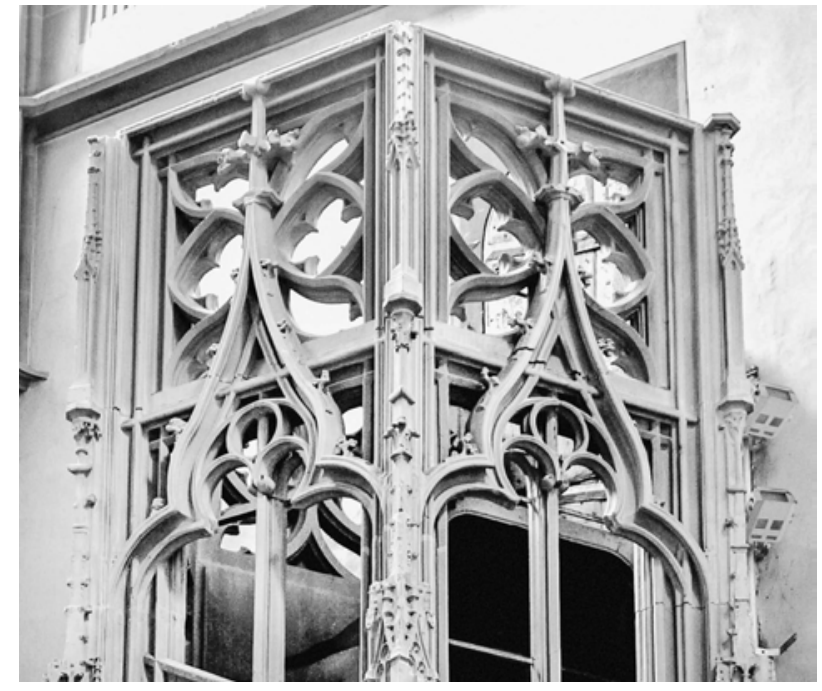

Abb. 5 Konstanz, Münster, Schnegg, Schulterzwiebelbogen. Auf Kragbögen sitzt ein eingezogener und mit Krabben besetzter Kielbogen, der die Form einer Zwiebel annimmt. (Foto: S. King / I. Stadie)

Bogenform ist einem Kielbogen, bei dem sich der innere Teil des Profils zu Nasen entwickelt, nicht unähnlich. Doch am Schnegg folgt auch die äußere Rahmung der Einschnürung zwischen Schultern und aufsitzender Zwiebel, sodass es sich nicht um Nasen handelt, sondern um die eigentliche Bogenform - ein zwar kleiner, aber gewichtiger Unterschied. Durch die Besetzung mit Krabben gibt sich der Bogen als Verdachung zu erkennen, sodass der Schulterzwiebelbogen eine Weiterentwicklung des spätgotischen Kielbogenmotivs darstellt, welches seinerseits aus der Verschmelzung von giebelförmigem Wimperg und Spitzbogenöffnung hervorgegangen war. Neben dieser auffälligen Bogenform wurden die für die gotische Architektur typischen Spitzbögen am Schnegg vermieden und stattdessen die Schirme der Ecksäulen sowie die Blendmaßwerke der Baldachine rundbogig und die Seiten des Schafts lediglich kaum merklich angespitzt ausgeführt.

Ein Schulterzwiebelbogen als oberer Abschluss der Gehäuseseiten war bereits im Bauriss vorgesehen, doch ist er im Vergleich zum ausgeführten Bauwerk erheblich nach oben verlagert und dort einer sehr viel höheren Brüstung einbeschrieben. Er ist auf seine äußere Rahmung reduziert, besitzt kein einbeschriebenes Maßwerk, seine Proportionen lassen Eleganz vermissen, und wie das Zusammenlaufen von Mittelstab und Zwiebelspitze erkennen lässt, war noch keine mehrschichtige Überlagerung vorgesehen. Bei der ausgeführten Form ist es dem 


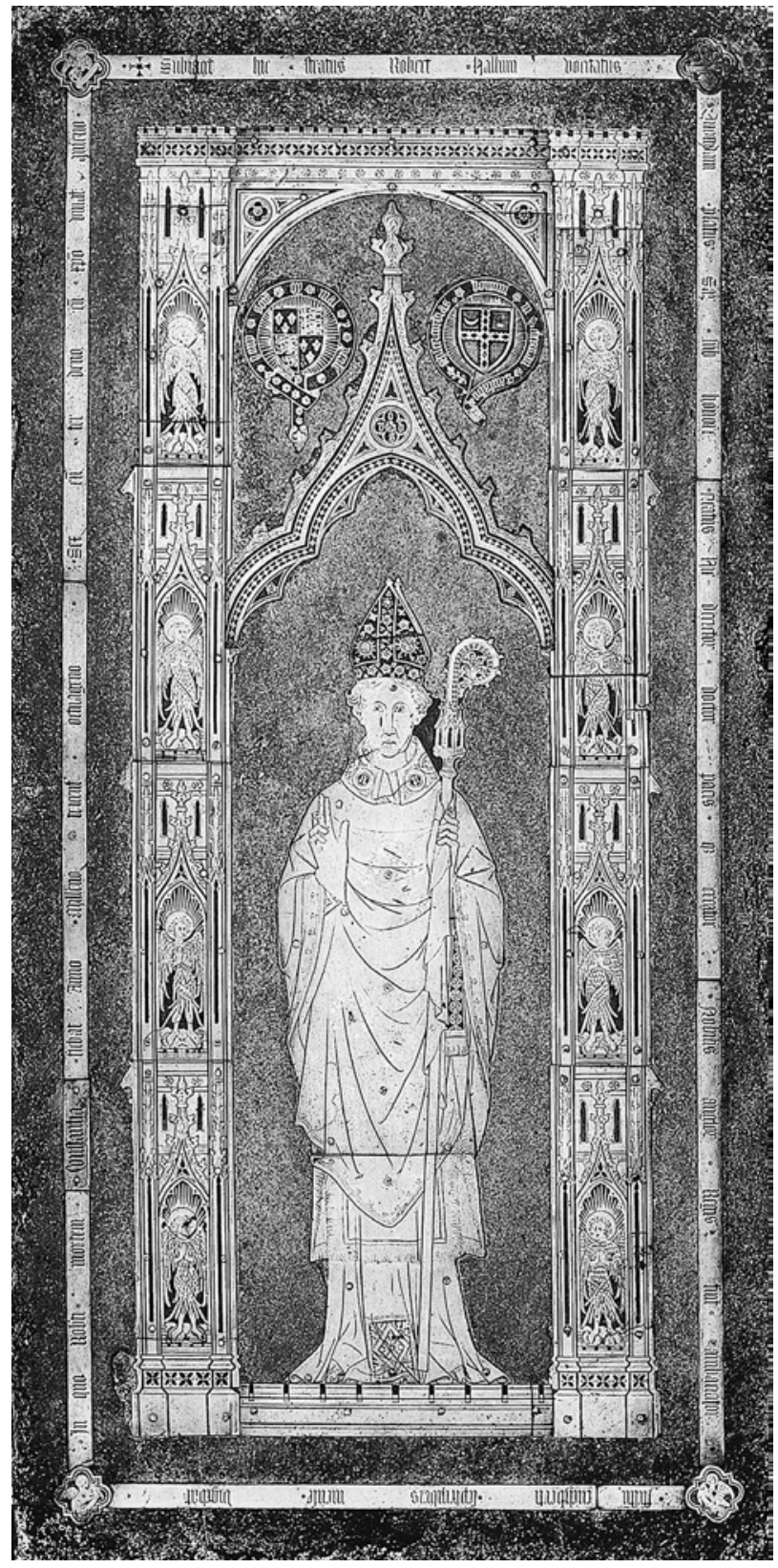

Abb. 6 Grabplatte für Robert Hallum, Bischof von Salisbury, verstorben während des Konzils 1417. Konstanz, Münster, Vierung (Foto: Franz-Josef Stiele-Werdermann, Konstanz)

Baumeister aber gelungen, der Zwiebelform mittels des einbeschriebenen, aus Kreissegmenten gebildeten Maßwerks und zweischichtiger Überlagerung einen besonders einprägsamen Ausdruck zu verleihen.

Die Suche nach möglichen Vorbildern führte nach England, wo das Motiv des geschulterten Kiel- oder Zwiebelbogens (triple arch) bereits im 14. Jahrhundert vielfach anzutreffen ist. ${ }^{20}$ Der Baukunst des »English Decorated « war - dem Namen gemäß - eine besonders dekorative, experimentierfreudige Formensprache zueigen. Möglicherweise geht dieses Bogenmotiv auf den gestuften Spitzbogen, Dreipass- bzw. Kleeblattbogen (trefoil arch), zurück, wie er im »Early English« auftritt. Vielleicht fand es aber auch über die zahlreichen reich beschnitzten hölzernen Innenausstattungen englischer Sakral- und Profanbauten in den Formenkanon der englischen Gotik, denn diese ließen in gewissem Umfang eine eigenständige, weniger statisch als vielmehr dekorativ aufgefasste Formensprache entstehen. Zugleich standen diese Schnitzarbeiten bezüglich Material und Bauweise den Dachwerken nicht fern, sodass es zur Übernahme des Kragarmprinzips weitgespannter »Hammerbeam«-Dächer über Kirchenräumen und Festsälen gekommen sein mag. Dies legen Schulterkielbögen mit vertikalen Schäften zwischen Schultern und zentralem Bogen nahe. ${ }^{21}$ Jean Bony suchte den Ursprung des Kielbogens hingegen im Orient und benennt auch Beispiele für Schulterkielbögen im Mittelmeerraum und im Nahen Osten. ${ }^{22}$

Diesseits des Ärmelkanals tritt das Motiv des Schulterzwiebelbogens erst im ausgehenden 15. Jahrhundert in Flandern, Spanien und Portugal gehäuft auf (siehe unten: Das Bogenmotiv in der Nachfolge). Da man dem Schulterzwiebelbogen am Schnegg jedoch schon in der ersten Hälfte des 15. Jahrhunderts begegnet, kann er nicht durch langsame Weitergabe von Baustelle zu Baustelle nach Konstanz gefunden haben. Eine direkte Verbindung zur englischen Gotik liegt daher nahe. Und tatsächlich wurde das Bogenmotiv wurde von der Insel geradewegs ins Münster vermittelt.

Bischof Robert Hallum von Salisbury starb als Teilnehmer des Konzils im Jahr 1417 und fand im Chor des Konstanzer Münsters seine letzte Ruhe. Auf seiner Grabplatte spannt sich über einer Figur des Bischofs ein Baldachin in Form eines krabbenbesetzten geschulterten Kielbogens mit einbeschriebenem Spitzbogen. Offensichtlich ließ sich der Künstler von der Grabplatte zum Bogenmotiv des Schneggs inspirieren und verlieh ihm durch stärkeres Einziehen des Kielbogens zur Zwiebel eine ausdrucksvollere Gestalt. ${ }^{23}$

\section{Die Grabplatte Bischof Hallums}

In der Vierung des Konstanzer Münsters liegt vor den Stufen zum Hochchor, und damit heute über der Con- 
fessio des hl. Pelagius, nur noch ein sichtbares Grabdenkmal: ${ }^{24}$ die Grabplatte für Robert Hallum (1360/70-1417), von 1407 bis 1417 Bischof von Salisbury (Abb. 6).

Vermutlich in Oxford geboren, erwarb er an der dortigen Universität verschiedene Abschlüsse ${ }^{25}$ und war von 1403 bis 1406 ihr Kanzler. ${ }^{26}$ Ab 1381 stand er in Diensten der Erzbischöfe von Canterbury. Nach einigen Querelen wurde er 1407 zum Bischof von Salisbury gewählt. Bereits beim Konzil von Pisa 1409 trat er als Führer der englischen Delegation auf und hatte auch beim Konstanzer Konzil (1414-18) eine leitende Stellung inne. Vermutlich war er auch an der Entscheidung des Konzils beteiligt, im kommenden Konklave nach Nationen und nicht nach Köpfen abzustimmen. ${ }^{27}$ Doch er erlebte die Papstwahl nicht mehr. Irgendwann im August 1417 begab er sich nach Schloss Gottlieben/Thurgau, wo er am 4. September 1417 an einer bisher unbekannten Todesursache verstarb. Die Richental-Chronik berichtet, dass der Leichnam im Bischofsornat per Schiff nach Konstanz transportiert und im Münster aufgebahrt wurde. ${ }^{28}$ Dort setzte man ihn in der Nähe des Hochaltars bei, wie er es in seinem auf den 23. August 1417 datierten Testament gewünscht hatte. ${ }^{29}$ Darin hinterließ er keine Angaben über das Aussehen seiner Grabstätte oder seines Grabdenkmals. Josua Eiselein berichtet, dass bei der Neubelegung des Vierungsbogens 1775 das Grab geöffnet wurde, wobei man den Toten in einem von einem Holzsarg umschlossenen Zinnsarg fand. Bei dieser Gelegenheit habe man das Grab an den heutigen Platz versetzt. ${ }^{30}$

Die Bodenplatte mit den Maßen ca. 2,50 × 1,20 m wurde aus grauem, weiß gesprenkeltem englischem Granit (Purbeck-Marble) geschaffen ${ }^{31}$ und nimmt in Vertiefungen die motivischen Verzierungen aus Messing auf. Die Metallstücke wurden gegossen, dann die Oberflächen nachgearbeitet und zum Schluss gravierte man die Feinheiten. Diese Metalleinlagen waren ursprünglich bündig in den Stein eingelegt und mit Metallstiften befestigt, von denen einige noch zu erkennen sind. ${ }^{32}$

Um die hochrechteckige Platte läuft ein schmales Inschriftenband ${ }^{33}$ aus Messing, das an den Ecken von Vierpässen mit Evangelistensymbolen unterbrochen wird. Die Typografie weicht beim Wort »Constantia« leicht von der restlichen Schrift ab, was wohl auf eine Restaurierung zurückgeht. ${ }^{34}$ Unter einer Bogenarchitektur steht die Darstellung einer den Betrachter frontal anblickenden Bischofsfigur im Ornat. In der linken Hand hält der Bischof den Bischofsstab, die rechte ist zum Segen erhoben, die Mitra reich geschmückt. Der zinnenartige Untergrund,

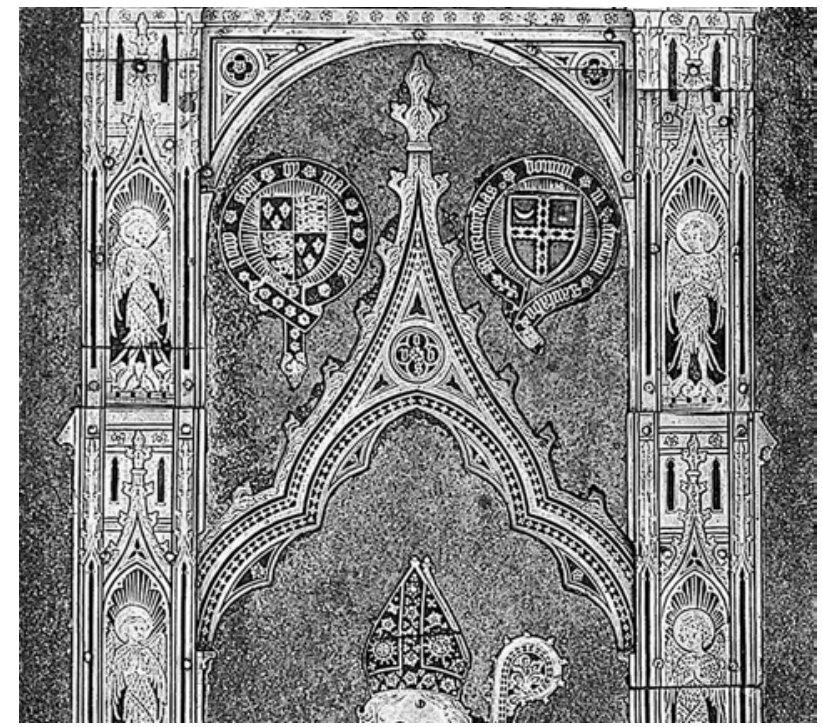

Abb. 7 Schulterkielbogen der Grabplatte Robert Hallums; heraldisch rechts das damalige Wappen des Königreichs England, heraldisch links das Wappen des Bischofs von Salisbury. Konstanz, Münster, Vierung (Foto: F.-J. Stiele-Werdermann)

auf dem der Bischof steht, ist gleichzeitig die Verbindung zwischen den beiden seitlichen Architekturelementen, die jeweils vier Etagen zeigen. Dort öffnen sich krabbenbesetzte Spitzbögen mit Kreuzblume und geben den Blick frei auf jeweils einen Seraphen mit Nimbus, der zur Bischofsfigur blickt. Auf Höhe des dritten Engels ist ein taillierter gotischer Wimperg (Schulterkielbogen) eingespannt, der den Bischof überfängt und in dessen Mitte in einem Vierpass die Buchstaben $»$ ROBS « zu lesen sind, die wohl für »Robertus«stehen (Abb. 7).

Oberhalb des Schulterkielbogens schließt ein zinnenbekrönter Rundbogen die Architektur ab. Im Zwischenraum befestigte man zwei Wappen. Das heraldisch rechte zeigt einen viergeteilten Wappenschild, bei dem im ersten und dritten Feld drei Lilien im Dreieck angeordnet sind, und in Feld zwei und vier drei übereinanderliegende Löwen: das im 15. Jahrhundert gebräuchliche Wappen Englands. Umgeben ist der Schild von einem Gürtel mit dem Motto »hony soit q[u]y mal y pense (Ein Schelm, wer Böses dabei denkt)«, der Devise des Hosenbandordens. Der andere, ergänzte, ebenfalls vierteilige Wappenschild zeigt im ersten Feld eine liegende Mondsichel vor gerastertem Grund und ist von einem Spruchband mit den Worten "misericordias domini in eternum cantabo ${ }^{35}$ umgeben. Es handelt sich hierbei um das persönliche Wappen des Bischofs von Salisbury. ${ }^{36}$ 


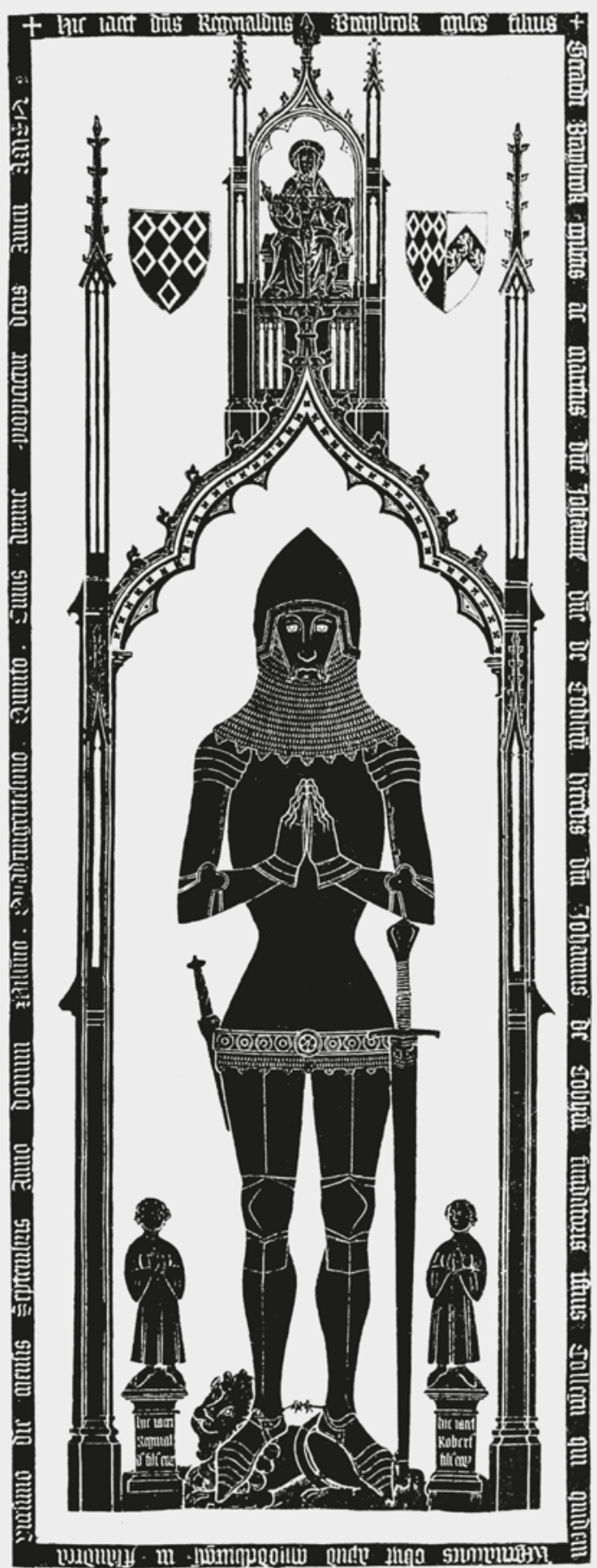

Abb. 8 Grabplatte von Sir Reginald Braybrok († 1405) und seinen Söhnen. Cobham (Kent), Kirche (ex: DruitT 1906, 264)
Zur Hallum-Grabplatte sind mehr Fragen offen als beantwortet. Weder ist der Künstler bekannt noch die Auftraggeber. Die in England geläufige Technik der Metalleinlegearbeiten in Stein und die Steinsorte selbst sowie die Kleinteiligkeit der Metallarbeiten deuten darauf hin, dass die Platte in England, vermutlich in London, hergestellt und dann nach Konstanz transportiert wurde. Auch das falsch angegebene Todesjahr 1416 (korrekt 1417) lässt vermuten, dass die Platte nicht vor Ort geschaffen wurde. Das Motto des Hosenbandordens ${ }^{37}$ und das englische Wappen zeigen, dass König Henry V. an der Auftragsvergabe und der Entstehung der Platte großen Anteil hatte. So konnte er sowohl seine Ehrbezeugung als auch Dankbarkeit gegenüber einem seiner wichtigsten Vertreter beim Konzil zum Ausdruck bringen. König Sigismund, der enge Kontakte zu Hallum unterhielt, wird seinen Einfluss geltend gemacht haben, um beim Domkapitel die Zustimmung für den exponierten Grabplatz zu erhalten.

Bei der Frage nach den Künstlern ist man auf Mutmaßungen angewiesen. Es wäre möglich, dass englische Künstler, die mit der Technik der Brasses ${ }^{38}$ vertraut waren, im Gefolge der Bischöfe in Konstanz die Platte gefertigt haben. Doch ist eine Herstellung in England sehr viel wahrscheinlicher. Da London in dieser Zeit die führenden Werkstätten der Brass-Herstellung besaß und der König als (Teil-)Auftraggeber höchstwahrscheinlich keine minderwertige Werkstatt beauftragt hätte, sind die Künstler auf jeden Fall in England, vermutlich in London, zu suchen.

Das auffälligste Merkmal der Platte ist zweifellos der gotische Wimperg, der den Bischof bekrönt. Dieses Motiv stellt einen weiteren Hinweis auf eine englische Herkunft der Hallum-Platte dar, da es auf vielen englischen Brasses zu finden ist. Sowohl weltliche als auch geistliche Personen ließen den Schulterkielbogen auf ihrer Grabplatte anbringen. Die Grabdenkmäler für Sir Peter de Grandison ( $†$ 1358) in der Kathedrale von Hereford und Sir Bernhard de Brocas ( $\dagger$ 1395) in der Kathedrale von Southwark weisen in der Architektur der das Grabdenkmal umgebenden Kastenbaldachine dieses Motiv ebenso auf wie die Chantry Chapel des Bischofs Robert Stratford (†1362) in der Kathedrale von Chichester. Auffällig ist, dass der Schulterkielbogen fast nur auf Grabplatten von Laien zu finden ist. So stehen die Ritter Sir Nicholas Hawberk ( $\dagger$ 1407) und sein Sohn in Cobham sowie Sir Reginald Braybok ( $\uparrow 1405)$ und seine Söhne in Cobham unter solchen Bögen (Abb. 8). 
Eine Häufung des Motivs ist auf den Platten aus der Gegend um Cobham festzustellen, sodass man vermuten kann, dass es von dort in das Formenrepertoire der Grabplatten überging.

\section{Das Bogenmotiv in der Nachfolge}

In der Folgezeit wurde das Motiv des Schulterkiel- und Schulterzwiebelbogens noch einige weitere Male im Konstanzer Münster aufgegriffen. In einem 1452 geschaffenen Wandbild des Tempelgangs Mariens in der Mauritiusrotunde ist eine besonders ausgeprägte Zwiebel Abschluss eines gemalten Altarretabels (Abb. 9).

An der nördlichen Rückseite des um 1470 fertiggestellten Chorgestühls ist ein filigraner Schulterzwiebelbogen unterhalb des Turmaufbaus zu entdecken. Der Hallum-Grabplatte am ähnlichsten ist der breitgelagerte, geschulterte Kielbogen am Epitaph des 1491 verstorbenen Bischofs Otto von Sonnenberg in der Franz-Xaver-Kapelle (Abb. 10).

Vom nördlichen Seitenschiff führt ein Portal in den Nordturm zur Orgelempore hinauf, mit der zusammen es um 1516 entstanden ist. Im Sturz zeigt es Maria mit dem Kind unter einem Schulterzwiebelbogen (Abb. 11).

Eine etwas andere Bogenform findet sich auf dem nur wenig früher gezeichneten sogenannten Wiesbadener Riss, der einen Vorschlag zum Wiederaufbau der 1511 abgebrannten Westtürme festgehalten hat. ${ }^{39}$ Er zeigt auf etwa halber Höhe des Mittelturms einen dem Mauerwerk aufgelegen, auf Schultern sitzenden und zu den Eckfialen aufsteigenden Scherbogen.

Sicherlich hat das Bogenmotiv noch weitere Anwendung im Konstanzer Münster gefunden, doch ging dessen reiche spätgotische Ausstattung in der Reformation größtenteils verloren, und der Auflösung des Bistums folgte ein Ausverkauf, durch den weitere Kunstwerke verschwunden sind. Heute ist das früheste Aufgreifen des Bogenmotivs der Hallum-Grabplatte am Schnegg festzustellen, doch kann nicht ausgeschlossen werden, dass sich zuvor schon andere Künstler und Baumeister in ähnlicher Weise haben inspirieren lassen. Wie der Vergleich des Bogenmotivs zwischen Bauriss und gebautem Schnegg erkennen lässt, erfolgte im Laufe des Entwurfsprozesses aber ein bemerkenswerter Gestaltungsprozess, sodass dem Schöpfer des Schneggs zumindest die Entwicklung der eindrücklichen, drallen Zwiebelform mit einbeschriebenem Pass zugeschrieben werden darf.

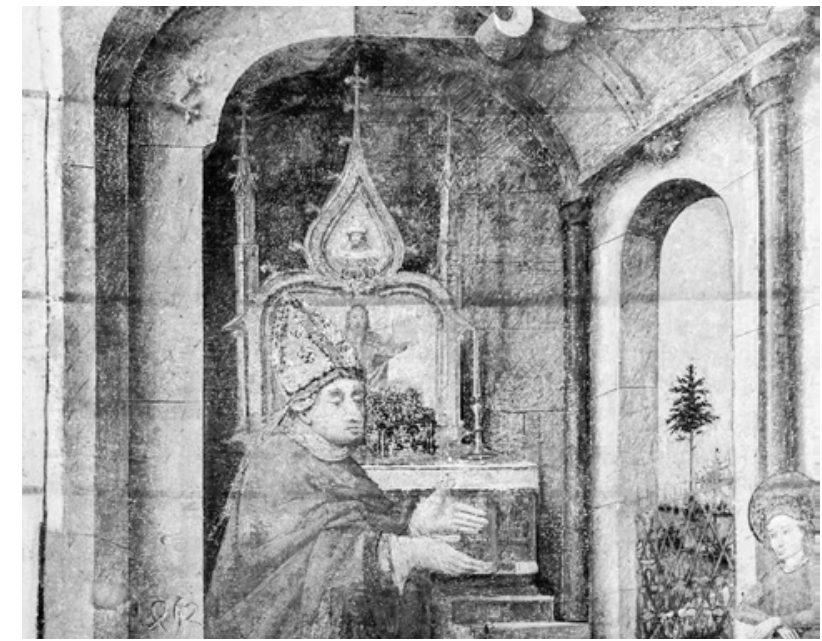

Abb. 9 Wandbild des Tempelgangs Marias (1452) mit Altarretabel in Schulterzwiebelbogenform. Konstanz, Münster, Mauritiusrotunde (Foto: S. King / I. Stadie)

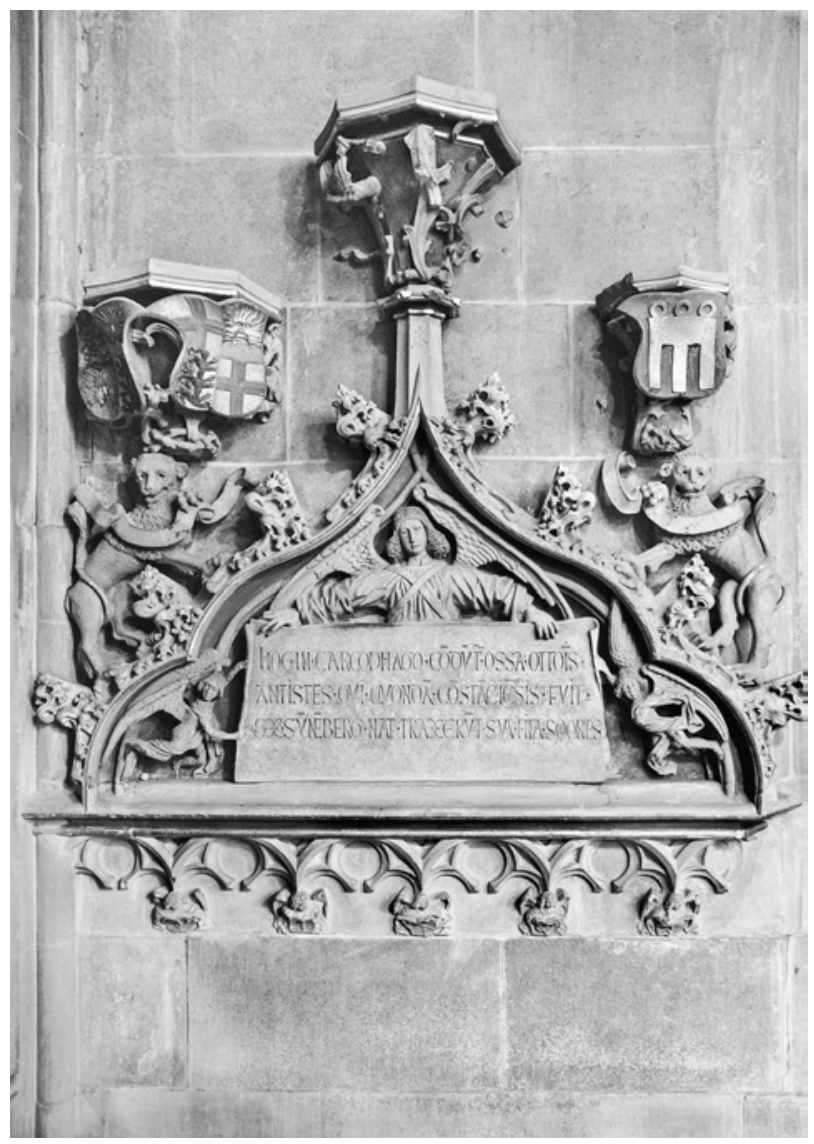

Abb. 10 Epitaph Bischof Ottos von Sonnenberg († 1491) mit breit gelagertem Schulterkielbogen. Konstanz, Münster, Franz-Xaver-Kapelle (Foto: S. King / I. Stadie) 


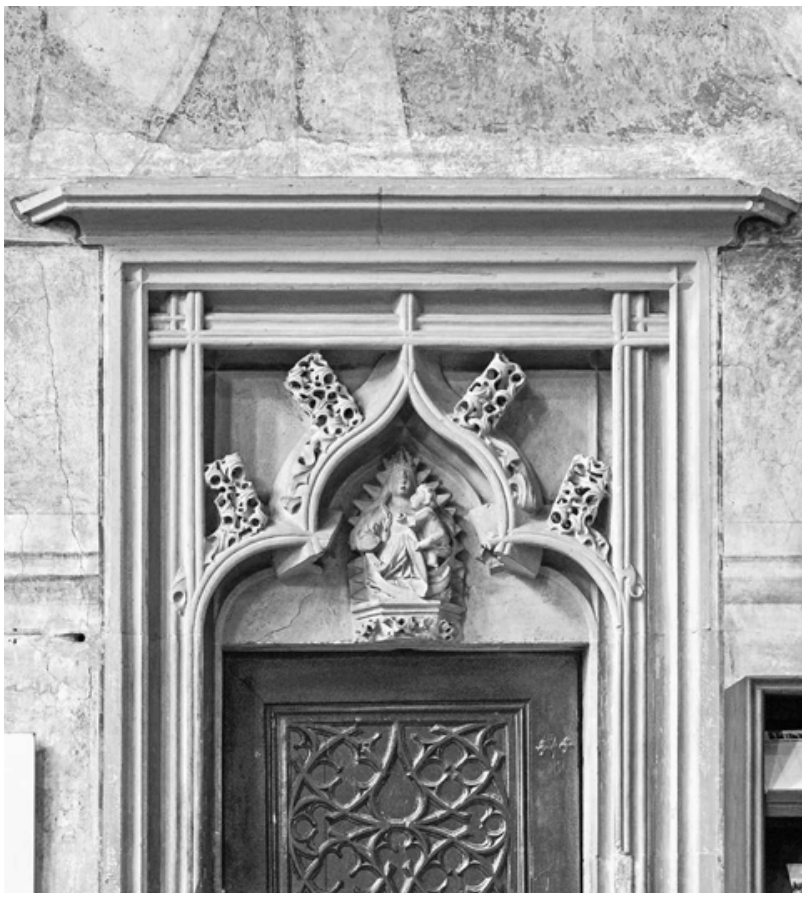

Abb. 11 Marienfigur in einem Schulterzwiebelbogen. Um 1516. Konstanz, Münster, Nordturm, Zugang zur Orgelempore (Foto: S. King / I. Stadie)

Außerhalb des Konstanzer Münsters hat das Bogenmotiv hingegen kaum Verbreitung gefunden. Es fällt auf, dass sich vereinzelte Beispiele meist in Verbindung mit Sakramentshäusern finden. Im Ulmer Münster nimmt ein Schulterzwiebelbogen die prominente Position unmittelbar über dem Tabernakelschrein ein und das Motiv taucht weit oben im turmartigen Baldachingesprenge abermals auf (Abb. 12). ${ }^{40}$

Dieses Sakramentshaus wurde um 1467 bis 1471 geschaffen, vermutlich nach einem 1462 gefertigten Riss durch Moritz Ensinger oder Hans Niesenberger. ${ }^{41}$ womit es zeitlich dem Schnegg am nächsten kommt. Das Sakramentshaus der ehemaligen Klosterkirche in Salem ist 1494 vermutlich unter Werkmeister Hans von Safoi entstanden und liegt in geringer Entfernung vom gegenüberliegenden Ufer des Bodensees. Hier bilden geschulterte Scherbögen die Basis für den ausladenden und hoch aufragenden Baldachin. Es steht heute an ungewöhnlicher Stelle vor der Stirnwand des nördlichen Querhausarms, wohin es um 1750 von der Nordseite des Chorraums umgesetzt worden ist. ${ }^{42}$ An dem 1493 bis 1496 von Adam Kraft geschaffenen Sakramentshaus von St. Lorenz in Nürnberg finden sich geschulterte Scherbögen an vergleichbarer Stelle, jedoch sehr viel kleiner und

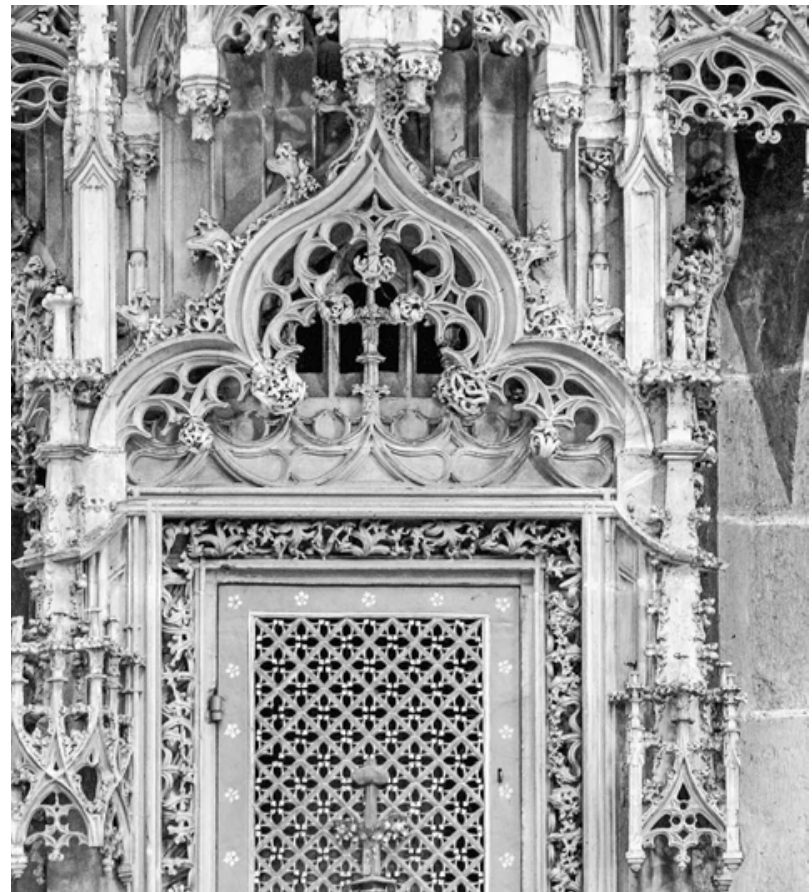

Abb. 12 Schulterzwiebelbogen am Sakramentshaus. 1467-71. Ulm, Münster (Foto: S. King / I. Stadie)

von verschlungenen Fialen bedrängt. ${ }^{43}$ Kaum augenfällig findet sich der Schulterzwiebelbogen auch am Gitter des einstigen, um 1513 entstandenen Sakramentshauses des Freiburger Münsters, wo er als einfacher Umriss und in vielfacher Wiederholung als ornamentales Band den oberen Rand ziert. ${ }^{44}$

Es stellt sich die Frage, warum ausgerechnet bei der architektonischen Gestaltung von Sakramentshäusern die Wahl wiederholt auf das ungewöhnliche Bogenmotiv fiel. Da der Schnegg wie ein überdimensioniertes Exemplar erscheint, könnte er die Anregung dazu gegeben haben. Das früheste Beispiel an einem Sakramentshaus findet sich in Ulm, sodass das Motiv dann von dort weitergetragen worden sein könnte. Näher läge es jedoch, das Vorbild im Konstanzer Münster selbst zu vermuten, wo sich einst ebenfalls ein hoch aufragendes Sakramentshaus im Chorraum befand. Seine Bauzeit ist nicht überliefert und Schriftquellen nennen nur eine Neufassung des »sacrament heißlin« sowie die Aufstellung von Figuren der beiden Münsterpatrone im Jahr $1589 .{ }^{45}$ In einem Stich von 1609 ist festgehalten, wie der turmartige Baldachin hinter dem Lettner aufragt. ${ }^{46}$ Die stark vereinfachte Darstellung lässt jedoch keine Einzelformen erkennen. Dem Stich zufolge hätte sich das Sakramentshaus nicht in der 
liturgisch üblichen Position auf der nördlichen Evangelienseite, sondern auf der Südseite des Chorraums befunden, doch kann bei dieser Art der Darstellung nicht ausgeschlossen werden, dass die Situation seitenverkehrt wiedergegeben ist. Sollte das Konstanzer Sakramentshaus tatsächlich das gesuchte Vorbild gewesen sein, würde dies auch bedeuten, dass es jenem des Ulmer Münsters, das gemeinhin als früheste Ausführung mit hochaufragendem, turmartigem Baldachin gilt, zeitlich vorausgegangen sein müsste.

Neben dem geschilderten Auftreten in Großbritannien, am Konstanzer Münster und an Sakramentshäusern in Süd- und Südwestdeutschland ist das Motiv von Schulterkiel- und Schulterzwiebelbogen innerhalb überreich dekorierter Architekturen in Flandern, Spanien und Portugal zahlreich anzutreffen, allerdings erst etwas später seit dem ausgehenden 15. Jahrhundert. ${ }^{47}$ Die dortige Architektur und Schnitzkunst der Spätgotik zeichnen sich durch eine ausgesprochene Experimentierfreude und Formenfülle aus, sodass die Künstler gewiss jede sich bietende Anregung begehrlich aufgegriffen haben. Sicherlich wurde das Bogenmotiv direkt aus England und nicht etwa über das Konstanzer Münster dorthin vermittelt. Dort durfte die Bogenform gelegentlich als bestimmende Großform zur Geltung kommen, doch zumeist kam ihm nur eine untergeordnete Rolle innerhalb einer großen Formenvielfalt zu. Durch brabantische Baumeister kamen Schulterkiel- und Schulterzwiebelbögen beim Bau der königlichen Abteikirche Brou bei Bourg-en-Bresse um 1530 als regelrechtes Leitmotiv zu Ehren und wurden an Architektur, Ausstattung und Grabdenkmälern in vielfältiger Variation eingesetzt. ${ }^{48}$ Sonst fand es in Frankreich aber kaum Verbreitung. ${ }^{49}$

Auch in Venedig gibt es ein inselartiges Auftreten von Schulterkiel- und Schulterzwiebelbögen seit dem frühen 14. Jahrhundert. Es handelt sich um Abschlüsse von zumeist mehrfach gereihten Fensteröffnungen mit Zwischensäulen. Ihr Auftreten wurde auf Vorbilder im Orient oder in England zurückgeführt, begründet durch die vielfältigen Handelsbeziehungen. ${ }^{50}$ Doch bei der Betrachtung der zeitlich und stilistisch vorausgehenden Fensterformen könnte man die Entstehung auch als eine lokale Entwicklungslinie interpretieren. Die früheren kielbogigen Öffnungen erfuhren einerseits durch Hinzufügen einbeschriebener Nasen und andererseits durch wechselweise vor- und zurückspringende Wulstabschnitte im Rahmenprofil eine Aufwertung. Doch die effektvolle Rahmung lässt die Nasen wie Fremdkörper erscheinen.
Dem wurde durch Einziehen der Rahmung in die Nasen begegnet, was diese zu einem Bestandteil von Rahmung und Umriss werden ließ und eine noch anmutigere Form - eben den Schulterkiel- bzw. Schulterzwiebelbogen entstehen ließ.

Im ausgehenden 15. und frühen 16. Jahrhundert werden Bogen- und Maßwerkmotive gebräuchlich, die aus separaten, sich mit den Enden überkreuzenden Rippenstücken zusammengefügt sind. Das Formenspektrum wird durch ineinander verschlungene Formen, Astwerk und die Verbreitung von Vorhangbögen und vielfältigen weiteren Bogenformen aus der niederländischen und flämischen Gotik noch unübersichtlicher. Eine klare Begriffsbestimmung von Schulterkiel- oder Schulterzwiebelbögen ist dann nicht mehr möglich.

Auf einige ähnliche Erscheinungen sei noch hingewiesen, bei denen vermutlich ebenfalls keine Verbindungen zur Grabplatte Hallums bestehen. Am Triumphbogenkreuz der Marienkirche in Salzwedel gibt es einen Schulterkielbogen, der in die Mitte des 15. Jahrhunderts datiert wird. Allerdings befinden sich dort schmale Fialen zwischen den einzelnen Abschnitten, sodass es sich möglicherweise nicht um ein zusammenhängendes Bogenmotiv, sondern um ein Arrangement gestaffelt angeordneter Einzelbögen handeln könnte. Daneben gab es die Möglichkeit, den Schultern andere Bogenformen aufzusetzen, was oben bereits mit den Scherbögen des Wiesbadner Risses und des Nürnberger Sakramentshauses angedeutet wurde. Am Regensburger Dom und in dessen Umfeld tritt im späten 14. und im 15. Jahrhundert ein Bogenmotiv gehäuft auf, bei dem Schultern einen Spitzgiebel mit geraden oder einschwingenden Schenkeln tragen. Möglicherweise kam so auch die ungewöhnliche Bogenform am Weltgerichtsportal der Esslinger Frauenkirche kurz vor 1400 zustande, wo einem breit gelagerten Korbbogen ein Wimperg mit einbeschriebenem Spitzbogen aufsitzt.

Als gotische Stilformen in der Epoche des Historismus zu neuer Blüte kamen, entstanden von der Mitte des 19. Jahrhunderts bis ins frühe 20. Jahrhundert zahlreiche Schulterkiel- und Schulterzwiebelbögen. ${ }^{51}$ Ihre weite Verbreitung ist sicherlich auf Vorlagen in Musterbüchern zurückzuführen, auf die - anders als im Mittelalter - die Kunstschaffenden zurückgreifen konnten. Innerhalb des Konstanzer Münsters wurde das Bogenmotiv zwar an keiner Stelle mehr aufgegriffen, doch in der unweit gelegenen Pfarrkirche St. Stephan steht seit 1863 ein Schulterkielbogen im Fokus des Kirchenraums, wo er den oberen 


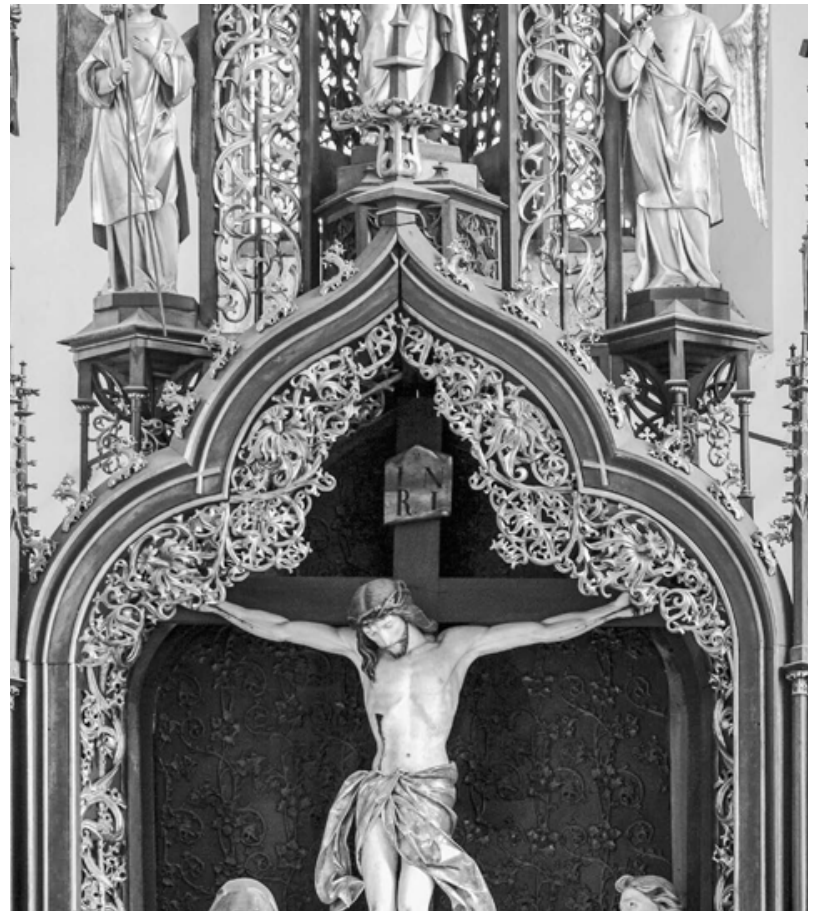

Abb. 13 Schulterkielbogen am Hochaltarschrein. Peter Metz aus Gebrazhofen bei Leutkirch, 1863. Konstanz, St. Stephan (Foto: S. King, I. Stadie)

Abschluss des von Peter Metz aus Gebrazhofen bei Leutkirch geschaffenen Hochaltarschreins bildet (Abb. 13). ${ }^{52}$

Die Nähe zur Grabplatte Bischof Hallums dürfte eher zufällig sein, denn mit Blick auf die zahlreichen Beispiele darf angenommen werden, dass das Bogenmotiv als Teil des nun allgemeinen Formenkanons dorthin gefunden hat. Zumindest für den südwestdeutschen Raum fällt wiederum eine bevorzugte Anwendung für ein bestimmtes Ausstattungselement auf, diesmal den Hochaltar.

Das Konstanzer Konzil jährte sich im Zeitraum von 2014 bis 2018 zum sechshundertsten Mal, woran mit zahlreichen Veranstaltungen erinnert wurde. Diese internationale Zusammenkunft erlauchter Häupter gilt als das bedeutendste Ereignis in der Geschichte der Stadt und hat sie in vielerlei Hinsicht stark geprägt. $\mathrm{Zu}$ den beachtenswerten Hinterlassenschaften der Konzilszeit innerhalb der Stadt gehört die Grabplatte Bischof Hallums. Bisher blieb jedoch unbeachtet, dass sie lokalen Künstlern als Inspirationsquelle diente und eine bescheidene Nachwirkung entwickeln konnte. Zwar blieb es bei einer kunsthistorischen Anekdote, die allerdings einige interessante Aspekte bietet. Zur damaligen Zeit waren neue Stilformen in aller Regel das Produkt einer kontinuierlichen Weiterentwicklung, die durch wandernde Steinmetze und enge Kontakte der Bauhütten Verbreitung fanden. Demgegenüber kann die inselartige Häufung von Schulterkielund Schulterzwiebelbögen im Konstanzer Münster und im südwest- und süddeutschen Raum, die in den Jahrzehnten nach dem Konstanzer Konzil entstanden, auf einen Direktimport über eine große Distanz zurückgeführt werden. Allerdings passte diese Bogenform offenbar doch nicht so recht ins zeitgenössische Formenrepertoire und wurde möglicherweise als zu exotisch empfunden. Dennoch war sie offenbar Steinmetzen und Baumeistern geläufig, die sie gelegentlich als dekoratives Element für die Kirchenausstattung adaptierten.

\section{Literatur}

Arslan, Edoardo: Das gotische Venedig. Die venezianischen Profanbauten des 13.-15. Jahrhunderts. München 1971.

[Ausst.-Kat. Konstanz 1989]: Ausst.-Kat. Glanz der Kathedrale. 900 Jahre Konstanzer Münster. Hg. von Björn R. Kommer. Konstanz, Städtische Museen, Rosgartenmuseum, 3.6.27.8.1989. Konstanz 1989.

[Ausst.-Kat. Ulm 2002]: Ausst.-Kat. Michel Erhart \& Jörg Syrlin d. Ä. Spätgotik in Ulm. Hg. von Brigitte ReInHARDT und Stefan Roller. Ulmer Museum, 8.9.-17.11. 2002. Stuttgart 2002.

Bоск, Sebastian: Repräsentation und Raumnot. Ausstattung und Inventar des Freiburger Münsterchores im frühen 16. Jahrhundert. In: Münsterblatt 20 (2013), 26-38.

Böker, Johann Josef: Architektur der Gotik. Bestandskatalog der weltgrößten Sammlung an gotischen Baurissen (Legat Franz Jäger) im Kupferstichkabinett der Akademie der bildenden Künste Wien. Salzburg/München 2005.

Böker, Johann Josef/Brehm, Anne-Christine/Hanschke, Julian/SAuvé, Jean-Sébastien: Architektur der Gotik. Rheinlande. Basel, Konstanz, Freiburg, Straßburg, Mainz, Frankfurt, Köln. Ein Bestandskatalog der mittelalterlichen Architekturzeichnungen. Salzburg u. a. 2013.

Bony, Jean: The English Decorated Style. Gothic Architecture Transformed 1250-1350. Oxford 1979 (Wrightsman Lectures 10).

Brenm, Anne-Christine: Hans Niesenberger von Graz. Ein Architekt der Spätgotik am Oberrhein. Basel 2013.

Buck, Thomas Martin (Hg.): Chronik des Konstanzer Konzils 1414-1418. Von Ulrich Richental. Ostfildern 2010 (Konstanzer Geschichts- und Rechtsquellen 41).

Crossley, Paul: Salem and the Ogee Arch. In: Gasser/FreiGANG/BOERNER 2006, 321-342. 
DruitT, Herbert: A Manual of Costume, as Illustrated by Monumental Brasses. London 1906; Neudruck Bath 1970.

Eberhardt, Tanja: Die Wandmalereien am Grabmal Bischofs Otto III. von Hachberg. Anmerkungen zur Maltechnik. In: LAULE 2013/I, 154-159.

EISElein, Josua: Geschichte und Beschreibung der Stadt Konstanz und ihrer nächsten Umgebung. Konstanz 1851.

Emmerling, Erwin/Knipping, Detlef/Niehoff, Franz: Das Westportal der Heiliggeistkirche in Landshut. Ein Symposium zur Geschichte und Farbigkeit des spätgotischen Figurenportals. Tagung Landshut, 21.-23.9.1997. München 2001 (Arbeitshefte des Bayerischen Landesamtes für Denkmalpflege 106).

Feger, Otto (Bearb.): Ulrich Richental: Das Konzil zu Konstanz 1414-1418. Faksimileausgabe, Kommentar und Text. Starnberg/Konstanz 1964.

Feger, Otto (Hg.): Die Chronik des Konstanzer Konzils 14141418, Textheft (ohne Wappenteil). Konstanz 1965.

[Festschrift Fleischhauer 1964]: Beiträge zur schwäbischen Kunstgeschichte. Festschrift zum 60. Geburtstag von Werner Fleischhauer. Konstanz/Stuttgart 1964.

Frebel, Volkhard: Das Ulmer Sakramentshaus und sein Meister. In: Ulm und Oberschwaben 44 (1982), 239-252.

Gasser, Stephan/Freigang, Christian/Boerner, Bruno (Hgg.): Architektur und Monumentalskulptur des 12.-14. Jahrhunderts. Produktion und Rezeption. Festschrift für Peter Kurmann zum 65. Geburtstag. Bern u. a. 2006.

Handke, Barbara: Die Wiler Altarbauer Müller und ihr Werk. Ein Beitrag zur Geschichte der Kirchenausstattungen des Historismus im Kanton Freiburg mit besonderer Berücksichtigung der Kathedrale Freiburg und der Pfarrkirche Alterswil. In: Freiburger Geschichtsblätter 62 (1979/80), 251-270.

Hertlein, Beata: Das Sakramentshaus von Adam Kraft in der Nürnberger Lorenzkirche. Zu Konstruktion und Werkprozeß. In: KAMMEL 2002, 195-212.

HöRsCH, Markus: Architektur unter Margarethe von Österreich, Regentin der Niederlande (1507-1530). Eine bau- und architekturgeschichtliche Studie zum Grabkloster St.-Nicolas-de-Tolentin in Brou bei Bourg-en-Bresse. Diss. Berlin (TU) 1991. Turnhout/Brüssel 1994 (Verhandelingen van de Koninklijke Academie voor Wetenschappen, Letteren und Schone Kunsten van Belgie, Klasse der Schone Kunsten 58).

Horn, Joyce M. (Hg.): The Register of Robert Hallum, Bishop of Salisbury, 1407-17. Torquay 1982 (Canterbury and York Society 72 ).

Hubert, Hans W.: Die Plastik des Schneggs. In: Laule 2013/I, $128-130$.

Humpert, Theodor: Chorherrenstift, Pfarrei und Kirche St. Stephan in Konstanz. Konstanz 1957.

Hundbiss, Stefan: Restauratorische Untersuchungen zur Farb- fassung des Westportals der Heiliggeistkirche in Landshut und ihre Konservierung. In: EmmerLing/Knipping/NieHOFF 2001, 73-102.

JАсов, Ernest Fraser/Johnson, H. C. (Hgg.): The Register of Henry Chichele, Archbishop of Canterbury 1414- 43, Bd. 2. Wills Provided before the Archbishop or his Commissaries. Oxford 1937.

JäGERS, Elisabeth: Naturwissenschaftliche Untersuchung der Malschichten und Klebstoffmassen. In: SEBALD 1999, 104105.

Kammel, Frank Matthias (Hg.): Adam Kraft. Die Beiträge des Kolloquiums im Germanischen Nationalmuseum. Nürnberg 2002.

KAVAlER, Ethan Matt: Renaissance Gothic in the Netherlands: The Uses of Ornament. In: The Art Bulletin 82 (2000), 226256.

Kavaler, Ethan Matt: Geometers at Brou. Architecture and Ornament in Spain, Brabant and Western Europe around 1500. In: PIERI 2009, 117-124.

[KING 2013/I]: KING, Stefan: Der Umbau von Chor und Querhaus im 15. Jahrhundert. In: LAULE 2013/I, 78-83.

[KING 2013/II]: KING, Stefan: Der Schnegg. In: Laule 2013/I, 122-125.

[KING 2013/III]: KING, Stefan: Ein Bauriss zum Schnegg. In: LAULE 2013/I, 126-127.

[KING 2013/IV]: KING, Stefan: Das Motiv des Schulterzwiebelbogens am Schnegg. In: LAULE 2013/I, 131-133.

KING, Stefan: Südkapellen und Südportal des Konstanzer Münsters. Anmerkungen zur Bautechnik, zum Entwurfsprozess und zu den Baumeistern. In: Schriften des Vereins für Geschichte des Bodensees und seiner Umgebung 133 (2015), 125-201.

KNAPP, Ulrich: Salem und Kaisheim. Zwei Auftraggeber der Erhart-Werkstatt. In: Ausst.-Kat. Ulm 2002, 128-145.

KNAPP, Ulrich: Salem. Die Gebäude der ehemaligen Zisterzienserabtei und ihre Ausstattung. Stuttgart 2004.

Koepf, Hans: Die gotischen Planrisse der Wiener Sammlungen. Wien 1969 (Studien zur österreichischen Kunstgeschichte 4).

Konrad, Bernd: Realistische Neuerungen in der Malerei aus dem Umkreis von Konrad Witz. Der Meister von 1445. In: LAULE 2013/I, 150-153.

KowA, Günter: Architektur der Englischen Gotik. Köln 1990 (DuMont Dokumente).

Kraus, Franz Xaver: Die Kunstdenkmäler des Kreises Konstanz. Freiburg/B. 1887 (Die Kunstdenkmäler des Großherzogthums Baden 1).

[LAule 2013/I]: LAule, Ulrike (Hg.): Das Konstanzer Münster Unserer Lieben Frau. 1000 Jahre Kathedrale, 200 Jahre Pfarrkirche. Regensburg 2013.

[LAULE 2013/II]: LAULE, Ulrike: Der sogenannte Wiesbadener 
Riss. Ein Vorschlag zum Wiederaufbau der Westturmanlage des Konstanzer Münsters nach dem Brand von 1511. In: Schriften des Vereins für Geschichte des Bodensees und seiner Umgebung 131 (2013), 115-133.

Marmor, Johann: Geschichtliche Topographie der Stadt Konstanz und ihrer nächsten Umgebung. Mit besonderer Berücksichtigung der Sitten- und Kulturgeschichte derselben. Konstanz 1860 .

Mielke, Friedrich: Die Geschichte der deutschen Treppen. Berlin u.a. 1966.

MülleR, Rainer (Hg.): Spätgotischer Taufstein mit Baldachin in der Erfurter Severikirche. Forschung, Untersuchung und Restaurierung. Altenburg 2010 (Arbeitshefte des Thüringischen Landesamtes für Denkmalpflege und Archäologie N. F. 35).

MülleR, Theodor: Zur Konstanzer Plastik in der Mitte des 15. Jahrhunderts. In: Festschrift Fleischhauer 1964, 101-114. Pieri, Caecilia (Hg.): Brou, un monument européen à l'aube de la Renaissance/Brou, a European Monument in the Early Renaissance. Tagung Bourg-en-Bresse, Oktober 2006. Paris 2009.

QUIRK, Roger Nathaniel: Bishop Robert Hallum and the Council of Constance. In: Friends of Salisbury Cathedral 22 (1952), 3-15.

Reiners, Heribert: Das Münster Unserer Lieben Frau zu Konstanz. Konstanz 1955 (Die Kunstdenkmäler Südbadens 1).

Reiners-Ernst, Elisabeth: Regesten zur Bau- und Kunstgeschichte des Münsters zu Konstanz. Konstanz 1956 (Schriften des Vereins für Geschichte des Bodensees und seiner Umgebung, Sonderheft).

ReISNER, Jacob: Ein Bauriß zum Konstanzer »Schnegg«. In: Oberrheinische Kunst 8 (1939), 65-70.

RöBER, Ralph: Archäologische Erkenntnisse zum Kreuzgang und $\mathrm{zu}$ den angrenzenden Gebäuden. In: Laule 2013/I, 288-290.

SAlter, Herbert E./Lobel, Mary Doreen (Hgg.): The Victoria History of the Counties of England, Bd. 3. The University of Oxford. Oxford 1954.

Sebald, Eduard: Das Südportal des Wormser Doms. Worms 1999 (Denkmalpflege in Rheinland-Pfalz, Forschungsberichte 5).

[STAdie 2013/I]: STAdie, Ines: Das Grabdenkmal für Robert Hallum im Chor. In: LAULE 2013/I, 87-88.

[STADIE 2013/II] : STAdie, Ines: Das Grabdenkmal für Bischof Otto III. von Hachberg-Sausenberg. In: LAULE 2013/I, 148149.

Staemmler, Thomas: Der Taufstein der Severikirche in Erfurt. Ergebnisse der restauratorischen Untersuchungen. In: MüLLER 2010, 70-81.

Troescher, Georg: Die Burgundische Plastik des ausgehenden
Mittelalters und ihre Wirkungen auf die Europäische Kunst. Textband. Frankfurt/M. 1940.

VöLKLE, Peter: Werkplanung und Steinbearbeitung im Mittelalter. Ulm 2016.

Wingenroth, Max/Gröber, Konrad: Die Grabkapelle Ottos III. von Hachberg, Bischofs von Konstanz, und die Malerei während des Konstanzer Konzils. Zweiter Teil. In: Schauinsland 36 (1909), 17-48.

Zimdars, Dagmar u.a.: Baden-Württemberg 2: Die Regierungsbezirke Freiburg und Tübingen. München/Berlin 1997 (DeHio-Handbuch der Deutschen Kunstdenkmäler).

\section{Anmerkungen}

1 Vortrag, gemeinsam gehalten beim Forum Kunst des Mittelalters am 20. September 2013 in Freiburg in der Sektion Zentralisierung und Diversifizierung. Englische Kunst im Schatten des Hundertjährigen Krieges ca. 1350-1450. In kurzen Einzelbeiträgen bereits veröffentlicht: KIng 2013/II, III, IV. - Stadie 2013/I. - Eine Dissertation von Ines Stadie zum Thema ist in Arbeit.

2 Marmor 1860, 331, berichtete von Thesen, wonach Teile des Schneggs die Reste eines Sakramentshauses gewesen seien, denen er sich aber selbst nicht anschloss. - KRAUS $1887,116,152-155$, vermutete eine Schaubühne zur Präsentation von Reliquien, was aber der Lage des obersten Treppenpodests wegen wenig praktikabel gewesen wäre. - WINGENROTH/GRÖBER 1909, 38, interpretierten die Treppe als bloßen Zugang ins Dach, was über die obere Sakristei jedoch sehr viel einfacher möglich gewesen wäre. - Nach Troescher 1940, 156, hätte es sich um einen Zugang der Domherren von den Kurien über den Kreuzgang hinweg gehandelt. - ReINERS 1955, 158, schlug die Treppe als Zugang zu einer früheren Schwalbennestorgel im Mittelschiff vor, wohin eine Verbindung aber gar nicht möglich ist.

3 RÖBER 2013.

4 Wie von Troescher 1940, 156, vermutet.

5 Reiners-Ernst 1956, 64, Kat.-Nr. 396; 134, Kat.-Nr. 833.

$6 \mathrm{Zu}$ den Umbauten von Chor und Querhausarmen KING 2013/I.

7 Reiners-Ernst 1956, 21 f., Kat.-Nr. 158-161, 165.

8 Reiners-Ernst 1956, 21, Kat.-Nr. 159.

9 MÜLLER 1964.

10 BÖKer 2005, 339. - BÖKeR/Brehm/HANSCHKe/SAUVÉ 2013, 59.

11 KING 2015

12 Zur Skulptur HUbert 2013.

13 Troescher 1940, 157. - Aufmaßzeichnungen der Grundrisse in KING 2013/III.

14 Akademie der Bildenden Künste Wien, Kupferstichkabinett, Inv.-Nr. 17.028, 17.055. - Wiedergegeben bei ReIsNer 1939, Abb. 1. - KoEPF 1969, Abb. 83, 83a. - Ausst.-Kat. Konstanz 1989, Kat.-Nr. 1, 2, 7. - Böker 2005, 339. - BöKer/Brehm/Hanschke/SAuvé 2013 , 59. - KING 2013/III.

15 Jägers 1999. - HUndbiss 2001, 76. - Hertlein 2002, 201 und Anm. 13. - VÖLKLE 2016, 154-156. - Am Freiburger Münster, das vom frühen 13. bis ins 16. Jh. kontinuierlich Baustelle war, kam diese Technik erstmals in den $1260 e r$ Jahren an den westlichen Langhaus- 
jochen zum Einsatz, bis sie am Chor im 15. und 16. Jh. besonders reichlich Anwendung fand (Beobachtungen aus der laufenden Arbeit des Verfassers/King).

16 Der 1467 geschaffene Baldachin über dem Taufstein der Erfurter Severikirche trug bis ins 17 . Jh. offenbar ebenfalls keine Fassung. Staemmler 2010, $76 \mathrm{f}$.

17 Stadie 2013/II. - Konrad 2013. - Eberhardt 2013.

18 Mielke 1966, 357 und Abb. 23.

19 Diese Vorbilder wurden von Georg Troescher und Heribert Reiners postuliert. Troescher 1940. - Reiners 1955, 158-165.

20 Beispiele aus Großbritannien in Werkstein: Abergavenny (Monmouthshire), St. Mary's Prior Church, Grabmäler von Sir John de Hastings ( $†$ 1326), Sir William de Hastings ( $†$ 1348) und Sir Lawrence de Hastings um 1350; Chichester Cathedral, Grabmal Bischof Robert Stratford ( $\dagger 1362$ ); Christchurch (Hampshire), Priory Church, Altarwand, 2. H. 14. Jh.; Durham Cathedral, Grabmal des Bischofs Thomas Hatfield in Kombination mit Bischofsthron nach 1362; Gloucester Cathedral, Grabmal König Edward II., 1330-35; Hanwell (Oxfordshire), St. Peter, Figurenfries nördliches Seitenschiff, 14. Jh.; Hereford Cathedral, Grabmal Sir Peter de Grandison ( $†$ 1358); Holbeach (Lincolnshire), Grabmal Sir Humphrey Littlebury, um 1360; Lincoln Cathedral, Figurennischen über dem Hauptportal, um 1380; London, Westminster Palace, Wandarkaden der St. Stephen's Chapel, um 1326 (KowA 1990, Abb. 139 f., 162); Northwold (Norfolk), St. Andrew, Heiliges Grab, 15. Jh.; Ottery St. Mary (Devon), St. Mary, Altarwand, 2. H. 14. Jh.; Stebbing (Essex), St. Mary the Virgin, Schranke, um 1350; Wells Cathedral, Bischofsthron um 1330. - Beispiele in Großbritannien in Holzschnitzwerk: Addlethorpe (Lincolnshire), St. Nicholas, Schranke, frühes 15. Jh.; Blundeston (Suffolk), St. Mary, Schranke 15. Jh.; Bristol Cathedral, Chorgestühl 1515-26; Carlisle Cathedral, Chorgestühl, um 1430; Cartmel Priory (Lancashire), Chorgestühl, frühes 15. Jh.; Cawston (Norfolk), St. Agnes, Schranke, 15. Jh.; Chester Cathedral, Baldachine des Chorgestühls, um 1380; Cirencester (Gloucestershire), St. John Bapt., Parclose-Schranke im südlichen Seitenschiff, frühes 16. Jh.; Dennington (Suffolk), St. Mary, Schranke der Bardolph Chapel, um 1441; Exeter Cathedral, Baldachin des Bischofsthrons 1313-17; Montgomery (Powys), St Nicholas, Mittelöffnung des westlichen Teils der Schranke, 15. Jh.; Scarning (Norfolk), St. Peter and Paul, Schranke, 15. Jh.; Winthorpe (Lincolnshire), St. Mary, Parclose-Schranke im nördlichen Seitenschiff, frühes 15. Jh.; Worstead (Norfolk), St. Mary, Schanke, um 1512. - Beispiele aus Großbritannien in Messingeinlegearbeit («Brasses«), s. u.: Die Grabplatte Bischof Hallums.

21 Cobham (Kent), St Mary Magdalene, Grabplatte von Sir Nicholas Hawberk ( $\dagger$ 1407); Montgomery (Powys), St Nicholas, Chorgestühl 15. Jh., vermutlich aus Chirbury Priory.

22 Bony 1979, 22-25.

23 An dieser Stelle sei auf die Beobachtung eines gleichzeitigen Auftretens des Kielbogenmotivs - ohne Schultern - im späten 13. Jh. in England und im Bereich von Bodensee und Oberrhein durch Crossley 2006 hingewiesen, was zwar mit der hier vorgestellten Vermittlung des Schulterkielbogens nicht in direkte Verbindung gebracht werden kann, mit ihr aber das bereitwillige Aufgreifen neuer Formen teilt.

24 Bisher konnte noch nicht geklärt werden, ob unter dem Fußboden weitere Grabdenkmäler erhalten sind.
251400 Baccalaureus beider Rechte, 1403 Doktorgrad der Rechte. HORN 1982, IX.

26 Salter/Lobel 1954, 39.

27 QUirk 1952, 3, 6, 8.

28 Feger 1965, Nr. 242. - BUCK 2010, 97.

29 ЈАсов/Johnson 1937, 126-128. - Das Originaldokument befindet sich im Lambeth Palace, London.

30 EISELEIN 1851, 190.

31 Zimdars 1997, 365.

32 Freundlicher Hinweis von Karin Hubert, Dipl.-Restauratorin, Kons$\tan z$.

33 »Subiacet hic stratus Robert Hallum vocitatus:/Quondam p(re)latus Sar(esberiensis) sub honore creatus:/Hic decretor(um) doctor pacis $\mathrm{q}(\mathrm{ue})$ creator:/Nobilis anglo(rum) Regis fuit ambaciator/Festu(m) Cuchberti septembris mense vigebat:/:In quo Rob(er)ti mortem Constantia flebat: Anno Milleno tricent(esimo) octuageno/:Sex $\mathrm{cu}(\mathrm{m})$ ter deno $\mathrm{cu}(\mathrm{m})$ xpo uiuat ameno (Hier unten liegt ausgestreckt der oft genannte Robert Hallum/einst ehrenvoll als Bischof von Salisbury gewählt./Er war Doktor des kirchlichen Rechts und Friedensstifter/Botschafter des vornehmen englischen Königs./Am Festtag des Cuthbert im Monat September lebte er in voller Stärke./ Im selben [Monat] beklagte Konstanz den Tod des Robert/im Jahre 1380 mit 6 mit $3 \times 10$ [= 1416], er möge mit dem lieblichen Christus leben«; Übers. d. A.).

34 Franz Xaver Kraus gibt an, dass die Inschrift »neuerdings und nicht ganz geschickt restauriert « wurde. KRAUS 1887, 162. - Eventuell bezogen sich diese Ausbesserungsarbeiten auf das Wort Constantia, das auch im Material von der restlichen Inschrift abweicht. REINERS 1955, 449 .

35 "Ich werde in Ewigkeit die Barmherzigkeit des Herrn besingen«, lautet Psalm 89,2, der dem »Misericordias-Domini«-Sonntag in der Osterzeit zugeordnet ist. Außerdem erscheint der Satz in den Minor Poems of Lydgate von John Lydgate (um 1370-1449/50).

36 Das heute sichtbare Wappen ist eine Ergänzung. Betrachtet man die erhaltenen Rubbings (Oberflächenreliefs durch Abreiben, meist mit Kreide oder Bleistift, dies dann in Originalgröße der Grabplatten oder von Details daraus) und Zeichnungen der Hallum-Platte in chronologischer Reihenfolge, ergibt sich für die Entstehung der Ergänzung der Zeitraum zwischen 1844 und 1887.

37 Die am Konstanzer Konzil teilnehmenden englischen Bischöfe waren keine Mitglieder des Hosenbandordens. König Sigismund wurde von König Henry V. im Jahr 1415 in den Orden aufgenommen.

38 Unter Brass versteht man im Englischen zunächst die Legierung aus Kupfer und Zink. Monumental Brasses, kurz Brasses genannt, sind eine spezielle Form der Grabdenkmäler. Sie bestehen aus Steinplatten mit Metalleinlagen. Da es sich meist um Bodenplatten handelt, störten sie den Ablauf des Gottesdiensts weniger als andere Grabdenkmäler. Auf dem Kontinent sind Monumental Brasses weitaus seltener zu finden als in England, Schottland und Irland. Der auffälligste Unterschied zwischen kontinentalen und englischen Brasses ist das Aussehen der Platten. Auf dem Kontinent ist der Trägerstein meist komplett mit Metallplatten bedeckt, in die die Motive eingearbeitet wurden, während die insularen Steinplatten Metalleinlegearbeiten aufweisen.

39 Zuletzt LAULE 2013/II.

40 Frebel 1982. Der Hinweis auf S. 251 auf Vorbilder in den Turmris- 
sen A und B bezieht sich auf Maßwerkformen innerhalb krabbenbesetzter Kielbögen.

41 BREHM 2013, 89-91.

42 KNAPP 2002. - KNAPP 2004, 270-272.

43 Kammel 2002, passim.

44 BOCK 2013.

45 Reiners-Ernst 1956, 89, Kat.-Nr. 552 f.

46 Stich des Monogrammisten P. S.; Ausst.-Kat. Konstanz 1989, Kat.-Nr. $1,5,11$.

47 Beispiele in Belgien (Flandern und Brabant): Aarschot, Onze-LieveVrouwekerk, Lettner, 1510-25; Antwerpen, Onze-Lieve-Vrouwekathedraal, südlicher Querhausgiebel, um 1492, Achteckgeschoss des Turms, 1502-08, und Nordportal, um 1515; Brüssel, Sint Michiels- en Sint-Goedelekathedraal, Figurenbaldachine in der Sakramentskapelle 1534-39; Löwen (Leuven/Louvain), Sint-Jacobskerk, Sakramentshaus, 1538; Tessenderlo, St. Martin, Lettner, um 1500; Gesprenge zahlreicher Schnitzaltäre des ausgehenden 15. und des ersten Viertel des 16. Jhs. in Kirchen und Museen. - Beispiele Spanien und Portugal: Batalha, Mosteiro de Santa Maria da Vitória, Westportal der Capelas Imperfeitas, um 1509; Burgos, Cartuja de Miraflores, Hochaltarretabel, 1496-99; Guadalajara, Palacio del Infantado, Innenhofarkaden, 1480-83; Salamanca, Catedral, Westportal, um 1513; Toledo, Catedral, Löwenportal, 1453-69, und Kapellenportal im Inneren; Toledo, San Juan de los Reyes, innere Querschiffwand, um 1472, und Hauptportal; Valladolid, San Pablo, Westportal, 1486-92; Valladolid, Colegio de San Gregorio, Portal 1487-96. - Beispiele Deutschland (in diesem Fall dem flämischen Kulturkreis nahestehend): Aachen, Domschatzkammer, goldene Monstranz durch Hans von Reutlingen um 1520; Lüneburg, Rathaus, Wandschrank der Gerichtslaube, um 1500.

48 Hörsch 1994. - Kavaler 2000 und 2009.

49 Clamecy, Stiftskirche Saint-Martin, Vorlagensockel zu Seiten des Westportals als Teil der Fassade des frühen 16. Jhs., welche mit vielen Vorhangbögen flandrische Einflüsse zeigt.

50 Arslan 1971, 77-90.
51 Beispiele Deutschland: Elzach, Neunlindenkapelle, Hochaltar durch J. Dettlinger, Freiburg, 1912; Freiburg, St. Martin, Mittelfenster des Marienkapellenvorraums durch Eduard Stritt, Freiburg, 1920. Haigerloch-Gruol, St. Clemens, Hochaltar um 1849; Nussdorf, Grabmal an der Außengruft auf der Südseite der Kirche nach Entwurf von $\mathrm{Au}-$ gust Beyer, Ulmer Münsterbaumeister, um 1880; Öhningen-Schienen, St. Genesius, Gnadenaltar durch Gebrüder Mezger, Überlingen, 1906; Partenkirchen, Mariä Himmelfahrt, Hochaltar um 1880 nach Entwurf von Mathias Berger; Rosenfeld-Heiligenzimmern, St. Patricius, Hochaltar um 1850; Steißlingen, St. Remigius und Cyrillus, Hochaltar durch die Bildhauer Hausch und Bayer, Horb, 1878 (am linken Seitenaltar ein geschulterter Spitzbogen); Tengen-Blumenfeld, St. Michael, Hochaltar durch Raimund Jeblinger und Gebrüder Mezger, Überlingen, 1910; - Beispiele Schweiz: Freiburg i.Ü., Kathedrale St. Nikolaus, Hochaltar durch Gebrüder Müller, Wil, Entwurf 1870, Ausführung 1875/76, Mittelteil 1926 reduziert; Schaffhausen, Stadtkirche St. Johann, Chorstuhl ebenfalls durch Gebrüder Müller, um 1879. - Beispiele Großbritannien: Chester Cathedral, Baldachin des Bischofsthrons durch George Gilbert Scott 1876; Ely Cathedral, Grabmal von Bischof Woodford ( $†$ 1885) durch G.F. Bodley; zahlreiche Rood Screens, die im 19. Jahrhundert nach dem Vorbild der wenigen erhalten gebliebenen mittelalterlichen Exemplare (siehe Anm. 20) neu hergestellt wurden. - Beispiele Belgien: Antwerpen, Huis »De Spieghel«, Grote Markt 9, durch Frans Van Dijck 1904; Brüssel, Broodhuis am Grote Markt durch Victor Jamaer 1873-96; Brüssel, Sint Michiels- en Sint-Goedelekathedraal, oberer Abschluss der seitlichen Bahnen eines Glasfensters im Südseitenschiff (fünftes von Westen) durch Charles de Groux und Jean-Baptist Capronnier 1856; Brüssel, Onze-Lieve-Vrouw ten Zavel, Figurenbaldachine der Westfassade und im Westportal durch Jules-Jaques und Maurice Van Ysendjick 1895-1912; Löwen (Leuven/Louvain), Sint-Pieterskerk, Kreuzwegstationen im Chorumgang, spätes 19. Jh. - Italien: Milano, Dom, Bronzeflügel des Westportals durch Lodovico Pogliaghi, Entwurf 1894, Ausführung bis 1906 bzw. 1908.

52 Humpert 1957, 154. 


\section{Plausible Fiktionen : König Sigismund und die englische RePräSEntation während DES Konstanzer Konzils}

"[...] the Wodnesday, the Thyrde Our efter Noon, oyer ner yer by, the Sevene and Twenty Day of Januer, zow Broder, Gracious Pryns, the Kyng of Rome entride the Cite of Constaunce wyth zour Lyvere of the Coler abowte his Necke (a glad Syghte to alle zour Lyge Men to se) wyth a solempne Procession of all Astayts, bothe of Cardenalys, and of alle Nationes [...] And onde the Morwe he sende efter theym agayn, ad ten of the Clokke, and theyr he Resseyved theym agayn every Man be Hand: And ther he made a Colation to owr Nation [...] and he tolde thame so gret Worchyp of zowr Ryal Person, and sythyn of alle my Lordis zour Brethers, and thenne of the Governaunce of Holy Kyrk, Dyvyn Servise, Operaments, and alle Stat ther of kepyd, as yoff hit wer in Paradys, in Comparison to ony Place that he evere came inne to for; so that, fro the heyeste unto the loweste, he commendit zour glorious and gracious Persone, zour Reme, and zour gode Governance $[\ldots] . \star^{1}$

Als der römische und ungarische König Sigismund von Luxemburg am 27. Januar 1417 von der Petershausener Brücke in die Stadt Konstanz einzog (Abb. 1), habe der Anblick des englischen »livery of the collar « an seinem Hals die englischen Lehnsmänner beglückt.

Davon berichtet der englische Autor Johannes Forester an König Heinrich V. von England in seinem oben zitierten Brief, den er nur wenige Tage später verfasste. ${ }^{2}$ Die Halskette mit S-förmigen Gliedern als Devise des Hauses Lancaster sei, so Forester, das auffälligste Zeichen englischer Präsenz an Sigismunds Hals gewesen, als dieser nach eineinhalbjähriger Abwesenheit zum Konzil von Konstanz zurückkehrte. ${ }^{3}$ Sigismund war im Juli 1415 von Konstanz nach Perpignan aufgebrochen, um zwischen dem aragonesischen, dem französischen und dem englischen Hof zur Beendigung des Schismas und des englisch-französischen Krieges zu vermitteln. In England hatte Heinrich V. den Luxemburger und sein Gefolge sechs Monate lang bis an den Rand des eigenen Staatsbankrotts unterhalten, beschenkt und zum Ritter des Hosenbandordens erwählen lassen. Die englischen Ansprüche auf französisches Gebiet und die Intention des Kirchenfriedens hatten beide Könige im August 1416 schriftlich im Vertrag von Canterbury bekräftigt. ${ }^{4}$ Im Januar 1417 zog die Prozession unverzüglich zum Konstanzer Münster, wo Sigismund die mit goldenen Textilien ausgezeichnete Kathedra des Papstes einnahm. ${ }^{5}$ Als der englische Bischof von Salisbury, Robert Hallum, so Forester weiter, den französischen Kardinal Pierre d'Ailly, der eigentlich zu predigen gedachte, überholt, die Kanzel vor ihm bestiegen und gepredigt habe, sei der Ärger der französischen nation (Gruppe) groß gewesen. ${ }^{6}$ Am Tag darauf habe Sigismund nur die englische nation empfangen, noch dazu zweimal, das zweite Mal mit Handschlag. Dort habe Sigismund König Heinrich V., dessen Brüder sowie die Führung und die Gottesdienste der englischen Kirche, deren Oberhaupt der König war, mit dem Paradies verglichen. Wenige Tage später sei Sigismund überdies im Mantel des Hosenbandordens erschienen und habe so beim Festbankett der Engländer, das von einem geistlichen Spiel begleitet wurde, zu Ehren seines Empfangs präsidiert. ${ }^{7}$

Halskette und Mantel taugten dem Schreiber des Briefs als weithin wahrgenommenes semiotisches Referenzsystem, das den Körper des Königs im Adventus als Medium englischer und ordensritterlicher Zugehörigkeit auszeichnete. Das Ausstellen der englischen Kette beim Einzug nach Konstanz bezeugte laut Forester die politische Unterstützung durch Sigismund. So wurde das allgemein sichtbare Tragen der Kette als Devise des Hauses Lancaster von einem anderen englischen Zeitgenossen auch als Zeichen der Unterstützung der englischen $n a-$ tion gegen die aragonesische und französische gewertet. ${ }^{8}$ Die Zugehörigkeit zum Hosenbandorden, die der Mantel markierte, war die andere Referenz, die Sigismund vor allen Teilnehmern des Konzils sinnfällig bekräftigt haben soll.

Dieses so plausible Referenzsystem, das Forester in seinem Brief suggerierte, ist eine Fiktion. Sigismund kann die Kette bei seiner Ankunft in Konstanz nicht wirklich getragen haben. Sie lag, glaubt man dem überzeugenden Bericht Eberhards von Windecke, eines Mainzer Kauf- 


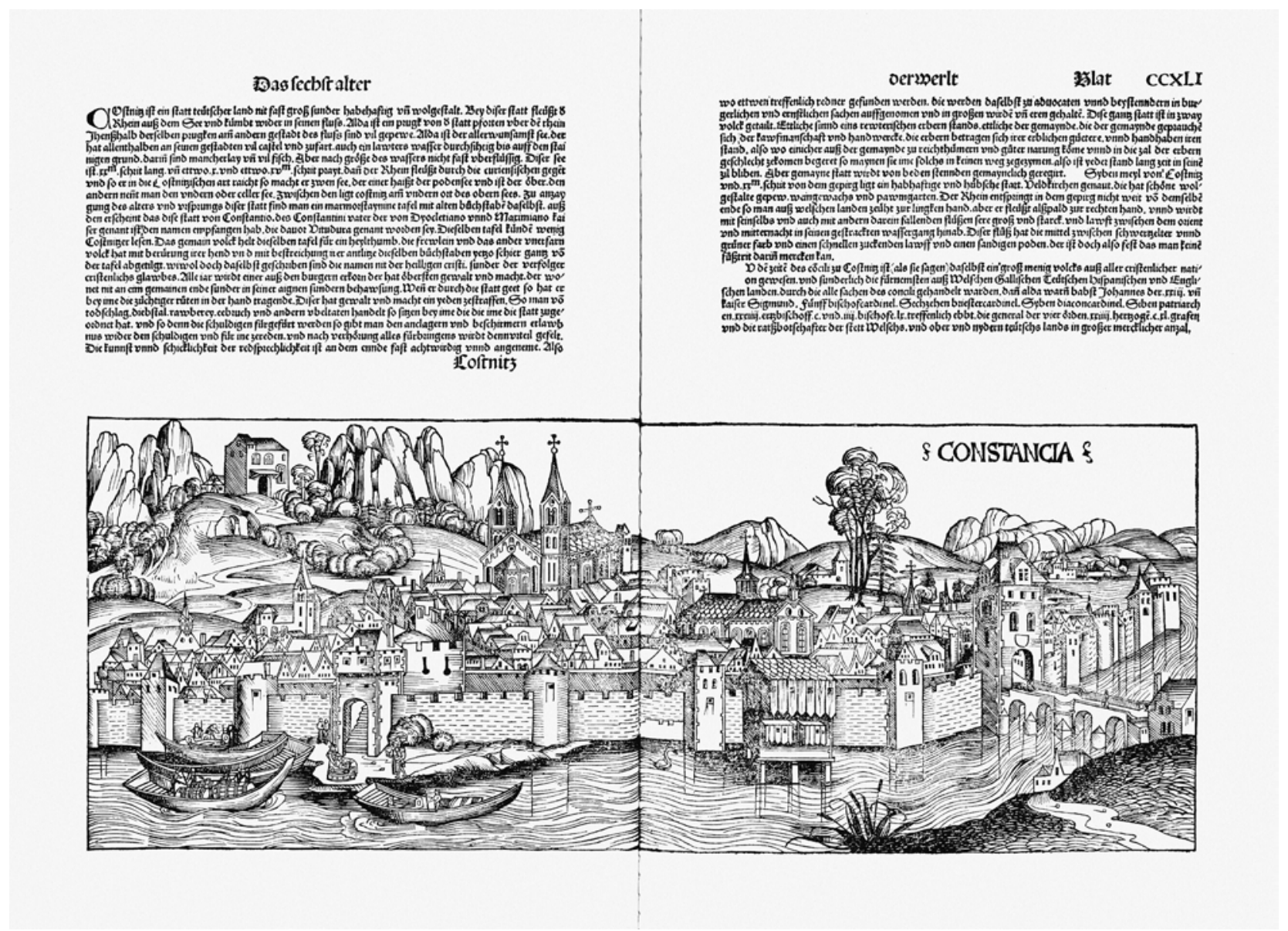

Abb. 1 Konstanz. Stadtansicht der Schedel'schen Weltchronik (ex: Hartmann Schedel: Liber chronicarum, deutsche Fassung. Nürnberg, Koberger, 1493, fol. 240v-241r)

manns und Chronisten der Taten und Reisen König Sigismunds, zur selben Zeit als Pfand in Brügge. ${ }^{9}$ Auf eine zweite Kette dieser Art gibt es keinen Hinweis. Zwar erwähnt auch der Franzose Jean de Montreuil die Kette beim Empfang in Konstanz, ${ }^{10}$ darüber hinaus erscheint sie in dem genannten Brief an den Bischof von Durham. ${ }^{11}$ Doch weder der französische Kardinal Guillaume Fillastre noch Ulrich Richental, Sohn des Konstanzer Stadtschreibers und detailfreudigster Chronist des Konzils, nennen Kette und Mantel, obwohl beide als Augenzeugen vom Empfang Sigismunds an der Petershausener Brücke berichten. ${ }^{12}$ Auch das Identifikationsporträt Sigismunds für die Konstanzer Augustinerkirche, das dieser im Mai 1417 in Auftrag gegeben hat, zeigt ihn mit zeittypischen Gesichtszügen, Haar- und Barttracht, aber ohne Kette. ${ }^{13}$

Foresters Fiktion ist bisher nicht aufgedeckt worden. Bis heute erzählen Historiker vom Einzug Sigismunds mit der Kette der Lancaster, die so wunderbar die tat- sächliche Allianz der beiden Könige visualisiere. ${ }^{14} \mathrm{Un}$ bestritten dagegen ist die deutliche Parteinahme Sigismunds für die englische Seite, die allein durch die Predigt des Bischofs von Salisbury von der Kanzel im Münster, die auch Fillastre überliefert, zu beweisen ist, wenn auch Fillastre die Blamage seines französischen Kardinalskollegen Pierre d'Ailly und auch die weiteren Aktionen der Engländer ausspart. ${ }^{15}$ Hat Forester den englischen König mit der visuellen Referenz auf die Kette möglicherweise wissentlich täuschen wollen, um die Zahlungsunfähigkeit Sigismunds und den Affront der Verpfändung eines so wertvollen Geschenks zu vertuschen? Oder war der englische König selbst Auftraggeber der Fiktion, da Foresters Brief die Grundlage für weitere Berichte anderer Chronisten war, wie Jean de Montreuil oder die oben zitierten modernen Autoren? So sind beispielsweise 1378 am Hof Karls V. von Frankreich Geschenkelisten modifiziert worden, um die Großzügigkeit des Herrschers zu über- 
treiben. ${ }^{16}$ Oder könnte es sein, dass die Vorstellung der Objekte als Träger des Gedankens existiert haben mag? Dass, vergleichbar beispielsweise der materiellen Präsenz versteckter Objekte - wie Reliquien in Altären - John Forester die Kette imaginiert hat, die Kette also für Forester unsichtbar anwesend war, er sie aber dem englischen König als für alle sichtbar geschildert hat ${ }^{17}$

Weder die Halskette noch der Mantel, die hier zu Beginn stellvertretend für weitere Objekte und Aktionen im englisch-deutschen Austausch zwischen Herbst 1414 und Februar 1417 stehen sollen, sind erhalten. Gleiches gilt für die meisten anderen Gegenstände, Umbauten und Bauwerke, die im Zuge dieser Verhandlungen in Konstanz und England präsent waren und im Folgenden auf ihren Wert in der Neuinszenierung der englischen Dynastie untersucht werden sollen. Form und Material der Kette, Mantel, Goldschmiedeobjekte und Architekturen erschließen sich zumeist nur aus Beschreibungen, Wertzuweisungen bei Verpfändung, Rechnungen oder späteren Abbildungen (Abb. 2). ${ }^{18}$

Ähnlich wie die verschwundenen Objekte sind auch die zeremoniellen, liturgischen und theatralen Situationen englischer Präsenz in Konstanz oder der auswärtigen Reisenden in Sigismunds Gefolge auf englischem Territorium nur textlich überliefert. Welches ist der Wert derartiger Berichte jenseits ihrer medialen Differenz? Ruft die Abwesenheit der Objekte und der Aktionen zur Zeit des Konzils nicht vielmehr zur präziseren Beschreibung der Objekte und Handlungen, der Präsenz der Handlungsträger, des realen Raums oder der, wenn auch ephemeren, Illusionsbühnen auf ${ }^{19}$

Dass Richental beinahe ausschließlich die herausragenden musikalischen Darbietungen englischer Musiker, die englischen Speisungen von Konstanzer Bürgern und Konzilsteilnehmern sowie vor allen anderen Ereignissen die Pracht kostbarster Kleider und Geschenke der englischen Gruppe rühmt, hat in der Konzilienforschung bisher kaum Beachtung gefunden. Könnte die klare Bevorzugung einer Beschreibung englischer Aktionen durch den Konstanzer Chronisten Richental mit dessen Fokus auf eine städtische Involvierung zu erklären sein? Auch die England-Reise Sigismunds ist bisher kaum auf die transkulturelle Wahrnehmung englischer Kunst und Architektur befragt worden. Dabei zeigte sich auch Eberhard von Windecke überwältigt von der englischen Präsenz bei seinem Bericht über die sechsmonatige Reise Sigimunds und dessen Entourage nach England im Jahr 1416. Der Konstanzer Auftritt der Engländer und der nach Kons-

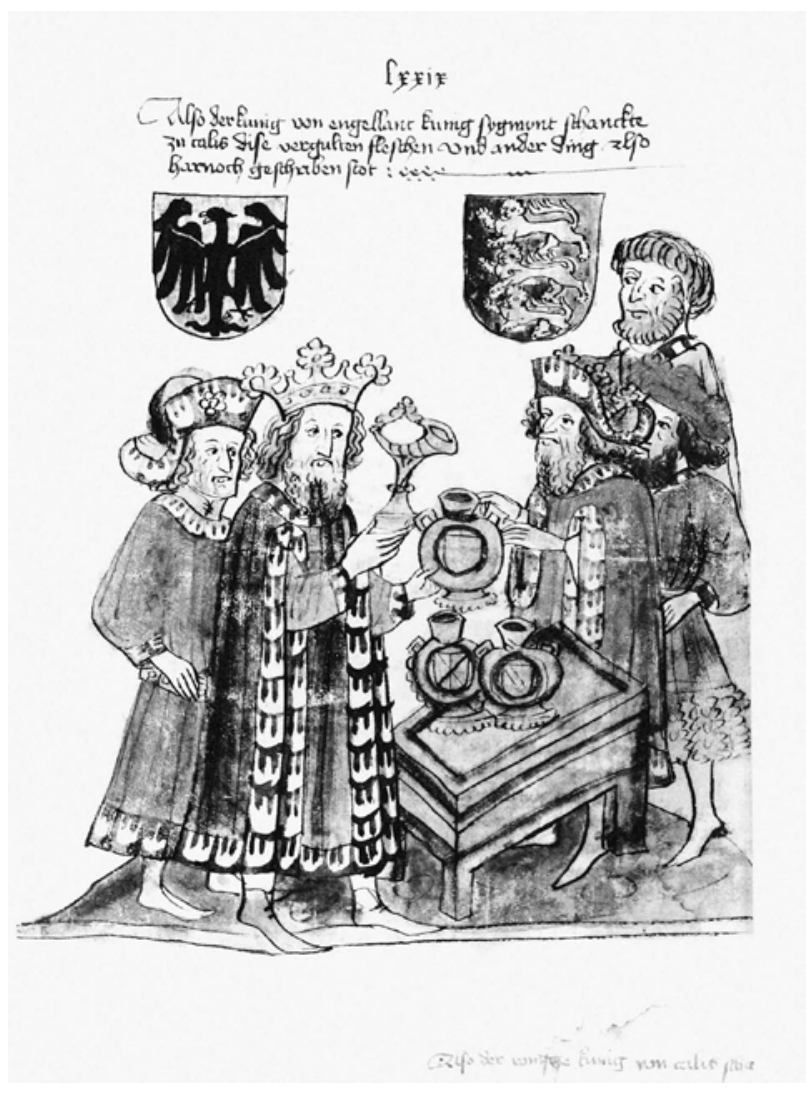

Abb. 2 Geschenkübergabe Heinrichs V. an Sigismund in Calais. Darstellung in Eberhard Windecke: Denkwürdigkeiten zur Geschichte des Kaisers Sigismund. Wien, ÖNB, cod. 13975, fol. 96v (ex: Ausst.Kat. Budapest 2006, Tagungsband, 149, Abb. 2)

$\tan z$ gemeldete Aufenthalt Sigismunds in England waren so erfolgreich, dass selbst ein italienischer Humanist wie Poggio Bracciolini 1418 eine Neuanstellung in England suchte, die ihm attraktiver vorkommen musste als eine untergeordnete Funktion am Hof des neuen Papstes Martin V. in Rom. ${ }^{20}$ Dass Poggio nicht nur aus Not nach England ging, wie oft behauptet wird, wird in der Forschung zumeist übersehen. ${ }^{21}$

Die neuartige Zusammenarbeit zwischen Heinrich V. und Sigismund, auf die Walter Brandmüller bereits 1990 hingewiesen hat, ist bisher nur vereinzelt thematisiert worden. ${ }^{22}$ Grundlegend zu den englisch-deutschen Verhandlungen dieser Zeit sind bis heute der Aufsatz von Max Lenz aus dem Jahr 1874 und das Kapitel zu Sigismund und Heinrich V. von James H. Wylie und William T. Waugh von 1929, das allerdings, da es Teil der Biografie Heinrichs V. war, das Konzil von Konstanz weitgehend ausklammerte. ${ }^{23}$ Christopher Crowder konzentrierte sich auf die englischen Verbindungen zum Konzil und die Be- 
strebungen zur Kirchenreform $;{ }^{24}$ von literaturwissenschaftlicher Seite reflektierte Albrecht Classen die literarische Qualität einzelner englischer und französischer Texte zur England-Reise Sigismunds. ${ }^{25}$ Insbesondere Arnd Reitemeier, aber auch Martin Kintzinger widmeten den diplomatischen Beziehungen zwischen England und dem Reich während des Konzils wichtige Analysen. ${ }^{26}$ Von ungarischer Seite beleuchtete Attila Bárány den Austausch zwischen dem ungarischen Hof Sigismunds und England. ${ }^{27}$ In seiner konzisen Studie über die Inszenierung und Handlungsweisen bei spätmittelalterlichen Herrschertreffen analysierte Gerald Schwedler auch die Typologie der Treffen von Heinrich V. und Sigismund. ${ }^{28}$ Jedoch sind weder die veränderte Strategie in der Inszenierung des englischen Königs und der englischen Kultur noch ihre Rezeption durch die in Konstanz anwesenden oder nach England mitreisenden Chronisten bisher untersucht worden. Das liegt sicher auch daran, dass zeitgenössische Abbildungen oder Objekte fehlen, die solche Lobpreisungen erhärten könnten, und dass, anders als zum Basler Konzil, nur wenige Dokumente des Austauschs zwischen London und Konstanz erhalten sind. ${ }^{29}$ Das Phänomen der Stadt als Bühne theatraler Praktiken ist in Zusammenhang mit Konstanz seitens verschiedener Disziplinen diskutiert worden, nicht aber die englischen Aufführungen, mit Ausnahme der musikwissenschaftlich bedeutenden mehrstimmigen Darbietungen in Gesang und Instrumentalmusik. ${ }^{30}$

Die sichtbaren Aktionen und Objekte setzen materielle Präsenz voraus, die ihrerseits das gegenseitige Kommunizieren, Nicht-Kommunizieren und Missverstehen verdeutlichen kann. Diese die Wahrnehmung durch verschiedene Sinne (akustisch, visuell, haptisch) ansprechenden Strategien und Verflechtungen waren Teil einer hoch entwickelten politischen Kommunikation, die eine Neuorientierung englischer Politik für das europäische Umfeld sichtbar machen sollte. Unter politischer Kommunikation verstehe ich mit Kintzinger und Schneidmüller »den Vorgang der Vermittlung von Geltungs-, Herrschafts- und Machtansprüchen, aber auch von Rechtsansprüchen, Anteilsforderungen und Mitwirkungsinteressen durch öffentliche Inszenierung. Politische Kommunikation ist zweitens zu verstehen als Prozess der Herstellung von Zustimmung, Gefolgschaft oder Konsens in demjenigen Publikum, das Adressat ihrer öffentlichen Inszenierung ist. ${ }^{31}$ Welches die »Kommunikationsmedien" waren, die Johannes Helmrath in Frageansätzen als methodisches Problem formuliert und insbesondere für das Basler Konzil angerissen hat, können wir oft nur durch diese Quellen erahnen. ${ }^{32}$ In seinen Überlegungen zu einer Ereignisgeschichte des Konstanzer Konzils argumentiert Thomas Rathmann, dass die Texte "als Teil des Geschehens selbst schon wieder Ereignischarakter besitzen. $\aleph^{33}$ Auch Rathmann entgeht allerdings die auffällige englische Präsenz.

Zentrum der englischen Entscheidungsprozesse war, wie aus den Akten hervorgeht, König Heinrich V., umgeben von einer Peripherie von Personen, deren Kleidung und Verhalten er im Vorfeld wesentlich gesteuert hat. Heinrich setzte dieselben Gesandten gemäß ihrer Kompetenz für verschiedene Aktionen und Verhandlungen an verschiedenen Orten ein, sodass sie ungewöhnlich häufig auf Reisen, aber immer gut informiert waren. Kleidung und Auftreten der englischen Fürsten unterschied sie von den französischen Repräsentanten bei der Reise Sigismunds in die jeweiligen Territorien: Auffällig ist die Repräsentation aller Personen, die den deutschen König empfingen und begleiteten, als Vertreter des englischen Königs, während sich die Franzosen keinesfalls mit dem als schwach und geisteskrank beschriebenen Karl VI. identifizieren wollten. ${ }^{34}$

Bei dem Briefautor Johannes oder John Forester, der dem englischen König so außergewöhnlich ausführlich diesen Empfang in Konstanz beschreibt, handelt es sich wahrscheinlich um den Geistlichen John Forest, der 1404 in Verbindung zum Bischof von Winchester, Henry Beaufort, genannt wird und als Delegierter des Erzbischofs Chichele von Canterbury nach Konstanz gereist war. ${ }^{35} \mathrm{Er}$ ist 1414 als Nachfolger John Cattericks als Archidiakon von Surrey und 1418 als Generalvikar Beauforts vermerkt; Beaufort und Catterick nahmen als Bischöfe und Gesandte des englischen Königs am Konstanzer Konzil teil.

Die Verhandlungen des Luxemburgers mit England und seine Reise an den Hof Heinrichs V., deren Erfolg durch das erwähnte Bündnis von Canterbury besiegelt wurde, bewertete bereits Lenz als »einen der merkwürdigsten politischen Vorgänge jener Zeit «. ${ }^{36}$ Das Interesse an einer Neuinszenierung des englischen Königshauses hat bereits vor dem Regierungsantritt Heinrichs V. 1413 begonnen. Die diplomatischen Verhandlungen, die seit 1411 in Gang waren, als Heinrich als Thronfolger agierte, avisierten nicht nur ein Bündnis zwischen dem Reich und England, sondern auch die Kirchenreform weit über eine bloße Beendigung des Schismas hinaus. ${ }^{37}$ Spätestens im November 1413 waren die Verhandlungen um die 
Hochzeit mit der jüngsten Königstochter von Frankreich, Katharina von Valois, wiederaufgenommen worden, denen mehrere Reisen von erfahrenen Diplomaten an den Pariser Hof galten. ${ }^{38}$ Die englischen Ansprüche bekräftigte Heinrich mit auffällig großen und gut ausgestatteten Gesandtschaften, die ihre Wirkung auf die Franzosen nicht verfehlten. ${ }^{39}$ Bereits in der Gesandtschaftsreise an den Hof Sigismunds am 23. Juli 1414 scheinen die Beendigung des Schismas und die Rolle der englischen nation, welche die zahlenmäßig kleinste Delegation in Konstanz stellte, auf höchster politischer Ebene verhandelt worden zu sein.

Tatsächlich bot das Konstanzer Konzil der englischen Krone eine ideale Plattform für die Propagierung einer Kirchenreform zur Beendigung des Schismas und für eine Neuinszenierung des englischen Königs. Doch erst am 20. Oktober 1414, über zehn Monate, nachdem Johannes XXIII. zum Konzil geladen hatte, ernannte Heinrich eine Delegation aus den fähigsten englischen Geistlichen und Laien, die nach Konstanz reisen sollte. ${ }^{40}$ Ziel dieses Konzils, das am 1. November beginnen sollte, war neben dem Kirchenfrieden auch die Beendigung des später so genannten Hundertjährigen Kriegs. ${ }^{41}$ Unmittelbar zuvor hatte ein anglo-burgundisches Bündnis den Streit zwischen England und Frankreich noch verschärft. Die späte Reaktion der englischen Krone wie der englischen Kirche auf die Einladung nach Konstanz dürfte eher sorgfältiger Planung als Desinteresse an der konziliaren Politik geschuldet sein. ${ }^{42}$

Wohl noch vor der Abreise der englischen Delegation Ende 1414, jedenfalls aber vor dem 5. Dezember 1414, setzte Heinrich sein erstes Testament auf. ${ }^{43}$ Darin plante er seine typologisch und liturgisch außergewöhnliche chantry chapel im Chorscheitel von Westminster Abbey und formulierte die Sichtbarkeit und Ausführung seines liturgischen Gedenkens im Obergeschoss über seinem Grabmal. ${ }^{44}$ In diesem Testament bedachte Heinrich auch den designierten Kaiser Sigismund, »electum in imperatorem $\lll,{ }^{45}$ als Verteidiger der Kirche und des Glaubens an prominenter Stelle direkt nach den Stiftungen für seine eigene Kapelle in der Abteikirche. Sigismund sollte Heinrichs prunkvolles, mit Edelsteinen besetztes Schwert im Wert von 500 Mark (gut 333 Pfund) erhalten. ${ }^{46}$ Englische Könige hatten bis dahin nie einen ausländischen Herrscher oder gar den designierten Kaiser im Testament bedacht. Das wertvolle Schwert untermauerte schon damals die politischen Absichten Heinrichs zu einer englisch-deutschen Allianz.
Wie wirkmächtig die Aktionen vom englischen Königshof geplant und dort wiederum reflektiert worden sein müssen, verdeutlicht schon der Zeitpunkt der Ankunft englischer Gesandter in Konstanz. Die englische Konzilsgesandtschaft hatte, begleitet von einem Gefolge mit geschätzt 800 Pferden, bereits an der Krönung Sigismunds am 8. November in Aachen teilgenommen. ${ }^{47}$ Während aber die anderen Delegationen von dort bald nach Konstanz geeilt waren und den römischen König an Heiligabend im kalten, obwohl mit Brettern ausgeschalten Konstanzer Münster erwarteten, wo dieser eine Lektion in der Messe lesen wollte, ${ }^{48}$ waren die Engländer wieder zurückgekehrt und folgte erst vier Wochen später, drei Tage vor Lichtmess, am 21. Januar 1415. Was erstaunt, ist die "protokollarische Aufmerksamkeit«, mit welcher man den Einzug der Engländer in Konstanz bedachte. ${ }^{49}$ Denn dass die Kardinäle und der päpstliche Haushofmeister sowie einige Adlige wie der Herzog von Sachsen, die schon in Konstanz waren, ihnen aus der Stadt entgegenzogen, war ein Zeichen außergewöhnlicher Ehre, die den anderen Nationen nicht zuteil wurde. ${ }^{50}$ Am folgenden Tag empfing Johannes XXIII. die Engländer, und Bischof Robert Hallum von Salisbury hielt eine viel kommentierte Predigt über die Einheit der Kirche. ${ }^{51}$

Die geistliche Gesandtschaft wurde angeführt von drei Bischöfen, Robert Hallum von Salisbury, Nicholas Bubwith von Bath und Wells sowie John Catterick von St. David's. ${ }^{52}$ Die englischen Bischöfe reisten mit je über 60 Gefolgsleuten, darunter zwölf Doktoren in Theologie der Universitäten Oxford und Cambridge, und reichlich Lasttieren an. Robert Hallum, der, wie zu Beginn erwähnt, auch am 27. Januar 1417 zu Ehren der Rückkehr Sigismunds im Konstanzer Münster predigen sollte, hatte bereits 1409 die englische Delegation zum Konzil nach Pisa geleitet und sich öffentlich für eine Kirchenreform ausgesprochen; er starb am 4. September 1417 in Kons$\operatorname{tanz}$ und wurde vor dem Hochaltar des Münsters begraben. ${ }^{53}$ Auch John Catterick, den der oben genannte Briefautor John Forester als Archidiakon von Surrey beerbt hatte, gehörte zu den erfahrensten Diplomaten Englands. Er war seit 1406 mehrfach zu Friedensverhandlungen in Frankreich, Deutschland und in den Niederlanden gewesen, war seit 1409 päpstlicher Notar und von Heinrich V. im Mai 1413 gleich nach dessen Krönung zum "proctor« der päpstlichen Kurie ernannt worden. Vom Kapitel von Coventry und Lichfield im Sommer 1414 zum Bischof gewählt, empfing er die Temporalien im Herbst 1414, wurde aber erst am 15. Februar 1415 geweiht, sodass er 
in Konstanz offiziell noch als Bischof von St. David's anreiste. ${ }^{54}$ Die Bitte des italienischen Kardinals Orsini einen Tag nach Hallums Tod, Catterick wegen seiner Verdienste auf dem Konzil zum Bischof von Salisbury zu ernennen, wollte der englische König gleichwohl nicht erfüllen. ${ }^{55}$ Nach der Wahl Martins V. war es Catterick, der als englischer königlicher "proctor« im Auftrag Heinrichs V. den Papst nach Rom, Mantua und Florenz begleiten sollte, wo er 1419 starb. ${ }^{56}$ Im Oktober 1417 , einen Monat vor der Papstwahl, erreichte ein weiterer Bischof, Henry Beaufort von Winchester, Konstanz. Beaufort war der vielleicht einflussreichste englische Kirchenmann, Onkel König Heinrichs V., Kanzler, zu der Zeit einer seiner engsten Vertrauten und wichtigster Kreditgeber. Im Gegensatz dazu stand sein Auftritt in Konstanz: Im Stillen, fast aus dem Nichts, »in habitu peregrini cum cruce«, vermeldet der französische Kardinal Guillaume Fillastre, habe Beaufort Konstanz erreicht. Dabei war seine Ankunft seit Monaten erwartet worden, da ihn Heinrich bereits im Juli auf Pilgerreise geschickt hatte. ${ }^{57}$ Beaufort wurde zum Mediator, der im November 1417 die Wahl Oddo Colonnas zum Papst Martin V. ermöglichte. Ob Beaufort, wie wegen seiner Pilgerkleidung vermutet wurde, eigentlich selber Papst werden wollte, ist eine Spekulation: Die Selbstinszenierung als demütiger Pilger auf Durchreise hätte durchaus dazu dienen können, um die Sympathien des Konklaves zu werben. Direkt nach seiner Wahl ernannte ihn Martin V. im Dezember 1417 zum Kardinal, was Heinrich V. jedoch nicht akzeptieren konnte. ${ }^{58}$

Unter den nach Konstanz abgeordneten Äbten war William Colchester, Abt von Westminster, nicht weniger erfahren. Er war seit 1377 mehrere Male erst zur Durchsetzung der Rechte der Abtei gegen die königliche Palastkapelle St. Stephen und dann für Richard II. zum päpstlichen Hof nach Avignon und Rom gereist. Wie Hallum war der Abt an den Verhandlungen zum Konzil von Pisa beteiligt gewesen. ${ }^{59}$

Als Anführer der Laien zog Richard Beauchamp, Earl of Warwick, mit 38 Gefolgsleuten am Obermarkt ein, dem zentralen Gerichtsplatz. ${ }^{60}$ Ihn begleiteten unter anderen Henry Lord FitzHugh, Kämmerer Heinrichs V. und wie Beauchamp Ritter des Hosenbandordens, und Sir Walter Hungerford; beide hatte Heinrich als Testamentvollstrecker benannt. ${ }^{61}$ Alle drei Adligen waren erfahrene Diplomaten und gehörten zu den engsten Vertrauten Heinrichs V. Beauchamp und Hungerford waren zentrale Gewährsleute für die Verhandlungen mit dem römischen König. ${ }^{62}$ Beauchamp hatte Sigismund persön- lich anlässlich dessen Krönung im November 1414 in Aachen getroffen. ${ }^{63}$ Hungerford war mit den Hofstrukturen Sigismunds bestens vertraut, war er es doch, den Heinrich 1414 an den Hof Sigismunds gesandt hatte. Die Erfahrungen mit den Strukturen, Kommunikationsmustern und Vorlieben am Hof Sigismunds bei Gesandtschaftsreise, Krönung und Konzil sollten Beauchamp, FitzHugh, Hungerford und damit auch Heinrich V. zugute kommen.

An Lichtmess, dem 21. Januar 1415, sprach die Kurie Birgitta von Schweden offiziell heilig und bestätigte damit die Kanonisation durch den schismatischen Papst Bonifaz IX. von 1393 (Abb. 3).

Die silberne Statuette der hl. Birgitta wurde unter Anwesenheit Sigismunds auf dem Altar des Konstanzer Münsters erhoben. Diese erste Aktion, der die Engländer beiwohnten, wurde wiederum sofort in England reflektiert: Nur einen Monat später legte Heinrich V., offenbar bestens informiert über moderne weibliche Heiligkeit, den Grundstein zum ersten Haus des Birgittenordens in England, dem Kloster Syon Abbey nahe seiner Residenz in Sheen bei London (heute Richmond). ${ }^{64}$ Möglicherweise ist die Initiative auf Heinrichs Kämmerer Henry FitzHugh zurückzuführen, welcher der Erhebung der heiligen Birgitta in Konstanz beiwohnte, oder auf Heinrichs Schwester, die Königin von Schweden, Philippa. FitzHugh, der in Philippas Gefolge nach Schweden gereist war, hatte 1406 das Mutterhaus des Ordens in Vadstena besucht und die Ansiedlung des Ordens in England vorbereitet. ${ }^{65}$ Als Oberhaupt der englischen Kirche konnten Heinrich und seine geistlichen Berater eine neue Religionspolitik bestimmen, von der dieser neue Orden profitierte, der vor allem von königlicher Seite propagiert wurde. $^{66}$

Fernab vom Konzil und dessen visuellen und akustischen Zerstreuungen begann Heinrich im Februar 1415 mit der Vorbereitung zum Krieg. Die bis dahin und seitdem einzigartige Verpfändung des königlichen Schatzes, der zum überwiegenden Teil von Richard II. angeschafft worden war, brachte ihm allein 10.000 Mark Sterling (beinahe 6.667 Pfund) von den Londoner Bürgern und beinahe 2.00o Pfund von seinem erwähnten Onkel Henry Beaufort, Lordkanzler und Bischof der reichen Diözese Winchester, ein. ${ }^{67}$ Im April stellte der König die Captains (Stadtkommandanten) ein, deren Gehälter ebenfalls durch die Verpfändung von Edelsteinen und Tafelgeschirr gesichert wurden. ${ }^{68}$ Zwischen Februar und April hatte er die weltlichen Gesandten, mindestens Beauchamp, Hungerford und FitzHugh, wieder aus Konstanz abberufen; 
im Juni war auch der Bischof Catterick wieder in Canterbury. ${ }^{69}$ Im Juli empfingen Heinrich, seine Brüder und seine Berater, darunter Catterick, die französischen Gesandten unter Leitung des Erzbischofs von Bourges in der eindrucksvollen Halle des bischöflichen Palasts in Winchester, nicht ohne die Franzosen zuvor zu einem Umweg über Canterbury und London genötigt zu haben. Zugeständnisse an ehemals englischem Territorium, welche die Engländer über die Heirat mit Katharina hinaus einforderten, wollte die französische Delegation jedoch nicht machen. ${ }^{70}$ Noch während dieser Verhandlungen rüsteten die Engländer zum Krieg. Im August erreichte Heinrich Harfleur, begleitet von Beauchamp und FitzHugh. Nach längerer Belagerung erwirkte Heinrich die Kapitulation der Stadt; auch hier setzte er die Übergabe sichtbar in Szene: Er empfing die Schlüssel von Harfleur in vollem Ornat in magnificentia, trat aber barhäuptig und barfüßig in humilitas in die Stadt ein. ${ }^{71}$ Im Juli war auch Sigismund aus Konstanz zu Friedensverhandlungen aufgebrochen, im September wurde er in Perpignan von Ferdinand I. von Aragon und dem Gegenpapst Benedikt XIII. feierlich empfangen. Dort erreichte ihn im Oktober die Nachricht vom englischen Sieg bei Azincourt, die Heinrich an verschiedene Fürstenhöfe kommunizieren ließ. ${ }^{72}$ Über Avignon, wo er Weihnachten verbrachte, und Lyon zog der Luxemburger am 1. März 1416 mit seinem Gefolge in Paris ein. ${ }^{73}$

Bereits während der am 16. März eröffneten Sitzung des Parlaments erreichte London die Nachricht von der bevorstehenden Ankunft Sigismunds, dessen Verhandlungen mit dem französischen König zu keinem Ergebnis geführt hatten. ${ }^{74}$ Bischof Henry Beaufort stimmte in seiner Position als Lordkanzler das Parlament mit einer Rede ein, welche die göttliche Legitimation des englischen Anspruchs auf den französischen Thron erneut begründete. ${ }^{75}$ Heinrich ordnete dem Empfang Sigismunds in den wichtigsten englischen Städten, die kein Geld vom römischen König und seinem Gefolge fordern durften, nicht nur die passenden Personen in aufsteigender höfischer Hierarchie zu, er stattete sie auch mit Livreen aus, die ihre Zugehörigkeit zum englischen Königshof deutlich machten. ${ }^{76}$ Zudem beorderte Heinrich alle Ritter und Esquires in ihrer besten Kleidung zum 16. April nach London. Walter Hungerford, der mit den Hofstrukturen Sigismunds am besten bekannt war, hatten der König und der Privy Council mit der Aufsicht über Unterkunft und Verpflegung betraut. ${ }^{77}$ Schnell auszuführende Umbauten seiner Burgen und Paläste sowie Transporte ephemerer

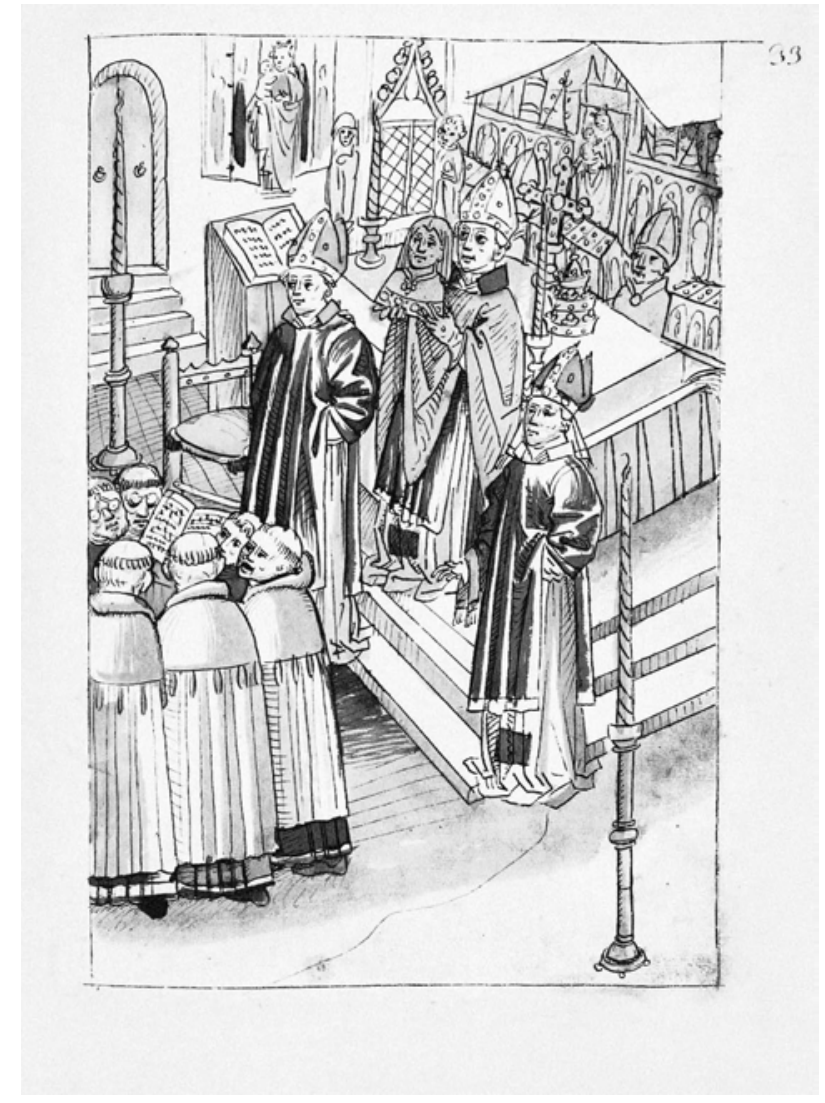

Abb. 3 Kanonisation der Birgitta von Schweden im Konstanzer Münster. Ulrich von Richental, Chronik des Konstanzer Konzils. Exemplar um 1465, Konstanz, Rosgarten-Museum, Ms. 1, fol. $33 \mathrm{r}$ (ex: FEGER 1964)

Architektur nach Calais ordnete Heinrich sogar noch während des Aufenthalts des Luxemburgers an. Gefiltert durch die Texte zweier Chronisten, zuvörderst des Autors der Gesta Henrici Quinti, ${ }^{78}$ eines Geistlichen der königlichen Kapelle, und Eberhard Windeckes, des aus Mainz stammenden Kaufmanns, ${ }^{79}$ bleibt unser Bild der Geschehnisse aber bekanntermaßen dürftig. Gransdens Vermutung, Heinrich könnte ein Exemplar der Gesta nach Konstanz geschickt haben, ist leider nicht verifizierbar. ${ }^{80}$

Sigismund und sein Gefolge erreichten die englische Stadt Calais am 25. April 1416. Dort empfingen ihn die ihm aus Aachen und Konstanz bekannten Richard Beauchamp, Earl of Warwick und Captain of Calais, sowie Henry FitzHugh. ${ }^{81}$ Mit den etwa 300 Schiffen des englischen Königs begann wenige Tage später die Überfahrt Sigismunds und seines Gefolges von etwa 1000 Reitern nach Dover. ${ }^{82}$ In seinem Gefolge reisten der Erzbischof 
von Reims, der zuvor als Gesandter Karls VI. aus Konstanz Bericht erstattet hatte, ${ }^{83}$ der Palatin Graf Miklós Garai von Ungarn, außerdem hohe Adlige aus Ungarn, Böhmen und Italien. ${ }^{84}$ In Dover wurde der König am 1. Mai vom jüngsten Bruder Heinrichs V., Humphrey of Gloucester, in Begleitung einiger Ritter erwartet. ${ }^{85}$ Der Basler Chronist merkt als einziger an, Sigismund sei bereits damals prachtvoll in der Burg Dover ausgehalten worden und habe dort gespeist. ${ }^{86}$

In Canterbury bereitete der Erzbischof Henry Chichele mit dem Kathedralklerus Sigismund einen gebührenden Empfang, indem er ihm vor den Stadttoren entgegenkam. ${ }^{87}$ Untergebracht wurde der König im Palast des Erzbischofs im Norden der Kathedrale. ${ }^{88}$ Während der drei Tage, die Sigismund auf die Ankunft der Nachhut wartete, hatte er Zeit, den Schrein des heiligen Thomas Becket in der Kathedrale zu besichtigen. Der Basler Chronist erwähnt als einziger, wenn auch summarisch, das vermutlich ehrgeizige Besichtigungsprogramm des Königs: »und besach die kilchen $«{ }^{89}$ Neben der Kathedrale muss der Luxemburger mindestens die gewaltige Kirche der Benediktinerabtei St. Augustine's mit ihren zahlreichen Schreinen gesehen haben. In der Kathedrale konnte Sigismund nicht nur die Architektur, die Glasfenster und den Schrein des heiligen Thomas Becket betrachten, sondern auch das Grabmal des Schwarzen Prinzen, eines Großonkels Heinrichs V., mit vergoldetem Brozegisant direkt südlich davon zwischen den Pfeilern des Binnenchors. Vermutlich war das direkt gegenüber liegende Grabmal mit den teilgefassten Alabastergisants Heinrichs IV. und dessen zweiter Frau Johanna von Navarra gerade fertiggestellt. $^{90}$ Windecke gibt von Sigismunds Aufenthalt kein Zeugnis, da sich seine Überfahrt verzögerte und er schnell nach London eilen musste, höchstens mit kurzem Halt in Canterbury. Seine Beschreibung der Kathedrale zielt nur auf den Thomas-Schrein mit dessen Reliquien. Hier verwendet er den Topos des allerschönsten und köstlichsten Kleinods, das je ein Mensch gesehen habe, in doppelter Verneinung. Die Form des Schreins beschreibt er nicht, sondern nur das geringstwertige Material Gold: "und sohent do das allerschonste und kostlichste cleinot sant Thomas sarche, das ich glouben, das nie keins monschenbilde bessers nie gesehen, wanne das ergeste, das dran ist, das ist golt. ${ }^{91}$ Bei seiner Aufzählung der Reliquien, die er auf der Reise gesehen habe, gesellt er dem Thomas-Schrein allerdings das Haupt des heiligen Dionysius zu - aus englischer wie aus französischer Sicht eigentlich ein unverzeihlicher Fehler. ${ }^{92}$
Je näher Sigismund dem Regierungszentrum im Westminster-Palast kam, desto höher standen die ihn empfangenden Personen in der Hierarchie. ${ }^{93}$ In Rochester war der zweitälteste Bruder Heinrichs, der Herzog von Bedford, in Dartford der älteste Bruder und Thronfolger, Thomas of Clarence, zum Empfang des Luxemburgers abgeordnet worden. ${ }^{94}$ Die Straße nach London führte von Dartford zum traditionellen Empfangsort Blackheath, fast neun Kilometer vor der mittelalterlichen Stadtgrenze Londons, wo auch jeder festliche Einzug eines siegreichen englischen Königs in die Hauptstadt begann. Dort sollte ihn der Bürgermeister mit den Ältesten, den Sheriffs und den Londoner »craftis« (ähnlich den Zünften organisierten Handwerkern) empfangen. ${ }^{95}$ Heinrich V. selbst erwartete Sigismund mit etwa 5.000 Gefolgsleuten, die auf sein Geheiß bereits seit dem 16. April in London warteten, zwei Kilometer vor den Toren an der Wasserstelle St. Thomas Watering. ${ }^{96}$ Sigismund, der von den englischen Chronisten wiederholt als Kaiser bezeichnet wird, zog zusammen mit Heinrich als Herrscher auf hierarchisch gleichwertiger Stufe nach London ein. ${ }^{97}$ In der Fortführung der ältesten englischen Prosa-Chronik Brut ist ein "worthi metyng " beschrieben, das durch gegenseitigen Kuss, Umarmung und Halten der Hände ausgezeichnet gewesen sei, und so zogen die Könige gemeinsam zur Kathedrale St. Paul, wo sie von den Bischöfen gesegnet wurden..$^{98}$ Nach dem Te Deum ritten die beiden Monarchen zum Königspalast in Westminster außerhalb der Londoner Stadtgrenze, wo Sigismunds Aufenthalt bis zum 16. Mai überliefert ist. ${ }^{99}$

Sigismund war der erste römische König des Mittelalters, der England besuchte, und als solcher wurde er in London mit großen Ehren empfangen. ${ }^{100}$ Seit dem Treffen Eduards III. mit Kaiser Ludwig IV. dem Bayern 1338 hatte kein Herrschertreffen zwischen englischem König und (zukünftigem) Kaiser stattgefunden. Auch Windecke zeigt sich sichtlich beeindruckt von der englischen Repräsentation:

»Do mein ich, das nie kein mensch einen konig oder fursten noch kein menschenbilde kostlicher hette empfohen, danne der konig von Engelant den Römschen konige Sigemont uf ein tag kostberlich und mit schoner herlicheit. von dem konige von Engelant selber die zwene bruder, die bischove und die lantherrn in dem lande ritter und knechte mit kostlichkeit der pferde und der gezúge, die edeln zarten schonen frouwen burger und burgerin uf das allerkostlichesto ußbereit, daz man erdenken möcht, zogen all uß zu velde 
gein dem Römschen konige und fürten in gon Lunden mit grosser herlicheit. $\ll^{101}$

Windecke kann als Augenzeuge für den Einzug vom 7. Mai gelten. Seine Bewertung des Einzugs als außergewöhnlich prachtvoll muss jedoch im Vergleich zu den Empfängen Sigismunds außerhalb Englands gesehen werden und nicht etwa zu den Einzügen englischer Herrscher nach London. Denn Heinrich V. selbst war wenige Monate zuvor, am 23. November 1415, nach seinem Sieg bei Azincourt von einer mit Statuen, Brunnen und Textilien geschmückten Stadt London und einer täuschend echten, die himmlische Stadt Jerusalem evozierenden Burgkulisse ungleich prächtiger als Sigismund begrüßt worden, dessen Einzug nicht von Festarchitektur begleitet war. ${ }^{102}$

Heinrich V. ließ Sigismund und sein Gefolge in der great hall im königlichen Palast von Westminster unterbringen. Die great hall war unter Richard II. ab 1393 mit einem in seiner Spannweite von 21 Metern einzigartigen spätgotischen Hammerbalken-Dachwerk ausgestattet worden (Abb. 4). ${ }^{103}$

Die normannischen Wände der 73 Meter langen Halle waren für den Aufenthalt des römischen Königs mit Wandteppichen aus Goldbrokat verkleidet worden. ${ }^{104}$ Die Engel an den Balkenköpfen trugen Fackeln und beleuchteten das technische Meisterwerk. ${ }^{105}$ Damit der englische König aber Zugang zum Raum des Schatzamtes (Exchequer) behielt, das nicht umgesiedelt wurde, ließ er in den Westminster-Palast eine Tür einbauen. ${ }^{106}$ Anders als der französische König, der Sigismund im Louvre logieren ließ ${ }^{107}$ verfügte Heinrich nicht über einen zweiten Palast nahebei. Daher zog er selber über die Themse in den Lambeth-Palast des Erzbischofs von Canterbury um, den er für diesen Zweck ebenfalls kurzfristig hatte umbauen lassen. ${ }^{108}$

Die anschließende Sitzung des Parlaments Anfang Mai - Heinrich ließ sie auf diesen Termin vertagen, um die Anwesenheit des hohen Gastes zu ermöglichen - fand nicht wie zuvor in der Painted Chamber, sondern in dieser imposanten großen Halle des Westminster-Palasts statt. Auch hier präsidierte Heinrich auf einem Thron. ${ }^{109}$ In dieser Kulisse trat Sigismund auf, pries vor allen anderen den englischen König und kündigte die Stiftung einer »imago sancti Georgii« an die Georgskapelle in Windsor an, wie der Chronist, wahrscheinlich der Mönch Thomas Walsingham von St. Albans, in seiner zeitgenössischen Chronik überliefert. ${ }^{110}$ Damit muss er das Herzreliquiar

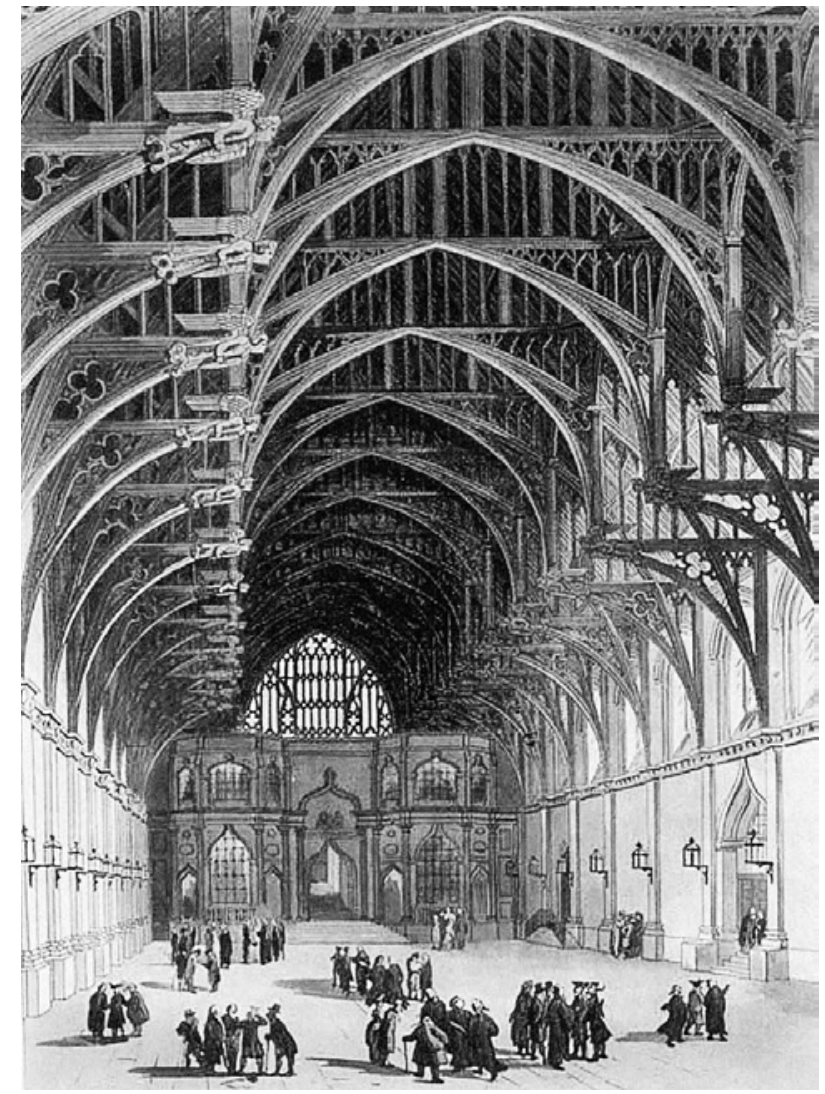

Abb. 4 London, Westminster Hall. Innenansicht von Thomas Rowlandson und Augustus Pugin (ex: COME/PYNE 1808-11, vor S. 235)

gemeint haben, da neben der ungefassten Schädelreliquie Georgs kein weiteres Objekt im Inventar der Ordenskapelle überliefert ist, das anlässlich des Ordensfestes von Sigismund gestiftet wurde. ${ }^{111}$ Sigismund hatte bei seinem Parisaufenthalt zuvor auch dem französischen Herzog von Berry eine goldene, kristallene Turmmonstranz geschenkt, die mit Rubinen und Saphiren besetzt war. ${ }^{112}$

Dass Sigismund auch die Abteikirche Westminster gesehen hat, können wir nur vermuten. Windecke berichtet aus Westminster Abbey erstaunlicher Weise nur, dass er selber »den stein, do got der harre ingestanden ist mit sinem rechten füß, do er gon himel füre " gesehen hat. ${ }^{113}$ War er etwa nur auf dem Lettner westlich des Mönchschors, wo sich der Stein befand? Hatte er keinen Zugang zum Binnenchor mit dem durch Heinrich III. erneuerten Eduardsschrein und der englischen Königsgrablege? Das Material der vergoldeten Bronzegisants wäre nach heutigen Maßstäben einer Beschreibung wert gewesen, doch schon in Canterbury entging dem vielleicht eiligen Chronisten der vergoldete Gisant des schwarzen Prinzen, die 
weitere Ausstattung und die Glasmalerei. Angesichts seines überlieferten Interesses am Thomas-Schrein spricht allerdings einiges dafür, dass Windecke den Chor der Abteikirche Westminster mit dem Eduardsschrein gar nicht betreten hat. ${ }^{114}$

Höhepunkt der Festlichkeiten in England war die Aufnahme Sigismunds in den Hosenbandorden in der Georgskapelle auf Burg Windsor. Für die erwartete Unterbringung des großen ausländischen Gefolges, "the greate multitude of peopul, straungers and others", hatte Heinrich V. den Dekan und das Kapitel im Vorfeld gebeten, den Überbringer des Briefs die Burg inspizieren zu lassen, die wesentlich unter Heinrich III. und Eduard III. errichtet worden war. ${ }^{115}$ Dem außergewöhnlich prächtigen Ordensfest, das für die Wahl Sigsmunds auf den 23. und 24. Mai verschoben worden war, wohnten »die mechtigesten, durlúchtigesten fúrsten und die gewaltigesten edeln des kúngriches « bei, wie der Basler Chronist beeindruckt vermerkt, darunter auch die von Heinrich in der Schlacht von Azincourt gefangengenommenen Herzöge von Orléans und Bourbon. Sigismund war allerdings nicht mit dem ganzen Gefolge, sondern nur mit "wennig edeler « angereist. ${ }^{116}$ Im Inventar der Wertsachen Heinrichs V., die sich nach seinem Tod im Besitz der Burg befanden, sind aufwändige Wandteppiche genannt, welche vielleicht schon diesen repräsentativen Anlass begleitet hatten. ${ }^{117}$

Im Zusammenhang mit seiner Wahl zum Ordensritter als erster römischer König stiftete Sigismund nun die im Parlament zuvor angekündigte Herzreliquie des heiligen Georg, die in einer Monstranz ausgestellt war, sowie eine sehr kleine Schädelreliquie, die erst Eduard IV. reich fassen ließ. ${ }^{118}$ Die Herzreliquie spielte fortan eine zentrale Rolle im Zeremoniell des Ordensfestes in Windsor. ${ }^{119}$ Georg war nicht nur der Patron des Hosenbandordens, sondern einer der wichtigen Heiligen des englischen Königshauses, dessen Gedenktag seit dem Sieg Heinrichs gegen die Franzosen in Azincourt im Oktober des vorherigen Jahres zum Hochfest aufgewertet worden war. ${ }^{120}$ Sigismund selbst hatte 1408 die Drachengesellschaft gegründet, deren Parallelen zum englischen Ritterorden nicht nur in ihrem Bezug auf den heiligen Georg als Drachentöter sinnfällig werden. ${ }^{121}$

Das Reliquiar von offenbar herausragender Qualität ist ebensowenig erhalten wie die meisten anderen Objekte, die anlässlich der Reise Sigismunds verschenkt wurden. Die einzige bildliche Überlieferung im erst 1483-84 aufgezeichneten Pageant of the Birth, Life and Death of Ri- chard Beauchamp zeigt es zeichenhaft als einfache Turmmonstranz ohne weitere Figuren, die in ihrer Mitte ein Herz ausstellt (Abb. 5).

Dargestellt ist Beauchamp im Vordergrund als Schwertträger vor Sigismund und dessen Gattin Barbara, durch die Kronen und den Reichsapfel als Kaiserpaar bezeichnet, in einer Prozession anlässlich der Ernennung zum Ordensritter, an der auch die Frauen der Ritter teilnahmen. Bis auf Sigismund tragen die Männer Halsketten. Darüber stehen auf einer Art Empore Sigismund und Beauchamp mit der Monstranz, die Sigismund Beauchamp überreicht. Beauchamp figuriert durch seine Position in der Mitte und durch den Wappenmantel als Hauptfigur, der dem Kaiser auf der Empore zwar barhäuptig, aber auf gleicher Höhe gegenübersteht. Die sichtbare Aura des Reliquiars, die sich auf Beauchamp überträgt, sowie die Funktion des Grafen als Empfänger stellvertretend für den Orden - die er wahrscheinlich nur in Konstanz innegehabt hätte -, werden in der retrospektiven Darstellung wirkungsvoller inszeniert, als dies im Text möglich gewesen wäre. ${ }^{122}$ Das Reliquiar hatte Sigismund in Windsor sicherlich dem König selbst oder dessen Onkel Henry Beaufort als Prälaten des Hosenbandordens überreicht.

Erst die Beschreibung im Inventar lässt auf die tatsächliche Form schließen. Thomas Walsingham, der formelhaft ein Objekt von außergewöhnlichem Material nennt, war offenbar nicht korrekt informiert über die Art des Objekts: »imaginem sancti Georgij de fulvo metallo fabrefactam, cuius >materiam superabat opus « $«{ }^{123}$ Er verwendet den Begriff »imago«, der üblicher Weise Skulpturen bezeichnet, aber für Reliquien ungebräuchlich war. Im Inventar der Georgskapelle von 1534 wird die silbervergoldete Monstranz mit einem Aufsatz auf dem Reliquienbehälter spezifiziert, der die Gottesmutter mit Kind und darüber die Kreuzigung zeigte. ${ }^{124}$ Ein »byrall«, also ein durchsichtiger Stein wie ein Bergkristall oder ein Beryll, umschloss die Herzreliquie. ${ }^{125}$ Möglicherweise ähnelte ihr Aufbau der vergoldeten kupfernen Monstranz aus Köln. ${ }^{126}$ Der Zeichner des Pageant illustriert nicht die tatsächliche Form des Reliquiars, sondern den Text auf derselben Seite, der das Objekt kurz als "seynt Georges hert « bezeichnet. ${ }^{127}$ Vergleichbare Phänomene hat Livia Cardenas bei der Darstellung von Monstranzen im Bamberger Heiltumsbuch von 1508/09 beobachtet. Sie bezeichnet die zeichnerische Umsetzung einer textuellen Beschreibung als »Begriffsgestalt«, die dem Objekt unabhängig von seinem tatsächlichen Aussehen eine weitere imaginierte, also fiktive Präsenz zugesteht. ${ }^{128}$ 


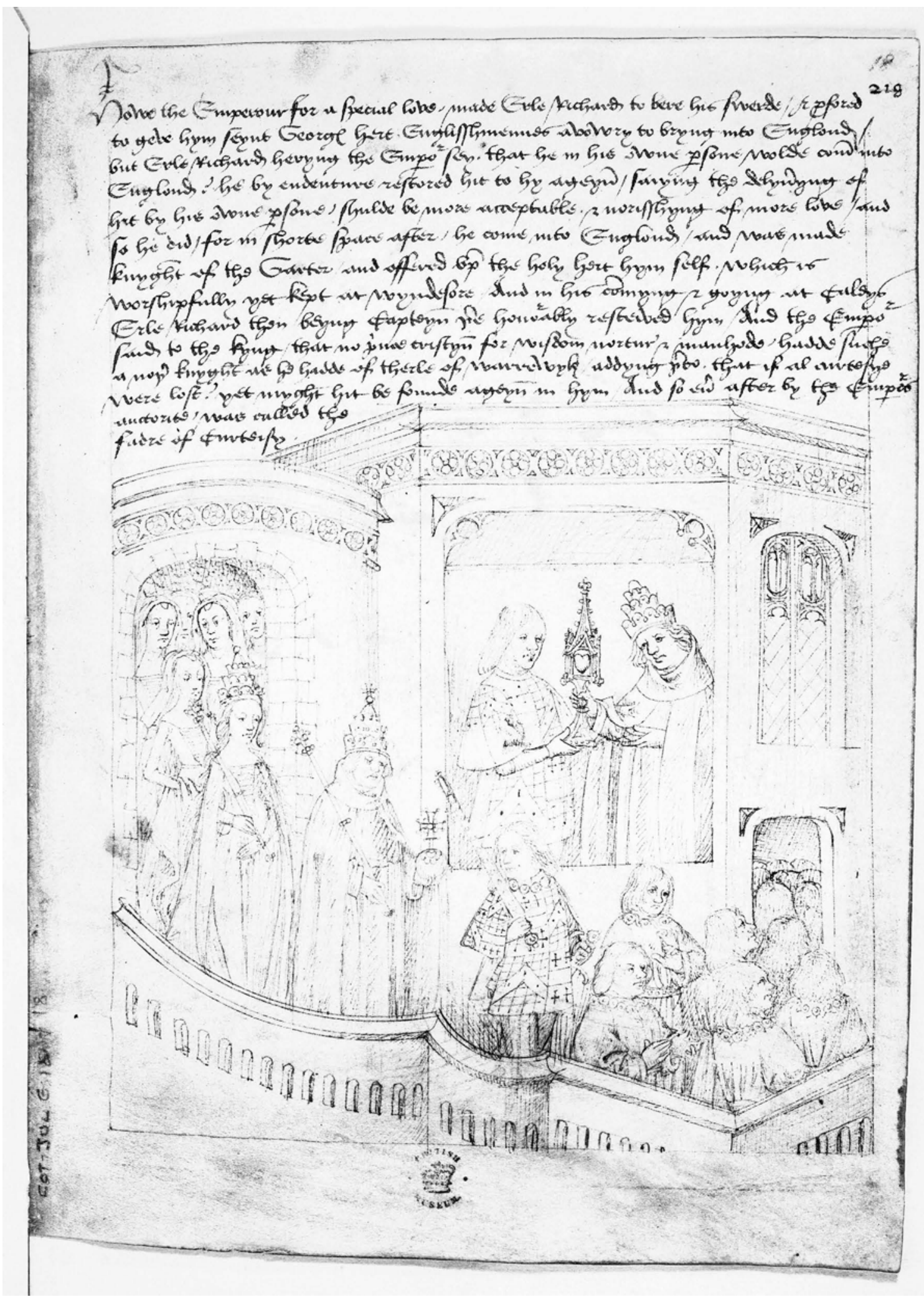

Abb. 5 Übergabe des Herzens des hl. Georg in einer (stilisierten) Monstranz. Pageant of the Birth, Life and Death of Richard Beauchamp, London, um 1483-84. London, British Library, Cotton Julius E. IV, art. 6, fol. 18r (Foto: London, The British Library Board) 
Im Mai 1416 fand die Ordens-Zeremonie in der Georgskapelle statt, die unter Heinrich III. errichtet und anlässlich der Ordensgründung unter Edward III. 1350 bis 1353 mit neuem Chorgestühl und Glasmalerei ausgestattet worden war. ${ }^{129}$ Der Umbau zu der wesentlich größeren Ordenskapelle in der heutigen Form wurde erst unter Eduard IV. ab 1477 veranlasst; Reste der alten Kapelle sind heute in der östlich anschließenden Lady Chapel erhalten. Auch die große Skulpturenwand aus Alabaster, die den Hochaltar hinterfing, ist nicht erhalten. Wir wissen nur, dass sie 1367 in zehn Karrenladungen nach Windsor transportiert worden war. ${ }^{130}$ Auf der Altarmensa standen zwei Statuen: Die Marienstatue aus vergoldetem Silber aus der Zeit Heinrichs III. und ein vermutlich hölzerner heiliger Georg mit Rüstung. ${ }^{131}$ Am Hochaltar, »infra Tabulam summi altaris«, möglicherweise unterhalb oder in dieser Alabasterwand, wurden die Reliquien aufbewahrt: das so genannte "Cross Gneth", eine Kreuzreliquie, die Eduard III. anlässlich der Gründung des Hosenbandordens gestiftet hatte, sowie eine Armreliquie und zwei Finger des heiligen Georg. ${ }^{132}$ Umso willkommener muss also Sigismunds Reliquienstiftung mit dem Herz des Heiligen gewesen sein.

Überraschend scheint zunächst, dass die Engländer zwei vorhergegangene Versuche zur Übergabe der HerzReliquie verhindert haben sollen. Bereits in Konstanz, noch vor seiner Englandreise, habe Sigismund, glaubt man dem Pageant, die Monstranz Beauchamp als Stellvertreter des englischen Königs schenken wollen. Richard Beauchamp aber habe sie zurückgegeben, als er gehört habe, dass Sigismund plane, selber nach England zu reisen. ${ }^{133}$ Anlässlich der Parlamentssitzung in der Westminster Hall schien die Schenkung an Heinrich ebenfalls unpassend, habe der englische König doch darauf bestanden, dass Sigismund das Objekt persönlich der Georgskapelle stiften müsse. Beide Ereignisse mögen das englische Wissen um die Eitelkeit des römischen Königs bezeugen, indem sie betonen, wie viel wertvoller die eigenhändige Übergabe der gestifteten Reliquie durch Sigismund selbst sei. Doch sie belegen auch, dass die Anwesenheit des künftigen Kaisers und seiner hochstehenden Begleiter in Windsor von englischer Seite ausdrücklich erwünscht und wiederum mit einer gut vorbereiteten Übergabe von hoher Bildmächtigkeit und heilsmächtiger Symbolik verbunden war. Erst der Genius Loci der Ordenskapelle in der Topografie der Festlichkeiten im Namen des Patrons erlaubte die herausragende Inszenierung der Übergabe des Reliquiars, das die Reliquien Georgs ausstellte, des
Stifters Sigismund, der in den Orden gewählt worden war, sowie Heinrichs und der Ordensherren, die fortan die kostbare Monstranz bei den Ordensfesten mitführten.

Die sichtbare Präsentation der Georgsreliquie oberhalb des Altars wird einige Jahre später präzisiert. Im Jahr 1429-30 ist eine als "ffauzeauter « bezeichnete Konstruktion für die Aufstellung der Reliquien erwähnt, die auf einem hölzernen Aufbau mit mehreren Brettern über dem Altar stand. ${ }^{134}$ Der Begriff »ffauzeauter« ist dokumentarisch nicht weiter spezifiziert. Vergleichbare Aufbauten scheint es in Canterbury, St. Augustine's, in Cismar oder in Basel gegeben zu haben. ${ }^{135}$ Ulrich Richental und die Regesten Sigismunds verzeichnen für den März 1417 einen mannshohen Kandelaber aus Kupfer oder Messing, den Sigismund als Geschenk für Heinrich V. bei einem Nürnberger für 1.100 Gulden günstig hatte erwerben können. Der Leuchter wurde in einem Fass verpackt und mit einem "wisan«, vermutlich einem lebenden Wisent, nach England gesandt. ${ }^{136}$ Wahrscheinlich war dies der große Leuchter, mit "pinnacula et flores" ornamentiert, dessen Hängung im Inventar der Georgskapelle vermerkt ist, weil für ihn ein stabiles Gerüst und eine gußeiserne Hängungsvorrichtung angefertigt wurden. ${ }^{137}$ Dann wäre dieses Geschenk Sigismunds an Heinrich V. keineswegs so kurios, wie Gerhard Fouquet spekuliert. ${ }^{138}$

Das Gestühl der Ordensritter zierten emaillierte Wappendevisen, Helme, Schwerter sowie zwei eigens angefertigte Kissen mit Georgswappen für Sigismund und Heinrich. ${ }^{139}$ Beim Tod eines Ordensritters wurde sein Schwert am Altar dargeboten. Als sichtbares Zeichen seiner Präsenz am Tag seiner Erhebung zum Ordensritter schenkte Sigismund ein vergoldetes Prunkschwert nach Windsor, das über seinem Platz im Ordensgestühl aufzuhängen war (Abb. 6).

Nach Sigismunds Tod gelangte das Schwert 1439 als Stadtschwert nach York als Schenkung eines Klerikers aus Windsor. ${ }^{140}$ Dieses Schwert ist in dem Pageant dargestellt. Da die Männer dort gleichartige mit Wappen des englischen Königs verzierte Mäntel tragen, handelt es sich um die Zeremonie anlässlich der Erhebung zum Ordensritter (Abb. 5). Heinrich selbst hatte Sigismund bereits vor Beginn des Konzils in seinem oben erwähnten Testament mit seinem prunkvollen, mit Edelsteinen besetzten Schwert bedacht. Das Schwert figuriert dort an prominentester Stelle, direkt nach den Stiftungen für Heinrichs eigene Kapelle; Sigismund wird zudem als Verteidiger der Kirche und des Glaubens bezeichnet. ${ }^{141}$ 


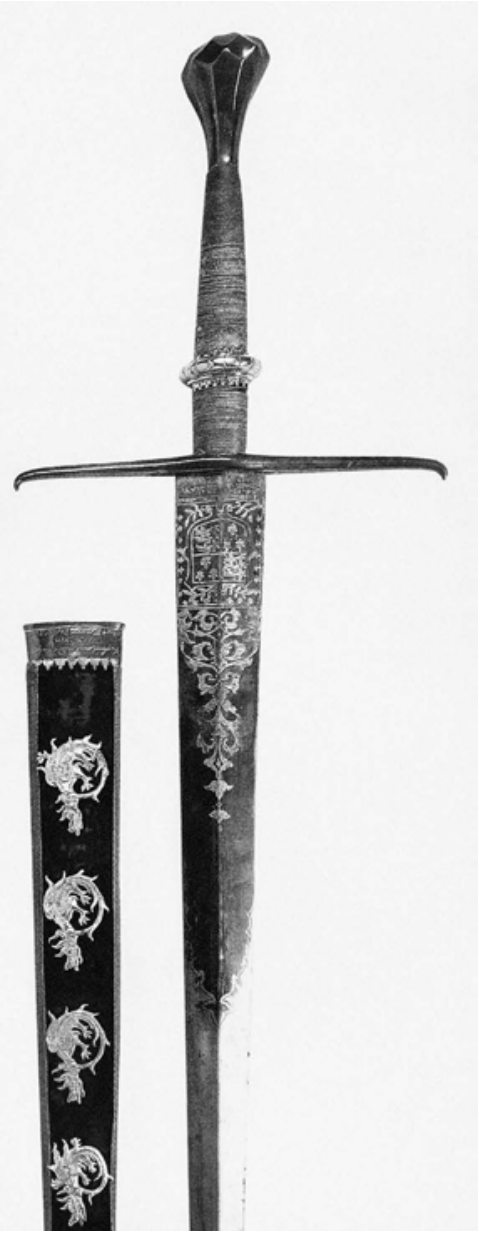

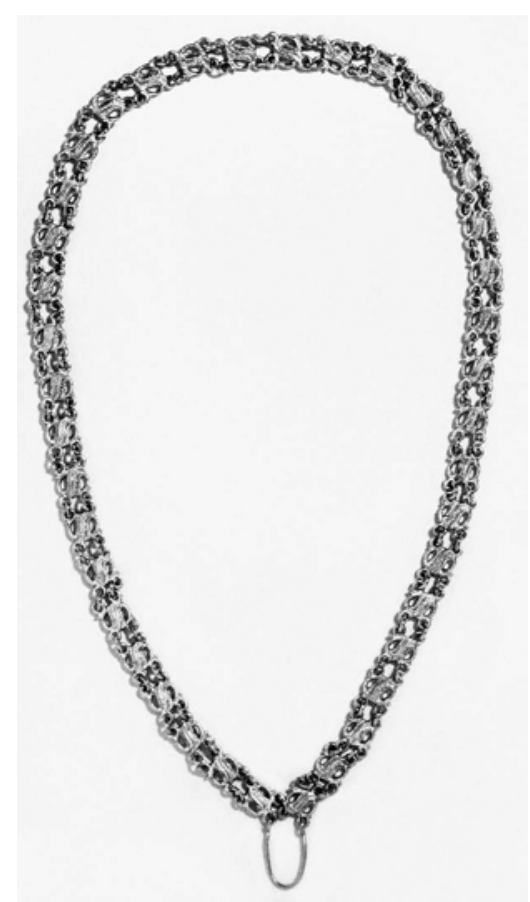

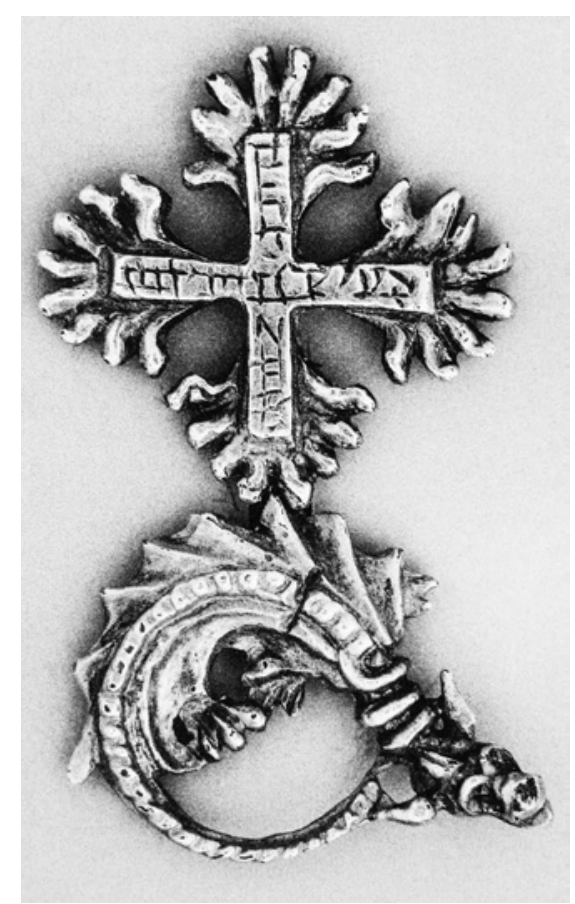

Abb. 6 Prunkschwert, Geschenk Sigismunds in die Ordenskapelle St. Georg zu Windsor, 1439 von dort an die Stadt York geschenkt (ex: Ausst.-Kat. Budapest 2006, 341)

Abb. 7 Ordenskette mit s-förmigen Gliedern. Silber vergoldet, England, Ende 15. / Anfang 16. Jh. London, Victoria \& Albert Museum (ex: Ausst.-Kat. Budapest 2006, 354)

Abb. 8 Ordenszeichen der Gesellschaft vom Drachen. Ungarn (?), wohl um 1429. Berlin, Staatliche Museen, Kunstgewerbemuseum (ex: Ausst.-Kat. Budapest 2006, 340)
Die in Brügge verpfändete und in Konstanz imaginierte Kette hatte Sigismund in Windsor angelegt. Heinrich hatte ihm die Halskette mit einem wertvollen Anhänger als Devise des Hauses Lancaster und als königliches Zeichen geschenkt. ${ }^{142}$ Eine Ordenskette kannte der Hosenbandorden damals noch nicht; die zeitliche Koinzidenz dieses Geschenks mit der Wahl zum Ordensritter ist daher umso mehr auf die sichtbare Bindung an Heinrich V. ausgelegt (Abb. 7).

Neben dem langen blauen, mit Pelz gefütterten Mantel mit Ordensabzeichen bekam Sigismund als erster ausländischer König das Hosenband, das üblicherweise unterhalb des linken Knies gebunden wurde, in Form eines Gürtels verliehen. ${ }^{143}$ Dass Sigismund im Gegenzug neben Monstranz, Schwert und Leuchter noch weitere Objekte nach Windsor geschenkt haben könnte, lässt sich in den Quellen bisher nicht nachweisen. María Verös Anregung, dass der Beinsattel mit vier Drachenfiguren und einer auf den heiligen Georg verweisenden Inschrift, der sich in der englischen königlichen Waffensammlung befindet, nicht erst um 1440, sondern bereits anlässlich des Ordensfestes von 1416 als Präsent Sigismunds an Heinrich V. geschnitzt und bemalt worden sein könnte, muss somit Spekulation bleiben. ${ }^{144}$ Ob Sigismund Heinrich das Drachenabzeichen mit Kreuz und die Mitgliedschaft im Drachenorden verliehen hat, ist gleichfalls umstritten. Es fanden sich mehrere reich vergoldete Exemplare im Nachlass Heinrichs V. vor; erhalten ist aber nur ein späteres Exemplar in Berlin (Abb. 8). ${ }^{145}$

Prozessions- und Sitzordnung sowie Speisenfolge stellten die Könige in der Rangfolge als beinahe ebenbürtig heraus. Heinrich stand Prozession und Messe in der Ordenskapelle vor. ${ }^{146}$ Beim Essen in der Great Hall von Windsor präsidierte dagegen Sigismund am Kopfende des Tisches, rechts von ihm der englische König und zwei Herzöge aus Sigismunds Gefolge, links von ihm der älteste Bruder Heinrichs, John of Bedford, sowie Bischof Beaufort als Prälat des Ordens. Zwischen den Gängen 
reichte man den beiden Königen, und nur ihnen, drei den Ordensheiligen evozierende "subtleties« oder »sotelties«. Diese kunstvollen kuchenähnlichen Aufbauten mit Heiligenfiguren und miniaturisierter Architektur oder Mikroarchitektur hoben die ranghöchsten Gäste der Festbankette heraus. ${ }^{147}$ Dargestellt waren der heilige Georg, dem die Jungfrau Maria und ein Engel die Rüstung anlegten, Georg im Drachenkampf zu Pferd sowie der Heilige vor einer verkleinerten Burg, an deren Tor die von Georg befreite Königstochter der Legende nach mit dem ebenfalls dem Drachen zum Fraß vorgeworfenen Lamm zu sehen war, die vielleicht zugleich als Personifikation Englands zu verstehen war, welche dem Lamm Gottes Einlass gewährte. Die übrigen Anwesenden erhielten je nach Rang andere »sotelties $« .{ }^{148}$

Sigismund kehrte aus Windsor nach Westminster zurück, wo er weitere vier Wochen verbrachte. Am 28. Mai war endlich auch Wilhelm II., Herzog von Bayern-Straubing und Graf von Hennegau, Holland und Seeland, mit großem Gefolge von etwa 600 Reitern per Schiff direkt in London angekommen. Nur das schlechte Wetter hatte den Ordensritter Wilhelm von der Teilnahme an diesem besonderen Hosenbandfest abgehalten. ${ }^{149}$ Er logierte mit einem Teil seines Gefolges im Palast des Bischofs von Ely in Holborn. ${ }^{150}$ Wiederum habe nur die englische Kenntnis höfischen Zeremoniells, so bezeugt diesmal Windecke, Sigismund vor einem Fehlverhalten bewahrt, denn als dieser dem Grafen vor den Toren Londons entgegenziehen wollte, habe Heinrich den römischen König davon abhalten müssen. ${ }^{151}$ Den fremden Herrscher in England zu empfangen, wäre nur dem englischen König zugekommen. ${ }^{152}$ Pfingsten und Trinitatis verbrachten die drei Herrscher gemeinsam. ${ }^{153}$ Jean de Waurin berichtet von einem großen Fest zu Ehren der ausländischen Gäste, an dem auch die gefangenen Fürsten und der Erzbischof von Reims teilnahmen. ${ }^{154}$ Auch das Verhalten des Engländers war dem burgundischen Chronisten eine Erwähnung wert, habe Heinrich doch wieder über eine "unvergleichliche Kenntnis höfischer Formen « verfügt. ${ }^{155}$ So sei der zukünftige Kaiser vom König und seinen Fürsten entsprechend dem Usus geehrt worden. ${ }^{156}$ Heinrich trug laut Waurin einen goldenen Mantel und eine goldene, mit Edelsteinen besetzte Halskette. ${ }^{157}$ Dies war wahrscheinlich eine wertvolle Kette, möglicherweise aber eine ebensolche Fiktion wie die Kette Sigismunds, da die wertvolle goldene Halskette namens "pusan" den Londoner Bürgern seit Juni 1415 als Pfand gegen 10.00o Mark Sterling überlassen war. ${ }^{158}$
Parallel zu alledem verfolgte Heinrich seine Regierungsgeschäfte, versammelte seine Truppen an der Küste zum Angriff auf Harfleur und sandte eine Delegation nach Frankreich. Beauchamp führte indes eine weitere Gesandtschaft an den burgundischen Hof nach Lille an, die der Herzog von Brieg von England aus als Abgeordneter Sigismunds begleitete. ${ }^{159}$ Nach diesen weiteren vier Wochen Aufenthalt im Westminster-Palast muss Sigismund seine Rückreise zum Konzil geplant haben, wo er bereits dringend erwartet wurde: Am 27. Juni erlaubte Heinrich die zollfreie Ausfuhr der königlichen Juwelen. ${ }^{160}$ Nach einem Aufenthalt in Eltham und auf Schloss Leeds brach Sigismund nach Canterbury auf. ${ }^{161}$

Am 15. August, als der Herzog von Bedford den Angriff der französischen und genuesischen Schiffe auf die englische Flotte nahe Harfleur zurückschlug, unterzeichneten Heinrich und Sigismund den wichtigen und zuvor ausgehandelten Vertrag von Canterbury, ein deutsch-englisches Bündnis, dessen Wirkung allerdings beschränkt blieb. ${ }^{162}$ Wie zuvor vereinbart, stand nicht nur das Bündnis, sondern auch der Kirchenfriede im Fokus des Bündnisses. ${ }^{163}$ Der Vertrag stellte beide Herrscher als Friedensstifter in Politik und Kirche heraus und formulierte den Gegensatz zum französischen König, der das Schisma nicht habe beenden wollen. Beide Könige beeideten den Vertrag in der Kathedrale von Canterbury, begleitet von einer Demonstration englischer Frömmigkeit und Kultur. Der Eid, bekräftigt durch das Berühren des Evangeliars mit ihren rechten Händen, war allerdings nicht auf Sichtbarkeit ausgerichtet, da die Könige ohne Gefolge Messe feierten. ${ }^{164}$ In der Messe ließ Heinrich zwei Motetten des berühmtesten englischen Komponisten der Zeit, John Dunstaple, aufführen. ${ }^{165}$ Erzbischof Chichele propagierte Heinrich als »miles christi« und ließ die Liturgie anpassen, und der Chronist der Gesta lobte an dieser Stelle die konzentrierte Frömmigkeit des englischen Königs, habe dieser sich doch von Beginn seiner Regierungszeit an weder bei der Messe noch beim privaten Gebet unterbrechen lassen. ${ }^{166}$ Vor seiner Krönung als wenig gottesfürchtig kritisiert, nutzte Heinrich als Oberhaupt der englischen Kirche diese Inszenierung englischer Frömmigkeit implizit als kirchenpolitischen Hinweis auf die Reformbedürftigkeit der römischen Kirche, aber auch auf seine rechtmäßige Thronfolge in England wie in Frankreich, war doch die Religiosität Heinrichs III. von England und Karls V. von Frankreich ein oft zitierter Topos. So ist auch der zu Beginn aus Foresters Brief zitierte Vergleich der englischen Kirche und ihrer Gottesdienste 


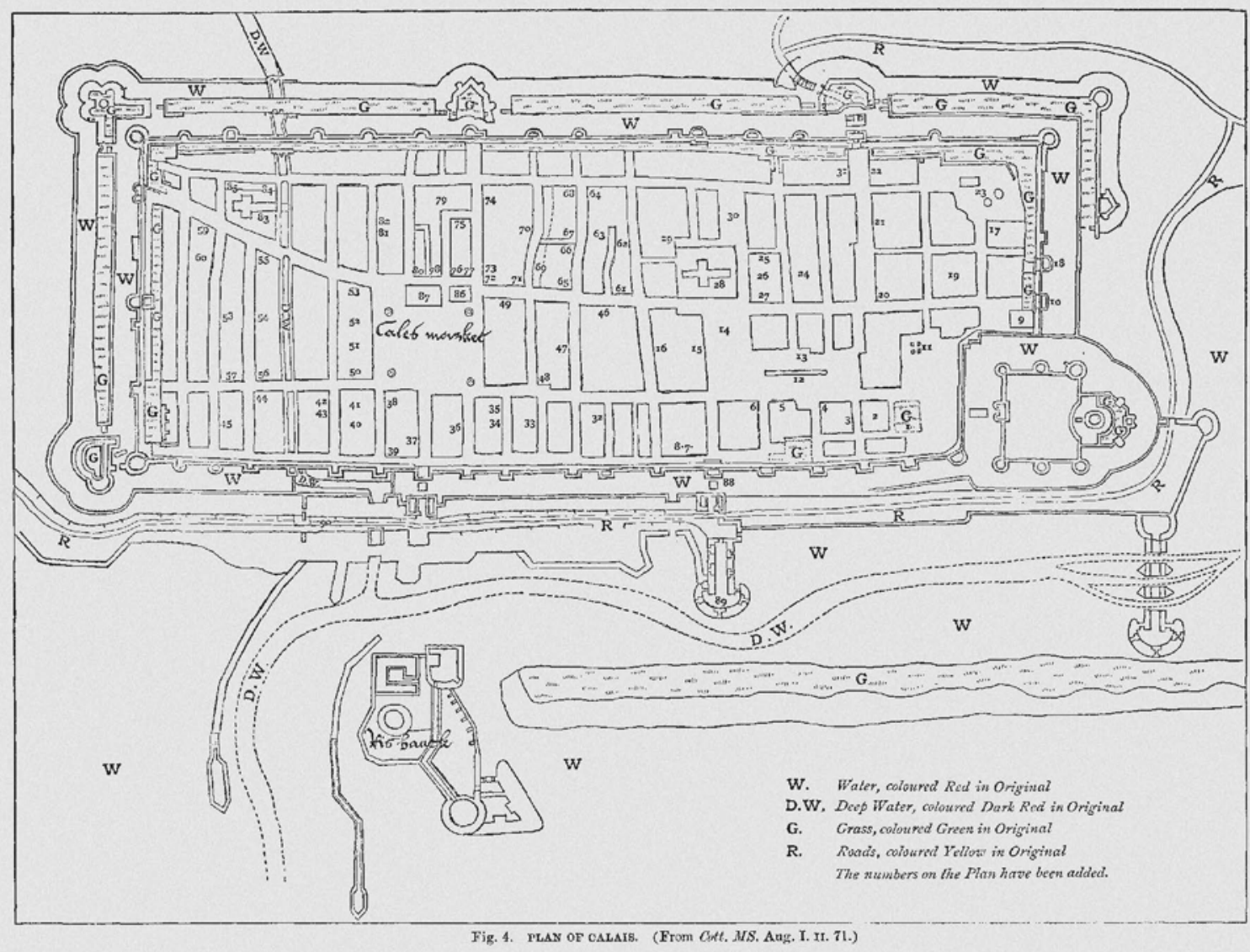

Abb. 9 Plan der Stadt Calais im Mittelalter (ex: DILLON 1893, Abb. 4)

mit dem Paradies zu verstehen, der Sigismund in den Mund gelegt wird. Die Zettel (sedulae), die Sigismund auf dem Weg nach Dover, welches er am 23. August erreichte, hinter sich verteilt haben soll, priesen entsprechend die Engelsnatur Englands. ${ }^{167}$ Ein Anglicus metrista wiederum antwortete mit Versen an Sigismund. ${ }^{168}$

Waren die Messe in der Kathedrale von Canterbury von den Mönchen des Klosters und das Ordensfest in Windsor von wenigen hochstehenden Adligen begleitet, bestellte Heinrich die wichtigsten englischen Rezipientengruppen, Fürsten, Ritter und Landadel aus ganz England, erst nach Dover, dann nach Calais. Auch seine siegreichen Truppen aus Harfleur hatten sich in Calais zu versammeln. ${ }^{169}$ Die Stadt wurde zur wohlinszenierten Bühne einer erfolgreichen Verbrüderung beider Könige und für diesen Zweck aufwändigst mit ephemerer Architektur und Ausstattung versehen. Fünf Tage vor Vertragsunterzeichnung hatte Heinrich 4.0oo Pfund Sterling nach Calais transportieren lassen, um die hohen Ausgaben zu begleichen. ${ }^{170}$ Sigismunds Aufenthalt in Calais ist vom 25. August bis zum 24. Oktober 1416 überliefert. Er war im Prince's Inn (später Staple Inn oder Hotel de Guise) südwestlich des Marktplatzes untergebracht, dem großen Gebäude der englischen Wollhändler. Auch dieses Gebäude war umgebaut und mit zwei Öfen ausgestattet worden (Abb. 9, 10). ${ }^{171}$

Heinrich, der selbst erst am 4. September eintraf, wohnte in der alten Burg Calais im Nordwesten der alten Stadt, die für diesen Zweck ebenfalls hergerichtet werden musste: An die Nordmauer der Burg wurde ein steinernes Gebäude von 21 Metern Länge, 7 Metern Breite und 6 Metern Höhe angebaut, das Heinrich und sein Gefolge beherbergte. ${ }^{172}$ Für den Aufenthalt beider Könige hatte Heinrich mit Goldbrokat und Teppichen ausgestattete Zelte nach Calais transportieren lassen, vermutlich die Zelte, in denen er selbst bei seinen Eroberungen in Frankreich logiert hatte. ${ }^{173}$ Dass neben der restaurierten Burg und den Zelten auch die ganze Stadt zur Kulisse des Herr- 


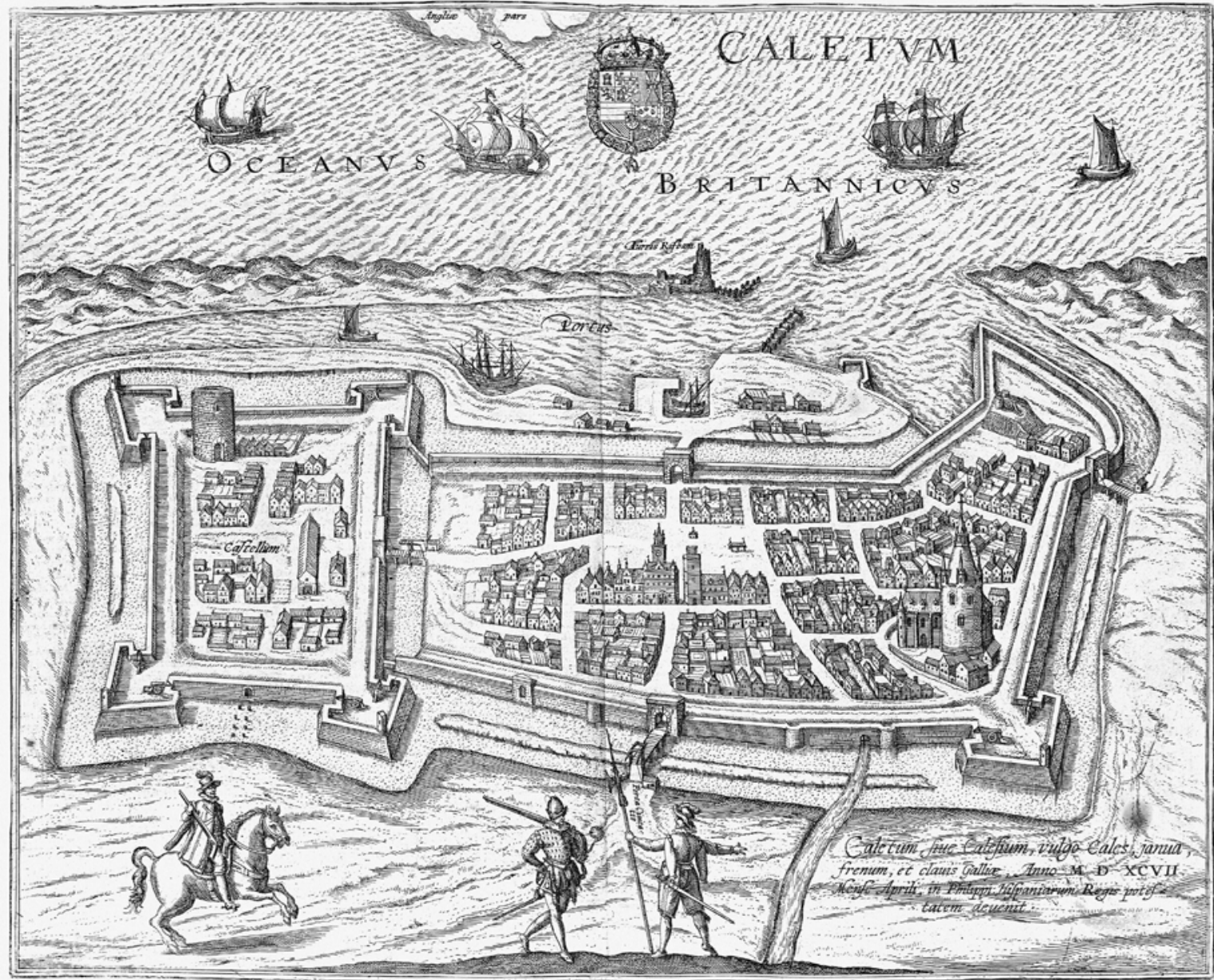

Abb. 10 Ansicht der Stadt Calais (Calesium/Caletum) (ex: Georg Braun / Franz Hogenberg: Civitates Orbis Terrarum, Liber quintus. Köln um $1597,68)$

schergesprächs wurde, bezeugt die Aussage des Gesta-Autors: Die beiden Könige und ihr Gefolge hätten die Stadt bei Spaziergängen in zweisamer Unterhaltung erkundet und in der Pfarrkirche Notre-Dame mit ihrem Gefolge den feierlichen Exequien des altgedienten Barons Thomas Morley beigewohnt. ${ }^{174}$ Zugleich mag diese Schilderung des Gesta-Autors wiederum als sorgsame Inszenierung der Freundschaft gelten, seien sich die Könige doch bereits bei der Ankunft in Calais im Zeichen der sicheren Überfahrt in die Arme gefallen. ${ }^{175}$ Anfang Oktober traf Herzog Johann Ohnefurcht von Burgund in Calais zu Verhandlungen ein und beendete die Spaziergänge zu zweit. ${ }^{176}$

Den Abschluss bildete der Geschenkeaustausch. In England überreichte allein Heinrich wertvolle Geschenke an den römischen König, der erst nach seiner Ankunft in Dordrecht Gegengeschenke schickte. Windecke und Justinger zeigen sich gleichermaßen überwältigt von der Großzügigkeit des englischen Königs. Trotz der Verpfändung des königlichen Schatzes seit Juni 1415 müssen sich noch ausreichend Goldschmiedeobjekte in den englischen Schatzkammern befunden haben, deren immenser Wert durch das Schatzverzeichnis aus dem letzten Regierungsjahr Richards II. bezeugt ist. ${ }^{177}$ Windecke nennt sehr detailliert Art und Wert der englischen Geschenke an Sigismund - nicht nur wegen ihrer Einzigartigkeit, sondern auch, weil er die "cleinöter « für Sigismund in Brügge für »achtzehen tusent cronen " (Gulden) verpfänden und für ihre Einlösung bürgen musste. ${ }^{178}$ Weil der König überall Schulden hatte, war die Pfandsumme weit niedriger, als es dem Wert der Gegenstände entsprochen 
hätte. ${ }^{179}$ Bei der Abreise aus Calais erhielt Sigismund von Heinrich zwei goldene Kannen, die mit 5.000 Nobeln (knapp 1.667 Pfund Sterling) gefüllt waren, einen goldenen Kopf und ein Mischkännchen, insgesamt ein Gewicht von 62 Goldmark oder etwa $14,5 \mathrm{~kg}$ Gold. ${ }^{180}$ Bei dem "gulden kopf « handelte es sich vielleicht um das wertvolle goldene Marienbild im Wert von 800 Nobeln (knapp 267 Pfund Sterling), das Windecke im Auftrag Sigismunds nach Dordrecht stiftete, weil man ihn dort in die Bruderschaft aufgenommen hatte. ${ }^{181}$ Außerdem schenkte ihm Heinrich 196 Saphire und »pallas«, wahrscheinlich sogenannte Balasrubine, 300 Perlen im Wert von 1200 Kronen sowie ein goldenes Fläschchen mit Perlen und Edelsteinen im Schätzwert von 2200 Kronen. ${ }^{182}$ Justinger nennt als Geschenke des englischen Königs: zwei »rubin«, einen Diamant (»adamast«) und zwei »berlen«, Steine, deren Wert auf mehr als $40.000 »$ Schildfranken « geschätzt würde. ${ }^{183}$

Unter den in Brügge verpfändeten Wertgegenständen beschreibt Windecke auch die Kette mit dem Anhänger und das Hosenband (»beinbant«), das einen Wert von 11.00o Kronen besaß. Der Anhänger (»fürspang«) aus Gold fasste einen Diamanten im Schätzwert von 9.000 Kronen ein, einen Rubin im Schätzwert von 11.00o Kronen und eine große Perle im Schätzwert von 1.200 Kronen. ${ }^{184}$ Auf dem Wilton-Diptychon trägt Richard II. beispielsweise einen vergleichbaren Anhänger mit seiner Devise, dem weißen Hirsch. Auch die Ketten Karls VI. von Frankreich und die der französischen Fürsten hatten Anhänger. ${ }^{185}$ Von dem Fürspang hatte Windecke einen Abdruck in gelbem Wachs angefertigt, offenbar um, gleich einem Siegel, eine Sicherheit gegenüber den Pfandleihern zu besitzen. Die Reproduktion des Originals in Wachs konnte demnach stellvertretend als Dokument des rechtmäßigen Besitzes fungieren, unabhängig vom Material, dem Objektzusammenhang mit der Kette und der Aura des Fürspangs, die Windeckes Bericht eingeschrieben ist. Die eindeutige mimetische Differenz des wächsernen Abdrucks unterschied diesen vom Original. Nach dessen Auslösung zeigte Windecke den Schatz, den er, wie er wortreich vermeldet, versteckt nach Köln transportieren ließ, in Mainz seinen Verwandten; Kette und Fürspang hängte er seiner Base um. ${ }^{186}$ Die Aura des Originals ging dadurch offenbar nicht verloren, wird aber durch seine Beschreibung selbstbewusst dokumentiert.

$\mathrm{Ob}$ Heinrich den aus zwei Halbkugeln zusammengesetzten kristallenen Tafelaufsatz, vermutlich ein Salzfass, an Sigismund geschenkt haben kann, wie im Sigis-
mund-Katalog spekuliert wird, ist nicht zu verifizieren, zumal er eher als französische Arbeit der Zeit um 1400 anzusehen ist. ${ }^{187}$ Beauchamp schenkte dem König zwei vergoldete Silberbecher im Wert von 18 Silbermark. ${ }^{188}$ Sigismund soll im Gegenzug die englischen Gesandten, darunter Sir John Tiptoft und Heinrichs jüngsten Bruder Humphrey of Gloucester, mit Geschenken bedacht haben, die der Gesta-Autor als einzigartig und übertrieben kostbar rühmt, ohne sie aber zu beschreiben. ${ }^{189}$

Aus Dordrecht wiederum übersandte Sigismund viele wertvolle Geschenke nach England, darunter goldene Gewänder und das Horn eines Einhorns, sechs Fuß lang; möglicherweise dasselbe Horn, das Paul Hentzner 1598 in Windsor gesehen hat. ${ }^{190}$ Sogenannte Hörner von Einhörnern waren begehrte Geschenke: Im selben Jahr bekam der Herzog von Berry ein Horn zum Namenstag geschenkt. ${ }^{191}$

Die im Sommer 1416 verpfändeten Kleinodien konnte Windecke erst im letzten Moment im Juli 1417 fristgerecht auslösen: Nachdem er 17 Wochen in Brügge ausgeharrt hatte, durfte er nach Konstanz reisen, zog sich zwar den Zorn des Königs zu, bekam aber Geld und einen Brief zur Auslösung Lübeck'scher Schulden und eilte in achteinhalb Tagen nach Brügge zurück. ${ }^{192}$

Während Windeckes Bezeichnung der Geschenke im Text einer genauen Kenntnis der Objekte entsprechen muss, da er als Bürge fungierte und ihren Rücktransport organisierte, ${ }^{193}$ bleibt die bildliche Illustration der Geschenke nicht ohne Grund summarisch. Der Maler des Wiener Codex bildet Sigismund stehend im Dreiviertelporträt mit einem goldenen Trinkhorn in der Rechten ab, während er mit der Linken eine goldene Flasche von Heinrich entgegennimmt. Auf dem Tisch stehen zwei weitere Flaschen (Abb. 2). Krone, roter Mantel, erhobenes Trinkhorn und die ganzfigurige Darstellung kennzeichnen Sigismund als Hauptperson, während Heinrich, dessen Krone über dem Hut kaum zu sehen ist, von dem goldenen Tisch verdeckt wird und mit seinen beiden Begleitern an den Rand gedrängt scheint. Die Inschrift oberhalb der Wappen bezeichnet die Flaschen nur als vergoldet: »diese vergulte fleschen und ander ding «. Die Illustration entstammt der wesentlich jüngeren, bis 1442 ergänzten Textfassung, die in zwei illustrierten Handschriften überliefert ist. Der Wiener Codex, der 1447 von einem Maler I illustriert wurde, wird ebenso wie die kürzlich versteigerte Handschrift mit der sogenannten Werkstatt des Diebold Lauber in Verbindung gebracht. ${ }^{194}$ Die zur Zeit des Konzils so wirkungsvolle Inszenierung 
Englands, die der Illustrator hier schon nicht mehr so prächtig vor Augen führte, war zu dieser Zeit durch die erfolglose Politik Heinrichs VI. in Vergessenheit geraten.

Während Sigismunds Abwesenheit hatten die Engländer Konzilsteilnehmer und Chronisten gleichfalls mit musikalischen Darbietungen und geistlichem Spiel überrascht. Das belegt die Beschreibung Richentals, der die Aufführungen der anderen Nationen kaum erwähnt. Drei Trompeter und vier Pfeifer hatten im Januar 1415 den Einzug Richard Beauchamps nach Konstanz begleitet. ${ }^{195}$ Richental bemerkt anerkennend, dass die englischen Trompeter dreistimmig spielten, wie er es sonst nur von den Sängern kannte, sie "prusonettend überainander mit dry stimmen, als man gewonlich singet $« .{ }^{196}$ Die Zeremonie zur Belehnung der Reichsfürsten durch Sigismund soll dagegen von einem Wettstreit von Posaunisten und Pfeifern verschiedener Nationen begleitet gewesen sein, die nur durch Lautstärke auffielen. ${ }^{197}$

Das Fest des hl. Thomas Becket am 29. Dezember 1416 begingen die Engländer in Konstanz mit schönem Geläut, großen Kerzen und offenbar dreistimmigem Gesang sowie einem dreistimmigen Vokalsatz im Münster mit Posaunen und Orgel. Die vier Posaunen waren durch englische Königswappen klar dem englischen König zugeordnet. ${ }^{198}$ Auch im Kölner Dom waren die englischen Sänger auf der Reise mit den Bischöfen Catterick und Wakering am 8. September 1416 durch die hohe Qualität ihres Gesangs aufgefallen. ${ }^{199}$

Über Aachen und Köln erreichte Sigismund am 27. Januar 1417 Konstanz und lobte und empfing die Engländer so wie zu Beginn beschrieben. War es der Vertrag von Canterbury, seine Verdrängung von der Kanzel oder die nachfolgende so offensichtliche Bevorzugung der Engländer in Konstanz durch Sigismund, die den französischen Kardinal Pierry d'Ailly bewegte, die englische nation doch mit der deutschen verschmelzen zu wollen? Der Protest Thomas Poltons, Dean von York, ließ nicht auf sich warten, sodass man die Spanier nicht als vierte, sondern als fünfte nation zulassen musste. ${ }^{200}$

Bereits im Februar 1415 hatte Heinrich V. trotz seiner hohen Anleihen für den geplanten Frankreicheinmarsch für die hohe Summe von 976 Pfund Sterling bei dem Londoner Goldschmied William Randolf zwölf Gedecke aus massivem Gold bestellt sowie vier Dutzend silberne Schüsseln und acht Dutzend silberne Gedecke. Wahrscheinlich waren es diese Tafelgedecke, die im September 1416 mit den englischen Bischöfen nach Konstanz transportiert worden waren und für die Speisung von Patriar- chen, Bischöfen und Gelehrten am Heiligenfest Beckets eingesetzt wurden. ${ }^{201}$

Die massiven Gedecke waren Teil eines Festessens für Sigismund anlässlich seiner Rückkehr nach Konstanz. Zur Generalprobe des Festessens hatten die Engländer einige Tage zuvor, am 24. Januar 1417, alle Räte und ehrbaren Leute aus Konstanz in das Haus am Burgtor eingeladen und ein Festmahl gegeben, dessen drei Gänge mit jeweils acht Speisen auf dem aus England exportierten goldenen und silbernen Geschirr serviert wurden. Zwischen den Gängen führten englische Darsteller die Geburt Christi, die Ankunft der Heiligen Drei Könige bis hin zu Herodes und den Kindermord auf, deren Wirkung auf das schwäbische Weihnachtsspiel diskutiert worden ist. Den Heiligen Drei Königen schwebte ein goldener Stern an einem kleinen Eisendraht voran; die Darsteller trugen kostbare Gewänder mit großen goldenen und silbernen Gürteln und spielten mit "großer Zierde und Demut ${ }^{202}$ Die Darbietung verfolgte zugleich einen höheren politischen Zweck: Die Engländer untermauerten die Predigt Surge Illuminare, die der Oxforder Theologe Richard Fleming drei Wochen zuvor am Epiphaniasfest am 6. Januar gehalten hatte, in der er den Stern und das Gold gedeutet sowie die Rolle der drei schismatischen Päpste mit Herodes verglichen und die Häresie verurteilt hatte. ${ }^{203}$ Wie Herodes habe das Schisma viele arme Seelen zugrunde gerichtet und der Hölle übergeben, der neue Papst hingegen solle rein sein wie das Jesuskind. Zudem war sicherlich die Darstellung Sigismunds als einer der drei heiligen Könige intendiert. Fleming mag das geistliche Spiel aus Lincoln mitgebracht haben, wo er Kanoniker war, denn in der Kathedrale von Lincoln wurde seit 1317 das Weihnachtsspiel aufgeführt mit den Heiligen Drei Königen und dem Stern. ${ }^{204}$ Ausschließlich »Bild und Gebärd « der Engländer erwähnt Richental, keine Aufführungen einer anderen Nation.

Ungleich auffälliger muss der Bau von acht Seeschiffen für Sigismund auf dem Bodensee gewesen sein. War es nur eine Geld- oder Transportfrage, oder sollten die holländischen Schiffbauer, die Sigismund mitgebracht hatte, den Entschluss des Königs in Szene setzen, die Engländer zu unterstützen $?^{205}$ Nicht nur bei seiner Ankunft in Konstanz, sondern auch an diesem Sonntag danach habe Sigismund, glaubt man Forester, die Halskette und den Ordensmantel getragen. ${ }^{206}$

Den Tod der für die Kirchenreform so zentralen Figur des Bischofs von Salisbury, Robert Hallum, nutzten die Engländer im September $1417 \mathrm{zu}$ einem weiteren Auftritt. Fleming hielt eine viel beachtete Predigt, die als 
Angebot zum Kompromiss der englisch-deutschen Seite gewertet wurde, auch kleinere Reformen zu akzeptieren. Eine große Prozession aus 80 Kerzenträgern, Geistlichen, Fürsten, Konstanzer Bürgern sowie König Sigismund begleitete den Sarg, den zwei goldene Tücher bedeckten, zum Münster, wo fünf Tage später die Totenmesse mit zahlreichen Kerzen, aber ohne Katafalk stattfand. ${ }^{207}$ Hallums Grab liegt vor den Stufen des Hochaltars über der Confessio des heiligen Pelagius. ${ }^{208}$ Es wurde durch eine Grabplatte ausgezeichnet, die aus England geliefert worden sein muss: Sie besteht aus dem dunkelgrauen sogenannten Purbeck-Marmor, in den eine vielteilige Messingplatte mit Ritzungen eingelassen ist. In einem architektonischen Rahmen aus einer Arkade mit zinnenbewehrtem Abschluss und Boden, der zwei Pfeiler vorgesetzt sind, steht der Bischof, der wiederum von einem Baldachin mit geschultertem, krabbenbesetzten Kielbogen überfangen wird. Der Vierpass im Bogenfeld trägt die einzelnen Buchstaben »rob[ertu]s«. Ungewöhnlich sind die fein gravierten gefiederten Seraphim in den je fünf Nischen der Pfeiler. Zwischen Kielbogen und Arkade sind links das von einem Hosenband eingefasste englische Königswappen, rechts ein vergleichbar mit einer Inschrift gerahmtes Medaillon eingelassen, dessen Wappen erneuert ist. Da Hallum kein Ordensritter war, wird hier offenbar auf seine Funktion als Gesandter des englischen Königs angespielt. Purbeck-Marmor, vielteilig geschichtete Architekturfragmente wie der krabbenbesetzte Kielbogen im Bogen und die zinnenbewehrte Platte, Wappen, Form und Qualität der Ritzungen im Metall sind typisch für Platten aus Londoner Werkstätten. ${ }^{209}$ Die hohe Qualität der Platte, die für England ungewöhnlich frühe Darstellung des Hosenbands in Verbindung mit dem königlichen Wappen und die ungewöhnlichen Seraphim in den Pfeilern sprechen für einen Auftrag Heinrichs V. ${ }^{210}$ Die Inschrift der Platte hingegen könnte in Konstanz angefertigt worden sein. Die außergewöhnliche Qualität der Grabplatte hat sicherlich die Konzilsteilnehmer beeindruckt. Dass aber die ungewöhnliche Form des Kielbogens in Bronze die Bildhauer der Schnegg im Konstanzer Münster zu den sehr plastischen eingezogenen Kielbögen inspiriert haben könnte, wie Ines Stadie und Stefan King vorschlagen, halte ich wegen seiner Form und Zweidimensionalität nicht für überzeugend. ${ }^{211}$

Das Konstanzer Konzil war nicht nur Drehscheibe für den Austausch von Kunst, Musik und geistlichem Spiel, sondern auch für Literatur. ${ }^{212}$ Die Kirchenreform, die wesentlich von den Engländern propagiert wurde, bediente sich humanistischer Ideen und Übersetzungen antiker und mittelalterlicher Texte. 1415 war Pier Paolo Vergerio als wichtigster Humanist in den Dienst von Sigismund getreten. Nicholas Bubwith und Robert Hallum waren zusammen mit Kardinal Amedeo di Saluzzo die treibenden Kräfte für eine lateinische Übersetzung von Dantes Göttlicher Komödie samt einem Kommentar zum Inferno, vermutlich angeregt durch einen Vortrag über Dante. Der Vortragende, Johannes de Serravalle, Bischof von Fermo, begann seine Übersetzung am 1. Februar 1416, stellte sie rechtzeitig vor Konzilsende am 16. Januar 1417 fertig und überreichte sie Sigismund mit einer Widmung. ${ }^{213}$ Sigismunds Vorleser soll sie ihm auf dem Konstanzer Konzil vorgelesen haben. Im Vorwort erklärt Serravalle die Bedeutung Dantes für die Reformpolitik des Konstanzer Konzils. ${ }^{214}$ Dass er sein Werk im Auftrag der Engländer für Sigismund verfasst haben könnte, das Vorlesen also als symbolischer Akt der Kirchenreform zu verstehen wäre, ist bisher nicht diskutiert worden. ${ }^{215}$

So ist es auch nicht erstaunlich, dass Poggio Bracciolini, der als Schreiber und Beinahe-Sekretär im Gefolge Johannes XXIII. nach Konstanz kam, aber mit der Neuwahl Martins V. arbeitslos wurde, sich an den englischen Bischof Beaufort wandte - nicht nur, weil der einer der reichsten Kirchenfürsten seiner Zeit war, sondern, weil die Inszenierung der englischen Delegation in Konstanz so außerordentlich erfolgreich war. Denn auch Sigismund hatte nach seiner Englandreise vermehrt Engländer in den Dienst gestellt. ${ }^{216}$ Dass Beaufort die Ernennung zum Kardinal ablehnen musste und wegen seiner Nähe zu Rom in Misskredit geriet, konnte Poggio damals nicht ahnen. Erst einmal in England, ist die Ernüchterung groß. Poggio beschwert sich bei seinem Briefpartner Niccolini, die Engländer seien nur am Essen interessiert, Beaufort sei immer auf Reisen, er, Poggio, habe keinen Kontakt zu den englischen Intellektuellen, keine Bücher gefunden, er sei weder in Oxford noch in einigen der großen Klosterbibliotheken gewesen, habe sich aber immerhin mit Gewinn in die Kirchenväter vertieft. Diese bislang als erfolglos gewerteten Jahre Poggios in England bildeten, wie Susannah Saygin herausstellte, dennoch den Grundstein seiner erfolgreichen Karriere als einer der führenden Humanisten seiner Zeit: Im Frühjahr 1423 kam er aus England zurück nach Rom und wurde sofort päpstlicher Sekretär, für 30 Jahre, dort im Wesentlichen zuständig für die englische Korrespondenz. ${ }^{217}$ Eine weitere Schlüsselfigur des kulturellen Austauschs war Kardinal Branda da Castiglione, päpstlicher Legat am Hof Sigismunds, auch 
er Teilnehmer des Konstanzer Konzils. Sein Neffe Zeno da Castiglione wurde später neben Piro da Monte zum wichtigsten Mittelsmann, über den der jüngste Bruder Heinrichs V., Humphrey of Gloucester, seine Übersetzungen antiker Autoren in Italien bestellte. ${ }^{218}$

Die Neuorientierung englischer Politik ab 1413 wurde transportiert durch eine präzise geplante und grandiose Inszenierung englischer Kultur im In- und Ausland, die auf verschiedenen Ebenen, in verschiedenen Medien und an verschiedene Rezipientengruppen kommuniziert wurde. Teil der Inszenierung waren die Halskette und das Hosenband, die Sigismund in Brügge verpfänden ließ, die aber dennoch als Fiktion dem Leib des Königs und zukünftigen Kaisers eingeschrieben wurden. Ulrich Richental, Eberhard Windecke, Konrad Justinger und der anonyme Basler Chronist schienen gleichermaßen beeindruckt von den englischen Festen, von Architektur, Kultur, Musik, Liturgie, den Geschenken und den Predigten zur Kirchenreform und ihrer Begleitung durch das geistliche Spiel während des Festmahls. Auch wenn so gut wie keine Objekte des Austauschs erhalten sind, vermittelt sich der Erfolg der neuartigen Kommunikation insbesondere durch die damit verbundenen Handlungen, performativen Akte und die Bedeutungszusammenhänge, welche die Chronisten ihnen zuschreiben. Sie stärkten den Ruhm Heinrichs V. als eines der erfolgreichsten englischen Könige überhaupt über die Grenzen seines Landes hinaus.

Heinrich V. instrumentalisierte den Auftritt des zukünftigen Kaisers Sigismund als höchtrangigstem Zeugen für seine groß angelegte Repräsentationskampagne, mit der sich die Engländer in Konstanz als Macht von gesamteuropäischem Rang zu etablieren suchten. Seine gleichzeitigen Vorbereitungen zum Krieg gegen Frankreich fanden hingegen beinahe unbemerkt statt. Mochte Sigismund auch die Halskette der Lancaster und das Hosenband durch die Verpfändung in Brügge der Öffentlichkeit entzogen haben, waren in der Zeugenschaft des Briefautors John Forester gerade sie es, die den Körper des römischen Königs mehr als alles andere auszeichneten und ihn mit dem englischen König verbanden. In den Beschreibungen der Chronisten wurden sie zum Teil eines Systems kollektiver Memoria, bezeugt von einem Teilnehmer und überliefert in seiner fiktionalen Beschreibung, die aber weder von den Zeitgenossen noch von den modernen Historikern als fiktional identifiziert wurde. ${ }^{219}$ Erst die Möglichkeit, die Macht der visuellen Evidenz des Abwesenden qua Imagination und Fiktion zu beschwö- ren, machte die textuelle Nachricht zwingend notwendig. ${ }^{220}$ Somit ist nicht der Auftritt des zukünftigen Kaisers, sondern die Fiktion desselben und deren Kommunikation entscheidend. Gleiches gilt für das Schwert - das einzige erhaltene Objekt des Austauschs - und die Monstranz mit der Georgsreliquie, die Sigismund nach Windsor stiftete. Die Chronisten fokussieren kaum auf die Objekte selbst, sondern auf die Prozesse ihrer Stiftung und der versuchten Übergabe. Obwohl die Monstranz in Windsor real anwesend war und eine große Rolle in den späteren Ordensfeierlichkeiten spielte, wo sie in der Prozession mitgeführt und auf einem hohen Gerüst sichtbar aufgestellt wurde, haben die Chronisten sie vermutlich nicht gesehen. Bei ihr unterscheidet sich die textuell überlieferte Form deutlich von der etwa 70 Jahre jüngeren visuellen Darstellung: Diese repräsentiert nur zeichenhaft die Reliquie des Georgsherzens in einem Behälter als Teil einer (versuchten) Aktion, statt den realen Gegenstand wiederzugeben. ${ }^{221}$

Diese Prozesse verdeutlichen den Wandel von Inszenierung und Wahrnehmung zu Beginn des 15. Jahrhunderts. Wo die Requisiten des Zeremoniells vorrangig als semiotische Zeichen dienten, wurden sie als greifbare Objekte entbehrlich, je plausibler die Fiktion war. ${ }^{222}$ Die Steuerung der Rezipienten gelang umso besser, weil Sigismund den Mangel an visueller Evidenz verbal und performativ ausglich, indem er die Engländer überschwänglich empfing, lobte und am Festmahl teilnahm. Wie überzeugend die englische Selbstdarstellung auf dem Konzil mit ihren realen und imaginären Elementen war, belegt neben den zeitgenössischen und modernen Texten auch die Reise Poggio Bracciolinis im Gefolge Bischof Beauforts nach Winchester. Die Enttäuschung des Gelehrten zeugt allerdings auch von der Kluft zwischen Konstanzer Inszenierung und britischer Wirklichkeit - der erwartete humanistische Glanz erwies sich zumindest aus Sicht des Italieners als ebenso fiktiv wie Sigismunds Halskette beim Einzug nach Konstanz.

\section{Quellen und Literatur}

Allmand, Christopher: Henry V. New Haven/London 1997 (Yale English Monarchs).

Altmann, Wilhelm (Hg.): Die Urkunden Kaiser Sigmunds 1410-1437. Innsbruck 1896 (Regesta Imperii XI).

Ashmole, Elias: The Register of the Most Noble Order of the Garter, from its Cover in Black Velvet, Usually Called the 
Black Book. Hg. von John Anstis. With notes placed at the bottom of the pages, and an introduction prefixed by the editor. 2 Bde. London 1724 .

[Ausst.-Kat. Budapest 2006]: Ausst.-Kat. Sigismundus Rex et Imperator. Kunst und Kultur zur Zeit Sigismunds von Luxemburg 1387-1437. Hg. von Imre TAKács. Budapest, 18. 3.-18.6.2006; Luxemburg, 13.7.-15.10.2006. Mainz 2006.

[Ausst.-Kat. Konstanz 2014]: Das Konstanzer Konzil 14141418. Weltereignis des Mittelalters. Große Landesausstellung Baden-Württemberg des Badischen Landesmuseums Karlsruhe, Konstanz, Konzil, 27.4.-21.9.2014. 2 Bde. Darmstadt 2014.

[Ausst.-Kat. London 2003] : Ausst.-Kat. Gothic Art for England 1400-1547. Hg. von Richard Marks und Paul Williamson. London, 9.10.2003-18.1.2004. London 2003 (Kataloge des Victoria \& Albert Museums).

BäUmer, Remigius (Hg.): Von Konstanz nach Trient. Festschrift für August Franzen. München/Paderborn/Wien 1972.

BÁrÁnY, Attila: A Joint Effort for a New Europe in the Early Fifteenth Century. Political Relations between Sigismund and King Henry V of England. King Sigismund's Visit to England in 1416. In: SCHмIDT/GUNST 2000, 83-102.

BÁrÁny, Attila: Anglo-Luxembourg Relations During the Reign of Emperor Sigismund. In: Ausst.-Kat. Budapest 2006, 43-59.

BÁrÁnY, Attila: English Chivalric Insignia In Hungary. In: Ausst.-Kat. Konstanz 2014, 55-59.

Bernoulli, August (Bearb.): Basler Chroniken, Bd. 5. Die Grösseren Basler Annalen 1238-1416. Die Kleineren Basler Annalen 1308-1415. Bericht über den Rotberg-Erenfelsischen Handel 1410. Die Röteler Chronik 1376-1428. Die Chronik Henmann Offenburgs 1413-1445. Die Chroniken Heinrichs von Beinheim 1365-1452, sammt Fortsetzung 1465-1473. Die Anonyme Chronik von 1445. Die Anonyme Chronik der Burgunderkriege 1473-1479. Leipzig 1895.

Bertram, Jerome: Brass of the Month. Online: Http://www.mbsbrasses.co.uk/brass $\% 2$ oof $\% 2$ othe $\% 2$ month $\% 2$ ojune $\% 20$ 2013.html (04.03.2015).

Bond, M. F.: The Inventories of St. George's Chapel, 1384-1667. Windsor 1947.

Bowers, Roger: The Liturgy of the Cathedral and its Music, c. 1075-1642. In: Collinson/RAmsay/SPARKS 2002, 408450.

Brandmüller, Walter: Das Konzil von Konstanz 1414-1418. 2 Bde. Paderborn/München/Wien/Zürich 1991/97 (Konziliengeschichte Reihe A, Darstellungen).

Brie, Friedrich W. D. (Hg.): The Brut or The Chronicles of England. Edited from Ms. Rawl. B 171, Bodleian Library, \&c. 2 Teile. London 1906/o8 (Early English Text Society 131, 136). Brown, R. Allen/Colvin, Howard M./Taylor, A. J.: The His- tory of the King's Works, Band I und II. The Middle Ages. London 1963.

Bruggisser-Lanker, Therese: Music goes public. Das Konstanzer Konzil und die Europäisierung der Musikkultur. In: SigNORI/STUDT 2014, 349-378.

[BUck 2010/I]: Buck, Thomas Martin (Hg.): Chronik des Konstanzer Konzils 1414-1418. Von Ulrich Richental. Ostfildern 2010 (Konstanzer Geschichts- und Rechtsquellen 41).

[BUCK 2010/II] : BUCK, Thomas Martin: Zur Überlieferung der Konstanzer Konzilschronik Ulrich Richentals. In: Deutsches Archiv für Erforschung des Mittelalters 66 (2010), 93-108.

Buck, Thomas Martin: Das concilium sass allweg in dem münster. Zur Topographie des Konstanzer Konzils nach der Chronik des Ulrich Richental. In: Annuarium Historiae Conciliorum 44 (2012), 119-142.

Buck, Thomas Martin: Das concilium sass allweg in dem münster. Zur Topographie des Konstanzer Konzils nach der Chronik des Ulrich Richental. In: LAULE 2013, 41-45.

BurkHARDT, Johannes (Hg.): Kommunikation und Medien in der Frühen Neuzeit. München 2005.

Burkart, Lucas/Cordez, Philippe/Mariaux, Pierre Alain u.a. (Hgg.): Le trésor au Moyen Âge. Discours, pratiques et objets. Firenze 2010.

Cardenas, Livia: Die Textur des Bildes. Das Heiltumsbuch im Kontext religiöser Medialität des Spätmittelalters. Berlin 2013.

CAtтo, Jeremy: Religious Change under Henry V. In: Harriss $1985,97-115$.

Cheetham, Francis W.: English Medieval Alabasters. Oxford 1984; 2. Aufl. Woodbridge 2005.

Classen, Albrecht: Emperor Sigismund's Visit to England in 1416. Its Observation and Reflection in Late Medieval English Chronicles. In: Archiv für das Studium der neueren Sprachen und Literaturen 226, 141. Jahresband, 2. Zweijahresband (1989), 276-290.

Cole, Charles August (Hg.): Memorials of Henry the Fifth, King of England. I. Vita Henrici Quinti, Roberto Redmanno Auctore. II. Versus rhytmici in laudem regis Henrici Quinti. III. Elmhami liber metricus de Henrico Quinto. London 1858.

Coleman, Janet: Ancient and Medieval Memories. Studies in the Reconstruction of the Past. Cambridge 1992.

Collins, Hugh E. L.: The Order of the Garter, 1348-1461. Chivalry and Politics in Late Medieval England. Oxford/New York 2000.

Collinson, Patrick/Ramsay, Nigel/Sparks, Margaret (Hgg.): A History of Canterbury Cathedral. 2. Aufl. Oxford/New York 2002.

Come, William/Pyne, William Henry: The Microcosm of London. Or, London in Miniature. Bd. III. London 1808-11. 
Cordez, Philippe: Schatz, Gedächtnis, Wunder. Die Objekte der Kirchen im Mittelalter. Regensburg 2015.

Crowder, Christopher Michael Dennis: Correspondence between England and the Council of Constance 1414-1418. In: Studies in Church History 1 (1962), 184-206.

Crowder, Christopher Michael Dennis: Henry V, Sigismund, and the Council of Constance, a Re-examination. In: Historical Studies, Bd. IV. Papers read before the Fifth Irish Conference of Historians. London 1963, 93-110.

Crowder, Christopher Michael Dennis: Unity, Heresy and Reform (1378-1460). The Conciliar Response to the Great Schism. New York 1977.

Curry, Anne: The Battle of Agincourt. Sources and Interpretations. Woodbridge 2000.

Davies, R. G.: Catterick, John (d. 1419). In: Oxford Dictionary of National Biography 2004. Online: www.oxforddnb.com/ view/article/15487 (10.01.2015).

Derschka, Harald: Konstruierte Vergangenheit. Die Wandbilder in der Konstanzer Augustinerkirche. In: Ausst.-Kat. Konstanz 2014, 136-137.

Devon, Frederick (Hg.): Issues of the Exchequer. Being a Collection of Payments Made Out of His Majesty's Revenue, from King Henry III. to King Henry VI. London 1837.

Dillon, Harold Arthur: XV. Calais and the Pale. In: Archaeologia 53 (1893), 289-388.

Dillon, Harold Arthur/ST. John Hope, William H. (Hgg.): Pageant of the Birth, Life and Death of Richard Beauchamp, Earl of Warwick, K. G., 1389-1439. London 1914.

DodD, Gwilym (Hg.): Henry V. New Interpretations. Woodbridge 2013.

Douët-D'ArcQ, L. (Hg.): La chronique d'Enguerran de MonSTRELET, en deux livres, avec pièces justificatives 1400-1444. Bd. III. Paris 1859.

Drews, Wolfram/Schlie, Heike: Zeugnis und Zeugenschaft. Perspektiven aus der Vormoderne. München 2011.

Feger, Otto (Bearb.): Ulrich Richental: Das Konzil zu Konstanz. Faksimile. Starnberg/Konstanz 1964.

Fehrmann, Antje: »Quasi castrum pulcherimum«. Englische spätmittelalterliche Festarchitektur im Spiegel ihrer zeitgenössischen Inszenierung und Beschreibung. In: VAVRA 2005 , 281-304.

Fehrmann, Antje: Grab und Krone. Königsgrabmäler im mittelalterlichen England und die posthume Selbstdarstellung der Lancaster. München/Berlin 2008.

FINKE, Heinrich: Forschungen und Quellen zur Geschichte des Konstanzer Konzils. Paderborn 1889.

Finke, Heinrich (Hg.): Acta Concilii Constanciensis, Bd. II. Konzilstagebücher, Sermones, Reform- und Verfassungsakten. Münster/W. 1923.
Fischer-Lichte, Erika: Performativität. Eine Einführung. 2. Aufl. Bielefeld 2013.

[Fouquet 2014/I] : Fouquet, Gerhard: Geldgeschäfte im Auftrag des römischen Königs. Eberhard Windeck, Brügge, Lübeck und König Sigmund (1415-1417). In: Zeitschrift für Historische Forschung 41 (2014), 375-399.

[Fouquet 2014/II]: Fouquet, Gerhard: Die unverzichtbaren Geldgeber. In: Ausst.-Kat. Konstanz 2014, 123-124.

Given-Wilson, Chris/Brand, Paul/Phillips, Seymour u.a. (Hgg.): Parliament Rolls of Medieval England. Woodbridge 2005. Online: http://www.british-history.ac.uk/no-series/ parliament-rolls-medieval/march-1416 (15.07.2016).

Gransden, Antonia: Historical writing in England, Bd. II. London 1982.

Grünbart, Michael (Hg.): Geschenke erhalten die Freundschaft. Gabentausch und Netzwerkpflege im europäischen Mittelalter. Akten des Internationalen Kolloquiums Münster, 19.-20. November 2009. Berlin/Münster u. a. 2011 (Byzantinistische Studien und Texte 1).

Guiffrey, Jules (Hg.): Inventaires de Jean, duc de Berry, 14011416. Paris 1894-96.

HACK, Achim Thomas: Das Empfangszeremoniell bei mittelalterlichen Papst-Kaiser-Treffen. Köln/Weimar/Wien 1999.

Harriss, Gerald Leslie (Hg.): The Practice of Kingship. Oxford 1985.

HArriss, Gerald Leslie: Cardinal Beaufort. A Study of Lancastrian Ascendancy and Decline. Oxford 1988.

Harvey, Barbara F.: Colchester, William (d. 1420). In: Oxford Dictionary of National Biography. Oxford 2004. Online: www.oxforddnb.com/view/article/54431 (10.01.2015).

Harvey, John H.: The Architects of St. George's Chapel. In: Report of the Society of the Friends of St. George's and the Descendants of the Knights of the Garter IV (1961), H. 2, 48-55; IV (1962), H. 3, 85-95.

Hasted, Edward: History of the Cathedral. In: The History and Topographical Survey of the County of Kent 11. Canterbury 1800, 294-303.

Heggelbacher, Othmar: Dantes Divina Commedia in ihren Beziehungen zur Kirchenreform des fünfzehnten Jahrhunderts. In: BÄUMER 1972, 15-26.

Heimpel, Hermann: Königlicher Weihnachtsdienst im späteren Mittelalter. In: Deutsches Archiv für Erforschung des Mittelalters 39 (1983), 131-206.

Helmrath, Johannes: Kommunikation auf den spätmittelalterlichen Konzilien. In: POHL 1989, 116-172.

Hengerer, Mark: Zur Konstellation der Körper höfischer Kommunikation. In: BURKHARDT 2005, 519-546.

Hentzner, Paul: A Journey Into England in the Year M.D.XC. VIII. [Twickenham] 1757.

Hirschbiegel, Jan: Étrennes. Untersuchungen zum höfischen 
Geschenkverkehr im spätmittelalterlichen Frankreich der Zeit König Karls VI. (1380-1422). München 2003.

Hoensch, Jörg K. (Hg.): Itinerar König und Kaiser Sigismunds von Luxemburg 1368-1437. Warendorf 1995.

Hoensch, Jürgen: Kaiser Sigismund. Herrscher an der Schwelle zur Neuzeit 1368-1437. München 1996.

Hruza, Karel/KaAr, Alexandra (Hgg.): Kaiser Sigismund (1368-1437). Zur Herrschaftspraxis eines europäischen Monarchen. Wien/Köln/Weimar 2012.

Huang, Yun Sheng/Mark, Robert/Wellman, Avery M.: Westminster Hall's Hammer-Beam Roof. A Technological Reconstruction. In: APT Bulletin 20 (1988), 8-16.

Hutchinson, Robert (Hg.): Drawings of Monumental Brasses and Incised Slabs by the Waller Brothers 1837-44. London 2001.

[Justinger/Studer 1871]: Studer, Gottlieb (Hg.): Die Berner-Chronik des Conrad Justinger. Bern 1871.

KING, Stefan: Das Motiv des Schulterzwiebelbogens am Schnegg. In: LAULE 2013, 131-132.

Kingsford, Charles L. (Hg.): Chronicles of London. Oxford 1905.

Kingsford, Charles L: An Historical Collection of the Fifteenth Century. In: The English Historical Review 29 (1914), 505-515.

KintZINGER, Martin: Westbindungen im spätmittelalterlichen Europa. Auswärtige Politik zwischen dem Reich, Frankreich, Burgund und England in der Regierungszeit Kaiser Sigmunds. Stuttgart 2000.

[KintZinger/SChneidmüLler 2011/I]: KintZinger, Martin/ Schneidmüller, Bernd (Hgg.): Politische Öffentlichkeit im Spätmittelalter. Ostfildern 2011 (Vorträge und Forschungen 75 ).

[KIntZinger/Schneidmüller 2011/II]: KIntZinger, Martin/Schneidmüller, Bernd: Politische Öffentlichkeit im Spätmittelalter. Eine Einführung. In: Kintzinger/ SCHNEIDMÜLLER 2011/I, 7-20.

KITE, Edward: The Monumental Brasses of Wiltshire. London/ Oxford 1860.

KLinkert, Thomas: Epistomologische Fiktionen. Zur Interferenz von Literatur und Wissenschaft seit der Aufklärung. Berlin/New York 2010.

Krohm, Hartmut/Krüger, Klaus/Weniger, Matthias (Hgg.): Entstehung und Frühgeschichte des Flügelaltarschreins. Wiesbaden 2001.

KRÜGER, Klaus: »Aller Zierde wunder trugen die altaere«. Zur Genese und Strukturentwicklung des Flügelaltarschreins im 14. Jahrhundert. In: KrOHM/KrüGER/WENIGER 2001, $69-85$.

Kurath, Hans: Middle English Dictionary. 5. Aufl. Ann Arbor 1998.
Laule, Ulrike (Hg.): Das Konstanzer Münster Unserer Lieben Frau. Regensburg 2013.

Lenz, Max: König Sigismund und Heinrich der Fünfte von England. Berlin 1874.

[LeXer]: Matthias Lexers Mittelhochdeutsches Taschenwörterbuch. Hg. von Ulrich Pretzel. 37. Aufl. Stuttgart 1986.

Logemann, Cornelia: Falsche Augenzeugen. Fingierte Echtheitsbeweise in spätmittelalterlicher Geschichtsschreibung. In: Drews/SCHLIE 2011, 77-98.

Luxford, Julian M.: The Art and Architecture of English Benedictine Monasteries 1300-1540. A Patronage History. Woodbridge 2005.

McFarlane, Kenneth B.: Henry V, Bishop Beaufort and the Red Hat, 1417-1421. In: The English Historical Review 60 (1945), 316-348.

Maurer, Helmut: Das Konstanzer Konzil als städtisches Ereignis. In: Müller/Helmrath 2007, 149-172.

Morrssey, Thomas: Surge, Illuminare. A Lost Address by Richard Fleming at the Council of Constance (Clm 28433). In: Annuarium Historiae Conciliorum 22 (1990), 86-130.

Müller, Heribert/Helmrath, Johannes (Hgg.): Die Konzilien von Pisa (1409), Konstanz (1414-1418) und Basel (14311449). Institutionen und Personen. Ostfildern 2007 (Vorträge und Forschungen 67 ).

Nicolas, Nicholas Harry (Hg.): A Chronicle of London, from 1089 to 1483 . Written in the Fifthteenth Century. London 1827.

Nicolas, Nicholas Harris: Proceedings and Ordinances of the Privy Council of England. 7 Bde. London 1834-37.

Nighman, Chris Lee: Reform and Humanism in the Sermons of Richard Fleming at the Council of Constance (1417). Diss. Toronto 1996.

Nighman, Chris Lee: Another Look at the English Staging of an Epiphany Play at the Council of Constance. In: Records of Early English Drama 22 (1997), 11-18.

Pohl, Hans (Hg.): Die Bedeutung der Kommunikation für Wirtschaft und Gesellschaft. Sigmaringen 1989.

Rathmann, Thomas: Geschehen und Geschichten des Konstanzer Konzils. Chroniken, Briefe, Lieder und Sprüche als Konstituenten eines Ereignisses. München 2000.

Rathmann, Thomas: Beobachtung ohne Beobachter? Der schwierige Umgang mit dem historischen Ereignis am Beispiel des Konstanzer Konzils. In: Müller/Helmrath 2007, 94-106.

Reitemeier, Arnd: Außenpolitik im Spätmittelalter. Die diplomatischen Beziehungen zwischen dem Reich und England 1377-1422. Paderborn 1999.

Ritter, Joachim (Hg.): Historisches Wörterbuch der Philosophie. Basel 1971.

Röckelein, Hedwig: Schätze in Altären. Profane Gebrauchs- 
gegenstände im sakralen Raum. In: BurKart/CORDEz/MARIAUX 2010, 179-197.

Roland, Martin: Was die Illustrationen zu Eberhard Windecks Sigismundbuch präsentieren, was man dahinter lesen kann und was verborgen bleibt. In: Hruza/KAAR 2012, 449-465.

Rymer, Thomas (Hg.): Foedera, conventiones, literae, et cujuscunque generis Acta publica, inter Reges Angliae, et alios quosvis Imperatores, Reges, Pontifices, Principes, vel Communitates (...). 2. Aufl. London 1729.

SAlzman, L. F. (Hg.): A History of the County of Cambridge and the Isle of Ely, Bd. II. London 1948.

SAYGIN, Susanne: Humphrey, Duke of Gloucester (1390-1447) and the Italian Humanists. Leiden u. a. 2002 (Brill's Studies in Intellectual History 105).

Schenk, Gerrit Jasper: Zeremoniell und Politik. Herrschereinzüge im spätmittelalterlichen Reich. Köln/Weimar/Wien 2003.

Schmeller, Johann Andreas (Hg.): Des böhmischen Herrn Leo's von Rožmital Ritter-, Hof- und Pilger-Reise durch die Abendlande 1465-1467. Beschrieben durch Gabriel Tetzel von Nürnberg. Stuttgart 1844.

Schmidt, Tilmann/Gunst, Péter (Hgg.): Das Zeitalter König Sigmunds in Ungarn und im Deutschen Reich. Debrecen 2000.

SCHNeIder, Joachim: Herrschererinnerung und symbolische Kommunikation am Hof König Sigismunds. Das Zeugnis der Chronik des Eberhard Windeck. In: HrUZA/KAAR 2012, 429-448.

Schuler, Manfred: Die Musik in Konstanz während des Konzils 1414-1418. In: Acta Musicologica 38 (1966), 150-168.

Schwedler, Gerald: Herrschertreffen des Spätmittelalters. Formen - Rituale - Wirkungen. Ostfildern 2008 (Mittelalter-Forschungen 21).

Schwedler, Gerald: Diplomatische Geschenke unter Königen im Spätmittelalter. Freundschaft und Gabentausch zwischen politischer Praxis und der schriftlichen Norm der Fürstenspiegelliteratur. In: GRÜNBART 2011, 145-186.

Signori, Gabriela/Studt, Birgit (Hgg.): Das Konstanzer Konzil als europäisches Ereignis. Ostfildern 2014.

Simms, Norman: The Visit of King Sigismund to England, 1416. In: Hungarian Studies Review 17 (1990), 21-29.

St. John Hope, William H.: Windsor Castle. An Architectural History. 2 Bde. London 1913.

STAdie, Ines: Das Grabdenkmal für Robert Hallum im Chor. In: LAULE 2013, 87-88.

Stratford, Jenny: Richard II and the English Royal Treasure. Woodbridge 2012.

StratFord, Jenny: «Par le special commandement du roy». Jewels and Plate Pledged for the Agincourt Expedition. In: DoDD 2013, 157-170.
[Strecche/Taylor 1932]: Strecche, John: The Chronicle of John Strecche for the Reign of Henry V (1414-1422). Hg. von Frank TAYLOR. In: Bulletin of the John Rylands Library, Manchester, 16 (1932), 137-187.

Strong, P. und F.: The Last Wills and Codicils of Henry V. In: English Historical Review 96 (1981), 89-90.

Swanson, R. N.: Hallum, Robert (d. 1417). In: Oxford Dictionary of National Biography. Oxford 2004. Online: www.oxforddnb.com/view/article/12005 (10.01.2015).

TAYlor, Frank/Roskell, John S. (Hgg.): Gesta Henrici Quinti. London 1975.

Tighe, Robert/Davis, James Edward: Annals of Windsor, Being a History of the Castle and Town. 2 Bde. London 1858.

Townsend, George Fyler: Some Account of a Visitation of the Royal Chapel of St. George at Windsor, in 1552. In: Archaeologia, or Miscellaneous Tracts relating to Antiquity 42 (1869), 77-98.

VAVra, Elisabeth (Hg.): Virtuelle Räume. Raumwahrnehmung und Raumvorstellung im Mittelalter. Akten des 10. Symposiums des Mediävistenverbandes, Krems. Berlin 2005.

[Walsingham/Galbraith 1937]: The Saint Albans Chronicle, 1406-1420. Hg. von Vivian Galbraith. Oxford 1937.

[Walsingham/Riley 1864]: Walsingham, Thomas: Thomae Walsingham, quondam monachi S. Albani, Historia Anglicana. Hg. von Henry Thomas RiLEy. London 1864 (Rerum Britannicarum medii aevi scriptores or Chronicles and Memorials of Great Britain and Ireland during the Middle Ages 28,2; Chronica Monasterii S. Albani 2).

WARD, Matthew: The Livery Collar in Late Medieval England and Wales. Politics, Identity and Affinity. Woodbridge 2016.

[WAURIN/HARDY 1886]: WAURIN, Jean de: Recueil des croniques et anchiennes istories de la Grant Bretaigne, à présent nommé Engleterre. Hg. von William HaRdy. London 1886 (Rerum Britannicarum Medii aevi scriptores or Chronicles and Memorials of Great Britain and Ireland during the Middle Ages 40).

[Windecke/Altmann 1893]: Windecke, Eberhard: Eberhart Windeckes Denkwürdigkeiten zur Geschichte des Zeitalters Kaiser Sigmunds. Hg. von Wilhelm Altmann. Berlin 1893.

Wilson, Christopher: The Medieval Monuments. In: CollinSON/RAMSAY/SPARKS 2002, 451-510.

Wimböck, Gabriele/Leonhard, Karin/Friedrich, Markus: Evidentia. Reichweiten visueller Wahrnehmung in der frühen Neuzeit. Berlin 2007.

Wischermann, Heinfried: Die englischen Papstwähler. In: Ausst.-Kat. Konstanz 2014, 155-158.

Wylie, James H.: The Council of Constance to the Death of Jan Hus (Vortragsreihe). London 1900.

Wylie, James H./Waugh, William T.: The Reign of Henry the Fifth. 3 Bde. Cambridge 1914-29. 


\section{Anmerkungen}

1 Brief von Johannes Forester aus Konstanz an Heinrich V. von England, 2. Februar 1417: Rymer 1729, IX, 433. Für Anmerkungen danke ich Britta Bode, Anne Breimaier, Livia Cardenas, Julia Crispin, Ute Engel, Christian Freigang, Ulrich Henze, Markus Hörsch, Eberhard König, Jens Rüffer, Holger Straßheim und Jenny Stratford.

$2 \mathrm{Zu}$ den sehr bewusst in Szene gesetzten Einzügen Sigismunds in die Konzilstadt Basel mit Verweis auf weitere Literatur und die unterschiedlichen Gepflogenheiten in Konstanz SCHENK 2003, besonders $403 \mathrm{f}$.

3 Auch als »Collar of ,SS « bezeichnet. Stratford 2012, 317. - Vgl. auch WARD 2016.

4 Hengerer 2005, 523. - LenZ 1874, 138, weist darauf hin, dass der Vertrag zu dieser Zeit noch nicht in Konstanz veröffentlicht war.

5 FINKe 1923, 187.

6 Nighman 1996, 182.

7 Siehe unten

8 »Post, Excellentissimi Principis, Sigismundi Romanorum et Vngariae Regis ad hanc Civitatem felicem introitum, Liberatam seu Devisam Metuendissimi Regis nostri continue deferentis, quae in Gallorum Oculis multum taediosa et nociva consistit, Ambaxiatores praefati, videntes« (Kursivierung im Original), Brief aus Konstanz, R[obert] A[ppilton] an T[homas Langley], Bischof von Durham, 14. März 1417: Rymer 1729, IX, 439. - Crowder 1962, 203.

9 Windeckes Chronik stammt aus den späten 143oer Jahren: WINDecke/Altmann 1893. - Schneider 2012, 430. - Es sind zwei von der Werkstatt des Diebold Lauber illustrierte Bände überliefert, siehe unten. Bei der zitierten Chronik handelt es sich um die zweite Text-Edition von 1442.

$10 »[\ldots]$ et id nunc vinculo obligatissimo manifestat, assidua scilicet Angliae regis ordinis seu Torquis latione«. Jean de Montreuil, zitiert nach LENZ 1874, 145 .

11 Siehe Anm. 8.

12 BUCK 2010/I, 83 f. - Finke 1923, 187.

13 Im ersten Zwickel an der Nordwand, allerdings übermalt. DerschKA 2014, 136f. - In den Klostergebäuden der Augustinereremiten war Sigismund zeitweise untergebracht.

14 LenZ 1874, 149. - Wylie/Waugh 1929, III, 31. - Simms 1990, 23. - Allmand 1997, 245. - BÁrány 2000, 98. - Schenk 2003, 296. BÁRÁNY 2014, 76. - WARD 2016, 35.

15 "Qui rex descendit ante primas cruces et secutus est processionem in ecclesiam cum pallio aureo supra se, et cardinalis episcopus Ostiensis cum mitra parata preciosa recepit eum in ecclesia cum evangelio et aqua benedicta, et dicta in ecclesia oracione, episcopus Sarisberiensis Anglicus in ambone fecit sermonem ad laudes regis, rege sedente in cathedra parata pannis aureis, in loco, ubi olim sedebat papa. Quo sermone finito cantatum est: 'Te Deum laudamusı." FINKE 1923, 187. - Siehe auch LenZ 1874, 136. - SCHENK 2003, 429, der Bischof Hallum allerdings versehentlich zum Erzbischof erhebt. - Zur Person Fillastres zuletzt Rathmann 2000, 157-164; zu Fillastres Taktik der Auslassung und der Streuung von Gerüchten ebenda, 168, $196 \mathrm{f}$.

16 SCHWEDLER 2008, 380-382.

17 So sind auch Reliquien nicht sichtbar, sehr wohl aber in der "unsichtbaren Anwesenheit« präsent. RöcKelein 2010, 179. - Für diesen Hinweis danke ich Livia Cardenas.
18 Ähnliche Collanen im Museum of London: Ausst.-Kat. London 2003, 206. - Ausst.-Kat. Budapest 2006, 252 f., 354 f.

19 Fischer-Lichte 2013, 56-62.

20 McFarlane 1945, 323. - Saygin 2002, 238.

21 Rathmann 2000, 136, Anm. 114.

22 Brandmüller 1991/97, I, 277.

23 Wylie/WAugh 1914-29, III, 9-35. - Siehe auch den Überblick bei Allmand 1997, 233-256. - Simms 1990 gibt lediglich eine Zusammenfassung.

24 Crowder 1962. - Crowder 1963. - Crowder 1977.

25 Classen 1989.

26 Reitemeier 1999, besonders 264-303, 451-460. - KintZinger 2000, besonders $96-107,151-153$.

27 BÁRÁNY 2000. - BÁRÁNY 2006. - BÁRÁNY 2014.

28 SCHWEdLER 2008.

29 Crowder 1962, $185 \mathrm{f}$.

30 Schuler 1966. - Maurer 2007. - Bruggisser-Lanker 2014.

31 KintZinger/SCHNEIDMÜLLER 2011/II, $11 \mathrm{f}$.

32 Helmrath 1989, bes. 127.

33 Rathmann 2007, 105. - Zu einer Ereignisgeschichte anhand von Texten auch Rathmann 2000.

34 Kintzinger 2000, 97.

35 Wylie/Waugh 1914-29, III, 32. - Crowder 1962, 203, konnte Forester nicht identifizieren.

36 LENZ 1874, 4.

37 LenZ 1874, 4. - Kintzinger 2000, 96-107, bes. 96f. - BÁrÁny 2006.

38 Allmand 1997, 67-72. - Zu den Reisen nach Paris Fehrmann 2008, 223.

39 So zählte Enguerrand de Monstrelet etwa 6oo Reiter, die im Februar 1414 in Paris einritten und die Pariser sehr beeindruckten, und berichtet von dem dreitägigen Fest zu Ehren der englischen Delegation. DouëT-D'ArCQ 1859, 59 f. - Allmand 1997, 67-71.

40 Devon 1837, 335, zum 27. Oktober, wo u. a. Beauchamp über 333 Pfund, FitzHugh 200 Pfund, Hungerford 100 Pfund Sterling erhält. BRANDMÜLLER 1991/97, I, 144.

41 Brandmüller 1991/97, I, 122-124, 136-159.

42 Erst am 1. Oktober 1414 stimmte die Synode in der Londoner Kathedrale St. Paul einer Steuer für das Erzbistum Canterbury zu, erst am 6. November, nach Beginn des Konzils, in der Kathedrale von York für die Erzdiözese York. WYLIE 1900, $79 \mathrm{f}$.

43 Rymer 1729, IX, 289. - Zur Diskussion Wylie/Waugh 1914-29, I, 539-543. - Strong 1981, 80-83. - Fehrmann 2008, 133.

44 Strong 1981, 89 f. - Fehrmann 2008, 134-136.

45 Taylor/Roskell 1975, 12.

46 »Item, Legamus, Excellentissimo Principi, Fratri nostro percharissimo, Sigismundo Romanorum Regi qui nunc est Ensem ornatum de Lapidibus pretiosis ad valorem D. Marcarum; Et, quia recepimus Ensem ab Altari ad fidem et Ecclesiam defendendas, eidem Romanorum Regi et in manus suas Ensem Ecclesiae et Christianitatis commendamus, tanquam illi qui est (Judicio nostro) et Ecclesiae et Fidei fidissimus Defensator.« Rymer 1729, IX, 289 (Kursivierung nach RYMER).

47 Rymer 1729, IX, 167, 169. - Zur Diskussion um die englische Gesandtschaft vor allem Crowder 1962. - Siehe auch LenZ 1874, 64 mit Anm. 1. - Wylie/WaUgh 1914-29, III, 6f., 11-16. - Hoensch 1995, 95-97. - HoENSCH 1996, 230. 
48 BUCK 2013, 41-45. - Zur widersprüchlichen Überlieferung HeımPEL 1983, 170-184. - Die Bilder in den Richental-Handschriften sind allerdings wegen ihrer späteren Datierung als Zeugnis für die Lesung zu vernachlässigen, siehe unten.

49 Brandmüller 1991/97, I, 185 f. - Siehe auch Finke 1889, 29.

50 BRANdmülLeR 1991/97, I, 147, $185 \mathrm{f}$.

51 Bericht des Jacopo de' Cerretani: Finke 1923, 208.

52 Richental nennt andere Namen und erhebt zwei der Bischöfe zu Erzbischöfen. BUCK 2010/I, 32. - LenZ 1874, 71, Anm. 1. - BrandMÜLLER 1991/97, I, $144 \mathrm{f}$. - Reitemeier 1999, 275 f. - Zu den Stiftungen in den Testamenten der englischen Delegation WischerMANN 2014, 156f., der einige der Geistlichen zu Unrecht in das Bischofsamt erhebt.

53 Swanson 2004. - Zum Grabmal siehe unten und den Beitrag von Stefan King und Ines Stadie in diesem Band.

54 DAVIES 2004

55 Crowder 1962, $194 \mathrm{f}$.

56 Brandmüller 1991/97, I, 144. - Davies 2004.

57 FINKE 1923, 147. - HaRRISS 1988, 92.

58 McFarlane 1945, 317 f. - Harriss 1988, 91-99.

59 Harvey 2004.

60 BUCK 2010/I, 32.

61 Das erste Testament unterzeichnete Heinrich am 24. Juli 1415: Rymer 1729, IX, 289. - Zur Diskussion Fehrmann 2008, 133, Anm. 94.

62 Reitemeier 1999, $366 \mathrm{f}$.

63 LenZ 1874, 63 f. - Wylie/Waugh 1914-29, III, 6f., 11-16. - HoENSCH 1995, 95-97. - HoENSCH 1996, 230.

64 WALSINGHAM 1864, 300 f. - LUXFORD 2005, 121.

65 Salzman 1948, 303. - Сатto 1985, 106, $110 \mathrm{f}$.

66 СатTO 1985.

67 Stratford 2013, 157 f., 160. - Nach der Schlacht wurden einige Gegenstände von den Pfandnehmern aufgekauft, wie z.B. dem Earl of Huntingdon.

68 STRATFORD 2013, 157-159.

69 LenZ 1874, 71, Anm. 1. - Davies 2004.

70 DouËt-d’Arce 1859, 70-75. - Allmand 1997, 73.

71 Allmand 1997, 81.

72 Hack 1999, 569-574. - Reitemeier 1999, 282.

73 LenZ 1874, 75, 81 f. - Hoensch 1995, 95 f.

74 TAylor/Roskell $1975,128 \mathrm{f}$.

75 TAylor/Roskell 1975, 122-126.

76 Nicolas 1834-37, II, 193 f. - KintZinger 2000, 97.

77 »Item pur conduire le dit Emperour et de surveier lestat et gouvernance de son houstell«. Nicolas 1834-37, II, 194. - SCHWEdLER $2008,326$.

78 Verfasst zwischen dem 20. November 1416 und Juli 1417. TAYLOR/ Roskell 1975, xxii-xxiv, xxxvii. - Wylie/Waugh 1914-29, III, 9-12. - GRANSDEN 1982, $201 \mathrm{f}$.

79 Siehe Anm. 9.

80 GranSDEN 1982, 202.

81 Nicolas 1834-37, II, 192 f. - Reitemeier 1999, 451, 49o f. - Zum Itinerar Hoensch 1995, $96 \mathrm{f}$.

82 Hoensch 1995, 95-97. - Vgl. auch LenZ 1874, $88 \mathrm{f}$.

83 Taylor/Roskell 1975, 76. - LenZ 1874, 89.

84 Ein zeitgenössischer Chronist gibt eine Liste der nach London einreisenden Adligen, die Kingsford 1905, 124, 306, Anm. 18, entschlüsselt.
$85 \mathrm{Zu}$ der erstmals bald nach 1447 überlieferten Legende, Herzog Humphrey of Gloucester habe von Sigismund mit gezogenem Schwert Tribut gefordert, bereits LenZ 1874, 89, Anm. 3. - WYLiE/WAUGH 1914-29, III, 9 f. Anm. 10. - Reitemeier 1999, 285. BÁRÁNY 2000, 89. - SCHWEDLER 2008, 82-85.

$86 »[\ldots]$ wart gar herlichen gehalten in der burg, do er zu ymbis asz und das maale nam.« Bernoulli 1895, 163.

87 Windecke/Altmann 1893, 66, 200. - Taylor/Roskell 1975, 76 f. - Siehe auch LenZ 1874, 91.

88 »Praesul metropolis sibi praesto palatia confert«. Elmhami Liber metricus. Cole 1858, 133. - Thomas of Elmham verfasste den Liber metricus, in dem er sich nach eigener Aussage auf eine selbst verfasste Prosafassung bezieht, um 1418. Er war Mönch der Augustinerabtei von Canterbury, möglicherweise Kaplan der Kapelle Heinrichs V. - Diese Prosafassung geht wiederum auf die Gesta Henrici Quinti zurück. Gransden 1982 206-210. - CURRY 2000, 40-42. - Hasted 1800. - Eine spätere Ansicht bei Collinson/ RAMSAY/Sparks 2002, Abb. 33.

89 BernOUlLi $1895,163$.

90 Zur Datierung Wilson 2002, 498-504. - Fehrmann 2008, 114$118,126$.

91 Windecke/Altmann 1893, 66.

92 "In Engelant zu Kandelberg [sach ich] sant Thoman von Kandelberg licham und den aller kostlichsten sarg, den ie mannesbilde ie gesach, als ich meine, und doselps sante Dionysius houpt.« WINDeCKe/Altmann 1893, 200.

93 Entsprechend der Darstellung der städtischen Ordnung bzw. der Rangordnung im Adventuszeremoniell: SCHENK 2003, $318 \mathrm{f}$.

94 Nicolas 1834-37, II, 193-195. - Anders der Autor der Basler Chroniken, demzufolge John of Bedford bereits nach Dover gekommen sein soll. BerNoulLi 1895, 163.

95 BRIE 1906/08, 380, 558.

96 Nicolas 1834-37, II, 194. - BRIE 1906/08, 380 f. - SCHWEdLER $2008,128$.

97 Taylor/Roskell 1975, 102. - Brie 1906/o8, 558. - Reitemeier 1999, 284. - SCHWEDLER 2008, 129.

98 BRIE 1906/o8, 381. - Zur Diskussion dieses Herrschertreffens und der Reihenfolge der gegenseitigen Ehrerbietung SCHWEDLER 2008, $128 \mathrm{f}$.

99 Taylor/Roskell 1975, 130. - Bernoulli 1895, 163.

100 TAYlor/Roskell 1975, 130. - DouËt-D'ArCQ 1859, $146 \mathrm{f}$.

101 Windecke/Altmann 1893, 66, Kat.-Nr. 76 (Kursivierung im Text).

102 So der gut informierte Autor der Gesta Henrici Quinti. TAYLOR/ Roskell 1975, 102. - Zum Einzug, der städtischen Topografie und der Diskussion der einzelnen Festarchitekturen Fehrmann 2005, 288-296, mit weiterer Literatur. - Der Besuch Sigismunds wurde keinesfalls als "the most significant event of the century" behandelt, wie BÁRÁNY 2000, 88, schreibt.

103 Gesta Henrici Quinti: »Et ex inde duxit eum Rex per medium civitatis usque palacium suum Westmonasterii quod pro mora sua ornatissime fecerat preparari«. TAYLOR/ROSKELL 1975, 130. - Zur Konstruktion des Dachwerks Huang/Mark/Wellman 1988.

$104 »[\ldots]$ where-as was the gret hall assignet to hym, which was ryolly hanget with clothes of gold and of Arras.« BRIE 1906/08, 558.

105 »And euery Angell in the hall-rof holdyng a torche in his honde; 
and iiij angeles at the hye deece, ich holdyng iiij torches«, vermeldet der Chronist im Brut. Brie 1906/08, $558 \mathrm{f}$.

106 Wylie/Waugh 1914-29, III, 11, Anm. 1.

107 LENZ 1874, 82.

108 Walsingham $1864,315 \mathrm{f}$.

109 "le roy nostre seignur tressoverain, seant en sa see roiale en la graund sale, dedeinz soun paloys de Westm.« Parliament Rolls. Given-Wilson/Brand/Phillips 2005.

110 "Quia vero tunc parliamentum Londonijs tenebatur, intravit imperator solempniter et diutissime concionatus est, effusus in laudes regis et fratrum suorum regnique nobilium atque tocius regni. Protulitque imaginem sancti Georgij de fulvo metallo fabrefactam, cuius >materiam superabat opus` (hier verweist Galbraith in der Fußnote auf Ovids Metamorphosen) quam voluit offerri apud Wyndeleshoram ubi sancto Georgio specialius a clericis regijs deservitur. Rex autem, cupiens omnem humanitatem deferre regi Romanorum, suspendit ad tempus cuncta parliamenti negocia, ducens eum ad festum sancti Georgij, honorans illic eum et tante fraternitatis titulo et religionis illius nobili indumento: signumque regalle imposuit collo suo quod imperator expost semper gessit in omni conventu publico vel actu notorio." Thomas Walsingham, dem Vivian Galbraith die Saint-Albans-Chronik (Oxford, Bodley Ms. 462) zuschreibt, die um 1421 entstanden sein muss, ist damit der einzige, der das Material des Reliquiars erwähnt. WALSINGHAM/Galbraith 1937, 100. - Bis auf den ersten Teil mit dem Reliquiar wortwörtlich zitiert in der Historia Anglicana: WALsINGHAM 1864, 316. - Das Herzreliquiar wurde bis zur Regierungszeit Heinrichs VIII. jährlich in den Prozessionen mitgetragen. Zu den Reliquien Ashmole 1724, I, 214.

111 Siehe unten.

112 »un reliquière d’or en façon d'une tour «. GUIFFrEY 1894-96, I, 19 f. - Ob die Reliquien darin auch von Sigismund stammen, ist unklar.

- Siehe auch SCHWEDLER 2008, 157.

113 Windecke/Altmann 1893, 200.

114 Zur Situation im Binnenchor Fehrmann 2008, 60, 133 f., 209213, passim.

115 »Therefore we desire you that ye wyll seuffre oure sayd huisshier to oversee your logyns and mansions of oure college, and for to loge and recepve as many p(er)sons as may be honestly and oonly for this tyme«. Unterzeichnet am 18. Mai 1416. Zit. nach Tighe/ DAVIS 1858 , I, $284 \mathrm{f}$.

116 Bernoulli 1895, 163. - Zum Datum Collins 2000, 169, Anm. 71. - TAYlor/Roskell 1975, 132, Anm. 2.

117 Die zehn Betten mit Vorhängen aus rotem und blauem Wollstoff aus dem Inventar sind vermutlich diejenigen, die Heinrich zuvor für die gefangenen Franzosen herrichten ließ: Rymer 1729, IX, 334. - St. John Hope 1913, I, 228; 235, Anm. 15.

118 Wie im Inventar von 1534 vermerkt. Bond 1947, 166, Anm. 5.

119 Siehe oben Anm. 110. - "Deinde, osculata venerabili particula Crucis Dominicae et corde Sancti Georgii, offerat." Ashmole 1724, I, 450 f. - 1466 wird das Reliquiar Zdeněk Lev von Rožmitál gezeigt: »Ibi postea monstratum est nobis cor Sancti Georgii, atque aliae reliquiae.« SCHMELLER 1844, 45. - Im Inventar von 1501 werden das Kreuz (ohne Fuß) und das silberne vergoldete Herz-Reliquiar erwähnt: »Item quoddam tabernaculum argenteum et deauratum in quo continetur cor beati Georgij «. BonD $1947,148$.
120 TAYlor/Roskell 1975, $132 \mathrm{f}$.

121 KintZinger 2000, $263 \mathrm{f}$.

122 Zum Phänomen der visuellen Fiktion in spätmittelalterlicher Buchmalerei Logemann 2011.

123 Siehe oben Anm. 110. Die Herausgeber der Gesta Henrici Quinti, TAYlor/Roskell 1975, 132, Anm. 1, und Collins 2000, 224, gehen gleichwohl von zwei Objekten aus, die allerdings im Inventar der Georgskapelle nicht nachweisbar sind.

124 »Item a monstrans of sylver gylt and seynt George is heart stondyng in golde closyd in byrall yn the myddst yn the vpper parte the image off the crucyfyx, vnder that the image off our Lady and the image off our Savyoure.« Inventar von 1534. - Bond 1947, 149, Nr. 3 (1501) und 167, Nr. 6 (1534).

125 Kurath 1998, 753 f. - Möglicherweise ist die Monstranz 1552 zusammen mit anderen Wertgegenständen verkauft worden. Townsend 1869, $77 \mathrm{f}$.

126 Datiert 1425-50: Köln, Schnütgen Museum, Inv.-Nr. G 563.

127 Dillon/St. John Hope 1914, fol. 18, Abb. 35. - Taylor/RosKELL 1975, 132 f. - Ausst.-Kat. Budapest 2006, 468 f., Kat.-Nr. 5.40.

128 Cardenas 2013, 63-72.

129 Sт. Јонn Hope 1913, II, 374.

130 Weder Wand noch Skulpturen sind erhalten. Ihr aufwändiger Transport von Nottingham nach Windsor ist bezeugt: CHeEthAM 2005, 13, 16. - Die heutige Skulpturenwand stammt von 1863: St. John Hope 1913, II, 374 f., 424 f. - Harvey 1961. - Im Inventar von 1416-30 ist eine »tabula de alabastro super altare « erwähnt, an der offenbar die Reliquien aufgehängt wurden. BonD 1947, 142, 144.

1311418 wurde die Maria auf Anweisung Heinrichs V. aufwändig überarbeitet: ST. JoHn Hope 1913, II, 374, 425.

132 Ashmole 1724, I, 64 f., 214; II, 28.

133 "saiyng the Delyveryng of hit by his owne persone shulde be more acceptable. \& norisshyng of more love«. Dillon/ST. JOHN HopE 1914, fol. 18r, Abb. 35.

134 »In j planca empta pro uno ffauzeauter super altare iiijd. In ij estrichbordis emptis pro brakettis inde faciendis ad supportandum idem ffauzauter pro Jocalibus superponendis xvjd." Sт. JоHN Hope 1913, II, 395, Anm. 5.

135 KRÜGER 2001, 75 f. - Für den Hinweis auf Basel und Cismar danke ich Ulrich Henze.

136 »In dem kam ain maister von Nüremberg, der bracht ain kupfrin [messingenen, A. F.] luchter oder ain kertzstall. Das was wol als lang [hoch, A. F.], als ain langer man raigen mag. Und unden als ain schib so wit, darob sechs mit ruben ze tisch wöl möchtind sitzen, und mocht man daz kertzstal wol zernemen. Daz bott er umm zway tusend gulden. Daz koft unßer herr der küng und gab im darumb xjc guldin. Und zernomend daz und stiessens in ain vass und sant das dem küng von Engeland [zu dem großen Tier, A. F.] uff dem Rin ab.« BucK 2010/I, 86. - Siehe auch in den Regesten: Altmann 1896, Nr. 2066, 2119a. - Zur Wortbedeutung LEXER 1986, 324 f. - Im Chor hing ein weiterer Leuchter (»candelabrum«). Sт. John Hope 1913, II, 374, 395, Anm. 16. - Zu einem polnischen Wisent auf dem Konzil Ausst.-Kat. Konstanz 2014, 215. 137 Zum Gerüst und dem Gebrauch von Gusseisen zur Anbringung St. John Hope 1913, II, 374, 396, Anm. 18.

138 Fouquet 2014/I, 376, Anm. 6. 
139 »In ij rubiis banqueris de armis sancti Georgij pro formulis chori vjs. viijd.«ST. John Hope 1913, II, 374, 395, Anm. 14.

140 Im Memorandum, einer Handschrift im Yorker Stadtarchiv, werden das Schwert und der Ort seiner Aufhängung genannt. Die Meistermarke, das lombardische $\mathrm{H}$ mit Kronreif, weist es nach Schramm als Produkt einer oberitalienischen Werkstatt aus; Pál Lővei lokalisiert es hingegen in eine Werkstatt aus Süddeutschland und Ungarn. Die gegossenen Drachen an der Schwertscheide sind nicht original, für diesen Hinweis danke ich Philipp Lankaster. St. John Hope 1913, 374. - Ausst.-Kat. London 2003, 82. Ausst.-Kat. Budapest 2006, 341.

141 Vgl. Anm. 46.

142 "signumque regalle imposuit collo suo quod imperator expost semper gessit in omni conventu publico vel actu notorio«. St. Albans Chronicle. Walsingham/Galbraith 1937, 100. - Zu Material und Schätzwert von Kette und Anhänger im Folgenden.

143 Zum Auftrag Heinrichs V. für die Anfertigung von Mänteln und Hosenbändern Rymer 1729, IX, 335.

144 Zur Datierung 1410/40 und zur Diskussion Ausst.-Kat. Budapest 2006, 273, 361 f., Kat.-Nr. 4.69 (María VERÖ).

145 Ausst.-Kat. Budapest 2006, 340, Kat.-Nr. 4.40 (Lothar LambACHER, Pál LŐVEI).

146 London, British Library, Cotton Julius B I. Nicolas 1827, 159.

147 Zur Maßstabsverkleinerung von Burgen FeHrmann 2005, 302.

148 »And the first sotelte was oure lady armyng seint George, and an angel doyng on his spores; the ijde sotelte was seint George ridyng and fightyng with the dragon, with his spere in his hand; the iijde sotelte was a castel, and seint George, and the kynges doughter ledynge the lambe in at the castle gates. And all these sotelties were served to the emperor and to the kyng, and no ferther: and other lordes were served with other sotelties after theire degrees." British Library, Cotton Julius B I. Nicolas 1827, 159. - Siehe auch SCHWEDLER 2008, 375, der die Königstochter mit Katharina (als französische Königstochter und zukünftige englische Königin Katharina von Valois) gleichsetzt und in Georg eine Personifikation des englischen Königs sieht. Da diese Ikonografie nicht ungewöhnlich ist, halte ich das nicht für überzeugend. Siehe auch Fehrmann 2008, 223.

149 Taylor/Roskell 1975, 133, Anm. 5. Daher auch die schnelle Einschiffung direkt nach London. Enguerrand de Monstrelet berichtet von 6oo Reitern: Doü̈T-D’ArCQ 1859, III, 144. - WyliE/ WaUgh 1914-29, III, $14 \mathrm{f}$.

150 KingsFord 1905, 125.

151 »do wolt der Römsch konig gein im sin ußgeritten; do sprach der Engelsch konig, er solte sin nit thün, er were minner geschetzet dann ein Römscher konig und solt nit goin im ziehen. « WINDeCKe/Altmann 1893, 68.

152 Reitemeier 1999, $290 \mathrm{f}$. - SchWedler 2008, $130 \mathrm{f}$.

153 Der Herzog brach dann sofort wieder auf. Reitemeier 1999, 288.

154 WAURIN/HARDY 1886, II, $232 \mathrm{f}$. - Waurin bezieht sich hier offenbar nicht auf das Ordensfest in Windsor.

155 "le roy dAngleterre, qui scavoit des honneurs mondains autant que prince vivant, vint devant la table de lempereur pour le festoyer et semondre de faire bonne chiere et les autre princes par deux foiz«. WAURIN/HARDY 1886, II, 233. - SCHWEDLER 2008, $76 \mathrm{f}$.

156 "grant reference, honneur et recœillote«. WAURIN/HARDY 1886, II, 232.
157 "vestu dun noble habit de drap dor, et autour de son col ung collier de fin or garni de moult riche pierrie.« WAURIN/HARDY 1886, II, 233.

158 »un Coler, appelle Pusan d'Oor, del'oeveraigne d'Antilopes, et oue certains Piers preciouses empressez en ycelle, en un Caas de Quire«. Rymer 1729, IX, 298 f. (Kursivierung im Original).

159 Wylie/Waugh 1914-29, III, 20. - Reitemeier 1999, 281-303.

160 RYMER 1729, IX, 365.

161 Taylor/Roskell 1975, 100 f. - LenZ 1874, 111 f. - Sigismunds Aufenthalt in Canterbury ist nachgewiesen am 12.-23. August.

162 Zur Bewertung des Vertrags von Canterbury Reitemeier 1999, 289, 296, passim. - Kintzinger 2000, 96-107. - SCHWEdLeR 2008, 125, 132-134.

163 Zur Mission des Hartung Klux, den Sigismund nach England zurückschickte, Altmann 1896, Nr. 12254 (Juli 1414) sowie Nr. 12265 (Ende 1414). - Siehe auch LenZ 1874. - KintZinger 2000, 103 f. - BÁRÁNY 2006, 44-46.

164 SChwedler 2008, 133 f., Anm. 56.

165 BOWERS 2002, 419. - SCHWEDLER 2008, 132-134.

166 TAYlor/Roskell 1975, 150-155. - Im November 1416 wurde das Fest des hl. Georg zum Hochfest erhoben. Сатто 1985, $107 \mathrm{f}$.

167 »Set tamen quando de Cantuaria versus Doveriam equitavit, post caudas equorum suorum multas proiecit sedulas sub hoc modo scriptas: Sigismundus imperator [...] O tu et felix Anglia et benedicta, quia quasi angelica natura gloriosa laude Ihesum adoras. Hanc tibi do laudem quam recto iure mereris. «STRECCHE/TAYLOR 1932, 155.

168 Strecche/TAYlor 1932, 155.

169 Devon 1837, 347. - Curry 2000, 40.

170 Neben weiteren 200 Pfund für den Aufenthalt Sigismunds in Eltham sind 8 Schiling erwähnt für ein Paar große »trussying cofers« für den Transport der 4.00o Pfund Sterling. Devon 1837, 348.

171 TAYlor/Roskell 1975, 156 f. - Dillon 1893, 302, Nr. 74; 305, 320. - Wylie/Waugh 1914-29, III, 21. - Brown/Colvin/TaYLOR $1963,445 \mathrm{f}$.

172 Zur Burg Dillon 1893, 304. - Brown/Colvin/Taylor 1963 , 445 f. - Der Umbau der Burgkapelle wurde wohl erst 1421 angewiesen.

173 Bezahlt wurden 20 Pfund "for the carriage of tents, ornamented with gold and cloth of arras, with hangings and sides of arras, and other their appurtenances whatsoever, for our said Lord the King and the Emperor to dwell in at Calais, during the time of their stay there «. Devon 1837, 347. - Brown/Colvin/Taylor 1963, 446.

174 TaYlor/Roskell 1975, 162 f. - Dillon 1893, 302, Nr. 83; 321 . Morley wurde später in Norwich begraben.

175 TAYlor/Roskell 1975, 156.

176 Douët-D’ArcQ 1859, 144. - BRIE 1906/08, 559.

177 StRATFORd 2012. - StRATFORD 2013, 164.

178 Windecke/Altmann 1893, 81.

179 FOUQUet 2014/I, 383.

180 "Also der Römsch konig von Calis schiet, do schankte ime der konig von Engelant zwo itel gulden kannen, die woren swere 24 mark goldes, und darinne funftusent nobeln und ein güldin kopf ein gulden müschkennichin, die hettent 18 marg gouldes.« Später folgt die Aufzählung: „Dis sint die cleinöter: item zwo gulden kannen, ein gulden kopf, ein guldin müschkennil, hetten 62 marg goldes.« Windecke/Altmann 1893, 79, 82. - Zur Umrechnung 
der Goldmark FouQuet 2014/I, 384. - Zu Gefäßen aus dieser Zeit sehr allgemein WischermanN 2014, 157.

181 "und under den cleinötern was ein itel gulden Marienbilde, das was wol acht10o nobeln wert. das selbe Marienbilde hette mich der konig geheissen geben zu unser frouwen brüderschaft gon Durdericht." Windecke/Altmann 1893, 82.

182 Windecke/Altmann 1893, 79-82. - Edelsteine gehörten zu den am häufigsten verschenkten Gütern. HiRsCHBIEGEL 2003, 153 f. Siehe auch den Index der im Inventar Richards II. erwähnten Edelsteine bei STRATFORD 2012.

183 »Sunder schankt er im zwen rubin, einen adamast und zwo berlen; die stein schatzt man besser denne viertzig thusent schiltfranken." Justinger/Studer 1871, 237, 489. - Der Berner Chronist nennt den Schätzwert der Steine, nicht des Colliers. 40.00o Schildfranken entsprachen 35.466 Florentiner Gulden. FouQueT 2014/I, 384 .

184 mein halßbant des koniges von Engelant geselleschaft, und daran hing ein fürspang; in dem fürspang was ein demant costlichen und schon, wart geschatzt für núntusent cronen, und ein rubin, wart geschatzt für 11tusent cronen, und ein perlin grösser wann ein bon, wart geschetzt für 12hundert cronen, das selbe fürspang drucket ich ab in ein gelbes wachs; und ein beinbant sant Jorgen geselleschaft, also sie es zu Engelant haltent, das wart geschatzet vor 11 tusent cronen«. Windecke/Altmann 1893, 82.

185 Z. B. Pierre Salmon, Dialogues, 1411-13 (Genf, Bibliothèque Publique et Universitaire, Ms. fr. 165, fol. 7r. - Stratford 2012, Abb. 13.), oder Jean de Berry in seinen Petites Heures, übereicht 1416 (Paris, Bibliothèque nationale de France, Ms. lat. 18014, fol. 288v. - Abgebildet Ausst.-Kat. Konstanz 2014, 58, Abb. 3 [Eberhard KöNIG]).

186 Windecke/Altmann 1893, 83.

187 Esztergom, Föszékesegyházi Kincstár 1964-30.1,2. Ausst.-Kat. Budapest 2006, 374 f., Kat.-Nr. 4.87.

188 Windecke/Altmann 1893, 80.

189 TAYlor/Roskell $1975,178$.

190 "Et insuper dicto domino Regi multa misit munera preciosa, inter que misit vestes aureas et vnum cornu vnicornis continens in longitudine vj pedes et vltra per virgam. « KINGSFORD 1914, 511. HeNTZNer 1757, $40 \mathrm{f}$.

191 Hirschbiegel 2003, 61, mit Anm. 129. - Zu Einhörnern in England auch CoRdez 2015, 141-145.

192 Bereits im März 1416, noch vor der Englandreise Sigismunds, war Windecke in Brügge gewesen, vermutlich ebenfalls zur Geldbeschaffung. Windecke/Altmann 1893, 81f. - FouQUet 2014/I, 384-389. - FOUQUET 2014/II, 124.

193 Windecke/Altmann 1893, 80.

194 Roland 2012, 452 f. (mit älterer Literatur). - Eine zweite illustrierte Fassung wird ebenfalls auf die Jahre 1445/50 datiert.

195 BuCk 2010/I, 32. - Siehe auch Devon 1837, 335. - LenZ 1874, $63 \mathrm{f}$.

196 SChUler 1966, 165.

197 Bruggisser-Lanker 2014, bes. 351 f., 357.

198 »Die hettend an den prusunen des küngs [von Engelland] wapen, und sungend die vesper zu dem thümb gar Ioblich mit großen brinnenden kertzen, mit schönem gelüt und in den organan «. BUCK 2010/I, 82. - SCHULER 1966, 165.
199 »dat wart alz wal van den Engelschen besungen, alz man in 30 jaren in dem dome e hort singen«. Zitiert nach SCHUler 1966, 158.

200 Crowder 1962, 203. - Crowder 1977, 111-126. - Nighman 1996, 125-127. - BRANDMÜLLER 1991/97, II, 303, 366, 373.

201 Devon 1837, 339f., zum 27. 2.1415. Im September 1416 hatten die Bischöfe John Wakering von Norwich und John Catterick von Coventry/Lichfield Konstanz erreicht, zwei Wochen später gefolgt von Bischof Richard Clifford von London.

202 "Und gab inn vast ain kostlich maul, drü gericht nachainander, jedes gericht besonder mit acht essen. Die trug man allweg ain mauls dar, dero allweg viere warn vergült oder versilbert. In dem maul machtend sy söllich bild und gebärd, als unßer frouw ir kind gott unßern herren gebar mit vast kostlichen tüchern und gewand. Und Josephen staltend sy zu ir und die hailgen dry küng, als sy dann inn ir opfer brachtend. Und hattend gemacht ain luter guldin sternen, der ging vor inn an aim klaine isentrat. Und machtend den küng Herodes, wie er den dryen küngen nachsant, und wie er die kindlin tötet. Daz machtend sy alles mit vast kostlichem gewand und mit großen guldinen und silbrinen gürteln. Und machtend daz mit großer gezierd und mit demut.«BUCK 2010/I, 82 f. Nighman 1997.

203 Finke 1923, 482 f. - Nighman 1997, 88. - Siehe auch Morrssey 1990, 86-97.

204 Wenngleich für die entsprechende Zeit 1387-1462 keine Ausgaben für das Spiel vermerkt sind. Nighman 1996, 92, Anm. 69.

205 LENZ 1874, $138 \mathrm{f}$.

206 »on Soneday, the last Day of Januarie, zour Brother the Kyng of Rome werede the Gowne of the Garterez wyth zour Coler opynly ad the Hyze Messe: and he was lereth that the Duk of Beyer and the Bourghgrave scholde Ete with my Lord of Londone the same Day, and Heyse he wolde ete wyth hem." Rymer 1729, IX, 433-437.

207 Die Totenmesse war bescheiden im Vergleich zum Katafalk anlässlich des Todes des Kardinals von Bari zwei Jahre davor. BUCK 2010/I, 69.

208 Kite 1860, 97-99. - Stadie 2013, $87 \mathrm{f}$.

209 Auch für die ältere Platte des Vorgängers von Hallum als Bischof von Salisbury, John de Warham († 1395), in Westminster Abbey vermutet Nigel Saul einen königlichen Auftraggeber. HutchinSON 2001, 17, 69, Nr. 28.

210 Bertram 2015. - Vgl. Abb. 6 u. 7 beim Aufsatz von Stefan King und Ines Stadie in diesem Band.

211 KING 2013, 131 f. - Vgl. allerdings ausführlicher den Beitrag von King/Stadie in diesem Band.

212 Helmrath 1989, 167-169. - Ausst.-Kat. Konstanz 2014, 245.

213 Eger, Föegyházmegyei Könyvtár, P.V. 1. Heggelbacher 1972, 17-19. - Ausst.-Kat. Budapest 2006, Kat.-Nr. 4.116 (mit Abb.). Ausst.-Kat. Konstanz 2014, 245.

214 Heggelbacher 1972, 18.

215 Als frühestes Beispiel eines »öffentlichen humanistischen Unterrichts« trug Benedictus da Pileo Valerius Maximus vor. HelmRATH 1989, 160.

216 "And after, the Emperoure went home in-to his cuntre, and many English men with hym made officers, for he trustid hem better then his oune nacion«. Brut: BRIE 1906/08, 559.

217 SAYGIN 2002, 238.

218 SAygin 2002, 149.

219 Zur Prozesshaftigkeit literarischer Fiktion KLINKERT 2001, 19-21. 
220 Zum Begriff der Evidenz Ritter 1971, II, Sp. 829-832. - Zur visuellen Evidenz WImböck/LeONHARD/FrIEDRICH 2007, $10 \mathrm{f}$.
221 Zur Differenz zwischen dem Objekt und seiner Darstellung im Bamberger Heiltumsbuch von 1508/09 CARDENAS 2013, 63-72. 222 Coleman 1992, 37. 
Früher Realismus - Junge Wilde?

Malerei an der Schwelle der Neuzeit (1430-50) 

Gerhard Weilandt

FrüHer ReAlismuS IM 15. JAHRHUNDERT?

Einige Überlegungen zur deutschen Malerei an der Schwelle der Neuzeit

Die Zeit um 1430 markiert einen epochalen Einschnitt in der abendländischen Malerei. In Florenz hatte Masaccio gerade seine Dreifaltigkeit vollendet, bei der erstmals konsequent die Zentralperspektive in der Malerei angewandt wurde. Jan van Eyck stand kurz vor der Vollendung seines Genter Retabels, des Hauptwerks der altniederländischen Malerei. Zwischen der Ars Nova der Altniederländer und der Frührenaissance in Florenz hat es die gleichzeitige Kunst in Deutschland schwer, sich zu behaupten. Und das liegt entgegen einem weit verbreiteten Vorurteil nicht daran, dass insbesondere die Malerei Süddeutschlands auf einem grundsätzlich anderen Qualitätsniveau anzusiedeln wäre. ${ }^{1}$ Tatsächlich treten um 1430 auch in der deutschen Malerei in massiver Weise neue Formideale zutage. Sie unterliegen jedoch anderen Prinzipien als in Italien und sind deshalb nicht kommensurabel mit Parametern, die an der italienischen Kunst gewonnen wurden. So spielt die Erfindung der Zentralperspektive nördlich der Alpen keine entscheidende Rolle. ${ }^{2}$ Bezeichnenderweise ist es mit Petrus Christus ein Maler der zweiten Reihe, der sie erstmals konsequent anwendet, ${ }^{3}$ ohne damit dauerhaften Einfluss auszuüben - weder in den Niederlanden noch jenseits des Rheins, in den südlichen und östlichen Gebieten des Reichs. Giorgio Vasaris Fortschrittsmodell der Entwicklung der Malerei aus einem barbarischen Tiefstand im Mittelalter, der sich schon seit der Zeit Konstantins des Großen abgezeichnet hätte, zu neuen Höhen im Florenz der Renaissance ist schon für Italien fragwürdig, für die nordalpine Malerei ist es völlig ungeeignet. Für Vasari war neben der Antikenrezeption das zweite wesentliche Kriterium für den Rang eines Künstlers in der Geschichte der Malerei seine Fähigkeit zur immer präziseren Naturnachahmung. Ob das für Italien ein treffendes Kriterium ist, steht an dieser Stelle nicht zur Debatte, nördlich der Alpen taugt es nur sehr bedingt. Und dennoch: Im wissenschaftlichen Diskurs gilt Naturnachahmung immer noch als ein Gradmesser für die Fortschrittlichkeit und damit die Bedeutung eines Künstlers des 15. Jahrhunderts. Erinnert sei an das Aufsehen, das Fritz Koreny erregte, als er eine Rosenstudie

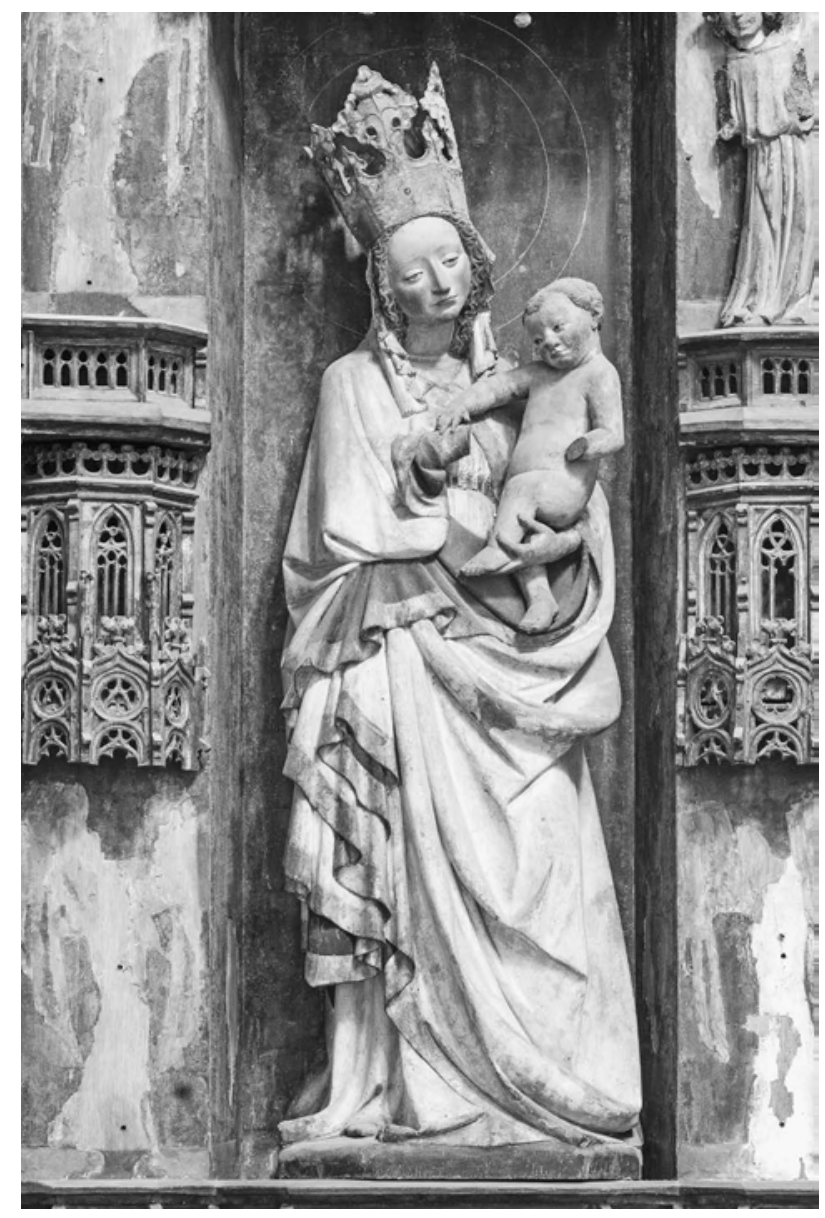

Abb. 1 Schöne Madonna, sog. Junge-Madonna. Stralsund, St. Nikolai (Foto: Detleff Witt)

von Martin Schongauer von ca. 1472 als »die mit Abstand früheste Naturstudie der deutschen Renaissance« publizierte. ${ }^{4}$ Als ob es nicht schon viel früher solche Studien gegeben hätte - wir kommen darauf zurück.

Ich möchte im Folgenden exemplarisch auf einige Eigenheiten und Unterschiede - aber auch Parallelen - der deutschen Malerei der Zeit um 1430-50 im Vergleich mit den Verhältnissen in Florenz und den Niederlanden verweisen. Beginnen wir mit den Parallelen. Die Basis bzw. der Ausgangspunkt für die Neuerungen in den 1430er 

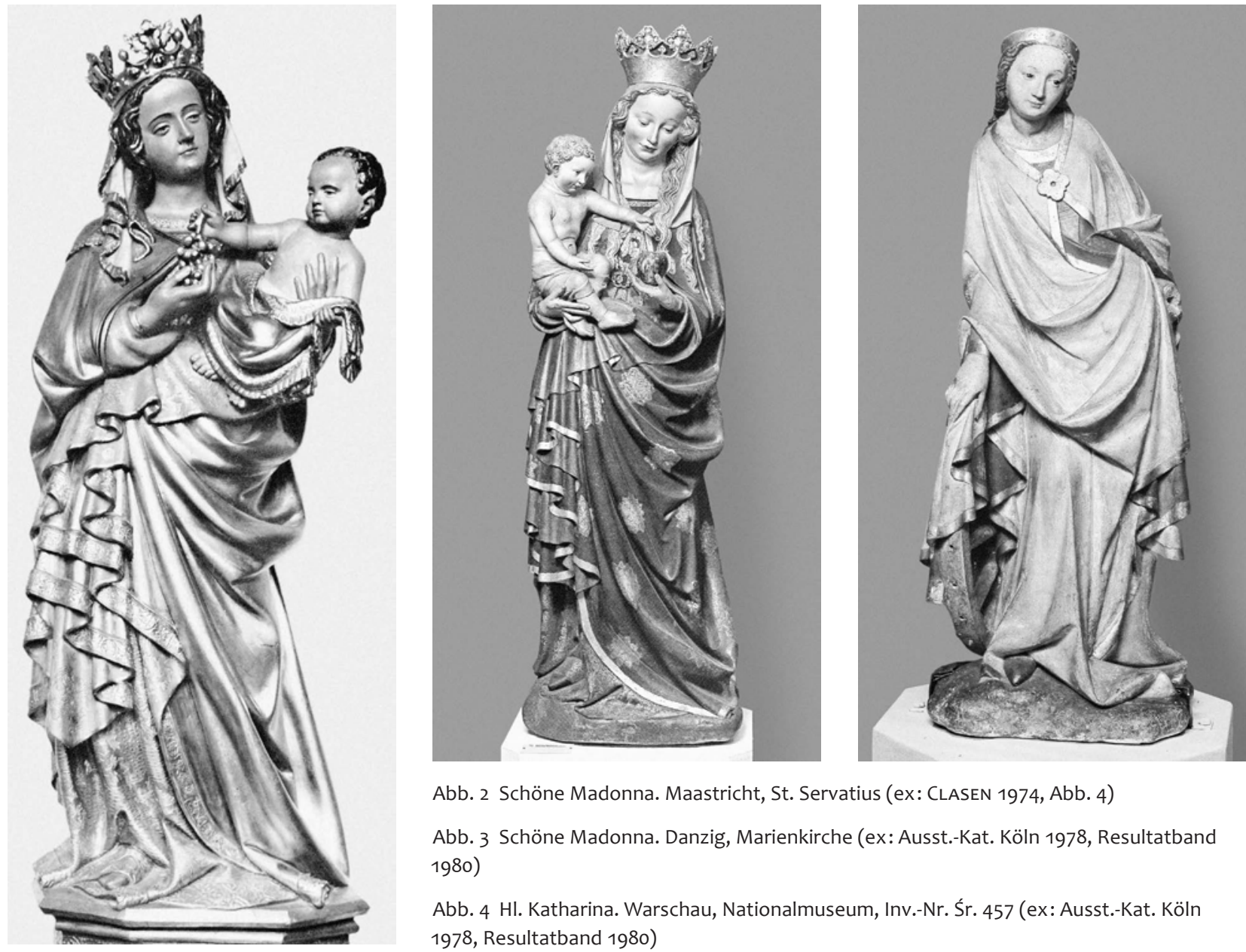

Abb. 2 Schöne Madonna. Maastricht, St. Servatius (ex: CLASEN 1974, Abb. 4)

Abb. 3 Schöne Madonna. Danzig, Marienkirche (ex: Ausst.-Kat. Köln 1978, Resultatband 1980)

Abb. 4 HI. Katharina. Warschau, Nationalmuseum, Inv.-Nr. Śr. 457 (ex: Ausst.-Kat. Köln 1978, Resultatband 1980)

Jahren unterschied sich in Deutschland nicht sehr von der Lage andernorts. Es war der Internationale Stil der Zeit um 1400, auch Schöner Stil genannt. Ich erinnere an die »Schönen Madonnen« dieser Zeit (Abb. 1-3).

Natürlich sind sie stilistisch heterogen, und sicher hatten die Zeitgenossen kaum jemals mehrere solcher Bildwerke gleichzeitig vor Augen. Aber den Künstlern, die sich auf Gesellenwanderschaft durch Europa befanden, ist sicher die Ähnlichkeit, ja Gleichheit der Formbildung in ganz verschiedenen Ländern und Regionen aufgefallen, wenn sie nicht sogar selbst über Exportwerke teil an der Verbreitung hatten. Der Versuch Karl-Heinz Clasens, einen »Meister der Schönen Madonnen« zu kreieren, der die wichtigsten Exemplare dieser weit verstreuten Gruppe selbst geschaffen habe, ${ }^{5}$ ist als gescheitert anzusehen. ${ }^{6}$ Aber es zeugt von der vergleichsweise großen Homogenität der Formsprache um 1400, dass ein solcher Versuch überhaupt unternommen werden konnte. Die »Schönen
Madonnen« waren weit verbreitet, wie die Beispiele aus Danzig, Stralsund und Maastricht zeigen, die sich bis in die Details der Faltenorganisation gleichen. Auch im Florenz der Frührenaissance ging man zunächst von dem Formenkanon des Schönen Stils der Jahrhundertwende aus - wie der Vergleich einer für Schlesien gefertigten hl. Katharina (Abb. 4) mit Ghibertis Johannes von Or San Michele (Abb. 5) zeigt. Bei aller Verschiedenheit der Figurenanlage sind die breit schwingenden Schüsselfalten erkennbar demselben Zeitstil verhaftet.

Ein gewisser Überdruss am Gleichmaß konnte sich im Laufe der Zeit auf Seiten der Künstler durchaus einstellen. Dennoch brachen diese internationalen, relativ gleich gelagerten Traditionen der Zeit um 1400 nicht schlagartig ab. Noch viel später findet sich der bewährte Formenkanon der Schönen Madonnen, etwa in der Nürnberger Pfarrkirche St. Sebald. Hier entstand mit der Strahlenkranzmadonna um die Jahre 1439/40 ein Bildwerk in die- 
Abb. 5 Hl. Johannes d. T. Lorenzo Ghiberti, 1414. Florenz, Or San Michele (Foto: Mongolo-1984, open source, bearb. durch Sarah Weiselowski)

Abb. 6 Maria im Strahlenkranz. Um 1439/40. Nürnberg, St. Sebald (Foto: S. Weiselowski)

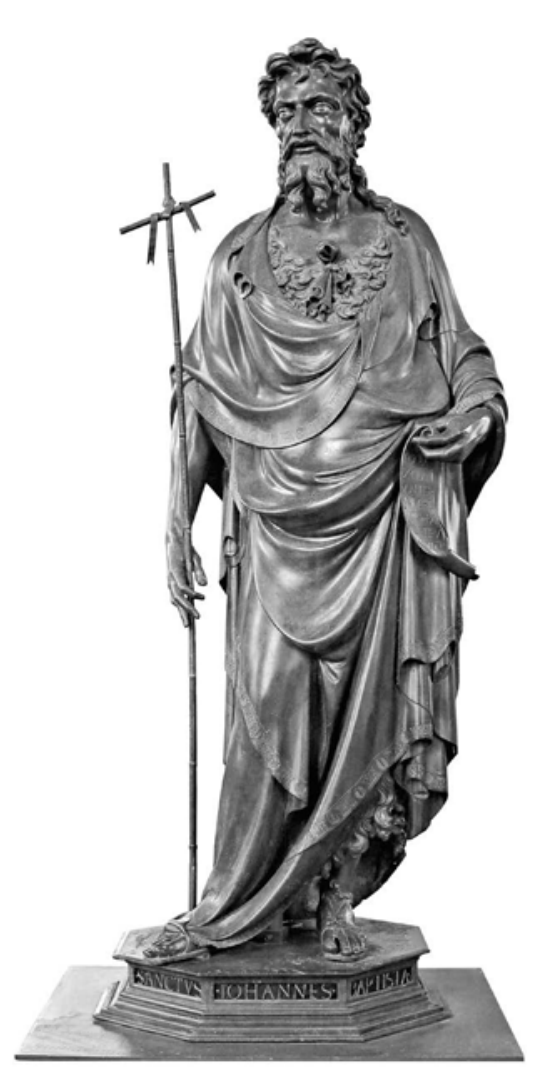

ser Tradition, und zwar nicht als schwächliche Nachfolge, sondern als Kunstwerk auf höchstem bildschnitzerischen Niveau (Abb. 6). ${ }^{7}$

Allerdings betrieb der Künstler der Nürnberger Strahlenkranzmadonna keine ungebrochene Fortschreibung älterer Stiltraditionen. Vielmehr wurden die alten Formen des Schönen Stils mit neuem Inhalt aufgeladen, indem man das zur Entstehungszeit der Figur intensiv diskutierte Dogma der Unbefleckten Empfängnis Mariens mit dem Bildtypus der Schönen Madonnen verband, was zuvor nicht geschehen war. ${ }^{8}$ Der bewusst konservative Formenapparat verweist auf die vermeintlich uralte Legitimation des neu verkündeten Dogmas. Solche außerkünstlerischen Motivationen für einen formalen Konservativismus, ja geradezu retrospektive Tendenzen, erschweren die Einordnung von Kunstwerken der Zeit allein auf stilkritischer Grundlage. Hinzu kommt, dass es einen »Gänsemarsch der Stile«, bei dem säuberlich getrennt ein bestimmter Zeitstil, bzw. eine Stiltendenz, von dem anderen zu einem fixen Zeitpunkt abgelöst wurde, kaum je gegeben hat. ${ }^{9}$ Auch um 1430 ist das nicht der Fall.

Diese Feststellung betrifft nicht nur die lang anhaltenden Traditionen des Schönen Stils, sondern auch die grundlegenden Neuerungen der Zeit um 1430, die sich schon viel früher ankündigten. Auf dem um 1400 entstandenen Retabel in Idar-Oberstein ${ }^{10}$ sieht man gewagte Verkürzungen, die einer anatomischen Analyse nicht standhalten. Um den Rock Christi würfeln wild prügelnde, überaus derbe Gestalten (Abb. 7), die so gar nicht zu den sonst üblichen sanften Charakteren der zeitgenössischen Malerei zu passen scheinen. Gerhard Schmidt hat diese Tendenz in der Malerei um 1400 als eine »realistisch-expressive Nebenströmung « im Zeitalter des Schönen Stils bezeichnet, auch als »voreyckischen Realismus «. ${ }^{11}$

Allerdings geht es dem Idar-Obersteiner Maler nicht um realitätsnahe Naturnachahmung. Zwar werden die Figuren nicht mehr nach einem verbindlichen Schönheitsbild idealisiert, doch kann man dies im eigentlichen Sinne nicht als Realismus bezeichnen, denn im Grunde wird der Schönheitsidealismus nur durch einen angepassten Situationsidealismus ersetzt: Die Guten bleiben weiterhin einer Vorstellung von unwandelbarer Schönheit verpflichtet, während die Bösen, die Schächer und Soldaten, nun derart monströs und körperlich wie geistig krank dargestellt werden, dass man von einem Hässlich- 


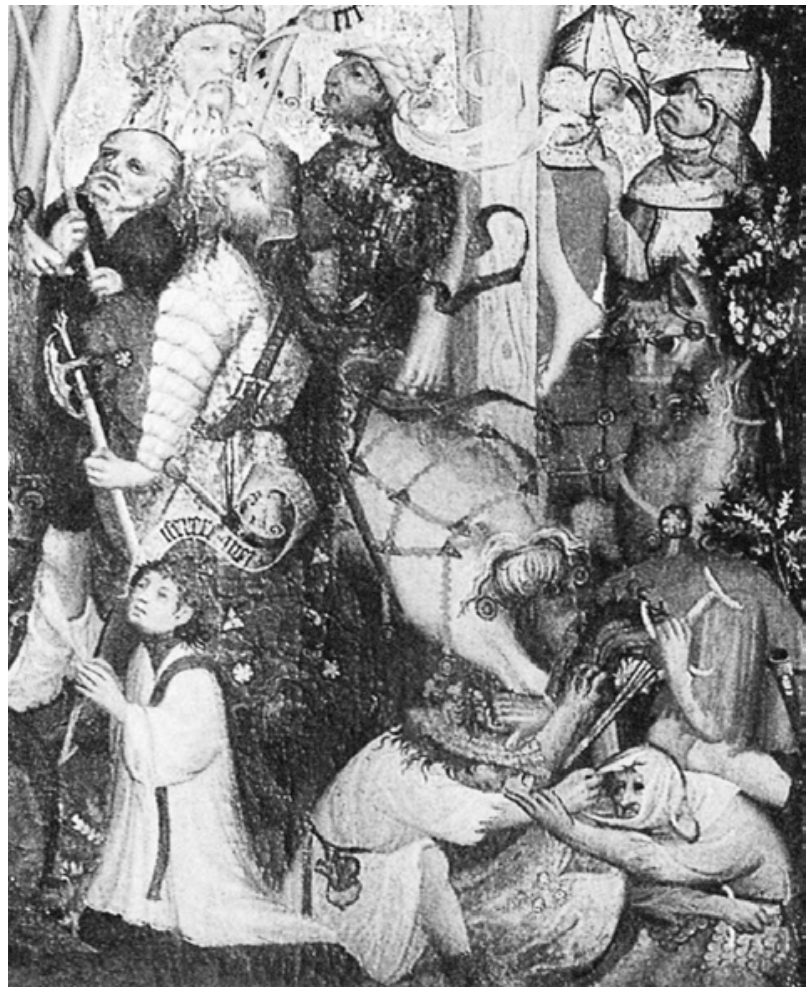

Abb. 7 Kreuzigungsretabel, Ausschnitt mit den sich streitenden Soldaten. Idar-Oberstein, Felsenkirche (ex: Ausst.-Kat. Frankfurt/M. 1975)

keitsideal der Künstler sprechen möchte. Es handelt sich nicht um eine Wirklichkeitsnähe anstrebende Wiedergabe von überaus hässlichen Gestalten, sondern um das Einsetzen von hässlichen Bildtypen in die ihnen zukommenden Rollen im Passionsgeschehen. Die Quälgeister sind auf eine Weise geschildert, dass man ihnen alles erdenklich Böse zutraut, auch dass sie vor dem Sohn Gottes nicht halt machen - und darauf kam es an, nicht auf ungeschönte Abbildung einer rekonstruierten historischen Wirklichkeit.

Auch der sog. »Passionsrealismus «, ${ }^{12}$ der darauf aus ist, die Leiden Christi derart drastisch zu zeigen, dass der Betrachter zur Compassio, zum innigen Mit- und Nacherleben der Passion Christi (nicht zum Mitleid mit dem Gottessohn $!^{13}$ ) angehalten wird, zielt im Grunde nicht darauf, mittels einer vermeintlich realen Wiedergabe des grausigen Passionsgeschehens zu überzeugen. Vielmehr verstärkt die stark akzentuierte Drastik der Blutgerinsel auf der Haut Christi, der zerstörten Glieder und gebrochenen Augen die Motivation zum emotionalen Nacherleben der Passion des Gottessohns. Spätgotischer »Passionsrealismus« ist expressiv, nicht realistisch. Er ist zudem theo- logisch motiviert: Je drastischer und damit anschaulicher das Leiden Christi dargestellt wird, desto höher ist seine Liebestat zu bewerten, dass der Gottessohn sein Leben für die Menschheit hingegeben hat. So paradox das klingt: Der »Passionsrealismus « nutzt die Darstellung übertriebener Grausamkeit als Mittel des Trostes für die sündige Menschheit. Wird die Epoche der Malerei um 1430-50 in der Forschung als »Früher Realismus« bezeichnet, so geht das an der Intention der Zeitgenossen vorbei. ${ }^{14}$ Häufig wird in diesem Zusammenhang von einem "ungeschönten Realismus" gesprochen, eine Wiedergabe von Wirklichkeit ohne Absicht einer Idealisierung. In Wahrheit handelt sich um eine Stilisierung des abnorm Hässlichen.

Zudem war diese Epoche auf dem Feld der mimetischen Anverwandlung der Natur, die ja stets als ein wesentliches Element von Realismus gilt, keinesfalls innovativ, sondern im Vergleich mit der Zeit um 1400 alles andere als weit getrieben. Auf dem berühmten Paradiesgärtlein aus der Zeit um 1410 (Abb. 8), das sich heute im Frankfurter Städel befindet, breitet sich teppichartig eine Fülle von Blumen und Pflanzen aus, auch zahlreiche Vögel sind derart präzise nach der Natur dargestellt, dass man sie ohne Weiteres zoologisch bestimmen kann. ${ }^{15}$

Diesem Gemälde müssen intensive Studien direkt nach der Natur vorausgegangen sein, auch wenn diese z.T. indirekt über Musterbücher vermittelt wurden. Vergleichbare üppige Menagerien finden sich in der deutschen Malerei um 1430/50 kaum noch. ${ }^{16}$ Auffällig ist aber ein Umstand, der den Betrachter zögern lässt, bei der Darstellung des Paradiesgärtleins von Realismus zu sprechen. Denn trotz des Detailnaturalismus ist das Bild insgesamt alles andere als die realistische Wiedergabe einer zeitgenössischen Szene. Es handelt sich um einen Hortus conclusus, eine symbolische Darstellung der Jungfräulichkeit Mariens. Und mit derselben Hingabe wie die Vögel und Blumen werden auch Phantasietiere wie Drachen dargestellt, deren Hautoberfläche inklusive Darmausgang mit äußerster Liebe zum Detail gestaltet ist. Liebliche Singvögel wie schreckliche Drachen sind nach den Vorstellungen der Zeitgenossen allesamt Geschöpfe des sich in ihnen offenbarenden Gottes und haben damit gleichermaßen ein Recht auf exakte Darstellung. Natürliches und Übernatürliches sind in dieser Zeit nicht Gegensätze, sondern komplementär. Die Welt des Jenseits - des Himmels wie der Hölle - war für die Zeitgenossen genauso real wie die sie umgebende Natur.

Das gilt auch für die Zeit nach 1430. Sicher, es gab damals neue Elemente, die aus Naturbeobachtung ent- 

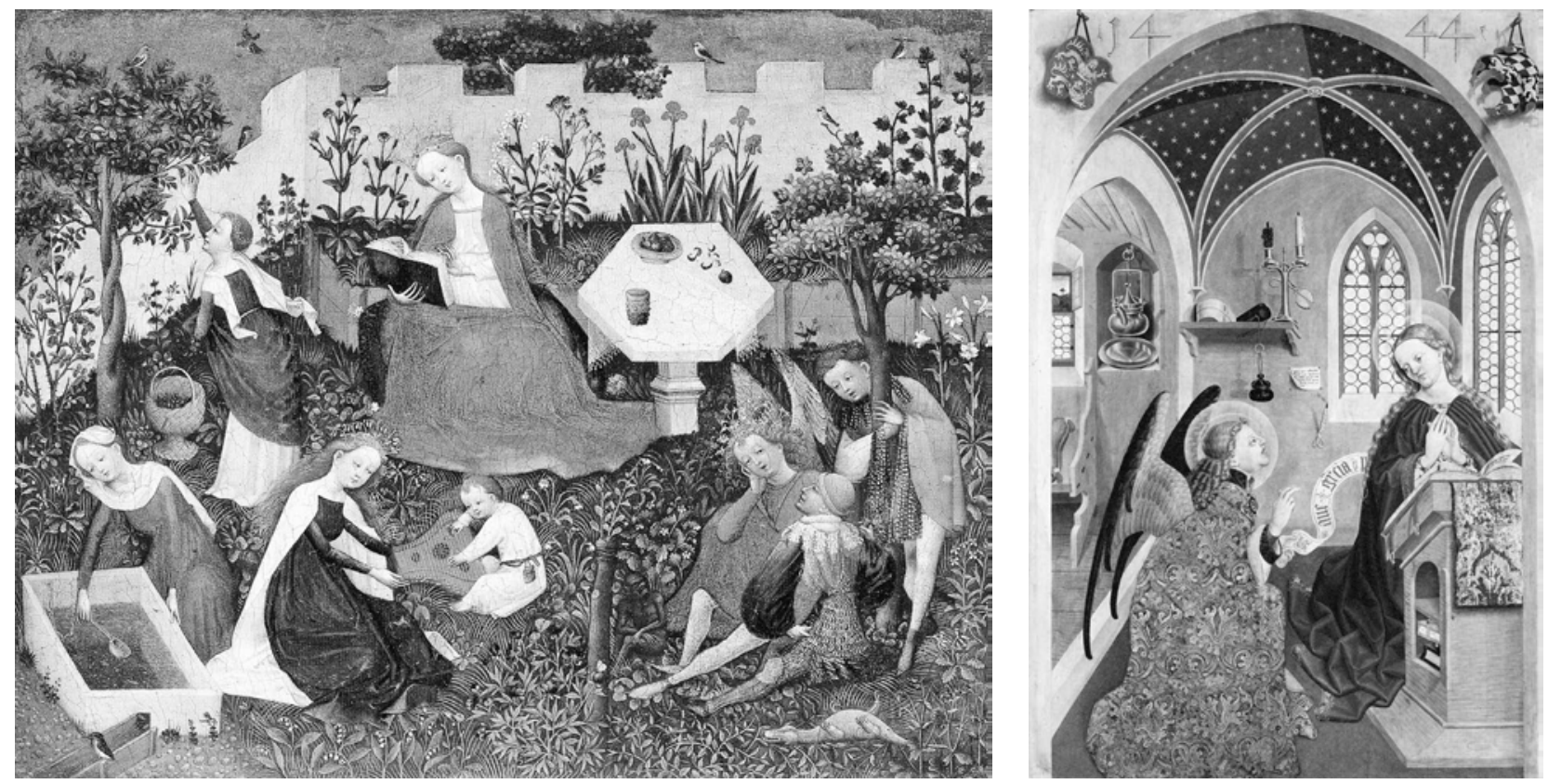

Abb. 8 Paradiesgärtlein. Straßburg, um 1410. Frankfurt/M., Städel Museum, Inv.-Nr. HM 54 (ex: BRINKMANN/KEMPERDICK 2002, 95)

Abb. 9 Verkündigung. Meister des Pollinger Retabels, 1444. München, Alte Pinakothek, Inv.-Nr. 6247 (ex: HofFMANN 2007, 144)

standen: Insbesondere die Wirkung von Licht und dessen Reflexionen auf Oberflächen finden bei den Malern deutlich erhöhte Beachtung. Auf der Verkündigungsdarstellung (Abb. 9) eines Meisters, der 1444 ein Werk für das bayerische Kloster Polling malte, das ihm den Notnamen Pollinger Meister bescherte, ${ }^{17}$ hat der Künstler die Wirkung des Lichts überdeutlich herausgestellt.

Zwei Wappenschilde hängen als schattenspendendes Trompe-l'œil an einer fiktiven Wand, die auch als Basis für die scheinbar in den Stein gehauene Datierung dient und gleichzeitig als Rahmen den Blick in die Verkündigungsstube öffnet. Dort kniet der Verkündigungsengel vor Maria, im Hintergrund des gewölbten Raums erkennt man ein Brett mit Kerzenständer, Spanschachtel und Tintenfass. An die Wand ist ein Gebetstext angepinnt, daneben eine geriffelte Kerze, die soeben erloschen ist. In einem links anschießenden Annexraum sieht man unter anderem eine Nische mit messingfunkelndem Waschgeschirr. Ein Horror vacui hat den Künstler befallen, der mit den Gegenständen - allesamt präzise nach der Natur wiedergegeben - die gesamte Bildfläche ausfüllt und dabei sorgfältig darauf achtet, dass es so gut wie keine Überschneidungen gibt. Er zeigt alles ganz deutlich. Doch hat dies etwas Gewolltes. Die Figuren sind übergroß dimensioniert und so angeordnet, dass sie die Leerstellen der
Komposition fast vollständig ausfüllen. Die Schlagschatten sind geradezu penetrant in Szene gesetzt, als wolle der Künstler etwas demonstrieren: insbesondere dass er die niederländische Malerei kennt, wo Derartiges schon früher dargestellt wurde. Die Schlagschatten auf der Wand sind Zitate, die gezielt auf Vorbilder verweisen. Sie sind nicht aus direkter Naturbeobachtung entstanden, nicht aus dem Studium der optischen Reflexe des raumschaffenden Lichts auf Oberflächen, sondern wirken wie die düsteren Doppelgänger all der Dinge im Raum, der Wappenschilde, Kerzen und des Waschgeschirrs.

Dieser Zitatcharakter bei der Rezeption niederländischer Maler durch ihre süddeutschen Kollegen wird noch deutlicher bei dem aus Schwaben stammenden Konrad Laib. Seinen Salzburger Kalvarienberg von 1449 (Abb. 10) hat er mit einer Signatur versehen, welche die berühmte Devise des Jan van Eyck »als ich kann« zitiert, offenbar ganz bewusst.

Auf dem Hinterteil eines Pferdes, das direkt unterhalb des Kreuzes Christi steht, liest man: "ALS ICH CHUN«. Laib hat nicht zufällig aus dem »kann« van Eycks ein »chun« gemacht, denn er nutzt die Gelegenheit - wie Antje-Fee Köllermann herausstellte - zu einem Hinweis auf seinen eigenen Vornamen Konrad, der sich zeitgenössisch »Chunrad « schrieb. ${ }^{18}$ Die Aneignung der De- 


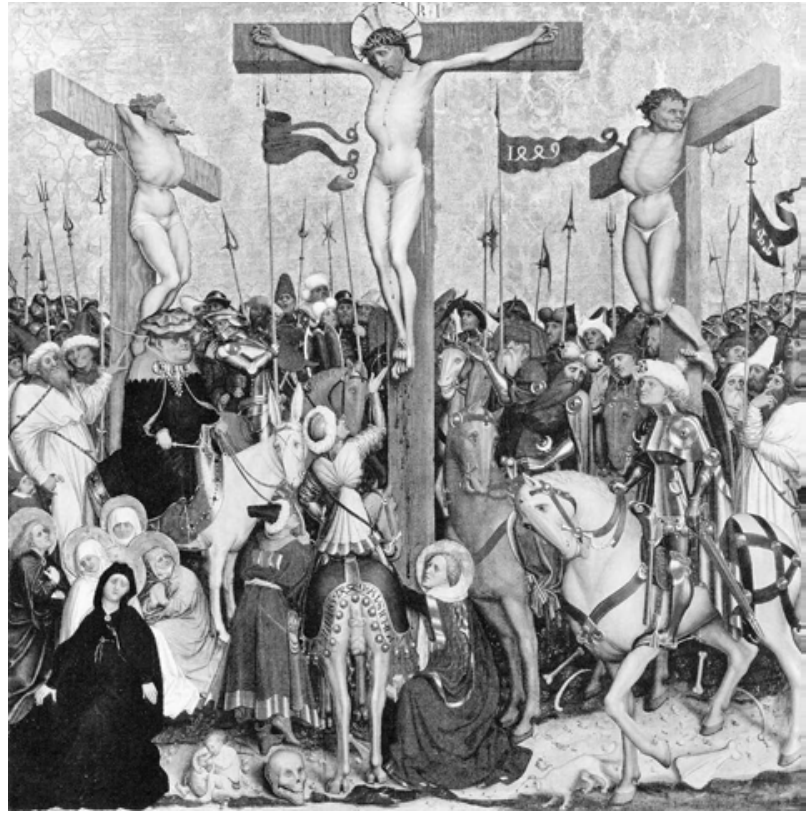

Abb. 10 Kreuzigungstafel aus der Salzburger Pfarrkirche. Konrad Laib, 1449. Wien, Österreichische Galerie Belvedere, Inv.-Nr. 4919 (ex: Ausst.-Kat. Wien 1997, 199)

Abb. 11 Anbetung der Könige, Ausschnitt. Stefan Lochner, 1445. Köln, Dom (ex: KEMPERDICK 1999, 82)

Abb. 12 Ausschnitt aus der Darbringung im Tempel des Columba-Retabels. Rogier van der Weyden, 1455. München, Alte Pinakothek, Inv.-Nr. WAF 1191 (ex: KEMPERDICK 1999, 81)

vise des Vorbilds erfolgte nicht ohne Augenzwinkern, ist doch die Inschrift auf dem breiten Hintern eines Pferdes angebracht. Das war offensichtlich eine zwar ins Auge springende, aber durchaus nicht »feine« Position für eine Künstlersignatur, vielmehr Zeichen einer durchaus ironisch gemeinten Distanz. Die Forschung hat die Frage nach Humor und Ironie bei Künstlern dieser Generation noch kaum gestellt, es wäre einen Versuch wert, diesen Aspekt der Kunst des 15. Jahrhunderts genauer zu untersuchen. Die bewusste, ja spielerische Übernahme von Künstlerinschrift und Schlagschatten, die sich nicht nur bei Konrad Laib und beim Pollinger Meister, sondern bei beinahe allen Neuerern der Zeit um 1430 findet $^{19}$ - übrigens auch in der Glasmalerei ${ }^{20}$ - ist nicht verwunderlich, im Gegenteil: Zitieren gehört zum Handwerk der Kunst der Spätgotik. Sie ist kein Zeichen unselbstständiger Abhängigkeit, sondern die notwendige Basis für den Werkstattbetrieb. Ein gut gefülltes Musterbuch und die Kenntnis der Darstellungstraditionen galten als Ausweis von Weitblick und Kenntnis.
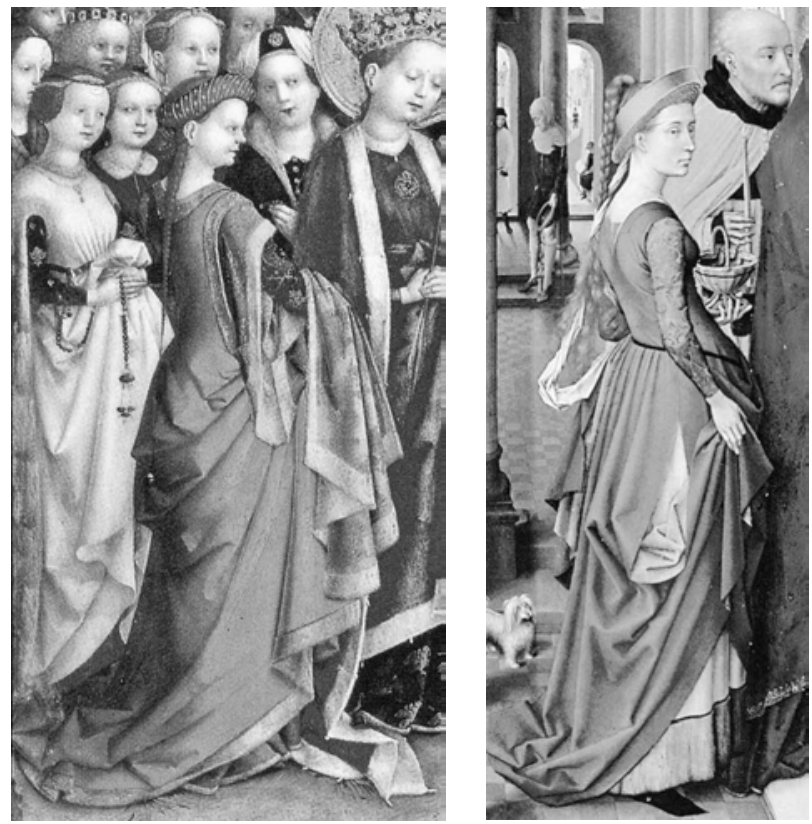

Ein beinahe unausrottbares Vorurteil bei der Beurteilung des Verhältnisses von deutscher und niederländischer Malerei ist der Dominanz der Niederländer. Die Vermittlung künstlerischer Ideen war jedoch keine Einbahnstraße. Bei dem berühmten Dombild Stefan Lochners für die Kapelle des Kölner Rathauses, das sich heute im Kölner Dom befindet, ${ }^{21}$ hat man immer wieder und zu Recht darauf hingewiesen, wie sehr der Kölner Maler sich an dem Vorbild des Jan van Eyck orientiert hat. Doch ein anderer Großer der Frühen Niederländer, Rogier van der Weyden, orientierte sich wiederum an Stefan Lochner: Auf seinem Columba-Retabel, das für eine Kölner Pfarrkirche bestimmt war, ist auf dem rechten Flügel die Darbringung im Tempel dargestellt. Die eindrucksvolle Rückenfigur der Assistentin mit dem Taubenopfer wurde maßgeblich von dem älteren Dombild Lochners angeregt (Abb. 11, 12). ${ }^{22}$

Die Körperhaltung ist vergleichbar, auch die Farbe der Kleidung, was darauf schließen lässt, dass Rogier Lochners Tafel vor Ort in Köln gesehen hat, dass er also in diesem Fall nicht auf Musterbücher angewiesen war.

Dass die herausragenden süddeutschen Künstler wie Lukas Moser, der Wurzacher Meister ${ }^{23}$ oder Konrad Laib in den Niederlanden so wenig wahrgenommen wurden, lag womöglich weniger an mangelndem Interesse als an mangelnder Möglichkeit der Kenntnisnahme. Der Kölner Fall zeigt, dass dort, wo ein Kontakt bestand, der Austausch sehr wohl funktionierte - und zwar keinesfalls nur als Einbahnstraße. 


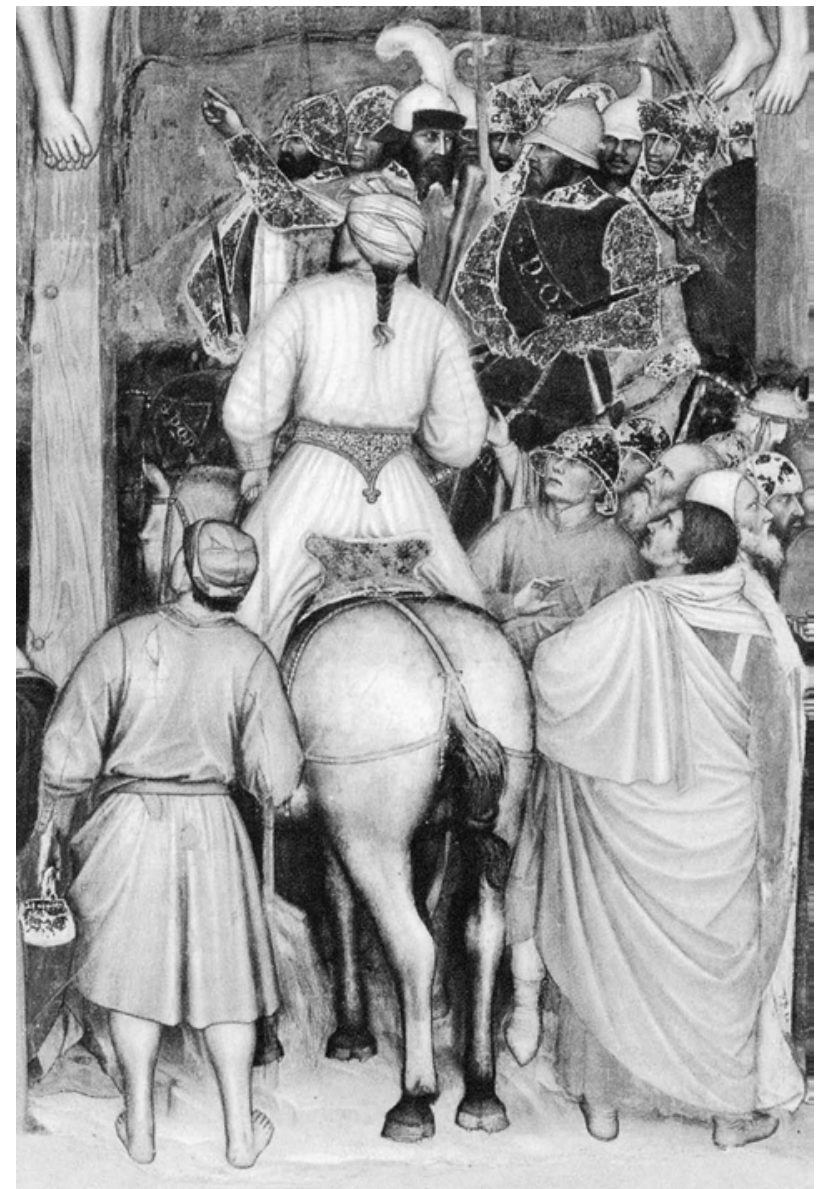

Abb. 13 Kreuzigung, Ausschnitt mit Rückenansichten. Altichiero da Zevio, 2. H. 14. Jh. Padua, Santo, Kapelle San Giorgio (ex: BAGGı/ COLALUCCI/BARTOLETTI 1999, Tav. XXV)

Bei der Benutzung von Vorlagen waren nicht allein die aktuellen künstlerischen Strömungen von Belang. Das lässt sich ganz gut an der Rezeption norditalienischer Anregungen in Süddeutschland zeigen. Es gab im 15. Jahrhundert wiederholt nachweisbare Kontakte der Künstler über die Alpen hinweg. Wir wissen, dass etwa der Münchner Stadtmaler Gabriel Angler, auch bekannt als Meister der Tegernseer Tabula Magna, nach Venedig reiste, um dort Farben einzukaufen. ${ }^{24}$ Auch Konrad Laib muss Kunstwerke Norditaliens studiert haben. Was ihn beeindruckte, waren allerdings nicht so sehr die aktuell tätigen Maler, wie man dies bei einem Künstler vermuten sollte, der sich auf der Höhe der Zeit zeigen wollte. Vielmehr suchte sich Laib Vorbilder aus dem Trecento, also einer zu seiner Zeit längst »überholten« Epoche. Das zeigt ein Vergleich seines Wiener Kalvarienbergs (Abb. 10) mit dem Kreuzigungsfresko des Altichiero da Zevio im Oratorio di San Giorgio am Santo in Padua aus der Zeit

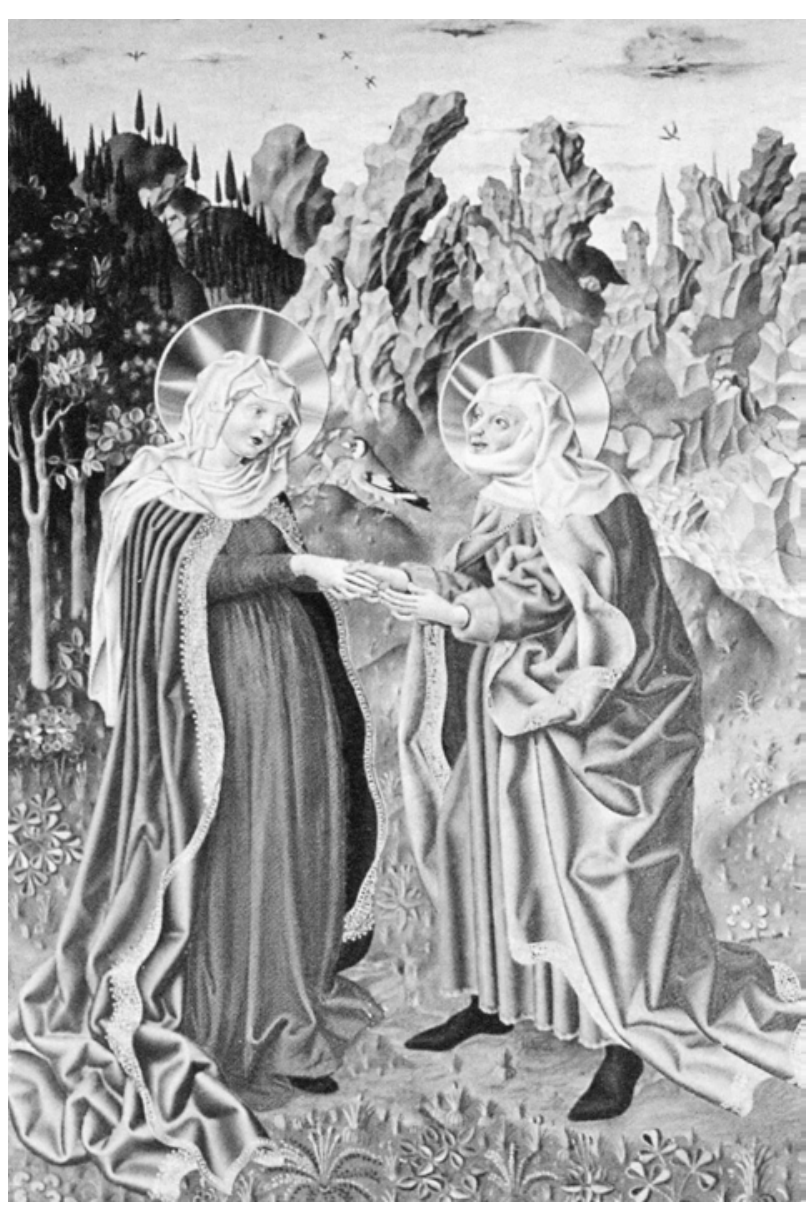

Abb. 14 Heimsuchung. Meister des Pollinger Retabels, 1439.

Kremsmünster, Stiftssammlung (ex: HOFFMANN 2007, 306)

um 1380-85. So ist u. a. das ungewöhnliche Pferd mit der Künstlerinschrift Laibs und dem Verweis auf Jan van Eyck von Altichiero angeregt (Abb. 13). ${ }^{25}$

Das gibt der Künstlerinschrift eine weitere ironische Note: Die Hommage an Jan van Eyck wird ausgerechnet auf demjenigen Bildelement eingefügt, das Laib nicht dem Niederländer verdankt. Diesen Hinweis konnte allerdings - wenn überhaupt - nur eine ganz kleine Anzahl von Zeitgenossen erkennen. Man fragt sich: Deutet sich hier ein spielerischer Appell des Künstlers an einen Betrachter an, der über mehr als das übliche Kunstverständnis verfügte, also ein Kenner war ${ }^{26}$ Wie dem auch sei, die deutschen Künstler der Zeit um 1430 wählten ganz gezielt aus, was ihren künstlerischen Intentionen entgegen kam; und das war nicht die damals aktuelle Kunst der Frührenaissance, sondern die ein halbes Jahrhundert ältere, expressive Malerei des späten Trecento. Der line- 


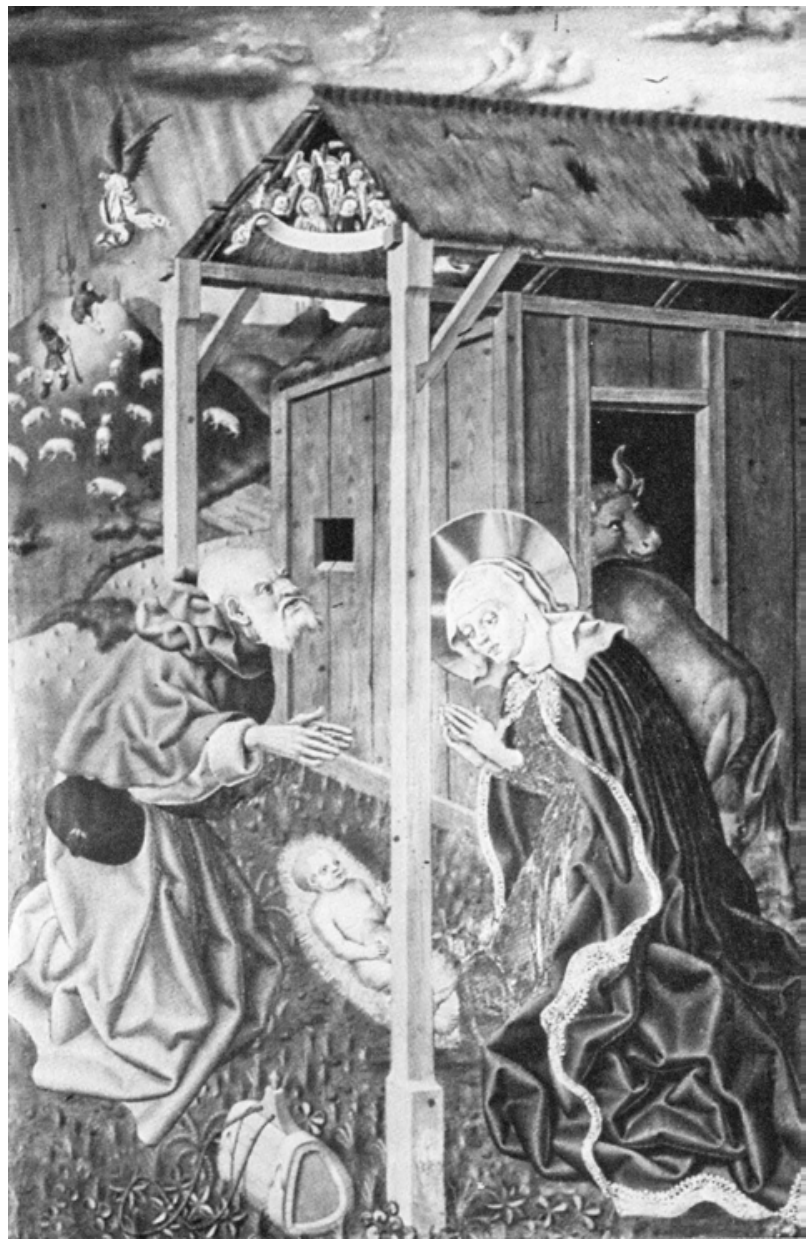

Abb. 15 Anbetung des Kindes. Meister des Pollinger Retabels, 1439. Kremsmünster, Stiftssammlung (ex: HOFFMANN 2007, 306)

are Fortschrittsgedanke Vasaris, nach dem nur das gerade Aktuellste relevant ist, greift hier nicht.

Bei aller Betonung der Abhängigkeit der deutschen Malerei der Zeit um 1430 von auswärtigen Vorbildern muss ein großer Anteil an Eigenständigkeit, ja Eigenheit konstatiert werden. Die süddeutsche Malerei der Zeit ist sehr vielgestaltig, aber unverwechselbar anders als die niederländische. Nirgendwo in der gleichzeitigen internationalen Kunst kommt eine ähnlich bizarre Felslandschaft vor wie auf dem Hintergrund der 1439 datierten Heimsuchungsszene des Pollinger Meisters, heute in Kremsmünster (Abb. 14). ${ }^{27}$

Ohne Parallele ist auch die Weihnachtsszene desselben Retabels, in der ein derart heftiges Gewitter wütet, dass die Engel für das Singen des Gloria in excelsis Schutz unter dem Dach des Stalles von Bethlehem suchen müssen (Abb. 15). Auf der Mitteltafel des Tiefenbronner Retabel

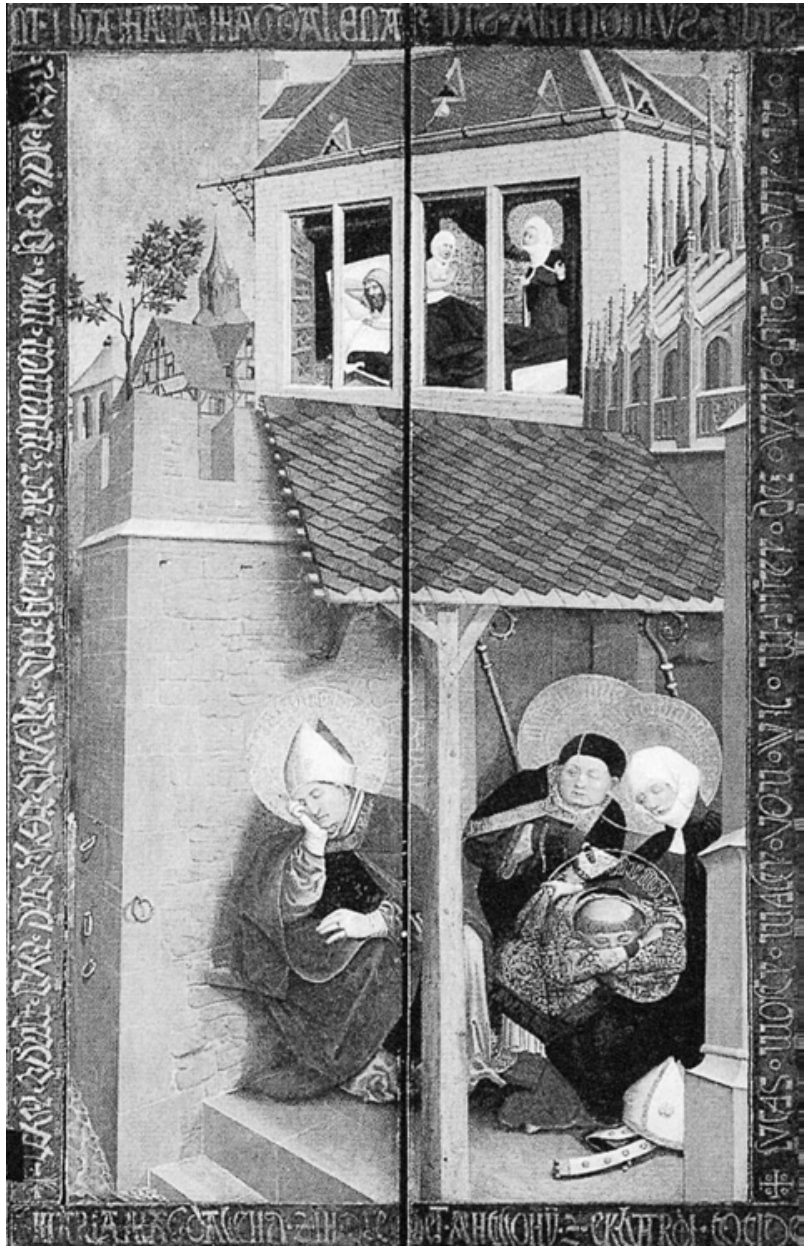

Abb. 16 Magdalenenretabel, Werktagsseite. Lukas Moser, 1432. Tiefenbronn, St. Magdalena (ex: HEInZMANN/KöHLER 1994)

des Lukas Moser von 1432 (Abb. 16) ${ }^{28}$ ruhen sich die erschöpften Gefährten der hl. Maria Magdalena nach einer langen Seereise an ihrem Ziel - der Hafenstadt Marseille aus.

Im Hintergrund sind die örtlichen Fürsten dargestellt. Das Ehepaar liegt im Bett, während ihm Magdalena im Traum erscheint. Welcher Künstler hätte jemals ein Retabel gemalt, auf dessen zentralem Bild fast alle Protagonisten schlafen? Und weiterhin: Wo sonst gibt es Bilder von der unmittelbaren Wucht des Wurzacher Retabels (Abb. 17)?

Bilder von einer solch delikaten, dennoch fahlen Farbigkeit, einer derart unräumlichen Anordnung der eindrucksvollen Köpfe der Zuschauer, bei denen der Maler sich um die korrekte Platzierung im Raum auch nicht das mindeste gekümmert hat? Nur die Einzelheiten sind mit dem Streben nach Naturnachahmung wiedergegeben, 
mit Recht kann man von einem »Detailrealismus« sprechen. Das Gemälde insgesamt jedoch hat mit »Frühem Realismus « nichts zu tun, es transzendiert die Realität.

Ein weiterer, mit einem vorgeblich verstärkten Realismus oft in Zusammenhang gebrachter Umstand ist die soziale Basis der Kunstproduktion. Bis zum Beginn des 15. Jahrhunderts waren die Bildhauer, aber auch manche Maler zumeist mit den großen Bauhütten verbunden. Die Mitglieder der mittelalterlichen Bauhütten waren in der Regel nicht dauernd in einer Stadt anwesend. Vielmehr zogen sie von Bauplatz zu Bauplatz, immer der Arbeit nach. Sie erwarben auch nicht das privilegierte Bürgerrecht. Das wurde seit dem Beginn des 15. Jahrhunderts anders: Die Maler und Bildhauer ließen sich permanent in einer Stadt nieder. ${ }^{29}$ So kann man als einen wesentlichen Unterschied zwischen Bauhütte und Zunft die Stetigkeit bezeichnen, mit der die Zunftmitglieder an einem Ort arbeiteten, während die Bauhüttenarbeiter von Ort zu Ort wanderten. Die Organisationsform der neuen Arbeitsweise war die Künstlerwerkstatt. Dieser Begriff meint sowohl das Gebäude, in dem die Werke entstanden, als auch die Organisationsform: Ein Meister war der Werkstattleiter, dazu gehörten Gesellen, die bereits mehrere Jahre gelernt hatten, und Lehrlinge, die für die einfachen Arbeiten wie das Zubereiten der Malmaterialien zuständig waren. Die Etablierung von festen, zünftisch organisierten Werkstätten führte zu einer regionalen, ja lokalen Aufsplitterung von künstlerischen Traditionen. Im Laufe des frühen 15. Jahrhunderts entwickelten sich mehr oder weniger ausgeprägte Regional- und Lokalstile, eine direkte Folge der Tatsache, dass die Künstler nicht mehr in dem Maße beweglich waren wie zuvor. Zwar gab es immer noch die Vorschrift der Wanderschaft für die Gesellen, bevor sie sich als Meister niederlassen durften, und der künstlerische Austausch auch über größere Strecken funktionierte durchaus. Doch die zünftische Organisation führte zur Verfestigung von Werkstatttraditionen, zum Anlegen von Mustervorräten über mehrere Generationen hinweg, zur kontinuierlichen Tätigkeit von Gesellen und Lehrlingen, die einem Meister zuarbeiteten und im besten Fall sogar die Möglichkeit hatten, die Werkstatt zu übernehmen. Auch die Koordination von Malern und Bildhauern war immer wieder notwendig, da man bei Retabeln und anderen Aufgaben eng zusammenarbeitete. Der Werkstattleiter war kontinuierlich in einer Stadt präsent, mitunter wurde er auch als Zunftvertreter Mitglied des städtischen Rats. Bekannte Beispiele dafür sind die Maler Stefan Lochner in Köln oder Hans

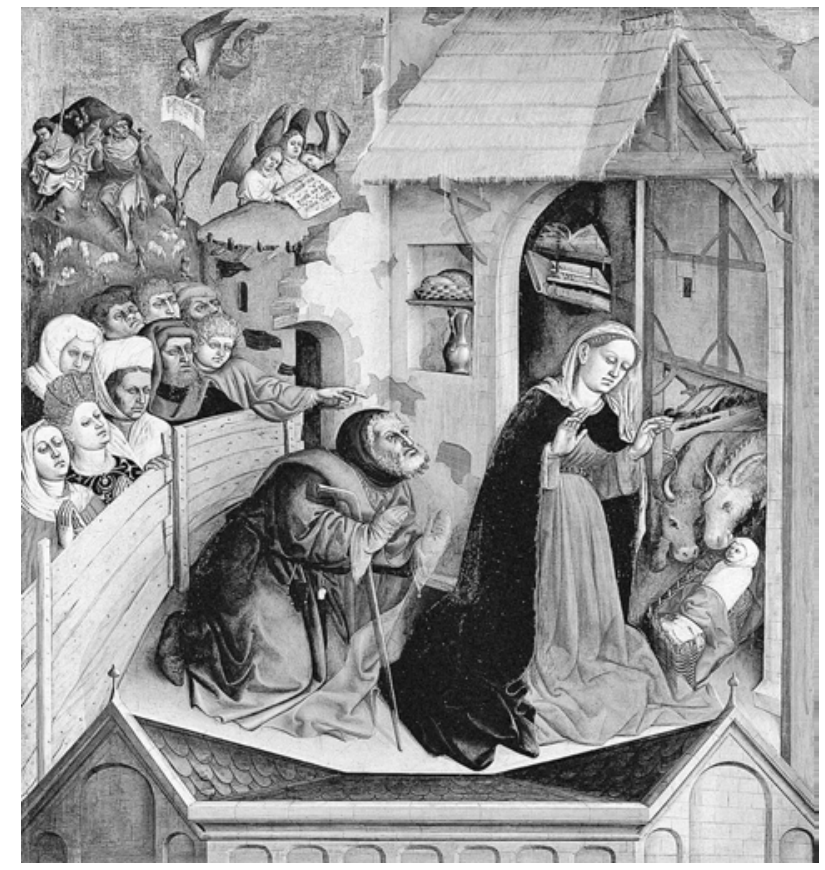

Abb. 17 Anbetung des Kindes aus dem Wurzacher Retabel. Unbekannter Maler in der Werkstatt Hans Multschers, 1437. Berlin, Staatliche Museen - Preußischer Kulturbesitz, Gemäldegalerie, Id.-Nr. 1621 (Foto: Staatliche Museen zu Berlin - Preußischer Kulturbesitz, Gemäldegalerie)

Schüchlin in Ulm, später auch der Bildschnitzer Tilman Riemenschneider in Würzburg. Kurz und gut: Die Künstler wurden bürgerlich.

Allerdings stehen soziale Stellung und Malweise nicht in direktem Bezug. $\mathrm{Zu}$ einer behäbigen, ruhigen Darstellungsweise, wie man sie bisweilen mit dem Stichwort »Bürgerlicher Realismus« verbindet, kam es nach 1430 durchaus nicht. Das hängt sicher auch mit modernen Vorstellungen von einer bürgerlich-biedermeierlichen Ästhetik zusammen, die in unangemessener Weise auf das Spätmittelalter übertragen wurden. Die Auftraggeber des 15. Jahrhunderts aus der Stadtbürgerschaft schätzten offenbar nicht nur Gefälliges. Und natürlich arbeiteten die besten Künstler der Zeit auch für hohe geistliche und weltliche Auftraggeber, so etwa Konrad Laib für Kaiser Friedrich III. ${ }^{30}$ und Hans Multscher für Herzog Ludwig VII. den Gebarteten von Bayern-Ingolstadt. ${ }^{31}$

Zusammengefasst ist unsere Suche nach intensivierter realistischer Darstellung in der Tafelmalerei um 1430 wenig erfolgreich gewesen. Mit dem Stichwort »Realismus« treffen wir offenbar nicht den Kern der Intentionen der Maler, sondern eher eine untergeordnete und durchaus nicht innovative Komponente des Schaffens dieser Zeit. 
Welchen Absichten aber folgen sie dann? Robert Suckale wies darauf hin, dass ein wesentliches neues Element in der Tafelmalerei dieser Zeit die gesteigerte Narrative war. ${ }^{32}$ Ich denke sogar, dieses Movens war das entscheidend Neue: Die Künstler erstrebten nicht so sehr einen gesteigerten Realismus als vielmehr eine nachvollziehbare Erzählung des Heilsgeschehens, insbesondere der Passion Christi, und zwar mit allen Mitteln, die ihnen zur Verfügung standen. Das erklärt auch die oben erwähnte intensive Rezeption italienischer Malerei des Trecento, die durch Giotto und dessen Nachfolge bereits früher eine Intensivierung erzählerischer Bildstrategien entwickelt hatte. Dahinter stand ganz offensichtlich die Absicht, den Betrachter nicht nur durch Kunstfertigkeit zu beeindrucken, sondern mehr noch ihn zur Andacht, zum intensiven Nacherleben der Passion anzuregen, ja geradezu zu zwingen, und zwar durch Bilder, die ihre Protagonisten in intensiver, überzeugend geschilderter Aktion zeigten. Dieses Movens der Innovation in der Zeit um 1430 vertiefend zu erforschen erscheint wesentlicher als die Suche nach mehr oder weniger intensiver Naturnachahmung.

\section{Literatur}

Auerbach, Erich: Mimesis. Dargestellte Wirklichkeit in der abendländischen Literatur. Bern/München 1946; zitiert nach der 5. Auflage 1971.

[Ausst.-Kat. Colmar 1991]: Ausst.-Kat. Der hübsche Martin. Kupferstiche und Zeichnungen von Martin Schongauer (ca. 1450-1491). Colmar, Musée d'Unterlinden, 1991. Strasbourg 1991.

[Ausst.-Kat. Frankfurt/Main 1975]: Ausst.-Kat. Kunst um 1400 am Mittelrhein. Ein Teil der Wirklichkeit. Hg. von Herbert Beck, Wolfgang BeeH und Horst Bredekamp. Frankfurt/M., Liebieghaus, 1975. Frankfurt/M. 1975.

[Ausst.-Kat. Köln 1978, Resultatband 1980]: Ausst.-Kat. Die Parler und der Schöne Stil 1350-1400. Europäische Kunst unter den Luxemburgern. Resultatband zur Ausstellung des Schnütgen-Museums in der Kunsthalle Köln. Hg. von Anton LEGNER. Köln 1980.

[Ausst.-Kat. Köln 1993]: Ausst.-Kat. Stefan Lochner, Meister zu Köln. Herkunft - Werke - Wirkung. Hg. von Frank Günter Zehnder. Köln, Wallraf-Richartz-Museum, 1993. Köln 1993.

[Ausst.-Kat. Ulm 1997]: Ausst.-Kat. Hans Multscher. Bildhauer der Spätgotik in Ulm. Katalog der Ausstellung des Ulmer Museums und des Württembergischen Landesmuseums Stuttgart. Ulmer Museum, 7.9.-16.11.1997. Ulm 1997.
[Ausst.-Kat. Wien 1997]: Ausst.-Kat. Conrad Laib. Wien, Österreichische Galerie Belvedere, Museum Mittelalterlicher Kunst - Unteres Belvedere, 19.9.-26.10.1997. Hg. von Arthur SALIGER. Wien 1997.

Baggio, Luca/Colalucci, Gianluigi/Bartoletti, Daniela (Hgg.): Altichiero da Zevio nell'oratorio di San Giorgio. Il restauro degli affreschi. Padova 1999.

Becksmann, Rüdiger (Hg.): Deutsche Glasmalerei des Mittelalters, Bd. II. Bildprogramme. Auftraggeber. Werkstätten. Berlin 1992.

BRENK, Beat: Tradition und Neuerung in der christlichen Kunst des ersten Jahrtausends. Studien zur Geschichte des Weltgerichtsbildes. Wien 1966 (Wiener byzantinistische Studien 3).

Brinkmann, Bodo/Kemperdick, Stephan: Deutsche Gemälde im Städel 1300-1500. Mainz 2002 (Katalog der Gemälde im Städelschen Kunstinstitut Frankfurt am Main 3).

Chapuis, Julien: Stefan Lochner. Image Making in FifteenthCentury Cologne. Turnhout 2004.

Clasen, Karl Heinz: Der Meister der Schönen Madonnen. Herkunft, Entfaltung und Umkreis. Berlin/New York 1974.

Collier, James Mitchell: Linear Perspective in Flemish Painting and the Art of Petrus Christus and Dirk Bouts. Phil. Diss. University of Michigan 1975; Ann Arbor 1983.

Dubois, Monique: Zentralperspektive in der florentinischen Kunstpraxis des 15. Jahrhunderts. Petersberg b. Fulda 2010 (Studien zur internationalen Architektur- und Kunstgeschichte 78).

Навеnicht, Georg: Die ungefassten Altarwerke des ausgehenden Mittelalters und der Dürerzeit. Diss. Göttingen 1999. Elektronische Publikation 2002: http://webdoc.sub.gwdg.de/ diss/2002/habenicht/index.html (09.02.2018).

Harms, Wolfgang (Hg.): Text und Bild, Bild und Text. DFGSymposion 1988. Stuttgart 1990 (Germanistische Symposien, Berichtsbände 11).

Heinzmann, Franz/Köhler, Mathias: Der Magdalenenaltar des Lucas Moser in der gotischen Basilika Tiefenbronn. Regensburg 1994 (Große Kunstführer 195).

Hoffmann, Sibylle: Der Meister der Pollinger Tafeln. Wege der Erneuerung in der bayerischen Malerei des mittleren 15. Jahrhunderts. Weimar 2007.

Kemperdick, Stephan: Rogier van der Weyden 1399/14001464. Köln 1999.

Köllermann, Antje-Fee: Conrad Laib. Ein spätgotischer Maler aus Schwaben in Salzburg. Berlin 2007 (Neue Forschungen zur deutschen Kunst 8).

Koreny, Fritz: Albrecht Dürer und die Tier- und Pflanzenstudien der Renaissance. Katalog der Ausstellung der Graphischen Sammlung Albertina Wien. München 1985.

Koreny, Fritz: A Coloured Flower Study by Martin Schongauer and the Development of the Depiction of Nature from 
van der Weyden to Dürer. In: The Burlington Magazine 133 (1991), 588-597.

Koreny, Fritz: Studienblatt Pfingstrosen. In: Ausst.-Kat. Colmar 1991, 107-111.

Lichte, Claudia: Meister Hartmann in Ulm. Ein Bildhauer "zwischen Hütte und Zunft«. In: Ausst.-Kat. Ulm 1997, 5360.

Lyna, Frédéric: Les miniatures d’un $\mathrm{ms}$. du »Ci nous dit« et le réalisme préeyckien. In: Scriptorium 1 (1946/47), 106-118.

Marrow, James H.: Passion Iconography in Northern European Art of the Late Middle Ages and Early Renaissance. A Study of the Transformation of Sacred Metaphor into Descriptive Narrative. Kortrijk 1979 (Ars Neerlandica 1).

Möhring, Helmut: Die Tegernseer Altarretabel des Gabriel Angler und die Münchner Malerei von 1430-1450. München 1997 (Beiträge zur Kunstwissenschaft 71).

Myers, Marshall Neal: Oberservations on the Origins of Renaissance Perspective: Brunelleschi, Masaccio, Petrus Christus. Phil. Diss. Columbia University 1978; Ann Arbor 1978.

Pinder, Wilhelm: Das Problem der Generation in der Kunstgeschichte Europas. Berlin 1926.

Pochat, Götz/WAgner, Brigitte (Hgg.): Internationale Gotik in Mitteleuropa. Graz 1990 (Kunsthistorisches Jahrbuch Graz 24).

RUPPRICH, Hans: Dürer. Schriftlicher Nachlass, Bd. 1. Autobiographische Schriften. Briefwechsel. Dichtungen. Beischriften, Notizen und Gutachten. Zeugnisse zum persönlichen Leben. Berlin 1956.

Schmidt, Gerhard: $\mathrm{Zu}$ einem Buch über den "Meister der Schönen Madonnen«. In: Zeitschrift für Kunstgeschichte 41 (1978), 61-92. Wieder in: Schмid t 1992, 229-268.

SCHмIDT, Gerhard: Kunst um 1400. Forschungsstand und Forschungsperspektiven. In: Pochat/Wagner 1990, 34-49.

ScнмidT, Gerhard: Gotische Bildwerke und ihre Meister. 2 Bde. Wien/Köln/Weimar 1992.

Scholz, Hartmut: Tradition und Avantgarde. Die Farbverglasung der Ulmer Besserer-Kapelle als Arbeit einer Ulmer »Werkstatt-Kooperative«. In: BECKSMANN 1992, 93-152.

Scholz, Hartmut: Die mittelalterlichen Glasmalereien in Ulm. Berlin 1994 (Corpus Vitrearum Medii Aevi Deutschland I,3).

Schürle, Wolfgang (Hg.)/Lichte, Claudia (Text): Meister Hartmanns Dornstadter Altar. Zwischen Hütte und Zunft. Ulm 2003 (Alb und Donau, Kunst und Kultur 37).

STANGE, Alfred: Kritisches Verzeichnis der deutschen Tafelbilder vor Dürer, Bd. 2. Oberrhein, Bodensee, Schweiz, Mittelrhein, Ulm, Augsburg, Allgäu, Nördlingen, von der Donau zum Neckar. Hg. v. Norbert Lieb. München 1970.

Suckale, Robert: Rezension von Clasen 1974. In: Kunstchronik 29 (1976), 244-255.

Suckale, Robert: Süddeutsche szenische Tafelbilder um 1420-
50. Erzählung im Spannungsfeld zwischen Kult- und Andachtsbild. In: HARMS 1990, 15-34; hier zitiert nach dem Wiederabdruck in: Suckale 2003 (2008), 59-85.

Suckale, Robert: Stil und Funktion. Ausgewählte Schriften zur Kunst des Mittelalters. Hg. von Peter Schmidt und Gregor Wedekind. München/Berlin 2003; 2. Aufl. 2008.

Suckale, Robert: Die Erneuerung der Malkunst vor Dürer. 2 Bde. Petersberg b. Fulda 2009.

WAgner, Berit: Bilder ohne Auftraggeber. Der deutsche Kunsthandel im 15. und frühen 16. Jahrhundert. Mit Überlegungen zum Kulturtransfer. Petersberg b. Fulda 2014 (Studien zur internationalen Architektur- und Kunstgeschichte 122).

Weilandt, Gerhard: Hans Multschers Lebensspuren. In: Ausst.-Kat. Ulm 1997, 17-30.

Weilandt, Gerhard: Die Sebalduskirche in Nürnberg. Bild und Gesellschaft im Zeitalter der Gotik und Renaissance. Petersberg b. Fulda 2007 (Studien zur internationalen Architekturund Kunstgeschichte 47).

Zipelius, Julia: Der »Utrechter Altar« und die Malerei um 1400 am Mittelrhein. In: Mainzer Zeitschrift 87/88 (1992/93), 11133.

\section{Anmerkungen}

1 Der hier vorgestellte Text ist die überarbeitete Fassung der Einleitung in die von mir geleitete Sektion »Früher Realismus - Junge Wilde? Malerei in Deutschland an der Schwelle der Neuzeit (143050)« auf dem II. Mittelalterforum Freiburg am 19. September 2013. Die Literaturhinweise beschränken sich auf das unbedingt Notwendige.

2 Zur Relativierung der überragenden Rolle der Zentralperspektive auch in der italienischen Malerei der Frührenaissance vgl. jetzt DuBOIS 2010.

3 Myers 1978. - Collier 1983.

4 Koreny 1994, 111. - Erstmals publiziert Koreny 1991. - Vgl. SUCKALE 2009, Textbd., 220.

5 Clasen 1974.

6 SucKale 1976. - SChmidt 1978.

7 Weilandt 2007, 683, Kat.-Nr. 10/V.1.b.1.

8 WeILANDT 2007, 196-202.

9 Diese Wortprägung verdanken wir PINDER 1926, 24: »Man ist schon weiter gekommen, wenn man weiß, daß auch Stile keine scharfen chronologischen Grenzen, keine einschichtig ihnen reservierten Zeiten haben; daß sie nicht im `Gänsemarsche` einander folgen, sondern sich übereinander, gegeneinander schieben, Gesamtstile nicht anders als Persönlichkeitsstile.«

10 Stange 1970, Kat.-Nr. 413. - Zipelius 1992/93, 79-82.

11 Schmidt 1990, 34f. - Der Begriff »réalisme préeyckien« wurde geprägt von LyNA 1946/47.

$12 \mathrm{Zu}$ dessen Quellen Brenk 1966, 235-237. - Marrow 1979, 5 , nennt dasselbe Phänomen »late medieval realism«. - Vgl. auch SuCKALE 2009, Textbd., $15 \mathrm{f}$. - Eine eindrückliche Beschreibung bei 
Auerbach 1946, 236-239, wo von einem »kreatürlichen Realismus« die Rede ist. Die Herleitung drastischer Passionsdarstellungen aus der erstarkenden bürgerlichen Kultur des 15. Jahrhunderts bei Auerbach ist allerdings fragwürdig, s. die folgenden Ausführungen.

13 Zu dieser Differenzierung vgl. Weilandt 2007, $98 \mathrm{f}$.

14 Eine Kritik der überkommenen Sehweise schon bei Suckale 2009, Textbd., 433-435.

15 BRINKMANN/KEMPERDICK 2002, 93-120, mit der älteren Literatur. Eine Identifizierung der botanischen und zoologischen Details S. 111. Es bleibt unverständlich, warum selbst ein Kenner der Naturstudien wie Fritz Koreny über die Malerei in Deutschland schreibt: »Die auf genauer Beobachtung beruhende Darstellungsweise geht letztlich auf die Eroberung der sichtbaren Welt durch die altniederländische Malerei zurück, als deren Begründer Jan van Eyck gilt.« KoRENY 1985, 14.

16 Erst in der zweiten Jahrhunderthälfte, bei Hans Pleydenwurff und Martin Schongauer, finden sie sich verstärkt wieder, s. Anm. 4 und Suckale 2009, Textbd., 362-365.

17 Zu dem Retabel von 1444 HofFMANN 2007, 79-129 und 227-231.

18 Köllermann 2007, $38 \mathrm{f}$.

$19 \mathrm{Zu}$ Hans Multschers steinernem Kargretabel mit seiner Signatur in Anlehnung an Jan van Eyck WEILANDT 1997, 18-20.

20 In erster Linie ist die Verglasung der Bessererkapelle des Ulmer Münsters zu nennen. Scholz 1992. - Scholz 1994, 135.

21 Ausst.-Kat. Köln 1993, 324f., Kat.-Nr. 46 (Dagmar R. TÄUBE). Chapuis 2004, 58-66.

22 Hierzu und zu weiteren Motivübernahmen Rogiers von Lochner Kemperdick 1999, 77.

23 Mit Bedacht wird der Maler der Wurzacher Retabelflügel in der Berliner Gemäldegalerie hier nicht Hans Multscher genannt, obwohl sich sein Name als vermeintliche »Signatur« auf den Tafeln befindet.
Die Skulpturen, die mit großer Sicherheit von Multscher stammten, sind verloren; auf sie und das Gesamtretabel bezieht sich die Künstlerinschrift, nicht auf die Malerei. WEILANDT 1997, 25-28.

24 Er erhält 1434 eine Abschlagszahlung »darumb ich varb und lasür zu Venedig gekauft hab«. MöHring 1997, 15.

25 Köllermann 2007, 37. - Zu Altichieros Fresken Baggio/ColaLUCCI/BARTOLETTI 1999.

26 Ein Appell an den kundigen Betrachter deutet sich auch bei Konrad Witz an (eine Publikation dazu bereite ich vor). Eine ausdrückliche Erwähnung von Kunstkennern gibt es jedoch erst in Albrecht Dürers Briefwechsel mit Jakob Heller, wo 1509 von den »kunstreichen « Menschen die Rede ist, die ein Meisterwerk von einer »baurn-tafel« zu unterschieden wissen. Rupprich 1956, 69, Nr. 16. - Auch der Sohn des Veit Stoß verweist bei der Einschätzung des letzten Schnitzretabels seines Vaters auf die »arteficiosi magistri in illa arte», vgl. jetzt grundlegend WAGNER 2014, bes. 36-42, wo zu Recht gegen die relativierende Interpretation von НАвENICHT 2002, 123-127, Stellung bezogen wird.

27 HOFFMANN 2007, 25-78 und 225-227.

28 HeInZMANN/KöHLER 1994.

29 Den Übergang von der Hütte zur Zunft zeigt LiChте 1997 an dem Beispiel des Ulmer Bildhauers Meister Hartmann, der zunächst für die Bauhütte des Ulmer Münsters als Steinbildhauer tätig war, dann aber das Ulmer Bürgerrecht erwarb und das älteste dort erhaltene Schnitzretabel, den sog. Dornstädter Altar, schuf. SCHÜRLE/Lichte 2003 .

30 Kreuzaltarretabel des Grazer Domes, 1457. Köllermann 2007, 135-146.

31 Steinerne Visierung für das Grabmal des Herzogs, um 1430. München, Bayerisches Nationalmuseum. Ausst.-Kat. Ulm 1997, 302-306. 32 Suckale 1990. 
Stavros Vlachos

\section{VorläUfer des Frühen Realismus in der Malerei um 1400}

Abb. 1 Bethlehemitischer Kindermord aus einem Marienretabel. Nürnberg, um 1400/10. Nürnberg, Germanisches Nationalmuseum, Inv.-Nr. Gm114 (Foto: Germanisches Nationalmuseum, Nürnberg)

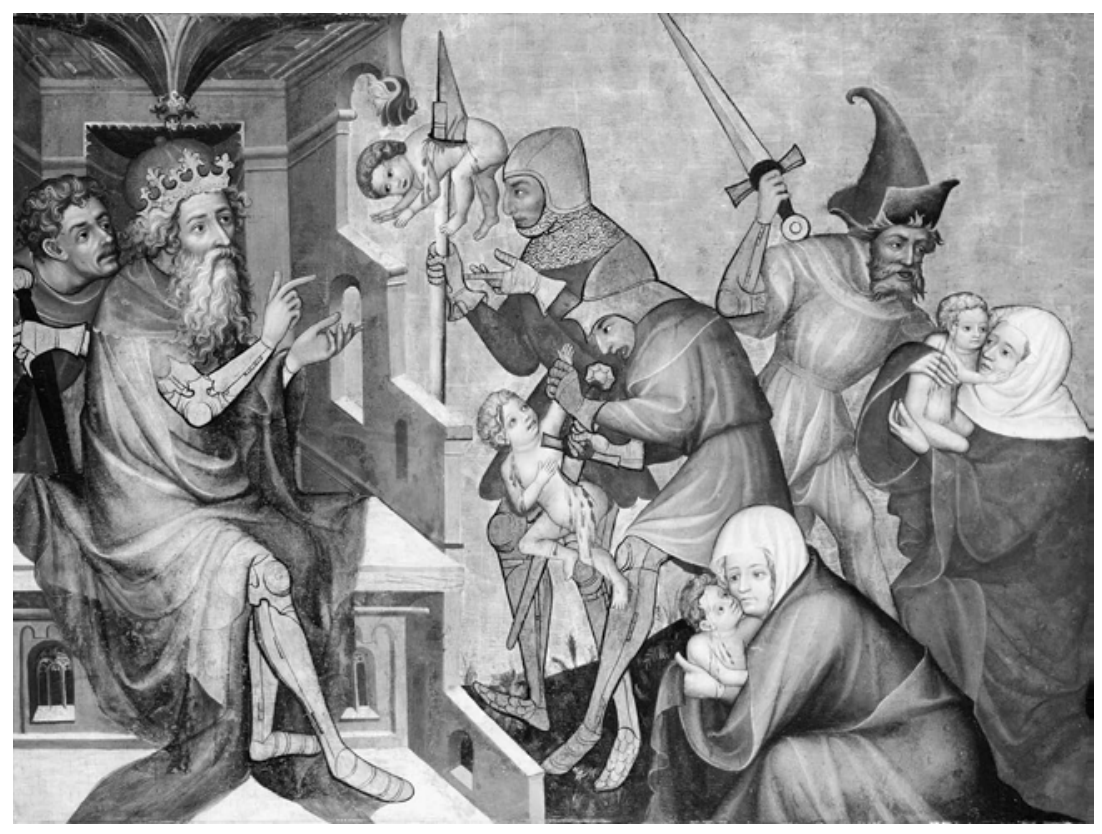

Die Malerei um 1400 gilt in der Kunstgeschichte als eine Stilepoche, in der europaweit ideale Schönheit herrschte. ${ }^{1}$ Weitere Stilmerkmale sind ein idealisierender Figurenstil höfischer Prägung, fließende Gewänder, helle Farben und die Zurückhaltung von Emotionen, auch in Darstellungen mit dramatischen Situationen wie den Leidensstationen der Passion Christi. Nicht zufällig bezeichnet man die Kunst dieser Zeit, außer mit den Begriffen »Internationaler Stil um 1400« oder »Internationale Gotik«, oft als »Schönen Stil «. ${ }^{2}$ Viele dieser Charakteristika sind im Bethlehemitischen Kindermord aus dem Marienaltar, der sich ursprünglich in der Frauenkirche in Nürnberg befand (um 1400/10), zu erkennen (Abb. 1). ${ }^{3}$

Trotz des brutalen Vorgangs zeigen die gerade getöteten Kinder keinen Ausdruck von Schmerz, und auf den Gesichtern der Mütter zeichnet sich keine Verzweiflung $\mathrm{ab}$.

Neben der Hauptströmung existierte jedoch eine Tendenz, deren Kennzeichen Expressivität und Dramati- sierung waren. Beispiel dafür ist der Bethlehemitische Kindermord Meister Bertrams (um 1345-1415) aus dem ehemaligen Altar der Hamburger Petri-Kirche von 1379/83 (Abb. 2). ${ }^{4}$

Die Komposition weist Ähnlichkeiten mit dem Bild des Nürnberger Marienaltars auf. Herodes sitzt in beiden Darstellungen am linken Bildrand und ordnet den Tod der Kinder an. In der Mitte und am rechten Rand des Hamburger Bildes vollzieht sich das Verbrechen. Meister Bertram mildert im Gegensatz zur Nürnberger Darstellung die Affektschilderung nicht ab, sondern begleitet die Grausamkeit des Vorgangs mit der entsprechenden Emotionalisierung. Dominierende Figur ist der Soldat mit der hasserfüllten Miene im Bildzentrum, der mit seiner linken Hand einen nackten Säugling in der Luft hält. ${ }^{5} \mathrm{Zu}$ gleich holt er mit der rechten Hand, in der ein krummes Kurzschwert zu sehen ist, zum Schlag aus. Die offenen Augen des Kindes verraten, dass es noch lebt, obgleich mehrere blutende Stichwunden zu sehen sind, eine davon 


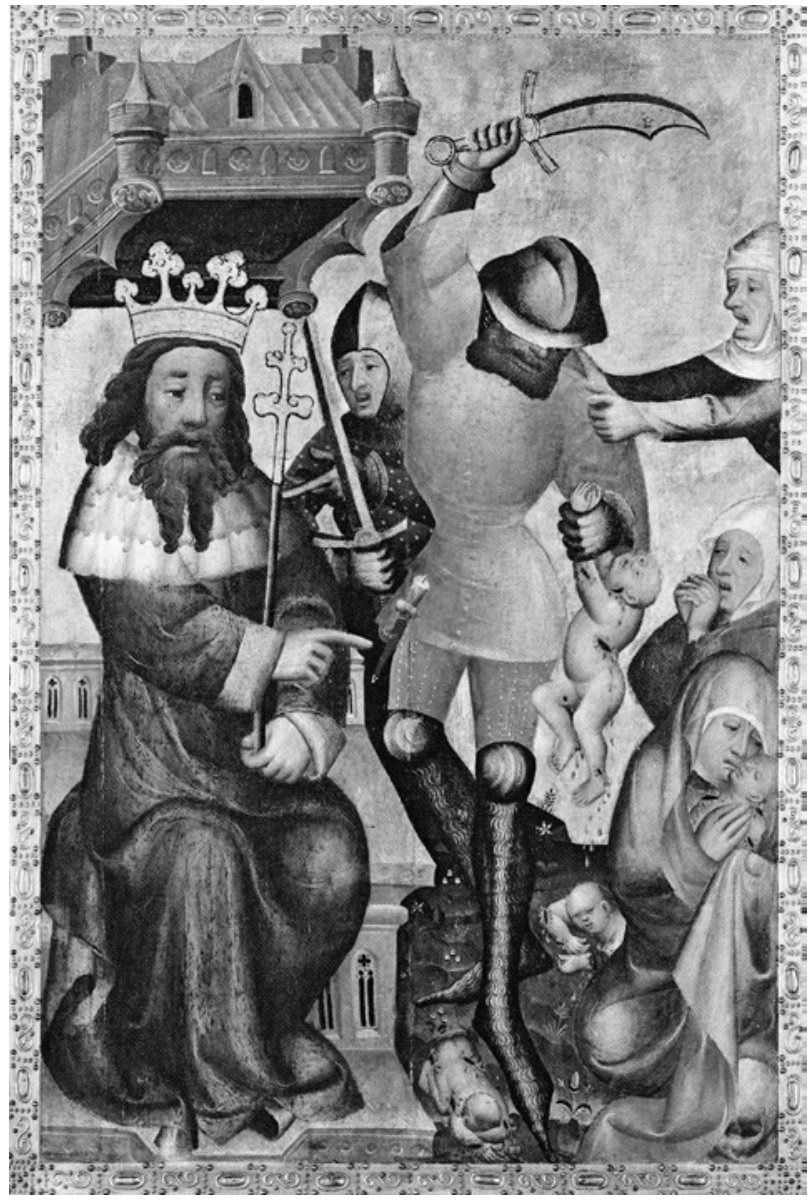

Abb. 2 Bethlehemitischer Kindermord des Hochaltarretabels der Hamburger St.-Petri-Kirche. Meister Bertram von Minden, 1379/83. Hamburg, Kunsthalle, Inv.-Nr. HK-500 (Foto: Archiv Stavros Vlachos)

im Gesicht. Meister Bertram suggeriert einen qualvollen und langsamen Tod der Kinder. Dramatischer noch wirkt die vom rechten Bildrand angeschnittene Mutter, die in einem verzweifelten Versuch, ihr Kind zu retten, mit beiden Händen den Soldaten an der linken Schulter packt. Der Maler reduziert diese Frau radikal, nur die Arme und ihr vom Schrei verzerrtes Gesicht stellt er dar, um den Blick des Betrachters auf das Wesentliche zu fokussieren, die Geste und den Gesichtsausdruck der leidenden Mutter. Am rechten Bildrand befinden sich noch zwei Mütter. Eine davon scheint mit gefalteten Händen Herodes anzuflehen, die zweite hält in ihren Armen ihr totes Kind und betrauert es. Den drei Frauen gemeinsam sind ihre vom Leid gezeichneten Gesichter. Andererseits verbildlicht Meister Bertram durch die differenzierte Mimik und Gestik der drei Mütter ein breites Spektrum an Ge- fühlen wie Verzweiflung, Trauer und Hilflosigkeit sowie individuellen Reaktionen. So verleiht er seinem Bild im Unterschied zu der eher stilisierten Mimik der Mütter und der Kinder der Nürnberger Altartafel eine abwechslungsreiche Handlung. Davon kündet ein ergreifendes Detail: der tote Säugling, der bäuchlings in der Mitte des Vordergrunds neben dem Soldatenfuß liegt. Das Kind suchte vor seinem Tod vergeblich Schutz und verbarg sein Gesicht in den Armen. Da Meister Bertram vom Schönheitsideal und der lyrischen Stimmung des Zeitstils abweicht und den Kindermord mit der dazu gehörenden Dramatik veranschaulicht, wirkt seine Darstellung "realistischer« als das Nürnberger Bild. Aber auch innerhalb des Petri-Altars überbietet keine andere Darstellung den Bethlehemitischen Kindermord an Ausdruckskraft. Die Kindermordszene zeigt, dass man beiden Darstellungsmodi um 1400, der Idealisierung und der Expressivität, im selben Werk begegnen kann, sei es ein Altar oder eine einzelne Darstellung.

Ziel des vorliegenden Beitrags ist es, sowohl einen kritischen Überblick über den Forschungsstand zur »Nebentendenz « zu geben als auch ihre Manifestation in der Malerei um 1400 exemplarisch zu untersuchen. Dies soll am Beispiel der Tafelmalerei im deutschsprachigen Raum geschehen. Ausgangspunkt ist die These, dass die Expressivität um 1400 zwar eine Nebenerscheinung zum Zeitstil bildet, aber keinesfalls ein Randphänomen ist. Hier stellt sich folgende Frage: Welche Stilmittel benutzen die Künstler, um Expressivität zu erzeugen, und wie wirkt sie sich auf den Inhalt der Bilder aus? Ausblicke gelten der französischen und niederländischen Buchmalerei, um gattungsspezifische Aspekte zu behandeln. Mit ihrem kleinen Format und der Bestimmung für individuelle Betrachter bot die Buchmalerei den Künstlern einen größeren Spielraum, um die tradierte Ikonografie zu differenzieren, ja sogar extreme Lösungen einzuführen.

Der Beitrag konzentriert sich auf Passionsdarstellungen, die wegen ihrer Thematik am häufigsten Gelegenheit $\mathrm{zu}$ expressiven Zügen boten. Ein weiteres Anliegen ist, Ausblicke auf die deutsche Tafelmalerei ab $1430 \mathrm{zu}$ geben. Diese Jahre gelten als Zäsur: Die ideale Schönheit wird zugunsten eines zunehmenden Realismus mit vermehrt drastischer Darstellungsweise aufgegeben. Mein Beitrag will zeigen, dass die Drastik der Schilderung ab 1430 bereits während des Internationalen Stils um 1400 vorbereitet wurde. 


\section{Die Erforschung der »Nebentendenz«}

Auf die Expressivität um 1400 hat die Forschung schon vor dem Zweiten Weltkrieg hingewiesen - ein Verdienst Karl Oettingers, der als erster das Phänomen erkannt hat. Oettinger bemerkte an Beispielen überwiegend böhmischer Tafelbilder des späten 14. Jahrhunderts einen "allgemeinen Verhäßlichungstrieb «. ${ }^{6}$ Von größerer Bedeutung ist seine Feststellung über die Verbreitung der Expressivität: "Dieser neue, ausdrucksuchende, wieder durchaus 'gotischer Stil ist keineswegs auf Böhmen beschränkt, sondern tritt, was bisher noch nicht herausgestellt worden ist, um 1390 allgemein in allen Kunstgebieten auf . $^{7}$ Falsch ist hingegen meines Erachtens seine weitere Feststellung über die kurze Dauer der »Ausdruckssteigerung «, die für Oettinger nur wenige Jahre geherrscht hat. ${ }^{8}$ Das heißt, dass sich die Expressivität seiner Auffassung zufolge auf das Ende des 14. Jahrhunderts beschränkt.

In einem Aufsatz von 1936 bezeichnete Oettinger die Expressivität am Ende des 14. Jahrhunderts als »wilden Stil «" ${ }^{9}$, malerisch-expressive 'wilde` Phase von $1390{ }^{10}$ oder auch als »italienfeindlich $«$ und $»$ widerrealistisch ${ }^{11}$. Die Mittel dieses »wilden Stils« umfassen für Oettinger vor allem die Hässlichkeit, die »Beweglichkeit und Wildheit der Gestalten ${ }^{12}$, die »derbe Untersetztheit $«^{13}$ der Figurenproportionen und die »Drastik der Köpfe und der Gesten ${ }^{14}$. Der Verfasser blieb auch hier bei seiner These der kurzen Dauer des Stilphänomens, das er auf den Zeitraum von 1385 bis 1395 festlegt. ${ }^{15}$

In einem kommentierten Überblick des Forschungsstands über die altböhmische Malerei charakterisierte Oettinger erneut die Nebentendenz um 1400 mit den unpräzisen und negativen Begriffen »häßlicher « und »wilder Stil«. ${ }^{16}$ Das Hauptcharakteristikum ist für Oettinger nach wie vor die Hässlichkeit: „Das auffälligste Merkmal dieses Stils, nach dem er zur Verständigung benannt werden sollte, ist die Verhäßlichungstendenz, die in den Köpfen glurende Augen, aufgebogene Nasen, gnomische Falten, froschartig große Münder sucht, beim Stehen eigentümlich plattfüßig die Fersen aus der Kontur hervorstoßen läßt und die Silhouetten, das Gesäß hervortreibend, plebeisch knickt und unterbricht $«{ }^{17}$ Trotz seiner stark gefühlsbestimmten Ausdrucksweise erfasste Oettinger eine Reihe von Merkmalen des Stilphänomens, scheint jedoch diese Abweichung von der Norm beziehungsweise von der Idealisierung zu kritisieren, indem er Worte wie "plebeisch « benutzt. Sein Verdienst besteht darin, auf die Internationalität des »wilden Stils« aufmerksam gemacht zu haben: "Auch seine Erscheinung ist nicht auf Böhmen beschränkt, sondern von allgemeiner Gültigkeit «. ${ }^{18}$

Oettinger beschäftigte sich mit dem Stilphänomen noch einmal kurz in einem letzten, nach dem Zweiten Weltkrieg entstandenen Aufsatz, in dem er allerdings seine gewohnte Terminologie beibehalten hat. So spricht er wieder vom » häßlichen « Stil der Achtzigerjahre « ${ }^{19}$ des 14. Jahrhunderts und von der »dumpfen und derben Häßlichkeit der Bertram-Phase «. ${ }^{20}$ In seinen Aufsätzen hat Oettinger keine Interpretation der Wirkung oder des Zwecks der Verhässlichung geliefert. Die Erklärung für die Manifestation der Tendenz suchte er im »dämonischen Geist des späten 14. Jahrhunderts «. ${ }^{21}$ Ein Verdienst Oettingers besteht jedoch darin, die Verbindung zwischen der Expressivität um 1400 und der ab 1430 erkannt zu haben: "Sie [die um 1390 Jungen, S. V.] aber hielten, wie es die späteren Arbeiten des Mainzer Meisters von Oberstein zu erweisen scheinen, auch in den nächsten Jahrzehnten des frühen 15. Jahrhunderts im Wesen an diesem Ausdruck fest und boten so die Brücke zu stellenweisem Wiederaufleben um 1430 (Worcester-Meister) bei schon neuen, der Stufe des Flémallers entsprechenden Sprachmitteln ${ }^{22}$

Unabhängig von den Studien Oettingers veröffentlichte Frédéric Lyna im Jahre 1946 einen Aufsatz über expressive Züge in der flämischen Buchmalerei der Zeit um 1390-1410. Für seine Untersuchung verwendete Lyna den Begriff des »Realismus vor Jan van Eyck« (»realisme préeyckien «). ${ }^{23}$ Lyna meint damit allerdings keinen Detailrealismus im Sinne der altniederländischen Malerei durch die Wiedergabe von Stoffen und Texturen, sondern einen Realismus der Handlung, des Ausdrucks und der Stimmung. ${ }^{24}$ Es ist allerdings fraglich, ob der Begriff Lynas das Stilphänomen wirklich trifft. Denn es handelt sich in vielen Fällen um eine ausdrucksstarke Zuspitzung des Dargestellten. So schreibt Lyna über eine »compréhension juste et dramatique des attitudes, des gestes et de l'expression de visages ${ }^{25}{ }^{25}$

Die Forschungen Oettingers und Lynas erfassten die Existenz der Expressivität um 1400 und einige ihrer Teilaspekte, sie fanden jedoch wenig Beachtung. Erst Erwin Panofsky hat das Stilphänomen mit seiner Studie über die altniederländische Malerei im Bewusstsein verankert und bezeichnete es auf seine eigene poetische Weise als »Nachtseite des Internationalen Stils «. ${ }^{26}$ Panofsky erklärt die Expressivität um 1400 durch eine tiefe Unsicherheit, Angst vor dem Tod und Melancholie der Zeit, die sich auch in der Dichtung ausdrückt, als Manifestation einer 
sozialen, wirtschaftlichen und religiösen Krise. ${ }^{27}$ Folgt man der Argumentation Panofskys, dann wäre jede Zeit, die zum Beispiel melancholische Dichtung hervorbringt, automatisch eine Krisenzeit. Darüber hinaus entstanden ausdrucksmächtige Bildformeln und Werke lange vor der Zeit um 1400. Bereits am Ende des 13. Jahrhunderts tauchen die ersten Vesperbilder und vor allem die so genannten Crucifixi dolorosi auf, die Leidenskruzifixe. Die überbetonten Leidenszüge von Jesus und Maria wurden jedoch in Skulpturen um 1400 erheblich abgemildert. Nicht zufällig charakterisiert man die Pietàdarstellungen dieser Zeit als »Schöne Vesperbilder «. Aber auch hier gibt es Ausnahmen. Diese sind meines Erachtens nicht auf eine vermeintliche Krise zurückzuführen, sondern auf den Wunsch des Auftraggebers oder auf den Personalstil einzelner Künstler.

Den Begriff Panofskys, »Nachtseite des Internationalen Stils«, übernahm der Ausstellungskatalog von 1975, dessen Thema die mittelrheinische Kunst um 1400 war, darunter die expressiven Tendenzen. ${ }^{28}$ Die Autoren des Katalogs griffen auch auf das Erklärungsmodell Panofskys zurück, das diese Expressivität als Ausdruck einer Krise interpretiert, und gingen einen Schritt weiter, indem sie das Stilphänomen im entsprechenden Katalogteil mit der Überschrift »Die geschichtliche Krise und ihr Ausdruck in der Kunst « kennzeichnen. ${ }^{29}$ Es stellt sich die Frage, ob die Expressivität um 1400 wirklich Ausdruck einer Krise oder eines »Krisenbewußtseins « der Kunstgeschichte seit 1900 ist, wie Jürgen Paul schreibt: »In diesem Krisenbewußtsein verfestigte sich das Bild der Kunst als `Symbol und Symptom` einer Zeit (Hans Sedlmayr), der Kunst als Spiegel der Wirklichkeit des geschichtlichen Lebens, seiner realen und geistigen Krisen und Umbrüche, das die deutsche Kunstgeschichtsschreibung (Georg Dehio, Wilhelm Pinder) besonders aus der Analyse der Geschichte der deutschen Kunst destillierte ${ }^{30}{ }^{30}$ Die Erklärungsproblematik der Kunst um 1400 allgemein formulierte Gerhard Schmidt treffend: "Ist es - beispielshalber - nicht paradox, daß in Prag jener Zeit einerseits schon die religiöse Krise gärte, während andererseits noch besonders zarte und raffinierte Kunstwerke entstanden? War hier ein kollektiver Verdrängungsmechanismus am Werk, oder dominierte einfach der `höfisch` geprägte Geschmack der maßgeblichen Auftraggeberschicht - unabhängig von der Parteinahme des einzelnen? Oder war die lokale Stiltradition schon so fest etabliert, daß sie ein flexibleres Reagieren der Künstler auf den geistesgeschichtlichen Wandel verhinderte? ${ }^{31}$ Selbstverständlich könnte man auch hier »krisenmäßig« interpretieren, um sowohl die Idealisierung als auch die Expressivität um 1400 als die beiden Seiten derselben Medaille zu sehen ${ }^{32}$, als Verdrängung und direkte Manifestation derselben »Krise«.

Die Expressivität in der deutschen Kunst nimmt jedoch ab ca. 1430 und während des 15. Jahrhunderts zu. Soll man das gesamte 15. Jahrhundert als "Krise« deuten? Wohl nicht, da diese Drastik überwiegend in religiösen Werken und vor allem in der Passion Christi auftritt, die dadurch dramatisiert wird, um an die Gefühle des Betrachters zu appellieren. In dieser Hinsicht sind ausdrucksmächtige Bilder als Zeugnisse einer zunehmenden Religiosität und Frömmigkeit zu verstehen. Dazu kommen der Erfindungsreichtum und die persönliche Bildsprache, ja Freiheit, bestimmter Künstler.

Ein solches Interpretationsmodell hat Robert Suckale für die Tafelmalerei ab ca. 1420 vorgeschlagen, der am Beispiel der Schergen in der Kreuztragung des in Regensburg tätigen Worcester-Meisters um 1425 schreibt: »Das ist nicht als Reflex einer zunehmenden brutalen Zeitwirklichkeit zu verstehen, die so nicht nachgewiesen ist. Sondern es handelt sich um 〉Passionsrealismus denn es verwirklicht bildlich den von Psalmisten ausgesprochenen Gedanken von der den Guten umringenden Hundemeute (circumdederunt me canes multi, Psalm 21,17) «. ${ }^{33}$ Erich Auerbach bezeichnete 1946 das Phänomen und seine drastische Darstellungsweise am Beispiel der Literatur des 15 . Jahrhunderts als »kreatürliche Realistik «. ${ }^{34}$ Auerbach schrieb, im 15. Jahrhundert habe die Einbettung der Ereignisse der Heilsgeschichte in das gegenwärtige tägliche Leben des Volkes einen so hohen Grad erreicht, dass der religiöse Realismus Zeichen von Übersteigerung und von roher Verkommenheit biete. ${ }^{35}$ Die Ursprünge dieser Übersteigerung sind bereits in der Malerei um $1400 \mathrm{zu}$ finden. Und die Begriffe "Passionsrealismus« oder »religiöser Realismus« decken oft die expressiven Stilmerkmale ab. Die Schergen in der Kreuztragung des Worcester-Meisters agieren brutal und sind darüber hinaus karikiert, während Jesus als passives Opfer und Dulder der Misshandlungen erscheint.

In jüngerer Zeit hat vor allem Gerhard Schmidt mit einem Aufsatz von 1990 auf die Nebentendenz in der Kunst um 1400 verwiesen und sie in einem weiteren Aufsatz von 1995 ausführlicher behandelt. Treffend ist seine Bemerkung: »Diese Nebenströmung ist aus dem Gesamtbild der Kunst um 1400 nicht wegzudenken und stellt deshalb deren generelle Qualifikation als `schön « nachdrücklich in Frage. Ihre Vertreter folgen zwar in forma- 
ler Hinsicht (namentlich in der üppigen Drapierung der Gewänder) durchaus dem Zeitstil, neigen aber zu Emotionalisierung und Dramatisierung der Bildinhalte und ganz allgemein - zur Übersteigerung des Ausdrucks bis an die Grenze der Karikatur «. ${ }^{36}$ Für seinen zweiten Aufsatz griff Schmidt auf den Begriff Lynas zurück und charakterisierte selbst die Expressivität um 1400 zumindest im chronologischen Sinne als "voreyckische[n] Realismus «. ${ }^{37}$ Eines ähnlichen Begriffs bediente sich auch Maurits Smeyers am Beispiel der flämischen Buchmalerei um 1400. Allerdings definiert er den Begriff widersprüchlich: »Man bezeichnet diese Strömung als prä-eyckschen Realismus, weil sie dem ausgesprochen realistischen Stil van Eycks und seiner flämischen Zeitgenossen vorausgeht. Der Begriff `Realismus` meint hier nicht, dass das Dargestellte eine präzise Nachbildung der Wirklichkeit sei «. ${ }^{38}$ Dass es um 1400 Versuche gab, die Wirklichkeit zu erfassen, steht außer Zweifel. Ist das aber ausreichend, um von einem »voreyckischen Realismus« zu sprechen? Smeyers schreibt zur Farbgestaltung in der flämischen Buchmalerei um 1400: "Diese außergewöhnliche Technik der Farbmodellierung steigert die Wirklichkeitsnähe und verweist auf die frühe flämische Tafelmalerei. Außerdem zeigt die Miniaturkunst jener Zeit eine Vorliebe für Detailrealismus und für die Wiedergabe von Texturen «. ${ }^{39}$ Andererseits schreibt er: "Auch in der Buchmalerei jener Zeit hatte der Realismus Einzug gehalten. Das führte zu einer thematischen Neuorientierung und einer gesteigerten Expressivität «. ${ }^{40}$ Folgt man den Bemerkungen von Smeyers, dann kombinierte die Malerei um 1400 Charakteristika, von denen einige auch in der späteren Malerei Kontinuität erfuhren. Ein grundlegendes Problem besteht hier darin, dass einerseits die altniederländische Tafelmalerei zum Maßstab erhoben wird, andererseits die eigene Entwicklung der Kunst um 1400 vernachlässigt wird. $\mathrm{Zu}$ Recht betonte Smeyers, dass die »realistischen " Tendenzen um 1400 andere Akzente setzten. Anders als der Verfasser behauptet, beschränkten sie sich aber nicht nur auf die flämische Malerei dieser Zeit. ${ }^{41}$

Der Begriff »vor- oder prä-eyckscher Realismus« Lynas, Schmidts und Smeyers' ist irreführend, da diese Autoren eine andere Bildsprache meinen als den (Detail-) Realismus eines Jan van Eyck. Schmidt hat gezeigt, dass expressive Züge bereits im zweiten Viertel des 14. Jahrhunderts anzutreffen sind, die in der Zeit ab 1350 vermehrt ins Bild gesetzt werden. ${ }^{42}$ Er hält jedoch die Expressivität um 1400 - der Zeitraum sind die Jahre zwischen 1390 und $1420^{43}$ - für ein eigenständiges Phä- nomen, das sich teilweise in der Malerei ab 1430 fortsetzt. ${ }^{44}$ Dazu konstatiert er: »Tatsächlich hat diese Richtung ihre, bis tief ins zweite Viertel des 15. Jahrhunderts ungebrochene, Vitalität mehrfach bewiesen; mit dem Hinweis auf Hans Multschers Wurzacher Altar von 1437 sei das wenigstens angedeutet. Man könnte sich, darüber hinaus, sogar fragen, ob es nicht auch so etwas wie einen nacheyckischen realismus gegeben hat, zu dem sich manche Maler der Spätgotik - vor allem in Deutschland - hingezogen fühlten; an Beispielen dafür mangelt es nicht ${ }^{45}$

Diese Ansicht möchte ich teilen und zeigen, dass es in der deutschen Tafelmalerei ab 1430 nicht nur einen Bruch gab, sondern auch Kontinuität in Bezug auf drastische Darstellungsweisen, die bereits in der Malerei um 1400 zu finden sind. Gleichzeitig geht es um die Frage, welche Merkmale die Drastik um 1400 konstituieren. Schmidt nennt zum Beispiel: »untersetzte, verhäßlichte Figuren; ausdrucksvolle Mimik und lebhafte Körpersprache; ein so enger wie seichter Bildraum, den die Dynamik der dargestellten Vorgänge gleichsam zu sprengen droht «. ${ }^{46}$

Schmidt und seine Vorgänger operierten in Bezug auf die Drastik um 1400 mit Feststellungen wie der oben erwähnten und Assoziationen, welche lediglich die Oberfläche des Stilphänomens streifen. Es fehlen jedoch grundlegende Bildanalysen der jeweiligen Werke und eine präzisere Erfassung der Darstellungsmittel. Alle bis jetzt genannten Autoren behandelten nur das auf den ersten Blick Offensichtliche. Es gibt jedoch in der Malerei um 1400 Besonderheiten, die über Karikierung, Proportionen und Gestik hinausgehen. Darauf hat Frank Olaf Büttner aufmerksam gemacht: »Eine stilisierende Tendenz läßt sich auch daran beobachten, daß in der frühniederländischen Tafelmalerei vermieden wurde, wofür die Malerei der Internationalen Gotik Extreme gekannt hatte, nämlich Hauptgestalten einer Szene in elliptischer Darstellung zu zeigen, das heißt, in einem verunklärenden Situationsrealismus: vom Bildrand überschnitten, verhüllt oder vom Betrachter abgekehrt «. ${ }^{47}$ Ähnliche Gestaltungsmittel, die ein Randphänomen der mittelalterlichen Kunst konstituieren, behandelt Büttner in einem weiteren Aufsatz über Werke der Zeit um 1300, in dem er auch Ausblicke über die Kunst um 1400, überwiegend die Buchmalerei, gibt. So zeigt er Varianten von Verhüllung und Entblößung Jesu durch seine Peiniger als ein Verfahren, um Jesus zu erniedrigen. ${ }^{48}$ Der Verfasser hat auch den Versuch unternommen, den Realismus um 1400 und ab 1430 zu präzisieren und klar zu definieren. So unter- 


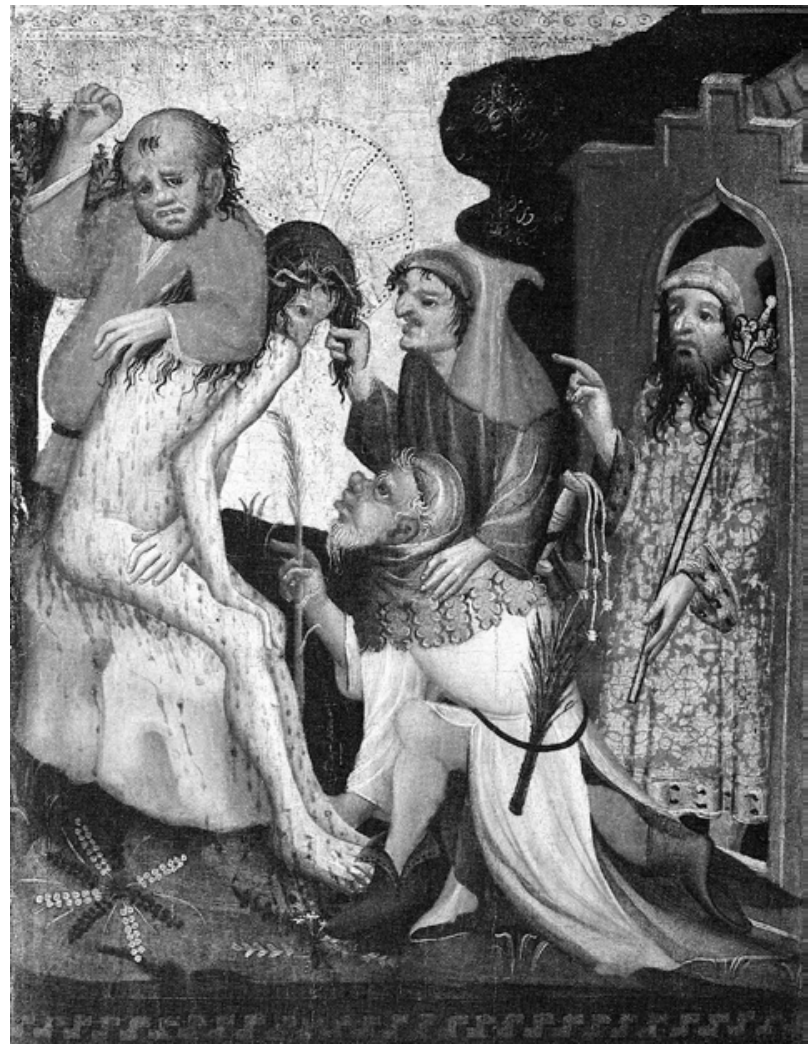

Abb. 3 Verspottung Christi aus dem Obersteiner Retabel. Meister des Obersteiner Altars, um 1400. Idar-Oberstein, Felsenkirche (Foto: Archiv S. Vlachos)

scheidet er zwischen einem "Realismus des Narrativen" um 1400 und einem »Realismus des Deskriptiven« der altniederländischen Tafelmalerei. ${ }^{49}$

Es ist meine These, dass zum Beispiel die Hässlichkeit der Schergen in gewissen Bildwerken an Ausdruckskraft gewinnt, da zugleich das Antlitz Christi nur partiell oder gar nicht zu sehen ist. Die Drastik um 1400 betrifft hier neuartige Formulierungen der Ikonografie, ungewohnte Kompositionen und Figurenkonstellationen, darunter extreme Verdeckungen oder Überschneidungen von Jesu Ansichtigkeit. Es handelt sich um eine besondere Realismusvariante, die nicht mit dem Oberflächenverismus oder Detailrealismus der altniederländischen Meister zusammenhängt. Diese Variante umfasst dagegen, wie oben gesagt, einen Realismus der Handlung und der Stimmung. Teil dieses Realismus war eine expressive Bildsprache. Diese kann auch ohne überzeichnete Mimik und Gebärden auskommen oder in Kombination mit solchen Mitteln operieren. Bestimmte Bilder gewinnen durch die Art der Inszenierung an Expressivität, ohne dass Charakteristika wie Physiognomien deformiert werden müssen.
In seltenen Fällen finden sich alle genannten Gestaltungsmittel in einer einzelnen Darstellung (Abb. 3).

Nicht zuletzt gehe ich von der These aus, dass die Expressivität um 1400 häufig in Werken unterschiedlicher Funktionszusammenhänge anzutreffen ist. Aus diesem Grund sind Gegenstand des Beitrags Altartafeln, kleinformatige Gemälde, die der privaten Andacht dienten, und illuminierte Handschriften.

\section{Aspekte der Nebentendenz um 1400}

Ein oberrheinisches Täfelchen aus der Zeit um 1410-20, das einst den linken Flügel eines für den privaten Gebrauch bestimmten Diptychons bildete, zeigt sowohl die Expressivität um 1400 als auch ihre Einflüsse auf die Tafelmalerei ab 1430 (Abb. 4). ${ }^{50}$

Michael Wolfson hat die Kreuztragung des Täfelchens zum Vergleich mit der Szene der Kreuztragung des Meisters der Karlsruher Passion (tätig in Straßburg zwischen 1420 und 1460) herangezogen. ${ }^{51}$ Es ging dabei um die Übernahme von Motiven aus dem Täfelchen seitens des Meisters der Karlsruher Passion. Hingewiesen wurde zum Beispiel auf die sich nach vorne bewegenden Soldaten und den Anführer, der Jesus an einem Strick zerrt, in der Kreuztragung des Täfelchens. ${ }^{52}$ Diese Komposition findet sich auch in der Kreuztragung des Meisters der Karlsruher Passion. Eine weitere Gemeinsamkeit bezieht sich nach Wolfson auf die Art und Weise, wie Jesus in beiden Kreuztragungen den Querbalken des Kreuzes mit den nach hinten gebogenen Armen hält. ${ }^{53}$ Auf den zweiten Blick erkennt man meines Erachtens noch ein weiteres ähnliches Bildelement. Der Schergenanführer, der in der Kreuztragung des Täfelchens Jesus vorantreibt, ist als Rückenfigur konzipiert. Er dreht jedoch seinen Kopf nach links, um Jesus anzuschauen. Eine ähnliche Körperhaltung hat auch der Soldat, der ebenfalls Jesus am Strick führt, in der Gefangennahme des Meisters der Karlsruher Passion. ${ }^{54}$

Von diesen ikonografischen Gemeinsamkeiten abgesehen wurde das Täfelchen als Zeugnis der expressiven Nebentendenz um 1400 bisher wenig gewürdigt. Im Unterschied zu den Altartafeln des Meisters der Karlsruher Passion fehlen im Täfelchen die realistische Charakterisierung von Stofflichkeit und Texturen, der Detailreichtum, die Plastizität der Figuren sowie die Tiefenräumlichkeit oder die Luftperspektive. Auch die Erzähltechnik ist einfacher; die Vielfalt der Aktionen des Bildpersonals 
in der Karlsruher Passion fehlt ebenso wie - bedingt durch den Goldgrund - die Angabe der Tageszeit. Demgegenüber ist die Gefangennahme der Karlsruher Passion durch den Sternenhimmel und den strahlenden Mond als Nachtszene konzipiert.

Doch die Werke beider Maler weisen gewisse Ähnlichkeiten auf, etwa die ausdrucksstarke Bildsprache oder die figurenreichen Kompositionen. Die Misshandlungen Jesu und die zahlreichen verhässlichten Schergen in beiden Werken verbildlichen den bekannten Psalm 21,17: ॥iele Hunde umlagern mich, eine Rotte von Bösen umkreist mich. Sie durchbohren mir Hände und Füße ${ }^{55}$ In gewissen Aspekten, die ich im Folgenden darstellen werde, geht allerdings der Maler des Täfelchens radikaler vor.

In den beiden oberen Bildfeldern mit dem Einzug Christi in Jerusalem und dem Letzten Abendmahl herrscht eine neutrale Atmosphäre - mit einer Ausnahme: Die karikierte zwergenhafte Gestalt des Verräters Judas mit den wulstigen rotbetonten Lippen im Abendmahl unterscheidet sich von den anderen Aposteln. Diese Polarisierung schafft der Maler, indem er Judas auf der anderen Tischseite allein platziert. Wie hässlich Judas ist, wird deutlich, wenn man ihn mit Johannes vergleicht, der in den Armen Jesu schläft und mit dem Verräter eine Diagonale bildet. Als Lieblingsschüler Jesu verkörpert Johannes gemäß der Bildtradition mit seinem runden Gesicht und den blonden lockigen Haaren Jugend und Schönheit. Und wir sehen zugleich, wie innerhalb der Abendmahlszene beide Darstellungsmodi der Zeit um 1400, die ideale Schönheit und die Expressivität, nebeneinander existieren.

Eine düstere Stimmung herrscht in den unteren Bildfeldern, in denen der Maler die Ohnmacht Jesu und die Wut seiner Peiniger inszeniert. Bei der Kreuztragung blutet Jesus aus den Geißelwunden, drei Frevler mit wulstigen Lippen wie Judas zerren ihn an einem Strick und an den Haaren voran. Zugleich versetzen ihm die gepanzerten Soldaten Faustschläge, einer holt mit der Hand zum Schlag aus. Dies deutet an, dass die Schläge in dichtem Takt auf Jesus niedergehen. Sogar zwei Kinder schlagen ihn mit einem Stock und bewerfen ihn mit Steinen. Nach Daniel Hess handelt es sich offenbar um die früheste Darstellung nördlich der Alpen, in der Kinder mit Stöcken und Steinen Jesus angreifen. ${ }^{56}$

Qualvoller noch erweist sich die darauffolgende Entkleidung, welche drei Schergen vollziehen. Nach den Meditationes Vitae Christi, dem Passionstraktat eines anonymen italienischen Franziskaners vom Ende des 13. Jahrhunderts, wurden die verkrusteten Geißelwun-

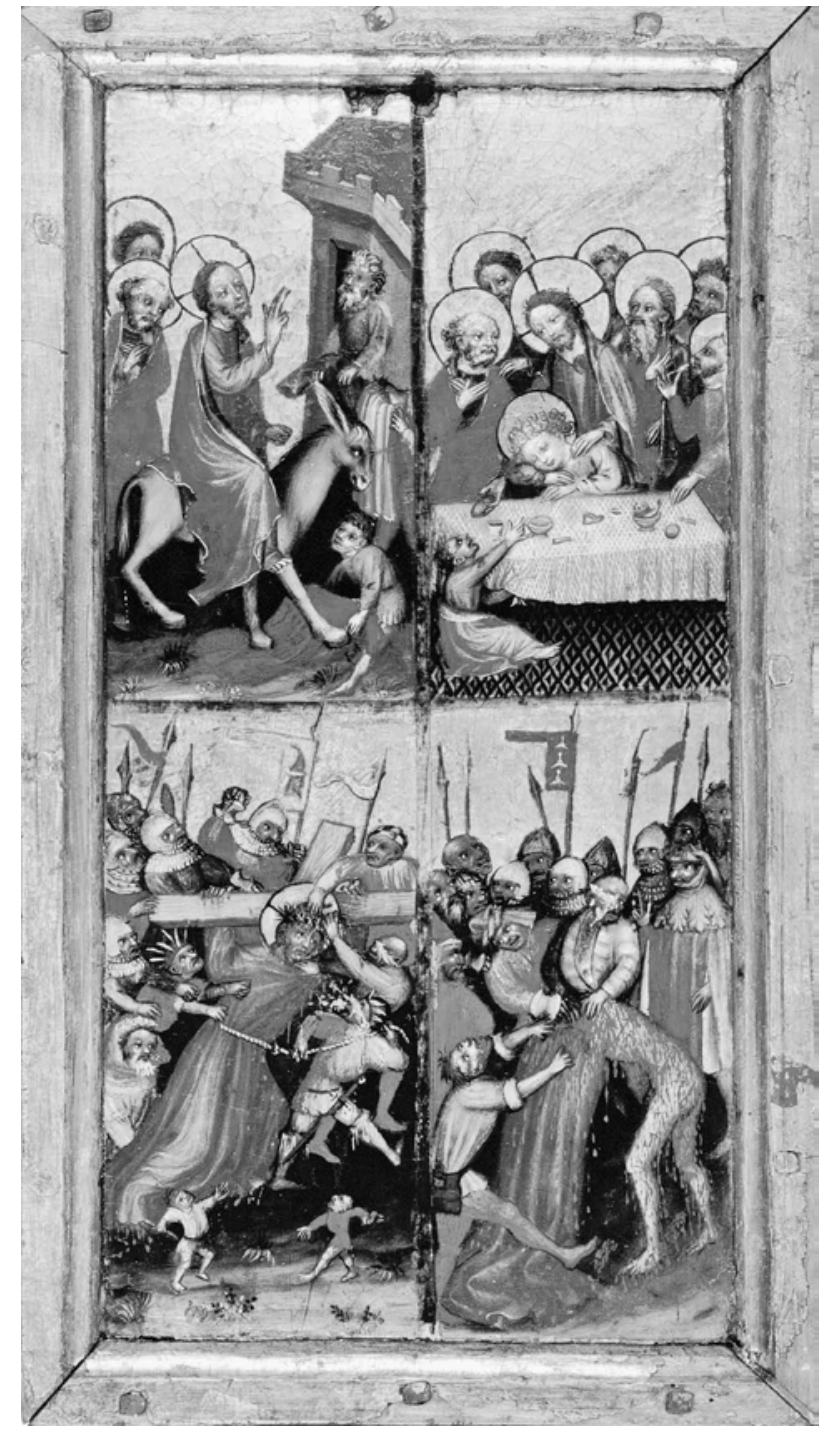

Abb. 4 Flügel eines Diptychons mit Passionsszenen. Oberrhein, um 1410/20. Nürnberg, Germanisches Nationalmuseum, Inv.-Nr. Gm1053 (Foto: Germanisches Nationalmuseum, Nürnberg)

den durch das gewaltsame Gewandaufreißen wieder aufgebrochen ${ }^{57}$ was das Bild visualisiert. Blutströme bedecken den Leib Jesu und entstellen seine Form. Arme und Haupt bleiben verhüllt; dadurch ist Jesus auf einen geschundenen Körper reduziert. Mit der Nichtsichtbarkeit des Gesichts Jesu manifestiert sich im Bild ein Randphänomen der mittelalterlichen Kunst. »In einer Darstellung christologischer Erzählikonographie das Antlitz Christi nicht zu zeigen, war stets ein Extrem ${ }^{58}$ Statt des Antlitzes Christi sieht der Betrachter in der Entkleidung eine Ansammlung derber Gesichter, ein effektvolles Mittel, das die Macht der Widersacher Jesu im szenischen Kon- 


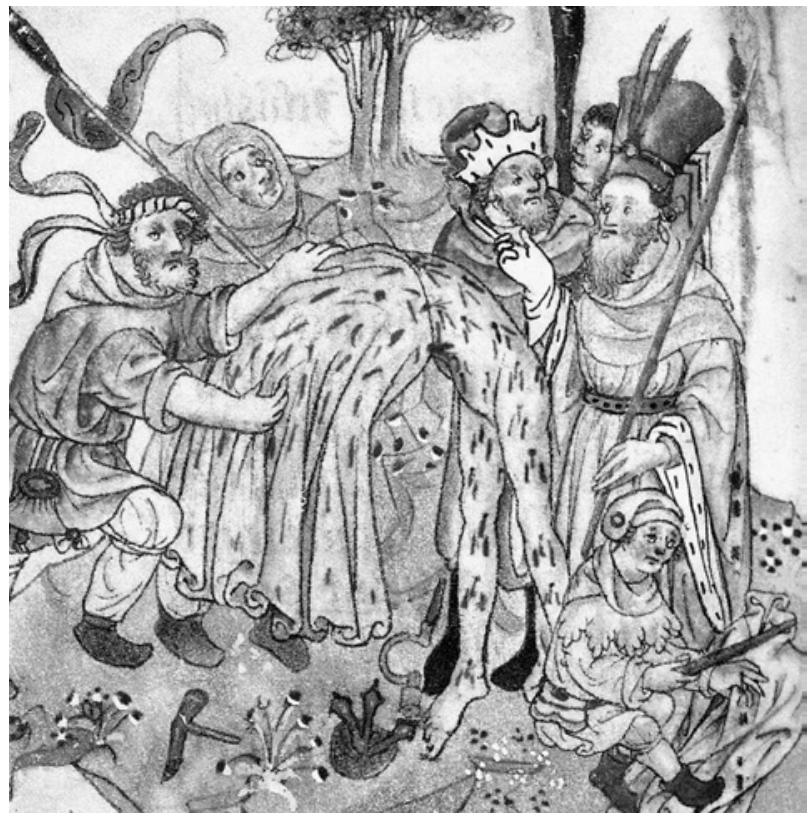

Abb. 5 Entkleidung Christi. Meister des Morgan-Kindheitszyklus, um 1420. London, The British Library, Add. 50005, fol. 112v (ex: Ausst.-Kat. Utrecht/New York 1989/90, Abb. 20)

Abb. 6 Entkleidung Christi. Meister der Karlsruher Passion, um 1450. Staatliche Kunsthalle Karlsruhe, Inv.-Nr. 1497 (ex: Ausst.-Kat. Karlsruhe 1996, Taf. 5)

text verdeutlicht. Die Abwesenheit des üblichen Lendentuchs und die gekrümmte Haltung vervollständigen die Erniedrigung Jesu. Erschütternd wirkt die Entblößung durch seine Feinde, die ihn zur Seite des Betrachters drängen. $\mathrm{Zu}$ seiner Darbietung gegenüber dem Betrachter trägt der unvertiefte Bildraum bei, den ein Goldgrund hinter der Schergenreihe abschließt.

Ikonografische Ähnlichkeiten mit der Entkleidungsszene, welche in der Forschungsliteratur bislang nicht wahrgenommen wurden, weist die Miniatur gleichen $\mathrm{Su}-$ jets eines nordniederländischen Stundenbuchs des Meisters des Morgan-Kindheitszyklus um 1420 auf (Abb. 5). ${ }^{59}$

Die Miniatur stellt die seltene Bildformel der vollständigen Entkleidung Jesu dar, während sein Haupt verhüllt bleibt. Ähnlich sind in beiden Bildern die gekrümmte Körperstellung Jesu als Manifestation seiner Erniedrigung, der blutende Leib und die Blutspuren, welche die geöffneten Geißelwunden auf seinem Gewand hinterlassen. Außerdem steht der Anführer der Schergen in beiden Bildern am rechten Rand und macht mit der rechten Hand die gleiche Gebärde: Er streckt Daumen und Zeigefinger aus. Es handelt sich wahrscheinlich um eine

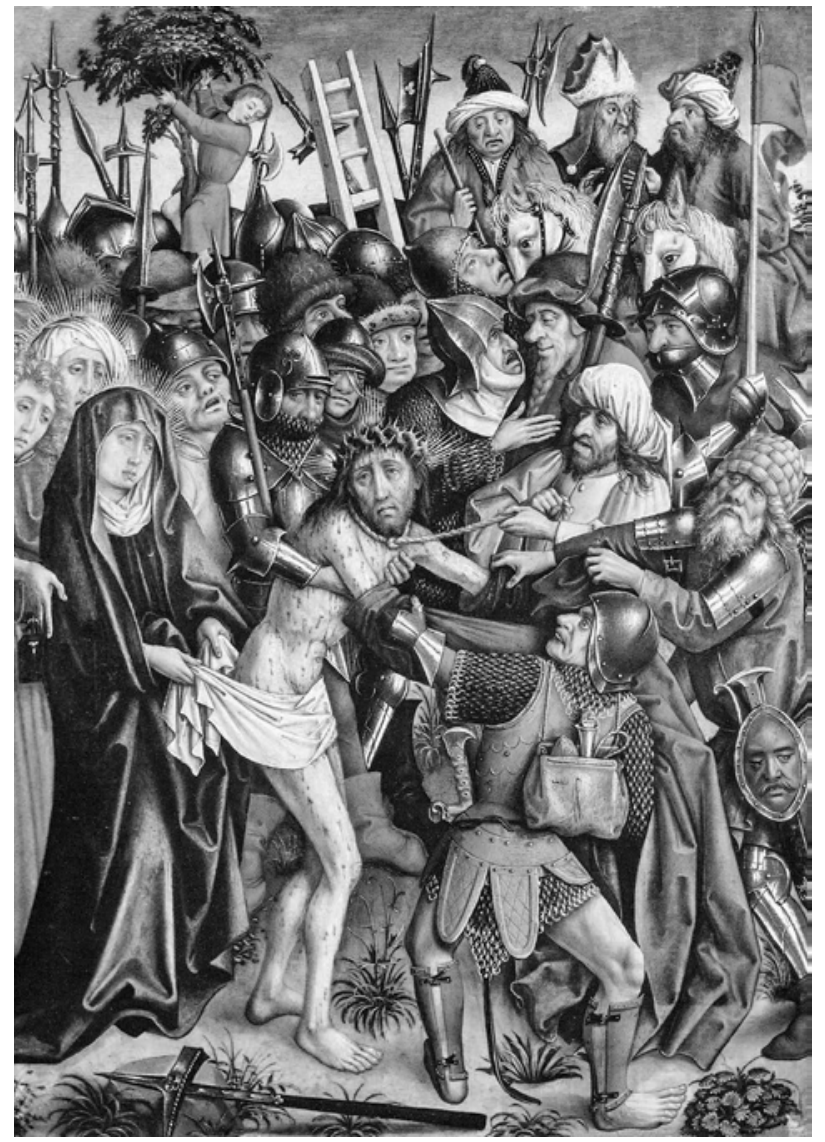

Befehlsgeste zur Entblößung Jesu. Diese Ähnlichkeiten deuten darauf hin, dass beide Darstellungen möglicherweise ein gemeinsames Vorbild hatten.

Die Nacktheit ist neben dem nicht sichtbaren Gesicht Jesu das zweite ungewohnte Motiv der Entkleidung. Jesus wird nicht nur körperlich gepeinigt, sondern auch entwürdigt. Die Radikalität der beiden Bildmotive, des verborgenen Gesichts und der Entblößung, ist besser zu verstehen, wenn man die Entkleidung des Täfelchens mit der Entkleidung der Karlsruher Passion vergleicht (Abb. 6) ${ }^{60}$

Dort sieht man das Antlitz Christi frontal; er blickt aus dem Bild heraus, um den Betrachter anzusprechen. Maria kommt ihm zur Hilfe und bedeckt mit einem weißen Tuch die Scham Jesu, um eine weitere Erniedrigung ihres Sohnes zu verhindern. Dabei handelt es sich um ein Motiv, das bereits am Ende des 13. Jahrhunderts auftauchte, ${ }^{61}$ mit dem Ziel, die komplette Entkleidung Jesu zu entschärfen. Das oberrheinische Täfelchen diente, wie bereits gesagt, wohl der privaten Andacht. Die Kreuztragung und die Entkleidung sind in dieser Weise konzipiert, um durch ihre Krassheit den Betrachter emotional einzunehmen. Dies ist in der Tafelmalerei um 1400 zwar eine 
Seltenheit, aber keine Ausnahme, und betrifft sowohl kleinformatige Werke als auch Altäre.

Ein solcher Fall ist das mittelrheinische Passionstriptychon in Idar-Oberstein (um 1400), das durch eine drastische Schilderungsweise gekennzeichnet ist. ${ }^{62}$ Ich möchte aus der Bildfolge die Verspottung ${ }^{63}$ isolieren und sie näher betrachten (Abb. 3). Als Vollstrecker der Misshandlung agieren drei Schergen unter der Anordnung von Pilatus rechts. Bereits auf den ersten Blick fällt die veränderte Komposition auf. ${ }^{64}$ Jesus ist entgegen der Bildtradition nicht im Zentrum der Szene zu sehen, wie es zum Beispiel in der mit der Verspottung verbundenen Dornenkrönung des Kölner Veronikameisters (tätig zwischen 1400 und 1430), datiert nach 1418, geschieht (Abb. 7) ${ }^{65}$

Vor allem hat der Betrachter im Kölner Bild die Möglichkeit, das Antlitz Christi als Hauptmotiv uneingeschränkt zu sehen und die Würde, mit der Jesus die Peinigung durch die eher neutral charakterisierten Schergen erträgt, zu spüren. Die Bedeutung des Antlitzes macht der Veronikameister durch eine Feinheit in der Wiedergabe Jesu anschaulich. Jesus ist leicht nach links gedreht, sein Haupt ist etwas nach links geneigt, sodass der Spalt der geschlossenen Flügel die Ansichtigkeit seines Konterfeis nicht beeinträchtigt oder es fragmentiert. Jesu Gesicht bleibt somit auch im geöffneten Zustand des Altärchens unangetastet.

Im Bild des Obersteiner Altars ist der bereits dornengekrönte Jesus an den linken Rand versetzt und im Profil dargestellt. Dazu kommt seine vollständige Nacktheit, ${ }^{66}$ welche einen mit Wunden übersäten Leib offenbart, ein Hinweis auf die vorausgegangene Geißelung. Das Ausmaß der Gewalt verrät auch der mit Blut befleckte Steinblock, auf dem Jesus sitzt. Die Bildmitte beanspruchen zwei der Peiniger als die eigentlichen Protagonisten der Szene, der kniende Spötter, der Jesus das Zepter anbietet, und ein weiterer Mann, der an den Haaren Jesu zieht. Beide tragen an ihren Gurten eine Rute und eine Stachelpeitsche als Hinweis auf die Auspeitschung Jesu. Und beide sind mittels Karikierung pejorativ charakterisiert. Der Kniende hat wulstige Lippen und eine aufgestülpte Nase. Der Stehende, dessen Fratze statt des Antlitzes Christi das zentrale Bildmotiv ist, wirkt durch den nach vorne gereckten Unterkiefer und die krumme Nase abstoßend und bösartig. Hinter Jesus steht der dritte Widersacher, der mit seinem linken Arm den Gepeinigten nach vorne drückt, während er zugleich mit der rechten Hand ausholt, um Jesus einen Faustschlag zu versetzen. Auch er ist verhässlicht, mit platter Nase und hasserfülltem Ge-

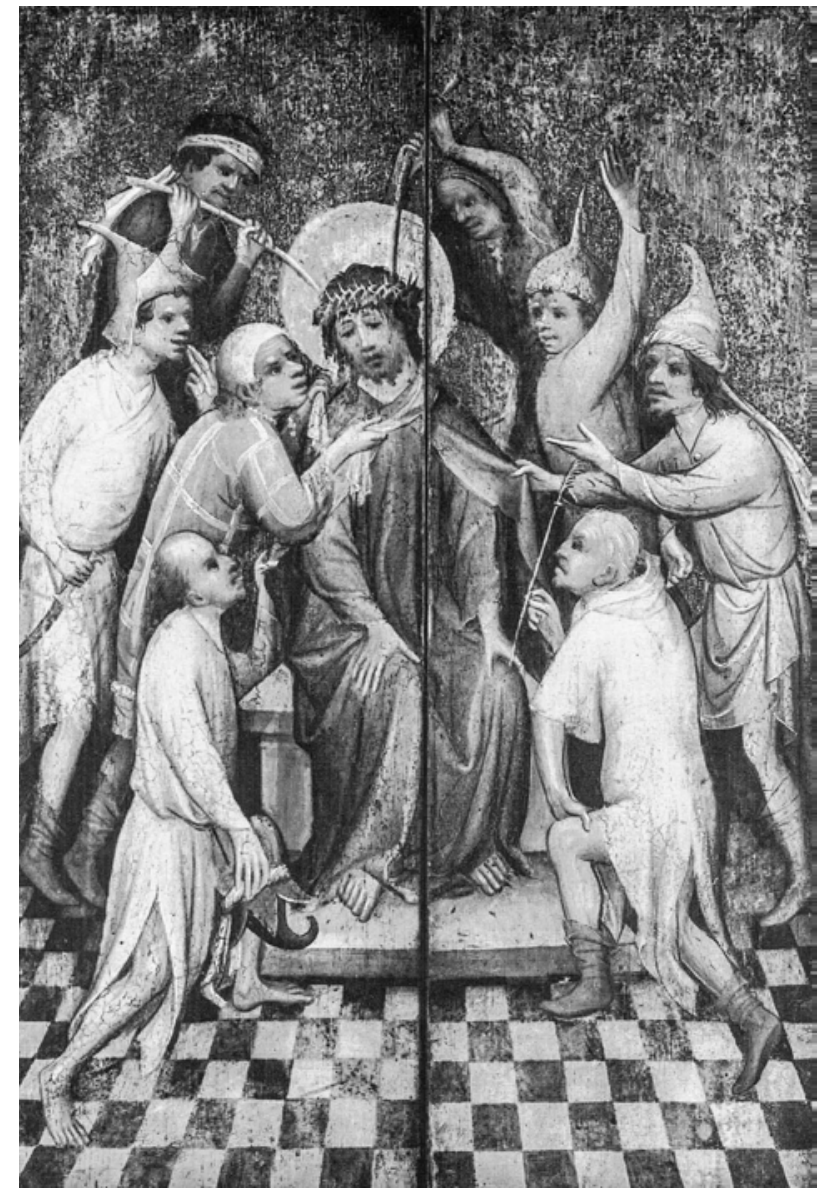

Abb. 7 Dornenkrönung Christi von der Außenseite des Triptychons der Muttergottes mit der Wickenblüte. Meister der Heiligen Veronika, nach 1418. Köln, Wallraf-Richartz-Museum, Inv.-Nr. WRM 0010 (ex: ZEHNDER 1990, Abb. 207)

sichtsausdruck. Nicht Jesus, sondern die Miene dieses Frevlers ist frontal zu sehen. Anders als in der Darstellung des Veronikameisters ist er derjenige, der aus dem Bild herausblickt und den Betrachter anspricht - eine extreme Umkehrung der tradierten Rollen in der Bildhierarchie. Das Antlitz Christi scheint dagegen als Zeichen seiner Erniedrigung keinen Platz in der Komposition zu haben. Die Seitenansicht mindert die Sichtbarkeit des Antlitzes. Außerdem überschneidet und verdeckt die rechte Schulter die untere Hälfte des Gesichts, sodass von Jesus lediglich ein verlorenes Profil übrig bleibt. Die Schergen dominieren das Bild, weil das Antlitz Christi kaum zu sehen ist. Hinzu kommt eine weitere Gemeinsamkeit mit der Entkleidung des oberrheinischen Täfelchens (Abb. 4): Jesus überkreuzt auf seinem Schoß die Hände, um Widerstand gegen den Druck des stehenden Peinigers zu leisten und um seine Scham zu verbergen. Er wurde also 


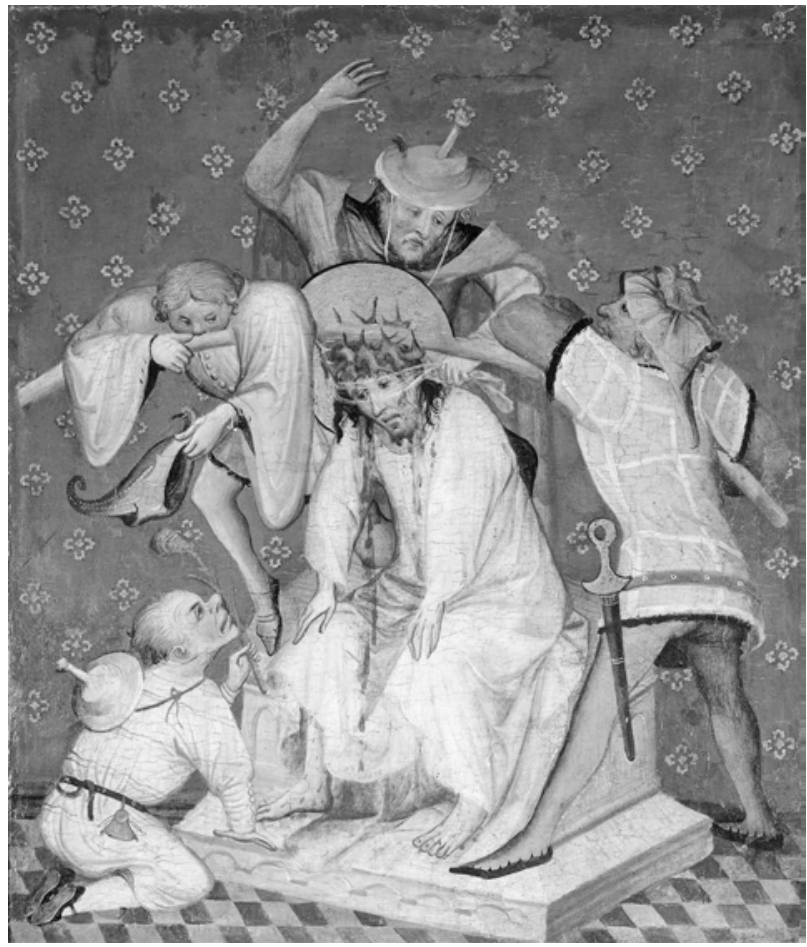

Abb. 8 Dornenkrönung Christi eines Passionsretabels. Mittelrhein (?), um 1410. Utrecht, Museum Catharijneconvent, Inv.-Nrr. ABM 525t/m s28; s156 t/m s158 (Foto: Museum Catharijneconvent, Utrecht, Ruben de Heer)

wie im oberrheinischen Täfelchen von seinen Feinden entblößt und entwürdigt. Ein Unterschied besteht in der zeitlichen Abfolge. Die Nacktheit Jesu in der Verspottung deutet an, dass die Schergen ihn vor der Geißelung entkleidet haben. Die seelische Peinigung ging also der körperlichen Gewalt voraus. Beide Werke zielten durch die ausdrucksmächtige Darstellungsweise auf die Erschütterung des Betrachters ab. Zugleich fasst das Obersteiner Verspottungsbild in seltener Weise viele Charakteristika der Expressivität in Passionsdarstellungen um $1400 \mathrm{zu}-$ sammen: die Verhässlichung der Schergen, die Drastik der Handlung, die Nacktheit Jesu sowie die Verdeckung seines Antlitzes als Folge der modifizierten Komposition.

Die fehlende Sichtbarkeit des Antlitzes Christi und seine Entblößung sind als Extreme des Passionsrealismus und der Expressivität immer wieder in der Malerei um 1400 anzutreffen, ohne dabei die Regel zu bilden. Sie treten häufig als gattungsspezifische Aspekte auf, insbesondere in der Buchmalerei. Da eine illuminierte Handschrift von einer einzelnen Person in Auftrag gegeben wurde, bot die Buchmalerei den Illuminatoren einen größeren Spielraum. Das Stundenbuch vom nordniederländischen
Meister des Morgan-Kindheitszyklus zeigt eine Miniatur mit der ersten Verspottung Christi; ${ }^{67}$ sie geschieht durch seine Blendung, welche die Evangelien von Lukas $(22,64)$ und Markus $(14,65)$ erwähnen (Taf. IX). ${ }^{68}$ Lukas erzählt, dass die Tempelwächter in demütigender Weise Jesus aufgefordert haben, seinen jeweiligen Schläger zu benennen. In der Miniatur bedeckt ein Tuch das ganze Gesicht Jesu, eine Steigerung der üblichen Augenbinde und ein Motiv, das Jacobus de Voragine (um 1230-98) in der Legenda aurea erwähnt. ${ }^{69}$ Schlagkräftiger noch wirkt dies, wenn man bemerkt, dass die Figur Jesu dem Betrachter als Zentralmotiv und in Frontalansicht dargeboten wird. Den prominenten Platz Jesu in der Darstellung unterstreicht der Thron, auf dem er sitzt; zugleich dient er der Verspottung als »König der Juden«. Der visuelle Dialog zwischen Jesus und dem Betrachter wird jedoch negiert, da Jesus eine Gestalt ohne Gesicht, aber auch »ohne Leib« ist. Weder Füße noch Hände oder andere Körperpartien werden sichtbar. Dabei zeigt der Miniaturist ein interessantes Detail: »Um so krasser wirkt es als Kontrast, daß am linken Blattrand ein Mann sein Wams anhebt, um seinen Unterkörper möglichst direkt der Wärme des Feuers auszusetzen . $^{70}$ Diese Beobachtung kann man erweitern. Während der Mann mit der linken Hand sein Obergewand anhebt, scheint er mit der rechten auf seine Genitalien hinzuweisen, die sich unter seiner Unterhose abzeichnen. Es ist nicht auszuschließen, dass es sich um eine obszöne Spottgeste gegen Jesus handelt, welche dieser zwar nicht sehen kann, dafür aber der Betrachter. Der Illuminator verwehrt diesem die Sicht auf Jesus und dessen Erhabenheit, die er als Gottessohn - ein großer Nimbus umgibt seinen Kopf - mitbringt, gewährt ihm jedoch den Blick auf das niedere Detail einer Randfigur. Durch die Verhüllung Jesu und die Aktionen der Peiniger konterkariert der Künstler die Bildhierarchie. Allein sie bestimmen die Handlung; Jesus wirkt einem Gegenstand gleich, obwohl er die Hauptfigur der Schilderung ist. Sein blasses Gewand mindert weiter seine Präsenz im Gegensatz zur bunten Kleidung der Frevler, welche auch farblich die Szene beherrschen. Umso interessanter ist es, dass der Miniaturist ohne Karikierung auskommt. Die Drastik der Handlung und der Komposition macht eine Verhässlichung der Schergen überflüssig.

Verschiedene Künstler haben versucht, die Wirkung der Blendung abzuschwächen. ${ }^{71}$ Eine Tafel aus einem wohl mittelrheinischen Altar der Zeit um 1410 vereint im Rahmen der zweiten Verspottung Christi (Matthäus 27,27-30, Markus 15,16-19, Johannes 19,2-3) durch die 
römischen Legionäre die Dornenkrönung mir der Blendung durch vier Peiniger (Abb. 8). ${ }^{72}$

Zwei davon tragen Judenhüte, wodurch das Bild eine antijüdische Aussage vermittelt. ${ }^{73}$ An den Seiten Jesu drücken zwei Folterknechte mit einem Stock die übermächtige Dornenkrone auf sein blutendes Haupt. Der dritte Frevler steht hinter Jesus und ist bereit, ihm mit der rechten Hand einen Schlag zu versetzen; zugleich hält er mit der linken eine durchsichtige Augenbinde vor Jesu Augen. Der Maler wollte zum einen der Ikonografie der Blendung treu bleiben, zum anderen den Blick Jesu intakt lassen. So sieht man unter der Augenbinde die geöffneten Augen Jesu. Dies gab dem Maler die Möglichkeit, einen Kontrast zu schaffen. Durch den ausgeübten Druck der an den Seiten stehenden Peiniger neigt Jesus trotz seines Widerstands seinen Oberkörper samt Kopf leicht nach unten und begegnet dem vierten Peiniger. Dieser kniet vor Jesus und bietet ihm das Spottzepter an. Jesus und der Spötter bilden damit eine Diagonale und scheinen miteinander in Blickkontakt zu treten. Wohl bewusst stellte der Maler Jesus und seinen Thron nicht frontal, sondern in Dreiviertel-Ansicht dar, wodurch gerade diese Konfrontation veranschaulicht wird: Der Spötter verkörpert das Gegenbild Jesu. Im Unterschied zu den anderen drei Peinigern, die neutral charakterisiert sind, trägt er Züge markanter Hässlichkeit. Seine Gestalt ist zwergenhaft und er hat eine lange, aufgestülpte Nase. Er scheint die Zähne als Ausdruck seines Hasses zusammenzubeißen, wodurch er sein Gesicht, insbesondere den Mund und die gerunzelte Stirn, verzieht, was seine überspitzte Fratze noch hässlicher erscheinen lässt. An Jesus fällt dafür das schmale Gesicht mit den verfeinerten Zügen auf. Die beiden Darstellungsmodi der Malerei um 1400 treten in diesem Bild wie im Letzten Abendmahl des oberrheinischen Täfelchens (Abb. 4) gemeinsam auf. Dort bilden der karikierte Judas und der idealisierte Johannes eine Diagonale. Der mittelrheinische Künstler verwendet in der Dornenkrönung die Karikierung auch selektiv. Sie betrifft nur den Spötter, dessen Agieren herausgehoben wird.

Die Blendung Jesu steigert die Passivität seiner Opferrolle, indem sich seine Feinde nicht nur seines Körpers, sondern auch seiner optischen Wahrnehmung bemächtigen. Das ist wortwörtlich umgesetzt in der seltenen Variante der Blendung, bei der ein Folterknecht Jesus mit der Hand den Blick raubt. Eine Zeichnung mit der Verspottung vom Anfang des 15. Jahrhunderts zeigt eben diese Formulierung $:{ }^{74}$ Ein Scherge bedeckt mit der einen Hand die Augen Jesu, während er mit der anderen zum

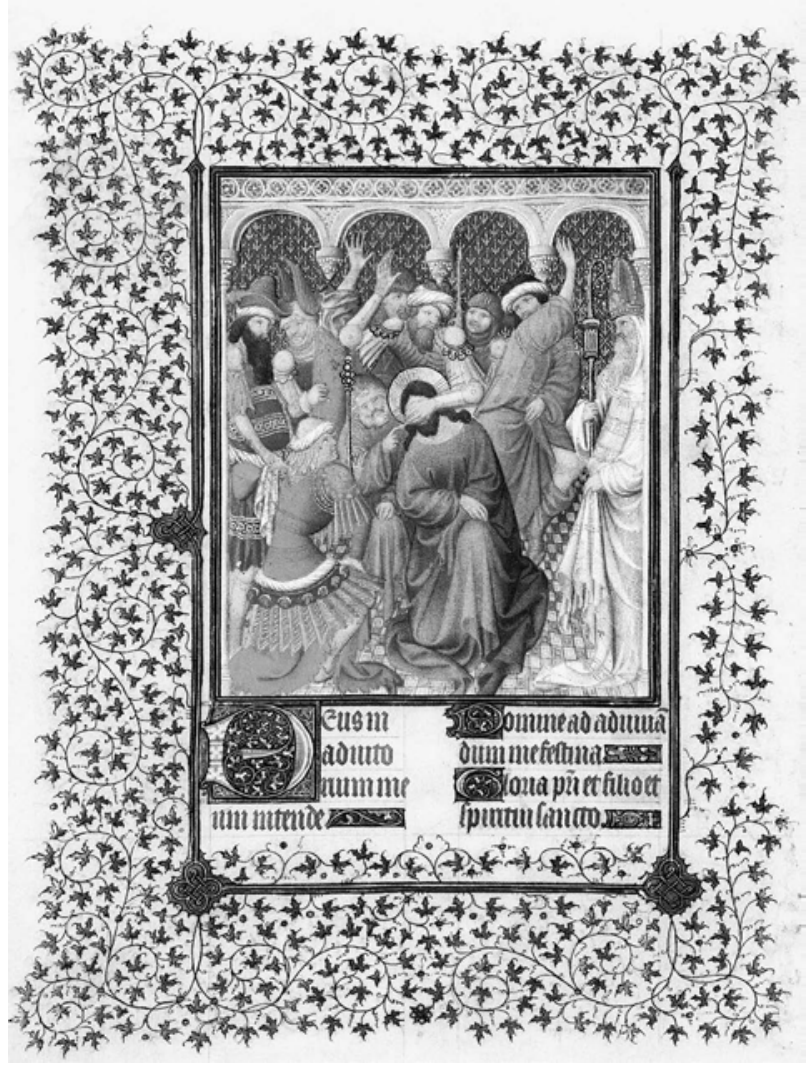

Abb. 9 Verspottung Christi der Belles Heures des Herzogs von Berry. Brüder Limburg, um 1405-08/09. New York, The Metropolitan Museum of Art, The Cloisters Collection, fol. 131v (ex: KöNIG 2004, Abb. S. 97)

Schlag ausholt. Die Forschung der letzten Jahre brachte diese Zeichnung in Verbindung mit einer Miniatur gleichen Sujets der Brüder Limburg aus den Belles Heures um 1405-1408/09, welche dieselbe Variation der Blendung Jesu darstellt (Abb. 9). ${ }^{75}$

Der Schwerpunkt der Beiträge liegt auf stilistischen und formalen Ähnlichkeiten. Unbeachtet blieben dagegen die Seltenheit sowie das Extreme dieser Art der Blendung. Die Brüder Limburg erzeugen auch in Passionsdarstellungen durch die Feinheit der Form und die leuchtende Farbgebung eine märchenhafte Atmosphäre, die über die Intensität bestimmter Formulierungen hinwegtäuschen kann. Dies mildert das Wirken der ausdrucksstarken Szene erheblich ab. Abgesehen davon erscheint Jesus in der Miniatur als das hilflose und blinde Opfer seiner Feinde, die ihn ohne Gnade malträtieren. Da am rechten Bildrand ein Hohepriester steht und den Vorgang beobachtet, ist mit diesem ungewöhnlichen Motiv wahrscheinlich die erste Verspottung Jesu gemeint, wel- 


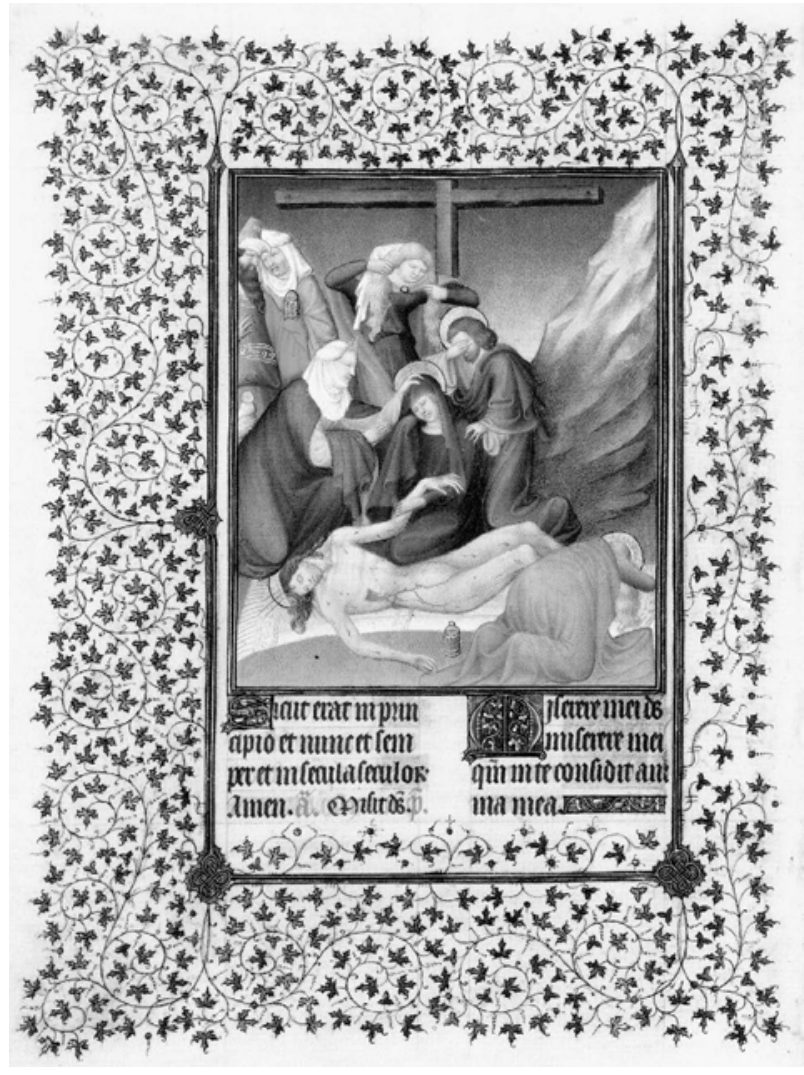

Abb. 10 Beweinung Christi der Belles Heures des Herzogs von Berry. Brüder Limburg, um 1405-08/09. New York, The Metropolitan Museum of Art, The Cloisters Collection, fol. 149v (ex: Ausst.Kat. Nijmegen 2005, Nr. 99)

che die Tempelwächter vollzogen haben (Lukas 22,6365). Von den vier Evangelisten schildert nur Johannes, dass Jesus nach der Gefangennahme zuerst zum Hohepriester Annas geführt wurde $(18,12-14)$. Lukas erwähnt allgemein, dass Jesus in das Haus des Hohepriesters gebracht wurde $(22,54)$. Die Präsenz des Hohepriesters reflektiert vielleicht die beiden Evangelisten oder wird auch im Rahmen einer antijüdischen Stimmung benutzt. Aus der Tafelmalerei dieser Zeit ist als vergleichbares Beispiel die Verspottung eines schlesischen oder böhmischen Meisters um 1410 überliefert, welche (mehrere) Hohepriester zeigt, wie Stephan Kemperdick nachgewiesen hat. ${ }^{76}$ Allerdings stellt die Tafel im Gegensatz zur Miniatur der Brüder Limburg die zweite Verspottung dar, die mit der Dornenkrönung verbunden ist.

Die Verspottungsszene der Belles Heures ist keinesfalls die einzige Darstellung dieses Stundenbuchs, die Jesus durch die Blendung als erniedrigten Menschen zeigt und seine Kreatürlichkeit zum Ausdruck bringt. Ein weite-

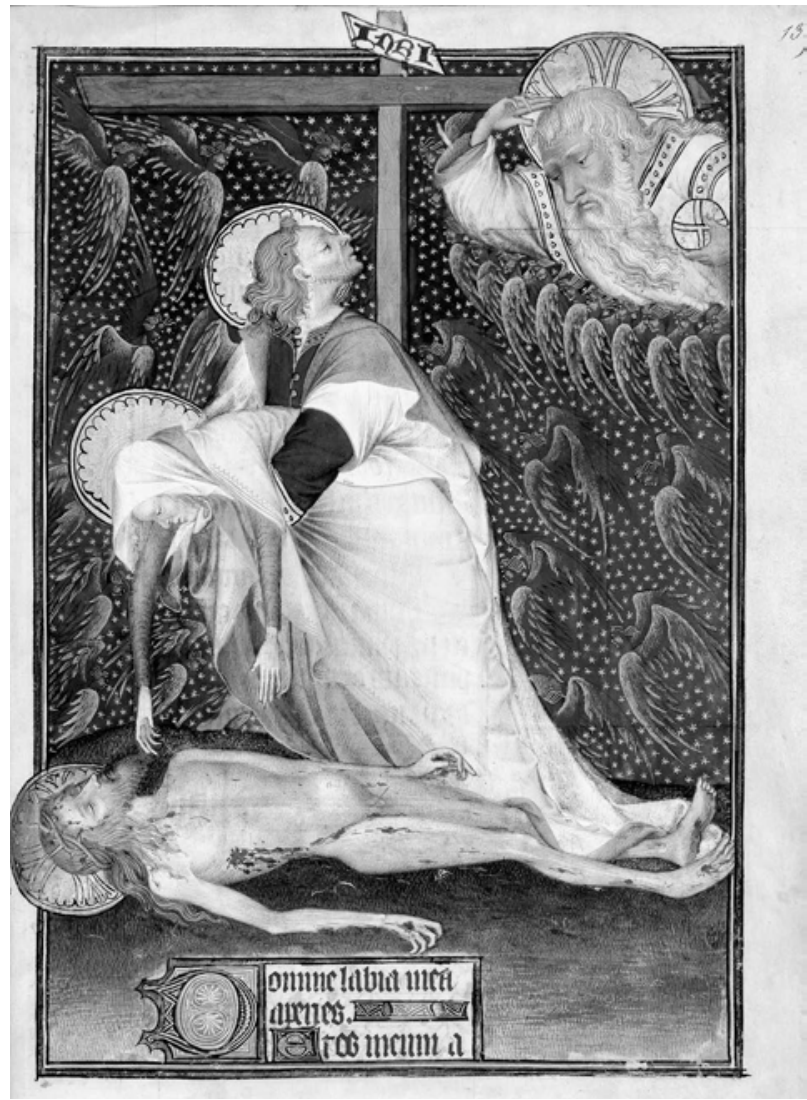

Abb. 11 Beweinung Christi. Rohan-Stundenbuch, um 1420-30. Paris, Bibliothèque nationale de France, lat. 9471, fol. 135 (ex: Ausst.Kat. Regensburg 2010, Abb. 2)

res und ebenfalls seltenes Mittel, um die Verletzlichkeit Jesu zu betonen, ist seine vollständige Nacktheit wie in der Verspottung des Obersteiner Altars (Abb. 3). Zwei Beweinungen der Buchmalerei sind in ihrem Realismus noch krasser. In der Miniatur der Gebrüder Limburg geht es der Ikonografie des Sujets entsprechend um eine mehrfigurige Komposition (Abb. 10) $;^{77}$ keine Person stützt allerdings, wie es sonst die Regel ist, den Leichnam Jesu, der stattdessen auf dem Boden liegt und der Hinfälligkeit überlassen ist. Lediglich Maria hält den linken Arm ihres Sohnes. Keine Figur hat die Scham Jesu bedeckt. Um diese einigermaßen zu verbergen, hat der Maler den ansonsten weich gefassten und idealisierten Leichnam mit gebeugten Beinen dargestellt. Darauf hat der Meister des Rohan-Stundenbuches um 1420-30 verzichtet, ebenso wie auf die vielen Trauernden (Abb. 11). ${ }^{78}$

Stattdessen reduzierte er sie auf Maria und Johannes, um die Dramatik zu erhöhen. Der tote Jesus erstreckt sich nackt auf dem Boden; man kann sein Glied sehen, 


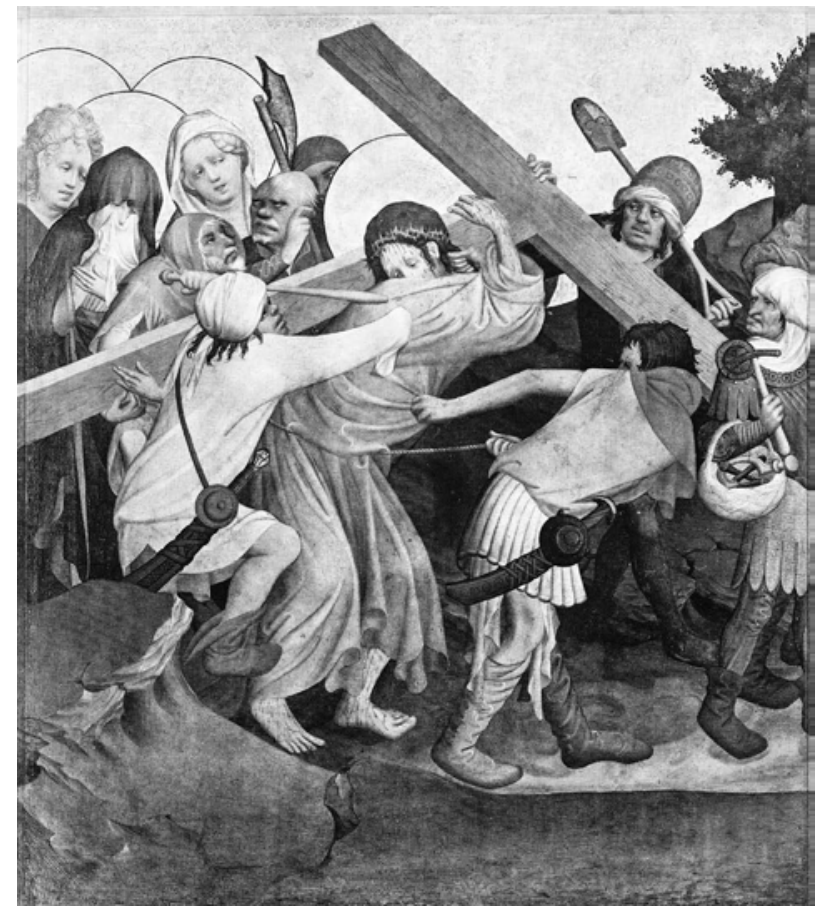

Abb. 12 Kreuztragung Christi des Thomas-Altars. Meister Francke, um 1424. Hamburg, Kunsthalle, Inv.-Nr. 495 (Foto: Archiv S. Vlachos)

Abb. 13 Kreuztragung Christi des Passionstriptychons. Berswordt-Meister, um 1390/95. Dortmund, Marienkirche (Foto: Archiv S. Vlachos)

was durchaus ungewöhnlich ist. Nicht einmal ein Leichentuch liegt unter seinem Körper wie in der Miniatur der Gebrüder Limburg. Jesus ist dem nackten Boden entwürdigt überlassen. Sein ausgemergelter, entblößter Leib nimmt ihm jede Erhabenheit und Würde. Über den Leichnam beugt sich Maria, die versucht, ihren toten Sohn zu umarmen. Die Kurve ihres Körpers akzentuiert das Ausmaß der Trauer und kontrastiert mit dem ausgestreckten Leichnam. Aus der Mischung von Starrheit und Lebhaftigkeit, von Reduktion und Steigerung resultiert die Ausdrucksqualität der Miniatur, deren Expressivität mit der Anmut und Eleganz der Malerei der Brüder Limburg kaum etwas gemein hat.

\section{Kontinuität von Darstellungsweisen nach 1430}

Die Verflechtungen zwischen der Malerei um 1400 und ab 1430 betreffen sowohl Mittel wie die Verhässlichung der Schergen als auch Darstellungsarten wie die reduzierte Sichtbarkeit des Antlitzes Christi. Dies soll hier am Beispiel einer Reihe von Kreuztragungen erörtert werden.

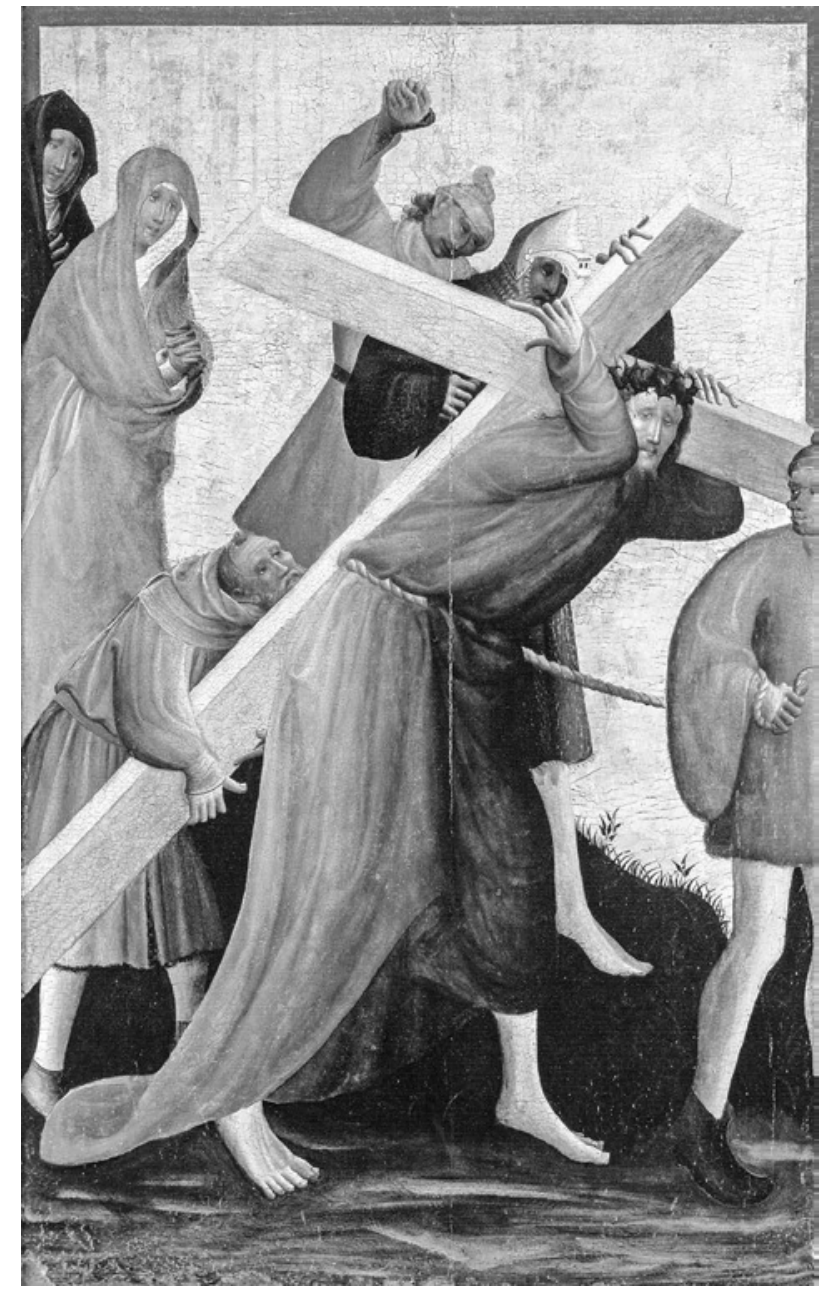

Im Ausklang des Internationalen Stils schuf Meister Francke (tätig zwischen 1420 und 1436?) um 1424 als Teil des Thomas-Altars eine Kreuztragung (Abb. 12), ${ }^{79}$ die eine Überschneidung des Gesichts Jesu im Sinne der Verspottung vom Obersteiner Altar um 1400 zeigt (Abb. 3).

Der rechte Oberarm Jesu verdeckt die untere Hälfte seines Gesichts. Eine ähnliche Überschneidung sieht man auch beim Schergen, der Jesus am Strick nach vorne zerrt. ${ }^{80}$ Es wirkt auf den ersten Blick paradox, dass Jesus als Hauptfigur in der Bildmitte zu sehen, aber sein Antlitz als Erkennungsmerkmal nur ansatzweise erkennbar ist. Mit der eingeschränkten Ansichtigkeit des Antlitzes leitet und konzentriert der Maler jedoch den Blick des Betrachters auf die gebrochenen Augen Jesu, die Leid ausstrahlen. Dieses manifestiert sich auch in den unbedeckten Körperpartien, welche die blutenden Wunden der Geißelung offenbaren. Meister Francke hebt damit sowohl die Schwäche Jesu als auch die Macht seiner Wi- 


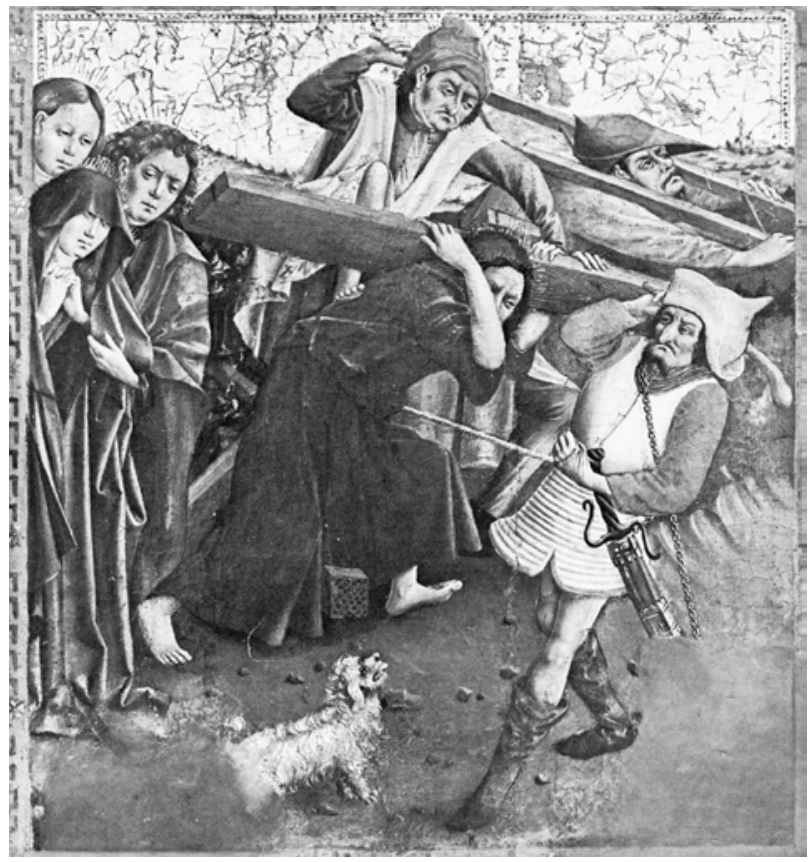

Abb. 14 Kreuztragung Christi des Langenhorster Altars. Johann Koerbecke, um 1440/50. Münster, LWL-Museum für Kunst und Kultur, Inv.-Nr. 34, 35 WKV (ex: PIEPER 1986, Abb. S. 147)

dersacher hervor, von denen die Fratzen der meisten im Gegensatz zu Jesu Gesicht zu sehen sind. Auch die Angehörigen und Freunde Jesu scheinen keinen Platz in der Szene zu haben. Die Muttergottes, Johannes und Maria Magdalena befinden sich an der oberen linken Ecke. Alle drei stellte der Maler mit ähnlich gebrochenen Augen wie Jesus dar, die ihre Trauer veranschaulichen und das Leid Jesu widerspiegeln und multiplizieren. Auf bedrohliche Weise schaut der Frevler mit der Axt Magdalena an und scheint mit der rechten Hand auf Jesus zu weisen. Seine Gebärde und seine Grimasse demonstrieren noch einmal, wer das Sagen hat. Bedrohlicher noch wirkt der Scherge mit der wulstigen Unterlippe und der krummen Nase an der Spitze des Zuges rechts, der vorausdeutend einen Hammer und einen Korb mit drei riesigen Nägeln trägt. Diese Motive verweisen nicht nur auf die bevorstehende Kreuzigung, sondern deuten an, dass Jesu Leid noch kulminieren wird, indem die Nägel Hände und Füße durchbohren werden.

Bestimmte Inszenierungen der Tafelmalerei um 1400 wurden zumindest auf regionaler Ebene fortentwickelt und modifiziert. Der in Westfalen tätige Berswordt-Meister malte auf dem linken Flügel eines Passionstriptychons, das man um 1390/95 datiert, die Kreuztragung (Abb. 13). ${ }^{81}$
Jesus hält das Kreuz derart, dass sein rechter Oberarm nach hinten und der Ellenbogen nach oben gebogen ist. Dadurch überschneidet und verdeckt der rechte Unterarm die rechte Wange Jesu, lässt aber das Auge frei. So kann Jesus an den Betrachter appellieren, indem er aus dem Bild herausblickt. Dieselbe Armhaltung Jesu sowie den Appell an den Betrachter verwendete der Maler auch in der Kreuztragung seines 1400 entstandenen Marienretabels. ${ }^{82}$ Anscheinend hatte der Berswordt-Meister Vorbehalte, einen Teil des Blicks Jesu der Sichtbarkeit zu entziehen und somit den visuellen Dialog mit dem Betrachter aufzuheben. Sein Bildgedanke fand allerdings Echo in der westfälischen Tafelmalerei nach 1430, was die Forschung bisher nicht wahrgenommen hat.

Um 1440/50 schuf Johann Koerbecke (um 1415/2091) eine Kreuztragung, die ursprünglich Teil des Langenhorster Altars war (Abb. 14) ${ }^{83}$

Jesus hält das Kreuz mit beiden Händen auf genau dieselbe Art und Weise wie in der Kreuztragung des Berswordt-Meisters: Der linke Arm fasst den Querbalken des Kreuzes von hinten, der rechte von vorne. Weil der rechte Unterarm auch hier nach oben abgewinkelt ist, überschneidet und verdeckt er mehr als beim Berswordt-Meister die rechte Hälfte des Konterfeis Jesu samt dem Auge. Der lange Unterarm verbirgt auch einen Teil der Nase und den ganzen Mund. Lediglich das linke Auge Jesu bleibt sichtbar, es scheint jedoch nach unten zu blicken, da Jesus im Bild Koerbeckes unter der Kreuzeslast stärker gebeugt ist als beim Berswordt-Meister. Mit dem partiellen Verlust der Ansichtigkeit des Antlitzes Christi geht auch der Appell an den Betrachter verloren. Darin besteht der wesentliche Unterschied zur Darstellung des Berswordt-Meisters, dessen Bildkonzept Koerbecke radikalisierte. Klar zu sehen sind im Gegensatz zu Jesus in der Kreuztragung Koerbeckes die karikierten Gesichter der Peiniger: nach unten gezogene Mundwinkel, welche Mitleidlosigkeit ausdrücken, und krumme Nasen. Der Frevler vorne, der Jesus am Strick führt, und sein Kamerad hinter Jesus, der ihn mit einem Stock schlägt, bilden eine Diagonale, in deren Mitte sich das Antlitz Christi befindet. Beide Schergen lenken also den Blick auf Jesus; dort begegnet man aber einem teilweise verborgenen Gesicht, das die Opferrolle Jesu unterstreicht. Gefragt ist die Vorstellungskraft des Betrachters, der nur mit seiner Imagination das Antlitz Christi ergänzen kann. Koerbeckes Überschneidung des Gesichts Jesu in der Kreuztragung bleibt im Kontext des Langenhorster Altars eine solitäre Lösung. Auch in seinem späteren CEuvre ist sie nicht anzutreffen. ${ }^{84}$ 
Gerade deshalb ist es ungewöhnlich, dass das, zumindest partiell, verborgene Antlitz Christi als extremes Motiv der mittelalterlichen Kunst dreimal in einem Bildzyklus der Tafelmalerei auftaucht. Gemeint sind die Verspottung durch die Blendung, der Fall unter dem Kreuz und die Kreuztragung Christi des Schlägl-Retabels eines westfälischen Meisters um 1440/50. ${ }^{85}$ Bereits Franzen bemerkte zu Recht die für diese Zeit einmalige Erscheinung von zwei Episoden der Kreuztragung. ${ }^{86}$

In der Darstellung des Falls unter dem Kreuz ist Jesus unter der Last des Kreuzes zusammengebrochen (Taf. X.a). Erschöpft liegt er auf dem Boden; seinen Zustand zeigt die linke Hand, die er zur Faust ballt im Versuch, nicht vollkommen zusammenzubrechen. Als ob sein Sturz nicht ausreichend wäre, stützt sich der Anführer der Schergen mit der rechten Hand auf den Rücken Jesu und hebt das Kreuz. So widerfährt Jesus im Bild eine doppelte Erniedrigung: durch den Fall ebenso wie durch den Anführer. Seine Qual macht ein weiteres Detail anschaulich: Der Scherge in grünem Gewand packt das Kreuz und hebt es mit beiden Händen an. Zwei Männer halten also mit Schwierigkeit das Kreuz, unter dem Jesus gefallen ist. Der Maler betont durch seine Inszenierung die Unmenschlichkeit des Vorgangs, indem er andeutet, dass dieses Kreuz von keinem Menschen allein zu tragen ist. Die Ohnmacht und Erniedrigung Jesu finden ihren Höhepunkt in seinem kaum sichtbaren Gesicht, das seine Präsenz innerhalb der Szene mindert. Jesu rechter Oberarm verdeckt die untere Hälfte des Antlitzes, hinzu kommt die Wiedergabe im Profil. Kaum zu sehen sind die Nase und das rechte, gebrochene Auge. Den Verlust des Gesichts kompensiert der Künstler mit der ausdrucksvollen Körperstellung Jesu. Diese verdeutlicht, dass Jesus an die Grenze seiner Kraft gekommen ist. Um den Realismus der Handlung zu verstärken, bedient sich der Maler einer interessanten Einzelheit: Auf der rechten Seite des Kreuzquerbalkens sieht man zwei Risse, vielleicht als Folge des Falls. Jedenfalls charakterisiert der Maler damit die Materialität des Holzes und lädt den Betrachter ein, das Instrument des Opfertodes Jesu genauer anzuschauen. Das Detail zeugt vom Interesse der Tafelmalerei nach 1430 für den Oberflächenverismus, den die altniederländischen Meister geprägt haben.

In der folgenden Kreuztragung trägt nun Jesus das Kreuz mit Hilfe Simons von Kyrene (Taf. X.b), der im vorherigen Bild am rechten Rand steht. Gedrückt vom Kreuz wendet Jesus seinen Oberkörper samt Haupt nach unten. Wie bereits Franzen bemerkte, überschneidet der rechte Arm Jesu sein Gesicht im Sinne Koerbeckes, ${ }^{87}$ jedoch mit einem Unterschied: In den Bildern des Berswordt-Meisters und Koerbeckes verdeckt der Unterarm das Gesicht, hier ist es der Oberarm. Dadurch bleiben sowohl die Nase als auch der Mund sichtbar. Dies ändert allerdings nicht die Tatsache, dass die Hälfte des Antlitzes Christi nicht zu sehen ist. So kann auch hier wie im Bild Koerbeckes kein Blickkontakt mit dem Betrachter stattfinden, auch weil Jesus die Augen vor Anstrengung zu schließen scheint. Zugleich verabreicht der Scherge, der im vorherigen Bild das Kreuz hob, Jesus Schläge, während der Anführer ihn mit einem Strick vorantreibt. Mit Ausnahme des grimmigen Anführers ist eine Karikierung der Feinde Jesu im Vergleich zur Darstellung Koerbeckes mit den verhässlichten Schergen kaum zu sehen. Die Handlung, insbesondere die Demütigung Jesu, ist allerdings durch den hinzugefügten Sturz unter dem Kreuz sowie die wiederholte Verdeckung des Antlitzes Christi drastischer.

Die Bilder Koerbeckes und des Schlägl-Altars setzen mit der Überschneidung des Antlitzes Christi als Hauptfigur der Passion eins der ungewohnten Merkmale der Malerei um 1400 - die »elliptische [...] Darstellung « nach dem Begriff F. O. Büttners - fort. Außerdem karikiert Koerbecke die Widersacher Jesu, um die Kreuztragung expressiver zu schildern, wie es auch in der Verspottung des Obersteiner Altars geschieht (Abb. 3). Beide Darstellungen wollen mit der fesselnden Drastik die Aufmerksamkeit des Betrachters gewinnen und sein Mitleid gegenüber Jesus anspornen. Andererseits nutzte Koerbecke die neuen Möglichkeiten, um die Heilsgeschichte darzustellen. So sind seine Figuren wie auch am Schlägl-Altar plastischer und die Wiedergabe der Stoffe getreuer als in den hier behandelten Tafeln um 1400. Damit gilt meines Erachtens die Unterscheidung zwischen einem »Realismus des Narrativen« der Malerei um 1400 und einem »Realismus des Deskriptiven« der altniederländischen Malerei für die deutsche Tafelmalerei um 1400 und ab 1430 nur bedingt, da diese eine eigene Entwicklung aufweist. Zwar übernehmen deutsche Maler den Oberflächenverismus der altniederländischen Meister, doch sie erweitern während des 15. Jahrhunderts auch die Möglichkeiten der Bildnarration und des Darstellungsverfahrens, darunter eine gesteigerte Expressivität. Diese Synthese vertritt überzeugend der Meister der Karlsruher Passion. Seine ausdrucksstarken Bilder oder die hier analysierten Szenen des Schlägl-Altars wären für die zeitgenössische Malerei in den Niederlanden undenkbar. 


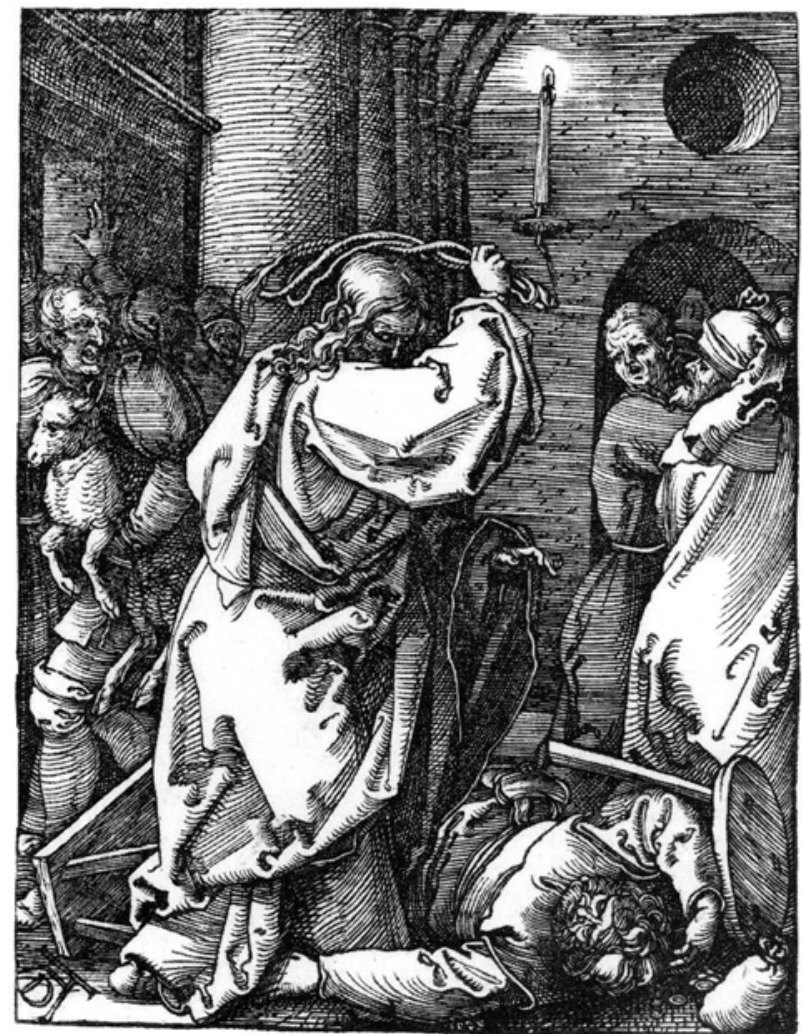

Abb. 15 Christus vertreibt die Händler aus dem Tempel, Kleine Passion. Albrecht Dürer, um 1509/10 (ex: Ausst.-Kat. Schweinfurt/ Bad Arolsen/Bottrop 1999-2001, Nr. 29)

\section{Ausblick}

Das Antlitz Christi zu überschneiden oder völlig zu verbergen gehörte zu den radikalen Mitteln des Passionsrealismus in der Malerei um 1400. Wohl in keiner anderen Zeit der mittelalterlichen Kunst ist das Motiv so häufig anzutreffen. Erst am Anfang des 16. Jahrhunderts gewann das nicht sichtbare Gesicht Jesu in der deutschen Grafik vergleichbare Bedeutung und Verbreitung. ${ }^{88}$ Initiator dieser Tendenz scheint Albrecht Dürer (1471-1528) mit der Holzschnittserie der "Kleinen Passion« um 1509/11 gewesen zu sein. Umso origineller erscheint sein Konzept dadurch, dass Dürer die Druckgrafik mit ihrem Öffentlichkeitscharakter wählte. Der von der Kunstgeschichte oft und nicht zu Unrecht als Renaissancekünstler gefeierte und hochstilisierte Dürer ging mit seiner Bildfolge der Kleinen Passion am weitesten. Denn er eignete sich mit dem häufig schraffierten und deshalb undeutlichen, überschnittenen oder durch die Disposition im Bild komplett verborgenen Antlitz Christi ein extremes Mittel der

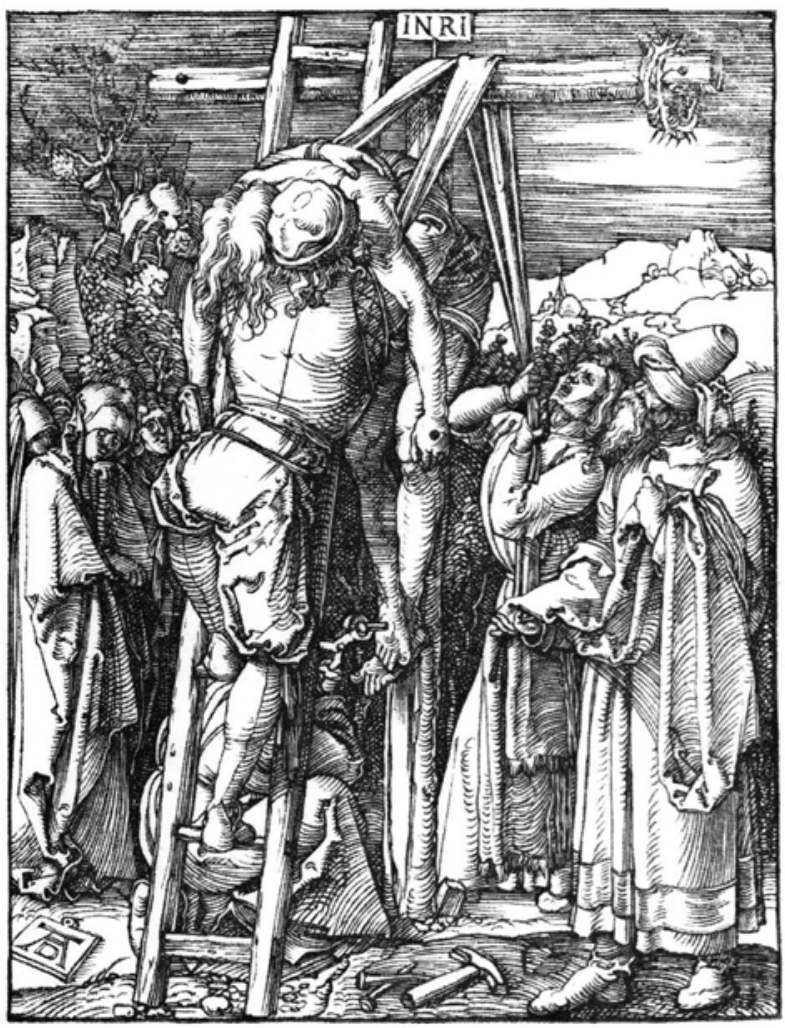

Abb. 16 Kreuzabnahme Christi, Kleine Passion. Albrecht Dürer, um 1509/10 (ex: Ausst.-Kat. Schweinfurt/Bad Arolsen/Bottrop 1999-2001, Nr. 48)

»mittelalterlichen « Kunst an, um wie die Maler um 1400 die Ohnmacht Jesu bei der Passion zu betonen, seinen entseelten Zustand zu akzentuieren oder die Wahrnehmung des Betrachters herauszufordern. ${ }^{89}$

Ein solcher Fall ist die Szene "Christus vertreibt die Händler aus dem Tempel« um 1509/10 (Abb. 15). ${ }^{90}$

Mit einer »Geißel aus Stricken « (Johannes 2,15) schlägt Jesus einen auf den Boden gefallenen Händler, während andere links und rechts erschrocken fliehen. Wie in der Kreuztragung Meister Franckes überschneidet auch bei Dürer der rechte Oberarm die untere Gesichtshälfte Jesu (Abb. 12), hier durch das Ausholen zum Schlag. Weil Dürer das Antlitz Christi dazu noch schattiert, ist von ihm kaum etwas zu erkennen. Eine Ausnahme bilden die zwei weiß gelassenen Punkte, mit denen Dürer die Augen Jesu andeutet. Durch die Verdeckung der unteren Gesichtshälfte und den Kontrast mit der schattierten oberen hebt Dürer die Augen Jesu heraus und leitet den Blick auf sie. Und diese hellen Augen strahlen Zorn aus. Die Kühnheit der Inszenierung Dürers wird noch deutlicher, wenn man 
bemerkt, dass große Teile des Körpers Jesu wie der zum Schlag ausholende Arm vom Licht, das von oben links einfällt, betont werden. Dürer verschärft damit die Dynamik der Bewegung, lässt aber auch das Antlitz Christi noch dunkler, beinahe wie eine Maske, wirken. So gelingt es dem Künstler, den Eindruck zu erzeugen, dass von Jesus Wut und Bedrohung ausgehen.

Bei bestimmten Sujets gab es im Laufe der Zeit eine gewisse Kontinuität im Hinblick auf das nicht sichtbare Gesicht Jesu. Dies ist der Fall bei zwei Darstellungen der Kreuzabnahme, zum einen des nordniederländischen Meisters des Morgan-Kindheitszyklus um $1420^{91}$, zum anderen Albrecht Dürers in der Kleinen Passion um 1509/10 (Abb. 16). ${ }^{92}$

In beiden Bildern wurden die Nägel aus den Händen Jesu gezogen, sodass sein Leichnam als Manifestation des entseelten Zustands nach vorne sinkt. Dementsprechend fällt auch der Kopf herab und die Haare verdecken das Gesicht Jesu vollständig. Die ausdruckssteigernde Komposition beider Darstellungen zeigt einen gebrochenen Körper ohne Selbstbestimmung und ohne Identität. Die Nicht-Sichtbarkeit des Antlitzes Christi veranschaulicht hier den Verlust seiner Existenz als Mensch. Im Tod, der das Ende jedes Menschen kennzeichnet, kulminiert die Kreatürlichkeit Jesu. Vielleicht deshalb bleibt in der Miniatur des Meisters des Morgan-Kindheitszyklus der Nimbus Jesu auf äußerst ungewohnte Weise am Kreuz stecken. ${ }^{93}$ Der Buchmaler scheint zu implizieren, dass sich Jesus mit seinem Tod von seiner göttlichen Natur, zumindest vorläufig, trennt. Bei Dürer hat Jesus keinen Nimbus.

Die Bilder, zwischen denen ungefähr 100 Jahre liegen, werfen die Frage auf, wie der nordniederländische Illuminator und Dürer auf diese Präsentation der Kreuzabnahme gekommen sind. Erica Tietze-Conrat konnte in Bezug auf Dürers Kreuzabnahme nachweisen, dass seine Vorlage höchstwahrscheinlich ein florentinischer Kupferstich der Zeit um 1490-1500 war, der in einem einzigen Exemplar überliefert ist. ${ }^{94}$ Trotz der unterschiedlichen Komposition zeigt der Kupferstich ebenfalls den nach vorne herabfallenden Leichnam Jesu, wodurch sein Gesicht verdeckt wird. Mark J. Zucker hat seinerseits darauf aufmerksam gemacht, dass die Komposition des florentinischen Kupferstichs sowie die Inszenierung des toten Jesus ohne Gesicht auf eine Zeichnung um 145060 zurückgeht, ${ }^{95}$ die ebenfalls in Florenz entstanden ist und aus dem Umkreis des Filippo Lippi (um 1406-69) stammt. ${ }^{96}$ Unklar bleibt nach wie vor, wie diese Variante

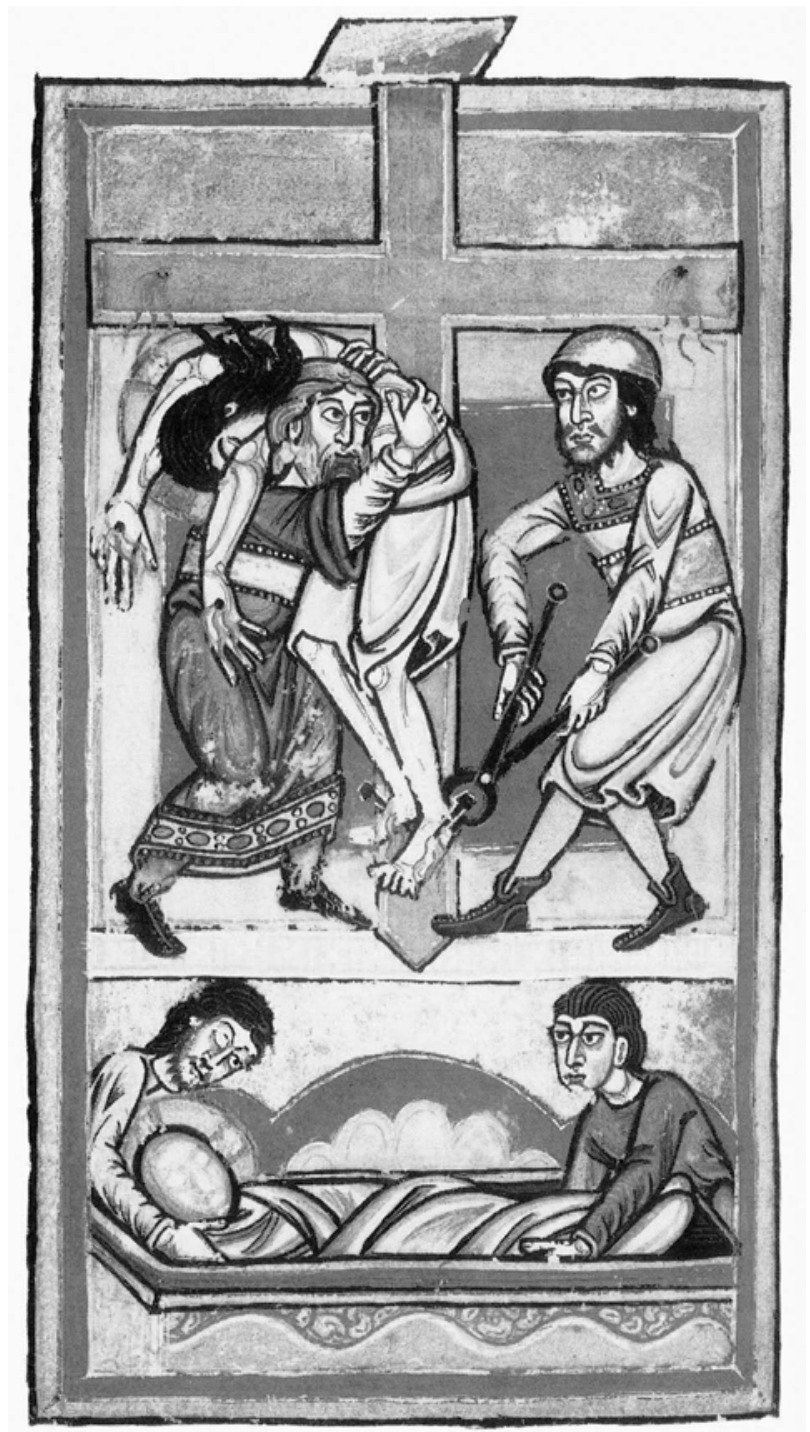

Abb. 17 Kreuzabnahme Christi. Flandern, um 1160-75. New York, The Morgan Library and Museum, Ms. M 883, fol. 51v (ex: KURYLUK 1991, Abb. 35)

der Kreuzabnahme nach Florenz kam und welche Vorbilder der nordniederländische Meister des Morgan-Kindheitszyklus' um 1420 kannte.

Eine ältere Form der Bildidee findet sich bereits in der Romanik. In der Zeit um 1160-75 entstand ein Lektionar in der Abtei Saint-Trond. ${ }^{97}$ Von besonderem Interesse ist eine ganzseitige Miniatur (Abb. 17), die in zwei Bildfelder geteilt ist. $^{98}$

Das obere Bildfeld stellt die Kreuzabnahme dar. Ein Helfer oder Knecht entfernt, wie es auch in der Miniatur des Stundenbuchs und im Holzschnitt Dürers geschieht, mit einer Zange die Nägel aus den Füßen Jesu; es sind 
hier zwei, da in dieser Zeit noch der sogenannte Viernagel-Typus des Gekreuzigten vorherrschte. Die Nägel aus den Händen sind schon gezogen - aus den Löchern im Querbalken des Kreuzes rinnt immer noch Blut - und Jesu Leichnam fällt nach vorne auf die Schulter eines älteren Mannes. Es handelt sich wahrscheinlich um Josef von Arimathäa, dem Pilatus gestattet hat, den toten Jesus vom Kreuz zu nehmen: »Er bat Pilatus, den Leichnam Jesu abnehmen zu dürfen, und Pilatus erlaubte es. Also kam er und nahm den Leichnam ab.« (Johannes 19,38) Damit der Leichnam nicht wie im Holzschnitt Dürers frontal herabsinkt und sowohl das Gesicht Jesu als auch des Mannes, der ihn hält, unsichtbar bleiben, präsentiert der Illuminator den toten Jesu in Dreiviertel-Ansicht. So bewahrte der Künstler das Gesicht Josefs und eine Partie des Antlitzes Christi. Trotz der Dreiviertel-Ansicht wird Jesu Gesicht von seinem linken Oberarm und Ellenbogen größtenteils verdeckt. $\mathrm{Zu}$ erkennen ist lediglich das linke, geschlossene Auge. Jesus ist auch hier ein Mensch ohne Gesicht, dessen Präsenz in der Szene auf die Kraftlosigkeit seines herabfallenden Leichnams reduziert ist. Nichtdestotrotz durfte er in diesem Bild seinen Nimbus "mitnehmen«.

Das untere Kompartiment zeigt die Grablegung und dabei eine gewisse Fortsetzung des vorherigen Bildes. Von den Evangelisten erzählt Johannes (19,39-42) den Vorgang am detailliertesten: "Sie nahmen den Leichnam Jesu und umwickelten ihn mit Leinenbinden, zusammen mit den wohlriechenden Salben, wie es beim jüdischen Begräbnis Sitte ist« (19,40). Der Illuminator folgt der Schilderung und stellt entsprechend den Leichnam Jesu verhüllt dar. Zwei Männer setzen ihn im Sarkophag bei. Sieht man in der Kreuzabnahme der Miniatur noch den leblosen Körper Jesu, so wirkt er hier durch die Umwickelung und ohne die Sicht auf etwaige Körperteile wie ein Gegenstand. Die Szene ähnelt der Verspottungsszene des Meisters des Morgan-Kindheitszyklus' (Abb. 5), wobei die Verhüllung Jesu dort als Folge seiner Peinigung zu verstehen ist, hier als Teil der Beisetzung. Betroffen ist ungewöhnlicherweise auch das Haupt, das jedoch weniger dicht umwickelt ist. ${ }^{99}$ Mit der Halbdurchsichtigkeit der Leinen ermöglicht der Buchmaler dem Betrachter einen verminderten Blick auf das Gesicht Jesu, dessen Züge sich unter dem Stoff abzeichnen. Lediglich der Nimbus unterscheidet Jesus von einem beliebigen Toten. Zwischen dem flämischen Lektionar, dem nordniederländischen Stundenbuch und der Kleinen Passion Dürers liegen Jahrhunderte, doch die ungewohnte Bildformel der
Kreuzabnahme mit dem nach vorne sinkenden Leichnam Jesu taucht in allen drei Kunstepochen auf. Die Wege der Überlieferung bleiben unklar; es ist allerdings denkbar, dass es vor allem in illuminierten Handschriften weitere Zeugnisse zu entdecken gibt.

\section{Literatur}

Auerbach, Erich: Mimesis. Dargestellte Wirklichkeit in der abendländischen Literatur. 10. Aufl. Tübingen/Basel 2001.

[Ausst.-Kat. Frankfurt/M. 1975]: Ausst.-Kat. Kunst um 1400 am Mittelrhein. Ein Teil der Wirklichkeit. Hg. von Herbert BeCK, Wolfgang BeEH und Horst BredeKamp. Frankfurt/M., Liebieghaus Museum Alter Plastik, 10.12.1975-15.2.1976. Frankfurt/M. 1975.

[Ausst.-Kat. Karlsruhe 1996]: Ausst.-Kat. Die Karlsruher Passion. Ein Hauptwerk Straßburger Malerei der Spätgotik. Hg. von Dietmar LüDKe und Stefan Roller. Karlsruhe, 4.4.30.6.1996. Ostfildern-Ruit 1996.

[Ausst.-Kat. Konstanz 2014]: Ausst.-Kat. Das Konstanzer Konzil 1414-1418. Weltereignis des Mittelalters. Hg. vom Badischen Landesmuseum. Konstanz, 27.4.-21.9.2014. Darmstadt 2014.

[Ausst.-Kat. Nijmegen 2005]: Ausst.-Kat. Die Brüder van Limburg. Nijmegener Meister am französischen Hof (14001416). Hg. von Rob Dückers und Pieter Roelofs. Nijmegen, 28.8.-20.11.2005. Stuttgart 2005.

[Ausst.-Kat. Nürnberg 2000]: Ausst.-Kat. Spiegel der Seligkeit. Privates Bild und Frömmigkeit im Spätmittelalter. Hg. von Frank Matthias KAMMEL. Nürnberg, 31.5.-22.10.2000. Nürnberg 2000.

[Ausst.-Kat. Regensburg 2010]: Ausst.-Kat. Unerträgliche Kreatürlichkeit. Leid und Tod Christi in der spätmittelalterlichen Kunst. Bearb. von Stavros Vlachos. Regensburg, 16.9.28.11.2010. Regensburg 2010.

[Ausst.-Kat. Schweinfurt/Arolsen/Bottrop 1999]: Ausst.-Kat. Dürer: Himmel und Erde. Gottes- und Menschenbild in Dürers druckgraphischem Werk. Bearb. von Erich Schneider. Schweinfurt, 17.10.1999-6.2.2000; Bad Arolsen, 20.5.-30. 7.2000; Bottrop, 2.9.-25.11.2001. Schweinfurt 1999 (Holzschnitte, Kupferstiche und Radierungen aus der Sammlung Otto Schäfer 2).

[Ausst.-Kat. Utrecht/New York 1989/9o]: Ausst.-Kat. Die goldene Zeit der holländischen Buchmalerei. Bearb. von Henri Defoer, Anne Korteweg und Wilhelmina Wüstefeld. Utrecht, 10.12.1989-11.2.1990; New York, 1.3.-6.5.1990. Stuttgart/Zürich 1990.

[Ausst.-Kat. Wien 1962]: Ausst.-Kat. Europäische Kunst um 
1400. Hg. von Otto Benesch und Zdravka Ebenstein. Wien, Kunsthistorisches Museum, 7.5.-31.7.1962. Wien 1962.

Bartlová, Milena: The Beautiful Style in Bohemia. An Argument in the Controversy of Christian Images. In: Braun/ Herweg/Hubert u. a. 2013, 189-193.

[Beck/Bredekamp 1975/I]: Beck, Herbert/Bredekamp, Horst: Die internationale Kunst um 1400. In: Ausst.-Kat. Frankfurt/M. 1975, 1-29.

[Beck/Bredekamp 1975/II]: Beck, Herbert/Bredekamp, Horst: Die mittelrheinische Kunst um 1400. In: Ausst.-Kat. Frankfurt/M. 1975, 30-40.

Benz, Richard (Übers.): Die Legenda aurea des Jacobus de Voragine. 15. Aufl. Gütersloh 2007.

Braun, Karl-Heinz/Herweg, Mathias/Hubert, Hans W./ Schneider, Joachim/Zotz, Thomas (Hgg.): Das Konstanzer Konzil 1414-1418. Weltereignis des Mittelalters. Essays. Darmstadt 2013.

Büttner, Frank Olaf: Zu Bildform, Stilmitteln und Ikonographie der Tafelmalerei um 1400. In: Kunsthistorisches Jahrbuch Graz 24 (1990), 62-87.

Büttner, Frank Olaf: Das Christusbild auf niedrigster Stilhöhe. Ansichtigkeit und Körpersichtigkeit in narrativen Passionsdarstellungen der Jahrzehnte um 1300. In: Wiener Jahrbuch für Kunstgeschichte 46/47 (1993/94), 99-130.

CARquĖ, Bernd: Europa 1400. Wunschraum und Wunschzeit des Internationalen und Schönen, Höfischen und Weichen. Zu den Imaginarien kunsthistorischer Stilbegriffe. In: CARQUĖ/RöCKELEIN 2005, 515-553.

Carquė, Bernd/Röckelein, Hedwig (Hgg.): Das Hochaltarretabel der St. Jacobi-Kirche in Göttingen. Göttingen 2005 (Veröffentlichungen des Max-Planck-Instituts für Geschichte 213; Studien zur Germania Sacra 27).

Degenhart, Bernhard/Schmitt, Annegrit: Corpus der Italienischen Zeichnungen 1300-1450, Teil I. Süd- und Mittelitalien. 4 Bde. Berlin 1968.

Dittmeyer, Daria: Gewalt und Heil. Bildliche Inszenierungen von Passion und Martyrium im späten Mittelalter. Diss. Hamburg 2012; Köln/Weimar/Wien 2014 (Sensus. Studien zur mittelalterlichen Kunst 5).

FAJT, Jiř́l/LAnger, Andrea (Hgg.): Kunst als Herrschaftsinstrument. Böhmen und das Heilige Römische Reich unter den Luxemburgern im europäischen Kontext. Tagung Prag, Mai 2006. Berlin/München 2009.

Fernandez-Gimenez, Elizabeth de/Lurie, Ann Tzeuschler/ Stechow, Wolfgang/Wixom, Nancy Coe: The Cleveland Museum of Art. European Paintings before 1500. Cleveland 1974 (Catalogue of Paintings, Part 1).

Franzen, Wilfried: Die Karlsruher Passion und das »Erzäh- len in Bildern«. Studien zur süddeutschen Tafelmalerei des 15. Jahrhunderts. Diss. Berlin (TU) 2000; Berlin 2002.

Harms, Wolfgang (Hg.): Text und Bild, Bild und Text. DFGSymposium 1988. Stuttgart 1990 (Germanistische Symposien, Berichtsbände 11).

Haug, Walter (Hg.): Mittelalter und frühe Neuzeit. Übergänge, Umbrüche und Neuansätze. Tübingen 1999 (Fortuna vitrea 16).

Hauschild, Stephanie: Farbe als Gestaltungselement von Meister Bertram. In: Sit T/Hauschild 2008, 53-72.

[Hess 2007/I] : Hess, Daniel: Stile und Regionen. Malerei und Glasmalerei. In: ZANDER-SEIDEL 2007, 265-275.

[Hess 2007/II] : Hess, Daniel: Die Bildwelt des Altars. In: ZANDER-SEIDEL 2007, 290-298.

[Hess 2007/III]: Hess, Daniel: Zwischen Frankreich und Böhmen: Nürnberger Malerei und Glasmalerei. In: ZANDER-SEIDEL 2007, 337-347.

Husband, Timothy: The Art of Illumination. The Limbourg Brothers and the Belles Heures of Jean de France, Duc de Berry. New Haven 2008.

Kemperdick, Stephan (Hg.): Deutsche und Böhmische Gemälde 1230-1430. Gemäldegalerie Berlin. Kritischer Bestandskatalog. Unter Mitarbeit von Beatrix Graf und Regina Cermann. Petersberg b. Fulda 2010.

KöNIG, Eberhard: Die Belles Heures des Duc de Berry. Sternstunden der Buchkunst. Stuttgart 2004.

KöNIG, Eberhard: Die Grandes Heures de Rohan. Eine Hilfe zum Verständnis des Manuscrit latin 9471 der Bibliothèque nationale de France. Simbach/Inn 2006.

KLIPA, Jan: Der Schöne Stil in Böhmen. Sinnlicher Realismus und ideale Schönheit. In: Ausst.-Kat. Konstanz 2014, 42-44.

Kuryluk, Ewa: Veronica and Her Cloth. History, Symbolism, and Structure of a »True« Image. Cambridge (Massachusetts) 1991.

Leppien, Helmut R.: Der Thomas-Altar von Meister Francke in der Hamburger Kunsthalle. Stuttgart 1992.

Lyna, Frédéric: Les miniatures d’un ms. du »Ci nous dit« et le réalisme préeyckien. In: Scriptorium 1 (1946/47), 106-118.

Marrow, James H.: Dutch Manuscript Illumination before the Master of Catherine of Cleves. The Master of the Morgan Infancy Cycle. In: Nederlands kunsthistorisch jaarboek 19 (1968), 51-113.

Marrow, James H.: Circumdederunt me canes multi. Christ's Tormentors in Northern European Art of the Late Middle Ages and Early Renaissance. In: The Art Bulletin 59 (1977), $167-181$.

Marrow, James H.: Passion Iconography in Northern European Art of the Late Middle Ages and Early Renaissance. A Study of the Transformation of Sacred Metaphor into De- 
scriptive Narrative. Diss. New York 1975; Kortrijk 1979 (Ars neerlandica 1).

Moraht-Fromm, Anna: Das Erbe der Markgrafen. Die Sammlung deutscher Malerei (1350-1550) in Karlsruhe. Ostfildern 2013.

Oettinger, Karl: Der Meister von Wittingau und die böhmische Malerei des späteren 14. Jahrhunderts. In: Zeitschrift des Deutschen Vereins für Kunstwissenschaft 2 (1935), 293307.

Oettinger, Karl: Zur Malerei um 1400 in Österreich. In: Jahrbuch der Kunsthistorischen Sammlungen in Wien N. F. 10 (1936), 59-96.

Oettinger, Karl: Altböhmische Malerei. In: Zeitschrift für Kunstgeschichte 6 (1937), 397-406.

Oettinger, Karl: Ein österreichischer Kreuzigungsaltar gegen 1400. In: Jahrbuch der Kunsthistorischen Sammlungen in Wien 50 (1953), 93-106.

Päснт, Otto: Die Gotik der Zeit um 1400 als gesamteuropäische Kunstsprache. In: Ausst.-Kat. Wien 1962, 52-65.

PANofsky, Erwin: Die altniederländische Malerei. Ihr Ursprung und Wesen. Übers. und hg. von Jochen Sander und Stephan Kemperdick. 2 Bde. Bd. 1: Text, Bd. 2 : Abbildungen. Köln 2001.

PAUL, Jürgen: Umbrüche in der Kunst des späten Mittelalters. Synchronismus und Asynchronismus unter stil-, inhaltsund funktionsgeschichtlicher Betrachtung. In: HAUG 1999, $471-498$.

Pfeiffer, Götz R.: Die Malerei am Niederrhein und in Westfalen um 1400. Der Meister des Berswordt-Retabels und der Stilwandel seiner Zeit. Diss. Berlin (TU) 2005; Petersberg b. Fulda 2009 (Studien zur internationalen Architektur- und Kunstgeschichte 73).

Pieper, Paul: Die deutschen, niederländischen und italienischen Tafelbilder bis um 1530. Münster 1986 (Westfälisches Landesmuseum für Kunst und Kulturgeschichte Münster. Landschaftsverband Westfalen-Lippe. Bestandskataloge).

Ragusa, Isa/Green Rosalie B.: Meditations on the Life of Christ. An Illustrated Manuscript of the Fourteenth Century. Paris, Bibliothèque nationale, Ms. Ital. 115. Princeton 1977 (Princeton Monographs in Art and Archaeology 35 ).

ScнміDт, Gerhard: Von den Anfängen des gotischen Expressionismus. In: SCHмIDT 2005, 215-218. Zuerst erschienen in: Alte und Moderne Kunst 4 (1959), 22-24.

Schmidt, Gerhard: Kunst um 1400. Forschungsstand und Forschungsperspektiven. In: Kunsthistorisches Jahrbuch Graz 24 (1990), 34-49.

Sснміdт, Gerhard: »Pre-Eyckian Realism«. Versuch einer Abgrenzung. In: SMEYERS/CARDON 1995, 747-769.

Scнмidt, Gerhard: Malerei der Gotik. Fixpunkte und Ausblicke. 2 Bde., hg. von Martin Roland. Graz 2005.
Schoch, Rainer/Mende, Matthias/Scherbaum, Anna: Albrecht Dürer. Das Druckgraphische Werk, Bd. 2. Holzschnitte und Holzschnittfolgen. München 2002.

Schooten, C. J. F. van/Wüstefeld, Helen (Hgg.): Goddelijk geschilderd. Honderd Meesterwerken van Museum Catharijneconvent [Göttlich gemalt. Einhundert Meisterwerke aus dem Museum Catharijneconvent]. Zwolle 2003.

Sit T, Martina: Die deutschen, englischen, französischen und spanischen Gemälde 1350-1800. Die Gemälde der Alten Meister. Unter Mitarbeit von Gerrit WALCzAK. Hamburg 2007 (Die Sammlungen der Hamburger Kunsthalle 1).

Sitt, Martina/Hauschild, Stephanie: Der Petri-Altar von Meister Bertram. Hamburg 2008.

Smeyers, Maurits: Flämische Buchmalerei. Vom 8. bis zur Mitte des 16. Jahrhunderts. Die Welt des Mittelalters auf Pergament. Aus dem Niederländischen von Marlene Müller-Haas (Einleitung bis Kapitel 2) und Franz J. Lukassen (Kapitel 3 bis Epilog). Stuttgart 1999.

Smeyers, Maurits/Cardon, Bert (Hgg.): Flanders in a European Perspective. Manuscript Illumination around 1400 in Flanders and abroad. Leuven 1995.

[Suckale 2008/I]: Suckale, Robert: Stil und Funktion. Ausgewählte Schriften zur Kunst des Mittelalters. Hg. von Peter Schmidt und Gregor Wedekind. 2. Aufl. München/Berlin 2008.

[SUCKALE 2008/II]: SUCKALE, Robert: Süddeutsche szenische Tafelbilder um 1420-50. Erzählung im Spannungsfeld zwischen Kult- und Andachtsbild. In: HARMs 1990, 15-34; hier zitiert nach dem Wiederabdruck in: SUCKALE 2008/I, 59-85.

Tietze-Conrat, Erica: Two Dürer Woodcuts and an Italian Model. In: The Burlington Magazine 62 (1933), 241-245.

Vlachos, Stavros: Deformation und Verfremdung. Eine Stiltendenz in der deutschen Kunst um 1500. Diss. Bamberg 2008; Kiel 2012.

Walcher, Jeanine (Red.): Die Sprache des Materials. Die Technologie der Kölner Tafelmalerei vom »Meister der heiligen Veronika« bis Stefan Lochner. Berlin/München 2013.

Weilandt, Gerhard: Das Hochaltarretabel der Nürnberger Frauenkirche. Ein Hauptwerk der Kunst um 1400. Standortstudien V. In: FAJT/LANGER 2009, 196-220.

Wolfson, Michael: Originalität und Tradition. $\mathrm{Zu}$ den ikonographischen und künstlerischen Quellen der Karlsruher Passion. In: Zeitschrift des Deutschen Vereins für Kunstwissenschaft 45 (1991), 67-87.

ZANDER-SEIDEL, Jutta (Red.) : Mittelalter. Kunst und Kultur von der Spätantike bis zum 15. Jahrhundert. Nürnberg 2007 (Die Schausammlungen des Germanischen Nationalmuseums 2). Zehnder, Frank Günter: Katalog der Altkölner Malerei. Köln 1990 (Kataloge des Wallraf-Richartz-Museums 11).

Zeman, Georg: The Copenhagen «Mocking of Christ» and the 
Early Style of the Limburg Brothers. In: Master Drawings 41 (2003), 204-215.

Zipelius, Julia: Der »Utrechter Altar« und die Malerei um 1400 am Mittelrhein. In: Mainzer Zeitschrift 87/88 (1992/93), 12133.

Zucker, Mark J.: The Illustrated Bartsch, Early Italian Masters, Band. 24. Commentary Part 2. New York 1994.

\section{Anmerkungen}

1 Einen Überblick über die Kunst um 1400 bietet der Ausst.-Kat. Wien 1962.

2 Otto Pächt benutzt auch den Begriff »höfischer Stil«, auf dessen Berechtigung und gleichzeitige Bedingtheit er verweist. Pächt erwähnt auch gewisse "realistische Tendenzen « der Malerei um 1400: »Aber wenn wir in französischen, deutschen und lombardischen Epiphaniebildern die Heiligen Drei Könige französisch-burgundische Prunkgewänder tragen sehen, so führt uns dies nicht nur die Vorbildlichkeit der westlichen höfischen Mode vor Augen, sondern mag uns auch als das einfachste Beispiel der Verbreitung einer neuen vom Westen her vordringenden Erzählungsweise gelten, die mit Hilfe eines Oberflächen- und Kostümrealismus ins Heute zu verlegen, ihre >Vergegenwärtigung« zu erzielen sucht«. РӒснт 1962, 55. - Zur Problematik der Begriffe in Bezug auf die Kunst um 1400 CARQuÉ 2005.

3 Nadelholz, H. 91,5 cm, B. $122 \mathrm{~cm}$. - Nürnberg, Germanisches Nationalmuseum, Inv.-Nr. Gm 114. - Hess 2007/II, 293 f. - Hess 2007/ III, 344 f. und 434, Kat.-Nr. 459, mit weiterer Literatur. - Zum ehemaligen Hochaltar der Frauenkirche WeILANDT 2009.

4 Eichenholz, H. $80 \mathrm{~cm}$, B. $51 \mathrm{~cm}$. - Hamburg, Kunsthalle, Inv.-Nr. 500. - Siтt 2007, 53-65, mit Abb. und weiterer Literatur. - Siтt/ HAUsChild 2008, Abb. 49 (in Farbe).

5 Herausgehoben wird dieser Soldat auch mittels der Farbgestaltung, rot und blau, wie Stephanie Hauschild gezeigt hat. HAUSCHILD 2008, 55.

6 Oettinger 1935, 297.

7 OetTinger 1935, 299.

8 Oettinger 1935, 299.

9 Oettinger 1936, 61.

10 Oettinger 1936, 64.

11 Oettinger 1936, 87.

12 Oettinger 1936, 62.

13 Oettinger 1936, 71.

14 Oettinger 1936, 71.

15 Oettinger 1936, 79.

16 OetTinger 1937, 403.

17 Oettinger 1937, 402.

18 Oettinger $1937,403$.

19 Oettinger 1953, 96.

20 Oettinger 1953, 97.

21 Oettinger 1953, 106.

22 Oettinger 1953, 106.

23 LYNA 1946/47.

24 „En de nombreux endroits, il marque une singulière prédilection, parfois morbide, pour la laideur sous ses formes multiples, non une laideur créée par une imagination grossière, mais une laideur inspirée par la réalité, grossie, exagérée, déformée et transformée à plaisir par un humour pessimiste et caustique et par une verve inépuisable et endiablée. Ajoutez à cela un sens juste et subtil de l'action, d'une action drue et véhémente atteignant parfois au paroxysme de la violence." LyNA 1946/47, 112.

25 LYNA 1946/47, 114.

26 PANofsky 2001, I, 70.

27 Panofsky 2001, I, 70-73, auch mit Beispielen zeitgenössischer Dichtkunst.

28 Beck/Bredekamp 1975/I, 19-29.

29 Beck/BredeKamp 1975/II, 64-95.

30 Paul 1999, $475 \mathrm{f}$.

31 Schmidt 1990, 42.

32 Es ist interessant, wie die böhmische Kunst um 1400 jüngst aus zwei unterschiedlichen Perspektiven interpretiert wurde. Milena Bartlová deutet die Idealisierung selbst um 1400 als Folge und Reaktion auf die religiöse Krise in Böhmen. BARTLOvÁ 2013, 192. - Jan Klipa betrachtet hingegen die Idealisierung nicht als Symptom der religiösen Krise, sondern als einen ihrer Auslöser. KLIPA 2014, 44.

33 Suckale 2008/II, 68, Abb. 8.

34 Auerbach 2001, 235.

35 Auerbach 2001, 236.

36 Schmidt 1990, 35.

37 SChMidt 1995.

38 SMeYers 1999, 175.

39 Smeyers 1999, 175.

40 SMeyers 1999, 175.

41 »Die Stilerneuerung stütze sich darüber hinaus auf eine noch unterentwickelte Technik. Der prä-eycksche Realismus sei - so gesehen qualitativ minderwertig. Diese Betrachtungsweise wird von denjenigen verteidigt, die die französische Kunst jener Zeit oder die spätere flämische Malerei als Norm heranziehen. Das ist ein ungerechtfertigtes Vorurteil: Der prä-eycksche Realismus hängt mit einer anderen Sichtweise, mit einer anderen Vorgehensweise und mit anderen Gefühlswerten zusammen, die eine Eigenart des Niederländischen und speziell des Flämischen bilden.«SMEYers 1999, 178.

42 Dazu Schмidt 2005, I, 215-218. Der Verfasser behandelt Beispiele aus illuminierten Handschriften der Zeit um 1325-50.

43 Sснмidt 1995, 758.

44 Schmidt 1995, 753.

45 SсHмidt 1995, 759.

46 Schmidt 1995, 759.

47 BÜtTner 1990, 63. - Über die elliptische Darstellung vgl. ausführlich 69 f. Auf S. 69 betont F. O. Büttner noch einmal: "Bei Figuren sind Randüberschneidung, Verhüllung oder eine der Übersichtlichkeit sich entziehende Stellung die Mittel eines Situationsrealismus, die der Darstellung selbst gehören. Die Malerei um 1400 wendet diese Darbietungsweisen auch gegenüber Gestalten an, die am zentralen Bildgeschehen beteiligt sind."

48 BüttNer 1993/94, $118 \mathrm{f}$., $123 \mathrm{f}$.

49 »Der Realismus des Narrativen, wie ihn die Malerei um 1400 vertritt, unterscheidet sich vom Realismus des Deskriptiven der frühniederländischen Tafelmalerei grundlegend durch eine andere Art der Stilisierung, durch das also, was die Darstellung von Wirklichkeit jeweils überhaupt erst zum Stilphänomen macht. Bei der Malerei der Internationalen Gotik lag eine - wie es uns heute vorkommt - Stili- 
sierung eher in den Konventionen der Formensprache. Dabei wird man aber nicht außer Acht lassen, daß in dem für die stilistische Entwicklung der mitteleuropäischen Malerei wichtigen Gebiet nach Mitte des 14. Jahrhunderts eine erhebliche Drastik zur Stilkonvention gehört hatte. Bei der frühniederländischen Tafelmalerei richtete sich andererseits eine rigorose Stilisierung auf die Redaktion der Ikonographie: das Narrative, das Anekdotische ging stark zurück«. BÜTTNER 1990, 63.

50 Eichenholz, H. $38 \mathrm{~cm}$, B. $21 \mathrm{~cm}$. - Nürnberg, Germanisches Nationalmuseum, Inv.-Nr. Gm 1053. - Wolfson 1991, 77. - Ausst.-Kat. Karlsruhe 1996, 218, Kat.-Nr. 13. - Ausst.-Kat. Nürnberg 2000, 219 f., Kat.-Nr. 48. - Hess 2007/I, 273 f. und 421, Kat.-Nr. 364. - Ausst. Kat. Regensburg 2010, 15f. - Vlachos 2012, 24 f. - Dittmeyer 2014, 179.

51 Staatliche Kunsthalle Karlsruhe, Inv.-Nr. 2180. - Wolfson 1991, 77-8o, Abb. 5. - Ausst.-Kat. Karlsruhe 1996, 75-89, Taf. 4. - FranZeN 2002, 33-43, Abb. 5 (in Farbe). - Jüngst Moraht-Fromm 2013, 249-260, mit Farbabb. aller Tafeln des Malers und ausführlicher Literatur. Vgl. auch den Beitrag von M. Hörsch in diesem Band.

52 WOLFSON 1991, 77.

53 Wolfson 1991, 77.

54 Köln, Wallraf-Richartz.Museum, Inv.-Nr. WRM 585. - Wolfson 1991, 74-76, Abb. 2. - Ausst.-Kat. Karlsruhe 1996, 41-55, Taf. 2. FranZen 2002, 25-29, Abb. 2 (in Farbe).

55 Dazu ausführlich Marrow 1977. - Marrow 1979, 33-43.

56 Ausst.-Kat. Nürnberg 2000, 219 (Daniel Hess).

57 Ragusa/Green 1977, 333.

58 BÜTTNER 1993/94, 112.

59 London, The British Library, Add. 50005, fol. 112v. - MARrow 1968, 93. - Ausst.-Kat. Utrecht/New York 1989/90, 63 f., Kat.-Nr. 14. - BütTNER 1993/94, 123 f. - Ungewöhnlich ist die Häufung der vollständigen Nacktheit Jesu in verschiedenen Leidensstationen der Handschrift, in denen Jesus oft auch wundenübersät ist. BÜTTNER 1993/94, 123.

60 Nussbaumholz, H. 66 cm, B. 47 cm. - Karlsruhe, Staatliche Kunsthalle, Inv.-Nr. 1497. - Wolfson 1991, 80 f., Abb. 6. - Ausst.-Kat. Karlsruhe 1996, 90-100, Taf. 5. - Franzen 2002, 43-45, Abb. 6 (in Farbe).

61 BÜTTNER 1993/94, 122.

62 Idar-Oberstein, Felsenkirche. - Ausst.-Kat. Frankfurt/M. 1975, 124, Kat.-Nr. 15, Taf. 1, Abb. 103. - Franzen 2002, 159-162, Abb. 59 f.

63 Fichtenholz, H. $132 \mathrm{~cm}$, B. 53,5 cm.

64 Auf die ungewöhnliche Ikonographie der Verspottung hat Wilfried Franzen hingewiesen. FrANZEN 2002, 160.

65 Walnuss- (Mitteltafel) und Eichenholz (Flügel), H. 58,9 cm, B. 19, 8 cm (Flügel). - Köln, Wallraf-Richartz-Museum, Inv.-Nr. WRM 10. Zehnder 1990, 316-323. - Zur Datierung Walcher 2013, 238, Nr. 9.

66 Die Nacktheit Jesu in Passionsbildern war als extremes Mittel der Erniedrigung selten, sie scheint jedoch im Laufe des 15. Jahrhunderts und besonders nach 1450, wohl als Manifestation einer zunehmenden Passionsfrömmigkeit, an Bedeutung zu gewinnen. VLACHOS 2012, 101-109. - DitTMEYer 2014, 174-181.

67 London, The British Library, Add. 50005, fol. 92v. - MARrow 1968, 92. - BÜTTNER 1993/94, 119.

68 Ausführlich zur Blendung Jesu BüTtNer 1993/94, 106-116, mit vielen Bildbeispielen.
69 Das Motiv scheint auf Bernhard von Clairvaux (um 1090-1153) zurück zu gehen, wie Jacobus schreibt: »Davon spricht Sanct Bernhard ,Guter Jesu, dein tröstlich Antlitz, das die Engel mit begierlicher Freude anschauen, das haben sie mit Speichel entehret, mit ihren Händen zerschlagen, und zum Spott mit einem Tuch verdecket, und haben die bittern Wunden nicht gesparet««. BenZ 2007, 202.

7 O BüTtNER 1993/94, 119.

71 BÜTTNER 1993/94, 110.

$72 \mathrm{Holz}$, H. $66,5 \mathrm{~cm}$, B. $56 \mathrm{~cm}$. Utrecht, Museum Catharijneconvent, Inv.-Nrr. ABM 525t/m s28; s156 t/m s158. - Zum Altar allgemein Zipelius 1992/93. - Schooten/Wüstefeld 2003, 26-33, Kat.-Nr. 2 (Marieke van Vlierden), mit Farbabb.

73 Dazu bereits Marieke van Vlierden in Schooten/Wüstefeld 2003, 30. - Dass in der spätmittelalterlichen Malerei häufig nur Juden als Folterknechte auftreten, hängt mit der Judenfeindlichkeit dieser Zeit zusammen. Franzen bezeichnete dieses Phänomen als »Judaisierung « der römischen Peiniger. Dies betraf in vielen Fällen den Spötter: "Mehrfach wird jener Knecht, der Christus das Spottzepter überreicht oder ihn verhöhnt, als `Jude` gekennzeichnet«. FranzeN 2002, 237 und Anm. 617 (Verweis auf die Verspottungsszene des mittelrheinischen Altars).

74 Kopenhagen, Statens Museum for Kunst, Kobberstiksamling, Inv.Nr. GB 2971. - BÜtTner 1993/94, 110. - Zeman 2003, Abb. 1. Ausst.-Kat. Nijmegen 2005, 412, Kat.-Nr. 122, mit Abb.

75 New York, The Metropolitan Museum of Art, The Cloisters Collection, Inv.-Nr. 54.1 1a, b, fol. 131v. - König 2004, 97 f. - Husband 2008, 172, 269, 288.

76 Berlin, Staatliche Museen - Preußischer Kulturbesitz, Gemäldegalerie, Inv.-Nr. 1221. - „Darüber hinaus schien dem Auftraggeber der Berliner Tafeln daran gelegen zu sein, in der Verspottung die auffallend einheitlich gekleideten Hohepriester als Anstifter der Misshandlungen einfügen zu können. Für dieses Motiv ist kaum ein zweites Beispiel aus der nordalpinen Malerei dieser Zeit bekannt. Augenscheinlich sollen damit die Juden als Feinde Christi hervorgehoben werden; das Bildpaar bekommt eine deutliche antijüdische Aussage«. Kemperdick 2010, 135, Kat.-Nr. 17 (Stephan KemperDICK), mit Abb. 141 (in Farbe).

77 New York, The Metropolitan Museum of Art, The Cloisters Collection, Inv.-Nr.54.1 1a, b, fol. 149v. - KöNIG 2004, 105 f. - Ausst.-Kat. Nijmegen 2005, 366, Kat.-Nr. 99. - HUSBAND 2008, 182.

78 Paris, Bibliothèque nationale de France, lat. 9471, fol. 135. - KöNIG 2006, 18-21. - Ausst.-Kat. Regensburg 2010, 16.

79 Eichenholz, H. 91,7 cm, B. 81,5 cm. - Hamburg, Kunsthalle, Inv.-Nr. 495. - Leppien 1992, 26-28. - Sitt 2007, 154.

80 Siehe auch LEPPIEN 1992, 26.

81 Eichenholz, H. 118,5 cm, B. 84 cm. - Dortmund, St. Marien. Pfeiffer 2009, $84 \mathrm{f}$.

82 Bielefeld, Kollegiatstift St. Maria und Georg. - Pfeiffer 2009, 59 f., Abb. 27, Taf. 19.

83 Eichenholz, H. 44,5 cm, B. 38,7 cm. - Münster, LWL-Museum für Kunst und Kultur, Inv.-Nr. 34, 35 WKV. - PIEPER 1986, 140-155, bes. 141. - Franzen 2002, 147-150.

84 Aus der Werkstatt oder dem Umkreis Koerbeckes stammt eine Kreuztragung (Steinhagen/W., Evangelische Dorfkirche), die Teil eines Passionsaltars ist. Der Maler modifizierte hier das Bildkonzept Koerbeckes. Nun sieht man Jesus von der Seite und von oben. Dementsprechend wird sein im Profil dargestelltes Gesicht von der 
rechten Hand und vom Querbalken des Kreuzes überschnitten. Lediglich das rechte Auge bleibt sichtbar. Marrow 1979, Abb. 64 .

85 Eichenholz, H. 36,2 cm, B. 39,9 cm (Fall Christi) bzw. H. 36,2 cm, B. $39,9 \mathrm{~cm}$ (Kreuztragung). - The Cleveland Museum of Art, Mr. and Mrs. William H. Marlatt Fund, Inv.-Nr. 1951.453. - FernanDeZ-Gimenez/Lurie/Stechow/Wixom 1974, 31-33, Kat.-Nr. 11 (Wolfgang Stechow), mit Abb. aller Tafeln. - Franzen 2002, $224 \mathrm{f}$. 86 »Bemerkenswert ist vor allem die ausführliche Behandlung der Kreuztragung, die in zwei Episoden erzählt wird und damit eine besondere Gewichtung erhält: der Sturz des Kreuztragenden und die Kreuztragung mit Simon von Kyrene. Die Darstellung zweier Ereignisse der Kreuztragung begegnet uns hier zum ersten Mal und bleibt auch in der nachfolgenden Tafelmalerei eine singuläre Erscheinung«. FrANZEN 2002, 224.

87 Franzen 2002, 148, Anm. 381.

$88 \mathrm{Zu}$ Beispielen der Beweinung und der Grablegung Christi VLaChos 2012, 183-195, 199-202, mit Abb.

89 Dazu Ausst.-Kat. Regensburg 2010, 63-67, Kat.-Nrr. 22-25, mit Abb. - Vlachos 2012, 94-97 (Gebet Christi am Ölberg), 128-131 (Christus vor Annas).

90 Holzschnitt, H. 12,7 cm, B. 9,7 cm. - Ausst.-Kat. Schweinfurt/Bad
Arolsen/Bottrop 1999, 82, Kat.-Nr. 29. - SCHOCH/Mende/ScherBAUM 2002, 296 f., Kat.-Nr. 192.

91 London, The British Library, Add. 50005, fol. 123v. - MARrow 1968, 81, Abb. 18.

92 Holzschnitt, H. 12,7 cm, B. 9,8 cm. - Ausst.-Kat. Schweinfurt/Bad Arolsen/Bottrop 1999, 102, Kat.-Nr. 48. - Schoch/Mende/ScherBAUм 2002, 328 f., Kat.-Nr. 212 - Ausst.-Kat. Regensburg 2010, 66 f., Kat.-Nr. 25. - Auf die Ähnlichkeit der beiden Darstellungen hat BütTNER 1993/94, 109 f., hingewiesen.

93 Darauf hat schon Marrow 1968, 81, aufmerksam gemacht.

94 London, The British Museum, Department of Prints and Drawings, Inv.-Nr. 1932,0616.1. - Tietze-Conrat 1933, Abb. A, B.

95 ZUCKer 1994, 227.

96 Firenze, Gabinetto Disegni e Stampe degli Uffizi, Inv.-Nr. 136 E. Degenhart/Schmitt 1968, II, 443, Kat.-Nr. 362 ; IV, Taf. 304b.

$97 \mathrm{Zu}$ diesem Lektionar allgemein Smeyers 1999, 96 f., Abb. 52.

98 New York, The Morgan Library and Museum, Ms. M 883, fol. 51v. Kuryluk 1991, 219.

99 Eine englische romanische Miniatur mit der Grablegung der Zeit um 1140 stellt ebenfalls den toten Jesus mit verhülltem Gesicht dar. London, Victoria and Albert Museum, Ms. 661 verso. BüttneR 1993/94, 112 . 

ADAM S. LABUDA

\title{
Das Zeugnis der KÜnstlerischen Form - DAs Zeugnis der Schriftquellen
}

\author{
Auf den Spuren der Schöpfer des Breslauer St.-Barbara-Altars und des ehemaligen \\ Hochaltars Der JaKobSKIRCHE IN NeISSE ${ }^{1}$
}

Die Forschungsdiskussion zum Breslauer St.-Barbara-Altar und zu anderen mit diesem führenden Retabel des spätmittelalterlichen Schlesien in Verbindung gebrachten Werken wird bereits seit fast 150 Jahren geführt. Von Beginn an bildeten Zuschreibungsfragen und die Suche nach den künstlerischen Wurzeln des ausführenden Werkstattteams die wichtigsten Elemente, wenn nicht gar den Kern der Untersuchungen. Vor über 30 Jahren veröffentlichte der Autor des vorliegenden Beitrags ein Buch, in dem er versuchte, den Forschungsverlauf nachzuverfolgen und eine Wiederaufnahme der Untersuchungen anzuregen. ${ }^{2}$ Nun sind besonders im letzten Jahrzehnt zahlreiche Publikationen erschienen, die von einem regen Interesse an der Thematik zeugen. Neben einer kurzen, doch bindenden Synthese zur Frage der Autorschaft von Anna Ziomecka ${ }^{3}$ sollte auch der Aufruf von Antoni Ziemba zu einer Revision der in meinem erwähnten Buch aufgestellten Thesen erwähnt werden. ${ }^{4}$ Besonders beachtenswert sind zudem die das Diskussionsmaterial erweiternden Studien. Krzysztof Chmielewski beschäftigte sich in seiner Dissertation mit dem technologischen Aufbau der Werkgruppe um den St.-Barbara-Altar und brachte damit neue Beobachtungsqualitäten in die Forschung ein, die ebenfalls für die Beleuchtung der Attributionsproblematik von Bedeutung sind. ${ }^{5}$ Robert Suckale erkannte, dass der Schöpfer der Frontseite der Neißer Tafel, den er als einen Schüler des Meisters des St.-Barbara-Altars ansah, auch an den Tafeln mit Szenen aus der Passion Christi am Hochaltarretabel der St.-Elisabeth-Kirche in Kaschau (Košice/Slowakei) tätig war. ${ }^{6}$ Mateusz Kapustka hat 2006 eine unbekannte, leider stark übermalte Vera-Ikon-Tafel, die sich im Museum in Neiße (Nysa) befindet, publiziert, die wohl im direkten Umkreis des Meisters der Barbara-Altars entstanden ist. ${ }^{7}$ Schließlich fügte Peter Knüvener dem Kreis des St.-Barbara-Altars das Triptychon aus Senftenberg in der Niederlausitz hinzu. ${ }^{8}$

Dies belegt die besondere Stellung, die dem St.-Barbara-Altar in Malerei und Altarkunst des 15. Jahrhunderts in Schlesien und Mitteleuropa zugewiesen wird. Im
Folgenden wird zunächst die Stichhaltigkeit dieser Ansicht aus heutiger Sicht erneut überprüft werden.

\section{Der Breslauer St.-Barbara-Altar - ein Werk des "Umbruchs"}

Das Retabel ${ }^{9}$ wurde für den Hochaltar der Barbarakirche in Breslau (Wrocław) geschaffen, die zugleich den Heiligen Felix und Adauctus geweiht war. ${ }^{10}$ Auskunft über seine Entstehungszeit gibt das in die steinerne Fußbodenfront "gemeißelte« Datum 1447. Das am westlichen Rand der Altstadt gelegene Gotteshaus diente als Friedhofskirche und war als solche ein Kultzentrum mit eschatologischer Prägung. Sowohl die Schriftquellen als auch die in der Kirche erhaltenen Kunstwerke und Grabmäler zeugen von einer regen Stiftungstätigkeit. Ihr Hauptmotiv war es, bereits zu Lebzeiten an den Tod zu denken, was als Verdienst auf dem Weg zur Erlösung und zum ewigen Leben verstanden wurde. Der St.-Barbara-Altar, ein Musterbeispiel für eine derartige Stiftung, verdankt seine Entstehung wahrscheinlich einer Initiative der an der Kirche tätigen St.-Barbara-Bruderschaft, die für eine würdige Beerdigung der verstorbenen Mitbrüder und für deren Memoria Sorge trug.

In geschlossenem Zustand präsentiert das Polyptychon den Triumph Mariens, ihr Verweilen im Himmelreich nach der Krönung durch ihren Sohn (Abb. 1).

Die erste Wandlung zeigt zehn Szenen, die dem Leiden, dem Tode und der Auferstehung Christi gewidmet sind, wobei zwei Ereignisse besonders herausgehoben sind, Kreuzestod und Kreuzabnahme (Abb. 2.a-b).

Ihre Darstellung nimmt jeweils die gesamte Außenfläche der Innenflügel ein. Bei der zweiten (und letzten) Öffnung wird die bei mehrflügeligen Altarretabeln grundsätzlich wichtigste, zumeist auch optisch am aufwändigsten gestaltete Festtagsseite mit dreiteiliger Struktur sichtbar (Taf. XI.a). Auf zwölf Tafeln wurde hier das irdische Leben der hl. Barbara dargestellt. Die sich durch 


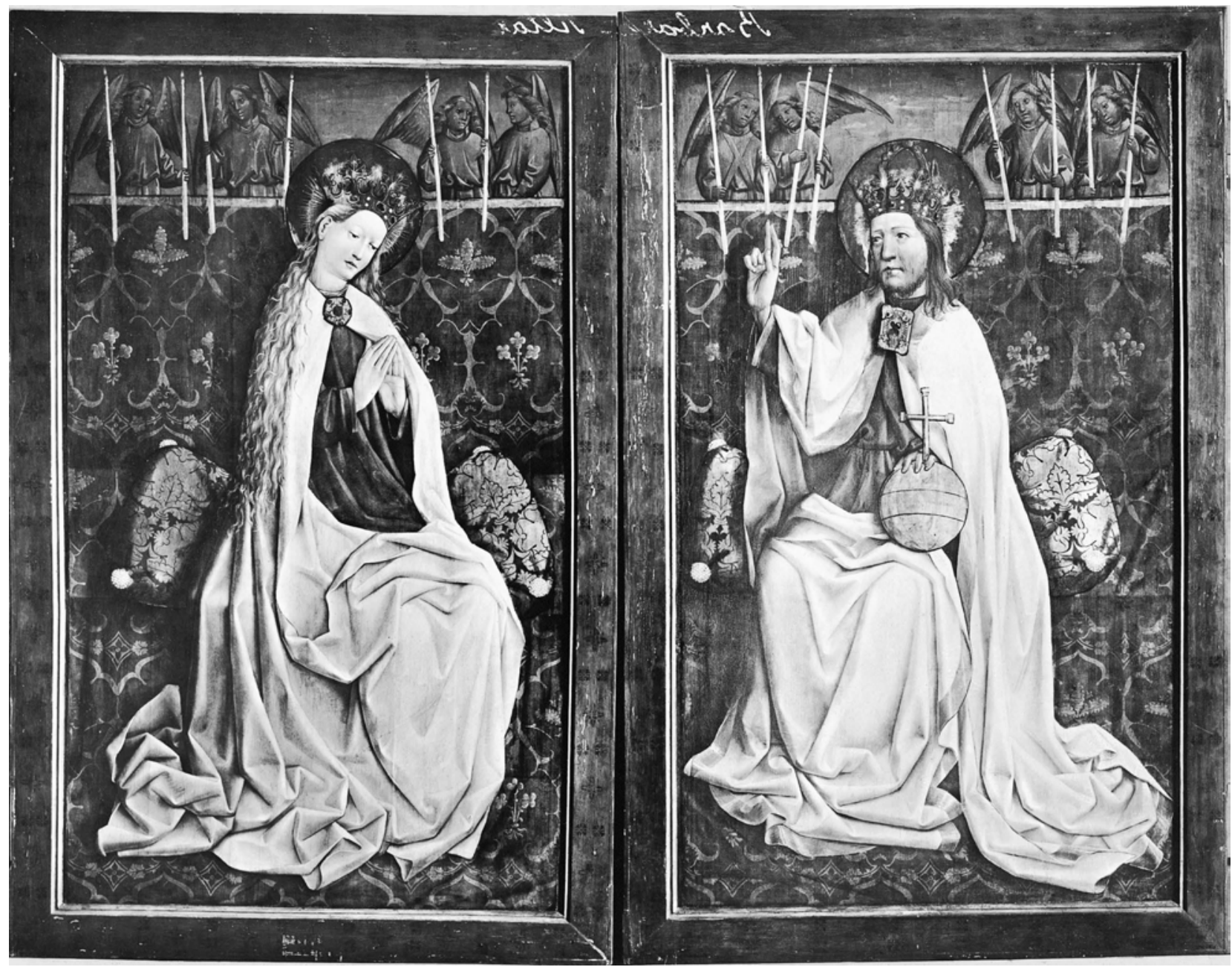

Abb. 1 Triumph Marias im Himmel von der Außenseite der Flügel des Barbararetabel. 1447. Früher Breslau, Schlesisches Museum für Kunstgewerbe und Altertümer, seit 1945 verschollen (ex: BRAUNE/WIESE 1929)

ihre Größe abhebende Mitteltafel zeigt dagegen das zeitlose, himmlische Dasein der hl. Barbara und der Hll. Felix und Adauctus (Abb. 3). Die Haupttafel ist in fünf Felder mit dominierender Mittelszene unterteilt; auf den Flügeln befinden sich jeweils vier Felder.

Die Überzeugung von dem hohen Status des Retabels als eines Umbruchswerks in der Entwicklung der schlesischen Kunst war bereits zu Beginn des 20. Jahrhunderts allgemein verbreitet. Spätere Forschungen bekräftigten diese Ansicht, sodass sie bis heute ihre Gültigkeit bewahrt hat. Der Charakter dieser Umbruchsrolle wurde verschiedenartig definiert, vor allem aufgrund der unterschiedlichen Meinungen bezüglich des Stils der Retabelgemälde, der Herkunft ihres Meisters und ihrer Platzierung in den Entwicklungstendenzen der mitteleuropäischen Malerei. Doch wie auch immer man diesen Umbruchscharakter definieren möchte, muss dies unter einem wichtigen Vorbehalt geschehen. Es ist bekannt, dass die bis heute erhaltenen bzw. aus späteren Überlieferungen bekannten sakralen Kunstwerke nur einen geringen Bruchteil dessen darstellen, was ursprünglich zur Innenausstattung der Kirchen gehörte. ${ }^{11}$ Bezüglich der Altarretabel muss gesagt werden, dass, wie es scheint, tatsächlich in keinem Breslauer Gotteshaus ein Retabel erhalten geblieben ist, zumindest nicht als Ganzes, das aus der Zeit vor 1450 stammen würde. Zugleich befand sich der St.-Barbara-Altar zwar in einer Kirche, die in der sakralen Topografie der Stadt eine wichtige Rolle spielte, die jedoch den zentralen Pfarrkirchen, den Klosterkirchen und vor allen andern natürlich dem Dom in Bezug auf Bedeutung und Prestige deutlich nachstand. Der künstlerische Rang unseres Altarwerks kann ein Zeugnis dessen sein, dass die damaligen Bres- 
Abb. 2.a und b Passionsszenen der ersten Wandlung des Breslauer Barbararetabels. 1447. Früher Breslau, Schlesisches Museum für Kunstgewerbe und Altertümer (ex: BRAUNE/WIESE 1929)
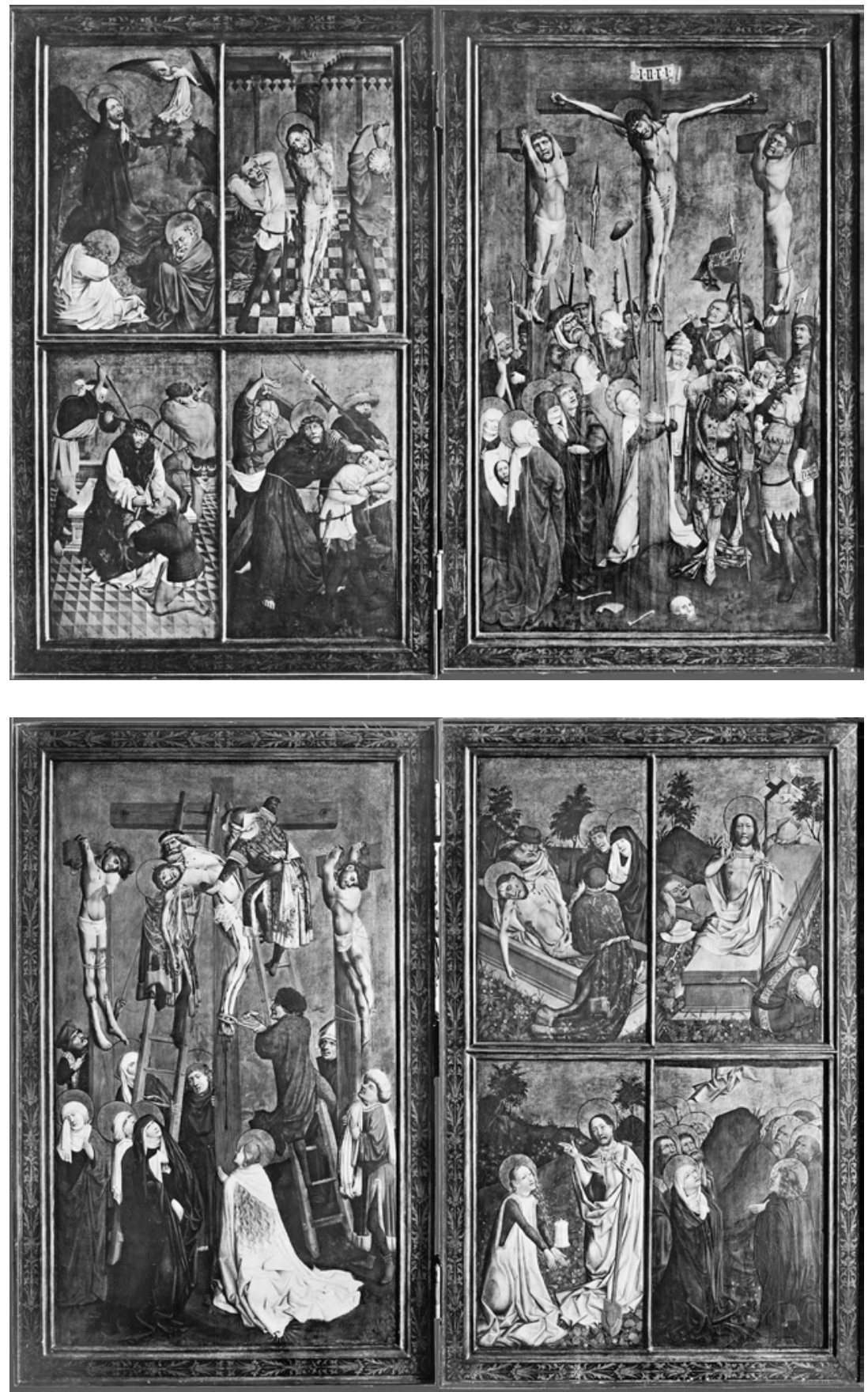

lauer Standards sehr hoch waren. Doch diese Erkenntnis zieht unweigerlich die Frage nach der uns nicht bekannten Ausstattung der anderen, prächtigeren Breslauer Kirchen in der ersten Hälfte des 15. Jahrhunderts nach sich.

Angesichts dessen wird die Frage nach der »Umbruchsrolle« des Barbara-Altars im Sinne eines Erstlingswerks sowie der Schaffung einer Zäsur im Entwicklungsprozess der Altarkunst in Schlesien, eventuell auch in überregionalem Kontext, wohl nie eindeutig geklärt werden können. Mit Sicherheit kann der Altar dagegen als äußerst unkonventionelles Werk gedeutet werden, zumindest unter drei Aspekten und deren Zusammenspiel: 1. weist sein ikonografisches Programm originelle Merkmale auf, die sicherlich eine bewusste Bezugnahme auf den Bestim- 


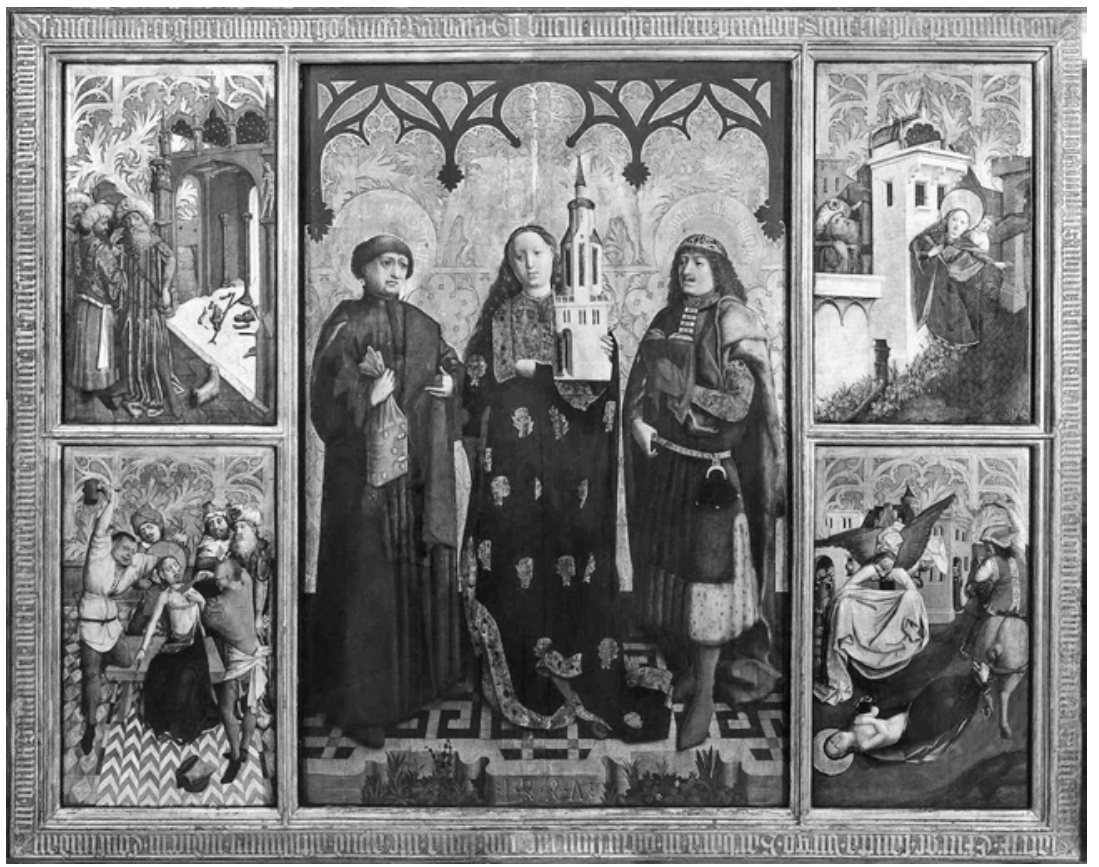

Abb. 3 Mitteltafel der Festtagsseite des Breslauer Barbararetabels mit den Kirchenpatronen Barbara, Felix und Adauctus. 1447. Warschau, Muzeum Narodowe w Warszawie (Foto: Muzeum Narodowe w Warszawie, Piotr Ligier)

mungsort darstellen; 2. ist das künstlerische Konzept, in diesem Fall das malerische Darstellungskonzept, ideell sehr aussagekräftig und passt schlüssig zu dem besagten Programm; 3. zeigt seine Struktur als vielflügeliges Retabel, das dem Betrachter wandelbare Ansichten bietet, Merkmale der Selbstreferenzialität, die den Betrachter zur Wahrnehmung der ideellen Bezüge zwischen den einzelnen Schauseiten des Werks anregen.

Diese vielseitige Originalität des Altarwerks - des Ganzen als eines Mediums eigener Art - gilt es zu betonen, da sein Rang lange Zeit an innerbildlichen, teils auch an stilistisch-darstellerischen Kriterien gemessen wurde, an der geringeren bzw. größeren Fähigkeit des Malers, sich in der Sprache des Realismus, insbesondere niederländischer Provenienz, auszudrücken. Dabei war das Verständnis des niederländischen Realismus sehr einseitig. Man sah darin vor allem, wenn nicht ausschließlich, den Wert einer einfachen (obwohl in künstlerisch-technischer Ausführung außergewöhnlich aufwändigen) Nachahmung der Außenwelt, also das, was als Detailrealismus bezeichnet wird. Eine Folge dieser Beschränkung war eine unvollständige Wahrnehmung des Werks. Dieser »malerische«, weiterhin wichtige Aspekt verlangt unzweifelhaft nach einer Re-Definition. Beginnen wir also mit dieser alten Angelegenheit.

Das Retabel als Ganzes bietet, besonders in seiner Festtagsansicht, ${ }^{12}$ ein Bild ausdrücklicher gegenständli- cher Realität, gebildet von den einzelnen Gemäldetafeln, ihren Rahmungen, der Gesamtrahmung sowie den uns nicht bekannten, doch ursprünglich wahrscheinlich existierenden Bestandteilen der Predella und des Gesprenges (Abb. 2, 3, Taf. XI.a). Das Bild, das dieses große Artefakt darbietet, schöpft seine Eigenheit, seine optische Lebendigkeit sowohl aus der dichten Gliederung der Oberfläche auf Mittelteil und Flügeln mithilfe der Felderung, der großzügigen Verwendung des »abstrakten«, selbst-scheinenden, kostbaren und kunstvoll bearbeiteten Goldgrunds (Taf. XI.b, XII.a) sowie der darstellerisch-bildlichen Ebene. Von Bedeutung ist hierbei jedoch, dass die bildlichen Darstellungen, die die Empirie der Außenwelt aufrufen, sie zugleich in entschiedener Weise transzendieren, sie - dank ihrer künstlerisch-technischen Gestaltung - auf eine vollendetere, erfülltere Ebene der Existenz heben, in eine prägnantere und aufgrund der vibrierenden Formen und Farben intensivere Präsenz übertragen. Wir sprechen hier von "Malerei« und verbinden diesen Begriff zunächst mit der Tradition Albertis (zu der auch das Werk Jan van Eycks gehört), doch wir merken sofort, dass wir über keinen passenden, bündigen Begriff verfügen, der die technische Komplexität der im Retabel vorgeführten Form der Malerei widerspiegeln würde. Diese Malerei wird auf Pigmentebene durch einen gleichsam in Goldschmiedetechnik bearbeiteten Bildgrund ergänzt; und auch die Pigmentebene selbst ist von goldschmiede- 


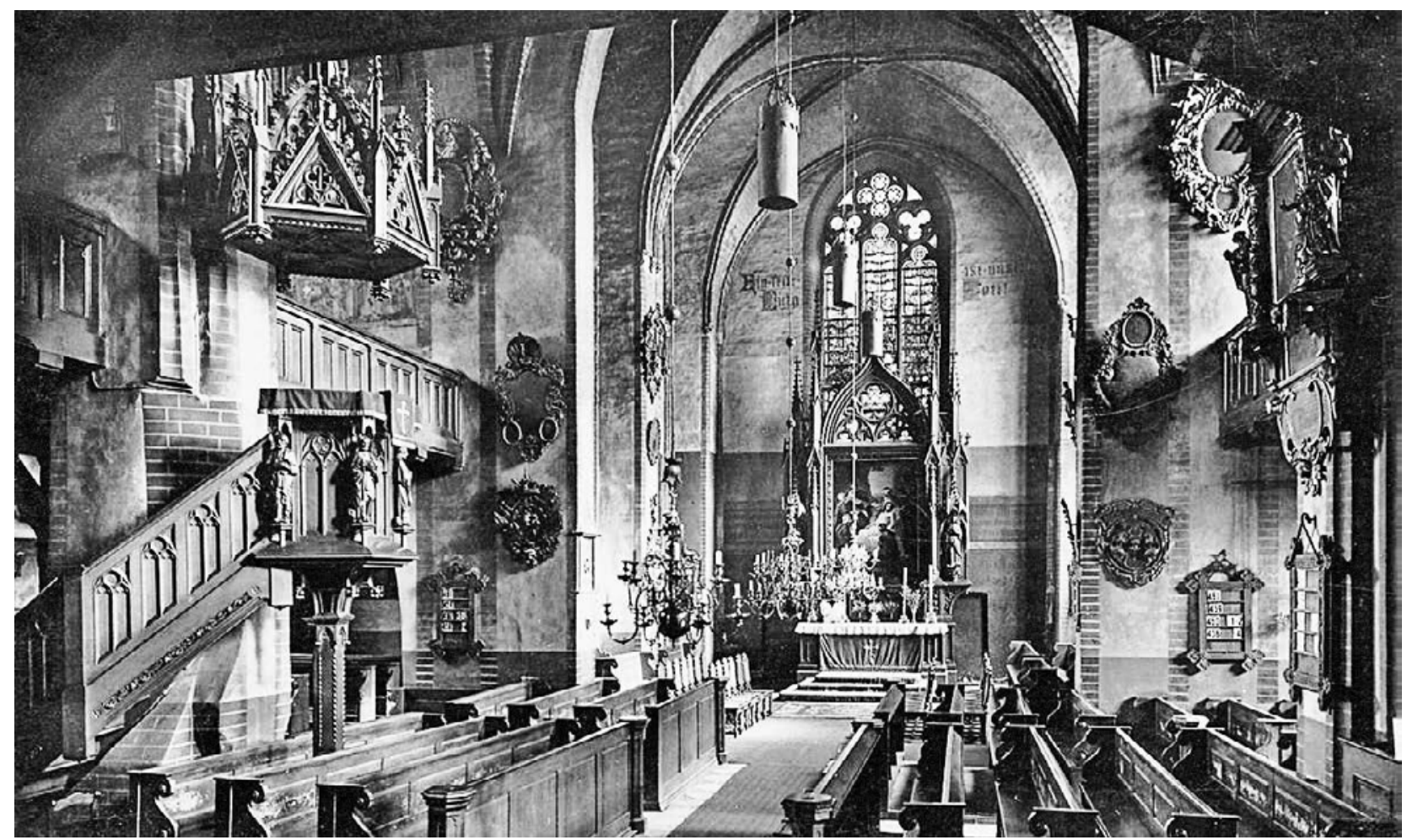

Abb. 4 Breslau, Barbarakirche, Inneres nach Osten (Foto: Hist. Ansichtskarte, Slg. A. Labuda)

artigen und real-dekorativen Elementen durchdrungen (Taf. XI.b, XII.a). Dieses technische Zusammenspiel ist natürlich nicht neu; es kam bereits in der früheren schlesischen Malerei zur Anwendung, die in vielerlei Hinsicht Verbindungen zur führenden böhmischen Kunsttradition aufwies. Neu ist die unter dem Gesichtspunkt der Schaffung einer spezifischen Bildrealität außergewöhnlich gelungene Verbindung der "alten « und der neuen Technik - und zwar der Technik der Kreation von Darstellungen unter ausschließlicher Verwendung von Pigmenten - was aus technologischer Sicht von Krzysztof Chmielewski sehr vielseitig aufgezeigt wurde. Diese neue Technik beruht auf einem Darstellungsaufbau »aus der Tiefe« des Bildgrunds und der Grundierung heraus, was durch das Auftragen vieler Farbschichten, die Verwendung von Lasierungen und eines reliefhaften Impasto, das dem "naturalistisch realen « Motiv materielle Präsenz verleiht, erreicht wird. ${ }^{13}$ Beide Techniken zusammen dienten der Imitation der realen Welt und der Schaffung einer Bildwelt von greifbarer Präsenz.

Diese imitierende und die empirische Realität überschreitende künstlerische Schöpfung zeigt sich am Retabel in geöffnetem Zustand in Form zweier Modi, die in unmittelbarer Beziehung zu ihrer ikonografischen Bedeutung stehen. Der lebendige, an naturalistischen Details reiche Zyklus zur Lebensgeschichte der Heiligen bleibt auf irdische Art und Weise zufällig und entwickelt sich in der zeitlichen Abfolge des Geschehens illo tempore. Die Mittelszene dagegen (Abb. 3), statisch und beschränkt auf die Darstellung von nur drei Figuren aus Fleisch und Blut, die real sind in einer überirdischen Wirklichkeit, ist komplett, vollkommen und zudem - gerade diese Szene am meisten! - real präsent mit einer aktuellen Präsenz und nicht als Repräsentation dessen, was abwesend ist. Der scheinbare Widerspruch zwischen dem abstrakten Schmuckreichtum und dem naturalistischen Verismus, die sich de facto gegenseitig aufheben und damit eine ganz eigene Realität der himmlischen Konversation schaffen, ist der Faktor, der entscheidenden Einfluss auf den Charakter der Mittelszene hat. ${ }^{14}$ Man könnte hier den Paragone-Diskurs im Vergleich zu anderen Typen zentraler Inszenierungen in Retabeln aufgreifen. Als Erstes würde man hier - auf natürliche, aber auch konventionelle Weise - an einen Wettbewerb mit geschnitzten Schreinretabeln oder, eher noch, mit den steinernen Konstruktionen von Nischenaltären denken. ${ }^{15}$ Doch die 
Breslauer Lösung zeigt eine beachtenswerte Unabhängigkeit von nischenartigen Schreinlösungen.

Der Vergegenwärtigungseffekt des himmlischen Daseins der Heiligen besitzt noch eine weitere Dimension. Die mittlere Szene ist dem Betrachter gegenüber offen. Das Licht, das die Figurenkörper umspielt und die kunstvollen Formen der Fußbodenfront unterstreicht, strömt von außen herbei, aus dem realen Kirchenraum, von rechts (Abb. 3), was der tatsächlichen Beleuchtung durch ein Fenster in der Südwand des Kirchenchors entspricht (Abb. 4). ${ }^{16}$

Obwohl das Retabel in dem relativ breiten und hohen Altarraum bezogen auf seine Größe keinen besonderen Akzent bildete, sicherte ihm seine Festtagsseite den Glanz eines erhabenen und unnahbaren Ausstattungsstücks. Zugleich war aber eine Betrachtung aus der Nähe nicht nur nicht ausgeschlossen, sondern sogar notwendig. Den Anreiz dafür bildete der flimmernde Detailreichtum in der Lebensgeschichte der hl. Barbara; die monumentale Präsenz der Gemeinschaft der Heiligen gewann wiederum durch die Verbindung der bildlichen Darstellungen mit dem Raum, in dem sich der fromme Betrachter aufhielt, an Überzeugungskraft. Doch diese Tatsache hob den distanzierten Status dieser Präsenz höheren Ranges nicht auf. Das Durchbrechen der ästhetischen Grenze hatte hier bewusst nur eine beschränkte Reichweite: die mittlere Szene ist kein Illusionsbild, das eine Immersion des Betrachters in die dargestellte Welt zulässt. ${ }^{17}$ Diese dialektische Beziehung zwischen der suggerierten Präsenz des Dargestellten und der dem Betrachter auferlegten Distanz dazu tritt hier mutmaßlich das erste Mal in der schlesischen Malerei auf.

Zum künstlerischen Charakter des Altarretabels in geschlossenem Zustand und dessen erster Wandlung können auf Grundlage des überlieferten Fotomaterials kaum bindende Aussagen getroffen werden. Es ist jedoch nicht ausgeschlossen, dass der himmlische Status der Szene des Triumphs Marias durch spezielle malerische Bearbeitungstechniken verstärkt wurde.

Mit dem Schaffen himmlischer Realitäten steht das originelle ikonografische Konzept des vielflügeligen Retabels im Einklang, das an die Bestattungs- und Memorialfunktion der Barbarakirche, die zum Nachdenken über die endgültigen Dinge des Lebens anregte, angepasst war. Es ist dies nicht der Ort, um alle Einzelheiten des ikonografischen Programms des Retabels zu vertiefen. ${ }^{18}$ Ich möchte nur auf die ungewöhnliche Dramaturgie des Hineintretens in das Innere des nach und nach geöffneten Altars hinweisen (Abb. 1, 2, 3). Wir wissen nichts über konkrete Tage oder Anlässe zum Öffnen respektive Schließen des Retabels, obwohl man annehmen sollte, dass es an Werktagen, also an den meisten Tagen des Jahres, geschlossen war. Es überrascht daher die Darstellung des Triumphs Marias auf der Werktagsseite, und sie überrascht umso mehr, als diese Lokalisierung des Themas einen Bruch mit der bisherigen Tradition der schlesischen (und nicht nur der schlesischen) Retabel darstellt, bei denen diese Szene meist im Zentrum der Festtagsseite auftrat. ${ }^{19}$ Auf diese Weise hatte der Betrachter tagtäglich die Gelegenheit, den himmlischen Glanz auf höchster Ebene zu bestaunen. Nach der Öffnung der Außenflügel wurde der Opfertod Christi sichtbar, als Voraussetzung für die Erlösung. Die heiligste und festlichste Schauseite war der Heiligen Barbara und den beiden anderen Kirchenpatronen in ihrem himmlischen Dasein vorbehalten. Die Hierarchie der Themenwahl wurde hier somit umgedreht. Dies kann als Konzession an das Patrozinium der Kirche gedeutet werden. Doch zugleich lud eben diese Umkehrung, also die Infragestellung der Gewohnheiten und Erwartungen des damaligen Betrachters hinsichtlich der ikonografischen Programme der Altarkunst, dazu ein, nach dem Sinn der angebotenen Themenreihung zu suchen. Auf der wichtigsten, künstlerisch sublimsten Schauseite fand er das den menschlichen Gegebenheiten nächste Vorbild zur Nachahmung und das damit verbundene Versprechen - die Schilderung des Lebens, des Märtyrertods und der Erhebung der Heiligen. Das bildreiche, über drei Schauseiten verfügende Polyptychon stellt unter semantischen Gesichtspunkten eine Relationsstruktur dar, in der ein wichtiger Grundsatz christlicher Bildsysteme zur Anwendung kommt. ${ }^{20}$ Gemeint sind damit Argumentationsverbindungen, die durch die einzelnen Schauseiten hindurch (oder auch quer dazu) verlaufen, die das Gedächtnis des Betrachters herausfordern, Parallelen zwischen den Zyklen, Themen, Personen- und Gegenstandsmotiven zu erkennen. ${ }^{21}$ Das Nachahmen des Lebens Christi durch den Heiligen stellt das Hauptthema hagiografischer Viten dar und so muss auch der Zusammenhang zwischen den beiden entsprechenden Schauseiten und den dazugehörigen Zyklen verstanden werden. Es sind auch einige Beispiele direkter Zusammenhänge zu nennen: Das Gebet Christi im Garten Gethsemane, das den Passionszyklus eröffnet, erklärt und begründet den tiefen Sinn der Entscheidung, die Barbara zu Beginn ihres Lebenswegs getroffen hat. Das wundersame Hindurchtreten Barbaras durch die Mauersubstanz des Turms lässt sie Christus ähnlich wer- 
den, der bei seiner Auferstehung durch die Steinplatte des Sarkophags hindurchtrat. Das irdische Lebensende Barbaras entspricht der Szene der Himmelfahrt Christi. Dieses Ereignis bezieht sich auch, à rebours, auf das Schicksal Dioskuros', der vom Höllenfeuer verschlungen wird. Des Weiteren fallen die zahlreichen weißen Tücher und Mäntel auf, die an die Hochzeitsgewänder denken lassen, mit denen die Erlösten am Tag des Jüngsten Gerichts bekleidet sein werden (Matth 22, 11-14): die heilige Barbara wird in der Szene der Schändung mit einem weißen Tuch bedeckt, weiß sind auch die Kleider Maria Magdalenas in der Kreuzabnahme und der Szene Noli me tangere. Die höchste semantische Referenz für diese Motive bilden die Kleider Christi und Marias in der Szene der Werktagsseite, in der Maria zur Vermählung von Mutter und Sohn im Himmelreich aufgenommen wird.

Erwähnenswert sind auch die starke ikonografische Verknüpfung des Triumphs Marias mit dem »Triumph« der bei einem Gespräch im Himmel versammelten Heiligen sowie der Entschluss desjenigen, der über die Verteilung und das Format der einzelnen Bildtafeln auf den Schauseiten des Polyptychons entschied, diese Verbindung über die beiden großformatige Passionstafeln zu vermitteln. Technisch gesehen bestand keine Notwendigkeit, die erste Wandlung so zu gestalten. Darüber entschieden inhaltliche Gesichtspunkte: die Kreuzigung präsentierte den Erlösungsakt, die Kreuzabnahme brachte das eucharistische Moment ein, was die Rolle der Kirche auf dem Weg zur Erlösung unterstrich. ${ }^{22}$ Eine bedeutungsvolle Bekräftigung bildete in dieser Hinsicht die Präsenz des Triumphs Marias auf der Werktagsseite, da diese Szene mit fundierten ekklesiologischen Assoziationen verbunden ist und Maria (die Kirche) in der Breslauer Version als Fürsprecherin dargestellt wurde. ${ }^{23}$

Der Altar besitzt eine komplexe, schlüssige Struktur, die eine vielseitige Perzeption des Ganzen sowie einzelner Aspekte des Werks aktiviert. ${ }^{24}$ Wir werden gewiss nicht mehr erfahren, ob es in Schlesien bereits früher ein anderes Retabel gegeben hat, das auf so vielseitige und wirksame Art und Weise das semantische und performative Potenzial dieses seit dem 14. Jahrhundert eine einzigartige Entwicklung erlebenden Elements der Kirchenausstattung genutzt hat. Es ist bekannt, dass ein noch größeres und in seiner Struktur dem Breslauer Werk sicherlich ähnliches Retabel vier Jahre später für den Hochaltar der St.-Jakobs-Kirche in Neiße (Nysa) geschaffen wurde - ein Werk Wilhelm Kalteysens aus Aachen, ${ }^{25}$ der aller Wahrscheinlichkeit nach auch der Schöpfer des

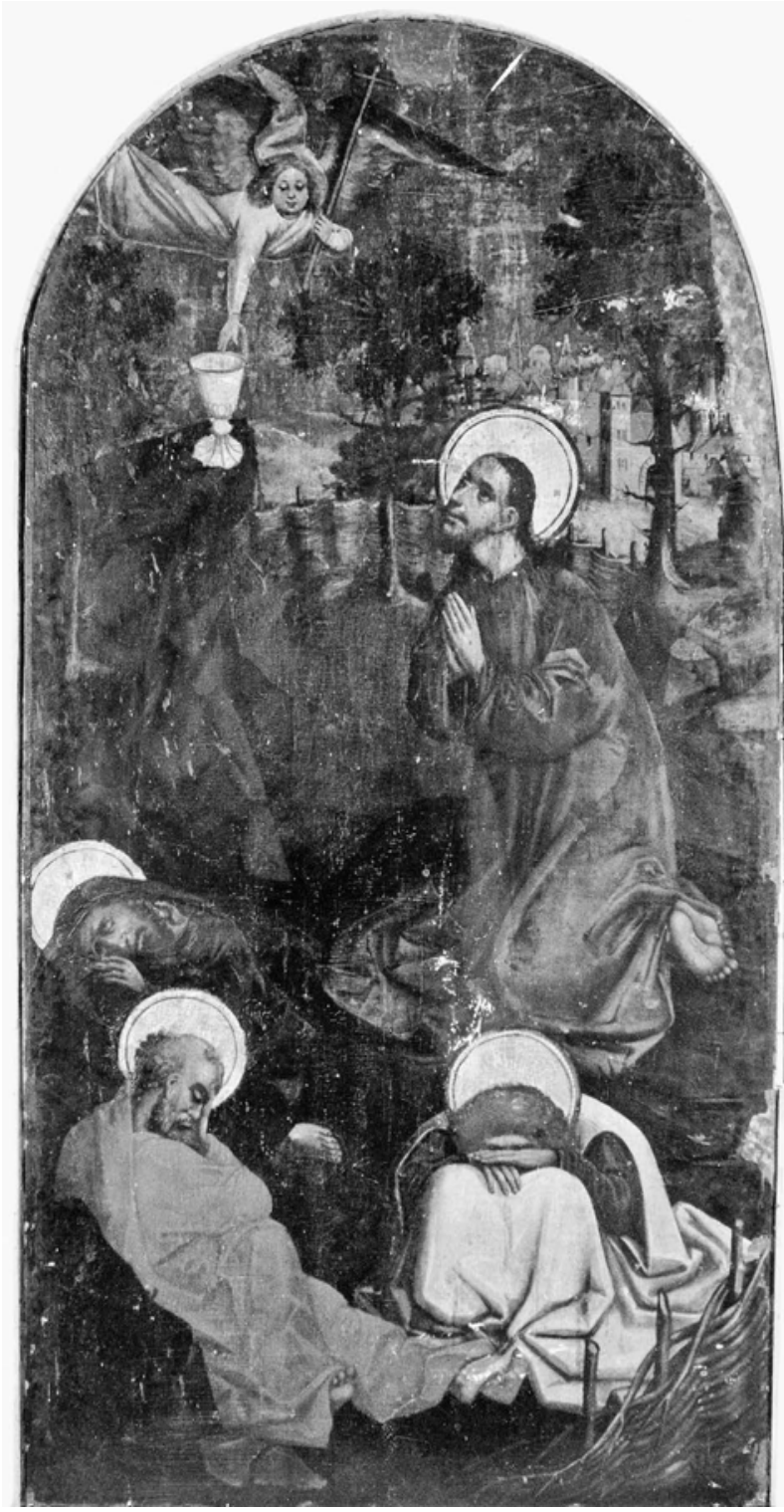

Abb. 5 Christi Gebet am Ölberg, Rückseite der einzigen vom ehemaligen Hochaltarretabel der Neißer Jakobskirche erhaltenen Tafel. Breslau, Muzeum Archidiecezjalne (ex: CHMIELEWSKI 2001, II, Abb. 101)

Breslauer St.-Barbara-Altars war. Von dem riesigen Neißer Retabel ist nur eine Tafel mit der Darstellung Jakobus' d. Ä. und Hermogenes' auf der Vorderseite und des Gebets im Garten Gethsemane auf der Rückseite erhalten geblieben (Taf. XII.b, Abb. 5). ${ }^{26}$

Demzufolge müssen der Künstler und sein (vermutlich) erstes Werk in Schlesien hohes Ansehen genossen haben. Von dem Prestige des Retabels zeugt wiederum die Tatsache, dass die exponierte, gleichwertige Darstel- 
lung von Kreuzigung und Kreuzabnahme in der Struktur des für den Hochaltar einer der beiden Hauptpfarrkirchen Breslaus, der St.-Elisabeth-Kirche, bestimmten Retabels wiederholt wurde. ${ }^{27}$ Dies bewog Paul Knötel dazu, zu fragen, weshalb damals der wohl wenig bekannte Hans Pleydenwurff von den Breslauer Bürgern diesen prestigeträchtigen Auftrag erhielt und nicht der Meister des Barbararetabels. ${ }^{28}$ Vielleicht gehörte der letztere in den Augen des Gemeindevorstands damals bereits zur künstlerisch älteren Generation, anders als Pleydenwurff, und zwar höchstwahrscheinlich als Maler, nicht als Schöpfer von Altarretabeln. Die Struktur des Retabels selbst, entwickelt von dem Maler, aber gewiss nicht zuletzt seinen geistlichen Beratern, erwies sich als Schöpfung von dauerhaftem Wert.

Die Frage nach dem Meister respektive den Meistern des Barbararetabels und seiner künstlerischen Herkunft soll demnächst einmal erörtert werden. An dieser Stelle soll nur festgehalten werden, dass ich 1984 die These formulierte, dass das Retabel ein Werk zweier Meister ist: des dominierenden »Meisters des Barbara-Altars«, des Autors der Festtagsseite, der auch auf die Gestaltung der übrigen Teile Einfluss nahm, insbesondere auf Kreuzigung und Kreuzabnahme, sowie des (wie ich ihn nannte) "Meisters der Passionszyklen $\ll{ }^{29}$ Bleibt man jedoch bei der Frage nach dem Umbruchcharakter des St.-BarbaraAltars in Schlesien und einem breiteren ostmitteleuropäischen Rahmen, sollte man auch nach dem Vorhandensein von Merkmalen, die die Hauptelemente der diesbezüglich getroffenen Aussagen bilden, in einem größeren historisch-geografischen Kontext fragen.

Der Typus eines mehrflügeligen Wandelaltars, in dem die einzelnen Schauseiten in einem System gegenseitiger Bezüge miteinander verbunden sind, war in Mitteleuropa bereits in der ersten Hälfte des 15. Jahrhunderts bekannt, um nur das in dieser Hinsicht gut bearbeitete, 1402 datierte Retabel der St.-Jakobi-Kirche in Göttingen zu nennen. ${ }^{30}$ Die Anordnung der einzelnen Felder auf der Festtagsseite erinnert wiederum an die Gestaltung einiger wichtiger westdeutscher Retabel: die um 1370 entstandenen Retabel der ehemaligen Zisterzienserinnenkirche Marienthal in Netze und einer unbestimmten Kirche in Osnabrück, nun im Kölner Wallraf-Richartz-Museum, das spätere, in das Jahr 1404 datierte Werk Konrads von Soest in der Pfarrkirche von Bad Wildungen und schließlich an den Altar der St.-Laurentius-Kirche in Warendorf aus den $1420 e r$ Jahren. ${ }^{31}$ Auch in diesen Retabeln ist die Haupttafel in fünf Felder mit dominanter Mittel- szene unterteilt, die Flügel wiederum in vier Felder. Der Unterschied besteht darin, dass die Mittelszene in all diesen Beispielen einen narrativ-historischen Charakter hat und die Kreuzigung darstellt. Daher sollte auch auf das um 1400 entstandene Retabel der Marienkirche in Bielefeld hingewiesen werden: zwar sind darin die narrativen Felder - anders als im St.-Barbara-Altar - in drei Zonen angeordnet, doch die Mittelszene hat eine zeitlose Dimension und zeigt Maria umringt von Heiligen in himmlischer Realität. ${ }^{32}$

Auch die Gattung der Altarmalerei, die den Charakter des Breslauer Retabels am stärksten bestimmte, hatte im westlichen Mitteleuropa ihren Ursprung. In der der künstlerischen Sprache der Festtagsseite des seit Jahrzehnten als "Meister des St.-Barbara-Altars« bezeichneten Künstlers sah man seit Langem einen allgemein "westlichen" Faktor; ich selbst habe mich entschieden für diese Provenienz des Konzepts der Festtagsseite ausgesprochen. ${ }^{33}$ Ein ähnliches Paradigma eines Gemälderetabels tritt im Schaffen Stefan Lochners, Lukas Mosers oder auch Konrad Witz' auf. Besonders die mittlere Szene mit den Hll. Barbara, Felix und Adauctus erlaubt es, das Breslauer Retabel mit den Werken dieser führenden, in der ersten Hälfte des 15. Jahrhunderts an sehr unterschiedlichen Orten am Rhein bzw. in Schwaben tätigen Künstler zu vergleichen. Der St.-Barbara-Zyklus ist, bezüglich seiner Ikonografie und seiner Darstellungsqualitäten, fester in der von der frankoflämischen Malerei des ersten Viertels des 15. Jahrhunderts inspirierten Kunst verankert, doch diese Tatsache stört den Gesamteindruck der Festtagseite des Retabels nicht, die, wie gesagt, gezielt dekorative Pracht mit der greifbaren Präsenz der dargestellten Wirklichkeit verbindet. Die Ansicht von der westdeutschen (rheinländischen) Provenienz des künstlerischen Konzepts für den St.-Barbara-Altar war und bleibt ein Ergebnis formvergleichender Analysen. Bestätigt wurde diese These durch die Entdeckung Ewa Wółkiewiczs, die in Wilhelm Kalteysen aus Aachen den Schöpfer des Neißer Jakobsaltars erkannte. Dieser ist, wie es scheint, mit dem Meister des Barbaraaltars zu identifizieren, dem Hauptautor des Breslauer Retabels. Trotz dieser Entdeckung besteht jedoch weiterhin die Notwendigkeit einer auf Grundsätzen der Stilkritik basierenden Suche nach den konkreten künstlerischen Wurzeln des Malers. 


\section{Das Hochaltarretabel der St.-Jakobs-Kirche zu Neiße und die bisherige Forschung}

Auch wenn Teile des Barbararetabels heute nicht mehr greifbar sind, so sind sie doch immerhin fotografisch dokumentiert - und somit ist es möglich, auch heute noch für das Ganze des Retabels gewisse Hypothesen aufzustellen. Sehr viel schwieriger ist dies für das einstige Hochaltarretabel der St.-Jakobs-Kirche zu Neiße, dem wir uns nun zuwenden wollen, und zwar im Lichte der bisherigen Überlegungen. Freilich ist der Zugang ein ganz anderer, verläuft er doch über Erschließung und Interpretation der im Neißer Stadtbuch dokumentierten Aufträge zur Anfertigung des Retabels. ${ }^{34}$ Wie bereits angedeutet, war die Entdeckung der bisher unbekannten Verträge über die Fertigung des Retabels durch Ewa Wółkiewicz, welche sie in einer separaten Studie veröffentlichte und mit umfangreichen Kommentaren versah, ${ }^{35}$ von großer Bedeutung. Aleksandra Szewczyk und Jacek Witkowski stellten wiederum eine Rekonstruktion der ursprünglichen Form des Neißer Retabels vor. ${ }^{36}$ Meine Überlegungen knüpfen am Inhalt der Werkverträge an, denn Wółkiewicz fand darin eine Reihe wichtiger Informationen, doch ist das Quellenmaterial nach wie vor offen für weitere Lesarten und Interpretationen. Wir werden ihre Thesen rekapitulieren und anschließend den Versuch einer erneuten Lesung der Vertragstexte vornehmen, auf deren Grundlage die ursprüngliche Form des Neißer Retabels und die Rollen der an dessen Anfertigung beschäftigten, in den Verträgen genannten Künstler diskutiert werden sollen. Diese Überlegungen werden wiederum zum Ausgangspunkt für weitere Beobachtungen zu den Fragen der Autorschaft des St.-Barbara-Altars und des St.-Jakobs-Altars sein, insbesondere deren kooperativer, auf der Grundlage der $\mathrm{Zu}$ sammenarbeit mehrerer Künstler beruhender Fertigung.

Das Vorhaben, den Hochaltar der Jakobskirche in Neiße mit einem großformatigen Retabel zu schmücken, ist bereits seit den 1440er Jahren greifbar. Das erste dokumentierte Legat über die Summe von acht Florin stammt aus dem Jahr 1444, ein weiteres von 1454. Es kann jedoch nicht ausgeschlossen werden, dass es vor Beginn der Arbeiten noch weitere Schenkungen gegeben hatte. Diese konnten, ohne belegt zu werden, direkt an die Kirchenvorsteher übergeben worden sein. Zumindest ist eine entsprechende Dokumentation nicht überliefert. ${ }^{37}$ Mit der Realisierung des Projekts begann man Ende 1451. Dies bestätigt ein erster Vertrag, der am 13. November 1451 niedergeschrieben und zwischen den Kirchenvorstehern
Hans Gunther und Wenzeslaus Riemer auf der einen Seite und zwei Künstlern, Meister Wilhelm von Oche und Meister Martin, auf der anderen Seite geschlossen wurde. In zwei weiteren Verträgen, vom 24. Januar 1453 und dem 12. September 1453, werden die Pflichten des in der Zwischenzeit verstorbenen Meister Martin auf Meister Nikolaus übertragen und nach dessen Rücktritt auf Meister Vinzenz Kelner. Die Tatsache, dass die Verträge von den genannten Kirchenvorstehern unterzeichnet wurden, also von wohlhabenden Bürgern, Mitgliedern der Stadtverwaltung, weist darauf hin, dass die Haupttriebkraft für das Vorhaben das Stadtbürgertum war. ${ }^{38}$ Der im ersten Vertrag genannte Wilhelm von Oche »sollte« - so schreibt Wółkiewicz - »die Führungsrolle einnehmen und seinen Mitarbeiter in allen technischen Angelegenheiten anleiten. Meister Martin war dagegen für alle Hilfsarbeiten verantwortlich, darunter den Einkauf von Farben und die Vorbereitung des Bildträgers. Zu seinen Aufgaben gehörte auch die Beschaffung des Goldes für den Goldgrund in den Darstellungen des Retabels und zur Vergoldung der Predella. Meister Wilhelm sollte für seine Arbeit eine Anzahlung in Höhe von dreißig ungarischen Gulden erhalten und anschließend jeweils einen Gulden für jede Arbeitswoche. Zusätzlich verpflichteten sich die Kirchenvorsteher dazu, ihm den Unterhalt während seiner Aufenthalte in Neiße zu sichern. Der zweite Maler erhielt dagegen beachtliche 425 Mark Heller und wurde von allen der Stadt geschuldeten Steuern und Leistungen befreit. Das Missverhältnis zwischen den ausgezahlten Summen liegt sicherlich darin begründet, dass Meister Martin die nötigen Farben und alle anderen zur Anfertigung des Altars notwendigen Materialien, darunter auch die kostbaren Goldfolien, aus eigenen Mitteln erwerben musste." Die Kosten des Neißer Retabels im Ganzen sollen sich auf eine Summe von etwa 500 Mark Heller belaufen haben. Die Autorin erwähnt zum Vergleich die Vergütung von Nikolaus Smid, der für die Anfertigung des Hochaltars der Pfarrkirche in Liegnitz (Legnica; Vertrag von 1481) »lediglich 170 Gulden und 8 Mark Heller lebenslanger Rente erhalten sollte [...]. Ein Vergleich dieser Summe mit den Kosten des Neißer Retabels, die 500 Mark Heller betrugen, deutet auf das Ausmaß des Neißer Vorhabens hin und womöglich auch auf die Bedeutung seiner Schöpfer «. ${ }^{39}$

Meister Martin verstarb Ende 1452 bzw. zu Beginn des Folgejahrs; die von ihm geführten Arbeiten wurden unter der Leitung Wilhelms von Oche zunächst von Meister Nikolaus und anschließend von Vincenz Kelner fortge- 
setzt. Es ist ungewiss, wann die Arbeit an dem Werk vollendet war. Wółkiewicz notierte lediglich, dass noch 1460 finanzielle Mittel im Zusammenhang mit dem Retabel mobilisiert wurden. Es handelte sich dabei um 4 Mark Heller für nicht näher beschriebene Glasmalarbeiten.

Ewa Wółkiewicz unternahm auch den Versuch, einige der oben aufgeführten vertraglichen Bestimmungen mit den bisherigen Forschungsergebnissen zum Neißer Jakobsretabel beziehungsweise zu der erhaltenen Tafel im Erzbischöflichen Museum in Breslau (Taf. XII.b, Abb. 5) und dem damit in Bezug auf die Urheberschaft in Verbindung gebrachten St.-Barbara-Altar zusammenzubringen. ${ }^{40}$ Besondere Beachtung schenkte sie der These über die Tätigkeit zweier Meister bei der Anfertigung der beiden Retabel. Die Autorin weist zwar darauf hin, dass auf Grundlage der Vertragstexte keine eindeutige Feststellung getroffen werden könne, welcher der vier darin genannten Maler der Autor der erhaltenen Tafel gewesen sein könnte, nimmt jedoch an, dass Wilhelm von Oche mit dem »Meister des St.-Barbara-Altars« zu identifizieren sei. Martin dagegen, der »zumindest einen Teil der Malarbeiten ausführte «, könne als »Meister der Passionszyklen « angesehen werden. ${ }^{41}$ Davon zeuge die Tatsache, dass Wilhelm aus Aachen stammte, was zu der in der Fachliteratur verbreiteten These von der rheinischen Herkunft des Konzepts für die Festtagsseite des Breslauer Retabels und des Malstils seines Schöpfers passe. Des Weiteren könne die Aachener Herkunft die in der Forschung angenommenen Einflüsse Stefan Lochners auf den St.-Barbara-Altar begründen.

Wółkiewiczs Erkenntnisse bezüglich der Werkverträge nahm Antoni Ziemba in seine Überlegungen auf. Er nahm grundsätzlich an, dass das Duo Wilhelm und Martin, das an der Ausführung des Neißer Altars tätig war, auch für die Ausführung des zuvor entstandenen St.-Barbara-Altars verantwortlich gewesen sei. Zugleich unterstreicht Ziemba jedoch, dass der letztere das Werk nur eines Meisters gewesen sei - Wilhelms aus Aachen. Diese Herkunft bestätige die kölnisch-rheinische Ausbildung des Künstlers, die er bei einer Wanderung durch Süddeutschland erweitert und während eines Aufenthalts in Nürnberg endgültig ergänzt habe. Von dort aus sei er nach Breslau gekommen. Die formal-stilistischen Unterschiede innerhalb des Altars seien Ergebnis der Arbeit mehrerer anonymer Gehilfen. Meister Martin zählt der Autor dabei nicht auf, doch paradoxerweise erwähnt er diesen, während er die These von der Existenz eines Meisters der Passionszyklen ablehnt: »Der angebliche
Meister der Passionszyklen kann wohl mit keinem der bekanntgewordenen Mit-Meister identifiziert werden: Meister Martin verstarb bereits um die Wende 1452/53, Meister Nikolaus übertrug 1452 seine Arbeit auf Meister Vinzenz Kelner, zu dem es keine weiteren Schriftquellen gibt. Die nach Labudas Meinung ein Jahrzehnt währende Zusammensammenarbeit der beiden Meister erscheint daher sehr unwahrscheinlich. ${ }^{42}$

Der von Szewczyk und Witkowski unternommene Versuch einer Rekonstruktion der ursprünglichen Gestalt des Neißer Retabels hat keinen direkten Bezug zu der Entdeckung der Vertragsunterlagen, deren Inhalt nicht einmal in die Argumentation miteinbezogen wurde. ${ }^{43}$ Nichtsdestoweniger bildet er einen festen Bestandteil der im Folgenden geführten Diskussion. Ausgangspunkt der Rekonstruktion ist die im Erzbischöflichen Museum in Breslau aufbewahrte Tafel. Die Thematik der beiden Schauseiten der Tafel verweist eindeutig darauf, dass sie jeweils zu umfangreicheren, der Passion Christi und der Vita des hl. Jacobus gewidmeten erzählenden Zyklen gehörten. Auf Grundlage der von Johann Felix Pedewitz 1682 überlieferten Angaben stellten die Autoren fest, dass es sich bei dem Werk um ein Polyptychon mit jeweils beidseits gemalten Flügeln handelte ${ }^{44}$. Die urheberschaftlichen Verbindungen zum Barbararetabel sowie entsprechende Ähnlichkeiten in der Verteilung der thematisch unterschiedlichen Zyklen auf die einzelnen Wandlungen führten die Autoren zu dem Schluss, dass beide Retabel eine analoge Struktur aufgewiesen haben müssten, insbesondere in Bezug auf die hagiografischen Zyklen und die Passion, die jeweils auf der Festtagsseite respektive der ersten Wandlung zu sehen gewesen seien. Bei der Festtagsseite habe somit auch in Neiße eine Szene vom Typus der Sacra Conversazione eine Dominante gebildet, höchstwahrscheinlich eine dreifigurige Szene mit dem hl. Jacobus oder Maria mit dem Kind in der Mitte, im ersteren Fall in Begleitung der Hll. Agnes und Johannes des Täufers, im letzteren der Hll. Jacobus und Agnes. ${ }^{45}$ Dafür, dass eine gemalte Tafel die Mitte des Altars bildete, spreche die Tatsache, dass Pedewitz grundsätzlich darauf hinweise, wenn ein Flügelretabel einen mit Schnitzwerk ausgestalteten Schrein besessen habe. ${ }^{46}$ Ein derartiger Hinweis fehle jedoch in Bezug auf den Neißer Altar. Das Werk als Ganzes hatte - ohne Berücksichtigung einer wahrscheinlich vorhandenen Predella - eine Höhe von etwa $4 \mathrm{~m}$, mit Gesprenge 4,5 m, und eine Breite von $4 \mathrm{~m}$ in geschlossenem, $8 \mathrm{~m}$ in geöffnetem Zustand. Somit 
fügte sich das eindrucksvolle Retabel gut in den Chor der Jakobskirche ein.

\section{Erneute Diskussion der schriftlichen Überlieferung und die Malerpersönlichkeiten im Licht der Quellen}

Betrachten wir also erneut die urkundliche Überlieferung, insbesondere den ersten Vertrag. Werkverträge werden aus dem Blickwinkel der Auftraggeber formuliert, die darin enthaltenen Bestimmungen beschreiben die Verantwortungsbereiche und die Aufgaben der Auftragnehmer sowie die Höhe der Vergütung. Ein wichtiges Merkmal des ersten Vertrags ist seine bereits von Wółkiewicz unterstrichene kurze und bündige Form, was eine Identifikation der darin genannten und beschriebenen Elemente und Tätigkeiten nicht erleichtert. ${ }^{47}$ Es wird grundsätzlich nicht näher auf die Form und den Aufbau des in Auftrag gegebenen Objekts eingegangen; man geht eher davon aus, dass es um ein wohlbekanntes Werk geht: das Hochaltarretabel für die Jakobskirche in Neiße. So wird kein zeichnerischer Entwurf (»Visierung«) erwähnt, der üblicherweise Bestandteil vollständiger Werkverträge war. Es gibt auch keine verbalen »Anordnungen zum ikonografischen Programm des Werks $«{ }^{48}$ die sich im Übrigen auch manchmal auf die im zeichnerischen Entwurf festgehaltenen Angaben bezogen. Dieserart Anweisungen vermittelten häufig eine Vorstellung von der Struktur des Retabels, der Anzahl der Öffnungen und sogar von dessen Maßen, von den technischen Eigenschaften und der Gattung der einzelnen Darstellungselemente, also von dem Anteil der gemalten und/oder geschnitzten Partien. Es bestand sicherlich Einigkeit bezüglich des Fertigstellungstermins des Altars, dennoch ist es erstaunlich, dass hier zwei empfindliche und in vielen bekannten Verträgen stark hervorgehobene Punkte nicht präzisiert wurden: eben der Termin des Abschlusses der Arbeiten an diesem sehr umfangreichen Werk und der damit verbundene Moment der Endabrechnung der geplanten und eventuell auch der unvorhergesehenen Kosten des Vorhabens. ${ }^{49}$ Sofern Martin eine festgelegte Summe erhalten sollte, so wurde die wöchentliche Vergütung Wilhelms, der eine relativ hohe Anzahlung in Höhe von 30 Gulden vorausgegangen war, mit keinerlei Kommentar bezüglich der Dauer seiner Tätigkeit in Neiße versehen. ${ }^{50}$

Der nun von Markus Hörsch in die moderne deutsche Sprache übertragene Vertragstext stellt die Grundlage für eine neue Sicht auf die Struktur des Werks dar sowie auf
Art und Umfang der Arbeiten, die von den im Vertrag genannten Künstlern ausgeführt wurden. Die folgende abschnittsweise Analyse des Vertrags hatte die Aufdeckung »neuer« Aspekte zum Ziel. Die von der Entdeckerin der Urkunden erhobenen und oben bereits angesprochenen Fakten werden dabei nicht erneut diskutiert.

Schenken wir zunächst einigen im Vertragstext auftretenden Begriffen Beachtung: Toffel (Toffil), Gemelde, Zarch, Bild(e)werk, Bilde sowie das Verb awsbereiten. Sie deuten darauf hin, dass die Struktur des Retabels aus gemalten sowie plastisch-figürlichen Elementen zusammengesetzt war. Der Begriff Gemelde bezieht sich zweifellos auf die zweidimensionale Malerei, das Bildwerk hat dagegen eine plastische, bildhauerische Bedeutung. Ebenso ist der Begriff Bilde mit dreidimensionalen Darstellungen konnotiert. Die Bezeichnung Zarch entspricht den in zahlreichen Verträgen auftretenden Begriffen sarg bzw. sarch und bedeutet Predella. ${ }^{51}$ In der Verwendung des Begriffs Toffil lässt sich eine gewisse Ambivalenz erkennen; dieser beschreibt drei verschiedene Dinge: das Retabel als Ganzes, die einzelne Bildtafel sowie den Altarschrein. Die jeweilige Bedeutung hängt vom Kontext ab. Das Verb awsbereiten ist mit dem heute allgemein verwendeten Begriff fassen gleichzusetzen: es beschreibt daher in weitestem Sinne das farbige Gestalten einer Oberfläche, einschließlich der Oberflächen von Skulpturen, häufig aber auch das speziell unterschiedene Beschichten figürlicher, dekorativer oder tischlerischer Elemente eines Retabels mit Blattgold oder mit Goldfarbe (vergolden). ${ }^{52}$

1. Abschnitt: Die Meister Wilhelm und Martin verpflichten sich zur Anfertigung (erbet) und zum Malen (Moelen) eines Retabels (Toffel) für den Hochaltar der Pfarrkirche St. Jakobus. Toffel bezeichnet hier das gesamte Retabel, was unterstrichen werden sollte, da im Abschnitt 2 von Bildewerk die Rede sein wird, also den bildhauerisch-plastischen Elementen, die anscheinend Teil des Ganzen waren. Es sollte daher nicht übersehen werden, dass in der allgemeinsten Formulierung der Aufgabe, die die Auftraggeber zu erfüllen hatten, lediglich die Tätigkeit des Malens erwähnt wird.

2. Abschnitt: Die Verantwortung für das Gesamtwerk trägt Wilhelm, wobei seiner fachlichen Obhut zwei Kunstgattungen unterstehen sollen: die Plastik (Bildewerk) und die Malerei bzw. sogar genauer: die Gemälde (Gemelde). So liegt der Schluss nahe, dass Wilhelm der Autor des Altarkonzepts gewesen ist. 
3. Abschnitt: Hier werden die Aufgaben Martins als desjenigen, der die Basis für Wilhelms Arbeit schaffen soll, festgelegt. Er soll die nötigen Malutensilien (die Farben und alles weitere, zum Malen notwendige Zubehör) besorgen und die Grundierung der Tafeln (dy Toffeln, Plural!) vollständig vorbereiten, worauf dann eine Unterzeichnung der Komposition (Entwerfen) ausgeführt werden soll, die anschließend mit einer Malschicht (moelen) bedeckt wird. Die Vorbereitung des Bildträgers musste zumindest eine entsprechende Bearbeitung der Oberfläche der Holztafeln und deren Grundierung umfassen sowie die Ausführung und sicherlich die Vergoldung der plastischen Bildhintergründe. Die letzten Worte des Abschnitts - »bas czum " = »bis zum«, evtl. »bis auf « - suggerieren, dass das Skizzieren und Malen jemand anders übernehmen sollte, d.h. es gehörte ausschließlich zu Wilhelms Aufgabenbereich.

4. Abschnitt: Die erste Information betrifft Martins Arbeit als Fassmaler (hier wird der Begriff awsbereiten verwendet) in Bezug auf den Mittelschrein (dy Toffil), insbesondere die geschnitzten Partien (Bildwerk) und andere dazugehörige Elemente. Martin soll dazu an der Innenseite (Inwen[d]ig) Blattgold, an der Außenseite des Schreins (uswen[d]ig) dagegen Goldfarbe verwenden. Anschließend erfahren wir, dass auch am Gesprenge (Awsczog) Goldfarbe verwendet werden soll, im Inneren der Predella dagegen blaue Farbe. Die darin befindlichen figuralen Skulpturen ( $d y$ Bilde) sollen mit Blattgold überzogen werden; dasselbe Material soll zum Fassen der dekorativen Elemente (die Gesprenge) mit den beiden Fenstern verwendet werden. ${ }^{53}$ Am Ende des Abschnitts lesen wir, dass Martin alle Farben und alle Dinge, die zum Malen (Moelen) und Fassen (usbereiten) notwendig sind, zu besorgen hat.

Der 5. Abschnitt betrifft die Holz- und Eisenelemente des Retabels. Dafür soll die Kirche Sorge tragen. ${ }^{54} \mathrm{Zu}-$ nächst geht es um die Zustellung von Metallteilen, sicherlich solchen Dingen wie Scharnieren, Winkeleisen und anderem Zubehör zur Sicherung der Stabilität des monumentalen Ausstattungsstücks. Gewiss sollte die Kirche auch die Zustellung des hölzernen Rohmaterials sicherstellen, obwohl nicht direkt die Rede davon ist; ausdrücklich erwähnt wird dagegen die Bearbeitung dieses Materials, wobei zwischen Zimmermannsarbeiten (Czymmerwerk) und Tischlerarbeiten (Tisschwerk) unterschieden wird. Man kann daher annehmen, dass sowohl der Schrein als auch die hölzernen Bildträger durch von der Neißer Kirche engagierte Handwerker geliefert wurden.
Im 6. Abschnitt werden Festlegungen bezüglich der Höhe von Meister Martins Honorar und der ihm garantierten Wohn- und Arbeitsstätte (haws) für die Zeit seiner Tätigkeit in Neiße getroffen. Es wird unterstrichen, dass er das (in Bezug auf die Farbfassung) vollendete Retabel (Toffel und Zarch werden genannt) persönlich übergeben soll. Martin hat auch die Aufgabe, unter Wilhelms Anleitung, jegliche unvorhergesehenen Nachbesserungen an den geschnitzten Figuren (Bylde) und am Retabel als Ganzem (Toffil) vorzunehmen.

Die beiden weiteren Verträge handeln ausschließlich von der Übernahme der Aufgaben Martins durch andere Personen, die den Titel eines Malermeisters führten. Die Witwe Meister Martins, die anscheinend über die Räumlichkeiten verfügte, in welchen an dem Altar gearbeitet wurde, sollte diese dem Nachfolger zur Verfügung stellen. Sie hatte auch das für die Ausführung des Retabels vorgesehene Geld geerbt und sollte nun Nikolaus' Arbeit bezahlen - auch dann, wenn sich höhere Kosten als im ersten Vertrag vorgesehen ergeben sollten.

Im Lichte des ersten Vertrags zeichnet sich in entschiedener Weise eine andere Struktur des Altars ab, als Szewczyk und Witkowski sie in ihrer Rekonstruktion vorstellten. Man muss gestehen, dass die Ähnlichkeit der Gestaltung zwischen der Neißer Tafel und der der Festtagsseite des Barbararetabel im Hinblick auf das Verhältnis zwischen malerischen Partien und Hintergrund sowie auf den Typus des Maßwerkdekors in dem besagten Hintergrund dazu verführt, sich auch den Mittelteil des Neißer Werks als Wiederholung des Breslauer Konzepts vorzustellen. Doch der Inhalt der Verträge zwingt uns zu dem Schluss, dass die Struktur hier eine andere gewesen sein muss. Einen bedeutsamen Unterschied bildet das Vorhandensein eines Schreins mit geschnitzten Skulpturen im Zentrum des Retabels. Es lässt sich nichts Bindendes über dessen Komposition oder Thematik sagen; es können lediglich Vermutungen aufgestellt werden in Anlehnung an die uns bekannten Altarschreine des dritten Drittels des 15. Jahrhunderts in Schlesien und dessen Nachbarländern und sogar in Westmitteleuropa, wenn man bedenkt, dass der in dieser Region ausgebildete Wilhelm die Arbeiten am gesamten Altar leitete. Die Flügel waren bemalt, den Unterbau des Schreins bildete die Predella. Das Innere des Schreins war mit Blattgold beschichtet, ähnlich auch die gemalten Tafeln der Flügel - was dem Befund des Hintergrunds der erhaltenen Tafel entspricht. Das Innere der Predella war blau gefasst. Ein Schrein als Mittelpunkt eines Flügelaltars in den von 
Szewczyk und Witkowski rekonstruierten Maßen bildete unweigerlich die passendere Lösung, die zugleich eine starke Wirkung des Retabels in dem monumentalen Innenraum der Neißer Hauptkirche mit ihrem langgestreckten Schiff garantierte. ${ }^{55}$

Einen weiteren Aspekt bilden die Künstler sowie Aufteilung und Umfang ihrer Arbeit. Wilhelms Rolle als Konzeptgeber und Leiter des Vorhabens wurde im ersten Vertrag beschrieben und teilweise im zweiten Vertrag wiederholt. Obwohl er die Aufsicht über das ganze, zwei Kunstgattungen umfassende Retabel ausüben sollte, wurde auch sein genauer Arbeitsbereich klar bestimmt er sollte die Malereien in den Feldern des Retabels ausführen. Zugleich fällt es jedoch schwer, ihm die Rolle eines Unternehmers im vollen Wortsinne zuzuschreiben, wie es z. B. Bernt Notke ${ }^{56}$ oder Friedrich Herlin ${ }^{57}$ waren, da eine Reihe von Koordinationsaufgaben auch Meister Martin zugeteilt wurden. Dieser kann nicht als zweitrangiger Gehilfe angesehen werden; allein die Tatsache, dass er den Meistertitel führte, sichert ihm einen hohen Rang in der Berufshierarchie der Handwerker. Er baute unzweifelhaft die Arbeitsstätte für Wilhelm auf, und das lag daran, dass er am Ort die ausführende Werkstatt leitete und über eine mit den Festlegungen des Vertrags übereinstimmende Fertigstellung wachte. Wilhelm hielt sich anscheinend nur zeitweilig in Neiße auf. Des Weiteren war es Martin, der das fertige Retabel an die Auftraggeber übergeben sollte, als ob Wilhelms Abwesenheit bei der Übergabe bereits eingeplant oder zumindest in Betracht gezogen wurde. Martin verfügte über die Fachkenntnisse und hoch geschätzten Fähigkeiten eines Fassmalers und Vergolders. ${ }^{58}$ Die zu Beginn des Vertrags genannte Aufgabe Bemolen bezieht sich in diesem Kontext in demselben Maße auf Wilhelm wie auf Martin. Indem letzterer den Schrein, das darin befindliche Schnitzwerk und das Gesprenge farbig fasste, die plastischen, vergoldeten Bildhintergründe schuf und die Rahmungen vergoldete, nahm er entscheidenen Einfluss auf die endgültige künstlerische Gestalt des Retabels.

Der Aspekt der im Schrein befindlichen Skulpturen ist nur teilweise im Vertrag enthalten. Es ist nämlich nicht von deren Anfertigung die Rede, sondern nur von deren Fassung. Da die Skulpturen jedoch vorhanden waren, ist anzunehmen, dass sie im Rohzustand aus einer anderen Werkstatt bezogen wurden. ${ }^{59}$ Möglicherweise kann aus dem Kontext der Bestellung der Skulpturen bei einer unbekannten Werkstatt der Schluss gezogen werden, dass der Vorstand der Neißer Kirche die Finanzierung des
Holzmaterials und der Fachleute zu dessen Bearbeitung, darunter sicherlich auch die Anfertigung des Retabelschreins, übernommen hatte.

Wie man sieht, war an der Ausführung des Retabels eine ganze Gruppe anonymer Handwerker beteiligt, die Elemente der Altarwerks anfertigten, an denen die im Vertrag genannten Meister nicht selbst Hand anlegten. Es können zahlreiche Beispiele ähnlich komplizierter $\mathrm{Zu}$ sammenarbeitsstrukturen genannt werden. ${ }^{60}$ Der oben genannte Friedrich Herlin signierte die Retabel in Nördlingen (1462) und Rothenburg ob der Tauber (1466). Er selbst war der Autor der malerischen Partien, mit den anderen wichtigen Bestandteilen beauftragte er als Unternehmer entsprechende Fachleute. Die heute nicht mehr existierende Architektur des Altars von Nördlingen (erhalten blieb nur der in den späteren Barockaltar verbaute Schreinkasten) stammte von dem Architekten Niclaus Eseler d. Ä., der sicherlich den zeichnerischen Entwurf lieferte. Den Schrein und die zugehörigen Dekorelemente fertigte Hans Waidenlich an. Die berühmten Skulpturen des Retabels wiederum werden entweder direkt Nikolaus Gerhaert aus Leiden oder einem Künstler aus seinem Umkreis zugeschrieben. ${ }^{61}$ Der genannte Waidenlich führte den Schrein und den ornamentalen Dekor des Retabels in Rothenburg aus. Die Heiligenfiguren im Schrein sind das Werk eines Meisters bzw. mehrerer Meister aus dem Umkreis Hans Multschers; der gekreuzigte Christus im Mittelpunkt des Schreins wird jedoch einem in Straßburg ausgebildeten Künstler zugeschrieben, höchstwahrscheinlich dem zuerst in Ulm, dann in Straßburg und Wien tätigen Hans Kamensetzer. ${ }^{62}$

Selbst bei dem berühmten Heilig-Blut-Altar der Rothenburger Jakobskirche (geschaffen 1499-1505) stammen nur die Skulpturen von Tilman Riemenschneider in Würzburg, der Schrein und sein Schnitzdekor sind hingegen das Werk des örtlichen Schreiners Erhart Harschner. Beide bekamen ein Honorar in gleicher Höhe von 50 Gulden. ${ }^{63}$ Im Zusammenhang der Lieferung von Skulpturen im Rohzustand ist der Realisierungsprozess des Altars von Münnerstadt erwähnenswert, dessen von Riemenschneider angefertigte Skulpturen erst nach vielen Jahren von Veit Stoß gefasst wurden. ${ }^{64}$

Einer Neubetrachtung bedarf die Kostenschätzung des Neißer Retabels. Wółkiewicz nannte eine Summe von etwa 500 Mark Heller, in der höchstwahrscheinlich auch Wilhelms Honorar enthalten sein sollte. Dies wäre keine besonders hohe Summe angesichts der Größe des Neißer Auftrags. Doch die realen Kosten des Vorhabens waren 
deutlich höher. Es kann keine konkrete Summe errechnet werden, nennen wir daher wenigstens die Elemente, die schwer zu greifen beziehungsweise in gewisser Weise versteckt sind. Wilhelms endgültiges Honorar kann nicht genau bestimmt werden, doch die malerische Bearbeitung des Werks bedurfte vieler, sicherlich Dutzender Arbeitswochen, die er in Neiße verbrachte. Des Weiteren muss beachtet werden, dass die Neißer Kirchenvorsteher nicht nur (wie üblich) die Kosten für die Metallarbeiten übernahmen, sondern auch - was eigentlich nicht die Regel war - für das bereits besprochene Holzmaterial sowie dessen Bearbeitung. Dies stellte eine bedeutende Ausgabe in dem Gesamtvorhaben dar. ${ }^{65}$ Darin waren sicherlich auch die Kosten für die Schreinskulpturen inbegriffen. $\mathrm{Zu}$ den Gesamtkosten des Altarwerks sind zudem Wilhelms Unterhaltszahlung während seiner Aufenthalte in Neiße und die Steuerbefreiung des hier ansässigen Martin $\mathrm{zu}$ addieren.

\section{Die Schöpfer des Neißer Altars und ihr Wirken in Schlesien}

In einer Hinsicht sind sich alle Forscher einig: Zwischen dem Neißer Retabel und dem Breslauer Barbaraaltar bestehen enge Beziehungen hinsichtlich der Urheberschaft. Wenn Wilhelm die malerischen Partien des Neißer Altars ausführte, von deren Form wir uns auf Grundlage der erhaltenen Tafel ein Bild machen können, dann können ihm auch die künstlerisch besten Teile des Breslauer Retabels zugeschrieben werden. Dessen künstlerisches Niveau, besonders eben das der Festtagsseite, bestätigt die hohen Fähigkeiten des Meisters. Diese waren sicherlich maßgebend dafür, dass die Kirchenvorsteher der Neißer Pfarrkirche ihm die Anfertigung des Gesamtentwurfs zum Altar, die Fachaufsicht über dessen Realisierung und die Ausführung der malerischen Partien anvertrauten.

Wilhelm führte den Familiennamen Kalteysen, ergänzt durch den Herkunftsnamen »von Oche«, der in den Urkunden an drei auf seine Person bezogenen Stellen auftaucht. Die Stellung des Herkunftnamens nach dem Familiennamen zeugt laut Wółkiewicz davon, dass "Oche«, also das bis heute mundartlich so ausgesprochene Aachen, sein Geburtsort und nicht sein letzter Aufenthaltsort gewesen sein müsse. ${ }^{66}$ Die Identifizierung einer Familie mit dem Namen Kalteysen in Aachen ist der $\mathrm{Au}-$ torin nicht gelungen, doch konnte sie bei ihrer Quellenrecherche nur auf das fragmentarisch veröffentlichte Ma- terial zurückgreifen. ${ }^{67}$ Nach dem Neißer Vertrag taucht eine zweite Erwähnung unseres Malers im Jahr 1466 im Zusammenhang mit der ihm anvertrauten malerischen Gestaltung der Orgel in der Augustinerchorherrenstiftskirche in Glatz (Kłodzko) auf. ${ }^{68}$ Ein drittes Mal wird ein gewisser, doch vermutlich derselbe Wilhelm von Oche im Jahr 1496 im Breslauer Stadtrechtsbuch erwähnt und als »moler oder glasesetczer» bezeichnet, was auf seine Fähigkeiten im Anfertigen und Montieren figürlicher Glasmalereien hinweist. ${ }^{69}$

Die urkundliche Überlieferung dokumentiert somit dreifach die Anwesenheit Wilhelms in Schlesiens in einem Zeitraum von 45 Jahren. Zugleich scheint die Annahme gerechtfertigt, dass der St.-Barbara-Altar vor Ort ausgeführt wurde..$^{70}$ Demnach müsste Wilhelm spätestens um das Jahr 1445 herum nach Breslau gekommen sein. Ließ er sich hier nieder, gründete er eine Meisterwerkstatt gemäß den rechtlichen Vorschriften, die dafür das Erlangen und die Annahme des Stadtrechts erforderlich machten ? $^{71}$ Die Tatsache, dass er sich erst 1496 um die Eintragung in das Breslauer Stadtrechtsbuch bemühte, zeugt davon, dass es seinerzeit nicht dazu gekommen war. Der Neißer Vertrag wiederum belegt eindeutig, dass er sich auch in Neiße nicht niederließ. Daher beleuchtet auch dieser urkundlich bestätigte Auftrag an einem konkreten Ort nicht den Status seiner Anwesenheit in Schlesien vor 1496. Zugleich ist zu bedenken, dass er sich während seiner Tätigkeit im Augustinerchorherrenstift in Glatz außerhalb der städtischen Jurisdiktion bewegte. Er mag sich in Schlesien aufgehalten haben, doch ebenso gut kann er in dem durch die bekannten Daten eingegrenzten Zeitraum auch außerhalb dieser Region tätig gewesen sein. Bereits die in Breslau, Neiße, Glatz und erneut in Breslau ausgeführten Arbeiten zeigen uns das Bild eines mobilen Künstlers, was im Berufsalltag des Spätmittelalters kein ungewöhnliches Phänomen war. Man ging dorthin, wo es Aufträge und Verdienstmöglichkeiten gab. Es ist nicht ausgeschlossen, dass die Mobilität Wilhelms ein Ergebnis der Initiative von Seiten der Auftraggeber war, die sich von den großen und in dieser Region neuen Fähigkeiten des Malers begeistern ließen. Möglicherweise bildete das ständige Nennen des Herkunftsortes "von Oche« nach Wilhelms Namen (der Familienname Kalteysen taucht nur einmal auf) eine Form der Selbstdarstellung, eine Art Eigenwerbung, indem er auf jene Kulturlandschaft hinwies, in der die als modern und neuartig angesehene Kunst eine Blüte erlebte. ${ }^{72}$ Über Wilhelms Leben und Wirken, bevor er nach Schlesien kam, können wir außer der Wahrscheinlich- 
keit, dass er in Aachen geboren wurde, nur anhand der von ihm hinterlassenen Werke Vermutungen aufstellen. Schließlich war die Annahme einer westeuropäischen Provenienz des Meisters des St.-Barbara-Altars bereits Ergebnis formvergleichender Analysen. Der aus Aachen stammende Wilhelm fügte sich hervorragend in die Erkenntnisse dieser Forschung ein, die eine entscheidende Bedeutung der westlichen, rheinischen Stilprovenienz des Meisters erkannt hatten. Die Entdeckung seines Namens verleiht dieser Herkunftsthese einen biografischen Akzent. Doch lässt sich nicht leugnen, dass, selbst wenn der Herkunftsort ein anderer gewesen wäre, dies die Ergebnisse einer kritischen vergleichenden Stilanalyse nicht hätte in Frage stellen können. Ebenso ist der berufliche Weg des Meisters über Süddeutschland nach Schlesien eine Rekonstruktion, die auf der Grundlage von Formuntersuchungen erarbeitet wurde.

Es sei daran erinnert, dass die Gestalt des vollständig geöffneten Altars alle Merkmale eines »westlichen« Werks besitzt (Taf. XI.a). In der originellen und deshalb weiterhin rätselhaften Mittelszene werden künstlerische Grundsätze aufgegriffen, die - wie oben bereits erwähnt aus dem Schaffen von mindestens seit den 1430er Jahren tätigen Meistern wie Stefan Lochner, Lukas Moser oder Konrad Witz bekannt sind. Entsprechend habe ich bisher die Bedeutung der Malerei der Regionen an Oberrhein und Bodensee stark unterstrichen; gegenwärtig würde ich diese Annahme zurückhaltender formulieren - ich halte sie dennoch für einen wichtigen Forschungspfad. Gleichzeitig ist der Zyklus der Barbara-Legende in der Poetik der franko-flämischen Malerei der ersten und des Beginns der zweiten Dekade des 15. Jahrhunderts verankert, deren langes Fortwähren in hagiografischen Erzählungen das von Meister Francke in den 1430er Jahren geschaffene Barbararetabel aus Kalanti bezeugt. ${ }^{73}$ Diesem Umkreis entstammt auch die figurale Komposition der Breslauer Kreuzabnahme (Abb. 6) ${ }^{74}$.

Die Neißer Tafel (Taf. XII.b, Abb. 5) bestätigt die stilistisch-geografische Zuordnung, besonders durch ihre erlesene Koloristik und die Kostümwahl der dargestellten Figuren. Doch die Detailbearbeitung erreicht nicht die malerische und technische Subtilität der meisterlichen Mitteltafel des Breslauer Barbaraaltars mit ihren vier narrativen Szenen und der Darstellung der drei Märtyrer. Das geringere Niveau ist besonders an dem schematisch wiederholten Gesichtstypus zu erkennen. ${ }^{75}$ Möglicherweise hatten die anderen Perzeptionsmöglichkeiten des Altars, dessen Betrachtung aus größerer Entfernung,

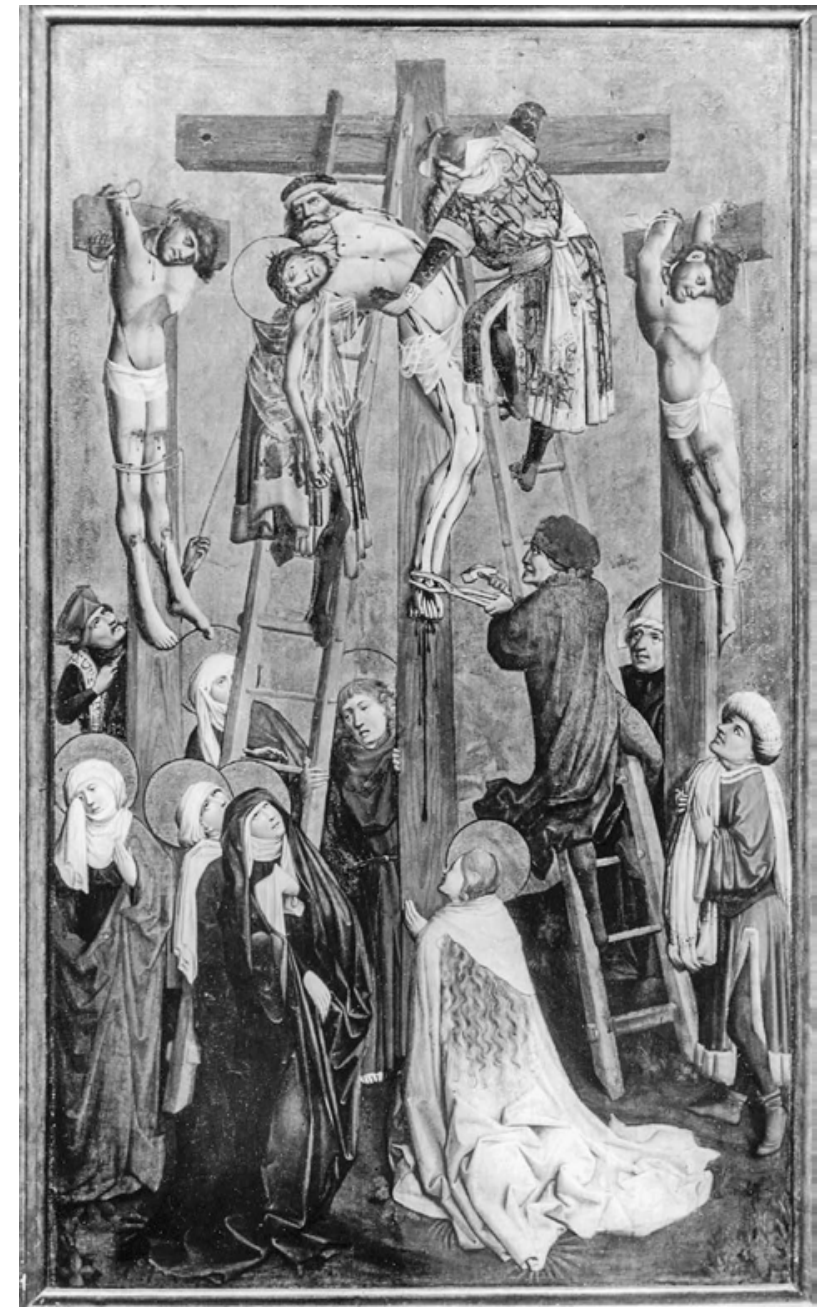

Abb. 6 Kreuzabnahme. Passionsseite des Breslauer Barbararetabels. 1447. Früher Breslau, Schlesisches Museum für Kunstgewerbe und Altertümer (Foto: Slg. Adam S. Labuda)

eine gewisse »Vergröberung « der Form zur Folge, doch es steht auch außer Frage, dass es sich hierbei um eine "preiswertere« und gegenüber einer Beteiligung von Mitarbeitern offenere Variante der Auftragsrealisierung handelt. So muss doch unterstrichen werden, dass der hier urkundlich nachgewiesene Aachener sein meisterliches Können an der einzig erhaltenen Tafel des Neißer Altar schwächer manifestiert als in dem Werk, das »nur « auf Grundlage einer kritischen Stilanalyse mit ihm in Verbindung gebracht wird.

Als Wilhelm von Oche nach Breslau kam, war er bereits ein ausgereifter, technisch außergewöhnlich gewandter Künstler. ${ }^{76}$ Seine Grundausbildung erhielt er sicherlich in den 143 oer Jahren. Es kann daher angenommen werden, dass er um 1420 geboren ist, obwohl angesichts der fran- 
koflämischen Elemente nicht auszuschließen ist, dass er bereits zehn Jahre früher zur Welt kam. Wenn sich die urkundliche Erwähnung von 1496 auf ihn bezieht, dann war er ein langlebiger Mann, denn er erreichte ein Alter von mindestens 75-80 Jahren.

Während die Person Wilhelms im Lichte der Quellenund Werkanalysen Konturen annimmt, bleibt die Gestalt des zweiten im Vertrag genannten Meisters unscharf. Wir verfügen über keine Überlieferungen, die seine Tätigkeiten vor dem Jahr 1451 dokumentieren würden. Der erste Vertrag deutet darauf hin, dass er extra im Zusammenhang mit der Ausführung des Altars nach Neiße gekommen war, wobei er mit einem langen Aufenthalt in der Stadt rechnete oder womöglich sogar seine Zukunft mit der Stadt verband, da er sich - wie der zweite Vertrag verrät - mit seiner Ehefrau in Neiße niederließ. ${ }^{77}$ Dennoch reichte die Zusammenarbeit mit Wilhelm höchstwahrscheinlich über den Neißer Auftrag hinaus. Denn wenn wir annehmen, dass Martin die kunstvollen Bildhintergründe der Neißer Tafel ausführte, dann kann auch seine Teilnahme an der Anfertigung des Breslauer Retabels, also eine länger währende Kooperation, nicht ausgeschlossen werden. Dies ist wahrscheinlich, doch die Wahrscheinlichkeit diesbezüglich ist nicht so groß wie in Bezug auf die Verbindung beider Altäre mit Wilhelm. Darauf könnte die Tatsache hinweisen, dass wiederholt Wilhelms Aufsichtsrolle über das Gesamtwerk unterstrichen wird, also auch über die von Martin auszuführenden Arbeiten, was freilich in keiner Weise Martins Kompetenzen schmälert, sondern nur darauf verweist, dass das künstlerische Konzept des Ganzen sowie der Details von Wilhelm stammte. Ein weiterer Umstand, der dies untermauert, ist die Tatsache, dass nach dem Tod Martins seine Aufgaben problemlos von zwei anderen Fachleuten übernommen werden konnten, wahrscheinlich von Fassmalern, wenn man die oben formulierte Hypothese annehmen möchte, dass Martin keine figürlichen Malarbeiten ausführte.

\section{Wilhelm und Martin vs »Meister des St.-Barbara- Altars« und der »Meister der Passionszyklen«}

Im Lichte der oben versuchten Aufteilung der Kompetenzen und Aufgaben erscheint es wenig sinnvoll, die Person Martins - neben dem "Meister des St.-Barbara-Altars", sprich Wilhelm aus Aachen - in die Diskussion über die Teilhabe anderer Maler (so des Meisters der Passionszyk- len respektive weiterer Gehilfen) an der Ausführung der malerischen Partien beider Altarretabel aufzunehmen. Wółkiewicz diskutierte an dieser Stelle verständlicherweise nicht die Stichhaltigkeit der auf kunsthistorischer Basis formulierten Vermutungen, sondern wies nur auf Möglichkeiten hin, diese mit den Aussagen der von ihr entdeckten Verträge in Einklang zu bringen. Dennoch hatte die urkundliche Bestätigung der Zusammenarbeit zweier Meister am Neißer Altar Einfluss auf die Überlegungen der Kunsthistoriker. Für Małgorzata Kochanowska-Reiche und Mateusz Kapustka scheint die Entdeckung der Namen der ausführenden Künstler eine Bestätigung der von mir angenommenen Aufgabenzweiteilung zu bedeuten. ${ }^{78}$ Szewczyk und Witkowski behaupteten wiederum, dass Martins Tod Ende 1452 bzw. Anfang 1453 die "Existenz einer $>$ Kooperative zweier Meister (d. h. der Meister des St.-Barbara-Altars und der Passionszyklen, A. S. L.), deren erstes gemeinsames Werk das Breslauer Retabel gewesen sein sollte und deren Zusammenarbeit in den 5 oer und 6oer Jahren des 15. Jahrhunderts fortgesetzt worden wäre«, unmöglich erscheinen lasse. ${ }^{79}$ Auch Ziemba, der grundsätzlich annahm, dass für die Gestalt beider Altäre nur eine Person, d.h. der Meister des St.-Barbara-Altars, sprich Wilhelm von Aachen, verantwortlich war, nutzte das Todesdatum Martins als Argument, um eine Fortsetzung der Tätigkeit des Meisters der Passionszyklen als eines angeblichen Mitarbeiters des Meisters des St.Barbara-Altars) in Frage zu stellen. ${ }^{80}$

Die Tatsache, dass im ersten Vertrag zwei Meister genannt werden, im zweiten wiederum der Tod eines von ihnen verzeichnet ist, kann weder als Bestätigung noch als Negation der Hypothese von der Existenz zweier Individualitäten als Hauptautoren der malerischen Darstellungen des Breslauer und des Neißer Retabels gewertet werden. Die weitere Diskussion über diese auf Basis einer Analyse der künstlerischen Formensprache formulierte These muss auf der Grundlage einer vergleichenden Stilkritik geführt werden - nicht anders als im Fall der Rekonstruktion der künstlerischen Biografie Wilhelms von Aachen.

Die Vorstellung, das St.-Barbara-Retabel sei das Werk nur eines einzigen »Meisters «, zu dessen Entstehung jedoch zahlreiche "weniger wichtige« Gehilfen einen Beitrag leisteten, ist seit Langem in der Fachliteratur vertreten. Dennoch regt Ziembas Infragestellung der These von einem Zusammenwirken zweier Künstlerindividualitäten und seine Rückkehr zu den alten Ansichten dazu an, die bisherigen Überlegungen zum Thema der beiden Retabel 


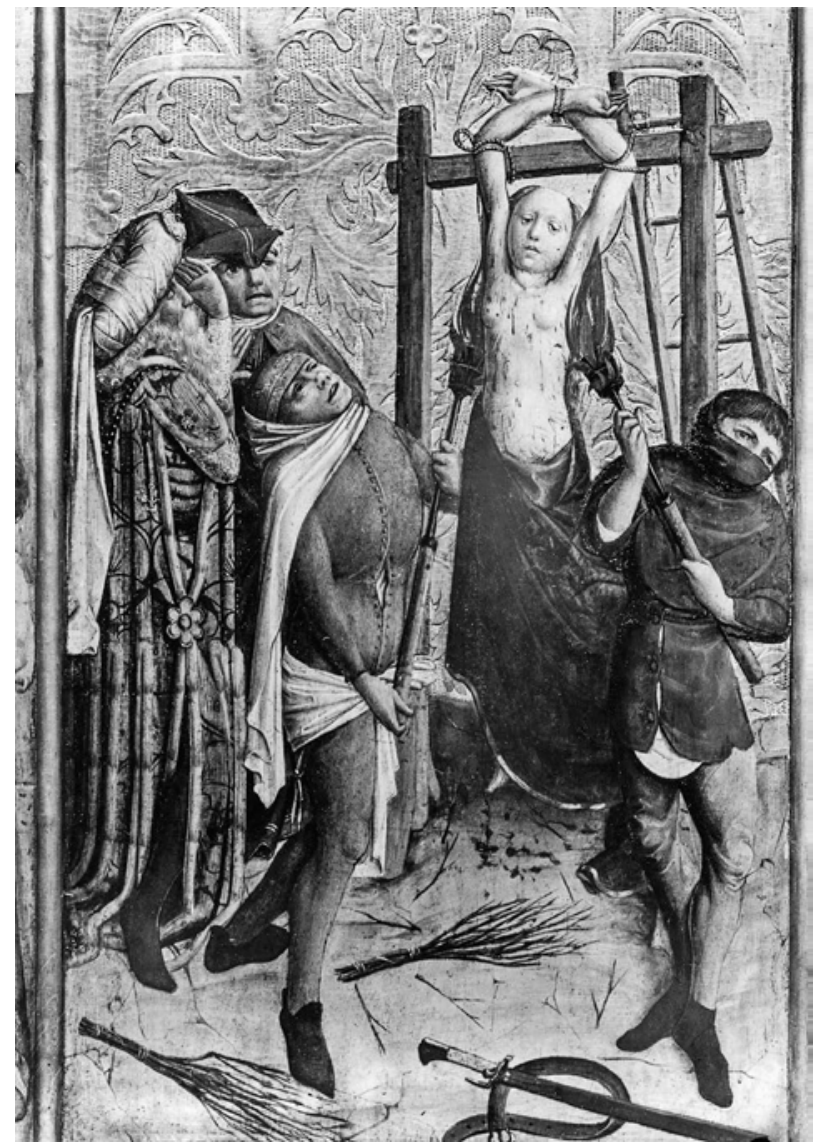

Abb. 7 Martyrium der hl. Barbara, Tafel VII der Festtagsseite des Breslauer Barbararetabels (Zählung nach LABUDA 1984). 1447. Warschau, Muzeum Narodowe w Warszawie (Foto: Bildarchiv Foto Marburg)

als Werke, die in dieser oder jener Hinsicht das Ergebnis einer Gemeinschaftsarbeit waren, noch einmal zu durchdenken. Es stehen sich hier zwei Modelle gegenüber: ein hierarchisches und ein nicht-hierarchisches, das letztere im Fall der Altäre aus Breslau und Neiße zweipolig, obwohl es die Mitarbeit einiger »weniger wichtiger« Hilfskräfte nicht ausschließt, die sich gewissermaßen zwischen den beiden Polen bewegen konnten. Im Fall des St.-Barbara-Altars schränkt ein grundlegendes Hindernis die Möglichkeiten zum Erreichen eines deutlichen Fortschritts der auf die Händescheidung abzielenden Untersuchungen ein: der Verlust der Flügel. Die vorhandene Fotodokumentation stellt keine zufriedenstellende Quelle dar.

Bei weiteren Überlegungen zu unserem Werkstattteam kann jedoch auf die umfangreichen in den letzten Jahrzehnten zusammengetragenen Ergebnisse jener Forschungen zurückgegriffen werden, deren Ausgangspunkt die Frage nach dem Status eines Werks der Vormoderne in

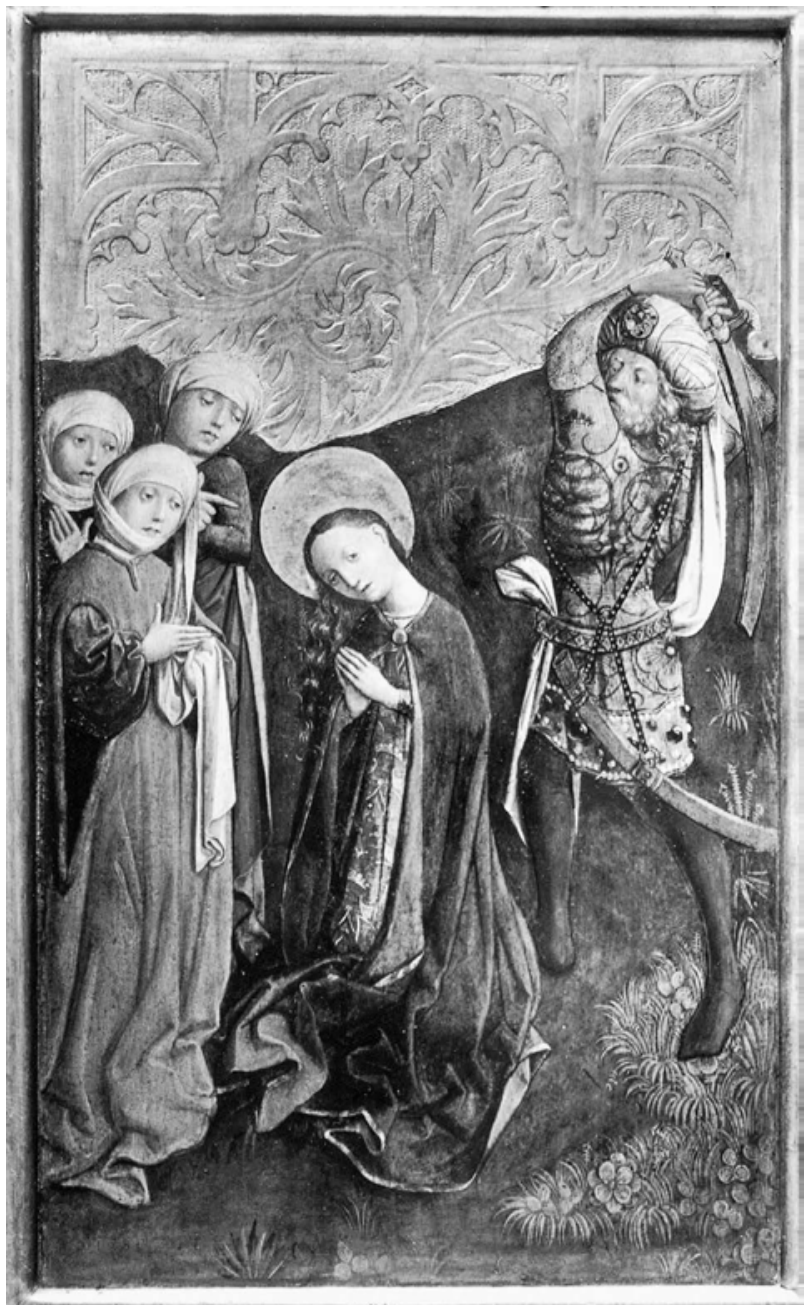

Abb. 8 Enthauptung der hl. Barbara, Tafel XI der Festtagsseite des Breslauer Barbararetabels. 1447. Warschau, Muzeum Narodowe w Warszawie (Foto: Bildarchiv Foto Marburg)

Bezug auf seinen individuellen Schöpfer bzw. eine Gruppe von Ausführenden war. Besonders die Untersuchungen zu Malerei, Bildhauerei und Altarbaukunst des Spätmittelalters trugen hierzu bedeutende, aufrührende Erkenntnisse bei, brachten eine Vielzahl von Kooperationskonstellationen ans Tageslicht und deckten Werkebenen auf, auch für das ungeschulte Auge unsichtbare Ebenen, auf denen man die für den historischen Empfänger uninteressante bzw. schlechthin »verdeckte« Beteiligung zahlreicher Personen am Schöpfungsprozess entdecken kann. ${ }^{81}$

Ich habe nicht die Absicht, dieses Problem in allen Einzelheiten zu erörtern. Ich möchte nur einige Bemerkungen formulieren und dabei teilweise, auch kritisch, meine alten Beobachtungen rekapitulieren. ${ }^{82}$ Zunächst sei festgehalten, dass ich den Meister des St.-Barbara-Al- 


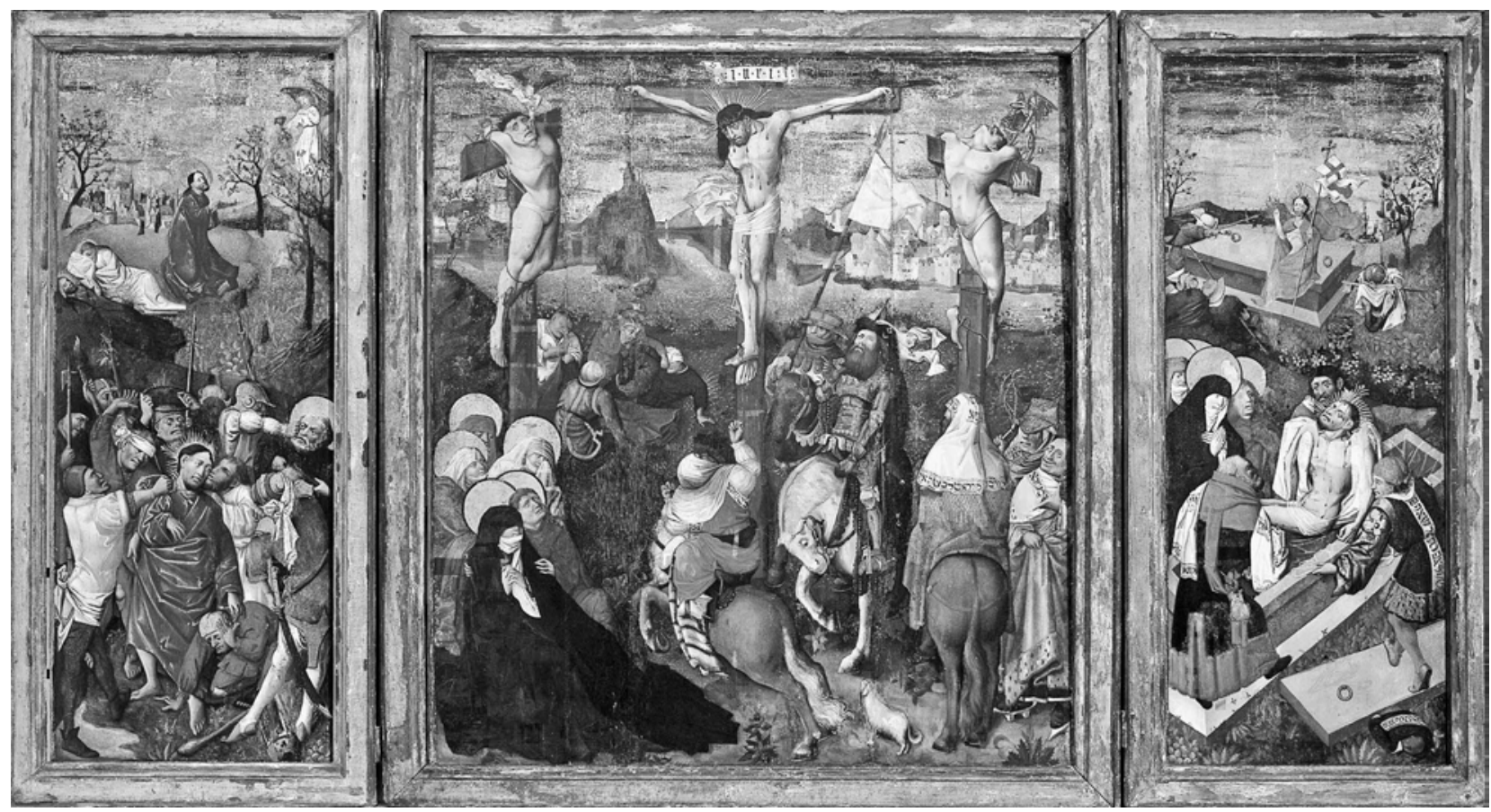

Abb. 9 Kreuzigungsretabel aus Heidau (Gać Śląska) in geöffnetem Zustand. Warschau, Muzeum Narodowe w Warszawie (Foto: Adam S. Labuda)

tars und den Meister der Passionszyklen als ausdrucksstarke Persönlichkeiten verstanden habe, die jedoch in ihren Errungenschaften nicht gleichwertig waren. Diese Ungleichwertigkeit hätte in Bezug auf den St.-BarbaraAltar stärker betont und der Anteil des Meisters des St. Barbara-Altars am Schöpfungsprozess erweitert werden müssen. Ich unterstrich z. B. das Einfließen seiner Inventionen in die Szenen der Kreuzigung und Kreuzabnahme (Abb. 6), ${ }^{83}$ in der Szene des Triumphs Marias hielt ich ihn dagegen für abwesend (Abb. 1) - an dieser Stelle irrte ich mich vermutlich. ${ }^{84}$

Genauerer Berücksichtigung bedarf die Tatsache, dass auch die einzelnen Tafeln der Festtagseite, die den Hauptanteil des Meisters des St.-Barbara-Altars ausmachen, bezüglich der Präzision ihrer Anfertigung nicht gleichwertig und stilistisch gesehen nicht ganz einheitlich sind. Meisterliches Niveau zeigt die Mitteltafel mit der zentralen Szene und den vier narrativen Feldern (Abb. 3). Unterschiede sind vor allem zwischen den Tafeln VII (Abb. 7) und VIII ${ }^{85}$ sowie XI (Abb. 8) und XII ${ }^{86}$ zu erkennen.

Sie könnten die Folge der Beschäftigung eines oder gar mehrerer Mitarbeiter an der Ausführung dieser Tafeln sein. Die Figuren der Folterknechte (vor allem die Art der Bewegung, die Grimassen) in den Tafeln VII und VIII zeigen Ähnlichkeiten mit den Tafeln des Passionszyklus
(Abb. 2). Von dem Ausführungsniveau der Vorderseite der erhaltenen Neißer Tafel, die nicht die Meisterschaft der Breslauer Mitteltafel erreicht, war bereits die Rede.

Gehen wir also zur Problematik des Meisters der Passionszyklen über. Ein wichtiges Glied in der Argumentationskette, die zur Hypothese von der Existenz einer solchen Künstlerpersönlichkeit als eines greifbaren Mitschöpfers der Retabel führte, ist der Kreuzigungsaltar aus dem schlesischen Heidau (Gać Śląska; Abb. 9, Taf. XIII), heute im Warschauer Nationalmuseum. ${ }^{87}$

Am augenfälligsten ist die Ähnlichkeit zwischen den Szenen des Gebets im Garten Gethsemane auf dem Kreuzigungsaltar (Abb. 12) und der Neißer Tafel (Abb. 5), die besonders nach der Reinigung der letzteren gut sichtbar wurde. Die Verbindungen betreffen die Komposition, das Raumkonzept sowie die Konzeption der Motive, der Koloristik und der Details. ${ }^{88}$

Für eine Charakterisierung der Art, in der sich die Präsenz des Meisters der Passionszyklen am St.-Barbara-Retabel äußert, ist die Erkenntnis wichtig, dass die Tafeln mit den Darstellungen der Passion Christi (Abb. 2) wenig homogen sind. An die beiden künstlerisch überzeugenden großen Tafeln grenzen schwächere Darstellungen, vor allem die Szenen des linken Flügels. Die Figuren füllen hier leer wirkende Räume von einfachem Aufbau. Die 
energischen, doch teilweise unbeholfenen Bewegungen der Folterknechte sind voller Aggression; ähnlich expressiv wirken deren abstoßende, deformierte Gesichter (Abb. 10).

Maskenhafte Gesichter sind auch in den großen Bildfeldern mit Kreuzigung und Kreuzabnahme vertreten (Abb. 2, 6). Auf dem rechten Flügel, der homogener ist als der linke, überrascht jeweils die monumentale Erscheinung eines figürlichen Elements auf der Bildfläche, wie sie hagiografischen Szenen sonst fremd ist.

Diese Verhältnisse scheinen die Folge der Einbeziehung anonymer, "weniger wichtiger" Gehilfen in die Ausführung der einzelnen Tafeln zu sein. Eine eindeutige Feststellung, in welcher Schicht der Bildentstehung (der Skizze? der Malschichten?) und in welchem Darstellungsausschnitt (z.B. den Gesichtern) ihr Beitrag in Erscheinung treten könnte, fällt ohne Autopsie des Originals schwer. Dass hier nicht nur eine Hand am Werk war, kann unter anderem das Triptychon aus Senftenberg ${ }^{89}$ bezeugen, das Knüvener überzeugend mit den Passionsszenen des Breslauer und Neißer Altars in Verbindung brachte (Abb. 11).

Möglicherweise hatte dessen Maler Anteil an der Ausführung des Passionssegments des Breslauer Altars, und die Einschränkung erscheint hier nur, da die Bezüge zwischen dem Lausitzer Retabel und den schlesischen Werken in gewisser Weise fließend sind. Obwohl die Handschrift des Malers des Senftenberger Triptychons erkennbar ist, können wir ihn in den Passionsszenen des St.-Barbara-Altars »nicht an der Hand fassen«. Wenn er

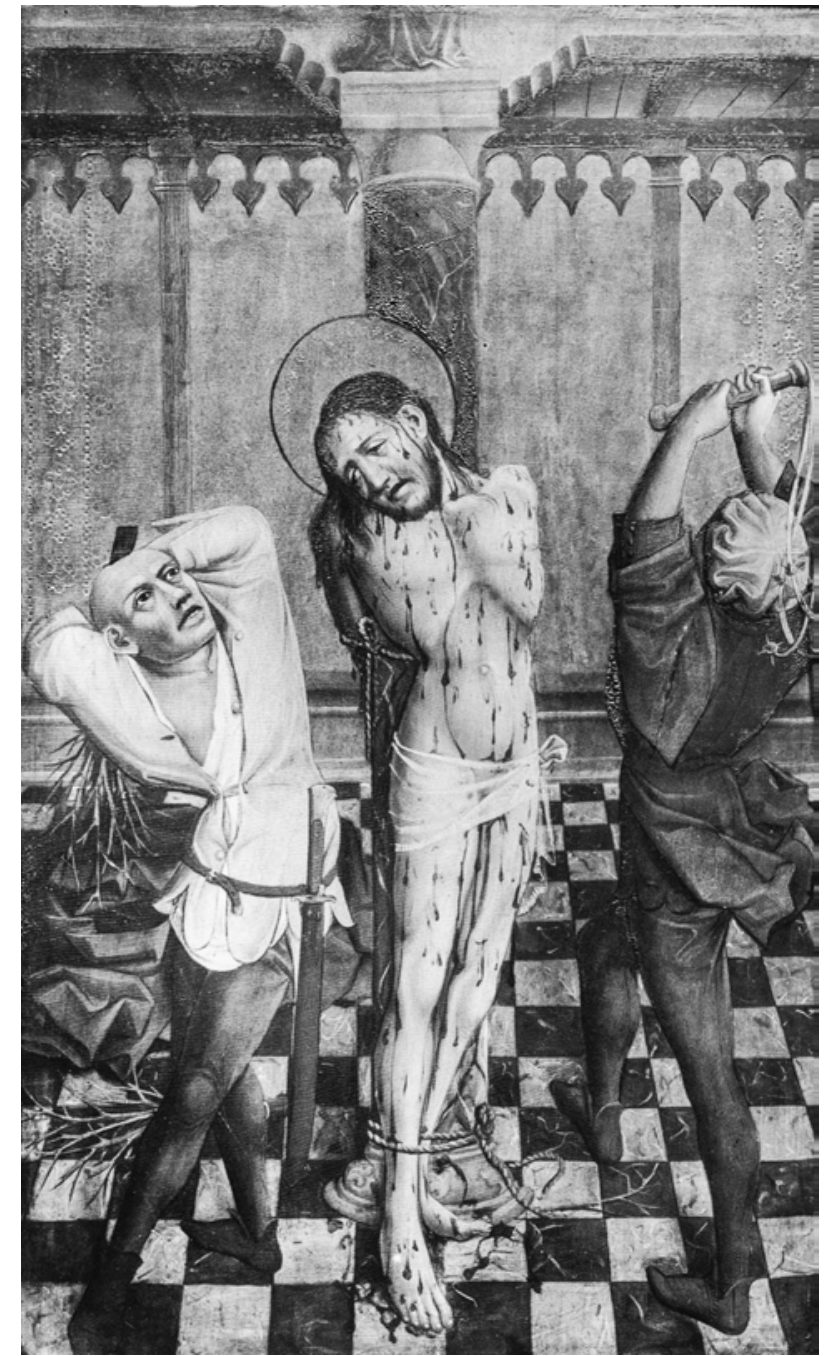

Abb. 10 Geißelung Jesu, Passionsseite des Breslauer Barbararetabels. 1447. Früher Breslau, Schlesisches Museum für Kunstgewerbe und Altertümer (Foto: Bildarchiv-Foto Marburg)

Abb. 11 Passionsretabel aus Senftenberg. Doberlug, ehem. Zisterzienserkirche (Foto: Peter Knüvener, Zittau)

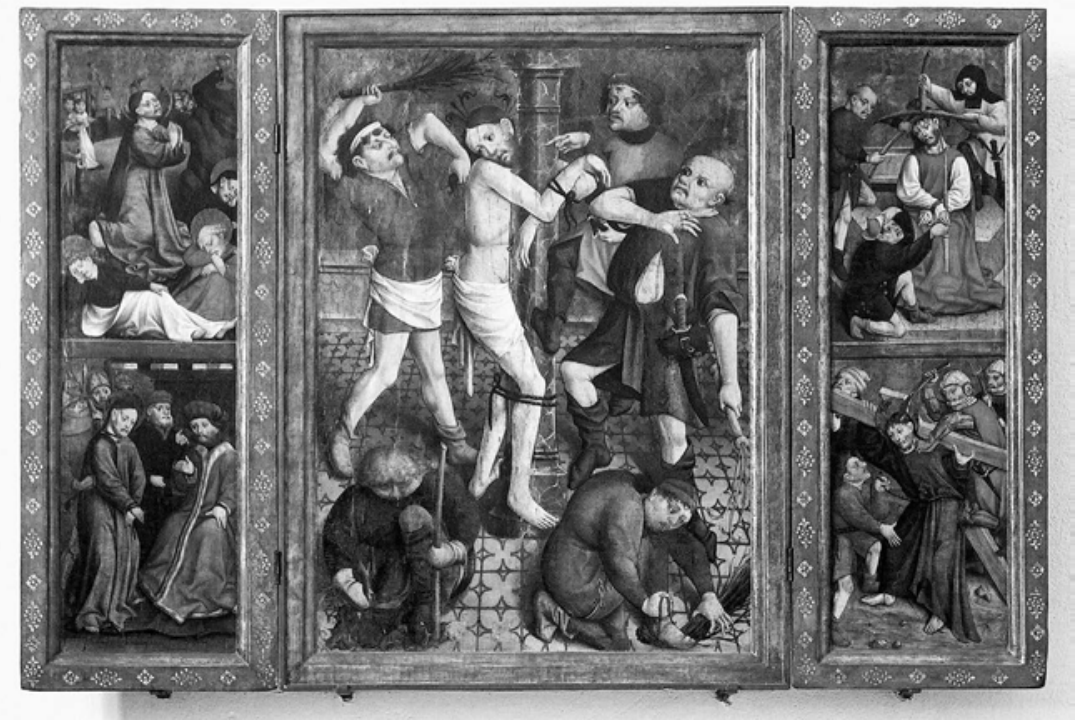




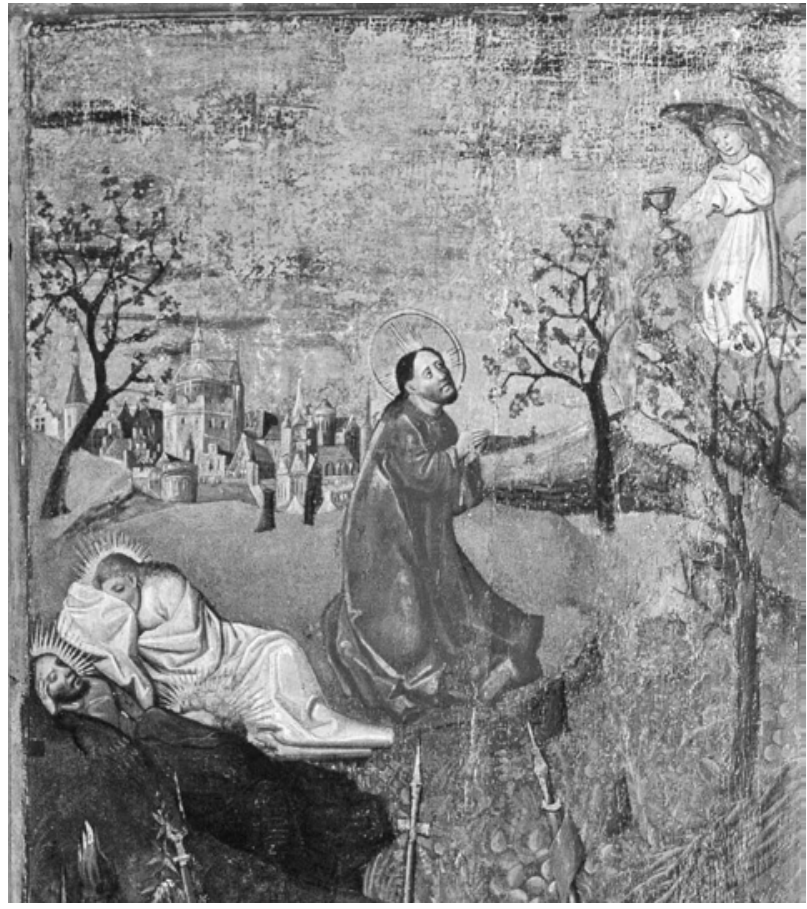

Abb. 12 Gebet Jesu am Ölberg vom linken Flügel des Kreuzigungsretabels aus Heidau (Gać Śląska). Warschau, Muzeum Narodowe w Warszawie (Foto: Adam S. Labuda)

Abb. 13 Gebet am Ölberg, Passionsseite des Breslauer Barbararetabels. 1447. Früher Breslau, Schlesisches Museum für Kunstgewerbe und Altertümer (Foto: Bildarchiv Foto Marburg)

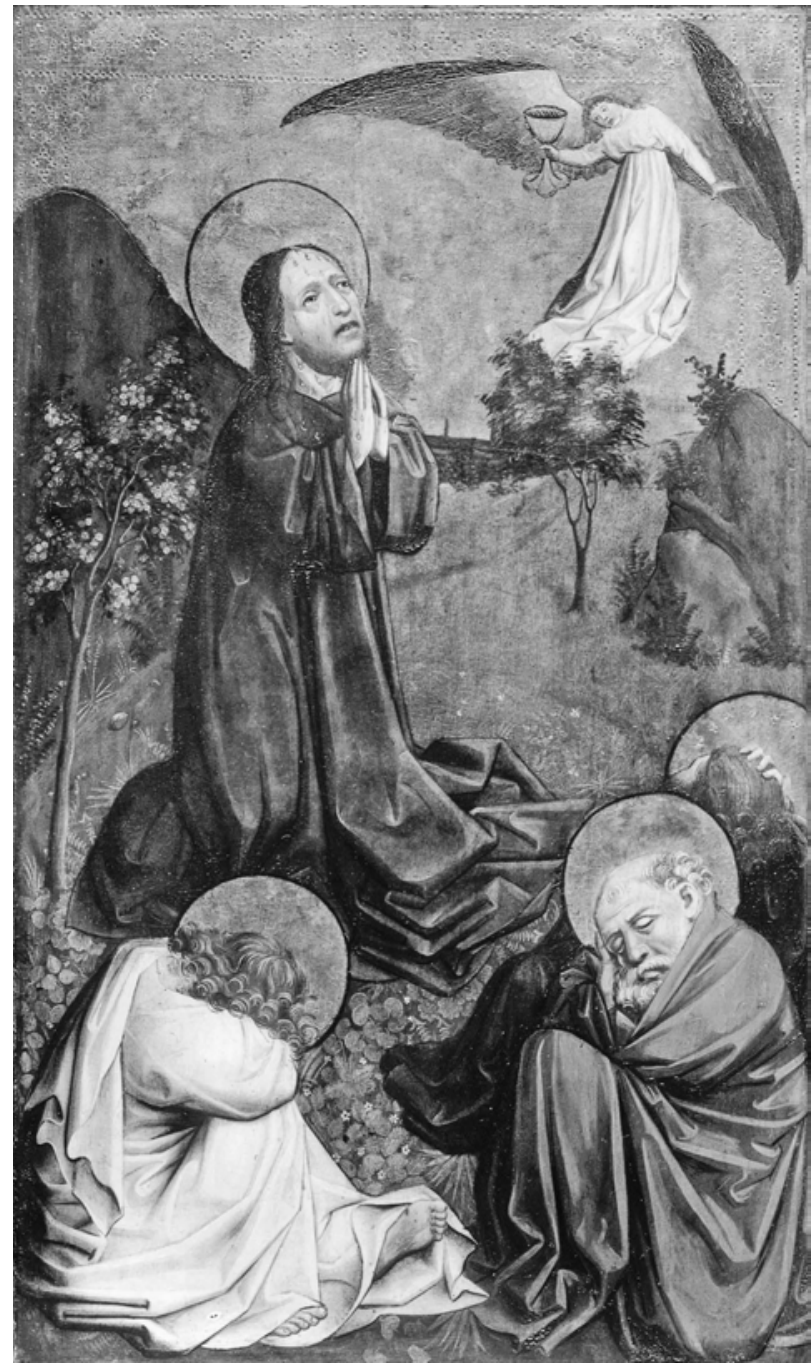

an und auch er selbst griff sicherlich gern darauf zurück und arbeitete nicht mit größter Sorgfalt. Vor diesem Hintergrund hebt sich die Rückseite der Neißer Tafel durch die Schlüssigkeit ihrer Konzeption und Ausführung ab, wobei nie vergessen werden darf, dass wir nur über eine einzige Tafel eines komplexen Passionszyklus' verfügen.

Die gesamte Passionserzählung des St.-Barbara-Altars, besonders die kleinen Tafeln, und die Rückseite des Neißer Retabels haben ihre Wurzeln bei Künstlern, deren Tätigkeit man in Städten des süddeutschen Bereichs des Heiligen Römischen Reichs nachweisen kann: Beim Meister der Worcester-Kreuztragung (Regensburg), dem Meister des ersten Hochaltarretabels der Nürnberger Augustinerkirche (d.h. dem sog. Meister des Tucheraltars) sowie dem Meister der Karlsruher Passion (Straßburg). Gewiss kann dieser Wissensschatz auch dem Meister des St.-Barbara-Altars, also Wilhelm von Aachen, bekannt malerische Umsetzung dieser Muster seinen Mitarbeitern 


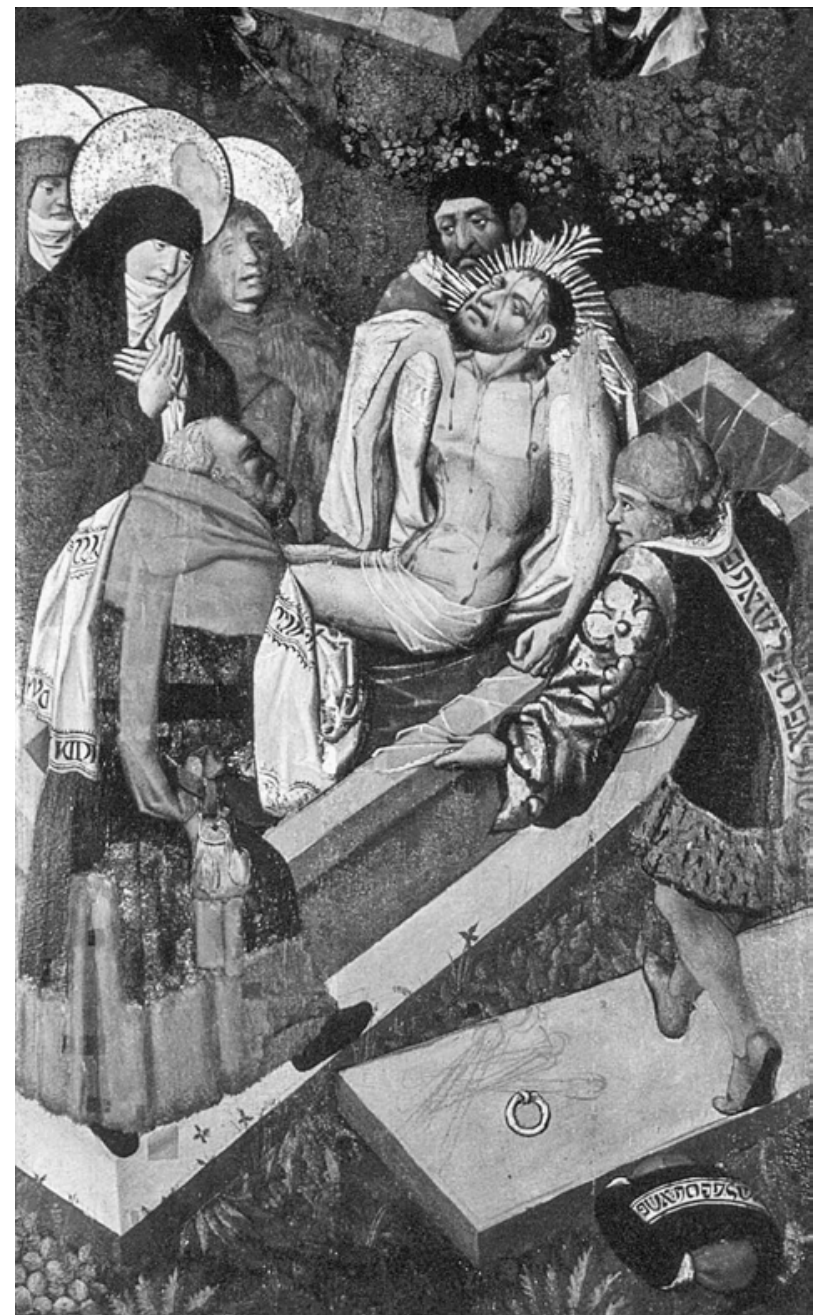

Abb. 14 Grablegung Jesu vom rechten Flügel des Kreuzigungsretabels aus Heidau (Gać Śląska). Warschau, Muzeum Narodowe w Warszawie (Foto: Adam S. Labuda)

gewesen sein, besonders, da einige Elemente seiner Handschrift ihren Ursprung in der Kunst der westlichen Regionen hatten, so Neuerungen des Meisters der Karlsruher Passion. Nicht ohne Bedeutung war auch seine höchstwahrscheinlich anzunehmende - ihn schließlich nach Schlesien führende - Wanderung durch Süddeutschland, wohl mit Stationen in Nürnberg und Regensburg. Diese These wird auch durch süddeutsche Elemente im Barbara-Zyklus gestärkt, die sich in den verschiedenartigen, oben erwähnten Tafeln VII (Abb. 7) und VIII ${ }^{91}$ sowie XI (Abb. 8) und XII ${ }^{92}$ manifestieren. Es scheint jedoch, dass der Meister der Passionszyklen in größtem Maße für die süddeutschen Elemente in den Altären aus Breslau und Neiße verantwortlich war. Er kannte sich mit den Bildinventionen dieser Region bestens aus. Es sei daran er-

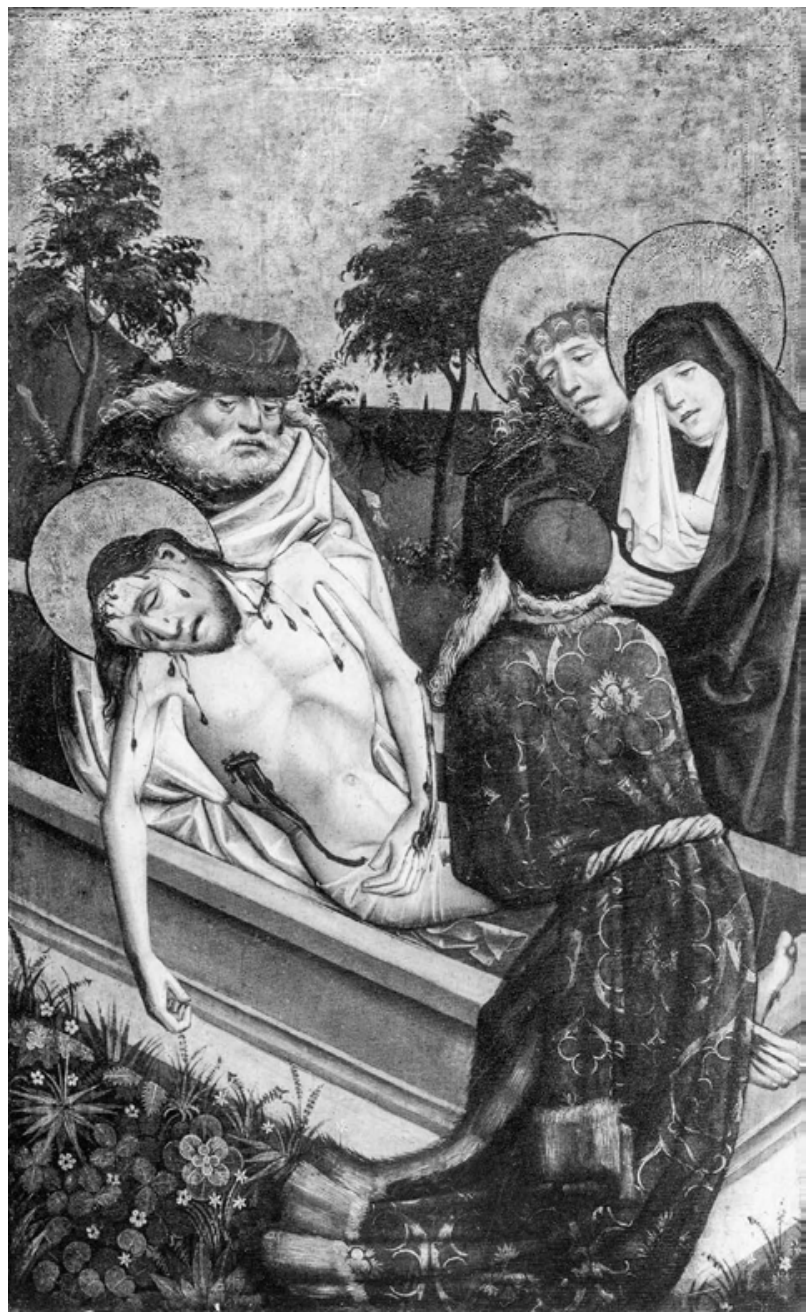

Abb. 15 Grablegung Jesu, Passionsseite des Breslauer Barbararetabels. 1447. Früher Breslau, Schlesisches Museum für Kunstgewerbe und Altertümer (Foto: Bildarchiv Foto Marburg)

innert, dass die Kreuzigungsszene aus Heidau (Taf. XIII) höchstwahrscheinlich die Rezeption eines verschollenen Gemäldes des Meisters der Worcester-Kreuztragung darstellt, und es ist nicht ausgeschlossen, dass auch die übrigen Darstellungen des Triptychons andere Tafeln des als Vorbild dienenden Retabels spiegeln. ${ }^{93}$ Im Kontext dieses Werks und seiner Verbindungen zum Breslauer und Neißer Retabel lassen sich sehr gut die Bezüge zu den Nürnberger Werken um das erste Hochaltarretabel der dortigen Augustinerkirche (das sog. Tucherretabel) erläutern. ${ }^{94}$ Auch dessen Meister hatte einen »kompilatorischen « Ausbildungshintergrund, mit einer künstlerischen Arbeitsweise, die auf Zusammenarbeit eingestellt war. Er vertrat demnach dieselbe Disposition, die den formalen Charakter des Passionszyklus' am St.-Barba- 
ra-Altar so stark determinierte. Doch an Bereitschaft zur Zusammenarbeit und zu Kompromissen mangelte es, wie aus unseren obigen Beobachtungen folgt, auch dem Meister des St.-Barbara-Altars nicht; darauf beruhte gewissermaßen die Natur der Produktion großformatiger Altarretabel.

\section{Das Auseinanderdriften und Zusammenlaufen der Zeugnisse}

Es ist nun Zeit, aus der Gegenüberstellung der beiden Zeugnisse - der Schriftquellen und der Aussage der künstlerischen Form des Werks - in dem uns interessierenden Kontext der Zuschreibungsproblematik Schlussfolgerungen zu ziehen.

Die Schriftquellen, also die Neißer Verträge, lieferten wichtige Informationen über die beiden Hauptschöpfer des Retabels für die St.-Jakobs-Kirche, Wilhelm von Oche und Martin, den Grad ihrer Spezialisierung und ihren Arbeitsumfang, die Vergütung und die praktischen Bedingungen ihrer Tätigkeit in Neiße und schließlich über den Beitrag des Auftraggebers zur materiellen, darunter auch künstlerischen Ausstattung des Retabels.

Aus dem ersten Vertrag erfuhren wir des Weiteren von der Herkunft des leitenden Meisters aus Aachen und aus den beiden Folgeverträgen vom frühen Tod seines Kollegen und von dessen beiden Nachfolgern. Der erste Vertrag bildete die Grundlage für die Hypothesen über Art und Weise der Zusammenarbeit zwischen den beiden namentlich genannten Hauptschöpfern des Werks, die für zwei verschiedene, zur Entstehung des Altars beitragende Tätigkeiten zuständig waren: die figürlichen Malereien und die Fassmalerei. Wilhelm und Martin waren die Adressaten des Vertrags. Doch in die Ausführung des Auftrags waren auch andere Personen einbezogen: der erste Vertrag gab somit, gewissermaßen indirekt, Auskunft darüber, dass über die Gestalt des Gesamtwerks die Arbeit anderer, in diesem Fall anonymer Handwerker - Schnitzer, Tischler-Dekorateure, Schlosser und anderer - entschieden hatte.

Das Bild, das jegliche Verträge von der Schöpfung eines Kunstwerkes bieten, ist von Natur aus unvollständig, und auch in unserem Fall ist es in der grundlegenden, die ausführenden Künstler betreffenden Überlieferung nur scheinbar klar. Beschränken wir uns an dieser Stelle auf die Malermeister. Die kritische Stilanalyse der Neißer Tafel und des damit in Verbindung gebrachten St.-Barba-
ra-Altars sprengt die von den Schriftquellen angebotene Struktur der Zuschreibung. Wir konnten feststellen, dass die Information zur Herkunft Wilhelms von Oche nur solange »sensationell« ist, wie sie mit den Ergebnissen der vergleichenden Stiluntersuchungen bezüglich der künstlerischen Provenienz der beiden genannten Werke übereinstimmt. Nimmt man wiederum die oben anhand der Quellen dargestellten urheberschaftlichen Zuweisungen für bare Münze, dann haben wir es mit zwei Hauptschöpfern des malerisch-figürlichen Bereichs zu tun, doch nur einer von ihnen kann mit einem der im Neißer Vertrag erwähnten Meister identifiziert werden, der zweite bleibt dagegen ein aus der Stilanalyse des Werks hergeleitetes Konstrukt. Letztere bringt des Weiteren die Beteiligung anderer, anonymer Maler niederen Ranges (Schüler, Gesellen?) ans Tageslicht, obwohl dies sicherlich keine umfangreiche Gruppe war; es mag sich dabei um nur eine, maximal zwei zusätzliche Personen gehandelt haben.

Das Bild, das sich als Ergebnis unserer Überlegungen zum Verlauf der Fertigung der beiden Titelwerke bietet, entspricht nur in einem geringen Teil dem, was den Schriftquellen entnommen werden kann. Mehr noch - es schürt Unruhe: Wie ist es möglich, dass die so bedeutsame Beteiligung des "Meisters der Passionszyklen« sich nicht im Vertrag spiegelt? Denn dieser klärte doch die Frage der Vergütung und der Verantwortung für die Gestalt des Retabels. Selbst wenn wir annehmen müssen, dass der Meister des St.-Barbara-Altars, sprich Wilhelm von Aachen, die Verantwortung für diese mehrköpfige "Urhebergemeinschaft« übernahm, tauchen Fragen nach deren Verhältnis zu den institutionell-rechtlichen Regelungen auf, die das Wirken von künstlerischen Werkstätten in spätmittelalterlichen Städten determinierten. Dies sollte zum Gegenstand weiterer Forschungen werden. An dieser Stelle kann lediglich festgehalten werden, dass das historiografische Bild der Tätigkeit von Meistern und Werkstätten komplexer ist - auch dank des Studiums von Schriftquellen -, als es aus den normativen Vorschriften beispielsweise der Zünfte hervorgehen könnte. Die aus der Analyse von Kunstwerken hergeleiteten Aussagen bereichern dieses Bild und verstärken die Notwendigkeit, die schöpferischen Prozesse der Vormoderne in enger Verbindung mit ihren institutionell-werkstattlichen und gesellschaftlich-historischen Abhängigkeiten tiefgründiger zu untersuchen. 


\section{Anhang}

Abschrift des Vertrags über die Ausführung und die Verpflichtung zur Vollendung des Hochaltarretabels für die St. Jakobuskirche in Neiße aus dem Stadtbuch der Stadt Neiße - 1451-1453 (Staatsarchiv in Oppeln / Archiwum Państwowe w Opolu, Aktensammlung der Stadt Neiße / Akta m. Nysy, Sign. 584) $)^{95}$

Die Übersetzung der Urkunden in die moderne deutsche Sprache und die Kommentare verfasste Markus Hörsch.

\section{Eynunge der kirchenbeter ummb dy Grose toffil}

Lib. act., fol. $165 \mathrm{r}-165 \mathrm{v}$

Vertrag der Kirchenpfleger betreffend die Große Altartafel

[1] Am Sonnobunde Bricii [1451] vor uns komen sint hanns gunther und wenclaw rymer kirchenbeter unser pharrekirchen czu sante Jocob und haben sich geeynet mit Meister Wilhelm von Oche und mit meister Merten alz ummb die erbet Und Moelen der Toffel do selbist in unser pharkirchen.

Am Sonnabend Bricii [7.12.1451] sind Hans Gunther und Wenzeslaus Riemer, Kirchenpfleger unserer Pfarrkirche zu St. Jakob, vor [zu] uns gekommen und haben sich mit Meister Wilhelm von Oche [Aachen] und Meister Martin bezüglich der Herstellung und des Bemalens der Hochaltartafel daselbst in unserer Pfarrkirche geeinigt.

[2] Namlich alzo das sie dem genanten meister Wilhelm Geben sullen czu voraws dreissig golden off das her seyn fleis tuen sal und vor dy erbet roten beide vor das Bildewerk und auch vor das gemelde zam sie em des wol czu getrawen und als lange als her erbten wird sal man em yde Woche eyn ungerischen golden geben und dorczu freye kaste wenn her erbit,

Und zwar so, dass sie dem genannten Meister Wilhelm im Voraus 30 Gulden geben sollen, auf dass er seine Möglichstes tue und für die Arbeit Rat gebe [= die Verantwortung übernehme], und zwar für beides, die skulpierten Teile und die Malerei, [wie] sie es ihm wohl zutrauen, und so lange er arbeiten wird, soll man ihm pro Woche einen ungarischen Gulden geben und dazu freie Kost, wenn er arbeitet,
[3] und meister Merten sal en vorsurgen mit allirley ffarben und was czum Moelen gehort und dorczu dy Toffeln dy her moelen wirt, die sal meister Merten gancz czubereiten bas czum entwerfen und czum moelen, etc.

und Meister Martin soll ihn versorgen mit allerlei [= allen nötigen] Farben und was zum Malen gehört und dazu die Tafeln ${ }^{96}$, die er [= Meister Wilhelm] bemalen wird, die soll Meister Martin vollständig zubereiten [= fertigen und grundieren] bis zum [= als Vorbereitung für das] Entwerfen [= die Unterzeichnung] und Malen usf.

[4] Item Meister Merten sal vor dy Toffil surgen und das Bildwerk und allis was dorczu gehorit gare awsbereiten Inwen(d)ig mit feynem golde und sust uswen(d)ig mit geferbetem golde und den Awsczog auch mit geferbtem golde und der Zarch Inwen(d)ig Bloe und dy Bilde sal her auch mit feynem golde vorgolden und die gesprenge mit den czween fenstern am zarche auch vorgolden und das Gold und ffarben sal allis meister Merten schicken und alle ding die czum Moelen und usbereiten gehoren.

Ebenso soll Meister Martin für die [Haupt]tafel ${ }^{97}$ sorgen und die geschnitzten Teile ${ }^{98}$ und alles, was dazu gehört, vollständig ausbereiten $[=\text { fassen }]^{99}$ innen mit feinem Gold [= Blattgold] und sonst außen mit gefärbtem Gold [= Goldfarbe] und den Auszug ${ }^{100}$ auch mit gefärbtem Gold[;] und der Sarg [= die Predella] innen blau und die Skulpturen soll er auch mit feinem Gold vergolden und die Gesprenge mit den beiden Fenstern am Sarg auch vergolden[;] und das Gold und [die] Farben, das soll alles Meister Martin schicken und alle Dinge, die zum Malen und Fassen gehören.

[5] Sunder was Czymmerwerk antrifft und den Smed ader eysenwerk und Tisschwerk das sal allis die kirche schaffen

Außer was das Zimmerwerk betrifft und den Schmied oder Eisenarbeit und Tischlerarbeit, das soll alles die Kirche leisten;

[6] und die kirchenbeter sullen meister Merten bestellen eyn haws dorynne her Erbit und sal frey sein Geschosses und der wache als lange her erbten wirt. Dorummb sullen die kirchenbeter meister Merten geben vierhundert mark heller und fumfundczwenczig mark heller vor Alle erbit und loen und vor allis das her dorczu haben sal und meister Merten sal En die Toffel und den Zarch antworten vor das 
hoe Altare wol auwsbereit an allis wandel und ap icht doran wandels wer ader vorkurczt wurde an den Bilden und Toffil, das sal meister Merten wandeln und bessern noch deme als en meister Wilhelm undirweizen wirt, etc.

und die Kirchenpfleger sollen Meister Martin ein Haus zur Verfügung stellen, in dem er arbeiten kann und er soll vom Schoss [ $=$ der Steuer] und vom Wachdienst befreit sein, solange er arbeiten wird. Für dies sollen die Kirchenpfleger Meister Martin 400 Mark Heller geben und 25 Mark Heller für die ganze Arbeit und Lohn und für alles, das er dazu haben soll [= benötigen wird], und Meister Martin soll ihnen die Tafel und den Sarg übergeben für den Hochaltar, vollständig gefasst ohne jede Abänderung, und wenn daran an den Skulpturen und der Tafel etwas verändert oder vermindert worden wäre, so soll das Meister Martin ändern und bessern, nach dem, wie ihn Meister Wilhelm unterweisen wird, usf.

Lib. act., f. $174 \mathrm{~V}-175 \mathrm{r}$

An der mittewoch vor Conversionis pauli [1453] vor uns gestanden hot Meister Niclas Moler und hot sich mit wolbedochtem mutte undirwunden des werkis der Toffil in unser pfarkichen.

Am Mittwoch vor Bekehrung Pauli [25.1.1453] hat vor uns gestanden Meister Nikolaus, Maler, und hat mit wohlüberlegter Einstellung das Werk [= den Auftrag] des Retabels in unserer Pfarrkirche übernommen.

Dasselbe werg in allerley mosse ausczurichten und volenden mit hulfe und rate des kunftigen meister Wilhems noch deme alz denne vormols begriffen ist und geczeichent oben in disem buche annorum $l^{\circ}$ am Sonnobende Bricty etc.;

Dasselbe Werk in jeder Hinsicht auszurichten und $\mathrm{zu}$ vollenden mit Hilfe und unter Anleitung des künftigen Meisters Wilhelm, so wie es vormals verstanden und aufgezeichnet wurde oben in diesem Buche im Jahre 51 am Sonnabend Brictii, usf.;

denselben meister Niclas hot Katerina, etwenne meister Mertins eliche fraw dem got gnade, dem das genannte werg vordingit was ofgenomen das zufolbrengen und hot geglobit bei alle dem das sy hot ap is gebrechen Wurde an dem gelde domitte das genonnte werg vordingit was $u(n) d$ bei zulchir vordingunge nicht mochte volendet werden, doran man vil- leichte ynbussen muste, das zal demselben meister Niclas unschedlich seyn und wil en des gancz vortretin.

Denselben Meister Nikolaus hat Katharina, früher Meister Martins, dem Gott gnädig sei, Ehefrau, dem das genannte Werk verdingt worden war, aufgenommen, um dies zu vollbringen und hat gelobt bei allem, was sie hat, wenn es an Geld fehlen sollte, zu dem das genannte Werk verdingt worden war und [es] zu diesen Vertragsbedingungen nicht vollendet werden könne, sodass man vielleicht einbüßen müsste [= nachzahlen müsste], so soll das demselben Meister Nikolaus nicht zum Schaden gereichen und [sie] will dafür ganz einstehen.

Lib. act., f. $180 \mathrm{ov}$.

Wincencius kelner Moler

Vinzenz Kelner, Maler

Aam obgenannten tag [12.9.1453] vor uns gestanden ist meister Niclas Moler der sich des Werkis der toffil in unserer pfarrki(r)chen underwunden hatt, alss denne oben in disem Jare eigentlich mit berurit, und hot solche vordingunge von guttem willen uffgelossen und entrewmit vor uns, sottanis obgenannte werkis hot sich meister veczencz Kelner undirwunden, dasselbe ausczurichten und volenden in allerley mosse alss von irsten Meister Merten seinem vorfar dem got gnad va wart vordingit etc.

Am oben genannten Tag [ $=12.9 .1453]$ ist vor uns gestanden Meister Nikolaus, Maler, der den Auftrag des Retabels in unserer Pfarrkirche übernommen hatte, wie es denn oben in diesem Jahre im Wesentlichen mit berührt [= im Wesentlichen festgehalten] [wurde], und hat diesen Vertrag aus gutem Willen aufgelöst und ausgeräumt vor uns; sodann hat sich [bezüglich] obgenannten Werks Meister Vinzenz Kelner bereit erklärt, dasselbe auszurichten und zu vollenden in jeglicher Hinsicht wie es vom ersten Meister Martin, seinem Vorgänger, dem Gott gnädig sei, vertraglich festgelegt worden war, usf.

\section{Literatur}

[Ausst.-Kat. Bratislava 2003] : Ausst.-Kat. Gotika. Hg. v. Dušan BurAn. Bratislava, Slovenská národná galéria, 2003. Bratislava 2003 (Dejiny slovenského výtvarného umenia).

[Ausst.-Kat. Brügge 2010]: Ausst.-Kat. Van Eyck bis Dürer. Altniederländische Meister und die Malerei in Mitteleuropa. 
Hg. von Till-Holger Borchert. Brügge, Groeninge-Museum, 29.10.2010-30.1.2011. Stuttgart 2010.

[Ausst.-Kat. Budapest 2008]: Ausst.-Kat. Matthias Corvinus, the King. Tradition and Renewal in the Hungarian Royal Court 1458-1490. Hg. von Péter Farbaky u.a. Budapest, Historisches Museum der Stadt, 2008. Budapest 2008.

[Ausst.-Kat. Frankfurt/M. 2011]: Ausst.-Kat. Niclaus Gerhaert. Der Bildhauer des Späten Mittelalters. Hg. von Stefan Roller. Frankfurt/M., Liebieghaus Skulpturensammlung, 27.10.2011-4.3.2012; Straßburg, Musée de l'Euvre Notre-Dame, 30.3.- 8.7.2012. Petersberg b. Fulda 2011.

[Ausst.-Kat. Freising 2004/05]: Ausst.-Kat. Jan Polack. Von der Zeichnung zum Bild. Malerei und Maltechnik in München um 1500. Hg. von Peter Bernhard Steiner und Claus Grimm. Freising, Diözesanmuseum, 29.10.2004-6.2.2005. Begleitende Dokumentation im Bayerischen Nationalmuseum München. Augsburg 2005.

[Ausst.-Kat. Legnica 2001]: Ausst.-Kat. 'Op Nederlandse Manier'. Inspiracje niderlandzkie w sztuce śląskiej XV-XVIII w. Katalog wystawy ['Op Nederlandse Manier'. Niederländische Inspirationen in der schlesischen Kunst des 15.-17. Jahrhunderts]. Hg. v. Mateusz Kapustka, Andrzej Kozie£ und Piotr OszczanowsKi. Legnica 2001.

[Ausst.-Kat. Prag/Legnica 2006]: Ausst.-Kat. Śląsk - perła w Koronie Czeskiej. Trzy okresy świetności w relacjach artystycznych Śląska i Czech [Schlesien - Perle in der Böhmischen Krone. Die drei Glanzzeiten in den künstlerischen Beziehungen zwischen Schlesien und Böhmen.] Hg. von Andrzej Niedzielenko und Vít Vlnas. Prag, Legnica, 2006. Praha 2006.

[Ausst.-Kat. Stuttgart 1993]: Ausst.-Kat. Meisterwerke massenhaft. Die Bildhauerwerkstatt des Niklaus Weckmann und die Malerei in Ulm um 1500. Stuttgart, Württembergisches Landesmuseum, 11.5.-1.8.1993. Hg. von Heribert Meurer und Gerhard Weilandt. Stuttgart 1993.

[Ausst.-Kat. Zeitz 2017]: Ausst.-Kat. Dialog der Konfessionen. Bischof Julius Pflug und die Reformation. Hg. von Markus Cottin und Holger Kunde. Zeitz, Museum Schloss Moritzburg, 5.6.-1.11.2017. Petersberg b. Fulda 2017.

Badach, Artur/Janiszewska, Monika/Tarkowska, Monika (Hgg.): ,Visibilia et Invisibilia' w sztuce średniowiecza. Księga poświęcona pamięci Profesor Kingi SzczepkowskieNaliwajek [>Visibilia et Invisibilia in der Kunst des Mittelalters. Festschrift zu Ehren von Prof. Kinga Szczepkowska-Naliwajek]. Warszawa 2009.

Bergsträsser, Gisela: Caspar Isenmann. Ein Beitrag zur oberrheinischen Malerei des 15. Jahrhunderts. Kolmar im Elsass 1941.

Bernhardt, Katja/Piotrowski, Piotr (Hgg.): Grenzen über- windend. Festschrift für Adam S. Labuda zum 6o. Geburtstag. Beiträge der Schülerfestschrift (CD-Rom). Berlin 2006.

BiaŁŁowicz-KrygierowA, Zofia: Studia nad snycerstwem XIV wieku w Polsce [Studien zur Schnitzkunst des 14. Jahrhunderts in Polen], Bd. 1. Początki śląskiej tradycji ołtarza szafowego [Die Anfänge der schlesischen Tradition des Schreinaltars]. Warszawa/Poznań 1981.

Bogen, Steffen/Brassat, Wolfang/Ganz, David (Hgg.): Bilder, Räume, Betrachter. Festschrift für Wolfgang Kemp zum 60. Geburtstag. Berlin 2006.

Borkowska, Urszula/Hörsch, Markus (Hgg.): Hofkultur der Jagiellonendynastie und verwandter Fürstenhäuser/The Culture of the Jagellonian and Related Courts. Akten des Kolloquiums in Lublin, 2./3. September 2002. Ostfildern 2010 (Studia Jagellonica Lipsiensia 6).

Braune, Heinz/Hahm, Konrad (Hgg.)/Hollos, Julius (Fotografie): Schlesien in Farbenphotographie. 2 Bde. Berlin 1923/24 (Deutschland in Farbenphotographie VIII-IX). Nachdruck Kiel 1990.

Braune, Heinz/Wiese, Erich: Schlesische Malerei und Plastik des Mittelalters. Kritischer Katalog der Ausstellung in Breslau 1926. Berlin 1929.

Brinkmann, Bodo/Kemperdick Stephan: Deutsche Gemälde im Städel 1300-1500. Mainz 2002 (Kataloge der Gemälde im Städelschen Kunstinstitut, Frankfurt/M. 4).

Brinkmann, Bodo/Krohm, Hartmut/Roth, Michael (Hgg.): Aus Albrecht Dürers Welt. Festschrift für Fedja Anzelewsky zum 8o. Geburtstag. Turnhout 2001.

Buck, Stephanie: Marterung der hl. Barbara. In: DiCkel 2009, 53-56.

CArqué, Bernd/Röckelein, Hedwig (Hgg.): Das Hochaltarretabel der St.-Jacobi-Kirche in Göttingen. Göttingen 2005.

Chapuis, Julien: Stefan Lochner. Image Making in FifteenthCentury Cologne. Tournhout 2004.

Chmielewski, Krzysztof: Technika warsztatowa Mistrza Poliptyku św. Barbary. Studium z zakresu wzajemnych relacji pomiędzy techniką a formą artystyczną w malarstwie XV wieku. Rękopis pracy doktorskiej [Die Werkstatttechnik des Meisters des St. Barbara-Polyptychons. Studien zu den gegenseitigen Beziehungen zwischen Technik und künstlerischer Form in der Malerei des 15. Jahrhunderts]. Diss. (Msc.) Krakau 2001.

Chmielewski, Krzysztof: Budowa technologiczna zachowanej części poliptyku św. Barbary z Wrocławia [Technologischer Aufbau des erhaltenen Teils des St.-Barbara-Polyptychons aus Breslau]. In: Roczniki Sztuki Śląskiej 19 (2010), 115-141.

Deceulaer, Harald/Diels, Ann: Artists, Artisans, Workshop Practices and Assistants in the Low Countries. In: PeEters 2007, 1-31. 
Dettloff, Szczęsny: Wit Stwosz [Veit Stoß], Bd. 1. Wrocław 1961.

Dickel, Hans (Hg.): Zeichnen vor Dürer. Die Zeichnungen des 14. und 15. Jahrhunderts in der Universitätsbibliothek Erlangen. Petersberg b. Fulda 2009.

Die Sprache des Materials. Die Technologie der Kölner Tafelmalerei vom »Meister der heiligen Veronika« bis Stefan Lochner. Hg. vom Wallraf-Richartz-Museum Köln, Fondation Corboud, Köln, Doerner Institut, Bayerische Staatsgemäldesammlungen München. Berlin/München 2013.

DomasŁowski, Jerzy: Znaczenie klasztorów kanoników regularnych we Wrocławiu, w Żaganiu i Kłodzku dla rozwoju sztuki śląskiej [Die Bedeutung der Klöster der regulierten Kanoniker in Breslau, in Sagan und Glatz für die Entwicklung der schlesischen Kunst]. In: Sztuki plastyczne 1988, $37-72$.

Dudek-Bujarek, Teresa (Hg.): Witraże na Śląsku. Materiały sesji Górnośląskiego Oddziału Stowarzyszenia Historyków Sztuki Chorzów 2001 [Glasmalereien in Schlesien. Materialien der Sitzung der Oberschlesischen Abteilung der Vereinigung der Kunsthistoriker Königshütte 2001]. Katowice 2002.

Dümpelmann, Britta: Das Flügelretabel als Bildmaschine. Techniken der Wahrnehmungssteuerung im Krakauer Marienaltar. In: SCHULZ/WYSS 2010, 219-241.

Eysymontt, Rafał/KaczmareK, Romuald (Hgg.): Procesy przemian w sztuce średniowiecznej. Przełom - regres - innowacja - tradycja. Studia $\mathrm{z}$ historii sztuki [Transformationsprozesse in der Kunst des Mittelalters. Umbruch - Regression - Innovation - Tradition. Studien zur Kunstgeschichte]. Warszawa 2014.

Folga-Januszewska, Dorota (Hg.): Muzeum Narodowe w Warszawie. Arcydzieła malarstwa [Das Nationalmuseum Warschau. Meisterwerke der Malerei]. Warszawa 2005.

Ganz, David/Lentes, Thomas (Hgg.): Ästhetik des Unsichtbaren. Bildtheorie und Bildgebrauch in der Vormoderne. Berlin 2004.

Goffen, Rona: Nostra Conversatio in Caelis Est. Observations on the Sacra Conversazione in the Trecento. In: The Art Bulletin LXI (1979), 198-222.

Grau Oliver: Virtuelle Kunst in Geschichte und Gegenwart. Visuelle Strategien. Berlin 2001.

Greub, Suzanne/Greub, Thierry/KochanowsKa-Reiche, Małgorzata (Hgg.): Meisterwerke mittelalterlicher Kunst aus dem Nationalmuseum Warschau. München 2006.

Hörsch, Markus: Nikolaus Gerhaert von Leyden. - Hans Geuch. In: Saur Allgemeines Künstler-Lexikon. Die Bildenden Künstler aller Zeiten und Völker, Bd. 52. Leipzig/München 2006, 101-106.

HöRsch, Markus: Der ehemalige Hochaltar der Stadtkirche
St. Michael zu Zeitz und Pankraz Grueber. In: Ausst.-Kat. Zeitz 2017, 143-156.

HolečKová, Barbora: The Sacra Conversazione in Czech Fourteenth-Century Art. In: Umění LXII (2014), 106-117.

HoŁownia, Ryszard/Kapustka, Mateusz (Hgg.) : Nysa. Sztuka w dawnej stolicy księstwa biskupiego [Neiße. Die Kunst in der einstigen Hauptstadt des Fürstbistums]. Wrocław 2008.

Horzela, Dobrosława/Organisty, Adam (Hgg.): Wokół Wita Stwosza. Materiały z międzynarodowej konferencji naukowej w Muzeum Narodowym w Krakowie 19-22 maja 2005 [Um Veit Stoß. Beiträge zur internationalen Fachtagung im Nationalmuseum in Krakau 19.-22. Mai 2005]. Kraków 2006 (Studia i materiały naukowe Muzeum Narodowego w Krakowie).

Huth, Hans: Künstler und Werkstatt der Spätgotik. 4. Aufl. Darmstadt 1981.

Jarzewicz, Jarosław: De constructione ecclesiae. O artystycznych i społecznych uwarunkowaniach architektury kościoła św. Jakuba w Nysie [De constructione ecclesiae. Die künstlerischen und gesellschaftlichen Bedingtheiten der Architektur der Kirche des Hl. Jakob in Neiße]. In: Artium Quaestiones VIII (1997), 27-59.

JARzEwiCz, Jarosław: Biskupi i mieszczański - kościół św. Jakuba w Nysie [Bischöflich und bürgerlich - die St.-JakobsKirche in Neiße]. In: HoŁownia/KapustKa 2008, 75-85.

Kahsnitz, Rainer (Hg.): Veit Stoß. Die Vorträge des Nürnberger Symposions. München 1985.

KAHSNitz, Rainer: Die großen Schnitzaltäre. Spätgotik in Süddeutschland, Österreich, Südtirol. München 2005.

Kahsnitz, Rainer: Das Hochaltarretabel in St. Jacobi zu Göttingen. In: Noll/WARNCKE 2012, 45-82.

KALINOWSKI, Lech: Malarstwo witrażowe [Glasmalerei]. In: LABUDA/SECOMSKA 2004, I, 190.

Kalinowski, Lech/MaŁkiewiczówna, Helena: Średniowieczne witraże Śląska [Mittelalterliche Glasmalereien Schlesiens]. In: NowAK 1995, 35-55.

Kalinowski, Lech/MaŁkiewiczówna, Helena: Co wiemy o średniowiecznych witrażach śląskich? [Was wissen wir über mittelalterliche schlesische Glasmalereien?]. In: DuDEK-BUJAREK 2002, 13-41.

KapustKa, Mateusz: Mistrz ołtarza św. Barbary [Der Meister des St.-Barbara-Altars]. In: Ausst.-Kat. Legnica 2001, 11-12.

[Kapustka 2006/I]: Kapustka, Mateusz: Mistrz Wrocławskiego Ołtarza św. Barbary (Wilhelm Kalteysen z Akwizgranu) [Der Meister des Breslauer St.-Barbara-Altars (Wilhelm Kalteysen von Aachen)]. In: Ausst.-Kat. Prag/Legnica 2006, 494.

[KAPUStKa 2006/II] : KAPUStKA, Mateusz: Das berührte Bild? Eine unbekannte Vera-Ikon-Tafel aus dem 15. Jahrhundert und die Fragen zur Funktion von Tuchdarstellungen. In: 
Bernhardt/Piotrowski 2006, ohne kontinuierliche Seitenzählung.

KapustKa, Mateusz: Rana - księga - zwierciadło. Uwagi o franciszkańskich obrazach naśladownictwa [Wunde - Buch - Spiegel. Gedanken zu franziskanischen Bildern der Nachahmung]. In: BADACH/JANiszewsKa/TARKowsKa 2009, 221-237.

Kemp, Wolfgang: Christliche Kunst. Ihre Anfänge, ihre Strukturen. München 1994 .

Kemperdick, Stephan: Martin Schongauer. Eine Monographie. Petersberg b. Fulda 2004.

KNötel, Paul: Der Pleydenwurffsche Hochaltar der Elisabethkirche in Breslau. In: Jahrbuch des Schlesischen Museums für Kunstgewerbe und Altertum IX (1928), 59-68.

Knüvener, Peter: Das Passionsretabel aus Senftenberg/Niederlausitz in der Klosterkiche zu Doberlug - ein Werk aus dem Umkreis des Breslauer Barbaraaltares? In: Biuletyn Historii Sztuki 69 (2007), 5-22.

Kobler, Friedrich: Fassung von Bildwerken. In: Reallexikon zur deutschen Kunstgeschichte, Bd. VII. Stuttgart 1978, Sp. $743-826$.

KoвLer, Friedrich: Flügelretabel. In: Reallexikon zur deutschen Kunstgeschichte, Bd. 9. München 2003, Sp. 1450-1536.

Kochanowska-Reiche, Małgorzata: Malarstwo średniowieczne [Mittelalterliche Malerei]. In: Folga-JAnuszewSKA 2005, 102-103.

KochanowsKa-Reiche, Małgorzata: St.-Barbara-Altar. In: Greub/Greub/Kochanowska-Reiche 2006, 84-85.

Köllermann, Antje-Fee: Conrad Laib. Ein spätgotischer Maler aus Schwaben in Salzburg. Berlin 2007.

Krohm, Hartmut/Albrecht, Uwe/Weniger, Matthias (Hgg.): Malerei und Skulptur des späten Mittelalters und der frühen Neuzeit in Norddeutschland. Künstlerischer Austausch im Kulturraum zwischen Nordsee und Baltikum. Braunschweig/ Berlin 2004.

KRÜGER, Ralf: Friedrich Herlin. Maler und Altarbauunternehmer. Rothenburg ob der Tauber 2005 (Jahrbuch des Vereins Alt-Rothenburg e. V. 2005).

[LABUdA 1984/I]: LabUdA, Adam S.: Wrocławski ołtarz św. Barbary i jego twórcy. Studium o malarstwie śląskim połowy XV wieku [Der Breslauer St.-Barbara-Altar und seine Schöpfer. Studien zur schlesischen Malerei um die Mitte des 15. Jahrhunderts]. Poznań 1984.

[LABUDA 1984/II]: LABUDA, Adam S.: Wort und Bild im späten Mittelalter am Beispiel des Breslauer Barbara-Altars (1447). In: Artibus et Historiae. Rivista internazionale di arte visive e cinema 9 (V) (1984), 23-57.

LABUdA, Adam S.: Wrocławski ołtarz św. Barbary - dzieło przełomowe. Aspekty, konstatacje, znaki zapytania [Der Breslauer St. Barbara-Altar - ein Umbruchswerk. Aspekte,
Erkenntnisse und Fragezeichen]. In: Eysymontт/KaCzmaREK 2014, 223-237.

LABudA, Adam S.: Świadectwo źródła pisanego, świadectwo formy artystycznej. Tropami twórców ołtarzy św. Barbary we Wrocławiu i św. Jakuba St. w Nysie [Das Zeugnis der Schriftquellen, das Zeugnis der künstlerischen Form. Auf den Spuren der Schöpfer des St. Barbara-Altars in Breslau und des St. Jakobus-Altars in Neiße]. In: WALANUs/WALCZAK 2016, $43-63$.

Labuda, Adam S./Secomska, Krystyna (Hgg.): Malarstwo gotyckie w Polsce [Gotische Malerei in Polen]. 3 Bde. Bd. 1: Synteza [Synthese]. Bd. 2: Katalog zabytków [Katalog der Kunstwerke]. Hg. v. in Zusammenarbeit mit Andrzej WŁODAREK. Warszawa 2004.

Leppien, Helmut R.: Francke, Meister. In: Saur Allgemeines Künstler-Lexikon. Die Bildenden Künstler aller Zeiten und Völker, Bd. 43. München/Leipzig 2004, 461-462.

MARCinkowski, Wojciech: Gotycka nastawa ołtarzowa u kresu rozwoju - 'Retabulum ze Ścinawy' (1514) w kościele klasztornym w Mogile [Das gotische Altarretabel am Ende seiner Entwicklung - Das »Retabel von Steinau« (1514) in der Klosterkirche zu Mogiła]. Kraków 2006.

Marcinkowski, Wojciech: Gotyckie retabula ołtarzowe w przestrzeni muzealnej. Uwagi na marginesie nowej aranżacji zbiorów sztuki dawnej Muzeum Narodowego w Krakowie [Gotische Altarretabel im musealen Raum. Gedanken am Rande eines neuen Arrangements der Sammlung alter Kunst im Nationalmuseum Krakau]. In: BADACH/JANISZEWSKA/ TARKOWSKA 2009, 487-503.

MöHLE, Valerie: Wandlungen. Überlegungen zum Zusammenspiel der Außen- und Innenseiten von Flügelretabeln am Beispiel zweier niedersächsischer Werke des frühen 15. Jahrhundert. In: Ganz/Lentes 2004, 146-169.

MöHLe, Valerie: Vielfalt - Argumentation - Gleichnis. Das Flügelretabel in St. Jacobi als Bildsystem. In: CARQUÉ/RöCKELEIN 2005, 273-302.

Möhle, Valerie: Déjà vu. Bildsysteme zum Klappen. In: BoGEN/BRASSAT/GANZ 2006, 54-73.

Möseneder, Karl/Schüssler, Gosbert (Hgg.): Bedeutung in den Bildern. Festschrift für Jörg Traeger zum 6o. Geburtstag. Regensburg 2002.

Mrozowicz, Wojciech (Bearb.): Cronica monasterii canonicarum regularium (S. Augustini) in Glacz. Wrocław 2003.

Noll, Thomas/Warncke, Carsten-Peter (Hgg.): Kunst und Frömmigkeit in Göttingen. Die Altarbilder des späten Mittelalters. Berlin/München 2012.

Nowak, Olga (Hg.): Między Wrocławiem a Krakowem. Sztuka gotycka na Górnym Śląsku [Zwischen Breslau und Krakau. Gotische Kunst in Oberschlesien]. Katowice 1995. 
Oellermann, Eike: Veit Stoß, Fassmaler seiner eignen Werke? In: KAHSNITZ 1985, 169-182.

Oellermann, Eike: »de makede meister bernt notkę dit stvke weres ... «. In: Krohm/Albrecht/Weniger 2004, 233-247.

Peeters, Natasja (Hg.): Invisible Hands? The Role and Status of the Painter's Journeyman in the Low Countries, c. 1450-c. 1650. Leuven u. a. 2007.

Petermann, Kerstin: Bernt Notke. Arbeitsweise und Werkstattorganisation im späten Mittelalter. Berlin 2000.

Petermann, Kerstin: Malender Mönch vom Niederrhein? Der Mythos »Meister Francke« wird dekonstruiert. Meister Francke und die Kunst des Ostseeraums im 15. Jahrhundert. Homburger Gespräch: Tagung der Böckler-Mare-Balticum Stiftung in Zusammenarbeit mit dem Finnischen Nationalmuseum und der Kunstgeschichtlichen Vereinigung Finnlands, Helsinki, 9./10. September 2013. In: Kunstchronik 67 (2014), H. 4, 189-195.

Pfeiffer, Götz J.: Die Malerei am Niederrhein und in Westfalen um 1400. Der Meister des Berswordt-Retabels und der Stilwandel der Zeit. Petersberg b. Fulda 2009.

Pietrusiński, Jerzy: O tym, jak Wit Stwosz do Krakowa przybył i jak go opuścił [Davon, wie Veit Stoß nach Krakau kam und wie er es verließ]. In: Horzela/Organisty 2006, 98111.

PILz, Wolfgang: Das Triptychon als Kompositions- und Erzählform in der deutschen Tafelmalerei von den Anfängen bis zur Dürerzeit. München 1970.

Reynaud, Nicole: Maître Francke et l'art autour de 1400. In: Revue de l'art 1970, H. 9, 89-92.

Rотт, Hans: Quellen und Forschungen zur südwestdeutschen und schweizerischen Kunstgeschichte im XV. und XVI. Jahrhundert, Bd. 1. Bodenseegebiet. Stuttgart 1933.

SAlomon, Hans: Der Breslauer Barbara-Altar. Ein Beitrag zur Geschichte der deutschen Malerei im 15. Jahrhundert. Diss. Breslau 1925.

Schlie, Heike: Wandlung und Offenbarung. Zur Medialität von Klappretabeln. In: Das Mittelalter 9 (2004), H. 1, 23-43.

Scholz, Hartmut: Hans Wild und Hans Kamensetzer. Hypotheken der Ulmer und Straßburger Kunstgeschichte des Spätmittelalters. In: Jahrbuch der Berliner Museen N. F. 36 (1994), 93-140.

Schulz, Alwin: Urkundliche Geschichte der Breslauer Maler-Innung in den Jahren 1345 bis 1523. Breslau 1866.

Schulz, Martin/Wyss, Beat (Hgg.): Techniken des Bildes. München 2010.

[Schwabacher Hochaltar 1982]: Der Schwabacher Hochaltar. Internationales Kolloquium anläßlich der Restaurierung. Schwabach, 30.6.-2.7.1981. München 1982 (Arbeitshefte des Bayerischen Landesamtes für Denkmalpflege 11).

Stein-Kecks, Heidrun: `Santa (sacra) Conversazione`. Viele
Bilder, ein Begriff und keine Definition. In: Möseneder/ SCHÜSSLER 2002, 413-442.

Strieder, Peter: Zur Struktur der spätgotischen Werkstatt. In: Schwabacher Hochaltar 1982, 24-28.

[Sztuki plastyczne 1988]: Sztuki plastyczne na średniowiecznym Śląsku. Studia i materiały [Die plastischen Künste im mittelalterlichen Schlesien. Studien und Materialien]. Wrocław/ Poznań 1988.

SuckAle, Robert: Malby retabula hlavného oltára w Dóme sv. Alžbety w Košiciach [Die Malerei des Hochaltarretabels im Dom St. Elisabeth zu Kaschau]. In: Ausst.-Kat. Bratislava 2003, 364-373.

Suckale, Robert: Regensburger Maler in Nürnberg (um 14351470). In: TAEgERT 2004, 251-266.

Suckale, Robert: The Central European Connections of Matthias Corvinus' Patronage of Late Gothic Art. In: Ausst.-Kat. Budapest 2008, 101-111.

Suckale, Robert: Die Erneuerung der Malkunst vor Dürer. 2 Bde. Petersberg b. Fulda 2009.

Suckale, Robert: Über einige nordalpine Vorbilder der Hofkunst des ungarischen Königs Matthias Corvinus. In: BoRKOWSKA/HöRSCH 2010, 261-279.

SzewCzyк, Aleksandra/Witkowski, Jacek: Gotycki ołtarz główny kościoła św. Jakuba w Nysie. Dzieło Mistrza Wilhelma z Akwizgranu [Der gotische Hochaltar der Jakobuskirche in Neiße. Ein Werk Meister Wilhelms von Aachen]. In: Ho£OWNIA/KAPUSTKA 2008, 105-116.

TAEgERT, Werner (Hg.): HORTULUS FlORIDUS BAMBERGENSIS. Studien zur fränkischen Kunst- und Kulturgeschichte, Renate Baumgärtel-Fleischmann zum 4. Mai 2002. Petersberg b. Fulda 2004.

TöRöк, Gyöngyi: Zum Verhältnis von Zeichnung und Malerei am Beispiel des Kaschauer Elisabethaltares. In: BRINKMANN/ KROHM/ROTH 2001, 11-15.

Walanus, Wojciech/WALCZAK, Marek (Hgg.): Imagines pictae. Studia nad gotyckim malarstwem $\mathrm{w}$ Polsce [Imagines pictae. Studien zur gotischen Malerei in Polen]. Kraków 2016 (Studia z Historii Sztuki Średniowiecznej Instytutu Historii Sztuki Uniwersytetu Jagiellońskiego IV).

Weilandt, Gerhard: Verträge mit Künstlern und finanzielle Abwicklung von Aufträgen. In: Ausst.-Kat. Stuttgart 1993, 311-317.

Weilandt, Gerhard: Der wiedergefundene Vertrag Jörg Syrlins des Älteren über das Hochaltarretabel des Ulmer Münsters. Zum Erscheinungsbild des frühesten holzsichtigen Retabels. In: Zeitschrift für Kunstgeschichte 59 (1996), 437-460.

Weniger, Matthias: Polack, Grasser, Blutenburger Meister. Die Polack-Werkstatt im Kontext einer Hochkonjunktur Münchner Kunst. In: Ausst.-Kat. Freising 2004/05, 27-46. 
Wernicke, Ewald: Zur schlesischen Künstlergeschichte. In: Schlesiens Vorzeit V (1892), Nr. 6, 159-167.

Wiesing, Lambert: Sztuczna obecność. Studia z filozofii obrazu [Artifizielle Präsenz. Studien zur Philosophie des Bildes]. Übersetzt v. Krystyna Krzemieniowa. Warszawa 2012 (Prolegomena 7).

Wolf, Norbert: Deutsche Schnitzretabel des 14. Jahrhunderts. Berlin 2002.

WóŁkiEwicz, Ewa: Twórcy retabulum w kościele św. Jakuba w Nysie. W kwestii organizacji i kosztów wyposażenia wnętrz kościelnych w połowie XV w. [Die Schöpfer des Retabels in der St. Jakobuskirche in Neiße. Zu Organisation und Kosten der Ausstattung von Kircheninnenräumen in der Mitte des 15. Jahrhunderts]. In: Kwartalnik Historii i Kultury Materialnej 52 (2004), 453-46o.

Wó£kiewicz, Ewa: Okoliczności fundacji XV-wiecznej nastawy ołtarza głównego w kościele św. Jakuba w Nysie [Die Stiftungsumstände des Retabels des Hochaltars in der St.-Jakobus-Kirche in Neiße]. In: Ho£ownia/Kapustka 2008, 99-104.

WozıŃski, Andrzej: Wokół kontraktu Mistrza Michała na nastawę ołtarzową dla Lęborka z 1512 r. [Zum Vertrag des Meisters Michael über das Altarretabel für Lauenburg in Pommern aus dem Jahr 1512]. In: Biuletyn Historyczny Lęborskiego Bractwa Historycznego i Muzeum w Lęborku 24 (2004), 57-68.

Ziemba, Antoni: Schlesien. In: Ausst.-Kat. Brügge 2010, 476$477,480$.

ZıомескA, Anna: Śląskie retabula szafowe w drugiej połowie XV i na początku XVI wieku [Schlesische Schreinretabel in der zweiten Hälfte des 15. Jahrhunderts und zu Beginn des 16. Jahrhunderts]. In: Roczniki Sztuki Śląskiej 10 (1976), 7-141.

[Ziomecka 2004/I]: Ziomecka, Anna: Malarstwo tablicowe na Śląsku [Tafelmalerei in Schlesien]. In: LABUdA/SECOMSKA 2004, I, 229-230.

[Ziomecka 2004/II]: Ziomecka, Anna: Poliptyk św. Barbary [Das St. Barbara-Polyptychon]. In: LABUdA/SecomskA 2004, II, 289-291.

\section{Anmerkungen}

1 Die vorliegende Studie fasst zwei in polnischer Sprache verfasste Beiträge zusammen: LABUDA 2014 und 2016. - Für den Anstoß, die o. g. Aufsätze in deutscher Sprache zu veröffentlichen, bin ich Markus Hörsch sehr dankbar. Unschätzbar war auch seine Hilfe bei der Redaktion des nun publizierten Textes.

2 LABUDA 1984/I. - Dort findet sich ein kurzer Bericht zu den früheren Untersuchungen.

3 Ziоmecka 2004/I und 2004/II. - Siehe zudem KapUstKa 2001. Kochanowska-Reiche 2005. - Ausst.-Kat. Prag/Legnica 2006,
150-152, Kat.-Nr. I.5.38 (Małgorzata Kochanowska-Reiche). KochanowsKa-Reiche 2006.

4 ZІемbа 2010.

5 Chmielewski 2001. - Chmielewski 2010.

6 Suckale 2003, 371. - Suckale 2008, 108. - Vgl. auch Suckale 2010.

7 KAPUSTKA 2006b.

8 KNÜVENER 2007.

9 Die Mitteltafel des Retabels mit der zentralen Repräsentationsszene und vier kleineren Feldern mit narrativen Darstellungen befindet sich seit 1945 im Nationalmuseum Warschau (Muzeum Narodowe w Warszawie), Inv.-Nr. Śr. 35. H. 203 cm, B. $260 \mathrm{~cm}$. Die beiden beweglichen Flügel sind verschollen. Vor 1945 wurde der Altar im Schlesischen Museum für Kunstgewerbe und Altertümer ausgestellt.

10 Heute dient die Kirche als orthodoxe Kathedrale der Geburt der seligen Jungfrau Maria.

11 Diese Problematik wurde instruktiv beleuchtet von MARCinkowski 2006, 121 und Anm. 579.

12 Diese Tatsache gilt es explizit zu betonen: Die Rekonstruktion der malerischen Ebene des Retabelkonzepts bezieht sich heute in Wahrheit nur auf die Festtagsseite. Zum einen bildete sie den repräsentativsten Teil des Retabels, zum anderen ist lediglich der Mittelteil im Original erhalten.

13 Chmielewski 2001. - Chmielewski 2010. - Siehe auch Labuda 1984/I, 79-90.

14 Zum Thema der "Sacra Conversazione» siehe den grundlegenden Aufsatz Goffen 1979. - Siehe auch Labuda 1984/I, 36-38. STEIN-KeCKS 2002. - HoleČKová 2014.

15 Vergleichselemente bei Labuda 1984/I, 108-120. - Die Problematik verlangt nach weiteren Untersuchungen.

16 Der Chor der Kirche stammt in seiner heutigen Form sicherlich aus dem zweiten Viertel des 15. Jahrhunderts. Labuda 1984/I, $21 \mathrm{f}$.

17 Zum »immersiven« Bild GRAU 2001. - Siehe auch WIESING 2012, 123-127. - KAPUSTKA 2001, 12, unterstreicht jedoch den Illusionscharakter: die Figuren »scheinen (...) dem Betrachter sentgegenzutreten «

18 Das Programm wurde detaillierter behandelt bei LABUda 1984/I, 67-76. - Siehe auch LABUDA 1984/II.

19 BiaŁŁowicz-KrygierowA 1981. - Ziomecka 1976, 4 of. - Vgl. auch die zahlreichen Beispiele außerhalb Schlesiens. WOLF 2002. KAHSNITZ 2005.

20 Kemp 1994, bes. 9-20 (Einleitung: Beziehungssinne).

$21 \mathrm{Zu}$ diesen Beziehungen LABUdA 1984/I, 73-75. - LABUDA 1984/II, 44. - Diese Art und Weise, Altarprogramme zu lesen, wird umfangreich behandelt von MöHLE 2004. - SCHLie 2004, 26-30. - Möhle 2005. - MÖHLE 2006. - KAPUSTKA 2009, 227-233.

22 LABUdA 1984/I, 73. - Zu erörtern wäre, ob eine derart nachdrückliche Präsentationsweise der Kreuzabnahme auf einem schlesischen Retabel nicht einen antihussitischen Unterton haben könnte, vgl. SuCKale 2009, I, 31, der auf eine derartige Konnotation dieser Thematik hinweist.

23 LABUDA 1984/I, 76.

24 Deutsche Forscher sprachen in diesem Kontext von einer "Bildmaschine«. Das Heranziehen der Wirkungsweisen von Bildern in der modernen Welt soll das Bewusstsein für den kombinatorischen und dynamischen Faktor im Umgang mit einem bzw. mit einer Gruppe von Bildern in der Zeit des Mittelalters wiederbeleben. SCHLIE 
2004, 30, Anm. 30. - Dümpelmann 2010, 219 f. - Letztere Autorin versucht diesen Aspekt in Bezug auf seine mögliche Bedeutung in der Zeit des Mittelaters zu untersuchen. - Vgl. auch MarcinkowSKI 2009, 487, der die Expositionsprobleme von Retabeln erörtert, welche über mehrere Schauseiten verfügen. - Schlie bemerkt, dass Retabel in mittelalterlichen Schriftquellen als "machina" bezeichnet werden, was auf den Prozess einer gewissen Mechanisierung der Bildmedien hinweisen würde. Den Begriff »machina magna" verwendete 1682 der Pfarrer der Jakobuskirche in Neiße, Johann Felix Pedewitz (Canon Ecclesiae Parochialis S. Jacobi Nissae compilatus, conscriptus, confestus per Joannem F. Ambrosi Pedewitz. Breslau 1682. Wrocław, Archiwum Archidiecezjalne, sign. Va 98, s. 93) in Bezug auf das 1451-52 entstandene Retabel des Hochaltars dieser Kirche. SzewCZYK/WitKowski 2008, 108.

25 Die Entdeckung des Namens des leitenden Künstlers des Retabels verdanken wir Wó£KIEWICZ 2004.

26 Breslau, Muzeum Archidiecezjalne. - Zıомеска 1976, 42. - LABUDA 1984/I, 125 f., 157 f. - ZIOMECKA 2004/I, 229 f. - WóŁKIEWICZ 2004 und 2008. - SZEWCZYK/WITKOWSKI 2008.

27 SucKale 2009, II, 24-29, Kat.-Nr. 10.

28 KNÖTEL 1928, 65 f.

29 LABUDA 1984/I.

30 Das Retabel wird auf Grundlage einer Inschrift auf dem Rahmen der Festtagsseite in das Jahr 1402 datiert. Zum Altar CARQUÉ/RÖCKelein 2005. - KaHSNitZ 2012. - Andere Beispiele wurden von SCHLIE 2004 und MöHLE 2004, 2005, 2006 untersucht.

31 Pilz 1970, 42-49. - Im Katalog - 278-281, Kat.-Nrr. 12 (Netze), 13 (Osnabrück), 15 (Bad Wildungen) - fasst der Autor diese Gruppe unter dem Oberbegriff »Felderung unter Betonung eines Mittelkerns« zusammen. Dies bezieht sich auf die Komposition der Retabelansicht bei vollständiger Öffnung; Ikonografie und narrative Gestaltung sind jedesmal verschieden.

32 Pilz 1970, 34f. (hier auch eine Erwähnung des Breslauer Altars), Kat.-Nr. 14. - Pfeiffer 2009, 68 f., bezeichnet die Szene als "sacra conversatio«, gewiss im Sinne des italienischen Darstellungstyps und Begriffs, siehe oben Anm. 14.

33 Labuda 1984/I, 113-118.

34 Als unabdingbar und von größtem Wert erwies sich hierbei die Hilfe meiner deutschen Kolleginnen und Kollegen, denen ich an dieser Stellen meinen herzlichsten Dank aussprechen möchte: Sabine Jagodzinski und Michael Lindner führten eine erste Lesung der Verträge durch, Markus Hörsch verfasste die definitive und für die weitere Interpretationsarbeit entscheidende Fassung, weshalb er auch als Autor der Übertragung der Vertragstexte in die moderne deutsche Sprache genannt wird, einer mit Anmerkungen versehenen Übersetzung, die im Anhang des Aufsatzes abgedruckt ist. Markus Hörsch möchte ich des Weiteren auch noch für den intensiven Gedankenaustausch zu den im Aufsatz berührten Themen danken. Ich bin auch Janusz Pałubicki und Jacek Witkowski für die Diskussionen und die während meiner Forschungsarbeit geleistete Unterstützung sehr dankbar.

35 Wó ŁKIEWICZ 2004 und 2008.

36 SZeWCZyк/Witkowski 2008.

37 WóŁKIEWICZ 2004, 454 f.

38 Wółkiewicz folgend betonen das auch SzewczyK/WitкоWsкI 2008, 115.

39 WóŁKIEWICZ 2004, 456.
40 Braune/Wiese 1929, 84. - Ziomecka 1976, 42.

41 Zitate aus WóŁKIEWICZ 2004, 456. - Sie wiederholt ihre Auffassung in Wó£KIEWICZ 2008, 101.

42 Ziemba 2010, 478.

43 Szewczyk/Witkowski 2008.

44 Szewczyk/Witkowski 2008. - Vgl. oben Anm. 24.

45 Die Autoren erwägen zudem weitere Möglichkeiten. SzewczyK/ WITKOWSKI 2008, $111 \mathrm{f}$.

46 SzewCZyk/ Wiткоwski 2008, 109. In dem Aufsatz ist auch von Visitationen die Rede. Jacek Witkowski präzisierte in einem Brief an den Autor vom 1. April 2014, dass es hier ausschließlich um Pedewitz gehe.

47 Er entspricht nicht dem von Hans Huth eingeführten Begriff des Formalvertrags, den dieser recht systhematisch behandelt. HuтH 1981, 25 f. - Siehe auch Kobler 2003, 1460-1466. - Weilandt 1993. - WeILANDT 1996. - WOZIŃSKI 2004.

48 WóŁKIEWICZ 2004, 455.

49 Auf das Fehlen eines Termins zur Fertigstellung des Retabels wies bereits WóŁKIEWICZ 2004, 455, hin.

50 Die Vorauszahlung in Höhe von 30 ungarischen Gulden stellt eine beachtliche Summe dar, wenn man bedenkt, dass z. B. Jörg Syrlin d. Ä. im Zusammenhang mit der Aufnahme seiner Arbeit am Chorgestühl für das Ulmer Münster, an dem er, dem Vertrag entsprechend, vier Jahre lang arbeitete, eine Vorauszahlung in Höhe von 50 rheinischen Gulden erhalten hatte. Insgesamt erhielt er 1.188 Gulden. Weilandt 1993, 311.

51 Dieses Wort meinte Wó£kiewicz 2004, 456, sicherlich, als sie von der Predella als einem Teil des Retabels schrieb.

52 Kobler 1978, Sp. 743. - Eine moderne Bezeichnung für Fassung ist Polychromie. Zum Begriff bereiten als gleichbedeutender Bezeichnung für fassen Kobler 1978, Sp. 743 und 746. - Die engen semantischen Bezüge zwischen den Worten ausbereiten, bereiten, fassen bespricht auch Нuтн 1981, 60. - Beachtenswert ist die Verwendung des Wortes uffzeberyten im Vertrag Caspar Isenmanns über das Hochaltarretabel für die St.-Martins-Kirche in Colmar, das BergsträsSer 1941, 9 f. (Abschrift des Vertrags), 11, 16, als fassen liest. Dieses Beispiel ist im Kontext des Neißer Retabels insofern instruktiv, als Isenmann nicht für die Tischler- und Schnitzarbeiten (darunter auch Skulpturen) zuständig war, sondern als Schöpfer reicher, malerischer Partien und der erwähnten Polychromien (fassen) angestellt war, darunter der einzeln aufgeführten Vergoldungen. Urheber des (möglicherweise bereits vorhandenes) Schnitzwerks war also eine andere Person.

53 Es könnte sich hier um eine ähnliche Lösung handeln wie z.B. im Fall von Multschers sog. Kargnische. MARCINKOwSKI 2006, 51-55. - Zu einem Gesprenge im Bereich der Predella im Vertrag mit Christoph Bockstorfer über einen Altar für die Klosterkirche St. Gallen (1522) siehe Rotт 1933, 41.

54 Im Lichte der Vertragsdokumente trug der Auftraggeber die Kosten für Material und Metallarbeiten. Нuтн 1981, 24.

55 Die monumentale Kirche in ihrer heutigen Gestalt existierte bereits seit den 1430er Jahren. Jarzewicz 1997 und 2008.

56 Petermann 2000. - Oellermann 2004.

57 KRÜGER 2005.

58 Ich beziehe mich hier auf die von MARCINKOWSKI 2006, 120, $138 \mathrm{f}$., verwendeten Begriffe.

59 Einen ähnlichen Fall behandelte jüngst Hörsch 2017: Das ehe- 
malige Hochaltarretabel der Stadtpfarrkirche St. Michael in Zeitz (heute Sachsen-Anhalt). Hier sollte der Maler Pankraz Grueber aus Großenhain (Sachsen) die explizit bereits vorhandenen Skulpturen, die dem Auftrag gebenden Stadtrat nicht in allen Punkten gefielen, verbessern lassen (!) und dann fassen.

60 Kahsnitz 2005, 17. - Vgl. auch Strieder 1982.

61 Zusammenfassend KaHSNitZ 2005, 17, 40, 45. - HöRSCH 2006. Für eine Zuschreibung an Gerhaert zuletzt Ausst.-Kat. Frankfurt/M. 2011, 225-238, Kat.-Nr. 6 (Stefan Roller).

62 Scholz 1994. - Kahsnitz 2005, 58, 62-64.

63 Kahsnitz 2005, 17, $222 \mathrm{f}$.

64 Dettloff 1961, $115 \mathrm{f}$ - Oellermann 1985, $174 \mathrm{f}$.

65 Große bzw. mehrere Branchen umfassende Werkstätten verfügten über entsprechendes Kapital, um im eigenen Rahmen Holzmaterial zu beziehen. Нuтн 1981, $23 \mathrm{f}$.

66 Wó£KIEWICZ 2008, 102. - Zur Unterscheidung zwischen dem locus natalis, dem Geburtsort einer Person, und dem locus fixus, dem Ort ihres letzten Aufenthalts, Pietrusiński 2006, 99.

67 Wó£KIEWICZ 2008, $102 \mathrm{f}$.

68 Es taucht hier auch der Name Kalteysen auf. Die in lateinischer Sprache verfasste Klosterchronik erwähnt ihn zweimal: zunächst als »magistro Wilhelmo de Aquisgrano« und anschließend als »Wilhelmo Kalteysen de Aquisgrano«. Mrozowicz 2003, 176, 179. Wó£KIEWICZ 2004, 457f. - Wó£KIEWICZ 2008, 102. - Siehe auch DomasŁoWsKi 1988, 50.

69 Schulz 1866, 83, 458, W1. - Kalinowski 2004, I, 190, beschreibt das Aufgabenfeld eines "glassetzers". - Wilhelm von Oche wird auch erwähnt von KALINOWSKI/MA£KIEWICZówNA 1995, 51. KALINOWSKI/MA£KIEWICZÓWNA 2001, 20.

70 Allerdings sollte man bedenken, dass auch Retabel nach Breslau importiert wurden: so die aus Nürnberg stammenden Flügelaltäre des »Meisters des Wolfgangsaltars in St. Lorenz« und Hans Pleydenwurffs.

$71 \mathrm{Zu}$ diesen Regelungen Schulz 1866, 31.

72 Analog dazu die Beobachtungen zur Wahl des Ausbildungsorts an Standorten mit einer gefestigten Position im jeweiligen Bereich der künstlerischen Produktion: Deceulaer/Diels 2007, 21.

73 Helsinki, Finnisches Nationalmuseum. - Nicole Reynaud stellte die traditionelle Datierung des Werks in die zweite Dekade des 15. Jahrhunderts in ihrer Rezension der Hamburger Ausstellung in Frage und schlug dafür die 1430er Jahre vor: ReynAUD 1970. - Dies griff LePpien 2004 auf. - Eine Reihe von Argumenten für die spätere Datierung wurden im Rahmen einer Meister Francke gewidmeten Tagung von Uwe Albrecht und Krista Andresen vorgestellt. PeterMANN 2014.

74 Siehe die Kreuzabnahme in Très Riches Heueres des Herzogs von Berry (1411/12-16), Chantilly, Musée Condé, Ms. 65, fol. 156v. LABUDA 1984/I, 155, Abb. 151.

75 Eine detaillierte Analyse bei LABUDA 1984/I, 125.

76 Siehe die hohe Bewertung der Fähigkeiten des Meisters nach Untersuchung der Maltechnik beider uns interessierender Retabel bei Chmielewski 2001, 167ff. - Chmielewski 2010, $133 \mathrm{f}$.

77 Es ist nichts über die Existenz einer Malerzunft in Neiße bekannt. WERNICKE 1892, 159-161, nennt nur zwei Namen in Neiße tätiger Maler - vom Beginn des 15. und von der Wende zum 16. Jahrhundert.

78 Kochanowska-Reiche 2006. - Kapustka 2006/I.
79 Szewczyk/Witkowski 2008, 105, Anm. 2. - Der Korrektheit halber sollte jedoch klargestellt werden, dass ich seinerzeit nicht annahm, dass die Zusammenarbeit auch in der sechsten Dekade des 15. Jh. fortdauerte (auch wenn womöglich der Titel des Kapitels VIII in dieser Hinsicht irreleitend formuliert war); nach meiner damaligen Auffassung endete die Zusammenarbeit kurz nach 1450. LABUDA 1984/I, 183 und 184. - Gegenwärtig, nach Bestimmung der Entstehungszeit des Neißer Retabels, müsste das Ende der Zusammenarbeit später, in die Zeit der Vollendung der Arbeiten, datiert werden.

80 Ziemba 2010, 478.

81 Siehe z. B. Chapuis 2004, 160-165. - Kemperdick 2004, 200-221 (über den Altar für die Dominikanerkirche in Colmar). - WENIGER 2004. - Die Sprache des Materials 2013, 185-203 (Text K. von Baum, I. Schaefer, R. Krischel) und passim. - Ein Beispiel extremer Verflechtungen ist die durch Kemperdick rekonstruierte Geschichte der Kreuzigung von 1445/50 (Frankfurt/M., Städel Museum). Brinkmann/Kemperdick 2002, 168f. - Die Ausstellung Meisterwerke massenhaft (Ausst.-Kat. Stuttgart 1993) wurde von der These begleitet, dass es generell schwer fällt, die Werke Weckmanns von denen seiner Werkstatt und seiner Nachfolger zu unterscheiden. - Einer separaten Erwähnung sind die Publikationen wert, die das Ergebnis der auf Initiative Dominique Hollanders-Favarts und Roger Van Schoutes seit 1975 an der Université Catholique in Louvain-la-Neuve unter dem Leitthema »Le dessin sous-jacent dans la peinture organisierten Kolloquien darstellen. Die Publikationen umfassen 17 Bände, die in den Jahren 1979-2012 erschienen sind.

82 LABUDA 1984/I.

83 Das letztere nach SALOMON 1925. - LABUDA 1984/I, $155 \mathrm{f}$.

84 Eine kritische Haltung gegenüber dem Ausschluss des Triumphs Marias aus dem Wirkungsfeld des Meisters des St.-Barbara-Altars äußerte Charles Sterling in einem Brief an den Autor vom 15. Februar 1985. Diesbezüglich sollten noch einmal die Ansichten von Vorkriegsforschern wie Hans Salomon oder Franz Landsberger betrachtet werden, die das Gesamtwerk noch im Original studieren konnten.

85 Tafelzählung nach LABUdA 1984/I. - Zu VII/VIII LABUdA 1984/I, 123 f., 140 .

86 LABUDA 1984/I, 123 f., $140 \mathrm{f}$.

87 Warschau, Muzeum Narodowe w Warszawie, Inv.-Nr. Śr. 366.

88 Auch Chmielewski 2001, 180, betonte die urheberschaftlichen Beziehungen zwischen dem Kreuzigungsaltar und der Rückseite der Neißer Tafel, die er eindeutig von der Vorderseite unterschied.

89 Heute in der ehem. Zisterzienserabteikirche Doberlug. - KNÜVENER 2007.

90 LABUda 1984/I, $158 \mathrm{f}$.

91 Labuda 1984/I, 140. - Über die Szenen VII und VIII in derselben Weise BUCK 2009.

92 Labuda 1984/I, 140 (Martinus Opifex).

93 Ein anderer, ebenfalls bedeutender Reflex dieses verloren gegangenen Werks ist die Kreuzigungstafel in der Sebalduskirche in Nürnberg. Vgl. Suckale 2004. - Auf den Erfindungsgeist des Meisters der Worcester-Kreuztragung deuten sowohl die Szene der Gefangennahme hin, die durch die Darstellung im Heidauer Triptychon dokumentiert wird, als auch eine weitere analoge, nur seitenverkehrte Darstellung in einer Grafik des Meisters des Kalvarienbergs. LABUdA 1984/I, 160-162 (hier die ältere Lit.), Abb. 155 (Nürnberg, 
St. Sebald), 161 (Meister des Kalvarienberges). - Kürzlich zu diesem Thema auch Köllermann 2007, 82-85. - Wie erwähnt, erkannte SuCKale 2003, 2008 und 2010 Reflexe einer »kreatürlichen"Sprache und Expressivität als Erbe des Meisters der Worcester-Kreuztragung in den Passionsszenen des später gefertigten Retabels der St.-Elisabeth-Kirche zu Kaschau. Er sah darin den Maler der Vorderseite der Neißer Retabels, den er für einen Schüler des Meisters des St.-Barbara-Altars hielt. Auch wenn diese Bezüge nicht zu bestreiten sind, scheint doch die Aufteilung in ein Lehrer-Schüler-Verhältnis dieser Art eine voreilige Schlussfolgerung, die die engen, urheberschaftlichen Verbindungen zwischen den schlesischen Werken außer Acht lässt. - Siehe auch TöRÖK 2001.

94 Heute Hochaltarretabel der Frauenkirche zu Nürnberg.

95 Die Abschriften veröffentlichte bereits Wó£KIEWICZ 2004, 458 f.

96 Plural, da der Schreiber weiter unten »dy Toffil« schreibt - und da das ganze Retabel meint. Die Tafeln, die bemalt werden sollen, sind höchstwahrscheinlich die Flügel.

97 Im vorigen Absatz geht es um Martins Zuarbeit für jene Teile, die Wilhelm bemalen wird; dementsprechend ist hier der Mittelteil des Retabel gemeint, also der Schrein mit seinen geschnitzten Anteilen, die Meister Wilhelm zwar mit verantwortet (als oberster Auftragnehmer), die er aber nicht selbst ausführt; alles, was dazu gehört, wird in die Subunternehmerschaft Meister Martins übergeben.

98 Bild $(\mathrm{e})=$ ymago bezeichnet in mittelalterlichen Quellen immer Skulpturen. Alles, was hier mit »Bildwerk « und »Bilden« bezeichnet wird, meint somit Skulpturen oder sonst geschnitzte Teile.
99 Das Wort »ausbereiten « hat eine Bedeutung von »vollständig fertig stellen «, meint aber, da Martin etwas später auch Wilhelm alles zum »ausbereiten « Nötige bereitstellen soll, sicher das Fassen einer Skulptur bzw. die technische ähnliche Grundierung eines zum Bemalen gedachten Bretts. Eine Bestätigung hierfür liefert der Vertrag mit dem Maler Kaspar Isenmann, betreffend das Retabel für St. Martin in Colmar. Siehe dazu oben die Anm. 52.

100 Die hier festzustellende terminologische Unterscheidung widerspricht heutigen wissenschaftlichen Gepflogenheiten, ist aber in sich logisch: "Auszug " meint offenbar das, was man heute als das "Gesprenge« bezeichnet, nämlich die architektonische Bekrönung auf dem Schrein in Form von Dreiecksgiebeln, die - der Rekonstruktion von A. Szewczyk und J. Witkowski zufolge - den Mittelteil des Retabulums bekrönten. Schon die Formulierung "die Gesprenge«, die wahrscheinlich den Plural meint, aber auch als Femininum verstanden werden könnte, deutet auf den anderen Wortgebrauch und somit wohl auch eine etwas andere Bedeutung hin. Mit »den Gesprengen" sind höchstwahrscheinlich Architekturelemente (Baldachine) im Innern des Schreins bzw. hier des "Zarchs« gemeint. Gesprenge im Inneren der Predella bzw. des Schreins finden sich auch in dem Vertrag mit Christoph Bockstorfer über den Altar für die Abteikirche von St. Gallen (1522): RotT 1933, 41 
Wilfried FranZen

\title{
... HERUFF VON Österland IN SCHWABEN UND HOCHDEUTSCHE LANDT ?
}

\author{
Albrecht VI. von Habsburg und der Meister von Schloss Lichtenstein
}

Gerade einmal anderthalb Jahrzehnte währte die Regentschaft Albrechts VI. von Habsburg (1418-63) über die Vorlande, die ihm sein Bruder, der römische König und spätere Kaiser Friedrich III. (reg. 1440-93), im März 1443 übereignet hatte, die er jedoch bereits im Mai 1458 an seinen Vetter Sigmund von Tirol (1427-96) abtrat. In den "wenigen Jahren seiner persönlichen Anwesenheit « hatte er gleichwohl »wesentlich dazu beigetragen, dass die habsburgische Position am Oberrhein gestärkt, in Schwaben wiederhergestellt und überhaupt bewahrt werden konnte. $\varkappa^{2}$ Ein bis heute existentes Vermächtnis seiner Herrschaft ist die Universität Freiburg, deren Stiftung sich 2017 zum 560. Male jährt. ${ }^{3}$ Das Wirken der Habsburger im Südwesten des Heiligen Römischen Reichs stellt jedoch nicht nur für die Zeit Albrechts VI. eine große Herausforderung für die Kunstgeschichtsschreibung dar. Aufgrund der Zersplitterung der Territorien am Oberrhein, Neckar und oberer Donau auf der einen und der Zerstörung und »Entwurzelung« zahlreicher Kunstwerke während Reformation und Säkularisation auf der anderen Seite ist das kunsthistorische Erbe »Vorderösterreichs« heute nur noch schwer zu fassen. Auch aus diesem Grunde ist die Stiftungstätigkeit der Habsburger sowie ihrer Verbündeten und Parteigänger in dieser Region bislang kaum erforscht. Für unser Fach war es aber ohnehin stets einfacher, mit kunstgeografischen Kategorien (Oberrhein, Schwaben, Bodenseeraum) zu operieren, die die tatsächlichen politischen Verhältnisse und die Nutzung der Kunst als Kommunikationsmittel durch die unterschiedlichen politischen Akteure ausblenden. ${ }^{4}$ Erst in den vergangenen Jahren hat diesbezüglich ein Umdenken eingesetzt.

\begin{abstract}
»Nun war eben zuo denen zytten hertzog Albrechten von Österrych, deß Römischen kaiser Friderichs bruoder, heruff von Österland in Schwaben und hochdeütsche landt kumen. (...) Der selbig hertzog Albrecht hett nun vil treffelicher lewt und hielt kostlichen, fürstlichen, ja wol küniglichen hoff.« Georg von Ehingen (1428-1508), Reisen nach der Ritterschaft ${ }^{1}$
\end{abstract}

\section{Albrecht VI., eine »Persona non grata«}

Nur wenige Werke sind heute gesichert mit Albrecht VI. in Verbindung zu bringen: Mit Ausnahme seines 1459 von Hans Ingeram verfassten Wappenbuchs ${ }^{5}$ hat sich lediglich ein Gebetbuch erhalten, mit dessen Fertigung bald nach seiner Rückkehr nach Wien im Jahr 1456 im Atelier des sogenannten Lehrbüchermeisters begonnen worden war $^{6}$ - eine der führenden Buchmalerwerkstätten Wiens der Jahrhundertmitte, die insbesondere für den kaiserlichen Hof und sein Umfeld tätig war. Das Gebetbuch sollte mit insgesamt 23 ganzseitigen Miniaturen ausgestattet werden, die neben dem Porträt des gekrönten, thronenden Erzherzogs (Abb. 1) vor allem die wichtigsten Heiligen des habsburgischen Herrscherhauses abbilden.

Für zwei dieser Miniaturen dienten den Buchmalern Stiche des Meisters der Spielkarten als Vorlage. Der oberrheinische Kupferstecher wurde von Albrecht offenbar derart geschätzt, dass dessen Spielkarten mit dem Blumen- und dem Wilde-Leute-König respektive der Blumen-Königin als Blaupause für die eigene Darstellung sowie für die Darstellung der hl. Cimburgis / Kineburga (fol. 49v), der Namenspatronin seiner Mutter Cimburgis von Masowien (1394-1429), dienen sollten. ${ }^{7}$ Dem zeitgenössischen höfischen Betrachter dürfte der mit diesem Zitat verbundene Subtext, die Selbstinszenierung als König, nicht entgangen sein. Im Januar 1453 von Friedrich III. zum Erzherzog ernannt, strebte Albrecht durchaus nach königlichen Würden und bot sich 1454 den Gegnern seines Bruders als Königskandidat an. ${ }^{8}$ Sein politisches Augenmerk richtete sich fortan auf die Erlangung der Vormachtstellung im Hause Habsburg. Höhepunkt dieser 


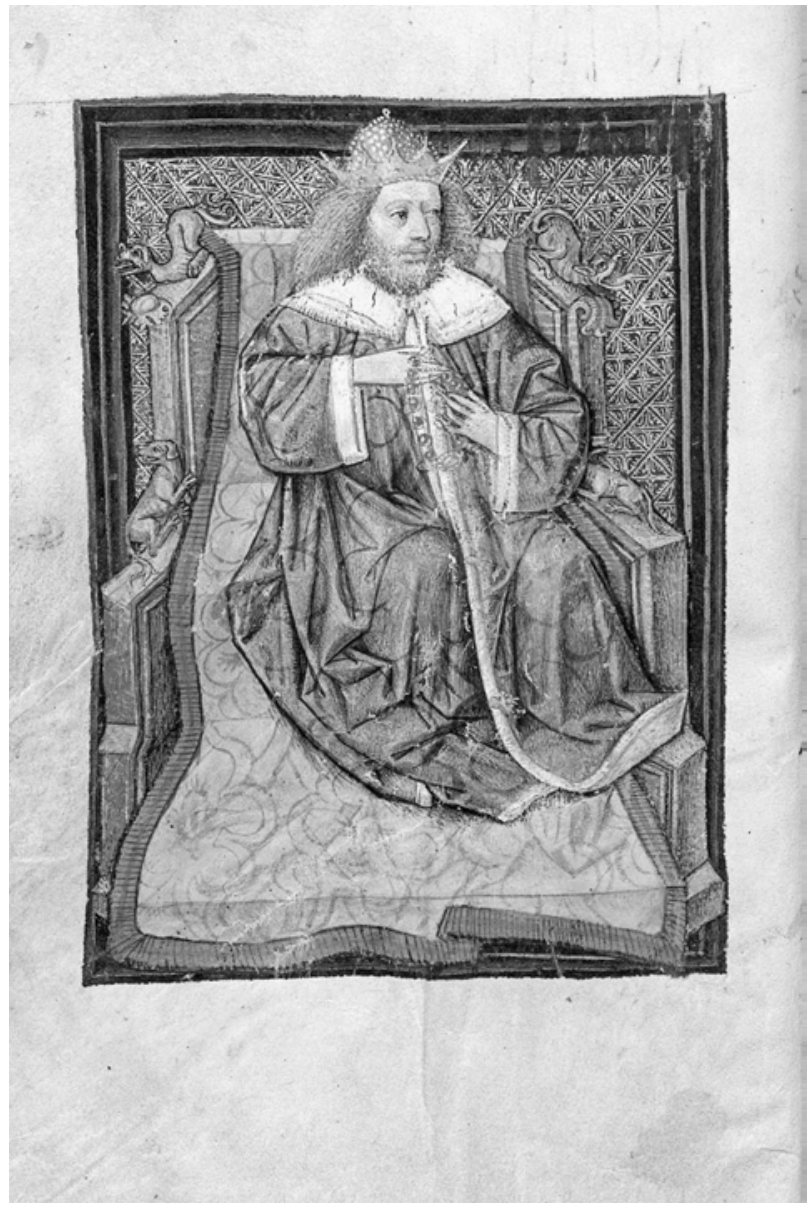

Abb. 1 Gebetbuch Herzog Albrechts VI., Titelminiatur. Lehrbüchermeister, Wien, um 1456/58. Wien, Österreichische Nationalbibliothek, Cod. 1846, fol. 1v (ex: PFÄNDTNER 2011)

Bestrebungen war die Belagerung der kaiserlichen Familie in der Wiener Hofburg Ende 1462. ${ }^{9}$ Gerade dieses Ereignis sollte aber zu einer damnatio memoriae des nur ein Jahr später unter nicht geklärten Umständen verstorbenen Albrecht führen, welche bereits unter Friedrich III. einsetzte, vor allem aber von dessen Sohn Kaiser Maximilian I. (reg. 1486-1519) betrieben wurde. ${ }^{10}$ Bezeichnenderweise fehlt denn auch ein Standbild Albrechts VI. unter den Bronzefiguren der Habsburger am Grabmal Maximilians in der Innsbrucker Hofkirche. Die Wirkung dieses damnatio ist bis heute in der Geschichtsschreibung zu spüren. ${ }^{11}$

Weit mehr als Albrecht VI. stand stets seine Ehefrau, Mechthild von der Pfalz (1419-82), im Fokus des Interesses, deren Hofhaltung in Rottenburg am Neckar posthum ebenso verklärt wie diffamiert wurde. ${ }^{12}$ Die Enkelin des Römischen Königs Ruprecht I. (reg. 1400-10), Tochter bzw. Schwester der Kurfürsten Ludwigs III. (reg. 141036) und Friedrichs des Siegreichen (reg. 1451-76), war in erster Ehe mit dem württembergischen Grafen Ludwig I. (reg. 1419-50) verheiratet. Es waren vor allem strategische Überlegungen zur Schaffung eines eigenen Fürstentums sowie die angestrebten neuen Bündniskoalitionen im Reich (insbesondere die Annäherung an den Pfalzgrafen), die Albrecht zu dieser Verbindung bewogen hatten. Die Ehe wurde im August 1452 auf Schloss Böblingen, dem Witwensitz Mechthilds, geschlossen. ${ }^{13}$ Ein nicht zu unterschätzender Faktor für den finanzschwachen Habsburger dürfte in diesem Zusammenhang das beträchtliche Vermögen Mechthilds gespielt haben. Sie brachte 73.000 Gulden in die Ehe mit ein, von denen ihr 30.000 aus der Verbindung mit Ludwig von Württemberg zustanden. Für die restliche 43.000 erhielt sie gemäß Ehevertrag die - im Jahr 1410 von den Habsburgern an die schwäbischen Reichsstädte verpfändete - Grafschaft Hohenberg (u.a. mit den Städten Rottenburg am Neckar und Horb), die Albrecht gleichwohl erst 1454 zurückgewinnen und seiner Frau übertragen konnte. ${ }^{14}$ Mechthild, durch die Vermählung nun Schwägerin des Kaisers und damit nach der Kaiserin ranghöchste Dame des Reiches, ermöglichte die Ehe wiederum eine Emanzipation von ihrem Schwager Graf Ulrich V. von Württemberg (reg. 1441-80), wodurch sie sich den Einfluss auf ihre beiden Söhne bewahren konnte. ${ }^{15}$

Welche Bedeutung Albrecht der angestrebten Verfügungsgewalt über die Herrschaft Hohenberg zumaß, wird dadurch deutlich, dass das Herzogspaar bereits eine Woche nach der Hochzeit nach Rottenburg zog, um mehrere Monate im (habsburgisch verbliebenen) Stadtschloss zu verweilen, und dass Rottenburg in den kommenden beiden Jahren neben Freiburg zum wichtigsten Residenzort des ansonsten äußerst umtriebigen Albrecht werden sollte. ${ }^{16}$ Seine Hofhaltung wird, so Konstantin Langmaier, "Zwar nicht außergewöhnlich groß« gewesen sein, doch könne man davon ausgehen, dass sie »sehr vornehm war und für die gesamte Region am Oberrhein vorbildhaft wirkte. ${ }^{17}$ Die eingangs zitierte Charakterisierung durch Georg von Ehingen, der ab 1453 als Kämmerer Albrechts gedient hatte (und sich nach seiner Pilgerreise ins Heilige Land 1454-56 erneut für ein Jahr am Rottenburger Hof aufhielt), ${ }^{18}$ ist zwar als panegyrische Überzeichnung $\mathrm{zu}$ werten, spiegelt aber nichtsdestoweniger das Selbstverständnis des ambitionierten Habsburgers wider. $\mathrm{Zu}$ diesem Zeitpunkt hatte Albrecht ein umfassendes Netzwerk an Gefolgsleuten aufgebaut: Ein wahrscheinlich 1454 verfasstes Verzeichnis benennt insgesamt 84 Räte 
und Bedienstete des Herzogs, unter ihnen die Bischöfe von Konstanz, Basel und Straßburg - letzterer (Ruprecht von Pfalz-Simmern) ein Cousin Mechthilds. ${ }^{19}$

Nachdem Albrecht die Vorlande 1456 verlassen hatte, um zunächst in der Auseinandersetzung zwischen Ladislaus Posthumus (1440-57) und Friedrich III. zu vermitteln und nach dem Tod Ladislaus' seine eigenen Interessen in Österreich zu vertreten, blieb Mechthild in Rottenburg. Eben hier richtete sie nach Albrechts Tod 1463 auch ihren (zweiten) Witwensitz ein. Zu Ehren ihres verstorbenen Mannes veranstaltete sie in der Stadt eine prächtige Trauerfeier, an der 19 Äbte und 700 Priester teilnahmen. ${ }^{20}$ Die Grafschaft Hohenberg konnte sie bis zu ihrem Lebensende gegen die Ansprüche Sigmunds von Tirol verteidigen; erst danach fiel das Territorium wieder an die Habsburger - als sichtbares Zeichen dieser Rückgewinnung diente der nach 1482 geschaffene Rottenburger Marktbrunnen, der mit den Bildnissen Sigmunds und Friedrichs III. versehen wurde. ${ }^{21}$

Mechthilds Nachruhm begründet sich vor allem auf ihrer Rolle als literarische Mäzenin, ${ }^{22}$ doch auch zahlreiche kirchliche Stiftungen werden mit ihr verbunden. Die überragende Bedeutung, die Mechthild speziell für ihren Residenzort gespielt haben dürfte, kann (bei aller Vorsicht in der Bewertung) der Rottenburger Chronik des Lutz von Lutzenhartt vom Anfang 17. Jahrhunderts entnommen werden: »Sie, deren Wappen und Gedächtniss hin und wieder in den Kirchen, Fenstern, Epitaphiis, Altären und und sonsten in der Stadt vielfaeltig zu finden, hat die Kirchen mit schönen Altären, Orgeln, Ornaten und anderen Gottesgaben herlich begabt, mit auf das schoenst und koestlichst zieren, auch die Stadt mannigfach mit nützlichen und nothwendigen Bauwerken erbessern lassen. $\ll^{23}$

Das Ausmaß ihrer Aktivitäten lässt sich anhand der überlieferten Zuwendungen für die nahe der Residenz Urach gelegene Kartause Güterstein, die Mechthilds erster Gemahl Ludwig zur neuen Grablege der Linie Württemberg-Urach erkoren hatte, erahnen. ${ }^{24}$ Kurz nach seinem Tod hatte Mechthild eine große Stiftung getätigt, die eine "golddurchwirkte und kostbar geschmückte Kasel" sowie 100 Gulden für die Widerherstellung des »domus inferior « der Kartause umfasste. ${ }^{25}$ Zugleich hatte sie für die Kartausenkirche bei keinem Geringeren als Hans Multscher ein Grabmal bestellt, von dem sich die Liegefigur erhalten hat, die nach der Aufhebung des Klosters Mitte des 16. Jahrhunderts in die Stiftskirche Tübingen überführt wurde. ${ }^{26} 1467$ erfolgte eine kostbare Heiltumsschenkung, darunter eine edelstein- und perlenbesetzte
"Barmherzigkeit« aus Gold und Silber im Wert von 1000 Gulden. ${ }^{27}$ In ihrem 1481 verfassten Testament bedachte sie die Kartause schließlich mit zahlreichen $\mathrm{Zu}$ wendungen, darunter auch das "Zubehör zu unnserm altar ${ }^{28}$ (vermutlich des Altars der Rottenburger Schlosskapelle). Erhalten hat sich von alldem wenig. So ist das mit dem Wappen Mechthilds versehene Triptychon aus der Pfarrkirche Ehningen, deren Patronatsrechte bei der Kartause Güterstein lagen, eines der raren Zeugnisse ihrer Stiftungstätigkeit. ${ }^{29}$ Aus Rottenburg selbst besitzen wir die schriftliche Nachricht einer Stiftung zur Fassung "der taffel im Chor" der Pfarrkirche St. Martin aus dem Jahr 1474, mit dem der Nürnberger Maler Albrecht Rebmann und dessen Schwager, Hans Schüchlin aus Ulm, ein Schüler Hans Pleydenwurffs, ${ }^{30}$ für die nicht unerhebliche Summe von 425 Gulden beauftragt worden waren - den halben Teil habe Mechthild, die andere Hälfte die »Heiligenpfleger " gezahlt. $^{31}$

Kaum etwas bekannt ist hingegen von den Stiftungsaktivitäten des Herzogspaares nach der Eheschließung 1452. Auch wenn mit den Hochzeitsfeierlichkeiten diverse fromme Stiftungen einhergingen (s. u.), sind keine Nachrichten überliefert, die Rückschlüsse auf die herrscherliche Repräsentation Albrechts ermöglichen. So ranken sich denn auch um das berühmteste spätmittelalterliche Werk mit mutmaßlicher Rottenburger Provenienz, das Retabel des Meisters von Schloss Lichtenstein, zahlreiche Fragezeichen. Im Jahr 1853 hatte Ernst Förster auf die beiden namengebenden großen Tafeln mit dem Tod und der Krönung Mariens ${ }^{32}$ (Taf. XIV) in der Sammlung Graf Wilhelms von Württemberg auf Schloss Lichtenstein aufmerksam gemacht, die, wie Förster vermerkt, »aus (der Stiftskirche zu) Rottenburg «, d.h. aus der Kirche St. Moriz des einstigen Chorherrenstifts in Rottenburg-Ehingen, in den Besitz des Grafen übergegangen seien. ${ }^{33}$ Die Frage aber, inwieweit sich ein Zusammenhang mit Albrecht und Mechthild herstellen lässt, wurde fortan je nach Datierung des Werkes unterschiedlich beantwortet. Zuletzt wurde die Rottenburger Provenienz gar grundsätzlich in Zweifel gezogen, was nun zum Anlass genommen werden soll, diesen Fall noch einmal aufzurollen.

\section{Der Meister von Schloss Lichtenstein und die habsburgische Hofkunst}

Als »Meister der Übergangszeit « charakterisierte dereinst Ludwig Baldass den Meister von Schloss Lichtenstein, ${ }^{34}$ 


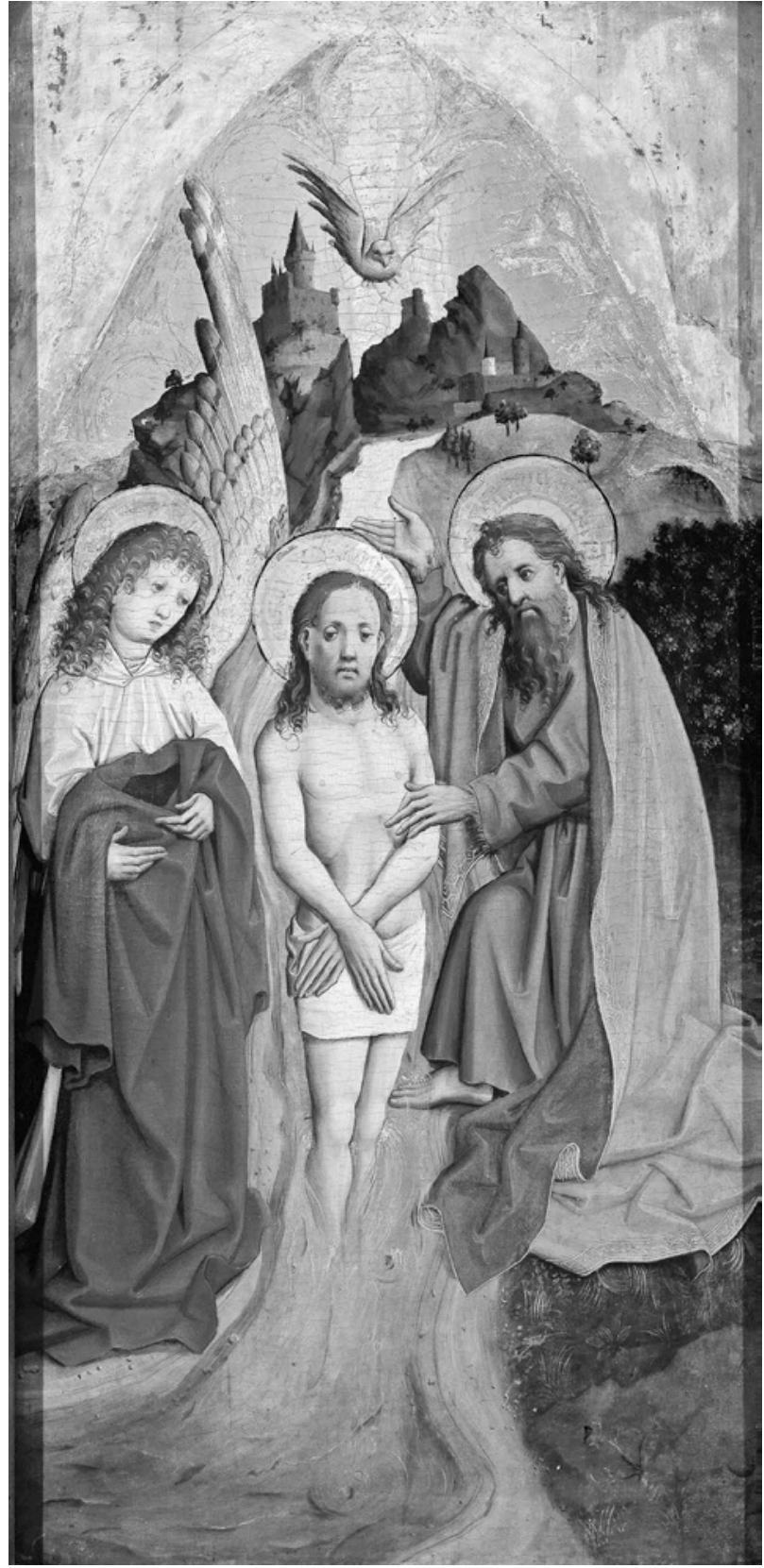

Abb. 2 Taufe Christi. Meister von Schloss Lichtenstein, um 1450. Warschau, Muzeum Narodowe, Inv.-Nr. 86 (Foto: Muzeum Narodowe w Warszawie)

der zu den bemerkenswertesten mitteleuropäischen Künstlern jener Generation um die Mitte des 15. Jahrhunderts gehört, die die Neuerungen der niederländischen Ars nova aufgreifen und in ihre eigene, noch durch den Schönen Stil geprägte Bildsprache übersetzen. ${ }^{35}$ Diese Neuerungen adaptiert er dabei vor allem auf malerischer Ebene (Lichtführung, Stofflichkeit); seine - harmonisch ausgewogenen - Kompositionen und die Konstruktion der Handlungsräume weisen hingegen auf eine eher konservative Haltung (Abb. 2, 3). ${ }^{36}$

Ludwig Baldass hatte sich als erster eingehender mit diesem Künstler auseinandergesetzt, mit gutem Gespür den Stil der Bilder sowie ihre künstlerische Herkunft analysiert und somit zahlreiche heute noch gültige Beobachtungen festgehalten. ${ }^{37}$ Die stilistischen Wurzeln des Meisters verortete er in der vorausgehenden Wiener Malerei beim Meister der St. Lambrechter Votivtafel und dem Meister der Darbringungen, aus dessen Werkstatt der "Lichtensteiner" hervorgegangen sei. Die Ausführung der ihm zuzuschreibenden Bilder sei im Wesentlichen durch zwei Maler erfolgt, die sich nur marginal unterschieden. Fälschlicherweise - wie wir heute wissen - verteilte Baldass das überlieferte Euvre auf zwei (bis drei) Altarwerke: einen Marienaltar aus den kleinen Marientafeln, den er gegen 1435/40 datierte, und einen Passionsaltar, der um die Jahrhundertmitte entstanden sei. Zu Letzterem hätten möglicherweise auch die Tafeln aus Schloss Lichtenstein gehört, die Baldass aufgrund der Gestaltung der Draperien ebenfalls erst gegen 1450 ansetzte. ${ }^{38}$ Vor allem die Frage der Datierung und der Rekonstruktion wurden fortan kontrovers diskutiert. Insgesamt schien die kunsthistorische Forschung jedoch lange wenig Neues beitragen zu können. ${ }^{39}$ Erst 1986 widmete sich Agnes Szendey dem Maler ausführlicher. ${ }^{40}$ Sie schlug eine Zusammenfügung sämtlicher bekannter Altartafeln $\mathrm{zu}$ einem großen doppelflügeligen Retabel vor, das die beiden großen Tafeln aus Schloss Lichtenstein auf den Innenflügeln seitlich eines nicht mehr erhaltenen Schreins, die Marientafeln nach der ersten Wandlung und den Passionszyklus auf der Werktagsseite präsentiert habe. ${ }^{41}$ Den Altaraufsatz datierte sie in die Jahre um 1430/40, womit Mechthild von der Pfalz und Albrecht VI. als potenzielle Stifter auszuschließen seien. ${ }^{42}$

Eine umfassende Würdigung erfuhr der Meister schließlich vor wenigen Jahren in einer eigens ihm gewidmeten, mit zahlreichen neuen Erkenntnissen aufwartenden Ausstellung, die aus einem Forschungsvorhaben zur Wiener Malerei des 15. Jahrhunderts hervorgegangen war. ${ }^{43}$ Im Zuge dieser Forschungen wurden die Tafeln erstmals einer eingehenderen technischen Untersuchung unterzogen, die eine Rekonstruktion der Altarflügel (und damit eine Bestätigung der Ein-Retabel-These) ermöglichten. ${ }^{44}$ Ebenso bedeutend sind die Erkenntnisse der dendrochronologischen Untersuchung, die als frühestmögliches Fälldatum der für den Bildträger verarbeiteten 
Tanne das Jahr 1440 angibt und damit den lang währenden Spekulationen um eine frühere zeitliche Ansetzung ein Ende bereitet hat. Ausgehend von einer Mindestlagerungsdauer des Tannenholzes von zwei Jahren, ist die Fertigung der Tafeln nunmehr mit 1442 plus x zu datieren. ${ }^{45}$ Hinsichtlich der Frage, ob das Werk vor oder nach der Hochzeit Albrechts und Mechthilds zu datieren sei, ist damit gleichwohl nichts entschieden.

Neben Rekonstruktion und Datierung standen die beiden weiteren Kernfragen zum Retabel des Meisters von Schloss Lichtenstein im Fokus der Ausstellung: die künstlerische Einordnung des Malers und die ursprüngliche Bestimmung des Altarwerks. Mit gut ausgewählten Vergleichsbeispielen wurden die Beziehungen zur Wiener Malerei aus dem 2. Viertel des 15. Jahrhunderts erörtert. Dadurch ließen sich die von Baldass getätigten Beobachtungen verifizieren und präzisieren, aber auch um weitere Argumente bereichern, die eine Herkunft des Malers aus Wien belegen können. ${ }^{46}$

Die Beweisführung ist dabei in methodischer Hinsicht keineswegs einfach: Wie in anderen Zentren ist auch die Kunst in Wien nicht autochthon, sondern durch Akteure und Impulse von außen geprägt. Dies gilt gerade auch für jene Großwerkstatt um den Meister der St. Lambrechter Votivtafel und den Meister der Darbringungen, mit der der Meister von Schloss Lichtenstein in Verbindung gebracht wird und die Jörg Oberhaidacher jüngst überzeugend nach Wien lokalisiert hat. ${ }^{47}$ Deren stilistische Vorbilder sind vor allem im Westen, unter anderem in der frankoflämischen Malerei des frühen 15. Jahrhunderts zu suchen; zudem lässt sie eine profunde Kenntnis der vorausgehenden oberitalienischen Kunst erkennen, die zum Teil ebenfalls über Frankreich vermittelt worden sein dürfte. ${ }^{48}$ Die für das 15. Jahrhundert außerordentlich gut dokumentierten Namen der Wiener Künstler bestätigen die Anziehungskraft Wiens als künstlerisches Zentrum. ${ }^{49}$ So finden sich Anfang des 15. Jahrhunderts unter den hier tätigen Malern u.a. ein Stefan von Elsass und ein Andre von Paris. Beide haben mit hoher Wahrscheinlichkeit gemeinsam mit den Brüdern Hans und Heinrich Gegenuns eine Werkstattgemeinschaft gebildet, worauf ihre engen verwandtschaftlichen Verhältnisse deuten: Stefan war mit Kathrein Gegenuns, der Schwester von Hans und Heinrich, verheiratet und erbte 1403 das väterliche Haus (des Malers Jakob Gegenuns) in der Wiener Strauchgasse. Sein Schwiegersohn sollte der ab 1411 nachweisbare Andre von Paris werden, der Stefans Tochter Margret geehelicht hatte. Andre wurde seinerseits 1434 Vormund

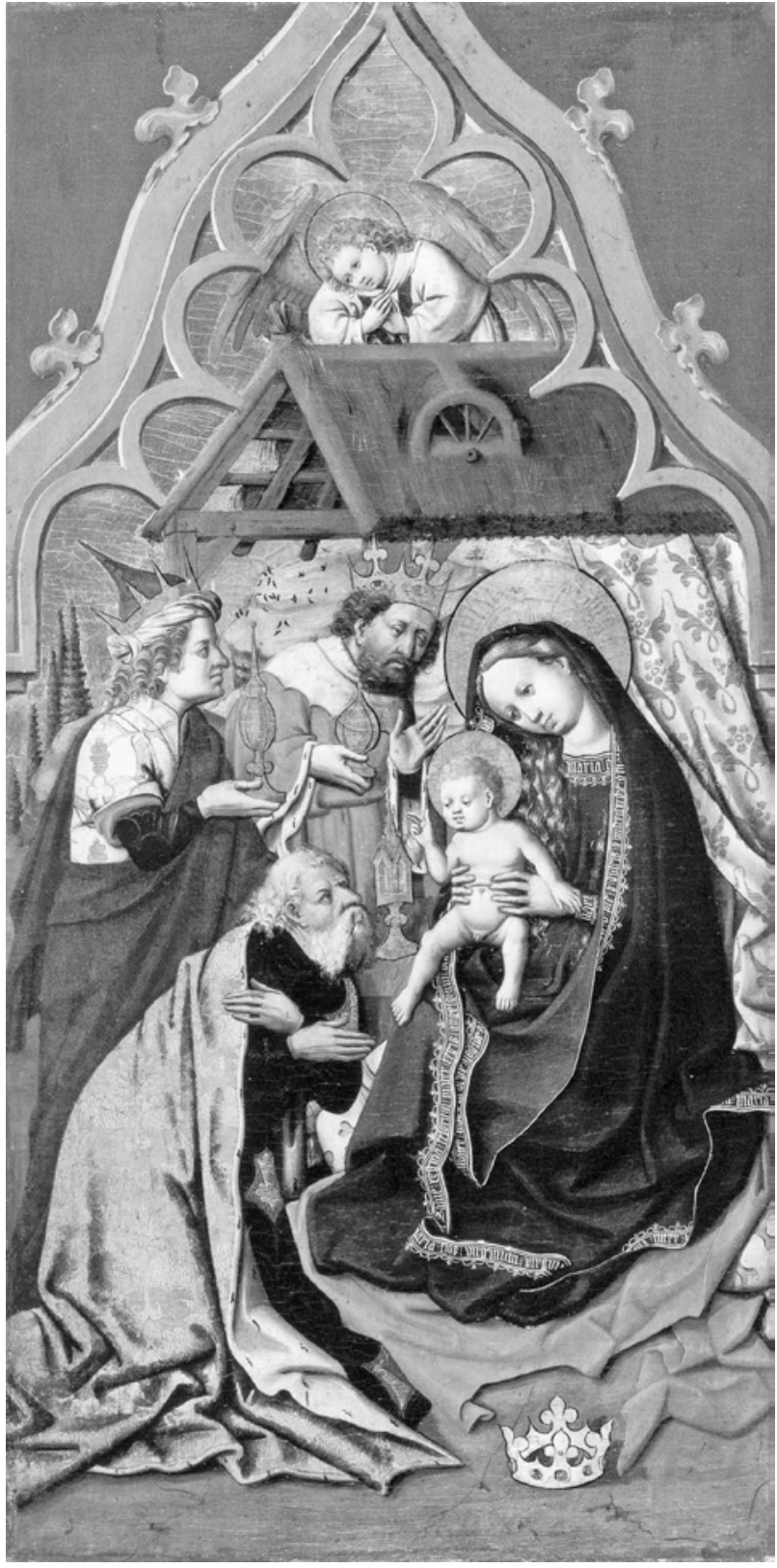

Abb. 3 Anbetung der Könige. Meister von Schloss Lichtenstein, um 1450. Moskau, Gosudarstvennyi muzei izobrazintel'nykh iskusstv imeni A. S. Pushkina / Staatliches Museum für Bildende Künste A. S. Puschkin, Inv.-Nr. 421 (ex: Ausst.-Kat. Wien 2013)

der Kinder des verstorbenen Hans Gegenuns. ${ }^{50}$ Den nahe liegenden Schluss, jene Malersippe mit der genannten Werkstatt des Votivtafel- und des Darbringungsmeisters gleichzusetzen, hat erstmals Lothar Schultes gezogen. ${ }^{51}$ Wichtige Indizien seien der französische Einschlag, der über Andre von Paris Eingang in die Werkstatt gefunden haben könnte, sowie die nur schwerlich zu ignorierende 


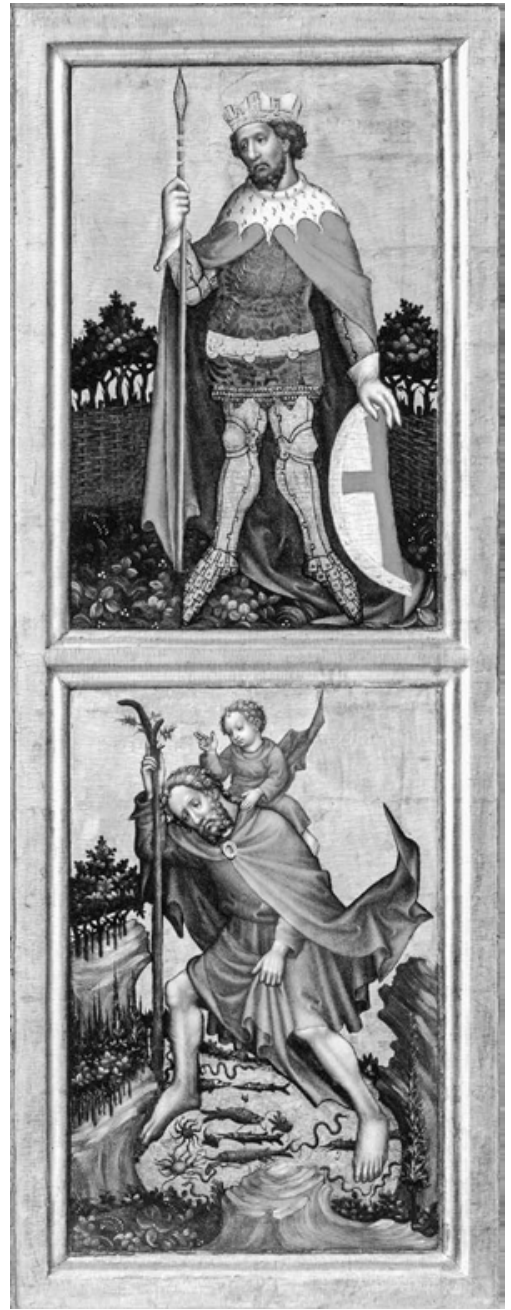

Abb. 4 Die hll. Florian und Christophorus, Flügel des Andreasaltars. Andreasmeister, um 1445/50. Wien, Erzbischöfliches Domund Diözesanmuseum, Inv.-Nr. 35 (ex: Ausst.Kat. Wien 2013)

Kryptosignatur auf dem Kreuztragungsbild in Wels, ${ }^{52}$ welches in den Kreis der Großwerkstatt gehört. Das dort zu lesende iонan ließe sich womöglich als Signatur des Hans Gegenuns deuten. ${ }^{53}$

Das überlieferte Euvre dieser Werkstatt ist bemerkenswert umfangreich. Außer in Wiener Neustadt und Klosterneuburg war sie vor allem für das Benediktinerstift St. Lambrecht in der Steiermark tätig. Die Mehrzahl der Werke ist dabei vor der Mitte der 1430er Jahre entstanden - danach gehen die erhaltenen Zeugnisse merklich zurück. Dies deckt sich mit den Sterbedaten 1434 bzw. vor 1436 der oben genannten Meister Hans und Stefan. ${ }^{54}$ Von den verschiedenen Mitgliedern der Großwerkstatt ist in den folgenden Jahren vor allem der sogenannte Meister des Andreasaltars aktiv, dessen Tätigkeit den neuesten Erkenntnissen zufolge etwas später anzusetzen ist, als bislang angenommen. ${ }^{55}$ So vermochte Ve- ronika Pirker-Aurenhammer anhand des Bildprogramms des namengebenden Werks aus Wiener Neustadt (Abb. 4) schlüssig darzulegen, dass dieses erst nach 1440 für eine der Kapellen der Wiener Neustädter Burg geschaffen worden sein kann. ${ }^{56}$

Und auch die auf die Sammlungen in Troppau (Opava), Wien und Budapest verteilten Tafeln eines wohl ebenfalls aus Wiener Neustadt stammenden Passionszyklus dieses Meisters seien aufgrund der dendrochronologischen Befunde nunmehr »frühestens 1441, wahrscheinlicher aber erst um 1445/50 « zu datieren. ${ }^{57}$ Diese Datierung und die mutmaßliche Bestimmung des Andreasaltars reihen den Andreasmeister in den Kreis der für den Hof Friedrichs III. tätigen Künstler ein. Sein für die Jahre um 1440/50 recht altmodischer Stil fügt sich in die konservativ-retrospektive Ausrichtung der Repräsentation Friedrichs in den ersten Jahren seiner Herrschaft als römisch-deutscher König.

Das Verhältnis des Meisters von Schloss Lichtenstein zu diesem Wiener Werkstattkollektiv, insbesondere zum Andreasmeister, geht nun, wie Antje-Fee Köllermann darlegen konnte, über eine allgemeine Kenntnis des Motiv- und Kompositionsrepertoires hinaus: Weitaus gewichtiger sind die stilistischen Gemeinsamkeiten in der Zeichnung der Physiognomien, die die Unterzeichnungen der Tafeln aus Schloss Lichtenstein mit den Bildern des Meisters des Andreasaltars verbinden. ${ }^{58}$ Sie weisen auf eine engere Zusammenarbeit beider Meister hin, obgleich sich der Meister von Schloss Lichtenstein in der malerischen Ausführung erheblich von seinem Wiener Kollegen unterscheidet: Die Handschrift des Andreasmeisters ist durch eine erheblich gröbere Pinselführung gekennzeichnet, und auch die Neuerungen der niederländischen Malerei finden bei ihm keinen nennenswerten Niederschlag. Wie der Andreasmeister scheint auch der Meister von Schloss Lichtenstein aus der Wiener Großwerkstatt hervorgegangen zu sein, bereichert jedoch das vorhandene Formenvokabular um eine neue Bildsprache. Wo er diese erlernt hat, bleibt indes unklar. ${ }^{59}$

\section{Keine Stiftung für die Rottenburger Morizkirche?}

Sollte das Retabel für Albrecht VI. in Rottenburg geschaffen worden sein, wie es die Herkunftsangabe für die beiden Tafeln aus Schloss Lichtenstein nahelegt, hätte sich Albrecht also eines Künstlers aus dem Umfeld des brüderlichen Hofs bedient, um seiner neuen Präsenz in der 

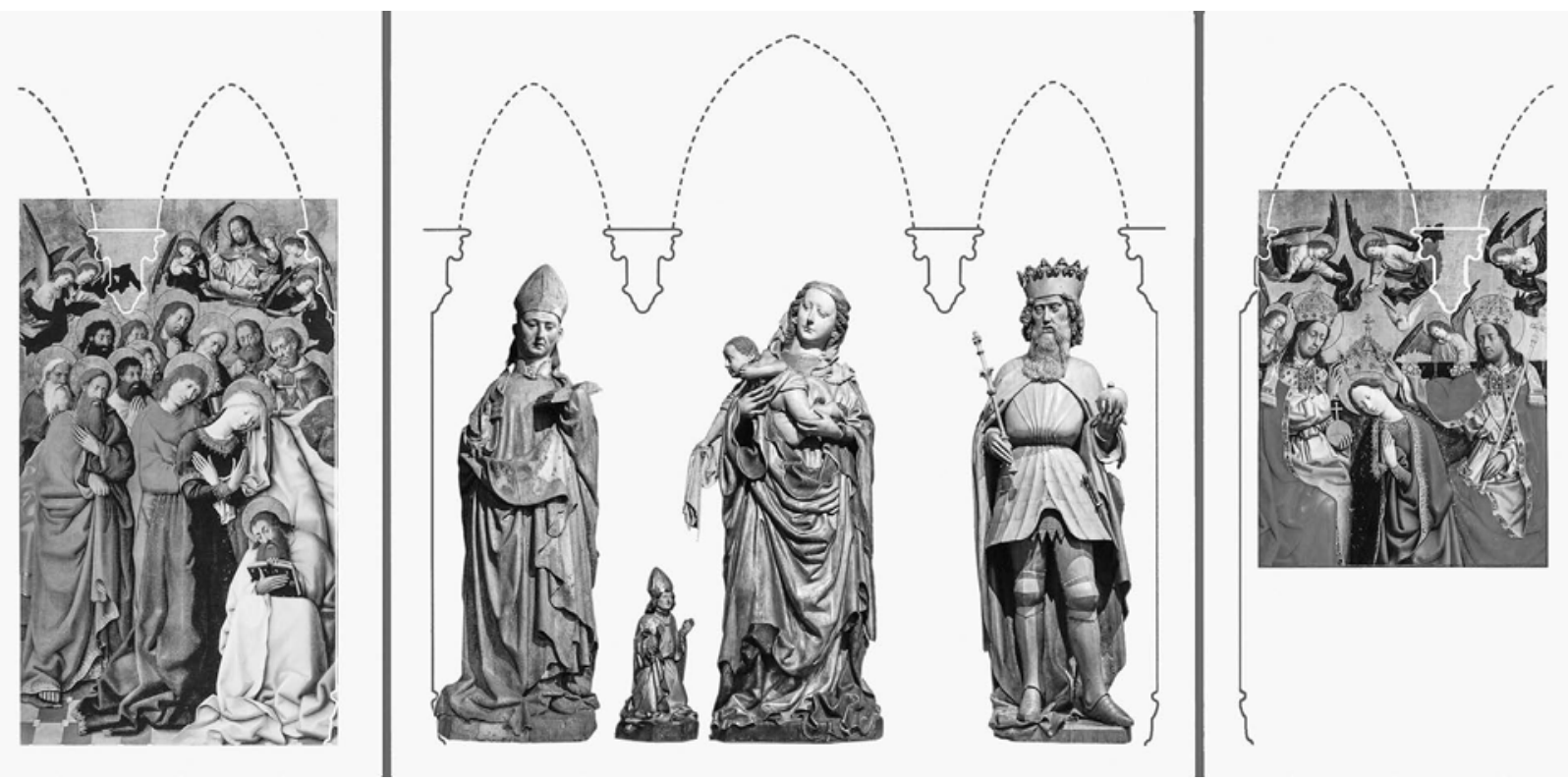

Abb. 5 Rekonstruktion des Freisinger Hochaltarretabels mit den Flügeltafeln aus Schloss Lichtenstein (nach Antje-Fee Köllermann; Montage: Wilfried Franzen)

Grafschaft Hohenberg visuellen Ausdruck zu verleihen $?^{60}$ Die an den Objekten gewonnenen Befunde legen einen solchen Schluss nahe, das Fehlen weitergehender Quellenbelege mahnt jedoch, sich dieser Frage mit Vorsicht anzunähern.

Für keine der weiteren 21 erhaltenen, heute weit verstreuten Tafeln des einstigen Retabels lässt sich die ursprüngliche Provenienz ermitteln, wie die akribische Zusammenstellung Veronika Pirker-Aurenhammers im Wiener Ausstellungskatalog darzulegen vermag. ${ }^{61}$ Nur in wenigen weiteren Fällen ist sie überhaupt bis in das 19. Jahrhundert zurückzuverfolgen. ${ }^{62}$ Aus den Provenienzforschungen ist zumindest ersichtlich, dass die Tafeln noch vor 1825 gespalten und auseinandergesägt wurden. ${ }^{63}$ Jenseits der Rottenburg-Spur, auf die uns der Hinweis Ernst Försters führte, tappen wir aber im Dunkeln.

Antje-Fee Köllermann wartet gleichwohl mit einer ebenso neuen wie reizvollen Hypothese auf, indem sie die Tafeln des Meisters von Lichtenstein den überlieferten Skulpturen des einstigen Freisinger Hochaltars zuordnet, die der Freisinger Bischof Nicodemus della Scala bekanntermaßen beim Wiener "Maler « Jakob Kaschauer bestellt hatte. ${ }^{64}$ Aufgrund ihrer Größe (die Madonna misst $1,73 \mathrm{~m}$ ) ließen sich die drei Schreinskulpturen recht überzeugend in das rekonstruierte Retabel einfügen.${ }^{65}$ Der stilistische Vergleich von Skulptur und Malerei weckt indes Zweifel an einer Zusammengehörigkeit. Wie bereits Ulrich Söding hierzu kritisch anmerkte, stehen die Draperien der Freisinger Figuren der Gewandgestaltung des Albrechtsmeisters erheblich näher als jener des Meisters von Schloss Lichtenstein. ${ }^{66}$ Dies betrifft ebenso die Proportionierung der Figuren, die in den Tafelbildern deutlich gelängt sind und kleinere Köpfe besitzen. Das ästhetische Missverhältnis wird offenkundig, wenn man die Rekonstruktion auch bildlich vornimmt und die Freisinger Skulpturen virtuell in die rekonstruierte Feiertagsseite des Retabels platziert (Abb. 5).

Selbstverständlich müssen die gemalten Partien eines Altarretabels nicht zwangsläufig dem Stil der Skulpturen im Schrein entsprechen. Doch scheinen mir die Unterschiede hier zu gravierend, weshalb dieser Hypothese (und der damit verbundenen Überlegung, den Meister von Schloss Lichtenstein mit Jakob Kaschauer zu identifizieren) große Skepsis entgegenzubringen ist.

Um aber überhaupt den Weg für diesen Vorschlag frei zu machen, war es selbstredend nötig, die lange als sicher geltende Bestimmung für die Morizkirche in Rottenburg-Ehingen zu hinterfragen. Durch eine systematische Analyse der Rottenburger Quellen versuchte Franz Quarthal in seinem Katalogbeitrag die wesentlichen Gegenargumente zusammenzutragen. ${ }^{67}$ Es sind vor allem drei Indizien, die für die Beweisführung herangezogen werden: erstens die wirtschaftliche Situation des Stifts, die kaum ausreichend finanziellen Spielraum für ein 
derart qualitätvolles Retabel zugelassen habe, zweitens eine »dichte Abfolge der bekannten Choraltäre«, in der das Werk des Meisters von Schloss Lichtenstein keinen Platz mehr gehabt hätte, und drittens die nicht existenten Nachrichten zu diesem Retabel in den Rottenburger Quellen, insbesondere in der ausführlichen Beschreibung der Kirche durch den Rottenburger Chronisten Weittenauer Ende des 17. Jahrhunderts.

Die Lokalisierung dieses Werks in das vergleichsweise bescheiden begüterte Stift mag in der Tat auf den ersten Blick erstaunen, doch sind hier die unterschiedlichen Rahmenbedingungen $\mathrm{zu}$ bedenken, die sich aus dem mehrfachen Wechsel der Patronatsherren ergaben. Die Ehinger Morizkirche war zu Beginn des 14. Jahrhunderts von den Grafen von Hohenberg als Grablege erkoren worden, die hier denn auch im Jahr 1330 ein Stift mit 12 Chorherrenpfründen gründeten. ${ }^{68} \mathrm{Zu}$ diesem Zeitpunkt dürfte bereits der Neubau des Kirchengebäudes im Gange gewesen sein, der von zahlreichen Stiftungen begleitet wurde. $\mathrm{Zu}$ Verbesserung der wirtschaftlichen Basis erfolgte 1364 die Übertragung der Pfarrrechte von der Ehinger Remigiuskirche auf die Morizkirche. Das Grafenhaus selbst befand sich vermutlich bereits in jenen Jahren als Folge seiner ambitionierten Hofhaltung sowie mehrerer Erbteilungen und hoher Mitgiften in finanziellen Schwierigkeiten. ${ }^{69}$ Verschuldet und ohne männliche Nachkommen verkaufte Rudolf III. von Hohenberg im Jahr 1381 schließlich die Grafschaft an Leopold III. von Habsburg, womit auch das Patronatsrecht des Ehinger Chorherrenstifts auf die Habsburger überging. ${ }^{70}$ Da die Grafschaft jedoch bereits 1410 an Ulm und weitere schwäbische Reichsstädte verpfändet wurde, blieb das Engagement der habsburgischen Patronatsherren überschaubar. Immerhin lassen sich diverse Versuche erkennen, die finanzielle Situation des Stifts aufzubessern. Hierzu gehörte auch die Förderung der Mauritius-Wallfahrt, die ab 1412/13 eine Vergrößerung der Kirche (um ein Joch im Westen des Langhauses) notwendig machte. Bald darauf konnte die Vollendung des Turms in Angriff genommen werden, für die Steinmetze der Parler-Werkstatt angeworben wurden. ${ }^{71}$ Die in diesen Jahren ausgeführten qualitätvollen Malereien am Obergaden des Langhauses verdeutlichen ebenso wie das Wandbild in der einstigen Sakristei (heute Annenkapelle) und die Fresken an den Rundpfeilern des Langhauses die repräsentativen Ansprüche des Stifts (und des durchaus vermögenden Rottenburger Patriziats). ${ }^{72}$ Die Baumaßnahmen hatten das Stift gleichwohl in finanzielle Bedrängnis gebracht. Um »Gebrechen und Notigkeit« zu mildern, übereignete 1420 Anna von Braunschweig, die Gemahlin Herzogs Friedrich IV. von Tirol (reg. 1382-1439), dem Stift die Pfarrkirche zu Remmingsheim. ${ }^{73} 1427$ sah man sich zudem genötigt, "wegen grossen auffgewente baukösten der stüfftsKürchen « einige Ländereien zu verkaufen. ${ }^{74}$

Mit der Eheschließung Albrechts VI. von Habsburg und Mechthilds von der Pfalz, ihrem Einzug in das Rottenberger Schloss und der Rückgewinnung der Grafschaft Hohenberg für das Haus Habsburg dürfte sich die Situation auch für das Ehinger Morizstift grundlegend geändert haben, da nun seine Patronatsherren wieder vor Ort residierten. Das frisch vermählte Herzogspaar tätigte und bestätigte im Anschluss an seine Hochzeitsfeierlichkeiten in Böblingen und nach seiner Umsiedelung nach Rottenburg eine Reihe frommer Stiftungen. Unter anderem sicherte Albrecht zu, die nächste frei werdende Pfründe in der Morizkirche nur an einen ihm von der Kartause Güterstein präsentierten Priester zu vergeben, der »Maister der siben freyer kunste« sein solle und »wol zu predigen wissen soll «. ${ }^{75}$ Für 1455 ist noch eine Seelgerätsstiftung des Ehepaars an die Kirche in Spaichingen und die Ausstattung des St. Morizstifts mit dem Spaichinger Kirchsatz nachgewiesen. ${ }^{76}$ Ansonsten ist die Überlieferungslage zu diesen Jahren äußerst lückenhaft. ${ }^{77} \mathrm{Ob}$ das Herzogspaar aus Anlass seiner Eheschließung also einen Altaraufsatz für »seine « Kirche stiftete, ist deshalb zwar naheliegend, aber nicht belegt.

Aufgrund der zweifachen Wandelbarkeit und der rekonstruierten Größe des Retabels des Meisters von Schloss Lichtenstein (im geöffneten Zustand war es dereinst 5,50 bis $6 \mathrm{~m}$ breit) ist davon auszugehen, dass es ursprünglich für einen Hochaltar bestimmt war. Mit seinen Dimensionen ließe es sich denn auch problemlos im fast $8 \mathrm{~m}$ breiten Chor der Ehinger Stiftskirche unterbringen. Wenn dem so wäre, hätte man diesen Altaraufsatz aber bereits nach weniger als 70 Jahren wieder ersetzt, wie überlieferten Rechnungen für ein neues Retabel aus dem Jahr 1520 belegen. ${ }^{78}$ Wäre eine derart kurze Nutzungsdauer also ein Ausschlusskriterium? Auch hier gilt es, die generell sehr dürftige Überlieferungssituation zu berücksichtigen. ${ }^{79}$ Die Gründe für einen neuen Altaraufsatz können vielfältig sein - angefangen mit möglichen Beschädigungen z. B. des Schreins bis hin zu in diesem Fall gar nicht so unwahrscheinlichen Bestrebungen, die Erinnerung an das im Haus Habsburg ungeliebte Stifterpaar auszulöschen. Beim Hochaltar der Morizkirche ist gewiss der Zeitpunkt der Beauftragung auffällig, die in das Jahr 
der Aachener Krönung Karls V. (reg. 1519-56) fällt, der als Erzherzog von Österreich zunächst auch Patronatsherr der Ehinger Stiftskirche war. Passend zu diesem Ereignis sollte das Zentrum des neuen Altarwerks eine Marienkrönung zieren, ${ }^{80}$ die beim Lichtensteiner Retabel zwar ebenfalls prominent, aber nur auf dem Flügel zu finden ist.

Unser Bild von der spätmittelalterlichen Ausstattung der Morizkirche wird ganz wesentlich durch den Umstand getrübt, dass die überlieferten Rechnungen erst ab den 1480er Jahren einsetzen; so ist denn auch von keinem der möglichen Vorgänger auf dem Hochaltar etwas überliefert. Nur bedingt aussagekräftig ist die eingehende Beschreibung durch den Probst des Morizstifts, den Chronisten Johann Evangelist Weittenauer (1640-1703), der außer dem Hochaltar weitere neun Altäre bzw. Altaraufsätze benennt. Das Retabel des Meisters von Schloss Lichtenstein lässt sich nicht bzw. nicht zweifelsfrei unter diesen identifizieren. ${ }^{81}$ Ohnehin wäre es keineswegs selbstverständlich, dass sich Ende des 17. Jahrhunderts ein fast 200 Jahre zuvor von seinem Standort entferntes Retabel überhaupt noch im Kirchenraum befand, noch dazu angesichts seiner Größe, die nur sehr wenige alternative Aufstellungsorte im Inneren der Morizkirche zugelassen haben dürfte. Auch von anderen demontierten Werken erfahren wir von Weittenauer nichts. ${ }^{82}$ Nicht ungewöhnlich wäre eine (zeitweilige) Unterbringung in einer der Filialkirchen von St. Moriz. Ein entsprechendes Schicksal wiederfuhr der monumentalen steinernen Marienfigur von ca. 1330/40, die zur Erstausstattung der Morizkirche gehört haben dürfte, aber in der 2. Hälfte des 17. oder Anfang des 18. Jahrhunderts in die zur Morizkirche gehörende St.-Jodok-Kapelle in Weiler verbracht worden war. ${ }^{83}$ Nach Weiler gelangten auch die beiden heute noch erhaltenen Skulpturen des Hochaltarretabels von 1520, das im Jahr 1693 seinerseits durch ein neues Retabel ersetzt worden war. Sie befinden sich heute in der 1828 errichteten Pfarrkirche St. Wolfgang ebendort.

All dies zeigt, dass die These einer Bestimmung für die St.-Moriz-Kirche in Rottenburg-Ehingen gewiss auf tönernen Füßen steht; doch ebenso wie es keine konkreten Belege für die Morizkirche gibt, ist bei kritischer Prüfung keines dieser Argumente geeignet, diese als Bestimmungsort mit absoluter Gewissheit auszuschließen. Weiterhin ernst zu nehmen ist also der dezidierte Herkunftshinweis Försters aus dem Jahr 1853, der noch zu Lebzeiten des Bauherren von Schloss Lichtenstein, Graf Wilhelms von Württemberg (1810-69), erfolgte, welcher die beiden Tafeln vor 1844 für seine romantische Felsenburg erworben hatte. ${ }^{84}$ Über wen der Ankauf erfolgte, ist nicht mehr zu eruieren. ${ }^{85}$ In die "Stiftskirche zu Rottenburg « können die Tafeln selbstredend auch erst sekundär, im Zuge der josephinischen Säkularisation Ende des 18. Jahrhunderts, gelangt sein (das Chorherrenstift wurde seinerseits 1806 aufgehoben). Dass sie aber nicht nur aus der Morizkirche stammen, sondern auch für diese bestimmt waren, muss weiterhin erwogen werden.

\section{Die Veitstafeln aus Breslau und Köln - das Werk eines Mitarbeiters?}

Eine Annäherung an diese Problematik soll von einer anderen Seite versucht werden, über einen Bilderzyklus, dessen Verhältnis zum Meister von Schloss Lichtenstein kontrovers diskutiert wird und der erst vor Kurzem wieder in den Fokus der kunstwissenschaftlichen Forschung gerückt ist: die Bildtafeln mit Darstellungen der Legende der hll. Vitus, Modestus und Crescentia, von denen sich zwei heute im Nationalmuseum Warschau (die Versuchung des hl. Veit und die Kesselmarter; Taf. XV, XVI) und eine weitere im Wallraf-Richartz-Museum zu Köln aufbewahrt werden (die Marter der Heiligen am Galgen; Abb. 6); zudem sind zwei Fragmente einer vierten Tafel (der Tod der Heiligen) bekannt - eines ist an die Kölner Tafel angestückelt, ein weiteres wurde kürzlich von Isolde Lübbeke im Wiener Kunsthandel entdeckt. ${ }^{86}$

Die Kölner Tafel hatte Alexander Schnütgen vor 1910 aus dem Münchener Kunsthandel erworben, die Warschauer Tafeln wurden 1925 von den Freunden des Schlesischen Museums für die Sammlung des Breslauer Museums angekauft. Auf ihre Zusammengehörigkeit machte erstmals Beutinger aufmerksam ${ }^{87}$ doch blieb sie nur einem kleinen Kreis der Fachöffentlichkeit bewusst. ${ }^{88}$ Nach der Übernahme der Kölner Tafel durch das Wallraf-Richartz-Museum, wo sie aufgrund ihres schlechten Erhaltungszustands recht bald ins Depot verlagert wurde, verschwand sie aus dem Blickfeld der Forschung. Doch auch die Warschauer Tafeln erfuhren weder in der polnischen noch der deutschen Forschung größere Beachtung. Anlass zu einer ersten eingehenderen Beschäftigung und auch zur technischen Untersuchung zumindest des Kölner Bildes gab jüngst die Entdeckung des Tafelfragments in Wien. ${ }^{89}$

Bemerkenswert sind die Abmessungen der Tafeln: die beiden Warschauer Bilder sind (ohne Rahmen) 138 bzw. 


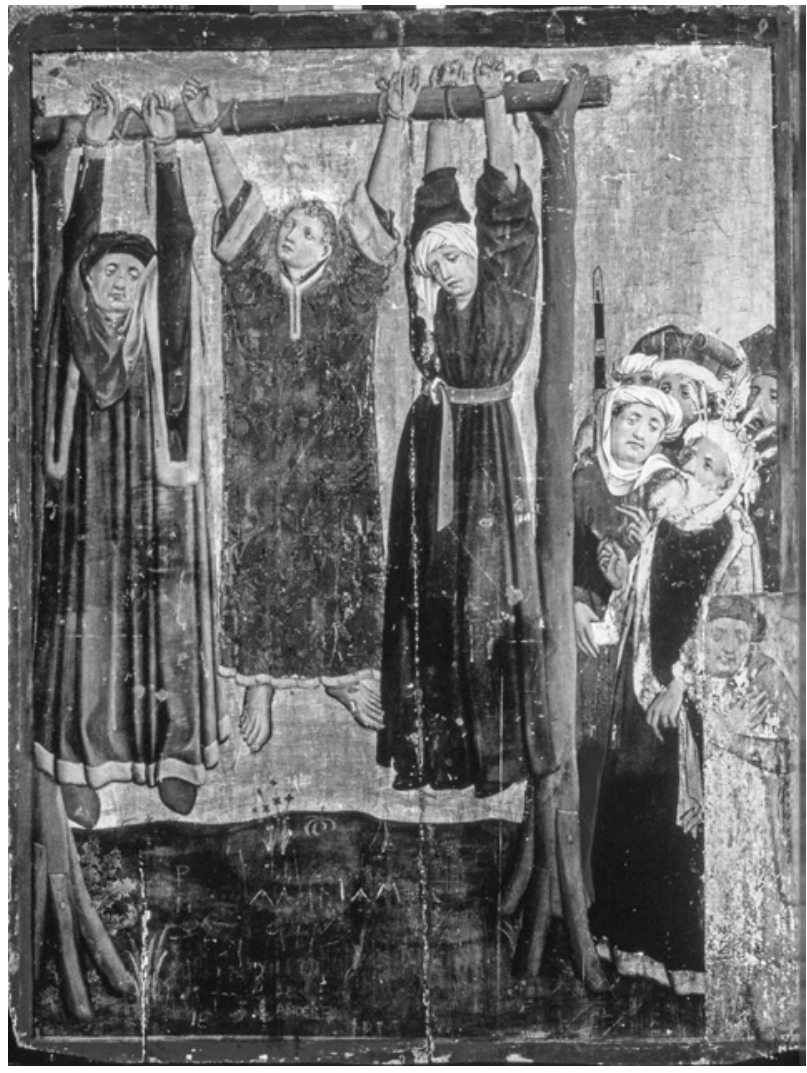

Abb. 6 Die hll. Vitus, Modestus und Crescentia am Galgen (rechts unten: Tafelfragment vom Tod der Heiligen). Oberrheinischer oder schwäbischer Maler, um 1440/50. Köln, Wallraf-Richatz-Museum \& Fondation Corboud, Inv.-Nr. 821 (Foto: Rheinisches Bildarchiv Köln)

$144 \times 110 \mathrm{~cm}$ groß, das Kölner Bild misst 148,5 × $113 \mathrm{~cm}$. Wenn, was anzunehmen ist, es sich hier um die Flügeltafeln eines Retabels handelt, dann ergibt sich für dieses (ohne Predella und Auszug) eine beträchtliche Größe von über $3 \mathrm{~m}$ Höhe und (geöffnet) mehr als $5 \mathrm{~m}$ Breite. Die Untersuchung der Rückseite der im Gegensatz zu seinen Warschauer Pendants ungedünnten Kölner Tafel ergab zudem Spuren, die auf Befestigung von Reliefs deuten. ${ }^{90}$ Die gemalten, mit Goldgrund versehen Tafeln befanden sich somit auf den Außenseiten der Flügel. ${ }^{91}$ Aufgrund der Bauweise und Größe ist eine Nutzung als Hochaltarretabel wahrscheinlich. Welche (Veits-)Kirche das Altarwerk aber einstmals zierte, ist beim derzeitigen Kenntnisstand nicht zu eruieren.

Die Tafeln sind ein Beispiel dafür, welche Probleme unser Fach mit kunstgeografischen Zuordnungen haben kann, so denn das Kunstwerk, wie in diesem Fall, gänzlich entwurzelt wurde. ${ }^{92}$ Ein erstes knappes Urteil erfolgte bereits durch Alexander Schnütgen, der 1910
Fotos seiner Sammlung inklusive knapper Beschreibungen der ausgestellten Objekte veröffentlicht hatte: »Das schwäbische Gemälde kurz nach 1450 (...) stellt auf Goldgrund das Martyrium der hh. Vitus, Modestus und Creszentia dar, etwas breit gemalt, aber zeichnerisch wie farblich eine virtuose Leistung. ${ }^{93}$ Etwas unbestimmter, als Werke eines »süddeutsche[n] (österr.?) Meister[s] um 1430«, charakterisierte Heinz Braune hingegen die für das Breslauer Museum neuerworbenen Bilder. ${ }^{94}$ Auf eine mögliche Verbindung mit dem Meister von Schloss Lichtenstein wies erstmals Ludwig Baldass hin, der in der "Modellierung der Köpfe" und "Haltung der Figuren" Gemeinsamkeiten beobachtete. ${ }^{95}$ Demgegenüber gliederte Alfred Stange die Tafeln in das Euvre der Krakauer Werkstatt des Nikolaus Haberschrack ein, wobei jener »Gehilfe«, der das Ölmatryrium ausgeführt habe, »zuvor in Breslau beim Meister des Barbaraaltars gearbeitet « habe. ${ }^{96}$ Einen Zusammenhang mit eben jenem Breslauer Meister, den wir heute als Wilhelm Kalteysen von Aachen identifizieren können, ${ }^{97}$ vermutete auch Agnes Szendey. Sie deutet den Maler der Veitstafeln als Schüler des Meisters von Schloss Lichtenstein, der später womöglich in der Werkstatt des Barbarameisters tätig gewesen sei. ${ }^{98}$ Die sonstigen Einschätzungen blieben vage. ${ }^{99}$ Im Wiener Ausstellungskatalog von 2013 firmieren die Warschauer Tafeln, die sich, so das knappe Urteil Antje-Fee Köllermanns, »kaum überzeugend « mit Meister von Schloss Lichtenstein in Verbindung bringen ließen, ohne weitere Erklärung unter dem Label »Nürnberger Maler um 1440 (?) «. ${ }^{100}$ All diesen Mutmaßungen versuchte zuletzt Isolde Lübbeke nachzuspüren, ohne jedoch zu einer schlüssigen Lösung gelangen zu können. ${ }^{101} \mathrm{Zu}$ viel scheint in diese Tafeln hineinzufließen und zu vielfältig scheinen für jene Jahre die Optionen, wo der Maler seine Prägungen erlangt haben könnte.

Stellt man die Veitsbilder neben die Tafeln des Meisters von Schloss Lichtenstein, fällt es auf dem ersten Blick in der Tat schwer, die von Baldass vorgenommene Einschätzung nachzuvollziehen. Gerade das, so Lübbeke, "monumentale Stilempfinden" des Wiener Meisters, das heißt die »kraftvolle Gestaltung bildfüllender Figurengruppen" und seine Gewandbehandlung mit den »voluminös geblähte(n) Draperien«, ist dem Maler der Veitstafeln fremd. ${ }^{102}$ Zudem unterscheiden sich wesentliche Aspekte der Komposition, wie die Anordnung der handelnden Personen im Bildraum. In den beiden Warschauer Bildern werden die zentralen Handlungsträger nach hinten gerückt und wird die Bildtiefe für die Er- 
zählung genutzt. In der Versuchung des hl. Veit misst der Maler dabei der Schilderung des Handlungsorts eine entsprechend große Bedeutung bei. Das Geschehen findet in einer verschachtelten, mit zahlreichen (auch figürlichen) Details angereicherten Architektur statt, die der Maler gezielt für die Bildaussage nutzt - unter anderem platziert er die Hofdamen, die den hl. Veit verführen sollen, hinter eine Säule und schafft damit eine Distanz zum Betrachter, während der Blick auf den Heiligen und die Engel unverstellt bleibt. Die beiden Martyrien finden hingegen an einer kaum definierten Örtlichkeit im Freien statt. Die Kesselmarter besticht durch eine Dramatisierung, die den Maler mit den »jungen Wilden« jener Generation verbindet: Er bedient sich des unter diesen Künstlern beliebten Figurenrepertoires, das - unter anderem über die Kupferstiche des Meisters des Kalvarienbergs und des Meisters der Spielkarten popularisiert - nicht nur am Oberrhein und in Franken, sondern auch um und nach 1450 in Breslau und Krakau zu finden ist. ${ }^{103}$ Bemerkenswert ist überdies ein Realismus in den Details, den wir vom Meister von Schloss Lichtenstein ebenfalls nicht kennen: Im Kölner Bild sind die Ärmel der weit geschnittenen Gewänder der am Galgen festgebundenen Veit und Crescentia derart heruntergerutscht, dass sich der Stoff am Oberarm bzw. Schulterbereich bauscht.

$\mathrm{Zu}$ einer gänzlich anderen Einschätzung kommt man jedoch, schaut man auf die Details der malerischen Handschrift. Denn neben den von Baldass beobachteten Übereinstimmungen sind es vor allem die Morelli'schen Merkmale (die Zeichnung der Ohrmuscheln, Kinnpartien, Nasen und Hände samt Fingernägeln), die den Maler der Veitstafeln in die Nähe des Meisters von Schloss Lichtenstein rücken lassen (Abb. 7, 8).

Welche Schlüsse dürfen wir aber aus diesen Ähnlichkeiten ziehen? Gewiss unterscheiden sich die beiden Künstler ansonsten zu sehr, als dass man vermuten könnte, der Schöpfer der Veitstafeln sei aus der Werkstatt des Meisters von Schloss Lichtenstein hervorgegangen. Ist es denkbar, dass er von dem Wiener Meister zur Bewältigung dieses großen Auftrags hinzugezogen wurde und an der Ausführung einiger Tafeln mitgewirkt hat? Für eine Verifizierung dieser Hypothese wären weitergehende, technologische Analysen notwendig. Wenn aber tatsächlich eine Zusammenarbeit beider Künstler stattgefunden hätte, erhielte die Klärung der künstlerischen Verortung des Malers der Veitstafeln einen zusätzlichen Anreiz, da sich damit auch Rückschlüsse auf die Bestim-

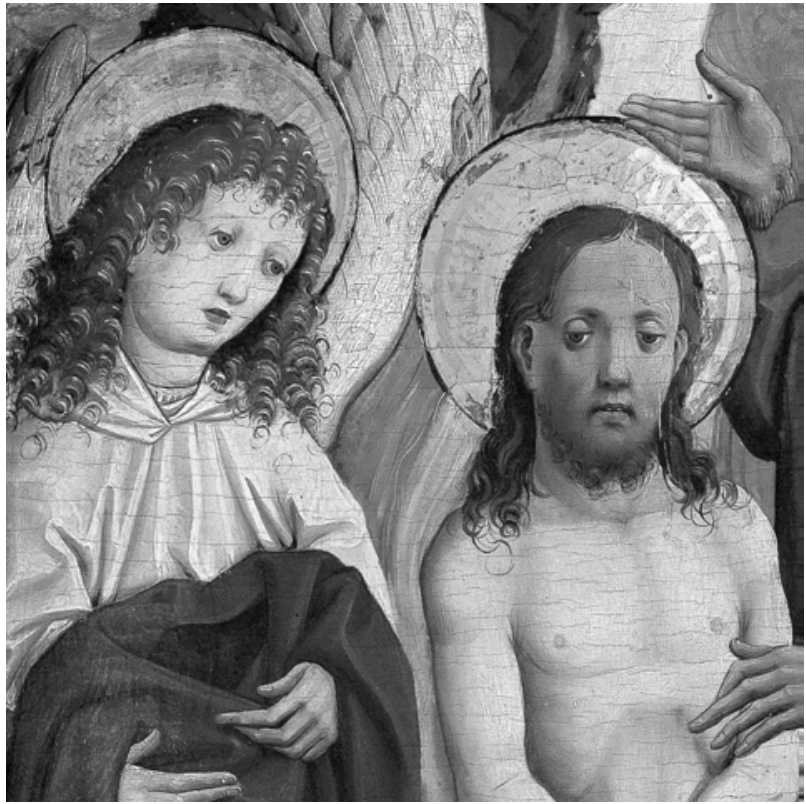

Abb. 7 Taufengel und Christus, Detail aus der Taufe Christi (Abb. 2). Meister von Schloss Lichtenstein, um 1450. Warschau, Muzeum Narodowe, Inv.-Nr. 86 (Foto: Muzeum Narodowe w Warszawie)

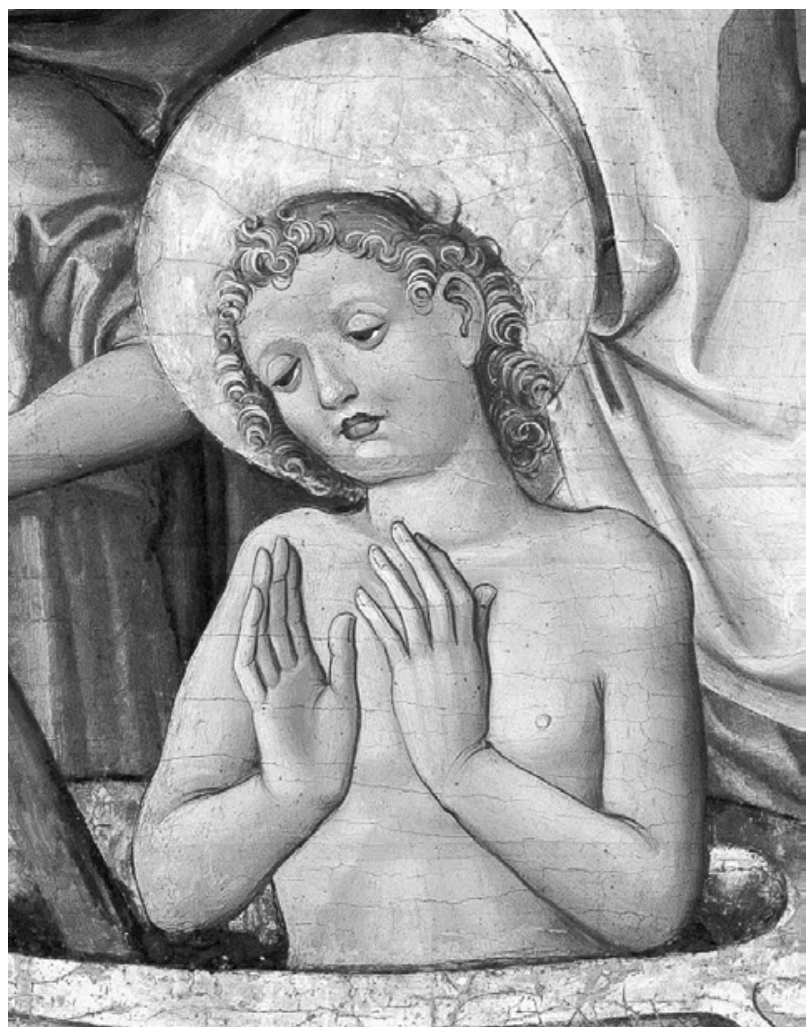

Abb. 8 Detail aus der Kesselmarter des hl. Vitus (Taf. XVI). Oberrheinischer oder schwäbischer Maler, um 1440/50. Warschau, Muzeum Narodowe, Inv.-Nr. 82/2 (Foto: Muzeum Narodowe w Warszawie) 


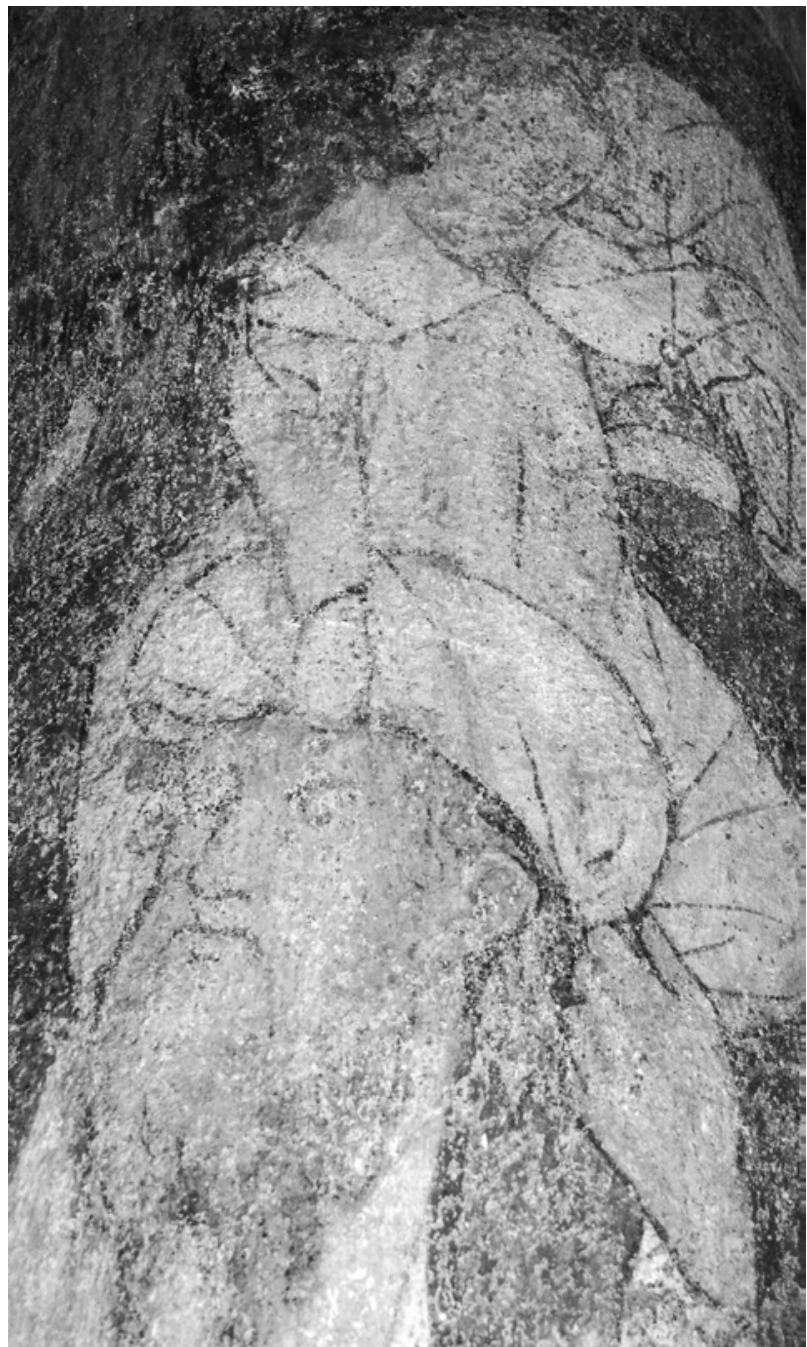

Abb. 9 Hl. Christophorus. Wandmalerei, Rottenburg/N., um 1430/40. Rottenburg-Ehingen, ehem. Stiftskirche St. Moriz, nordwestlicher Pfeiler des Langhauses (Foto: Wilfried Franzen)

mung des Retabels des Meisters von Schloss Lichtenstein erzielen ließen.

In ihrer abschließenden Bewertung der Veitsbilder greift Isolde Lübbeke die von Schnütgen vorgenommene Etikettierung "schwäbisch" auf und ordnete den Maler versuchsweise zwischen die beiden Pole Wurzacher und Sterzinger Altarretabel ein. ${ }^{104}$ Mit der Ulmer Kunst der vorausgehenden Jahre, insbesondere mit den Werkstätten Hans Multschers und Lukas Mosers oder den Glasmalern der Besserer-Kapelle, verbindet die Veitstafeln vor allem die Rezeption niederländischer Vorbilder - weitergehende Rückschlüsse auf eine Ulmer respektive schwäbische Herkunft (oder Schulung) des Malers bieten diese Vergleiche jedoch kaum.
Sucht man nach Parallelen innerhalb der schwäbischen Kunst, geraten für unseren Kontext natürlich auch die Wandmalereien der Morizkirche in Ehingen in das Blickfeld - hier in erster Linie das Bild des hl. Christophorus, das zeitlich den Veitsbildern am nächsten steht (Abb. 9).

Mit ihrer körperlichen Präsenz hebt sich die Christophorus-Darstellung nicht nur deutlich von den übrigen (älteren) Heiligendarstellungen an den Langhauspfeilern $\mathrm{ab}$, sondern auch von den Gestalten des Figurenfrieses am Obergaden, der wohl um 1420/30, bald nach der Erweiterung des Kirchenschiffes, angebracht worden war. Der Maler, den Alfred Stange als Mitarbeiter Hans Multschers deutete, ${ }^{105}$ bediente sich für seine Komposition einer mutmaßlich niederländischen Vorlage, von der er die Körperhaltung und Gewandfältelung übernahm. ${ }^{106}$ Der Zustand der 1909 freigelegten und vor wenigen Jahren restaurierten Malerei erlaubt nur ein vorsichtiges Urteil, da wir heute vor allem die Vorzeichnungen und Konturlinien sehen können. Nichtsdestotrotz lassen sich bei der Zeichnung der Physiognomien des Christophorus und des Jesusknaben Analogien zu den Veitstafeln konstatieren (insbesondere beim Vergleich mit den Darstellungen des Diokletian und seiner Begleiter sowie des hl. Veit). Diese Gemeinsamkeit gehen jedoch nicht weit genug, um hieraus belastbare und gewiss verführerische Schlüsse ziehen zu können. Gerade das in den Veitstafeln zu beobachtende Repertoire an Physiognomien entspricht wiederum auch jenem Typenvorrat, der um die Mitte des 15. Jahrhunderts vor allem in den oberrheinischen Zentren Verbreitung gefunden hat - zu finden u.a. in den Stichen des Meisters der Spielkarten, im möglicherweise in Straßburg gemalten Stuttgarter Kartenspiel ${ }^{107}$ oder in den um 1440/50 illustrierten Büchern der Werkstatt Diebold Laubers in Hagenau. ${ }^{108}$

Auch wenn wir uns also in der Frage nach der künstlerischen Herkunft des Malers der Veitstafeln nur langsam an eine Lösung herantasten können, scheinen doch die wenigen Referenzwerke auf eine Lokalisierung im Südwesten des Reichs hinzuweisen, in die Grauzone zwischen der schwäbischen und oberrheinischen Kunst der Jahrhundertmitte - eine Grauzone, die dann ihre Rätselhaftigkeit verlieren dürfte, rückt man entschieden im Detail forschend von einer diffusen Vorstellung der "Kunstlandschaft» $a b$ und wendet sich den konkreten Gegebenheiten zu, in den über die ganze Region zwischen Günzburg an der Donau und Thann im Elsass verteilten habsburgischen Territorien. Mit einer solchen Einordnung der Veitstafeln wäre auch das Retabel des 
Meisters von Schloss Lichtenstein wieder in diesen Raum einzusortieren. Aufgrund der politischen Rahmenbedingungen ist eine Bestimmung dieses Altarwerks für eine Kirche in den habsburgischen Vorlanden am wahrscheinlichsten - und damit auch ein Zusammenhang mit Albrecht VI. und (je nach Datierung des Retabels vor oder nach 1452) mit seiner Frau Mechthild.

\section{Literatur}

[Ausst.-Kat. Rottenburg/Schallaburg/Freiburg 1999]: Ausst.Kat. Vorderösterreich, nur die Schwanzfeder des Kaiseradlers? Die Habsburger im deutschen Südwesten. Rottenburg/Neckar, Zehntscheuer, 20.2.-24.5.1999; Schallaburg, 19.6.-1.11.1999; Freiburg/Breisgau, Augustinermuseum, 1.12.1999-27.2.2000. Stuttgart 1999.

[Ausst.-Kat. Rottenburg 2015]: Ausst.-Kat. Glaube - Kunst Hingabe. Johann Baptist Hirscher als Sammler. Rottenburg/ Neckar, Diözesanmuseum, 6.10.2015- 6.3.2016. Ostfildern 2015.

[Ausst.-Kat. Ulm 1997]: Ausst.-Kat. Hans Multscher. Bildhauer der Spätgotik in Ulm. Eine Ausstellung des Ulmer Museums und des Württembergischen Landesmuseums Stuttgart. Hg. von Brigitte Reinhardt und Michael Roth. Ulmer Museum, 7.9.-16.11.1997. Ulm 1997.

[Ausst.-Kat. Wien 2013]: Ausst.-Kat. Wien 1450. Der Meister von Schloss Lichtenstein und seine Zeit. Hg. von Agnes HussLein-Arco und Veronika Pirker-Aurenhammer. Wien, Orangerie des Unteren Belvedere, 8.11.2013-23.2.2014. Wien 2013.

BAldass, Ludwig: Der Marienalter des Meisters von Schloss Lichtenstein. In: Jahrbuch der preußischen Kunstsammlungen 56 (1935), 6-21.

BAUm, Julius: Gotische Bildwerke Schwabens. Augsburg/Stuttgart 1921.

BAUM, Julius: Altschwäbische Kunst. Augsburg 1923.

BAUM, Wilhelm: Die Habsburger in den Vorlanden 1386-1486. Krise und Höhepunkt der habsburgischen Machtstellung in Schwaben am Ausgang des Mittelalters. Köln/Wien/Weimar 1993.

Benesch, Otto: Neuerwerbungen (Wien). In: Pantheon 1 (1928), 223-226.

Beutinger, Stina: Der heilige Veit und seine bildliche Darstellung bis zum ausgehenden Mittelalter. Frankfurt/Main 1939.

Braune, Heinz (Bearb.): Katalog der Gemälde und Skulpturen. Schlesisches Museum der bildenden Kunst Breslau. Breslau 1926.
Chmel, Joseph: Materialien zur österreichischen Geschichte. Bd. 2. Linz/Wien 1838.

Deigendesch, Roland: Die Kartause Güterstein. Geschichte, geistiges Leben und personales Umfeld. Leinfelden-Echterdingen 2001 (Schriften zur südwestdeutschen Landeskunde 39).

Ehrmann, Gabriele: Georg von Ehingen. Reisen nach der Ritterschaft. Bd. I: Edition. Bd. II: Untersuchung, Kommentar. Göppingen 1979.

FAJT, Jiří/Hörsch, Markus (Hgg.): Künstlerische Wechselwirkungen in Mitteleuropa. Ostfildern 2006 (Studia Jagellonica Lipsiensia 1).

FeIL, Joseph: Wien's älteste Kunst und Gewerbsthätigkeit. In: Berichte und Mitteilungen des Alterthums-Vereins zu Wien 3 (1859), 204-307.

Elm, Kaspar/Gönner, Eberhard/Hildebrand, Eugen (Hgg.): Landesgeschichte und Geistesgeschichte. Festschrift für Otto Herding zum 65. Geburtstag. Stuttgart 1977.

Fischer, Joachim: Das Testament der Erzherzogin Mechthild von Österreich vom 1. Oktober 1481. In: MAURER 1994, $111-163$.

FÖRSTER, Ernst: Geschichte der deutschen Kunst, Bd. II. Vom Anfang des 15. bis zur Mitte des 16. Jahrhunderts. Leipzig 1853 .

Frange, Melanie: Der »Boisserée Süddeutschlands«. Geschichte und Bedeutung der Kunstsammlung Johann Baptist Hirschers. In: Ausst.-Kat. Rottenburg 2015, 69-103.

Franzen, Wilfried: Nikolaus Haberschrack und der "Meister der Chöre«. Beobachtungen zur Krakauer Retabelkunst um 1460/70. In: FAJT/HörsCH 2006, 183-201.

Geppert : Die Erwerbung der Grafschaft Hohenberg durch die Habsburger. In: Ausst.-Kat. Rottenburg/Schallaburg/Freiburg 1999, 120-127.

Gratianus, Karl Christian: Die Ritterburg Lichtenstein. Tübingen 1844 .

Hérold, Michel/Gatouillat, Françoise: Les vitraux de Lorraine et d'Alsace. Paris 1994 (Corpus Vitrearum Medii Aevi, France V).

JAHN, Das Retabel des Meisters von Schloss Lichtenstein aus restauratorischer Sicht. Aufbau - Material und Maltechnik Erhaltungszustand - Restaurierung. In: Ausst.-Kat. Wien $2013,67-85$.

Kahsnitz, Rainer: Der Freisinger Hochaltar des Jakob Kaschauer. In: KAHSNITZ/KRÜGER/WENIGER 1998, 86-109.

KAhsnitz, Rainer/KrÜGer, Klaus,/Weniger, Matthias (Hgg.): Skulptur in Süddeutschland, 1400-1770. Festschrift für Alfred Schädler. München/Berlin 1998.

Kempf, Karl: Die Chronik des Lutz von Lutzenhartt aus Rottenburg am Neckar. Forschungen zu Werk und Lebensgeschichte eines schwäbischen Chronisten am Ausgang des 
humanistischen Zeitalters und Edition des Textes. Vaihingen/Enz 1986.

[Köllermann 2013/I]: Antje-Fee Köllermann: Der Meister von Schloss Lichtenstein. In: Ausst.-Kat. Wien 2013, 31-52.

[Köllermann 2013/II]: Antje-Fee Köllermann: Der Meister von Schloss Lichtenstein. Drei Bildfolgen - ein Retabel. Zur Rekonstruktion eines Wiener Flügelaltars aus der Mitte des 15. Jahrhunderts. In: Ausst.-Kat. Wien 2013, 53-66.

KrusKa, Renate: Mechthild von der Pfalz. Im Spannungsfeld von Geschichte und Literatur. Frankfurt/M./New York/Paris u. a. 1989 (Europäische Hochschulschriften I/1111).

Langmaier, Konstantin Moritz Ambrosius: Erzherzog Albrecht VI. von Österreich (1418-1463). Ein Fürst im Spannungsfeld von Dynastie, Regionen und Reich. Köln/Weimar/ Wien 2015 (Forschungen zur Kaiser- und Papstgeschichte des Mittelalters. Beihefte zu den Regesta Imperii 38).

Lehrs, Max: Geschichte und kritischer Katalog des deutschen, niederländischen und französischen Kupferstichs im XV. Jahrhundert, Bd. 1. Die Primitiven. Wien 1908.

Lüвекке, Isolde: Neun Personen suchen einen Maler. Die Veitsmarter im Wallraf-Richartz-Museum und zugehörige Tafeln. In: Wallraf-Richartz-Jahrbuch 75 (2014), 37-50.

Manz, Dieter: Rottenburger Miniaturen 4. Rottenburg/Neckar 2004.

Manz, Dieter: Die Gotteshäuser der katholischen Kirchengemeinde St.Moriz in Rottenburg-Ehingen. Geschichte, Kunstwerke. Horb 2008.

Maurer, Hans-Martin (Hg.): Eberhard und Mechthild. Untersuchungen zu Politik und Kultur im ausgehenden Mittelalter. Stuttgart 1994 (Lebendige Vergangenheit. Zeugnisse und Erinnerungen 17).

Meurer, Heribert: Das Stuttgarter Kartenspiel. The Stuttgart Playing Cards. Stuttgart 1991.

Moraht-Fromm, Anna: De Dedicationibus. Altäre in Bewegung. Ein Beitrag zur Ausstattungsgeschichte der ehem. Chorherrenstiftskirche St. Vitus in Ellwangen. In: Ellwanger Jahrbuch 44 (2012/13), 237-263.

Oberhaidacher, Jörg: Die Wiener Tafelmalerei der Gotik um 1400. Werkgruppen, Maler, Stile. Wien 2012.

Oettinger, Karl: Hans von Tübingen und seine Schule. Berlin 1938.

Perger, Richard: Die Wiener Künstler des Mittelalters und der beginnenden Neuzeit. Wien 2005.

Pfändtner, Karl Georg: Die Handschriften des Lehrbüchermeisters. Purkersdorf 2011 (Codices Manuscripti. Zeitschrift für Handschriftenkunde, Supplementum 4).

Pirker-Aurenhammer, Veronika: Geschichte(n) einer Fragmentierung. Der zerteilte Marienaltar des Meisters von Schloss Lichtenstein 1825-1982. In: Ausst.-Kat. Wien 2013, 95-111.
[QUaRThal 2000/I]: Quarthal, Franz: Vorderösterreich. In: SchaAB/SChWARZMaIER/Taddey 2000, 587-780.

[Quarthal 2000/II]: Quarthal, Franz (Hg.): Die Habsburger im deutschen Südwesten. Neue Forschungen zur Geschichte Vorderösterreichs. Stuttgart 2000.

Quarthal, Franz: Geschichte eines Forschungsirrtums. Der Altar des Meisters von Schloss Lichtenstein stand nie in St. Moriz in Rottenburg. In: Ausst.-Kat. Wien 2013, 87-93.

Retтich, Edeltraut/Klapproth, Rüdiger/Ewald, Gerhard (Bearbb.): Staatsgalerie Stuttgart. Alte Meister. Stuttgart 1992.

Roo, Gerard de: Annales - oder: Der durchleuchtigsten Fürsten und Herren Ertzhertzogen zu Oesterreich Habspurgischen Stammens [...]. Augsburg 1621.

Rотт, Hans: Quellen und Forschungen zur südwestdeutschen und schweizerischen Kunstgeschichte im XV. und XVI. Jahrhundert, Bd. 2. Alt-Schwaben und die Reichsstädte. Stuttgart 1934 .

Saurma-Jeltsch, Lieselotte E.: Spätformen mittelalterlicher Buchherstellung. Bilderhandschriften aus der Werkstatt Diebold Laubers in Hagenau. Wiesbaden 2001.

SchaAb, Meinrad/Schwarzmaier, Hansmartin/Taddey, Gerhard (Hgg.): Handbuch der Baden-Württembergischen Geschichte. Bd. 1. Allgemeine Geschichte. Teil 2: Vom Spätmittelalter bis zum Ende des Alten Reiches. Stuttgart 2000.

Schatткоwsкi, Martina (Hg.): Witwenschaft in der frühen Neuzeit. Fürstliche und adelige Witwen zwischen Fremdund Selbstbestimmung. Leipzig 2003 (Schriften zur sächsischen Geschichte und Volkskunde 6).

SchмidT, Gerhard: Die österreichische Kreuztragungstafel in der Huntington Library. In: Österreichische Zeitschrift für Kunstgeschichte 20 (1966), 1-15.

Schnütgen, Alexander: Die Sammlung Schnütgen. In: Zeitschrift für christliche Kunst 23 (1910), 97-100, $129 \mathrm{f}$., $161 \mathrm{f}$., 193 f. 225 f., 257 f., 289-292, 321 f., 353 f.

Schön, Petra/Stemmler, Eugen/Steuer, Peter (Bearbb.): Vorderösterreichische Regierung und Kammer 1753-1805. Oberamt Rottenburg. Stuttgart 1999 (Veröffentlichungen der staatlichen Archivverwaltung 50/6).

Scholz, Günter: Mechthild von der Pfalz und Barbara Gonzaga von Mantua. In: SCHATTKOWSKI 2003, 427-440.

Schultes, Lothar: Die gotischen Flügelaltäre Oberösterreichs, Bd. I. Von den Anfängen bis Michael Pacher. Weitra 2002 (Studien zur Geschichte von Oberösterreich 11).

SCHWINEKÖPER, Berent: Der Marktbrunnen in Rottenburg am Neckar. Spätmittelalterliche Brunnen südwestdeutscher Städte als staatliche und städtische Hoheitszeichen. In: ELM/ GönNER/HILdEBRAND 1977, 131-169.

SöDING, Ulrich: Grabfigur der Gräfin Mechthild von Württemberg. In: Ausst.-Kat. Ulm 1997, 340-344. 
SöDING, Ulrich: Wien 1450. Der Meister von Schloss Lichtenstein und seine Zeit. In: Kunstchronik 2014, 487-493.

SPECK, Dieter: Landesherrschaft und Universität. In: QUARTHAL 2000/II, 217-271.

Stamm [SAurma-Jeltsch], Lieselotte E.: Zur Verwendung des Begriffes Kunstlandschaft am Beispiel des Oberrheins im 14. und 15. Jahrhundert. In: Zeitschrift für Schweizerische Archäologie und Kunstgeschichte 41 (1984), 85-91.

Stange, Alfred: Deutsche Malerei der Gotik, Bd. 4. Südwestdeutschland in der Zeit von 1400 bis 1450. Berlin 1951.

StAnge, Alfred: Deutsche Malerei der Gotik, Bd. 11. Österreich und der ostdeutsche Siedlungsraum von Danzig bis Siebenbürgen in der Zeit von 1400-1500. Berlin 1961.

Steinborn, Bożena/Ziemba, Antoni (Bearbb.): Malarstwo Niemieckie do 1600 roku. Katalog Zbiorów/Deutsche Malerei bis 1600 . Bestandskatalog. Warszawa 2000.

STrauch, Philipp: Pfalzgräfin Mechthild in ihren litterarischen Beziehungen. Ein Bild aus der schwäbischen Litteraturgeschichte des 15. Jahrhunderts. Tübingen 1883.

Suckale, Robert: Die Hofkunst Kaiser Ludwigs des Bayern. München 1993.

Suckale, Robert: Die Erneuerung der Malkunst vor Dürer. 2 Bde. Petersberg b. Fulda 2009.

Sendey, Agnes: Der Meister von Schloß Lichtenstein. Diss. Wien 1986.

WAnd-Wittrowski, Christine: Pfalzgräfin Mechthild und ihr literarischer Zirkel. Ein Irrtum der Mediävistik. In: Internationales Archiv für Sozialgeschichte der deutschen Literatur 30 (2005), 1-27.

Weniger, Matthias: Der Freisinger Hochaltar des Jakob Kaschauer. Geschichte, Kontext und Nachwirkung. In: Sammelblatt des Historischen Vereins Freising 42 (2012), 26-59.

\section{Anmerkungen}

1 EhrmanN 1979, I, 21.

2 Quarthal 2000/I, 637. - Siehe auch BAUM 1993, 229-378. - Speck 2000. - Eine fundierte Untersuchung zum Leben und Wirken des in der Forschung lange vernachlässigten Albrecht VI. bietet LANGMAIER 2015.

3 BAum 1993, 364-367. - SPeCK 2000. - LANgmaier 2015, 424-435.

4 Diese Problematik hat Stamm [SAUrma-Jeltsch] 1984 am Beispiel des Oberrheins dargestellt.

5 Wien, Kunsthistorisches Museum, Inv.-Nr. A 2302.

6 Deckfarben auf Pergament, H. 13,8 cm, B. 10,1 cm (Titelminiatur). - Wien, Österreichische Nationalbibliothek, Cod. 1846. - Hierzu Pfändtner 2011, 176-179, Kat.-Nr. 40. - Dem Lehrbüchermeister ist die Titelminiatur zuzuschreiben. Die weiteren Miniaturen sind wahrscheinlich erst nach Albrechts Umzug in seine neue Residenz Linz 1458 entstanden.

7 PFÄNDTNER 2011, 21 f. - Darüber hinaus wurden vom Rankenmaler des Gebetbuchs auf fol. 2 r die hockende Wilde Frau der Wilde-Leute-Fünf und auf fol. 24v eine Blume der Blumen-Neun übernommen. Ebenda, 106.

8 LANGmaier $2015,379-388$.

9 LANGMAier 2015, 569-578.

10 LANGMAIER 2015, 572.

11 LANGMAier 2015, 1.

12 Scholz 2003. - LANgmaier 2015, 333 f. (mit weiterer Literatur). - Graf Froben Christoph von Zimmern (1519-66), der Autor der Zimmerischen Chronik, verunglimpfte sie als »überflaischgirige(s) weib«. KRUSKa 1989, 52.

13 Langmaier 2015, 273 und 327. - Siehe auch Baum 1993, $330 \mathrm{f}$.

14 Der Ehevertrag ist abgedruckt bei Chmel 1838, 22-24. - LANGMAIER 2015, $329 \mathrm{f}$.

15 LANGMAier 2015, $328 \mathrm{f}$.

16 Siehe das Itinerar in LANGmaier 2015, 666-668 (1452-55).

17 LANGMaier 2015, 234.

18 Ehrmann 1979, II, 86-93.

19 HHStA Wien, HS Blau 138, fol. 7r. - SPECK 2000. - Laut LANGMAIER 2015, 275, standen möglicherweise nicht alle hier verzeichneten Personen bereits 1454 im Dienst Albrechts.

20 Roo 1621, 295.

21 SCHWINEKÖPER 1977.

22 KRUSKA 1989. - WAND-WittKoWSKI 2005.

23 Stuttgart, Württtembergische Landesbibliothek, Cod. Hist. Fol. 764, Bd. 4, 65. - Strauch 1883, 4. - SChWineköPer 1977, 137. - In der Edition von Keмpғ 1986 fehlt die entsprechende Seite.

24 Zur Kartause Güterstein Deigendesch 2001.

25 Als Gegenleistung wurde das generelle Verbot des Zutritts von Frauen in der Marienkirche dahingehend aufgehoben, dass sie am Jahrtag ihres Mannes einer Messe beiwohnen durfte. Deigendesch $2001,63$.

26 SöDING 1997. - Die Liegefigur ihres Mannes ist bei der Überführung offenbar zerstört worden, sodass sie neu angefertigt werden musste.

27 Eventuell mit dieser Stiftung, spätestens aber aus ihrem Nachlass (s. u.) gelangte auch ein Stück des blutbefleckten Schleiers Mariens in den Besitz der Kartause.

28 Das Zubehör umfasst u. a. einen Kelch, ein Messkännlein, einen Weihkessel, ein Messgewand und »alle Heiligenbilder«. Fischer 1994, 116. - Finanzielle Zuwendung erhielten u. a. auch die Pfarrkirche in Rottenburg, die Stiftskirche in Rottenburg-Ehingen und das Rottenburger Kartäuserkloster.

29 Heute Stuttgart, Staatsgalerie, Inv.-Nr. 1125 a-e. - Mechthilds Stifterwappen ist über der Darstellung der Pforte angebracht, die in einen hortus conclusus führt. RetTich/KLAPPROTH/EWALD 1992, 207-209 (Edeltraut RetTiCh).

30 SuCKale 2009, I, 166-173.

31 Da Rebmann in jener Quelle als "Bürger von Rottenburg« bezeichnet wird und bereits 1471 als Hausbesitzer identifiziert werden kann, darf man zumindest eine zeitweilige Tätigkeit am Rottenburger Hof Mechthilds vermuten. MAnz 2004, 144. - Ob Albrecht Rebmann - als mutmaßlicher Nachfolger Pleydenwurffs, der die Neuerungen der niederländischen Malkunst in Mitteleuropa vermittelte - mit dem Meister des Ehninger Triptychons identifiziert werden kann, wie es bereits Rотт 1934 vermutete, ist nach dem derzeitigen Kenntnisstand nicht zu entscheiden. 
32 Tannenholz, H. 141,5 cm, B. 109,5 cm (Krönung). - Stuttgart, Staatsgalerie, Inv.-Nr. L 1191.

33 FöRSTER 1853.

34 Baldass 1935, 11

35 Vgl. hierzu auch die Beiträge von Stavros Vlachos, Adam S. Labuda und Markus Hörsch in diesem Band.

36 Söding 2014, 490. - Taufe Christi: Tannenholz, H. 100 cm, B. 50 cm. - Warschau, Muzeum Narodowe, Inv.-Nr. 86. - Anbetung der Könige: Tannenholz, H. $101 \mathrm{~cm}$, B. $50 \mathrm{~cm}$. - Moskau, Gosudarstvennyi muzei izobrazintel'nykh iskusstv imeni A. S. Pushkina/Staatliches Museum für Bildende Künste A. S. Puschkin, Inv.-Nr. 421.

37 Insbesondere BaLdass 1935.

38 BALDASS 1935, 14.

39 Siehe den Forschungsüberblick durch KöLlermanN 2013/I.

40 Sendey 1986.

41 Diese These hatte erstmals Benesch 1928 formuliert, ohne allerdings alle Tafeln zu kennen.

42 Sendey 1986, 209-225.

43 Ausst.-Kat. Wien 2013.

44 Köllermann 2013/II.

45 JAHN 2013, 67. - Nicht alle Tafeln konnten indes dendrochronologisch untersucht werden. $\mathrm{Ob}$ nun die untersuchten Tafeln tatsächlich die jüngsten für das Retabel verwendeten Bretter aufweisen, ist folglich keineswegs gewiss.

46 Ausst.-Kat. Wien 2013, insbes. 188-233, Kat.-Nr. 7-24.

47 Oberhaidacher 2012, 163-257 und passim. Zuvor verortete sie die Forschung u. a. in Wiener Neustadt und Graz.

48 Zur Rezeption der frankoflämischen Buchmalerei OBERHAIDACHER 2012, 163-167. - Zum französischen "Akzent« bereits SCHMIDT 1966.

49 Rund 20 Maler, die in der ersten Hälfte des 15. Jahrhunderts in Wien wohnhaft waren, konnten erfasst werden. Perger 2005.

50 Perger 2005, 32 f., 39 f. 131. - Zu Heinrich siehe auch Feil 1859, 249.

51 SChultes 2002, 87 .

52 Wels, Stadtmuseum, Inv.-Nr. 29.627.

53 Schultes 2002, 87. - Die Signatur hatte Oettinger 1938 irrtümlich auf Hans von Tübingen schließen lassen; bisweilen wird auch Hans von Judenburg genannt (SCHultes 2002, 87). - Die Welser Tafel wird von Jörg Oberhaidacher 2012, 381, dem sog. Pseudo-Darbringungsmeister zugeschrieben. Eine Identifikation mit Hans Gegenuns lehnt er jedoch ab, da er eine Tätigkeit dieses Malers über das Todesjahr des Hans Gegenuns (1434) hinaus annimmt. Sein wesentliches Argument ist die Gleichsetzung des Pseudo-Darbringungsmeisters mit dem Schöpfer der nach 1437 entstandenen Glasfenster in St. Leonard/Tamsweg (Oberndorffer-Fenster, 2a-4c); ebenda 378 f., Kat.-Nr. 64.

54 Perger 2005, 33 und 40.

55 So datiert sie Oberhaidacher 2012, 245-257, noch in die $1430 \mathrm{or}$ Jahre.

56 Fichtenholz, H. $122 \mathrm{~cm}$, B. 46,2 cm (Flügel mit den hll. Florian und Christophorus). - Wien, Erzbischöfliches Dom- und Diözesanmuseum, Inv.-Nr. 35. - Ausst.-Kat Wien 2013, 224-229, Kat.-Nr. 23 (Veronika Pirker-Aurenhammer). - Möglicher Bestimmungsort sei die Christophorus-und-Florians-Kapelle der Wiener Neustädter Burg.

57 Ausst.-Kat Wien 2013, 230-233, Kat.-Nr. 24/1-3 (Guido Messuing).
58 Köllermann 2013/I, 41.

59 Oettinger 1938, 67, vermutet, dass sich der Meister von Schloss Lichtenstein in seinem neuen schwäbischen Tätigkeitsgebiet »im Bannkreis der Multscher-Werkstatt die neue, schon der niederländischen Kunst verpflichtete Malweise angeeignet« habe.

60 Ein eben solches Szenario entwarf bereits Oettinger 1938, 68.

61 Pirker-Aurenhammer 2013.

62 Die Kreuzigung und die Beweinung Christi (Augsburg, Staatsgalerie, L. 1025, 1026) sind erstmals 1825 nachgewiesen; die Geißelung und Dornenkrönung (Esztergom, Christliches Museum, 54.17, 54.18) wurden 1864 in Csegöld (Ungarn) erwähnt. Pirker-AurenhamMER 2013, 97 f., 106.

63 Die meisten Tafeln sind einheitlich auf 0,5 $\times 1 \mathrm{~m}$ zugeschnitten, was auf eine gemeinsame sekundäre Verwendung hinweisen könnte. Die akkurate Aufspaltung der Tafeln lässt fragen, warum die untere Hälfte der Marienkrönung fehlt, deren Rückseitentafeln erhalten sind. Sie dürfte kaum durch eine unsachgemäße Aufspaltung zerstört worden sein, sondern wurde möglicherweise gezielt abgetrennt (um etwaige Stifterdarstellungen zu entfernen?).

64 Köllermann 2013/I, 46-50. - Zu den Freisinger Skulpturen KahSNitZ 1998. - Weniger 2012.

65 Köllermann 2013/I, 51, Anm. 57.

66 SöDING 2014, 490.

67 Quarthal 2013.

68 Hierzu und zum folgenden MANZ 2008.

69 Geppert 1999, 121 (mit weiterer Literatur).

70 GePpert 1999, $121 \mathrm{f}$.

71 Dies belegen zahlreiche Steinmetzzeichen im zweiten und dritten Turmgeschoss. MANZ 2008, 11.

72 Das Sebastianswandbild am nordwestlichen Langhauspfeiler ist durch das Wappen als Stiftung der Rottenburger Familie Gut von Sulz ausgewiesen. Johannes Gut ( $†$ 1432) ist zwischen 1413 und 1418 als Chorherr in St. Moriz belegt. MANZ 2004, $132 \mathrm{f}$.

73 Manz 2008, 79.

74 Quarthal 2013, 91.

75 Langmaier 2015, 332, Anm. 54. - Das Stift war zu diesem Zeitpunkt mit 11 Chorherren fast vollständig besetzt, was in seiner Geschichte nur selten der Fall gewesen sein soll. SCHÖN/STEMmLER/ Steuer 1999, Kat.-Nr. 3422. - MANZ 2008, 78.

76 Hauptstaatsarchiv Stuttgart, B 491, Bü 35. LANGmaier 2015, 332, Anm. 55.

77 Auch das Anniversar des Stiftes ist nur noch fragmentarisch erhalten.

78 Überliefert in der Chronik des Johannes Ev. Weittenauer (Rottenburg-Ehingen, Pfarrarchiv St. Moriz, Bestand Bd. 76). - QuarthaL 2013, 91.

79 Die Veränderungen und Translozierungen von Altarretabeln untersuchte Moraht-Fromm 2012/13 beispielhaft an der Ausstattung der Chorherrenstiftskirche St. Vitus in Ellwangen. - Eine ähnlich »bewegte« Geschichte kann für die Ausstattung der Nürnberger Augustinereremitenkirche St. Veit beobachtet werden.

80 Gemäß Vertrag von 1520, zitiert in Quarthal 2013, 91. - Bemerkenswert ist die Wahl des ausführenden Künstlers, da man auf keine der in dieser Zeit in Rottenburg bevorzugten lokalen Werkstätten zurückgriff (MANZ 2004, 145-156), sondern den Schaffhausener »burger und schreiner« Matthias Hagemüller beauftragte. QUARTHAL 2013, 91. - Die noch erhaltenen Skulpturen jenes neuen Reta- 
bels ragen qualitativ aus den überlieferten Schnitzwerken Rottenburgs des frühen 16. Jahrhunderts heraus und deuten die gehobenen Ansprüche dieser Stiftung an. Eine Erforschung steht indes noch aus.

81 Quarthal 2013, $91 \mathrm{f}$.

82 So z. B. von jenem noch 1499/1500 reparierten Annenretabel, das 1507 einem neuen Aufsatz weichen musste. MANZ 2004, 151.

83 Heute Stuttgart, Württembergisches Landesmuseum. BAUM 1921, Kat.-Nr. 33. - Nachdem die Kapelle gegen 1810 abgebrochen worden war, kam die Skulptur zunächst in Privatbesitz und 1911 in den Kunsthandel. MANZ 2008, 75 f. - Das Werk wurde exemplarisch von Suckale 1993, 269, behandelt.

84 Der Marientod in der »Kapelle« wird in der 1844 veröffentlichten Beschreibung des Schlosses erstmals genannt. Gratianus 1844.Die Marienkrönung befand sich in der Bildergalerie im Obergeschoss.

85 Dass sich, wie Quarthal 2013, 92 f., vorschlägt, hinter der Provenienzangabe möglicherweise einer der bekannten Kunstsammler aus der Rottenburger Diözese verberge, ist wenig wahrscheinlich, da keiner der ins Feld geführten Sammler (Hirscher, Dursch, Jauer) überhaupt in Beziehung zur Stiftskirche stand. Es wäre also bestenfalls ein Zwischenschritt. - Vor allem Hirschers Sammlung und seine Verkäufe sind außerordentlich gut dokumentiert (zuletzt FrANGE 2015) - so wissen wir u. a. vom Verkauf zweier Tafeln des Rottweiler Altars an Graf Wilhelm von Württemberg für das Schloss Lichtenstein. Die Tafeln des Meisters von Schloss Lichtenstein sind in keinem der diversen Inventare Hirschers erwähnt.

86 LÜвекке 2014, 41 f. - Versuchung des hl. Vitus: Fichtenholz, H. $139 \mathrm{~cm}$, B. $110 \mathrm{~cm}$. - Warschau, Muzeum Narodowe w Warszawie, Inv.-Nr. 82/1. - Die hll. Vitus, Modestus und Crescentia am Galgen: Fichtenholz, H. $148,5 \mathrm{~cm}$, B. $113 \mathrm{~cm}$. - Köln, Wallraf-Richatz-Museum \& Fondation Corboud, Inv.-Nr. 821. - Kesselmarter des hl. Vitus: Fichtenholz, H. 144 cm, B. 110 cm. - Warschau, Muzeum Narodowe, Inv.-Nr. 82/2.

87 Beutinger 1939, 39.
88 Der Hinweis findet sich später immerhin auch bei Agnes SendeY 1986 und in den Warschauer Bestandskatalogen (z. B. STEINBORN/ ZIEMBA 2000, dort mit falschem Hinweis auf ein viertes Bild).

89 LÜвекKе 2014, 41 f. und 49, Anm. 13.

90 LÜвЕKKE 2014, 42.

91 Nicht auszuschließen wäre ein weiteres Flügelpaar. Eine Ergänzung um weitere Veits-Szenen wäre insofern plausibel, da sich die erhaltenen Bilder kompositorisch nicht überzeugend auf einer Schauseite mit vier Tafeln gruppieren lassen.

92 Siehe den Forschungsüberblick von LÜBEKKE 2014, $43 \mathrm{f}$.

93 SChnütgen 1910, 162, Taf. VI.

94 Braune 1926, 99.

95 BALDASS 1935, 21.

96 StANGE 1961, 145.

97 Siehe den Beitrag von Adam S. Labuda in diesem Band.

98 Sendey 1986, 126-132, 193-196.

99 »Süddeutschland, 2. Viertel des 15. Jahrhunderts« bzw. »Deutsch, um 1450« heißt es in den Sammlungskatalogen Kölns und Warschaus.

100 Köllermann 2013, 46.

101 LÜBEKKE 2014, 47.

102 LÜBEKKE 2014, 45.

103 Franzen 2006, 192.

104 LÜвеKKE 2014, 47f. - Möglicherweise beruhte Schnütgens Einschätzung auf einer Händlerinformation zur Provenienz der Tafel (ebd., 43).

105 Stange 1951, 85.

106 BAUm 1923, 4, verweist auf Parallelen zu einer Zeichnung in Dessau, die auf ein gemeinsames Vorbild schließen lassen.

107 Meurer 1991.

108 Vgl. hier z. B. den vom »Maler B«i illustrierten dritten Teil der fünfbändigen Bibel (Heidelberg, Bibliotheca Palatina, Cod. Pal. Germ 21) oder die Parzival-Handschrift des »Malers O« (Cod. Pal. germ. 339). - Zur Werkstatt Diebold Laubers SAURMA-Jeltsch 2001. 

Manuel Teget-Welz

\title{
Die Höchstädter Anbetung Der Könige
}

\author{
Ein Hauptwerk der Tafelmalerei in Augsburg um 1440 ?
}

Die Augsburger Tafelmalerei der ersten Hälfte des 15. Jahrhunderts ist bis heute ein weitgehend im Dunkeln liegendes Feld der Kunstgeschichte geblieben. Ernst Buchner hat sich 1928 in einem umfangreichen Aufsatz mit Augsburgs Tafelmalerei der Spätgotik beschäftigt, zu ihrer Frühzeit jedoch nur Disparates zusammengestellt, das zumeist ohne nähere Gründe bzw. auf Basis vager Provenienzangaben in die Lechstadt lokalisiert wurde. ${ }^{1}$ Dazu ein Beispiel: Als bedeutendes Augsburger Werk aus der Zeit vor 1450 galt das Tafelbild einer thronenden Madonna mit Stiftern, das sich heute in der Staatlichen Kunsthalle in Karlsruhe befindet (Abb. 1). ${ }^{2}$

Die korrekte Identifizierung der dargestellten Wappen führt allerdings eindeutig nach Franken. Demnach wird es sich um eine Stiftung von Hans Erlbeck aus Nürnberg und dessen Frau, einer Tochter des Goldschmieds Georg
Dietherr, handeln, und dementsprechend dürfte das Epitaph auch kaum in Augsburg entstanden sein. ${ }^{3}$

Ein zum Objektbestand gegensätzliches, nämlich durchaus deutliches Bild ergeben die reichen Quellen der Stadt Augsburg, die von Johannes Wilhelm für die fragliche Periode in mustergültiger Weise aufgearbeitet wurden. ${ }^{4}$ Summiert man, dürften hier in der Zeit zwischen 1430 und 1450 ungefähr ein Dutzend Meister tätig gewesen sein, zuzüglich Lehrlinge und Gesellen. Was von diesen bislang fehlt, ist ein erhaltenes Tafelbild, das durch archivalischen Beleg mit einem der Augsburger Malernamen verbunden werden kann. Potenzial versprechen zwei fragmentierte, zusammengehörende Tafeln, die sich heute im Besitz des Diözesanmuseums Freising befinden (Taf. XVII.a-b, Abb. 3$)^{5}$

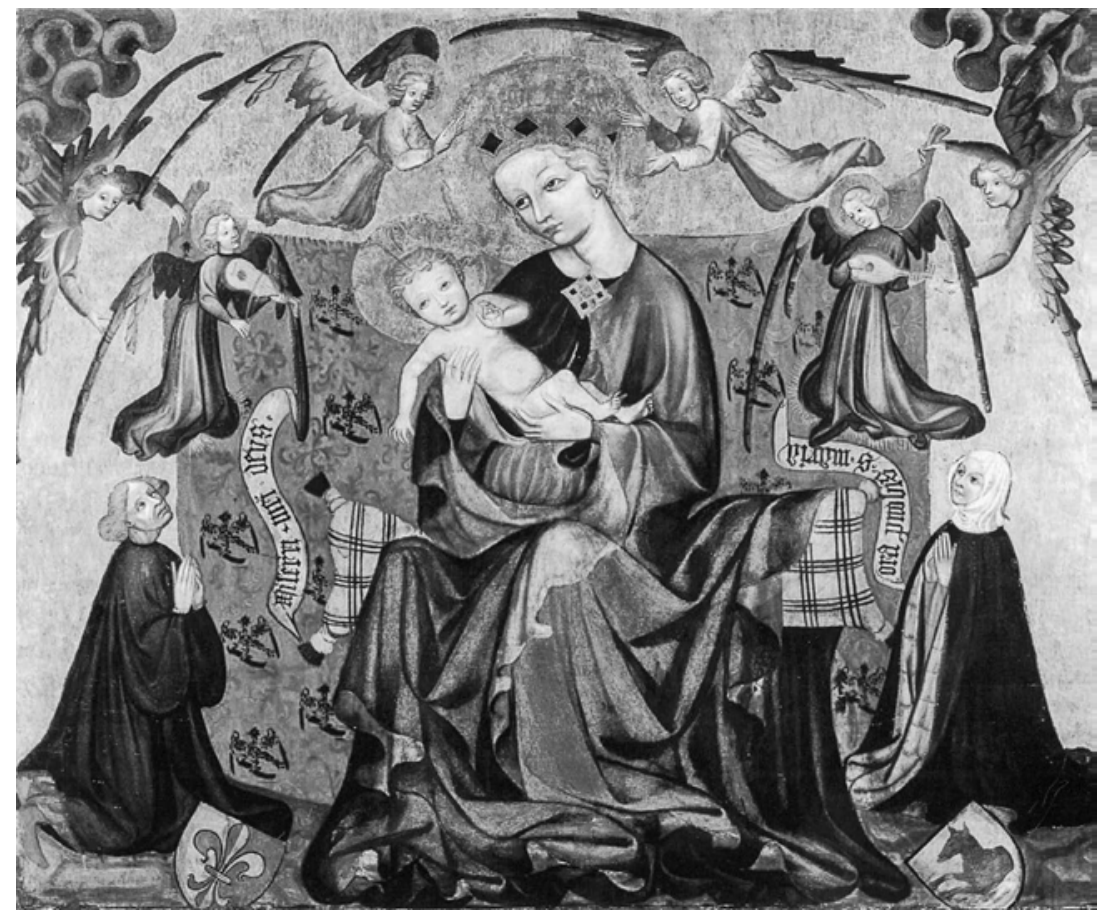

Abb. 1 Thronende Madonna mit Stiftern. Nürnberger Meister, gegen 1450. Karlsruhe, Staatliche Kunsthalle, Inv.-Nr. 2220 (Foto: Bildarchiv Manuel Teget-Welz)

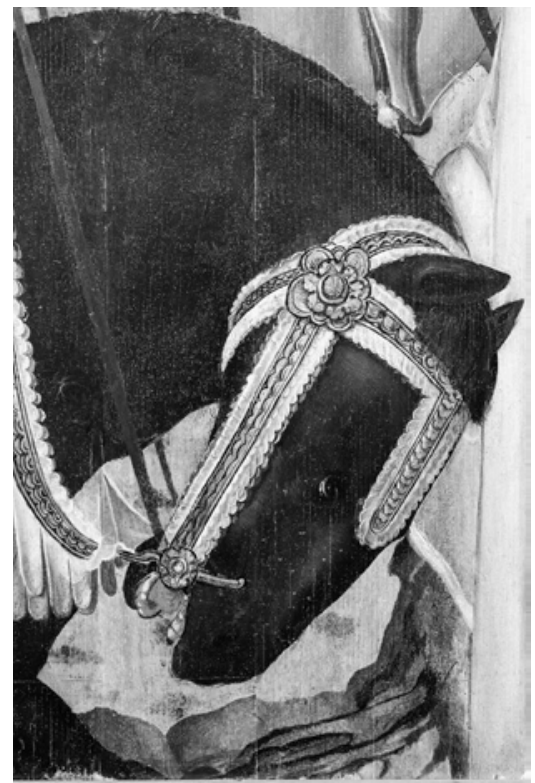

Abb. 2 Detail eines Pferdekopfs aus der Anbetung der Könige aus Höchstädt/ Donau. Augsburger Meister (?). Freising, Diözesanmuseum (Foto: Rainer A. Gimmel, Regensburg) 
Beide Tafeln messen je ca. $82 \times 110 \mathrm{~cm}$. Sie sind oben um vielleicht $10 \mathrm{~cm}$ und unten um vielleicht $25 \mathrm{~cm}$ beschnitten worden. An den Schmalseiten weisen sie ihren originalen Malrand bzw. Grundiergrat auf. Wann die Gemälde in das einheitliche »Galerieformat " gebracht wurden, ist nicht bekannt. Der Bildträger besteht aus Nadelholz, angeblich Fichte. Das Aussehen der rechten Tafel wird durch eine Restaurierung des 19. Jahrhunderts wesentlich beeinträchtigt. Bei der linken wurden der vergilbte Firnis und die großflächigen Übermalungen 1974 durch Rudolf Wackernagel abgenommen. ${ }^{6}$ Ihr Erhaltungszustand ist nicht optimal: Die Maloberfläche wirkt stark berieben, Fehlstellen sind insbesondere entlang der vertikal verlaufenden Brettfugen auszumachen, und die Vergoldung scheint aus dem 17. Jahrhundert zu stammen. Die Rückseiten wurden im 19. Jahrhundert parkettiert, nachdem man sie zuvor glattgehobelt hatte.

Dargestellt sind der Zug und die Anbetung der Heiligen Drei Könige. Die Weisen aus dem Morgenland werden von zahlreichen Bediensteten und schwer gerüsteten Soldaten begleitet. Die meisten Protagonisten erscheinen hoch zu Ross. Die drei Könige sind in vorderster Ebene dargestellt. Sie tragen luxuriöse Hoftracht, ihr Reichtum setzt sich im kostbaren Zaumzeug der Pferde fort. Der König vorne rechts ist abgesessen und kniet nieder, seine Krone hält ein Diener hinter ihm. Mit seinen Händen offeriert er eine offene Goldschatulle, die er nach rechts reicht. Dort anschließend muss sich eine Darstellung der Heiligen Familie befunden haben, mit dem Christusknaben, der die Geschenke der Könige entgegennahm.

Die Fragmente in Freising stammen laut alter, glaubwürdiger Überlieferung aus der Pfarrkirche von Höchstädt an der Donau. Erworben wurden sie 1860 durch Pfarrer Heinrich Gotthard, der sie dann 1864 dem Freisinger Priesterseminar geschenkt hat. ${ }^{7}$ Schon 1862 hatte Joachim Sighart, der »Gründungsvater « einer bayerischen Kunstgeschichte, die Gemälde publiziert, und zwar als Werke Hans Holbeins d. Ä. ${ }^{8}$ Seitdem wurden sie merkwürdigerweise kaum mehr beachtet. Alfred Stange übergeht sie offenbar in der "Deutschen Malerei der Gotik", gelistet sind sie dann immerhin im zweiten Band des Kritischen Verzeichnisses der deutschen Tafelbilder vor Dürer als »Augsburger Meister, um 1440«, allerdings ohne jeglichen begründenden Kommentar. ${ }^{9}$

Hans Ramisch machte bezüglich des Entstehungskontexts der Freisinger Fragmente auf ein Schreiben im Stadtarchiv Augsburg aufmerksam. ${ }^{10}$ Es datiert vom 22. Juni 1439 und ist gerichtet vom Rat der Stadt Augsburg an den Bürgermeister und den Rat der Stadt Höchstädt. ${ }^{11}$ Gegenstand der Korrespondenz ist "ain Taflen«, die der Augsburger Maler Jörg Aman für »den fronalltar Jn ewer pfarrkirchen «, also derjenigen von Höchstädt, gefertigt hat. Als Entlohnung waren 100 rheinische Gulden vereinbart. Nun aber erbittet sich Aman noch eine sogenannte Besserung, sprich eine Prämie oder einen Aufschlag, weil er dieses Werk hinsichtlich "gestalt vnd kostlichkeit« "vil pesser " gemacht habe und weil die vertraglich vereinbarte Summe nicht zur Deckung von Arbeits- und Materialaufwand ausreiche. Ramisch vermutete, die Tafeln in Freising könnten mit dem in der Quelle genannten Retabel für den Hochaltar von Höchstädt identisch sein, verzichtet aber auf eine nähere Erörterung. ${ }^{12}$ Die Hypothese ist verlockend, denn damit wäre ein Werk gewonnen, das mit einem der urkundlich dokumentierten Augsburger Meister verknüpft ist. Die nachgewiesene Provenienz aus Höchstädt, das nur knapp $45 \mathrm{~km}$ Wegstrecke von Augsburg entfernt liegt, scheint hier zunächst Hoffnung zu machen. Allerdings lassen sich auch Gegenargumente anführen, die zumindest skeptisch stimmen.

Zunächst wird sich das Schreiben von 1439 kaum auf die heutige Pfarrkirche von Höchstädt beziehen, denn dieser Bau wurde in seiner jetzigen Gestalt erst 1442 begonnen. ${ }^{13}$ Stattdessen dürfte die zweite und ältere Höchstädter Kirche gemeint sein, die man über 100 Jahre später, genauer gesagt 1557, abgerissen hat. Über die spätmittelalterliche Ausstattung dieses Gotteshauses konnte bislang nichts weiter in Erfahrung gebracht werden. Geweiht war es - und entsprechend vermutlich ebenso der Hochaltar nachweislich der seligen Jungfrau Maria. ${ }^{14}$ Mit diesem Patrozinium geht das Bildthema der Freisinger Tafeln, die Anbetung der Könige, nicht ganz zusammen, und leider sind auch die Nebenpatrone des Hochaltars nicht dokumentiert. Immerhin kommt der hl. Jungfrau bei der Epiphanie eine zentrale Rolle zu, und zudem gehört die Anbetung der Könige bei spätgotischen schwäbischen Retabeln mit einer auf Maria bezogenen Ikonographie quasi standardmäßig zum Bildprogramm: Derartige Darstellungen finden sich u. a. auf den Flügeln von Hans Multschers Schnitzretabeln aus Wurzach und in Sterzing sowie an Hans Schüchlins Tiefenbronner Hochaltar von 1469. ${ }^{15} \mathrm{Im}$ Fall der Freisinger Anbetung scheint es jedoch unwahrscheinlich, dass hier die Reste eines Altarflügels vorliegen. Dagegen spricht schon das Format der beiden Bildstücke, aus dem sich ein Flügelaltar von mehr als acht Metern Spannweite im geöffneten Zustand bei gerade einmal knapp einem Meter Höhe errechnen würde. In 
Abb. 3.a-b Ulrichslegende. Augsburger Meister. Augsburg, St. Ulrich und Afra (Foto: Bildarchiv M. Teget-Welz)
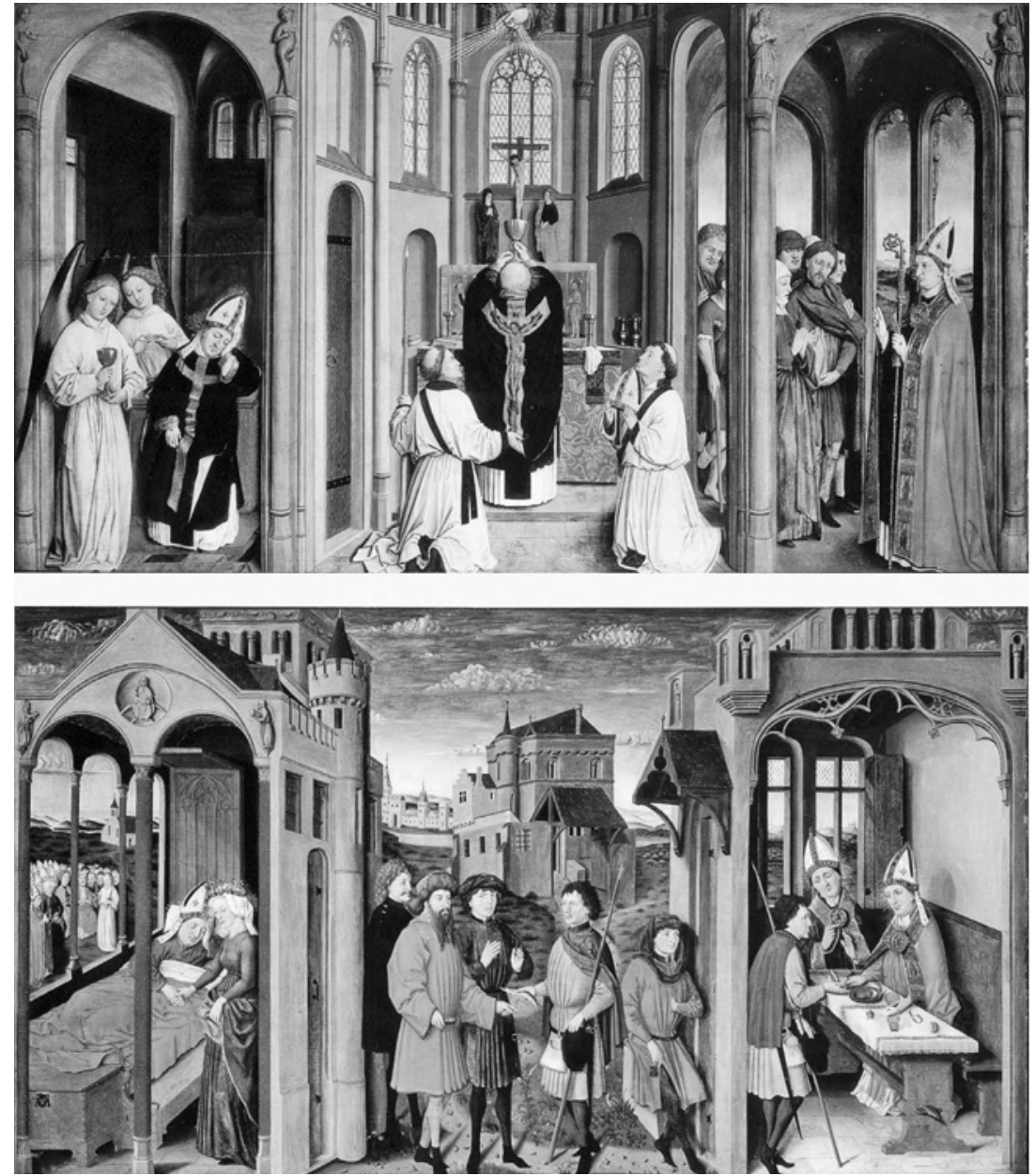

einem ca. $1 \times 4 \mathrm{~m}$ messenden Mittelstück wäre, passend zu den Freisinger Königen, die Heilige Familie zu sehen gewesen, doch sind Dimensionen und Thema meiner Meinung nach nicht miteinander zu vereinbaren.

Wesentlich plausibler erscheint ein einzelnes Tafelbild im Querformat. Rechts des zweigeteilten Reiterzugs wäre hier auf einer dritten, gleich großen Tafel die Heilige Familie zu ergänzen. Dass die Tafel dreigeteilt gewesen ist, erschließt sich daraus, dass die erhaltenen Fragmente rechts und links den originalen Malrand aufweisen. Die Zusammenfügung der Einzelstücke könnte mittels Leisten erfolgt sein. Allerdings sind groß dimensionierte Tafelbilder in einem ausgeprägten Querformat im schwäbischen Kunstkreis des 15. Jahrhunderts eine Seltenheit. Bekannt sind zumindest die beiden Tafeln mit den Wundern des hl. Ulrich in der ehemaligen Benediktinerabteikirche St. Ulrich und Afra in Augsburg von ca. 1450 (Abb. 3). ${ }^{16}$

Wie jüngst Stephan Kemperdick darlegte, handelt es sich um das Werk eines lokalen Meisters, der sich um
1440 in der Werkstatt Rogiers van der Weyden aufgehalten haben wird. ${ }^{17}$ Unklar ist: Waren die Ulrichs-Tafeln übereinander zu einem Altarretabel zusammengefügt oder schon früher, wie heute, nebeneinander an einer Wand montiert? Letztgenannte Anbringungsmöglichkeit ist auch für die Höchstädter Anbetung der Könige denkbar, diese Option wurde bereits im Freisinger Bestandskatalog erwogen. ${ }^{18}$ Für eine Bilderwand könnte die Komposition der Anbetung sprechen, die keine Akzentuierung der Mitte erkennen lässt, wie sie bei einem Altaraufsatz eigentlich zu erwarten wäre, vergleichbar etwa Stefan Lochners Kölner Dombild. Stattdessen gehorchen die Tafeln einer kontinuierlichen Leseabfolge, vom berittenen König links bis zum knienden Weisen rechts. Die Komposition könnte so auf eine plastische Darstellung Marias mit dem Christuskind, beispielweise an einem Altar im Raumzentrum, ausgerichtet gewesen sein. ${ }^{19}$

Bei formanalytischer Betrachtung fällt zunächst auf, dass die Qualität der Ausführung innerhalb der Gemälde 


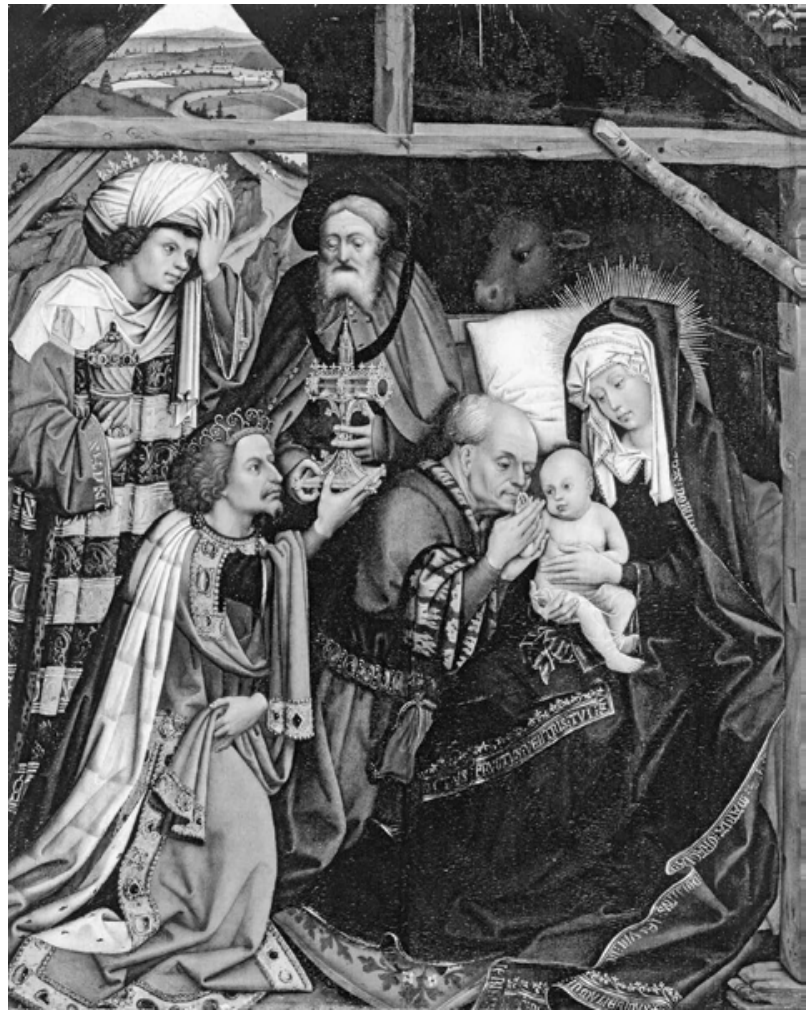

Abb. 4 Anbetung der Könige. Kopie nach Jacques Daret. Berlin, Staatliche Museen - Preußischer Kulturbesitz, Gemäldegalerie, Inv.-Nr. 538 (Foto: Bildarchiv M. Teget-Welz)

Abb. 5 Hl. Katharina. Hans Multscher. Augsburg, Maximilianmuseum (Foto: Bildarchiv M. Teget-Welz)

deutlich schwankt. So ist schwer vorstellbar, dass die gut proportionierten und durchaus überzeugend im Raum platzierten Reiterfiguren von derselben Hand wie die ungeschickt verdrehten, »hölzernen" Hintergrundakteure ausgeführt wurden. Eher dürfte hier das Resultat einer typisch spätmittelalterlichen Arbeitsteilung vorliegen. Die künstlerischen Feinheiten treten demnach primär bei den großen Gestalten zutage und hier vor allem und gerade in der Nahsicht. Auf dem linken - von Übermalungen freigelegten - Fragment lässt sich beobachten, wie bemüht detailgenau und wirklichkeitsnah Menschen und Tiere, beispielsweise der Kopf des schwarzen Pferdes (Abb. 2), ausgearbeitet wurden. Der Maler dürfte selbst genau beobachtet und verstanden haben, wie z. B. das Auge oder das geöffnete Maul eines Tieres aussehen und wie diese im Bild umzusetzen sind.

Durch seinen technisch versierten Einsatz von Höhungen und Schattierungen war er auch in der Lage, den Verlauf des Schädels unter Haut und Muskeln im Ansatz anzudeuten.

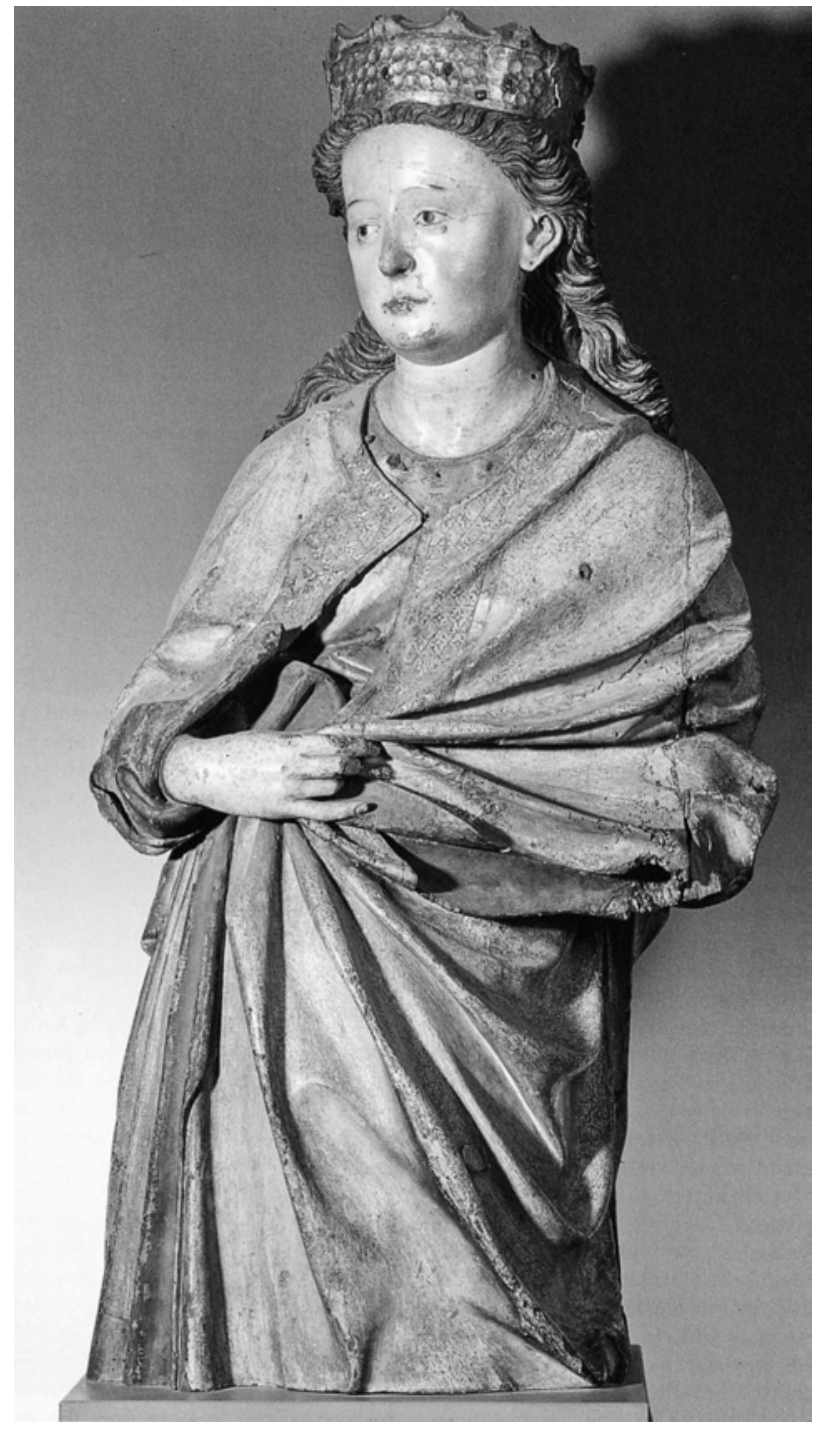

Unter Berücksichtigung des in Schwaben wie den übrigen Kunstregionen im süddeutschen Raum im 15. Jahrhundert prägenden Einflusses der Kunst der burgundischen Niederlande wird man kaum fehlgehen, wenn man bei der Höchstädter Anbetung zunächst gleichfalls von einer Orientierung an der altniederländischen Malerei ausgeht. ${ }^{20}$ Dafür sprechen auch die so unterschiedlichen wie extravaganten Kostümformen. Auffällig sind vor allem die geschlitzten Umhänge und die luxuriösen Kopfbedeckungen der Könige. Sie sind nicht ohne die burgundische Mode der Zeit denkbar und lassen sich mehrfach auch auf Tafelbildern nachweisen, beispielsweise bei Jacques Daret in einer nur in Kopie überlieferten Anbetung der Könige in Berlin (Abb. 4). ${ }^{21}$ 


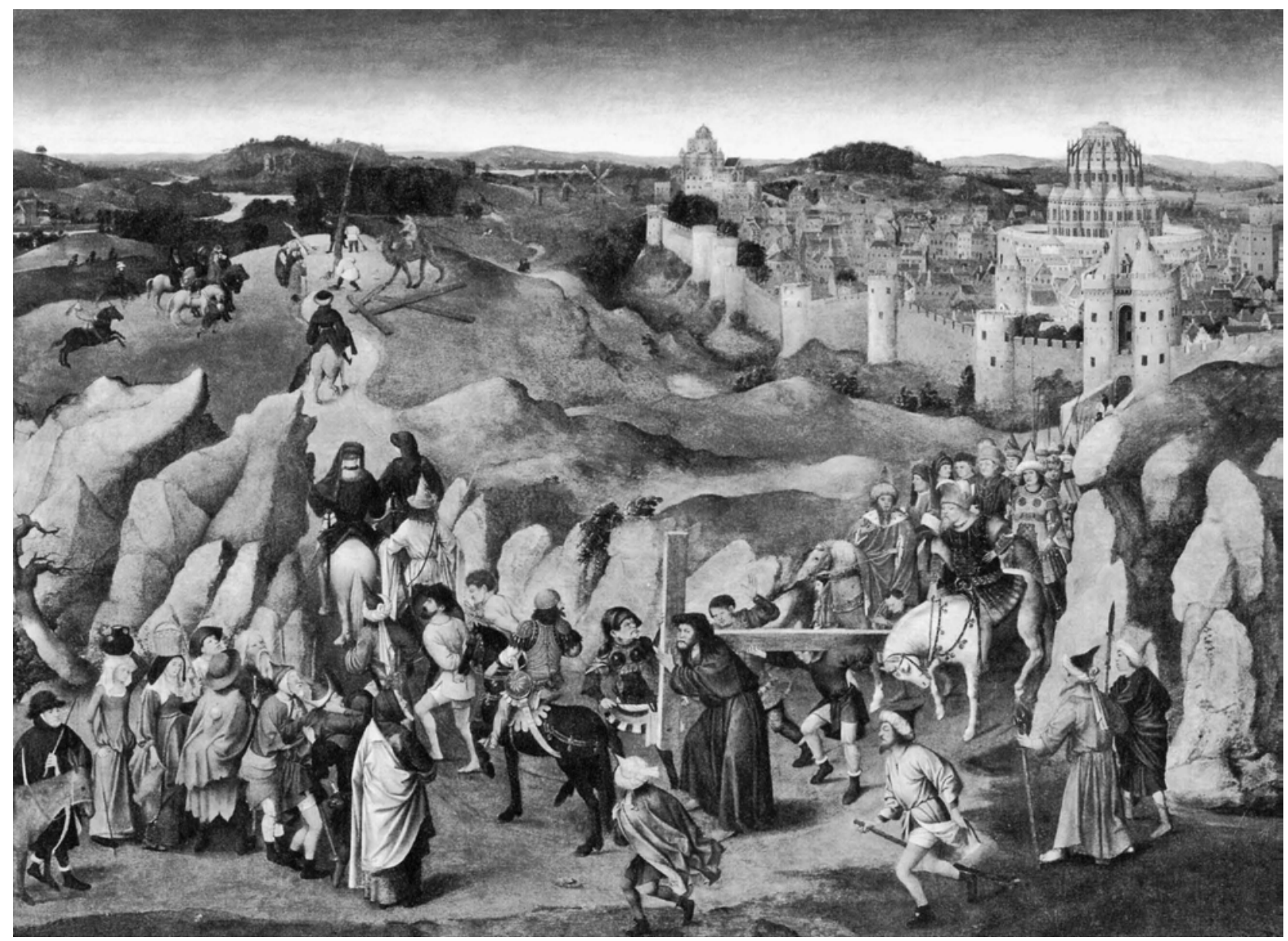

Abb. 6 Zug nach Golgatha. Kopie nach Jan van Eyck. Budapest, Szépművészeti Múzeum, Inv.-Nr. 2531 (Foto: Bildarchiv M. Teget-Welz)

Offen bleibt, ob der Höchstädter Maler selbst bis in die Niederlande gewandert ist, um hier unmittelbar Kenntnis von der neuartigen Kunstrichtung zu erlangen. Alternativ waren spätestens um 1450 niederländische Gemälde direkt in Augsburg zu studieren. Dokumentiert ist eine 1455 in Flandern für den Fronaltar von St. Ulrich und Afra bestellte Tafel. ${ }^{22}$ Zudem ist insbesondere die Rolle Hans Multschers als Vermittler der Ars Nova in Schwaben sowohl in der Skulptur als auch in der Malerei nicht hoch genug einzuschätzen. Der ab 1432 dauerhaft in Ulm ansässige Meister unterhielt beste Verbindungen nach Augsburg: Dokumentiert ist sein Export eines Palmesels nach St. Ulrich und Afra, heute in Kloster Wettenhausen bei Günzburg. ${ }^{23}$ Ebenfalls wird Multscher ein Altarretabel für die Benediktinerabtei geliefert haben, von dem sich zumindest eine fragmentierte Skulptur der hl. Katharina im Maximilianmuseum erhalten hat (Abb. 5). ${ }^{24}$

In der Diskussion um eine mögliche NiederlandeReise des Malers ist noch einmal auf dessen hypotheti- sche Identität mit dem Augsburger Meister Jörg Aman zu sprechen zu kommen. Aman lässt sich spätestens ab 1422 in der Lechstadt nachweisen und von da an durchgängig bis 1459 , ehe er nach Tegernsee abwandert. ${ }^{25}$ Dokumentiert sind daneben eine ganze Fülle von städtischen Aufträgen und Ämtern, sodass es in summa nicht leicht vorstellbar ist, ein derart viel beschäftigter Meister habe für längere Zeit seine Werkstatt allein gelassen, um - salopp formuliert - eine längere »Fortbildungsreise« zu unternehmen. Im Übrigen kann davon ausgegangen werden, dass Aman und Multscher sich persönlich kannten. Jedenfalls war es der Augsburger Maler, der 1456 für das Fassen des aus Ulm für St. Ulrich und Afra gelieferten Palmesels entlohnt wurde. ${ }^{26}$

Sigmund Benker versuchte, das Vorbild im niederländischen Kunstkreis präziser zu greifen. Aufgrund der »Würde und Körperhaftigkeit der Vordergrundfiguren" vermutete er ein verlorenes Werk der Brüder Hubert und Jan van Eyck als unmittelbares Referenzwerk. ${ }^{27}$ Sicher zu 


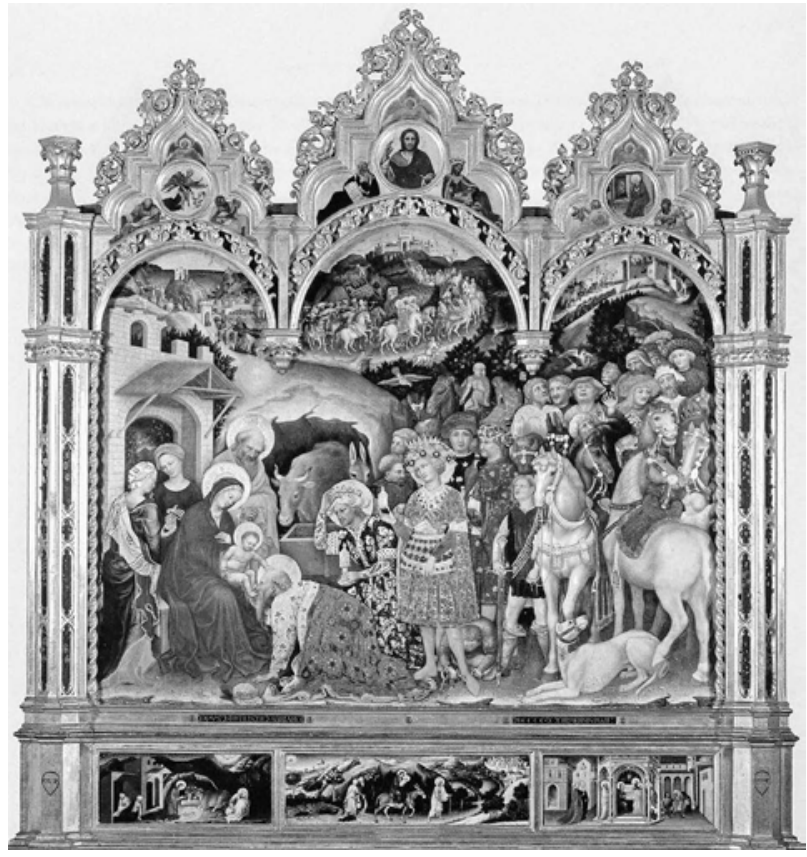

Abb. 7 Anbetung der Könige. Gentile da Fabriano. Florenz, Galleria degli Uffizi, Inv.-Nr. 1890-8364 (Foto: prometheus Bildarchiv)

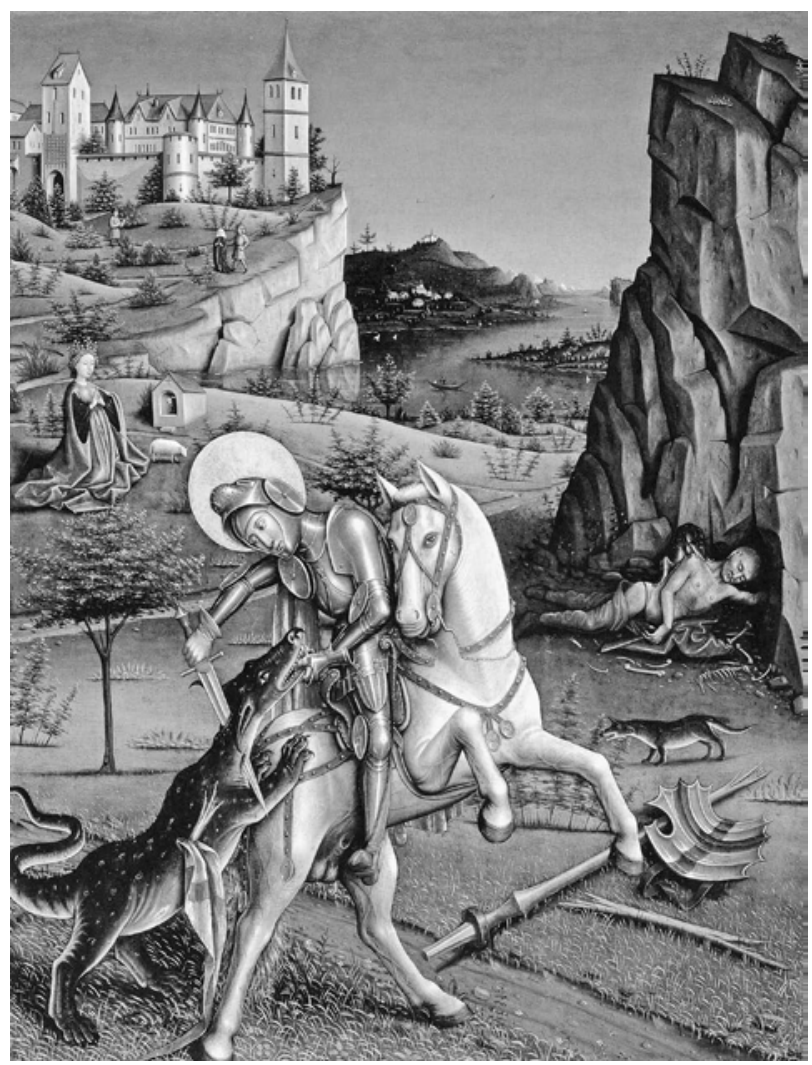

Abb. 8 HI. Georg im Drachenkampf. Meister von Sierentz. Basel, Kunstmuseum, Inv.-Nr. 31 (Foto: Bildarchiv M. Teget-Welz) oberflächlich, weil auf einer rein motivischen Übereinstimmung basierend, ist dabei der Verweis auf den Reiterzug am Genter Altar von 1432. Zwar sind vielfigurige Kompositionen in der Tat nicht untypisch für van Eyck, erinnert sei auch an den in Kopien überlieferten Zug nach Golgatha (Abb. 6). ${ }^{28}$

Allerdings mangelt es den Freisinger Tafeln an einem weitläufigen Bild- und Handlungsraum, wie er sowohl auf dem Genter Altar als auch dem verschollenen Kreuzigungszug angelegt ist. Zudem ist die Wahl der Perspektive eine andere und es fehlt van Eycks Weiträumigkeit.

Im Hinblick auf die ikonografische Tradition sollte die Besprechung der Fragmente aus Höchstädt nicht auf die altniederländische Kunst als einzige potenzielle Quelle beschränkt bleiben. Der Bildtypus der figurenreichen Anbetung mit Reiterzug lässt sich im burgundisch-niederländischen Kunstkreis zwar schon bei den Gebrüdern Limburg nachweisen, ist dann aber im fortgeschrittenen 15. Jahrhundert auch international verbreitet. ${ }^{29}$ Als vermutlich prominentestes Werk darf Gentile da Fabrianos Dreikönigsretabel von 1423 in Florenz gelten (Abb. 7).

Die Bildformel ist hier nicht unähnlich den Freisinger Tafeln angelegt, insbesondere was die Handlungsbühne im Vordergrund anbelangt. Abweichend gestaltet ist freilich das Verhältnis von Figur zu Rahmen, da in Höchstädt mit großen, flächenfüllenden Protagonisten gearbeitet wird. Mit dieser Gegenüberstellung soll natürlich nicht behauptet werden, der Höchstädter Meister sei unmittelbar von Gentile beeinflusst gewesen. Wenigstens aber sollte eine Orientierung an Vorbildern aus dem Süden nicht kategorisch ausgeschlossen werden. ${ }^{30}$ Der künstlerische Austausch zwischen Süddeutschland und Italien lässt sich bekanntlich lange vor Albrecht Dürer belegen, etwa für Gabriel Angler, der 1434 zwecks Farbenkauf nach Venedig reiste, ${ }^{31}$ oder den 1450 verstorbenen Maler Johannes von Ulm, der zusammen mit Antonio Vivarini eine gut gehende Werkstatt in der Lagunenstadt unterhalten hat. ${ }^{32}$

Stilistisch besteht vielleicht auch ein Zusammenhang mit Konrad Witz und seinem Umkreis bzw. der Nachfolge. ${ }^{33}$ Gewisse Vergleichsmöglichkeiten mit den Höchstädter Tafeln bieten die Altarflügel des sogenannten Meisters von Sierentz (Abb. 8). ${ }^{34}$

Verwandt erscheinen hier, neben den Typen, die stellenweise auffallend ungelenken bis verdrehten Körperund Armhaltungen, die bei den Höchstädter Gemälden merkwürdig deplatziert wirken. Konträr ist hingegen der Umgang mit der Landschaft, die bei den Werken in 
Freising so gut wie gar nicht inszeniert wird. Hier ist der Meister von Sierentz dem niederländischen Kunstkreis fraglos enger verbunden.

Schließlich darf bei der Diskussion der Höchstädter Gemälde die lokale, also schwäbische Kunsttradition nicht unberücksichtigt bleiben. So lässt sich bei den Gesichtstypen eine gewisse Verwandtschaft zum Werk des sogenannten Meisters der Sterzinger Altarflügel aufzeigen, der von ca. 1450 an in Ulm arbeitete. Beispielsweise steht der reitende König mit Trinkhorn, ferner auch einige der Figuren im Hintergrund, den Protagonisten auf einem Reiterzug der Heiligen Drei Könige aus Kloster Heiligkreuztal durchaus nahe (Abb. 9). ${ }^{35}$ Hier wie dort wirken die Gesichter etwas "puppenhaft« überzeichnet, in der Mimik wie "stumm«, und haben einen schmalen, dünnlippigen Mund mit zumeist auffällig nach unten gezogenen Winkeln sowie ungewöhnlich lang gezogene Nasen mit tropfenförmigen Spitzen.

Für die schwäbische Malerei der Spätgotik charakteristisch ist bei den Höchstädter Gemäldefragmenten zudem die verwendete Farbpalette. Es dominieren im Kolorit helle, klare Töne. Augenfällig ist ebenfalls der Einsatz eines kontrastierenden Lachsrosa, u. a. im geschlitzten Umhang des bärtigen Königs zu Pferd. Ein ähnlich geartetes Farbspektrum gilt als typisch für die Ulmer Tafelmalerei des 15. Jahrhunderts und begegnet schon beim Sterzinger Meister, etwas später dann auch bei Hans Schüchlin und seinen Mitarbeitern, und setzt sich noch im Pfullendorfer Altar von ca. 1510 fort. $^{36}$

Die Parallelen zwischen der Anbetung der Könige in Freising und der Ulmer Tafelmalerei sprechen nicht zwingend gegen eine Herkunft der Gemäldefragmente aus Augsburg und damit gegen ihre Identifizierung mit dem in den Quellen genannten Hochaltarretabel Jörg Amans. Bis heute herrscht eben keine klare Vorstellung von der Augsburger Tafelmalerei vor 1450, sodass sich auf Basis von Stilmerkmalen keine weiteren Schlüsse zum genaueren Entstehungsort innerhalb Schwabens ziehen lassen. Hinzu kommt, dass der künstlerische Austausch zwischen Augsburg und Ulm sehr eng gewesen sein muss, sowohl zur Multscher-Zeit als auch später, als Michael und Gregor Erhart für Augsburg arbeiteten und Hans Holbein d. Ä. 1493 für ein Jahr nach Ulm übersiedelte. ${ }^{37}$

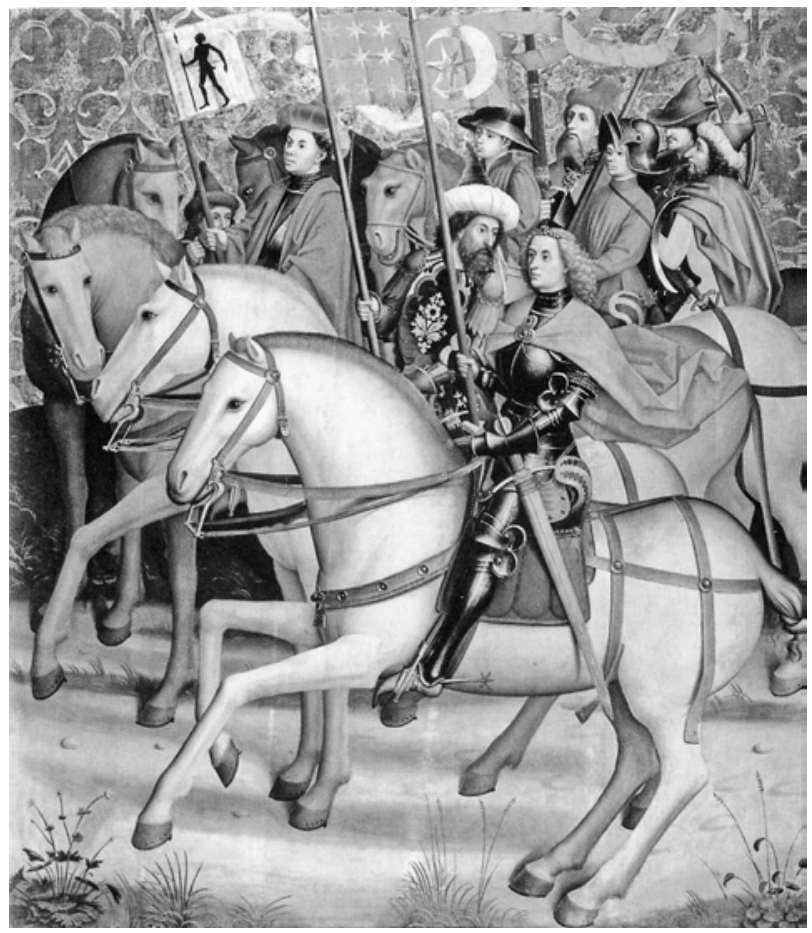

Abb. 9 Reiterzug der Könige aus Heiligkreuztal. Meister der Sterzinger Altarflügel. Stuttgart, Staatsgalerie, Inv.-Nr. 32 (Foto: Bildarchiv M. Teget-Welz)

\section{Literatur}

[Ausst.-Kat. Basel 2007]: Ausst.-Kat. Kreis und Kosmos. Ein restauriertes Tafelbild des 15. Jahrhunderts. Bearb. von Stephan Kemperdick, unter Mitarbeit von Amelie Jensen. Basel, Kunstmuseum, 18.8.-11.11.2007. Petersberg b. Fulda 2007.

[Ausst.-Kat. Basel 2011] : Ausst.-Kat. Konrad Witz. Bearb. von Peter Berkes, Bodo Brinkmann u. a. Basel, Kunstmuseum, 6.3.-3.7.2011. Ostfildern 2011.

[Ausst.-Kat. Brügge 2010]: Ausst.-Kat. Van Eyck bis Dürer. Altniederländische Meister und die Malerei in Mitteleuropa. Hg. von Till-Holger Borchert. Brügge, Groeningemuseum, 29.10.2010-30.1.2011. Tielt/Brügge/Stuttgart 2010.

[Ausst.-Kat. Frankfurt a. M./Berlin 2008]: Ausst.-Kat. Der Meister von Flémalle und Rogier van der Weyden. Hg. von Stephan Kemperdick und Jochen SANder. Frankfurt/M., Städel Museum, 22.11.2008-22.2.2009; Berlin, Gemäldegalerie der Staatlichen Museen, 20.3.2009-21.6.2009. Ostfildern 2008.

[Ausst.-Kat. Rotterdam 2012]: Ausst.-Kat. De weg naar Van Eyck/The Road to Van Eyck. Bearb. von Stephan KEM- 
Perdick und Friso Lammertse. Rotterdam, 13.10.201213.1.2013. Rotterdam 2012.

[Ausst.-Kat. Ulm 1997] : Ausst.-Kat. Hans Multscher. Bildhauer der Spätgotik in Ulm. Hg. von Brigitte Reinhardt. Ulm, Ulmer Museum, 7.9.-16.11.1997. Ulm 1997.

[Ausst.-Kat. Ulm 2002]: Ausst.-Kat. Michel Erhart und Jörg Syrlin d. Ä. Spätgotik in Ulm. Hg. von Brigitte ReinHardT und Stefan Roller. Ulm, Ulmer Museum, 8.9.-17.11.2002. Stuttgart 2002.

Baumann-Engels, Marianne u.a.: Diözesanmuseum Freising. Christliche Kunst aus Salzburg, Bayern und Tirol. 12. bis 18. Jahrhundert. Freising 1984 (Diözesanmuseum für Christliche Kunst des Erzbistums München und Freising. Kataloge und Schriften 2).

Bosch, Dietlinde: Bartholomäus Zeitblom. Das künstlerische Werk. Ulm 1999 (Forschungen zur Geschichte der Stadt Ulm 30).

Brinkmann, Bodo/Kemperdick, Stephan: Deutsche Gemälde im Städel. 1500-1550. Mainz 2005 (Kataloge der Gemälde im Städelschen Kunstinstitut Frankfurt am Main 5).

Buchner, Ernst: Die Augsburger Tafelmalerei der Spätgotik. In: Buchner/Feuchtmayr 1928, 1-92.

Buchner, Ernst/Feuchtmayr, Karl (Hgg.): Augsburger Kunst der Spätgotik und Renaissance. Augsburg 1928 (Beiträge zur deutschen Kunst 2).

Glaser, Curt: Italienische Bildmotive in der altdeutschen Malerei. In: Zeitschrift für Bildende Kunst N. F. 25 (1914), $145-158$.

Hartig, Otto: Münchner Künstler und Kunstsachen, Teil 1. Auszüge aus Archivalien und handschriftlichen Aufzeichnungen der staatlichen und städtischen Archive und Bibliotheken Münchens. Nebst Ergänzungen aus der gedruckten Literatur. In: Münchner Jahrbuch der bildenden Kunst N. F. 3 (1926), 273-370.

Krause, Katharina: Hans Holbein der Ältere. München 2002 (Kunstwissenschaftliche Studien 101).

MAIER-Lörcher, Barbara: Ulmer Kunst in aller Welt. Plastische Bildwerke des 15. und 16. Jahrhunderts. Ulm 1996.

Meyer, Werner: Landkreis Dillingen an der Donau. München 1972 (Die Kunstdenkmäler von Schwaben 7).

Moraht-Fromm, Anna: Ulmer Künstlerkollektive. Michel Erhart und die Malerei. In: Ausst.-Kat. Ulm 2002, 146-153.

Moraht-Fromm, Anna: Das Erbe der Markgrafen. Die Sammlung deutscher Malerei (1350-1550) in Karlsruhe. Ostfildern 2013.

Rettich, Edeltraud/Klapproth, Rüdiger/Ewald, Gerhard: Staatsgalerie Stuttgart. Alte Meister. Stuttgart 1992.

Roller, Stefan/Weilandt, Gerhard: Der Dreikönigsaltar in St. Lorenz und Hans Pleydenwurff. In: Schmidt/Stolz 2004, 35-44.
Schмidt, Christian/Stolz, Georg (Hgg.): Hundert Jahre Verein zur Erhaltung der St. Lorenzkirche 1903-2003. Sammelband der Referate des Kolloquiums aus Anlass des Vereinsjubiläums. Nürnberg 2004 (Schriftenreihe des Vereins zur Erhaltung der St. Lorenzkirche in Nürnberg 2).

SigharT, Joachim: Geschichte der bildenden Künste im Königreich Bayern von den Anfängen bis zur Gegenwart. München 1862 .

STANGE, Alfred: Kritisches Verzeichnis der deutschen Tafelbilder vor Dürer, Bd. 2. Oberrhein, Bodensee, Schweiz, Mittelrhein, Ulm, Augsburg, Allgäu, Nördlingen und von der Donau zum Neckar. München 1970.

Teget-Welz, Manuel: Martin Schaffner. Leben und Werk eines Ulmer Malers zwischen Spätmittelalter und Renaissance. Diss. Erlangen 2007; Stuttgart 2008 (Forschungen zur Geschichte der Stadt Ulm 32).

Tripps, Manfred: Hans Multscher. Seine Ulmer Schaffenszeit 1427-1467. Weißenhorn 1969 (Forschungen zur Geschichte der Stadt Ulm 8).

Wilhelm, Johannes: Augsburger Wandmalerei 1368-1530. Künstler, Handwerker und Zunft. Augsburg 1983 (Abhandlungen zur Geschichte der Stadt Augsburg 29).

\section{Anmerkungen}

1 BuChNER 1928, 1-6.

2 Inv.-Nr. 2220.-Stange 1970, 148, Kat.-Nr. 670.-Moraht-Fromm 2013, 179-182.

3 Moraht-Fromm 2013, 181.

4 Wilhelm 1983.

5 Inv.-Nr. P 220, 221. - StAnge 1970, 149, Kat.-Nr. 676. - BAUMANNENGELS u.a. 1984, 54 f. mit weiterer Literatur (Sigmund BENKER/ Hans Ramisch).

6 Alle Angaben zu Technik und Zustand sind entnommen dem unpublizierten Restaurierungsbericht von Rudolf Wackernagel, München, vom 6.12.1974.

7 Baumann-Engels u.a. 1984, 55 (Sigmund Benker).

8 Sighart $1862,596$.

9 Stange 1970, 149, Kat.-Nr. 676.

10 Baumann-Engels u. a. 1984, 55 (Hans Ramisch).

11 Stadtarchiv Augsburg. Sign. Reichstadt, SCH. Nr. 105/IVa. Ediert bei Wilhelm 1983, 670, Beilage IX.

12 Baumann-Engels u. a. 1984, 55 (Hans Ramisch).

13 Mitgeteilt in einer alten Bauinschrift. MEYER 1972, 388.

14 Meyer 1972, 385.

15 Stange 1970, 121 f., Kat.-Nr. 554; 124, Kat.-Nr. 569; 128, Kat.-Nr. 585.

16 Stange 1970, 146, Kat.-Nr. 677.

17 Ausst.-Kat. Basel 2007, 21-28, 57, Kat.-Nr. 2 (Stephan KemperDICK).

18 Baumann-Engels u.a. 1984, 54 (Sigmund Benker), 54.

19 Mündlicher Vorschlag zur Rekonstruktion von Stephan Kemperdick vom 19.9.2013. Einschränkend ist zu bemerken, dass die Komposi- 
tion weniger dem Anbringungsort, sondern primär der vorbildhaft wirkenden Bildtradition geschuldet sein dürfte, worauf im Folgenden eingegangen wird.

20 Zur Niederlanderezeption in Schwaben vgl. zuletzt Ausst.-Kat. Brügge 2010, bes. 277-284 (Anna Moraht-Fromm).

21 Berlin, Staatliche Museen - Preußischer Kulturbesitz, Gemäldegalerie. Inv.-Nr. 538. - Ausst.-Kat. Frankfurt a. M./Berlin 2008, 258-261, Kat.-Nr. 14 (Antje-Fee KöllermanN).

22 Wilhelm 1983, 29.

23 Tripps 1969, 250, 270, Kat.-Nr. 23. - MAier-LörCher 1996, 40.

24 Ausst.-Kat. Ulm 1997, 324-326, Kat.-Nr. 24 (Elisabeth Krebs).

25 Wilhelm 1983, 398-401, Kat.-Nr. 8.

26 Tripps 1969, 250. - Wilhelm 1983, 400.

27 Baumann-Engels u. a. 1984, 54 (Sigmund Benker).

28 U. a. Budapest, Szépművészeti Múzeum, Inv.-Nr. 2531. - Ausst.-Kat. Rotterdam 2012, 307, Kat.-Nr. 88 (Friso LaMmerTSE).

29 Zur Rezeption des Bildtypus im süddeutschen Raum vgl. auch RoLLER/WEILANDT 2003, $37 \mathrm{f}$.
30 Zum künstlerischen Austausch Süddeutschlands mit Italien vor Dürer noch immer lesenswert ist GLASER 1914.

31 Hartig 1926, 309, Kat.-Nr. 147.

32 Teget-Welz 2008, 101.

33 Freundlicher Hinweis von Ulrich Söding, München, und Christof Metzger, Wien, vom 19.7.2013.

34 Basel, Kunstmuseum, Inv.-Nr. 31. - Stange 1970, 26, Kat.-Nr. 29 Ausst.-Kat. Basel 2011, 275-284, Kat.-Nr. 59 (Katharina Georgi).

35 Stuttgart, Staatsgalerie, Inv.-Nr. 32. - STANGE 1970, 124, Kat.-Nr. 568 - Rettich/Klapproth/Ewald 1992, 262 (Edeltraut Rettich).

36 Frankfurt a. M., Städel Museum. Inv.-Nr. SG 453 f., 555 f.. - Stuttgart, Staatsgalerie. Inv.-Nr. 1703 f., 3388 f.. - Bosch 1999, 275-302, Kat.-Nr. 26. - BRINKMANN/KeMPERDICK 2005, 477-502 (Stephan KeMPERDick),

37 Krause 2002, 325. - Moraht-Fromm 2002. 

MARKuS HöRSCH

\section{Zu Art und Umfang eines Realismus als konstituierendem Merkmal des Werks des Meisters der Karlsruher Passion}

\begin{abstract}
»Die Geste der äußern Lebensbewegung war sein Ausdrucksgebiet. Seine Phantasie neigt den sichtbar gewordenen menschlichen Affekten zu.» Lilli Fischel ${ }^{1}$
\end{abstract}

Spätestens mit Lilli Fischels $(1891-1978)^{2}$ bis heute lesenswerter Monografie von $1952^{3}$ wurde die Karlsruher Passionsfolge ${ }^{4}$ (Abb. 1-3, 5-8 und Beitrag Vlachos, Abb. 6), für die Forschung zu einem zentralen Werk der oberrheinischen Malerei des mittleren 15. Jahrhunderts. Zudem gelang es in glücklicher Ankaufspolitik der Karlsruher Kunsthalle zunächst fünf Tafeln der Serie ${ }^{5}$ nach und nach zu erwerben und zuletzt 1999 die lange in Privatbesitz verschollene Geißelung Christi hinzuzufügen. ${ }^{6}$

Durch die Leihgabe des Wallraf-Richartz-Museums Köln ${ }^{7}$ wurden alle erhaltenen Tafeln in Karlsruhe vereint. Zuvor war der Zyklus nach erfolgter Restaurierung in einer Jubiläumsausstellung 1996 ausführlich gewürdigt worden. ${ }^{8}$

Diese Aufmerksamkeit kommt nicht von ungefähr und sie ist gewiss nicht unverdient - malerische Qualität und erzählerische Lebendigkeit der Karlsruher Passion haben schon die Zeitgenossen des 15. Jahrhunderts immer wieder auf Werke des "Meisters der Karlsruher Passion" zurückgreifen lassen. ${ }^{9}$ Freilich rückt durch helle Beleuchtung anderes vielleicht zu sehr in den Schatten, und sei es nur die Tatsache, dass von der gesamten oberrheinischen Tafelmalerei verschwindend wenig erhalten ist. Auch sind die Kontexte, denen die Tafelbilder entstammten, anders als beispielsweise bei der Glasmalerei, meist nur mühsam rekonstruierbar. Immerhin, im Falle der Karlsruher Passion hat akribische Forschung einige Erkenntnisse gesammelt und plausible Hypothesen erstellt. Im Folgenden sollen einige Aspekte der Forschungsgeschichte resümiert und mit dem Vorsatz diskutiert werden, das bisher Erreichte nicht im Klischee erstarren zu lassen. Dem dienen verschiedene Ansätze: zuvorderst der Versuch, den »Realismus« der Karlsruher Passion noch einmal genauer zu greifen, dann die Rekonstruktion einer ursprünglichen Anordnung der Tafeln vor dem Hintergrund von

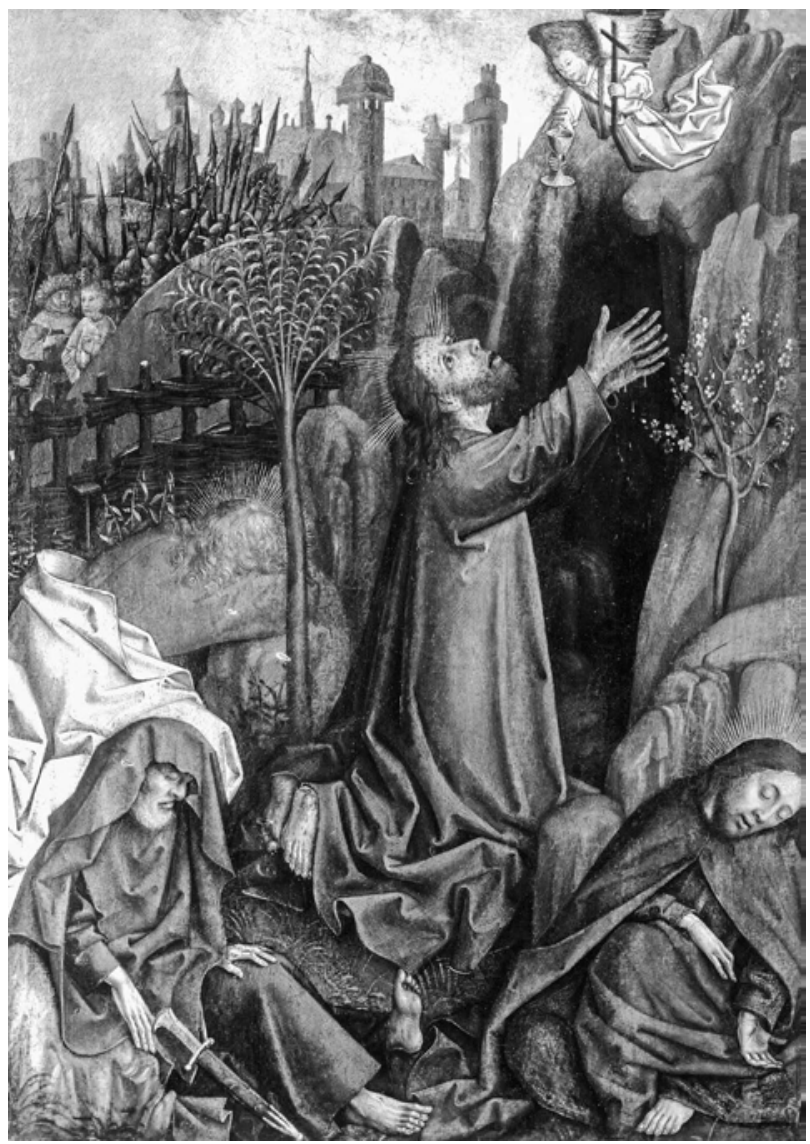

Abb. 1 Christi Gebet am Ölberg. Erste Tafel der Karlsruher Passion. Karlsruhe, Staatliche Kunsthalle, Inv.-Nr. 2436 (ex: Ausst.-Kat. Karlsruhe 1996)

Anna Moraht-Fromms neuer Hypothese und schließlich die Frage, ob sich historische wie kunsthistorische Einordnung der Tafeln künftig noch ein wenig genauer fassen lassen, nicht zuletzt im Kontext zeitgenössischer Straßburger Glasmalerei. 


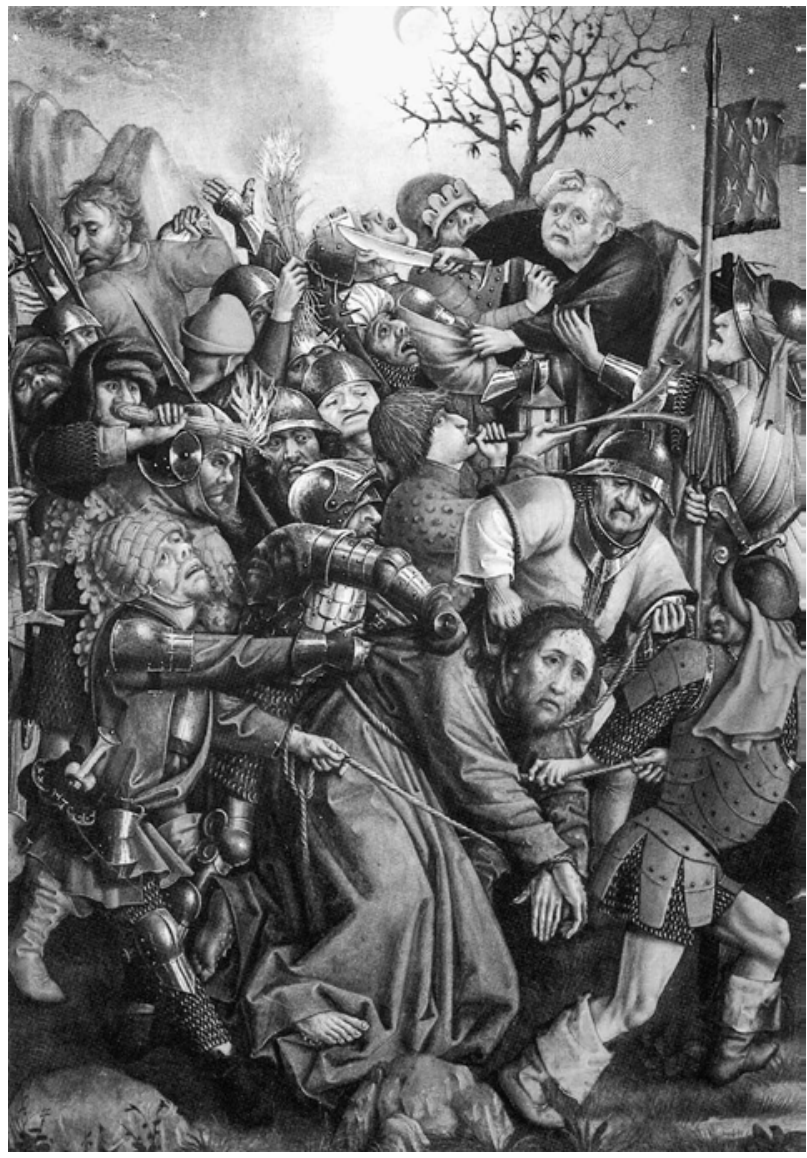

Abb. 2 Gefangennahme Christi. Zweite Tafel der Karlsruher Passion. Karlsruhe, Staatliche Kunsthalle (Leihgabe Köln, Wallraf-Richartz-Museum, Inv.-Nr. WRM 585) (ex: Ausst.-Kat. Karlsruhe 1996)

\section{Zum »Realismus« der Karlsruher Passion vor dem Hintergrund der Darstellungstradition}

Den »Realismus" der Karlsruher Passion haben alle, die sich mit ihr beschäftigten, herausgestellt. So spricht Alfred Stange davon, der Meister sei »mehr Realist als (Konrad) Witz und (Hans) Multscher«, seine beiden berühmteren Zeitgenossen, ja »nichts als Realist will er anscheinend sein $\ll^{10}$ - ohne dies freilich zu präzisieren. Bei den früheren Autoren wird dieser sogenannte Realismus zumeist mit »Derbheit « und »Bäuerischkeit» konnotiert. ${ }^{11}$ Zurecht bemängelt also Friederike Blasius im Vorwort ihrer Dissertation, ${ }^{12}$ der Begriff Realismus werde im Zusammenhang mit der Karlsruher Passion unreflektiert verwendet. Leider verspielte sie die Chance, zur Klärung der Begriffe beizutragen, indem sie die von ihr wiederum als sehr krass empfundene und beschriebene Darstellungsweise der Karlsruher Passion unver-

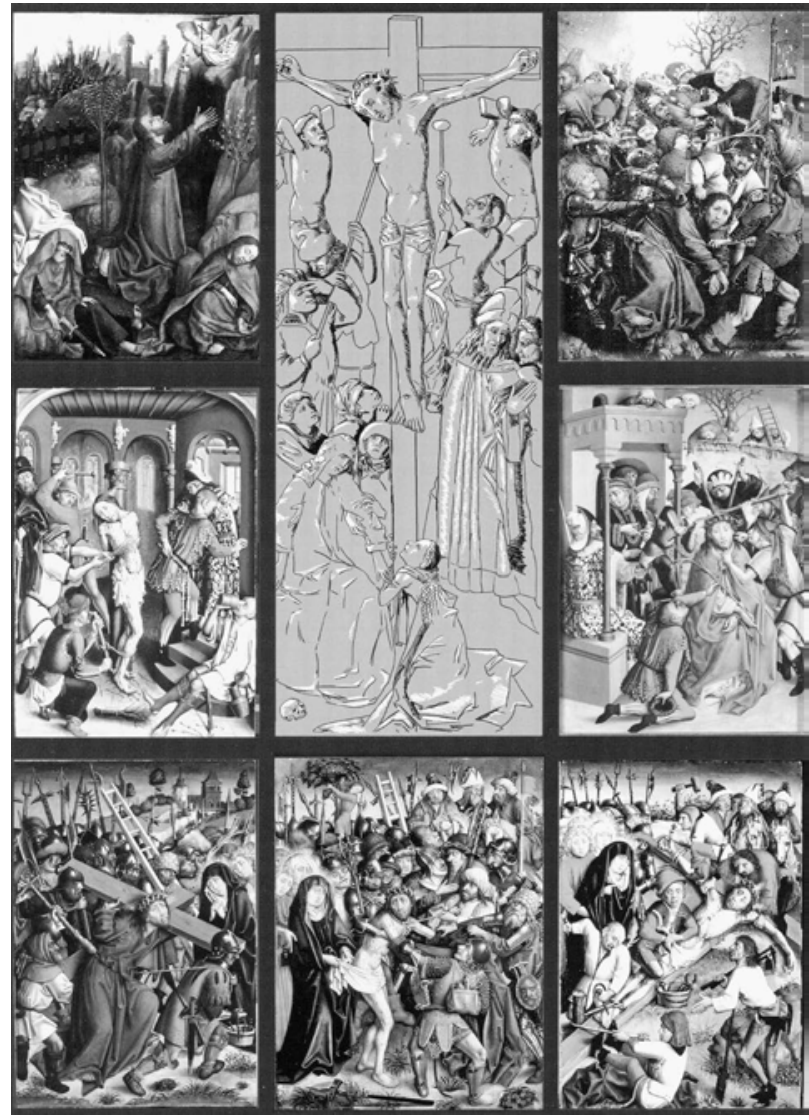

Abb. 3 Die Karlsruher Passion. Rekonstruktion einer Altartafel mit ergänzter Kreuzigung (ex: MORAHT-FROMM 2013)

mittelt mit Intentionen verband, was schon in den Überschriften ihrer Kapitel anklingt: So unterstellte sie dem Meister Polemik gegen die unteren sozialen Schichten, ${ }^{13}$ gegen die marodierenden Armagnaken und den oberrheinischen Adel, ${ }^{14}$ gegen die Juden, ${ }^{15}$ weil entsprechende Gestalten unter den negativ bewerteten Figuren der Passionsszenen auftauchen. Solch kurzschließende Verknüpfung historischer Phänomene mit einer als neuartig herausgestellten Kunst geht an der Wirklichkeit der Entstehung von Bilderfindungen gewiss zu einem wesentlichen Teil vorbei.

Robert Suckale hat die Darstellungsweisen, die damals (nicht nur) den »oberdeutschen« Raum erfassten, im Rückgriff auf Erich Auerbach mit dem Ausdruck des "Passionsrealismus « zu fassen versucht, ${ }^{16}$ welcher auch in vielen anderen Werken der Zeit - der Worcester-Kreuztragung in Chicago, ${ }^{17}$ dem Tegernseer Hochaltar des Gabriel Angler, ${ }^{18}$ dem Wurzacher Altar des Hans Multscher ${ }^{19}$ 
usf. - in jeweils individueller Form, aber als prinzipiell gleichartiges Phänomen anzutreffen sei.

Allerdings wäre ein wesentlicher Aspekt der von Suckale erfassten Darstellungsweise der Passion, d.h. eine Verähnlichung des biblischen Geschehens mit jeweiligen zeitgenössischen Gepflogenheiten oder Moden, zeitlich weiter auszudehnen: Schon in vielen Malereien des 14. Jahrhunderts tragen die Schergen der Passion zeitgenössische Kleidung, treten andere der beschriebenen Charakteristika auf. ${ }^{20}$ So hat bereits vor dem reichen Vergleichsmaterial, das Wolfgang Lüdke im Ausstellungskatalog von 1996 sammelte, Michael Wolfson auf die zugrundeliegenden Bildtypen und Abweichungen von diesen verwiesen. ${ }^{21}$ Damit folgte er der Erkenntnis, dass es eigene Bildtraditionen gibt, die sich nicht unbedingt immer wieder aufs Neue an den biblischen, apokryphen oder legendarischen Texten ausrichteten. Zugleich aber führte Wolfson auch erstmals eingehender aus, dass die Kunst des Straßburger Malers nur vor dem Hintergrund der zeitgenössischen Passionsfrömmigkeit zu verstehen sei. Speziellen Einfluss schrieb er der Schrift über das Leben Christi des Kartäusers Ludolf von Sachsen $(\dagger 1377)$ zu, der lange in Straßburg gelebt hatte und dessen Werk in verschiedenen Klöstern der Stadt nachzuweisen ist. ${ }^{22}$ Suckale hingegen verwies, eben im Sinne einer eigenständigen Bildtradition und zugleich künstlerischer Innovationen, darauf, dass die Bibelliteratur (Meditationes Vitae Christi des Pseudo-Bonaventura, Ludolf von Sachsen, Birgitta von Schweden) zwar »karge Bibeltexte zu lebendiger Erzählung « machten, wie wir dies auch in den hier vorgestellten Bildern in einer Parallelerscheinung feststellen können, dass aber die Verbindung solcher Texte zu den neuen Bildern nicht zu direkt gesehen werden sollte. ${ }^{23}$

Lilli Fischel hat sich der Karlsruher Passion in einer bisher kaum übertroffenen sprachlichen Charakterisierung genähert; dies kann hier selbstverständlich nicht in derselben Ausführlichkeit geschehen. Doch sei zunächst noch einmal der Versuch unternommen, zu verdeutlichen, was denn eigentlich die von den meisten Autoren so betonte "realistische« Seite der Karlsruher Passion ausmacht, worin die Aufnahme von Gegenständen und Themen der sozialen und historischen Wirklichkeit besteht, die wir mit dem Wort »realistisch» bezeichnen.

Durch die klassische kunsthistorische Methode des Vergleichens mit Darstellungen verwandten Themas versuchte man zunächst kunsthistorische Chronologien zu erstellen und Abhängigkeiten aufzuzeigen. So sah Alfred

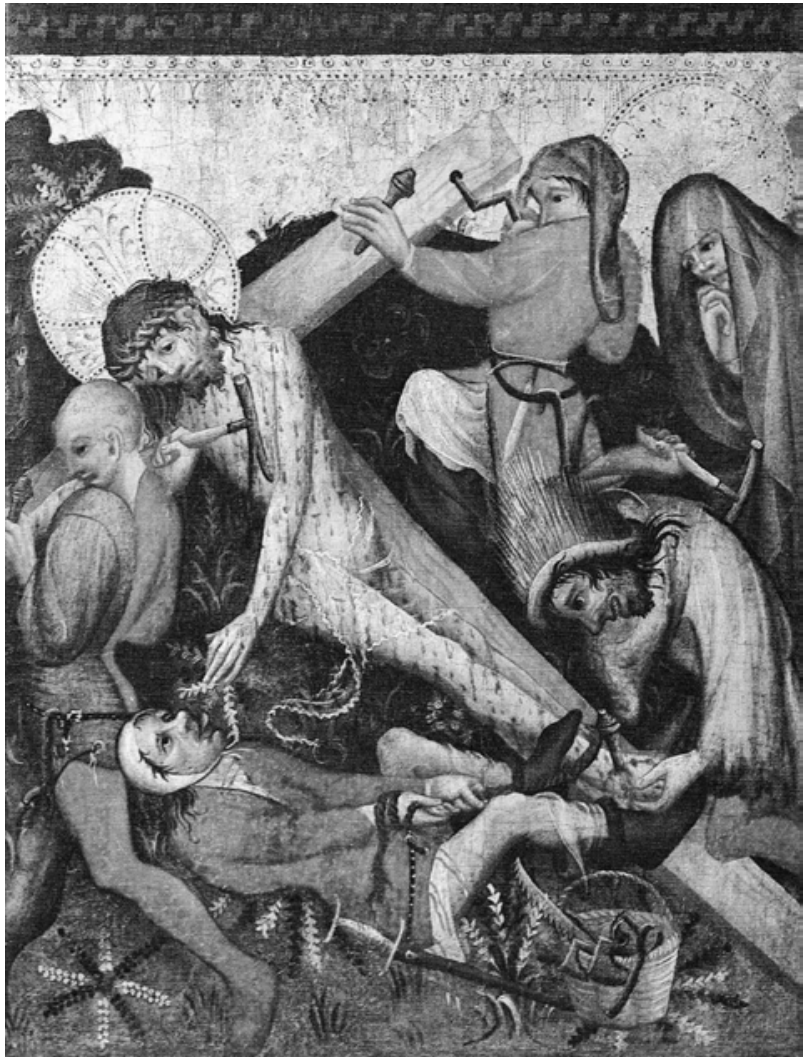

Abb. 4 Kreuzannagelung. Idar-Oberstein, Felsenkirche, Retabel (Foto: Archiv M. Hörsch)

Stange in dem Maler des Passionsretabels der Felsenkirche von Idar-Oberstein, das wohl zu Beginn des 15. Jahrhunderts entstanden ist, ${ }^{24}$ den Lehrmeister des Meisters der Karlsruher Passion; wohl weil er meinte, ein Maler von so heftiger Ausdrucksweise müsse einen noch »brutaleren« Lehrer gehabt haben. Da kam die "wilde Dramatik» der Obersteiner Bilder gerade recht. ${ }^{25}$ Stange behauptete, bei der Kreuzannagelung gingen die Ähnlichkeiten zwischen dem Obersteiner Altar und dem Karlsruher Bild bis in die Details: Es ist aber nicht mehr zu entdecken als eine gewisse Übereinstimmung des Darstellungstyps; die Darstellungsweise ist völlig verschieden.

Die Flügelbilder ${ }^{26}$ des Obersteiner Altars (Abb. 4 und Beitrag Vlachos, Abb. 3) sind von ausgesprochener Ruppigkeit; wenige Figuren agieren auf einer schmalen Bodenfläche vor nicht näher definiertem Horizont; der Himmel ist als Goldgrund gegeben.

Die Komposition ist unausgewogen und nimmt keinerlei Rücksicht auf den Betrachter: Der Blick wird gleich von dem stehenden Schergen im blau-roten Mi-parti-Gewand aufgefangen; die räumliche Situation ist dem Maler 


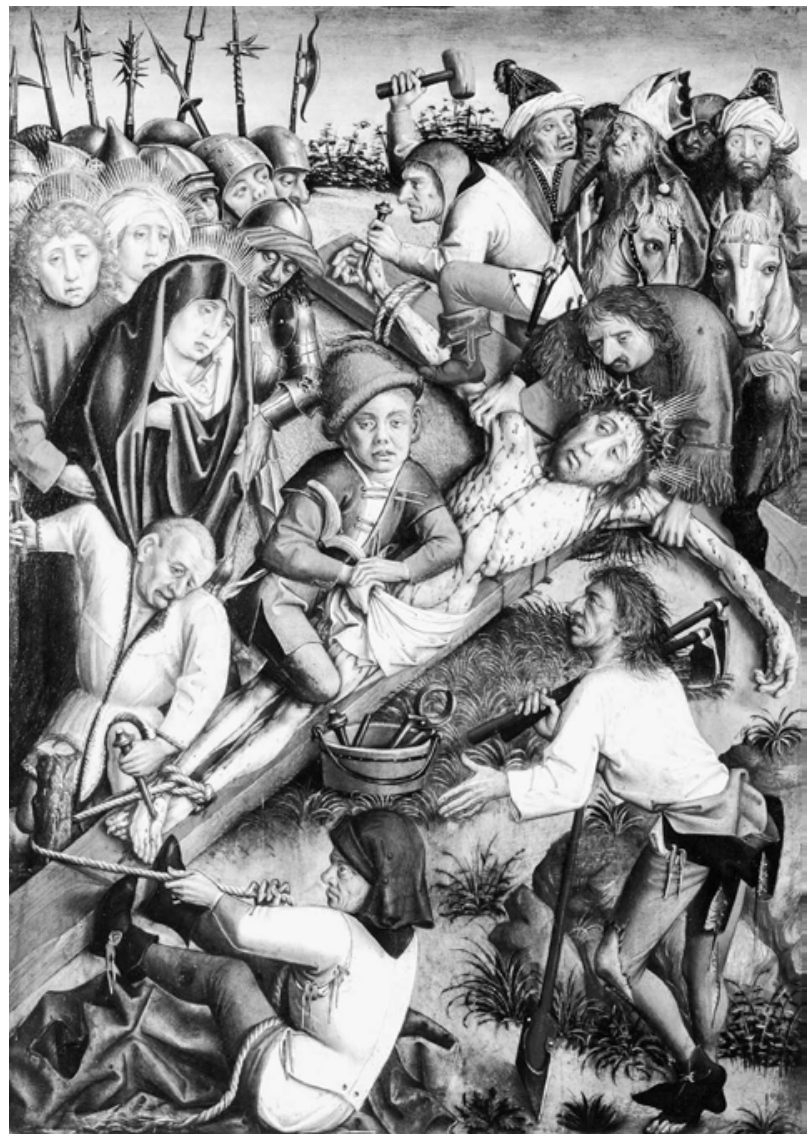

Abb. 5 Kreuzannagelung. Siebte Tafel der Karlsruher Passion. Karlsruhe, Staatliche Kunsthalle, Inv.-Nr. 1375 (ex: Ausst.-Kat. Karlsruhe 1996)

gleichgültig: Das Kreuz wird in die vordere Bildebene geklappt, der linke Arm Christi hängt in die linke Bildhälfte herunter, der liegende Scherge überschneidet mit dem Kopf den stehenden, rechts beugt sich noch Maria ins Bild. Man beachte auch den in Kreuzannagelungen häufig vorkommenden Schergen, der sich weit zurücklehnt und an einem Seil, das er sich zweimal um das rechte Handgelenk gewickelt hat, zieht, um den Körper Christi zum Annageln in die richtige Position zu strecken. Um mehr Kraft zu haben, stemmt er sich mit den Füßen am Kreuzesstamm ab. Der Maler der Karlsruher Passion hat sich zu derselben Figur, die nicht selten vorkommt (es sei nur an die der Karlsruher Passion in vielen ikonografischen Details verwandte Seite aus dem Sobieski-Stundenbuch des Bedford-Meisters in Windsor erinnert ${ }^{27}$ ), überlegt, dass der Strick, an dem der Scherge unten zieht, eine Führung braucht, da er sonst den Leib Christi nicht strecken, sondern vom Kreuzesbalken herunterziehen würde - wie es auf dem Obersteiner Altar de facto sein müsste.
Auf eine naturnachahmende Räumlichkeit kommt es auch dem Maler der Karlsruher Passion nicht primär an. Aber er komponiert seine Bilder so, dass der Betrachter bei der Vielzahl der Einzelheiten leicht den Sinn der Darstellung ablesen kann. Der Kreuzbalken der Annagelung (Abb. 5) leitet den Blick über den Körper auf das Haupt Christi; der Scherge darüber und die drei dahinter bzw. darüber aufgereihten Reiter (deren räumlicher Zusammenhang mit der eigentlichen Annagelungsszene unklar bleibt) stoppen diesen Blickweg.

Christus bleibt kompositorischer und inhaltlicher Mittelpunkt. Rechts vorn steht ein Scherge mit Hacken und Spaten, der drauf wartet, das Kreuz aufrichten zu können, und zugleich den Blick des Betrachters ins Geschehen zurücklenkt. Ein weiterer, mit dem Bohrer unterm Arm, drückt mit dem Knie die Oberschenkel Jesu auf das Kreuzesholz, um ihn so weiter zu strecken; zu diesem Zweck zieht er wohl auch am Lendentuch, denn dass er es befestigt, scheint nach der Handhaltung unwahrscheinlich. Er hält aber gleichsam inne und blickt aus dem Bild. Dadurch, dass er den Blick des Betrachters auffängt, wird er, zumal er sich in der zentralen Bildposition befindet, zum direkten Ansprechpartner, der den Blick gleichzeitig festhält und in die Kreuzesdiagonale weist. ${ }^{28}$

Die Kleiderfarben auf den Obersteiner Bildern bilden grelle, einheitliche Flächen; dagegen wirken die Farben der Karlsruher Passion fast gedämpft in ihrer ausgewogenen Verteilung über die Bildfläche und der Nuancierung der Einzelheiten. Die Schergen sind nicht bloß bunt und böse, sondern realistisch gekleidet; man betrachte die ausgezogene, um die Hüfte befestigte Jacke des stehenden Schergen mit den Hacken in der Annagelung. Wie man sich Verschlüsse, die Anknüpfungen abtrennbarer Ärmel und Beinlinge in jener Zeit vorzustellen hat, wird genau wiedergegeben.

Der Mainzer Maler war der Meinung, dem grausamen Geschehen sei eine unschöne, widerspenstige Komposition am angemessensten. So ist in Oberstein der Christus der Verspottung aus der Achse gerückt, gänzlich unheroisch, blutig zermartert (Beitrag Vlachos, Abb. 3) ${ }^{29} \mathrm{Im}$ Gegensatz dazu umringen in der Karlsruher Dornenkrönung (Abb. 6) die Schergen den quasi thronenden Christus in ausgeklügelter Komposition.

Die Gesichter der vier oberen Schergen umgeben das Christushaupt in fast idealer Kreisform. Unten links ist dieser Kreis durch das Schilfrohr eines stoppelhaarigen Spötters angedeutet, der Jesus das Rohr als Szepter in die rechte Hand schiebt und dem König der Juden spottend 
huldigt, indem er niederkniet und seine Fellkappe zieht. Diese kniende Rückenfigur, die nach oben rechts agiert und blickt, ist eine typische Einleitungsfigur; damit ein kompositorisches Gleichgewicht gewahrt wird, hat der Maler oben rechts einen grün gekleideten Schergen mit Hut eingefügt, nahezu eine Wiederholung des Mannes mit der komplementärfarbigen roten Kappe und der genieteten Lederrüstung davor. Diese Figur ist der Endpunkt der Schräge, die von dem Spötter angegeben wird, und leitet den Blick zurück.

Die wohldurchdachte Komposition des Bildes dient der Lesbarkeit, ermöglicht dem Betrachter eine intensivere Rezeption. Sie unterstreicht die Heftigkeit des Geschehens: Der rechts Stehende mit Turban und Rute im Gürtel spuckt Christus ins Gesicht, packt mit der Linken den Ausschnitt des Untergewands Jesu und mit der Rechten einen Ast, mit dessen Hilfe er und sein Gegenüber die Dornenkrone auf das Haupt drücken. Ein weiterer, zum größten Teil verdeckter Scherge der rechten Seite reißt Christus an den Haaren und presst mit der linken, behandschuhten Hand ebenfalls den Ast nieder. Über dem Haupt Christi schließlich drückt einer die Dornenkrone mit zwei kurzen Stöcken fest. Sein stark verkürzt gegebener Kopf erscheint dadurch in dem v-förmigen Zwischenraum der beiden Hölzer, die wie Radien des imaginären Kreises wirken, in dem die Bösewichter Jesus umzingelt haben.

Es ist der Unterschied zwischen gut und böse, der alle Bilder der Karlsruher Passion polarisierend durchzieht. Die Schergen sind im Profil oder in starker Verkürzung gegeben, das Gesicht Jesu en face, leicht geneigt, mit sehr ebenmäßigen Zügen, geradem, langem Nasenrücken und kleinem Mund, in der Art der Vera ikon. Auch ist Christus, was Gesicht und Körper betrifft, maßstäblich größer gegeben als die Schergen. Die Schergen und sonstigen Juden sind durch Furchen, Haken- und Knollennasen in eindeutiger Weise abgesetzt. Diese Unterscheidung geht bis in die Malweise: Ist die Farbe in den Gesichtern Jesu und seiner Angehörigen stets sehr fein verrieben, so gleicht sich die Pinselführung in denen der Bösen und Grausamen ihren durchfurchten, groben Zügen an. Und wird bei der Tracht der Bösewichter mit penibler Detailtreue auf die Gestaltung mehr oder minder zeitgenössischer, skurriler, zum Teil geckenhafter Rüstungs- und Kleidermode geachtet, tragen »die Guten « idealisierende Gewänder ohne zeittypische Merkmale. Ein wenig offenbart sich hier der alte Widerspruch: Die Schlechten sind zugleich die Interessanteren, die das Augenmerk des Malers und des Betrachters fesseln.

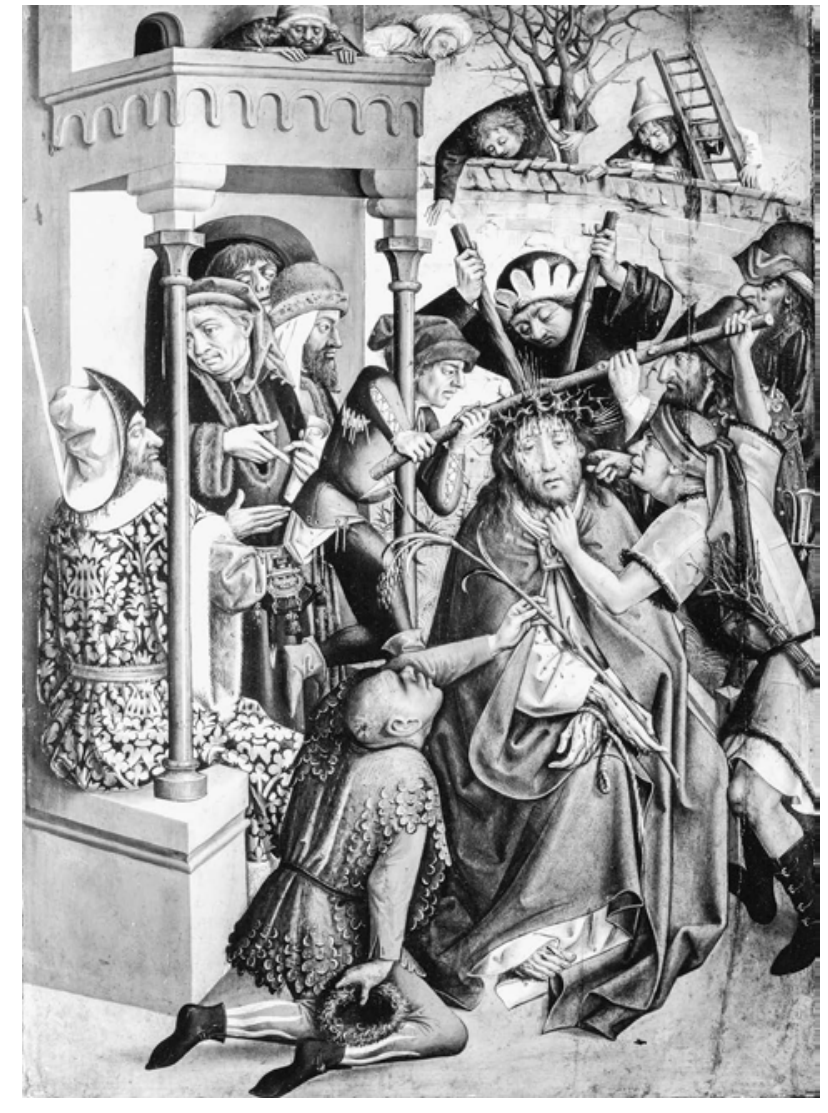

Abb. 6 Dornenkrönung. Vierte Tafel der Karlsruher Passion. Karlsruhe, Staatliche Kunsthalle, Inv.-Nr. 1136 (ex: Ausst.-Kat. Karlsruhe 1996)

Die in der Karlsruher Passion verwendeten Darstellungstypen sind nicht neu, auch nicht derjenige der Dornenkrönung. Wir finden ihn zum Beispiel auf der vermutlichen Außenseite des Tennenbacher (früher auch sogenannten Staufener $)^{30}$ Retabels, ${ }^{31}$ dessen zerteilte Überreste heute in den Museen von Karlsruhe ${ }^{32}$ und Freiburg ${ }^{33}$ zu finden sind. Innen war das Marienleben in sieben Szenen dargestellt, der Mittelteil des Retabels ist nicht erhalten. Die Bilder werden früher als die Karlsruher Passion auf etwa 1420-35 datiert, aufgrund der Tatsache, dass sie noch stärker dem Schönen Stil verbunden sind, besonders in der Darstellung der Angehörigen Christi. Deswegen hat man sich auch angewöhnt, die Malereien des Tennenbacher Retabels zwei »Händen « zuzuordnen: ${ }^{34}$ Die eine habe die stärker dem Schönen Stil verbundenen Marienszenen geschaffen, die andere die Passionsszenen. Dies sei nicht bestritten, auch wenn zunächst einmal auf den völlig unterschiedlichen Charakter dieser beiden klassischen Erzählzyklen christlicher Bildkunst zu verweisen 


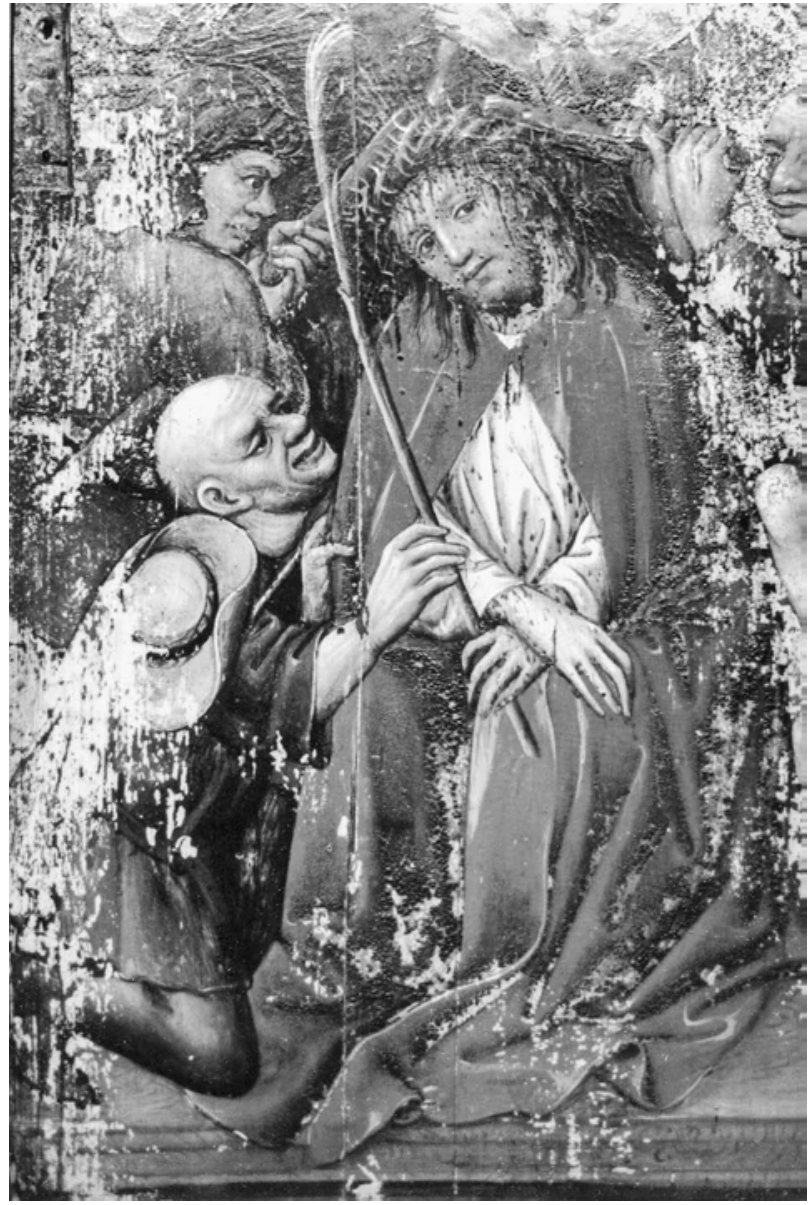

Abb. 7 Dornenkrönung (Ausschnitt), Tafel vom ehem. Tennenbacher Retabel. Freiburg, Augustinermuseum (Foto: M. Hörsch)

ist, der gerade bei diesem Beispiel auch unterschiedliche Ausdrucksniveaus verlangt zu haben scheint. ${ }^{35}$ Auch die Position der Szenen im Gesamt des Tennenbacher Retabels spielte eine Rolle: So sind die Darstellungen des Marienlebens im Inneren des Retabels etwas reicher mit Requisiten, die z.T. auch Raum schaffen, ausgestattet, während die Passionsszenen einfacher und offenbar auch recht schnell gemalt wurden.

Robert Suckale hat den Versuch unternommen, die Künstler Hans Stocker und Hans Tiefental, die wohl der Generation vor dem Meister der Karlsruher Passion angehörten, künstlersoziologisch (und dies auch stilkritisch untermauert) genauer zu greifen. ${ }^{36}$ Letzteren setzt er, in der Tradition Rotts, ${ }^{37}$ mit dem Meister des Frankfurter Paradiesgärtleins $^{38}$ gleich, zu dessen »Werkstatt « oder Umfeld zumindest auch die Marienszenen des Tennenbacher Retabels zu zählen sind. ${ }^{39}$ In jüngeren Publikationen wird dies nicht diskutiert. ${ }^{40}$
Im Gegensatz zur Karlsruher Passion sind die Tennenbacher Passionsszenen (noch?) reduziert: Vor einem mit regelmäßigen Sternreihen besetzten Hintergrund handeln auf einer schmalen Bodenfläche wenige, d.h. 3-7 Personen. Sie wirken dadurch monumentaler als die Figurenhäufungen der Karlsruher Passion. Die Einbindung in einen als irdisch gekennzeichneten Umraum wird nicht angestrebt; jede Passionsszene ist ein in seiner Gesamtheit leicht zu erfassendes "Bildzeichen «; auch die Kreuzigung wird den anderen gleichgeordnet. Und doch wird gerade bei Geißelung und Dornenkrönung (Abb. 7) ganz ähnlich erzählt:

Auch in Freiburg sitzt Christus in der Mitte, links unten der Scherge, der das Rohr überreicht, rechts und links die beiden, die die Krone mit dem waagrechten Ast festdrücken, oben einer, der mit einem kurzen Stock nachhilft. Auch hier wird Wert auf den Gegensatz zwischen dem demütig leidenden Christus und den ihn umgebenden bösartigen Schergen mit ihren derben Gesichtern gelegt. Und wenn man Typen wie die Kahlköpfigen, die jeweils das Rohr überreichen, vergleicht; die Art, wie der Scherge darüber sich mit ganzer Wucht auf den Stab lehnt; die Mimik der zusammengezogenen Augenbrauen; die schmalgliedrigen Hände; selbst den Typus des Christusgesichts und der Falten, so wird die Ähnlichkeit in der Darstellung der Figuren, ihrer Physiognomien, ihres Handelns deutlich. Hier stellt sich m.E. doch die tiefer gehende Frage, in welcher Weise Tennenbacher und Karlsruher Passion verwandt sein könnten: Nach älterer Vorstellung wäre es ja so gewesen, dass ein älterer Maler, der »Meister der Tennenbacher Passion «, der Sphäre des Schönen Stils entsprungen, nun für das Leiden Jesu "realistischere" Kompositionen erfand, die dann vom »Meister der Karlsruher Passion" aufgegriffen und bereichert wurden: Eine lineare Kunstentwicklung, aufgereiht anhand der wenigen erhaltenen Beispiele, die jeweils als »integrale« Werke einer »Künstlerpersönlichkeit« für sich stehen. Dass dies nicht dem Entstehungsprozess spätmittelalterlicher Kunst entspricht, ist mittlerweile hinreichend bekannt. So fragt es sich, ob nicht angesichts der doch überraschenden Ähnlichkeiten zwischen Tennenbacher und Karlsruher Charakteren eine größere Nähe anzunehmen wäre: Das heißt, ob nicht der Meister der Karlsruher Passion zunächst zeitweilig in der Werkstatt des »Marienmeisters« respektive des »Meisters des Paradiesgärtleins", mit dem er ja in Verbindung gebracht wurde, mitgearbeitet hat - zumindest in der Weise, dass 
er Entwürfe für die Passionsszenen einbrachte, die dann dem Stil der Marienszenen angepasst wurden.

Allerdings ist dann doch eine Entwicklung zu konstatieren: Neben den ins Karikaturhafte verzerrten Fratzen der Schergen des Obersteiner Retabels, aber auch den ruhiger wirkenden, abstrahierten Szenen des Tennenbachers wirken die Karlsruher Szenen und Personen in der Tat weitaus realistischer. Zwar kann man ihnen nicht gerade Milde bescheinigen, doch psychologische Differenzierung. Es ist nicht unmöglich, solchen Typen auf der Straße zu begegnen. Die Karlsruher Passion erzählt viel breiter, kohärenter und differenzierter bei der Darstellung psychischer Vorgänge. Bei der Geißelung z.B. (Abb. 8) wird durch das im Verhältnis zum übrigen Körper größere Christushaupt, das zur Seite abknickt, durch die drastische Darstellung des geschundenen Körpers, durch die Einführung so realistischer Details wie der herumliegenden, abgebrochenen Ästchen der Rute die Intensität der Darstellung bedeutend erhöht.

Wie der scheel auf Jesus schielende Pilatus ${ }^{41}$ dem Schergen mit der Knotengeißel die Hand auf die Schulter legt und ihm etwas zuflüstert; wie der Scherge rechts unten sich durch einen Schluck aus dem Becher stärkt, die Geißel eben an die unterste Stufe gelehnt; wie ebendieser in der Dornenkrönung, mit seinen kurz geschorenen Haaren und der grindigen Kopfwunde, auf der sich eine Fliege niedergelassen hat, mit einer weit ausholenden Geste die Fellkappe gezogen hat, den Kopf in gespielter Devotheit weit zurücklegt: das alles ist intensiv durchdacht und gestaltet, will weitaus genauer betrachtet werden, ermöglicht es dem Betrachter, sich in die Einzelheiten zu vertiefen, auf dem Bild mit dem Blick zu wandern, die Handlung identifizierend nachzuvollziehen.

Auf dem Tennenbacher Retabel sind die Köpfe kindlicher gegeben, während beim Karlsruher Zyklus Haut wirklich zur Haut, Körper zu Körper wird - man vergleiche nur den blutüberströmten Leib Christi. Der Tennenbacher Maler hat (noch) nicht so großes Interesse, die Passions-Ereignisse bis ins letzte Detail, in einem glaubhafteren Raum zu verwirklichen. Man kann nicht sagen, dass der Tennenbacher Altar ein »schlechtes« Werk wäre - doch an erzählerischer Kraft bedeutet die Karlsruher Passion einen gewaltigen Schritt darüber hinaus.

Lilli Fischel betonte in ihrem Buch einen "niederländischen Einfluß«, der sich in der Karlsruher Passion feststellen lasse. Wolfson konstatiert hingegen zunächst: "Wie auch beispielsweise Konrad Witz in Basel kann dem in Straßburg tätigen Karlsruher Meister aufgrund stilkri-

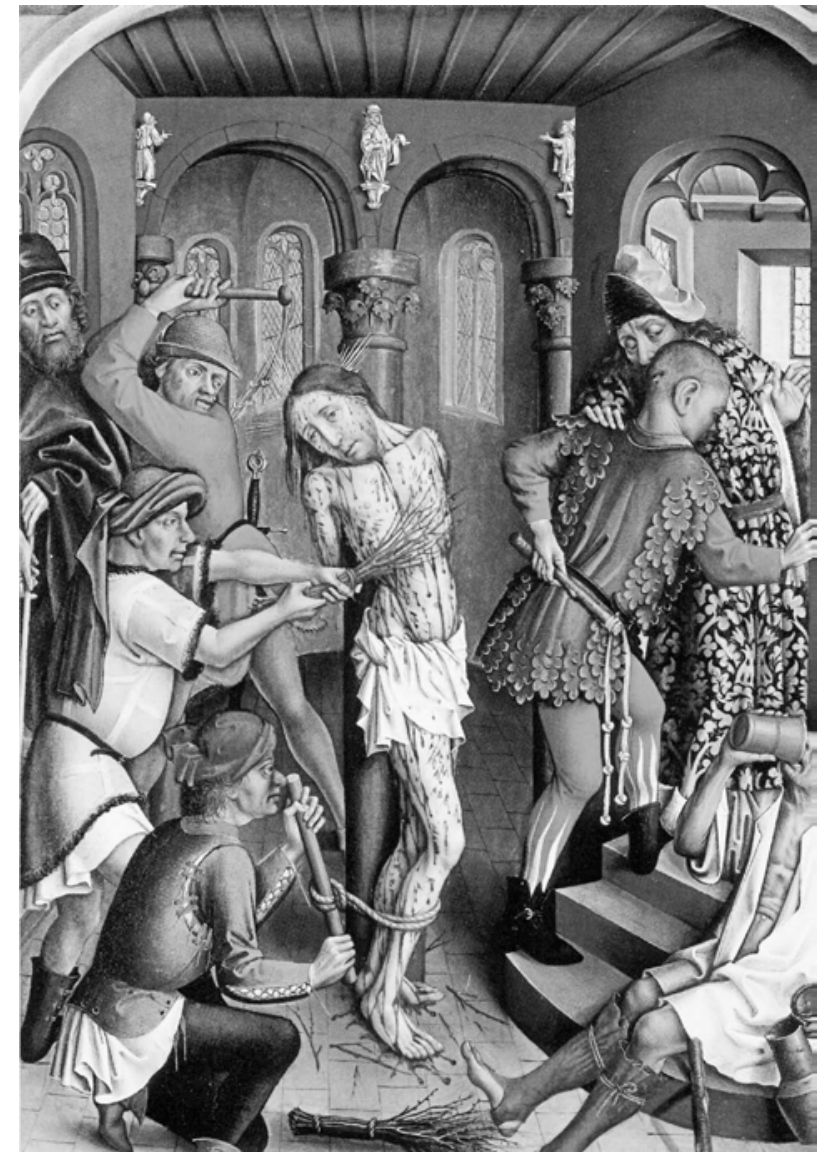

Abb. 8 Geißelung. Dritte Tafel der Karlsruher Passion. Karlsruhe, Staatliche Kunsthalle, Inv.-Nr. 2911 (ex: Ausst.-Kat. Karlsruhe 1996)

tischer Überlegungen kaum eine sniederländische Schulung verpaßt werden. Weder sein Kolorit noch seine Technik noch sein Stil weisen auf eine dortige Ausbildung hin, und auf gar keinen Fall dürfte er von dort stammen. « $^{42}$ Doch auch Wolfson sieht niederländischen Einfluss im Karlsruher Zyklus am Werk, freilich einen sozusagen verdünnten, einen Einfluss des Hörensagens, der »Mundpropaganda ${ }^{43}$ allenfalls durch reisende niederländische Maler am Oberrhein vermittelten. Einzelne Elemente seien in »selektiver Rezeption « übernommen worden. In der Tat sind ja erst seit der Mitte des 15. Jahrhunderts die durch die großen Niederländer, den Meister von Flémalle, die Gebrüder van Eyck, Dirk Bouts und Rogier van der Weyden, in ganz neuer Weise verwandten Mittel der naturalistischen Darstellung des Raums und der irdischen Gegenstände in Deutschland in breiter Weise und vor allem kohärent rezipiert worden.

Allerdings geschieht dies am Oberrhein keineswegs gleich so kohärent wie zum Beispiel in Franken. Eine 


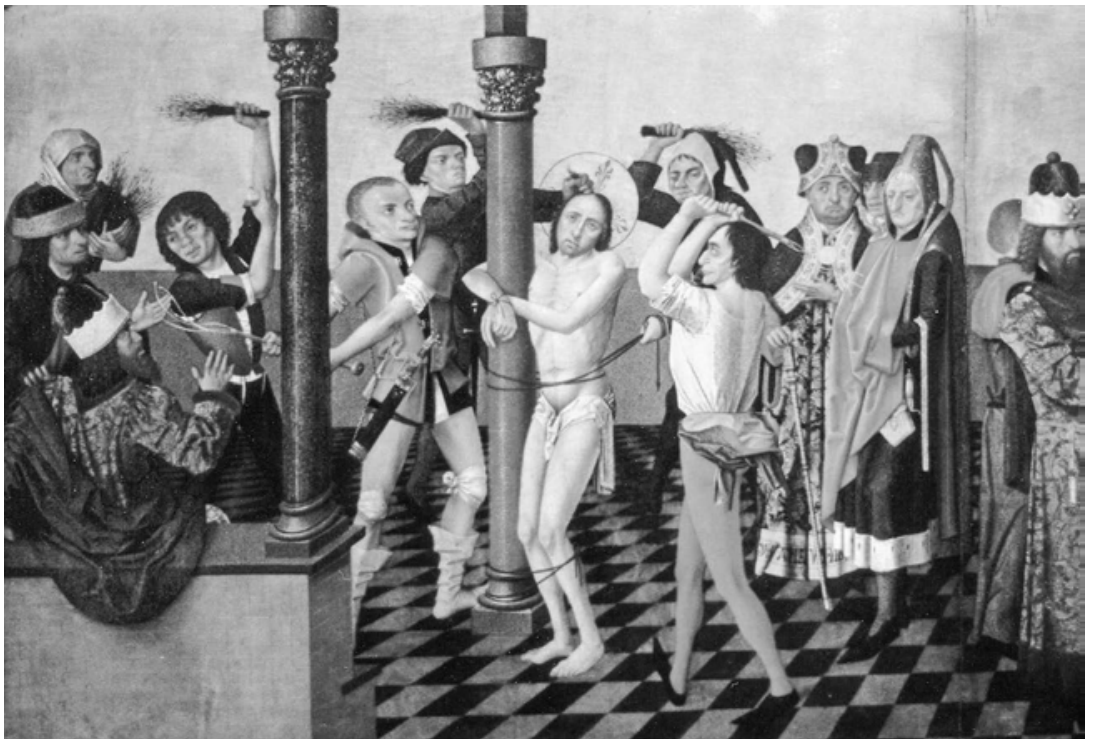

Abb. 9 Geißelung. Caspar Isenmann, Colmarer Retabel. Colmar, Musée d'Unterlinden (Foto: M. Hörsch)

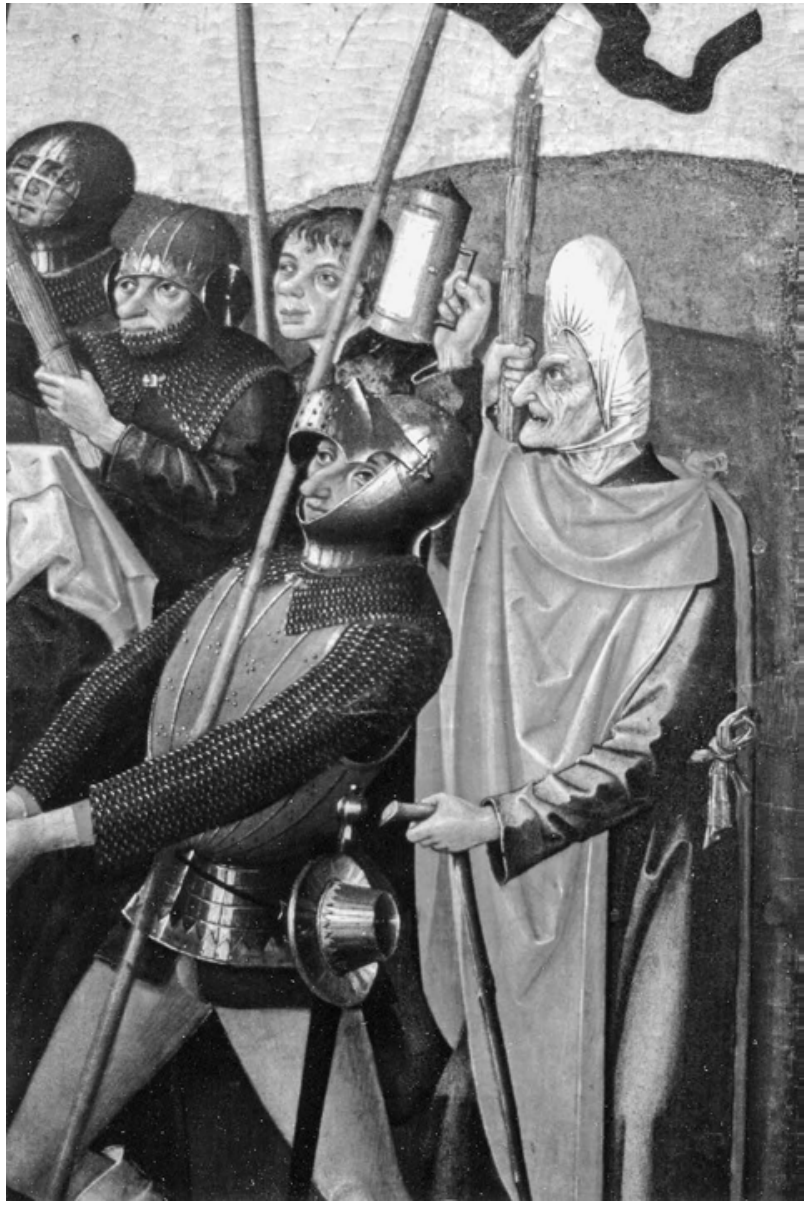

Abb. 10 Hässliche Alte aus der Darstellung der Gefangennahme Christi. Caspar Isenmann, Colmarer Retabel. Colmar, Musée d'Unterlinden (Foto: M. Hörsch) neue Stufe der Niederlande-Rezeption ist mit dem $\mathrm{Na}$ men Caspar Isenmanns verbunden, ${ }^{44}$ dessen Retabelfragmente von 1462-65, heute im Colmarer Unterlinden-Museum, sozusagen eine Mittlerstellung zu Martin Schongauer einnehmen, der seinerseits ja niederländische Kunst wiederum sehr eigenständig anverwandelte. Isenmann hingegen ist noch Eklektizist, übernimmt in seinen Passionsszenen viel von der Heftigkeit der etwa eine halbe Generation älteren Kollegen und zitiert den Meister der Karlsruher Passion in vielen Details. ${ }^{45}$ Man betrachte nur die seitlich angeordnete Architektur der Geißelung (Abb. 9) oder die hässliche Alte bei der Gefangennahme (Abb. 10), aber auch ein ganz zentrales Motiv wie das Haupt Christi in der Dornenkrönung.

Die Lebendigkeit und Konsistenz der Karlsruher Passion erreicht er nicht, die Fratzen der Schergen werden wieder klischeehafter (der debil Glotzende mit der Schachbrettfrisur, der Christus das Spottszepter in der Dornenkrönung überreicht!). Hingegen führt er anders geartete, ruhig dastehende und nicht karikierte »niederländische«, in ihrer Schlichtheit sogar italianisierende Betrachterfiguren ein (vgl. ebenfalls die Dornenkrönung), dazu modische Kopfbedeckungen und gestrecktere Proportionen; auch die kahlen, weiträumigen Landschaften und öden Fliesenböden schlagen einen neuen Ton an.

Wenn also niederländische Vorbilder für die Entstehung der Karlsruher Passion eine Rolle gespielt haben, dann nicht im Sinne einer vollständigen Übernahme von Landschafts- und Figurendarstellung, sondern allenfalls, darin ist Wolfson Recht zu geben, in Form gewisser Anregungen. Er nennt vor allem die früheyckische Kunst, 
insbesondere die leider verbrannte Darstellung der Gefangennahme Christi aus dem Mailand-Turiner Stundenbuch, als Anregung für die »Behandlung des Lichtes und den Naturalismus der Nachtdarstellung « ${ }^{46}$ Ob man aus der deutlich verschiedenen Mal- und Darstellungsweise z.B. der Karlsruher Ölbergszene allerdings wirklich schließen kann, deren Maler habe solche niederländischen Bilder »auf keinen Fall im Original gesehen « $?^{47} \mathrm{Be}$ trachtet man das Rotterdamer Bild der drei Frauen am leeren Grab aus der früheyckischen Gruppe, ${ }^{48}$ so erinnert man sich in der Tat der atmosphärischen Darstellung des Ölbergs in Karlsruhe. Freilich sind sowohl Himmel als auch Stadtdarstellung des Rotterdamer Bildes viel detaillierter dargestellt - offensichtlich ist der beabsichtigte Porträt-Charakter der Jerusalemdarstellung, ${ }^{49}$ während sich das Karlsruher Bild in zeichenhafter Verkürzung mit einer fernen, nur schemenhaft erkennbaren Stadtsilhouette und nur wenigen orangefarbigen Wölkchen am Nachthimmel begnügt. Das liegt an der insgesamt nahsichtigeren, alles mehr in die Fläche bringenden Darstellungsweise der Karlsruher Passion, die auf die ausführliche Raumdarstellung bewusst zugunsten höherer Ausdrucks-Intensität der näher herangezogenen Figuren verzichtet. Auf der anderen Seite möchte der Maler aber auch nicht das schlichte Herauslösen von kleinen Figurengruppen, wie es der Maler des Tennenbacher Altars praktizierte, sondern er ist von der neuen Freude am wirklickeitsnahen Detail der niederländischen Malerei den Spiegelungen des Lichts auf glänzenden Waffen etc. fasziniert gewesen. Er reduziert, was er sehr wohl in seiner Ausbildung oder auf einer Reise gesehen haben kann, um damit anderen Ausdruck zu erlangen.

Welche Intensität der Meister der Karlsruher Passion aus dieser realistischen Detailfreude einerseits, der kompositorischen Konzentration andererseits erzielt, wird deutlich, vergleicht man die in der Grundstruktur nicht unverwandten Passionsszenen auf den Außenseiten des Triptychons mit simultanen Darstellungen des Marienlebens im Rijksmuseum Twenthe in Enschede (Abb. 11).

Sie wurden bereits von Wolfgang Lüdke im Vergleich mit der Karlsruher Geißelung herangezogen, ${ }^{50}$ doch zeigt gerade diese Zusammenstellung besonders deutlich die Originalität des Straßburger Malers. Nun ist die auf etwa $1450 \mathrm{zu}$ datierende, spröde-routinierte nordniederländische Tafel gewiss kein Meisterwerk, aber sie scheint doch, gerade weil sicher keine direkte Verbindung zur Karlsruher Passion hergestellt werden kann, eine gewisse Darstellungsnorm zu spiegeln, die mit eng zusammen-

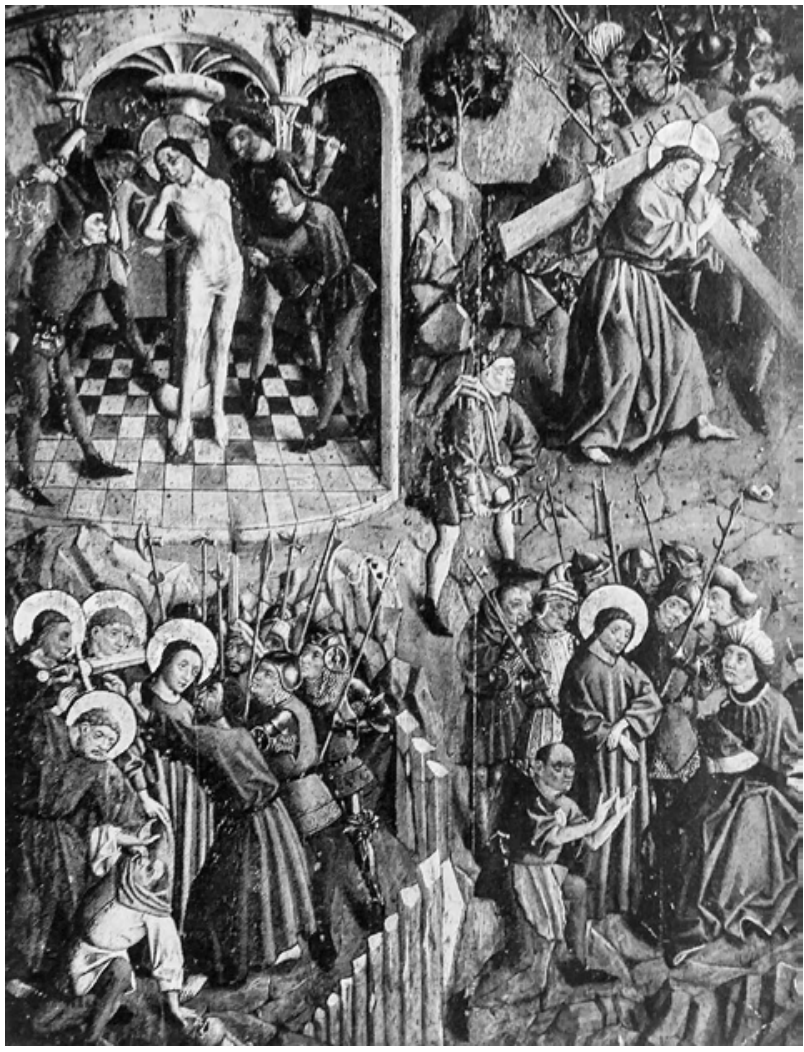

Abb. 11 Vier Passionsszenen auf der Außenseite des linken Flügels des Marienretabels. Enschede, Rijksmuseum Twenthe (ex: Rijksmuseum Twenthe 1938)

gestellten Personengruppen, schmalen Bildräumen und realistischen Details z.B. der Bewaffnung arbeitet. Es ist keinesfalls auszuschließen, dass sich der Straßburger Maler mit solchen (und womöglich doch qualitätvolleren!) Vorlagen in den Niederlanden auseinandergesetzt hat, wobei man tendenziell solche Vorbilder eher in den nördlichen Niederlanden suchen sollte, wie dies bereits Lilli Fischel getan hat. ${ }^{51}$

Der erneute kurze Überblick über bereits bekannte Vorbilder und Rezeptionen sollte zunächst einmal verdeutlichen, dass der Versuch, das Phänomen einer »realistischen « oder "expressiven" Malerei der Mitte des 15. Jahrhunderts von einer allgemeineren Warte $\mathrm{zu}$ fassen, ${ }^{52}$ auch zu eher allgemeinen Ergebnissen führt, die vielleicht etwas von einem "Zeitgeist « oder bestimmten gesellschaftlichen Bewegungen zu erspüren vermögen, aber nicht darauf abzielen können, den spezifisch künstlerischen Ausdruck eines Zyklus wie der Karlsruher Passion zu erfassen. Zunächst einmal ist der »Realismus « der Karlsruher Passion nicht mit dem Wunsch gleichzusetzen, soziale, historische oder ökonomische Wirklichkeit 
vollständig ins Bild zu setzen. In erster Linie bemühte sich der Maler darum, eine dramatische Passionserzählung zu gestalten, und dazu schienen ihm detailgenaue Objektbeschreibung, auch Lichtstimmungen, vor allem aber psychologisierende und historisierende Mittel geeignet. Es entsteht eine den Betrachter ins Bild gleichsam hineinziehende Kunst, die eine bis dahin nicht gekannte Logik der Interaktionen mit sich bringt. Gewiss, hier gibt es Grenzen: Wolfson ${ }^{53}$ wies zurecht darauf hin, dass gewisse ikonografisch streng vorgeprägte Momente auch in der Karlsruher Passion nicht aufgegeben wurden. So behält Maria ihren Schleier, obwohl sie ihn ja zugleich um Christi Scham hüllt: Eine unverschleierte Maria war unvorstellbar. Aber die Genauigkeit, die der Maler in anderen Fällen anstrebt, die zugleich mit einer sonst im süddeutschen Bereich so nicht geübten Feinmalerei einhergeht, ist das besondere Merkmal dieses Malers - und sie wurde auch am Oberrhein danach so nicht mehr erreicht.

\section{Zum Stand der Rekonstruktion der Karlsruher Passion}

Die vorausgegangene Analyse einiger darstellerischer Aspekte der Karlsruher Passion ruft ab einem gewissen Punkt nach einem Verständnis der einstigen Gesamtheit jenes Werks, dem der zerlegte und wieder zusammengeführte Zyklus ja offenkundig entstammt, ebenso nach dem tieferen Begreifen der historischen Kontexte.

Straßburg stand als Herstellungsort des Zyklus' bald fest, Bestimmungsort war höchstwahrscheinlich das dortige Stift St. Thomas, denn dessen Kirche ist auf dem Bild der Kreuztragung recht naturgetreu dargestellt: Ihr wuchtiger Westturm und der achteckige Vierungsturm sind klar zu erkennen. Über die Auftraggeber der Tafel ${ }^{54}$ wissen wir hingegen nichts und nur wenig über ihre Betrachter. Eines kann man sich jedoch kaum vorstellen: Dass die ungemein feine, teils stimmungsvolle Malerei nicht aus der Nähe betrachtet werden sollte.

Gehen wir davon aus, dass die Tafel für einen Platz in der St.-Thomas-Kirche bestimmt war, so lässt sich zunächst festhalten, dass die Stifte von St. Thomas und St. Peter nach dem Domkapitel die bedeutendsten geistlichen Institutionen Straßburgs waren. Kothe hat für den Zeitraum von 1300 bis 1400 eine Aufschlüsselung der Zusammensetzung des Thomasstifts nach der sozialen Herkunft der Kanoniker geliefert: ${ }^{55}$ Danach waren die überlieferten Kapitulare in der überwiegenden Mehrzahl Patrizier oder cives, d.h. stadtsässige Ritter und Bürger, die schon vor 1332, als den Nicht-Patriziern der Zutritt zum Rat genehmigt werden musste, dem Rat angehören durften. Neben 58 Mitgliedern dieser Schicht nehmen sich 17 Nicht-Patrizier und 9 Ritter eher bescheiden aus; immerhin 31 weitere Kapitels-Mitglieder werden von Kothe unter der Rubrik »sonstige Fremde« geführt. Man kann also auch für das frühe 15. Jahrhundert noch davon ausgehen, dass St. Thomas (wie St. Peter) ein "Patrizier-Kapitel « war, ${ }^{56}$ und dass die diesem Stift gemachten Zuwendungen und Pfründenstiftungen größtenteils aus den Reihen des Stadtbürgertums kamen. Im Zeitraum von 1300 bis 1400 sind an St. Thomas 21 Priesterpfründen (Präbendenstiftungen) nachweisbar; die Stifter gehörten, »soweit sie nicht geistlichen Standes sind, durchweg der städtischen Hautevolée an «. ${ }^{57}$

Interessant wäre es, herauszufinden, ob sich nach den unruhigen Jahren 1419-22, dem Krieg von Dachstein und den damit verbundenen Verwerfungen der städtischen Körperschaften und Schichtungen, an der Zusammensetzung der Kapitulare oder dem "Auftraggeberprofil « von St. Thomas etwas änderte. ${ }^{58} 1419$ versuchte nämlich das Patriziat, die vor 1332 nicht ratsfähigen Familien der Handwerker und kleineren Kaufleute wieder aus der Macht zu verdrängen. Als der Rat beschloss, um die Ordnung wieder herzustellen, den Stadtadel an das geltende Recht zu binden, verließen nach der Verlesung des Dekrets am 24. April 141936 Mitglieder des Patriziats, darunter auch Stettmeister und Ratsmitglieder, die Stadt und zogen nach Hagenau. Die Flüchtigen verbündeten sich mit dem Landadel, und es kam zum sogenannten Krieg von Dachstein gegen die Bürgerstadt. Im folgenden Jahr setzte sich der Bischof, der bereits seit Langem außerhalb der Stadt, in Zabern und Molsheim, residierte, offiziell an die Spitze der Adels- und Patrizierpartei. Das städtische Heer war zunächst nicht sonderlich erfolgreich und verbündete sich, um den Kampf fortsetzen zu können, auf die Dauer von fünf Jahren mit den Städten Basel, Freiburg, Colmar, Schlettstadt, Mühlhausen und anderen. Dies führte zum Sieg der Stadt: Am 24. April 1422 wurde durch Vermittlung des Erzbischofs von Mainz und des Markgrafen von Baden in Speyer ein Vertrag unterzeichnet, der es dem Stadtadel erlaubte zurückzukehren, so er sich den Bedingungen des Rats beugte. Zwischenzeitlich hatten Rat und Zünfte die Situation genutzt. In einer Verfassungsänderung von 1420 war festgelegt, dass sich der Rat nur noch aus 14 Mitgliedern des Patriziats gegenüber 
28 Zunftmitgliedern zusammensetzte. ${ }^{59}$ Dies beschreibt zunächst die Situation des 15 . Jahrhunderts in der Stadt Straßburg, in der die Karlsruher Passion entstand. Sie unterscheidet sich in ihrer sozialen Unruhe deutlich von der in anderen Reichsstädten wie Nürnberg. Aber es ist zu bezweifeln, dass sich dies, wie die ältere Forschung zumindest implizit immer wieder annahm, auch in der besonderen Dramatik, dem so genannten "Realismus«, der Malerei des Karlsruher Zyklus ausdrückte. Aus der Darstellungsweise ist gewiss nichts über den Stifter herauszufinden, es sei denn, der Maler selbst wäre der Stifter gewesen.

Völlig auszuschließen ist dies nicht, denn hier könnte zum ersten Mal der Name des vielzitierten Meisters Hans Hirtz ins Spiel kommen: 1453 ließ er zusammen mit seiner Frau eine jährliche Schenkung von einem Pfund Straßburger Münze zu Gunsten des St.-Thomas-Stifts eintragen. ${ }^{60}$ Das Kapital stammte aus einer Rente aus einem Haus, ebenso das einer zweiten Stiftung 1455 für das Straßburger Spital. ${ }^{61}$ Mit letzterer verbunden war ein ständiges Jahrgedächtnis, nach dem Tode der Stifter eine Seelmesse. Doch begraben wurden Hirtz und seine Gemahlin später vor dem Marienaltar der Thomaskirche. ${ }^{62}$ Es scheint nun allerdings wenig wahrscheinlich, dass der Passionszyklus als Retabel für diesen Altar gedacht gewesen sein könnte, denn dies würde zumindest voraussetzen, dass es daran eine die Altarpatronin heraushebende Darstellung gegeben hätte. Wenn man die bisherigen Rekonstruktionsversuche ernst nimmt, gibt es dafür aber keinen Anhaltspunkt.

Auch die Provenienzforschung konnte bisher für die Karlsruher Passion wenig Erhellendes zu Tage fördern. Am weitesten lässt sich die Tafel mit der Darstellung des Gebets Christi am Ölberg zurückverfolgen. Sie gelangte zu bisher unbekanntem Zeitpunkt nach Waldersbach im Steintal. Ein hinten aufgeklebter alter Zettel hält fest: "Porte du tabernacle de la / Chapelle catholique de Walsbach / datant d'avant la Réformation / introduite au Ban de la Roche / par le Seigneur de Rathsamhausen «. ${ }^{63}$ Die Angaben stammen nach Otto Fischer von einem Pfarrer der Gemeinde, dem »Großvater« des späteren Besitzers des Bildes, F. Andreae in Arlesheim. ${ }^{64}$ Es handelt sich bei jenem um Charles Emmanuel Witz (1815-96), der die Tafel von der Kirchengemeinde und aus der Kirche von Waldersbach erwarb. ${ }^{65}$ Jedenfalls zog der Schreiber der Zeilen, der die übrigen Passionstafeln gewiss nicht kannte, nahe liegende Schlüsse: Die Tafel ist offenkundig vorreformatorisch, also musste sie aus der noch katholi- schen Kapelle zu Waldersbach stammen, wo die Herren von Rathsamhausen, denen die Herrschaft Stein (Ban de la Roche) bis 1584 gehörte, die Reformation eingeführt hätten. Bis heute erkennbare Spuren eines Schlüssellochs und von Scharnieren ${ }^{66}$ deuteten auf eine Funktion als Türchen, somit musste sie für die mittelalterliche Vorgängerkapelle in Waldersbach geschaffen und wegen ihres Themas und ihrer Größe für eine Tabernakelnische gedacht gewesen sein. In Wahrheit stellt sich die Situation ganz anders dar: Es ist nicht unwahrscheinlich, dass vor der Reformation in Waldersbach überhaupt keine Kapelle bestand, denn ein Bericht des Pfarrers Nicolas Marmet von 1661 belegt, dass in der Herrschaft Stein der Priester der Pfarrei Rothau nur dort und in Urbach (Fouday) die Messe feierte. ${ }^{67}$ Die Pfarrei Waldersbach wurde erst gegen $1616^{68}$ oder kurz danach ${ }^{69}$ von Rothau abgespalten. Zuvor hatte Pfalzgraf Georg Johann I. der Scharfsinnige von Pfalz-Veldenz (1543-92) den Ort erworben und hier - vielleicht 1589 - die Reformation eingeführt. ${ }^{70}$

In einer nunmehr lutherischen Kirche erscheint eine Tabernakeltür im herkömmlichen Sinne unnötig. Dass eine solche in Waldersbach der ursprüngliche Bestimmungsort der Ölbergszene gewesen sein könnte, ist schon deshalb auszuschließen, weil sich die Tafel mit den anderen erhaltenen Passionsszenen, die nie in Waldersbach gewesen sind, zu einem Zyklus vereinen lässt. Seit Beginn der wissenschaftlichen Forschung wurde daher vermutet, dass einer der beiden bekannten Waldersbacher Pfarrer Johann Georg Stuber (1722-97) und Johann Friedrich Oberlin (1740-1826) das Gemälde nach Waldersbach gebracht haben dürfte. Ersterer könnte dies bereits 1750 getan haben, als er die Pfarrstelle antrat und zunächst einmal die Kirche mithilfe wohlhabender Straßburger Gönner renovieren ließ ${ }^{71}$ Oberlin wiederum trat die Stelle nach einer schicksalshaften Begegnung mit Stuber an, ${ }^{72}$ der 1767 als Pfarrer an St. Thomas in Straßburg tätig wurde. So scheint es wahrscheinlicher, dass Oberlin die Tafel direkt von diesem aus der Thomaskirche erhielt. Jedenfalls könnte es dem »Retter « ein Anliegen gewesen sein, die auch für fromme Protestanten eindrucksvolle Ölberg-Darstellung aus einer für unwürdig gehaltenen Verwendung zu befreien, denn es ist nach dem Gesagten mehr als wahrscheinlich, dass die Tafel im Straßburger Thomasstift als Türchen verwendet worden war. Dies belegt die Tatsache, dass auch bei der Kreuzannagelung vor der Dünnung der Tafel zum Zwecke der Parkettierung durch den Restaurator Albert Schenck 1920 Spuren zweier Türbänder festzustellen waren. Diese entsprachen 
symmetrisch den Spuren auf der Ölberg-Tafel, in die zudem ein Loch für ein Schloss gebohrt worden war. ${ }^{73} \mathrm{Da}$ Ölberg und Kreuzannagelung ursprünglich sicher nicht nebeneinander liegend gedacht waren, muss es sich bei dieser Verwendung um eine sekundäre handeln. Ich möchte aber in Zweifel ziehen, ob man wirklich von » Tabernakeltüren « sprechen sollte, denn man mag eigentlich kaum glauben, dass man das ursprüngliche Werk noch in vorreformatorischer Zeit für ein Sakramentshaus oder Ähnliches verwendet haben sollte. Eher wäre zu vermuten, dass man die Tafeln nach der Reformation nach Auflösung des ursprünglichen Verbands an einem Sakristeischrank oder Ähnlichem wiederverwendete.

Alle übrigen Tafeln lassen sich nicht so weit zurückverfolgen wie diejenige mit dem Ölberg und wurden aus Privatsammlungen erworben, sodass sie für die Rekonstruktion des ursprünglichen Bestimmungsorts nichts auszusagen vermögen.

Ebenso wird sich die bedeutsame und deswegen viel diskutierte Frage, wie die sieben erhaltenen Tafeln der Karlsruher Passion ursprünglich angeordnet waren, ${ }^{74}$ wohl nie mit vollkommener Sicherheit klären lassen. Doch es gibt wahrscheinlichere und weniger wahrschein liche Lösungen, denn Format, Anzahl und Abfolge, aber auch der restauratorische Befund der erhaltenen Tafeln geben Informationen preis, die Manches ausschließen.

So dürften, wie die (nur leicht verminderte) Stärke von $1,8 \mathrm{~cm}$ des nicht parkettierten Ölbergs zeigt, die Tafeln nicht zersägt worden sein. Auch trägt die Rückseite des Ölbergs keinerlei Spur einer Bemalung. Man kann somit zwar nicht beweisen, dass die Rückseiten der Passion ursprünglich unbemalt waren, aber es spricht doch mehr dafür als dagegen.

Die Nussbaumtafeln sind Einzelstücke; keine ließ sich als Vorder- oder Rückseite einer andern identifizieren, keine war mit einer anderen auf derselben Tafel zwingend übereinander angeordnet. Der restauratorische Befund erwies zudem, dass sie zuerst in Rahmen eingenutet und so grundiert wurden. ${ }^{75}$ Dann wurde dieses Gerüst wieder entfernt, die einzelnen Gemälde wurden ohne Rahmung und mit einer Bleiweiß-Öl-Imprimitur homogenisiert und anschließend bemalt, wobei der Grundiergrat stets etwas überschritten wurde. ${ }^{76}$ Was danach mit den Tafeln geschah, bleibt unklar, aber vermutlich wurden sie erneut gerahmt. Dass die relativ kleinen Bilder ringsum eingenutet waren, ist bei Altarflügeln eigentlich nicht $\mathrm{zu}$ beobachten, da solche starken Rahmungen Gewicht und Kosten deutlich erhöhen. Bildtrennende Rahmen oder
Leisten waren normalerweise aufgemalt, allenfalls aufgeleimt.

Erhalten ist eine sehr kohärente Abfolge von Szenen, deren Erzählstruktur von Robert Suckale in größeren Zügen, ${ }^{77}$ dann von Wilfried Franzen so überzeugend im Detail herausgearbeitet wurde ${ }^{78}$ dass es schwierig erscheint, sich jeweils noch ergänzende Szenen vorzustellen.

Der Zyklus ist nicht nur eine Ansammlung unzähliger genau beobachteter Einzelheiten, es ist auch nicht allein die Komposition der Einzelbilder, die den Betrachter zu genauer Betrachtung animiert. Die Szenen sind untereinander verknüpft. So ist der Erzählzusammenhang zwischen Geißelung und Dornenkrönung denkbar eng, denn in beiden Szenen handeln dieselben Protagonisten: Pilatus, der auf der Geißelung einem Schergen etwas ins Ohr flüstert, ist in der Dornenkrönung in der Diskussion begriffen. Derjenige, dem in der Geißelung etwas zugeflüstert wird, überreicht in der Dornenkrönung das Rohr. Der Mann im pelzgefütterten, hellbraunen Lederwams, der in der Geißelung mit der Rute auf die Brust Christi schlägt, zieht Christus in der Dornenkrönung an den Haaren und spuckt ihm ins Gesicht. Der den Knebel auf der Geißelung anzieht, »umarmt« auf der Dornenkrönung die Säule.

Betrachtet man den ganzen Zyklus, ist festzustellen, dass so enge Verbindungen wie in diesen beiden Bildern sonst nirgends zu entdecken sind. Die Reihe beginnt, was die Zahl der Personen angeht, ziemlich zurückhaltend mit der Ölbergszene. Jesus hat sein Haupt in Todesangst weit zurückgeworfen, das Gesicht ist von blutigem Schweiß benetzt, die Arme weit von sich gestreckt, die Hände sind flehentlich geöffnet $;^{79}$ verzweifelt allein, mitten unter seinen Jüngern. Zugleich ist schon klar, dass dieser Kelch nicht an ihm vorübergehen wird, denn der Engel bringt Kelch und Kreuz. Hinten naht die Menge der grauen Soldaten, von dem gelbgekleideten Judas und einem roten Hauptmann angeführt. Nur das hellgrüne Bäumchen links und das gerade rosafarben erblühte rechts deuten an, dass das Geschehen als Ursprung neuen, ewigen Lebens zu interpretieren ist. ${ }^{80}$

Das wilde Getümmel der Gefangennahme setzt hierzu einen heftigen Kontrapunkt. Christus, eben noch im Schmerz gen Himmel gestreckt, sackt nun zusammen, über ihm türmen sich die Schergengestalten, wobei nur vier wirklich Hand an Christus legen; eine Fackel und ein brennendes Strohbündel beleuchten die Szenerie, und der Bläser mit dem gespaltenen Blasinstrument zeigt, dass man sich das Geschehen nicht nur als optisches Getöse 
vorzustellen hat. Am oberen Rand flieht nach links Judas, sich noch einmal umblickend, mit dem Geldsack; rechts haut Petrus, weit ausholend, sich ins Getümmel stürzend dem aufschreienden Malchus das Ohr ab, während ein Gewappneter sich dazwischen stemmt und ihn bei der Stirnlocke packt. Die Stimmung der Tageszeit ist zu ahnen: Am Himmel einige zarte Wölkchen und Sterne, über Petrus die Silhouette eines kahlen Baumes.

Es folgen die beiden Szenen der Geißelung und Dornenkrönung, die freieren Raum erfordern und lockerer komponiert sind. Danach setzt wieder die GetümmelDarstellung ein. Der Himmel ist nun strahlend hellblau, die Bäume tragen stilisiertes Blattwerk und sind in abgekürzter Kugelform gegeben. Das Bild der Kreuztragung ist durch die schräg liegenden Kreuzarme, vor deren Schnittpunkt Christi Kopf erscheint (wodurch er betont wird), strukturiert, auch öffnen sich rechts die dichten Reihen der Hellebarden und Morgensterne, um Raum für Landschaft zu lassen, die von der genannten Darstellung der Straßburger Thomaskirche überragt wird. Im Bild der Entkleidung Christi wird die figurenstrotzende Darstellung gesteigert, sodass nun gerade noch der Baum mit dem darauf gekletterten Zuschauer sowie drei Hauptleute zu Pferde vor dem Himmel erscheinen. Die Kreuzannagelung erfordert wieder freieren Raum, damit das Kreuz zur Geltung kommen kann. Diese drei letzten erhaltenen Szenen streben wieder erzählerische Kohärenz an. Die Angehörigen Jesu werden fast stereotyp wiederholt (immerhin wird eine Steigerung insofern angestrebt, als Johannes erst im Annagelungsbild die Tränen kommen), ebenso die drei Hauptleute auf ihren Pferden, mit der Abwechslung, dass sich mal die beiden rechten, mal die beiden linken unterhalten. Die Schergentypen sind hingegen nicht durchgehalten - man braucht nur auf den Träger des Bienenkorb-»Helms« zu achten: Es ist nie wirklich derselbe.

So wird eine abwechslungsreiche Erzählfolge erreicht: Die beiden ersten Szenen bieten jeweils eine originelle Abwandlung des Darstellungstyps ${ }^{81}$ ein Gegensatzpaar, bei dem die qualvolle Einsamkeit Christi inmitten seiner schlafenden Jünger von der ebenso großen unter der tumultuarischen Übermacht der Soldateska abgelöst wird. Bei den beiden Szenen im Innen- bzw. Hofraum bildet Christus in besonderer Weise den leidenden Mittelpunkt; sie sind besonders sorgfältig komponiert und erzählerisch durch die hier besonders konsequenten Figurenwiederholungen zusammengeschlossen; die drei letzten Darstellungen fügen sich in ähnlicher Weise eng zusammen, scheinen aber um einige Nuancen typisierter. ${ }^{82}$ Kreuztragung und Entkleidung sind unmittelbar aneinander anzuschließen, insofern die Angehörigen Christi im ersten Bild eine Repoussoirgruppe am rechten Bildrand bilden, um sich dann in kontinuierender Erzählung $\mathrm{zu}$ »wenden « und im zweiten Bild die Einleitungsgruppe zu bilden. Die Annagelung wiederholt dann den Aufbau der vorhergehenden Tafel noch einmal.

Lilli Fischels bevorzugte Vorstellung von der ursprünglichen Anordnung der Tafeln zielte auf eine große, vielszenige Schautafel, wie sie aus dem Kölner und niederdeutschen Raum überliefert sind.$^{83}$ Doch die stets deutlich kleineren Kölner Einzelszenen beschränken sich auf das unbedingt Notwendige der Handlung. Die Darstellungen enthalten weniger Figuren und narrative Details, was zu einer einfachen Polarisierung der Guten und Bösen beiträgt. Zudem sind am Oberrhein bisher keine entsprechenden Werke bekannt geworden. Aber vor allem die Tatsache der Einzelrahmung und die in sich stimmige Erzählstruktur der erhaltenen Tafeln widersprechen einer solchen Hypothese.

Die Alternative schien ein Wandelretabel mit gemaltem oder geschnitztem Mittelteil, wofür Dietmar Lüdke Vorschläge durchgespielt hat, ohne letztlich eine Entscheidung zu treffen. ${ }^{84}$ Das Problem dabei ist stets, dass man eine mehr oder minder große Anzahl von Szenen ergänzen müsste, während man doch nur von einer einzigen Szene mit einiger Sicherheit annehmen darf, dass sie einst vorhanden war: der Kreuzigung.

Eine Rekonstruktion in der Art des Hannoveraner Altars des Meisters Bertram (um 1390/1400), ${ }^{85}$ also als Triptychon mit gleichwertig gereihten Darstellungen, befriedigt aufgrund der Erzählweise ebensowenig - es ist das gleiche Problem wie bei der Rekonstruktion einer nicht wandelbaren Passionstafel. Und im Grunde gilt dies auch für anders aufgeteilte Retabel. Ganz unwahrscheinlich wäre z.B. die Rekonstruktion aller erhaltenen Szenen als linker Flügel eines Retabels. Dabei entstünde ein monumentales Retabel von über $6 \mathrm{~m}$ Breite und 2,10 m Höhe, wobei nur eine Anzahl von neun Szenen eine einigermaßen vorstellbare Form ergäbe. Im Zentrum stünde eine plastische Kreuzigung oder ein gemalter, volkreicher Kalvarienberg, der rechte Flügel hätte Szenen von der Grablegung bis zum Pfingstgeschehen umfasst - und wäre vollkommen verloren. Ein so monumentales Werk mit schweren Flügeln könnte allenfalls als Hoch- oder Kreuzaltar der Straßburger Thomaskirche in Frage kommen. Plausibler wäre da eine Rekonstruktion in der Art 


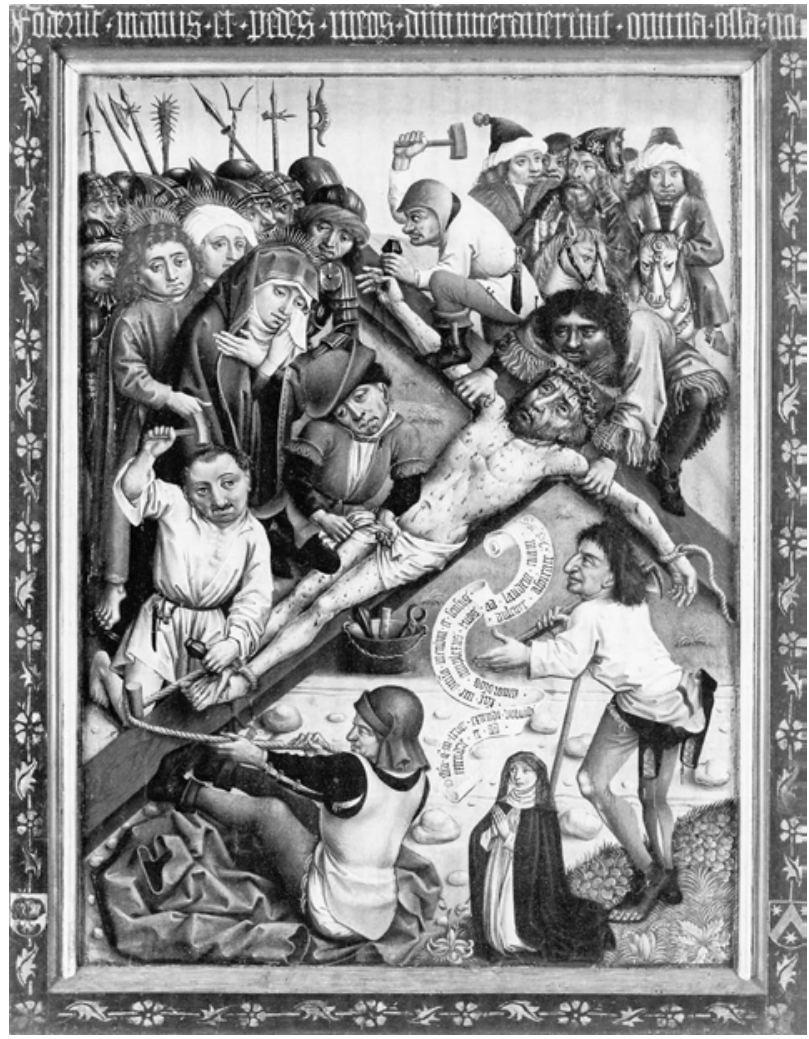

Abb. 12 Kreuzanheftung Christi. Kopie nach der entsprechenden Szene der Karlsruher Passion. Darmstadt, Hessisches Landesmuseum, Inv.-Nr. GK 53 (ex: Ausst.-Kat. Karlsruhe 1996)

des »Halderner « Retabels des Meisters von Schöppingen $(1450 / 60),{ }^{86}$ das auch auf der Mitteltafel noch vier weitere Passionsszenen beidseits eines volkreichen Kalvarienbergs unterbringt. ${ }^{87}$ Allerdings würden auch hier die Erzähl-Paare Ölberg / Gefangennahme, Geißelung / Dornenkrönung und die Dreierkonstellation Kreuztragung / Entkleidung / Annagelung in eine größere Abfolge eingepresst. ${ }^{88}$

Anna Moraht-Fromm scheint also bis zum Beweis des Gegenteils den Stein der Weisen gefunden zu haben, indem sie endgültig vorschlug, sich auf den erhaltenen Bestand zu beschränken ${ }^{89}$ und nur eine zentralen Kreuzigungsszene hinzuzufügen - eine Rekonstruktion als Einzeltafel, gleichsam als »italianisierende«Pala (Abb. 3). ${ }^{90}$ In Moraht-Fromms Rekonstruktion werden die beiden Szenen-Paare nun jeweils beidseits einer hochrechteckigen Kreuzigung angeordnet, die Dreierfolge darunter. Dies ist vollkommen logisch und erklärt zudem, warum gerade sieben recht nah aufeinander bezogene Szenen erhalten blieben, während keine Darstellung zeitlich vorausgehender oder nachfolgender Geschehnisse aufzu- finden ist. Einziger Schönheitsfehler ist das Fehlen der (größeren) Kreuzigung, doch sind glückliche Zufälle ja nicht auszuschließen.

\section{Umriss der Tätigkeit der Werkstatt der Karlsruher Passion}

Die nicht zu bestreitende Zuschreibung der ehemaligen Wandmalereien in der Straßburger Dominikanerkirche an den Meister der Karlsruher Passion ${ }^{91}$ erhärtet zunächst einmal lediglich die ohnehin wahrscheinliche These, die ausführende Werkstatt habe ihren Sitz in Straßburg gehabt. Wie aber lässt sich die zuerst von Hans Rott ${ }^{92}$ vertretene, durch Fischel untermauerte These, es handle sich bei dem Künstler um den dort aktenkundigen Maler Hans Hirtz, die bis heute den Charakter einer letztlich unbewiesenen Hypothese hat, weiter untermauern - oder auch widerlegen ${ }^{93}$ ? Fischel dachte zunächst einmal deshalb an Hans Hirtz, weil sie der Auffassung war, einem so qualitätvollen Werk wie der Karlsruher Passion könne nur ein einigermaßen bedeutender Maler zugeordnet werden. Und der im Kirchspiel von St. Thomas ansässige Hans Hirtz war noch Jahrzehnte nach seinem Tod im Bewusstsein: Geiler von Kaisersberg erwähnt ihn - vorgeblich spontan - in einer Predigt: Den Hirtz führte er an als einen, den alle Anwesenden als Maler noch kannten. ${ }^{94}$ 1505 schreibt der Historiker Jakob Wimpheling ${ }^{95}$ in den Epithoma rerum germanorum über »Joannes Hirtz Argentinensis«: "non est obmittendus, qui dum in humanis esset, apud pictores omnes in magna fuit veneratione, cuius in pictura peritiam clarissime ac speciosissime imagines tum alibi, tum Argentinae natali solo testantur «. Und von solch einem Maler sollte gar nichts mehr fassbar sein?

Allerdings wäre dies selbstverständlich denkbar, angesichts der zahlreichen überlieferten Malernamen und angesichts der geringen Zahl erhaltener Werke. Zunächst käme also jeder der in Straßburg zahlreich belegten Maler als Schöpfer der Karlsruher Passion in Frage - nur wenige, wie Jost Haller, scheiden aus. Dieser konnte als Meister der Tafeln eines ehemals für Saarbrücken bestimmten Retabels identifiziert werden. ${ }^{96}$

Eine Erweiterung des CEuvres des Meisters der Karlsruher Passion oder wenigstens konkrete Hinweise auf ihre Rezeption wären selbstverständlich hilfreich, denn so könnten weitere historische Anhaltspunkte gefunden und vielleicht auch die - ja keineswegs festliegende! Datierung der Karlsruher Passion abgesichert werden. 
Abb. 13 Kreuzanheftung Christi, Ausschnitt. Darmstadt, Hessisches Landesmuseum (Foto: M. Hörsch)

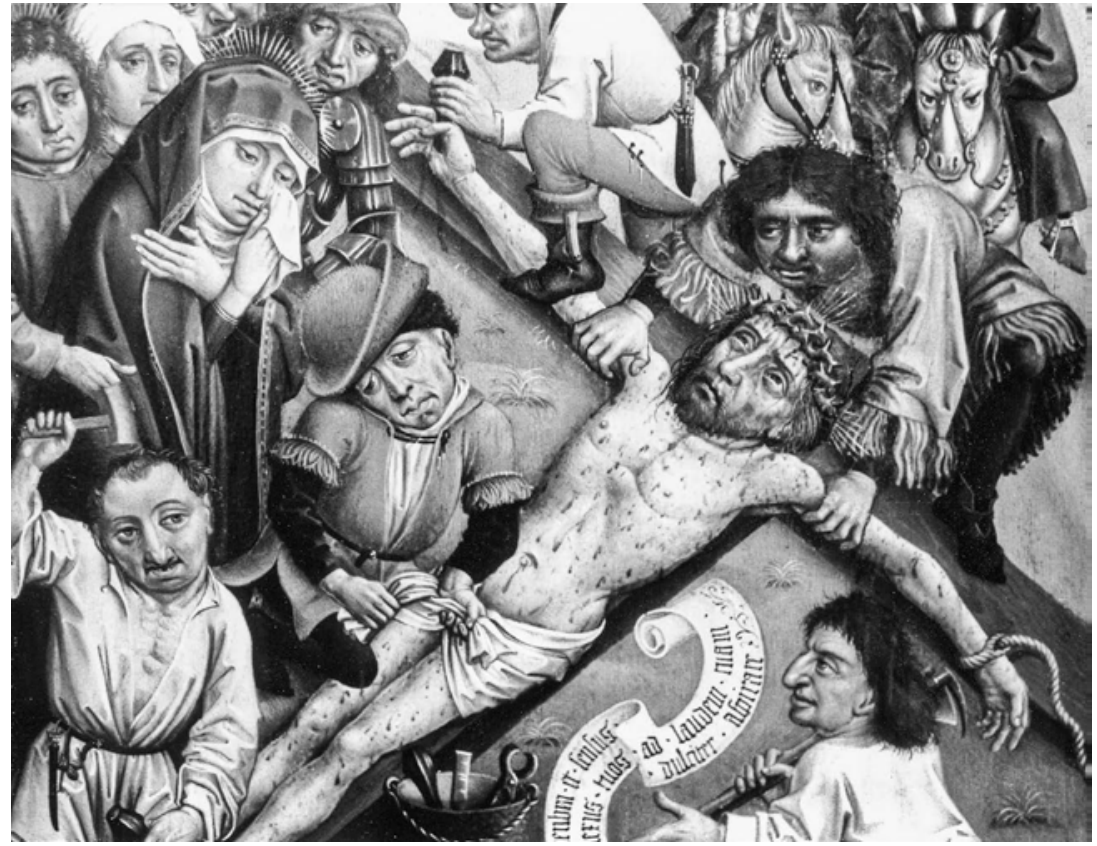

Leider sind aber die meisten der z.B. von Lilli Fischel angeführten Zuschreibungen eher vage, in den Bereich einer allgemeinen Zeit- oder Stilschicht oder der »künstlerischen Herkunft« einzuordnen. Dies verweist schon auf die schmale Basis an Objekten, auf denen solche Überlegungen ansetzen können. Aber vielleicht kann man ein wenig weiterkommen, wenn man bereits vorhandene Ansätze weiterverfolgt und bekanntes Material erneut befragt.

Da ist zunächst einmal die ungewöhnliche Tatsache, dass die Kreuzannagelung der Karlsruher Passion direkt kopiert wurde, und zwar durch die von Stefan Roller erstmals ausführlicher diskutierte Tafel des Hessischen Landesmuseums (Abb. 12, 13). ${ }^{97}$

Es handelt sich somit um die Vereinzelung und Abwandlung einer Szene aus einem Zyklus, die ganz offenkundig dem Willen, der Frömmigkeit und der Stiftung der in kleinerem Format eingefügten betenden Nonne entsprangen. Die eindrucksvolle Repoussoirfigur des abwartenden Hackenträgers rechts unten verweist nun nicht mehr nur auf das Geschehen selbst, sondern zugleich auf das sich emporwindende Spruchband, das das Gebet der Nonne enthält: »o ih(es)u . q(ui) . in . cruce . extendi . voluisti . / fac . me . om(n)ia . menbra [sic] . et . sensus . / ad . laudem . tuam . / extendere . et . ad . / amorosos . amplexus . tuos . / dulciter . aspirare . (O Jesus, der du gewollt hast, am Kreuz ausgestreckt zu werden, mach mich durch alle Glieder und Sinne zu deinem Lob ausstrecken und auf deine liebenden Umarmungen süß hinstreben).« Dies ist nicht nur die passionsmystische Versenkung einer einzelnen Klosterfrau, sondern zugleich ein Hinweis auf das allgemeine Verständnis dieser ja häufig dargestellten Szene, ${ }^{98}$ und das Gebet wandelt zugleich eine Passage aus einem der wichtigsten Passionstraktate ab, nämlich der Mitte des 14. Jahrhunderts entstandenen Vita Christi des Straßburger und später Mainzer Kartäusers Ludolf von Sachsen $(*$ um 1300, $\dagger 1377 / 78)$. Hier heißt es in größerem Zusammenhang: »Exaltabo te, Domine, quoniam suscepisti me.< Ad conformandum se huic articulo, poterit homo brachia et omnia membra sua, sive stando, sive procumbendo in modum crucis, etiam corporaliter, et vires spirituales intentionaliter ad laudem Dei extendere rememorandos illos amorosos amplexus extensionis Christi cum Augustino et sic orare: Jesu, qui in cruce extendi voluisti ita atrociter, ut omnia ossa tua possent dinumerari, fac me omnia membra viresque corporis et anima mea ad laudem tuam extendere, et ad amorosos amplexus tuos dulciter aspirare. (>Preisen will ich Dich, Herr, denn Du hast mich aufgenommen.< Um sich diesem Vers [des Offertoriums, nach Ps. 29 (30),2; Anm. M. H.] anzuverwandeln, wird der Mensch die Arme und alle seine Glieder, sei es stehend, sei es sich beugend in der Form des Kreuzes, auch körperlich, und bewusst spirituelle Kräfte zum Lobe Gottes ausstrecken können, sich mit Augustinus jener liebenden Umarmungen der Dehnung Christi erinnernd und so beten: O Jesus, der du gewollt 


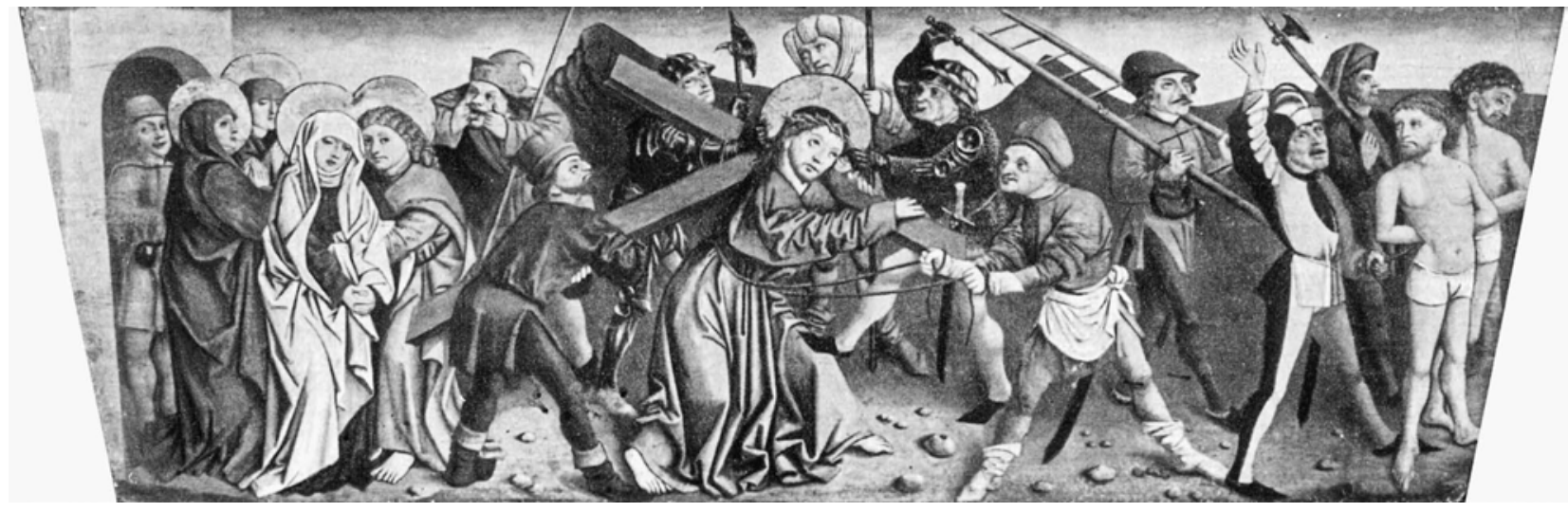

Abb. 14 Kreuztragung. Oberrheinisch, möglicherweise aus Straßburg. Privatbesitz (ex: FISCHEL 1934)

hast, am Kreuz so grässlich ausgestreckt zu werden, dass all deine Knochen gezählt werden könnten, mach mich durch alle Glieder und Kräfte des Körpers und durch meine Seele zu deinem Lob ausstrecken und auf deine liebenden Umarmungen süß hinstreben.) «"99

Der in dem Ludolf-Zitat enthaltene Verweis auf Psalm 21 (22),17-18 (»foderunt manus meas et pedes meos (18) dinumeraverunt omnia ossa mea (durchgraben haben sie meine Hände und meine Füße, sie zählten alle meine Knochen«) entfällt in der Bitte der Nonne, wurde aber auf dem Rahmen oben in gotischer Minuskel gleichsam als Überschrift angebracht: »Foderu(n)t $\$$ manus $\$$ et $\$$ pedes $₫$ meos $₫$ dinumerauerunt $₫$ omnia $₫$ ossa $₫$ mea . Aus diesem Grund ist es unverständlich, weshalb man den Rahmen für zwar wahrscheinlich alt, aber für »nicht zugehörig " hielt. ${ }^{100}$ Entsprechend dürften die Wappen, die heraldisch rechts einen aus einer Wurst herauswachsenden Krautkopf, links einen Sparren mit drei in die Zwickel eingefügten Sternen zeigen, ${ }^{101}$ etwas über die Person oder Familie der dargestellten Nonne aussagen, die man bisher für eine Zisterzienserin hält. ${ }^{102}$ Es dürfte sich aber wegen des fehlenden Skapuliers, des weißen Habits, schwarzen Mantels und schwarzem Schleier eher um eine Dominikanerin handeln. Leider ist die Identifizierung bisher nicht gelungen. Da die Karlsruher Passion sich aber in Straßburg befand, sollte man im engeren Umfeld der Reichsstadt auch nach dem Bestimmungsort der Darmstadter Tafel suchen - und da bieten sich St. Nikolaus am Gießen (in undis) in Straßburg selbst, Unterlinden in Colmar oder das weithin wirkende elsässische Reformkloster Schönensteinbach an. ${ }^{103}$ Da dieses Kloster unter den Armagnakenraubzügen 1444/45 besonders zu leiden hatte und sich alle Nonnen in weit entfernte Konvente flüchteten, könnte man die Darmstädter Tafel als
Zeichen einer besonderen Identifikation mit dem leidenden Jesus am Kreuz interpretieren, vielleicht in der Art einer Votivtafel. Aber dies sind vorderhand nur Versuche, Rolle und Herkunft des Bildes zu fassen - konkrete Spuren fanden sich nicht.

Auch der Stil der Tafel könnte ein Hinweis sein, allerdings finden sich nur wenige Vergleichsbeispiele. Verwiesen sei auf eine querformatige, leicht trapezförmig zugeschnittene Tafel der Kreuztragung Christi in Privatbesitz (Abb. 14), ${ }^{104}$ aufgeteilt in drei Gruppen.

Links kommen die Angehörigen Jesu, ausgezeichnet durch goldene Nimben, aus dem Stadttor Jerusalems. Durch die frontale Stellung Marias und die Rückwendung des rot gewandeten Johannes, der sie stützt, entsteht eine Zentralisierung der Gruppe, die noch durch einen die Zunge bleckenden Schergen mit Zipfelhut verstärkt wird, der sich hinter Simon von Kyrene zurückwendet. Dieser, der nach biblischem Text Christus das Kreuz tragen helfen musste, ist wiederum nach rechts gewandt und leitet zur Zentralszene über, in deren Mitte der grauviolett gewandete Christus steht, umgeben von vier weiteren Schergen, die ihn an den Haaren reißen, mit einem Morgenstern schlagen und am Seil voranziehen. Der vierte, hellrot gekleidete Mann mit Turban im Hintergrund scheint die Funktion eines Aufsehers zu haben. Auch die Schergen und Simon umgeben Christus in einem Halbkreis, zentrieren also die eigentlich voran drängende Bilderzählung. Das Voranschreiten der Handlung wird nur durch den in der zweiten Ebene im Hintergrund stehenden Schergen bewirkt, der - bei Passionsdarstellungen des 15. Jahrhunderts ein nicht seltenes Motiv - seinen Kopf durch die Sprossen der Leiter gesteckt hat, die später zur Kreuzigung und wieder zur Kreuzabnahme gebraucht werden wird. Schließlich versuchen zwei weitere Schergen, der 
vordere in scheckiger Mi-parti-Kleidung, die beiden Schächer voranzutreiben, die etwas unschlüssig am Bildrand $\mathrm{zu}$ verharren scheinen. Der Eindruck entsteht vor allem durch die Rückwendung des vorderen Schächers, der seine spätere Hinwendung zum Erlöser am Kreuz schon vorwegzunehmen scheint, indem er sich zurückwendet, während der andere, finster vor sich hin blickend, ausschreitet.

Die Bilderzählung spielt auf einem schmalen, kaum gegliederten und nur durch einzelne Steine aufgelockerten Weg. Den Hintergrund bildet eine felsige Hügelszenerie, die vor einem morgenhellen Himmel aufragt, der nach oben verblaut und in dem einzelne Wölkchen sichtbar zu werden scheinen. Diese atmosphärische Darstellung erinnert an die Ölberg-Tafel der Karlsruher Passion. Allerdings ist die Verwandtschaft insgesamt eher eine entfernte, zumal die Kleiderfalten schon verhärteter und grafischer wirken. Dem Darmstädter Bild ähnelt die Kreuztragung in vielen Details, wirkt aber geglätteter, in manchem nicht so übersteigert (man vergleiche zum Beispiel die bei dem Darmstädter Bild oft übergroßen Köpfe!).

Mit diesen Rezipienten entfernt man sich ebenso stark vom künstlerischen Kern der Karlsruher Passion wie bei dem eingangs genannten Caspar Isenmann. Immerhin deuten sie die Bedeutung des Meisters respektive einer spezifisch ausgerichteten Werkstatt an, ebenso wie die vielen druckgrafischen und zeichnerischen Reflexe, die zu den in der Literatur zur Karlsruher Passion am besten untersuchten Bereichen gehören. ${ }^{105}$ Verwiesen sei hier nur auf frühere Beispiele, die eine Entwicklung des Ausdrucksrepertoires der Karlsruher Passion bereits im Straßburg der Zeit seit 1440 nahelegen wie die Gefangennahme des sog. Meisters der Spielkarten, ${ }^{106}$ wobei nicht geklärt ist, wer hier Henne und wer Ei war: Kopierte, wie Fischel annahm, der frühe Kupferstich die Malerei oder regte er sie an ( $^{107}$ Gewiss ist eins: Die Frage ist schon falsch gestellt, man wird von einer sich gegenseitig befruchtenden, parallelen Entwicklung der Medien ausgehen können. Der Stich zeigt eine Fülle modischer und rüstungstechnischer Details, so Kopfbedeckungen von der einfachen Lederkappe des Judas bis zu federgeschmückten Helmen. Die Malchus-Episode wirkt höchst lebendig und spontan: Malchus kauert, die Hand vor Schmerz vor den Mund gepresst, am Boden: Petrus wendet sich um, weil er von hinten von einem Soldaten am Gewand gezerrt wird, der ihm einen Kinnhaken verpassen will, und schwingt das Schwert; die ruhige Christusgestalt bildet den Mittelpunkt einer hauptsächlich aus vielen Köpfen bestehenden Menge. Dies alles ist der Darstellung der Karlsruher Passion vergleichbar. Abgesehen davon, dass der Kidron-Bach die Szenerie vorn bereichert, sind der schmale Handlungsraum, die kulissenhaften Felsen und schließlich das kahle Bäumchen ähnlich eingesetzt. Der Gewappnete links ergäbe (beachtet man die Seitenverkehrung durch den Druckvorgang) eine gute Repoussoirfigur, was man von Malchus nicht behaupten kann. Immerhin lässt der Stecher Petrus mit der Rechten ausholen; aber selbst wenn er noch andere Einzelheiten abgewandelt haben sollte, ist die Nähe zur Karlsruher Passion noch immer schlagend - und Fischels These, hier die Rezeption eines Hirtz-Werkes vorliegen zu haben, wahrscheinlich richtig.

Ähnliches gilt für den Passionszyklus des »Meisters von $1446 \ll,{ }^{108}$ auch wenn der Stecher, wie Franzen zuletzt nachgewiesen hat, manche Szenen der neunteiligen Folge seitenverkehrt wiedergibt, ${ }^{109}$ andere jedoch nicht, und auch wenn er bei manchen seiner Versatzstücke nicht völlig logisch vorgeht. ${ }^{110}$ Dies verweist deutlich auf den rezeptiven Charakter solcher Stiche, wenn eben z. B. die hinter dem Golgatha-Hügel erscheinende Soldateska nicht überzeugend in die Komposition eingebaut wird. Die von Dietmar Lüdke vertretene Meinung, die 1446 datierte Passion sei »kurz vor der Karlsruher Passionsfolge « entstanden, mag durchaus zutreffen; ${ }^{111}$ sie geht aber sicher auf ähnliche Vorlagen des Malers der Karlsruher Passion zurück, zu verwandt sind die gesamte Raumund Szenenauffassung, der kahlköpfige Rutenbinder und andere Details. Was aber weder heißen muss, dass eine einheitliche Folge die Vorlage war, noch, dass der Stecher eine kohärente Erzählung anstrebte. Letzteres lag ohnehin gar nicht im Rahmen seiner Fähigkeiten, auch wenn die Stiche ihren Reiz haben - und auf dem Markt sicher auch Abnehmer fanden.

Bei späteren Werken wie manchen Zeichnungen des sog. Meisters der Gewandstudien ${ }^{112}$ ist das Verhältnis dann sicher ein nehmendes. ${ }^{113}$ Viel schwieriger wäre es, das früher viel diskutierte Verhältnis des Meisters der Karlsruher Passion zum Konvolut des sog. Meisters ES respektive die Art der Rezeption dort nochmals zu durchdenken. Doch dies würde den Rahmen dieses Beitrags sprengen - und wohl letztlich wenig zu der hier interessierenden Frage, wie man die Werkstattproduktion des Meisters der Karlsruher Passion eingrenzen und definieren kann, beitragen, denn die ES-Stiche scheinen einen freieren Umgang mit Vorbildern und dies zudem in verschiedenen Ausführungsdichten zu belegen. 
Hingegen soll ein Beispiel aus einem anderen Genre, der Glasmalerei, eingeführt werden, das merkwürdigerweise nie im Zusammenhang mit der Karlsruher Passion diskutiert wurde. Zwar spielte Glasmalerei in der Forschung zur Karlsruher Passion eine bedeutende Rolle, insbesondere Teile der Verglasung von St. Wilhelm in Straßburg und der 1461 datierte Zyklus von Walburg bei Hagenau. Doch sind die Verhältnisse besonders komplex und schwer durchschaubar, gerade weil von der Glasmalerei ein relativ hoher Anteil erhalten blieb.

Lilli Fischel sah vor allem die Wilhelmer Scheiben ${ }^{114}$ als dem Meister der Karlsruher Passion nahestehend an, ja sie fand hier den Kern eines Euvres auch von Darstellungen, die nicht die Passion Christi zum Thema haben. ${ }^{115}$ Allerdings ist das Ensemble ein komplexes Konglomerat und hat eben deswegen zu Zeiten eines Paul Frankl zu Zuschreibungsdiskussionen geführt, ${ }^{116}$ deren Meisterbezogenheit heute eigenartig anmutet und als überholt gelten muss, ist es doch gerade bei der Glasmalerei Straßburgs offensichtlich, dass es zahlreiche fähige Meister gab, die in einer bestimmten wirtschaftlichen Hochphase eine enge Zusammenarbeit unter Führung Peter Hemmels suchten - und dabei eben eher hochwertige Markenprodukte als individuelle Kunstwerke fertigten. Zudem ist immer zu bedenken, dass auch nicht primär für den Glasmalereimarkt produzierende Künstler für Entwürfe herangezogen werden konnten. Stefan Roller hat dementsprechend einige motivische Übernahmen in dem Walburger Zyklus herausgestellt, ${ }^{117}$ die exemplarisch zeigen, wie solche Vorlagen aus dem Umfeld der Karlsruher Passion adaptiert - und dabei vor allem den Bedingungen aus weiter Ferne zu betrachtender Glasmalereien angepasst wurden, indem nämlich die drangvolle Enge der gemalten Tafeln aufgelöst und die Darstellung vor Teppichgründen auf wenige Figuren beschränkt wurden. Da aber die gesamte Auffassung der Szenen mit ihren gedrungenen Figuren, den teils realistischen Kleidungsdetails und den natürlichen Bewegungen (man betrachte vor allem die Kreuzannagelung ${ }^{118}$ ) derjenigen der Karlsruher Tafeln im Künstlerisch-Grundsätzlichen so nahe steht, ist doch an eine Zusammenarbeit der Maler-Werkstatt mit den Glasmalern zu denken. Dies umso mehr, als man ja von einem wesentlich größeren Umfang an Vorlagen aus der Werkstatt der Karlsruher Passion ausgehen darf während wir heute alles immer wieder auf dieses eine Werk beziehen müssen.

\section{Tafelmalerei und Glasmalerei - das Beispiel der sogenannten Erbacher Scheiben in Berlin}

Ein weiteres Beispiel für diesen Problembereich soll hier zur Diskussion gestellt werden, das in der einschlägigen Forschung bisher erstaunlicherweise keine Rolle spielte. Niemand ist offenbar auf die Verwandtschaft aufmerksam geworden, die Teile des im Berliner Kunstgewerbemuseum aufbewahrten Zyklus von - heute - acht Rundscheiben aus dem Ulmer Rathaus (den früher sogenannten Erbacher Scheiben) zu den Werken des Meisters der Karlsruher Passion zeigen. Nur in einer Andeutung weist Eva Heye auf eine Verwandtschaft zur älteren Kunst, "etwa (...) des Hans Hirtz«, hin. ${ }^{119}$ Hermann Schmitz hingegen hingegen datierte die Scheiben auf das Ende des 15. Jahrhunderts ordnete sie der "Schongauer-Richtung" $\mathrm{zu},{ }^{120}$ was bis heute nachwirkt.

Das Kunstgewerbemuseum erwarb die Folge 1927 aus dem Besitz der Reichsgrafen Erbach-Erbach. ${ }^{121}$ In deren Sammlung sind sie, samt dem Bruchstück einer neunten, das sich seit 1943 im Darmstädter Hessischen Landesmuseum befindet, ${ }^{122}$ zwischen 1803 und 1805 durch den Grafen Karl (1782-1832) aus Ulm gelangt. ${ }^{123}$

In dieser Stadt befindet sich auch - in größerem Maßstab und an prominenter Stelle - ein Zyklus von Glasmalereien, der thematisch mit den Erbacher Scheiben aufs Engste verwandt ist: Das 1480 datierte Ratsfenster im Achsfenster des Ulmer Münsterchores zeigt die Versuchungen Christi (Mt 4,1-11), Christus und die Kanaanäerin (Mt 15,21-28), die Heilung des stummen Besessenen (Lk 11,14-28), die Speisung der Fünftausend (Joh 6,1-14), die versuchte Steinigung Christi (Joh 8,46-59) und den Einzug in Jerusalem (Mt 21,1-9). Während sich diese Szenen jeweils zu Dreiergruppen zusammengefasst in hochrechteckigen Darstellungen über zwei Zeilen, beginnend mit der zweiten Zeile von unten (in der untersten befinden sich Heilige sowie das Reichs- und Stadtwappen) erstrecken, sind den darüber folgenden Darstellungen der Auferstehung und der Himmelfahrt jeweils alle drei Bahnen gewidmet. Das größere Format des Bildfelds und der Figuren kommt dem Betrachter entgegen. ${ }^{124}$ In den sechs Szenen der Wirksamkeit Christi sind die vortridentinischen Perikopen der Fastensonntage zusammengestellt. ${ }^{125}$

Die Folge der Erbacher Scheiben zeigt im Kern dieselbe Szenenauswahl der Wirksamkeit Jesu zu Lebzeiten: Die nur in Rudimenten erhaltenen Versuchungen (im Hessischen Landesmuseum Darmstadt), Christus und die Ka- 


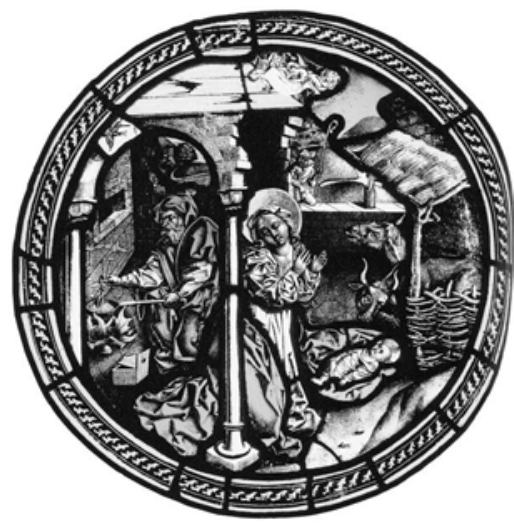

Abb. 15 Anbetung des Kindes. Rundscheibenzyklus, wohl aus dem Ulmer Rathaus. Berlin, Staatliche Museen - Preußischer Kulturbesitz, Kunstgewerbemuseum (ex: Ausst.-Kat. Ulm 1995)

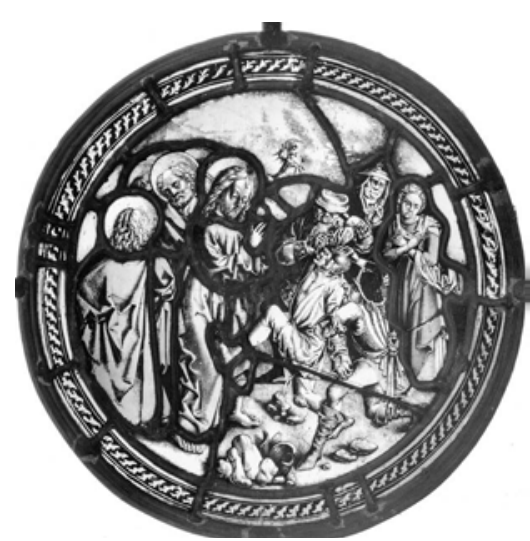

Abb. 16 Heilung eines Besessenen. Rundscheibenzyklus, wohl aus dem Ulmer Rathaus. Berlin, Staatliche Museen - Preußischer Kulturbesitz, Kunstgewerbemuseum (ex: Ausst.-Kat. Ulm 1995)

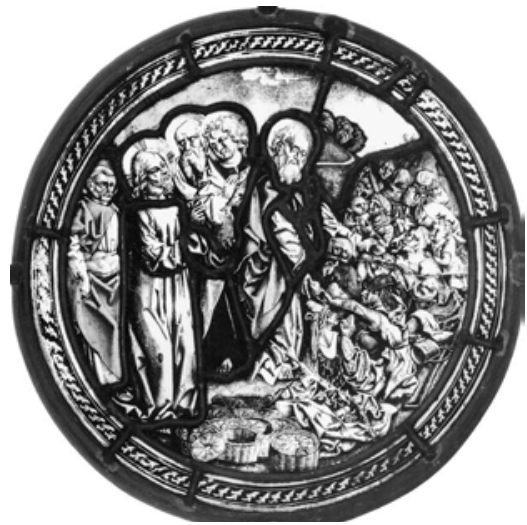

Abb. 17 Speisung der Fünftausend. Rundscheibenzyklus, wohl aus dem Ulmer Rathaus. Berlin, Staatliche Museen - Preußischer Kulturbesitz, Kunstgewerbemuseum (ex: Ausst.-Kat. Ulm 1995) naanäerin, Heilung des stummen Besessenen, Speisung der Fünftausend, die versuchte Steinigung Christi, Einzug in Jerusalem. Ergänzt wird der Zyklus um die Szenen der Verkündigung an Maria ${ }^{126}$ und die Geburt Christi (Abb. 15), genauer die Anbetung des Kindes durch Maria im Stall von Betlehem, sowie die Auferstehung, wobei der letzteren Darstellung heute die Figur Christi fehlt.

Für diese Szenen lagen geläufige Darstellungstypen vor, wie sie schon 50 Jahre früher in den Bildern des Schönen Stils in anderer stilistischer Form verwendet worden waren. So ist der Brei kochende Josef bei Darstellungen der Geburt Christi ein schon bei Conrad von Soest und anderen beliebtes Detail. Ob der Zyklus ursprünglich weitere Scheiben umfasste, ist bisher nicht nachweisbar, aber nicht unwahrscheinlich, da man neben dem "Auftakt" von Verkündigung und Geburt auch noch einen entsprechenden, umfangreicheren Abschluss der Erzählung zumindest mit der Ölbergszene, der Kreuzigung und vielleicht noch einer Szene nach der Auferstehung vermuten möchte.

Können die Szenen aus dem Leben Jesu im Ratsfenster des Münsterchors einleuchtend in einen liturgischen $\mathrm{Zu}$ sammenhang gesetzt werden, fällt dies bei den kleinen, im Durchmesser $36 \mathrm{~cm}$ großen Rundscheiben schwerer. Ihre Ausführung ist so außerordentlich fein - es wurden Höhungen durch Auskratzen des Überfangs mit aufs Subtilste gestupfter Schwarzlotzeichnung kombiniert, z.T. auch mit dem Pinsel schraffiert -, und die Szenen sind z.T. so vielfigurig, dass sich der Wert dieser für Kenner geschaffenen Scheiben ausschließlich in Nahsicht eröff- net. ${ }^{127}$ Der Perikopenzyklus schließt eine Verwendung an privater Stelle, z. B. in einer Hauskapelle, zwar nicht vollständig aus, doch ist eine Verwendung in einer Kapelle mit ausgeprägter liturgischer Nutzung wahrscheinlicher. Da der Rat das thematisch entsprechende Fenster im Münster gestiftet hat, hat die Vermutung, die sogenannten Erbacher Scheiben hätten ihren ursprünglichen Platz im Rathaus gehabt, die höchste Wahrscheinlichkeit. ${ }^{128}$

Die künstlerische Grundidee bei fast allen Darstellungen der Wirksamkeit Jesu ist es, einen Gegensatz zwischen Jesus und seinen Jüngern einerseits, den übrigen Beteiligten andererseits mit allen der Glasmalerei zur Verfügung stehenden Mitteln herauszustreichen: Erstere tragen stark farbige Gewänder, wofür der Glasmaler verschiedene Überfanggläser, z. T. noch um Silbergelb bereichert, verwendet. Die übrigen beteiligten Personen - die Steine erhebenden Juden, der Besessene und seine Begleiter (Abb. 16), die Menge der 5000, das jubelnde Volk von Jerusalem - sind in Grisaille, auf größeren, schattierten Weißscheiben dargestellt, nur durch die Verwendung von Silbergelb differenziert. Ins Extrem wird dieses Prinzip bei der Darstellung der Speisung der 5000 getrieben (Abb. 17), die in zwei völlig verschiedene Teile zerfällt:

Die linke Hälfte mit Jesus und seinen Jüngern ist durch mehrere kleinere, einzeln verbleite Scheiben geprägt. Die Figuren erheben sich nicht nur durch ihr Stehen, sondern auch maßstäblich über die am Boden rastende $\mathrm{Zu}$ hörerschaft, die auf nur einer Grisaillescheibe dargestellt werden konnte. ${ }^{129}$ Während die schlichten, der üblichen antikisierenden, togaähnlichen Darstellungsweise folgen- 


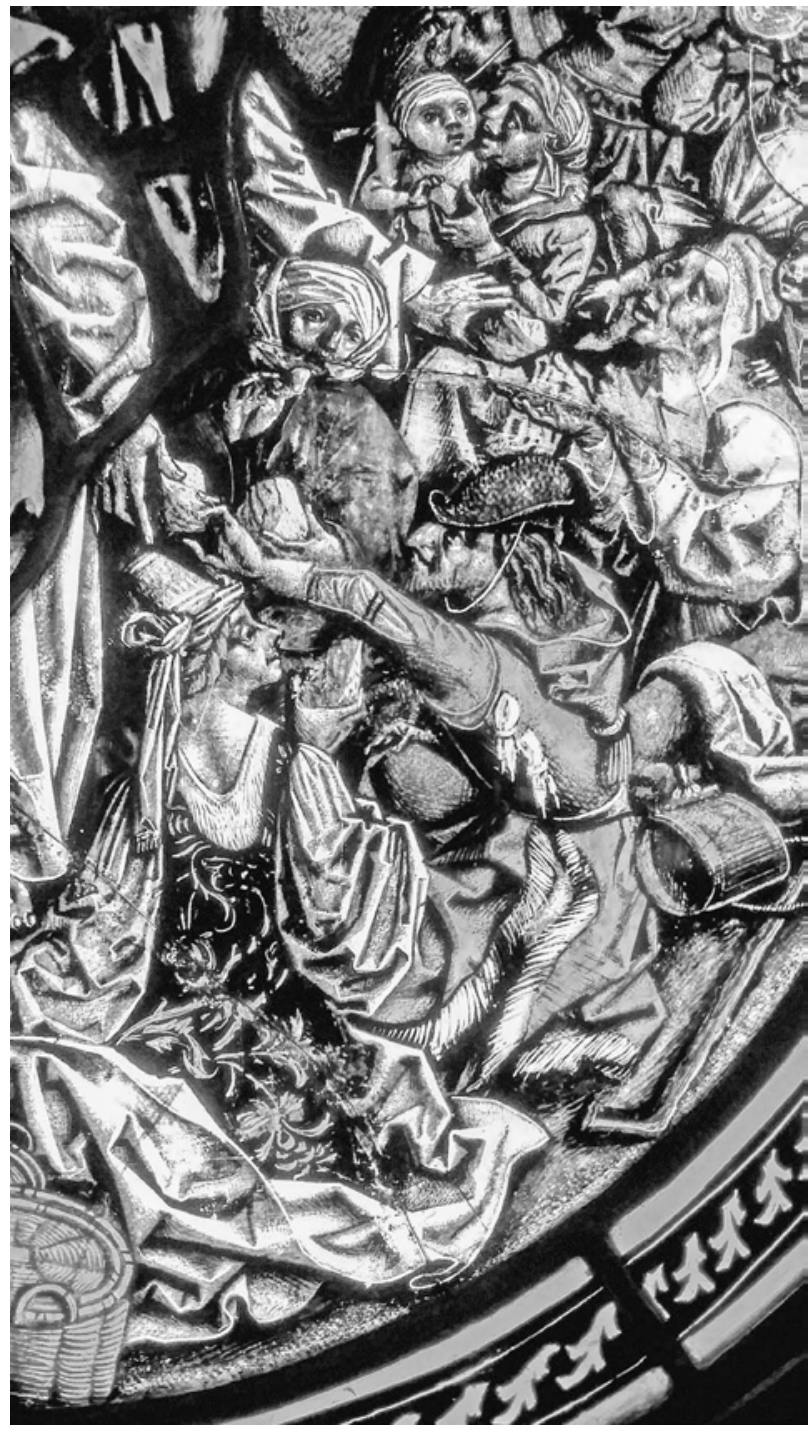

Abb. 18 Speisung der Fünftausend, Detail des Publikums. Rundscheibenzyklus, wohl aus dem Ulmer Rathaus. Berlin, Staatliche Museen - Preußischer Kulturbesitz, Kunstgewerbemuseum (Foto: M. Hörsch)

den Apostelgewänder starke farbige Akzente setzen, verschwimmt die detailreich, in zeitgenössischen Kleidern geschilderte Menge der 5000 schon auf geringe Entfernung (Abb. 18).

Petrus verteilt zwar das wunderbar vermehrte Brot, einige Männer wenden sich ihm zu, es entsteht also Interaktion zwischen den beiden Gruppen. Doch obwohl der linke Ärmel des Apostels in weißer Farbe auf der Grisaillescheibe dargestellt wurde, wodurch eine formale Verknüpfung zwischen beiden Bildhälften hergestellt werden sollte, entsteht kein glaubwürdiger räumlicher Zusammenhang zwischen den Bildhälften.
Weniger krass fallen farbige und Grisaille-Partien bei den übrigen Szenen auseinander: Sehr eindrucksvoll wird der tobende Besessene, von zwei Begleitern nur mühsam gebändigt, der Gruppe Christi und der Jünger gegenübergestellt; die zornentbrannten Juden in der Versuchten Steinigung sind gleichwertige Gegner des sich abwendenden Jesus; beim Einzug in Jerusalem bildet das Stadttor den zusammenfassenden Rahmen für die herausquellende Volksmenge.

Bei der knienden Kanaanäerin wird die Grisailletechnik zur Schilderung eines prächtigen Brokats genutzt. Hier sind es die Jünger, die auf Seiten der Frau dem isolierten Christus gegenüberstehen. Nur in den sprechenden Händen, die eigens verbleit wurden, begegnen sich die argumentierenden Gruppen. Bei der wiederum anders konzipierten Auferstehung schließlich bildeten die um das Grab verteilten Kriegsknechte einst wohl den notwendigen Kontrast, der den siegreichen Christus in rotem (?) Gewand erst richtig zur Wirkung brachte.

$\mathrm{Zu}$ dieser Polarisierung mag den (oder die) Glasmaler der Erbacher Scheiben das Medaillonformat ermutigt haben: Die schmalhohen Ulmer Ratsscheiben erlauben die beschriebene Erzählweise in viel geringerem Maß. Die schlanken Figuren müssen hier zueinander gerückt werden, füllen fast den ganzen Bildraum, der zudem noch von reichen Baldachinen überfangen und abgegrenzt wird. In besonders logischer Weise geschieht dies bei der Tempelszene, wo Baldachin und Tempel verschmolzen werden können. Der die Figuren umgebende Raum wird in den Ratsscheiben fast völlig verdrängt, was mit der Wirkung, die der Künstler bei höherer Anbringung im Chor der Pfarrkirche noch erreichen wollte, erklärt werden kann.

Aber zugleich sind verschiedene künstlerische Temperamente am Werk - das hat schon Eva Heye gesehen, ${ }^{130}$ sie ging von einer »Berührung « des Meisters der Erbacher Scheiben "mit der Kunst Peter Hemmels« aus. Deutlich wird dies besonders beim Vergleich der beiden Heilungen des Besessenen. Der Besessene der Erbacher Scheiben, ein durch schwarzafrikanische Züge aus damaliger Sicht abgewerteter Kahlkopf, muss von zwei Männern gehalten werden, und noch jetzt tritt er mit dem linken Fuß nach Christus, während er die Rechte zur Faust ballt. Der Teufel ist zwar schon ausgefahren, aber dem Maler kommt es darauf an, die Heftigkeit des letzten Aufbäumens zu zeigen. Ganz anders im Ulmer Münster: Hier ist der Besessene zwar ähnlich gekleidet - er trägt einen hemdartigen, vorn aufklaffenden Kittel und Beinlinge -, aber er ist ein alter, kraftloser Mann, zusammengesunken schon 
während ihn der Teufel verlässt. Der hinter ihm stehende Helfer verhindert, dass er mit verdrehten Gliedern gänzlich zu Boden sinkt. Der Künstler der Rundscheibe legt alles auf den dramatischen Effekt an, die Landschaft, die der Ulmer (gewiss auch wegen des Bildformats) schildert, interessiert ihn nicht.

Dieses Interesse an der dramatischen Erzählung ist ein Hauptkennzeichen des Meisters der Karlsruher Passion und rückt ihn dem Erbacher Zyklus ganz nahe. In der Dornenkrönung beispielsweise streicht er auf verwandte Weise den Unterschied zwischen einem ruhigen Pol (hier der leidende Christus) und heftig agierenden Figuren heraus, am Rande des Geschehens sehen wir Personen, die es untereinander kommentieren und so den Betrachter ebenfalls zur Reflexion auffordern. Die Proportionierung der Figuren, ihre naturnahe Beweglichkeit, in komplizierten, manchmal nicht hundertprozentig geglückten Verkürzungen ausgedrückt - man vergleiche den nach Brot greifenden Arm des Mannes im Vordergrund der Szene der Brotvermehrung oder den die Säule umarmenden Schergen der Karlsruher Dornenkrönung mit dem vorderen der beiden Männer, die den Besessenen halten -, all dies spricht von einer eng verwandten Einstellung der Künstler. Der Blick auf die Menschen in der Darstellung der Brotvermehrung (im Gegensatz dazu sehen wir Jesus und die Jünger frontal), das durch Übereinanderstaffeln von Köpfen erzielte Gedränge: Ähnlich wird eine Menschenmenge in Gefangennahme, Kreuztragung und Entkleidung der Karlsruher Passion geschildert.

Auch im Detail lassen sich enge Verbindungen zu Motiven der Karlsruher Passion feststellen: Der kniende, geschorene Spötter der Dornenkrönung kehrt in der Gestalt des Besessenen wieder. Der vordere der beiden Männer, die den Exorzierten halten, entspricht den spezifisch jüdisch gemeinten Typen der Dornenkrönung mit ihren großen Nasen und den vorn hochgekrempten Hüten. Die Juden, die Christus beim Einzug in Jerusalem begrüßen, sind, so könnte man überspitzt formulieren, schon dieselben, die ihn kurze Zeit darauf verraten und martern werden: Ihre verquollenen Gesichter drücken keine Freude aus und der rechte Mann mit dem Stirnband besitzt dasselbe Hakennasen-Profil wie der Scherge, der Christus in der Gefangennahme voranzerrt. Immer wieder finden sich auf der Karlsruher Passion ähnlich ausgestreckte Arme und von unten gezeigte Nasenlöcher wie bei dem Mann unter dem Tor. Der Mann in der Palme ist ein - knappen Bibeltexten folgendes - uraltes Motiv des Einzugs in Jerusalem (Matth 21,8, Joh 12,12), das gut zu den italienischen Passionsdarstellungen mit ihren vielen erzählerischen Details passte, man denke nur an Pietro Lorenzettis Fresken in Assisi. Solche wurden dann auch gern nördlich der Alpen rezipiert, nicht zuletzt in der Karlsruher Passion, wo das Motiv in Dornenkrönung und Entkleidungsszene verwendet wurde, ebenso im Straßburger Dominikanerfresko.

Im Hintergrund der Brotvermehrungs-Szene trinkt einer mit in den Nacken gelegtem Glatzkopf aus einer runden, flachen Feldflasche: Das Motiv ähnelt dem Trinkenden der Geißelung des Karlsruher Passionszyklus'. Im Einzelnen wird es modifiziert. Aber die vom Wesen her verwandte Art, wie die Verkürzung des Kopfes und die Bewegungsdarstellung bewältigt werden, beweisen, dass hier derselbe Entwerfer am Werk ist, der eine Idee nicht einfach abkupfert, sondern abwandelt. Solches hat Lilli Fischel auch schon für das Verhältnis der Karlsruher Passion zu den verlorenen Straßburger Dominikanerfresken herausgearbeitet. ${ }^{131}$ Viele Ideen verwendet der Maler mehrfach; aber stets sucht er die Variation, nie wiederholt er sich wörtlich. So wird ein ähnliches Profil bei dem stehenden Hackenträger der Karlsruher Kreuzannagelung und beim Mann mit der flachen Kappe im Vordergrund der Brotvermehrung verwendet, Details der modischen Kleidung des letzteren, wie die Nesteln, bei verschiedenen anderen Figuren der Karlsruher Passion. Die neben ihm liegende Trommel erinnert an den gestürzten Trommler der Ölbergszene der Dominikanerfresken.

In den Erbacher Scheiben sind somit viele Motiv- und Stileigenheiten des Meisters der Karlsruher Passion zu entdecken; und zwar so eng verwandt, wie es sonst kaum je anzutreffen ist. Doch nicht grundlos war bisher fast ausschließlich von den en grisaille dargestellten Menschen einiger spezifischer Szenen die Rede: Heilung des Besessenen, Brotvermehrung, Einzug in Jerusalem. Die Bewertung wird komplizierter, beziehen wir auch andere Figuren mit ein, denn innerhalb der Erbacher Scheiben sind so große stilistische Unterschiede festzustellen, dass auch an die Ausführung durch verschiedene Hände gedacht werden muss.

Weil der allgemeine Habitus der Figuren, die unterschiedliche Dramatik der Darstellung, keine Möglichkeit eröffnen, Ulmer Ratsfenster und Erbacher Rundscheiben ein und demselben entwerfenden Meister zuzuschreiben, kann nur von Übereinstimmung des Programms und entfernter Verwandtschaft der Komposition und Motivstruktur der Einzelszenen die Rede sein. Rüdiger Becksmann betonte das enge Verwandtschaftsverhältnis 
zwischen dem Ulmer und dem Erbacher Zyklus zu sehr: ${ }^{132}$ Er gibt zwar zu, dass der Maler der monumentalen Ulmer Bilder das "gemeinsame Vorbild" beider Zyklen stark habe umarbeiten müssen, behauptet aber zugleich, beide seien von einem Künstler geschaffen. Damit verkennt er den Temperamentsunterschied in den Darstellungen.

Umso mehr muss es stutzig machen, dass die Christusdarstellung der Erbacher Brotvermehrung fast genau derjenigen der Versuchungen im Münster entspricht. Hans Wentzel schrieb letztere Scheibe dem »besten« der seiner Meinung nach vier in Ulm tätigen Maler zu und das hieß für ihn: Peter Hemmel von Andlau selbst. ${ }^{133}$ Das längliche Gesicht mit flach verlaufenden Brauenbögen, spitzem Kinn, Stirnlocke und in einzelnen Strähnen gedrehten Haaren unterscheidet sich deutlich von dem in seiner Gesamtform etwas volleren Christusgesicht der Heilung des Besessenen mit seinen gerundeten Brauenbögen. Dasselbe gilt für den volleren Christuskopf beim Einzug in Jerusalem, dessen Augen weiter geöffnet sind, während sie beim Christus der Brotvermehrung schmaler, in Nuancen schlitzförmiger ausfallen. Die gesamte Gestalt Christi ist bei der Brotvermehrung schlanker und ähnelt daher mehr der großen Christusdarstellung der Versuchung im Münster als denen der übrigen Erbacher Scheiben. Eine ähnliche, schlank proportionierte Christusfigur findet sich in der Erbacher Steinigungsszene. Bei ihr weisen die Darstellungen der Juden zwar die gleiche Plastizität der Gesichter wie beim Einzug in Jerusalem auf, doch sind sie wiederum in der Proportion schlanker als die Figuren der meisten anderen Rundscheiben. Die Grabwächter der Auferstehung entsprechen ihnen - und es ist schade, dass die Christusfigur gerade dieser Scheibe verloren ist. Allerdings dürfte sie dem jüngeren, dem Ratsfenster des Münsters näheren Typus entsprochen haben. Martin Schongauer, der in seinem Zyklus ja auch sonst das oberrheinische Passionstreiben klärt und veredelt, dürfte aus einer Vorlage dieses Straßburger Typs das Motiv des Engels übernommen haben, der den schräggelegten Deckstein der Tumba abhebt. ${ }^{134}$

Es sind also zwei vor allem in der Proportionierung von Gesichtern und Gestalten unterschiedliche künstlerische Tendenzen innerhalb der Erbacher Scheiben zu erkennen. Die Erzählweise ist davon nicht berührt: Die lebendige Beobachtung, mit der die Grabwächter geschildert werden - einer schiebt erwachend das Visier hoch, rechts macht einer seinen noch schlafenden Kollegen durch Schubsen und Zeigen auf das Geschehen aufmerksam -, entspricht derjenigen der übrigen Scheiben.
Auch ändert der stilistische Unterschied innerhalb der Erbacher Scheiben nicht Technik und Qualität der Ausführung. Die Scheiben sind sicher in derselben Werkstatt ausgeführt worden. Unterschiedliche Künstler hatten somit die Möglichkeit, einzelne Szenen, freilich wohl nach einem gemeinsamen Urkonzept, zu gestalten: einer, dessen künstlerisches Temperament und viele Einzelheiten mit dem Meister der Karlsruher Passion in Verbindung zu bringen sind, verantwortete den Großteil der Scheiben (Verkündigung, Anbetung des Kindes, Heilung des Besessenen, Christus und die Kanaanäerin, Einzug in Jerusalem, die rechte Hälfte der Brotvermehrung); der andere, der uns auch im Ulmer Ratsfenster von 1480 begegnet, schuf den Rest (die versuchte Steinigung, Auferstehung und die linke Hälfte der Brotvermehrung). Die Art der Aufteilung mit einem Bruch in der Szene der Brotvermehrung und die Abfolge des Stils lässt darauf schließen, dass der etwas fortgeschrittenere Künstler mit den gelängteren Figuren den älteren ersetzte und den Zyklus zu Ende brachte, und dies vermutlich ohne allzu großen zeitlichen Abstand.

Im Gegensatz zu Hartmut Scholz ${ }^{135}$ sehe ich allerdings keinerlei Grund, in dem Scheibenzyklus einen Einfluss Martin Schongauers zu erkennen - ganz im Gegenteil. Ein so origineller und in weiten Teilen in sich konsistenter Zyklus wie die Erbacher Rundscheiben kann sehr wohl auch als Zeugnis für eine gebende Stufe der Straßburger Kunst angesehen werden, ja dies erscheint bei genauer Analyse des jeweiligen künstlerischen Impetus' eigentlich als die einzig denkbare Reihenfolge. Es wird eben nicht "peinlich jedes umfänglichere Zitat vermieden $"{ }^{136}$ sondern die Glasscheiben sind eine eigenständig erarbeitete, äußerst durchdachte Rezeption u.a. niederländischer Vorbilder, nicht Schongauers. Wäre der zunächst tonangebende, in seiner Auffassung so lebendige Künstler, der in seinem ganzen Geist der Karlsruher Passion so nahe steht, wirklich derart rezipierend gewesen, dass er aus Schongauers Anbetungsstichen den seinen "zusammengebaut« hätte - hätte er dann nicht doch in irgendeiner Weise Schongauers Stil übernommen? Doch genau dies ist nicht der Fall. Die von Scholz zu Recht hervorgehobene »rührend interessierte Haltung des Ochsen ${ }^{137}$ findet doch auf der Scheibe ihre wesentlich überzeugendere und den Bewegungen eines realen Rindviehs abgeschaute Lösung. ${ }^{138}$ Sie entspricht genau der realistischen Tendenz so vieler Szenen des Rundscheibenzyklus.

Vielmehr hätte sogar der zweite Glasmaler, derjenige der Auferstehung, trotz einer Schongauer-Rezeption im 
Motivischen zu einer originellen älteren Gestaltungsweise zurückgefunden. Man beachte nur die kühn von oben gezeigte Szene links (Abb. 19), wo einer der Wächter den anderen am Kopf berührt, um ihn zu wecken.

Dies entspricht der älteren Aufassung in der Nachfolge der Karlsruher Passion, die Schongauer gerade eliminierte. Man sollte Schongauer, der mit seiner an Rogier geschulten Kühle diese ältere Tradition gerade überwindet, somit nicht zum Maß aller Dinge machen. Schongauer war es, der eindeutig Anleihen bei der Karlsruher Passion und verwandten Werken machte, um sie gleichsam programmatisch in den Stil seines gegen Mitte der $1470 e r$ Jahre und vielleicht noch ein wenig darüber hinaus geschaffenen grafischen Zyklus' einzuschmelzen.

Für eine Datierung des Rundscheibenzyklus kann die Ähnlichkeit z. B. des Tumbendeckel-Motivs keinesfalls ausreichen. Auch der Stil der (innerhalb des Zyklus fortgeschritteneren) Auferstehungsscheibe deutet sehr wohl darauf hin, dass diese noch vor Schongauers vermutlich gegen 1475 entstandener Passion gefertigt wurde. ${ }^{139}$ Es gibt im Übrigen einen sehr ernst zu nehmenden Hinweis, wann die Scheiben im Ulmer Rathaus eingebaut worden sein könnten, wird doch im Jahre 1470 ein Hainz Glaser « »um das Finsterwerk uff das rathhauß « mit »XV Pfund, 1 Sch. 6 Heller « bezahlt. ${ }^{140}$ Für einen eigenständigen Zyklus von hoher künstlerischer Qualität, bei dem wesentliche Teile noch »im Geiste« der Karlsruher Passion geschaffen wurden, ist dies keineswegs ein »frühes Datum " (so Scholz), sondern im Grunde, angesichts der beobachteten Beteiligung des zweiten Künstlers, das genau passende: Es ist eben auch nicht mehr ganz der Stil der Karlsruher Passion. Die Falten brechen härter, man merkt den Einfluss der Kunst Rogers, der dann im Stil des »jüngeren Künstlers« auch in der Proportionierung durchschlägt, wahrscheinlich, weil dieser in seiner Ausbildung schon anderen Leitbildern gefolgt war. Ein Abstand von zehn Jahren zum Ratsfenster des Münsters scheint nach allem Gesagten durchaus noch passend.

Der »jüngere« Künstler, der dann auch am Ratsfenster beteiligt war, ist aber, folgt man Hans Wentzel und der jüngeren plausiblen Begründung Hartmut Scholz, niemand anderes als Peter Hemmel von Andlau selbst, denn das Ulmer Fenster steht einem der wenigen für Hemmel direkt gesicherten Werke, dem Klaner-Fenster im Salzburger Stift Nonnberg, fertiggestellt 1480, besonders nahe. ${ }^{141}$ Der wohl in den $1420 e r$ Jahren geborene Hemmel erweist sich, was gewiss nicht verwundert, als ein gegenüber der Karlsruher Passion etwas progressiverer

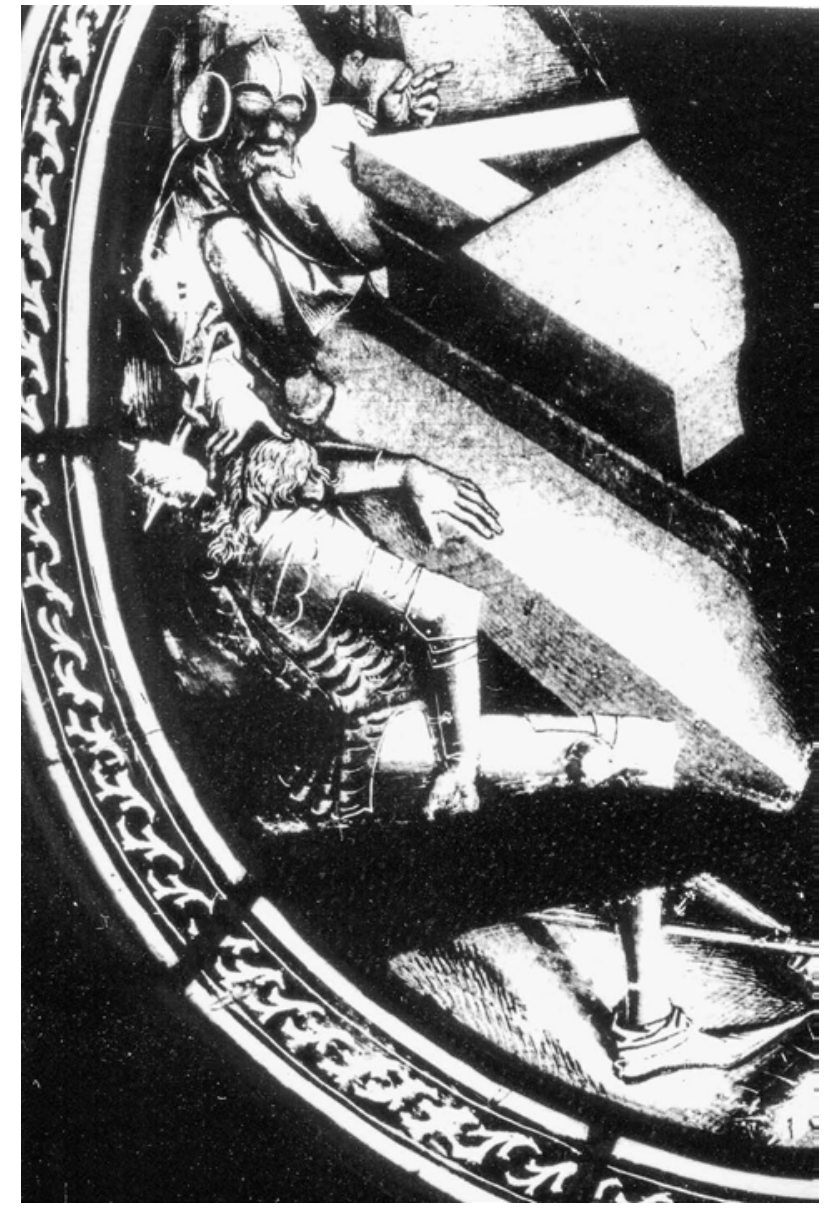

Abb. 19 Auferstehung Christi, Detail zweier erwachender Soldaten am linken Bildrand. Rundscheibenzyklus, wohl aus dem Ulmer Rathaus. Berlin, Staatliche Museen - Preußischer Kulturbesitz, Kunstgewerbemuseum (Foto: M. Hörsch)

Künstler, aber keinesfalls als der progressivste der Straßburger Glasmaler-Verbindung von $1477 .{ }^{142}$ Gerade im Ratsfenster finden sich noch deutliche Anklänge an die Karlsruher Passion, wenngleich eben nicht die unmittelbare stilistisch-motivische Ähnlichkeit, die sich in den Erbacher Scheiben feststellen ließ. ${ }^{143}$

\section{Hans Hirtz - der Meister der Karlsruher Passion?}

Es ist bekannt, dass in dem Straßburger Bezirk (vicus) Alte Kurdewongasse, an der Hauptachse der Oberstraße, der späteren Langenstraße und heutigen Place bzw. Rue Gutenberg, nördlich von St. Thomas ${ }^{144}$ während des ganzen 15. Jahrhunderts ein Künstlerviertel bestand, das die Bedeutung dieses Erwerbszweigs in Straßburg belegt, 
auch wenn hier selbstverständlich nicht alle Künstler der Reichsstadt lebten und arbeiteten. Drei Mitglieder des Straßburger Glasmalerei-Kartells, das sich Martini 1477 in Straßburg zusammengeschlossen hatte, ${ }^{145}$ Theobald (Diebolt) von Lixheim, Hans von Maursmünster und Peter Hemmel von Andlau, waren unmittelbare Nachbarn (letzterer Bürger und Meister seit $1447^{146}$ ), ebenso aber der gerühmte Maler Hans Hirtz und der ebenso bekannte Bildhauer Hans Geuch (Jöuch). Und diese sind nur die bekannten Spitzen dieses Künstlerviertels, denn von den anderen hier Tätigen wissen wir einfach nicht mehr, was sie geschaffen haben - wobei dies ja auch für Hirtz und Geuch keineswegs als völlig gesichert gelten kann. ${ }^{147}$ Es ist also keine Frage, dass Tafel- und Glasmaler, aber eben auch Bildhauer, hier aufs Engste zusammenlebten, -arbeiteten und untereinander wohl auch über das bisher mehr oder minder zufällig Bekanntgewordene hinaus verwandt und verschwägert waren. $\mathrm{Zu}$ den bekannten Tatsachen zählt, dass Hans Ulrich gen. Meyenblüt, Sohn des Glasmalers Ulrich von Pforzheim und seiner Frau Margarethe Knebelin, Hans Hirtzens Patenkind war. Ulrich von Pforzheim lebte einige Häuser von Hirtz' An wesen entfernt in jenem Haus, in dem dann auch Hans Geuch nachweislich tätig war. ${ }^{148}$ Meyenblüt machte sich 1447 in Köln als Maler selbstständig. Rott nahm an, dass er bei Hirtz gelernt habe, und schrieb ihm die Tafeln des von Peter Kannegießer ( $†$ 1473) gestifteten Georgsretabels unbekannter Provenienz zu, ${ }^{149}$ was von Frank Günter Zehnder zuletzt ohne Diskussion vom Tisch gewischt wurde. ${ }^{150}$

1421 erwarb Hans Hirtz mit seiner Frau Ennelin das Haus Zum Blochschuh oder Holzschuh an der Oberstraße. ${ }^{151}$ Zuvor hatte es Hermann, "dicto maler «, gehört. ${ }^{152}$ Seit 1473 steuerte auf dem Haus der »moler« Heinrich Lützelmann. ${ }^{153}$ Einer der typischen Zufälle der spätmittelalterlichen Steuerregistrierung überliefert uns die Tatsache, dass Heinrich Lützelmann, der zwischen 1500 und 1506 für das Frauenwerk im Steuerviertel St. Martin III lb zinste, dies ebenso schon 1475/76 getan hatte, hier aber als »Heinrich von Ulme, der moler «. ${ }^{154}$ Er stammte also aus der schwäbischen Reichsstadt. Es gibt Argumente, Lützelmann mit dem erwähnten Meister der Coburger Rundblätter respektive der Gewandstudien ${ }^{155} \mathrm{zu}$ identifizieren: In dem großen Zeichnungskonvolut, welches man dieser Werkstatt zuschreibt, finden sich Motive und Darstellungen aus dem Umfeld des Meisters der Karlsruher Passion rezipiert, den man wiederum mit Hans Hirtz identifizieren möchte. Aber man wird bei solchen
Indizienbeweisen vorsichtig bleiben müssen, umso mehr, als ja die genaue Besitzerabfolge des Hirtz'schen Anwesens nicht völlig geklärt ist, denn dieser war bereits 1463 oder kurz davor verstorben, nachdem er vom Grafen Alwig von Sulz nebst fünf weiteren Straßburger Bürgern als Geisel genommen worden war. ${ }^{156}$

Mit der Identifizierung Lützelmanns beschäftigte sich zuletzt eingehend Hartmut Scholz ${ }^{157}$ der plausibel machte, dass der Maler eine sich über drei Fensterbahnen erstreckende Pietà im Chor des Ulmer Münsters in einer Zeichnung (Chantilly, Musé Condé) zumindest rezipierte und möglicherweise sogar im dortigen Kramerfenster seine abgekürzte Signatur hinterließ. Dies ist im vorliegenden Zusammenhang insofern bedeutsam, als Scholz mit dem Kramerfenster eine fortschrittlichere Kompositions- und Stilstufe definierte - im Grundlegenden zunächst erkennbar an der Ausdehnung von Szenen über mehrere Bahnen -, die über das lange anerkannte Schaffen Peters von Andlau deutlich hinausging. Und dieser war, wie oben bereits angedeutet, höchstwahrscheinlich der führende Künstler der am Ratsfenster des Ulmer Münsters beteiligten. ${ }^{158}$

Geht man davon aus, dass Peter Hemmel demnach zumindest auch die »fortgeschritteneren « Teile der Erbacher Scheiben geschaffen und diese möglicherweise vollendet hat, dann ist eine Zusammenarbeit der Hemmel-Werkstatt mit derjenigen des Meisters der Karlsruher Passion doch etwas konkreter fassbar, als es bisher möglich war.

Eine solche Zusammenarbeit mit einem Glasmaler hatte schon Wentzel erwogen, und zwar unter der Annahme, Hans Hirtz habe mit jenem Heintz zusammengearbeitet, dessen Witwe 1447 "Peter Hemmel von Andelo « heiratete, was diesem mit Bürgerrecht und Glasmaler-Werkstatt den Grundstock seines späteren Erfolgs einbrachte. ${ }^{159}$ Wentzel schloss dies aus dem von Rott publizierten Eintrag in einem Verzeichnis der Straßburger Malergesellen aus der Mitte der 1440er Jahre: ${ }^{160}$ "Item disse nochgeschriben sint die knecht (...), item Heinrich ist bi Hirtzen. « Im ersten Mannschaftsbuch werden ein »Heinrich, glaser « und ein »Heintz, glaser « erwähnt. ${ }^{161}$ Letzterer könnte der 1447 als verstorben gemeldete Glaser Heintz sein, doch ob dieser dann mit dem unter den Gesellen aufgeführten Heinrich zu identifizieren wäre, wie dies die Aufzählung bei Wentzel suggeriert, ${ }^{162}$ ist doch sehr fraglich. Ebenso ist unklar, ob der in einer weiteren Liste von 1444 erwähnte Heinrich Snewel ${ }^{163}$ mit dem Glaser Heinrich identisch ist. Schließlich wird in den Akten der Zunftstreitigkeiten von 1447 noch ein »Maler« 
Heinrich erwähnt, der neben Hirtz und anderen Mitglied bei der Goldschmiedezunft sein oder werden wollte, vielleicht, wie Blasius vermutet, um über die Mitgliedschaft in dieser reichen Zunft durch einen von seinem eigentlichen Beruf unabhängigen Zuerwerb (den Handel mit Geld oder Edelmetallen?) größere Einnahmequellen zu erlangen. ${ }^{164}$

Es ist also kaum möglich, hier letztendliche Klarheit zu schaffen, zumal auch bei den Berufsbezeichnungen von "Malern" und "Glasern" Schwankungen auftreten, wie oben am Beispiel der Nennungen Peters von Andlau im Jahre 1466 bereits auffallen musste. Dies zeigt selbstverständlich auch, dass Maler und Glasmaler ihre Tätigkeiten nicht immer säuberlich gegeneinander abgrenzten, wie dies ja gerade auch bei den Erbacher Scheiben feststellbar ist, wo gerade die feinteilig-differenzierten Partien, die man mit der Karlsruher Passion in Verbindung bringen kann, eher »unglasmalerisch" wirken.

Wieder drängt sich der Eindruck auf, dass gerade auch Peter Hemmel, der Erbe und zweite Gemahl der Witwe des Heintz, sehr bald mit einem der übrigen, im Tafelmalergewerbe tätigen Nachbarn zusammengearbeitet haben könnte - und der berühmteste war unter diesen nun einmal der bereits seit Langem ansässige Hans Hirtz. Noch immer ist dies kein endgültiger Durchbruch in der HansHirtz-Frage. $\mathrm{Zu}$ viele Unwägbarkeiten verbleiben in der Reihe der Argumente. Sollte der Meister der Karlsruher Passion mit Hans Hirtz identisch sein und nehmen wir eine direkte Beteiligung des Malers an dem Entstehungsprozess der Erbacher Scheiben an, so müssen die Erbacher Scheiben einige Zeit vor 1463 zumindest begonnen worden sein, als er in Gefangenschaft geraten und bereits verstorben war. Dass Hirtz selbst als Glasmaler tätig war, ist nicht undenkbar, aber bisher nicht zu beweisen. Wahrscheinlicher ist es, dass ein Glasmaler bzw. seine Werkstatt Hirtzsche Entwürfe umsetzte - und dass nach dessen Tod diese in einem moderneren Geschmack fertiggestellt wurden, wobei man durchaus an eine Beteiligung Hemmels denken darf. 1470 wurden die Scheiben in Ulm durch einen Glaser Heintz, der durchaus auch aus Straßburg angereist gewesen sein könnte, wo es ja mehrere Namensträger gab, eingesetzt. Der Glasmaler (Peter von Andlau) hat dann später, gegen 1480, für den Ulmer Rat die Passionsperikopen nochmals dargestellt. Dabei griff er, wie es vom Ulmer Rat gewünscht war, auf die Rundscheiben zurück und transponierte deren Darstellungen in das größere, dem Münsterchor angemessene Format. Dass hierbei das künstlerische Temperament der Dar- stellungen "abkühlte«, dürfte mit dieser Vergrößerung des Maßstabs, aber auch der generellen Entwicklung des Zeitstils zusammenhängen: Er war über die Psychologie und Dramatik eines Meisters der Karlsruher Passion hinweggegangen, der sich in den sog. Erbacher Scheiben wahrscheinlich ein spätes letztes Mal manifestiert hatte.

Wenn es allein um die Klärung von Namen ginge, wäre es sicher müßig, eine Künstler-Werk-Zusammenstellung auch nur zu versuchen. Aber dieses Forschen zielt ja auf wesentlich mehr: Gewiss ist es nicht leicht, im 14./15. Jahrhundert Persönlichkeiten, ihre sozialen Bindungen, ihr künstlerisches Potenzial zu rekonstruieren. Aber gerade das Beispiel Hans Hirtz zeigt, dass man bis zu einem gewissen Grad Vergangenes überprüfbar wieder zum Leben erwecken kann. Und sofern dies zu einem besseren Verständnis der Kunst führt, sollte man nichts unversucht lassen. Es sind auch bei Weitem noch nicht alle Möglichkeiten ausgelotet - zum Beispiel die hier angedeuteten gattungsübergreifenden Ansätze, die über den Vergleich der Tafelbilder mit Druckgrafik hinausgehen. Die «alte« Methode des Stil- und Motivvergleichs weist eine Richtung, in die weiterzuforschen sich lohnt.

In jedem Fall zeigen die Erbacher Scheiben einen Künstler, der hergebrachte Gestaltungsweisen, wohl auch seine eigenen, verlässt, einen originellen Darsteller menschlichen Verhaltens und der Vielfalt der Details der Ding-Welt, bis zu einem gewissen Grade bereits um ihrer selbst willen, doch zugleich noch immer im Dienste der Intensivierung der verbildlichten Inhalte.

\section{Literatur}

[Ausst.-Kat. Darmstadt 1995]: Ausst.-Kat. Vom Jenseits ins Diesseits. Sakrale Bilder des Spätmittelalters aus den Beständen des Hessischen Landesmuseums und aus Privatbesitz. Bearb. von Moritz Woelk. Darmstadt, Hessisches Landesmuseum, 16.9.-12.11.1995. Darmstadt 1995.

[Ausst.-Kat. Frankfurt/Main 1975]: Ausst.-Kat. Kunst um 1400 am Mittelrhein. Ein Teil der Wirklichkeit. Frankfurt/M., Liebieghaus, 1975. Hg. von Herbert BECK, Wolfgang BEEH und Horst BredeKamp. Frankfurt/M. 1975.

[Ausst.-Kat. Karlsruhe 1996]: Ausst.-Kat. Die Karlsruher Passion. Ein Hauptwerk Straßburger Malerei der Spätgotik. Karlsruhe, Staatliche Kunsthalle, 3.4.-30.6.1996. Ostfildern-Ruit 1996.

[Ausst.-Kat. Köln 1978]: Ausst.-Kat. Die Parler und der Schöne Stil 1350-1400. Europäische Kunst unter den Luxemburgern. Hg. von Anton Legner. 3 Bde. Köln 1978. 
[Ausst.-Kat. Nürnberg 1983]: Ausst.-Kat. Veit Stoß in Nürnberg. Werke des Meisters und seiner Schule in Nürnberg und Umgebung. Ein Handbuch zum Werk des Nürnberger Bildhauers, aus Anlaß der 450. Wiederkehr seines Todesjahres herausgegeben vom Germanischen Nationalmuseum Nürnberg. Konzeption und Redaktion Rainer KaHsNitz. Nürnberg, Germanisches Nationalmuseum, 1983. Nürnberg 1983.

[Ausst.-Kat. Nürnberg 1990]: Ausst.-Kat. 800 Jahre Deutscher Orden. Nürnberg, Germanisches Nationalmuseum, 1990. München/Gütersloh 1990.

[Ausst.-Kat. Regensburg 1987]: Ausst.-Kat. Regensburger Buchmalerei. Von frühkarolingischer Zeit bis zum Ausgang des Mittelalters. Hg. von Florentine Mütherich und Karl DAcHs. Regensburg, Leerer Beutel, 19.5.-9.8.1987. München 1987.

[Ausst.-Kat. Straßburg 2008]: Ausst.-Kat. Strasbourg 1400, un foyer d'art dans l'Europe gothique. Hg. von Cécile Dupeux und Philippe Lorentz. Straßburg, Musée de l'CEuvre Notre-Dame, 28.3.-6.7.2008. Strasbourg 2008.

[Ausst.-Kat. Ulm 1995]: Ausst.-Kat. Bilder aus Licht und Farbe. Meisterwerke spätgotischer Glasmalerei. »Straßburger Fenster « in Ulm und ihr künstlerisches Umfeld. Hg. von Brigitte Reinhardt und Michael Roth. Ulmer Museum, 5.2.-26.3. 1995. Ulm 1995.

BAIER, Walter: Untersuchungen zu den Passionsbetrachtungen in der Vita Christi des Ludolph von Sachsen. 3 Bde. Salzburg 1977 (Analecta Cartusiana 44).

BAIER, Walter/RuH, Kurt: Ludolf von Sachsen. In: Verfasserlexikon, 2. Aufl., Bd. 5, Berlin/New York 1985, Sp. 967-977.

BAIER, Walter: Ludolf von Sachsen. In: Neue Deutsche Biographie, Bd. 15. Berlin 1987, 300-301. Online: http://daten. digitale-sammlungen.de/ooo1/bsbooo16333/images/index. html? seite $=314(11.2017)$.

BAUCH, Kurt: Schongauers Frühwerke. In: Oberrheinische Kunst. Jahrbuch der Oberrheinischen Museen V (1932), 171-184.

BAUCH, Kurt (Hg.): Festschrift für Hans Jantzen. Berlin 1951.

BAudisch, Jens: Technologische Untersuchung und Restaurierung der Karlsruher Passion. In: Ausst.-Kat. Karlsruhe 1996, 187-200.

Becksmann, Rüdiger (Bearb.): Die mittelalterlichen Glasmalereien in Schwaben von 1350-1530. Berlin 1986 (Corpus vitrearum medii aevi, Deutschland I,2).

Becksmann, Rüdiger: Deutsche Glasmalerei des Mittelalters. Eine exemplarische Auswahl. Stuttgart-Bad Cannstatt 1988.

Becksmann, Rüdiger (Bearb.): Die mittelalterlichen Glasmalereien in Freiburg im Breisgau. Münster Unserer Lieben Frau. Berlin 2010 (Corpus vitrearum medii aevi II, Baden und Pfalz, Teil 2).

BeEH, Wolfgang: Deutsche Malerei um 1260 bis 1550 im Hes- sischen Landesmuseum Darmstadt. Darmstadt 1990 (Kataloge des Hessischen Landesmuseums 15).

Beeh-Lustenberger, Suzanne: Glasmalereien um 800-1900 im Hessischen Landesmuseum in Darmstadt. Textteil. Hanau 1973.

Bergsträsser, Gisela: Caspar Isenmann. Colmar 1941.

Blasıus, Friederike: Bildprogramm und Realität. Untersuchungen zur oberrheinischen Malerei um die Mitte des 15. Jahrhunderts, am Beispiel der »Karlsruher Passion«. Frankfurt/ M./Bern/New York 1986.

Bосн, Karl Eduard: Das Steintal im Elsass. Eine geschichtliche Studie über die ehemalige Herrschaft Stein und deren Herren, sowie über die Entwicklung des gesamten Wirtschaftsund Geisteslebens im Steintal. Straßburg 1914.

Bosch, Lynette M. F.: Terminus »ante quem« for two of Martin Schongauer's Crucifixions. In: The Art Bulletin 64 (1982), $632-635$.

Brinkmann, Bodo/Kemperdick, Stephan: Deutsche Gemälde im Städel 1300-1500. Mainz 2002 (Kataloge der Gemälde im Städelschen Kunstinstitut Frankfurt am Main 4).

BÜTtNer, Nils: Johannes arte secundus? Oder: Wer signierte den Genter Altar? In: SCHILP 2004, 179-200. Online: http:// archiv.ub.uni-heidelberg.de/artdok/1046/ (02.11.17).

Dhanens, Elisabeth: Hubert und Jan van Eyck. Königstein/ Taunus 1980 .

FIschel, Lilli: Studien in der altdeutschen Abteilung der badischen Kunsthalle. Bd. III. Der Meister der Karlsruher Passion; sein verschollenes Euvre. In: Oberrheinische Kunst. Jahrbuch der oberrheinischen Museen VI (1934), 41-6o.

Fischel, Lilli: Oberrheinische Malerei im Spiegel des frühen Kupferstiches. In: Zeitschrift für Kunstwissenschaft I (1947), $23-28$.

Fischel, Lilli: Die Karlsruher Passion und ihr Meister. Karlsruhe 1952.

Fischer, Otto: Der Meister von Waldersbach im Elsaß. In: Zeitschrift für Kunstgeschichte II (1933), 333-347.

Fischer, Otto: Der Meister von Waldersbach. Nachträge. In: Zeitschrift für Kunstgeschichte III (1934), 281-283.

FrAnkL, Paul: Peter Hemmel, Glasmaler von Andlau. Berlin 1956.

FrANKL, Paul: Die Glasmalereien der Wilhelmerkirche in Straßburg. Rekonstruktion, Datierung, Attribution. BadenBaden 1960.

Franzen, Wilfried: Die Karlsruher Passion und das »Erzählen in Bildern«. Studien zur süddeutschen Tafelmalerei des 15. Jahrhunderts. Diss. Berlin 2000; Berlin 2002.

Futterer, Ilse: Eine Gruppe oberrheinischer Tafelbilder des 15. Jahrhunderts. In: Oberrheinische Kunst II (1926/27), $15-28$.

Harms, Wolfgang (Hg.): Text und Bild, Bild und Text. DFG- 
Symposion 1988. Stuttgart 1990 (Germanistische Symposien, Berichtsbände XI).

Haussherr, Reiner: Überlegungen zu spätgotischen Bildzyklen mit Szenen aus der öffentlichen Wirksamkeit Christi. In: Zeitschrift für schweizerische Archäologie und Kunstgeschichte 43 (1986), 124-134.

Hérold, Michel/Gatouillat, Françoise: Les vitraux de Lorraine et d'Alsace. Paris 1994 (Corpus vitrearum medii aevi. France V).

Herzner, Volker: Jan van Eyck und der Genter Altar. Worms 1995.

Hess, Daniel: Der sogenannte Staufener Altar und seine Nachfolge. Zur oberrheinischen Malerei um 1450. In: KAMMEL 2000, 77-87.

Heye, Eva: Die Rundscheiben aus Schloß Erbach. In: Berliner Museen N. F. 15 (1965), 49-57.

HörsCH, Markus: Rezension zu Ausst.-Kat. Karlsruhe 1996. In: Kunstchronik 50 (1997), H. 2, 53-61.

Hörsch, Markus: Nikolaus Gerhaert von Leyden; Hans Geuch. In: Allgemeines Künstlerlexikon, Bd. 52. Leipzig 2006, 101-106.

http://www.culture.gouv.fr/public/mistral/merimee_fr?AC TION=RETROUVER \&REQ $=(($ IA67013040 $)+\% 3$ AREF +$)$ (Red. Olivier HaEgel und Florent Fritsch; aufgerufen 14.09.17).

Kammel, Frank Matthias (Hg.): Begegnungen mit Alten Meistern. Altdeutsche Tafelmalerei auf dem Prüfstand. Nürnberg 2000.

Kотне, Wilhelm: Kirchliche Zustände Strassburgs im 14. Jahrhundert. Ein Beitrag zur Stadt- und Kulturgeschichte des Mittelalters. Diss. Breslau 1902; Freiburg/B. 1903.

Krohm, Hartmut/Nicolaisen, Jan (Hgg.): Martin Schongauer - Druckgraphik im Berliner Kupferstichkabinett. Berlin 1991 (Bilderhefte der Staatlichen Museen Preußischer Kulturbesitz Berlin).

Krohm, Hartmut/Oellermann, Eike (Hgg.): Flügelaltäre des späten Mittelalters. Berlin 1992.

Lasch, Gustav: Geschichte der Wilhelmer Kirche zu Straßburg im Elsaß. Straßburg 1909.

LAuts, Jan: Katalog Alte Meister bis 1800 der Staatlichen Kunsthalle Karlsruhe. Karlsruhe 1966.

Lehrs, Max: Geschichte und kritischer Katalog des deutschen, niederländischen und französischen Kupferstichs im XV. Jahrhundert, Bd. 2, mit Tafelband. Wien 1910.

Löcher, Kurt: Christi Geburt mit Deutschordenspriester als Stifter. In: Ausst.-Kat. Nürnberg 1990, 27, Kat.-Nr. I.3.6.

[Lorentz 2008/I]: Lorentz, Philippe: Un grand artiste à Strasbourg au tournant du XVe siècle: le Maître de la Crucifixion au Dominicain, Hermann Schadeberg. In: Ausst.-Kat. Straßburg 2008, 36-53.
[Lorentz 2008/II]: Lorentz, Philippe: Le Maître de Paradiesgärtlein, peintre de la candeur enfantine. In: Ausst.-Kat. Straßburg 2008, 54-71.

[Ludolf/Rigollot 1878]: Ludolphus de Saxonia: Vita Jesu Christi ex evangelio et approbatis ab ecclesia catholica doctoribus sedule collecta editio novissima. Hg. von Louis Marie Rigollot. 4 Bde. Paris/Bruxelles 1878. Online: https:// archive.org/details/vitajesuchristio3ludogoog (30.09.17).

LüDKE, Dietmar: Der Meister der Karlsruher Passion und sein Werk. In: Ausst.-Kat. Karlsruhe 1996, 9-26.

LÜDKE, Dietmar: Die Geißelung (Erwerbungsbericht). In: Jahrbuch der Staatlichen Kunstsammlungen in Baden-Württemberg 37 (2000), 141-147.

LüDKE, Dietmar: Die Geißelung vom Meister der Karlsruher Passion. Karlsruhe 2008 (Patrimonia 198).

Meier, Albert: Oberlin, Friedrich. In: Neue Deutsche Biographie 19 (1999), 395-396. Online: https://www.deutsche-biographie.de/gnd118589199.html\#ndbcontent (18.09.17).

Möhring, Helmut: Beobachtungen zu Tabula Magna und Lettnerkreuzigung aus Tegernsee. In: Кrohm/OellermanN 1992, 127-143.

Möhring, Helmut: Die Tegernseer Altarretabel des Gabriel Angler und die Münchner Malerei von 1430-1450. München 1997 (Beiträge zur Kunstwissenschaft 71).

Moraht-Fromm, Anna: Das Erbe der Markgrafen. Die Sammlung deutscher Malerei (1350-1550) in Karlsruhe. Ostfildern 2013.

NoAcK, Werner: Weicher Stil am Oberrhein. Stand und Aufgaben der Forschung. In: BAUCH 1951, 110-116.

Päснт, Otto: Van Eyck. Die Begründer der altniederländischen Malerei. München 1989.

Reuss, Rodolphe: Histoire de Strasbourg depuis ses origines jusqu’à nos jours. Paris 1922. Neudruck 1981.

[Rijksmuseum Twenthe 1938]: Rijksmuseum Twenthe, Enschede. De Meesters der 15de en 16de eeuw. Enschede 1938.

[Roller 1996/I]: Roller, Stefan: Ein verlorenes Werk des Meisters der Karlsruher Passion. Zu einer aquarellierten Zeichnung in den Graphischen Sammlungen München und einem Kupferstich in der Staatlichen Kunsthalle Karlsruhe. In: Ausst.-Kat. Karlsruhe 1996, 117-141.

[Roller 1996/II]: Roller, Stefan: Der Meister der Karlsruher Passion und seine Wirkung. In: Ausst.-Kat. Karlsruhe 1996, 149-171.

[Roller 1996/III]: Roller, Stefan: Straßburger Zeichnungen in der Nachfolge der Karlsruher Passion. In: Ausst.-Kat. Karlsruhe 1996, 173-183.

Rотн, Michael: Die Zeichnungen des »Meisters der Coburger Rundblätter«. 2 Bde. Diss. Berlin (FU) 1988.

Rотн, Michael: Straßburger Zeichnungen in der Nachfolge der Karlsruher Passion. In: Ausst.-Kat. Karlsruhe 1996, 173-185. 
Rотт, Hans: Quellen und Forschungen zur südwestdeutschen und schweizerischen Kunstgeschichte, Bd. III/1. Der Oberrhein. Quellen. Stuttgart 1936.

Rotт, Hans: Quellen und Forschungen zur südwestdeutschen und schweizerischen Kunstgeschichte, Bd. III/2. Der Oberrhein. Textband. Stuttgart 1938.

Schilp, Thomas (Hg.): Dortmund und Conrad von Soest im spätmittelalterlichen Europa. Bielefeld 2004.

Schmitz, Hermann: Die Glasgemälde des königlichen Kunstgewerbemuseums zu Berlin. Mit einer Einführung in die Geschichte der deutschen Glasmalerei. Berlin 1913.

Schmitz, Hermann: Rund- und Kabinettscheiben. München 1923.

[Scholz 1994/I]: Scholz, Hartmut: Die mittelalterlichen Glasmalereien in Ulm. Berlin 1994 (Corpus vitrearum medii aevi Deutschland $\mathrm{I}, 3$ ).

[Scholz 1994/II] : Scholz, Hartmut: Hans Wild und Hans Kamensetzer. Hypotheken der Ulmer und Straßburger Kunstgeschichte des Spätmittelalters. In: Jahrbuch der Berliner Museen 36 (1994), 93-140.

[Scholz 1995/I]: Scholz, Hartmut: Die Straßburger Werkstattgemeinschaft. Ein historischer und kunsthistorischer Überblick. In: Ausst.-Kat. Ulm 1995, 13-26.

[SCHOLZ 1995/II] : SchOLZ, Hartmut: Neun Rundscheiben aus dem großen Ratssaal des Ulmer Rathauses (Kat.-Nr. 10-18). In: Ausst.-Kat. Ulm 1995, 91-109.

SöDING, Ulrich: Hans Multschers »Wurzacher Altar». In: Münchner Jahrbuch der bildenden Kunst 3. F. 42 (1991), 69-116.

Stange, Alfred: Deutsche Malerei der Gotik, Bd. 4. Südwestdeutschland in der Zeit von 1400 bis 1450. Berlin 1951.

Stange, Alfred: Deutsche Malerei der Gotik, Bd. 7. Oberrhein, Bodensee, Schweiz und Mittelrhein in der Zeit von 1450 bis 1500. München/Berlin 1955.

Stange, Alfred/Lieb, Norbert: Kritisches Verzeichnis der Tafelbilder vor Dürer, Bd. 2. Oberrhein, Bodensee, Schweiz, Mittelrhein, Ulm, Augsburg, Allgäu, Nördlingen, von der Donau zum Neckar. München 1970.

Sterling, Charles: Jost Haller, Maler zu Straßburg und zu Saarbrücken in der Mitte des 15. Jahrhunderts. In: Wiener Jahrbuch für Kunstgeschichte 33 (1980), 99-126.

SuCKale, Robert: Die Regensburger Buchmalerei von 1350 bis 1450. In: Ausst.-Kat. Regensburg 1987, 93-110.

SuCKAle, Robert: Süddeutsche szenische Tafelbilder um 14201450. Erzählung im Spannungsfeld zwischen Kult- und Andachtsbild. In: HARMS 1990, 15-34. - Wieder in: SUCKale 2008, 59-85.

SuCKAlE, Robert: Les peintres Hans Stocker et Hans Tiefental. L' « ars nova » en Haute Rhénanie au XVe siècle. In: Revue de l'art 120 (1998), H. 2, 58-67.
Suckale, Robert: Stil und Funktion. Ausgewählte Schriften zur Kunst des Mittelalters. Hg. von Peter Schmidt und Gregor Wedekind. München/Berlin 2. Aufl. 2008.

Theben, Judith: Die mystische Lyrik des 14. und 15. Jahrhunderts. Untersuchungen - Texte - Repertorium. Berlin/New York 2010 (Kulturtopographie des alemannischen Raums 2).

Wendland, Ulrike: Biographisches Handbuch deutschsprachiger Kunsthistoriker im Exil. Leben und Werk der unter dem Nationalsozialismus verfolgten und vertriebenen Wissenschaftler. 2 Bde. München 1998.

Wentzel, Hans: Das Ratsfenster von 1480 im Chor des Ulmer Münsters und sein Meister Peter Hemmel von Andlau. In: Ulm und Oberschwaben N. F. I, 32 (1951), 9-46.

Wentzel, Hans: Meisterwerke der Glasmalerei. 2. Aufl. Berlin 1954.

Wolff, Martha A. W.: The Master of the Playing Cards. Diss. Yale University; Ann Arbor 1979.

Wolfson, Michael: Originalität und Tradition. $\mathrm{Zu}$ den ikonographischen und künstlerischen Quellen der Karlsruher Passion. In: Zeitschrift des Deutschen Vereins für Kunstwissenschaft 45 (1991), H. 1-2, 67-87.

Wolfson, Michael (Bearb.): Niedersächsisches Landesmuseum Hannover. Landesgalerie. Die deutschen und niederländischen Gemälde bis 1550. Kritischer Katalog mit Abbildungen aller Werke. Hannover 1992.

Zehnder, Frank Günter: Katalog der Altkölner Malerei. Köln 1990 (Kataloge des Wallraf-Richartz-Museums XI).

Zinke, Detlef: Augustinermuseum. Gemälde bis 1800. Auswahlkatalog. Freiburg/B. 1990.

\section{Anmerkungen}

1 Fischel 1934, 58.

2 Wendland 1999, I, 144-147.

3 FisChel 1952. - Eine erste Stufe ihrer Forschungen publizierte Lilli Fischel schon vor dem Zweiten Weltkrieg: FisCHEL 1934.

4 Moraht-Fromm 2013, 249-260, mit den technischen und Provenienz-Angaben. Ausgeführt in Mischtechnik auf Nussbaumholz, wobei jeweils zwei Bretter stumpf verleimt wurden; die Einzeltafeln variieren in der Höhe um ca. 66-67 cm, in der Breite um $47 \mathrm{~cm}$.

5 1. Christus im Ölberg (Karlsruhe, Staatliche Kunsthalle, Inv.-Nr. 2436), Ausst.-Kat. Karlsruhe 1996, 201, Kat.-Nr. 1. - 3. Geißelung (Inv.-Nr. 2911), im Ausst.-Kat. Karlsruhe 1996 noch ohne Kat.-Nr., nur Abb. 34; jetzt Moraht-Fromm 2013. - 4. Dornenkrönung (Inv.-Nr. 1136), Ausst.-Kat. Karlsruhe 1996, 208, Kat.-Nr. 3. - 5. Kreuztragung (Inv.-Nr. 2180), Ausst.-Kat. Karlsruhe 1996, 209, Kat.-Nr. 4. - 6. Entkleidung (Inv.-Nr. 1497), Ausst.-Kat. Karlsruhe 1996, 209, Kat.-Nr. 5. - 7. Kreuzannagelung (Inv.-Nr. 1375), Ausst.Kat. Karlsruhe 1996, 209, Kat.-Nr. 6.

6 LÜDKE 2000 und 2008.

7 2. Gefangennahme. Köln, Wallraf-Richartz-Museum, Inv.-Nr. WRM 585. Ausst.-Kat. Karlsruhe 1996, 201-208, Kat.-Nr. 2. 
8 Ausst.-Kat. Karlsruhe 1996. Zum Stand der Forschung hier die Zusammenfassung von Stefan Roller, 16f. - Zuletzt MorahtFrомм 2013, 255-257.

9 Roller 1996/II und 1996/III.

10 Stange 1951, 78.

11 Vgl. die diversen Zitate bei Wolfson 1991, 67.

12 Blasius 1986, $10 \mathrm{f}$.

13 Blasius 1986, 47.

14 Blasius 1986, 54.

15 Blasius 1986, 61.

16 Suckale 1990, $25 \mathrm{f}$.

17 Suckale 1987, 93-110. - Suckale 1990.

18 Möhring 1992. - MöHring 1997.

19 SÖDING 1991.

20 Vgl. hierzu auch den Beitrag von Stavros Vlachos in diesem Band.

21 WOLFSON 1991, 68, 71 etc.

22 Wolfson 1991, 72 f., 84.

23 Suckale 1990, 29.

24 Das Obersteiner Retabel wurde von einem Diakon gestiftet, der auf dem Mittelbild am Kreuzesfuß betend dargestellt ist. Es ist vermutlich der 1419 verstorbene Scholasticus und Domherr zu Mainz, Eberhard von Oberstein. Stange/Lieb 1970, 94, Kat.-Nr. 413. Ausst.-Kat. Frankfurt/M. 1975, 124, Kat.-Nr. 15, Abb. nach S. 22 und 123; hier wird das Retabel sogar ans Ende des 14. Jahrhunderts datiert.

25 Stange 1951, 79. - Das zweiflüglige Passions-Retabel mit einer Kreuzigung als Mittelbild wird dem »Meister der Mainzer Verspottung«, früher in St. Stefan in Mainz, jetzt im dortigen Landesmuseum, zugeschrieben. Vgl. auch das eng verwandte Kreuzigungsbild im Hessischen Landesmuseum Darmstadt. BEEH 1990, 34f., Kat.-Nr. 4. - Ausst.-Kat. Darmstadt 1995, 35-37, Kat.-Nr. 7.

26 Tempera auf Leinwand über Fichtenholz, Mittelbild H. $132 \mathrm{~cm}, \mathrm{~B}$. $131 \mathrm{~cm}$; Flügel jeweils H. $132 \mathrm{~cm}$, B. 53,5 cm, H. des Einzelbilds daher ca. $65 \mathrm{~cm}$.

27 Vgl. die Ausführungen von Wolfson 1991, 82 f., zur speziellen Bedeutung und den alttestamentarischen Typen dieses Themas, vor allem aber die vielen Abbildungen in: Ausst.-Kat. Karlsruhe 1996, 101-113, hier auch die Obersteiner Annagelung (Abb. 79).

28 Vgl. hierzu die Charakterisierung der Figur durch Roller 1996/II, $149 \mathrm{f}$.

29 Vgl. die ausführliche Analyse durch Stavros Vlachos in diesem Band. 30 Die ältere Literatur gab stets das Zisterzienserkloster Tennenbach als Herkunftsort an. Vgl. Moraht-Fromm 2013, 243, Anm. 25. NOACK 1951, 114f., stellte fest, dass die Tafeln sich wohl nach 1829 im Pfarrhaus von Staufen b. Freiburg befanden, und schloss daraus, dass sie zu dem dort belegten Hochaltarretabel gehört haben müssten. Die Herkunft des relativ kleinen Retabels aus einer Seitenkapelle der ab 1824 abgerissenen und translozierten Tennenbacher Abteikirche scheint jedoch plausibler. - Hess 2000, $77 \mathrm{f}$., rechtfertigte die Benennung nach Staufen.

31 Stange/Lieb 1970, 19 f., Kat.-Nr. 13. - Blasius 1986, 36-39. ZINKE 1990, 12-21. - Ausst.-Kat. Karlsruhe 1996, 216, Kat.-Nr. 9-11, Taf. 9 (Dietmar LüdKe). - Franzen 2002, 91-95. - Hess 2000. - Moraht-Fromm 2013, 242-248.

32 Drei Bilder dieses Retabels (Gefangennahme, Kreuzigung und Grablegung) befinden sich in der Badischen Kunsthalle Karlsruhe: LaUts 1966, 198 f., Kat.-Nr. 51, 51a und 52. Gefangennahme und
Grablegung sind beschnitten und messen nur je $36 \times 32$ bzw. $34,9 \times$ $29,7 \mathrm{~cm}$, die Kreuzigung 64,2 × 31,3 cm. - Мoraht-Fromm 2013, $242-248$.

33 Im Freiburger Augustinermuseum befinden sich Verkündigung an Maria, Heimsuchung, Geburt Christi, Anbetung der Könige auf zwei Tafeln, Beschneidung, Darstellung im Tempel, Gebet am Ölberg, Verhör vor Pilatus, Geißelung, Dornenkrönung und Krönung Mariens. Die Maße: H. ca. $62 \mathrm{~cm}$, mit bis zu $3 \mathrm{~cm}$ Unterschied; B. ca. $33 \mathrm{~cm}$. Maße des rekonstruierten Retabels: H. ca. 1,30 m, B. ca. 2,70 m. Ein achtes Bild fehlt; Futterer 1926/27, 19, und NoACK 1951, 114f., meinen, es sei eine Auferstehung gewesen. Alle Bilder sind von gemalten Rahmen umgeben, woraus man schließen kann, dass sie demselben Altarwerk angehörten. Rekonstruktionen des Retabels bei STANGE 1951, Taf. 97-98, dort aber sicher falsch, vgl. Futterer 1926/27, 19, und, mit weiteren Korrekturen, NoACK 1951, 115. - Moraht-Fromm 2013, 244-246, rekonstruiert, wegen des Formats der Tafeln höchstwahrscheinlich richtig, ein Baldachinretabel, dessen Flügel eine Muttergottesstatue umschlossen.

34 Seit Futterer 1926/27 unterscheidet man einen dem Meister des Frankfurter Paradiesgärtleins näherstehenden, »qualitätvolleren« Maler der Innenbilder sowie einen zunächst als »älter « eingeschätzten Maler, von dem die Außenbilder der Passion inklusive Beschneidung und Geburt Jesu stammen. Dieser habe in engerer Anlehnung an Bilder wie die Colmarer Kreuzigung von ca. 1400 gearbeitet, z. B. bei der Übernahme der Kopftypen (zu dieser Ausst.-Kat. Köln 1978, I, 289f. [Roland Recht]. - Suckale 1998. - Lorentz 2008/I.). Wahlweise wurde seine "realistischere" Darstellungsweise aber auch als fortschrittlicher, der Maler damit als jünger eingeschätzt, so LAUTS 1966, 199, der ihn »zeitlich entwickelter» findet. Vgl. FISCHEL 1952, $8 \mathrm{f}$.

35 Vgl. die Analyse bei Moraht-Fromm 2013, 246. - Vgl. auch weitere Beiträge in diesem Band, v. a. den von Stavros Vlachos.

36 SuCKale 1998 (mit älterer Literatur). - Quellen zu Hans Tiefental ab 1437: Rотт 1936, 199-201. - Frühere, Basel betreffende Quellen bei RotT 1938, 52. - SUCKALE 1998, $62 \mathrm{f}$.

37 Rотт 1938, $53 \mathrm{f}$.

38 Neuere Gesamtdarstellungen: Brinkmann/Kemperdick 2002, 97-102. - LORENTZ 2008/II.

39 Futterer 1926/27, 15. - Lorentz 2008/II, 63. - Hingegen sieht Rотт 1938, 53, Anm. 1, einen anderen Meister am Werk. - So auch Moraht-Fromm 2013, 243, die allerdings nur Passionsfragmente behandelt.

40 Lorentz 2008/II. - Moraht-Fromm 2013, 239, spricht nur von einem »in Straßburg angesiedelten Werkstattverband «. - Das Werk, das Suckale Stocker zuschrieb, wird nun dem Hermann Schadeberg zugeordnet: LoRENTZ 2008/I.

41 Dass es Kaiphas ist, wie Blasius 1986, 19f., meint, ist ausgeschlossen; gegeißelt wird Christus auf Befehl des Pilatus (was Blasius auch weiß), nicht des Kaiphas. Die Kleidung und Kopfbedeckung des Pilatus hat auch nichts gemein mit den mitraähnlichen und orientalisierenden Hüten der drei Schriftgelehrten auf Entkleidung und Annagelung; vielmehr ist ein weltlicher Würdenträger, eine Art Herzog gemeint. Die Kaiphas-Theorie passte nur in das Konzept, möglichst viele Schandtaten durch Juden ausgeführt zu sehen, um dann ausführlich auf die mittelalterlichen Judendiskriminierungen eingehen zu können - die in ihren Perversionen und Schrecken gewiss nicht zu leugnen sind. Dieser Aspekt wird von Blasius jedoch überinter- 
pretiert, zugleich aber vereinfacht, wirklicher Kritik wird somit die Spitze genommen.

42 WolfSON 1991, 85-87, Zitat 86.

43 WOLFSON 1991, 87.

44 Bergsträsser 1941. - Franzen 2002, 103-107.

45 Roller 1996/II, 154-158.

46 Wolfson 1991, $75 \mathrm{f}$.

47 Wolfson 1991, 76.

48 Dhanens 1980, 358, datierte das Werk spät, auf »um 1450«. Рёснт 1989, 171 f., schrieb es noch Hubert van Eyck zu, bevor dieser wenig später als Bruder Jans von der Wissenschaft verstoßen wurde: HERZNER 1995. - BÜTTNER 2004.

49 Рёснт 1989, $171 \mathrm{f}$.

50 Ausst.-Kat. Karlsruhe 1996, 64, Abb. 42.

51 FisChel 1952, 54f., 57. - Ihre Formulierungen sind aber nicht historisch eindeutig zu nehmen, da sie zunächst von "holländischer" Schulung spricht, dann von besonderer Nähe zu Rogier van der Weyden, der bekanntlich in Brüssel ansässig war. Den Schluss ihres Buchs durchdringt dann ohnehin eine geradezu dichterische Gewissheit einer Schulung des »Hirtz« in den Niederlanden - ein Text, den man heute zwar noch immer fasziniert lesen kann, der aber, wie man angesichts des wenigen Erhaltenen sagen muss, trotz immer wiederkehrender Relativierungen doch zu sehr der Imagination einer Künstlerpersönlichkeit auf dem Boden wirkmächtiger »Kunstlandschaften« erliegt.

52 Grundlegend Marrow 1979. - Büttner 1983.

53 Wolfson 1991, 81.

54 Die Einlassungen von BLAsius 1986, 93-99, sind eine grobe Skizze der gesellschaftlichen und politischen Verhältnisse im Straßburg des 15. Jahrhunderts. Ihre Annahme, die Figur des Nikodemus in der Dornenkrönung sei wegen ihrer Individualisierung eine Stifterdarstellung, ist mit ziemlicher Sicherheit irrig.

55 Котне 1903, $26 \mathrm{f}$.

56 Котне 1903, 98, belegt diesen Status für das vorangegangene Jahrhundert auch dadurch, dass die Stiftskapitel von St. Peter und St. Thomas im Streit um die Ausübung der Seelsorge eine etwas widersprüchliche Haltung einnahmen: Einerseits fühlten sie sich durch die Mendikanten in der Ausübung ihrer Pfarrrechte und ihren hieraus fließenden Einnahmequellen bedroht, die diese, unterstützt durch den Papst, mehr und mehr an sich gebracht hatten. Das hatte zu einer bedeutenden Verlagerung der Stiftungs-Tätigkeit der Bürger weg von den alten Pfarreien geführt. Die auf dem Konzil von Vienne 1311 gefassten Beschlüsse zur Einschränkung der Rechte der Bettelorden, die 1317 publizierten Clementinen, versuchten die Stifte im Schulterschluss mit dem Bischof durchzusetzen. Einem 1319 von den Domstiftsherren gegen die Mendikanten gegründeten Bund traten die Stifte jedoch nicht bei, da sie darin eher eine Aktion gegen die Stadt sahen, die hinter den Bettelorden stand. Gegen die Interessen der Stadt aber wollten die »Patrizier-Kapitel« nicht handeln.

57 Котне 1903, 83.

58 Котне 1903 konnte dies wegen seines begrenzten Untersuchungszeitraums nicht feststellen.

59 Reuss $1922,89 \mathrm{f}$.

60 Blasius 1986, 103.

61 Fischel 1952, 18. - Blasius 1986, 103.

62 Blasius 1986, 103.
63 Moraht-Fromm 2013, 251. - Vgl. schon Fischer 1933 etc.

64 FISCHER 1933, 344.

65 Moraht-Fromm 2013, 250, Anm. 46, nennt zuerst dessen Vornamen, bezeichnet ihn jedoch einmal als Schwieger-, einmal als Großvater Andreaes. Hier vermischen sich zwei Überlieferungen: Fischer 1933, 344, nennt ihn wie gesagt Großvater; etwas besser informiert scheint Rотт 1938, 58, Anm. 1, gewesen zu sein: Er schreibt, die Tafel stamme "von dem 1842-76 zu Waldersbach amtierenden Pfarrer Witz (...) (die Tochter heir. den Schweizer Andreae)«.

66 Moraht-Fromm 2013, 251. - Mit ca. 1,8 cm Tiefe ist die ÖlbergTafel die einzige, die ihre ursprüngliche Stärke bewahrt hat.

67 Восн 1914, 175 f. - Eine zweite Pfarrei entstand 1464 in Helmsgereut/St-Blaise-de-la-Roche, vgl. ebd., 176. - Zu Marmet Bocн 1914, 179-181.

68 So http://www.culture.gouv.fr/public/mistral/merimee_fr?ACTION $=$ RETROUVER\&REQ $=(($ IA67013040 $)+\% 3$ AREF +$) \quad($ Red. Olivier HAEgel und Florent Fritsch; aufgerufen 14.09.2017). - Eine Wiedergründung musste nach dem Dreißigjährigen Krieg 1666 erfolgen, vgl. ebd. und BocH 1914, 190.

691619 war nach dem erwähnten Pfarrer Marmet (1661) das Waldersbacher Pfarrhaus datiert. Восн 1914, 176 f. - Entsprechend Rотт 1938, 58, der 1618 als Gründungsjahr der Pfarrei erwähnt.

70 Восн 1914, 176-178.

$71 \mathrm{http} / /$ www.culture.gouv.fr/public/mistral/merimee_fr?ACTION $=$ RETROUVER $\&$ REQ $=(($ IA67013040 $)+\% 3$ AREF +$)($ O. HAEGEL, $\mathrm{F}$. FritsCh; aufgerufen 14.09.2017). - Stuber ließ eine Inschrift mit Chronogramm anbringen, die an die Vollendung der Renovierung der »bescheidenen Kirche« erinnert: "MoDesta eCCLesIa«. - Auf Stuber geht wohl auch die Meinung zurück, die Rathsamhausen hätten Waldersbach reformiert, wie auf der Tafel vermerkt, denn er vermerkt dies in seinem Tagebuch. BocH 1914, 176. - Oberlin hingegen wusste, dass es der »Prinz« von Veldenz gewesen war, vgl. ebd.

72 Oberlin entschloss sich, Pfarrer im Steintal zu werden, und verließ dieses dann für Jahrzehnte nurmehr ganz selten. MeIER 1999.

73 BAUdisch 1996, 194. - Leider wurde für die Verwendung als Türchen auch die Rückseite glatt überarbeitet, vgl. ebd., 194, Anm. 32.

74 Vgl. zu Rekonstruktion und Befund die Beiträge LÜDKE 1996. BAUDISCH 1996. - HÖRSCH 1997. - FRANZEN 2002, 61-76. - LÜDKE 2008, 43-58.

75 BAUdisch 1996, 192.

76 BAUdisch 1996, 188.

77 Suckale 1988, 24-26.

78 Franzen 2002.

79 Über die Todesangst Jesu Wolfson 1991, 72. - Ausst.-Kat. Nürnberg 1983, 243-252 (zu: Kat.-Nr. 20). - LÜDKE 1996, 28-32.

80 Das Motiv kommt auch schon auf der Ölbergszene des Tennenbacher Retabels vor. Auch hier zeigt sich jedoch deutlich der Unterschied der erzählerischen Intensität.

81 Vgl. Wolfson 1991, 72-74. - Ausst.-Kat. Karlsruhe 1996, 22-55. FRANZEN 2002, 22-29.

82 Mir scheinen kleine Unterschiede zwischen der Gefangennahme einerseits und den drei letzten Szenen andererseits festzustellen zu sein: So in der Gestaltung des Bodens, dessen Bewuchs auf dem Kölner Bild dichter, natürlicher ist; bei dem Christushaupt, das auf den beiden Karlsruher Tafeln schmaler und härter zu sein scheint, während es in Köln runder ist, eher wie auf der Dornenkrönung; in 
der Art der Baum-, Stimmungs- und Landschaftsdarstellung, die auf den drei letzten Bildern ziemlich summarisch behandelt wird.

83 LÜDKE 2008, 43-52.

84 Ausst.-Kat. Karlsruhe 1992, 158-169, Kat.-Nr. 25 (Dietmar LÜDKE). - LÜDKE 1996, 11-15. - LÜDKE 2008, 43-58.

85 Hannover, Landesmuseum, Inv.-Nr. PAM 922 a-c. - Wolfson 1992, 39-47, Kat.-Nr. 2. - Ausst.-Kat. Karlsruhe 1996, Abb. 5. - LÜDKE 2008, 48f., Abb. 33. - Ein deutlich kleineres Beispiel im Baseler Kunstmuseum.

86 Münster/Westf., LWL-Landesmuseum für Kunst und Kultur, Inv.-Nr. 1038 LM. - Ausst.-Kat. Karlsruhe 1996, Abb. 6. - LÜDKE 2008, 50, Abb. 36 .

87 Dies entspricht dem Typus des Breslauer Barbara-Retabels, vgl. den Beitrag von Adam S. Labuda in diesem Band.

88 LÜDKE 2008, 51, Abb. 38.

89 Ähnlich schon Lauts 1966, 189, der nur eine Szene als fehlend annahm. - Franzen 2002, 75.

90 Moraht-Fromm 2013, 257-260.

91 Anlässlich der Verleihung des Privilegs der Doktorpromotion an die Straßburger Dominikaner-Universität durch Kaiser Ferdinand II. im Jahr 1621 wurden die »alte(n) verfinsterte(n) und mit Näglen übel zugerichtete(n) und verderbte(n) aber sehr kunstreiche(n) gemähl(de)« im Chor der Klosterkirche durch den Maler Hilarius Dietterlin renoviert, da die Urkunde hier in würdigem Rahmen verlesen werden sollte. Thomas-Archiv 9, 102, Akten über die Restaurierung von Chor und Kollegiengebäuden der Dominikaner, 1621. Fischel 1952, 20. - Der damals erst 11 jährige Sohn des Malers, Bartholomäus, fertigte ein Aquarell, heute in der Staatlichen Graphischen Sammlung München, Inv.-Nr. 40598 (H. 230 bzw. 365 mm, B. 764 mm), das dann, in Kupfer gestochen, mit einer Grußadresse und zeitgenössischem Zierat versehen, dem Kaiser gewidmet wurde (Exemplare in den Museen in Straßburg und Karlsruhe). Dass es sich bei den beiden Szenen Ölberg und Gefangennahme um Wandmalereien gehandelt hat, beweist das Türsegment auf der Zeichnung, dessen Bogenführung die Darstellung geschickt angepasst war. Die Bilder gingen endgültig vielleicht erst bei der Zerstörung der Dominikanerkirche im deutsch-französischen Krieg von 1870/71 zugrunde. Vgl. hierzu, besonders zur Herkunft der Bildmotive, Roller 1996/I. - Ausführlich nochmals, insbesondere auch zum Anbringungsort Franzen 2002, 78-90. Seiner Rekonstruktion der überlieferten Darstellungen an der östlichen, den Chor gegenüber einer Süd-Nord-Passage abschließenden Wand, die später von einer Empore überbaut wurde, ist grundsätzlich zuzustimmen: FrANzen 2002, 88. Allerdings spricht die öfters zitierte historische Beschreibung des Anbringungsortes "In gedachten Chor auf der rechten hand wann man hinein gehet, ist ein von farben wohlgemahlter (...) Oelberg zu besehen « (zit. nach Franzen 2002, 86) - eher dafür, dass sich der Ölberg an der westlichen Seite dieser Wand befunden hat. Mir erscheint das im Hinblick auf die quasi den Prozess des Hineingehens festhaltende Formulierung plausibler als die von Franzen vorgeschlagene Version, der Beschreiber habe sich dann nach Durchschreiten des mittleren Portals in der Wand (vgl. Franzen 2002, 87, Abb. 13 und 14) umgedreht und dann das Bild rechts vom Portal (also nördlich desselben) erblickt. Folgt man dieser Überlegung, hätte sich ein Passionszyklus an die Nutzer der besagten Passage, also möglicherweise nicht nur den Konvent im engeren Sinne, gewendet, ähnlich der Situation in der erhaltenen Erfurter Predigerkirche, wo an verwandter Örtlichkeit ja das berühmte gemalte Kalvarienberg-Retabel und die sog. Schmedestedt'sche Madonna zu finden sind. - Dass es sich in Straßburg um einen Zyklus gehandelt hat, deutet Franzen 2002, 90, wie immer umsichtig, an. Mir erscheint dies schon aufgrund der Erzählweise der überlieferten Szene nahe liegend - und wird durch den Kostenvoranschlag des Restaurators Hilarius Dietterlin belegt, in dem ein »alt gemäldt in dem chor prädiger closter welches in acht historien verfasst« sei (zit. nach FranZEN 2002, 89) als zu erneuern beschrieben wird. Diese Formulierung erweist, dass Dietterlin die Malerei als aus einem Guss gefertigt verstand und dass sie aus acht erzählten Szenen (historien) bestand.

92 Rotт 1936, 189-194. - RotT 1938, 57 f.

93 Blasius 1986, 104f., trug zu dieser Frage zwei noch weniger begründete Vermutungen bei: Dass Lienhard Jude der Maler der Passionstafeln sei, weil er darin als getaufter Jude den besonders antijüdischen Affekt eines Renegaten zum Ausdruck gebracht habe, ist eine völlig unbelegte Vermutung. In dem von ihr nach Rotт 1936, 162, zitierten Auftrag an »meister Clementz, de(n) moler von Baden«, ist eindeutig von »bilde(n)«, nämlich einer skulpierten Kreuzigungsgruppe, die Rede, die dieser nach dem Vorbild der »bilde zu sant Thoman zu Straßburg uff dem lattener « fassen möge, aber »beßer und ertiger" als diese. Dies geschah 1488 und Clemens erhielt 12 Gulden dafür. Zwei Jahre zuvor hatte er den Auftrag erhalten, "Zwene schecher zum crutzfix uff dem lattener zu snyden und eyme vesperbild zu snyden und faßen«, die er 1487 lieferte. Nun also sollte er eine weitere Kreuzigungsgruppe (ob er diese selbst geschaffen hatte, wird nicht deutlich) und - das geht aus der Stellung ihrer Erwähnung innerhalb der Quelle von 1488 hervor - eben diese beiden Lettner-Schächer fassen (»dozu ouch die zwene schecher mit iren lipfarwen, noch dem aller besten, als ime umb die L gulden verdingt sint, daran er lop dang beholt und sinen eren wol an stet«). Es ist wohl der Gesamtauftrag des Schnitzens und Fassens der Schächer, der ihm für 50 Gulden verdingt wurde und der hier noch einmal erwähnt wird. Wie die Autorin diese Äußerungen auf die Karlsruher Passion zu beziehen weiß (sie postuliert, es handle sich bei der 1488 erwähnten Kreuzigung um Tafelbilder!), bleibt ihr Geheimnis. - Zu vorsichtig war seinerzeit der Gemäldekatalog des Freiburger Augustinermuseums: ZINKE 1990, 19 f., wo die Karlsruher Passion zwar nur am Rande erwähnt, jedoch durch die Auswahl allein des damals neuesten Literaturtitels (der Blasius'schen Dissertation) die grundlegende ältere Forschung ignoriert wurde.

94 Rотт 1936, 194.

95 Rott 1936, 194. - Fischel 1952, 17. - Blasius 1986, 100.

96 STERLING 1980 (mit älterer Literatur). - LöCHER 1990.

97 Darmstadt, Hessisches Landesmuseum, Inv.-Nr. GK 53. - RolleR 1996/II, 149-151.

98 Vgl. u. a. die Beispiele im Ausst.-Kat. Karlsruhe 1996, 101-113.

99 Ludolf/Rigollot 1878, IV, 97. - Ausführlich zu den Meditations-»Techniken« Ludolfs BAIER 1977, III, 479-500, zu Annagelung und Kreuzigung u. a. ebd. 508 f. - Zu Ludolf BAIER 1985 und 1987. 100 BeEH 1990, 180, Kat.-Nr. 47.

101 Ersteres dürfte eine wohl dem bürgerlichen Stand entstammende Person mit dem nicht seltenen Namen Krautwurst bezeichnen; das Sparrenwappen ist recht häufig. Leider konnten bisher keine passenden Personen ausfindig gemacht werden - und dies dürfte angesichts der Überlieferungslage spätmittelalterlicher stadtbürgerlicher Wappen auch schwierig sein. 
102 So auch Roller 1996/II, 149.

1031397 in einem verlassenen Birgittenkloster gegründet. Theben 2010, 65 f. - Das Kloster ist heute völlig verschwunden.

104 Fischel 1934, 59, Abb. 13 (hier der Werkstatt des Meisters der Karlsruher Passion zugeschrieben). - Die Tafel war damals in Frankfurter Privatbesitz. Anfang der 20ooer Jahre konnte ich sie einmal im Bamberger Kunsthandel begutachten.

105 Vor allem: FischeL 1952. - Rотн 1996.

106 Lehrs 1910, Kat.-Nr. 2. - Fischel 1952, 34 u. Abb. 40. - Ausst.Kat. Karlsruhe 1996, 50 u. 51, Abb. 30; 243, Kat.-Nrr. 76 (Ölberg) u. 77 (Gefangennahme).

107 Von Wolff 1979, 63 f., wurden die Prioritäten vertauscht. WolfSON 1991, 74, deutet an, dies übernehmen zu wollen. - Vgl. jedoch Fischel 1952, 34f. - Ausführlich nochmals FranzeN 2002, 96-98.

108 Ausst.-Kat. Karlsruhe 1996, 238, Kat.-Nr. 67, u. 239, Abb. 205.

109 Dies beobachtete schon Fischel 1947, 26. - Vgl. Hörsch 1997, 60.

110 Franzen 2002, $101 \mathrm{f}$.

111 Ausst.-Kat. 1996, 238.

112 Rotн 1988.

113 Rотн 1996.

114 LASCH 1909. - HÉrold/Gatouillat 1994, 217-222.

115 FisCHel 1952, 25-33.

116 FrankL 1960.

117 ROLLER 1996/II, $152 \mathrm{f}$.

118 Roller 1996/II, 153, Abb. 120. - Der gesamte Zyklus: Ausst.-Kat. Karlsruhe 1996, 114-116, Abb. 91, 92.

119 HeYe 1965, 57.

120 Sснмitz 1913, 119f. - Der These, die Scheiben stammten aus dem Umkreis des Hausbuchmeisters, hat schon Beeh-LustenBERGER 1973, 173 f., vage widersprochen.

121 Berlin, Staatliche Museen, Kunstgewerbemuseum, Inv.-Nr. AE 562ff. - SсhмitZ 1913, 119-121. - SChMitZ 1923, 6 f. - WentZeL 1954, 102, Abb. 224. - Heye 1965. - Becksmann 1986, LVI, 246. - Becksmann 1988, 169, Kat.-Nr. 52. - ScholZ 1994/I, 257-259. - SCHOLZ 1995/II.

122 Beeh-Lustenberger 1973, $173 \mathrm{f}$.

123 SCHolZ 1994/I, 257. - Ausst.-Kat. Ulm 1995, 91.

124 Ähnlich war die ebenfalls in der Werkstatt der Straßburger Glasmaler-Gesellschaft unter Leitung Peter Hemmels geschaffene, mit 135 Scheiben umfangreiche Verglasung der Straßburger St.-Magdalenen-Kirche gegliedert, die wohl gleichzeitig in Arbeit war (Bauzeit der Kirche 1475-81). Wentzel 1951, 30, 41.

125 HAUSSHERR 1986, $124 \mathrm{f}$.

126 Die Figur des Erzengels wurde bei einer späteren Restaurierung durch einen wohl aus einer Marienkrönung ebenfalls des 15. Jahrhunderts stammenden Oberkörper Gottvaters ergänzt. Darüber befinden sich weitere Füllscheiben aus ursprünglich anderem $\mathrm{Zu}$ sammenhang.

127 Eine genauere Beschreibung der Einzelscheiben bei Heye 1965, 52-54. Allerdings sind die Figur am linken Rand der Brotvermehrung und die Frau im Hintergrund der Heilung des Besessenen keine Einflickungen.

128 SCHOLZ 1994/I, 257, hat die Argumente überzeugend zusammengestellt.
129 Sie ist später zerbrochen, dann mit einem Notblei gesichert und schließlich geklebt worden.

130 Heye 1965, 54.

131 FisCHeL 1952, 22.

132 Becksmann 1988, 169.

133 Wentzel 1951, 33.

134 ScholZ 1995/II, 108, sah hingegen in Schongauers Auferstehung das Vorbild für die Scheibe. Vgl. hierzu noch im Folgenden.

135 SCHOLZ 1995/II, 100, 108.

136 Scholz 1995/II, 100.

137 Scholz 1995/II, 100.

138 Auch die ungewöhnlicherweise aus dem Bilde blickende, die Arme anbetend erhebende Maria, die Scholz gleichsam als Missgeschick des zitierenden Künstlers interpretiert, kann nicht absichtslos oder "aus Versehen « gestaltet worden sein.

139 Ein gewichtiger Datierungshinweis bei Bosch 1982, 634f. - Manche Stiche können vielleicht auch noch nach 1475 entstanden sein: Kroнm/Nicolaisen 1991, 95, Kat.-Nr. 12 (Angela Brown, Ortrun DAUTERT); hier auch Abbildungen von Schongauers Passion (die Auferstehung 174, Abb. 26).

140 Scholz 1994/I, 258.

141 Ausst.-Kat. Ulm 1995, 73.

142 Als solcher wird inzwischen eher Hans von Maursmünster gesehen, vgl. z. B. BECKSMANN 2010, 50, dem neben vielen anderen Werken in Ulm das Kramerfenster zugeschrieben wird: "Innerhalb der Werkstattgemeinschaft war es nicht Peter Hemmel, sondern, wie wir dank der Untersuchungen von Hartmut Scholz inzwischen mit Gewißheit annehmen können, Hans von Maursmünster, der für die Entwicklung der bahnübergreifenden, an geschnitzte Flügelaltäre gemahnenden architektonisch gerahmten Bildkompositionen verantwortlich war. Diese Monumentalisierung (...) wird 1480/81 im (...) Kramerfenster gesteigert (...).«

143 Ausst.-Kat. Ulm 1995, bes. 8o f., Kat.-Nr. 4 (Hartmut SCHOLz), mit Abb. - Vgl. auch Roller 1996/II, der sich nur auf das Ratsfenster bezieht.

144 Scholz 1994/II, 136, Abb. 47

145 Neben den folgend genannten gehörten dazu noch Lienhart Spitznagel und Werner Störe. - Rotт 1936, 244 f. - Wentzel 1951, 21. - Ausst.-Kat. Ulm 1995, darin v. a. SCHOLZ 1995/I.

146 Rотт 1936, 244. Im Jahre 1466 wird »Peter, moler zu Andla« als Besitzer eines Hauses, das "uff $\mathrm{dz}$ wasser « gerichtet war (identifiziert als Steinstraße), und »Peter von Andlo, der glaser« als Besitzer des Anwesens an der Oberstraße genannt.

$147 \mathrm{Zu}$ Geuch zusammenfassend Hörsch 2006.

148 Rotт 1936, 192. - RotT 1938, 56.

149 Köln, Wallraf-Richartz-Museum, Inv.-Nr. 114-118. - Rотт 1938, 56f. - Zehnder 1990, 250-258; zur unklaren Provenienz $252 \mathrm{f}$. (am wahrscheinlichsten die Herkunft aus der Benediktinerinnenkirche St. Agatha in Köln, in der das Ehepaar Kannegießer begraben wurde).

150 Zehnder 1990, 256. Das Argument: Die dendrochronologische Einordnung des Tafelholzes erfolgte mit der Regionalchronologie für den Großraum Polen und baltische Gebiete (»dieses Holz war in den Niederlanden hauptsächlich in Gebrauch«) und »für Brett VII von Nr. 114 mit der westdeutschen Regionalchronologie«, was die kunsthistorischen Argumente nachhaltig unterstütze. Zunächst einmal ist daraus aber nur abzuleiten, dass die Tafeln in Köln ent- 
standen, und zwar hauptsächlich mit aus dem Nordosten Europas importiertem (und wenig lokalem) Holz. Auch Zehnder bestreitet ja nicht, dass der »Meister der Georgslegende« zwischen 1460 und 1490 in Köln tätig gewesen sei (S. 250). Es scheint eindimensional, künstlerische Beziehungen nur direkt von den Niederlanden nach Köln erkennen zu wollen. Bekanntlich waren auch Straßburg und der Oberrhein direkt mit den niederländischen Kunstentwicklungen verbunden - und die drastischen Darstellungsweisen in den Georgstafeln, die man auf die Karlsruher Passion bezogen hat, bedürfen gerade in Köln, wo die Georgstafeln recht einsam in der Landschaft stehen (vgl. ZEHNDER 1990, 254f.), doch näherer Erklärung. Diese kann aber (da z.B. Meyenblüt ja in Köln tätig war) nur über eine Bewertung des Künstlerischen und eventuell des Maltechnischen erfolgen, nicht aber über die Technik der Tafelherstellung, die der Maler ja in Köln vorfand und nutzen musste, geht man nicht davon aus, dass er alles in Eigenregie herstellte. Die seltsame Mischung aus niederländischer Gesamtkonstruktion und karikierend drastischen Einzelheiten scheint gerade für eine Adaption eines (nicht aus den Niederlanden!) zugewanderten Künstlers an das kölnische Milieu zu sprechen, und die dendrochronologische Datierung auf frühestens 1454 +/- 2 (ZEHNDER 1990, 257, 673 f.) widerspricht dem selbstverständlich nicht.

151 Rotт 1936, 189. - Blasius 1986, 100. - Für Ennelin wurde bereits 1422 die Totenglocke geläutet. Rотт 1936, 190.

152 Rотт 1936, 189 f.

153 Rотт 1936, 189.

154 Rotт 1936, 210 f. - Rotт 1938, 84f. - Scholz 1994/II, 137, mit dem Nachweis weiterer Träger des Namens Lützelmann in Straßburg wie in Ulm.
$155 \mathrm{Zu}$ diesem umfassend Rотн 1988.

156 Aufgeführt im Schlichtungsvertrag der Fehde Pfalzgraf Friedrichs bei Rhein und seines Gegenspielers, eben des Grafen Alwig. Rот T 1936, 193 f. - Rотт 1938, 56.

157 SCHOLZ 1995/II, 137-139.

158 Wentzel 1951, 19-21, 33. - Ebd., 31, stellte Wentzel allerdings fest, dass sich Ulm in der "vorzüglich(en) und meisterlich(en) (...) Ausführung des Kleinen und Kleinsten« von den übrigen Scheiben Hemmels abhebe: Er sah nur die Komposition als das Werk Hemmels an, während er für die Einzelheiten keinen Mitarbeiter dingfest machen konnte. Dies ist aber zu einem wesentlich Anteil der damals noch wenig differenzierten Betrachtungsweise der Produkte der Straßburger Glasmaler der 1470er/8oer Jahre geschuldet, die alle unter dem Sammelnamen Peter Hemmel subsumiert wurden. - BeCKSMAnN 1988, 169, Kat.-Nr. 52, charakterisierte den Hauptmaler des Ratsfensters zwar als eigenständigen Künstler, identifizierte ihn aber zugleich mit dem Meister der Erbacher Scheiben.

159 Rотт 1936, $244 \mathrm{f}$.

160 »In einem wohl gleichzeitigen Verzeichnis«, passend zum zweiten Mannschaftsbuch des Armagnacenzugs, Straßburg, Stadtarchiv, A.A. Nr. 195. - Rot T 1936, 199.

161 Erstes Mannschaftsbuch des Armagnacenzugs, Straßburg, Stadtarchiv, A.A. Nr. 195. - Rотт 1936, 199.

162 Wentzel 1951, 23.

163 Rотт 1936, 199.

164 Blasius 1986, $102 \mathrm{f}$. 



\section{Realismus und Symbolik in Der Deutschen Tafelmalerei}

\section{VON 1430 BIS $1450 / 60^{1}$}

Seit den Ausführungen von Erwin Panofsky zum »disguised symbolism « in der niederländischen Malerei des 15. Jahrhunderts ist das Verhältnis von Realismus und Symbolik zu einem viel behandelten, ja geradezu berüchtigten Spezialthema in der kunsthistorischen Forschung geworden. ${ }^{2}$ Davon wurde die wissenschaftliche Auseinandersetzung mit der deutschen Tafelmalerei der Spätgotik allerdings nur in geringem Maße tangiert. In der sie betreffenden Literatur standen zunächst Fragen der kunstlandschaftlichen Einordnung, der Zuschreibung und der Händescheidung oder Probleme der Rekonstruktion von Retabeln und ihrer Bildprogramme im Zentrum des Interesses. Beim Vergleich mit der niederländischen Malerei aber begnügte man sich meist mit dem Nachweis der Übernahme von Figuren, Raumelementen oder bestimmten Kompositionsmustern. Deshalb soll in dem folgenden Beitrag - im Anschluss an die lehrreiche Ausstellung »Van Eyck bis Dürer « im Groeningemuseum in Brügge $^{3}$ - die bisher nie im Zusammenhang diskutierte Frage nach dem Symbolwert der Bildgegenstände in der deutschen Malerei der Ars nova und dem diesbezüglichen Rezeptionsverhalten der Künstler erörtert werden.

\section{Die Voraussetzungen in den Niederlanden}

Beginnt man zunächst mit den für alle deutschen Meister vorbildlichen Werken der Altniederländer, so ist die Kontroverse um einen "versteckten « oder »offenen « Symbolismus einerseits und eine ungebremste Freude an der realistischen Wiedergabe der Alltagswelt andererseits mit einem salomonischen "sowohl als auch « entschieden worden. Noch immer nicht genügend berücksichtigt wird dabei aber, dass der mögliche Symbolgehalt nicht nur von bestimmten Bildtraditionen, von Texten unterschiedlichen Anspruchs oder der zeitgenössischen Meditationspraxis abhängig ist, sondern ganz entscheidend auch vom Bildungsniveau und der Einstellung des betreffenden Malers. ${ }^{4}$ Manche von ihnen waren mit Sicherheit fähig, sich in der überlieferten Symbolsprache auszudrücken und

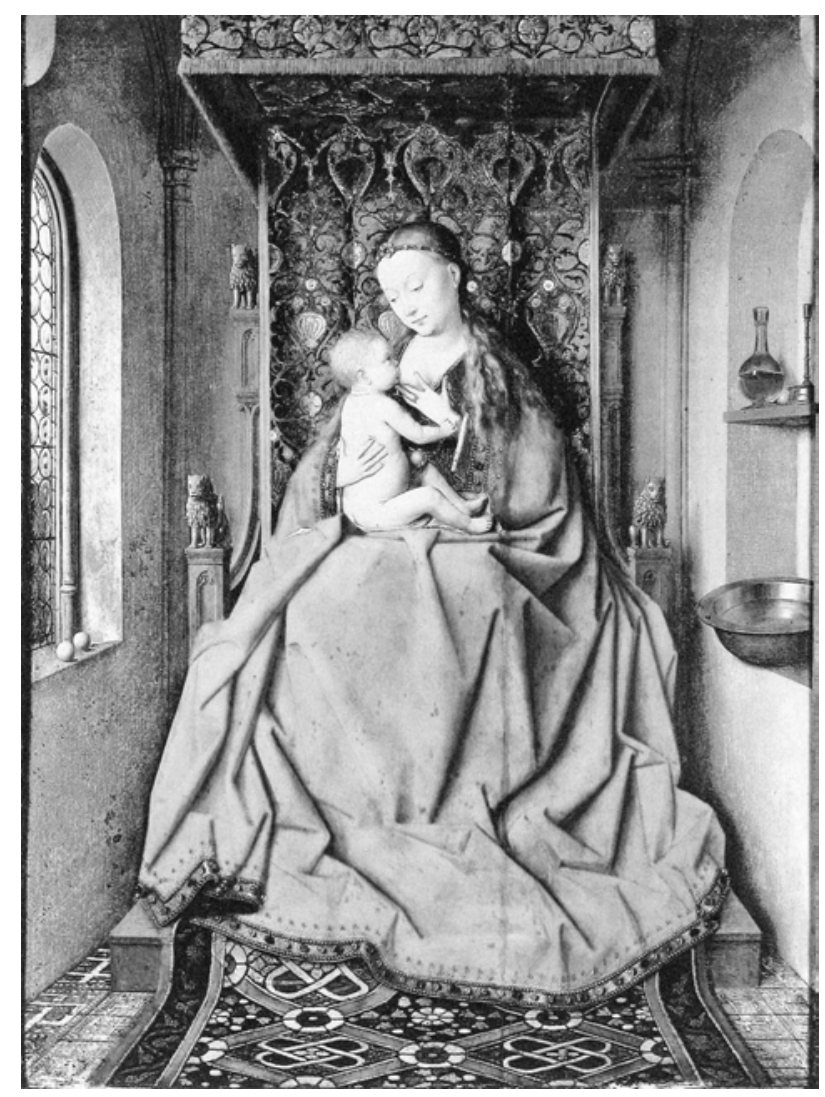

Abb. 1 Lucca-Madonna. Jan van Eyck. Frankfurt/M., Städel Museum, Inv.-Nr. 944 (ex: SANDER 1993, Taf. 17)

daraus eigene Gedanken zu entwickeln, während andere sich eher passiv verhielten oder den Dialog mit dem Auftraggeber bzw. einem gelehrten Berater suchen mussten.

Bei Jan van Eyck, einem der größten Intellektuellen in der europäischen Kunstgeschichte, hat es natürlich keinen Sinn, lange über solche Fragen zu debattieren. Er kommt Panofkys Ideal eines pictor doctus zweifellos am nächsten. Seine Madonna in der Kirche (um 1438/39) verkörpert in besonders tiefsinniger Weise die Gleichsetzung von Maria und Ecclesia und wird durch zahlreiche ikonografische Spitzfindigkeiten, darunter den Lichteinfall von Norden, zu einem höchst komplexen Andachts- 

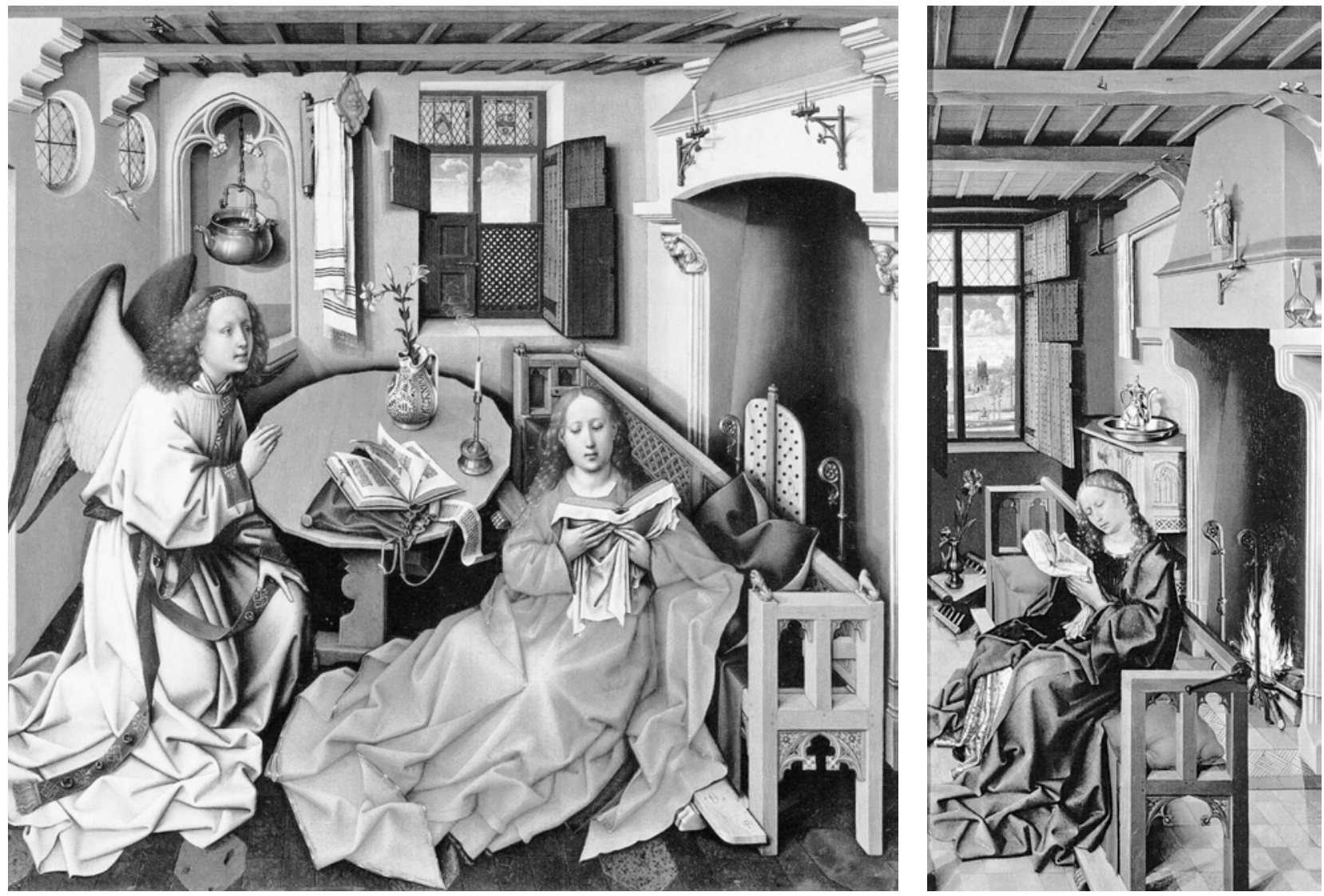

Abb. 2 Verkündigung an Maria, Mérode-Triptychon. Meister von Flémalle. New York, The Metropolitan Museum of Art, Inv.-Nr. 5670.a-c (ex: THÜRLEMANN 2002, 59)

bild. ${ }^{5}$ Auch bei der Lucca-Madonna (um 1436/37) wird man den wenigen, klug verteilten Gegenständen eine marianische Konnotation zusprechen können (Abb. 1).

Der Löwenthron bezieht sich auf Maria als sedes sapientiae, die Waschschüssel auf ihre Reinheit, die gläserne Karaffe auf ihre unbefleckte Empfängnis, der Kerzenleuchter auf Maria als Christusträgerin und Lichtbringerin. ${ }^{6}$ Die feierliche Ruhe, die Ordnung und die Sauberkeit, die in dem Gemach herrschen, sind ihrerseits symbolisch zu verstehen.

Andere Maler wie der sogenannte Meister von Flémalle (Robert Campin und seine Werkstattgenossen) scheinen sich in ihren Gemälden dagegen mehr der Alltagswelt und einem handfesten Realismus verschrieben zu haben, sodass man sich fragen muss, wie weit hier die Deutung vorangetrieben werden darf. Der Prüfstein dafür war seit jeher das mit zahlreichen Objekten bestückte Mérode-Triptychon in New York, das zuerst von Meyer Schapiro und dann von Panofsky, seinen Nachfolgern
Abb. 3 Hl. Barbara, Werl-Altar, Innenseite des rechten Flügels. Rogier van der Weyden, 1438. Madrid, Prado, Inv.-Nr. P001513 (ex: Ausst.-Kat. Frankfurt/Berlin 2008, 287)

und Kritikern als Schlüsselwerk für das damalige Bildverständnis herangezogen wurde (Abb. 2). ${ }^{7}$

Heute ist nun insofern ein neuer Diskussionsstand erreicht, als Reindert Falkenburg auf einen zeitgenössischen Meditationstext hingewiesen hat, in dem die Ausstattung solcher Räume tatsächlich symbolisch interpretiert wird. ${ }^{8}$ Die Gegenstände, die wir suchen, sind allerdings nicht unter den dort beschriebenen, weshalb - wenn man es böswillig formulieren möchte - als kleinster gemeinsamer Fixpunkt doch nur der Krug mit der weißen Lilie als Hinweis auf die Reinheit Mariens und ihre "Lichtgeburt", nämlich Christus, übrig bleibt. ${ }^{9}$ Trotzdem wird Panofskys Deutungsmodell durch diesen Text prinzipiell legitimiert, was auch Bastian Eclercy in einem Essay zur Forschungsgeschichte des »disguised symbolism« ähnlich resümiert hat. $^{10}$

Werke wie die Mérode-Verkündigung und das ihr direkt vorausgehende Gemälde gleichen Themas in Brüssel sind aber auch deshalb so wichtig, weil sie in zahlrei- 
Abb. 4 Vermählung Mariens. Meister von Flémalle. Madrid, Prado, Inv.-Nr. P1887 (ex: Ausst.-Kat. Frankfurt/Berlin 2008, 224)

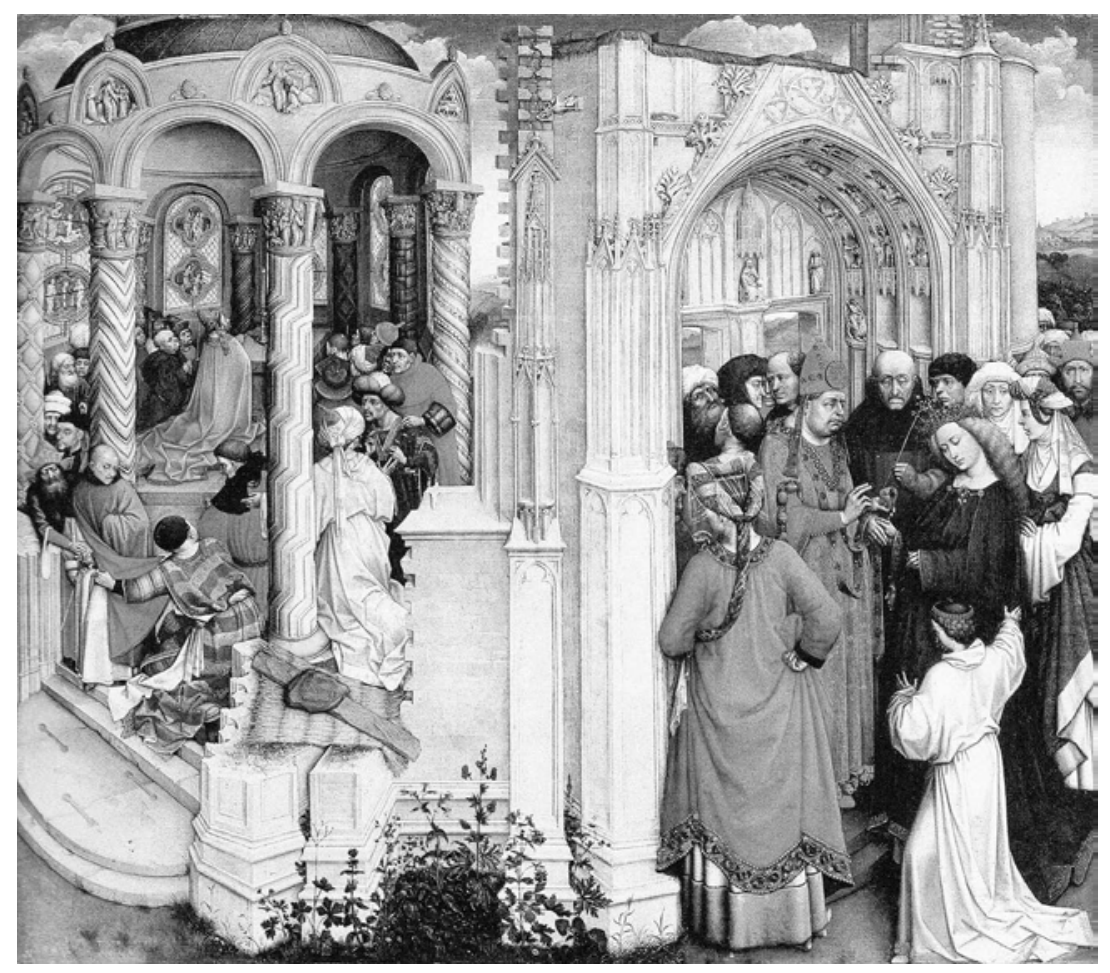

chen Kopien und Paraphrasen verbreitet waren und viel zur Akzeptanz des niederländischen Realismus bzw. zur Übernahme bestimmter Bildzeichen beigetragen haben. ${ }^{11}$ Eines dieser Derivate, der auf 1438 datierte Werl-Altar, der nun mehrheitlich Rogier van der Weyden zugeschrieben wird, gelangte wohl zuerst nach Köln und wurde wenig später vor allem in Westfalen rezipiert. Auf dem rechten Innenflügel ist in einem ganz ähnlichen Ambiente wie bei den beiden Verkündigungstafeln die heilige Barbara zu sehen, die nur beim Blick aus dem Fenster durch den weit hinten aufragenden Turm als solche identifiziert werden kann (Abb. 3). ${ }^{12}$ Alle anderen Gegenstände sind aber auf die wohl im verlorenen Mittelbild dargestellte Gottesmutter zu beziehen: das Waschgeschirr und die Glaskaraffe, im Besonderen auch die Schwertlilie, mit der oft auf die Weissagung Simeons (Lk 2,35) und damit auf die Schmerzen Mariens und die Passion Christi angespielt wird. ${ }^{13}$

Manche Objekte kehren also immer wieder; es sind Alltagsgegenstände, die aber aus dem Bildzusammenhang heraus als Symbole interpretiert werden können. Ihre Verwendung fußt auf bestimmten mittelalterlichen Traditionen, ist allgemein verständlich und hat, anders als es Panofsky suggerierte, wenig von einem »Geheimcode«, der erst vom Künstler perfektioniert und dann vom Betrachter dechiffriert werden müsste. Bedenken sollte man allerdings, dass fast immer von einer Polyvalenz der dargestellten Gegenstände, Pflanzen und Tiere auszugehen ist, wodurch sich - mit Bezug auf entsprechende Textstellen - verschiedene Deutungsoptionen eröffnen. Es gibt also nicht nur einen Schlüssel zum Bildverständnis, sondern oft mehrere, sich ergänzende oder einander widersprechende Alternativen. Das bezeugt in einem wichtigen Teilbereich schon das Buch von Lottlisa Behling zur spätmittelalterlichen Pflanzenikonografie mit seinen vielfältigen, oft divergierenden $»$ Deutungsangeboten $« .{ }^{14}$ Aber erst Falkenburg hat ein tragfähiges Erklärungsmodell entwickelt, das auf einer intendierten »Polysemantik« der Motive und damit auch der Gemälde basiert. Bei den von ihm untersuchten Marienbildern konnte er zudem auf Motivwanderungen, Bedeutungsverschiebungen und das enge Wechselverhältnis zwischen sakraler und profaner Ikonografie verweisen. Demnach ergeben sich sowohl für den Bilderfinder, seinen Auftraggeber oder Berater als auch für das zeitgenössische Publikum gewisse inhaltliche Spielräume. ${ }^{15}$

Panofskys Methode der Bildanalyse wurde also an die veränderten Forschungsperspektiven angepasst und auf die Lebenswirklichkeit des 15. Jahrhunderts »zurückgeschnitten «. Trotzdem lebt sie fort und prägt weiterhin die wissenschaftliche Diskussion um die altniederländischen Tafelbilder. Wie fruchtbar sie letztlich war, sieht man auch 


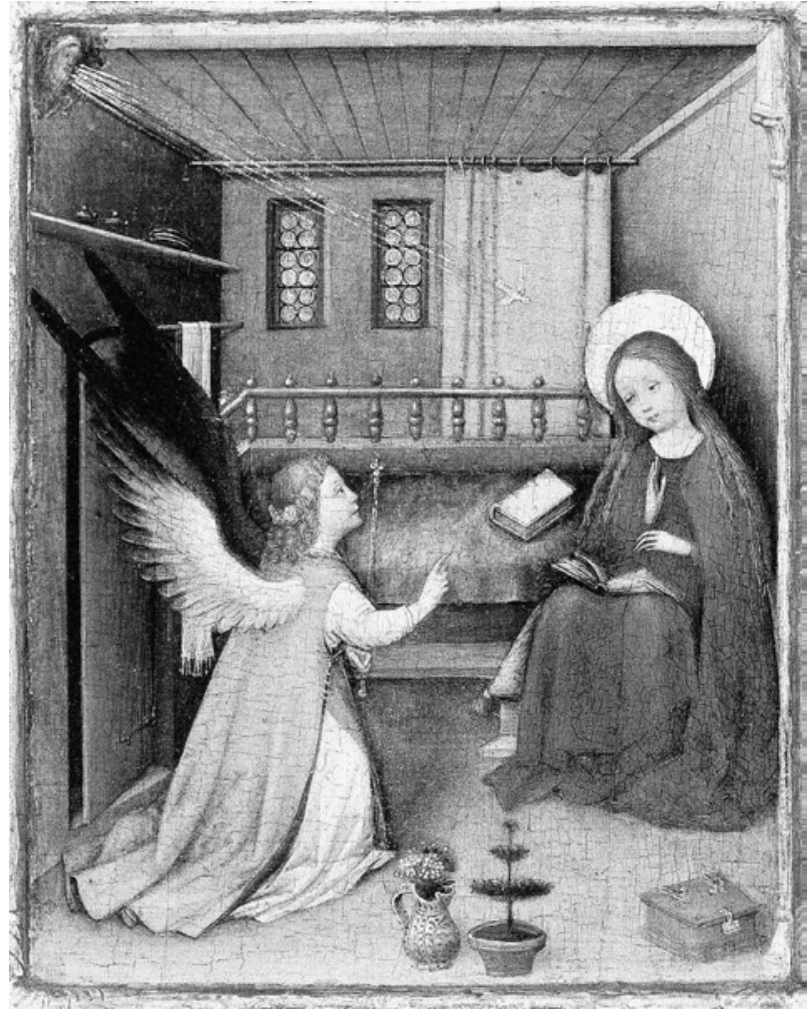

Abb. 5 Verkündigung an Maria. Meister des Paradiesgärtleins (Werkstatt). Winterthur, Sammlung Oskar Reinhart (ex: REINHARD/FELICE 2003, 109)

daran, dass einige Ergebnisse von der Kritik ausgespart und parteiübergreifend akzeptiert wurden. Das betrifft zum Beispiel die leicht nachvollziehbaren Überlegungen zur Architektursymbolik, zur antithetischen, auf den Alten und den Neuen Bund bezogenen Gegenüberstellung von Gebäuden in unterschiedlichen Baustilen. Dafür ist die Flémallesche Vermählung Mariens mit dem altertümlichen Rundtempel und der in Bau befindlichen gotischen Kirche noch immer der beste Beleg (Abb. 4). ${ }^{16}$ Damit zusammen hängt der Einsatz von fingierten Skulpturen an Portalen und Rahmenarchitekturen, an Konsolen und Kapitellen oder an Einrichtungsgegenständen, wodurch weitere typologische Bezüge erschlossen werden können.

Festzuhalten bleibt noch, dass Panofsky für seine Untersuchungen vorzugsweise Darstellungen der thronenden Madonna oder der Heiligen Familie sowie Szenen des Marienlebens und der Kindheitsgeschichte Jesu, vor allem der Verkündigung und der Geburt Christi, herangezogen hat. Immer dann, wenn in den Gemälden das Bezugssystem von Altem und Neuem Testament, die unbefleckte Empfängnis, das Geheimnis der Inkarnation oder der nachfolgende Erlösungstod Christi thematisiert werden, war die ikonografische Analyse besonders ertragreich. Daran hat man sich in der Forschung auch im Folgenden orientiert, was die offenkundige Vorliebe für die Beschäftigung mit den zahlreichen, gut vergleichbaren Verkündigungsbildern erklärt, sei es in den Niederlanden, in Deutschland oder in Italien. ${ }^{17}$

\section{Werke am Oberrhein und in Schwaben}

Ein kreativer Umgang mit den niederländischen Vorbildern zeigt sich vor allem in den süddeutschen Landesteilen, zuerst am Oberrhein und in Schwaben. Einige der hier tätigen Maler kannten die Gemälde der Altniederländer wohl aus eigener Anschauung, was sich anhand der Übernahme von Einzelmotiven oder ganzer Kompositionen sowie malerischer Eigenheiten immer wieder vermuten lässt. Aber wie viel vom ikonografischen Gehalt wurde bei aller Begeisterung für den Realismus und die neue Präsenz der Gegenstände mitrezipiert? Im Vorgriff sei schon gesagt, dass man aufgrund der unterschiedlichen Disposition der Künstler mit sehr individuellen, teilweise auch recht ausgefallenen Lösungen konfrontiert wird.

\section{Der Meister des Paradiesgärtleins und sein Umkreis}

Den Anfang am Oberrhein bezeichnen die noch von der »Internationalen Gotik" geprägten Werke des Meisters des Frankfurter Paradiesgärtleins. ${ }^{18}$ Seine Raumkonzepte sind teilweise altertümlich, seine Figuren zart und von etwas kindlichem Ausdruck. Nichts wirklich Progressives steckt in diesen Tafeln, und doch findet hier die Ars nova, vor allem in Form der realistisch wiedergegeben Bildgegenstände, bereits ihren Niederschlag.

Dass mit der Freude an den Objekten auch eine inhaltliche Zielsetzung verbunden ist, zeigt beispielhaft die miniaturhaft kleine Tafel mit der Verkündigung an Maria in Winterthur, welche dem Paradiesgartenmeister nahe steht und um oder nach 1430 entstanden sein dürfte (Abb. 5). ${ }^{19}$

In diesem - oft nur als »Puppenstube« apostrophierten - Gemälde waltet nämlich eine bemerkenswerte Ratio, die in der Anordnung der Figuren, in der perspektivischen Verkürzung des Innenraums und dem auf der Polarität von Rot und Blau basierenden Farbkonzept zum Ausdruck kommt. Auch die Zahlensymbolik hat das Denken des Meisters bis zu einem gewissen Grade geprägt. 
Durch einen schmalen Rahmen leicht distanziert, blickt man in einen bildparallel angelegten Kastenraum, der gleichsam um die Figuren herumgebaut wurde. Der Erzengel Gabriel ist von links hereingekommen und beugt anmutig das Knie vor der ihm schräg gegenüber sitzenden Gottesmutter; diese hat ihre Lektüre unterbrochen und schaut ihm andächtig und demütig entgegen. Ganz oben im Bildzwickel erscheint noch der Kopf Gottvaters, während die Geisttaube auf goldenen Strahlen zu Maria herabfliegt. Deutlich zu erkennen sind die einen Spalt breit geöffnete Tür und die beiden Fenster in der Rückwand. Ein anzunehmendes drittes Fenster, das auf die Trinität verweisen würde, ist hinter einem Vorhang verborgen, wird aber durch die genau davor schwebende Taube »ersetzt «.

Die Raumausstattung besteht außerdem aus einer bildparallel aufgestellten, einseitig abgewinkelten Sitzbank mit neun (drei mal drei) sichtbaren Balustern; die zehnte Stütze ist halb verdeckt, was vielleicht als Hinweis auf die mit der Zahl zehn verbundene Vorstellung von der Vollkommenheit und im Sinne einer "perfectio « der auf zehn Monate festlegten Schwangerschaft gedeutet werden könnte. ${ }^{20}$ Auf der Sitzfläche aber hat Maria ein geschlossenes Buch abgelegt, mit dem wohl das Alte Testament gemeint ist, während das Neue Testament geöffnet auf ihrem Schoß liegt. Ferner erkennt man ein Regalbrett mit verschiedenen Gefäßen und ein Handtuch, das auf ein verborgenes Lavabo schließen lässt.

Weitere Gegenstände, wiederum drei, sind wie ein Stillleben ganz in den Vordergrund gerückt worden. Dicht nebeneinander, an der Schwelle zwischen Betrachter und Bildraum, sieht man einen Majolikakrug mit Blumen und einen Topf mit einer zugeschnittenen Grünpflanze, welche zusammen den Abstand zwischen den Figuren überbrücken. Davon abgerückt steht ein verschlossener, in Schrägansicht gezeigter Holzkasten auf dem Fußboden; dieser wurde - im Einklang mit der Raumperspektive der unteren rechten Bildecke eingepasst und Maria zugeordnet.

Der helle Krug mit dem blauen Dekor und der eingeschnürten Tülle ist ein beliebter Alltagsgegenstand und begegnet in ähnlicher Form in den Flémalleschen Verkündigungen (Abb. 2). ${ }^{21}$ Verwendet wird er für das Sinnbild der Maria als Vase, als "auserwähltes Gefäß«, welches Christus, das wahre Manna, in sich birgt. ${ }^{22}$ Auffällig ist aber, dass in Winterthur keine Lilien darin stehen, sondern kleinblütige weiße und rote Blumenbüschel. Dabei dürfte es sich um genau jene Pflanzen handeln, die im Frankfurter Paradiesgärtlein hinter Maria auf dem Hochbeet wachsen und als Levkojen oder Goldlack identifiziert wurden. ${ }^{23}$ Welche spezifische Bedeutung sie hier als Marienblumen haben sollen, wird man jedoch kaum ermitteln können.

Der daneben stehende Blumentopf aber ließe sich ebenso auf das Epitheton der Maria als Vase beziehen. Da er aus unglasierter Terrakotta besteht, käme dadurch die Vorstellung von Gottvater als dem Töpfer dieses Gefäßes sogar noch deutlicher zur Anschauung. ${ }^{24}$ Und die darin wachsende Pflanze würde dann als immergrüner Baum des Lebens auf die göttliche Mutterschaft Mariens verweisen. ${ }^{25}$ Im Hinblick auf die Verdoppelung der Gefäße im Bildvordergrund wäre allerdings zu überlegen, ob der Blumentopf hier nicht auch den Hortus conclusus (Hld $4,12)$ symbolisieren könnte. ${ }^{26}$ Dieses zur Verkündigungsikonografie gehörige Sinnbild für die Keuschheit Mariens und ihre unbefleckte Empfängnis ist üblicherweise als Zinnenmauer, die einen Garten umschließt, in die Gemälde integriert. Wird aber die Szene in einen Innenraum verlegt und kein Ausblick gewährt, kann der Blumentopf wie ein Substitut verwendet werden.

Bestätigen lässt sich diese Vermutung, indem man eine weitere Tafel des Paradiesgartenmeisters, den etwa gleichzeitig entstandenen Straßburger Josefszweifel, in die Betrachtung einbezieht: Dort nämlich steht der Topf vorn in der Bildmitte und hat zur Verdeutlichung der Aussage noch einen Zinnenkranz bekommen (Abb. 6). ${ }^{27}$ In dieser Form findet er um 1450/60 Eingang in das druckgrafische Werk des Meisters E. S., etwa in die Maria mit dem badenden Jesuskind (Abb. 7). ${ }^{28}$

Der Kupferstecher bezieht sich damit wahrscheinlich direkt auf den Josefszweifel, weil auch das in einer Nische stehende Lavabo in Form eines zylindrischen Behälters mit Hahn und Deckel sowie einem darunter befindlichen Auffangbecken in seiner Darstellung wiederkehrt. Der Topf ist nun unauffälliger und der Gebrauchspraxis entsprechend auf der Bank des rückwärtigen Biforienfensters aufgestellt worden, hat aber dieselbe Bedeutung und passt ikonografisch gut zu dem neuen Thema. ${ }^{29}$ Außerdem erscheint der zinnenbewehrte Blumentopf beim Meister E. S. auch noch in profanem Zusammenhang, nämlich bei seinem Liebespaar auf der Rasenbank, wo er direkt neben der von ihrem Galan bedrängten Frau platziert wurde (Abb. 33).$^{30}$ Hier fungiert er als Mahnzeichen, als Symbol für die gefährdete Keuschheit, was ein »marianisch» geschulter Betrachter problemlos verstehen konnte. $\mathrm{Zu}$ - 


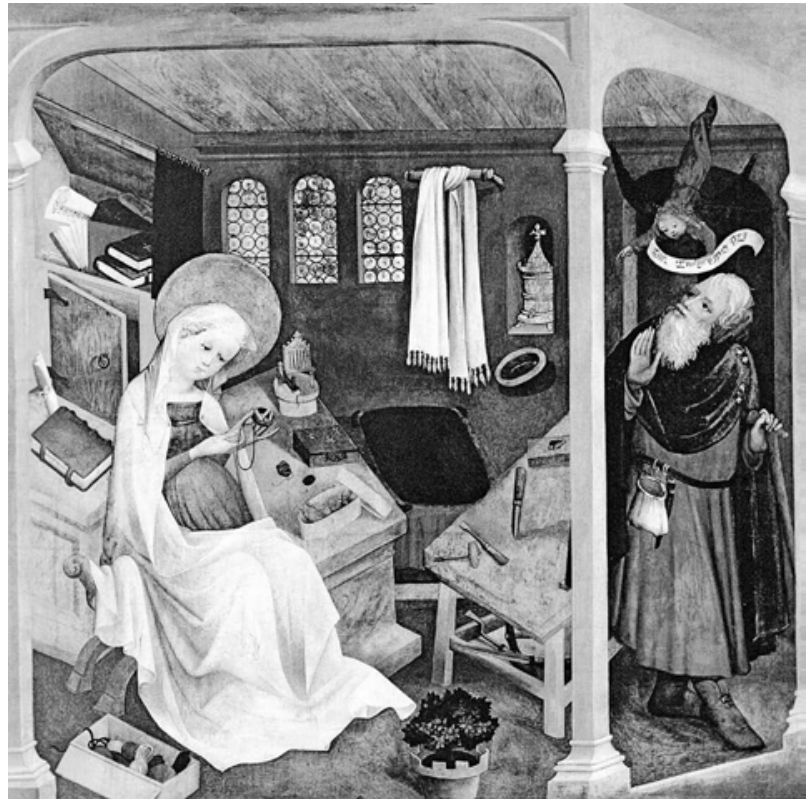

Abb. 6 Josefszweifel. Meister des Paradiesgärtleins. Straßburg, Musée de l'CEuvre Notre-Dame (ex: Ausst.-Kat. Straßburg 2008, 166)

Abb. 7 Maria mit dem badenden Jesuskind. Meister E. S. (ex: BEVERS 1987, 134)

mindest am Oberrhein lässt sich die Geschichte dieses Bildzeichens also noch genauer verfolgen.

Das Topfsymbol hat in der Marienikonografie aber schon eine längere Vorgeschichte. Eine interessante Spur führt nach Italien, zu einem Freskofragment der $\mathrm{Ma}$ donna gravida von Simone di Filippo (Simone dei Crocifissi) im Chorumgang von S. Maria dei Servi in Bologna; hier schaut die schwangere Maria nachdenklich auf einen Blumenständer mit einem ringsherum gelochten Topf und einem darin befindlichen Bäumchen (Taf. XVIII). ${ }^{31}$ Vielleicht findet sich auch noch ein frühes Beispiel in den Niederlanden, doch fehlt das Motiv gerade bei den so oft zitierten Prototypen des Meisters von Flémalle. Für ein Vorhandensein im niederländischen Repertoire spricht aber, dass es auch im grenznahen Westfalen vorkommt, wo es der Meister des Schöppinger Altars (1453-57) demonstrativ in seine Paraphrase einer Flémalleschen Verkündigung implantiert hat (Abb. 9). ${ }^{32}$ Wer als erster den Zinnenkranz hinzugegeben und damit eine Deutungsmöglichkeit konkretisiert hat, bleibt jedoch offen.

Was für Pflanzen aber wachsen in den Blumentöpfen? Bei einigen der genannten Darstellungen könnte es sich um eine Myrte handeln. Diese ist als lange tradiertes Hochzeits- und Fruchtbarkeitssymbol auch in der

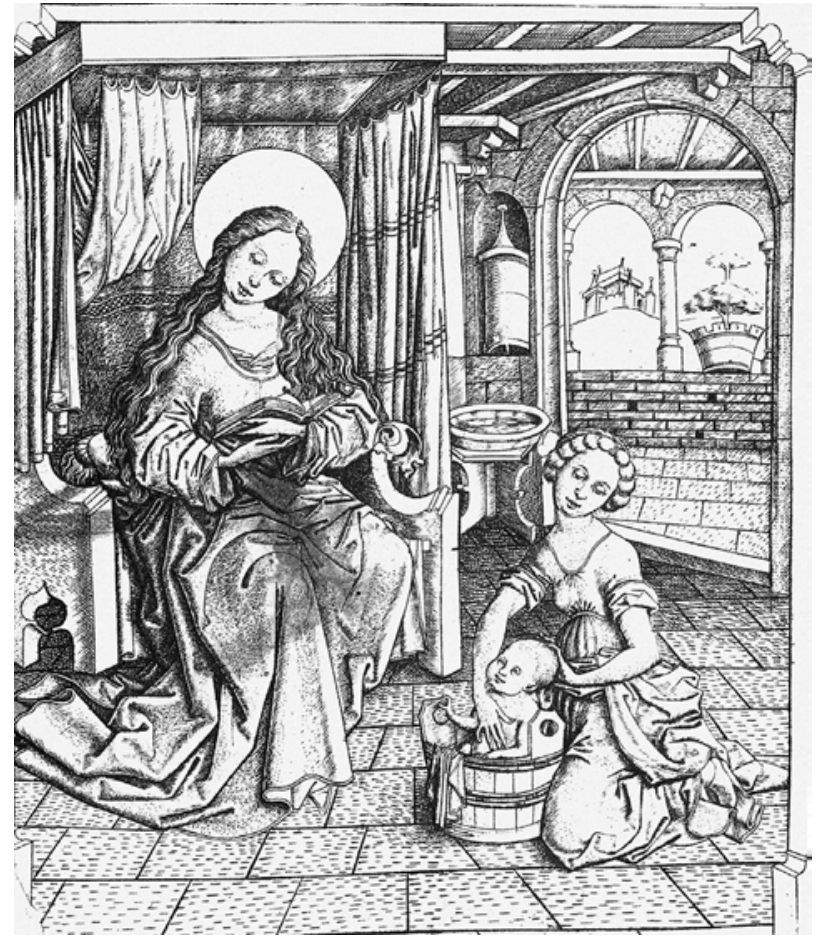

Marienikonografie präsent. ${ }^{33}$ Botanisch einwandfrei bestimmen lässt sich die weiß blühende Myrte aber nur selten, etwa bei einer Geburt Christi in Köln (1. Viertel des 15. Jahrhunderts), wo sie Behling merkwürdigerweise gar nicht als solche identifiziert hat (Abb. 8). ${ }^{34}$ Im Falle der übrigen, unterschiedlich gebildeten Pflanzen wird man aber auch andere Blatt- oder Nadelgewächse in Betracht ziehen müssen. ${ }^{35}$

Außerdem könnten sich aus der Form der miniaturhaft wiedergegebenen Bäumchen weitere Deutungsansätze ergeben. In Bologna ist es kreuzförmig zugeschnitten, wodurch der fast angstvolle Blick Mariens eine einleuchtende Erklärung findet, in Winterthur ist es in drei Etagen pyramidenförmig "getrimmt«, was im Zusammenhang mit den Fenstern der Rückwand und der axial über dem Topf schwebenden Taube trinitarisch interpretiert werden könnte. Sind hingegen - wie bei der Maria mit dem badenden Jesuskind - nur zwei Stufen zu sehen, sollte damit vielleicht an die Zweinaturenlehre, an die Auffassung von Christus als Gott und Mensch, erinnert werden. Das Ziehen von Pflanzen in dieser Form und ein Etagenschnitt im Sinne der »ars topiaria« entsprechen aber auch einer weit verbreiteten gärtnerischen Praxis, die aus den mediterranen Ländern in den Norden gelangte. Zahlreiche Bäume und Büsche, auch Myrten, können in eine solche Form gebracht werden. Dafür gibt es sogar Bild- 


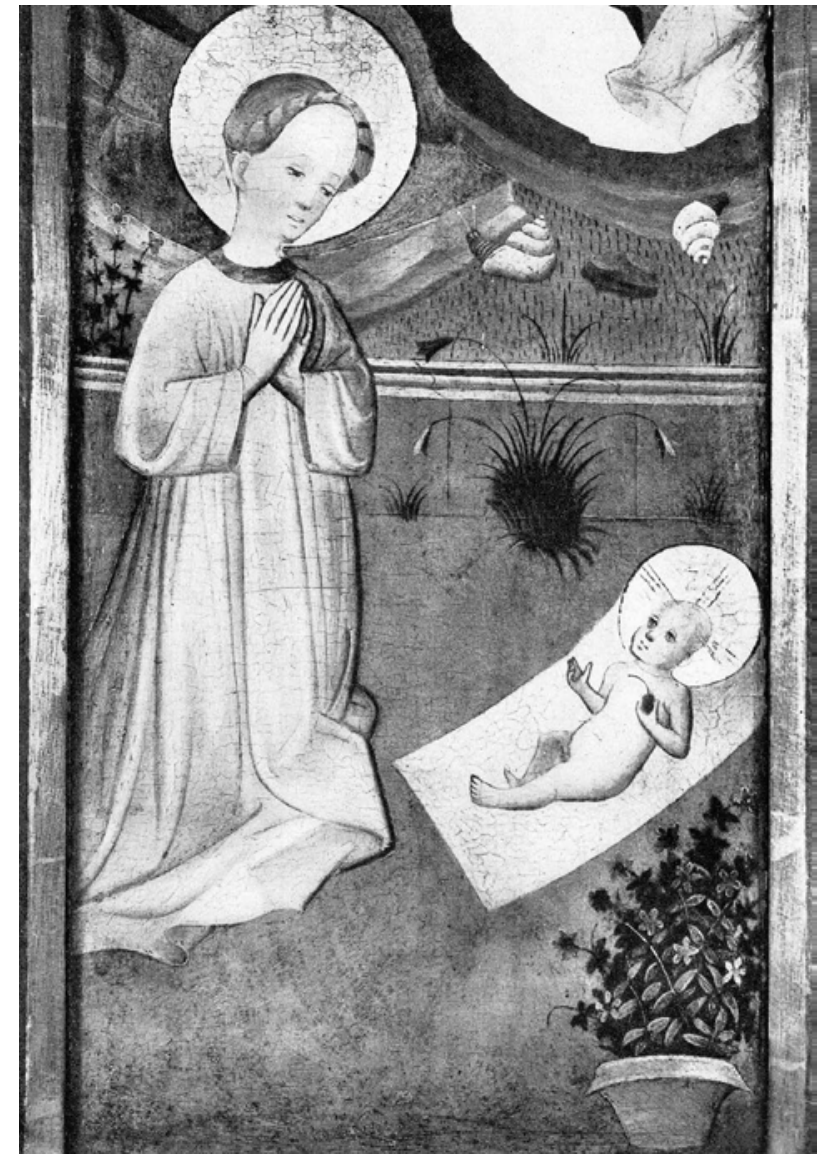

Abb. 8 Geburt Christi. Köln, Wallraf-Richartz-Museum (ex: BEHLING 1967, Taf. XVIII)

zeugnisse aus der Gartenliteratur des 15. Jahrhunderts. ${ }^{36}$ Dass die Zahlensymbolik trotzdem eine Rolle spielt, sieht man indes an der buschigen Pflanze in der Schöppinger Verkündigung, die mit sieben Spitzen vor den beiden Protagonisten aufwächst.

Das dritte Objekt im Winterthurer Bild, das Holzkästchen mit zwei lilienförmigen Beschlägen und einem einfachen Schloss, könnte dagegen auf die Gleichsetzung Mariens (arca domini) mit der Bundeslade (arca testamenti) verweisen. Diesbezügliche Textstellen finden sich sowohl im Speculum humanae salvationis als auch in der Lauretanischen Litanei. ${ }^{37}$ Im Josefszweifel des Paradiesgartenmeisters kommt der Kasten ebenfalls vor, nun unter den um die Gottesmutter verteilten Schachteln mit den für ihre Handarbeit benötigten Garnrollen und Wollknäulen. Da aber auch in diesem Gemälde die Schwangerschaft Mariens thematisiert wird, wäre die Bedeutung des Holzkastens wohl dieselbe. Weitere Beispiele können in der deutschen Tafelmalerei dieser Zeit allerdings nicht

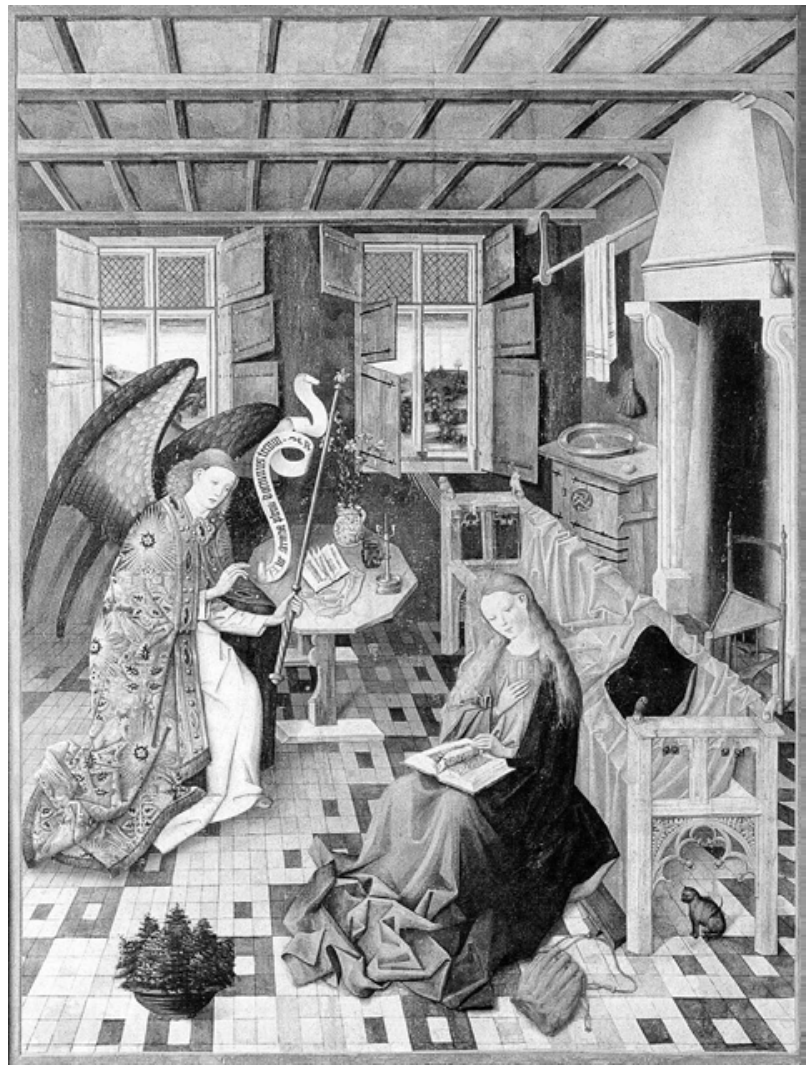

Abb. 9 Verkündigung an Maria. Meister der Schöppinger Altars. Schöppingen, Pfarrkirche (ex: Ausst.-Kat. Brügge 2010, 220)

angeführt werden; auch in den niederländischen Gemälden der Ars nova sucht man dieses Bildzeichen vergebens. ${ }^{38}$

Für die allgemeine Verständlichkeit der - vielleicht sogar in mehreren Exemplaren verbreiteten - Verkündigung des oberrheinischen Meisters aber spricht, dass sie in diversen Bildmedien noch über einen längeren Zeitraum zitiert wurde. Denn für ihr Weiterleben sorgten die seitenverkehrte Reproduktion in einem Kupferstich des Meisters der Nürnberger Passion (um 1450), und, davon abgeleitet, die Wiederaufnahme der Komposition in einem Straßburger Bildteppich (um 1470/90). ${ }^{39}$ Zuletzt hat man allerdings eine ikonografische Korrektur vorgenommen, indem anstelle des Krugs eine Zinnkanne mit dem obligatorischen Lilienstengel eingefügt wurde; der Blumentopf entfiel, doch das Holzkästchen blieb. 


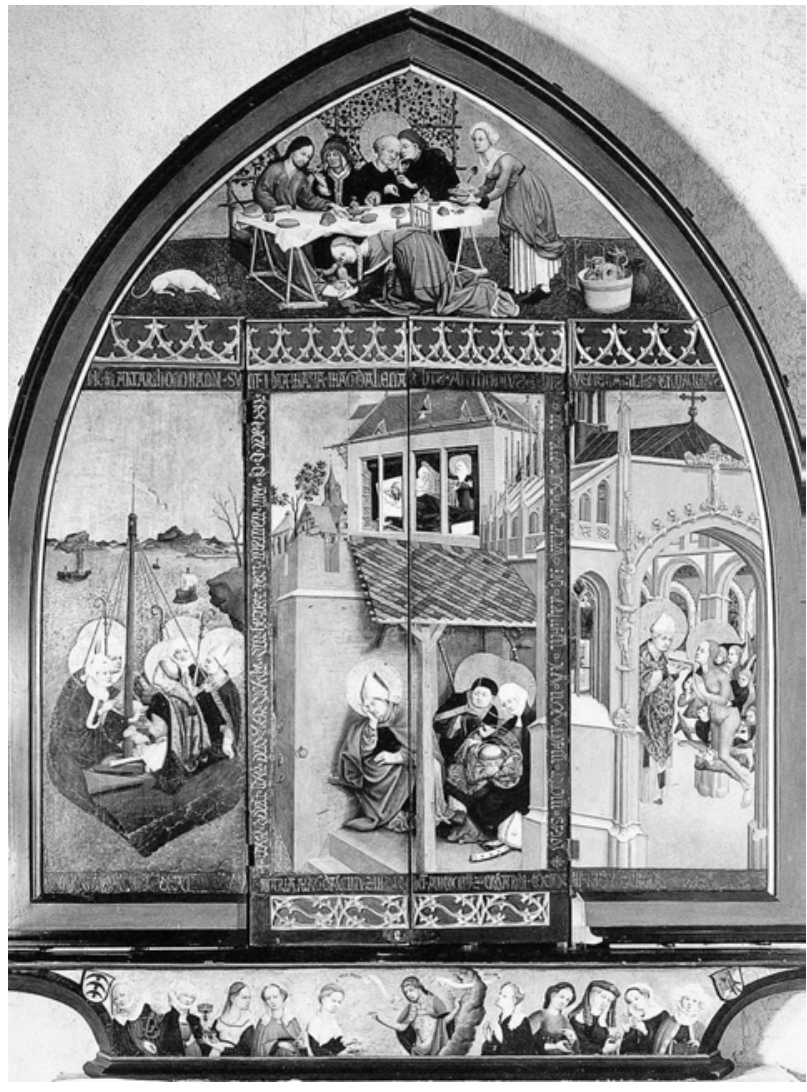

Abb. 10 Magdalenenaltar, Außenseite. Lukas Moser, 1432. Tiefenbronn, Pfarrkirche (Foto: Zentralinstitut für Kunstgeschichte, München)

\section{Lukas Moser}

Den Status eines Pioniers in der deutschen Tafelmalerei der Spätgotik hat freilich erst Lukas Moser, dessen 1432 signierter Magdalenenaltar in der Pfarrkirche von Tiefenbronn die Reihe der schwäbischen Retabel im Stil des neuen Realismus eröffnet (Abb. 10). ${ }^{40}$

Die Auseinandersetzung mit der Ars nova im Westen basiert hier wiederum auf den Werken des Meisters von Flémalle, aber auch auf den Tafelbildern und Miniaturen des Jan van Eyck. Dadurch erklärt sich Mosers außerordentlich hohe Malkultur, die ihn gegenüber anderen deutschen Kollegen auszeichnet.

Ikonografisch am interessantesten ist die Letzte Kommunion der heiligen Maria Magdalena auf der Außenseite des Retabels mit einem in Schrägansicht gezeigten Kirchengebäude, das sich - wie bei einigen niederländischen Triptychen - über die Rahmengrenzen hinweg im Nachbarbild fortsetzt. Es besteht aus einem älteren Innenbau, einem romanischen Mittelschiff und einem für die Ein- wölbung vorbereiteten Seitenschiff, sowie einem gotischen Außenbau. Das erinnert im Hinblick auf die antithetische Verwendung unterschiedlicher Bauformen an die Vermählungstafel des Meisters von Flémalle (Abb. 4). Auch das Motiv der Baustelle ist wohl von solchen Vorbildern entlehnt worden, wobei die von Moser dargestellte Modernisierungsmaßnahme ganz der zeitgenössischen Baupraxis und dem Umgang mit älteren Baudenkmälern entspricht.

Diesen Prozess der Erneuerung im Sinne eines vorgegebenen Heilsplans bezeichnen noch konkreter die fingierten Skulpturen am Portal der Kirche (Abb. 11).

An einer Standsäule übereinander angebracht sind: erstens ein angebundener Affe, der einen Vogel traktiert, welcher seinerseits eine Schnecke im Schnabel hat, zweitens die mehrfach beschädigte Statue eines nackten Mannes, der den Affen an einer Kette hält, und drittens eine Standfigur der Maria mit dem Kind. Außerdem befindet sich im Scheitel der Portalrahmung noch ein Kruzifix, welches ebenfalls monochrom wiedergegeben ist, so als sei es zusammen mit der Architektur und den anderen Bildwerken aus dem im deutschen Südwesten oft verwendeten Buntsandstein angefertigt worden (Abb. 12). ${ }^{41}$

Zutreffend gedeutet wurde dieses Programm bereits von Charles Sterling, indem er die Figuren als Chiffren für die Zeit »ante legem «, »sub lege« und »sub gratia« verstanden und Moser implizit ein den Niederländern vergleichbares gedankliches Niveau attestiert hat. ${ }^{42}$

Wie intelligent der Maler seine inhaltlichen Ziele verfolgte, zeigt sich aber auch im Detail, vor allem an der Skulptur des nackten Mannes, der wie ein Atlant oder ein niedergebeugter Sklave unter der Madonna steht. ${ }^{43}$ Dieser hat buchstäblich einen »Gesichtsverlust« erlitten, wobei nur die dunkle Öffnung des nun lippenlosen Mundes übrig geblieben ist. ${ }^{44}$ Abgeschlagen sind außerdem der rechte Ellenbogen und die vordere Fußspitze zusammen mit der Kette. Das erinnert an Darstellungen der blinden Synagoge mit der zerbrochenen Lanze und der verlorenen Krone. Jedenfalls wurde die Figur nicht mutwillig zerstört, wie bei einem Bildersturm, sondern gezielt fragmentiert. Trotzdem vermeint man noch gewisse Lebenszeichen zu spüren, wenn der Mann das hauchdünne Lendentuch hochzieht oder wenn sich seine weiche Haut beim Einknicken der Hüfte verschiebt. Das verweist auf den nur wenig früheren Frankfurter Gnadenstuhl des Meisters von Flémalle, wo solche Finessen in großem Maßstab vorgeführt werden. ${ }^{45}$

Direkt darüber erhebt sich die makellos erhaltene Madonna, die im Portalzusammenhang auch als Personi- 


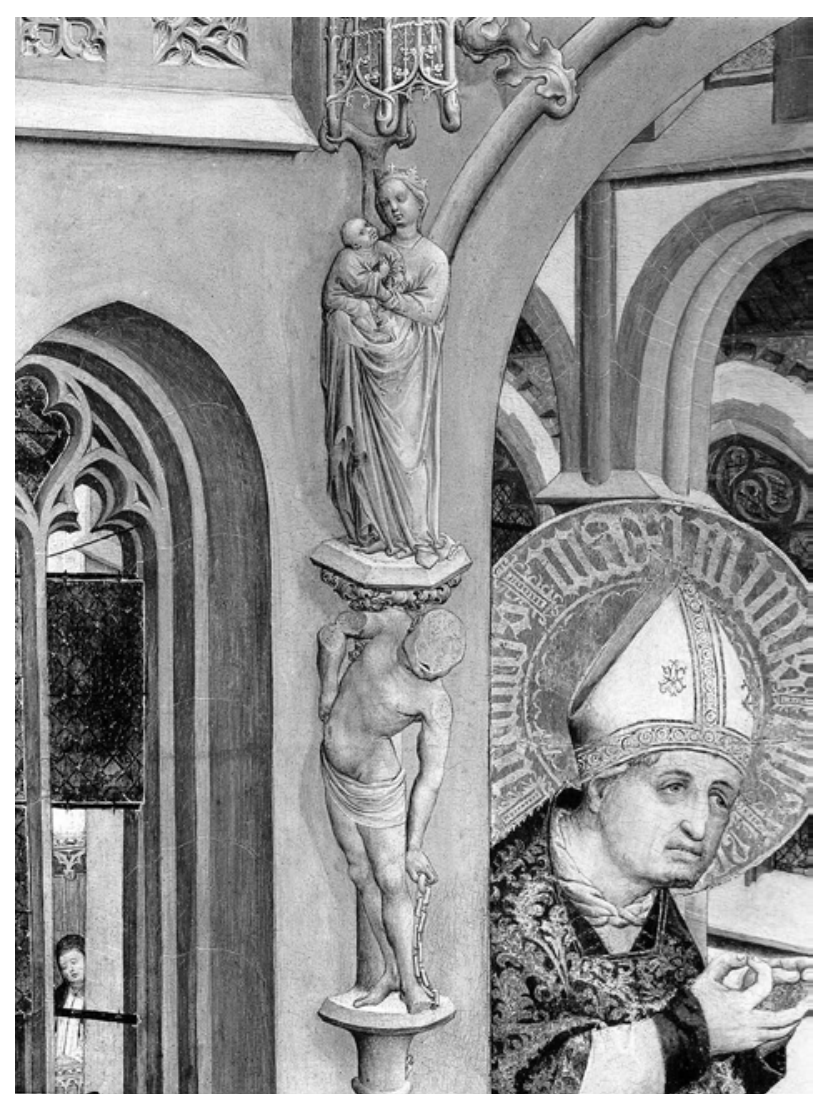

Abb. 11 Die letzte Kommunion der hl. Maria Magdalena, Detail. Magdalenenaltar, Außenseite. Lukas Moser, 1432. Tiefenbronn, Pfarrkirche (Foto: Zentralinstitut für Kunstgeschichte, München)

fikation der Ecclesia aufzufassen ist. Mit ihrem sicheren Stand- und Haltemotiv, dem wohlgeordneten, dabei dünnen und hell schimmernden Gewand, hat sie der Künstler so weit belebt, dass sich der Gedanke an eine Steinfigur gar nicht erst einstellen möchte. Besonders aktiv ist auch das Jesuskind, das den dicken Apfel kaum zu halten vermag und steil zum Gekreuzigten emporschaut. Der Baldachin über der Statue aber gehört - ganz im Sinne einer Transformation - nicht mehr zu der steinernen Säule, sondern entwächst einem kräftigen, sich genau über den Köpfen von Mutter und Kind verzweigenden Ast; dieser ist so kunstvoll verschlungen, als sei damit das Ende einer Wurzel Jesse erreicht oder als stünden der Knabe und seine Mutter als neuer Adam und neue Eva unter dem Baum der Erkenntnis.

Am Portalbogen entlang führt schließlich eine mit Krabben verzierte, sich im Scheitel verknotende Archivolte hinauf zum Kruzifixus. Das Kreuz Christi bildet den Zielpunkt des ganzen Programms und ist nach alter Tradition als lignum vitae dargestellt worden; es wird von

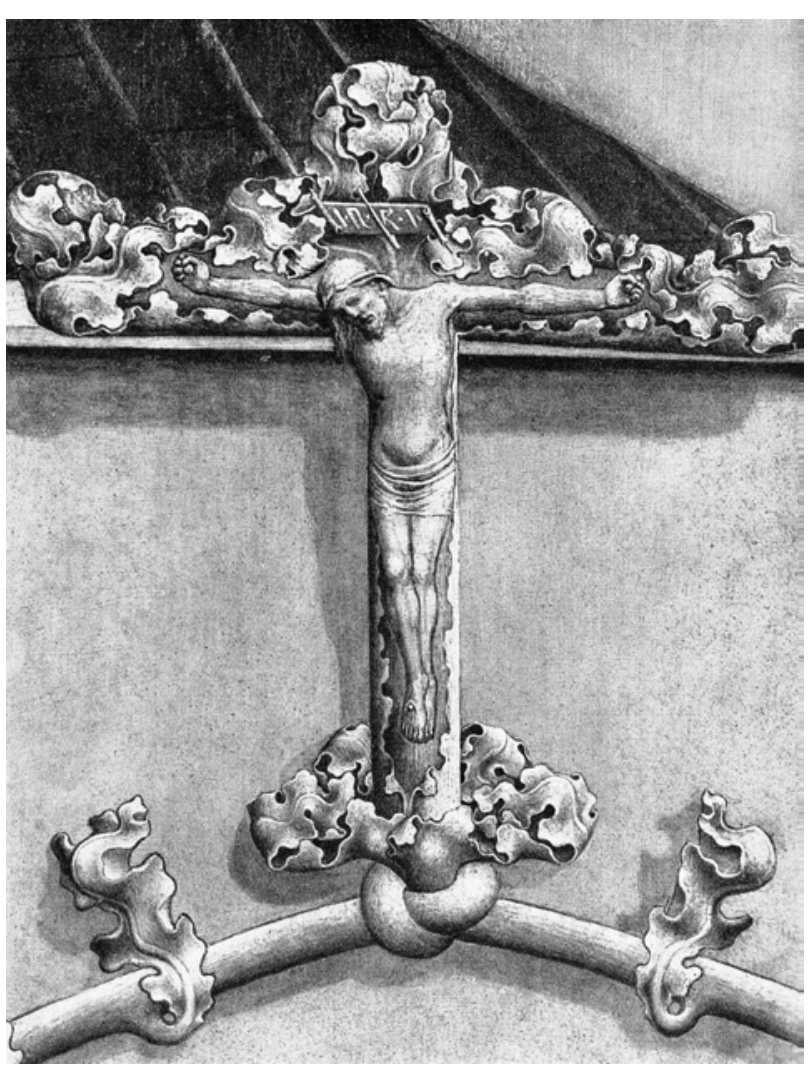

Abb. 12 Die letzte Kommunion der hl. Maria Magdalena, Detail. Magdalenenaltar, Außenseite. Lukas Moser, 1432. Tiefenbronn, Pfarrkirche (ex: BOECK 1951, Abb. 24)

den breitlappigen Krabben ornamental umschlossen und schält sich gleichzeitig aus ihnen hervor.

Die Figuren Mosers scheinen also vielfältige Deutungsmöglichkeiten $\mathrm{zu}$ beinhalten, die seitens des Betrachters ein gewisses Bildungsniveau, aber auch eine hohe gedankliche Flexibilität im Umgang mit den Inventionen des Künstlers erfordern. Wie weit man allerdings die Interpretation über die von Sterling erkannte Grundaussage hinaustreiben darf, wird man nie sicher festlegen können, weil weder ein bestimmtes Vorbild noch ein das Programm erklärender Text vorauszusetzen sind. Bei den maßgeblichen Altniederländern gibt es noch nicht einmal genaue Entsprechungen für die das Portal flankierenden Bildsäulen; denn deren fingierte Skulpturen stehen meist auf Konsolen oder in einem Gewände und sind in eine gotische Architektur mit Tabernakeln und Blendmaßwerk integriert. Als »reale« Exempla aus der älteren deutschen Monumentalskulptur könnten aber die beiden Standsäulen mit Ecclesia und Synagoge am Südportal des 


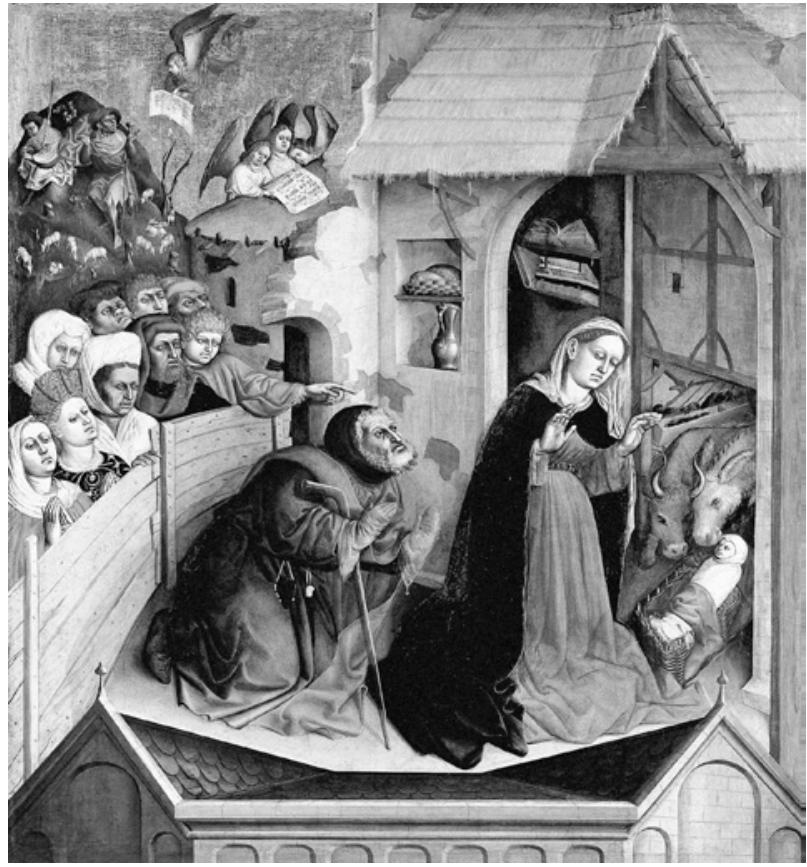

Abb. 13 Geburt Christi, Wurzacher Altar. Hans Multscher, 1437. Berlin, Gemäldegalerie, Id.-Nr. 1621 (Foto: Berlin, Staatliche Museen - Preußischer Kulturbesitz, Gemäldegalerie)

Straßburger Münsters und am Fürstenportal des Bamberger Doms angeführt werden.

\section{Hans Multscher}

Ein Hauptwerk der deutschen Tafelmalerei in Schwaben ist ferner der sogenannte Wurzacher Altar mit der doppelten Signatur des Ulmer Bildhauers Hans Multscher und dem Datum 1437. Sowohl die Eigenhändigkeit der Ausführung als auch die Rekonstruktion des Retabels sind nach wie vor umstritten, doch sollen an dieser Stelle nur einige ikonografische Probleme bei den vier Marienszenen angesprochen werden. ${ }^{46}$

Dargestellt sind auf den oberen Tafeln die Geburt Christi und die Anbetung der Könige, welche kompositionell genau aufeinander abgestimmt wurden (Abb. 13, 14).

Beide Male ragen die Dächer der Gehäuse aus den unteren Szenen in die Bildfelder hinein und »tragen « Maria und Joseph, die hintereinander angeordnet und zur rechten Seite hin orientiert sind, sowie die von links herangekommenen Könige. Unter dem jeweils gleichen Blickwinkel werden auch die Stallgebäude gezeigt, bestehend aus einer schräg gestellten ruinösen Mauer, einer Rückwand mit Fachwerk und einer Holzstütze für das Strohdach mit

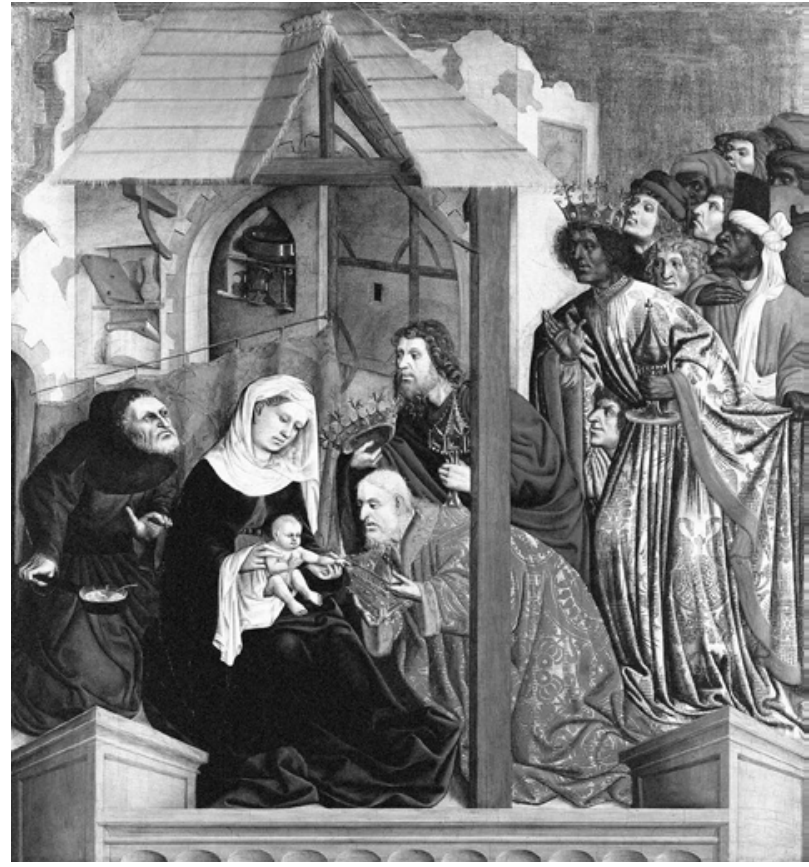

Abb. 14 Anbetung der Könige, Wurzacher Altar. Hans Multscher, 1437. Berlin, Gemäldegalerie (Foto: Berlin, Staatliche Museen Preußischer Kulturbesitz, Gemäldegalerie)

dem Giebel. Dieser sitzt beide Male über Maria und dem Kind und übernimmt die Funktion eines Baldachins.

Auffallend sind indes die in die Wände eingelassenen Nischen mit den teilweise schon bekannten, marianisch gedeuteten Gegenständen. Sie gehören keineswegs zur Grundausstattung dieser Szenen und waren, wie man anhand der Infrarotaufnahmen deutlich erkennen kann, anfangs auch nicht vorgesehen. Darunter kommen nämlich nicht ganz verständliche Balkenkonstruktionen zum Vorschein, die für beide Tafeln analog konzipiert wurden. ${ }^{47}$ Warum es dann zu einer Umgestaltung kam, bleibt offen, doch ist die Freude an solchen Objekten wohl durch ein ähnliches Stillleben im Pfingstfest der Besserer-Scheiben des Ulmer Münsters stimuliert worden (um 1430/31). ${ }^{48}$

Betrachtet man nun die insgesamt vier Nischen mit ihren Gegenständen genauer, so entsteht zunächst der Eindruck, als seien hier Bildzeichen aus der gar nicht dargestellten Verkündigung in neue Zusammenhänge integriert worden: Ein offenes Buch, mehrere geschlossene Bücher und auch der Kerzenleuchter finden sich wieder. Zur Verkündigung gehört ferner die gesiegelte Urkunde, die der Engel diesmal nicht Maria, sondern den Hirten auf dem Felde entgegenhält. Das ist kurios, denn man wird davon ausgehen müssen, dass die einfachen, illiteraten Hirten damit überfordert sind. 
Abb. 15 Geburt Christi, Detail. Wurzacher Altar. Hans Multscher, 1437. Berlin, Gemäldegalerie (Foto: Berlin, Staatliche Museen - Preußischer Kulturbesitz, Gemäldegalerie)

Abb. 16 Geburt Christi aus der Josefstafel. Meister von Hoogstraten. Hoogstraten, Sint-Katelijnekerk (Foto: U. Söding)

Trotzdem ist auch das Bemühen um eine neue Sinnstiftung festzustellen. Sind in der einen Nische des Geburtsbilds nämlich ausschließlich Bücher zu sehen, die sich nicht zufällig genau über dem Kopf der Maria befinden, so hat Multscher über dem Kopf des Nährvaters Joseph ein eucharistisches Stillleben eingefügt (Abb. 15). Nicht anders können nämlich der Zinnkrug und die Korbschüssel mit dem Brot interpretiert werden. Das ist sinnfällig und leicht verständlich; es entspricht einerseits dem Gebot einer gewissen Ärmlichkeit und ist andererseits ein Aushängeschild für die malerische Ambition und das koloristische Empfinden des hier nur mit neutralen Farben operierenden Künstlers. So wird man darin wohl eine Eigenschöpfung vermuten dürfen und nicht eine »Kopie« nach einem niederländischen Vorbild. Im Kreis des Meisters von Flémalle gibt es aber zumindest Schrankmöbel (Dressoirs), die auch eine Kanne und verschiedene Brote enthalten. Das belegen einige in Deutschland entstandene Nachfolgewerke, etwa die um 1440/50 datierte Madonna im Gemach des Meisters von Iserlohn (Abb. 35) ${ }^{49}$ und die Heilige Familie eines vielleicht bayerischen Meisters im Museum von Chicago (um 1450/60). ${ }^{50}$

Wie um den eucharistischen Bezug noch zu betonen, hängen außerdem einzelne Ähren vom Strohdach der Hütte herab: drei über der Nische mit dem Brot, eine genau über dem Jesuskind. Auf der benachbarten Tafel mit der Epiphanie wird das noch einmal wiederholt - an der langen Seite sieht man zwei Ähren, an der kurzen eine Ähre -, um fast pedantisch für die Einheitlichkeit der Ortsangaben zu sorgen. Dennoch sollte das Motiv der Ähren nicht unbedingt zu den Neuerungen Multschers gezählt werden, da die Geburtsszene in der Josefstafel des Meisters von Hoogstraten (um 1440/70), die auf verlorene Darstellungen des Meisters von Flémalle zurückgeht,

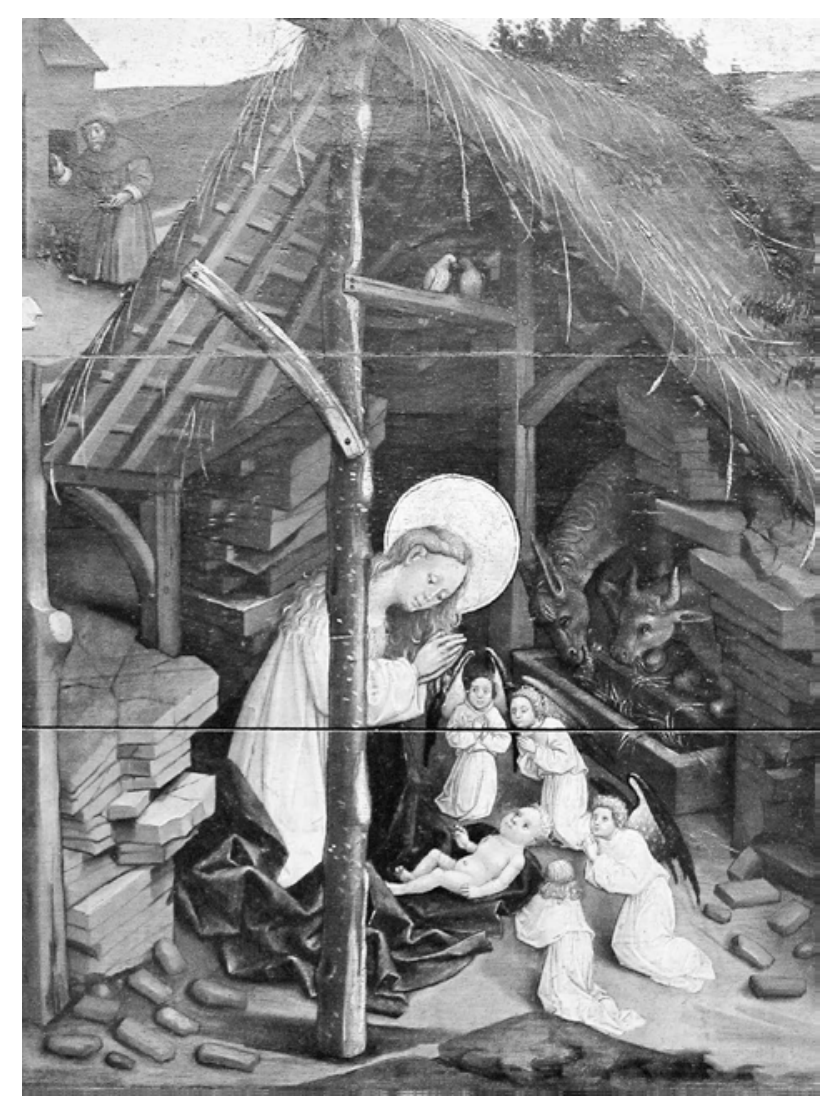

dieses Detail ebenfalls enthält (Abb. 16). ${ }^{51}$ Dort gibt es allerdings ein Überangebot an unordentlich herabhängenden Ähren, während sie bei den Wurzacher Tafeln »trinitarisch" abgezählt sind.

Ikonografisch interessant ist außerdem die Beigabe der Josefshosen auf der Krippe mit dem Jesuskind (Abb. 17). Joseph de Coo hat diesem Motiv zwei wichtige Aufsätze gewidmet und nachgewiesen, dass es seit etwa 1330 vorkommt und sich besonders von Aachen aus, wo die Josefshosen zu den Heiltümern des Münsters gehören, in der deutschen Malerei der Spätgotik verbreitet hat. ${ }^{52}$ Multscher war - wie der von ihm geschaffene Engel unter einer Chorpfeilerfigur im Dom und sein von dort übernommenes Meisterzeichen belegen - sogar selbst in Aachen, sodass in diesem Fall ein direkter Anknüpfungspunkt bestünde. ${ }^{53}$

Wie die Nischen mit den Stillleben wurden aber auch die Josefshosen erst während des Malprozesses hinzugegeben, über und unter das schon gut gewickelte Jesuskind gelegt. Der Knabe müsste ja eigentlich nackt sein und frieren, damit das Ausziehen der Hosen in der kalten Weihnachtszeit motiviert ist. Multschers Josef aber trägt Schuhe (und sogar Handschuhe) und hat seine Hosen 
Abb. 17 Geburt Christi, Detail. Wurzacher Altar. Hans Multscher, 1437. Berlin, Gemäldegalerie (Foto: Berlin, Staatliche Museen - Preußischer Kulturbesitz, Gemäldegalerie)

Abb. 18 Geburt Christi vom Sterzinger Retabel. Meister der Sterzinger Altarflügel. Sterzing, Multscher-Museum (ex: SöDING 1991/l, Abb. 47)

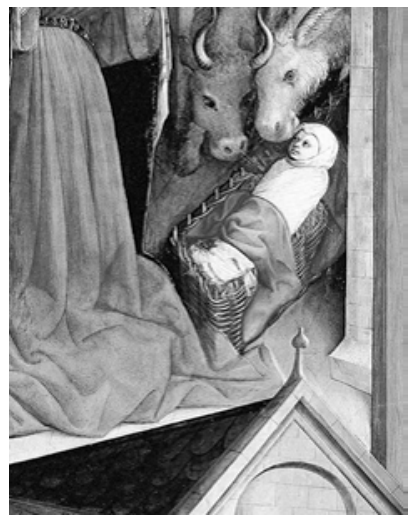

sicher noch an. Eine ikonografisch richtige Version der Geschichte bietet also erst der in der Multscher-Werkstatt tätige Meister der Sterzinger Altarflügel in seiner Darstellung von $1456 / 58$ (Abb. 18). ${ }^{54}$

Gewisse Ungereimtheiten zeigen sich auch bei der Ausstattung der Wurzacher Epiphanie. Über dem Kopf der Gottesmutter mit dem Kind erscheinen ein Messingleuchter und zwei weitere Objekte, ein undefinierbares Gefäß und möglicherweise ein Messer, sowie eine massive metallene Schüssel oder ineinander gestellte Teller. Weitere Gegenstände befinden sich in der vorderen $\mathrm{Ni}$ sche: eine geschlossene Spanschachtel, zwei Bücher und eine irdene Vase. Letztere wird man wohl wieder auf Maria als tönernes Gefäß beziehen dürfen, selbst wenn der Hinweis hier nur beiläufig gegeben wird. Prominenter ist dagegen die Spanschachtel, die im Verkündigungskontext, sofern sie denn geöffnet ist, Garn und Wolle enthält und über deren Bedeutung nicht weiter spekuliert werden sollte (vgl. Abb. 6, 37). ${ }^{55}$ Hier liegt eine solche Bestimmung auch insofern nahe, als hinter der heiligen Familie nachträglich ein roter Vorhang eingezogen wurde, der wohl mit dem Tempelvorhang gleichzusetzen ist, für den Maria Wolle gesponnen hat. ${ }^{56}$ Gleichzeitig wird dieser auch als halbhohe Raumbegrenzung eingesetzt, so wie der Zaun in der Geburt Christi oder der grüne Vorhang hinter der thronenden Madonna in der vierten Tafel mit dem Pfingstfest.

Die Anordnung der Gegenstände lässt aber insofern zu wünschen übrig, als sie im Flächenverband eher mit Josef als mit Maria zusammenzusehen sind. Der Nährvater kniet nämlich unterhalb der Spanschachtel direkt vor dem Vorhang und drängt andererseits, mit einer Pfanne in der Hand, an Maria und das Kind heran. Das Pfannenmotiv gehört meist zur Geburt Christi, seltener auch zur Anbetung der Könige, nimmt sich hier aber etwas son-

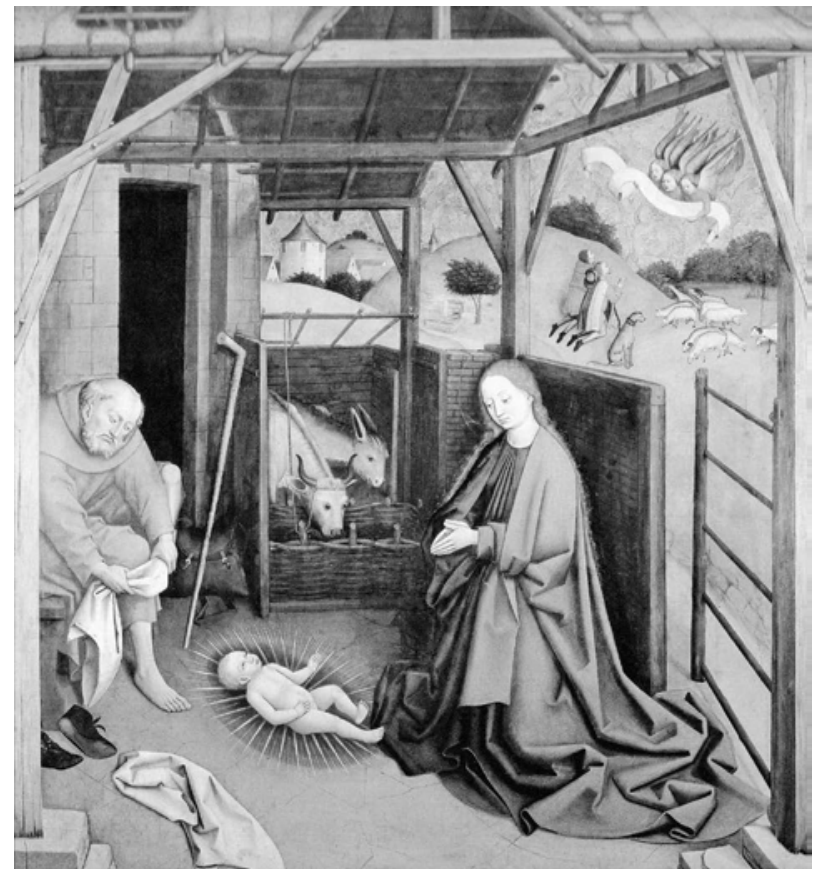

derbar aus, weil es keine anderen Hinweise auf die Essenszubereitung, das heißt auf eine Feuerstelle oder einen Nebenraum mit einer Küche, gibt. ${ }^{57}$

Erwähnt werden muss schließlich noch ein Unterschied im Arrangement der vier Wurzacher Stillleben. In der Geburt sind die Nischen mit den darin befindlichen Gegenständen aufgeräumt und perspektivisch halbwegs überzeugend dargestellt, in der Anbetung wirken sie jedoch vollgestopft und unübersichtlich. Das hat wohl etwas mit der Reihenfolge der Entstehung zu tun, soll aber wohl auch im Sinne einer Variation und eines Rückbezugs auf niederländische Vorbilder verstanden werden. Denn gerade was die »Eigenbeweglichkeit« der Objekte betrifft, finden sich hier einige Vorstufen. Man denke an die Flémalle'sche Verkündigung in Madrid, wo der Wandschrank wie von Zauberhand geöffnet wurde und die übereinander gestapelten Gegenstände fast aus ihm hervorplatzen. ${ }^{58}$ Kunstvolle Unordnung gibt es bei den frankoflämischen Malern natürlich auch; erinnert sei an die beiden Stilleben über den Prophetennischen auf den Innenflügeln des Barthélemy d'Eyck zugeschriebenen Verkündigungsaltars aus Aix-en-Provence (1442/45). ${ }^{59}$

Mit den in den Niederlanden und dann ebenso in Deutschland beliebten Blumenstilleben hat Multscher hingegen den Wurzacher Marientod in einem zweiten Arbeitsschritt ausgestattet (Abb. 19). Das ist überraschend. Denn was man in dieser Szene sinnvoll an Gegenstän- 


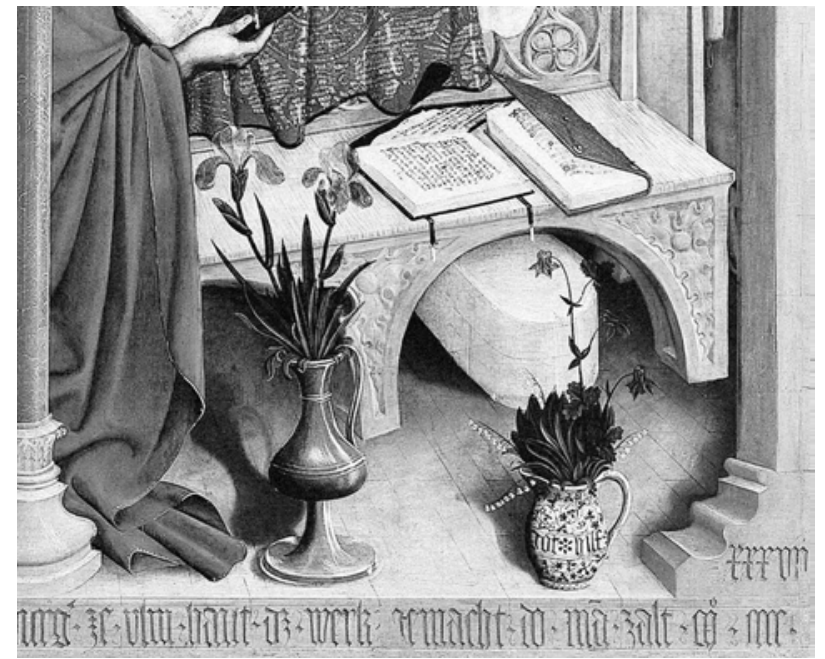

Abb. 19 Marientod, Detail. Wurzacher Altar. Hans Multscher, 1437. Berlin, Gemäldegalerie (Foto: Berlin, Staatliche Museen - Preußischer Kulturbesitz, Gemäldegalerie)

Abb. 20 Marientod des Albrechtsaltars. Meister des Albrechtsaltars. Stift Klosterneuburg, Sebastianikapelle (ex: RöHRIG 1981, 49)

den hinzugeben kann, zeigt gut die wohl in Kenntnis des Wurzacher Altars um 1438/40 gemalte Tafel des Albrechtsaltars im Stift Klosterneuburg (Abb. 20). ${ }^{60}$

Dort sieht man eine ähnliche Bettstatt mit einer Bank und einer darunter geschobenen Spanschachtel sowie zwei geschlossene Bücher und einen doppelarmigen Messingleuchter mit einer erloschenen Kerze. Multscher hingegen zeigt - betrachternah und wie zur Betonung der darunter befindlichen Signatur - einen Zinnkrug mit Schwertlilien und einen Majolikakrug mit Maiglöckchen und Akelei; "got hilf« ist darauf geschrieben.

Der Zinnkrug mit der Iris begegnet mehr oder weniger identisch auf dem allerdings ein Jahr später gemalten Barbara-Flügel des Werl-Altars (Abb. 3). Er wurde von Multscher wie ein Signum für den niederländischen Realismus verwendet, gehört aber zu Madonnenbildern, zur Verkündigung oder zur Geburt Christi, wo er meist auf die Passion verweist. Von solchen Darstellungen übernommen wurde auch der Krug mit den Maiglöckchen, die zu den Marienblumen zählen, und den Akeleien, welche gewöhnlich Christus zugeordnet werden. Im $\mathrm{Ma}$ rientod sind beide fehl am Platze, doch könnte die Akelei ("agla«) vielleicht mit der Aufschrift "got hilf« am Krug zusammengelesen werden. ${ }^{61}$ Die Maiglöckchen ließen sich aber nur dann sinnvoll einfügen, wenn mit ihnen Christus als »salus mundi« bezeichnet würde. ${ }^{62}$

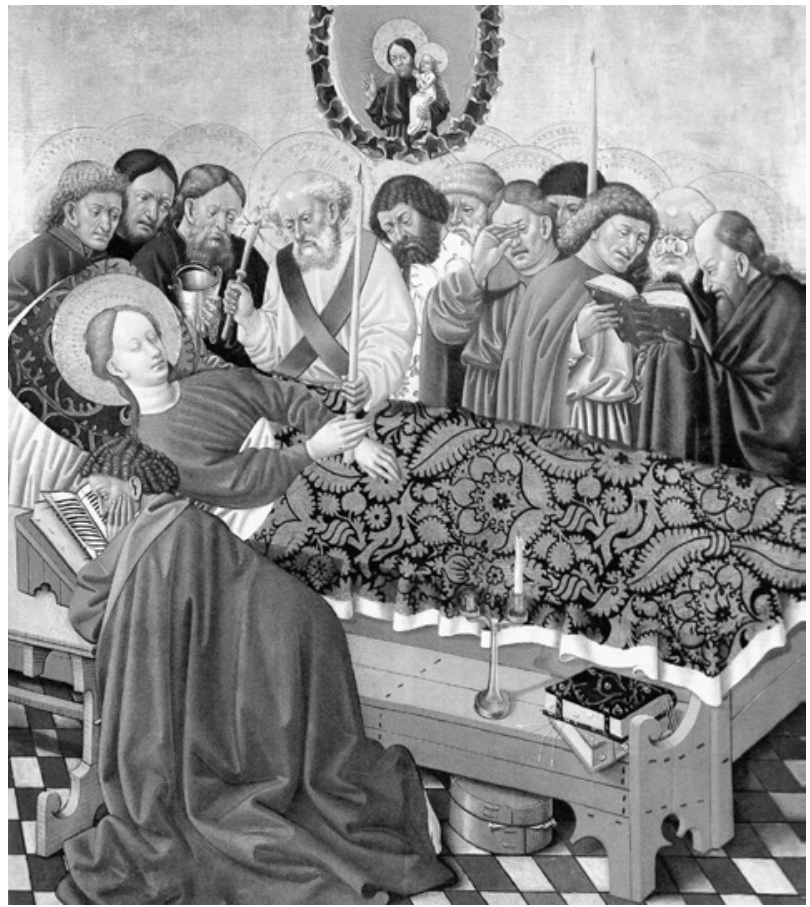

$\mathrm{Ob}$ die auch bei diesem Thema häufig vorkommenden Spanschachteln symbolisch interpretiert werden sollen, erscheint jedoch fraglich. Nur selten sind sie geöffnet, so bei einem dem Meister von Großgmain zugeordneten Marientod in der Österreichischen Galerie Belvedere (um 1480), wo man Zuckerwerk und Kekse darin erblickt (Abb. 21). ${ }^{63}$

Hier gehört die Schachtel zu einem hübschen Stilleben mit einer Zinnkanne, einem leeren Glas und einem geschlossenen Buch, das auf einer niedrigen Kastentruhe vor dem Sterbebett angerichtet wurde. Die Auswahl der Gegenstände und das Arrangement lassen aber doch den Gedanken an einen sorgfältig "gedeckten« Altartisch aufkommen.

Die Wurzacher Marientafeln wurden also einerseits ikonografisch "nachgerüstet" und andererseits bedenkenlos geschmückt. Originelles findet sich neben unkritisch Übernommenem und sogar Missverstandenem. Von einer absichtsvollen Aufwertung oder gar Verschlüsselung mit Blick auf ein intellektuelles Publikum aber kann hier wohl am wenigsten die Rede sein; vielmehr stehen die Freude an der Konkretisierung und der unmittelbare Wirklichkeitsbezug überall im Vordergrund. 


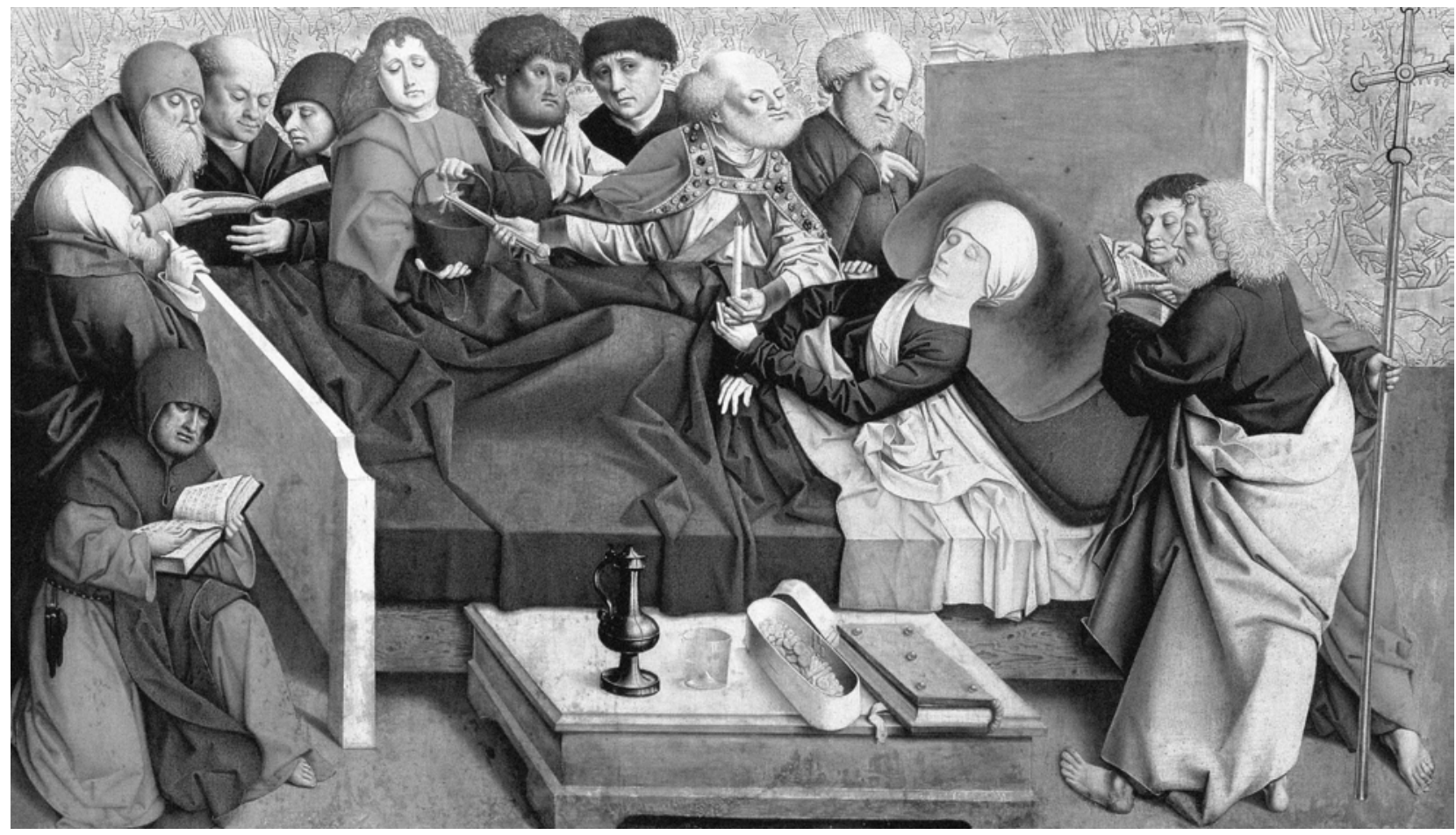

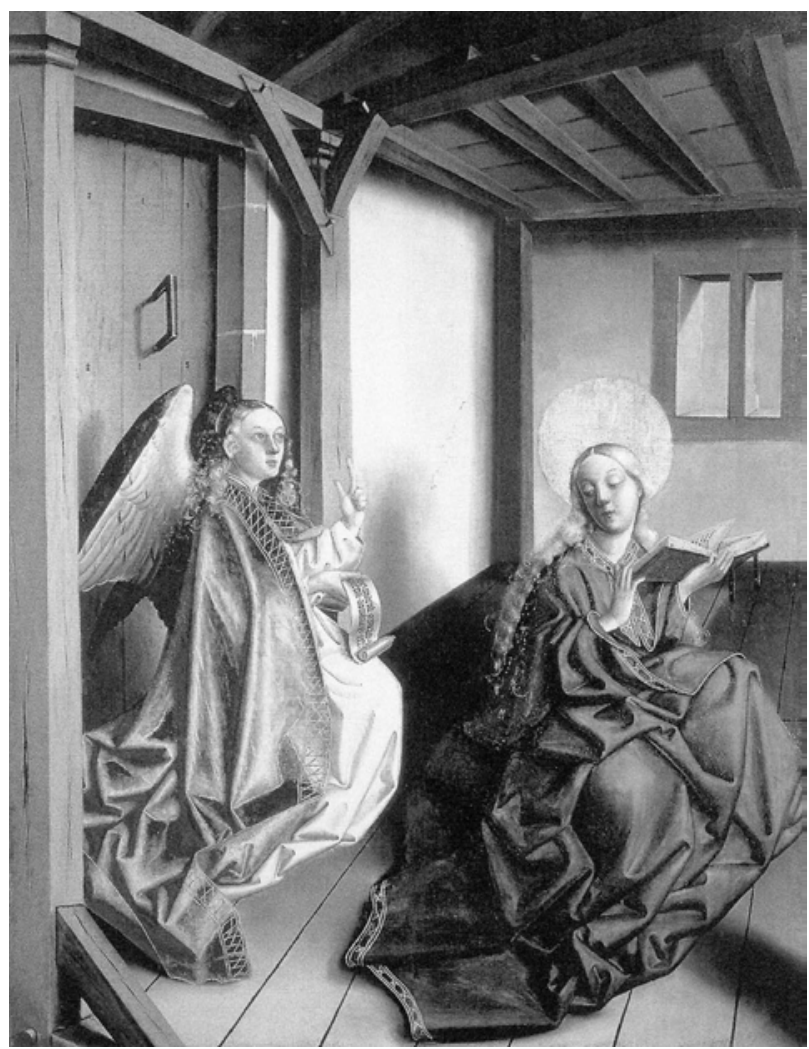

Abb. 22 Verkündigung an Maria. Konrad Witz. Nürnberg, Germanisches Nationalmuseum, Inv.-Nr. Gm878 (Foto: Nürnberg, Germanisches Nationalmuseum)
Abb. 21 Marientod. Meister von Großgmain. Wien, Österreichische Galerie Belvedere, Inv.-Nr. 4857 (ex: HANNESSCHLÄGER 1999, Abb. 35)

\section{Konrad Witz}

Eine andere Position vertritt demgegenüber der in Basel tätige, aber aus Rottweil stammende Konrad Witz, der wohl eigenwilligste Maler unter den deutschen Realisten der ersten Generation, den Emil Maurer in einem knappen Aufsatz vortrefflich charakterisiert hat. ${ }^{64}$ Witz kannte wahrscheinlich den Genter Altar der Brüder van Eyck und war - wie alle Deutschen - von den Werken des Meisters von Flémalle fasziniert. Außerdem ist er ein Künstler, der erfolgreich versuchte, den Niederländern auch bei der Wiedergabe unterschiedlicher Materialien und Stoffe nachzueifern.

Sein Euvre umfasst ebenfalls einige Marienszenen, die sich für eine vergleichende Betrachtung eignen. Witz hatte - im Unterschied zu Multscher - sogar die Gelegenheit, die Verkündigung darzustellen und sich gerade bei diesem Thema aus dem niederländischen Fundus an Bildzeichen und Schmuckformen reichlich zu bedienen. In seiner Nürnberger Tafel lässt er jedoch eher eine Verweigerungshaltung erkennen, denn kein anderes Verkündigungsbild dieser Zeit ist so kahl und leer (Abb. 22) ${ }^{65}$ 

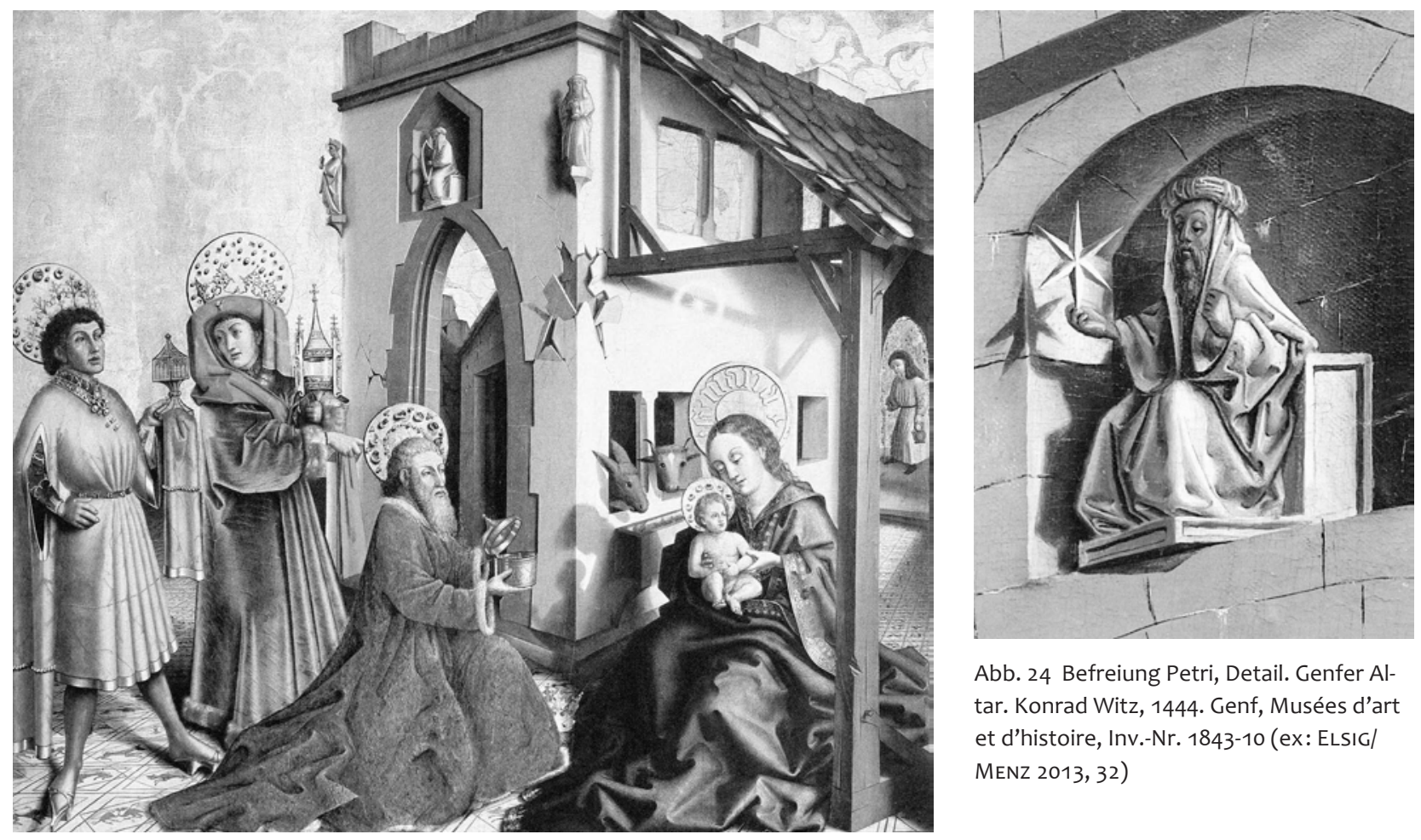

Abb. 24 Befreiung Petri, Detail. Genfer Altar. Konrad Witz, 1444. Genf, Musées d'art et d'histoire, Inv.-Nr. 1843-10 (ex: ELSIG/ MENZ 2013, 32)

Abb. 23 Anbetung der Könige. Genfer Altar. Konrad Witz, 1444. Genf, Musées d'art et d'histoire, Inv.-Nr. 1843-11 (ex: Ausst.-Kat. Basel 2011, 133)

Der Maler konzentriert sich vorrangig auf die beiden Figuren, die von ihrem Buch aufschauende Maria und den durch die geschlossene Tür eingetretenen Engel mit dem erhobenen Zeigefinger und dem ausgerollten Spruchband. In dem einfachen Raum steht hingegen kein einziges Möbel. Betont werden nur die Massivität der Mauern und die Stabilität der geradezu aufdringlich dargestellten Holzbalkenkonstruktion. Das einzige auffällige Detail ist der eiserne Griff an der Tür, der den Blick des Betrachters schneller und länger auf sich zieht, als er das wohl sollte. Dieser fungiert einerseits als Synonym für den »handfesten « Realismus des Konrad Witz, andererseits auch als Spannungsträger in dieser ungewöhnlich lapidaren Komposition.

Dass der Maler trotzdem mit den ikonografischen Verweisen der Niederländer vertraut war und diese auch gezielt eingesetzt hat, sieht man dagegen in der Anbetung der Könige des 1444 vollendeten Retabels für die Kathedrale in Genf - an den kostbar gemusterten Fliesen, mit denen der Platz vor dem Stall ausgelegt ist, und mehr noch an den fingierten Skulpturen (Abb. 23). ${ }^{66}$ So ist über dem Eingang des übereck gestellten, scharf beleuchteten Stallgebäudes eine Nische mit der Sitzfigur König
Davids angebracht. Auf ähnliche Weise bezeichnet später auch Hugo van der Goes ein Haus im Portinari-Altar mit einer reliefierten Harfe im Tympanon als den Palast Davids und gibt ihm ein altertümliches und damit alttestamentliches Aussehen. ${ }^{67}$ Das Witzsche Gebäude aber ist noch mit weiteren Prophetenfiguren umstellt, während vorn an der Kante, wie bei einem Erdbeben, der Putz von den Mauern abgesprengt wird. Das ist eine eigene Invention des Malers, mit der er in ebenso drastischer wie anschaulicher Weise den Wendepunkt zwischen Altem und Neuem Bund markiert.

Darunter wiederum, von der Mauerkante in eine klar konturierte und eine unschärfere Hälfte gebrochen, sieht man den Schatten der am Boden sitzenden Maria mit ihrem Kind. Im Schattenbild erscheinen beide im Profil und sind den von links herankommenden Königen zugewandt, während Maria realiter in Schrägansicht wiedergegeben ist und der Jesusknabe, von den Königen weggedreht, mit beiden Händen einen Apfel hält. ${ }^{68}$ Für den Wirklichkeitssinn des Meisters aber spricht, dass Maria und das Kind mit scheibenförmigen goldenen Nimben ausgezeichnet sind, die als einzige keinen Schatten an die Hauswand werfen. Überstrahlt wird die Gruppe schließ- 
lich durch den Stern von Bethlehem, welcher in scharfem Gelb genau über dem Schatten des Dachbalkens aufgetragen und von einem diffusen Strahlenkranz umschlossen ist.

Weniger ergiebig sind demgegenüber die Außentafeln des Genfer Retabels mit den Simultandarstellungen zum Leben Petri. Doch in der Befreiungsszene knüpft Witz zumindest partiell an die Anbetung der Könige an. ${ }^{69}$ So ist der Kerker offenkundig ein "Nachfolgebau « des Stalles, schon weil er unter dem gleichen Blickwinkel und in ähnlichem Beleuchtungslicht gezeigt wird. Über seinem Eingang befindet sich wieder eine Nische mit einer Sitzfigur, nun mit einem Stern in der Hand, die als Balaam (Bileam) zu identifizieren ist (Abb. 24).

Wegen seiner Weissagung »orietur stella ex Iacob« $(\mathrm{Nm} 24,17)$ wird dieser zu den Propheten gezählt und des Öfteren mit dem Sternenattribut dargestellt. In der Exegese wurde schon früh ein Zusammenhang mit dem Stern von Bethlehem und den Heiligen Drei Königen gesehen, während eine Verknüpfung mit der Geschichte des heiligen Petrus bisher nicht gelungen ist. ${ }^{70}$ In Genf scheint die Absicht auch eher darin zu bestehen, eine motivische Verbindung und eine ikonografische Klammer zwischen den Außen- und den Innenflügeln herzustellen. Nicht nur das Leitsymbol des Sterns legt das nahe, sondern auch der aufplatzende Putz im Innern des Kerkers, der zwar auf die Befreiung Petri verweist, sich aber doch nur wie in eine Vorstufe zur "Explosion" in der Dreikönigsszene ausnimmt. Durch solche Korrespondenzen ergab sich beim Öffnen der Flügel also fast ein Art Drehbühneneffekt.

Vom persönlichen Profil des Meisters im Verhältnis zu den Niederländern kündet außerdem die Art und Weise, wie Konrad Witz die fingierten Bildwerke malerisch behandelt. Sein Balaam soll mit Sicherheit eine Steinskulptur sein, die - wie der David in der Epiphanie - mit ihrer Plinthe schräg vorsteht und einen Schatten auf die nachlässig verfugte, mit weißen Mörtelschlieren versehene Mauer wirft. Bezeichnend ist aber die Lebendigkeit der Figur, das Agieren mit den Händen, im Besonderen das Vorweisen des frei in den Bildraum hineinragenden Sterns, der - wie die Madonna in der Anbetung - einen Schatten auf die Mauerkante wirft und dadurch »umgelenkt « wird. Noch dazu sind das Gesicht und die Hände des Propheten leicht gerötet - nicht so, als sei er farbig gefasst worden, sondern als würde er allmählich durchblutet. Sogar der temperamentvolle Pinselduktus trägt zur Verlebendigung bei, was den Abstand zur hochkulti- vierten Skulpturenmalerei des Lukas Moser noch einmal vergrößert (Abb. 11, 12).

\section{Altartafeln in Bayern}

Für unsere Fragestellung relevant ist außerdem eine Reihe von Tafelbildern, die in dem betreffenden Zeitraum in Bayern entstanden sind. Sie vervollständigen die Kenntnis von der Auseinandersetzung mit den Errungenschaften der Niederländer und erweitern, kunstgeografisch bedingt, das Blickfeld auch in Richtung Österreich und Oberitalien. Entwicklungen spiegeln sich darin insofern, als man eine stufenweise Rezeption verfolgen kann, die von der einfachen Adaption bis hin zu kreativeren Lösungen reicht.

\section{Der Meister der Pollinger Tafeln}

Von den in Bayern tätigen Malern verdient der »Meister der Pollinger Tafeln«, in dem man hin und wieder einen Schüler des Wiener Albrechtsmeisters vermutet hat, besondere Beachtung. ${ }^{71}$ Seine Werkstatt befand sich mit großer Wahrscheinlichkeit in München, wo er mit Aufträgen vom herzoglichen Hof für das Kloster Polling bedacht wurde. Neuerdings hat ihn Björn Statnik mit Hans Gleismüller identifiziert. ${ }^{72}$

Die Pollinger Verkündigung von 1444 fügt sich besonders gut in den bisher skizzierten Zusammenhang, sowohl im Hinblick auf die Komposition als auch die realistische Grundhaltung des Malers (Abb. 25). ${ }^{73}$

Die Tafel gehörte zu einem vierteiligen Zyklus zum Marienleben bzw. zur Kindheitsgeschichte Jesu auf den Außenseiten eines Retabels. Als vorderer Raumabschluss dient eine rahmende Arkade, welche den Blick in einen kapellenartigen Raum mit Kreuzrippengewölbe und Sternenhimmel sowie einen bürgerlichen Nebenraum mit Holzbalkendecke freigibt. Im Hauptraum erscheinen der am Boden niederkniende Engel und die von ihrem Betpult zu ihm herabschauende Maria, wobei gar nichts Geheimnisvolles in dieser Begegnung liegt. Das hat seinen Grund auch darin, dass auf Gottvater und die Taube oder das Jesuskind, die beide auf Strahlen zum Kopf der Maria herabfliegen können, diesmal verzichtet wurde. Dafür hat der Meister ein altertümliches Spruchband mit dem etwas dilettantisch geschriebenen "aue gr(a)cia $\mathrm{p}($ lena) « eingefügt, das gerade in Bauchhöhe hinter Maria verschwindet. 
Das Anknüpfen an die Flémalleschen Prototypen ist auch in diesem Fall evident. Die aggressive Präsenz der Objekte und die kräftigen Schlagschatten erinnern besonders an die Mérode-Verkündigung (Abb. 2). Der Raum, die Figuren und die Ausstattungsstücke sind in der Pollinger Tafel jedoch noch heller ausgeleuchtet und wie zum Greifen nahe. Dieser Eindruck des Dreidimensionalen und Haptischen sollte wahrscheinlich auch durch den - in der Tafelmalerei dieser Zeit noch neuen - stark reliefierten Pressbrokat am Chormantel des Engels unterstützt werden, doch hat dessen großflächige, nur auf einen ungestörten Musterrapport abzielende Verwendung genau den gegenteiligen Effekt.

Inhaltliche Akzente aber werden hier durch die auf einem Regalbrett an der Rückwand befindlichen Gegenstände gesetzt. Man sieht wieder die Spanschachtel und daneben ein Schreibzeug mit einem herabhängenden Tintenfass, ein Motiv, das zuerst im Pfingstfest der Ulmer Besserer-Kapelle nachzuweisen ist und sich in Bayern einiger Beliebtheit erfreute. ${ }^{74}$ Zitiert wird es aber auch in der Madonna im Gemach des Meisters von Iserlohn, sodass man es wohl auf eine flémalleske Urwurzel zurückführen kann (Abb. 35). Als drittes und wichtigstes Objekt steht schließlich noch ein doppelarmiger Messingleuchter mit einer schwarzen und einer längeren weißen Kerze auf dem Brett. Dieser ähnelt dem Leuchter am Sterbebett der Maria in der Tafel des Albrechtsmeisters (Abb. 20), doch findet sich eine schwarze Kerze nirgendwo sonst. Deshalb wurde schon vermutet, dass damit im Sinne der Farbikonografie auf den Tod Christi angespielt werden solle. ${ }^{75}$ Doch könnte mit der etwas plakativen farbigen Antithese beider Kerzen vielleicht auch der Beginn einer neuen Zeitrechnung gemeint sein. Dazu passte wiederum die am Leuchter aufgehängte, halb geöffnete Lichtputzschere, die schon einmal als Sinnbild für die beiden Testamente interpretiert wurde. ${ }^{76} \mathrm{Da}$ sie schräg zu Maria herabweist, so wie der hier fehlende Strahl mit dem Kind oder der Taube, sollte man sie jedenfalls ernst nehmen und nicht als einfache Realie aus dem Deutungskontext ausklammern. ${ }^{77}$

Bereichert wird dieses sorgfältig arrangierte Stillleben noch durch einen Gebetszettel, der unterhalb des Regalbretts, direkt neben dem Fenster, an die Wand geheftet ist. Eine Ecke hat sich gelöst, so als solle der Illusionismus mit allen Mitteln gefördert und ein weiterer Schattenwurf ermöglicht werden. Vielleicht ist dies sogar das Ergebnis eines Luftzugs, der durch das halb geöffnete Fenster im Nebenraum eintritt und gleichzeitig das unter dem

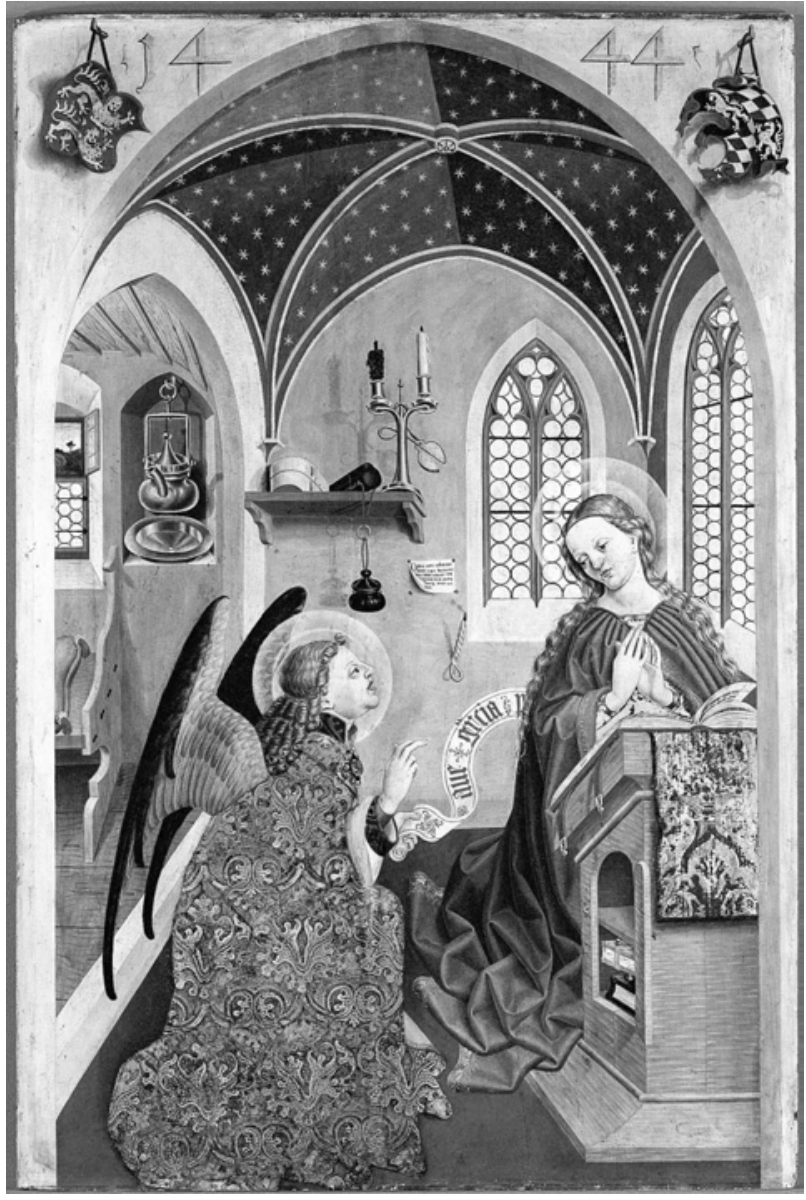

Abb. 25 Verkündigung an Maria. Meister der Pollinger Tafeln. München, Alte Pinakothek, Inv.-Nr. 6247 (Foto: München, Bayerische Staatsgemäldesammlungen)

Zettel befestigte Wachslicht ausgeblasen hat. Dieses Detail einer erloschenen und noch rauchenden Kerze gibt es bekanntlich ebenso in der Mérode-Verkündigung, wo es ganz unterschiedlich gedeutet wurde. ${ }^{78} \mathrm{Ob}$ es in der Pollinger Tafel nur übernommen oder auch in einer bestimmten Weise verstanden wurde, wird man also kaum entscheiden können; eigenartig ist aber doch, dass es gerade in einem Gemälde, in dem wiederum auf die Darstellung des Heiligen Geistes verzichtet wurde, nochmals an prominenter Stelle auftaucht.

Vom Meister von Flémalle entlehnt wurde außerdem die in den Nebenraum integrierte Wandnische mit dem Waschgeschirr, bestehend aus einem Kessel und einer Schüssel. Nur das Glänzen des Metalls wollte dem Maler nicht so recht gelingen. Die Bedeutung des Objekts aber dürfte die gleiche sein wie in den niederländischen Tafeln, auch weil kein anderes Symbol für die Reinheit 
Mariens übrig geblieben ist. Dagegen wird nicht ersichtlich, warum das Geschirr auf die adelige Sachkultur und den Ritus einer »Reinigung der Hände vor und nach den Mahlzeiten « verweisen sollte. ${ }^{79}$

Die Pollinger Verkündigung lehrt also, dass nicht nur die Auswahl, sondern auch die Anordnung der Dinge über Sinn und Unsinn solcher Darstellungen entscheidet. Denn gerade das Stillleben vor der nackten Wand besticht durch seine Übersichtlichkeit und die durchdachte Komposition im Hinblick auf die darunter befindlichen Figuren. Von einer »Überinstrumentierung « der Szene sollte deshalb wohl nicht die Rede sein. ${ }^{80}$ Angesichts der gestalterischen und malerischen Defizite des Meisters, die in den übrigen Flügelbildern noch sichtbarer werden, bleibt aber immer die Frage, ob er nicht nur das Schreibzeug, sondern auch weitere Motive von anderen, ihm gedanklich überlegenen Malern entlehnt haben könnte.

\section{Der Meister der Münchener Marientafeln}

In Bayern lokalisiert werden außerdem eine Verkündigung und eine Geburt Christi im Kunsthaus Zürich, die mit zwei Passionsszenen und einer großen Kreuzigung in der Münchener Frauenkirche zu einem Retabel kombiniert und um 1450/60 datiert worden sind. ${ }^{81}$ Den anonymen Maler bezeichnet man nach Ernst Buchner weiterhin als »Meister der Münchener Marientafeln «, nachdem der Vorschlag von Friedrich Winkler, es handele sich um den in Genua bezeugten Jost Ammann aus Ravensburg, keine Zustimmung fand. ${ }^{82}$ Dessen ungeachtet wird Winkler die bisher beste Charakterisierung des Meisters verdankt, indem er ihn einerseits als "Erzrealisten " und andererseits als "geborenen Koloristen « vorgestellt hat. ${ }^{83}$ Etwas vergessen wurde dabei nur, dass er auch zu den vergleichsweise anspruchsvollen Ikonografen gerechnet werden kann.

Die Verkündigung gehört sicher zu den vollsten, mit Gegenständen geradezu überfrachteten Bildern in der Jahrhundertmitte (Abb. 26). Maria kniet - wie in der entsprechenden Pollinger Tafel - an ihrem Betpult und wendet sich dem Erzengel Gabriel zu, der die Urkunde in Händen hält und sein »Ave Maria« spricht. Gottvater fehlt wiederum, doch wurde an seiner Stelle im Rahmenzwickel der Prophet Moses als fingierte Relieffigur eingefügt. Direkt daneben fliegt die Geisttaube herab, die hier nicht nur zeichenhaft, sondern in realistischer Größe im Verhältnis zu den Figuren wiedergegeben wurde. Die
Raumdarstellung ist hingegen altertümlicher, indem vom Innenraum zwei aufeinander treffende Wände mit je einem Segmentbogen und dazu ein kleinerer Anraum, vom Außenraum nur der von einer Mauer abgeteilte Hortus conclusus mit einem Birnbaum gezeigt werden.

Die Reihe der Mariensymbole beginnt mit der Lilie, die hier als Topfpflanze groß in die Bildmitte gerückt wurde. Sie steht genau zwischen den beiden Akteuren - nicht mehr am Boden, sondern auf einem erhöhten, von zwei Metallstangen getragenen Brett. Ganz offenkundig aber wird der gärtnerische Trieb des Meisters, wenn er auch die Schwertlilie aus einem Majolikatopf in der unteren rechten Bildecke hervorwachen lässt. Diese steht genau vor dem Betpult mit den darin befindlichen Gegenständen - zwei Büchern, einem Notenblatt, dem Schreibzeug und dem herabhängenden Tintenfass - und bildet mit der etwa gleich groß dargestellten Lilie einen leicht erfassbaren Sinnzusammenhang.

Direkt darüber, auf dem Tisch hinter Maria, erblickt man eine große messingfarbene Kanne ohne Deckel und ohne Tülle. Wahrscheinlich gehört sie zu einem Waschgeschirr, denn für eine Messkanne ist sie zu groß ${ }^{84}$ Die Einfügung dieses Objekts wird freilich auch dem Prinzip der Flächenfüllung geschuldet sein und der Freude des Malers an der Wiedergabe des blinkenden Metalls.

Mehr Interesse beansprucht dagegen der nur selten dargestellte Vogelkäfig, der an der Rückwand des Nebenraums an einem Nagel aufgehängt ist (Taf. XIX). Liebevoll beschrieben werden die Gitterstruktur, der Sitzbalken und die Futterrinne sowie das von außen eingehängte Trinkhorn. Zweifellos handelt es sich um einen funktionstüchtigen Alltagsgegenstand, den der Maler wirklichkeitsgetreu erfasst hat. Überliefert ist zudem, dass solche Käfige tatsächlich in den Stuben aufgehängt wurden, weshalb man zunächst an eine nur genrehafte Ausschmückung der Szene denken könnte. ${ }^{85}$ Das spiegelt sich zum Beispiel auch in der Klassifizierung des Käfigs als »Zeichen von Häuslichkeit« mit einem »minderen Prestigewert $«{ }^{86}$ Dem entgegen steht allerdings die traditionelle Deutung des Vogels im Käfig als Sinnbild der im Körper gefangenen Seele und dessen Verbindung mit dem Leidensweg, der Auferstehung und der Himmelfahrt Christi in der Exegese. ${ }^{87}$

Nicht unwichtig für die Frage nach dem Symbolgehalt ist ferner die ornithologische Bestimmung des dargestellten Vogels. Es dürfte sich hier um einen Finken, vielleicht einen Zeisig, handeln, sodass all jene Deutungen, die mit dem artverwandten Distelfinken (Stieglitz) verbunden 


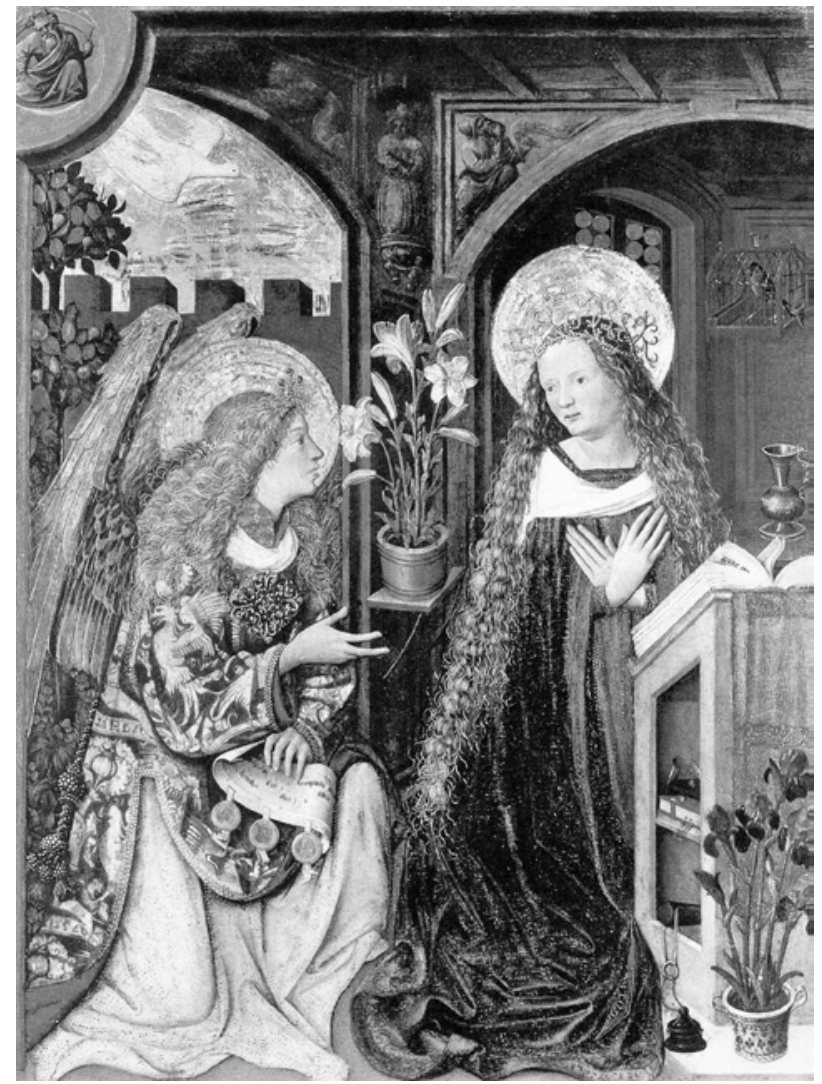

sind, mitbedacht werden sollten. ${ }^{88}$ Dieser beliebte, auch in Käfigen gehaltene Singvogel wird wegen seines Namens vor allem mit der Passion Christi verbunden, kann aber auch in anderem Bedeutungskontext auftauchen. Im Falle der Marientafel befindet sich der Käfig nun genau über der Schwertlilie, was eine Deutung als Passionssymbol zumindest unterstützt. Rechtfertigen lässt sich eine solche Auffassung auch durch einen vergleichenden Blick auf die Verkündigung des Wiener Schottenaltars von 1469 (Abb. 27) ${ }^{89}$ In der Fensterlaibung hängt dort ein Käfig von ganz ähnlicher Machart, und darin sitzt tatsächlich ein Distelfink, der mit dem herabschwebenden Christusknaben, welcher sein Kreuz geschultert hat, fast auf gleicher Höhe angeordnet ist. ${ }^{90}$

Bestätigt wird diese Bestimmung des Distelfinken auch durch die Heilige Familie eines oberrheinischen Meisters im Kunsthistorischen Museum in Wien (um 1460/70). Bei diesem Gemälde vermutet man mit Recht, dass es wiederum in Anlehnung an ein Vorbild aus dem Kreis des Meisters von Flémalle geschaffen wurde (Abb. 28). ${ }^{91}$

Hier sind, wie in einem separaten Stilleben, der an einem Nagel festgebundene Stieglitz, ein Wassernapf mit

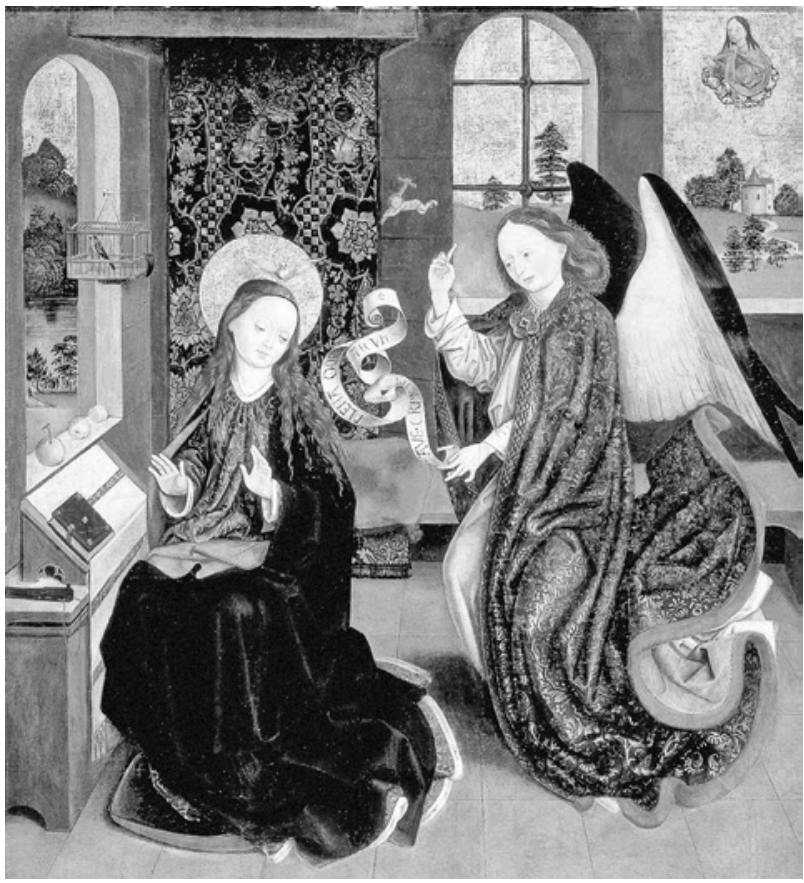

Abb. 26 Verkündigung an Maria. Meister der Münchener Marientafeln. Zürich, Kunsthaus (ex: Ausst.-Kat. Basel 2011, 362)

Abb. 27 Verkündigung an Maria, Schottenaltar. Meister des Wiener Schottenaltars, 1469. Wien, Museum im Schottenstift (Foto: Wien, Museum im Schottenstift)

herabperlenden Tropfen und einzelne Körner zu sehen, aber auch eine halbe Nuss, die wohl auf den Kreuzestod Christi und die damit verbundene Erlösungserwartung zu beziehen ist. ${ }^{92}$ Ein großer Apfel liegt genau über dem Haupt des Jesusknaben und verdeutlich seine Rolle im gesamten Heilsplan.

Bedeutender noch als die Verkündigung des Meisters der Münchener Marientafeln ist aber die zugehörige $\mathrm{Ge}$ burt Christi, die mit realistischem Impetus erstmals als reines Winterbild gestaltet wurde. Sie enthält zudem ein ikonografisch interessantes Detail: das nackte Jesuskind, das in der Bildmitte in einer halb liegenden, halb sitzenden Position erscheint und nicht nur von seinen auf dem Boden knienden Eltern, sondern auch von einer Schar rot gewandeter Engel angebetet wird (Taf. XX). Nach niederländischem Vorbild müsste es auf den Mantel Mariens gebettet sein oder ungeschützt auf dem Boden liegen; hier aber bilden die Engel eine Art Ehrentuch bzw. ein Polster für den Knaben und sind um ihn herum verteilt worden, so als sollte der Nimbus noch um eine Gloriole aus roten Seraphim erweitert werden. ${ }^{93}$ Diese Wesen sind winzig klein, vor allem im Verhältnis zu den in natürli- 


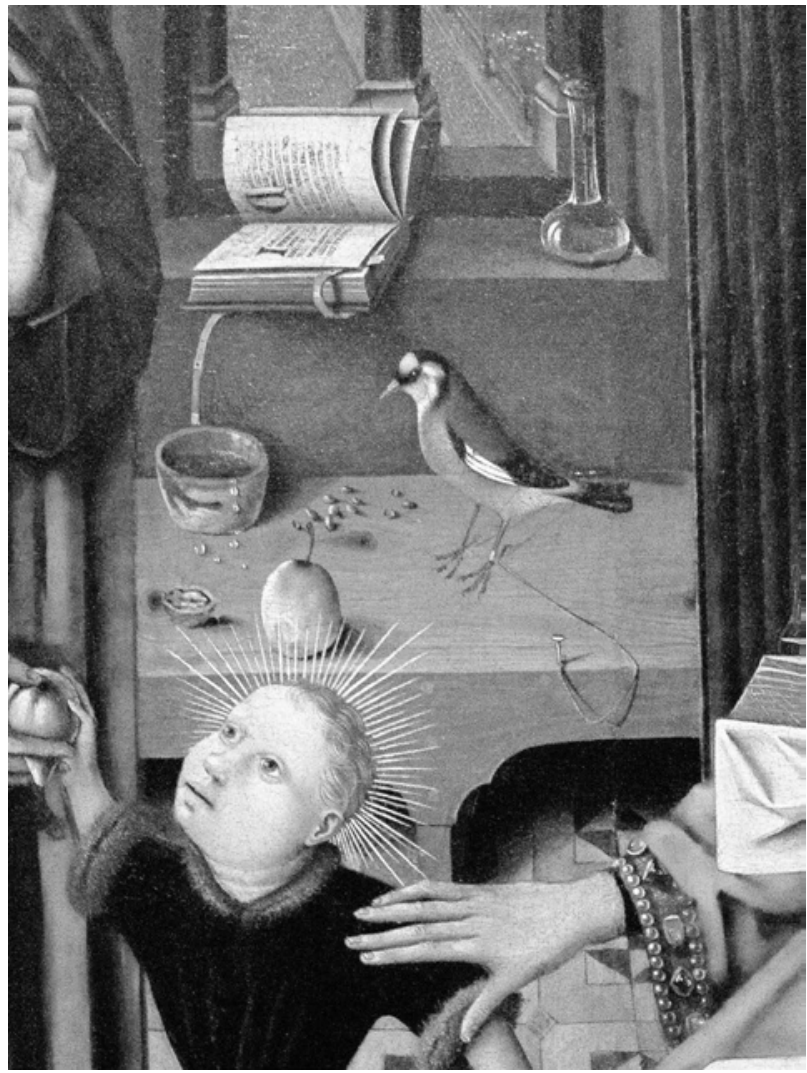

Abb. 28 HI. Familie, Detail. Oberrheinischer Meister. Wien, Kunsthistorisches Museum (Foto: U. Söding)

chem Maßstab wiedergegebenen Engeln, die den Mantel der Gottesmutter um sie herum ausbreiten. Ihre Größe nimmt nach oben hin ab, wobei sie zunächst in Rückenansicht, dann im Profil und zuletzt en face gezeigt werden. Öfter wenden sie sich einander zu, sodass sich kleine, episodenhafte Handlungszusammenhänge ergeben.

Außergewöhnlich ist auch die koloristische Gestaltung dieser Engelgruppe auf der Basis eines gemeinsamen roten Fonds. Der Maler arbeitet an Gewändern und Flügeln teilweise mit feinen gelben Höhungen und verdichtet diese an manchen Köpfen zu rosafarbenem Inkarnat und natürlicher Haarfarbe. Das bewirkt ein schemenhaftes Auftauchen der ganzen Engelschar und lässt diese geheimnisvoll und übersinnlich in einem durch und durch realistischen Umfeld erscheinen. Die Machart aber erinnert ein wenig an die Punzierungen von Goldgründen, an die punktierten oder gestrichelten Stoffmuster in Tafelbildern von Gentile da Fabriano ${ }^{94}$ und an die Pracht der »Schwarzen Stundenbücher" im Umkreis Herzog Karls des Kühnen. ${ }^{95}$

\section{Die Werke deutscher Wandermeister in Italien}

Nicht zu vergessen ist, dass auch die Italiener mit der niederländischen Ars nova in Berührung kamen. Dafür sorgten die - nur selten dokumentierten - Italienreisen einiger Meister, vor allem jedoch die zahlreichen Importe niederländischer Tafelbilder in Genua und Florenz, in Venedig und Ferrara sowie in Neapel. ${ }^{96}$ Aber auch eine indirekte Vermittlung durch die Maler aus verschiedenen deutschen Regionen, die sich temporär als Wanderkünstler in Italien aufhielten, war für die Verbreitung des niederländischen Realismus und bestimmter Bildsymbole bedeutsam.

\section{Der Meister des deutsch-niederländischen Altars}

Von primärem Interesse ist in diesem Zusammenhang ein um 1450 entstandenes Verkündigungsbild in der Galleria Estense in Modena, ein kleines Schmalformat, das ehemals zu einem Polyptychon gehörte (Abb. 29).

Friedrich Winkler hat dieses nur schwer rekonstruierbare Werk als »deutsch-niederländischen Altar» in die Literatur eingeführt und wollte dafür ebenfalls den Meister der Münchener Marientafeln alias Jost Ammann verantwortlich machen. ${ }^{97}$ Das wurde zwar von den nachfolgenden Autoren abgelehnt, doch haben auch sie wegen der Form des Polyptychons und der Aufbewahrungsorte einiger Täfelchen (Modena, Venedig) an einen in Italien tätigen bayerischen Meister gedacht. ${ }^{98}$ Dass solche Überlegungen prinzipiell berechtigt sind, belegt inzwischen ein anderes, glaubwürdiger dem Meister der Münchener Marientafeln zugeschriebenes Madonnenbild in New York, das - nach neuesten Untersuchungen - auf das in Italien so geschätzte Pappelholz gemalt wurde. ${ }^{99}$

Die Modeneser Verkündigung gibt sich bereits durch das gewählte Kompositionsschema, die Raumanlage sowie die betont realistisch aufgefassten Figuren und Gegenstände als ein Werk zu erkennen, das in vielfacher Weise flémallesk konnotiert ist, aber auch mit oberrheinischen Werken aus dem Kreis des Konrad Witz in Verbindung steht. ${ }^{100}$ Das Hochformat war für die Darstellung dieser Szene jedoch denkbar ungeeignet und überforderte den Maler ganz offensichtlich. Notgedrungen hat er die beiden Protagonisten schräg über- und hintereinander angeordnet, was durch die Verteilung der Möbel auf der Gegendiagonalen "rechnerisch" ausgeglichen werden soll. Da außerdem noch eine starke Aufsicht gewählt 
wurde, die weiter oben in eine Untersicht umschlägt, erhält man ein mehr als spannungsreiches Flächenmuster und ein sehr widersprüchliches Raumbild.

Eröffnet wird die komplexe Bildkomposition durch den links unten platzierten, etwas von hinten gesehenen Erzengel Gabriel. Dieser kniet auf einer gemauerten Stufe, die abrupt an einer abgewinkelten halbhohen Mauer endet. Er ist merkwürdig herabgeduckt, schaut aber gleichzeitig zur Gottesmutter auf und hat die Hand zum Segensgruß erhoben. Maria sitzt hingegen wie auf einem Podium, ja wie in einem Schaufenster; sie neigt sich aus ihrer engen Stube herab und erwidert mit der vorgestreckten rechten Hand den englischen Gruß. Ein hoher Bündelpfeiler, an dem fingierte Skulpturen - man erkennt Moses und einen weiteren Propheten - angebracht sind, sorgt für die Begrenzung des Wohnraums wie auch eines sich links davon erstreckenden Kirchenchors mit einem Altarraum und trägt zwei fast rechtwinklig aneinander stoßende Rundbögen. Wie der Pfeiler am Boden über dem Proszenium aufsteht, sieht man allerdings nicht, weil der Schnittpunkt der Architekturangaben durch den Körper des Engels absichtlich verdeckt wird.

Die gestalterischen Probleme dürfen nun nicht davon ablenken, dass es sich bei dieser Verkündigung um eine ikonografisch gehaltvolle Darstellung handelt. So ist ganz vorn an der Stufe die Inschrift "O EMANVEL XPS" eingemeißelt worden. Das bezieht sich auf die Prophezeiung des Isaias: „Ecce virgo concipiet et pariet filium et vocabitis nomen eius Emmanuhel« (Is 7,14). Die Stufe, der Steinfußboden und die Mauer aber sind schadhaft, zeigen zahlreiche Risse und Ausbrüche, was auf den Alten Bund verweist, der im Zeichen der Inkarnation vom Neuen Bund abgelöst wird.

Auf diesem »alttestamentlichen" Boden kniet vorn der in eine weiße Albe mit Stola gekleidete Engel. Er umfasst einen Kreuzstab mit flatternden Fahnenenden und ein schmales Spruchband mit dem Schriftzug "AVE GRA(TIA) PLENA D(OMI)N(U)S TECUM «. Neben ihm, auf einem Klapptisch und einem darüber gebreiteten Handtuch, steht das Waschgeschirr mit Schale und Kanne, so prominent wie sonst nie und fast so, als solle dem Tisch und den Utensilien eine liturgische Funktion zugesprochen werden. ${ }^{101}$ Große Aufmerksamkeit gilt zudem der Wiedergabe der unterschiedlichen Materialien, dem gemaserten Holz, dem gemusterten Tuch sowie dem einmal kupfer- und einmal messingfarbenen Metall. Die Kanne aber wurde sehr detailreich ausgeführt und erinnert mit ihrer Drachentülle an die älteren Aquamanilien.
Abb. 29 Verkündigung an Maria, deutsch-niederländischer Altar. Modena, Galleria Estense (ex: Ausst.-Kat. Brügge 2010, 374)

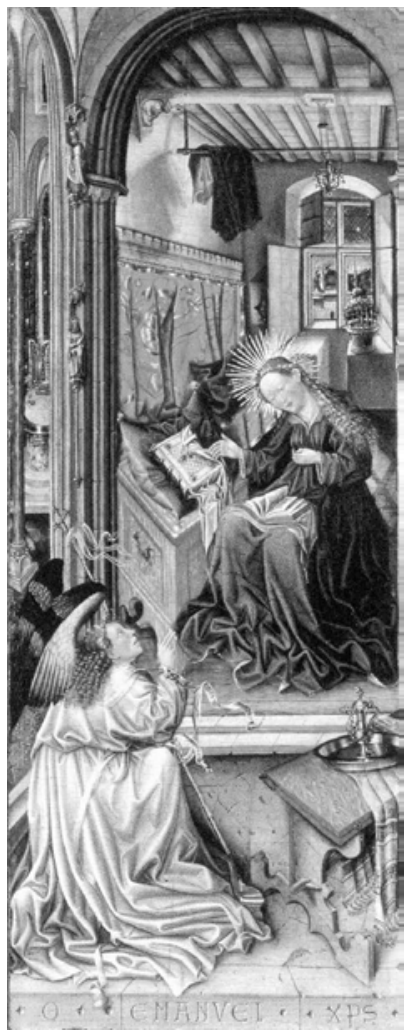

Genau darüber sitzt die wiederum lesend dargestellt Maria neben einer truhenförmigen Bank mit hoher Lehne. Sie hat kaum Platz in der flémallesken Stube, welche etwas zwanghaft, ja fast gewaltsam umgeräumt und ummöbliert wurde. ${ }^{102}$ Nicht zu den üblichen Ausstattungsstücken gehört nur der Blumentopf, der am geöffneten Fenster auf der steinernen Sitzbank aufgestellt ist (Abb. 30).

Umgeben von einem Spalier, wächst darin eine der beliebten Grünpflanzen mit Etagenschnitt, die bereits in den oberrheinischen Bildbeispielen zu sehen waren (Abb. 5, 7). Schaut man schließlich mit einem mikroskopischen Blick auf das Modeneser Bild, so erkennt man noch ein weiteres Detail: Der obere Abschluss des Blumentopfs ist rundherum eingekerbt, sodass er an einen Zinnenkranz erinnert. Es handelt sich also wieder um einen Hortus conclusus im oder besser als Blumentopf, der durch die Vergitterung mit dem Spalier noch einmal an Aussagekraft gewinnt. Beim Blick aus dem Fenster aber fällt der Blick auf eine zweite Mauer, sodass eine Verdoppelung des Bildzeichens vorliegen und die vorgeschlagene Deutung angezweifelt werden könnte. Da die zinnenbewehrte Mauer mit dem Tor jedoch keinen Garten, sondern eine dahinter befindliche Stadt mit einem aufragenden Kirchturm umschließt, ist in diesem Fall wohl das Sinnbild der 


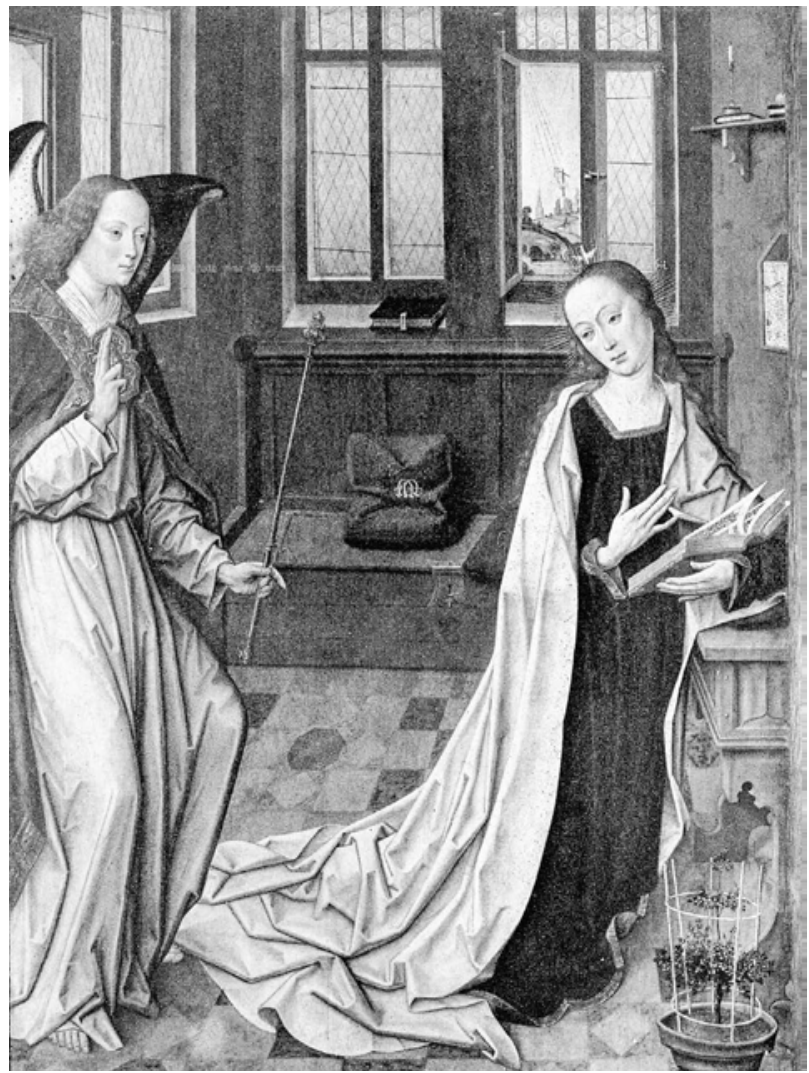

Abb. 30 Verkündigung an Maria, Detail, deutsch-niederländischer Altar. Modena, Galleria Estense (Foto: U. Söding)

Maria als Porta clausa, als verschlossenes Tor zum Heiligtum, gemeint (Ez 44,2). ${ }^{103}$

Ein Blumentopf mit Spalier findet sich indes nur selten in den Verkündigungsdarstellungen des 15. Jahrhunderts. Man entdeckt ihn vergleichsweise spät noch einmal in einem Tafelbild aus Köln in der Bamberger Staatsgalerie (um 1480/85), wo er bedeutungsvoll in den Vordergrund gerückt wurde (Abb. 31). ${ }^{104}$ Hin und wieder steht er aber neben der Madonna auf der Rasenbank, so in einer Zeichnung Martin Schongauers in Berlin, die auf ein niederländisches Vorbild zurückgehen dürfte. ${ }^{105} \mathrm{Ganz}$ ähnlich konzipiert ist nämlich noch ein Gemälde des Jan Provoost in London (um 1520), das sich als ausgesprochen retrospektiv erweist und Rückschlüsse auf verlorene Darstellungen der Vertreter der Ars nova erlaubt. ${ }^{106}$ Ferner stehen zwei kleinere Töpfe in der Salzburger Heimsuchung Mariens des Meisters der Virgo inter Virgines (um 1480/90) nebeneinander auf dem äußeren Fenstersims. ${ }^{107}$ Letztere zeigen besonders gut, dass solche Objekte zu den Alltagsgegenständen zählten und in den Niederlanden wie in anderen Gegenden Europas sehr beliebt waren.

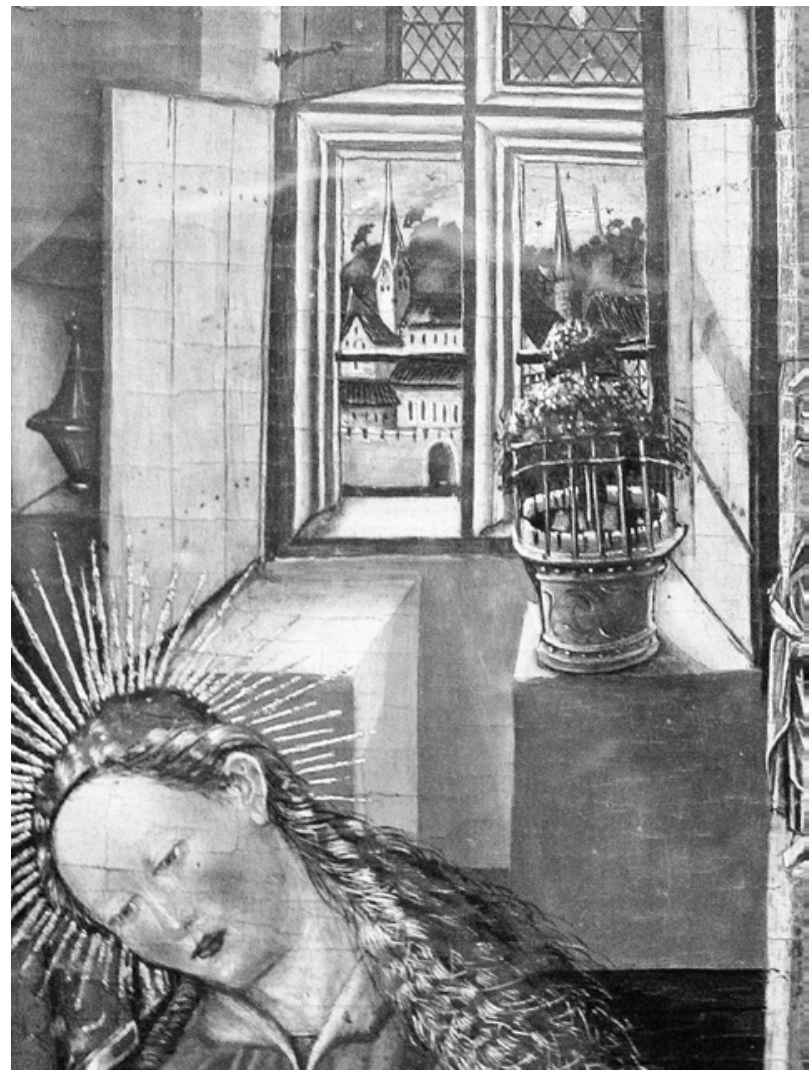

Abb. 31 Verkündigung an Maria. Bamberg, Staatsgalerie (ex: GOLDBERG/SCHEFFLER 1972, Abb. 81)

Deshalb verwundert es nicht, wenn Blumentöpfe dieser Art auch bei profanen Bildthemen eine gewisse Rolle spielen. Als frühes Beispiel dafür sei eine nur wenig beachtete Tapisserie mit einem Liebespaar im Musée des Arts décoratifs in Paris genannt, die um 1450/60 vielleicht in Tournai entstanden ist und in die Zeit Rogier van der Weydens zurückführt (Abb. 32). ${ }^{108}$ Der in burgundischer Hofmode gekleidete junge Mann steht hier im gespreizten Ausfallschritt neben seiner Dame und wendet sich ihr zu, während er mit dem Gehstock seinen Hund neckt und offenbar nicht ganz bei der Sache ist. Die ebenfalls vornehm gewandete Frau bleibt hingegen reserviert, hält eine Gießkanne in der Hand und besprüht damit die von einem Spalier gestützten Blumen in einem Topf mit Zinnenkranz. Letzterer wurde offenbar der Marienikonografie entnommen, genauso wie die beiden Engel mit dem geöffneten Zeltbaldachin, dessen Vorhänge hinter dem jungen Paar ausgespannt sind. ${ }^{109}$ Folglich enthält diese Darstellung, die von Betty Kurth noch als »Dame und Jüngling bei der Gartenarbeit « bezeichnet wurde, ${ }^{110}$ eine moralisierende Botschaft: Wäh- 


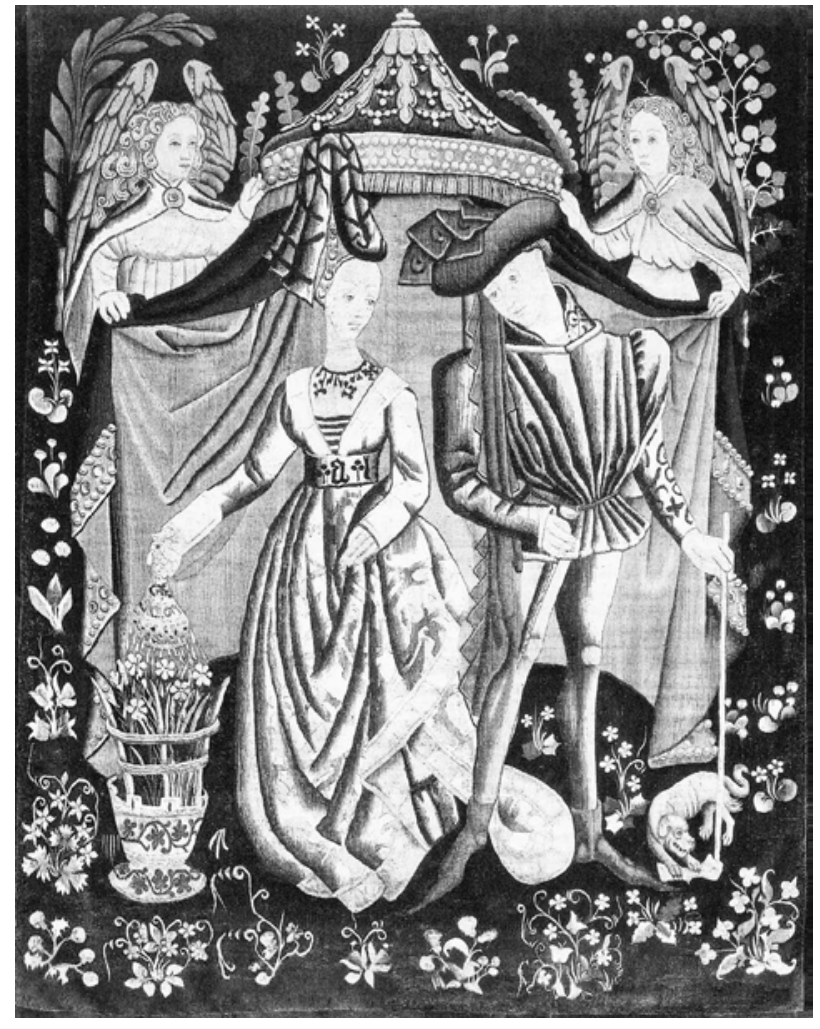

rend der Mann leichtsinnig mit den Hund, dem Symbol der Treue, spielt, begießt die umworbene Frau standhaft und keusch ihre Pflänzchen. So wie von Falkenburg an anderen Beispielen erläutert, hat man also gerade beim Gartenthema von einer Wechselwirkung zwischen sakraler und profaner Ikonografie durch die Adaption bestimmter Bildzeichen auszugehen. ${ }^{111}$ Insofern ist dieser Bildteppich ein niederländisches Pendant zum Liebespaar auf der Rasenbank des Meisters E. S., in dem sich der Prozess der »Symbolwanderung «, nun bezogen auf die oberrheinischen Madonnenbilder, ebenso deutlich widerspiegelt (Abb. 33).

Wie das Bildzeichen der Topfpflanze verstanden und sogar für neue Themenbereiche genutzt wurde, zeigt schließlich Albrecht Dürer in seinem Kupferstich Die Hexe (um 1500). ${ }^{112}$ Von den vier Putten, die unterhalb der auf einem Ziegenbock reitenden Hexe ihr übermütiges Spiel treiben, trägt nämlich einer den nun hinlänglich bekannten Topf mit einer zweistufig beschnittenen Pflanze auf seiner Schulter. Rainer Schoch meint zwar, das alles sei »unverständlich ${ }^{113}$ doch scheint es sich auch in diesem Fall um ein Keuschheitssymbol zu handeln, das angesichts der von der Hexe ausgehenden Gefahr eilig beiseite geschafft wird.

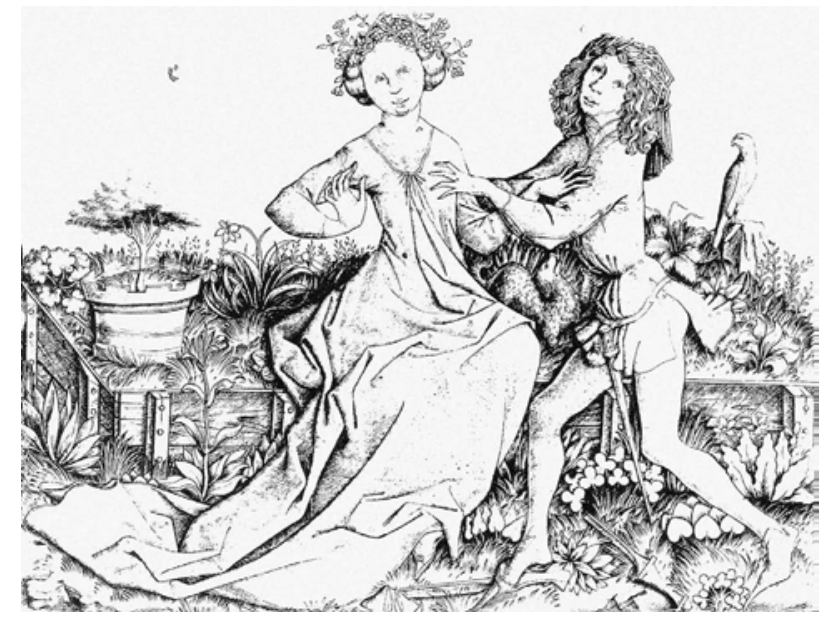

Abb. 33 Das Liebespaar auf der Rasenbank. Meister E. S. (ex:

Ausst.-Kat. Gotha 1998, 115)

Abb. 32 Liebespaar, Bildteppich. Paris, Musée des Arts Décoratifs (ex: Ausst.-Kat. Paris 2002, 171)

\section{Jost Ammann}

Der bereits genannte Maler Jost Ammann aber ist mit einem anderen Werk in Italien als Vermittler der Ars nova hervorgetreten. Er kam nicht aus Bayern, sondern aus dem oberschwäbischen Ravensburg und ist für das Jahr 1451 in Genua dokumentiert. Dort hat er im Auftrag der Brüder Manuele und Lionello Oliva Grimaldi eine Verkündigung als zentrales Wandbild und vielleicht auch einige der Darstellungen in den Gewölben des Kreuzgangs im Dominikanerkloster S. Maria di Castello geschaffen (Abb. 34) ${ }^{114}$ Andere Werke, vor allem solche aus dem Bereich der Altarmalerei, konnten ihm bisher nicht glaubwürdig zugeschrieben werden; da die Verkündigung aber letztlich nur »ein vergrößertes Tafelbild « ist, wie Winkler treffend bemerkt, sei sie in diesem Zusammenhang ebenfalls behandelt. ${ }^{115}$

In dem lünettenförmigen Wandfeld, welches durch eine vorgeblendete Rahmenarchitektur in drei $\mathrm{Ab}$ schnitte eingeteilt wird, kniet Maria rechts an ihrem Betpult. Sie ist en face wiedergeben, so wie beim Pollinger Meister und beim Meister der Münchener Marientafeln, und wendet sich dem von links herangekommen Engel $\mathrm{zu}$, der in gebührendem Abstand auf dem gefliesten Bo- 


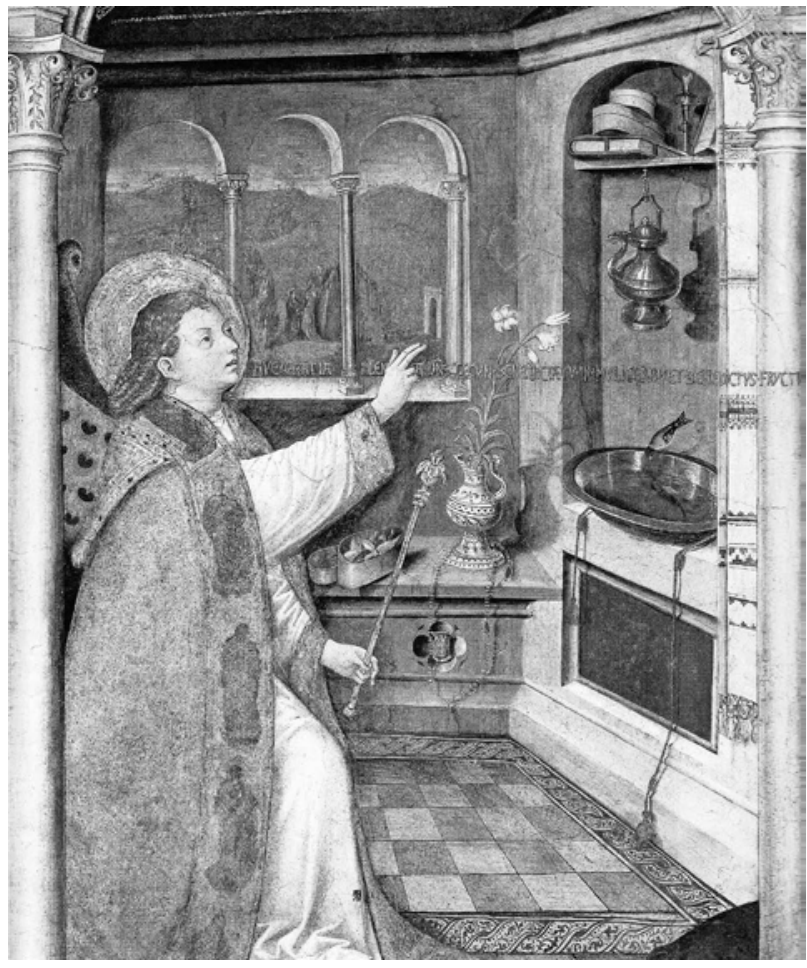

Abb. 34 Verkündigung an Maria, Detail. Jost Ammann. Genua, S. Maria di Castello (ex: ALGERI 1997, 47)

Abb. 35 Madonna im Gemach. Meister von Iserlohn. Münster/W., LWL Landesmuseum, Inv.-Nr. 965 LM (ex: PIEPER 1990, 211)

den niederkniet. Hoch über ihnen, noch vor der Außenwand des Gebäudes und zwischen den beiden fingierten Prophetenstatuen, erscheint die Halbfigur Gottvaters in einer Gloriole.

In der Ausstattung dieses Raums aber begegnen sich der Norden und der Süden: Das vorn aufgestellte intarsierte Betpult ist zweifellos ein italienisches Möbel, während die weiter hinten in einem Raumwinkel verteilten Gegenstände aus den Niederlanden »importiert « wurden . Ammann erweist sich sogar als ein besonders ambitionierter Stillebenmaler, indem er die richtigen Dinge an passender Stelle zeigt und diese um ein paar interessante Neuigkeiten bereichert.

So stehen auf der niedrigen Steinbank unter dem Fenstersims eine offene Spanschachtel mit Garnrollen und ein Majolikakrug mit einer Lilie, um den noch eine mit zwei Schmuckstücken verzierte Perlenkette herumgelegt ist. Letztere könnte als Hinweis auf "Maria als Bewahrerin der Perle« verstanden werden, doch dürfte hier wohl eher die häufig vorgenommene Gleichsetzung von Perlen und Edelsteinen mit den Tugenden Mariens verbildlicht

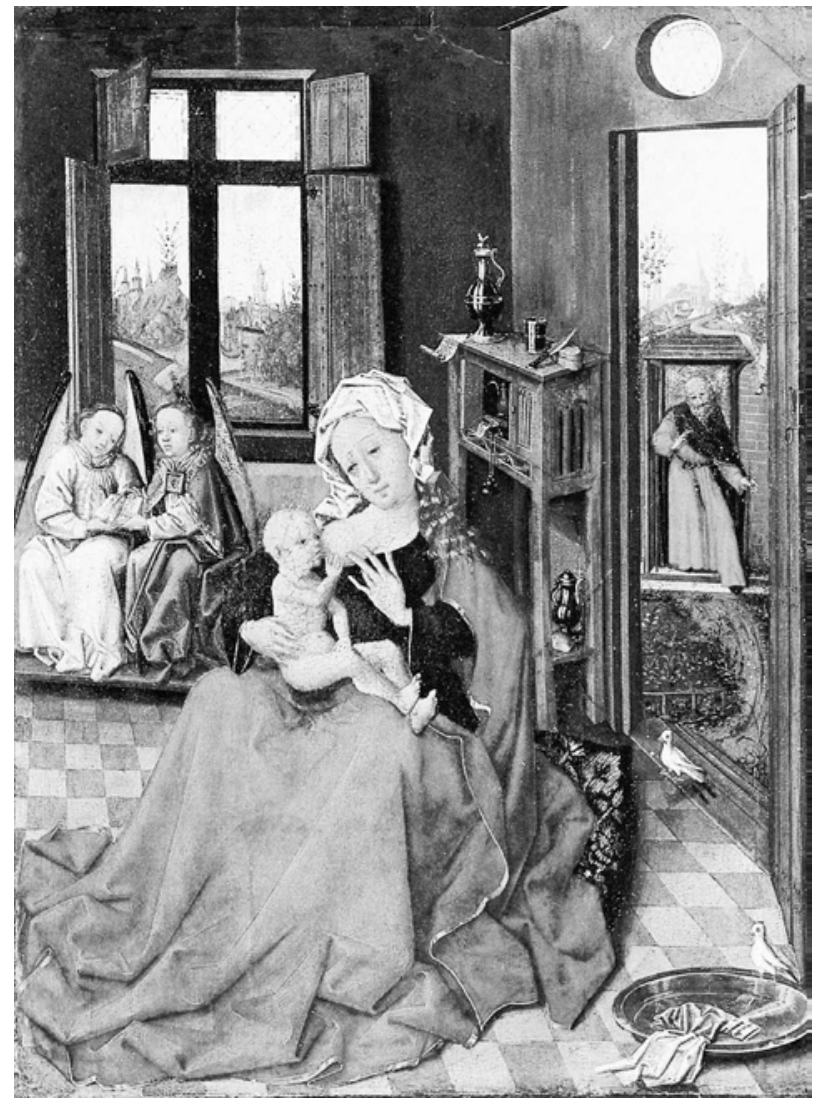

worden zu sein. ${ }^{116}$ Der Schmuck steht aber auch für den Wohlstand und das fromme Mäzenatentum der Familie Grimaldi, deren Wappen in die Fensterbank eingemeiBelt ist und von der Kette umspielt wird. So ergibt sich der Eindruck, als hätten die Stifter selbst diese schönen Gegenstände der Jungfrau Maria dargebracht. Man denkt bereits an die beiden Fensterbilder im Stundenbuch der Maria von Burgund (um 1475/80), vor allem an die in ihrem Gebetbuch lesende Frau und die auf der Fensterbank, vor der im Kirchenschiff thronenden Madonna, ausgelegten Gegenstände, unter denen auch eine Kette mit einem perlenverzierten Rubin zu finden ist. ${ }^{117}$

Die benachbarte Wandnische wurde hingegen mit einer Waschschüssel, einer hoch darüber hängenden Kanne sowie einem Brett mit einem Leuchter, Büchern und zwei weiteren Spanschachteln ausgestattet. Hinzu kommt noch ein Vogel, der auf dem Rand der Schüssel sitzt, sich vorbeugt und im Wasser spiegelt. Gemeint ist wohl wieder ein Distelfink, auch wenn die Zeichnung des Gefieders differiert und die rote Haube nicht mehr genau zu erkennen ist. Von der Schale herab hängt schließlich 
noch eine lange, mehrfach umwundene Kordel mit quastenartigen Enden, vielleicht ein Cingulum, dessen Bedeutung aber noch nicht geklärt werden konnte.

Fragt man nun nach den Anregungsquellen für die ungewöhnliche Ergänzung des Motivs der Waschschüssel, dann lässt sich kein Vorbild benennen, das von Ammann vollständig zitiert würde. Trotzdem gibt es bestimmte Anknüpfungspunkte. So findet sich in der flémallesken $\mathrm{Ma}$ donna im Gemach des Meisters von Iserlohn zumindest eine weiße Taube, die auf der vorn am Boden stehenden Waschschüssel Platz genommen hat, über die außerdem noch das Hemd des - nackt auf dem Schoß der Mutter sitzenden - Jesuskindes gebreitet ist (Abb. 35). Eine weitere Taube sitzt auf der Türschwelle und erinnert daran, dass diese Vögel fast immer paarweise auftreten, um auf die Liebesbeziehung zwischen Mutter und Kind zu verweisen. ${ }^{118}$ In Betracht käme aber auch jenes Taubenpaar, das bei der Darbringung im Tempel, zu Mariä Lichtmess, geopfert wurde (Lk 2,22-24). Da bei Ammann jedoch der Distelfink auf dem Rand der Schüssel sitzt, beinhaltet die Motivübernahme eine ikonografische Umdeutung.

Noch schwieriger ist es, die Spiegelung des Vogels sinnvoll zu erklären. Anführen ließe sich nur die Zeichnung mit einer Madonna im Gemach aus der Nachfolge des Konrad Witz (um 1440/50), in der sich der Jesusknabe über die Schüssel beugt und sein Spiegelbild erblickt, womit ein Erkenntnisvorgang beschrieben werden soll. ${ }^{119}$ Man begibt sich aber ins Reich der Spekulation, wenn man postulierte, dass Ammann derartig seltene Motive rezipieren und mit anderen zu einem neuen Bildzeichen kombinieren konnte. ${ }^{120}$

Dessen ungeachtet, waren dem Deutschen die Tafelbilder der Niederländer sehr wohl vertraut. Spätestens in Genua konnte er einige Werke des Jan van Eyck und anderer Meister studieren. Malerisch reflektiert sich dieser Einfluss in der Wiedergabe der verschiedenen Materialien, im Glänzen der einzelnen Gegenstände und im differenzierten Schattenwurf, der die illusionistische Wirkung wesentlich steigert. Ob das Motiv der Spiegelung außerdem noch einen Rückbezug auf die den antiken Malern nachgesagte Kunst der Augentäuschung beinhalten könnte, sei jedoch dahingestellt. ${ }^{121}$

Ammann hat mit seiner Verkündigung jedenfalls einen wichtigen Beitrag zur Verbreitung der Ars nova geleistet - sogar in ikonografischer Hinsicht, was bisher kaum gewürdigt wurde. Das Gemälde zeigt nämlich, dass man in Italien nicht nur am Realismus, sondern auch an der Symbolsprache der Niederländer interessiert war und mit

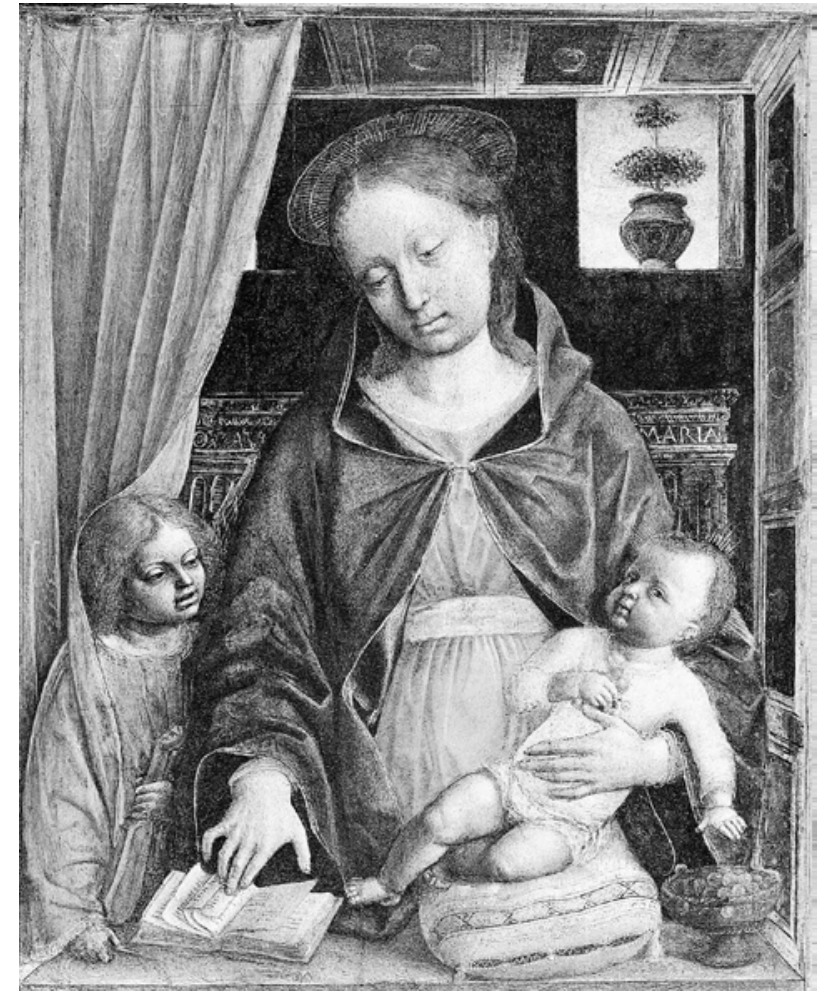

Abb. 36 Maria mit Kind und einem Engel. Vincenzo Foppa. Florenz, Uffizien, Inv.-Nr. 1890-9492 (ex: Ausst.-Kat. Brescia 2003, 127)

der Leistung eines ihrer gelehrigen Schüler, eines deutschen Wandermeisters, selbst unter diesem Aspekt zufrieden sein konnte.

\section{Reflexe in Italien}

Die Auseinandersetzung mit der niederländischen Tafelmalerei im Süden führte also zu einer komplexen Transfersituation, an der Wandermeister aus verschiedenen Ländern, exportierte Bilder und schließlich auch die Druckgrafik einen Anteil hatten. Direkte und indirekte Kontakte, wechselseitige Einflüsse sind zu konstatieren, sodass durch die Einbeziehung Italiens auch Rückschlüsse auf das Beziehungsgeflecht im Norden ermöglicht werden.

Auf Oberitalien bezogen, lässt sich die inhaltliche Relevanz der transalpinen Gemälde besonders gut anhand der Madonnenbilder des Vincenzo Foppa, eines lombardischen Meisters, der sich mehrfach in Genua aufgehalten hat, studieren. Eines davon, wohl um $1465 \mathrm{zu}$ datieren, ist in Abhängigkeit von Kompositionen des Dieric Bouts entstanden und enthält zusätzlich den symbolischen Blu- 


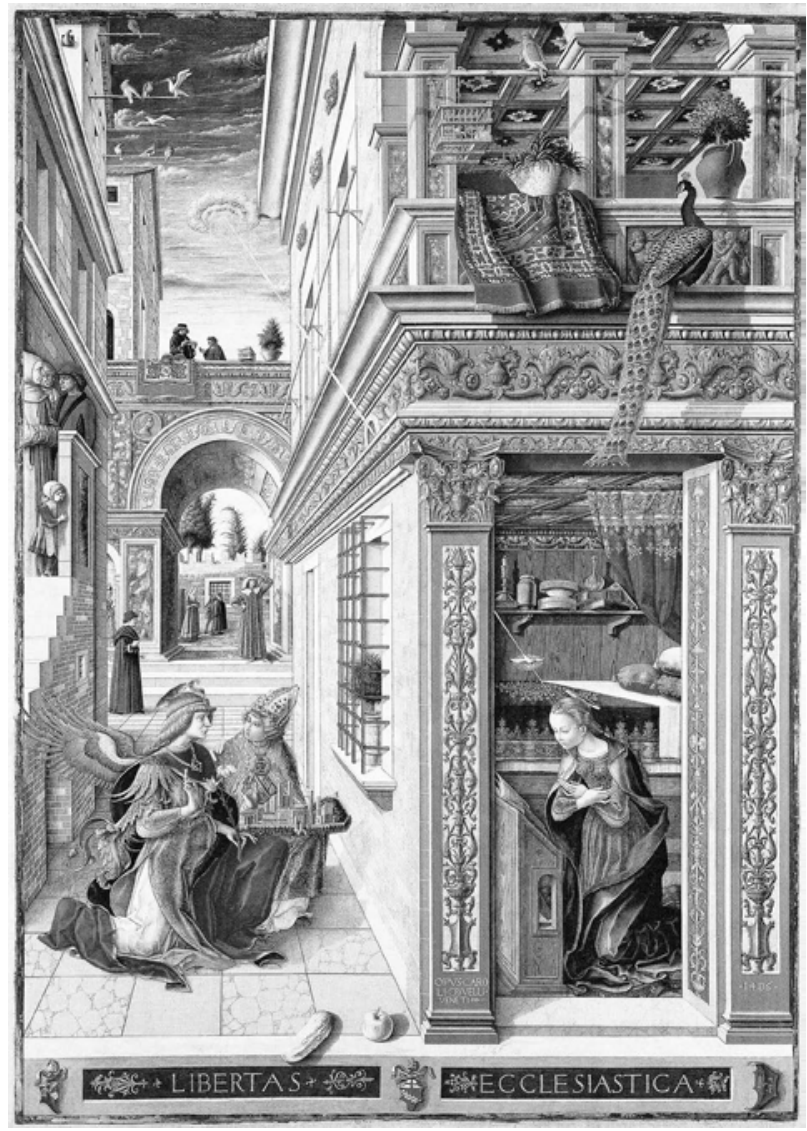

Abb. 37 Verkündigung an Maria. Carlo Crivelli. London, National Gallery, Inv.-Nr. 739 (ex: LIGHTBROWN 2004, 322)

mentopf, welcher in Italien zwar schon früher bekannt war, nun aber - genau über der Inschrift »AVE MARIA « in deutsch-niederländischer Weise auf der Fensterbank steht (Abb. 36). ${ }^{122}$

Weitere Reflexe sind in Venedig nachzuweisen, wo niederländische Tafelbilder gesammelt wurden und wohin auch deutsche Maler gerne reisten. ${ }^{123}$ Antonio Vivarini arbeitete mit Giovanni d'Allemagna wie mit einem »alter ego" zusammen, und sein Bruder Bartolomeo Vivarini zeigt in dem späteren der beiden Polyptychen in der Frarikirche (1482) eine thronende Madonna, vor der - wie in den zuvor beschriebenen deutschen Gemälden - ein Majolikatopf mit einer buschigen Grünpflanze aufgestellt ist. ${ }^{124}$

Am besten verstanden hat die Symbolsprache jedoch der Venezianer Carlo Crivelli: Mit seiner Verkündigung von 1486 aus Ascoli Piceno, heute in London, antwortete er den Niederländern selbstbewusst auf Italienisch (Abb. 37). ${ }^{125}$
Für die deutsche "Übersetzung " dieser Bildsprache empfänglich war er indes auch, wie seine Auseinandersetzung mit der Druckgraphik des Meisters E. S. eindrucksvoll belegt. ${ }^{126}$ So enthält die Verkündigung fast alle Symbole, von denen bisher die Rede war, manche sogar in doppelter Ausführung. Darunter findet sich wieder ein Blumentopf, der nun zwischen dem Engel und Maria im Gitterfenster steht und über dem sich der Goldstrahl mit der Taube ein eigenes Schlupfloch suchen musste. Deshalb ist es nur allzu verständlich, wenn Panofskys Methode der Inhaltsdeutung gerade auf dieses Gemälde angewendet wurde. ${ }^{127}$ Trotzdem hat Anna Degler, die manche dieser Objekte nur als »Parerga « (Beiwerk) ansehen möchte, kürzlich eine Gegenposition eingenommen und versucht, diese literarisch und kunsttheoretisch $\mathrm{zu}$ begründen. Einigen könnte man sich vielleicht insofern, als man Gegenstände, für die es in den Niederlanden keine Deutungstradition gibt, aus neutralerer Perspektive betrachtet und sie nicht zwanghaft in bestimmte Interpretationsmuster einfügt. Davon betroffen wäre wohl auch die rätselhafte Gurke, welche Crivelli fast schon wie eine Signatur verwendet. ${ }^{128}$

\section{Fazit}

Fasst man das bisher Gesagte zusammen, so lässt sich festhalten, dass die deutsche Tafelmalerei für die Diskussion um das Verhältnis von Realismus und Symbolik kaum Argumente für den von Panofsky propagierten »disguised symbolism«, sondern vielmehr für einen »obvious symbolism« bereitzuhalten scheint. Oft sind die Bilder weniger »sophisticated « als diejenigen der Niederländer, und nur selten ist so etwas wie ein genau durchkalkuliertes, ikonografisch stimmiges Gedankengebäude zu erkennen. Man lebt meist von den Übernahmen, ist aber unbefangener in der Kombination der Motive. Trotzdem sind auf diese Weise bedeutsame Neuformulierungen entstanden.

Festhalten lässt sich ferner, dass schon die Anordnung der Objekte über das Verständnis oder Unverständnis eines Meisters und die Deutbarkeit der Dinge entscheidet. Das wird bei einem einfachen »Absuchen« der Tafeln nach Motiven gern vergessen. Aber auch das Weglassen von Personen und Gegenständen ist deutungsrelevant und nicht immer als Zeichen intellektueller Verarmung anzusehen. Dagegen kann das Anhäufen von Gegenständen durchaus gefährlich sein und eine Aussage nivellie- 
ren. Es gilt also stets, die Deutungsspielräume auszuloten und exakte Einzelanalysen durchzuführen.

Unsicherheiten bei der Interpretation ikonografischer Sachverhalte bleiben aber insofern bestehen, als nur zu mutmaßen ist, was ein Künstler wirklich wusste und was auf die Einflussnahme eines Auftraggebers oder eines Beraters zurückgehen könnte. Wenig wahrscheinlich ist es jedoch, dass bei den oft standardisierten Themen für die Flügelbilder eines Retabels minutiöse Vorschriften gemacht wurden.

Ohnedies ergibt sich schon eine längere »Kommunikationskette", wenn polyvalente Bildzeichen, von denen viele eine mittelalterliche Vorgeschichte haben, von den niederländischen Tafelmalern verbreitet und von ihren deutschen Kollegen bereitwillig aufgenommen werden und dann sogar in Italien Beachtung finden. Im Idealfall haben sie der gebende und der nehmende Maler gleichwertig verwendet, doch muss auch mit Umdeutungen, Missverständnissen und Trivialisierungen gerechnet werden. Das gilt ebenso für die Auftraggeber und das breitere Publikum. Derselbe Gegenstand kann also für den einen Betrachter ein mehrdeutiges Symbol und für den anderen nur eine harmlose Realie sein. Dennoch lehrt die Analyse der meisten deutschen Tafelbilder dieser Zeit, dass es einen gewissen Konsens über den Einsatz der Bildzeichen gab und dass man nicht auf ihre Exklusivität, sondern auf ihre allgemeine Akzeptanz und ihre Verständlichkeit abzielte.

Beurteilt man abschließend noch den Beitrag der deutschen Künstler zum Gesamtphänomen des Realismus, so scheinen ihre Absichten und ihre malerischen Möglichkeiten stärker zu differieren als bei den Niederländern. Daran ändert auch das oft einseitige Interesse an der Kunst des Meisters von Flémalle nur wenig. Zu berücksichtigen ist ferner, dass individuelle und regionale Unterschiede sowie häufige Wanderbewegungen - sei es im Zuge der Ausbildung, sei es zum Zwecke der Auftragsübernahme oder der Werkstattgründung - eine größere Rolle spielen. In Süddeutschland dominieren anfangs jedenfalls die Solitäre, und nur im Nordwesten, im Rheinland und in Westfalen, kommt es vergleichsweise früh zu einer Schulbildung. Schwerer fällt es in den deutschen Kunstzentren auch, einen Konnex zwischen dem Wirklichkeitszugriff, der malerischen Leistung und dem intellektuellen Niveau eines Künstlers herstellen: Nicht immer sind die besseren Maler auch die versierteren Ikonografen.

\section{Literatur}

Ainsworth, Maryan W. (Hg.): Petrus Christus in Renaissance Bruges. An Interdisciplinary Approach. New York/Turnhout 1995.

Ainsworth, Maryan W. (Hg.): Early Netherlandish Painting at the Crossroads. A Critical Look at Current Methodologies. New Haven/London 2001.

Ainsworth, Maryan W./Waterman, Joshua P. (Hgg.): German Paintings in the Metropolitan Museum of Art, 13501600. New Haven/London 2013.

Alexander-Skipnes, Ingrid (Hg.): Cultural Exchange between the Low Countries and Italy (1400-1600), Turnhout 2007.

Algeri, Giuliana: Testimonianze e presenze fiamminghe nella pittura del Quattrocento. In: BocARdo/Di FABIO 1997, $38-57$.

[Ausst.-Kat. Amsterdam/Frankfurt 1985]: Ausst.-Kat. Vom Leben im späten Mittelalter. Der Hausbuchmeister oder Meister des Amsterdamer Kabinetts. Hg. von Jan Piet Filedt KOK. Amsterdam, Rijksmuseum, 14.3.-9.6.1985; Frankfurt am Main, Städelsches Kunstinstitut, 5.9.-3.11.1985. Stuttgart-Bad Cannstatt 1985.

[Ausst.-Kat. Basel 2011]: Ausst.-Kat. Konrad Witz. Red. von Bodo Brinkmann und Katharina Georgi. Basel, Kunstmuseum, 6.3.-3.7.2011. Ostfildern 2011.

[Ausst.-Kat. Bologna 2012]: Ausst.-Kat. Simone \& Jacopo. Due pittori bolognesi al tramonto del Medioevo. Hg. von Daniele Benati und Massimo Medica. Bologna, Museo Civico Medievale, 24.11.2012-3.3.2013. Ferrara 2012 (Incontri \& arrivi 11).

[Ausst.-Kat. Brescia 2003]: Ausst.-Kat. Vincenzo Foppa. Hg. von Giovanni Agosti, Mauro Natale und Giovanni RoMANO. Brescia, Santa Giulia, 3.3.-30.6.2002. Mailand 2003.

[Ausst.-Kat. Brügge 2002]: Ausst.-Kat. Jan van Eyck und seine Zeit. Flämische Meister und der Süden 1430-1530. Hg. von Till-Holger Borchert. Brügge, Groeningemuseum, 15.3.30.6.2002. Stuttgart 2002.

[Ausst.-Kat. Brügge 2010]: Ausst.-Kat. Van Eyck bis Dürer. Altniederländische Meister und die Malerei in Mitteleuropa. Hg. von Till-Holger Borchert. Brügge, Groeningemuseum, 29.10.2010-30.1.2011. Stuttgart 2010.

[Ausst.-Kat. Colmar 1991]: Ausst.-Kat. Le beau Martin. Gravures et dessins de Martin Schongauer (vers 1450-1491). Bearb. von Albert Châtelet u.a. Colmar, Musée d'Unterlinden, 13.9.-1.12.1991. Colmar 1991.

[Ausst.-Kat. Colmar 2001]: Ausst.-Kat. Jost Haller. Le peintre des chevaliers et l'art en Alsace au XVe siècle. Bearb. von 
Philippe Lorentz. Colmar, Musée d'Unterlinden, 15.9.-16. 12.2001. Paris 2001.

[Ausst.-Kat. Florenz 2008] Ausst.-Kat. Firenze e gli antichi Paesi Bassi 1430-1530. Dialoghi tra artisti. Da Jan van Eyck a Ghirlandaio, da Memling a Raffello. Hg. von Bert Meijer. Florenz, Palazzo Pitti, 20.6.-26.10.2008. Livorno 2008.

[Ausst.-Kat. Frankfurt 2017]: Ausst.-Kat. In neuem Glanz. Das Schächer-Fragment des Meisters von Flémalle im Kontext. Hg. von Jochen SANDER. Frankfurt/M., Liebieghaus, 15.11.2017-18.2.2018. Regensburg 2017.

[Ausst.-Kat. Frankfurt/Berlin 2008]: Ausst.-Kat. Der Meister von Flémalle und Rogier van der Weyden. Hg. von Stephan Kemperdick und Jochen Sander. Frankfurt/M., Städel Museum, 21.11.2008-22.2.2009; Berlin, Staatliche Museen Preußischer Kulturbesitz, Gemäldegalerie, 20.3.-21.6.2009. Ostfildern 2008.

[Ausst.-Kat. Gotha 1998]: Ausst.-Kat. Jahreszeiten der Gefühle. Das Gothaer Liebespaar und die Minne im späten Mittelalter. Hg. von Allmuth Schut twolf. Gotha, Schlossmuseum, 1.5.-28.6.1998. Ostfildern 1998.

[Ausst.-Kat. Großgmain 1999]: Ausst.-Kat. 500 Jahre Meister von Großgmain 1499-1999. Hg. von Karl Heinz Ritschel. Großgmain, Pfarr- und Wallfahrtskirche, 31.7.-22.8.1999. Großgmain 1999.

[Ausst.-Kat. Karlsruhe 2001]: Ausst.-Kat. Spätmittelalter am Oberrhein. Maler und Werkstätten 1450-1525. Hg. von Dietmar LÜDKE. Karlsruhe, Staatliche Kunsthalle, 29.9.20013.2.2002. Stuttgart 2001.

[Ausst.-Kat. München/Berlin 1986]: Ausst.-Kat. Meister E. S. Ein oberrheinischer Kupferstecher der Spätgotik. Bearb. von Holm Bevers. München, Staatliche Graphische Sammlung, 10.12.1986-15.2.1987; Berlin, Staatliche Museen, Kupferstichkabinett, 11.4.-14.6.1987. München 1986.

[Ausst.-Kat. New York 2005]: Ausst.-Kat. Prague. The Crown of Bohemia 1347-1437. Hg. von Barbara Drake Bовнм und Jiří FAJT. New York, The Metropolitan Museum of Art, 20.9.2005-3.1.2006. New Haven/London 2005.

[Ausst.-Kat. Paris 2002] : Ausst.-Kat. Sur la terre comme au ciel. Jardins d'Occident à la fin du Moyen Âge. Hg. von Élisabeth Antoine. Paris, Musée national du Moyen Âge, Thermes de Cluny, 6.6.-16.9.2002. Paris 2002.

[Ausst.-Kat. Salzburg 2010]: Ausst.-Kat. Ars sacra. Kunstschätze des Mittelalters aus dem Salzburg Museum. Hg. von Peter Husty und Peter Laub. Salzburg 2010 (Jahresschrift des Salzburg Museums 53).

[Ausst.-Kat. Straßburg 2008]: Ausst.-Kat. Strasbourg 1400. Un foyer d'art dans l'Europe gotique. Hg. von Philippe Lorentz. Straßburg, Musée de l'Euvre Notre-Dame, 28.3.-6.7.2008. Strasbourg 2008.

[Ausst.-Kat. Stuttgart 2010]: Ausst.-Kat. Hans Holbein der Äl- tere. Die Graue Passion in ihrer Zeit. Hg. von Elsbeth WIEMANN. Stuttgart, Staatsgalerie, 27.11.2010-20.3.2011. Ostfildern 2010.

[Ausst.-Kat. Ulm 1997]: Ausst.-Kat. Hans Multscher. Bildhauer der Spätgotik in Ulm. Hg. von Brigitte ReinhardT und Michael Rотн. Ulmer Museum, 7.9.-16.11.1997. Ulm 1997.

[Ausst.-Kat. Wien 1969]: Ausst.-Kat. Alltag und Fest im Mittelalter. Gotische Kunstwerke als Bilddokumente. Wien, Österreichische Galerie Belvedere, 14.11.1969-15.11.1970. Wien 1969.

[Ausst.-Kat. Wien 2007] : Ausst.-Kat. Gartenlust. Der Garten in der Kunst. Hg. von Agnes Husslein-Arco. Wien, Österreichische Galerie Belvedere, 22.3.-24.6.2007. Wien 2007.

[Ausst.-Kat. Wien 2017]: Ausst.-Kat. Rueland Frueauf d. Ä. und sein Kreis. Hg. von Stella Rollig und Björn Blauensteiner. Wien, Österreichische Galerie Belvedere, 23.11.201711.03.2018. München 2017.

BAum, Elfriede: Katalog des Museums mittelalterlicher österreichischer Kunst. Wien/München 1971 (Österreichische Galerie Wien, Kataloge 1).

Becksmann, Rüdiger (Hg.): Deutsche Glasmalerei des Mittelalters, Bd. II. Bildprogramme - Auftraggeber - Werkstätten. Berlin 1992.

Behling, Lottlisa: Die Pflanze in der mittelalterlichen Tafelmalerei. 2. Aufl. Köln/Graz 1967.

Benati, Davide: Protagonisti del secondo Trecento bolognese. In: Ausst.-Kat. Bologna 2012, 5-13.

Bergström, Ingvar: Disguised Symbolism in Madonna Pictures and Still Life I/II. In: The Burlington Magazine 97 (1955), $303-308,342-349$.

Boccardo, Piero/Di Fabio, Clario (Hgg.): Pittura fiammingha in Liguria. Secoli XIV-XVII. Cinisello Balsamo 1997.

Boeck, Wilhelm: Der Tiefenbronner Altar von Lucas Moser. München 1951.

Borchert, Till-Holger: Mobile Maler. Aspekte des Kulturtransfers zwischen Spätmittelalter und Frühneuzeit. In: Ausst.-Kat. Brügge 2002, 32-51.

Brinkmann, Bodo/Kemperdick, Stephan: Deutsche Gemälde im Städel 1300-1500. Mainz 2002 (Kataloge der Gemälde im Städelschen Kunstinstitut Frankfurt am Main 4).

BuCHner, Ernst: Der Meister der Münchener Marientafeln. In: Die Kunst und das Schöne Heim 54 (1955), 81-84.

Campbell, Lorne: The Fifteenth Century Netherlandish Schools. London 1998 (National Gallery Catalogues).

Campbell, Lorne: The Sixteenth Century Netherlandish Paintings with French Paintings before 1600, Bd. 1-2. New Haven/London 2014 (National Gallery Catalogues).

Challeat, Claire: Dalle Fiandre a Napoli. Committenza artistica, politica, diplomazia al tempo di Alfonso il Magnanimo e Filippo il Buono. Roma 2012. 
DE Coo, Jozef: In Josephs Hosen Jhesus ghewonden wert. Ein Weihnachtsmotiv in Literatur und Kunst. In: Aachener Kunstblätter 30 (1965), 144-184.

De Coo, Jozef: Addenda zum Weihnachtsmotiv der Josefshosen. In: Aachener Kunstblätter 43 (1972), 249-261.

Degler, Anna: Parergon. Attribut, Material und Fragment in der Bildästhetik des Quattrocento. Paderborn 2015.

Duwe, Gert: Die Verkündigung an Maria in der niederländischen Malerei des 15. und 16. Jahrhunderts. Frankfurt/M. u. a. 1994.

Eclercy, Bastian: Von Mausefallen und Ofenschirmen. Zum Problem des »disguised symbolism« bei den frühen Niederländern. In: Ausst.-Kat. Frankfurt/Berlin 2008, 132-147, 173-175.

EınHoRN, Jürgen Werinhard: Spiritalis unicornis. Das Einhorn als Bedeutungsträger in Literatur und Kunst des Mittelalters. 2. Aufl. München 1998.

Elsig Frédéric/Menz, Cäsar (Hgg.): Konrad Witz. Le maîtreautel de la Cathédrale de Genève. Histoire, conservation et restauration. Genève 2013.

Falkenburg, Reindert Leonard: The Fruit of Devotion. Mysticism and the Imagery of Love in Flemish Painting of the Virgin and Child, 1450-1510. Amsterdam/Philadelphia 1994 (Oculi 5).

Falkenburg, Reindert Leonard: The Houshold of the Soul. Conformity in the "Mérode Triptych». In: Ainsworth 2001, 2-17.

Friedmann, Herbert: The Symbolic Goldfinch. Its History and Significance in European Devotional Art. Washington 1946 (The Bollingen Series 7).

Fritz, Rolf: Aquilegia. Die symbolische Bedeutung der Akelei. In: Wallraf-Richartz-Jahrbuch 14 (1952), 99-110.

Geroni, Luca: Carlo Crivelli e il monogrammista E. S. In: Mitteilungen des Kunsthistorischen Institutes in Florenz 40 (1996), 222-231.

Gerstenberg, Kurt: Hans Multscher. Leipzig 1928.

Giltaij, Jeroen/Wolters, Margreet: Der Marien-Altar des Meisters der Virgo inter Virgines im Salzburg Museum. In: Ausst.-Kat. Salzburg 2010, 19-35.

Gnudi, Cesare: Vitale da Bologna. Mailand 1962.

Goldberg, Gisela/Scheffler, Gisela: Altdeutsche Gemälde. Köln und Nordwestdeutschland. 2 Bde. München 1972 (Bayerische Staatsgemäldesammlungen, Alte Pinakothek München, Gemäldekataloge 14).

Gottlieb, Carla: Respiciens per Fenestras. The Symbolism of the Mérode Altarpiece. In: Oud Holland 85 (1970), 65-84.

Grabar, André: Un thème de l'iconographie chrétienne: L'oiseau dans la cage. In: Cahiers archéologiques 16 (1966), $9-16$.
Grosshans, Rainald: Maerten van Heemskerck. Die Gemälde. Berlin 1980.

Hannesschläger, Ingonda: Die Problematik um den Meister von Großgmain und die Tafeln des ehemaligen Flügelaltars aus dem Jahr 1499. In: Ausst.-Kat. Großgmain 1999, 11-67.

Harbison, Craig: Realism and Symbolism in Early Flemish Painting. In: The Art Bulletin 66 (1984), 588-602.

Harbison, Craig: Fact, Symbol, Ideal. Roles for Realism in Early Netherlandish Painting. In: Ainswort H 1995, 21-34.

HARBISON, Craig: Iconography and Iconology. In: RidDERBos/ VAN Buren/VAN VeEn 2005, 378-406, 436-438.

HARTwieg, Babette/LÜDKe, Dietmar: Vier gotische Tafeln aus dem Leben Johannes' des Täufers. Karlsruhe 1994.

Haussherr, Reiner: Der Magdalenenaltar in Tiefenbronn. Bericht über die wissenschaftliche Tagung am 9. und 10. März 1971 im Zentralinstitut für Kunstgeschichte in München. In: Kunstchronik 24 (1971), 177-212.

Hilger, Hans Peter: Der Skulpturenzyklus im Chor des Aachener Domes. Ein Beitrag zur Kunstgeschichte des RheinMaas-Gebietes. Essen 1961 (Die Kunstdenkmäler des Rheinlandes, Beiheft 8).

Hiller, Irmgard/Vey, Horst: Katalog der deutschen und niederländischen Gemälde bis 1550 (mit Ausnahme der Kölner Malerei). Köln 1969 (Kataloge des Wallfraf-Richartz-Museums 5).

HJort, Øystein: L'oiseau dans la cage. Exemples médiévaux à Rome. In: Cahiers archéologiques 18 (1968), 21-32.

Hoffmann, Ingrid-Sibylle: Der Meister der Pollinger Tafeln. Wege der Erneuerung in der bayerischen Malerei des mittleren 15. Jahrhunderts. Weimar 2007.

ЈАкову, Barbara: Der Einfluss der niederländischen Tafelmalerei des 15. Jahrhunderts auf die Kunst der benachbarten Rheinlande am Beispiel der Verkündigungsdarstellung in Köln, am Niederrhein und in Westfalen (1440-1490). Köln 1987 (Kölner Schriften zu Geschichte und Kunst 12).

Kemperdick, Stephan: Der Meister von Flémalle. Die Werkstatt Robert Campins und Rogier van der Weyden. Turnhout 1997 (Ars nova 2).

Krause, Katharina: An der Grenze der Bilder. Inschriften, Kerzen, Blumen. In: Ausst.-Kat. Stuttgart 2010, 147-161.

[KüHnel 1980/I]: KüHnel, Harry (Hg.): Europäische Sachkultur des Mittelalters, Wien 1980 (Veröffentlichungen des Instituts für mittelalterliche Realienkunde Österreichs 4).

[KüHNEL 1980/II] : KüHNEL, Harry: Abbild und Sinnbild in der Malerei des Spätmittelalters. In: KüHNEL 1980/I, 83-100.

[KüHNEL 1986/I] : KüHNEL, Harry (Hg.): Alltag im Spätmittelalter. 3. Aufl. Graz/Wien/Köln 1986.

[KüHNEL 1986/II]: KüHNEL, Harry: »Lebensqualität« im Spätmittelalter. In: KüHNEL 1986/I, 64-66.

Kurth, Betty: Gotische Bildteppiche aus Frankreich und Flan- 
dern. München 1923 (Sammelbände zur Geschichte der Kunst und des Kunstgewerbes 7).

Kutschbach, Doris: Das irdische Paradies. Liebesgärten im späten Mittelalter. In: Ausst.-Kat. Gotha 1998, 82-92.

LAne, Barbara G.: Sacred versus Profane in Early Netherlandish Painting. In: Simiolus 18 (1988), 106-115.

LeChner, Gregor Martin OSB: Zur Symbolik der Majolika-Vasen auf mittelalterlichen Verkündigungstafeln. In: Mitteilungen des Kremser Stadtarchivs 17/18 (1978), 89-104.

Levi D'Ancona, Mirella: The Garden of the Renaissance. Botanical Symbolism in Italian Painting. Firenze 1977 (Arte e Archeologia, studi e documenti 10).

Liebrich, Julia: Die Verkündigung an Maria. Die Ikonographie der italienischen Darstellungen von den Anfängen bis 1500 Köln/Weimar/Wien 1997.

Lightbrown, Ronald: Carlo Crivelli. New Haven/London 2004.

Lorentz, Philippe: Le Maître du Paradiesgärtlein, peintre de la candeur enfantine. In: Ausst.-Kat. Straßburg 2008, 54-71.

LucAs, Jana: Europa in Basel. Das Konzil von Basel (14311449) als Laboratorium der Kunst. Basel 2017.

LükeN, Sven: Die Verkündigung an Maria im 15. und frühen 16. Jahrhundert. Historische und kunsthistorische Untersuchungen. Göttingen 2000 (Rekonstruktion der Künste 2).

Marcelli, Fabio: Gentile da Fabriano. Cinisello Balsamo 2005.

Marienlexikon. Hg. von Remigius BÄUmer und Leo ScheffCZYK. 6 Bde. St. Ottilien 1988-94.

Marrow, James: Symbol and Meaning in Northern European Art of the Late Middle Ages and the Early Renaissance. In: Simiolus 16 (1986), 150-179.

Maurer, Emil: Konrad Witz und die niederländische Malerei. In: Zeitschrift für schweizerische Archäologie und Kunstwissenschaft 18 (1958), 158-166, Taf. 47-52.

Meyer, Heinz: Die Zahlenallegorese im Mittelalter. Methode und Gebrauch. München 1975 (Münstersche MittelalterSchriften 25).

Meyer, Heinz/Suntrup, Rudolf: Lexikon der mittelalterlichen Zahlenbedeutungen. München 1987 (Münstersche Mittelalter-Schriften 56).

Van Miegroet, Hans: De invloed van de vroege Nederlandse schilderkunst in de eerste helft van de 15 de eeuw op Konrad Witz. Brussel 1986 (Verhandelingen van de Koninklijke Academie voor Wetenschappen, Letteren en Schone Kunsten van België, Klasse der Schone Kunsten 48/42).

MöHring, Helmut: Die Tegernseer Altarretabel des Gabriel Angler und die Münchner Malerei von 1430-1450. München 1997 (Beiträge zur Kunstwissenschaft 71).

Moxey, Keith: Das Ritterideal und der Hausbuchmeister (Meister des Amsterdamer Kabinetts). In: Ausst.-Kat. Frankfurt/M. 1985, 38-51.
Neuwirth, Markus: Ex Voto. Die "Allgemeinen und ungemeinen Gnaden« als ikonographische Mitbestimmung. In: Kunstgeschichtliche Studien - Innsbruck N. F. 1 (1994) (Veröffentlichungen der Universität Innsbruck 198), 63-87.

Nuttall, Paula: From Flanders to Florence. The Impact of Netherlandish Painting 1400-1500. New Haven/London 2004.

PÄснт, Otto: Panofsky’s «Early Netherlandish Painting« - Bd. I/II. In: The Burlington Magazine 98 (1956), 110-116, 267279.

PÄснт, Otto/Thoss, Dagmar: Flämische Schule II. 2 Bde. Wien 1990 (Die illuminierten Handschriften und Inkunabeln der Österreichischen Nationalbibliothek 7).

Pallucchini, Rodolfo: I Vivarini (Antonio, Bartolomeo, Alvise). Venezia 1962 (Saggi e studi di storia dell'arte 4).

Panofsky, Erwin: Early Netherlandish Painting. Its Origins and Character. 2 Bde. Cambridge/Mass. 1953.

Pieper, Paul: Die deutschen, niederländischen und italienischen Tafelbilder bis um 1530. Münster/W. 1990 (Westfälisches Landesmuseum für Kunst und Kulturgeschichte Münster, Bestandskataloge).

Pirker-Aurenhammer, Veronika: Im Himmel wie auf Erden. Gärten des Mittelalters als Ausdruck von Frömmigkeit und Sinnesfreuden. In: Ausst.-Kat. Wien 2007, 16-37.

Purtle, Carol J.: The Marian Paintings of Jan van Eyck. Princeton 1982.

Reinhard-Felice Mariantonia (Hg.): Sammlung Oskar Reinhart »Am Römerholz« Winterthur. Gesamtkatalog. Basel 2003.

Rensing, Theodor: Der Meister von Schöppingen. München 1959.

Ridderbos, Bernhard/Van Buren, Anne/Van Veen, Henk (Hgg.): Early Netherlandish Paintings. Rediscovery, Reception and Research. Amsterdam 2005.

Rohlmann, Michael: Auftragskunst und Sammlerbild. Altniederländische Tafelmalerei im Florenz des Quattrocento. Alfter 1994.

Rohlmann, Michael: The »Annunciation« by Joos Ammann in Genoa: Context, Function and Metaphorical Quality. In: Alexander-Skipnes 2007, 23-40.

Röhrig, Floridus (Hg.): Der Albrechtsaltar und sein Meister. Wien 1981.

Rosenauer, Artur/Weber, Gerold (Hgg.): Kunsthistorische Forschungen. Otto Pächt zu seinem 70. Geburtstag. Salzburg 1972.

Roth-Bojadzhiev, Gertrud: Studien zur Bedeutung der Vögel in der mittelalterlichen Tafelmalerei. Köln/Wien 1985.

SAliger, Arthur: Der Wiener Schottenmeister. München/Berlin/London/New York 2005.

Salzer, Anselm: Die Sinnbilder und Beiworte Mariens in der deutschen Literatur und lateinischen Hymnenpoesie des 
Mittelalters. Mit Berücksichtigung der patristischen Literatur. Eine literar-historische Studie. Seitenstetten 1893; Neudruck Darmstadt 1967.

SANDER, Jochen: Niederländische Gemälde im Städel 14001550. Mainz 1993 (Kataloge der Gemälde im Städelschen Kunstinstitut Frankfurt am Main 2).

SANDER, Jochen: Italienische Gemälde im Städel 1300-1550. Oberitalien, die Marken und Rom. Mainz 2004 (Kataloge der Gemälde im Städelschen Kunstinstitut Frankfurt am Main 7).

Schädler, Alfred: Die Frühwerke Hans Multschers. In: Zeitschrift für Württembergische Landesgeschichte 14 (1955), 385-444.

Schapiro, Meyer: »Muscipula Diaboli«. The Symbolism of the Mérode Altarpiece. In: The Art Bulletin 27 (1945), 182-187.

SCHILlER, Gertrud: Ikonographie der christlichen Kunst, Bd. 4,2. Maria. Gütersloh 1980.

Scheil, Elfriede: Fayencen in der Malerei des Mittelalters. Phil. Diss. (masch.) Universität München. Ottobrunn 1977.

Schoch, Rainer/Mende, Matthias/Scherbaum, Anna: Albrecht Dürer. Das druckgraphische Werk, Bd. 1. Kupferstiche. München/London/New York 2001.

Scholz, Hartmut: Tradition und Avantgarde. Die Farbverglasung der Besserer-Kapelle als Arbeit einer Ulmer »Werkstatt-Kooperative«. In: BECKSMANN 1992, 93-152.

SEIDEL, Katrin: Die Kerze. Motivgeschichte und Ikonologie. Hildesheim/Zürich/New York 1996 (Studien zur Kunstgeschichte 103).

SIMON, Achim: Österreichische Tafelmalerei der Spätgotik. Der niederländische Einfluß im 15. Jahrhundert. Berlin 2002.

[SöDING 1991/I]: SöDING, Ulrich: Hans Multscher. Der Sterzinger Altar. Bozen 1991.

[SöDING 1991/II]: SöDING, Ulrich: Hans Multschers »Wurzacher Altar«. In: Münchner Jahrbuch der bildenden Kunst 3. F. 42 (1991), 69-116.

SöDING, Ulrich: Die Bildwerke Hans Multschers. Ein Beitrag zur europäischen Kunst im 15. Jahrhundert. In: Ausst.-Kat. Ulm 1997, 31-51.

Statnik, Björn: Sigmund Gleismüller - Hofkünstler der Reichen Herzöge zu Landshut. Petersberg b. Fulda 2009 (Studien zur internationalen Architektur- und Kunstgeschichte 69).

[STerling 1972/I]: Sterling, Charles: Observations on Moser's Tiefenbronn Altarpiece. In: Pantheon 30 (1972), 19-32.

[Sterling 1972/II]: Sterling, Charles: The Master of the "Landsberg" Altar-wings. In: Rosenauer/Weber 1972, $150-165$.

Sterling, Charles: Jost Haller. In: Wiener Jahrbuch für Kunstgeschichte 33 (1980), 99-126.
Stoichita, Victor I.: Eine kurze Geschichte des Schattens. München 1999.

Strieder, Peter: Tafelmalerei in Nürnberg 1350-1550. Königstein im Taunus 1993.

Suckale, Robert: Les peintres Hans Stocker et Hans Tiefental. L'«ars nova» en Haute Rhénanie au XVe siècle. In: Revue de l'art 120 (1998), H. 2, 58-67.

TERrier, Laurence/Wirth, Jean: L'iconographie du retable. In: Elsig/Menz 2013, 137-151.

Thürlemann, Felix: Robert Campin. Eine Monographie mit Werkkatalog. München/Berlin/London/New York 2002.

Tripps, Manfred: Hans Multscher. Seine Ulmer Schaffenszeit 1427-1467. Weißenhorn 1969.

Unger, Claudia: Die Tafelgemälde des Meisters der Virgo inter Virgines. Ein Beitrag zur Erforschung des Kunstgebietes der nördlichen Niederlande im 15. Jahrhundert. Diss. Berlin (FU) 2004.

Winkler, Friedrich: Jos Ammann von Ravensburg. In: Jahrbuch der Berliner Museen N. F. 1 (1959), 51-118.

Wolffhardt, Elisabeth: Beiträge zur Pflanzensymbolik. Über die Pflanzen des Frankfurter »Paradiesgärtleins«. In: Zeitschrift für Kunstwissenschaft 8 (1954), 177-196.

\section{Anmerkungen}

1 Herzlich gedankt sei Wolfgang Augustyn (München, Zentralinstitut für Kunstgeschichte) und Veronika Pirker-Aurenhammer (Wien, Österreichische Galerie Belvedere) für ihre Hilfe bei einigen ikonografischen und realienkundlichen Fragen. Detaillierte Auskünfte zu den Topfpflanzen und zum Etagenschnitt werden Ehrentraud Bayer (Universität München, Botanischer Garten) verdankt. Anregende Kommentare zu den beiden dieser Publikation vorangehenden Vorträgen gaben ferner Gerhard Weilandt (Universität Greifswald), Paul Naredi-Rainer und Martin Neuwirth (Universität Innsbruck). Stephan Kemperdick (Berlin, Gemäldegalerie), Martin Schawe (München, Alte Pinakothek) und Pater Augustinus Zeman (Wien, Schottenstift) haben freundlicherweise Abbildungsvorlagen bereitgestellt.

2 Panofsky 1953, I, 131-148. - PÄCHT 1956, 275-279. - Harbison 1984. - Marrow 1986. - LANe 1988. - Harbison 1995. - HarbiSON 2005.

3 Ausst.-Kat. Brügge 2010.

4 Harbison 1984, $600 \mathrm{f}$.

5 Panofsky 1953, I, 144-148; II, Abb. 236, 237. - Purtle 1982, 144156, Abb. 64.

6 SAlzer 1893, 38 f., 71-74, 88 f. - PANOFSKY 1953, I, 144, 184 f.; II, Abb. 252. - Purtle 1982, 97-126, Abb. 47. - SANder 1993, 245263, Taf. 17.

7 Schapiro 1945. - Panofsky 1953, I, 142 f.; II, Abb. 204. - GottLIEB 1970. - KeMPeRdicK 1997, 77-99, Abb. 94, 97-102. - ThüRLEMANN 2002, 58-76, 269-272, Kat.-Nr. I.12. - Ausst.-Kat. Frankfurt/Berlin 2008, 192-201, Kat.-Nr. 4 (Jochen SANDER).

8 Falkenburg 2001. 
9 Salzer 1893, 162-170. - Lechner 1978, 95.

10 ECLerCy 2008, bes. 142-144.

11 Zur Verkündigung in Brüssel Kemperdick 1997, 77-99, Taf. 5, Abb. 93, 95-96. - Thürlemann 2002, 74-76, 305 f., Kat.-Nr. III.C.1. - Ausst.-Kat. Frankfurt/Berlin 2008, 188-191, Kat.-Nr. 3 (J. SANDER).

12 Kemperdick 1997, 133-148, Abb. 165-170. - Thürlemann 2002, 247 f., 302-304, Kat.-Nr. III.B.4b. - Ausst.-Kat. Frankfurt/Berlin 2008, 285-290, Kat.-Nr. 22 (Stephan Kemperdick). - Ausst.-Kat. Brügge 2010, 170 f., 523, Kat.-Nr. 42 (Till-Holger Borchert).

13 Behling 1967, 38 f. - Lechner 1978, 97 f. - Liebrich 1997, $82 \mathrm{f}$.

14 Behling 1967. - Vgl. auch Levi d’Ancona 1977.

15 Falkenburg 1994, bes. 12 f., 89 f. - Pirker-Aurenhammer 2007 , $17-19$.

16 Panofsky 1953, I, 136; II, Abb. 199. - Thürlemann 2002, 55 , 195 f., 309-312, Kat.-Nr. III.D.1a. - Ausst.-Kat. Frankfurt/Berlin 2008, 224-233, Kat.-Nr. 9 (St. KeMPerdick).

17 JAкову 1987. - DUwe 1994. - Liebrich 1997. - LÜKen 2000.

18 Hartwieg/LÜDKe 1994. - SuCKale 1998, 62-65. - BrinkmanN/ KeMPERDICK 2002, 93-120 (St. KeMPERDICK/Bodo BRINKMANN). - Lorentz 2008. - Ausst.-Kat. Straßburg 2008, 162-67, 169-172, Kat.-Nrr. 21-24, 26, 27 (Philippe LoRentz).

19 Hartwieg/Lüdke 1994, 79 f., Abb. 65. - Suckale 1998, 63, 64, Abb. 4. - Brinkmann/Kemperdick 2002, 98, 103, 104f., 108. Reinhard-Felice 2003, 108-112, Kat.-Nr. 1 (Mariantonia ReinHARD-FeliCe). - LoRENTZ 2008, 63, 65 f., Abb. 8 [seitenverkehrt]. Auf Zuschreibungsfragen und Kontroversen bei der Datierung der ganzen Werkgruppe kann hier nicht näher eingegangen werden.

20 Meyer 1975, 142-145. - Meyer/Suntrup 1987, Sp. 591-615, bes. Sp. 606.

21 Es handelt sich jeweils um einen Florentiner oder Faentiner Fayencekrug mit monochromer Blaumalerei. ScheIL 1977, 119, Kat.-Nr. 165, Taf. 81,83 .

22 Salzer 1893, 17 f., 115. Vgl. aber auch die Bezeichnung Mariens als »Tugendgefäß«; ebd., 327 f. - Lechner 1978, 93-95. - Liebrich 1997, 76 f., 162.

23 Wolffhardt 1954, 178, 181. - Behling 1967, 20. - LÜKen 2000, 390, Anm. 658. - Bei Brinkmann/Kemperdick 2002, 111, Abb. 99, werden die Blumen als rotes und weißes Tausendgüldenkraut bezeichnet, was aber wegen der unterschiedlichen Anzahl der Blütenblätter nicht zutreffen kann.

24 Lechner 1978, 94. - LüKen 2000, 321 f., Anm. 101.

25 Salzer 1893, 6 f., 113. - Liebrich 1997, 77, 162.

26 SAlzer 1893, 15 f., 115. - Marienlexikon 3 (1991), 247-250 (Hortus conclusus, Genoveva NITZ).

27 Brinkmann/Kemperdick 2002, 98, 106-108. - Ausst.-Kat. Straßburg 2008, 164-166, Kat.-Nr. 23 (Ph. LoRentz).

28 L. 77. - Ausst.-Kat. München/Berlin 1986, 49 f., Kat.-Nr. 38 (Holm Bevers), Abb. 38. - Ausst.-Kat. Karlsruhe 2001, 141, Kat.-Nr. 59 (Holger Jacob-Friesen).

29 Töpfe ohne Zinnenkranz, aber mit ganz ähnlichen Bäumchen finden sich auch in Darstellungen der "Geburt Christi« des Meisters E. S. (L. 20, L. 22). - Vgl. ferner eine "Verkündigung « des Meisters der Gewandstudien in Berlin, wo das Motiv des Zinnentopfes auf der Fensterbank, nun in unmittelbarer Nähe Mariens, wiederkehrt; Ausst.-Kat. Karlsruhe 2001, 119, Abb. 42/2, bei Kat.-Nr. 42 (Dietmar LÜDKE).

30 L. 211. - Moxey 1985, 42. - Ausst.-Kat. Amsterdam/Frankfurt 1985,
158 f., Kat.-Nr. 75e (Jan Piet Filedt KOK). - Kutschbach 1998, 82. - Ausst.-Kat. Gotha 1998, 115, Kat.-Nr. 55 (Doris KutschBach). - Pirker-Aurenhammer 2007, 30. - Das Motiv des Topfs blieb bisher unkommentiert.

31 Gnudi 1962, 60. - Benati 2012, 7.

32 Rensing 1959, 24 f., Abb. 52-55. - Jaковy 1987, 117, 142, Abb. 32. Kemperdick 1997, 89 f., Abb. 109. - LÜKen 2000, 113, 116, Abb. 18. - Ausst.-Kat. Brügge 2010, 220 (Abb.).

33 Salzer 1893, 174-176. - Liebrich 1997, 80.

34 Behling 1967, XVIII. - Hiller/Vey 1969, 139-141, Kat.-Nr. 354, Abb. 182. - Die Blätter und Blüten der dargestellten Pflanze sind allerdings stark vergrößert gegenüber dem Naturvorbild.

35 Die Bäumchen wurden bisweilen schon als Wacholder identifiziert; vgl. Ausst.-Kat. Karlsruhe 2001, 141, Kat.-Nr. 59 (H. JACOB-FrieSEN). - Bei Jost Haller, in der Verkündigung des Saarbrücker Altars (um 1455), steht dagegen eine rot blühende Blattpflanze vorn auf dem Boden. Sterling 1980, bes. 103 f., Abb. 106. - Ausst.-Kat. Colmar 2001, 133 (Ph. LoRentz).

36 Ausst.-Kat. Paris 2002, 208 f., Kat.-Nr. 93 (Élisabeth Antoine).

37 Salzer 1893, 10-12, 114. - Marienlexikon 1 (1988), 615-617 (Bundeslade, Peter HAWEL). - Neuwirth 1994, 73 und Anm. 57-59 (mit Textstellen).

38 Zur Verwendung im Barock Neuwirth 1994, 73 und Abb. 6.

39 Ausst.-Kat. Karlsruhe 2001, 332, 340-342, Kat.-Nr. 192 (D. LÜDKE). Ausst.-Kat. Colmar 2001, 50-52 (Ph. Lorentz). - Reinhard-FeLICE 2003, 112, Abb. 2, 4. - Ausst.-Kat. Straßburg 2008, 180, Kat.-Nr. 37 (Ph. Lorentz).

4 O Boeck 1951. - Haussherr 1971. - Sterling 1972/I.

41 Boeck 1951, Abb. 17, 24.

42 Sterling 1972, $20 \mathrm{f} ., 32$.

$43 \mathrm{Ob}$ dafür ein antikes Vorbild Pate gestanden hat, wie Sterling 1972, 28, behauptet, sei aber dahingestellt.

44 Dazu Sterling 1972, 21.

45 SAnder 1993, 88-128, Taf. 7. - Kemperdick 1997, 12-28, Abb. 10. Ausst.-Kat. Frankfurt/Berlin 2008, 206-214, Kat.-Nr. 6 (J. SANDER). Ausst.-Kat. Frankfurt 2017, 102-113, Kat.-Nr. 2 (J. SANDER).

46 Gerstenberg 1928, 67-118. - Tripps 1969, 86-125, Abb. 151-162, 167-170. - STERLING 1972/II. - SÖDING 1991/II.

47 Söding 1991/II, 78 f., Abb. 8.

48 Scholz 1992.

49 Pieper 1990, 209-211, Kat.-Nr. 83. - Ausst.-Kat. Brügge 2010, 231 f., 525, Kat.-Nr. 82 (T.-H. Borchert).

50 Ausst.-Kat. Brügge 2010, 377, 529, Kat.-Nr. 197 (T.-H. BorcherT).

51 Thürlemann 2002, 50-58, 261-263, Kat.-Nr. I.7/C. - Ausst.-Kat. Brügge 2010, 176, 523, Kat.-Nr. 47 (T.-H. Borchert).

52 De Coo 1965. - De Coo 1972.

53 SChädler 1955, 426-428, Taf. X. - Hilger 1961, 43, 46, 121, 124, Abb. 34. - SöDING 1997, 31.

54 De Coo 1965, 144f., 170-172, Kat.-Nr. 20, 21. - SöDING 1991/I, Abb. 46-47.

55 Bergström 1955, 346, Kühnel 1980/II, 93, und LüKen 2000, 63, sehen darin einen Hinweis auf Maria als "scrinium deitatis«. - LIEBRICH 1997, 77, glaubt, dass die Spanschachtel auch als Pyxis, als Hostienbehältnis, zu verstehen sei.

56 SCHILLER 1980, 72-75.

57 Man vergleiche etwa das dem Meister des Tucher-Altars zugeschriebene Epitaph der Klara Imhoff im Germanischen Nationalmuseum 
(um 1438), wo der Anraum des Stallgebäudes als Küche genutzt wird. Josef hantiert hier an einer Truhe und kocht das Essen in einem Kessel, der über dem offenen Feuer hängt. STRIEDER 1993, 181, Kat.-Nr. 20.

58 Kemperdick 1997, 100-112, Abb. 120. - ThÜrlemanN 2002, 309312, Kat.-Nr. III.D.1b. - Ausst.-Kat. Frankfurt/Berlin 2008, 224-233, Kat.-Nr. 9 (St. Kemperdick).

59 Ausst.-Kat. Basel 2011, 338-348, Kat.-Nr. 88-90 (Ph. Lorentz).

6o RöHrig 1981, 48 f., Taf. 7 .

61 Fritz 1954, 100-104, bes. 101. - Behling 1967, 37, Taf. XIII. SCheil 1977, 36-38, Kat.-Nr. 38, Taf. 11,12. - Lechner 1978, 98.

62 SCHILler 1980, 209.

63 Ausst.-Kat. Wien 1969, 80 f., Kat.-Nr. 44. - BAUm 1971, 103 f., Kat.-Nr. 66. - HannessChläGER 1999, 24, 28, 29, Abb. 35. - Ausst.-Kat. Wien 2017, 145-154, Kat.-Nr. 9/1-3 (Björn Blauensteiner). - Bisher wurde der Inhalt der Schachtel als "Konfekt» bezeichnet. Um Hostien (vgl. Anm. 55) handelt es sich jedenfalls nicht, und Manna müsste wohl in einem kostbareren Gefäß aufbewahrt werden.

64 Maurer 1958. - Van Miegroet 1986. - Zum Gesamtwerk Ausst.Kat. Basel 2011. - Zur Stellung von Witz in der Kunst der Basler Konzilszeit LuCAS 2017, 86-120, 211-251.

65 Ausst.-Kat. Basel 2011, 110-125, bes. 122, Kat.-Nr. 14 (B. BRINKMANN und Gabriel DetTe).

66 Ausst.-Kat. Basel 2011, 1, 126-148, bes. 141 f., Kat.-Nr. 19 (Katharina Georgi und G. Dette).

67 Panofsky 1953, I, 334.

68 Stoichita 1999, 82-86. - Ausst.-Kat. Basel 2011, 141 (G. Dette). Terrier/Wirth 2013, $145 \mathrm{f}$.

69 Ausst.-Kat. Basel 2011, 126-148, bes. 139 f., Kat.-Nr. 18 (K. GeOrgI und G. Dette)

70 Terrier/Wirth 2013, 145 .

71 Hoffmann 2007.

72 STATNiK 2009, $206 \mathrm{f}$.

73 Hoffmann 2007, 79-129, bes. 90-98.

74 SCHOLZ 1992, $108 \mathrm{f}$.

75 Seidel 1996, 188, Anm. 66.

76 SEIDEL 1996, $188 \mathrm{f}$.

77 LÜKEN 2000, 243.

78 ThÜrLEMANN 2002, $70 \mathrm{f}$

79 LÜKEN 2000, 244.

80 KraUSE 2010, 155.

81 Ausst.-Kat. Brügge 2010, 370f., 529, Kat.-Nr. 189 (Matthias WenIGER). - Ausst.-Kat. Basel 2011, 362-365, Kat.-Nr. 99-100 (K. GEORGI).

82 BUCHNER 1955. - WINKLER 1959.

83 WINKLER 1959, 80, 84.

84 Vgl. das Gemälde Maria als Tempeljungfrau im Straßburger Frauenhaus: Ausst.-Kat. München/Berlin 1986, 40 f., bei Kat.-Nr. 25. Ausst.-Kat. Karlsruhe 2001, 57 f., Kat.-Nr. 3 (D. LÜDKE). - Ausst.Kat. Basel 2011, 290-293, Kat.-Nr. 64 (B. BrinkmanN).

85 KÜHNEL 1986/II, 65, 66.

86 LÜKEN 2000, 244

87 Grabar 1966. - Hjort 1968. - Liebrich 1997, $165 \mathrm{f}$.

88 Friedmann 1946. - Roth-Bojadzhiev 1985, 23-30.

89 SimON 2002, 160, 245, Abb. 34. - SAliger 2005, 144-146, Taf. IV.

90 SAliger 2005, 146, erkennt einen Buntfinken und ist unschlüssig, ob er diesen als Genremotiv oder als Hinweis auf das Paradies interpretieren soll.
91 Ausst.-Kat. Brügge 2010, 303, 527, Kat.-Nr. 138 (Anna MorahtFromm/T.-H. Borchert).

92 Bergström 1955, 304. - Grosshans 1980, 200, bei Kat.-Nr. 75.

93 Das Motiv basiert auf einer etwas älteren, ebenfalls von den Visionen der hl. Birgitta von Schweden inspirierten Darstellungstradition, für die sich in einem Prager Stundenbuch (um 1390/95) ein gutes Vergleichsbeispiel findet. Ausst.-Kat. New York 2005, 218-219, Kat.-Nr. 83 (Hana HlaváčKová). - Vgl. auch die roten Seraphim auf einer Tafel des Albrechtsaltars. RöHRIG 1981, 52 f., Taf. 9 .

94 MarCelli 2005, 75-81, 148, 223.

95 Рёснт/Тноss 1990, I, 17-35; II, Abb. 12-41, Taf. II-III.

96 Rohlmann 1994. - Boccardo/Di Fabio 1997. - Ausst.-Kat. Brügge 2002. NUtTAL 2004. - Ausst.-Kat. Florenz 2008. - CHALLEAT 2012.

97 WinKLER 1959, 88-97.

98 Brinkmann/Kemperdick 2002, 226-243, Abb. 200 (B. Brinkmann). -Thürlemann 2002, $208 \mathrm{f}$. - Ausst.-Kat. Brügge 2010, 374-376, 529, Kat.-Nr. 192-196 (T.-H. BORCHERT).

99 Ausst.-Kat. Brügge 2010, 373, 529, Kat.-Nr. 191 (Joshua P. WATERMAN). - Ainsworth/Waterman 2013, 206-210, 315, Kat.-Nr. 49 (J. P. Waterman).

100 Thürlemann 2002, $208 \mathrm{f}$.

101 Zur Deutung solcher Tische als Altar Gotтlieb 1970, 73.

102 Man vergleiche nicht nur die Verkündigungsbilder, sondern auch die kleine Madonna am Kamin in London. Dort erscheint Maria unter einem ähnlichen Blickwinkel in einem Gemach mit Bank und Kleiderstange sowie einer Balkendecke mit Unterzügen. CAmpbell 1998, 83-91. - ThÜrlemann 2002, 327 f., Kat.-Nr. III.F.6b.

103 SAlzer 1893, 26-28, 117. - Vgl. auch die Bezeichnung Mariens als "Schloß, das nie aufgetan ward «. SALZER 1893, 93 f. - Zur Kombination von Porta clausa und Hortus conclusus bei der Mystischen Einhornjagd EInhorn 1998, 477-496. - Pirker-Aurenhammer 2007, 21-24, 37.

104 Goldberg/Scheffler 1972, I, 369-377; II, Abb. 81. - JАкову 1987, 131, Abb. 26.

105 Ausst.-Kat. Colmar 1991, 190f., Kat.-Nr. D29 (Emmanuel STARCKY).

106 CAMpbell 2014, II, 638-645.

107 KÜHNel 1986/II, 66. - UngER 2004, 183-194, Kat.-Nr. 4.2.1. Giltaij/Wolters 2010, Abb. 2

108 Kurth 1923, XI, 6, Abb. 26. - Ausst.-Kat. Paris 2002, 170 f., Kat.-Nr. 70 (É. AntoIne).

109 Vgl. Rogiers Medici-Madonna in Frankfurt. SANDER 1993, 316335, Taf. 23. - Ausst.-Kat. Frankfurt/Berlin 2008, 360-363, Kat.-Nr. 39 (J. SANDER).

110 Kurth 1923, XI.

111 FalKenburg 1994.

112 Schoch/Mende/Scherbaum 2001, 86f., Kat.-Nr. 28 (Rainer $\mathrm{SCHOCH)}$.

$113 \mathrm{Schoch} / \mathrm{Mende} / \mathrm{Scherbaum}$ 2001, 86.

114 Winkler 1959, 51-59. - Gottlieb 1970, 67, Abb. 8. - Algeri 1997, 44 f., Abb. 9, 10. - Borchert 2002, 32, 34. - ThÜrLemanN 2002, 206-210. - RoHLMANN 2007.

115 WINKLER 1959, 67.

116 Salzer 1893, 114, 222-225, 243-248. - Die Perlenkette ist ein sel- 
tenes Motiv in spätgotischen Marienbildern. Vgl. eine Anbetung der Könige im Kölner Wallraf-Richartz-Museum. - BeHLing 1967, Taf. XVI. - Hiller/Vey 1969, 139-141, Kat.-Nr. 354, Abb. 182. 117 Рёснт/Тноss 1990, I, 69-85, bes. 73 und 75; II, Abb. 122, Taf. X.

118 Salzer 1893, 134-140. - Roth-Bojadzhiev 1985, 58 f., 62. Thürlemann 2002, 55, 219 und Anm. 65.

119 Ausst.-Kat. Basel 2011, 242-245, Kat.-Nr. 50 (B. Brinkmann).

120 Gottlieb 1970, 67, negiert die Spiegelung und meint, dass der Vogel ins Wasser des Lebens eintauche; symbolisiert werden solle die Rettung der menschlichen Seele durch die Ankunft Christi.

121 Rohlmann 2007, $35 \mathrm{f}$
122 Ausst.-Kat. Brescia 2003, 126 f., Kat.-Nr. 20 (Massimiliano CALDERA).

123 Schon der Münchener Maler Gabriel Angler, der Meister der Tegernseer Tabula magna, begab sich vor dem 21. Februar 1434 dorthin, um »varb und lasür« einzukaufen. MöHRING 1997, 14.

124 Pallucchini 1962, 50 f., 126, Kat.-Nr. 197, Abb. 197.

125 Lightbrown 2004, 322-344.

126 Geroni 1996. - SANDer 2004, 63-65.

127 Liebrich 1997, 161-167. - Lightbrown 2004, 333-344.

128 Degler 2015, 80-86, Taf. VI, VII. 
Tafelteil 



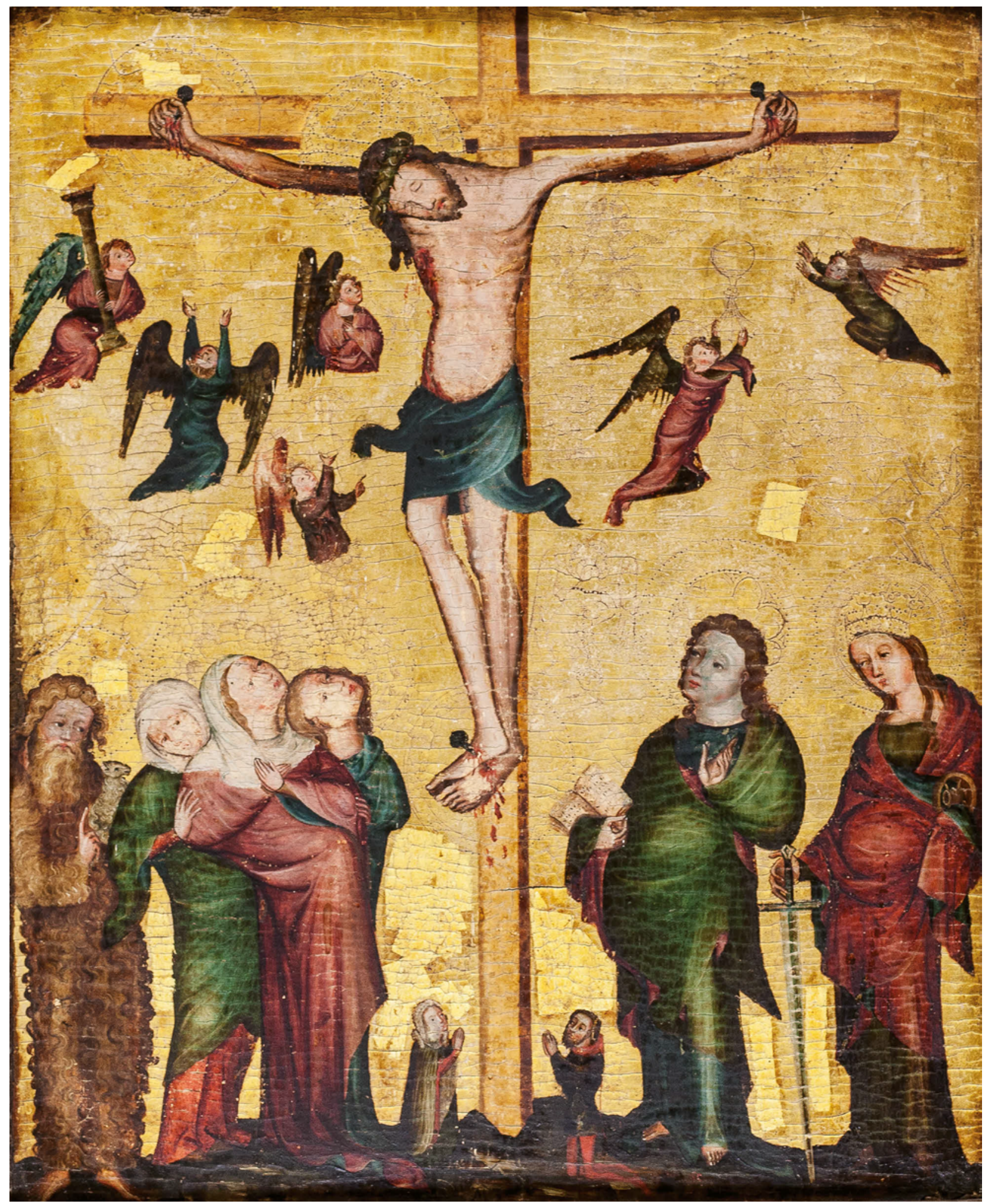

Taf. I Kreuzigung Christi. Franken, um 1370/80. Worms, Museum der Stadt Worms im Andreasstift (Foto: Norbert Seilheimer / Stadtarchiv Worms) 


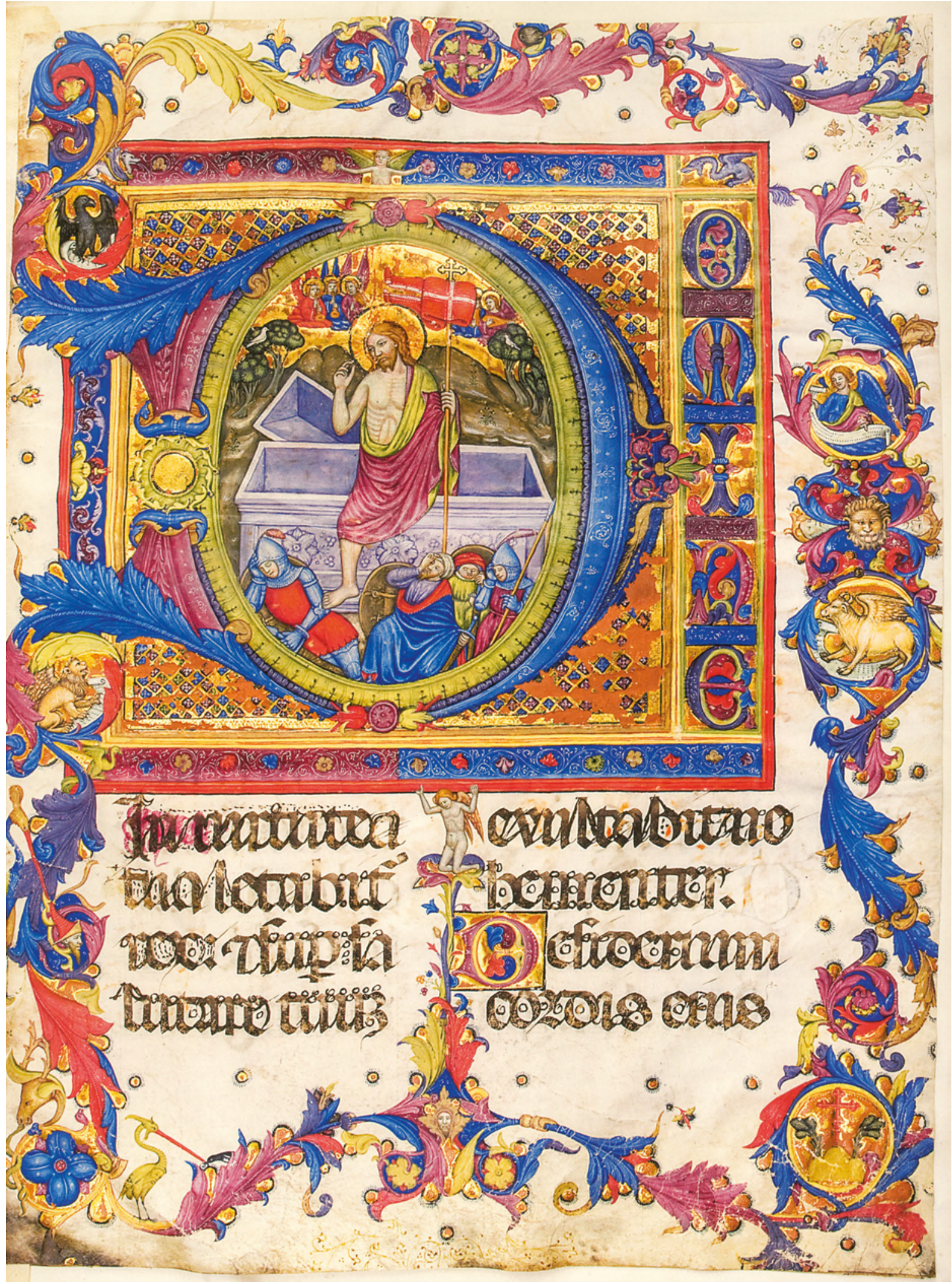

Taf. II Detached leaf with the Resurrection. Toledo, Biblioteca Capitular, Ms. 39.1, f. 69r (Foto: Toledo, Biblioteca Capitular) 


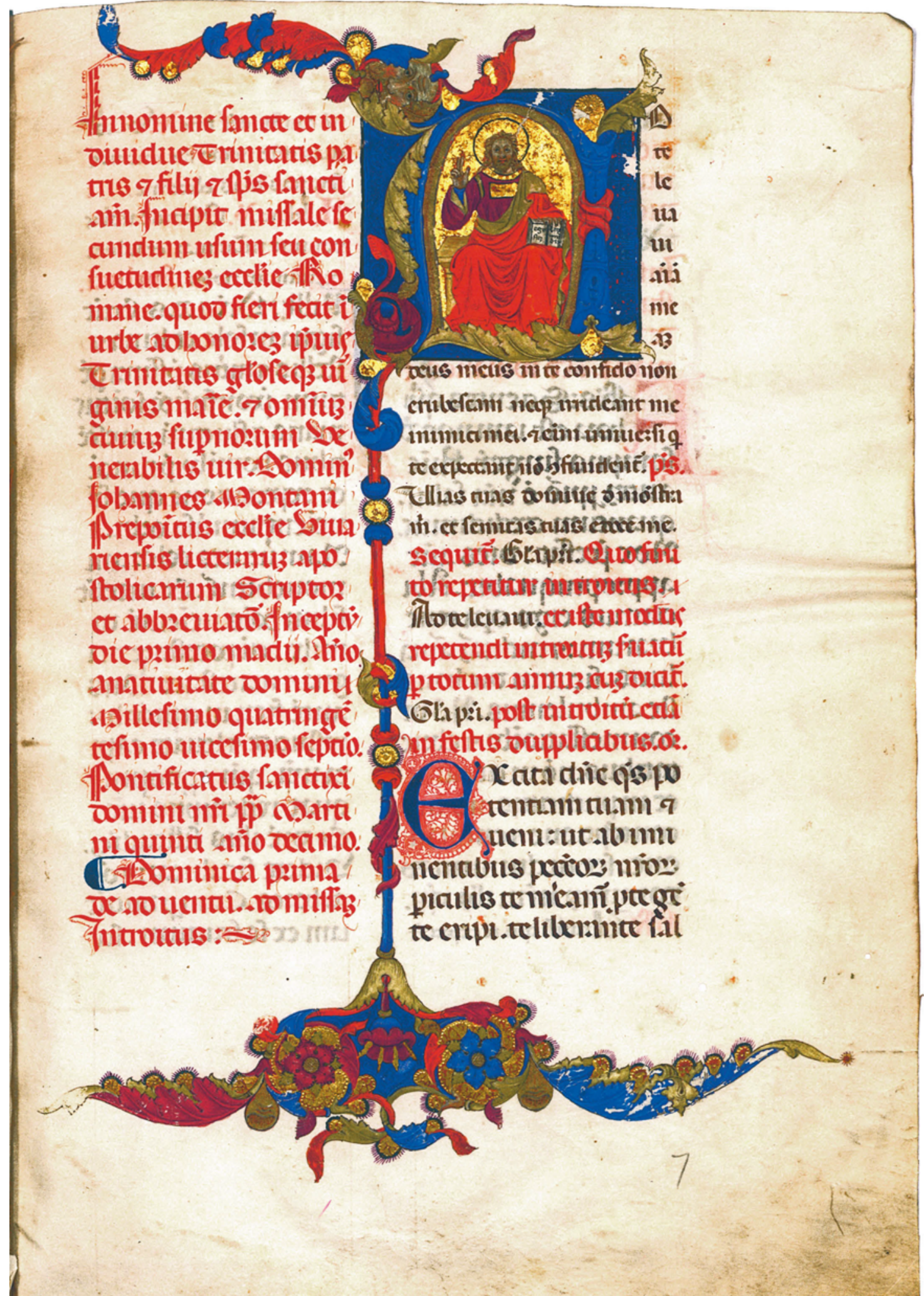

Taf. III Lord enthroned. Missal of Johannes Montanus, f. 7r. Città del Vaticano, Vatican Library, Arch. Cap. S. Pietro B.65 (Foto: Città del Vaticano, Biblioteca Apostolica Vaticana) 


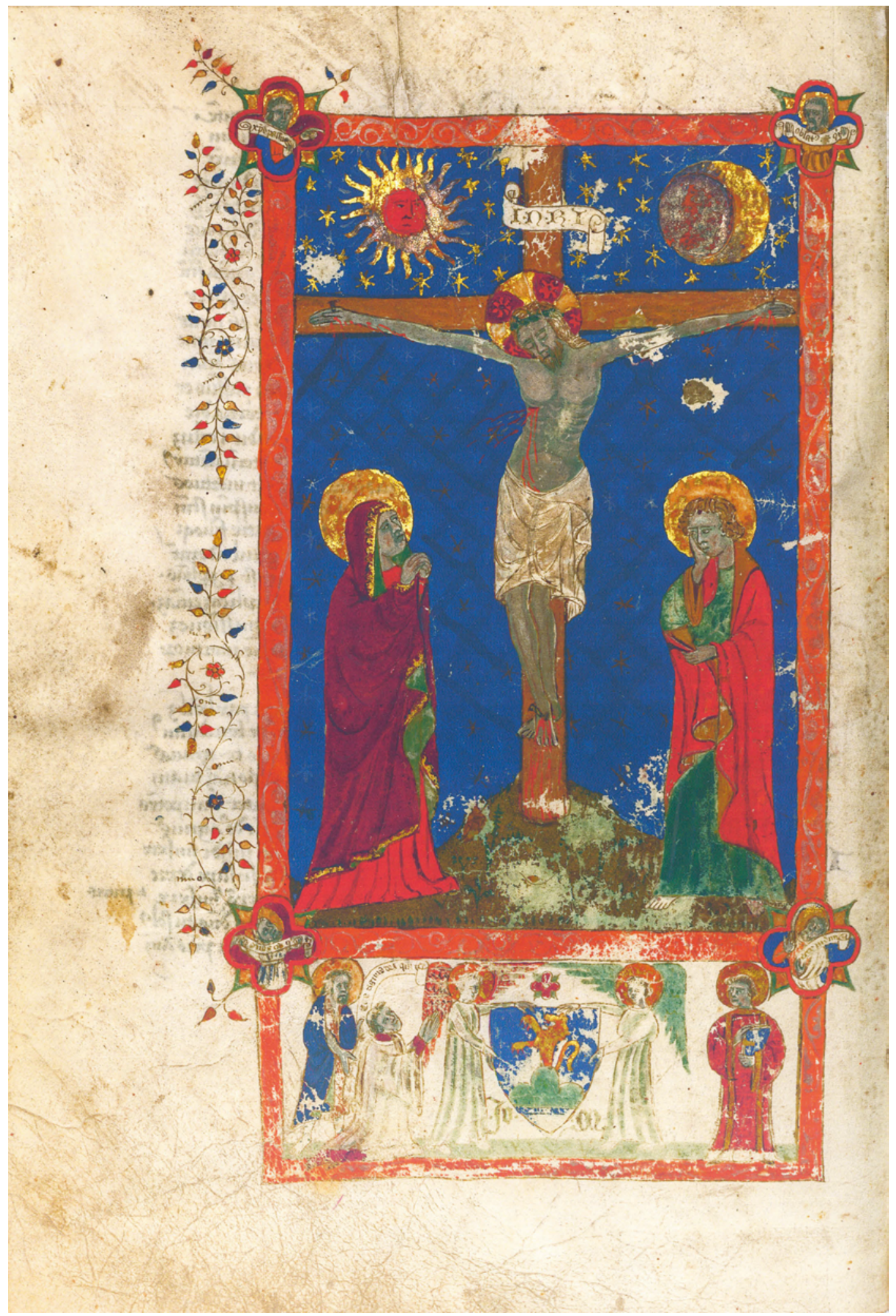

Taf. IV Crucifixion. Missal of Johannes Montanus, f. 148v. Città del Vaticano, Vatican Library, Arch. Cap. S. Pietro B.65 (Foto: Città del Vaticano, Biblioteca Apostolica Vaticana) 


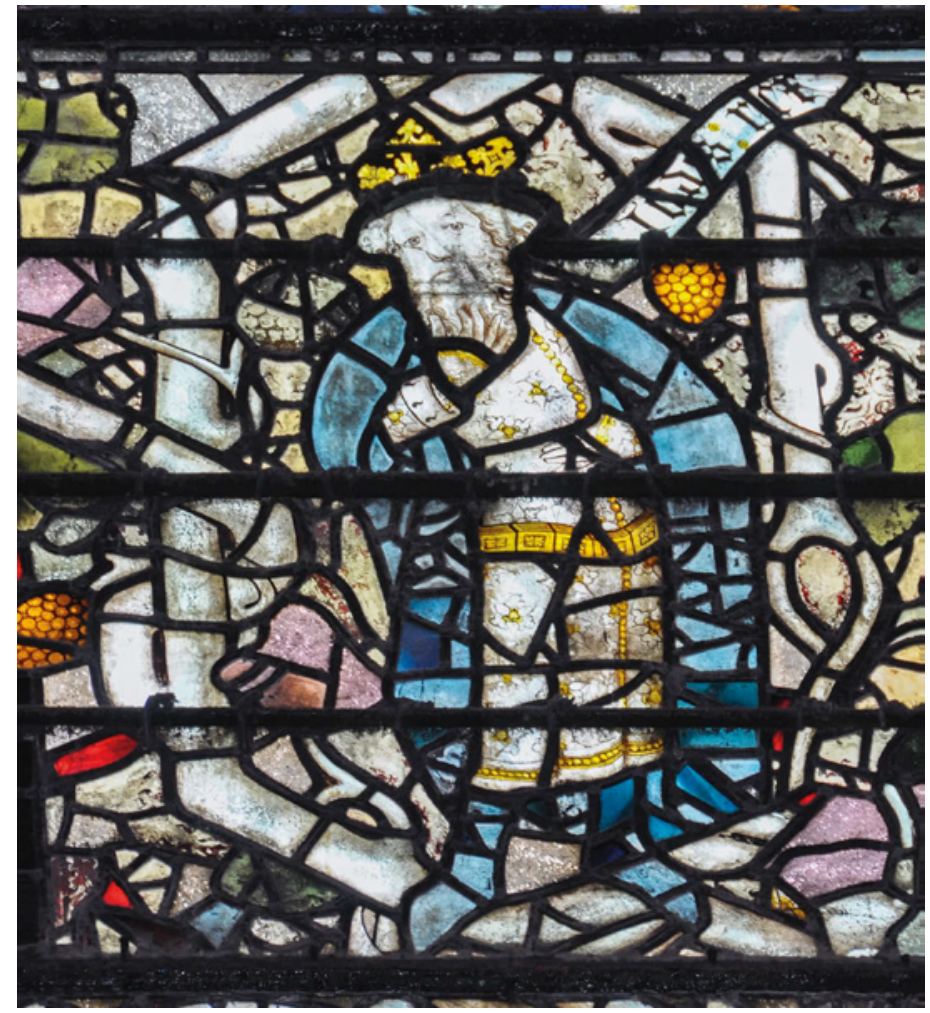

Taf. V.a loas. Fragment des Westfensters der Kapelle von New College, Oxford. York, Kathedrale, sVII (Foto: Veronika Decker)

Taf. V.b Jeconias. Fragment des Ostfensters der Kapelle von Winchester College. Winchester College, Fromond-Kapelle (Foto: V. Decker)

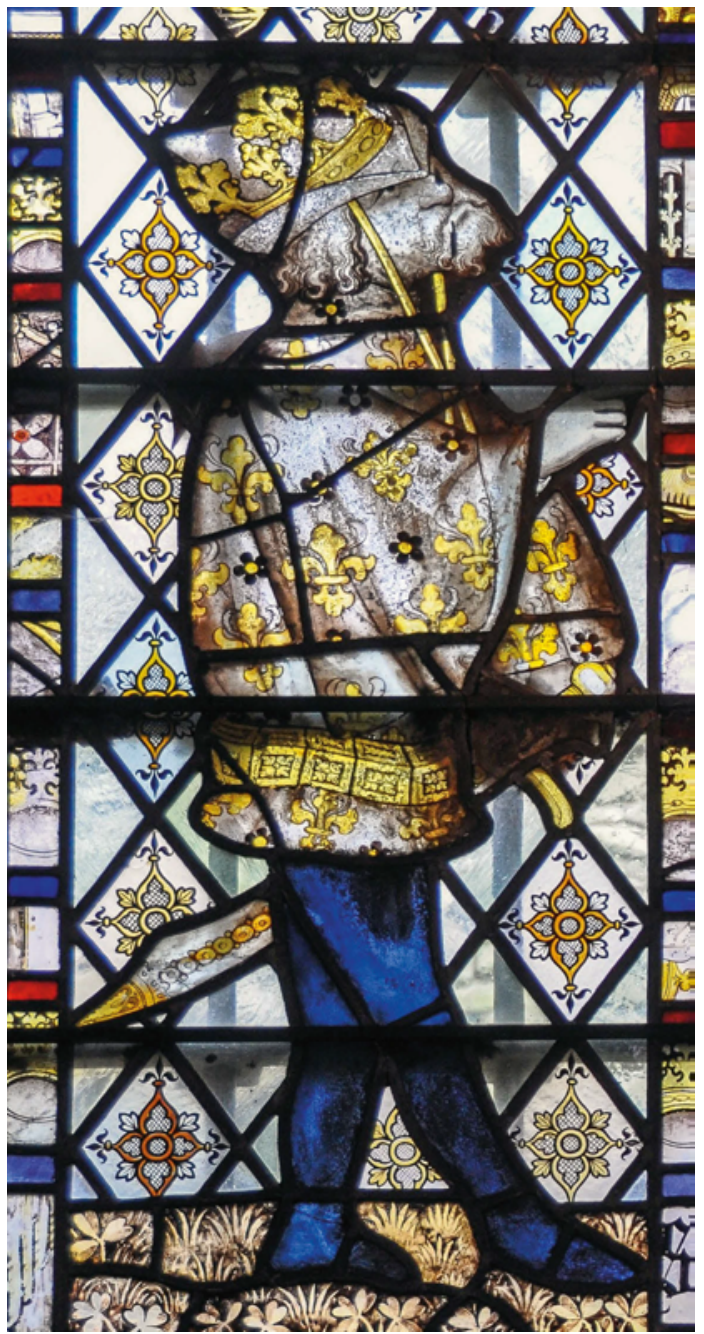




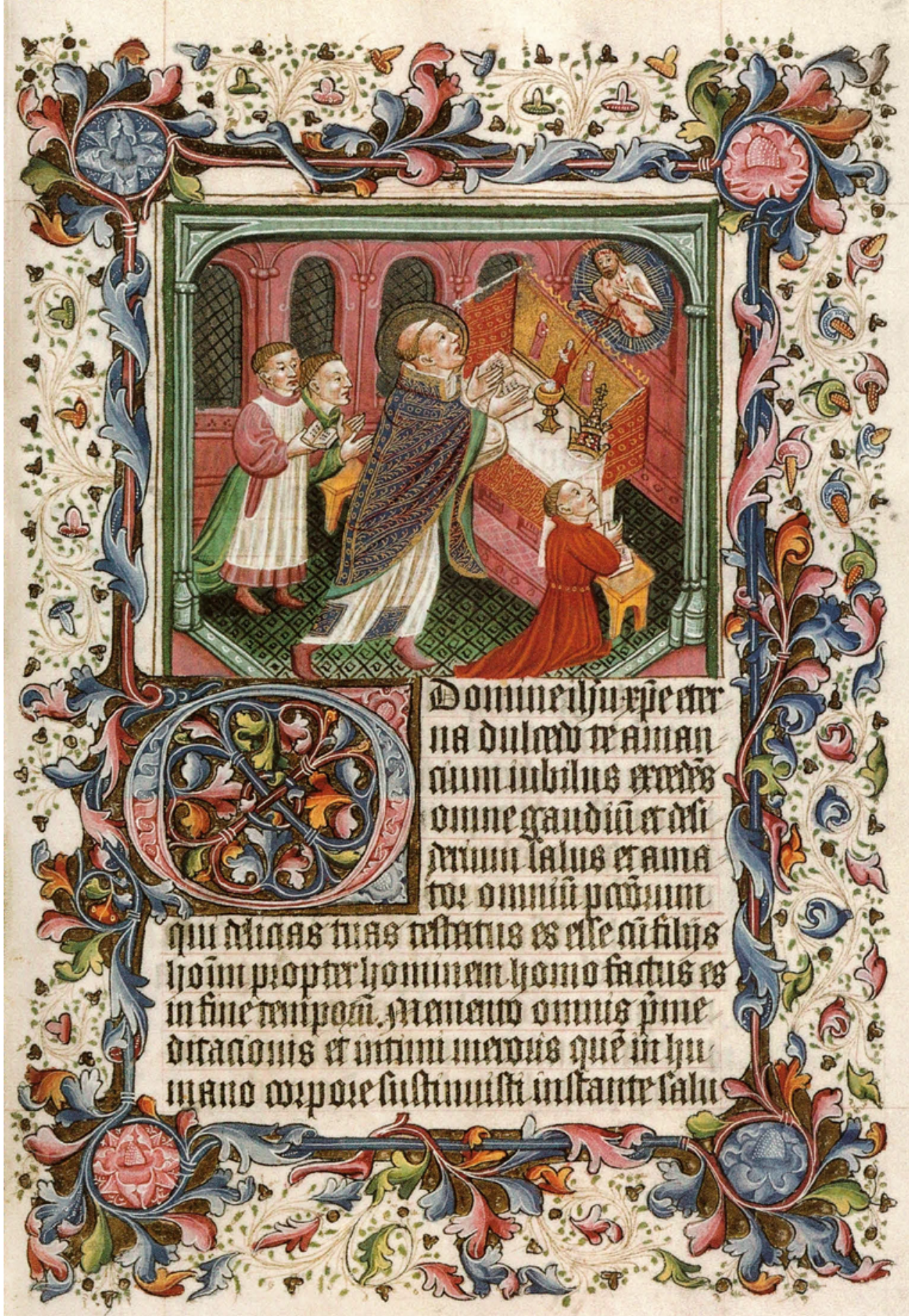

Taf. VI Gregorsmesse. Gebetbuch, wohl von Richard Beauchamp für seinen Sohn Henry in Auftrag gegeben. New York, Pierpont Morgan Library, MS M. 893, fol. 106r (ex: Ausst.-Kat. London 2003, 227, Kat.-Nr. 91) 


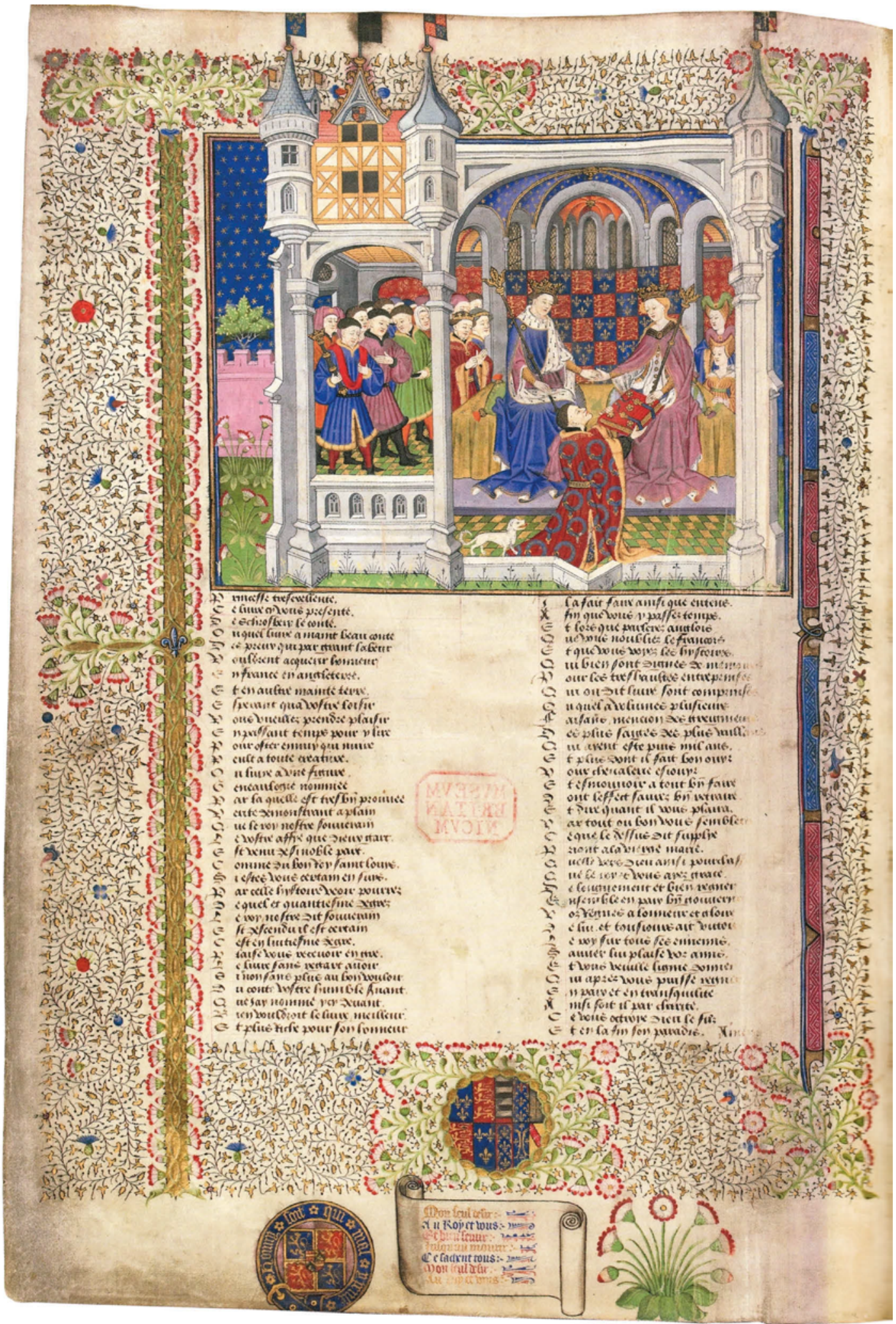

Taf. VII Shrewsbury Book, Widmungsseite links. London, British Library, Royal MS 15 E VI, fol. 2v (Foto: (C) The British Library Board) 


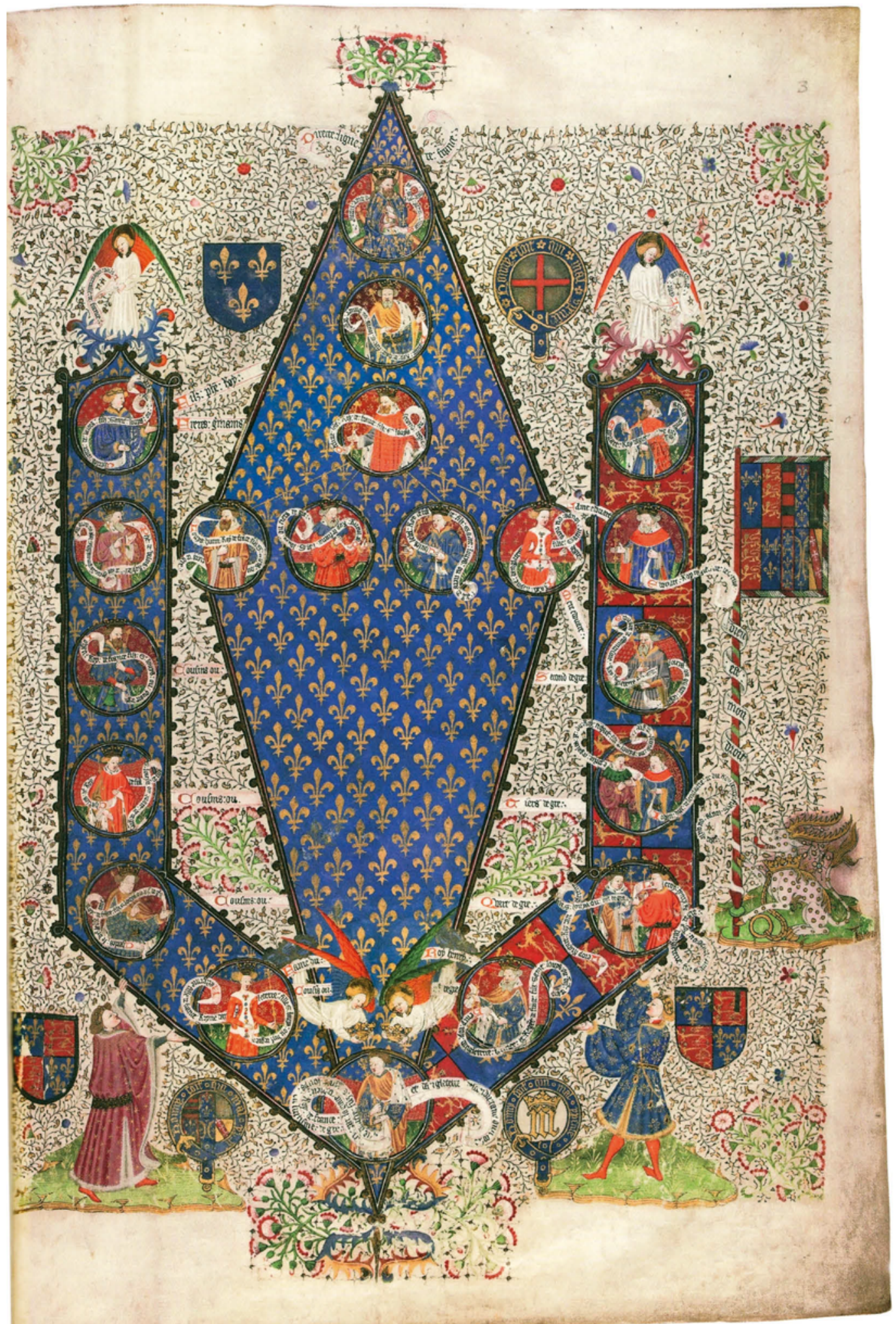

Taf. VIII Shrewsbury Book, Widmungsseite rechts. London, British Library, Royal MS 15 E VI, fol. 3 r

(Foto: (C) The British Library Board) 


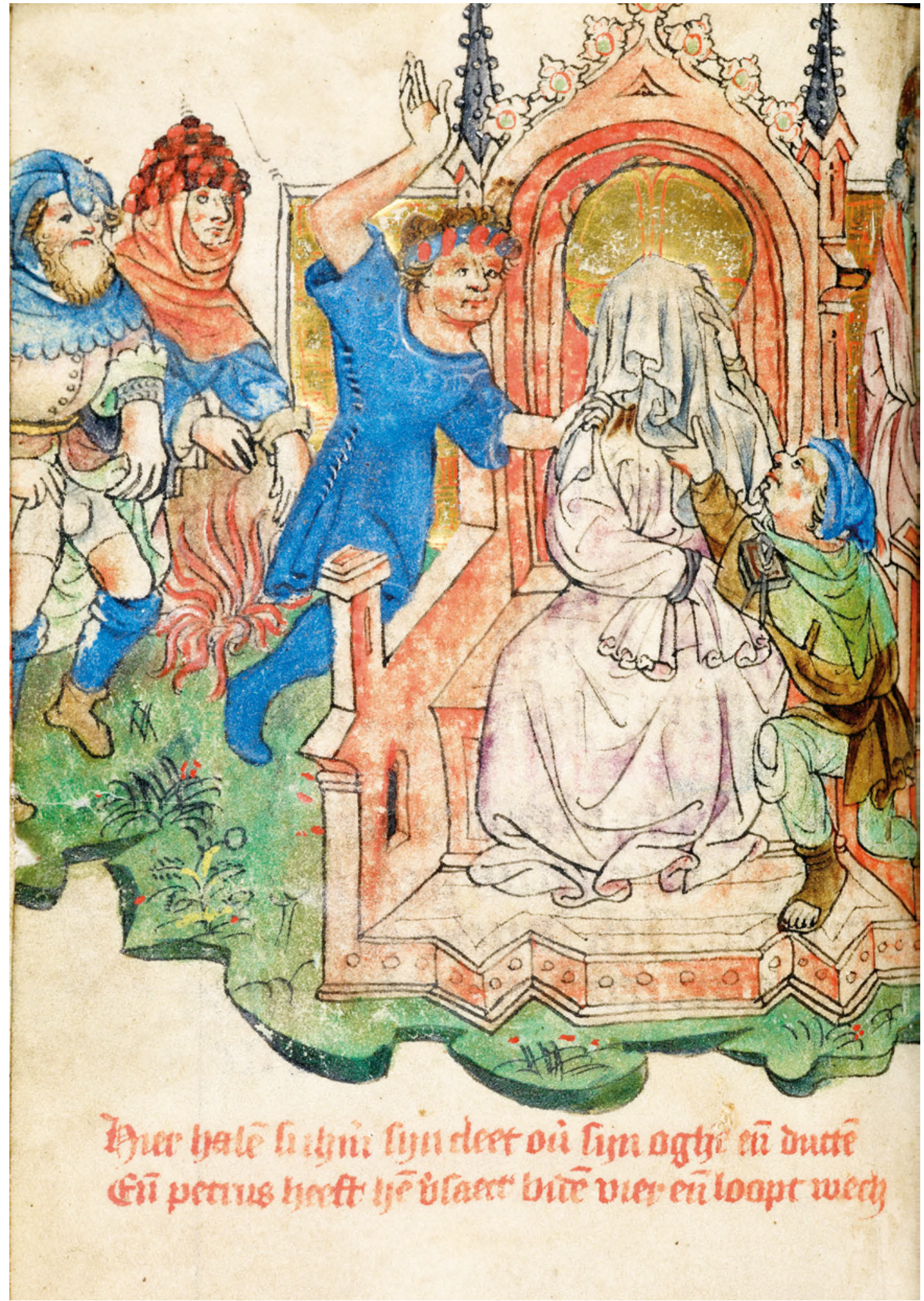

Taf. IX Verspottung Christi. Meister des Morgan-Kindheitszyklus, um 1420. London, The British Library, Add. 50005, fol. 92V (Foto: ๑ The British Library Board) 


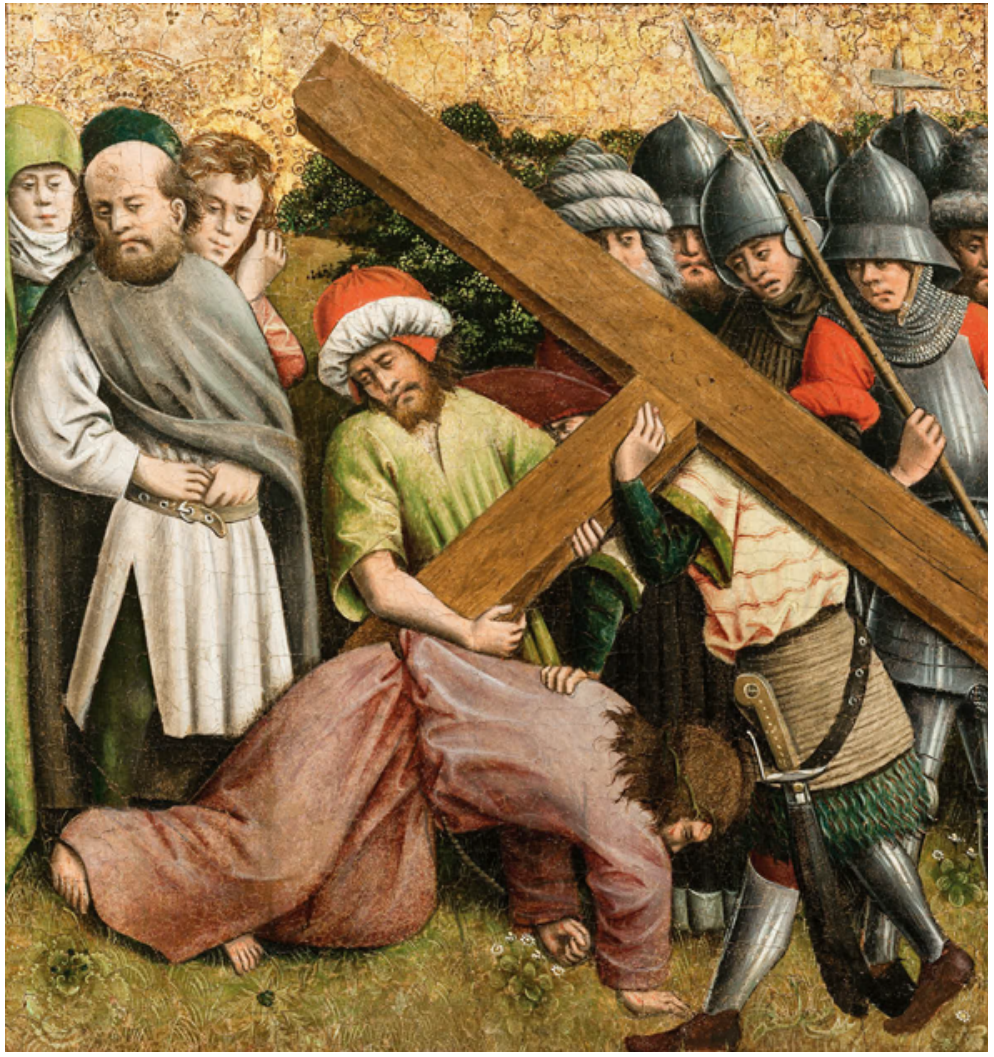

Taf. X.a Der Fall Christi unter dem Kreuz. Flügelszene des sog. Schlägl-Altars. Westfalen, um 1440/50. The Cleveland Museum of Art, Mr. and Mrs. William H. Marlatt Fund 1951.453C (Foto: ๑ The Cleveland Museum of Art)

Taf. X.b Kreuztragung Christi. Flügelszene des sog. Schlägl-Altars. Westfalen, um 1440/50. The Cleveland Museum of Art, Mr. and Mrs. William H. Marlatt Fund 1951.453C (Foto: ๑ The Cleveland Museum of Art)

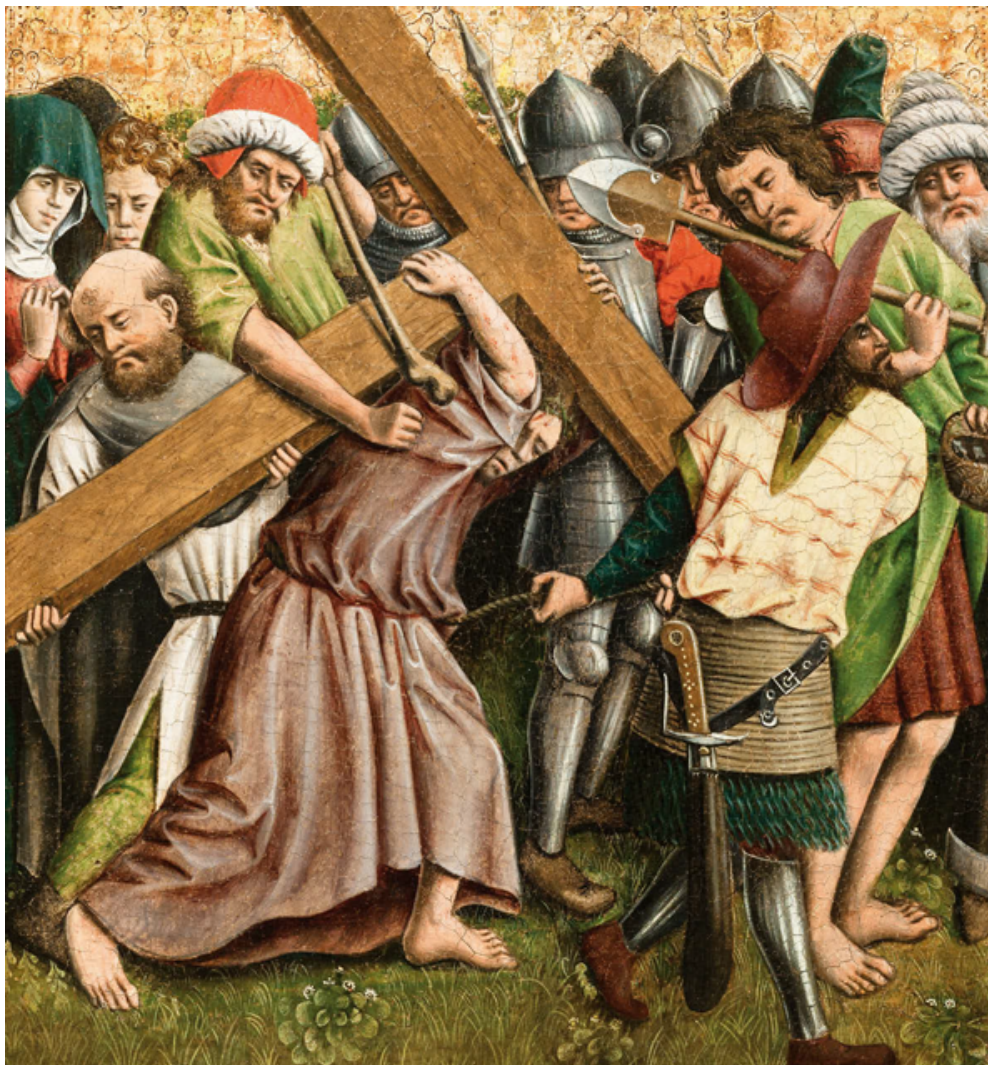



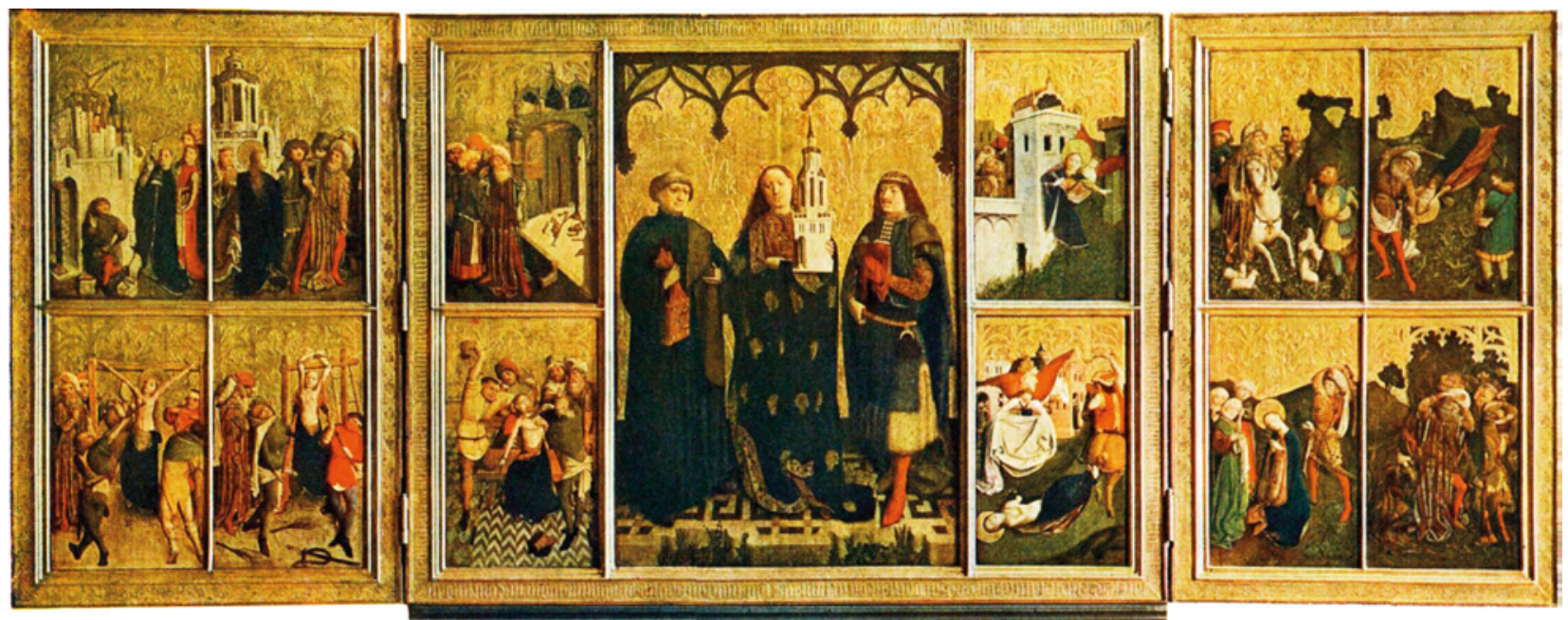

Taf. XI.a Festtagsseite des Breslauer Barbararetabels mit der Legende der hl. Barbara und den drei Patronen der Barbarakirche im Zentrum (Barbara, Felix und Adauctus). 1447. Warschau, Muzeum Narodowe w Warszawie (Foto: BRAUNE/HAHM 1923/24, I, Taf. 23)

Taf. XI.b Dioskuros mit Begleitern vor einem heidnischen Tempel, Festtagsseite des Breslauer Barbararetabels. 1447. Warschau, Muzeum Narodowe w Warszawie (Foto: Adam S. Labuda)

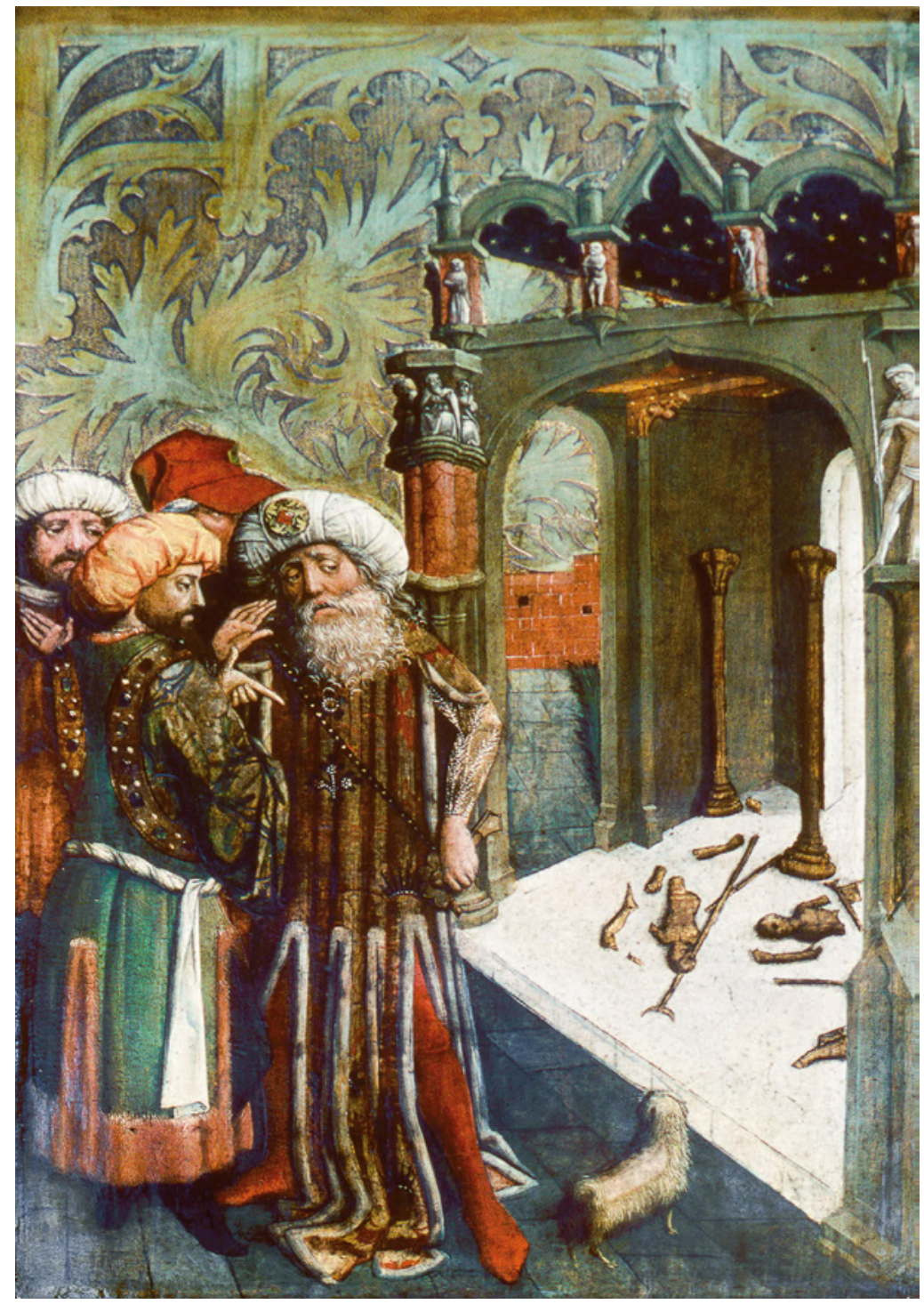




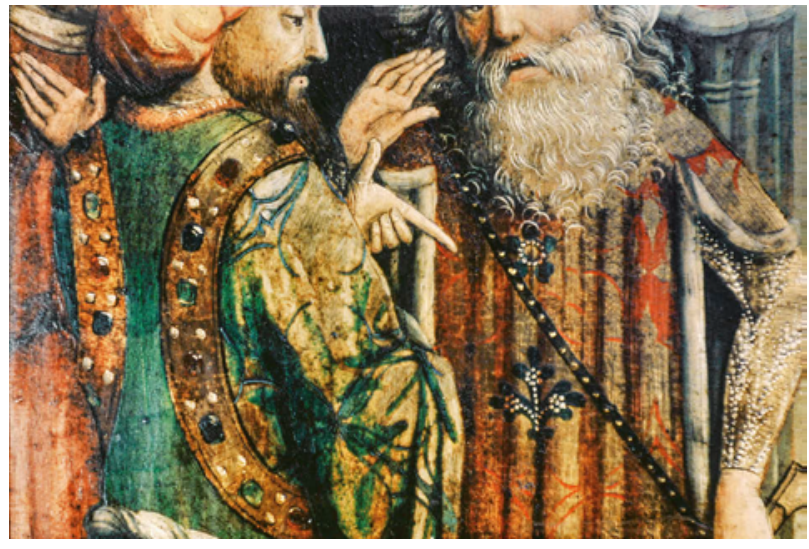

Taf. XII.a Festtagsseite des Breslauer Barbararetabels, Malfarbe über der Metallfolie der Textil-Ornamente. Technische Analyse von Krzysztof Chmielewski (ex: CHMIELEWSKI 2001)

Taf. XII.b Jacobus d. Ä. und Hermogenes, Vorderseite der einzigen vom ehemaligen Hochaltarretabel der Neißer Jakobskirche erhaltenen Tafel. Breslau, Muzeum Archidiecezjalne (ex: CHMIELEWSKI 2001, II, Abb. 88)

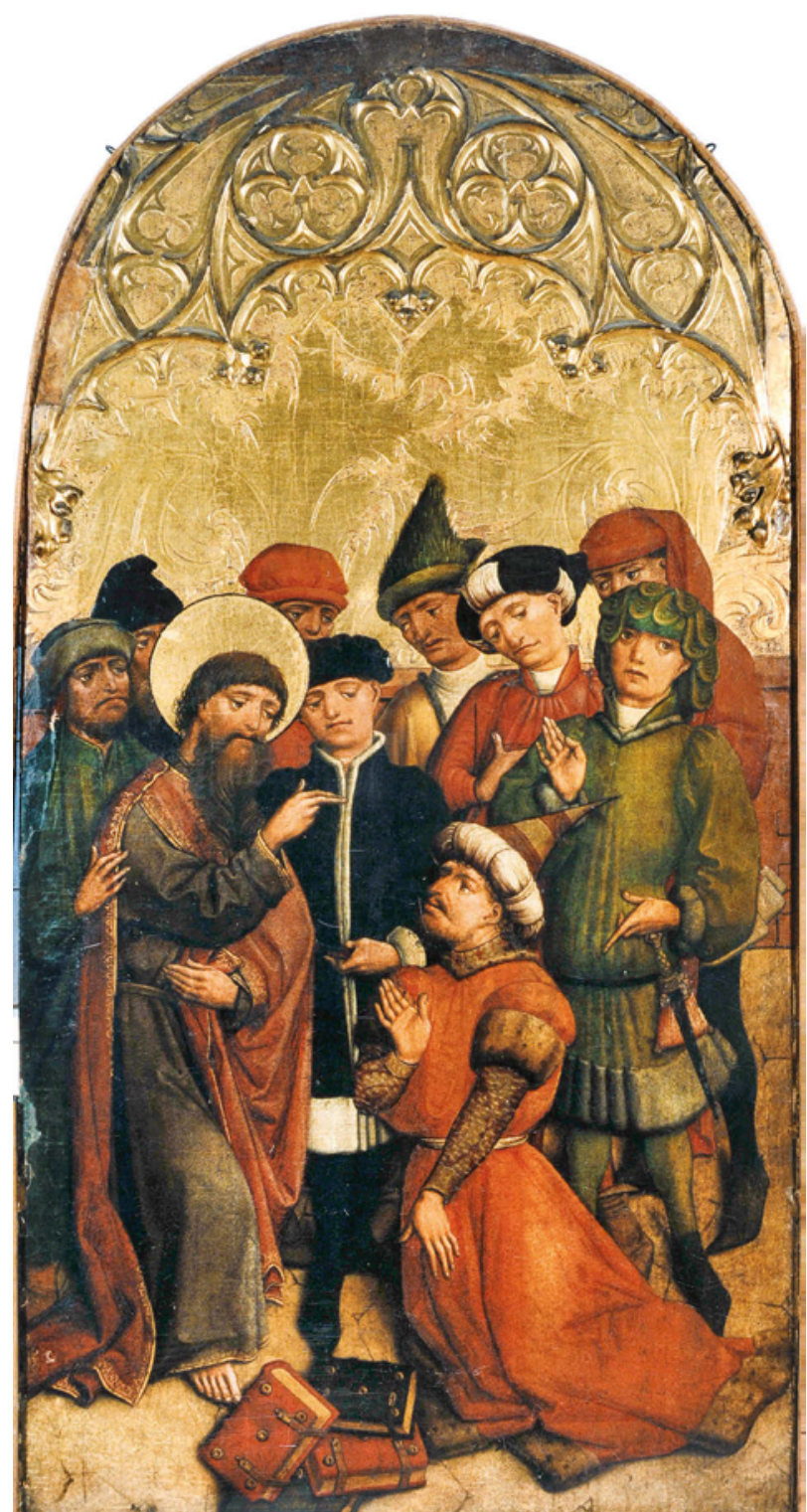




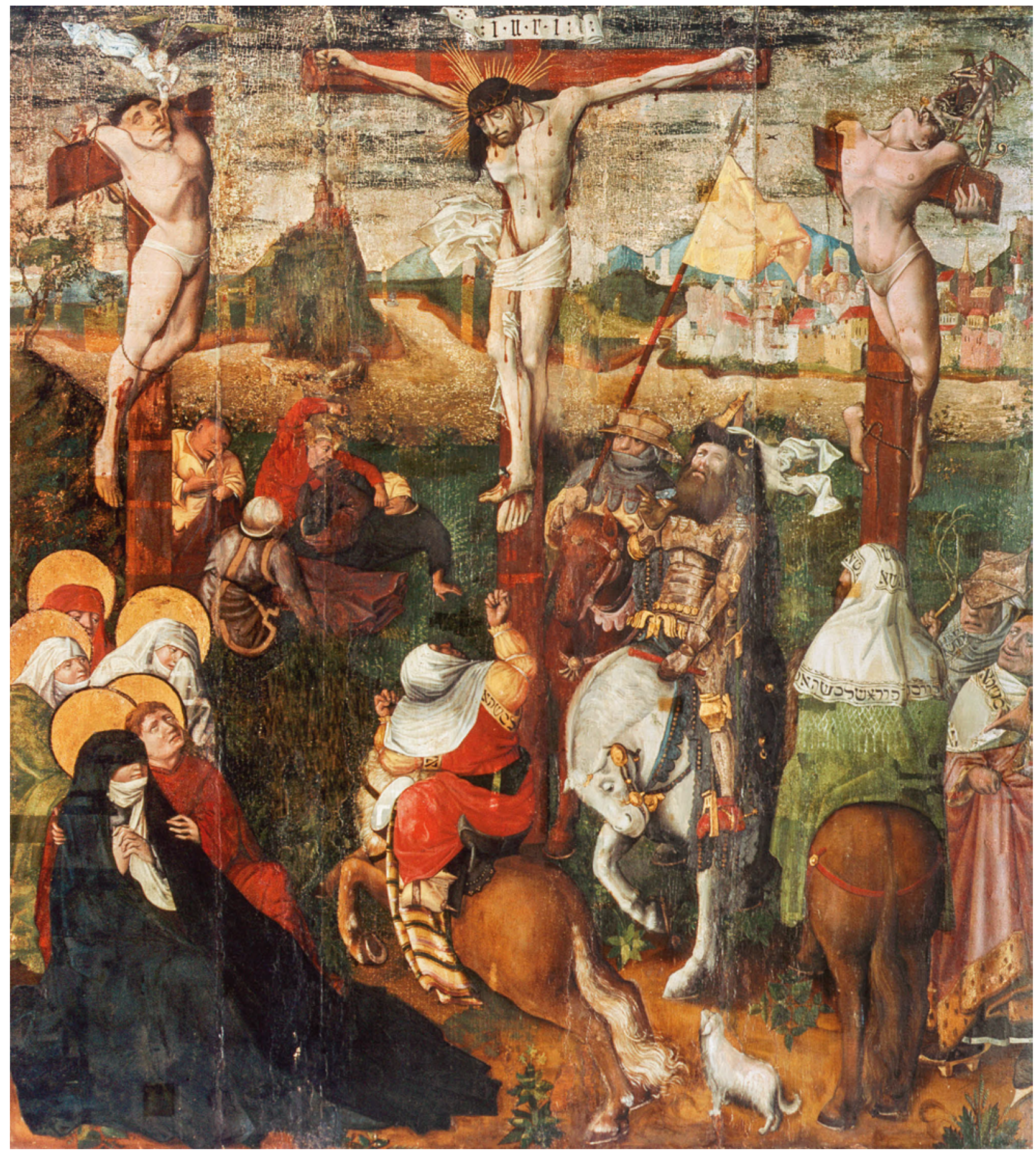

Taf. XIII Kreuzigungsretabel aus Heidau (Gać Śląska), Mitteltafel. Warschau, Muzeum Narodowe w Warszawie (Foto: Muzeum Narodowe w Warszawie) 


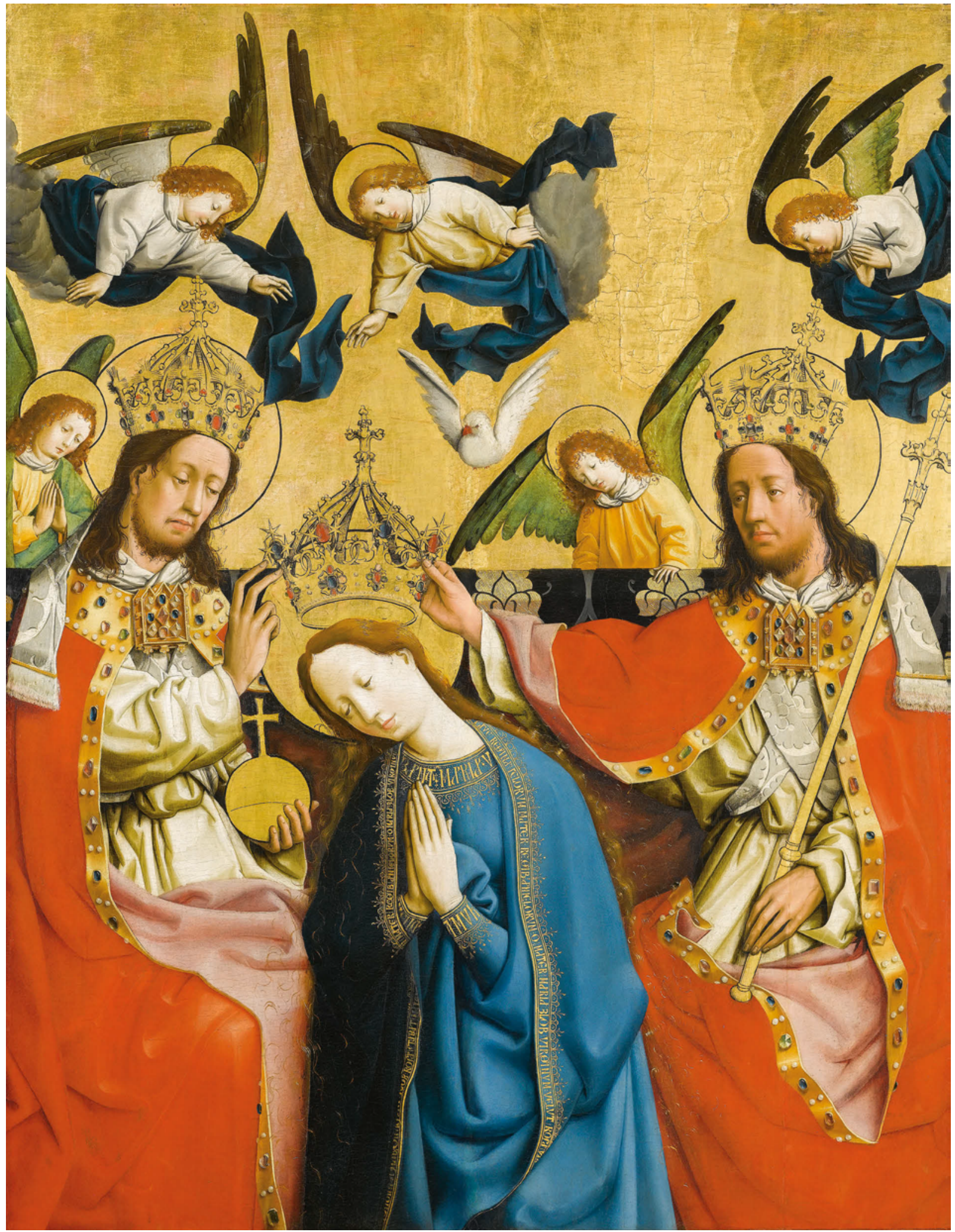

Taf. XIV Fragment der Krönung Mariens. Meister von Schloss Lichtenstein, um 1450. Stuttgart, Staatsgalerie, Inv.-Nr. L 1191 (Foto: Staatsgalerie Stuttgart) 


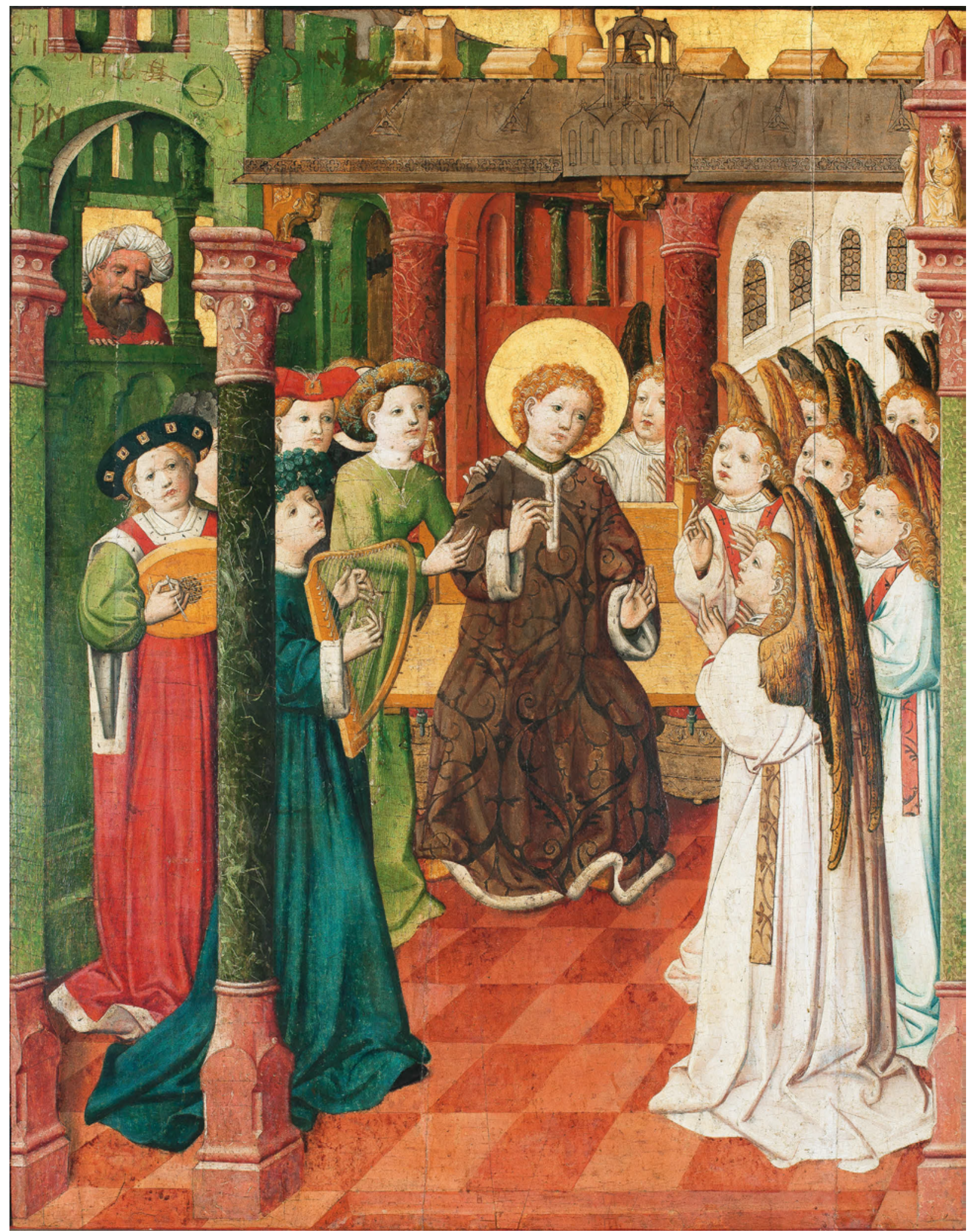

Taf. XV Versuchung des hl. Vitus. Oberrheinischer oder schwäbischer Maler, um 1440/50. Warschau, Muzeum Narodowe w Warszawie, Inv.-Nr. 82/1 (Foto: Muzeum Narodowe w Warszawie) 


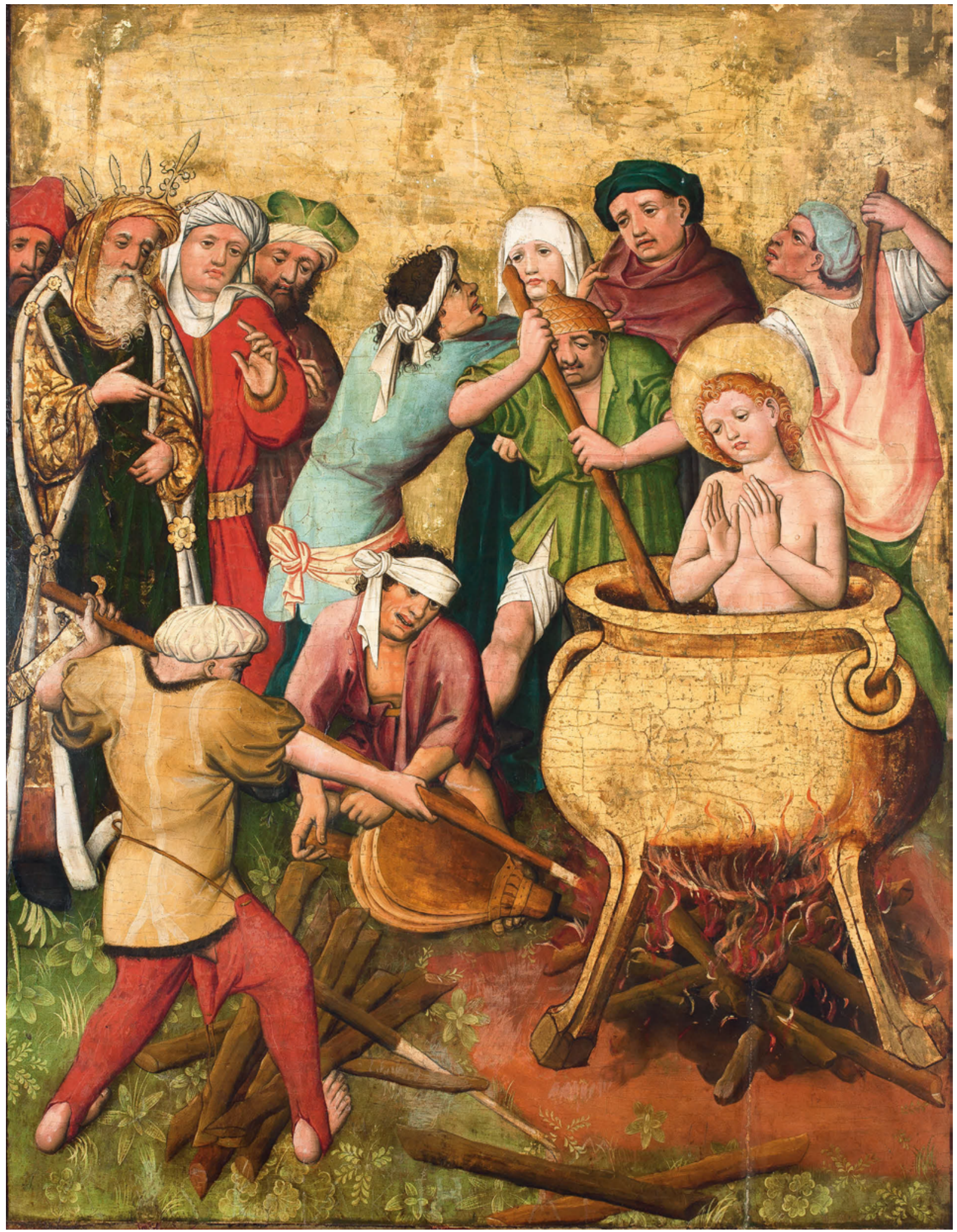

Taf. XVI Kesselmarter des hl. Vitus. Oberrheinischer oder schwäbischer Maler, um 1440/50. Warschau, Muzeum Narodowe, Inv.-Nr. $82 / 2$ (Foto: Muzeum Narodowe w Warszawie) 

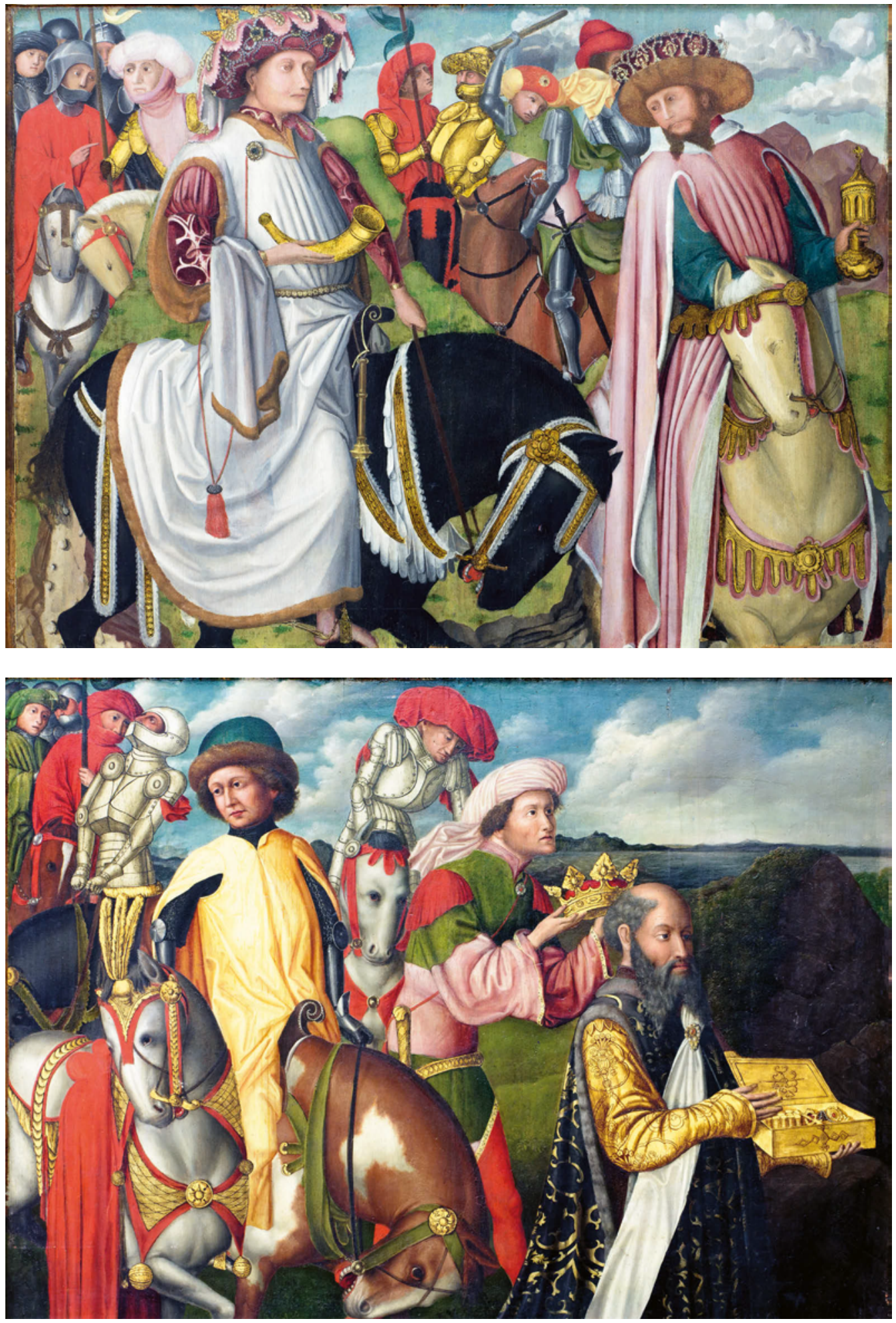

Taf. XVII.a Anbetung der Könige aus Höchstädt/Donau. Augsburger Meister (?). Freising, Diözesanmuseum (Foto: Rainer A. Gimmel, Regensburg)

Taf. XVII.b Anbetung der Könige aus Höchstädt/Donau. Augsburger Meister (?). Freising, Diözesanmuseum (Foto: R. A. Gimmel) 


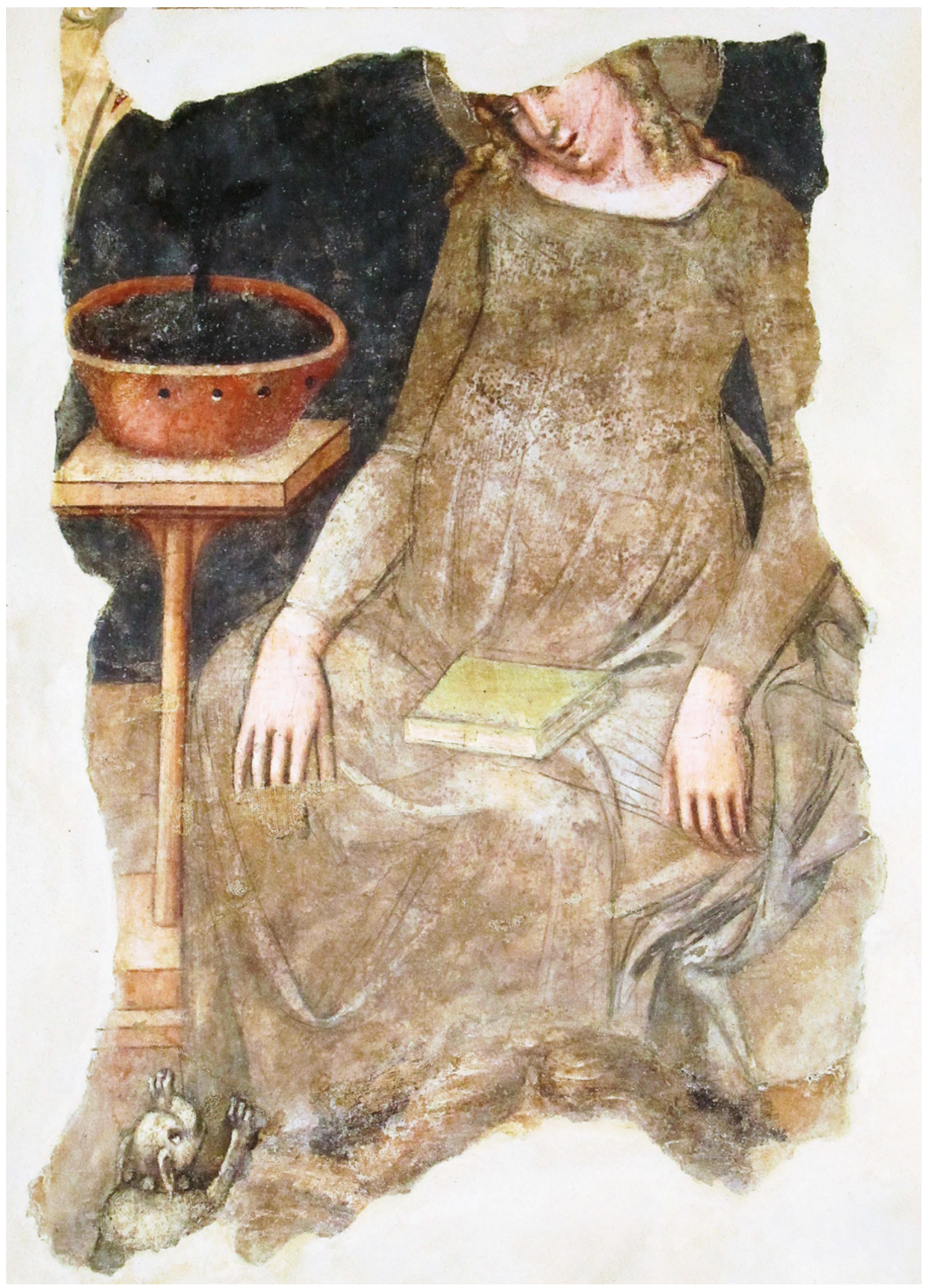

Taf. XVIII Madonna gravida. Simone di Filippo. Bologna, S. Maria dei Servi (Foto: Ulrich Söding) 


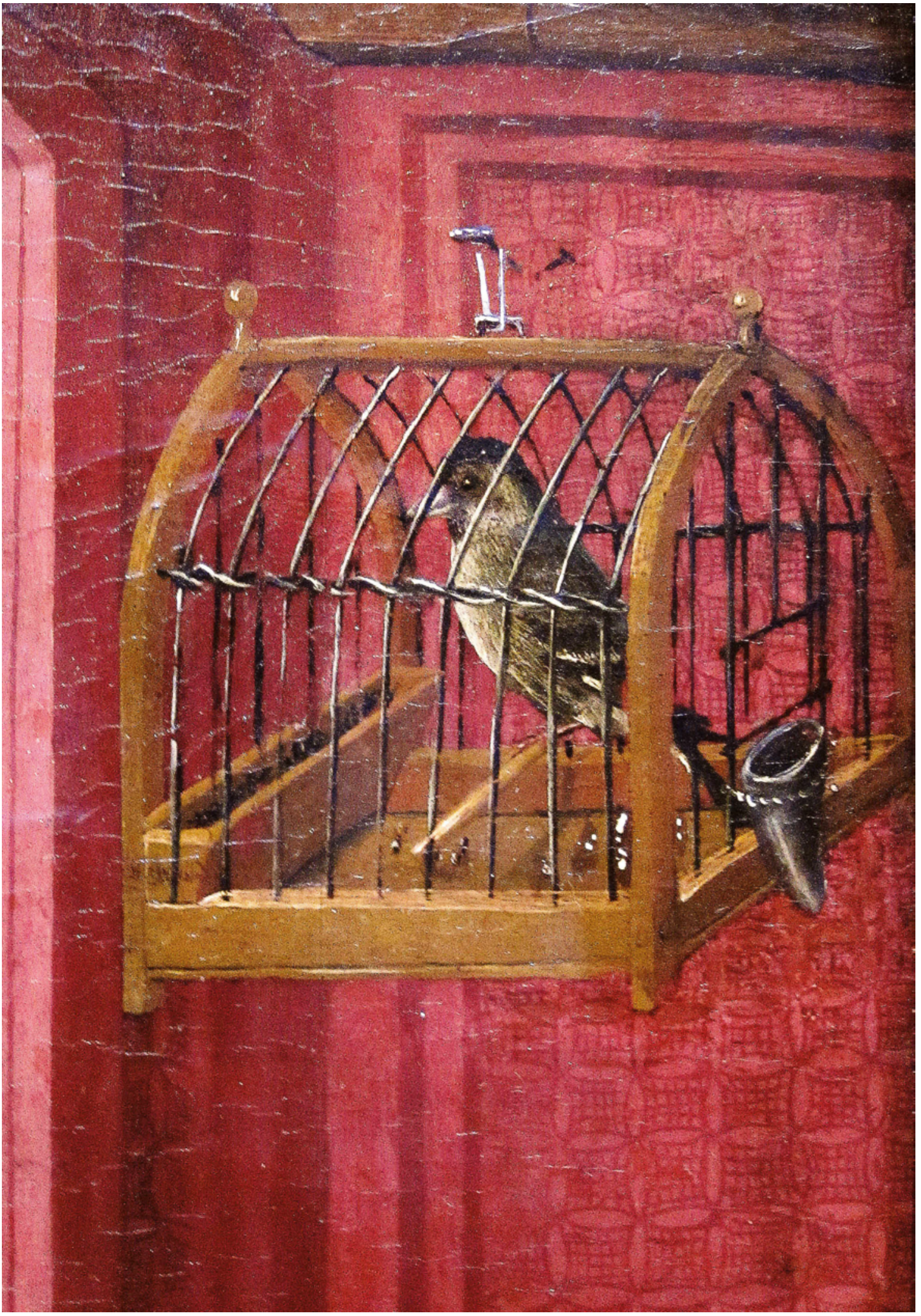

Taf. XIX Vogelbauer in der Verkündigung an Maria. Meister der Münchener Marientafeln. Zürich, Kunsthaus (Foto: U. Söding) 


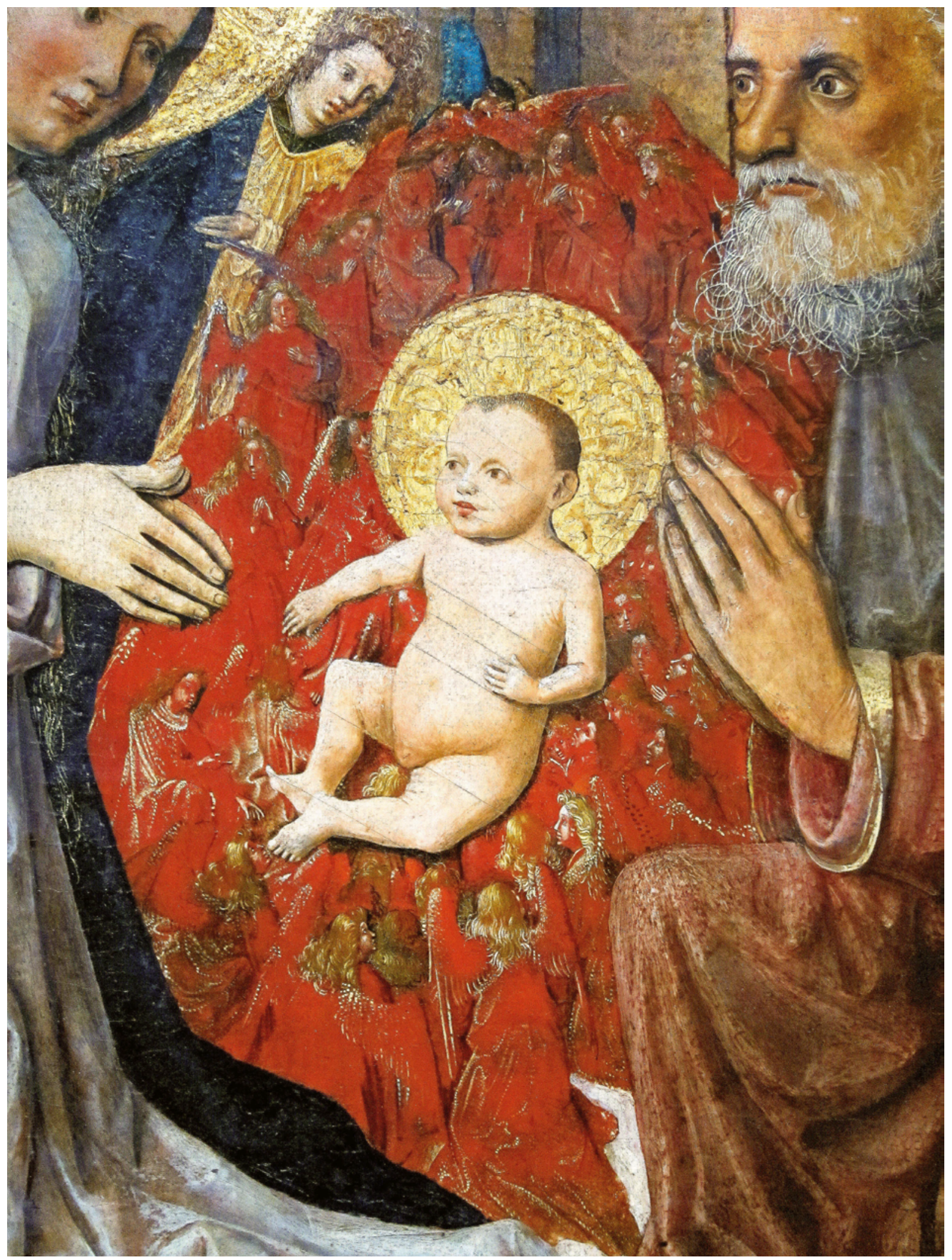

Taf. XX Geburt Christi, Detail. Meister der Münchener Marientafeln. Zürich, Kunsthaus (Foto: U. Söding) 


\section{REGISTER}

\section{Abkürzungen}

Ä. $=$ Ältere. - Bf. $=$ Bischof. - d. $=$ der $/$ des. - dt. $=$ deutsch. - Gem. $=$ Gemahlin. - gen. = genannt. - Gf. $=$ Graf. - Gf.in $=$ Gräfin - J. = Jün gere. - Ebf. = Erzbischof. - Erzhg. $=$ Erzherzog. - Hg. = Herzog. Hg.in = Herzogin. - Inv.-Nr. = Inventarnummer. - Kf. = Kurfürst. Kg. = König. - Kg.in = Königin. - kgl. = königlich. - Ks. = Kaiser. Landgf. $=$ Landgraf. $-\mathrm{m} .=$ mit. - Mkgf. $=$ Markgraf. - o. $=$ oder. Pfalzgf. $=$ Pfalzgraf. - röm. $=$ römisch. - Sign. $=$ Signatur. - u. $=$ und. Verf. $=$ Verfasser. $-\mathrm{v} .=$ von .

\section{Personen}

\section{A}

Acciaiuoli, Angelo, d. J. (1340-1408), Kardinal u. Bf. v. Florenz 120, 144

Adolf I. von Nassau (1353-90), Bf. v. Speyer (1371-88) u. Ebf. v. Mainz (seit 1381) 55, 66

Alasaud, Jaume, Steinmetz 106

Alberti, Leon Battista (1404-72), Architekt, Humanist, Schriftsteller,

Kunst- u. Architekturtheoretiker 270

Albrecht VI. (1418-63), Erzhg. v. Österreich 299-304, 306, 311, 313

Alighieri, Dante (1265-1321), Dichter u. Philosoph 217

Altdorfer, Albrecht (um 1480-1538), Maler u. Baumeister 70

Alwig von Sulz (um 1530-72), Gf. v. Sulz 350, 359

Aman, Jörg (um 1450-1514/15), Maler in Augsburg 318, 321, 323

Amedeo di Saluzzo (1361-1419), Kardinal 217

Ameihl, Pierre ( $†$ 1389), Kardinal 108f., 115

Ammann, Jost (1539-91), Zeichner, Kupferstecher, Maler u. Autor $378,380,383-385$

André von Paris, Maler 303

Andrea di Michele di Francesco di Cione, gen. Il Verrocchio (1435-88),

Bildhauer, Maler und Goldschmied 120

Androin de la Roche († 1369), Kardinal u. Abt v. Cluny 97

Angler, Gabriel (ca. 1404-83), Maler in München 237, 328, 394

Anna von Braunschweig (ca. 1390-1432), zweite Gem. $\rightarrow$ Friedrichs IV. v. Tirol 306

Anna von Schweidnitz (1339-62), dritte Gem. $\rightarrow$ Ks. Karls IV. 59

Anne de Beauchamp (1426-92), 16th Countess of Warwick 180

Antonio Isimbardi da Milano (lat. Antonius de Ysimbardis de Medio-

lano), Maler u. Buchmaler 138 f.

Arnaud de Via († 1335), Kardinal 92

Aubert, Etienne († 1369), Kardinal 92

Autor d. Chronik "Gesta Henrici Quinti” 205, 212, 215, 224

Aycelin, Hugues (Seguin de Billom; † 1297), Franziskaner 121

Baldemar von Petterweil (ca. 1320-82/83), Frankfurter Kanoniker 70 Basler Chronist 206, 208, 218, 224, 227

Barbara von Cilli ( $\uparrow 1451)$, zweite Gem. $\rightarrow$ Ks. Sigismunds 208

Barthélemy d'Eyck († 1476), Maler 372

Battista di Biagio Sanguigni (1393-1451), Maler 138, 145

Beaufort, Henry (ca. 1375-1447), Bf. v. Winchester u. Kardinal 17of., 202, 204f., 208, 211, 217
Beauneveu, André (ca. 1335-1400), Maler u. Bildhauer 70

Becket, Thomas (1118-70), Hl., Lordkanzler u. Ebf. v. Canterbury (seit 1162) 206, 216

Benedikt XII. (Jacobus Novelli, 1285-1342), Papst (seit 1334) 90

Benedikt XIII. (Pedro Martínez de Luna y Pérez de Gotor, 1328-1423), avignonesischer Gegenpapst (seit 1377) 89-92, 94, 97f., 102f., 107, 110, 119, 129-131, 143f., 205

Berengarius, avignonesischer Steinmetz 101, 106

Bernhard de Brocas (1330-95), Kommandeur 190

Bernhard von Clairvaux (ca. 1090-1153), Hl., Abt v. Clairvaux, Prediger u. Mystiker 264

Bertram von Minden (ca. 1345-1415), Maler in Hamburg 243f., 339

Bertrand de Deaux ( $†$ 1355), Kardinal 106, 113

Birgitta von Schweden (1303-73), Hl. (1391), Mystikerin u. Gründerin d. Erlöserordens 57, 171, 204, 329, 393

Boccaccio, Giovanni (1313-75), Dichter u. Humanist 171, 176

Bockstorfer, Christoph, Bildschnitzer u. Maler 296, 298

Bodley, George Frederick (1827-1907), Architekt 198

Bonifaz VIII. (Benedetto Caetani, ca. 1230-1303), Papst (seit 1294) 93, 120, 123

Bonifaz IX. (Pietro Cybo Tomacelli, 1350-1404), Papst (seit 1389) 117 , 121, 129 f., 134-136, 143f., 204

Boucicaut, Geoffrey, Feldherr 92, 103

Bourgeois de Paris, anonymer Chronist 173

Bouts, Dieric (ca. 1410/20-75), Maler 333, 385

Bracciolini, Poggio (1380-1459), Humanist 201, 217

Branda da Castiglione (1350-1443), Humanist u. Kardinal 217

Braybok, Reginald ( $†$ 1405), Ritter 190

Brewster, John, Chronist 174

Brüder von Limburg (Hermann, Johann u. Paul) († 1416), Miniaturenmaler 70, 253-255, 322

Brut, Chronist 174, 206

Bubwith, Nicholas ( $†$ 1424), Bf. v. Bath u. Wells (seit 1407) 203, 217

Bulcano (auch Vulcani), Marino ( $†$ 1394), Kardinal (seit 1384) 139

Bureau de la Rivière ( $\dagger$ 1400), Kämmerer $\rightarrow$ Karls V. des Weisen u. Berater $\rightarrow$ Karls VI. des Vielgeliebten 102

Burdon, William, Hofmaler 167

Calderini, Francesco, Bf. v. Ceneda (1378-85) 136

Calot, Laurence, Notar u. Dichter 172f., 175, 181

Campin, Robert (ca. 1375-1444), Maler 362

Capogalli, Giovanni ( $\dagger 1413)$, Abt v. S. Maria in Grottaferrata u. Administrator v. San Paolo fuori le mura (1386-94), Bf. v. Belluno-Feltre (seit 1398) u. Novara (seit 1402) 139

Catterick, John († 1419), Bf. v. St. David's (1414-15), Bf. v. Coventry u. Lichfield (1415-19), Bf. v. Exeter (1419) 202-205, 216, 227

Cavallini, Giovanni, Autor 139

Chaucer, Geoffrey (ca. 1343-1400), Dichter 176

Chichele, Henry († 1443), Ebf. v. Canterbury 202, 206, 212

Christus, Petrus (ca. 1410/20-1475/76), Maler 231

Ciaconius ( $\dagger$ 1601), Dominikaner u. Chronist 134

Clifford, Richard († 1421), Bf. v. London (seit 1407) 227 
Clemens VI. (Pierre Roger o. Peter von Fécamp, 1260-1352), Papst (seit 1342) 18, 9of., 97, 123

Clemens VII. (Robert von Genf, 1342-94), avignonesischer Gegenpapst (seit 1378) 89-94, 97f., 101-104, 107-110, 113f., 119, 121, 129f., 143

Coelestin V. (Pietro da Morrone, 1209/1210-96), Papst (Juli-Dez. 1294) u. Gründer d. Cölestinerordens 93, 97

Colchester, William († 1386), Abt v. Westminster 204

Cristoforo da Piacenza, Diplomat d. Gonzaga 119

Crivelli, Carlo (ca. 1430/35-1500), venezianischer Maler 386

Dietherr, Georg, Nürnberger Goldschmied 317

Dietrich von Harras (1430-99), Ritter 77

Dietrich III. von Schönberg (1400-76), Bf. v. Meißen (seit 1463) 74f., 82

Dietterlin, Hilarius, Maler 357

Dietterlin, Bartholomäus, Maler, Sohn d. $\rightarrow$ Dietterlin, Hilarius 357

Don Simone Camaldolese, Buchmaler 139

Donato di Neri ( $† 1371 / 72)$, sienesischer Chronist 123

Dürer, Albrecht (1471-1528), Maler, Grafiker, Kunsttheoretiker 242, $258-261,318,322,361,383$

Dunstaple, John (ca. 1390-1453), Komponist 212

Easton, Adam (ca. 1328/38-97), Kurienkardinal v. Sta. Cecilia in Trastevere 117-121

Eberhard von Oberstein, Scholastiker u. Domherr zu Mainz 355

Ébrard, Guillem, Steinmetz 106

Edington, William († 1366), Bf. v. Winchester (seit 1346), kgl. Schatzmeister (1344-56) u. Kanzler (1356-63) 156

Edward III. (1312-77), Kg. v. England (seit 1327) 153-156, 159, 163, $166,206,208,210$

Edward IV. (1442-83), Kg. v. England (seit 1461) 208, 210

Edward of Woodstock, the Black Prince (1330-76), Sohn $\rightarrow$ Kg. Edwards III. 206f.

Elmham, Thomas, Chronist 224

Elizabeth de Berkeley (1386-1422), Countess of Warwick u. Gem. d. $\rightarrow$ Richard de Beauchamp 180

Engel, Andre, Baumeister 42

Enguerrand de Monstrelet ( $\dagger$ 1453), Chronist 223, 226

Ensinger, Vincenz (ca. 1422/23-93), Baumeister u. Steinmetz 184

Ensinger, Moritz (ca. 1430-83), Baumeister u. Steinmetz 192

Erhart, Gregor (1465-1540/41), Schnitzer u. Bildhauer 323

Erhart, Michael (ca. 1440/45-1522), Schnitzer u. Bildhauer 323

Erlbeck, Hans (ca. 1419-48), Nürnberger Bürger 317

Eseler, Nicolaus, d. Ä. (1410-83), Architekt 279

Eyck, Hubert (Huybrecht) van (1370-1426), Maler 321, 333, 356, 374

Eyck, Jan van (ca. 1390-1441), Maler 231, 235-237, 242, 245, 247, 270, 321f., $333,356,361,368,374,385$

Ferdinand I. (1380-1416), Kg. v. Aragon, Sizilien u. Sardinien (seit 1412) 205

Ferdinand II. (1578-1637), röm.-dt. Ks. (seit 1619) 357

Fillastre, Guillaume (1348-1428), Kardinal 200

FitzHugh, Henry (ca. 1365-1425), Diplomat u. Kämmerer $\rightarrow$ Kg. Heinrichs V. 204f., 223

Fleming, Richard (ca. 1395-1431), Bf. v. Lincoln, Theologe u. Gründer d. Lincoln College in Oxford 216
Foppa, Vincenzo (ca. 1427-1516), Maler 385

Forester, Johannes, Schriftsteller 199-203, 223

Friedrich I. der Siegreiche, (1425-76), Pfalzgf. bei Rhein (seit 1451) 300, 359

Friedrich I. (IV.) der Streitbare (1370-1428), Mkgf. v. Meißen, Landgf. v. Thüringen, Kf. v. Sachsen (seit 1423) 73, 78-80

Friedrich III. (1415-93), Hg. d. Steiermark, von Kärnten u. Krain (seit 1424), röm.-dt. Kg. (seit 1440), röm.-dt. Ks. (seit 1452) 77, 239, 299-301, 304

Friedrich IV. mit der leeren Tasche (1382-1439), Gf. v. Tirol (seit 1406) 306

Froben Christoph von Zimmern (1519-66), Graf u. Verf. einer Chronik 313

Froissart, Jean (1337-1405), Dichter u. Chronist 155, 174

Garai, Miklós (1367-1433), Palatin v. Ungarn (seit 1402) 206

Gegenuns, Hans 303f., 314

Gegenuns, Heinrich 303

Gegenuns, Jakob, Maler 303

Gegenuns, Kathrein, Gem. d. $\rightarrow$ Stefan von Elsass, Schwester v. $\rightarrow$ Hans u. Heinrich Gegenuns 303

Geiler von Kaisersberg, Johann (1445-1510), Prediger 340

Gentile da Fabriano (eigtl. Gentile di Niccolò di Giovanni di Massio, 1370-1427), Maler 70, 322, 380

Georg Johann I. der Scharfsinnige (1543-92), Pfalzgf. v. Pfalz-Veldenz 337

Georg von Ehingen (1428-1508), Reichsritter, Diplomat u. Kämmerer $\rightarrow$ Albrechts VI. v. Österreich (seit 1453) 300

Gerlach von Nassau (1322-71), Kfst. u. Ebf. v. Mainz (seit 1346) 66 Gerthener, Steinmetzfamilie, v. a. in Frankfurt a. M. tätig 66 Gerthener, Madern (1356-1430), Baumeister in Frankfurt a. M. 47, $69-71$

Geuch, Hans, Bildhauer 350

Giotto di Bondone (ca. 1267-1337), Maler u. Architekt 239

Giovanetti, Matteo (ca. 1300-69), Maler 91

Giovanni da Serravalle (ca. 1350-1445), Humanist u. Bf. v. Fermo 217

Giovanni d’Allemagna ( $†$ 1450), Maler 386

Giovanni d'Ambrogio, florentinischer Architekt u. Bildhauer 120

Giovanni di Bartolo Guidi, sienesischer Goldschmied 90

Glasyer, Thomas, Glasmalermeister 157-159, 167

Gleismüller, Hans, Maler 376

Goes, Hugo van der (ca. 1430/40-82), Maler 375

Gonthier, Sancho, Buchmaler 91, 131

Gotthard, Heinrich, Pfarrer 318

Grandisson, John († 1369), Bf. v. Exeter 159

Gregor XI. (Pierre Roger de Beaufort, ca. 1329-78), Papst (seit 1370) 90, 97, 119, 120f., 123, 126

Grimaldi, Lionello Oliva 383

Grimaldi, Manuele 383

Grueber, Pankraz, Maler 297

Guarnerio d'Artegna (1410-66), Humanist 145

Gudiel, Gonzalez Pérez ( $†$ 1299), Kardinal 120

Guelders, Buchmaler 131

Guillaume d'Aigrefeuille le Jeune (1339-1401), Kardinal 107f., 114

Guillaume de Chanac ( $\uparrow 1383)$, Benediktiner u. Kardinal 117, 119

Guiniforte da Vimercate, Buchmaler 138

Gunther, Hans, Breslauer Bürger u. Kirchenvorsteher 275, 289 
Günther XXI. (1304-49), Gf. v. Schwarzburg-Blankenburg u. Gegenkönig zu $\rightarrow$ Karl IV. 64

Gut, Johannes ( $†$ 1432), Kanoniker 314

Guy de Boulogne (1313-73), Kardinal $108 \mathrm{f}$.

Guy de Luxembourg (1340-71), Gf. v. Saint-Pol (seit 1360) u. Gf. v. Ligny (seit 1364) 93

Haberschrack, Nikolaus (poln. Mikołaj Haberschrack, ca. 1454-86), Maler in Krakau 308

Hagemüller, Matthias, Schreiner 314

Haller, Jost, Maler 340, 392

Hallum, Robert (1360/70-1417), Bf. v. Salisbury (seit 1407) 151, 183, 188-190, 193f., 196, 199f., 203f., 216f., 223, 227

Hans von Judenburg, Schnitzer u. Maler 314

Hans von Maursmünster, Glasmaler in Straßburg 350, 358

Hans von Savoyen (ca. 1450-1500), Baumeister u. Bildhauer 192

Hans von Tübingen (ca. 1400-62), Maler 314

Harschner, Erhart, Schreiner 279

Hawberk, Nicholas ( $†$ 1407), Ritter 190

Heinrich (Henricus / Jindřich), Prager Kanoniker, vgl. a. $\rightarrow$ Schatz, Heinrich 19

Heinrich I. der Milde († 1416), Hg. zu Braunschweig-Lüneburg 78

Heinrich II. (973/978-1024), Kg. v. Italien (seit 1004), röm.-dt. Ks.

(seit 1014) 71

Heinrich III. (1207-72), Kg. v. England 207f., 210, 212

Heinrich IV. Bolingbroke (1366/67-1413), Kg. v. England (seit 1399) 149, 169, 206

Heinrich V. (1387-1422), Kg. v. England (seit 1413), Sohn $\rightarrow$ Kg. Heinrichs IV. 149-151, 169, 173f., 175, 180, 190, 196, 199, 201-208, 210f., $212-218,223-226$

Heinrich VI. (1421-71), Kg. v. England (1422-61 u. 1470-71) 169$177,182,216$

Heinrich VII. (1275-1313), röm.-dt. Kg. (seit 1308) u. Ks. (seit 1312) $60,63 f$., 123

Heinrich VIII. (1491-1547), Kg. v. England (seit 1509) u. Kg. v. Irland (seit 1541) 225

Heintz, Glaser in Straßburg 35 of.

Helena von Konstantinopel (Flavia Julia Helena; ca. 252-330), Augusta u. Mutter $\rightarrow$ Konstantins d. Großen 17

Heller, Jakob (ca. 1460-1522), Patrizier u. Ratsherr in Frankfurt/M. 242 Hemmel von Andlau, Peter (ca. 1420-1506), Glasmaler 346, 348-351, $358 \mathrm{f}$.

Henry de Beauchamp (1425-46), 14th Earl u. 1st Duke of Warwick $17 \mathrm{of}$., $18 \mathrm{of}$.

Herland, Hugh (ca. 1330-1411), Zimmermeister $\rightarrow$ Kg. Richards II. v. England 156, $158 \mathrm{f}$.

Herlin, Friedrich (1430-1500), Maler 279

Higden, Ranulph (ca. 1280-1364), Benediktiner u. Chronist 154

Hirtz, Hans, Maler in Straßburg 337, 340, 343f., 349-351, 356

Hoffmann von Schweidnitz, Johann (1375-1451), Bf. v. Meißen (seit 1427), Rektor d. Universität Leipzig 82

Holbein, Hans, d. Ä. (1465-1524), Maler 318, 323

Hollar, Wenzel (1607-77), Zeichner u. Kupferstecher 160

Humphrey of Gloucester (1390-1447), 1st Duke of Gloucester, 1st Earl of Pembroke, Bruder $\rightarrow$ Kg. Heinrichs V. 17of., 176f., 180, 205f., 215 , 218,224

Hungerford, Walter (1378-1449), Ritter 204f., 223
Ingeram, Hans ( ${ }^{*}$ vor 1459), Herold 299

Innozenz VI. (Étienne Aubert o. Stephan Aubert, 1285/92-1362), Papst (seit 1352) 18, 64, 70, 73, 92, 113

Innozenz VII. (Cosma dei Migliorati, 1336-1406), Papst (seit 1404) 135

Isabeau (ca. 1370-1435), Prinzessin aus d. Hause Wittelsbach, Gem. $\rightarrow$

Kg. Karls VI. v. Frankreich (seit 1380) 40, 78

Isenmann, Caspar (ca. 1430-80), Maler 296, 298, 334, 343

Jacques de Causans, Abt v. Cluny 97

Jacobus de Voragine (ca.1230-98), Ebf. v. Genua, Verf. der Legenda aurea 252

James de Berkeley († 1463), 1st Baron of Berkeley 180

Jean de la Grange (1325-1402), Bf. v. Amiens (seit 1372) u. Kardinal

92, 94, 98, 100-104, 106-108, 114f., 117, 119-123, 126

Jean de Montreuil (1354-1418), franz. Gelehrter 200, 223

Jean de Murat de Cros, Bf. v. Limoges (1347-71) u. Kardinal 107

Jean de Toulouse, Buchmaler 91, 94

Jean de Vienne (1341-69), Admiral u. Ritter 102

Jean de Waurin (ca. 1398-1474), Chronist 212

Johann Ohnefurcht (1371-1419), Hg. v. Burgund (seit 1404) 214

Johann I. von Moosburg ( $†$ 1409), Bf. v. Regensburg (seit 1384) 33, 40

Johann II. der Gute (1319-64), Hg. d. Normandie (1332-50), Kg. v.

Frankreich (seit 1350) 108, 154

Johann II. von Jen(zen)stein (Jan z Jenštejna, 1348/50-1400), Bf. v. Meißen, Ebf. v. Prag (1378-94), Patriarch v. Alexandria, Kanzler Kg. $\rightarrow$ Wenzels IV., Autor 82, 121

Johann II. von Nassau († 1419), Kf. u. Ebf. v. Mainz (1397-1419) 48f., $51,54 f ., 66,69 f$.

Johann von Kittlitz (1350-1408), Bf. v. Lebus (1382-92), Bf. v. Meißen (1392-98) 82

Johann von Valois le Magnifique (1340-1416), Hg. v. Berry u. Auvergne, Gf. v. Poitiers, Étampes et Montpensier, Gf. v. Auvergne u. Boulogne 78, 97, 207

Johann von Neumarkt (Jan ze Středy, 1310-80), Bf. v. Naumburg, Bf. v. Leitomischl, Bf. v. Olmütz, Elekt v. Breslau, Autor frühhumanistischer Schriften, Kanzler $\rightarrow$ Ks. Karls IV. 18, 28, 59, 66

Johann "Očko" von Vlašim (Jan Očko z Vlašimi, ca. 1292-1380), Bf. v. Olmütz, Ebf. v. Prag (seit 1364) u. Kardinal 31, 78

Johanna I. von Anjou († 1382), Kg.in v. Neapel (seit 1343) 97, 113

Johanna I. von Auvergne (auch de Boulogne, 1326-60), Kg.in v. Frankreich (seit 1350) u. zweite Gem. $\rightarrow$ Kg. Johanns II. des Guten 108

Johanna von Navarra (ca. 1370-1437), zweite Gem. $\rightarrow$ Heinrichs IV. Bolingbroke 206

Johannes XXII. (Jacques Arnaud Duèze, 1245/1249-1334), Papst (seit 1316) 89

Johannes XXIII. (Baldassare Cossa, 1370-1419), avignonesischer

Gegenpapst (1410-15) 92, 203, 217

Johannes de Berlandia 135

Johannes Montanus, Propst v. Viviers 136, 138

Johannes von Hildesheim ( $†$ 1375), Theologe u. Autor 55

Johannes von Ulm ( $† 1450)$, Maler 322

John Lydgate of Bury (ca. 1370-1451), Mönch u. Dichter 173-177

John de Warham († 1395), Bf. v. Salisbury 227

John of Gaunt (1340-99), Hg. v. Lancaster (seit 1362), Sohn $\rightarrow$ Kg. Edwards III. 163

John of Lancaster (1389-1435), 1. Duke of Bedford, Bruder $\rightarrow$ Kg. 
Heinrichs V. v. England 170-173, 175-177, 180, 182, 205f., 211f., 224

Jost (Jobst) von Mähren (1351-1411), Mkgf. v. Mähren (seit 1375) u.

Hg. v. Luxemburg (seit 1388), röm.-dt. Kg (seit 1410) 65

Jude, Lienhard, Maler 357

Justinger, Konrad ( $†$ 1438), Chronist von Bern 214f., 218

Kalteysen, Wilhelm (ca. 1420-96), Maler (273-282, 286f., 288-29o, 297f., 308

Kamensetzer, Hans, Bildschnitzer in Ulm, Straßburg u. Wien 279

Kannegießer, Peter († 1473) 350

Karl der Große (747/48-814), Kg. d. fränkischen Reiches (seit 768), Ks. (seit 8oo) 63, 66

Karl I. der Kühne (1433-77), Hg. v. Burgund u. Luxemburg 380

Karl II. (1630-85), Kg. v. England (seit 1660) 159

Karl IV. (1316-78), Kg. v. Böhmen (seit 1346), röm.-dt. Kg. (seit $1346 / 48$ ) u. Ks. (seit 1355) 15, 18, 20, 28f., 31, 48, 57-66, 70, 73, 84, 93

Karl V. der Weise (1338-80), Kg. v. Frankreich (seit 1364) 94, 102, 108, $119 f ., 122,182,200,212$

Karl V. (1500-58), Kg. v. Spanien (seit 1516), röm.-dt. Kg. (seit 1519) u. Ks. (1530-56) 307

Karl VI. der Vielgeliebte (1368-1422), Kg. v. Frankreich (seit 1380) 78 , 93f., 98, 102-104, 108, 114, 119, 122, 172, 202, 206, 215

Karl VII. der Siegreiche (1403-61), Kg. v. Frankreich (seit 1422) 170

Karl von Valois (1270-1325), Gf. v. Valois, Gf. v. Anjou (seit 1290), Begründer d. Valois-Dynastie 119

Karl zu Erbach-Erbach (1782-1832), Gf. v. Erbach-Erbach, Gf. v. Wartenberg-Roth (seit 1806) 344

Kaschauer, Jakob (ca. 1400-63), Maler u. Bildhauer 305

Katharina von Braunschweig-Lüneburg (1395-1442), Gem. $\rightarrow$ Kf. Friedrichs I. v. Sachsen $78-80$

Katharina von Valois (1401-37), Gem. $\rightarrow$ Kg. Heinrichs V. von England (seit 1420) 149, 203, 205, 226

Katharina zum Wedel, zweite Gem. $\rightarrow$ Siegfrieds zum Paradies 65

Kelner, Vinzenz, Maler 275f., 290

Knebelin, Margarethe, Gem. d. $\rightarrow$ Ulrich, Hans, gen. Meyenblüt 350

Koerbecke, Johann (ca. 1415/20-91), Maler 256f., 264

Konrad III. von Daun († 1434), Kf. u. Ebf. v. Mainz (seit 1414) 69

Konrad von Soest (ca. 1370-1422), Maler 345

Konstantin der Große (Flavius Valerius Constantinus) (270/288-337), röm. Ks. (seit 306) 18, 231

Kraft, Adam († 1509), Baumeister u. Bildhauer in Nürnberg 192

Ladislaus Postumus (tschech. Ladislav Pohrobek, ung. V. László, 1440-57), Hg. v. Österreich, Kg. v. Böhmen, Kg. v. Ungarn 301 Lagier, Kardinal 97

Laib, Konrad, Maler in Salzburg 235-237, 297

Langham, Simon (1310-76), Benediktiner u. Kardinal 120

Langley, Thomas († 1437), Bf. v. Durham (seit 1406) 200

Lauber, Diebold (ca. 1427-71), Produzent u. Händler v. Handschriften $215,223,310$

Laugier, Jaume, Steinmetz 106

Lehrbüchermeister $299 \mathrm{f}$.

Lecourt, Johannes, avignonesischer Steinmetz 119

Leopold III. der Gerechte (1351-86), Hg. v. Österreich, Steiermark, Kärnten u. Krain 306
Lindsey, John, Bildschnitzer u. Maler 167

Lippi, Filippo Tommaso (ca. 1406-69), Maler 259

Lochner, Stefan (ca. 1400/10-51), Maler 239, 274, 276, 281, 319

Lorenzetti, Pietro (ca. 1280-1348), Maler 347

Louis de Valois (1372-1402), Hg. v. Orléans u. Gf. v. Angoulême, Sohn

$\rightarrow$ Kg. Karls V. des Weisen 101f., 108, 122

Louis d'Orléans, kgl. Statthalter $\rightarrow$ Kg. Karls VI. des Vielgeliebten $93 \mathrm{f}$.

Louis I. von Anjou (1339-84), Hg. v. Anjou (seit 1351/1360) 93, 97

Ludolf von Sachsen († 1377), Kartäuser 329, 341f.

Ludwig I. (1412-50), Gf. v. Württemberg-Urach (seit 1419) $300 f$.

Ludwig III. der Bärtige (1378-1436), Pfalzgf. bei Rhein (seit 1410) 300

Ludwig IV. der Bayer (1282/86-1347), röm.-dt. Kg. (seit 1314) u. Ks.

(seit 1328) 61f., 64, 206

Ludwig VII. der Gebartete († 1447), Hg. v. Bayern-Ingolstadt (seit 1413) 239

Ludwig IX. (1214-70), Kg. v. Frankreich (seit 1226) 172, 174

Lützelmann, Heinrich, Maler 350

Lutz von Lutzenhart, Christoph, Chronist 301

Maître d'Orose, Buchmaler 131

Margaret de Beauchamp (1404-68), Countess of Shrewsbury, Gem. d.

$\rightarrow$ John Talbot 17of., 174, 180

Margret, Tochter d. $\rightarrow$ Stefan von Elsass, Gem. d. $\rightarrow$ Andre von Paris 303

Marguerite d'Anjou (1430-82), Hg.in v. Lothringen u. Bar, Gem. $\rightarrow$ Kg.

Heinrichs VI. v. England 171, 173f., 175

Marie d'Anjou (1404-63), Kg.in v. Frankreich (seit 1422) 108

Marie von Châtillon-Blois (1343-1404), Gem. d. $\rightarrow$ Louis I. von Anjou 93

Martin V. (Oddo di Colonna, 1368-1431), Papst (seit 1417) 92, 129,

136, 140, 201, 204, 217

Masaccio (eigtl. Tommaso di Ser Giovanni di Mone Cassai, 1401-28), Maler 231

Mathilde d'Auvergne, gen. de Boulogne, Gf.in v. Genf, Mutter Paost $\rightarrow$ Clemens' VII. 97

Matteo d'Aquasparta († 1302), Kardinal 120

Matthias von Arras (1290-1352), Architekt d. Prager Doms 31

Maximilian I. (1459-1519), Hg. v. Burgund (seit 1477), röm. Kg. (seit 1486), Herr d. österreichischen Erblande (seit 1493), Ks. (seit 1508) 300

Mechthild von der Pfalz (1419-82), Gem. $\rightarrow$ Albrechts VI. v. Österreich 300-303, 306, 311, 313

Meister Anton, Kaplan am Ottilienaltar d. Konstanzer Münsters 151, 184

Meister Antze, Bildhauer 61

Meister der Darbringungen, Maler $302 f$.

Meister der Erbacher Scheiben 346, 359

Meister der Gewandstudien, Maler 343, 350, 392

Meister der heiligen Veronika, Maler 251

Meister der Karlsruher Passion, Maler, vgl. auch $\rightarrow$ Hirtz, Hans 248 ,

257, 286f., 327-330, 332-335, 337, 340, 343f., 347f., 351, 358

Meister der Mainzer Verspottung, Maler 355

Meister der Münchener Marientafeln, Maler 378-380, 383

Meister der Passionszyklen, Maler 276, 282, 284, 286-288

Meister der Pollinger Tafeln, Maler 235f., 238, 376, 378, 383

Meister der St. Lambrechter Votivtafel, Maler $302 \mathrm{f}$.

Meister der Spielkarten, Kupferstecher 299, 309f., 343 
Meister der Tafeln des Sterzinger Multscher-Retabels, Maler 323, 372 Meister der Tennenbacher Retabels, Maler 332f., 335

Meister der Virgo inter Virgines, Maler 382

Meister der Worcester-Kreuztragung, Maler 245f., 286f., 297f.

Meister der Wurzacher Tafeln, Maler 236, 242

Meister des Albrechtsaltares zu Klosterneuburg, Maler $376 f$.

Meister des Andreasaltars, Maler 304

Meister des Berswordt-Altars, Maler 256 f.

Meister des deutsch-niederländischen Altars, Maler 380

Meister des Flöhaer Retabels, Bildschnitzer 77

Meister des Frankfurter Paradiesgärtleins, Maler 332, 355, 364

Meister des Morgan-Kindheitszyklus, Buchmaler 250, 252, 259 .

Meister des Obersteiner Altars, Maler 245

Meister des Rohan-Stundenbuches 254

Meister des Rossiano-Missales (zweiter), Buchmaler 136

Meister des Schöppinger Altars, Maler 340, 366

Meister des Tucher-Altars, Maler 286f., 367, 392

Meister E. S., Kupferstecher 343, 365, 386, 392

Meister Francke (1383-1436), Dominikaner u. Maler 255f., 258, 281, 297

Meister Hartmann, Bildhauer u. Bildschnitzer in Ulm 242

Meister H. W., Bildschnitzer 77

Meister Martin, Maler 275-279, 282, 288-290, 298

Meister Nikolaus, Maler 275f., 278f., 290

Meister von Flémalle, Maler, vgl. auch $\rightarrow$ Campin, Robert 254, 333 , $362,368,371,374,377,379 f ., 387$

Meister von Großgmain, Maler 373

Meister von Hoogstraten, Maler 371

Meister von Iserlohn, Maler 371, 377, 385

Meister von Monteoliveto, Buchmaler und wohl Olivetaner 138

Meister von Schloss Lichtenstein, Maler 299, 301-311, $314 \mathrm{f}$.

Meister von Sierentz, Maler $322 \mathrm{f}$.

Meister von 1446, Maler 343

Membury, Simon, Baumeister 159

Mercati, Venturino, Mönch u. Buchmaler 138

Metz, Peter, Steinmetz 194

Monaco, Lorenzo (um 1370-um 1425), Maler 145

Montanhac, Petrus, avignonesischer Steinmetz 101, 106

Morel, Jacques, Baumeister, Sohn d. $\rightarrow$ Pierre Morel 98

Morel, Pierre, Baumeister 92, 94, 98, 100-102, 106, 114

Moser, Lukas (1390-1434), Maler 236, 238, 274, 281, 310, 368 f., 376

Multscher, Hans (ca. 1400-67), Bildhauer u. Schnitzer 239, 247, 279,

$296,301,310,318,321,323,328,370-374$

Neville, Cecily (1425-50), 1st Duchess of Warwick, 1st Countess of Worcester u. erste Gem. d. $\rightarrow$ Henry de Beauchamp 180

Nicolaus V. (1397-1455), Papst (seit 1447) 144

Niesenberger, Hans (ca. 1415-93), Baumeister u. Steinmetz 192

Nikolaus Gerhaert von Leyden (1430-73), Bildhauer 279

Notke, Bernd († 1509), Maler 279

Oberlin, Johann Friedrich (1740-1826), Pfarrer u. Sozialreformer 337,356

Olivetan Master $\rightarrow$ Meister von Monteoliveto

Orsini, Giordano (1360/1370-1438), Ebf. v. Neapel u. Kardinal (seit 1405) 138f., 204

Orsini, Giovanni Gaetano (ca. 1285-1335), Kardinal 120
Otto der Reiche, (1125-90), Mkgf. v. Meißen 82

Otto der Tarentier (1319/20-1399), Hg. v. Braunschweig-Grubenhagen u. Fürst v. Taranto (seit 1376) 97

Otto III. (ca. 980-1002), röm.-dt. Kg. (seit 983) u. Ks (seit 996) 70

Otto III. von Hachberg (1388-1451), Bf. v. Konstanz (1410-34) 184, 187

Pancera (auch Panciera), Antonio (1350-1431), Kardinal u. Patriarch v. Aquileia (1402-12) 133, 134f., 145

Paradies, Peter zum, Sohn d. $\rightarrow$ Siegfried zum Paradies $65 f$.

Paradies, Siegfried zum ( $\dagger$ 1386), Patrizier in Frankfurt a. M. $64 f$.

Parler, Heinrich, d. J., Bildhauer u. Architekt 46,85

Parler, Johann, d. J. (ca. 1359-1405/06), Architekt, Sohn d. $\rightarrow$ Parler,

Peter 32, 40

Parler, Peter (1330/33-99), Bildhauer u. Architekt 31-33, 37, 40, 42, 45,55

Paul II. (Pietro Barbo, 1417-71), Papst (seit 1464) 144

Pedewitz, Johann Felix, Pfarrer 276, 296

Peter de Grandison (1295-1358), 2nd Baron of Grandison 190

Petroni, Riccardo (1250-1314), Kardinal 123

Petrus de Mera (ca. 1464), Propst 20

Philipp II. der Kühne (1332-1404), Hg. v. Burgund 101

Philipp III. der Gute (1396-1467), Hg. v. Burgund (seit 1419) 17 of.

Philipp IV. der Schöne (1268-1314), Kg. v. Frankreich (1285-1314) 93

Philipp VI. (1298-1350), Kg. v. Frankreich (seit 1328) 119

Philippa von Lancaster (1394-1430), Kg.in v. Schweden, Norwegen u.

Dänemark, Schwester $\rightarrow$ Kg. Heinrichs V. 204

Philippe II. d’Alençon (1339-97), Ebf. v. Rouen (1359-78) u. Kardinal, Sohn $\rightarrow$ Karls von Valois 117-121

Philippe de Mézières (1327-1405), Soldat u. Schriftsteller 121

Pierre d'Ailly (1350-1420), Theologe u. Kardinal 199f., 216

Pierre de la Jugie (1319-76), Benediktiner u. Ebf. von Narbonne 122

Pierre de Murat de Cros (ca. 1320-88), Ebf. v. Arles (seit 1374) u. Kardinal 92, 94, 97, 101, 106-108, 114

Pierre de Luxembourg (1369-87), Bf. v. Metz (seit 1384) u. Kardinal, Sohn d. $\rightarrow$ Guy de Luxembourg 92-94, 97, 103, 108f.

Pisano, Andrea, auch Andrea da Pontedera (1290-1348), Architekt u. Bildhauer 123

Pleydenwurff, Hans (1420-72), Maler 242, 274, 297, 301, 313

Pogliaghi, Lodovico (1857-1950), Bildhauer, Maler, Szenograf u. Dekorateur 198

Polton, Thomas († 1433), Bf. v. Hereford, Bf. v. Chichester, Bf. v.

Worcester, Dekan d. Yorker Münsters 216

Postier de Salon, Jean, Steinmetz 106

Premierfait, Laurent de (ca. 1460/70-18), Dichter, Humanist u. Übersetzer 171

Provoost, Jan (1465-1529), Maler 382

Pseudo-Darbringungsmeister, Maler 314

Quarton, Enguerrand († 1466), Maler und Buchmaler 91

Randolf, William, Londoner Goldschmied 216

Rebmann, Albrecht, Maler 301, 313

Richard II. (1367-1400), Kg. v. England (1377-99) 120, 149, 156f., $162,167,204,214 \mathrm{f}$.

Richard de Beauchamp (1382-1439), 13th Earl of Warwick u. General 149f., 169-177, 180-182, 204f., 208, 210, 212, 215f., 223 
Riemenschneider, Tilman (1460-1531), Bildhauer 239, 279 Riemer, Wenzeslaus, Breslauer Bürger u. Kirchenvorsteher 275, 289 Robert de Stratford (ca. 1292-1362), Bf. v. Chichester (seit 1337) 190 Roritzer (Roriczer), Baumeisterfamilie, v. a. in Regensburg tätig 41 Roritzer (Roriczer), Conrad, Sohn d. $\rightarrow$ Wenczlaw Roritzer $41 \mathrm{f}$. Roritzer (Roriczer), Elspet, Gem. d. $\rightarrow$ Wenczlaw Roritzer 41 Roritzer (Roriczer), Mathes (1430/40-92/95), Baumeister, Autor 42 Roritzer (Roriczer), Wenczlaw, Baumeister $41 \mathrm{f}$.

Roritzer (Roriczer), Wenczlaw, Sohn d. $\rightarrow$ Wenczlaw Roriczer 41 Roritzer (Roriczer), Wolfgang, Baumeister 42 Rudolf III. († vor 1389), Gf. v. Hohenberg 306 Rudolf von Sachsenhausen, Ritter u. Schuldheiß v. Frankfurt a. M. 64 Ruprecht I. (1352-1410), Pfalzgf. bei Rhein (seit 1398), röm. Kg. (seit 1400) 300

Ruprecht von Pfalz-Simmern (1420-78), Bf. v. Straßburg (seit 1440) 301

Salterelli, Simone (1261-1342), Ebf. v. Pisa 123

Sardo, Ranieri, Chronist 123

Scala, Nicodemus della ( $†$ 1443), Fürstbf. v. Freising (seit 1422) 305

Schadeberg, Hermann, Maler 355

Schatz, Heinrich (Heinricus Thesauri), Kanzlist $\rightarrow$ Ks. Karls IV. 19

Schongauer, Martin ( $†$ 1491), Kupferstecher u. Maler 231, 242, 334, 348 f., 358,382

Schüchlin, Hans († 1505), Maler 239, 301, 323

Scott, George Gilbert (1811-78), Architekt 198

Serra, Pedro (Pere) († 1404), Kardinal 134, 144

Shirley, John († 1456), Autor 174, 181

Sigismund (1368-1437), Kf. v. Brandenburg (seit 1387), röm.-dt. Kg. (seit 1411), Kg. v. Böhmen (seit 1419), röm. Ks. (seit 1433) 47,

65-67, 71, 73, 79, 84, 151, 174, 190, 196, 199-208, 210-218, 223-227

Sigmund der Münzreiche (1427-96), Erzhg. v. Österreich, Regent v.

Oberösterreich 299, 301

Simone di Filippo, gen. Simone dei Crocifissi (1330-99), Maler 366, 414

Sittich von Hohenems, Markus (1533-95), Bf. v. Konstanz (1561-89) u. Kardinal 120

Sluter, Claus (ca. 1350-1405), Bildhauer 94

Smid, Nikolaus, Maler 275

Spenser, Henry, Architekt u. Baumeister 168

Sponlee, John († ca. 1386), Architekt 156

Stefan von Elsass, Maler $303 \mathrm{f}$.

Stefano dell'Aquila (Stephanus de Aquila), Kalligraph 136, 138f., 144

Stephan III. (1337-1413), Hg. v. Bayern (seit 1375), Hg. v. Bayern-Ingolstadt (seit 1392) 33

Stocker, Hans, Maler 332, 355

Stoß, Veit (1447-1533), Bildhauer, Kupferstecher, Maler 279 Stuber, Johann Georg (1722-97), Pfarrer u. Sozialreformer 337, 356

Syrlin, Jörg, d. Ä. (ca. 1425-91), Schreiner u. Bildhauer 296

Taddeo di Bartolo (1362-1422), Maler 140

Talbot, John (1384/85-1453), 1st Earl of Shrewsbury, 1st Earl of Waterford u. General 17of., 173-175, 180

Theobald von Lixheim, Glasmaler 350

Thimo von Colditz († 1410), Bf. v. Meißen (seit 1399) 82

Thomas de Beauchamp, 11th Earl of Warwick (1313-69) u. General 169

Thomas de Morley (1393-1435), 5th Baron of Morley 214, 226
Thomas the Magnificent (1352/53-1417), 5th Baron of Berkeley u. Admiral 173

Thomas von Lancaster (1388-1421), 1. Duke of Clarence, Bruder $\rightarrow \mathrm{Kg}$. Heinrichs V. $205 \mathrm{f}$.

Tiefental, Hans, Maler 332, 355

Tino di Camaino (ca. 1280-1337), Bildhauer 123

Tiptoft, John (1427-70), 1st Earl of Worcester 215

Trevisa, John (1342-1402), Autor u. Übersetzer 174

Ulrich, Hans, gen. Meyenblüt, Glasmaler u. Sohn d. $\rightarrow$ Ulrich von Pforzheim 350

Ulrich von Pforzheim, Glasmaler 350

Ulrich von Richental ( $†$ 1437), Chronist 20of., 205, 210, 216, 218, 224

Ulrich V. der Vielgeliebte (1413-80), Gf. v. Württemberg (1433-41) bzw. v. Württemberg-Stuttgart (seit 1441) 300

Urban V. (Guillaume de Grimoard, 1310-70), Papst (seit 1362) 31, 89, 91, 94, 97, 107f., 110, 117, 156

Urban VI. (Bartolomeo Prignano, ca. 1318-89), Papst (seit 1378) 89f., $97,107 f ., 110,117,119,121,129,135,139$

Vasari, Giorgio (1511-74), Architekt, Maler u. Biograf 231, 238 Vergerio, Pier Paolo, d. Ä. (1370-1444/45), Humanist 217 Visconti, Bernabò (1323-85), Herr v. Mailand (seit 1355) 123 Vivarini, Antonio, auch da Murano (1418-76/84), Maler 322, 386 Vivarini, Bartolomeo (ca. 1432-99), Maler 386

Waidenlich, Hans, Maler 279

Wakering, John († 1425), Bf. v. Norwich (1408-15) 216, 227

Walsingham, Thomas († 1422), Chronist 207f., 225

Weinschröter, Sebald ( $†$ vor 1363), Hofmaler $\rightarrow$ Ks. Karls IV. in Nürnberg 22

Weittenauer, Johann Evangelist (1640-1703), Propst d. Morizstifts in Rottenburg-Ehingen, Chronist 306f., 314

Wenzel IV. (1361-1419), Kg. v. Böhmen (1363-1419), röm.-dt. Kg. (1367-1400), Kf. v. Brandenburg (1373-78), Sohn $\rightarrow$ Ks. Karls IV. $59,64,66,85$

Wenzel von Radeč (ca. 1379-1417), Prager Kanoniker, Bauverwalter am Veitsdom zu Prag 37

Weyden, Rogier van der (1399/1400-1464), Maler 236, 318, 333, 349, $356,363,382$

Wilhelm I. der Einäugige (1343-1407), Mkgf. v. Meißen 73, 79

Wilhelm II. der Reiche (1371-1425), Mkgf. v. Meißen 85

Wilhelm II. von Bayern-Straubing (1365-1417), Hg. v. Bayern-Strau-

bing, Gf. v. Holand u. Zeeland, Gf. v. Hennegau 212

Wilhelm Nicolaus von Württemberg (1828-96), General 301, 307, 315 Wilhelm von Oche (Aachen) $\rightarrow$ Kalteysen, Wilhelm

William de Mulsho († ca. 1376), Kanoniker in Windsor (1361-68), kgl. Kämmerer $\rightarrow$ Kg. Edwards III. (1365-75) 155

William von Wykeham (1324-1404), Bf. v. Winchester 149f., 154-161, $163,166 f$

Wimpheling, Jakob (1450-1528), Historiker 340

Windecke, Eberhard († 1440/1441), Chronist u. Kaufmann 199, 205208, 212, 214f., 218, 223, 227

Wintingham, William, Architekt u. Baumeister 168

Witney, Thomas, Baumeister 159

Witz, Charles Emmanuel (1815-96), Pfarrer 337 
Witz, Konrad (1400-46), Maler 274, 281, 322, 328, 333, 374-376, 380, 385

Woodford, James Russell (1820-85), Bf. v. Ely (seit 1873) 198

Worcester, William (ca. 1415-82), Chronist u. Antiquar 174

Wurmser von Straßburg, Nikolaus (ca. 1298-1367), Maler 58

Wynford, William (um 1360-1405), Steinmetzmeister 150, 156, 158f., 163,166

Yevele, Henry (ca. 1320-1400), Steinmetzmeister 150, 156-158, 167

Zeno da Castiglione 218

\section{Orte}

Aachen 20, 64, 204 f., 216, 280 f., 288, 307, 371

Aachen | Dom 63

Aachen | Dom | Domschatz | Büstenreliquiar Karls des Großen, Inv.-Nr. Gr 6963

Aachen | Dom | Domschatz | Goldene Monstranz v. Hans v. Reutlingen 198

Aachen | Dom | Domschatz | Reliquiar m. Karl dem Großen u. Kir-

chenmodell, Inv.-Nr. Gr 70 63

Aachen | Dom | Engel v. Hans Multscher 371

Aarschot | Onze-Lieve-Vrouwekerk | Lettner 198

Aberdeen | University of Aberdeen | Stundenbuch, Sign. Blair's College MS 1171,180

Abergavenny (Monmouthshire) | St. Mary's Prior Church | Grabmäler d. William de Hasting, John de Hastings und Lawrence de Hastings 197

Adderbury | St. Mary 157

Addlethorpe (Lincolnshire) | St. Nicholas | Schranke 197

Aix-en-Provence | Kathedrale Saint-Sauveur | Verkündigung an Maria 372

Altötting | Wallfahrtsmuseum | Goldenes Rössl 79

Altzelle | Zisterzienserkloster 82

Amiens 119

Amiens | Kathedrale Notre-Dame 107

Amiens | Kathedrale Notre-Dame | Beau Pilier 102, 121 f.

Anagni 107

Annaberg-Buchholz|St.-Annen-Kirche 77

Antwerpen | Huis „De Spieghel“, Grote Markt 9198

Antwerpen | Kathedrale Onze-Lieve-Vrouw 198

Antwerpen | Museum Mayer van den Bergh | Madonna aus St-Louis in

Poissy, Inv.-Nr. MMB.0210 82

Arlesheim 337

Ascoli Piceno 385

Ascoli Piceno | Sant'Angelo Magno | Biblioteca Comunale | Chorbücher

u. Fragmente, Sign. 4, 8, 10138,145

Assisi | San Francesco | Freskenzyklus d. Unterkirche 347

Assisi | San Francesco | Kapelle S. Nicola | Grabmal d. Giovanni Gae-

tano Orsini 120

Augsburg 317f., 321, 323

Augsburg | St. Ulrich und Afra 321

Augsburg | St. Ulrich und Afra | Tafeln m. d. Wundern d. hl. Ulrich

319

Augsburg | Maximilianmuseum | Skulptur d. hl. Katharina $320 \mathrm{of}$
Augsburg | Staatsgalerie | Kreuzigung u. Beweinung Christi, Inv.-Nr. L 1025,1026314

Avezzano | Curia vescovile | Graduale von Trasacco 136, 138, 145

Avignon 87, 89-93, 97f., 102f., 105-110, 113, 115, 117, 119, 129, 131, 140, 143f., 204f.

Avignon | Bibliothèque municipale | Constitutiones des Coelestinerordens in Avignon, Sign. Ms 72793

Avignon | Cathédrale Notre-Dame des Doms 103, 107

Avignon | Musée du Petit Palais | Fragment des Grabmals v. Clemens

VII. aus St-Pierre-Célestins 92, 94, 101, 109, 114

Avignon | Musée du Petit Palais | Fragmente des Grabmals v. Jean de la Grange aus St-Martial, Inv.-Nr. 28A 92, 94f., 98, 100-104, 107, 114, $117,119,121-123$

Avignon | Musée du Petit Palais | Fragment einer Bauskulptur Urbans V. aus St-Martial $108 \mathrm{f}$.

Avignon | Musée du Petit Palais | Kopffragment der Bauskulptur d.

Guillaume d'Aigrefeuille 115

Avignon | Papstpalast 90-92, 110

Avignon | St-Didier 93, 105-107, $113 \mathrm{f}$.

Avignon | St-Martial 92-94, 97-110, 113f., 123

Avignon | St-Martial | Grabmal Pierre de Murat de Cros 92, 101

Avignon | St-Pierre-Célestins 92-94, 97-110, 114

Avignon | St-Pierre-Célestins | Grabmal Pierre de Luxembourg 92f.,

109

Azincourt 205, 207f.

Bad Urach 301

Bad Wildungen | St. Nikolaus | Retabel d. Konrad v. Soest 274

Bamberg 20

Bamberg | Dom St. Peter und Georg 20

Bamberg | Dom St. Peter und Georg | Fürstenportal 370

Bamberg | Staatsbibliothek | Bamberger Apokalypse, Sign. Msc. Bibl. 14070

Bamberg | Staatsgalerie | Kölner Tafelbild, Inv.-Nr. WAF 628382

Basel 210, 223, 333, 336, 374

Basel | Kunstmuseum | Altarflügel d. Meisters v. Sierentz, Inv.-Nr. 31 322

Batalha | Mosteiro de Santa Maria da Vitória | Westportal d. Capelas Imperfeitas 198

Berlin 382

Berlin | Staatliche Museen - Preußischer Kulturbesitz, Bodemuseum | Trauernde Frauen d. Kreuztragung aus Lorch am Rhein, Inv.-Nr. $849953 \mathrm{f}$.

Berlin | Staatliche Museen - Preußischer Kulturbesitz, Gemäldegalerie | Anbetung d. Könige, Inv.-Nr. 538320

Berlin | Staatliche Museen - Preußischer Kulturbesitz, Gemäldegalerie | Madonna in der Kirche d. Jan van Eyck, Inv.-Nr. 525C 361

Berlin | Staatliche Museen - Preußischer Kulturbesitz, Gemäldegalerie | Verspottung Christi, Inv.-Nr. 1221254

Berlin | Staatliche Museen - Preußischer Kulturbesitz, Gemäldegalerie | Wurzacher Altar, v. Hans Multscher signiert, Inv.-Nr. 1621 238f., 242, 247, 310, 318, 328, 370-373

Berlin | Staatliche Museen - Preußischer Kulturbesitz, Kunstgewerbemuseum | Ordenszeichen der Gesellschaft vom Drachen 211

Berlin | Staatliche Museen - Preußischer Kulturbesitz, Kunstgewerbemuseum | Rundscheibenzyklus (sog. Erbacher Scheiben), wohl aus dem Ulmer Rathaus, Inv.-Nr. AE 562ff. 344-351, 358 
Berlin | Staatliche Museen - Preußischer Kulturbesitz, Kupferstichkabinett | Madonna mit Kind in einem Gemach, Inv.-Nr. KdZ 1971 385

Berlin | Staatliche Museen - Preußischer Kulturbesitz, Skulpturensammlung | Kopf eines Propheten v. Schönen Brunnen zu Nürnberg, Inv.-Nr. 365a 53

Bielefeld | Marienkirche (ehem. Kollegiatstift St. Maria und Georg) | Marienretabel 256, 274

Billom | Saint-Cerneuf-de-Billom | Grabmal Kardinal Hugues Seguin 121

Bishop's Waltham | Schloss d. Bischofs v. Winchester 154, 156-158

Blackburn | Museum | Serra Missal, Sign. Ms. Hart 20918 134f., 140, 145

Bloomington | Indiana University | Lilly Library | Alphabet-Schablonen $\mathrm{m}$. Signatur v. Guiniforte da Vimercate 138

Blundeston (Suffolk) | St. Mary | Schranke 197

Böblingen 306

Böblingen | Schloss 300

Bologna 91, 139, 366

Bologna | San Michele in Bosco, Benediktinerkloster 139

Bologna | Sta. Maria dei Servi | Fresko der Madonna gravida 366, 414

Bourg-en-Bresse | Kloster Brou 193

Bourges | Schloss 187

Breslau $\rightarrow$ Wrocław

Bristol | Kathedrale | Chorgestühl 197

Brno | St. Thomas (ehem. Augustinereremitenkirche) | Pietà 85

Brügge (Bruges, Brugge) 200, 211, 214 f., 218, 227

Brügge | Groeningemuseum 361

Brünlos | Kirche 74, 76

Brünn $\rightarrow$ Brno

Brüssel (Bruxelles, Brussel) 356

Brüssel | Broodhuis am Grote Markt 198

Brüssel | Onze-Lieve-Vrouw ten Zavel | Figurenbaldachine an Westfassade u. Westportal 198

Brüssel | Kathedrale St. Michael und St. Gudula | Glasfenster im Südseitenschiff 198

Brüx $\rightarrow$ Most

Budapest 304

Budapest | Budavári palota 71

Budapest | Szépművészeti Múzeum | Zug nach Golgatha, Inv.-Nr. 2531 $321 f$.

Budweis $\rightarrow$ České Budějovice

Burgos | Cartuja de Miraflores | Hochaltarretabel 198

Calais 170, 205, 213-215, 226

Calais | Notre-Dame 214

Cambridge 203

Cambridge | Corpus Christi College 161, 163

Cambridge | Fitzwilliam Museum | Stundenbuch, Sign. 40-1950 171, 180

Cambridge | Pembroke College 161f.

Cambridge | University Library | Handschrift, Sign. MS Ll. V. 20173

Canterbury 205-207, 212, 223f., 226

Canterbury | Abtei St. Augustinus 206, 210

Canterbury | Canterbury College 157

Canterbury| Kathedrale 206, 212, 213
Canterbury | Kathedrale | Grabmal Heinrichs IV. u. d. zweiten Gem. Johanna von Navarra 206

Canterbury | Kathedrale | Grabmal d. hl. Thomas Becket 206, 208

Canterbury | Kathedrale | Grabmal d. Schwarzen Prinzen, Edward of Woodstock 206f.

Canterbury| Old Palace 206

Carisbrooke Castle 156

Carlisle | Kathedrale zur hl. Trinität | Chorgestühl 197

Cartmel Priory (Lancashire) | Chorgestühl 197

Cawston (Norfolk) | St. Agnes | Schranke 197

České Budějovice | Madonna $\rightarrow$ Hluboká nad Vltavou, Südböhmische Aleš-Galerie

Český Krumlov | Madonna $\rightarrow$ Wien | Kunsthistorisches Museum

Chantilly | Musée Condé | Musikalisches Manuskript, Ms. 564134

Chantilly | Musée Condé | Très Riches Heures d. Duc de Berry, Ms. 65 79, 297

Chemnitz 73,77

Chemnitz | St. Jakobi 76

Chemnitz | Städt. Kunstsammlungen, Schlossbergmuseum 73, 75, 84

Chemnitz | Städt. Kunstsammlungen, Schlossbergmuseum | Hausaltar des Dietrich von Schönberg, Inv.-Nr. SAV 0104 74f., 82

Chemnitz | Städt. Kunstsammlungen, Schlossbergmuseum | Heiligenfiguren aus Gersdorf, Inv.-Nr. ZV 2701a-c 75f.

Chemnitz | Städt. Kunstsammlungen, Schlossbergmuseum | Kruzifix aus St. Jakobi in Chemnitz, Inv.-Nr. II 48/K 76

Chemnitz | Städt. Kunstsammlungen, Schlossbergmuseum | Madonna aus Oberhermsdorf, Inv.-Nr. II $27 / \mathrm{K}_{3} \quad 75 \mathrm{f}$., 82

Chemnitz | Städt. Kunstsammlungen, Schlossbergmuseum | Madonna aus Wilsdruff, Inv.-Nr. SAV 0133b $75 \mathrm{f}$.

Chemnitz | Städt. Kunstsammlungen, Schlossbergmuseum | Retabel aus Topfseifersdorf, Inv.-Nr. SAV 2007 74f., 81f.

Chemnitz-Ebersdorf s. $\rightarrow$ Ebersdorf (Stadt Chemnitz)

Chertsey (Surrey) 156

Chester | Kathedrale hl. Erlöser u. St. Maria (ehem. Benediktinerabteikirche St. Werburgh) | Chorgestühl u. Bischofsthron $197 \mathrm{f}$.

Chicago | The Art Institute of Chicago | Heilige Familie, Inv.-Nr. 1933.1044371

Chicago | The Art Institute of Chicago | Worcester-Kreuztragung, Inv.-Nr. 1947.79328

Chichester | Kathedrale hl. Trinität | Grabmal d. Robert de Stratford 190, 197

Chiusi | Museo del Duomo | Chorbücher d. Klosters Monte Oliveto Maggiore 138

Christchurch (Hampshire) | Prioratskirche | Altarwand 197

Chomutov| Oblastní muzeum v Chomutově 84

Cismar 210

Cirencester (Gloucestershire) | St. Johann Bapt. | Parclose-Schranke 197

Cividale del Friuli | Biblioteca Guarneriana | Manuskript, Sign. Guarner. 138134,145

Clamecy | Stiftskirche Saint-Martin | Vorlagensockel zu Seiten d. Westportals 198

Cleveland | The Cleveland Museum of Art | Mr. and Mrs. William H. Marlatt Fund | sog. Schlägl-Retabel, Inv.-Nr. 1951.453.c 257, 406

Cluny 97

Cobham (Kent) | Stadtkirche | Grabplatte d. Nicholas Hawberk u. seines Sohnes 190, 197 
Cobham (Kent) | Stadtkirche | Grabplatte d. Reginald Braybrok u. seiner Söhne 190

Collepardo | Certosa di Trisulti 135

Colmar 336

Colmar | Dominikanerinnenkloster Unterlinden 342

Colmar | Musée d’Unterlinden | Colmarer Retabel 334, 355, 358

Colmar | St. Martin | Hochaltarretabel 296, 298

Danzig $\rightarrow$ Gdańsk

Darmstadt | Hessisches Landesmuseum | Fragment d. Erbacher Scheiben 344

Darmstadt | Hessisches Landesmuseum | Kreuzanheftung Christi,

Kopie nach Karlsruher Passion, Inv.-Nr. GK 53 340-343

Darmstadt | Hessisches Landesmuseum | Ortenberger Retabel, Inv.-Nr. GK 4B 51f., 66

Darmstadt | Hessisches Staatsarchiv | Wiesbadener Riss, Bauriss d.

Westfassade d. Konstanzer Münsters, Sign. 2945191

Dartford 206

Dennington (Suffolk) | St. Mary | Schranke der Bardolph Chapel 197

Doberlug-Kirchhain | ehem. Zisterzienserabteikirche Doberlug | Triptychon aus Senftenberg 285

Dordrecht 214 f.

Dortmund | St. Marien | Passionstriptychon 256

Dover 156, 205f., 213, 224

Dover | Burg 155, 206

Dresden 80

Dresden | Palais im Großen Garten $74 f$.

Dresden | Staatliche Kunstsammlungen $84 \mathrm{f}$.

Dresden | Staatliche Kunstsammlungen | Slg. Sächsischer Altertumsverein $\rightarrow$ Chemnitz | Städt. Kunstsammlungen, Schlossbergmuseum 79

Durham | Kathedrale | Bischofsthron u. Grabmal Thomas Hatfield 197

East Meon | Bischofspalast 156

Easthampstead (Berkshire) 155

Ebersdorf (Stadt Chemnitz) 77f., 81

Ebersdorf (Stadt Chemnitz) | Ev.-Luth. Pfarrkirche (ehem. Wallfahrtskirche) $77 \mathrm{ff}$.

Ebersdorf (Stadt Chemnitz) | Pfarrkirche | Bilderkammer 79

Ebersdorf (Stadt Chemnitz) | Pfarrkirche | Chor 79

Ebersdorf (Stadt Chemnitz) | Pfarrkirche | Grabmal d. Dietrich v.

Harras 77

Ebersdorf (Stadt Chemnitz) | Pfarrkirche | Hochaltarretabel 77

Ebersdorf (Stadt Chemnitz) | Pfarrkirche | Muttergottes 80

Ebersdorf (Stadt Chemnitz) | Pfarrkirche | Pietà 78

Ebersdorf (Stadt Chemnitz) | Pfarrkirche | Pulthalterfiguren 77

Ebersdorf (Stadt Chemnitz) | Pfarrkirche | Retabel m. Muttergottes u. Stifterfiguren $78-82$

Ebersdorf (Stadt Chemnitz) | Pfarrkirche | Retabelflügel m. Verkündigung u. Darstellung im Tempel 79

Ebersdorf (Stadt Chemnitz) | Pfarrkirche | Thronende Muttergottes $77 f$.

Ehningen | Pfarrkirche, ehem. St. Maria 301

Ehrenberg 74

Ellwangen | St. Vitus 314

Eltham 226

Eltham | Königspalast 155
Ely | Kathedrale hl. Trinität | Grabmal d. Bischofs Woodford 198 Elzach | Neulindenkapelle | Hochaltar 198

Emmerich | St. Martini | Kirchenschatz | Kalvarienberg 19 f.

Enschede | Rijksmuseum Twenthe | Marienretabel 335

Erfurt | Kathedrale St. Marien 39

Erfurt | Predigerkirche 357

Erfurt | Predigerkirche | Kalvarienberg 357

Erfurt | Predigerkirche | sog. Schmedestedt'sche Madonna 357

Erfurt | St. Severi (ehem. Stiftskirche) | Baldachin über dem Taufstein

197

Esher (Surrey) 157

Esslingen a. Neckar | Frauenkirche | Weltgerichtsportal 193

Esztergom | Christliches Museum | Geißelung u. Dornenkrönung,

Inv.-Nr. 54.17, 54.18314

Exeter | Kathedrale St. Peter | Baldachin d. Bischofsthrons 197

Farnham (Surrey) | Burg d. Bischöfe v. Winchester 156

Ferrara 380

Feuchtwangen $\mid$ ehem. Stiftskirche St. Salvator 20

Florenz (Firenze) 120, 204, 231f., 259, 380

Florenz | Orsanmichele | Johannes d. Täufer d. Lorenzo Ghiberti $232 \mathrm{f}$.

Florenz | Orsanmichele | Tabernakel d. Jungfrau 120

Florenz | Uffizien | Dreikönigsretabel, Inv.-Nr. 1890-8364 322

Florenz | Uffizien | Maria mit Kind u. Engel d. Vincenzo Foppa, Inv.-Nr. 1890-9492 $385 \mathrm{f}$.

Florenz | Uffizien | Portinari-Altar d. Hugo van der Goes, Inv.-Nr. 1890-3191-3193 375

Florenz | St. Maria Novella | Dreifaltigkeit d. Masaccio 231

Fondi 97, 107-109, 113

Frankfurt a. M. 48, 54, 60, 63-65, 70

Frankfurt a. M. | Dominikanerkloster 70

Frankfurt a. M. | Liebfrauenkirche 55, 65 f., 69

Frankfurt a. M. | Liebfrauenkirche | Dreikönigsportal 47-51, 53-55, 57-60, 65f., 69f., 71

Frankfurt a. M. | Nikolaikirche | Grabstein d. Siegfried zum Paradies 65,71

Frankfurt a. M. | St. Bartholomäus (sog. Dom) 63-65, 70

Frankfurt a. M. | St. Bartholomäus | Nordportal 6of., 70

Frankfurt a. M. | St. Bartholomäus | Tympanon d. Südportals 6o-66, 70

Frankfurt a. M. | St. Bartholomäus | Stifterfigur Karls des Großen m. Kirchenmodell im Chorgestühl 63

Frankfurt a. M. | Städel Museum | Baldachinretabel aus d. Nürnberger Klarissenkirche, Inv.-Nr. SG $44321 \mathrm{f}$.

Frankfurt a. M. | Städel Museum | Gnadenstuhl, Inv.-Nr. 939B 368

Frankfurt a. M. | Städel Museum | Lucca-Madonna, Inv.-Nr. $944361 \mathrm{f}$

Frankfurt a. M. | Städel Museum | Medici-Madonna, Inv.-Nr. 850393

Frankfurt a. M. | Städel Museum | Paradiesgärtlein, Inv.-Nr. HM 54 234f., 365

Frankfurt a. M. | Städel Museum | Pfullendorfer Altar, Inv.-Nr. SG 453f., 555323

Frauenberg s. $\rightarrow$ Hluboká nad Vltavou

Freiberg (Sachsen) 77

Freiburg i. Br. 336

Freiburg i. Br. | Augustinermuseum | Tafeln d. Tennenbacher Retabels $331-333,355 f$.

Freiburg i. Br.| Münster (Kathedrale) 47, 69, 299 
Freiburg i. Br. | Münster | Sakramentshaus 192

Freiburg i. Br. | St. Martin | Mittelfenster im Vorraum d. Marienkapelle 198

Freiburg i. Ü. | Kathedrale St. Nikolaus | Hochaltar 198

Freising 323

Freising | Diözesanmuseum | Anbetung d. Könige, Tafelbild-Fragmente aus Höchstadt/Donau, Inv.-Nr. P 220 u. 221 317-320, 322f., 413

Freising | Dom St. Maria und Korbinian | ehem. Hochaltarretabel v. Jakob Kaschauer $\rightarrow$ München | Bayerisches Nationalmuseum

Garmisch-Partenkirchen | Mariä Himmelfahrt | Hochaltar 198 Gdańsk (Danzig) | Marienkirche | Schöne Madonna 232

Genf (Genève) 376

Genf | Bibliothèque de Genève | Pierre Salmon, Dialogues (1411-13), Sign. Ms. fr. 165227

Genf | Musées d'art de d'histoire | Genfer Altar d. Konrad Witz, Inv.-Nr. 1843-10 375f.

Gent | Kathedrale St. Bavo | Genter Altar d. Jan van Eyck 231, 322, 374

Genua (Genova) 378, 380, 383, 385

Genua | Dominikanerkloster Sta. Maria di Castello | Kreuzgang | Fresken 383 f.

Gersdorf b. Chemnitz 75 f.

Gersdorf b. Chemnitz | Heiligenfiguren $\rightarrow$ Chemnitz $\mid$ Städt. Kunstsammlungen, Schlossbergmuseum

Glatz $\rightarrow$ Kłodzko

Gloucester | Kathedrale St. Peter | Grabmal König Edwards II. 197

Göttingen | St. Jakobi | Retabel 274

Gottlieben (Thurgau) | Schloss 189

Graz 314

Guadalajara | Palacio del Infantado 198

Günzburg a. d. Donau 310

Güterstein | Kartause 301

Haigerloch-Gruol | St. Clemens | Hochaltar 198

Haguenau (Bas-Rhin) 310, 336

Hamburg | Kunsthalle | Kreuztragung, Inv.-Nr. 495 255, 258

Hamburg | Kunsthalle | Hochaltarretabel der Hamburger Petri-Kirche, Inv.-Nr. 500243 f.

Hamburg | Kunsthalle | Triptychon d. Kölner Klarissenklosters, Inv.-Nr. $325 \quad 17$

Hamburg | St. Petri 243

Hannover | Landesmuseum | Hannoveraner Altar, Bertram von Minden zugeschrieben, Inv.-Nr. PAM 922 a-c 339

Hanwell (Oxfordshire) | St. Peter 197

Harfleur 205, 212

Harvard | Houghton Library | Pontifical, Sign. Typ. 1136

Heiligkreuztal | ehem. Zisterzienserinnenkloster | Reiterzug der hl. Drei Könige $\rightarrow$ Stuttgart | Staatsgalerie

Heilsbronn | St. Maria und Jakob (ehem. Zisterzienserabteikirche) | Retabelflügel mit Passionsszenen 24

Helsinki | Finnisches Nationalmuseum | Barbararetabel aus Kalanti 281

Henley-on-the-Heath (Surrey) 155

Hereford | Kathedrale St. Maria und Ethelbert | Grabmal d. Peter de Grandison 190, 197

Highclere (Hampshire) | Bischofspalast 154, 156-158
Hluboká nad Vltavou | Südböhmische Aleš-Galerie | Madonna aus České Budějovice / Budweis 82, 85

Hluboká nad Vltavou | Südböhmische Aleš-Galerie | Madonna aus St. Nikolai in Suchdol 82, 85

Höchstädt a. d. Donau 318

Höchstädt a. d. Donau | Pfarrkirche Mariä Himmelfahrt 318

Hohenfurth $\rightarrow$ Vyšší Brod

Hohenfurth (Vyšší Brod) | Zyklus aus Hohenfurth $\rightarrow$ Prag | Národní galerie

Holbeach (Lincolnshire) | Allerheiligenkirche | Grabmal d. Humphrey Littlebury 197

Hoogstraten | Sint-Katelijnekerk | Joseftafel 371

Horb am Neckar 300

Huy | Notre-Dame | Betlehem-Portal 566 .

Idar-Oberstein | Felsenkirche in Oberstein | Passionstriptychon, 233f., 248, 251f., 254f., 257, 329f., 333, 355

Karlsruhe 327

Karlsruhe | Staatliche Kunsthalle | Tafelbild der Thronenden Madonna, Inv.-Nr. 2220317

Karlsruhe | Staatliche Kunsthalle | Tafeln d. Tennenbacher Retabels 331-333, 355f.

Karlsruhe | Staatliche Kunsthalle | Karlsruher Passion, Hans Hirtz zugeschrieben, Inv.-Nr. 1136, 1375, 1497, 2180, 2436, 2911 248-251, 327-344, 347-351, 357, 359

Karlstein $\rightarrow$ Karlštejn

Karlštejn | Burg | Heilig-Kreuz-Kapelle | Fresko m. Anbetung der Könige 58

Karlštejn | Burg | Kleiner Turm | Marienkapelle | Thronende Madonna m. Ks. Karl IV. u. Anna von Schweidnitz $58 \mathrm{f}$.

Kaschau $\rightarrow$ Košice

Kenilworth Castle (Warwickshire) 163

Kiedrich | St. Valentin 47

King’s Langley | Königspalast 155

Kłodzko (Glatz) 280

Kłodzko | Mariä Himmelfahrt (ehem. Augustinerchorherrenstiftskirche) | Orgel 280

Klosterneuburg 304

Klosterneuburg | Augustinerchorherrenstift | Albrechtsaltar 373, 377, 393

Klosterneuburg | Augustinerchorherrenstift | Klosterneuburger Altar $23 \mathrm{f}$.

Köln 20, 65, 131, 216, 236, 239, 350, 358f., 363

Köln | Dom | Dreikönigsaltar v. Stefan Lochner 236, 319

Köln | Dom 40, 56, 216

Köln | Klarissenkloster St. Klara | Triptychon $\rightarrow$ Hamburg | Kunsthalle

Köln | Museum Schnütgen | Epiphanie von der Rückseite des Kölner

Dom-Hochaltars, Inv.-Nr. 210a, e, m 55 f.

Köln | St. Agatha 358

Köln | Wallraf-Richartz-Museum 327

Köln | Wallraf-Richartz-Museum | Anbetung der Könige 394

Köln | Wallraf-Richartz-Museum | Die hll. Vitus, Modestus u. Crescentia am Galgen, Inv.-Nr. 821 307-310

Köln | Wallraf-Richartz-Museum | Gefangennahme Christi, zweite Tafel d. Karlsruher Passion, Inv.-Nr. WRM 585, Dauerleihgabe $\rightarrow$ Karlsruhe | Kunsthalle 328 
Köln | Wallraf-Richartz-Museum | Georgsretabel, Inv.-Nr. 114-118 $350,358 \mathrm{f}$

Köln | Wallraf-Richartz-Museum | Madonna m. d. Wickenblüte, Inv.-Nr. WRM 0010251

Köln | Wallraf-Richartz-Museum | Retabel aus einer Osnabrücker Kirche 274

Köln | Wallraf-Richartz-Museum | Triptychon m. Epiphanie u. Kreuzigung 366f.

Kolín 42

Kolín | St. Bartholomäus 32f., 42

Konstantinopel 17

Konstanz 188-190, 197, 199f., 201-205, 208f., 211, 215-217, 218, 223 , 227

Konstanz | Dreifaltigkeitskirche (ehem. Augustinereremitenkirche) | Identifikationsporträt König Sigismunds 200

Konstanz | Münster (ehem. Kathedrale) 46, 183f., 188, 191-194, 199f., 203f., $216 f$.

Konstanz | Münster | Confessio des hl. Pelagius 188f., 217

Konstanz | Münster | Franz-Xaver-Kapelle | Grabplatte d. Bf. Otto von Sonnenberg 191

Konstanz | Münster | Grabplatte d. Bf. Robert Hallum 151, 188-191, 193f., 197, 203, 217

Konstanz | Münster | Hochchor 188

Konstanz | Münster | Mauritiusrotunde | Wandbild des Tempelgangs Mariens 191

Konstanz | Münster | Obere Sakristei 183

Konstanz | Münster | Schnegg 149, 151, 183-188, 191-193, 217

Konstanz | Münster | Thomaschor $183 \mathrm{f}$.

Konstanz | Münster | Untere Margaretenkapelle | Liegefigur Bf. Ottos III. von Hachberg 184, 187

Konstanz | Rosgartenmuseum | Chronik d. Konstanzer Konzils, Sign. Ms. 1 205, 224

Konstanz | Rosgartenmuseum | Portal d. Zunfthauses Zum Rosengarten 184

Konstanz | St. Stephan | Hochaltarschrein $193 \mathrm{f}$.

Konstanz | Zunfthaus Zum Rosengarten $\rightarrow$ Konstanz | Rosgartenmuseum

Kopenhagen | Statens Museum for Kunst | Kon. Kobberstiksamling | Verspottung Jesu, Inv.-Nr. GB 2971253

Košice (Kaschau) | St. Elisabeth | Hochaltarretabel 267, 298

Krakau $\rightarrow$ Kraków

Kraków 309

Kremsmünster | Stiftssammlung | Anbetung d. Kindes, Meister d. Pollinger Retabels 238

Kremsmünster | Stiftssammlung | Heimsuchung, Meister d. Pollinger Retabels 237f.

Krumau $\rightarrow$ Český Krumlov u. $\rightarrow$ Wien | Kunsthistorisches Museum

L'Aquila 136,145

La Sarraz | Grabmal François’ I. de La Sarraz († 1363) 123

Lauffen am Neckar | Regiswindiskirche | Chorfenster 45

Legnica (Liegnitz) | Kathedrale St. Peter und Paul | ehem. Hochaltarretabel 275

Leipzig $73,77,79$

Leipzig | Stadtgeschichtliches Museum 85

Leipzig | Stadtgeschichtliches Museum | Muttergottes, Inv.-Nr. PL 2 76, 82
Leipzig | Stadtgeschichtliches Museum | Fragmente des Retabels aus der Pfarrkirche v. Leipzig-Eutritzsch, Inv.-Nrr. L/4/2010, L/6/2010 76,82

Leipzig-Eutritzsch | Pfarrkirche 76

Leipzig-Eutritzsch | Pfarrkirche | Retabel $\rightarrow$ Leipzig | Stadtgeschichtliches Museum

Leuven (Louvain) | St. Jakob | Sakramentshaus 198

Leuven | St. Peter | Kreuzweg im Chor 198

Libiš $\mid$ St. Jakob 70

Lichtenstein (Württemberg) | Schloss 301f., 307, 315

Lichtenstein | Schloss | Marientod d. Meisters von Schloss Lichtenstein $301 f$.

Liegnitz $\rightarrow$ Legnica

Lille 212

Limoges 119

Limoges | St-Martial | Hochalter 119

Lincoln 216

Lincoln | Kathedrale St. Maria 216

Lincoln | Kathedrale St. Maria | Hauptportal 197

London 149, 156, 190, 202, 205-207, 212, 226

London | British Library | Pageant of the Birth, Life and Death of Richard Beauchamp, Sign. Art. 6 208-210

London | British Library | Shrewsbury Book, Sign. Royal MS 15 E VI $171,173,175,18$ of., 403 f.

London | British Library | Stundenbuch, Sign. Add. 50005 250, 252, 259f., 405

London | Ely Place 212

London | Fulham Palace 156

London | Lambeth Palace 207

London | National Gallery | Kleine Madonna am Kamin, Inv.-Nr. NG2609 393

London | National Gallery | Maria mit Kind v. Jan Provoost, Inv.-Nr. $\mathrm{NG} 713382$

London | National Gallery | Verkündigung mit hl. Emidius aus Ascoli Piceno, v. Carlo Crivelli, Inv.-Nr. NG739 386

London | National Gallery | Wilton Diptychon, Inv.-Nr. NG4451 149, 157,215

London | St. Paul's Cathedral 206, 223

London | The British Museum | Department of Prints and Drawings | Kupferstich m. Kreuzabnahme, Inv.-Nr. 1932,0616.1 259

London | Tower | Byward Tower 167

London | Victoria and Albert Museum | Drei Fensterglasfiguren aus $\mathrm{d}$. Kapelle d. Winchester College 167

London | Victoria and Albert Museum | Ordenskette mit s-förmigen Gliedern 211

London | Westminster Abbey 170, 173, 203, 207, 227

London | Westminster Abbey | Binnenchor | Schrein St. Edwards des Bekenners 207f.

London | Westminster Abbey | Grabmal des Simon Langham 120

London | Westminster Abbey | Grabmal Kg. Richards II. u. Annas von Böhmen 149

London | Westminster Abbey | Porträt Richards II. 149

London | Westminster Hall 156f., 167, 207, 210

London | Westminster Palace 149, 154, 205, 207, 212

London | Westminster Palace | St. Stephen's Chapel 197, 204

Los Angeles | John Paul Getty Museum | Missale Johannes' XXIII. u. 
Fragment eines Missale aus Santa Maria del Popolo in Rom, Inv.-Nr. Ms. 34134

Löwen $s . \rightarrow$ Leuven

Louvain s. $\rightarrow$ Leuven

Lüneburg | Rathaus | Wandschrank d. Gerichtslaube 198

Lyon 94, 98, 102, 205

Maastricht | St. Servatius | Schöne Madonna 232

Madrid | Prado | Vermählung Mariens, Inv.-Nr. P1887 363f., 368, 372

Madrid | Prado | Werl-Retabel, Inv.-Nr. Poo1513 362f., 373

Maidstone | Leeds Castle 212

Mailand (Milano) | Dom Geburt Mariä | Westportal 198

Mainz 5of., 53f., 65f., 205, 215, 355

Mainz | Dom 48, 50, 55, 69

Mainz | Dom | Grabmal Erzbischof Konrads III. von Daun 69

Mainz | Dom | Grabstein Bischof Johanns II. von Nassau 48f., 51, 54f., 70

Mainz | Dom | Kreuzgang | Schlussstein m. kniendem König 52f.

Mainz | Dom | Kreuzgang | Schlussstein m. thronender Madonna 51, 54,69

Mainz | Karmeliterkloster | Kreuzzeptermadonna 54f.

Mainz | Landesmuseum | Relief des Kurfürst-Pfalzgrafen bei Rhein v. ehem. Kaufhaus 62

Mainz | Landesmuseum | Wappenhalterin, Inv.-Nr. S 3123 51, 54, 69

Mainz | St. Stephan 355

Mantua (Mantova) 204

Marburg a. d. Lahn 64

Marienthal (Netze) | Zisterzienserinnenkloster | Retabel 274

Marseille | St-Victor | Grab Urbans V. 108, 114

Meißen 73, 79

Meißen | Albrechtsburg 73, 75

Meißen | Dom St. Johannes u. Donatus $73 \mathrm{f}$.

Meißen | Dom St. Johannes u. Donatus | Allerheiligenkapelle | Retabel

73

Meißen | Dom St. Johannes u. Donatus | Fürstenkapelle $73 \mathrm{f}$.

Meißen | Dom St. Johannes u. Donatus | Südportal 73

Meißen | Dom St. Johannes u. Donatus | Westportal73

Modena 380

Modena | Galleria Estense | Marienretabel mit Verkündigung, Inv.-Nrr. 221, $226380-382$

Molsheim 336

Montecassino | Benediktinerabtei | Archivio dell'Abbazia | Fragment

eines Missale Benedikts XIII., Sign. Ms. 539 13of., 144

Monte Oliveto Maggiore | Benediktinerabtei 138

Montfavet | Notre-Dame-de-Bon-Repos $105 \mathrm{f}$.

Montgomery (Powys) | St. Nicolas | Chorgestühl 197

Montgomery (Powys) | St. Nicolas | Mittelöffnung d. west. Teils d. Schranke 197

Moskau | Staatliches Museum für Bildende Künste A. S. Puschkin | Tafel d. Anbetung d. Könige, Meister Schloss Lichtenstein, Inv.-Nr. 421303

Most (Brüx) | Regionalmuseum | Pietà aus Schwetz, Inv.-Nr. UP 0396 78

Mühlhausen am Neckar (Stadt Stuttgart) 336

Mühlhausen am Neckar | St. Veit | Hochaltarretabel $\rightarrow$ Stuttgart | Staatsgalerie
Mühlhausen (Thüringen) | Marienkirche | Anbetung d. Könige am Südquerhaus $61 \mathrm{f} ., 70$

München 18,376

München | Alte Pinakothek | Columba-Retabel d. Rogier van der Weyden, Inv.-Nr. WAF 1191236

München | Alte Pinakothek | Verkündigung, Meister d. Pollinger Retabels, Inv.-Nr. 6247 235, 376-378

München | Bayerisches Nationalmuseum | zwei Madonnenfiguren, Inv.-Nrr. MA 2293f. 23

München | Bayerisches Nationalmuseum | Skulpturen des ehem. Hochaltarretabels des Freisinger Doms, Inv.-Nrr. 16/71, L 93/982 305

München | Bayerisches Nationalmuseum | Tafeln d. Tabula magna aus der Abteikirche Tegernsee, Gabriel Angler zugeschrieben, Inv.-Nr. L BStGS 1436 328, 394

München | Bayerische Staatsbibliothek | Perikopenbuch Heinrichs II., Sign. Clm 445271

München | Frauenkirche (heute Kathedrale) 378

Münnerstadt | St. Maria Magdalena | Hochaltarretabel v. Tilman Riemenschneider 279

Münster (Westfalen) | LWL-Museum für Kunst und Kulturgeschichte | Halderner Retabel, Inv.-Nr. 1038 LM 340

Münster (Westfalen) | LWL-Museum für Kunst und Kulturgeschichte | Kreuztragung, Inv.-Nr. 34, 35 WKV 256

Münster (Westfalen) | LWL-Museum für Kunst und Kulturgeschichte | Madonna im Gemach des Meisters v. Iserlohn, Inv.-Nr. 965 LM 371, $377,384 f$.

Neapel 90, 380

Neiße $\rightarrow$ Nysa

New York | The Metropolitan Museum of Art | Fragment eines Missales Benedikts XIII., Sign. 28.140 13of.

New York | The Metropolitan Museum of Art | Kupferstich „Die Hexe“ v. Albrecht Dürer, Inv.-Nr. 19.73.75 383

New York | The Metropolitan Museum of Art | Robert Lehman Collection | Madonna mit Kind u. d. hl. Hieronymus m. einem Stifter, Inv.-Nr. 1975.I.I.33 380

New York | The Metropolitan Museum of Art | The Cloisters Collection | Belles Heures, Sign. 54.1 1a, b $253 \mathrm{f}$.

New York | The Metropolitan Museum of Art | The Cloisters Collection | Bildteppich mit Szenen aus dem Marienleben, Inv.-Nr. 57.126 367

New York | The Metropolitan Museum of Art | The Cloisters Collection | Mérode-Triptychon v. Rogier van der Weyden, Inv.-Nr. 56.70a-c $362,365,377$

New York | The Morgan Library and Museum | Lektionar aus SaintTrond, Sign. Ms. M 883 259f.)

New York | The Morgan Library and Museum | Morgan-Diptychon, Inv.-Nr. AZo22.1 57, 64

New York | The Morgan Library and Museum | Psalter und Stundenbuch des Henry Beauchamp, Sign. MS M. 893 17of., 402

Nördlingen | St. Georg | Hochaltarretabel 279

Northwold (Norfolk) | St. Andrew | Heiliges Grab 197

Norwich 226

Nottingham 149, 225

Novara | Biblioteca Capitolare | Polistoria, Sign. Ms. 24, olim Ms. XLII $139 f$.

Nürnberg 19f., 21, 65, 276, 287, 297, 317, 337 
Nürnberg | Augustinereremitenkirche St. Veit 314

Nürnberg | Frauenkirche 20, 243

Nürnberg | Frauenkirche | Tucher-Altar, ehemals Hochaltar der Augustinerkirche St. Veit in Nürnberg 287, 298

Nürnberg | Frauenkirche | Tympanon des inneren Westportals 57

Nürnberg | Germanisches Nationalmuseum | Epitaph der Klara Imhoff $392 f$.

Nürnberg | Germanisches Nationalmuseum | Flügel des Marienretabels der Nürnberger Frauenkirche, Inv.-Nr. Gm $114243 \mathrm{f}$.

Nürnberg | Germanisches Nationalmuseum | Oberrheinisches Diptychon, Inv.-Nr. Gm 1053 248f., 251-253

Nürnberg | Germanisches Nationalmuseum | Tafel d. Tabula magna aus der Abteikirche Tegernsee, Gabriel Angler zugeschrieben 328, 394

Nürnberg | Germanisches Nationalmuseum | Verkündigung, Inv.-Nr. Gm 878 374f.

Nürnberg | St. Jakob (Deutschordenskirche) | Hochaltarretabel $22 \mathrm{f}$.

Nürnberg | St. Katharina (Dominikanerinnenkloster) 22

Nürnberg | St. Katharina (Dominikanerinnenkloster) | Urkunde $\rightarrow$ Nürnberg | Stadtarchiv

Nürnberg | St. Klara (Klarissenkloster) | Baldachinretabel $\rightarrow$ Frankfurt a. M. | Städel Museum

Nürnberg | St. Lorenz 61

Nürnberg | St. Lorenz | Sakramentshaus 192

Nürnberg | Stadtarchiv | Urkunde m. Madonna aus dem Nürnberger

Dominikanerinnenkloster St. Katharina, Sign. 234 20-22

Nürnberg | St. Sebald 297

Nürnberg | St. Sebald | Strahlenkranzmadonna $232 \mathrm{f}$.

Nysa (Neiße) 275-280, 282f., 288f., 297

Nysa | St. Jakobus 275, 277, 280, 288f., 296

Nysa | Museum | Vera Ikon-Tafel 267

Oberhermsdorf | Pfarrkirche | Madonna $\rightarrow$ Chemnitz | Städt. Kunstsammlungen, Schlossbergmuseum

Öhningen-Schienen | St. Genesius | Gnadenaltar 198

Opava (Troppau) 304

Oppenheim | St. Katharinen 47

Orte (Provinz Viterbo) | Kathedrale 140

Orte (Provinz Viterbo) | Museo Diocesano | Madonna Assunta aus d.

Kathedrale Santa Maria Assunta in Orte, Inv.-Nr. 8140

Osek (Ossegg) | Zisterzienserabteikirche $\mid$ Pietà $\rightarrow$ Teplice | Regionalmuseum

Ossegg $\rightarrow$ Osek

Ottery St. Mary (Devon) | St. Mary | Altarwand 197

Oxford 153, 157f., 189, 203

Oxford | Bodleian Library | Saint-Albans-Chronik, Sign. Ms. 462225

Oxford | Merton College 162f., 168

Oxford | Merton College | Kapelle 158

Oxford | New College 150, 154-163, 166-168

Oxford | Oriel College 168

Oxford | St. Mary the Virgin 157

Padua | San Antonio | Oratorio di San Giorgio | Kreuzigungsfresko d. Altichiero da Zevio 237

Panschwitz-Kuckau $\rightarrow$ St. Marienstern

Paris 93, 107f., 17of., 205, 223
Paris | Bibliothèque nationale de France | Handschrift d. Decamerone, Sign. ms. fr. 12421 171f., 175 ff., 181

Paris | Bibliothèque nationale de France | Petites Heures des Herzogs von Berry, Sign. Ms. lat. 18014 79, 227

Paris | Bibliothèque nationale de France | Rohan-Stundenbuch, Sign. ms. lat. 9471254

Paris | Châtelet 173

Paris $\mid$ Collège de la Sorbonne 160

Paris | Kathedrale Notre-Dame 172

Paris $\mid$ Les Enluminures | Fragment einer Missale $\rightarrow$ Montecassino 130-132, 144

Paris | Louvre 187, 207

Paris | Musée des arts décoratifs | Tapisserie m. Charles d’Orléans u. Marie de Clèves, Inv.-Nr. $21121382 \mathrm{f}$.

Paris | Musée du Louvre | Département des arts graphiques | Parament von Narbonne, Inv.-Nr. M.I. 112123

Parma | Biblioteca Palatina | Offida-Missale, Sign. Pal. 670 136, 145

Peñiscola 90, 144

Perpignan 199, 205

Pfullendorf | Pfarrkirche | Retabel $\rightarrow$ Frankfurt a. M. | Städel Museum

Pilsen $\rightarrow$ Plzeň

Pisa $64,70,123,203$

Pisa | Sta. Caterina | Grabmal d. Erzbischofs Simone Salterelli 123

Pisa | Sta. Maria Assunta | Grabmal Heinrichs VII. 123

Plzeň | Kathedrale St. Bartholomäus | Schöne Madonna 81f.

Poissy | St-Louis (Dominikanerkloster) | Madonna $\rightarrow$ Antwerpen |

Museum Mayer van den Bergh

Poitiers 154

Polling | Kloster 376

Portchester (Hampshire) | Schloss 162

Prag 15, 18-20, 29, 31, 39, 79, 82, 246

Prag | Burg 31

Prag | Karlov (Karlshof) | St. Maria Himmelfahrt und hl. Karl der Große 63

Prag | Kathedrale St. Veit 19, 31-33, 36-39, 70, 167

Prag | Kathedrale St. Veit | Chor | Triforium 31f., $36 f$.

Prag | Kathedrale St. Veit | Martiniz-Kapelle 36, 40

Prag | Kloster Na Slovanech (Emauskloster) 20

Prag | Knihovna Národního muzea | Missale d. Kanonikers Henricus, Sign. XVI B 1219

Prag | Knihovna Národního muzea | Liber viacticus, Sign. XIII A 12 $18,28,59,66$

Prag | Národní galerie | Kreuzigungstafel aus dem Prager Kloster Na Slovanech, Inv.-Nr. O $125219 f$.

Prag | Národní galerie | Zyklus aus Hohenfurth / Vyšší Brod, Inv.-Nrr. O 6786-6794 19, 23, 56f., 70

Rappoltsweiler $\rightarrow$ Ribeauvillé

Ravensburg 378, 383

Regensburg 31, 33, 36f., 40, 287

Regensburg|Bistum 31

Regensburg | Dom St. Peter 29-34, 35-42, 193

Regensburg | Dom St. Peter | Hasenburgkapelle 37

Regensburg| Obermünster (reichsfreies Damenstift) 41

Regensburg | St. Johann (Stiftskirche) 29, 33

Reims 119, 206

Remmingsheim | Pfarrkirche 306 
Ribeauvillé (Haut-Rhin) | St. Georg | Tympanon des Westportals $16 f$. Rhens 64f.

Rochester (Kent) 206

Rochlitz 77, 81

Rom 64, 89-91, 97, 109f., 117, 12of., 129, 131, 134-136, 138-140, 143, 145, 201, 204, 217

Rom | Archivio di Stato | Codex, Sign. Ms. 1006140

Rom | San Giovanni in Laterano | Hochaltar 120

Rom | San Lorenzo in Damaso 120

Rom | San Paolo fuori le mura 139

Rom | San Pietro in Vaticano $\rightarrow$ Vatikanstadt | St. Peter

Rom | San Silvestro in Capite 144

Rom | Sta. Cecilia in Trastevere 120

Rom | Sta. Cecilia in Trastevere | Grabmal des Adam of Easton 11712

Rom | Sta. Cecilia in Trastevere | Grabmal des Philippe d'Alençon 117-122

Rom | Sta. Francesca Romana (Sta. Maria Nova) 139

Rom | Sta. Maria in Aracoeli | Grab d. Matteo d'Aquasparta 120

Rom | Sta. Maria in Trastevere | Brancacci-Tabernakel 140

Rom | Sta. Maria Maggiore | Grabmal d. Gonzalez Pérez Gudiel 120

Rosenfeld | St. Patricius | Hochaltar 198

Rothau (Bas-Rhin) 337

Rothenburg o. d. Tauber | Heilig-Geist-Kirche | Sakramentsnische 24

Rothenburg o. d. Tauber | St. Jakob | Heilig-Blut-Altar 279

Rothenburg o. d. Tauber | St. Jakob | Zwölf-Boten-Altar 279

Rottenburg am Neckar 30of., 304, 313, 315

Rottenburg am Neckar | Dom St. Martin 301, 313

Rottenburg am Neckar | Schlosskapelle | Altar 301

Rottenburg am Neckar | St. Moriz (Chorherrenstift R.-Ehingen) 301, 306f., 313, 315

Rottenburg am Neckar | St. Moriz | Annenkapelle | Wandbild 306

Rottenburg am Neckar | St. Moriz | Wandbild m. hl. Sebastian 306, 310,314

Rottenburg am Neckar | St. Remigius 306

Rottenburg am Neckar-Weiler $\rightarrow$ Weiler (Stadt Rottenburg a. N.)

Rottweil 374

Rouen 170

Saarbrücken 340

Saarbrücken | Kommende St. Elisabeth | Retabel v. Jost Haller 392

Sächsischer Altertumsverein (Sammlung) $\rightarrow$ Chemnitz | Städt. Kunstsammlungen, Schlossbergmuseum

Saint-Denis | Kathedrale Saint-Denis 114

Salamanca | Kathedrale St. Maria | Westportal 198

Salem | Münster | Sakramentshaus 192

Salzburg | Museum Carolino Augusteum | Flügelretabel d. Meisters d.

Virgo inter virgines, Inv.-Nr. 214-32 382

Salzburg | Nonnbergstift | Klaner-Fenster 349

Salzwedel | St. Maria | Triumphbogenkreuz 193

Saverne (Zabern) 336

Scarning (Norfolk) | St. Peter und Paul | Schranke 197

Schaffhausen | St. Johannes | Chorstuhl 198

Schlettstadt $\rightarrow$ Sélestat

Schneeberg | St. Wolfgang 77

Schönsteinbach | Dominikanerinnenkloster 342

Schöppingen | St. Brictius | Hochaltarretabel 366f.
Schotten | Liebfrauenkirche | Hochaltarretabel 23

Schwertz b. Most (Brüx) | Pietà $\rightarrow$ Most | Regionalmuseum

Sélestat (Schlettstadt) 336

Senftenberg (Niederlausitz) | Triptychon $\rightarrow$ Doberlug-Kirchhain

Sheen | Königspalast 155

Siena 90

Siena | Dom Assumptio Mariae | Grabmal des Riccardo Petroni 123

Southampton 156

South Waltham 156

Southwark | Kathedrale | Grabmal d. Bernhard de Brocas 190

Spaichingen | St. Peter und Paul 306

Sperlonga 97, 107

Staufen i. Br. 355

Stebbing (Essex) | St. Mary | Schranke 197

Steinhagen (Westfalen) | Pfarrkirche | Retabel v. Johann Koerbecke 264

Steißlingen | St. Remigius und Cyrillus | Hochaltar 198

Sterzing | Multschermuseum | Retabel d. Hans Multscher 310, 318 , 372

Stralsund | St. Nikolai | Schöne Madonna, sog. Junge-Madonna $231 \mathrm{f}$. Straßburg (Strasbourg) 248, 279, 310, 333, 336f., 340, 342f., 349-351, $355,357,359$

Straßburg | Magdalenenkirche 358

Straßburg | Münster St. Maria (Kathedrale) 40

Straßburg | Münster | Fassade 31, 40

Straßburg | Münster | Katharinenkapelle 40

Straßburg | Münster | Südportal 369f.

Straßburg | Münster | Wendelstein am Nordturm 187

Straßburg | Saint-Pierre-le-Vieux 336, 356

Straßburg | Stadtarchiv | Mannschaftsbuch des Armagnacenzugs, Sign. A.A. Nr. 195358

Straßburg| St. Nikolaus 342

Straßburg | St. Thomas 336f., 339f., 349, $356 f$.

Straßburg | St. Wilhelm | Glasmalereien 344

Straßburg | Musée de l'Oeuvre Notre-Dame | Maria als Tempeljungfrau, Inv.-Nr. MBA 1642393

Straßburg | Musée de l'Oeuvre Notre-Dame | Josefszweifel, Inv.-Nr.

MBA 1482 365f., 367

Stuttgart | Landesmuseum Württemberg | Kartenspiel 310

Stuttgart | Landesmuseum Württemberg | Madonna 307

Stuttgart | Staatsgalerie | Hochaltarretabel der St.-Veits-Kapelle Mühlhausen am Neckar, Inv.-Nr. 103823

Stuttgart | Staatsgalerie | Marienkrönung d. Meisters v. Schloss Lichtenstein, Inv.-Nr. L1191 301f., 307, 410

Stuttgart | Staatsgalerie | Reiterzug d. Heiligen Drei Könige v. Maler des Sterzinger Retabels, Inv.-Nr. 32323

Stuttgart-Mühlhausen | St. Veit | Hochaltarretabel $\rightarrow$ Stuttgart | Staatsgalerie

St. Gallen | Stiftskirche | Altar 296, 298

St. Lambrecht (Steiermark) 304

St. Marienstern | Zisterzienserinnenkloster 80

St. Petersburg | Eremitage | Missale Bonifaz' IX., Inv.-Nr. Orr-23 129f., $134 \mathrm{f}$.

Suchdol | St. Nikolai | Madonna $\rightarrow$ Hluboká nad Vltavou | Südböhmische Aleš-Galerie

Tanneberg| Pfarrkirche | Madonna 82 
Tegernsee 321

Tegernsee | Klosterkirche | Hochaltar, sog. Tabula magna $\rightarrow$ München, Bayerisches Nationalmuseum u. $\rightarrow$ Nürnberg, Germanisches Nationalmuseum

Tengen | St. Michael | Hochaltar 198

Tennenbach | ehem. Zisterzienserabtei 355

Teplice | Regionalmuseum | Pietà aus Osek (Ossegg), Inv.-Nr. Osek 75 78

Teplitz $\rightarrow$ Teplice

Tessenderlo | St. Martin | Lettner 198

Thann (Haut-Rhin) 310

Thann (Haut-Rhin) | Münster St. Theobald | Tympanon des Westportals 55

Tiefenbronn | St. Maria Magdalena | Magdalenenretabel 238, 318, 368f., 376

Toledo | Biblioteca Capitular | Fragment eines Missales Benedikts XIII., Sign. Ms. 38.4130

Toledo | Biblioteca Capitular | Fragment eines Missales, Sign. Ms. 39.1 135f., 139, 145, 398

Toledo | Kathedrale Assumptio Mariae | Kapellenportal 198

Toledo | Kathedrale Assumptio Mariae | Löwenportal 198

Toledo | San Juan de los Reyes | Hauptportal 198

Toledo | San Juan de los Reyes | Querschiff 198

Topfseifersdorf $\mid$ Pfarrkirche | Retabel $\rightarrow$ Chemnitz | Städt. Kunstsammlungen, Schlossbergmuseum

Toulouse 91

Tournai 382

Trier 20, 65

Troyes 169, $174 \mathrm{f}$.

Troppau $\rightarrow$ Opava

Tübingen | St. Georg (Stiftskirche) 301

Turin | Museo Civico | Turin-Mailänder Stundenbuch, Inv.-Nr. 47335

Ulbersdorf 74

Ulm 192, 239, 279, 301, 321, 323, 344, 348, 351, 359

Ulm | Münster 242, 296, 345f., 348, 350

Ulm | Münster | Besserer-Kapelle 310

Ulm | Münster | Besserer-Kapelle | Glasmalereien 370, 377

Ulm | Münster | Kramerfenster 358

Ulm | Münster | Ratsfenster 344-351, 358

Ulm | Münster | Sakramentshaus 192f.

Ulm | Münster | Tympanon d. Marienportals 55

Urach s. $\rightarrow$ Bad Urach

Urbach (Fouday) 337

Utrecht | Museum Catharijneconvent | Tafelbilder, Inv.-Nrr. ABM $525 \mathrm{t} / \mathrm{m} \mathrm{s} 28 ; \mathrm{s} 156 \mathrm{t} / \mathrm{m} \mathrm{s1} 58252 \mathrm{f}$.

Vadstena| Kloster Pax Mariae 204

Valladolid | Colegio de San Gregorio | Portal 198

Valladolid | San Pablo | Westportal 198

Vatikanstadt | Papstpalast 110

Vatikanstadt | St. Peter 110

Vatikanstadt | St. Peter | Grabmal Papst Bonifaz’ VIII. 119, 120

Vatikanstadt | St. Peter | Grabmalfragmente m. Wappen d. Kardinals

Antonio Panciera 134

Vatikanstadt | Vatikanische Bibliothek | Breviar d. Kardinals Giordano Orsini, Sign. Arch. Cap. S. Pietro B.82 138f., 145
Vatikanstadt | Vatikanische Bibliothek | Fragment eines Missales Benedikts XIII., Sign. Vat. lat. 4764-4765 129-131, 145

Vatikanstadt | Vatikanische Bibliothek | Missale für Bonifaz IX., Sign. Arch. Cap. S. Pietro E. 3 133f., 145

Vatikanstadt | Vatikanische Bibliothek | Missale aus Santa Maria Paganica, Sign. Ross. 276 136, 145

Vatikanstadt | Vatikanische Bibliothek | Missale aus der Sakristei von St. Peter, Sign. Arch. Cap. S. Pietro B.65 129, 136-138, 140, 145, 399 f.

Vatikanstadt | Vatikanische Bibliothek | Praeparatio ad Missam, Sign. Vat. lat. 3747 134, 144

Vatikanstadt | Vatikanische Bibliothek | Zeichnung d. Grabes d. Kardinals Adam Easton, Inv.-Nr. Barb. Lat. 3084, fol. 282r $117 \mathrm{f}$.

Vatikanstadt | Vatikanische Bibliothek | Zeichnung d. Grabes d. Kardinals Jean de la Grange, Inv.-Nr. Barb. Lat. 4426, fol. 34 100, 102, 117,123

Vatikanstadt | Vatikanische Bibliothek | Zeichnung d. Grabes Papst Bonifaz' VIII. in Alt-St. Peter, Inv.-Nr. Barb. Lat. 2733, fol. 8r $119 f$.

Venedig (Venezia) 193, 237, 322, 380, 386

Venedig | Sta. Maria Gloriosa dei Frari (Franziskanerkirche) | Polyptychon 386

Vienne | Kathedrale St-Maurice 94

Villeneuve-lès-Avignon 91f., 107, 113

Villeneuve-lès-Avignon | Kartause Notre-Dame-du-Val-de-Bénédiction | Grab Papst Innozenz' VI. 92

Vyšší Brod (Hohenfurth) | Zisterzienserabtei | Kreuzigungstafel $\rightarrow$ Prag | Národní galerie

Walbourg (Walburg) | ehem. Klosterkirche | Glasmalereien 344

Waldersbach (Elsass) 337,356

Waldersbach | Kirche 337, 355

Warendorf | St. Laurentius | Hochaltarretabel 274

Warschau (Warszawa) | Muzeum Narodowe w Warszawie | Hl. Katharina, Inv.-Nr. Sr. 457232

Warschau | Muzeum Narodowe w Warszawie | Hochaltarretabel der Breslauer St.-Barbara-Kirche, Inv.-Nr. Śr. 35 267-276, 280-288, 295, 297f., 357, 407f.

Warschau | Muzeum Narodowe w Warszawie | Kreuzigungsgruppe aus d. Dumlose-Kapelle in Wrocław (Breslau), Inv.-Nr. Śr.6/a-c 81

Warschau | Muzeum Narodowe w Warszawie | Kreuzigungsretabel aus Gać Śląska (Heidau), Inv.-Nr. Śr. 366 284, 286f., 297, 409

Warschau | Muzeum Narodowe w Warszawie | Legende d. hl. Vitus, Kesselmarter, Inv.-Nr. 82/2 307-309, 412

Warschau | Muzeum Narodowe w Warszawie | Legende d. hl. Vitus, Versuchung, Inv.-Nr. 82/1 $307-309,411$ )

Warschau | Muzeum Narodowe w Warszawie | Tafel d. Taufe Christi, Meister v. Schloss Lichtenstein, Inv.-Nr. 86 301, 309

Weiler (Stadt Rottenburg a. N.) | St. Jodok 307

Weiler (Stadt Rottenburg a. N.) | St. Wolfgang 307

Wells | Kathedrale St. Andreas | Bischofsthron 197

Wels | Stadtmuseum | Kreuztragung, Inv.-Nr. 29.627304

Wettenhausen | ehem. Augustinerchorherrenstift | Palmesel, Hans Multscher 321

Wien 279, 299, 303f., 314

Wien | Akademie der Bildenden Künste | Kupferstichkabinett | Architektur-Stiche, Inv.-Nr. 17.028, $17.055 \quad 185,187$

Wien | Erzbischöfliches Dom- und Diözesanmuseum | Flügel d. Andreasaltars, Meister d. Andreasaltars, Inv.-Nr. 35304 
Wien | Kaiserliche Schatzkammer | Heilige Lanze, Inv.-Nr. WS XIII 19 18,28

Wien | Kunsthistorisches Museum | Gemäldegalerie | Heilige Familie im Gemach, Inv.-Nr. $928379 f$.

Wien | Kunsthistorisches Museum | Madonna aus Český Krumlov (Krumau), Inv.-Nr. 10156 81f.

Wien | Kunsthistorisches Museum | Wappenbuch, Inv.-Nr. A 2302299

Wien | Österreichische Galerie Belvedere | Kreuzigungstafel d. Konrad Laib, Inv.-Nr. 4919 235-237

Wien | Österreichische Galerie Belvedere | Marientod d. Meisters von Großgmain, Inv.-Nr. 4857 373f.

Wien | Österreichische Nationalbibliothek | Gebetbuch, Sign. Cod. 1846 299f., 313

Wien | Österreichische Nationalbibliothek | Denkwürdigkeiten zur Geschichte des Kaisers Sigismund, Eberhard Windecke, Sign. 13975 201, 215

Wien | Österreichische Nationalbibliothek | Stundenbuch der Maria von Burgund, Sign. Cod. 1857384

Wien | Schottenstift | Museum | Tafelbilder des ehem. Hochaltarretabels der Schottenkirche 379

Wiener Neustadt 304, 314

Wiener Neustadt | Burg 304, 314

Wilsdruff | Pfarrkirche | Madonna $\rightarrow$ Chemnitz | Städt. Kunstsammlungen, Schlossbergmuseum

Winchester 150, 153, 157f., 167

Winchester | Kathedrale Hl. Trinität 150, 154, 156f., $166 f$.

Winchester | Kathedrale Hl. Trinität | Glasmalerei 158

Winchester | Kathedrale Hl. Trinität | Hl. Genoveva 158, 167

Winchester | Winchester College 154, 156-159, 167

Winchester | Winchester College | Kapelle | Glasmalerei 157-159, 401 Winchester | Wolvesey Castle 205
Windsor 153-156, 168, 208, 210-213, 215, 225

Windsor | Schloss 150, 153-156, 159-161, 167

Windsor | Schloss | Kapelle St. Georg 151, 153, 160, 207f., 21 of., 225

Windsor | Schloss | Sobieski-Stundenbuch, Bedford-Meister 330

Winterthur | Sammlung Oskar Reinhart | Verkündigung an Maria, 364f., 367,381

Winthorpe (Lincolnshire) | St. Mary | Parclose-Schranke 197

Worms | Dom St. Peter | Annenkapelle 40

Worms | Dom St. Peter | Südportal 45

Worms | Stadtmuseum | Kreuzigung (o. Inv.-Nr.), 15, 17-24, 397

Worstead (Norfolk) | St. Mary | Schranke 197

Wrocław (Breslau) 82, 276, 28of., 283, 297, 308f.

Wrocław | Muzeum Archidiecezjalne we Wrocławiu | Tafel d. Altarretabels d. Jakobuskirche in Nysa (Neiße) 273-282, 284-290, 296-299, 408

Wrocław | Muzeum Narodowe we Wrocławiu | Madonna, Inv.-Nr. XI 30681

Wrocław | St. Elisabeth | Dumlose-Kapelle | Kreuzigungsgruppe $\rightarrow$ Warschau | Muzeum Narodowe w Warszawie

Würzburg 239, 279

York 210, 223

York | St. Peter 156, 167, 223

York | St. Peter | Ioas, Fragment d. Westfensters d. Kapelle d. New College, Oxford 158, 401

Zeitz | St. Michael | ehem. Hochaltarretabel 297

Zürich | Kunsthaus Zürich | Geburt Christi, Meister d. Münchener Marientafeln 378-380, 415

Zwickau | St. Marien 77 